\title{
1994 Triggered Lightning Test Program: Measured Responses of a Reinforced Concrete Building Under Direct Lightning Attachments \\ Volume 2: Test Data
}

George H. Schnetzer, Jerry Chael, and Raymonard Davis

Electromagnetic Analysis and Test Department

Sandia National Laboratories

Albuquerque, NM 87185-0865

Richard J. Fisher

Engineering Consultant

Philip J. Magnotti

U.S. Army Armament Research, Development and Engineering Center

Picatinny Arsenal, NJ 07806-5000

\begin{abstract}
A rocket-triggered lightning test was carried out during the summer of 1994 on a specially designed steel reinforced concrete test building located at Ft. McClellan, Alabama. Currents, voltages, and magnetic fields were measured at 24 instrumented locations during 42 return strokes triggered to designated points on the structure and its lightning protection system. Detailed descriptions of the test structure, measurements, and test procedures are given in Volume 1 of this report. The present volume contains plots of the complete set of test data.
\end{abstract}

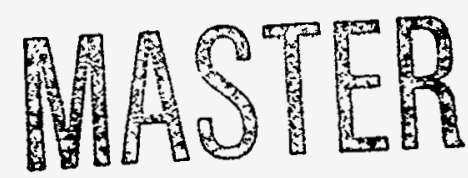




\section{Acknowledgments}

The authors acknowledge the technical contributions of M. E. Morris and K. O. Merewether of Department 2753, SNL, and J. D. Struck of ARDEC during the test structure design phase of this project. Important on-site logistical and technical support was provided throughout the fielding period by ARDEC's T. Tran, K. Haynes, and R. Branstetter of the SOTS facility at Ft. McClellan, Alabama. Special thanks are due to B. J. Hawley for her extensive help in the plotting of the test data. The excellent discussions with and substantial input from M. E. Morris, K. O. Merewether and B. J. C. Burrows, (formerly of the Lightning Test and Technology Center, Culham Laboratory, United Kingdom) are gratefully acknowledged. The enthusiastic management support and encouragement provided by M. E. Morris of SNL and by M. A. Chiefa and J. E. Grenert of ARDEC's Fire Support Armaments Division is acknowledged to have contributed substantially to the success of the entire project.

\section{DISCLAIMER}

This report was prepared as an account of work sponsored by an agency of the United States Government. Neither the United States Government nor any agency thereof, nor any of their employees, makes any warranty, express or implied, or assumes any legal liability or responsibility for the accuracy, completeness, or usefulness of any information, apparatus, product, or process disclosed, or represents that its use would not infringe privately owned rights. Reference herein to any specific commercial product, process, or service by trade name, trademark, manufacturer, or otherwise does not necessarily constitute or imply its endorsement, recommendation, or favoring by the United States Government or any agency thereof. The views and opinions of authors expressed herein do not necessarily state or reflect those of the United States Government or any agency thereof. 


\section{Contents}

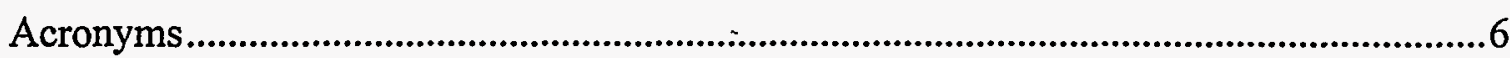

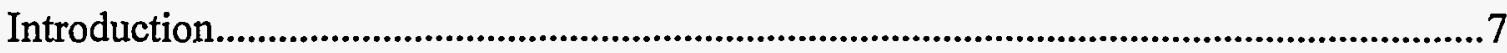

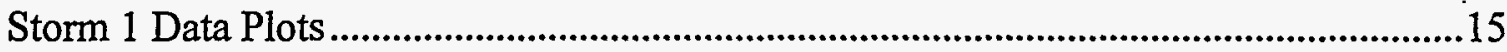

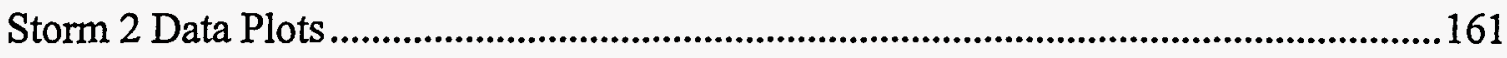

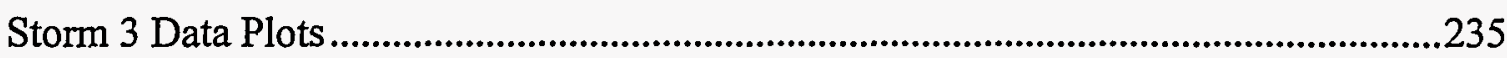

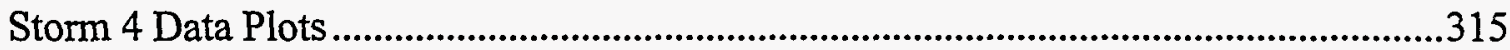

\section{Illustrations}

1 Main features of the simulated munitions handling building ..................................11

2 Diagram of the lightning protection system installed on the test structure during part of the present tests ..............................................................................................11

3 Map of test point locations throughout the test structure...........................................12

\section{Tables}

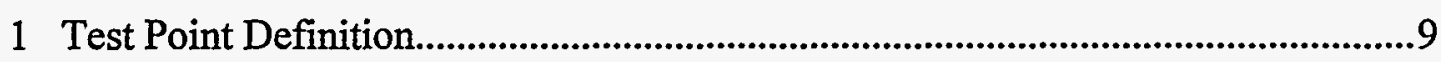

2 Triggered Lightning Attachment Points ...............................................................10

3 Building Configurations Tested During Various Storms .......................................10

4 Summary of 1994 Triggered Flashes ...................................................................12

5 Incident Stroke Current Summary ........................................................................13 


\section{Acronyms}

ARDEC

U.S. Army Armament Research, Development, and Engineering Center

AT air terminal (lightning rod)

CTG cloud-to-ground (lightning)

CVR current viewing resistor

CVT current viewing transformer

EM electromagnetic

EMT electrical metal tubing (conduit)

FM frequency modulated

FOL fiber optic link

GRE ground ring electrode

LPS lightning protection system

LTA launch tube assembly

$\mathrm{M} \& \mathrm{~A}$ maintenance and assembly

OD outside diameter

PVC polyvinyl chloride (pipe)

rebar concrete reinforcing bar

RTL rocket-triggered lightning

SATTLIF Sandia Transportable Triggered Lightning Instrumentation Facility

SNL Sandia National Laboratories

SOTS

U.S. Army Security Operational Test Site

TP test point 


\section{Triggered Lightning Test Program: Measured Responses of a Reinforced Concrete Building Under Direct Lightning Attachments}

\section{Introduction}

During the summer of 1994, rocket-triggered lightning tests were performed on a specially designed and constructed facsimile of a weapon maintenance and assembly (M\&A) building. This structure was designed jointly by The Department of the Army's Armament Research, Development, and Engineering Center (ARDEC) and Sandia National Laboratories (SNL) to incorporate many of the design and constructional features found in real M\&A buildings that most influence electromagnetic responses at critical points throughout the structure. Furthermore, the test structure was designed to allow the inclusion or removal of various key features during the course of the testing. In this way, assessment of the influence of each feature of interest could be accomplished through direct comparison of test results with and without its presence, all other factors being the same. Because one of the most significant questions was the effect on overall current flow within a structure attributable to the degree of connectivity between the individual steel concrete reinforcing rods (rebar) within the walls, the building was divided into two volumes, separated electromagnetically by a steel barrier. On one side of the barrier, the so-called "bad" side, the rebar within the walls was of a type in which the individual steel rods were coated with an epoxy layer, thereby ensuring that they were normally isolated electrically from one another at their crossover junctions throughout the walls and floor. On the other, "good," side, the rebar intersections were welded together at regular intervals.

Construction of the building was the responsibility of ARDEC and was accomplished using the U. S. Army Corps of Engineers as their contracting and construction supervision agency. The test structure was completed in September 1993 at ARDEC's Security Operations Test Site (SOTS), located at Ft. McClellan, Alabama. This is the same site at which previous triggered lightning tests in this program were carried out in 1991 and 1993. Technical planning of the 1994 experiments was developed jointly by SNL and ARDEC, with the testing itself being conducted by SNL personnel using the Sandia Transportable Triggered Lightning Instrumentation Facility (SATTLIF) with onsite technical and logistical assistance from ARDEC.

The SATTLIF arrived at the test site on April 19. Setup and checkout of the facility and instrumentation of the building was completed by early May. However, administrative impediments to the shipping of the triggering rockets delayed their arrival until June 6. Test readiness was achieved on June 7 and continued without interruption throughout the duration of the summer lightning season until September 2. During that period, which represented an unusually poor season for thunderstorms in Alabama, 
triggering operations were carried out during the occurrence of overhead storms on seven different days. Data were acquired during four storms, in which a total of 10 flashes, comprising 51 individual return strokes, were successfully triggered to designated points on the test structure. High resolution digital data were acquired during 42 of the return strokes. Peak amplitudes of stroke currents ranged from 4.2 to $29.6 \mathrm{kA}$, while the range of return-stroke current rise times was from 0.06 to $7.0 \mu \mathrm{s}$.

Data were acquired at all 24 planned test points and for attachments to all five planned terminus points on the structure and its lightning protection systems. In addition to the incident lightning flash currents, response currents were measured in the walls, on the LPS down conductors, on the two $100-\mathrm{ft}$ long buried electrical power conduits, on the buried LPS ground ring electrode around the structure, and at several miscellaneous points inside the building. Voltages with respect to the floor rebar were recorded on the simulated overhead crane rail, on the metallic ventilation stack, and on elements of the interior power distribution system. Also measured were the transient potentials developed between the wall and floor rebar at six locations around the inside perimeter of the building. Magnetic fields were recorded at floor level in the two corners of the building that were adjacent to the exterior LPS down conductors.

Presented in Volume 1 of this report are detailed descriptions of the test structure, test procedures, and instrumentation. In that volume, the test data are also summarized and discussed, with the peak values of the entire set of measured responses being given in Tables 3-4 through 3-13. The set of plotted data found in the present volume includes all of the measurements for which high resolution digital data were obtained. Table 1 lists the set of measurements that were performed, while Tables 2 and 3 define the designated points $t ;$, which lightning flashes were triggered and the variations of building configurations that were tested during the four storms for which data were acquired. Figures 1 and 2 depict the key features of the test structure and its baseline lightning protection system. For the sake of reference, Figure 3 is included to indicate the locations of the various test points defined Table 1 . Tables 4 and 5 provide information on the incident triggered lightning flashes.

The data that follow are organized according to storm, flash and stroke. The instrumentation employed during each of the four storms is documented by means of a two page drawing that appears at the beginning of the section related to that particular storm. For each stroke in a given flash, the associated data are given in ascending test point number order. 
Table 1. Test Point Definition

\begin{tabular}{|c|c|c|c|}
\hline Test Point & Description & Channel Type ${ }^{1}$ & Priority $^{2}$ \\
\hline & Current & & \\
\hline 1 & Buried Conduit & $S$ & 1 \\
\hline 2 & Buried Conduit & $S$ & 1 \\
\hline 3 & Conduit Entry & $\mathrm{S} / \mathrm{F}$ & 1 \\
\hline 4 & Conduit Entry & F & 2 \\
\hline 5 & $\mathrm{GRE}^{3}$ & $\mathrm{~S} / \mathrm{F}$ & 1 \\
\hline $5^{\prime}$ & GRE & $\mathrm{S} / \mathrm{F}$ & 1 \\
\hline 6 & GRE & $\mathrm{S} / \mathrm{F}$ & 1 \\
\hline $6^{\prime}$ & GRE & $\mathrm{S} / \mathrm{F}$ & 1 \\
\hline 7 & GRE & $\mathrm{S} / \mathrm{F}$ & 1 \\
\hline 8 & GRE & $\mathrm{S} / \mathrm{F}$ & 1 \\
\hline 9 & GRE Stub, Good Side & $S$ & 1 \\
\hline $9^{\prime}$ & GRE Stub, Bad Side & $S$ & 2 \\
\hline 10 & Wall-to-Floor Rebar & S & 1 \\
\hline 11 & Wall-to-Floor Rebar & $s$ & 1 \\
\hline 12 & Wall-to Floor Rebar & $\mathrm{s}$ & 1 \\
\hline 13 & Wall-to-Floor Rebar & $S$ & 1 \\
\hline 14 & Wall-to-Floor Rebar & $\mathrm{S} / \mathrm{F}$ & 1 \\
\hline \multirow[t]{2}{*}{15} & Wall-to-Floor Rebar & $\mathrm{S} / \mathrm{F}$ & 1 \\
\hline & Voltage & & \\
\hline 16 & Wall-to-Floor Rebar & $\mathrm{F}$ & 1 \\
\hline 17 & Wall-to-Floor Rebar & F & 1 \\
\hline 18 & Wall-to-Floor Rebar & $\mathrm{F}$ & 1 \\
\hline 19 & Wall-to-Floor Rebar & $F$ & 1 \\
\hline 20 & Crane-to-Floor & $\mathrm{F}$ & 1 \\
\hline 21 & Vent-to-Floor & $F$ & 1 \\
\hline \multirow[t]{2}{*}{22} & $\begin{array}{l}\text { Distribution } \\
\text { Conduit/Floor }\end{array}$ & $F$ & 2 \\
\hline & Magnetic Field & & \\
\hline 23 & Field $^{4}$ & $\mathrm{~S} / \mathrm{F}$ & 2 \\
\hline 24 & Field & $\mathrm{S} / \mathrm{F}$ & 2 \\
\hline
\end{tabular}

$1 \mathrm{~S}=$ FM tape channel; F = LeCroy digitizer channel; $\mathrm{S} / \mathrm{F}=$ digitizer with tape backup.

2 Priority applies to those shots on which the listed TP is included.

3 Ground Ring Electrode system.

4 Floor level, $1 \mathrm{ft}$ from walls in corners of each side adjacent to exterior down conductors; sensor axis at $45^{\circ}$ with respect to the walls. 
Table 2. Triggered Lightning Attachment Points

\begin{tabular}{|ccc|}
\hline Point & Location & Remarks \\
\hline \hline A-1 & SW AT & \\
A-2 & NE AT & \\
A-3 & Vent Stack AT & \\
A-4 & Conduit Riser Stub & Remove AT's and \\
& & conductors \\
A-5 & LPS Mast & Remove AT's and \\
& & conductors \\
\hline
\end{tabular}

Table 3. Building Configurations Tested During Various Storms

\begin{tabular}{|c|c|c|}
\hline Storm No. & Attachment Point & Configuration and Test Points \\
\hline 1 & $\begin{array}{l}A-1 \\
A-2\end{array}$ & $\begin{array}{l}\text { Floor and wall rebar connected; vent } \\
\text { bonded; buried conduit floating1; } \\
\text { TP's: } 1-2,5,5 \text {, } 6,7-8,10-15,20-24\end{array}$ \\
\hline 2 & $\begin{array}{l}A-1 \\
A-3\end{array}$ & $\begin{array}{l}\text { Floor and wall rebar disconnected; vent } \\
\text { unbonded; conduit floating; } \\
\text { TP's: } 1-2,5,5 \text { ', 6, 6', 7-8, 16-24 }\end{array}$ \\
\hline 3 & $\begin{array}{l}A-2 \\
A-4\end{array}$ & $\begin{array}{l}\text { Floor and wall rebar disconnected; vent } \\
\text { bonded; conduit grounded to GRE inside } \\
\text { structure; TP's: } 1-2,3-4,5-9,16-24\end{array}$ \\
\hline 4 & $\begin{array}{l}A-4 \\
A-5\end{array}$ & $\begin{array}{l}\text { Floor and wall rebar connected; vent } \\
\text { bonded; LPS AT's and conductors } \\
\text { removed; TP's: } 1-2,5-5,6^{\prime}-6 \text { ' } 7-8,10-15 \text {, } \\
20-24\end{array}$ \\
\hline
\end{tabular}

${ }^{1}$ Buried conduit electrically disconnected from GRE. 


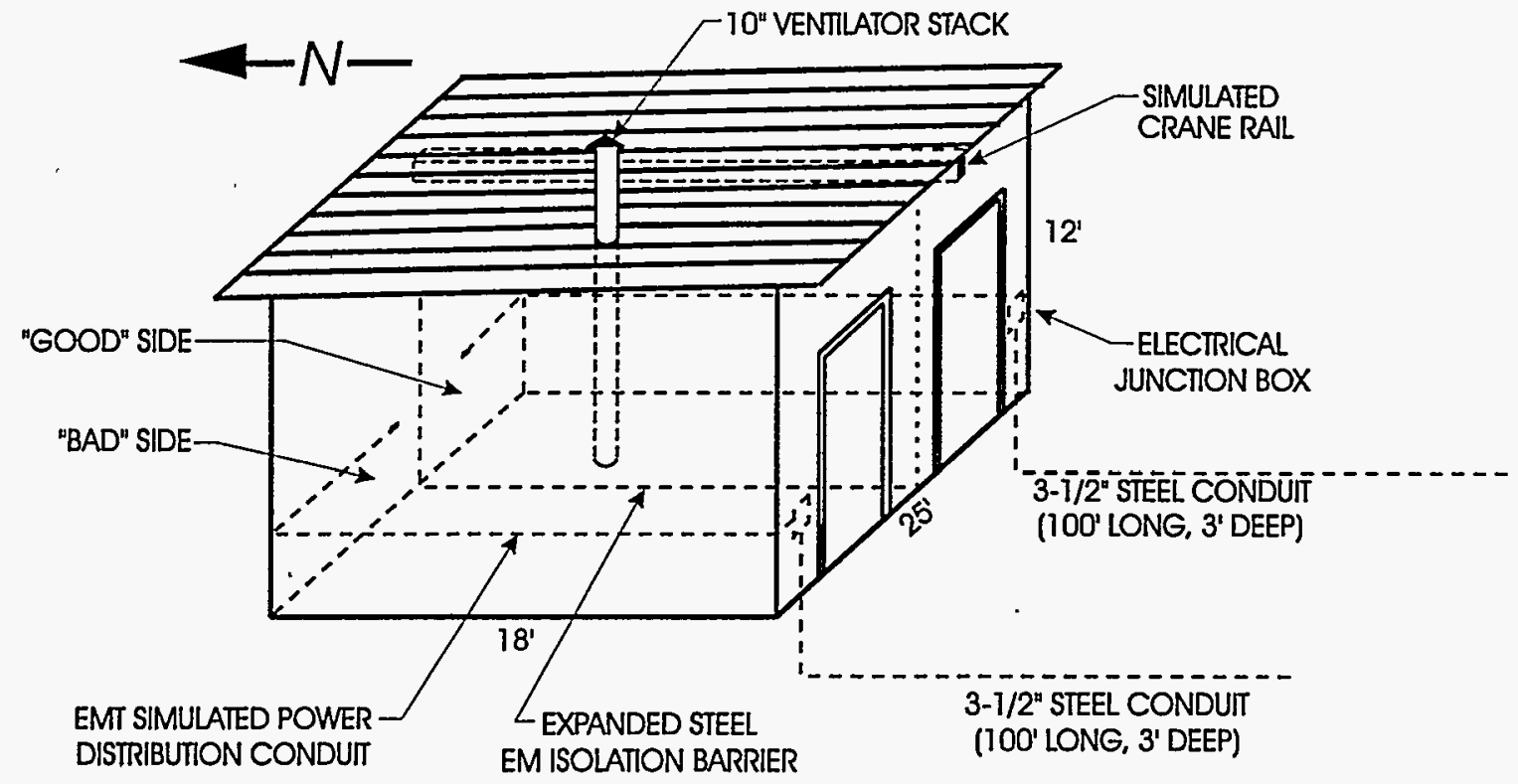

Figure 1. Main features of the simulated munitions handling building

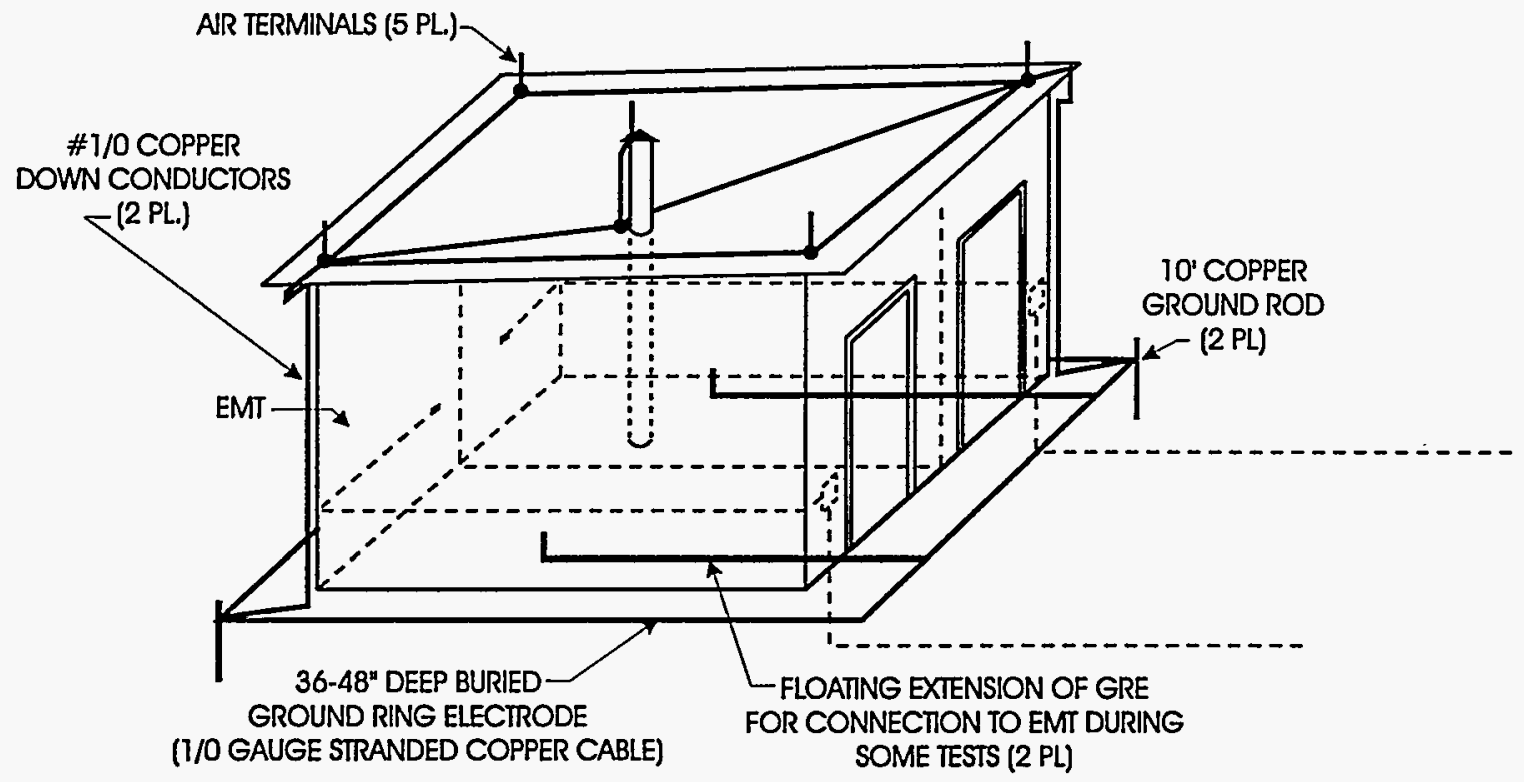

Figure 2. Diagram of the lightning protection system installed on the test structure during part of the present tests. During Storm 4, a single 49-ft high mast system was tested for comparison with the one shown in this figure. 


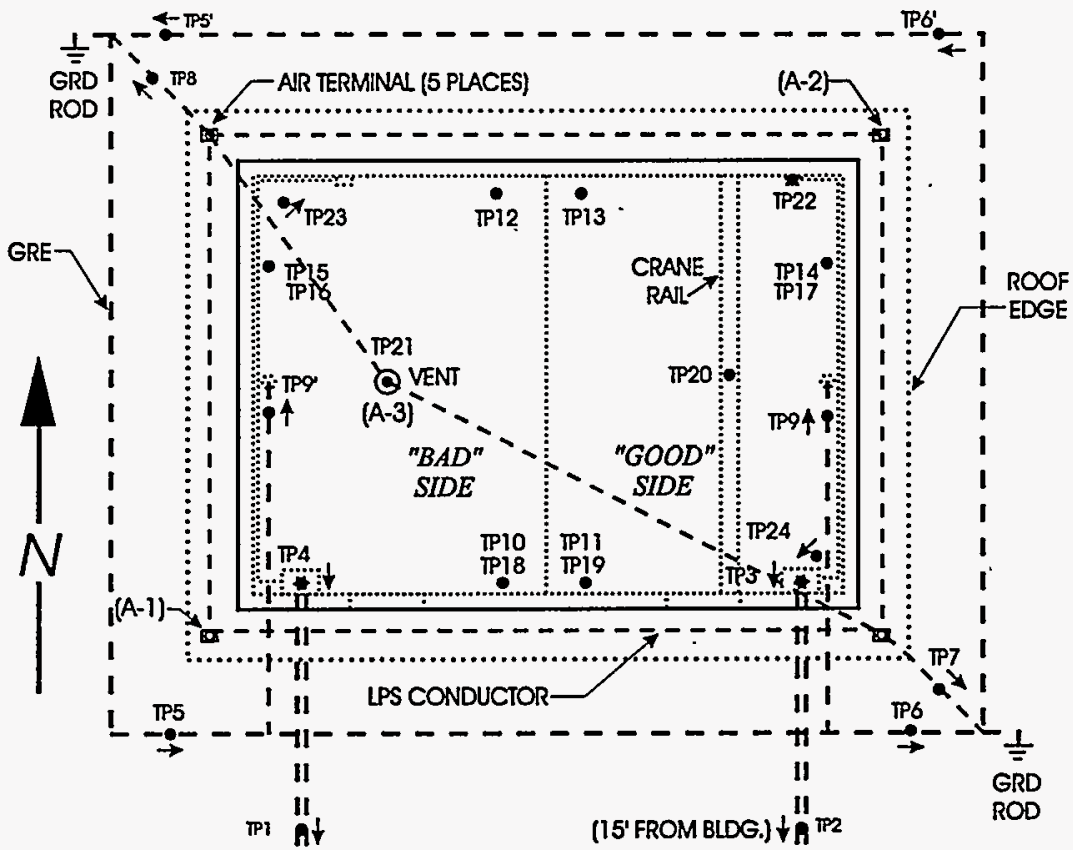

Figure 3. Map of test point locations throughout the test structure

Table 4. Summary of 1994 Triggered Flashes

\begin{tabular}{|cccccc|}
\hline $\begin{array}{c}\text { Flash } \\
\text { ID }\end{array}$ & Date & Time1 $^{\text {Electric }}$ & $\begin{array}{c}\text { Field } \\
(\mathbf{k V / m})^{2}\end{array}$ & $\begin{array}{c}\text { No. } \\
\text { Strokes }\end{array}$ & $\begin{array}{c}\text { Attachment } \\
\text { Point }\end{array}$ \\
\hline $\begin{array}{c}\text { Storm 1 } \\
94-04\end{array}$ & $6 / 22$ & $16: 15: 17.5$ & -4.7 & 3 & NE AT \\
$94-06$ & $6 / 22$ & $17: 12: 09.5$ & -3.6 & 10 & SW AT \\
\hline $\begin{array}{c}\text { Storm 2 } \\
94-07\end{array}$ & $6 / 29$ & $16: 38: 17.5$ & -4.3 & 4 & Vent Stack \\
$94-09$ & $6 / 29$ & $16: 59: 59.6$ & -4.7 & 3 & SW AT \\
$94-10$ & $6 / 29$ & $17: 25: 27.1$ & -4.4 & 1 & Vent Stack \\
\hline Storm 3 & & & & & \\
$94-14$ & $7 / 16$ & $14: 13: 11.0$ & -5.3 & 4 & NE AT \\
$94-15$ & $7 / 16$ & $14: 21: 32.6$ & -3.1 & 3 & Conduit Riser \\
\hline Storm 4 & & & & & \\
$94-21$ & $8 / 5$ & $15: 23: 34.4$ & -5.8 & 8 & LPS Mast \\
$94-22$ & $8 / 5$ & $15: 38: 03.6$ & -4.4 & 3 & Conduit Riser \\
$94-24$ & $8 / 5$ & $16: 07: 43.3$ & -5.5 & 12 & Conduit Riser \\
\hline
\end{tabular}

1 Local Alabama time of wire-burn.

2 Electric field at time launch was initiated. 
Table 5. Incident Stroke Current Summary ${ }^{1}$

\begin{tabular}{|c|c|c|c|c|c|c|}
\hline $\begin{array}{l}\text { Flash } \\
\text { ID }\end{array}$ & $\begin{array}{c}\text { Stroke } \\
\text { No. }\end{array}$ & $\begin{array}{c}\text { Ip } \\
(\mathrm{kA})\end{array}$ & $\begin{array}{l}\dot{\tau}_{\mathbf{r}}{ }^{2} \\
(\mu \mathrm{s})\end{array}$ & $\begin{array}{c}\mathrm{di} / \mathrm{dt}^{3} \\
\left(10^{10} \mathrm{~A} / \mathrm{s}\right)\end{array}$ & FWHM ${ }^{4}$ & $\mathrm{CC}^{5}$ \\
\hline $94-04$ & $\begin{array}{l}1 \\
2 \\
3 \\
4 \\
\end{array}$ & $\begin{array}{c}12.7 \\
5.7 \\
\text { (False Trig) } \\
11.3 \\
\end{array}$ & $\begin{array}{l}1.2 \\
1.3 \\
\overline{0.32}\end{array}$ & $\begin{array}{c}0.72 \\
0.07 \\
- \\
2.6\end{array}$ & $\begin{array}{l}71 \\
20 \\
20 \\
\end{array}$ & $\begin{array}{l}\mathrm{N} \\
\mathrm{Y} \\
\mathrm{Y}\end{array}$ \\
\hline $94-06$ & $\begin{array}{l}1 \\
2 \\
3 \\
4 \\
5 \\
6 \\
7 \\
8\end{array}$ & $\begin{array}{c}10.9 \\
6.0 \\
10.7 \\
4.2 \\
6.5 \\
15.7 \\
12.1 \\
7.4\end{array}$ & $\begin{array}{l}0.50 \\
0.65 \\
0.70 \\
0.52 \\
0.52 \\
0.28 \\
0.16 \\
0.24\end{array}$ & $\begin{array}{c}1.6 \\
0.45 \\
2.8 \\
0.31 \\
1.3 \\
5.0 \\
5.7 \\
2.5\end{array}$ & $\begin{array}{l}46 \\
34 \\
62 \\
23 \\
34 \\
46 \\
26 \\
34\end{array}$ & $\begin{array}{l}\mathrm{N} \\
\mathrm{Y} \\
\mathrm{N} \\
\mathrm{N} \\
\mathrm{N} \\
\mathrm{N} \\
\mathrm{N} \\
\mathrm{Y}\end{array}$ \\
\hline 94.07 & $\begin{array}{l}1 \\
2 \\
3 \\
4\end{array}$ & $\begin{array}{c}19.5 \\
8.8 \\
16.5 \\
14.6\end{array}$ & $\begin{array}{l}0.24 \\
0.12 \\
0.24 \\
0.26\end{array}$ & $\begin{array}{l}6.8 \\
5.0 \\
5.5 \\
4.2\end{array}$ & $\begin{array}{l}40 \\
5.7 \\
21 \\
5.9\end{array}$ & $\begin{array}{l}N \\
N \\
N \\
Y\end{array}$ \\
\hline 94.09 & $\begin{array}{l}1 \\
2 \\
3\end{array}$ & $\begin{array}{c}9.5 \\
10.9 \\
(<4)^{6}\end{array}$ & $\begin{array}{l}0.59 \\
0.16 \\
-\end{array}$ & $\begin{array}{l}1.6 \\
5.1 \\
--\end{array}$ & $\begin{array}{l}43 \\
31 \\
-\end{array}$ & $\begin{array}{l}\mathrm{N} \\
\mathrm{N} \\
-\end{array}$ \\
\hline $94-10$ & 1 & 12.9 & 0.44 & 4.6 & 7.9 & $\mathrm{Y}$ \\
\hline $94-14$ & $\begin{array}{l}1 \\
2 \\
3 \\
4\end{array}$ & $\begin{array}{l}24.9 \\
11.9 \\
20.2 \\
10.3 \\
\end{array}$ & $\begin{array}{l}0.16 \\
0.20 \\
0.21 \\
0.15\end{array}$ & $\begin{array}{c}14.2 \\
4.0 \\
7.3 \\
5.9\end{array}$ & $\begin{array}{l}35 \\
2.1 \\
20 \\
1.9\end{array}$ & $\begin{array}{l}\mathrm{N} \\
\mathrm{Y} \\
\mathrm{N} \\
\mathrm{Y}\end{array}$ \\
\hline $94-15$ & $\begin{array}{l}1 \\
2 \\
3\end{array}$ & $\begin{array}{c}17.4 \\
10.9 \\
8.4\end{array}$ & $\begin{array}{l}0.22 \\
0.12 \\
0.48\end{array}$ & $\begin{array}{l}6.1 \\
4.4 \\
1.7\end{array}$ & $\begin{array}{c}48 \\
6 \\
34\end{array}$ & $\begin{array}{l}\mathrm{Y} \\
\mathrm{Y} \\
\mathrm{N}\end{array}$ \\
\hline $94-21$ & $\begin{array}{l}1 \\
2 \\
3 \\
4 \\
5 \\
6 \\
7 \\
\end{array}$ & $\begin{array}{c}7.5 \\
7.2 \\
5.2 \\
16.3 \\
12.3 \\
18.5 \\
8.0 \\
\end{array}$ & $\begin{array}{l}0.62 \\
0.76 \\
1.76 \\
0.28 \\
0.33 \\
0.32 \\
0.06 \\
\end{array}$ & $\begin{array}{c}0.73 \\
1.2 \\
0.73 \\
4.7 \\
2.3 \\
4.9 \\
8.0 \\
\end{array}$ & $\begin{array}{l}30 \\
36 \\
34 \\
29 \\
38 \\
7.3 \\
3.8\end{array}$ & $\begin{array}{l}\mathrm{N} \\
\mathrm{N} \\
\mathrm{N} \\
\mathrm{N} \\
\mathrm{Y} \\
\mathrm{Y} \\
\mathrm{N}\end{array}$ \\
\hline $94-22$ & $\begin{array}{l}1 \\
2 \\
3 \\
\end{array}$ & $\begin{array}{c}9.9 \\
20.1 \\
10.9 \\
\end{array}$ & $\begin{array}{l}0.37 \\
0.21 \\
0.24 \\
\end{array}$ & $\begin{array}{l}2.0 \\
6.6 \\
3.8 \\
\end{array}$ & $\begin{array}{l}32 \\
33 \\
7.3 \\
\end{array}$ & $\begin{array}{l}\mathrm{Y} \\
\mathrm{Y} \\
\mathrm{Y}\end{array}$ \\
\hline $94-24$ & $\begin{array}{l}1 \\
2 \\
3 \\
4 \\
5 \\
6 \\
7 \\
8 \\
\end{array}$ & $\begin{array}{c}7.8 \\
8.1 \\
5.7 \\
29.6 \\
\text { (False Trig) } \\
9.1 \\
11.9 \\
19.0 \\
\end{array}$ & $\begin{array}{c}7.0 \\
6.0 \\
4.0 \\
0.18 \\
- \\
5.5 \\
0.86 \\
0.24 \\
\end{array}$ & $\begin{array}{c}0.02 \\
0.04 \\
0.03 \\
10.8 \\
- \\
0.20 \\
0.52 \\
5.8\end{array}$ & $\begin{array}{l}47 \\
45 \\
50 \\
57 \\
39 \\
40 \\
5.8\end{array}$ & $\begin{array}{l}\mathrm{Y} \\
\mathrm{Y} \\
\mathrm{Y} \\
\mathrm{Y} \\
\mathrm{Y} \\
\mathrm{Y} \\
\mathrm{Y}\end{array}$ \\
\hline
\end{tabular}

1 Table includes only strokes for which high resolution digital data are available.

2 Rise time between 10 and 90 percent points.

3 Average slope between 10 and 90 percent points.

4 Full Width to Half Maximum is the width of return stroke current between the 50-percent amplitude points.

5 Return stroke followed by continuing current of duration greater than $10 \mathrm{~ms}$.

6 No digital data. 


\section{Storm 1 Data Plots}

\section{Flashes 94-04 and 94-06}




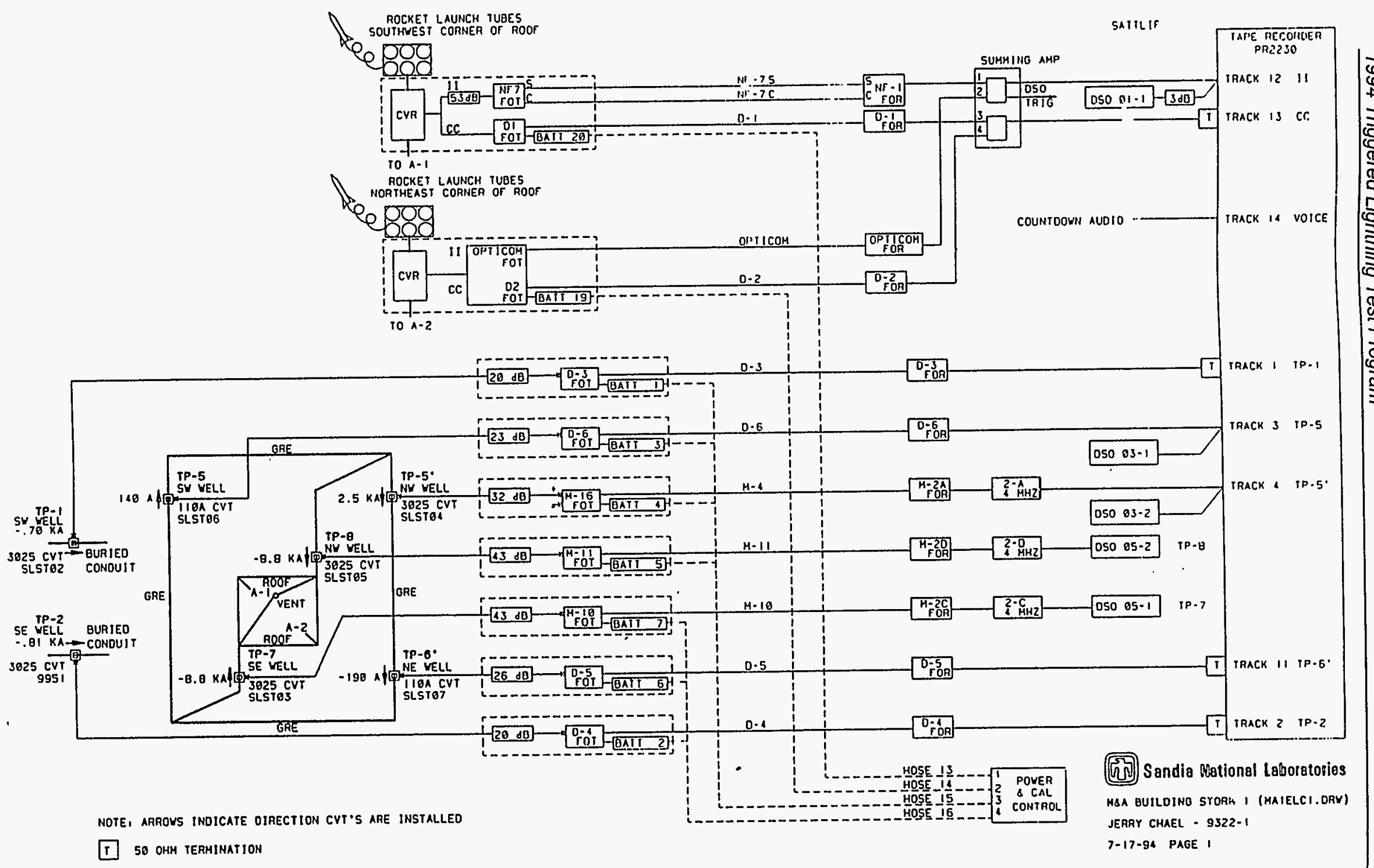

One-line drawing of the instrumentation installed during Storm 1 (page 1 of 2) 


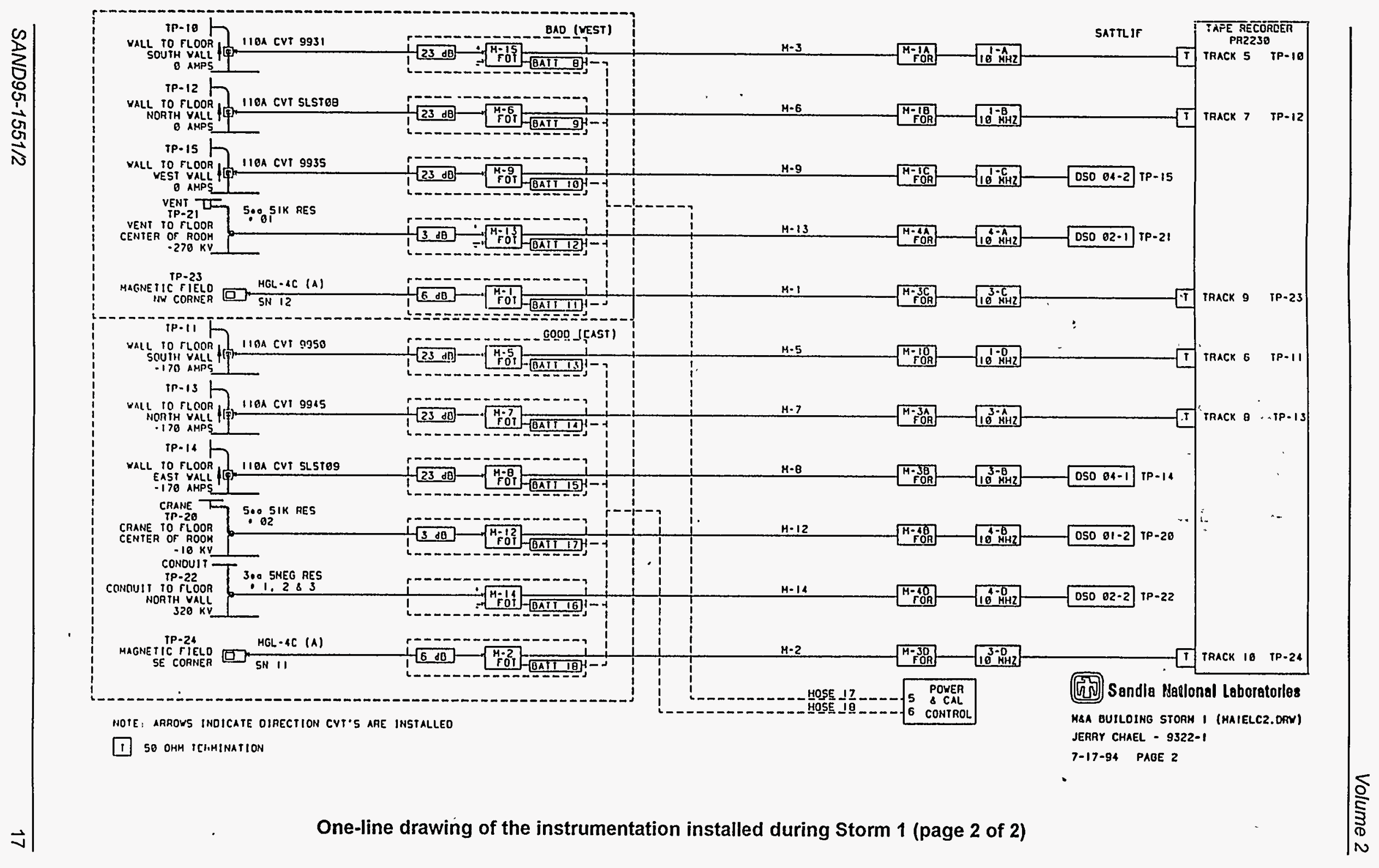




\section{4-04 STROKE 1 \\ INCIDENT CURRENT}
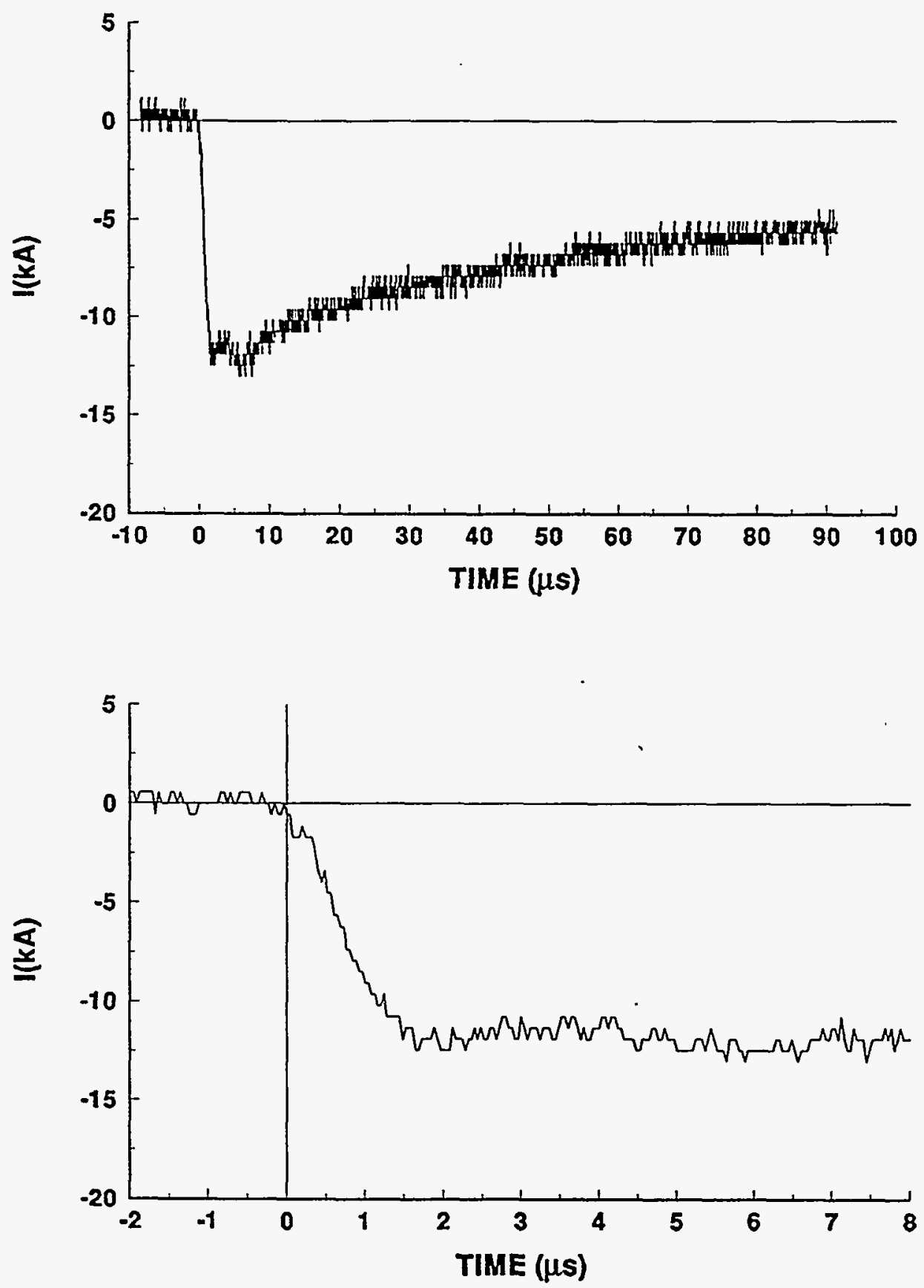


\section{4-04 STROKE 1}

TEST POINT 1

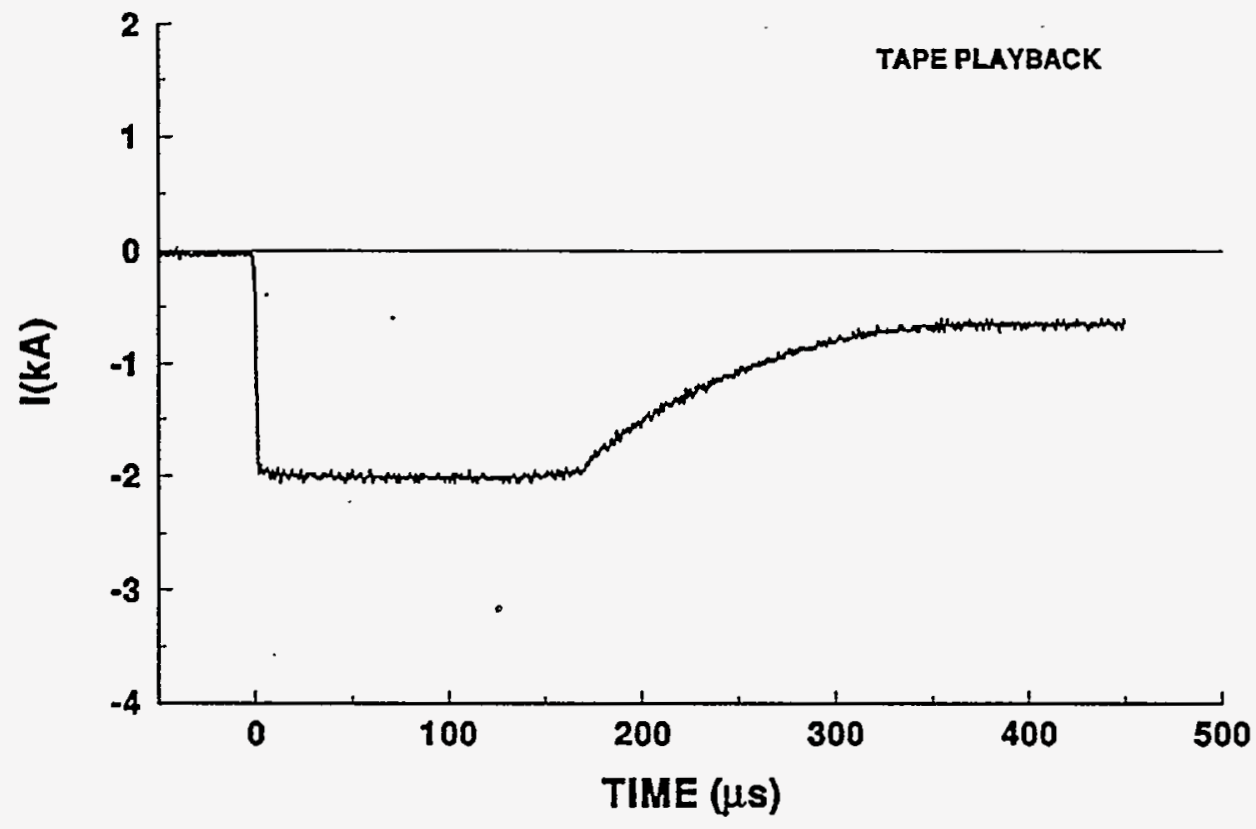

\section{4-04 STROKE 1} TEST POINT 2

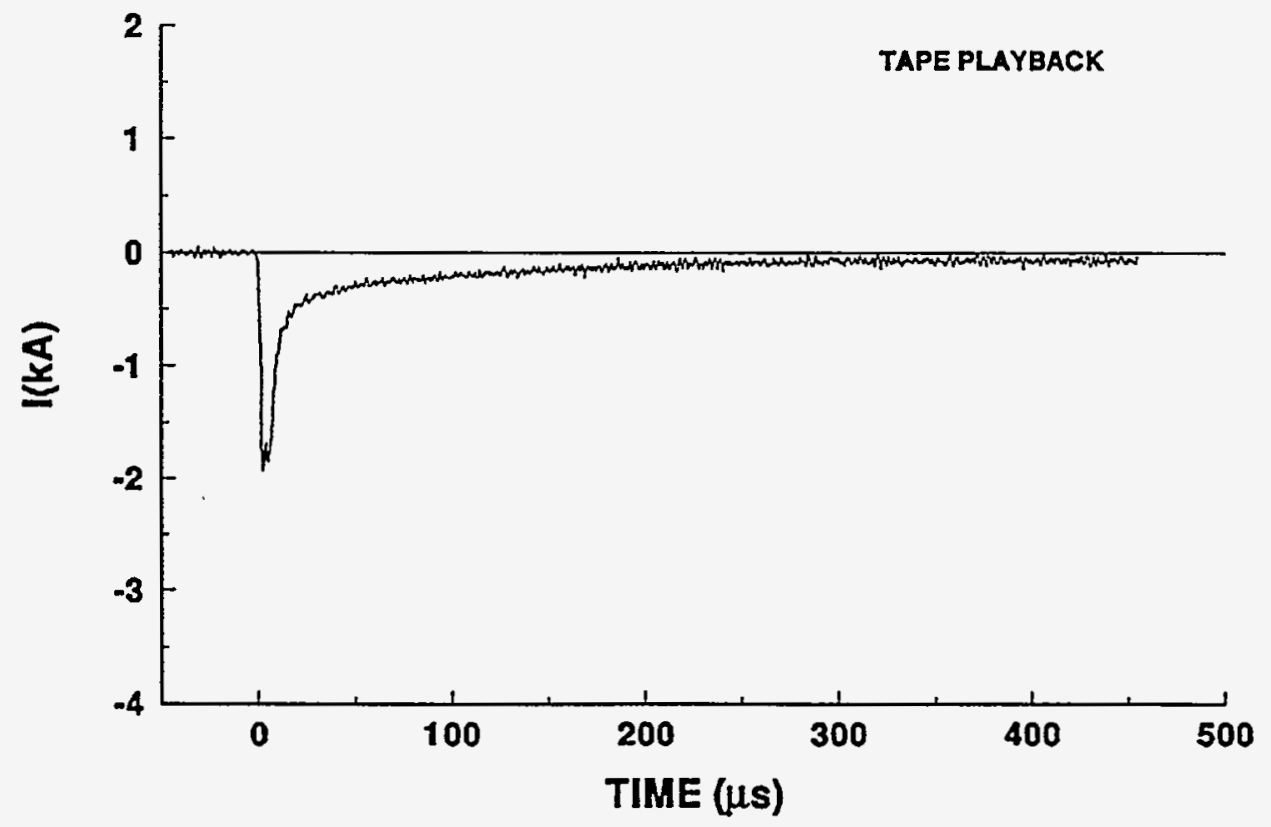


94-04 STROKE 1

TEST POINT 5
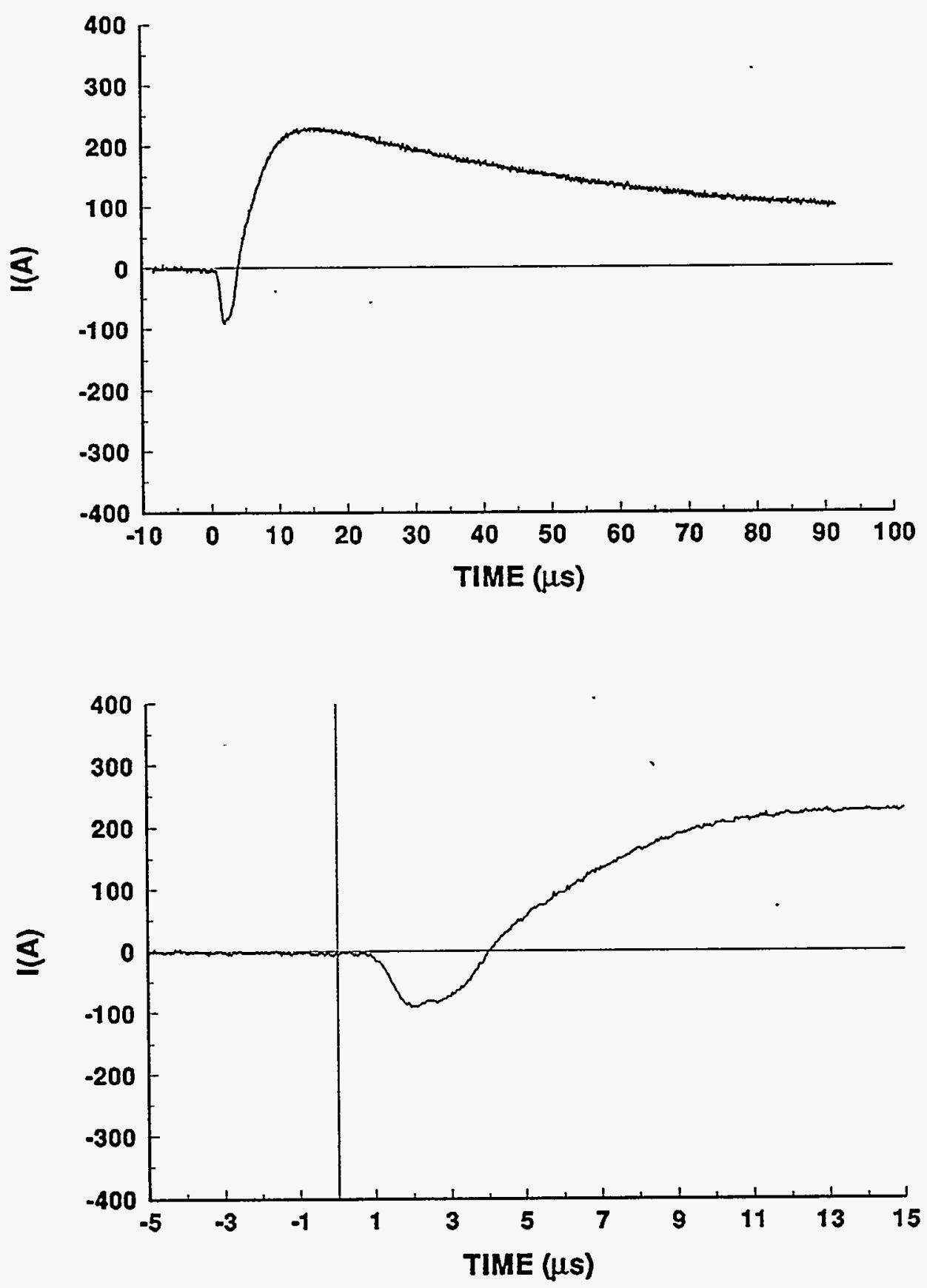
94-04 STROKE 1

TEST POINT 5'
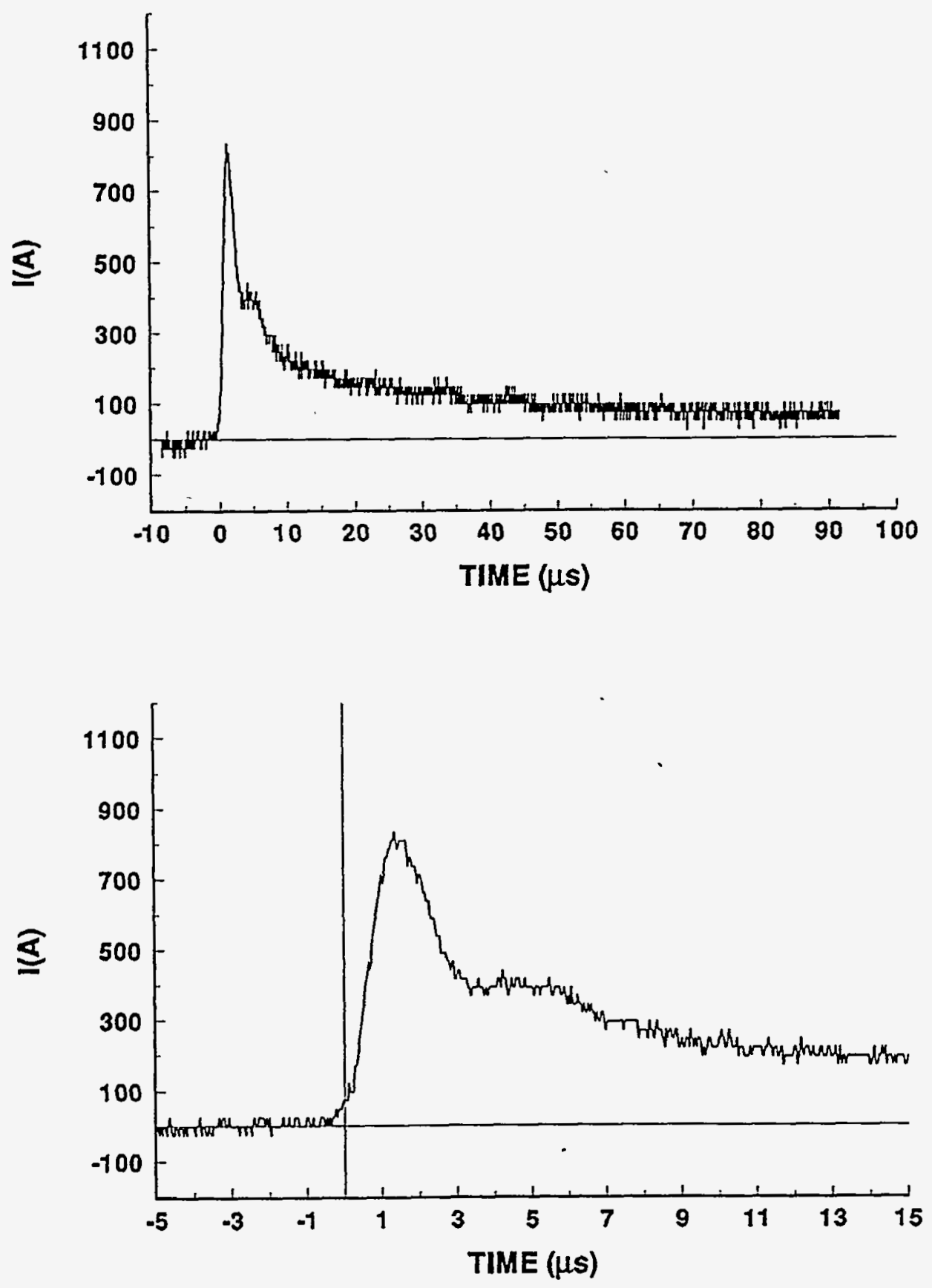


\section{4-04 STROKE 1}

TEST POINT 6'

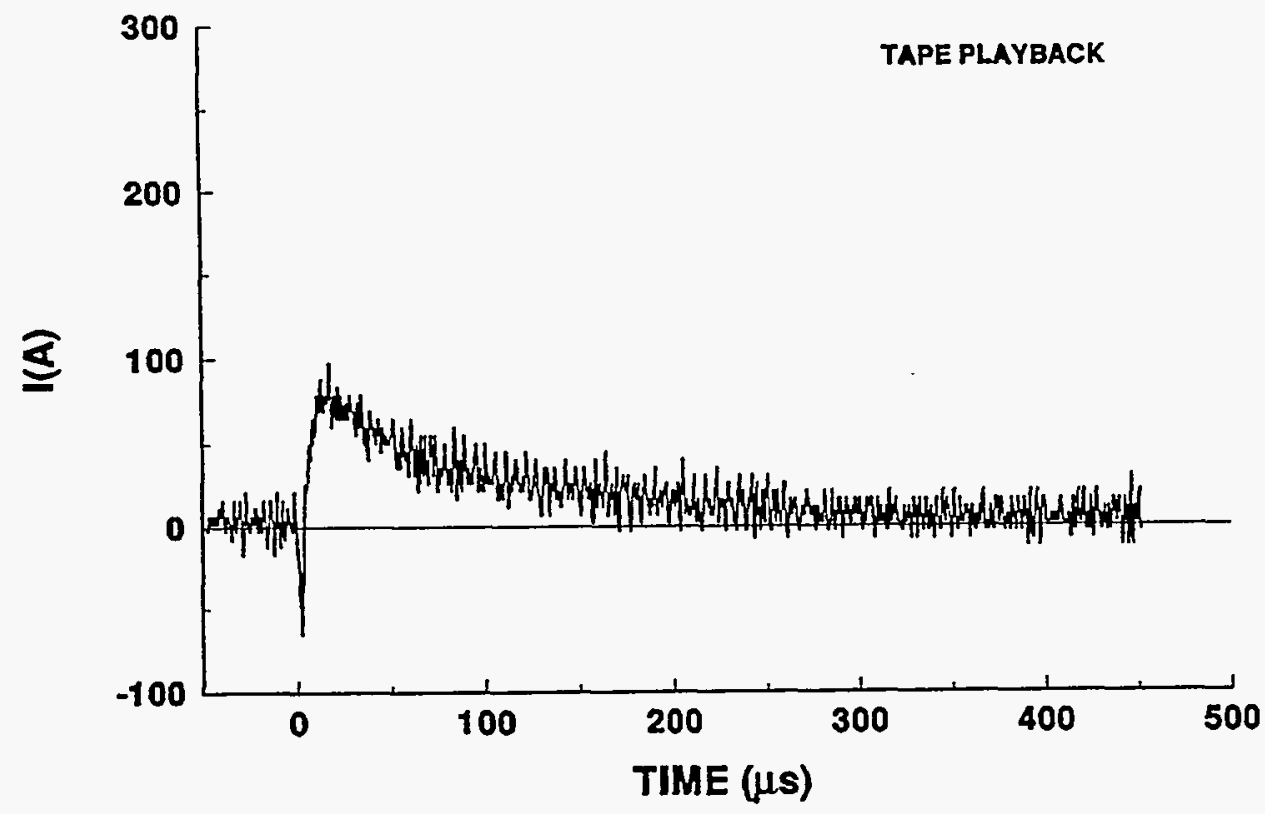


94-04 STROKE 1

TEST POINT 7
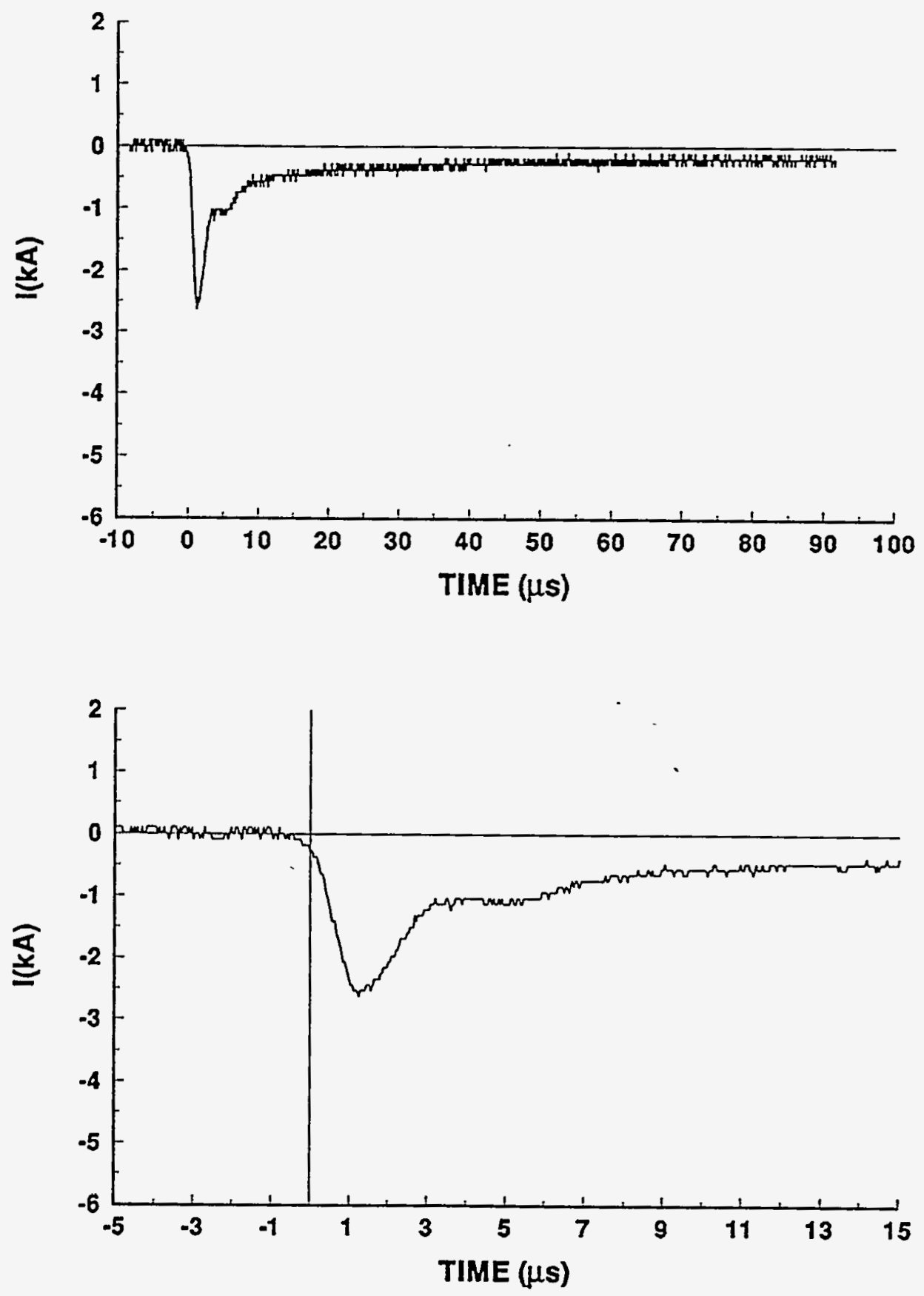


\section{4-04 STROKE 1}

TEST POINT 8
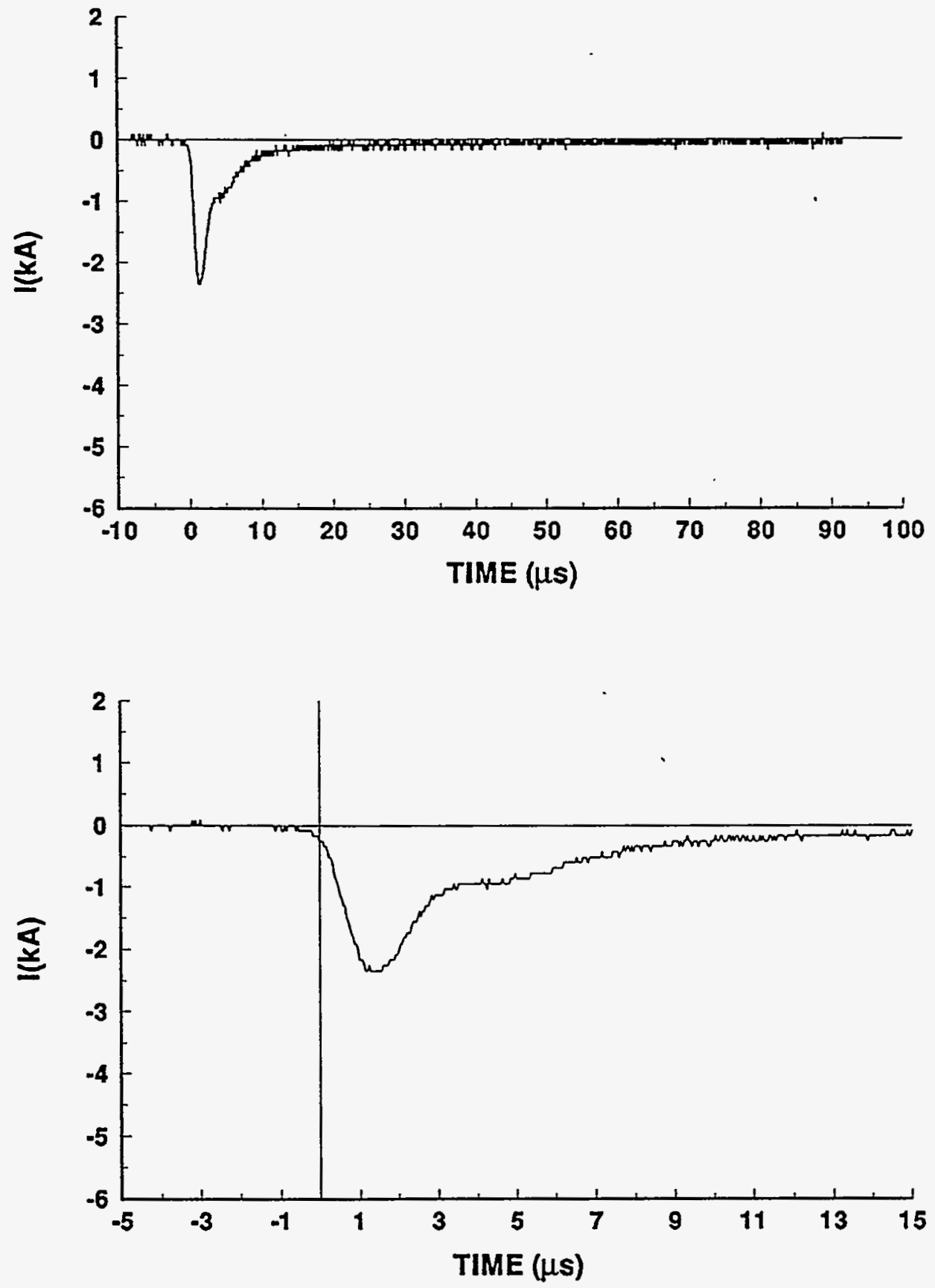


\section{4-04 STROKE 1}

TEST POINT 10

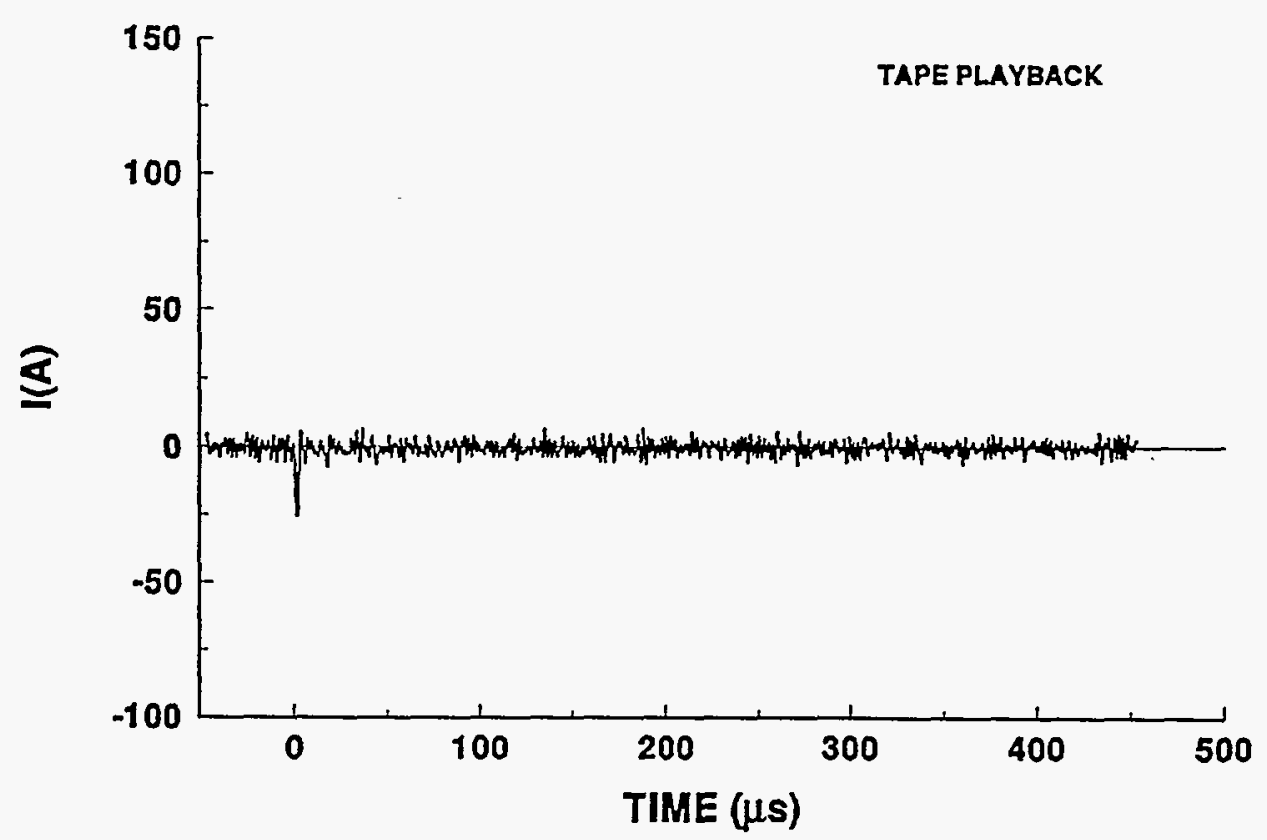

94-04 STROKE 1

TEST POINT 11

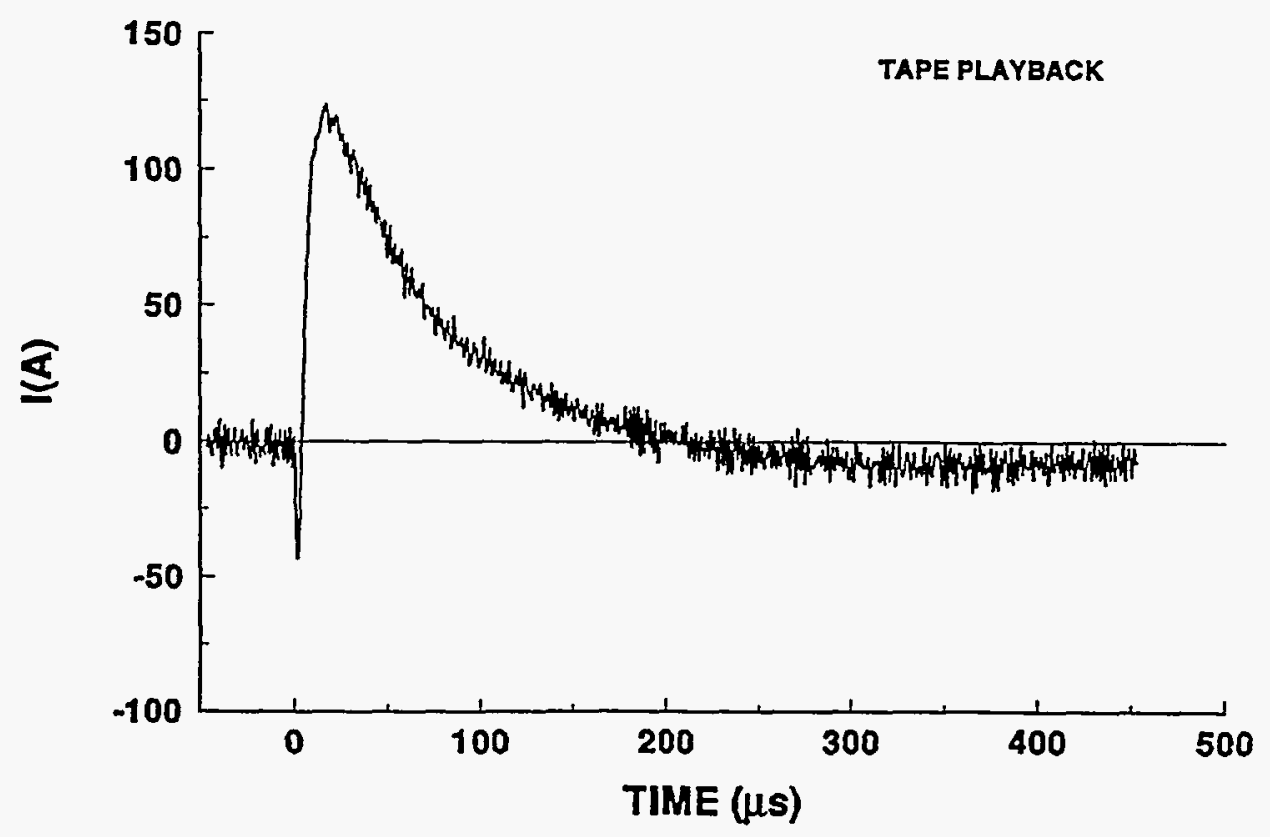




\section{4-04 STROKE 1 \\ TEST POINT 12}

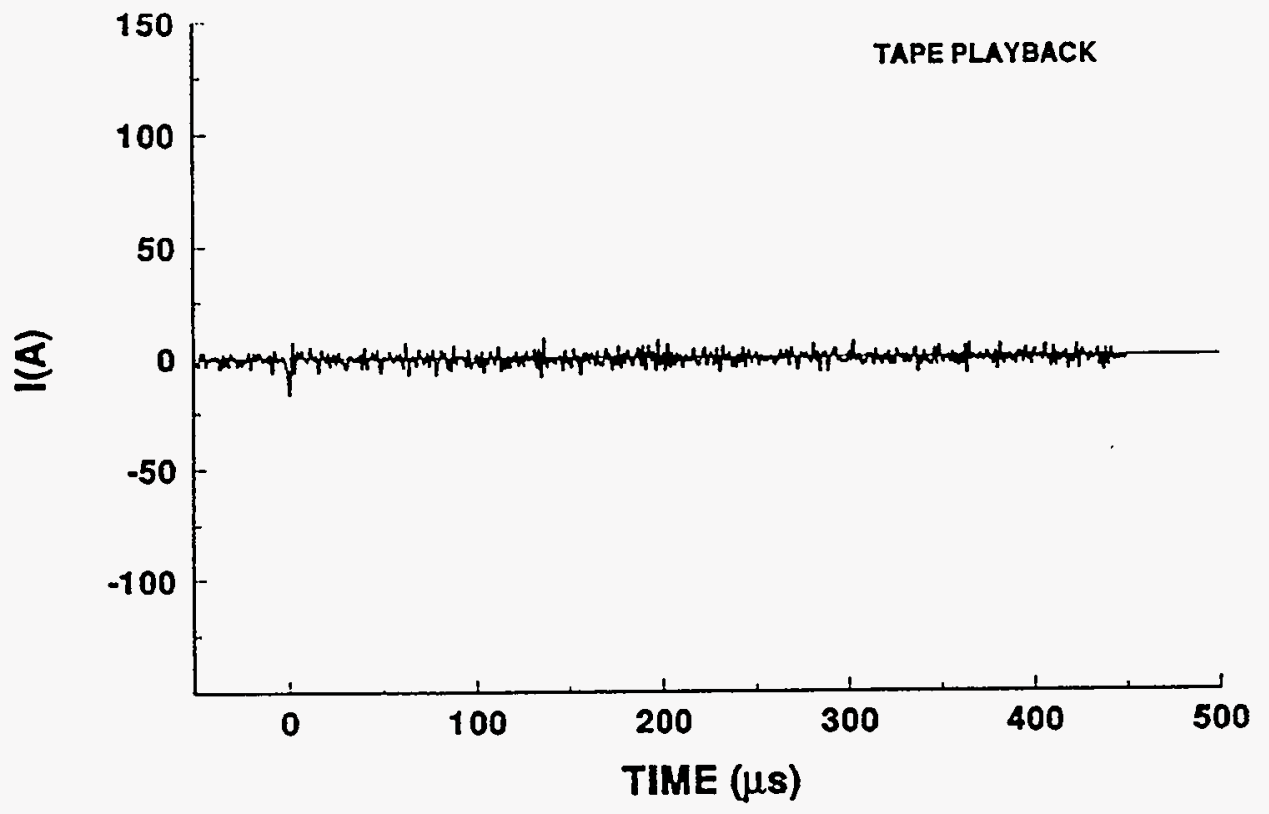

\section{4-04 STROKE 1}

TEST POINT 13

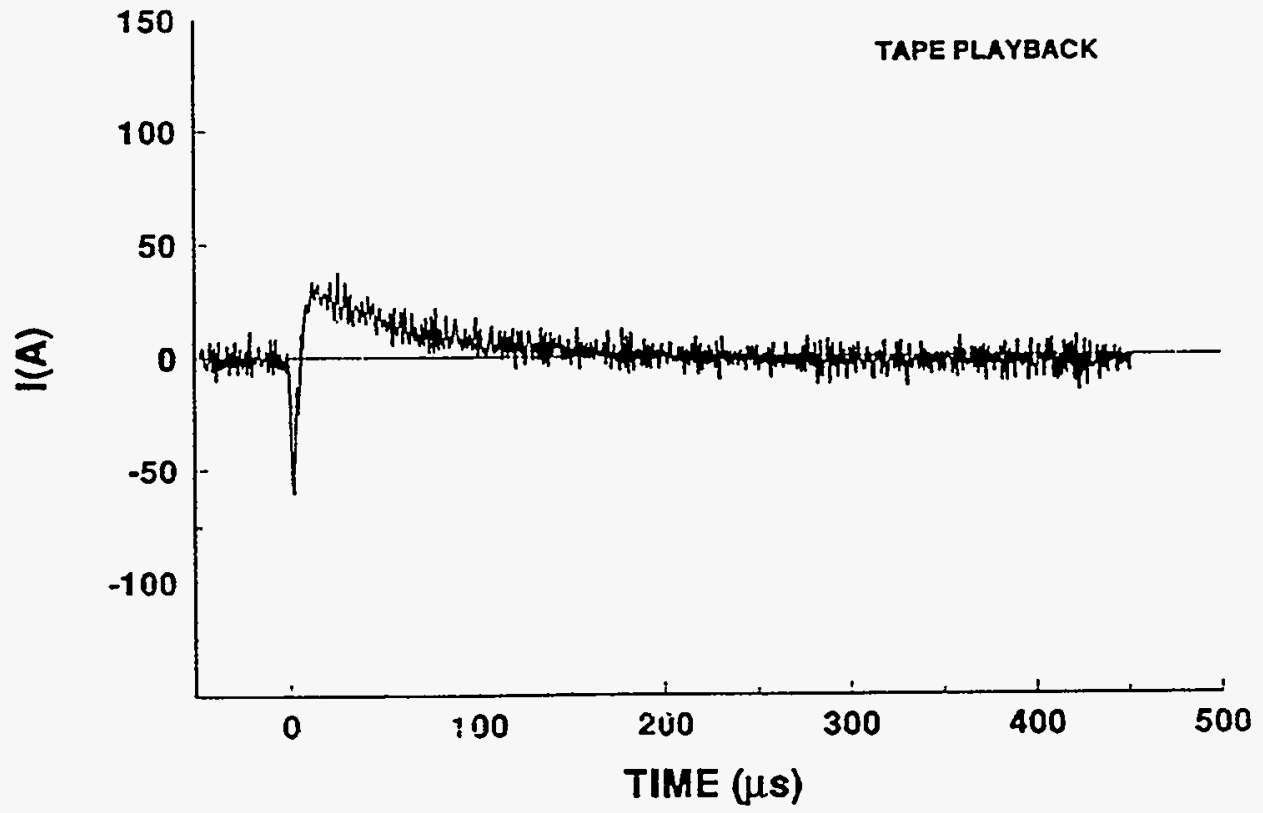




\section{4-04 STROKE 1}

TEST POINT 14
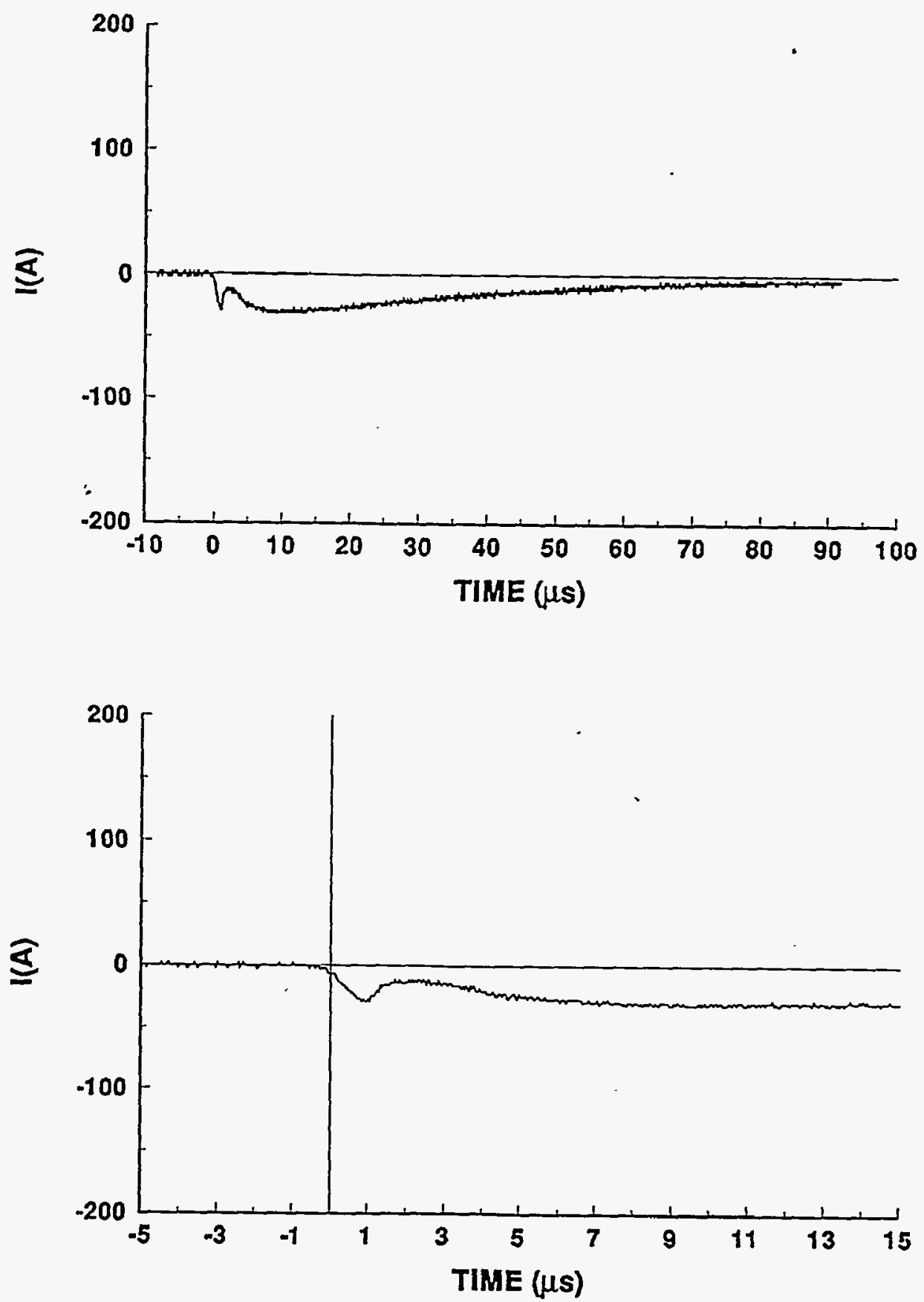
94-04 STROKE 1

TEST POINT 15
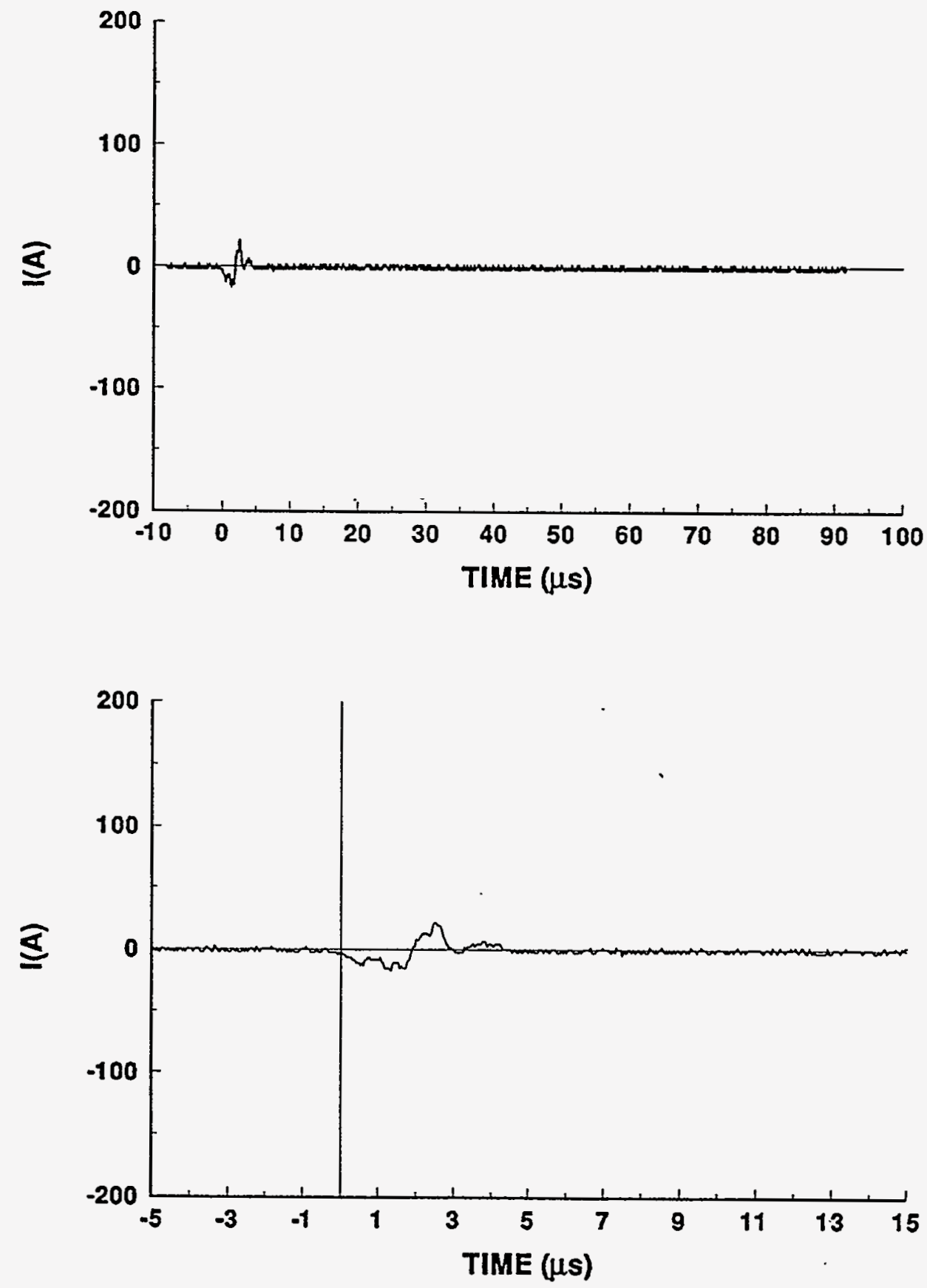


\section{4-04 STROKE 1}

TEST POINT 20

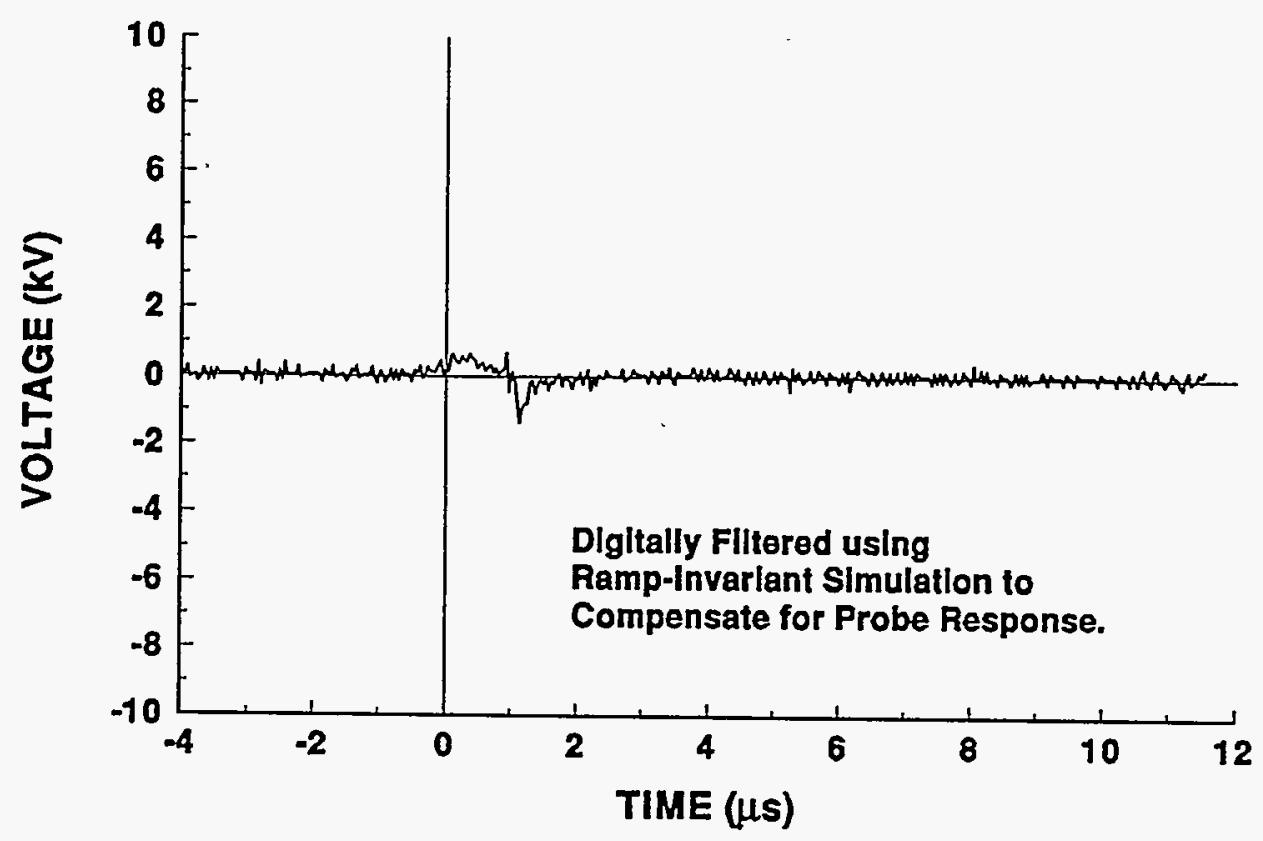

\section{4-04 STROKE 1}

TEST POINT 21

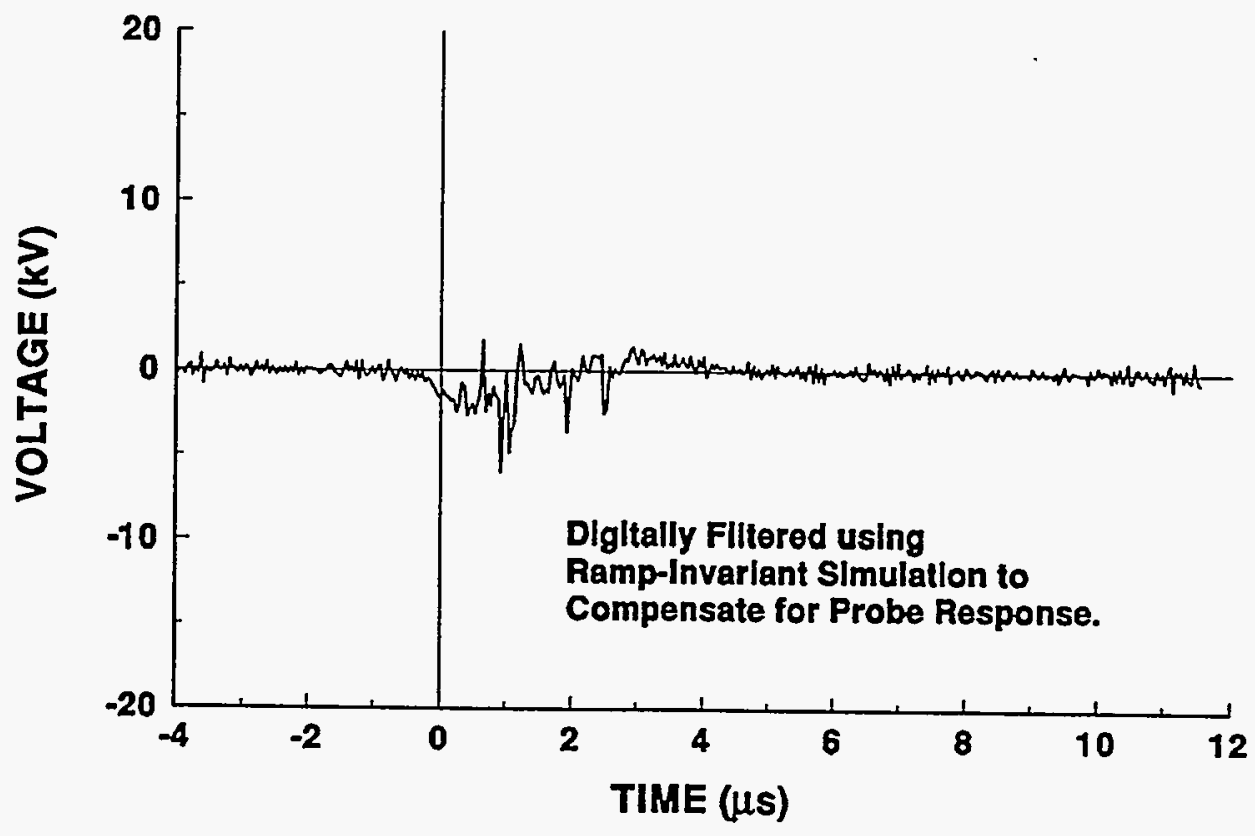




\section{4-04 STROKE 1}

\section{TEST POINT 23}
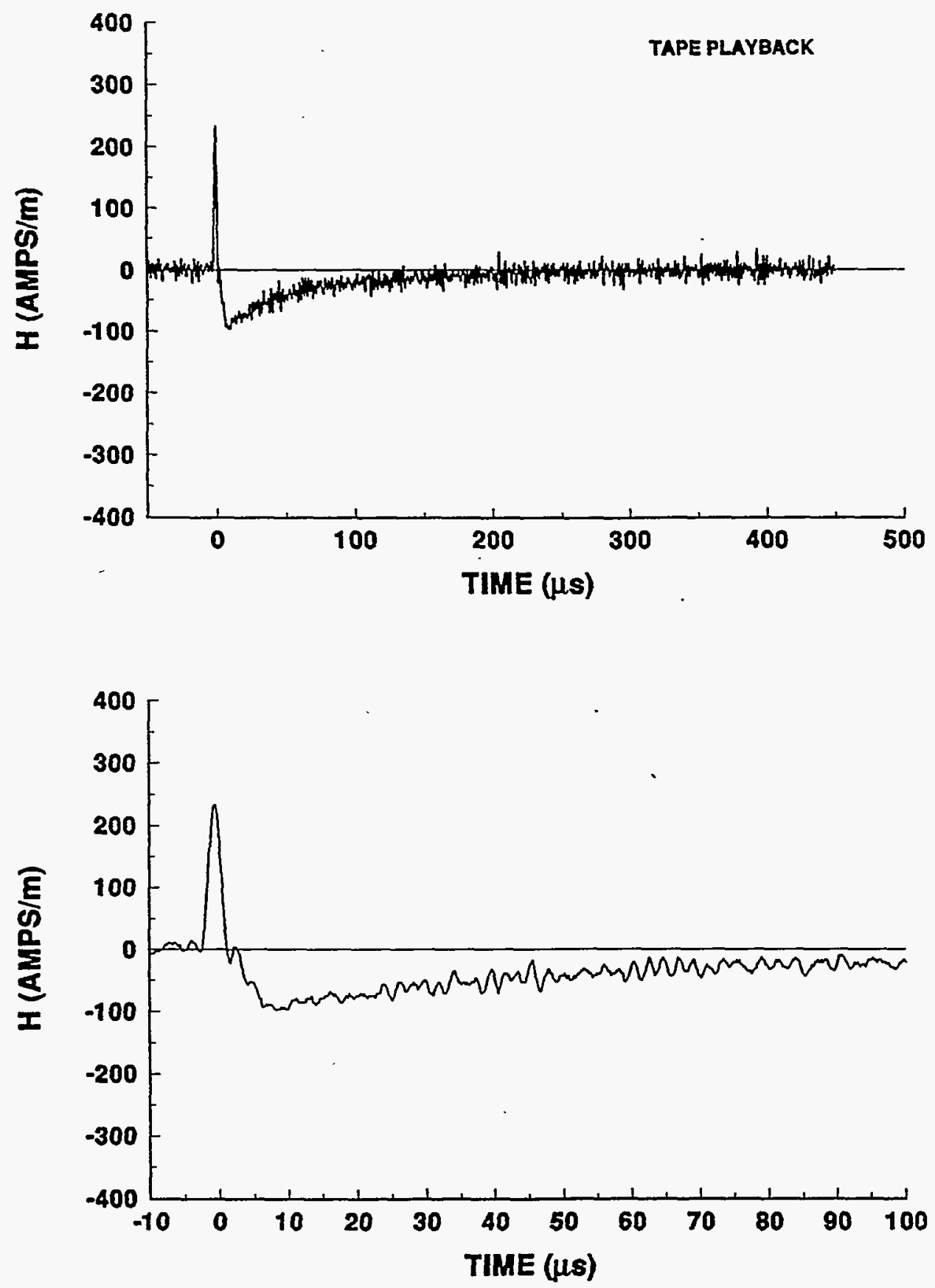


\section{4-04 STROKE 2 \\ INCIDENT CURRENT}
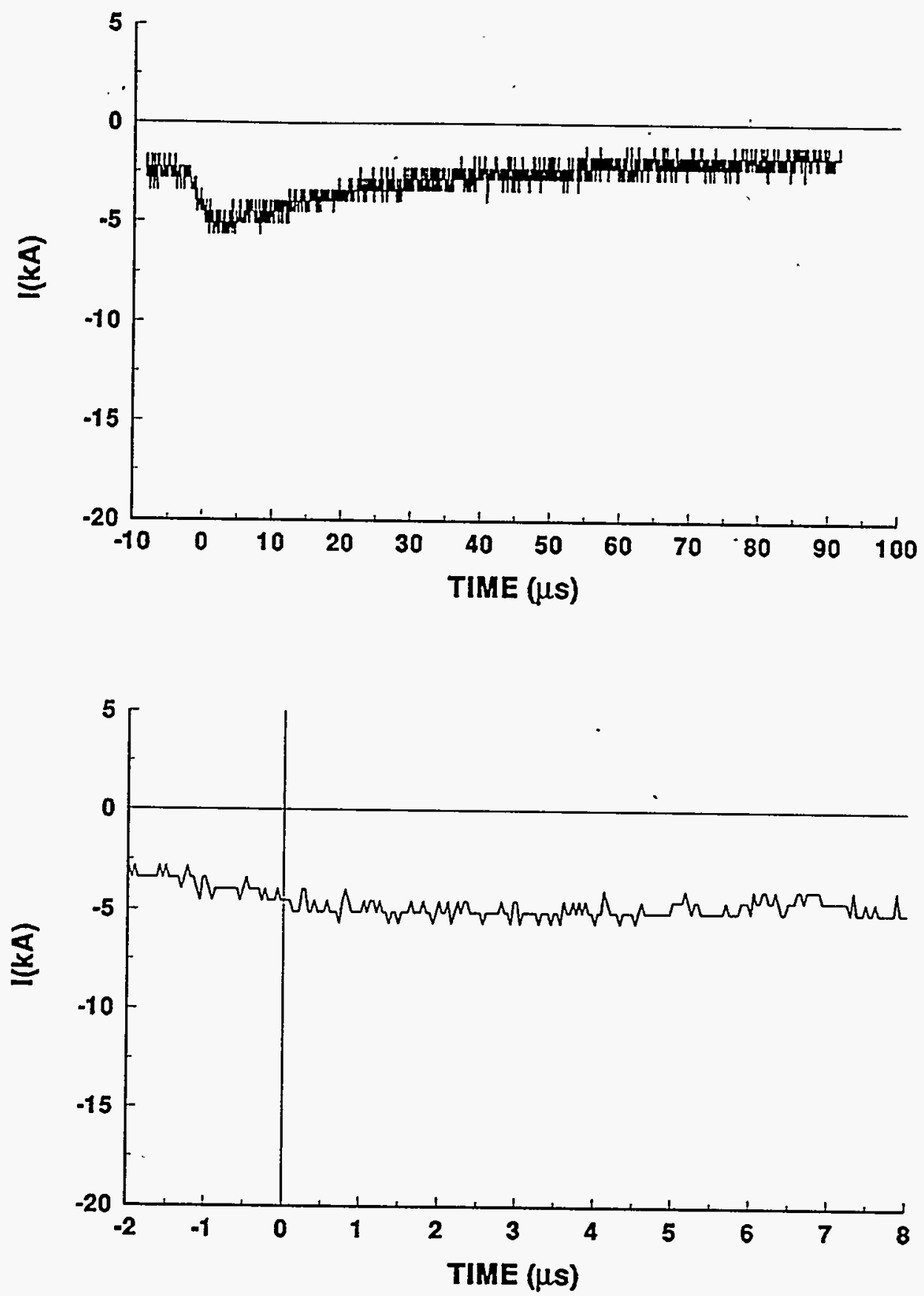


\section{4-04 STROKE 2}

TEST POINT 1

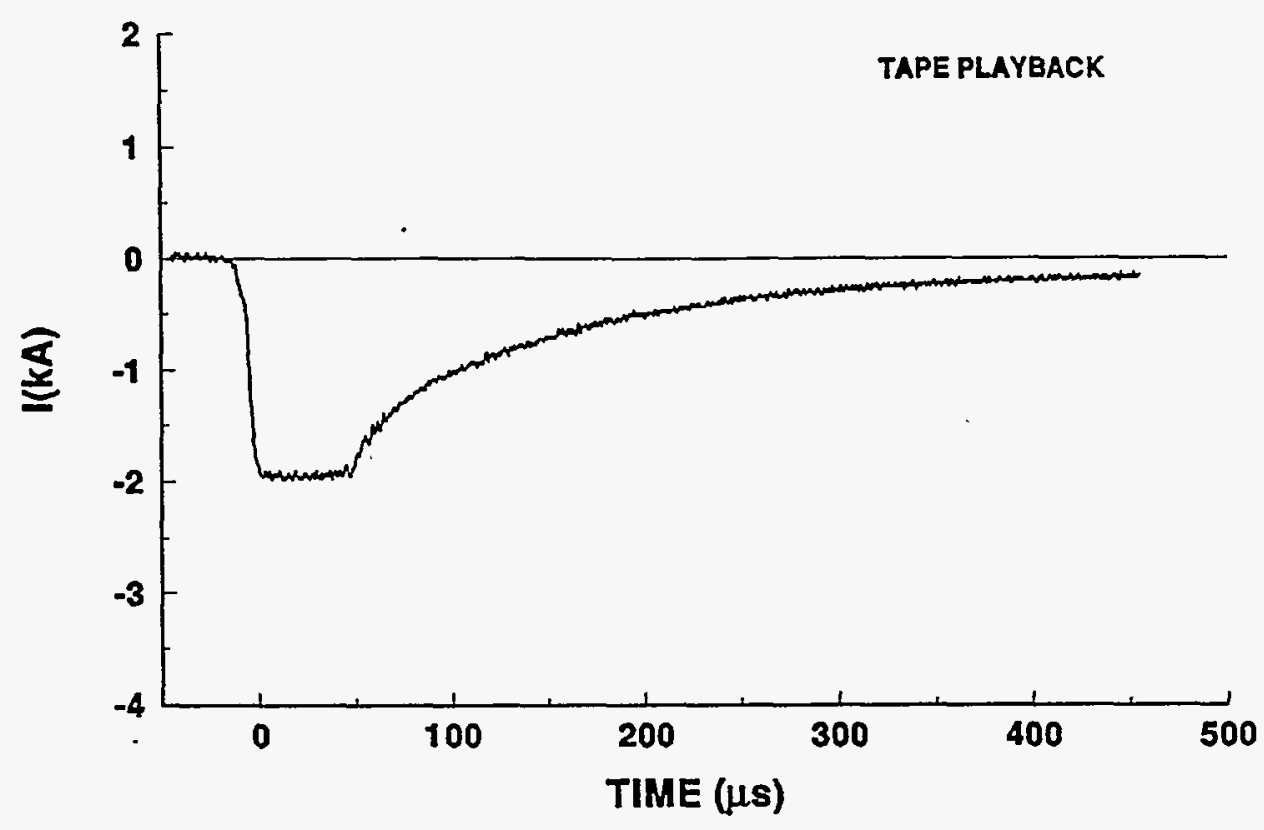

94-04 STROKE 2

TEST POINT 2

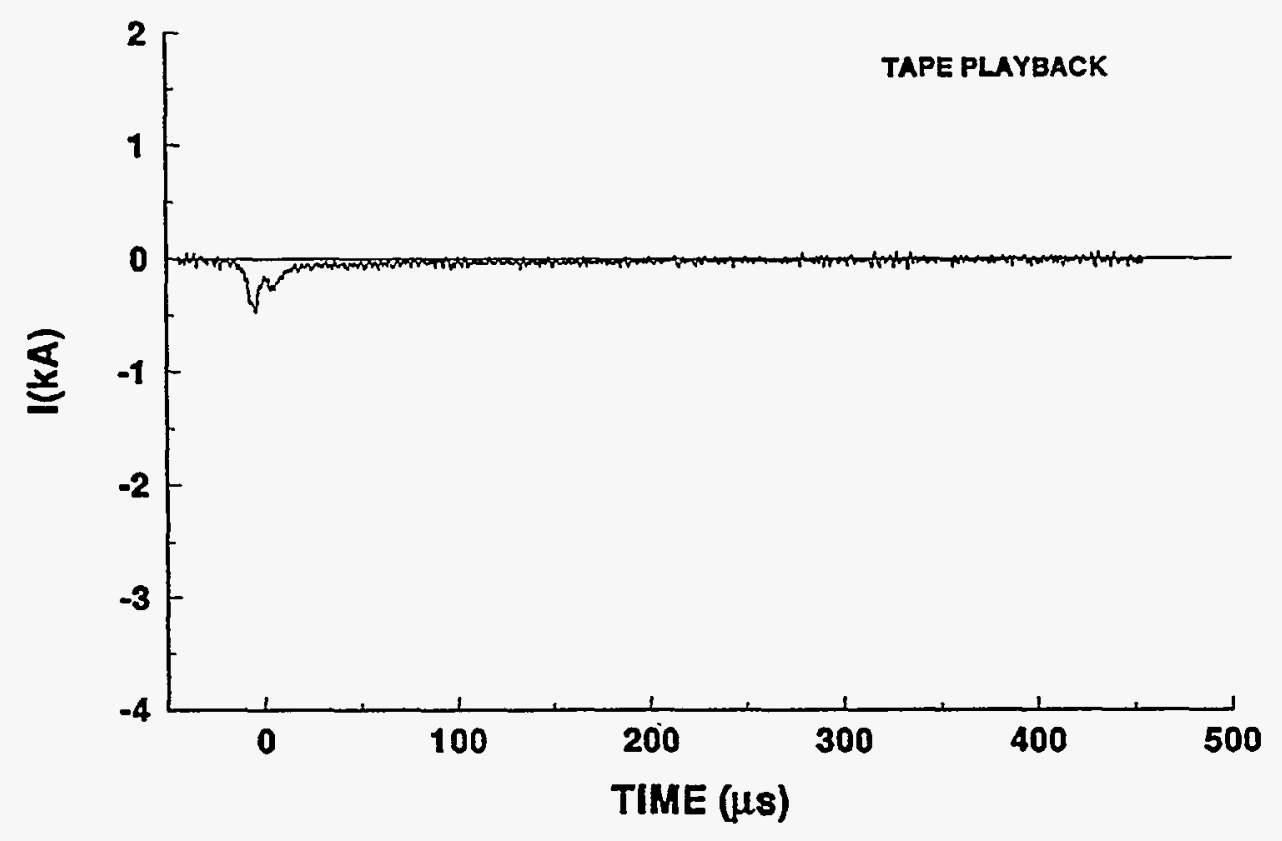




\section{4-04 STROKE 2}

\section{TEST POINT 5}
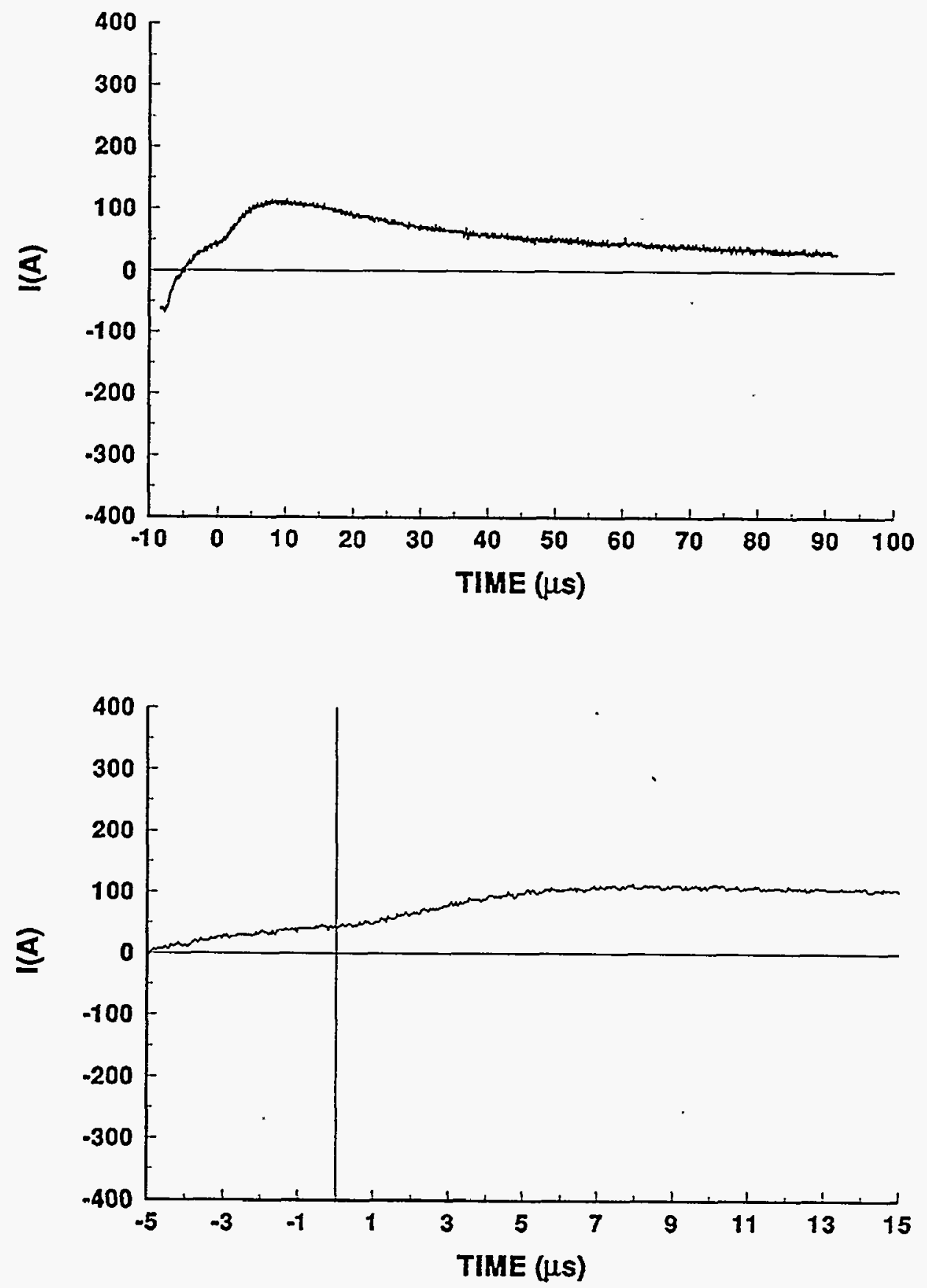


\section{4-04 STROKE 2}

TEST POINT 5'
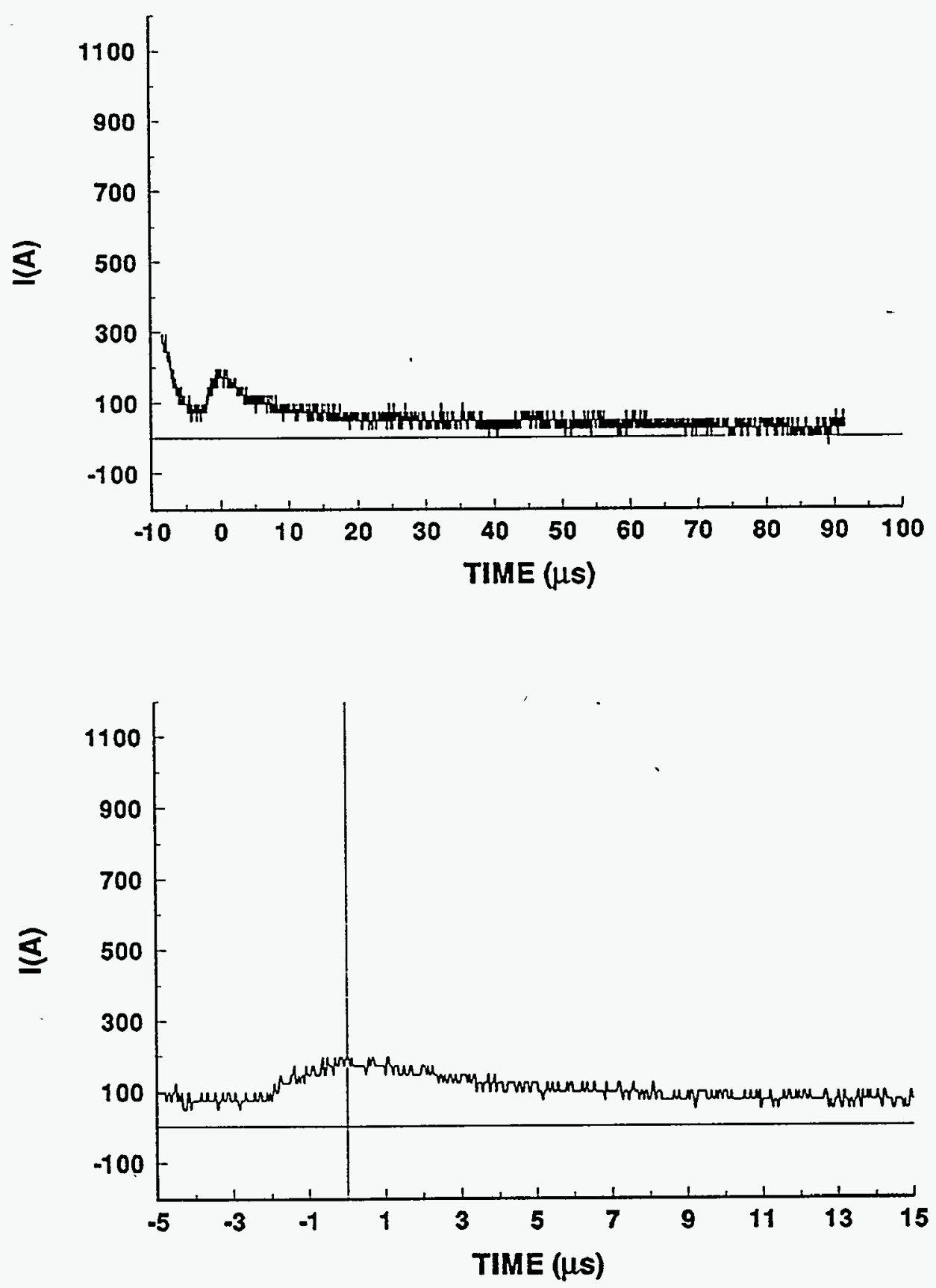


\section{4-04 STROKE 2}

\section{TEST POINT 6'}

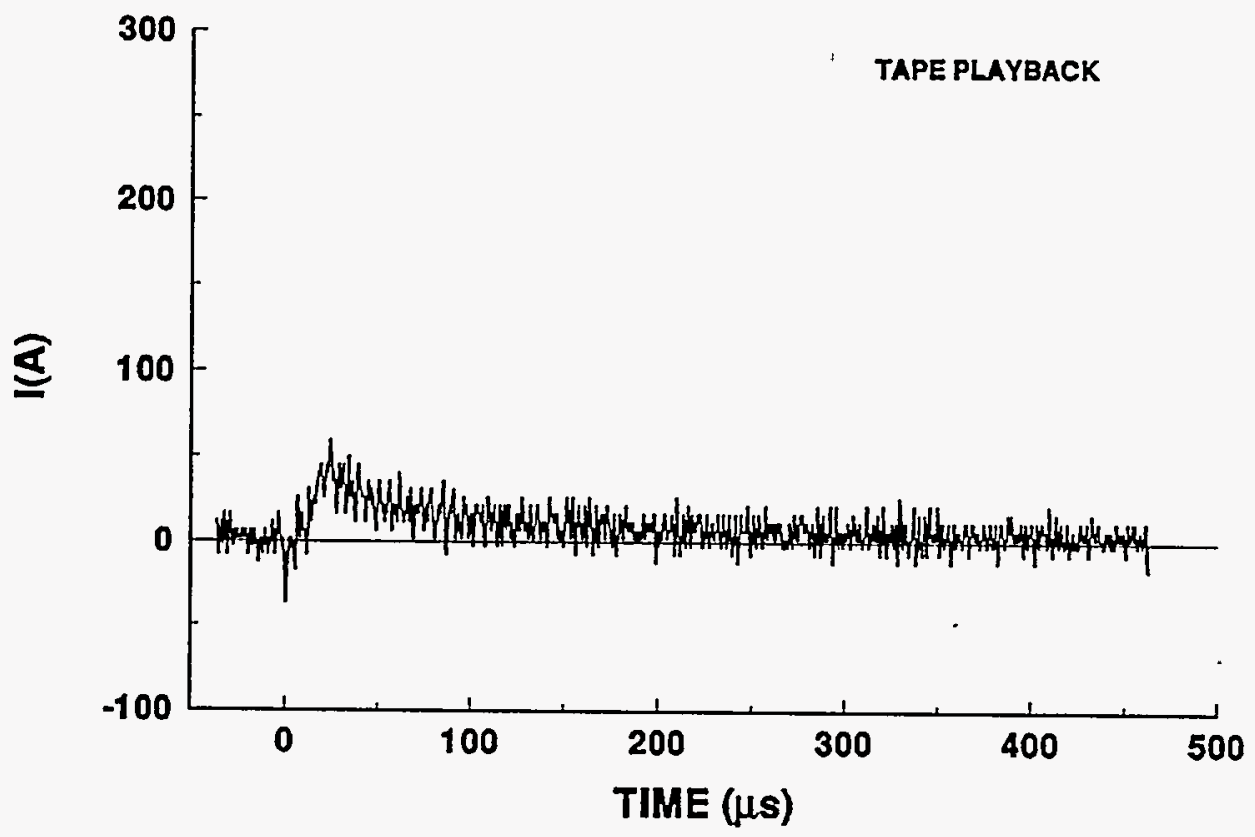




\section{4-04 STROKE 2}

TEST POINT 7
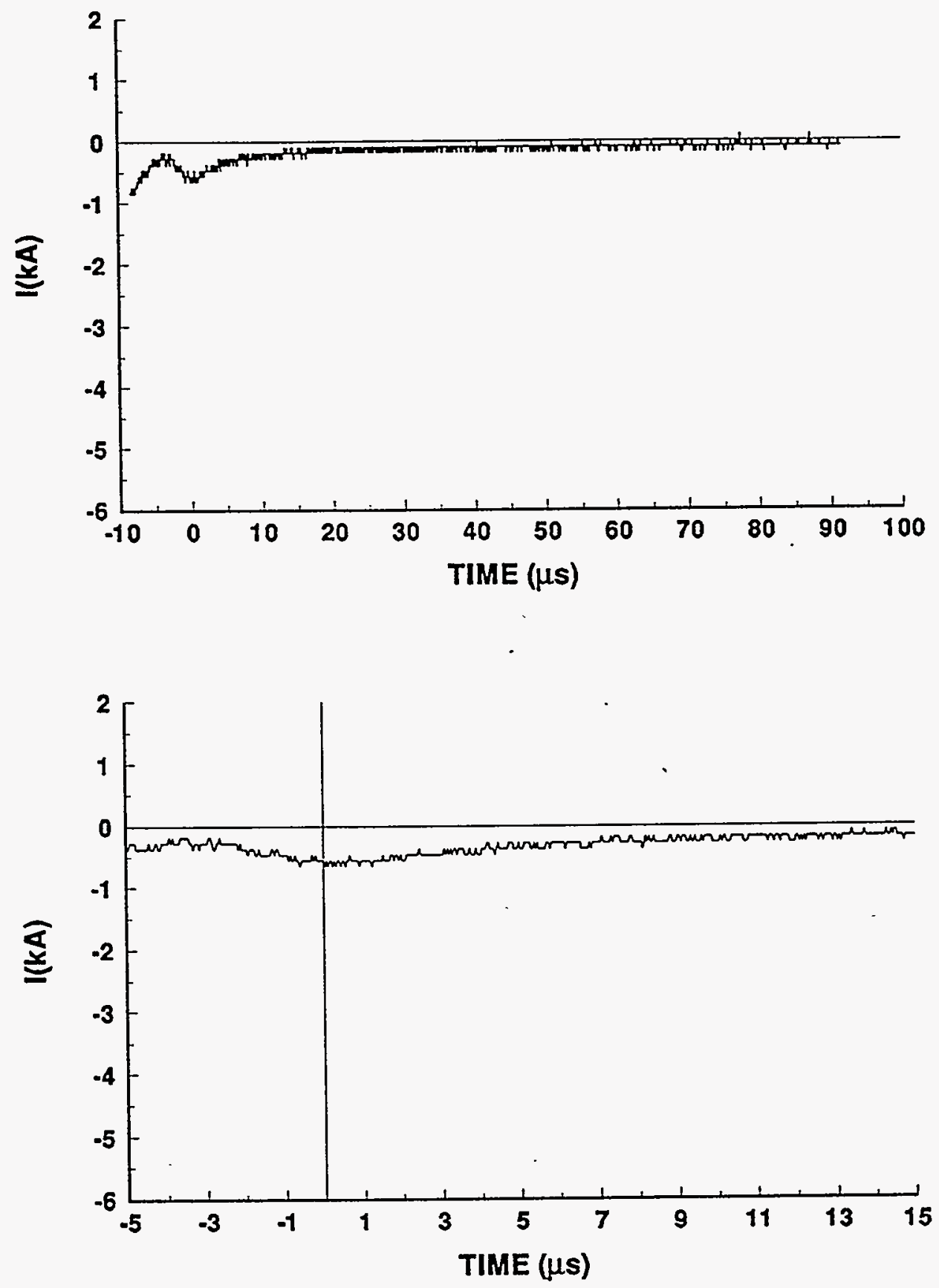
94-04 STROKE 2

TEST POINT 8
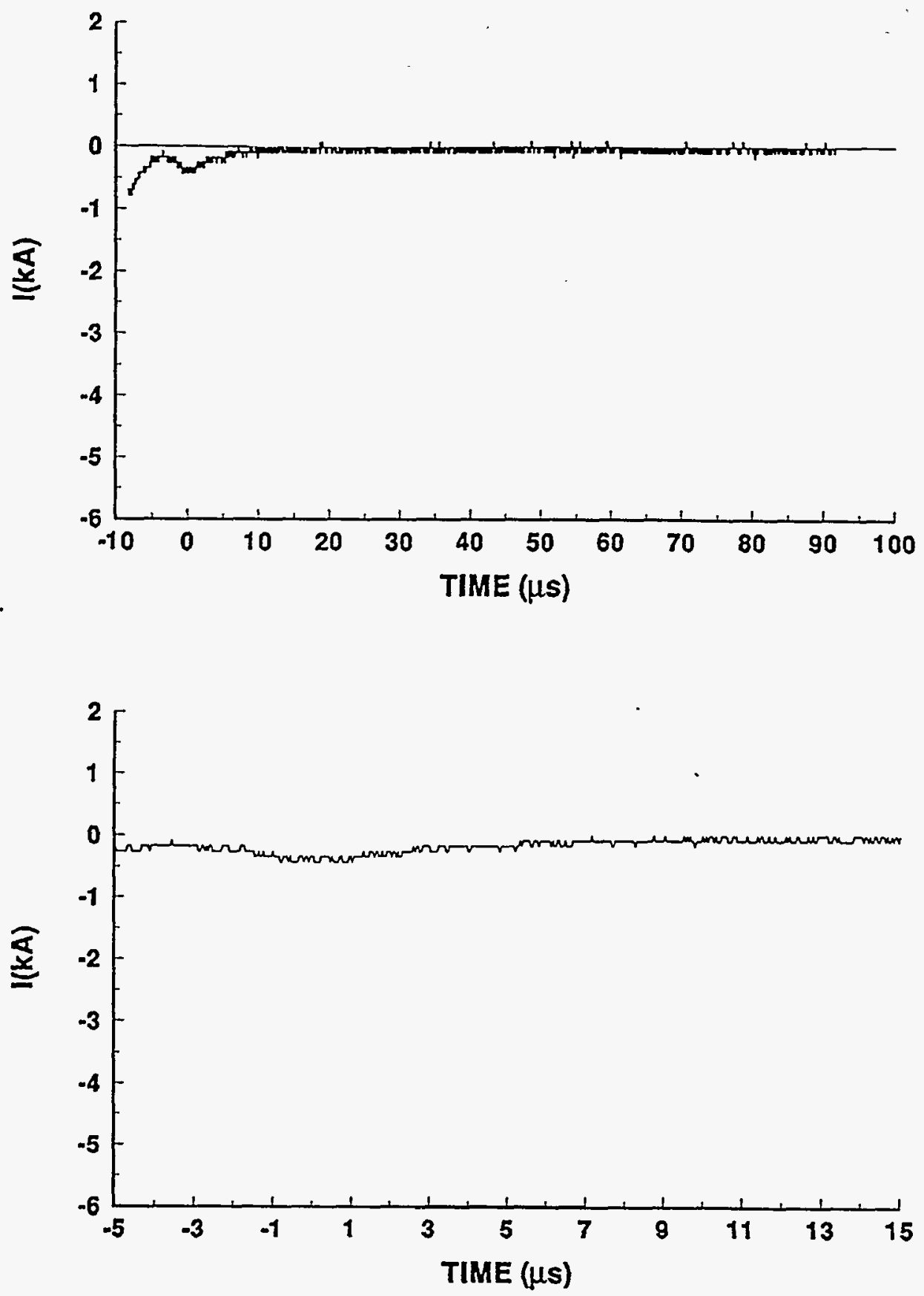


\section{4-04 STROKE 2}

TEST POINT 10

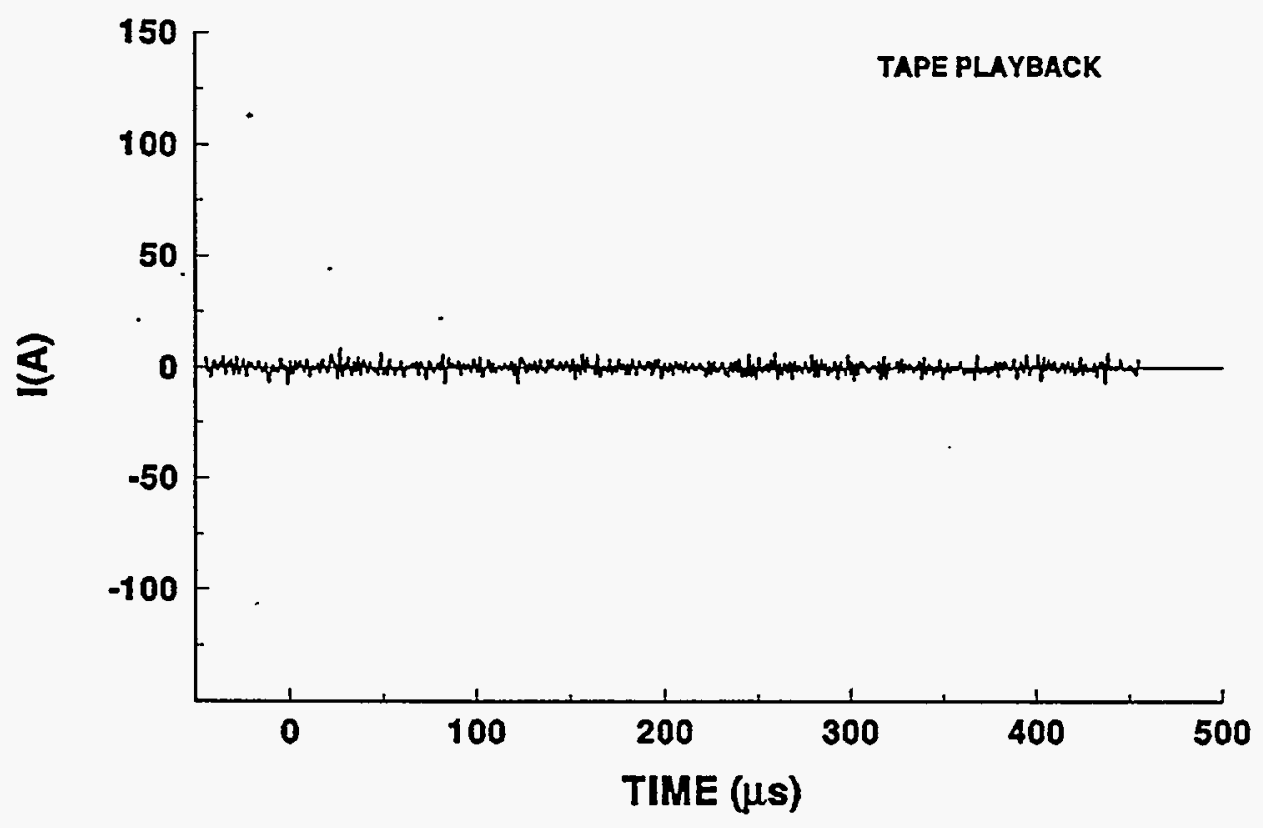

\section{4-04 STROKE 2}

TEST POINT 11

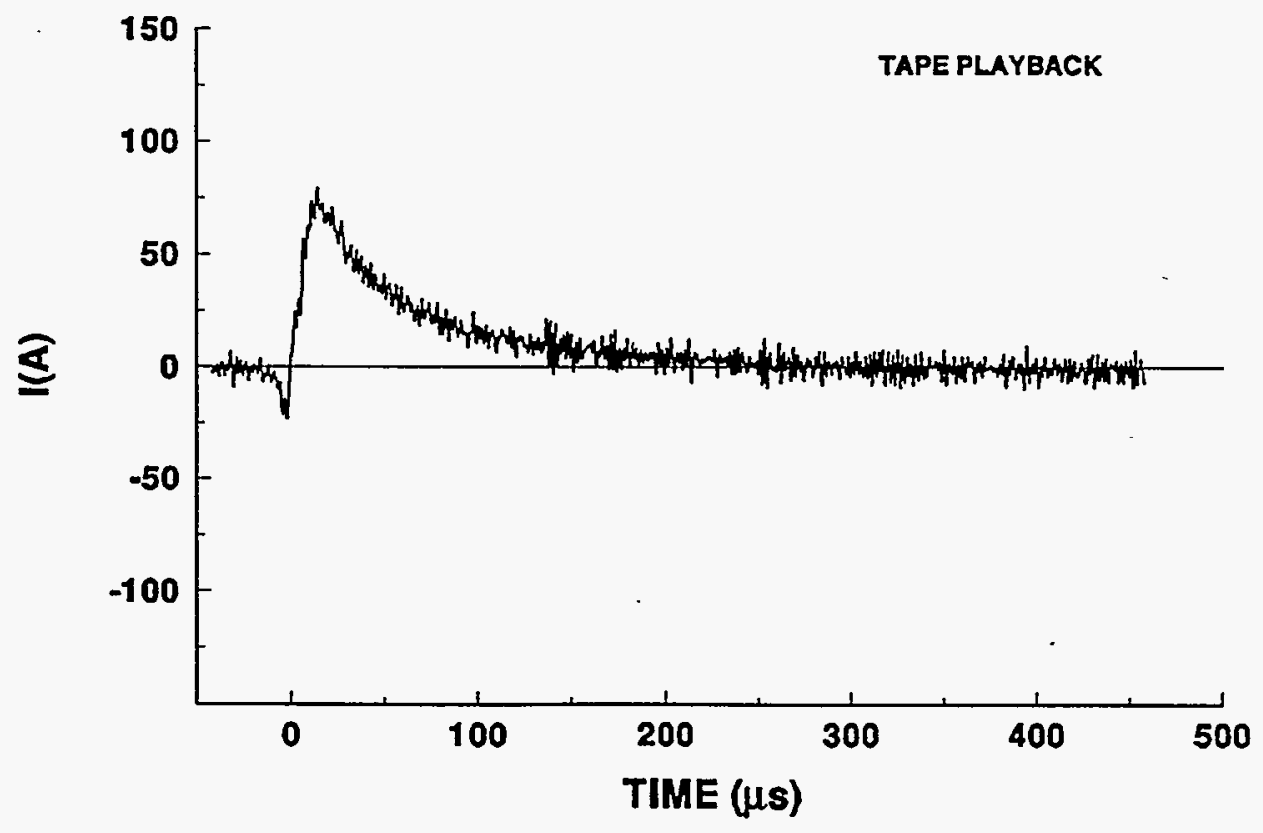




\section{4-04 STROKE 2}

TEST POINT 12

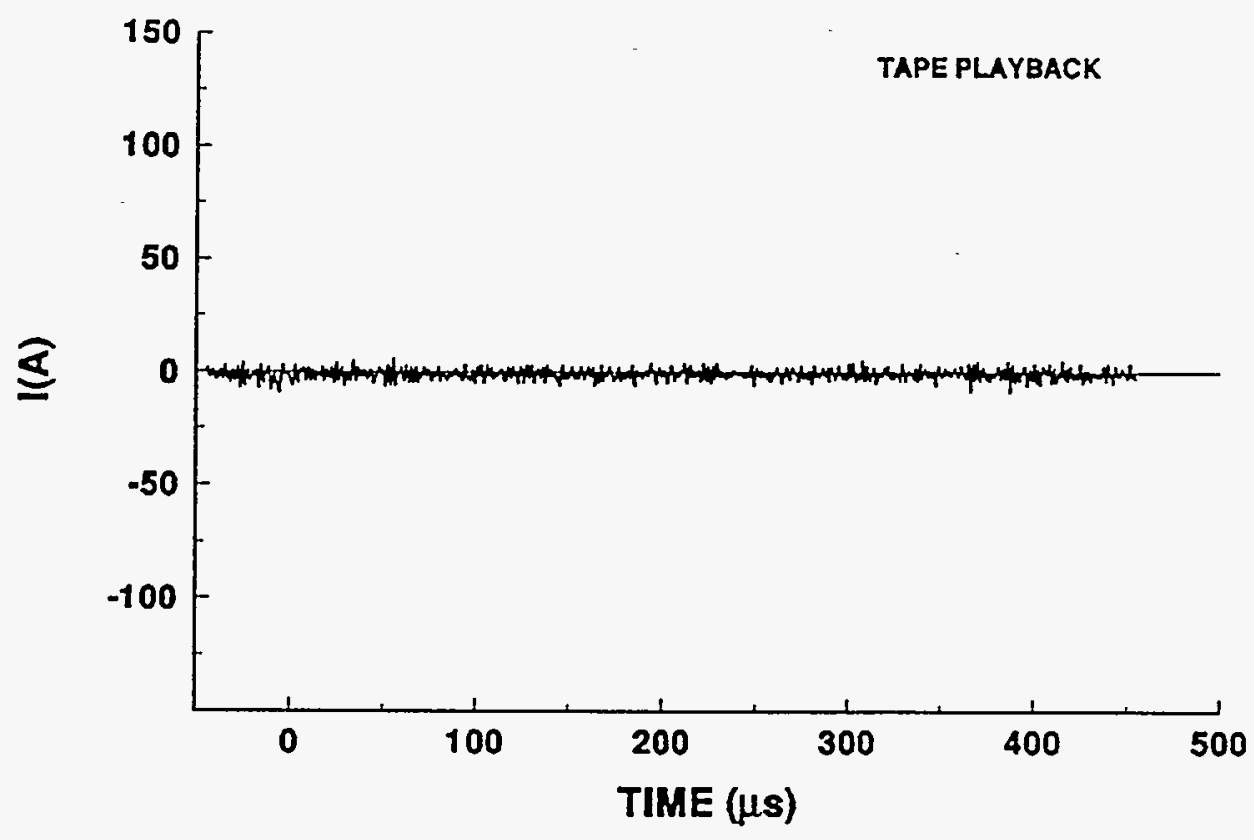

94-04 STROKE 2

TEST POINT 13

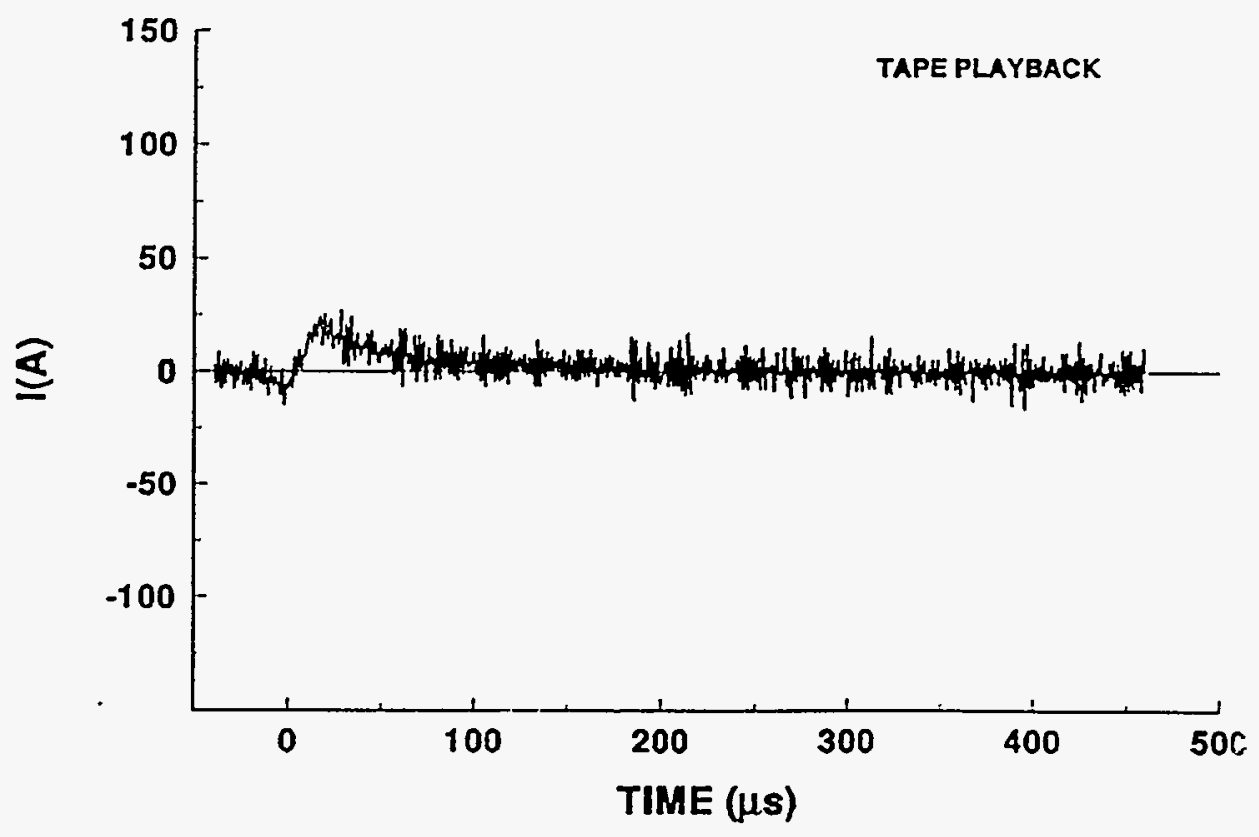


94-04 STROKE 2

TEST POINT 14
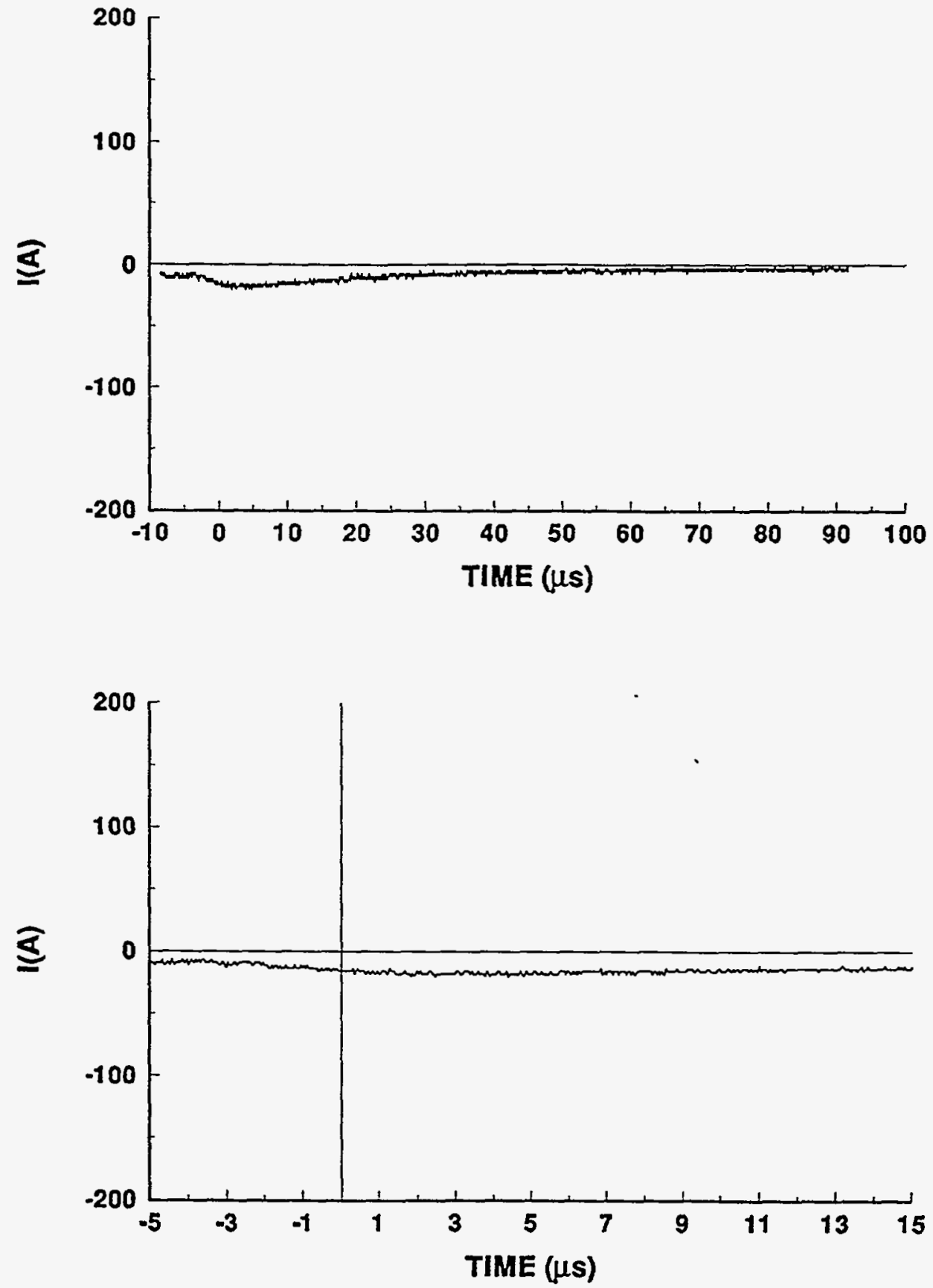


\section{4-04 STROKE 2}

TEST POINT 15
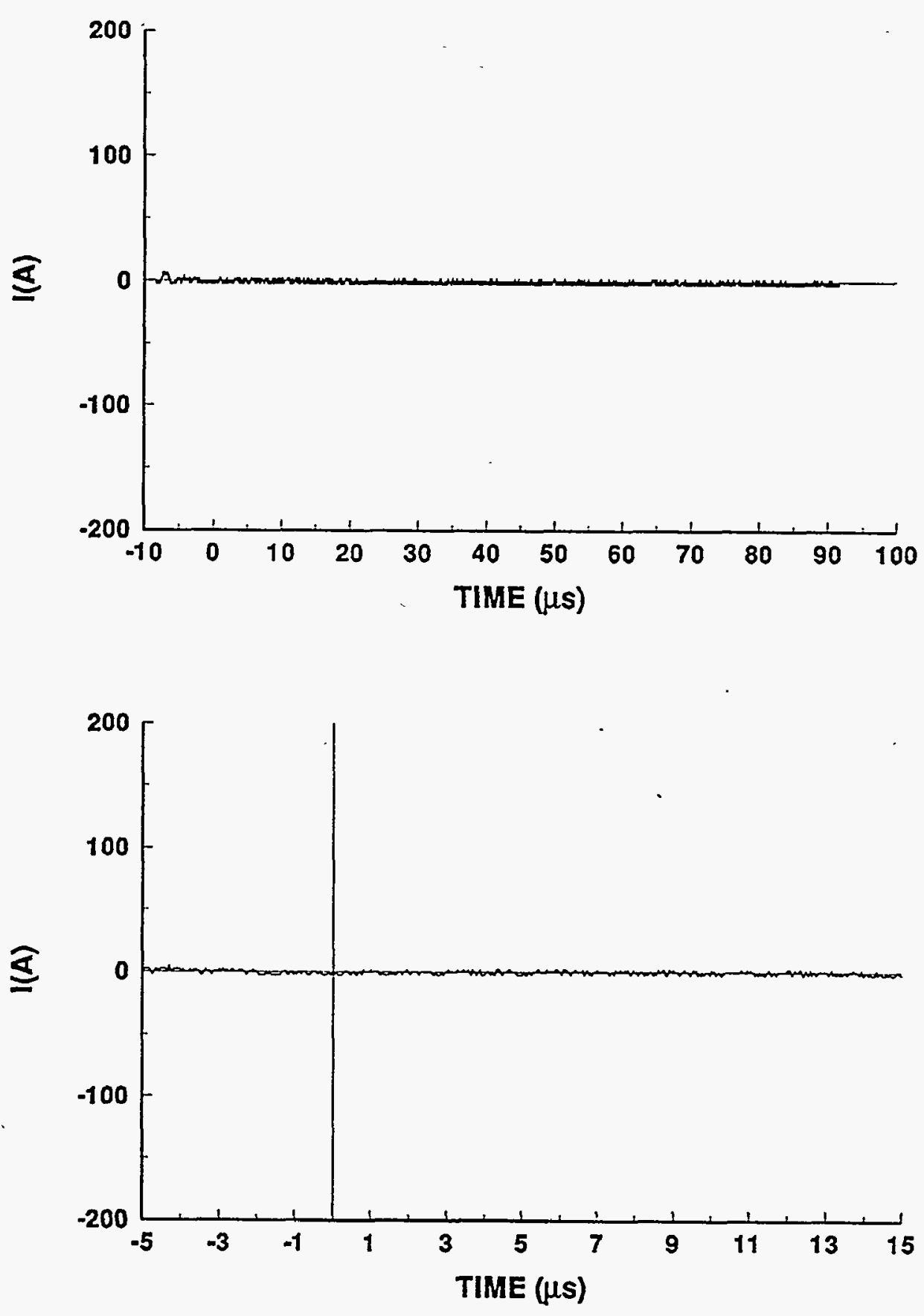


\section{4-04 STROKE 2}

TEST POINT 20

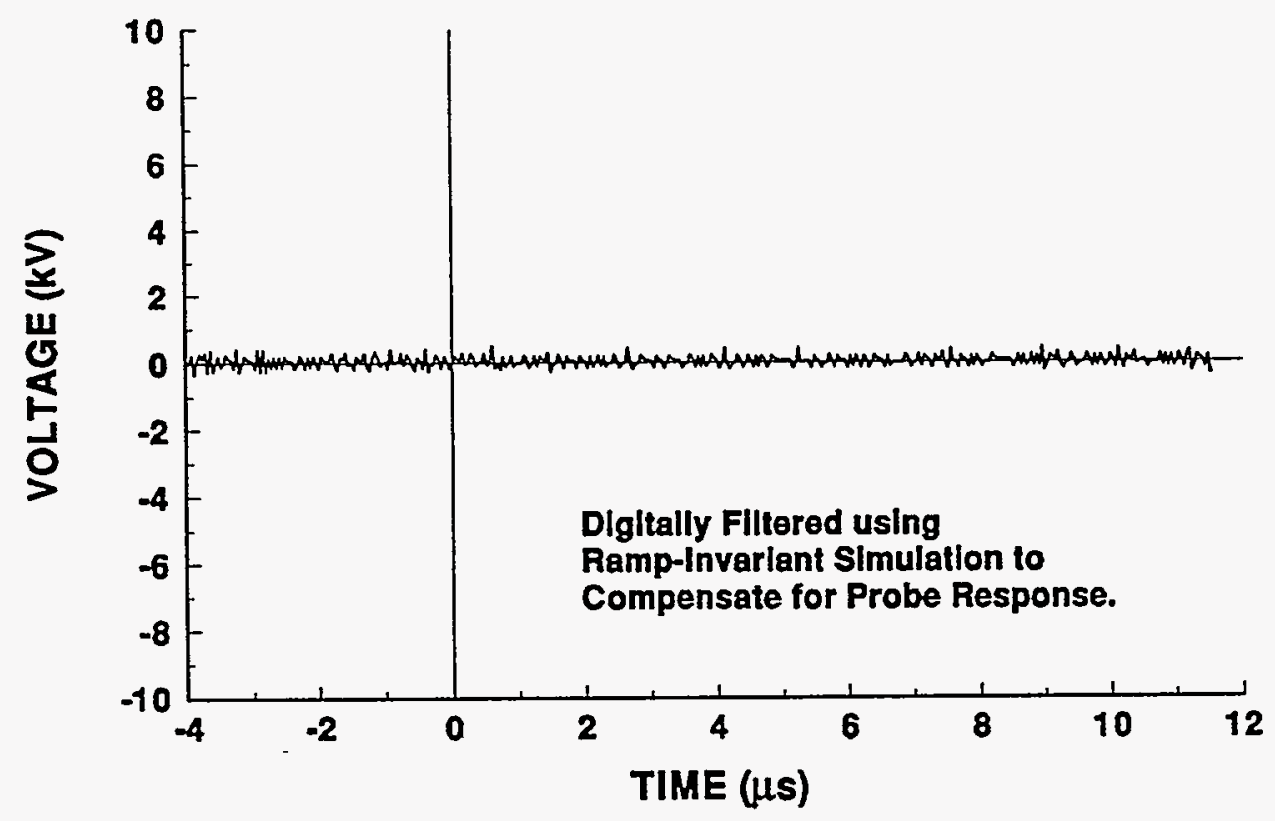

94-04 STROKE 2

TEST POINT 21

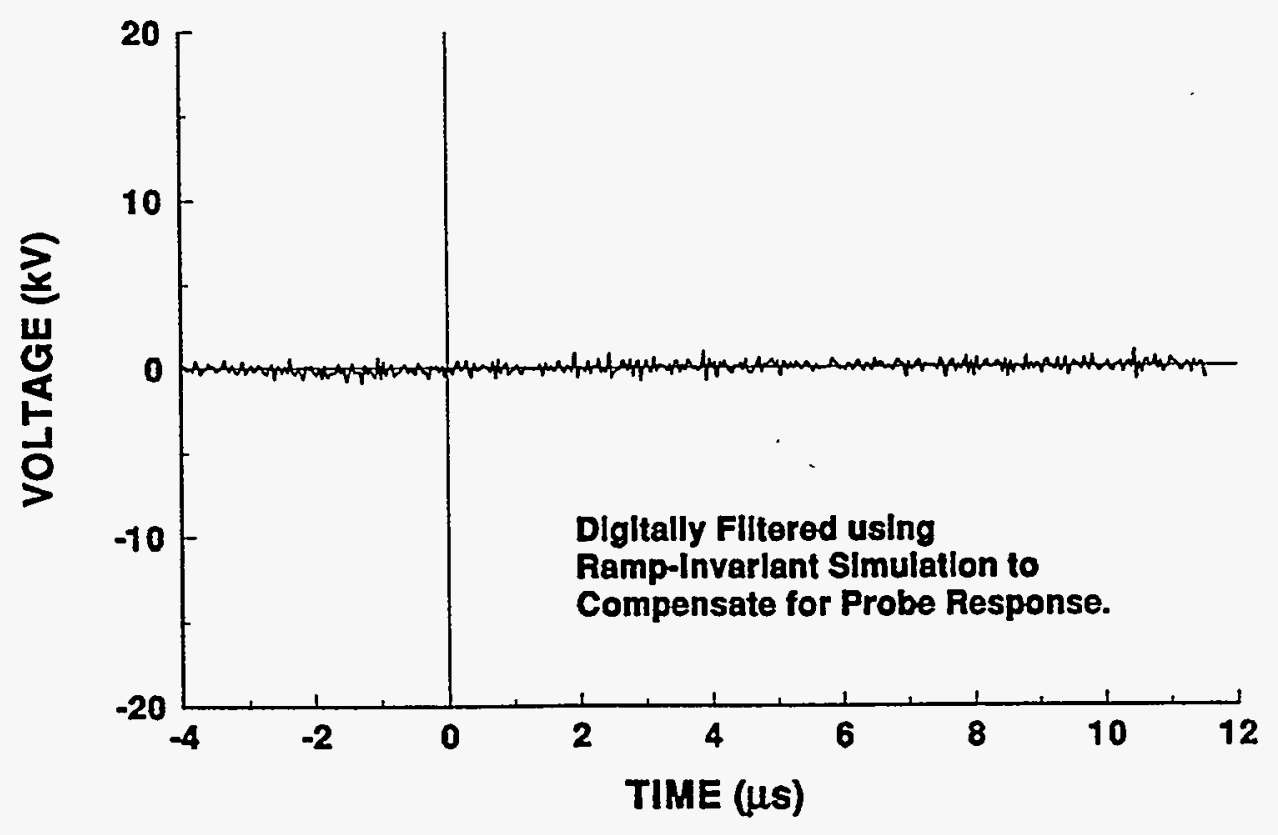




\section{4-04 STROKE 2}

TEST POINT 23
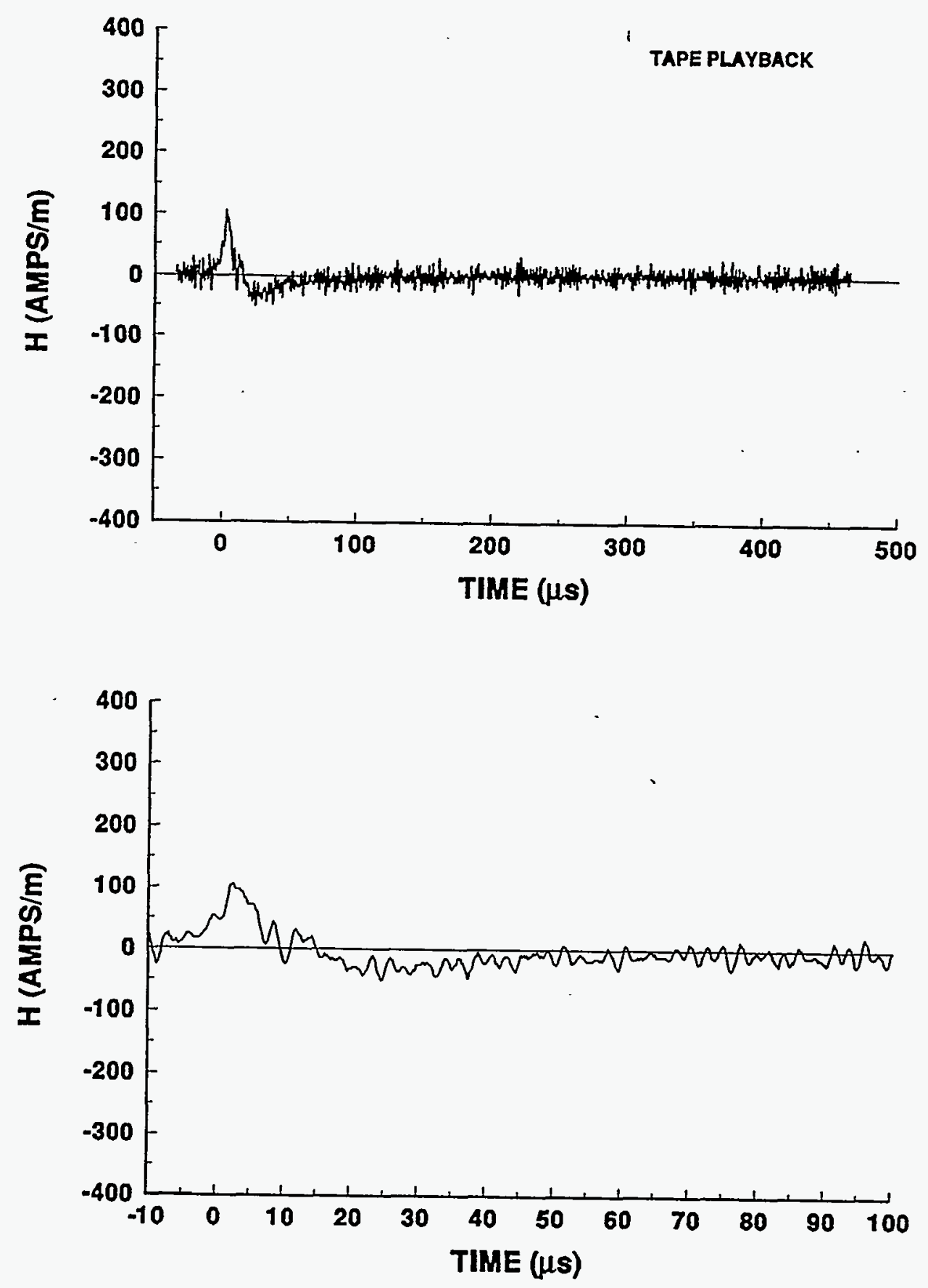


\section{4-04 STROKE 4 \\ INCIDENT CURRENT}
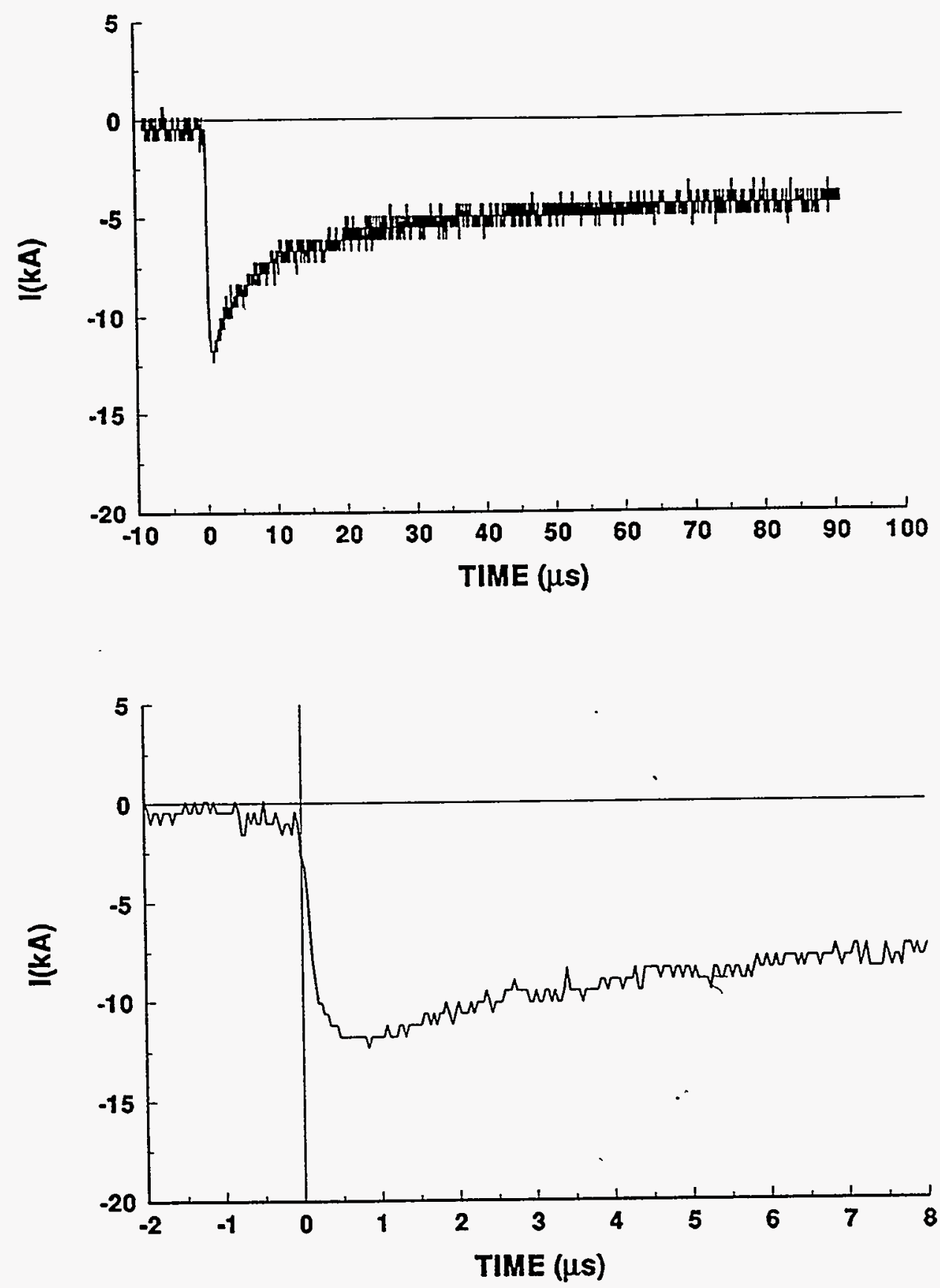


\section{4-04 STROKE 4}

TEST POINT 1

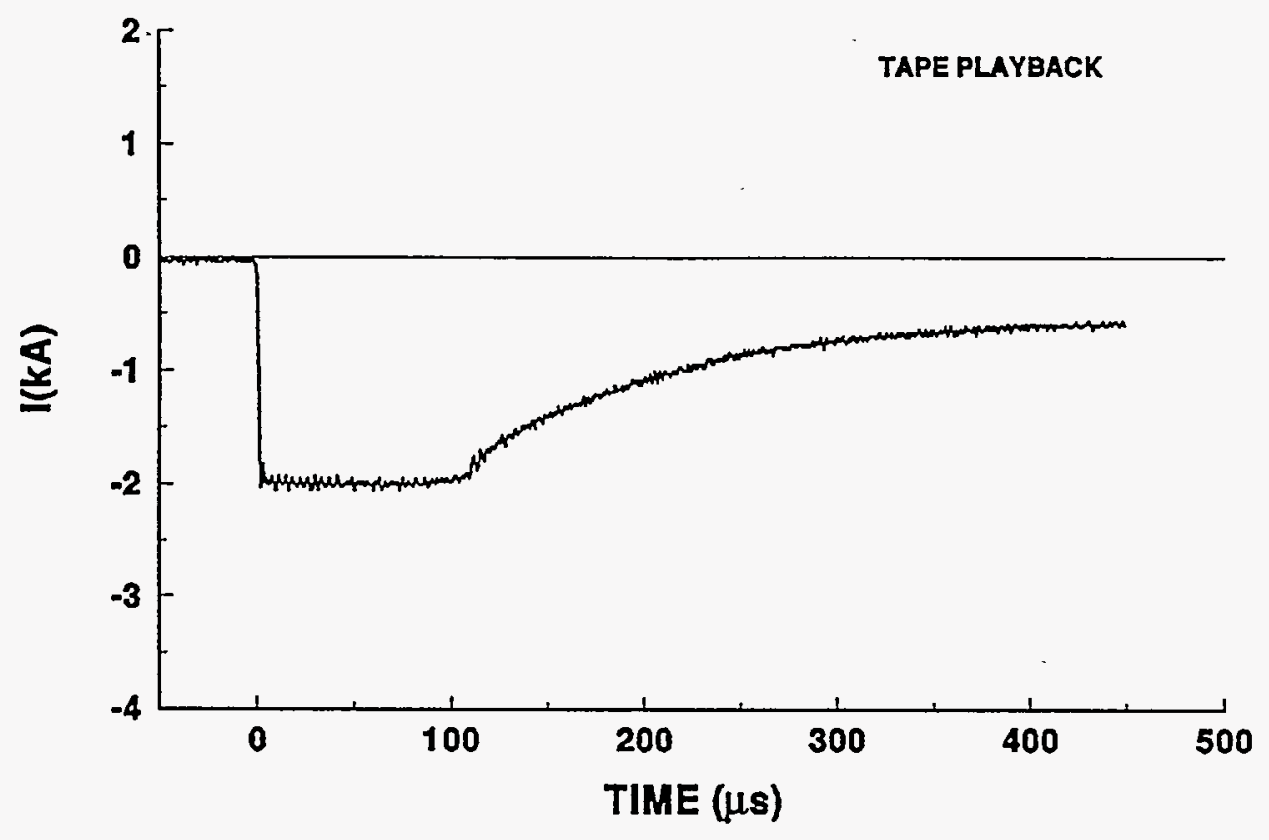

\section{4-04 STROKE 4}

TEST POINT 2

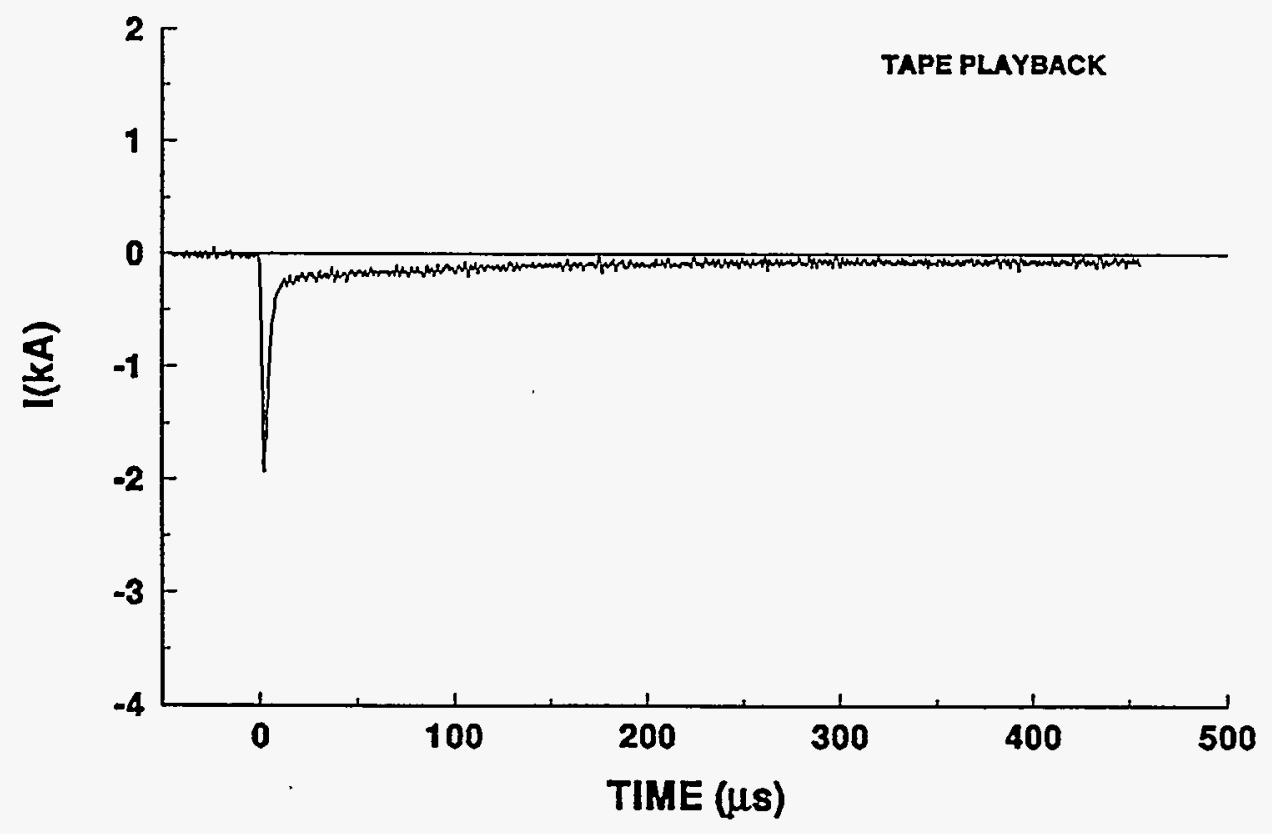


94-04 STROKE 4

TEST POINT 5
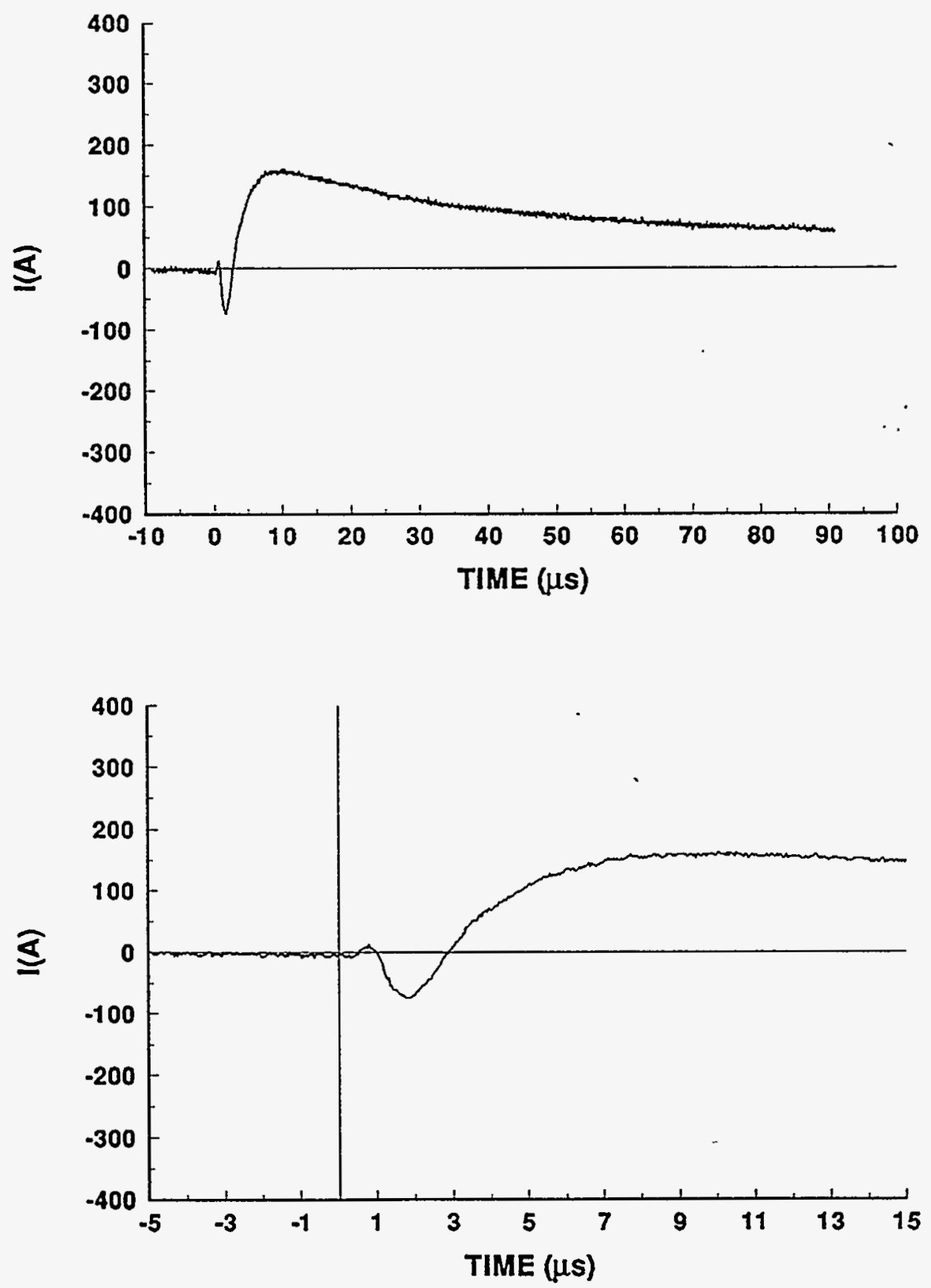


\section{4-04 STROKE 4}

TEST POINT 5'
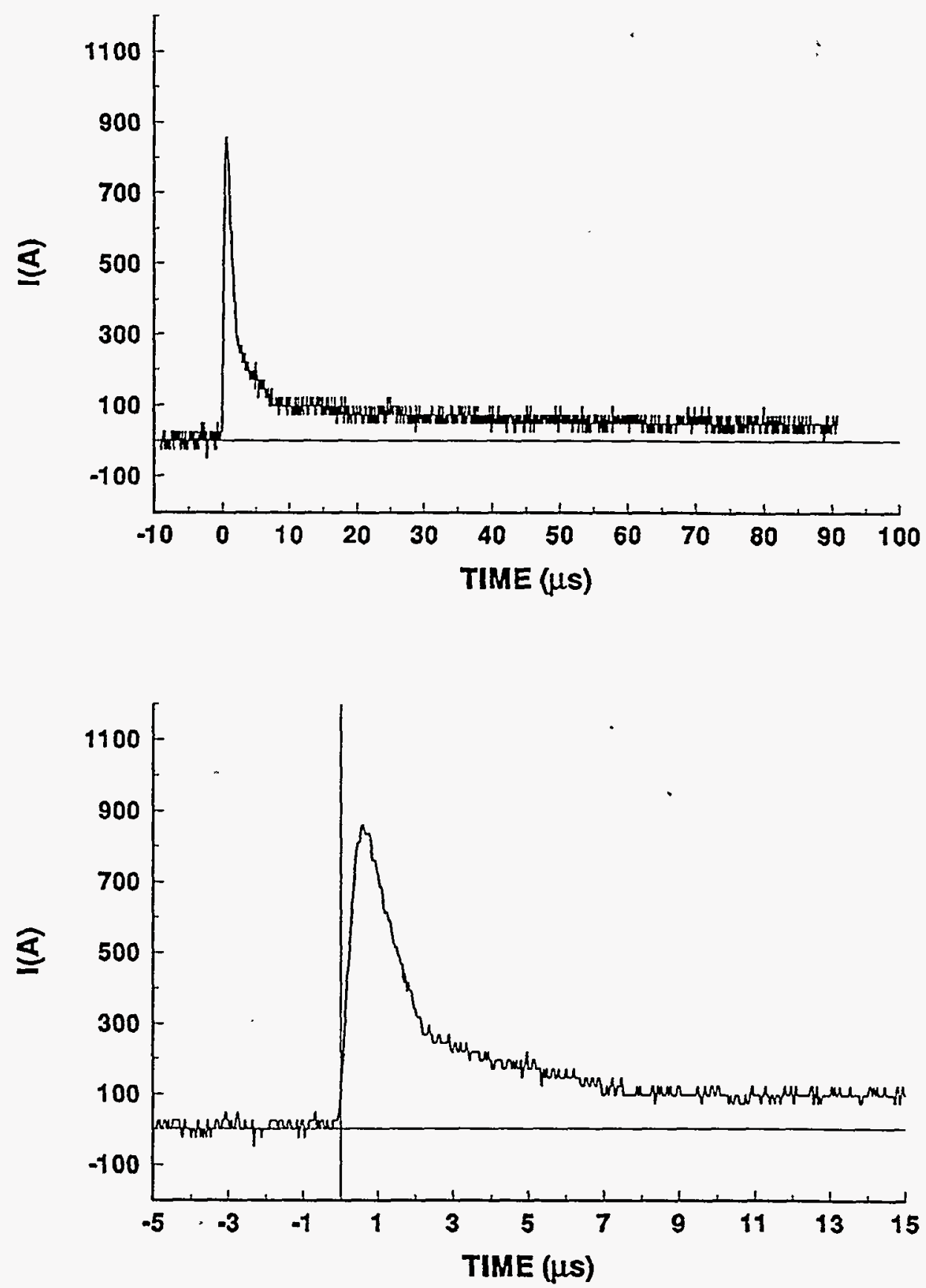


\section{4-04 STROKE 4}

TEST POINT 6'

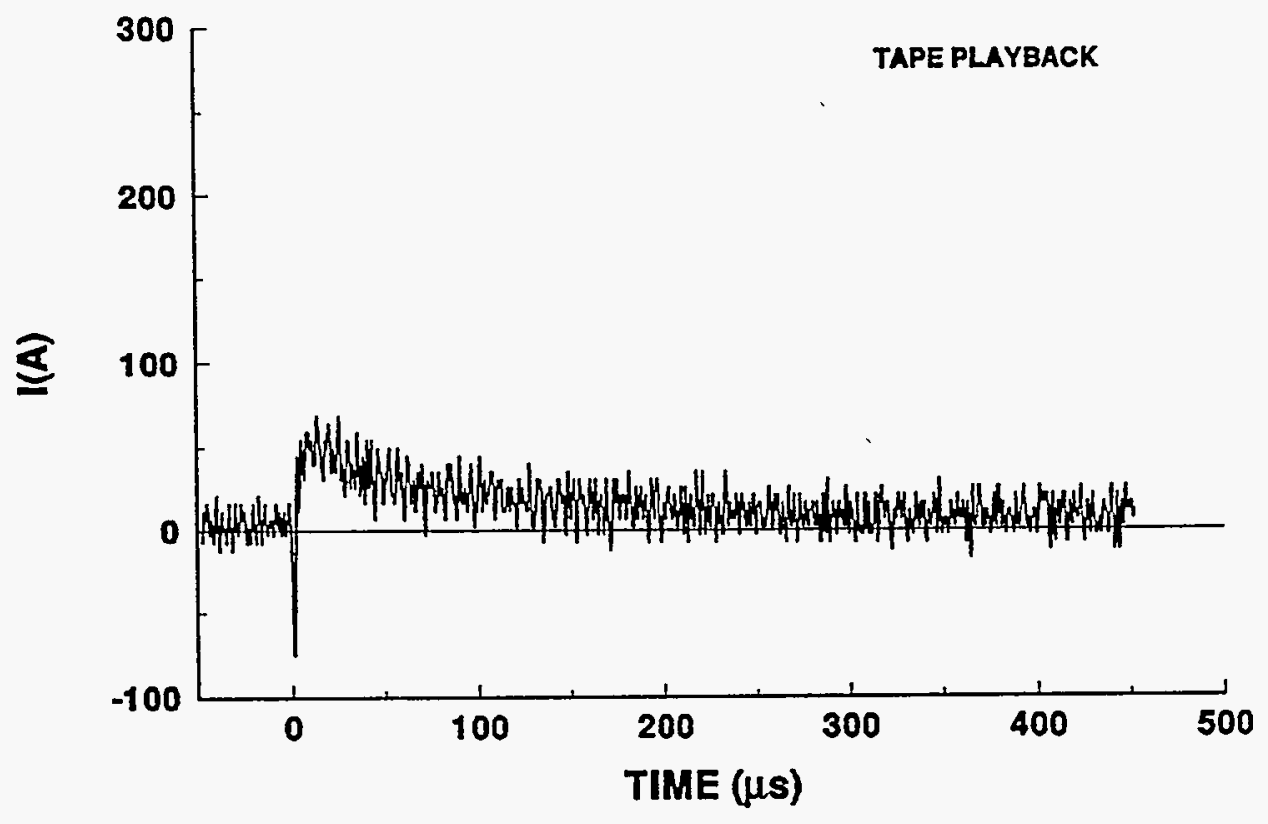


94-04 STROKE 4

TEST POINT 7
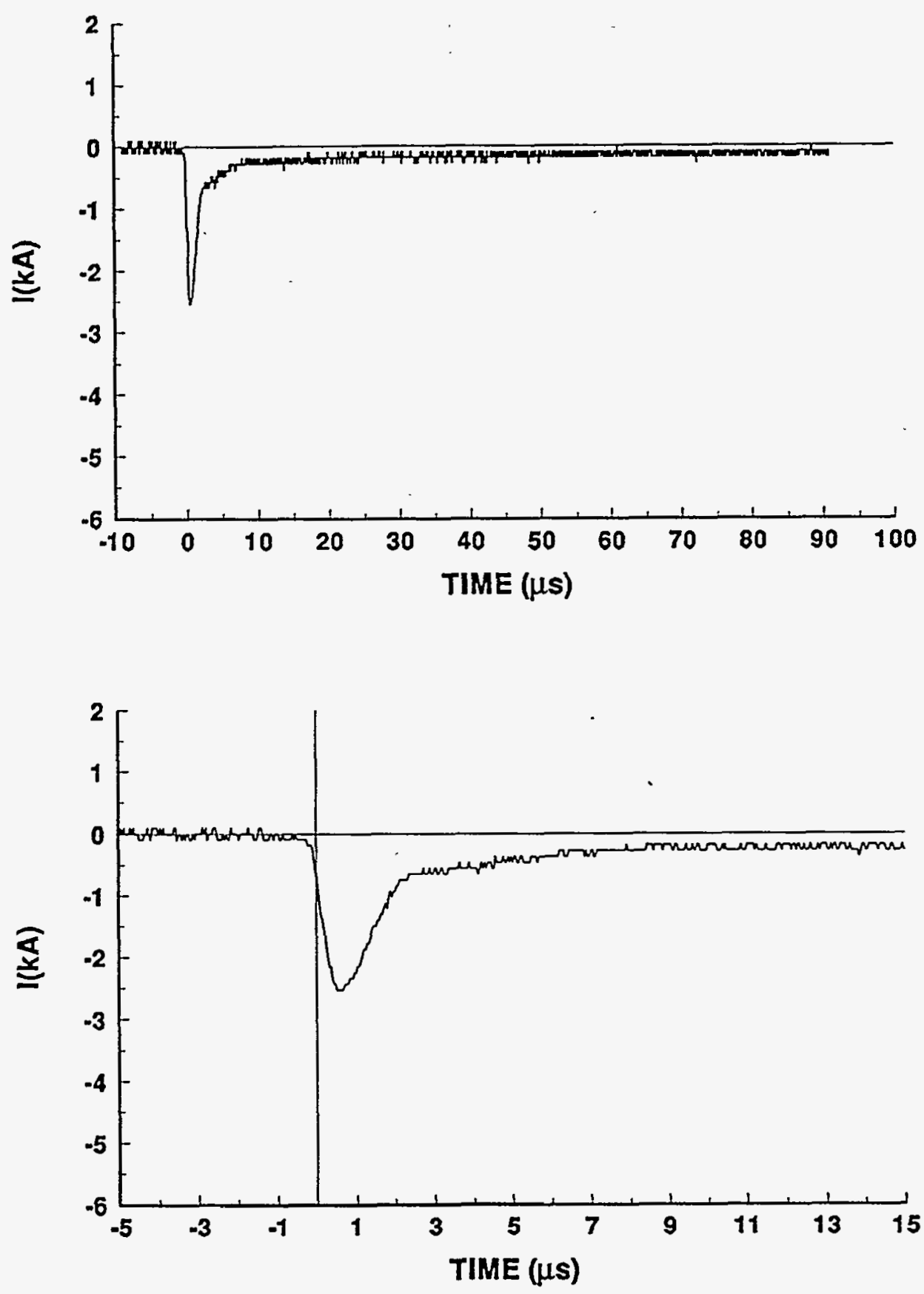


\section{4-04 STROKE 4 \\ TEST POINT 8}
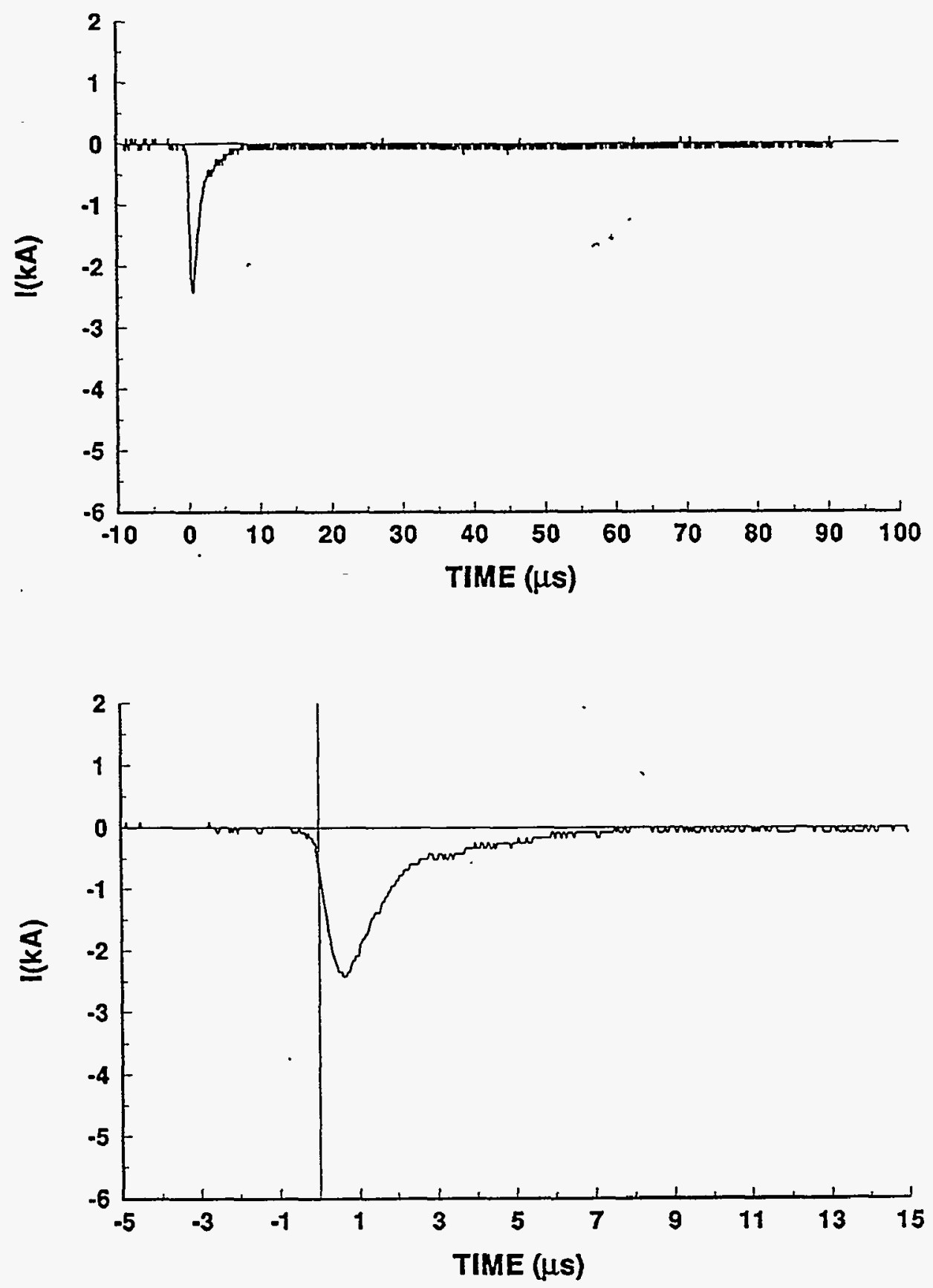


\section{4-04 STROKE 4}

TEST POINT 10

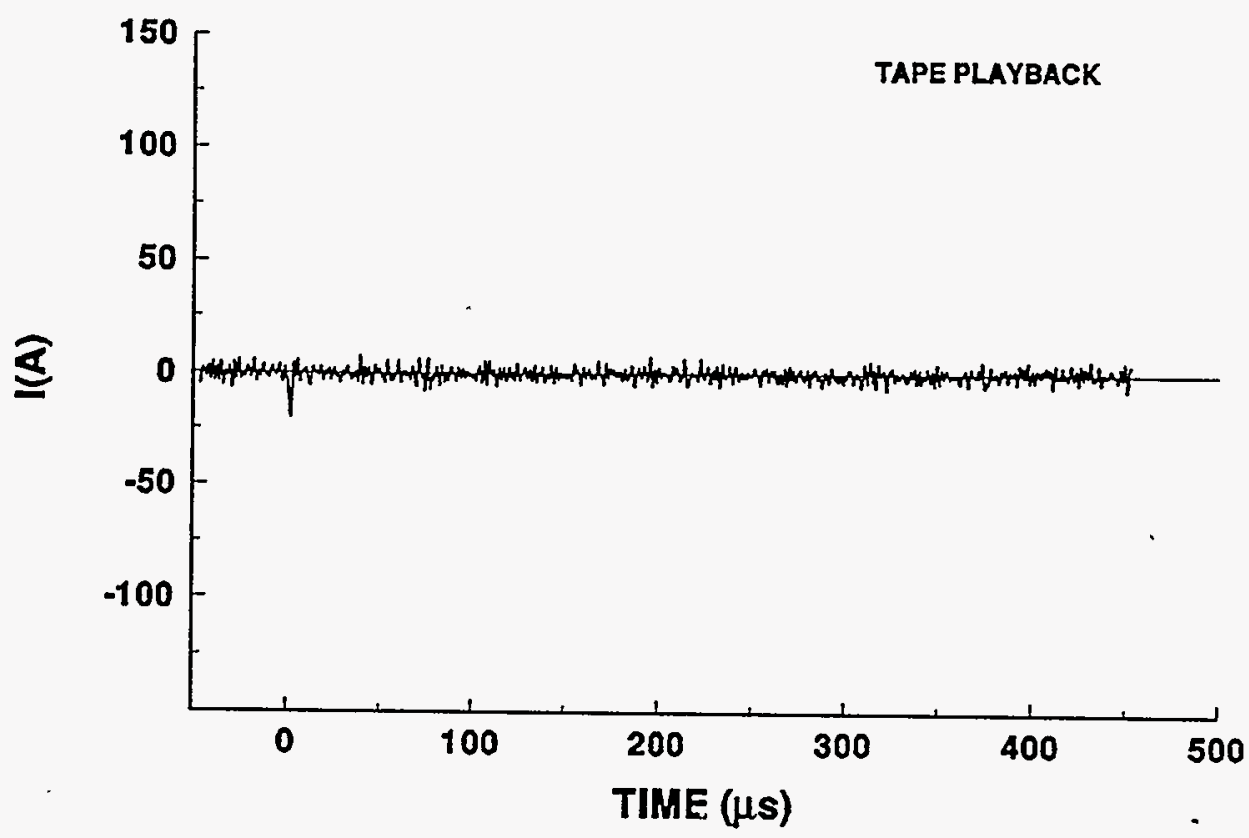

94-04 STROKE 4

TEST POINT 11

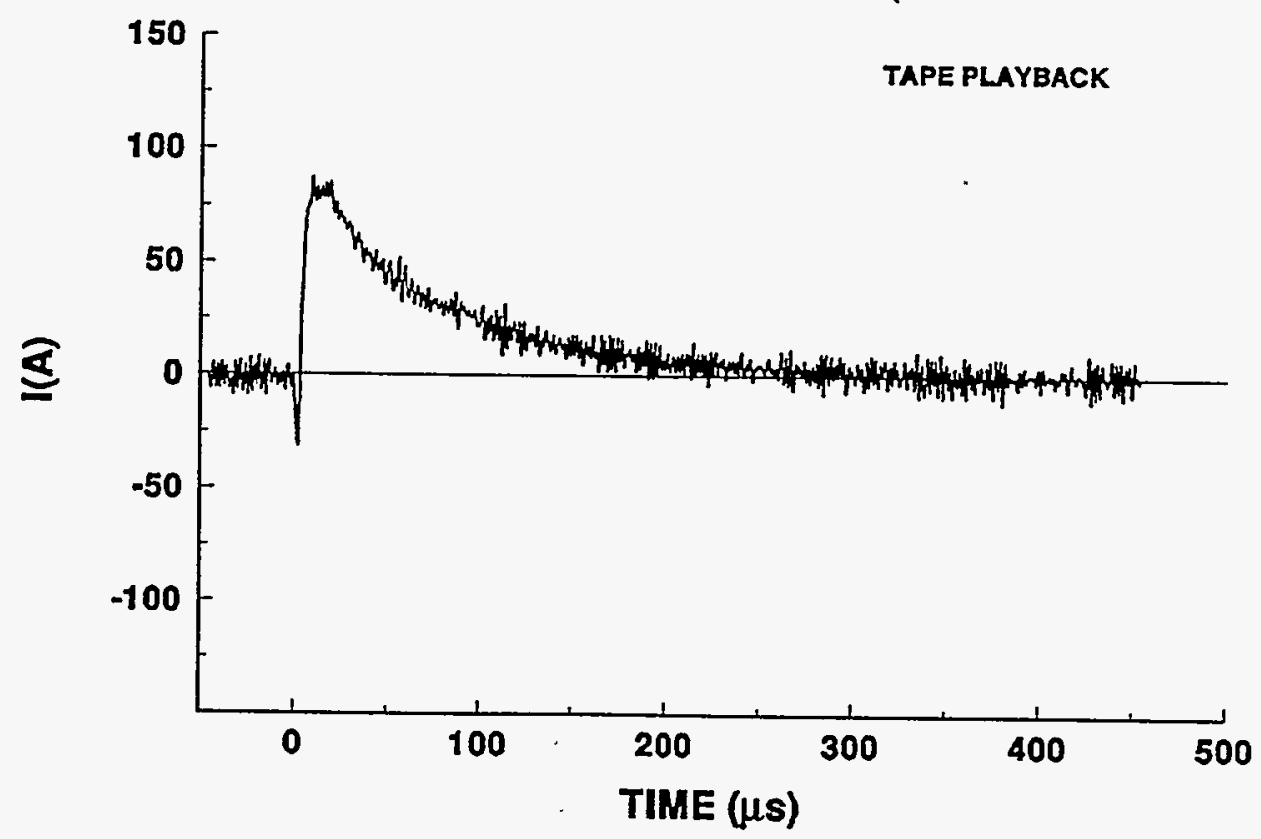




\section{4-04 STROKE 4}

TEST POINT 12

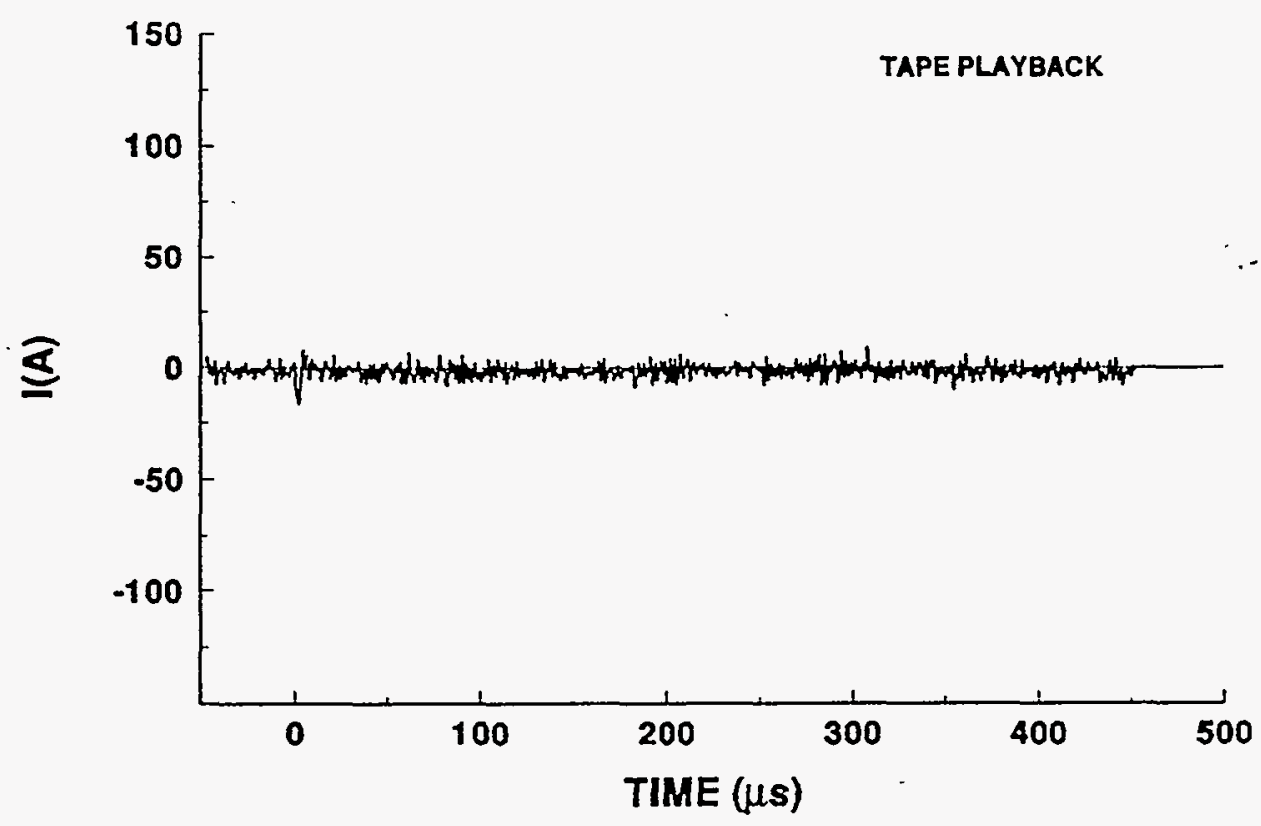

94-04 STROKE 4

TEST POINT 13

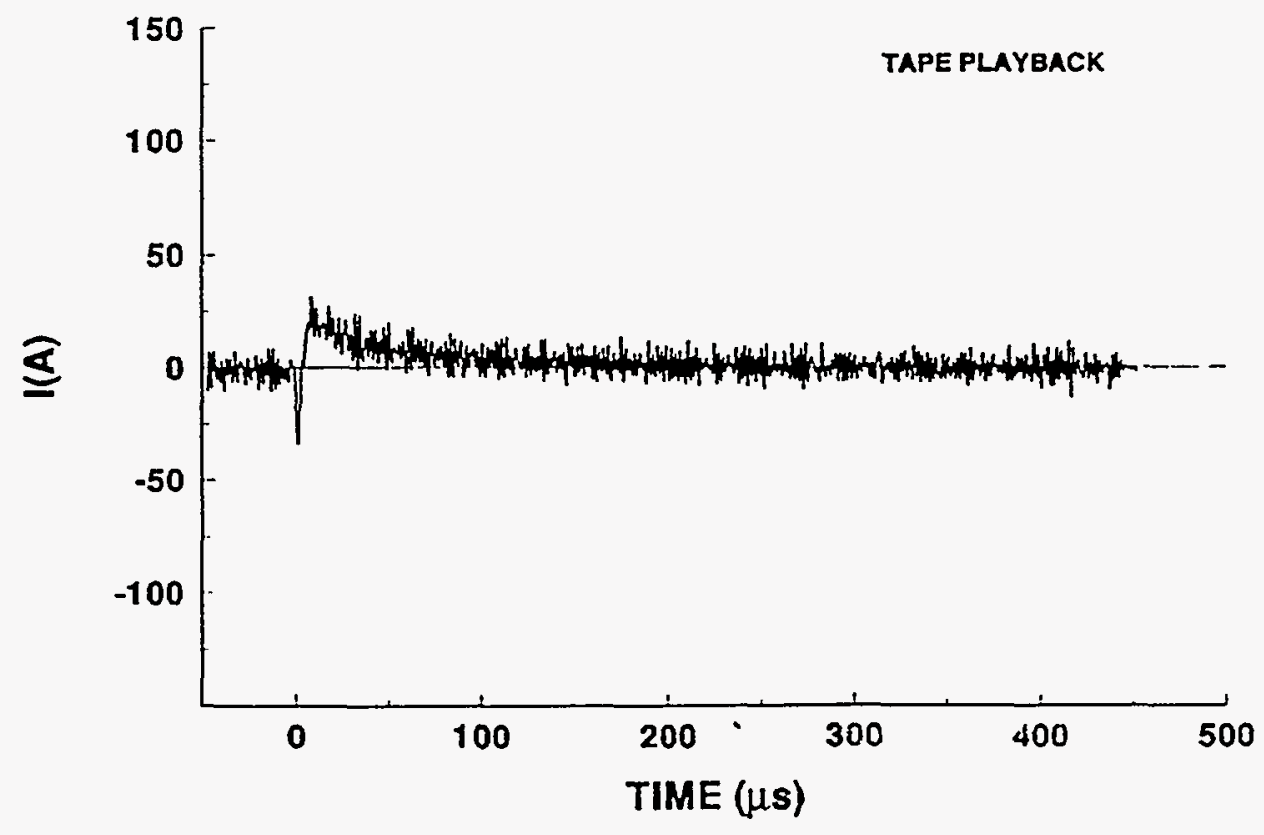




\section{4-04 STROKE 4}

\section{TEST POINT 14}
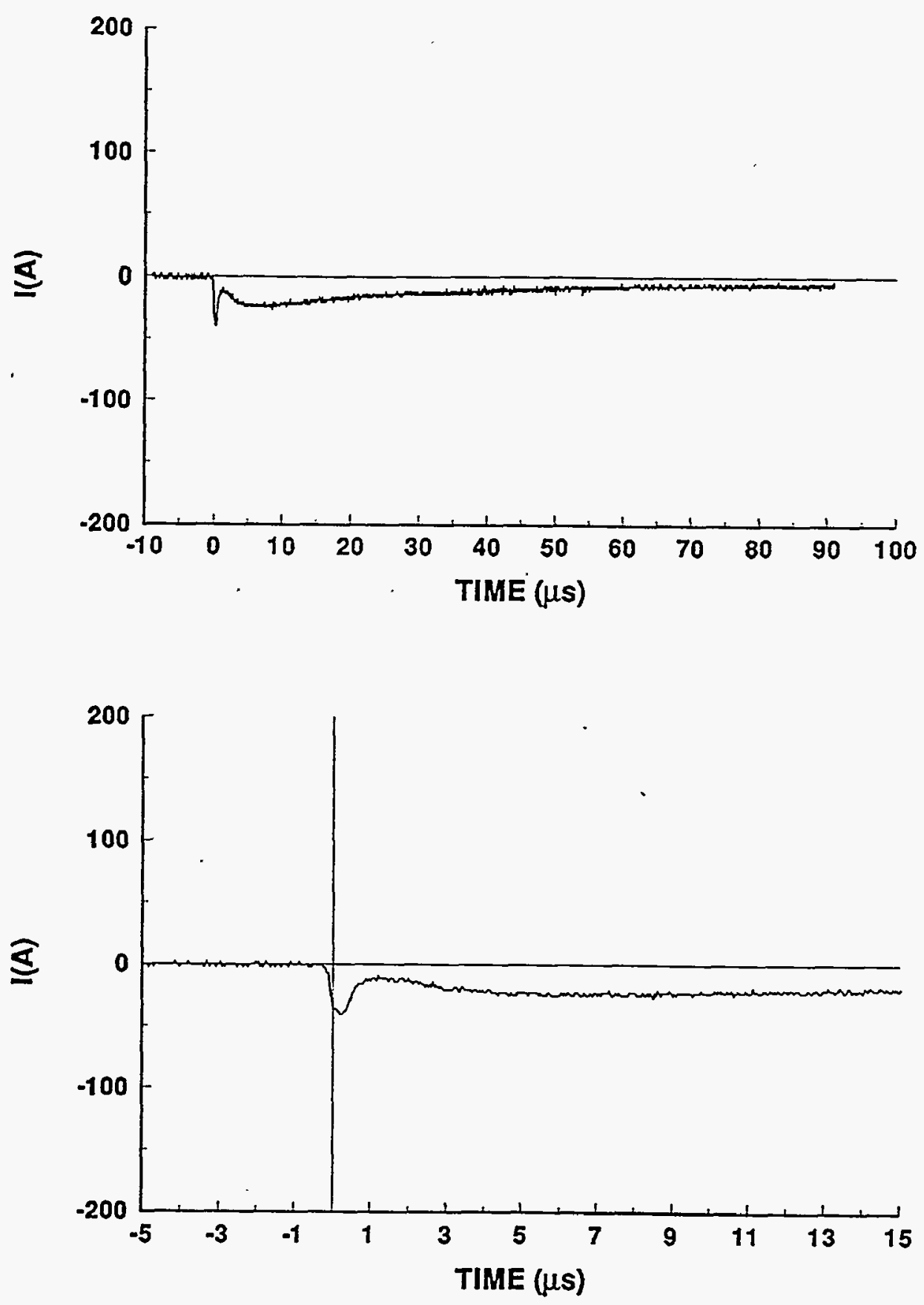
94-04 STROKE 4

TEST POINT 15
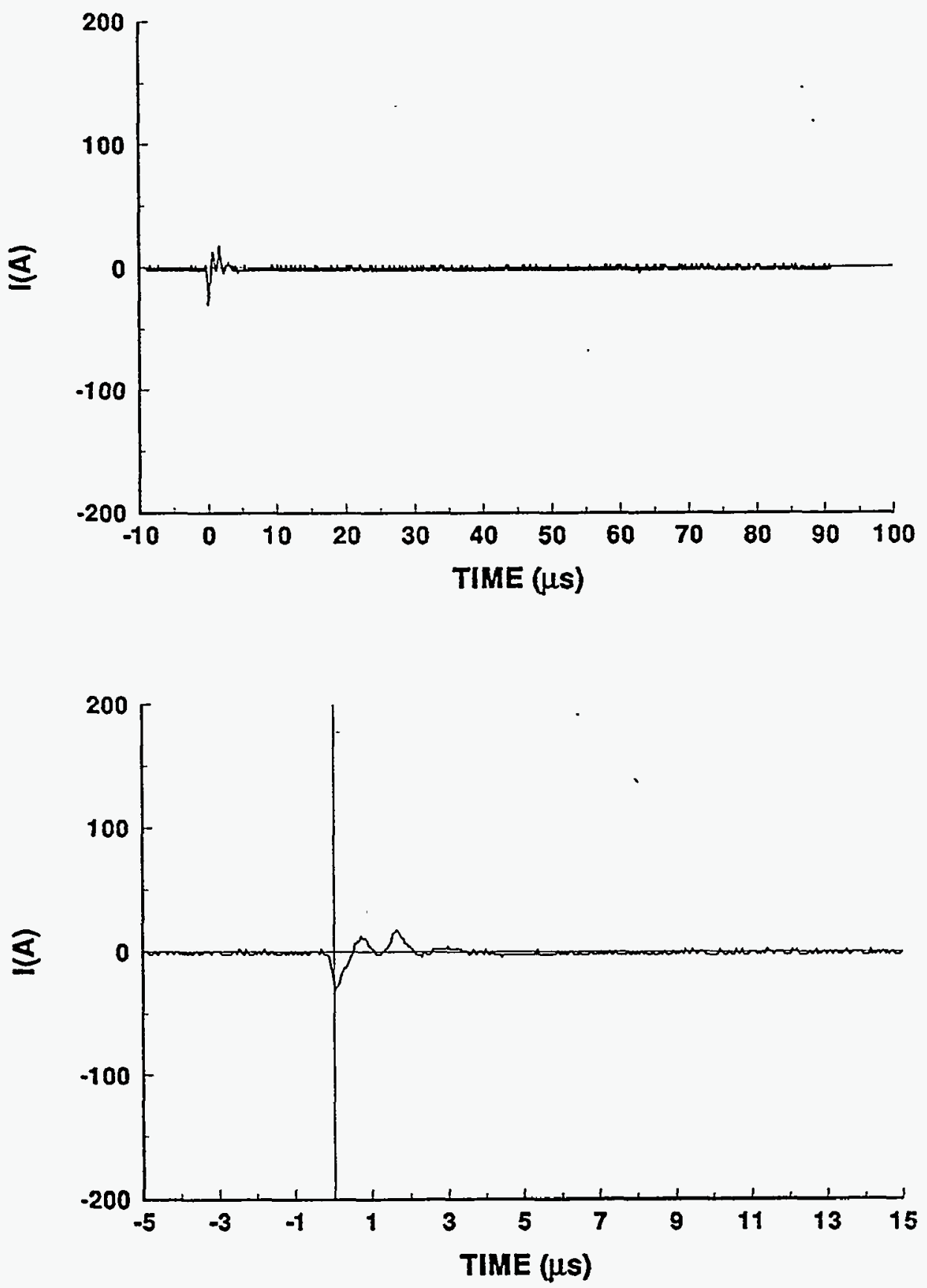


\section{4-04 STROKE 4}

TEST POINT 20

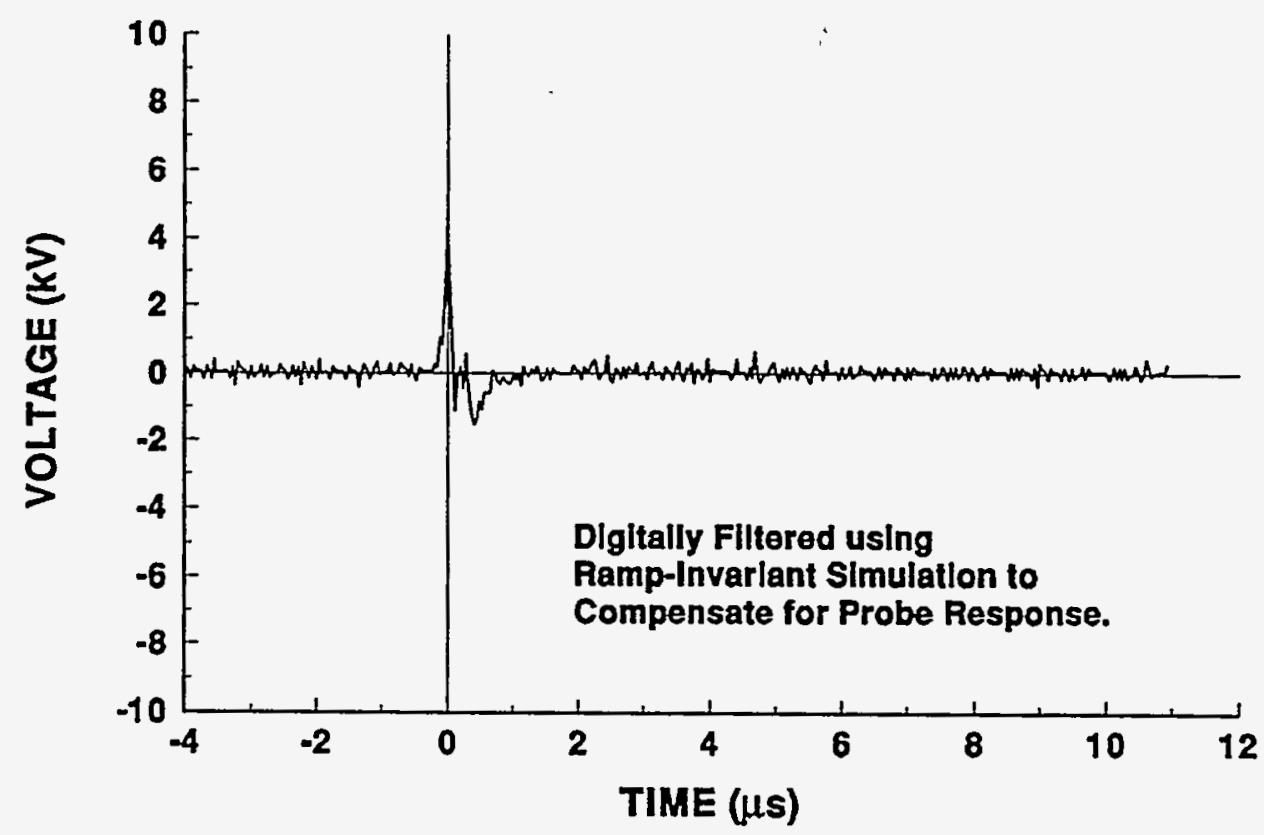

94-04 STROKE 4

TEST POINT 21

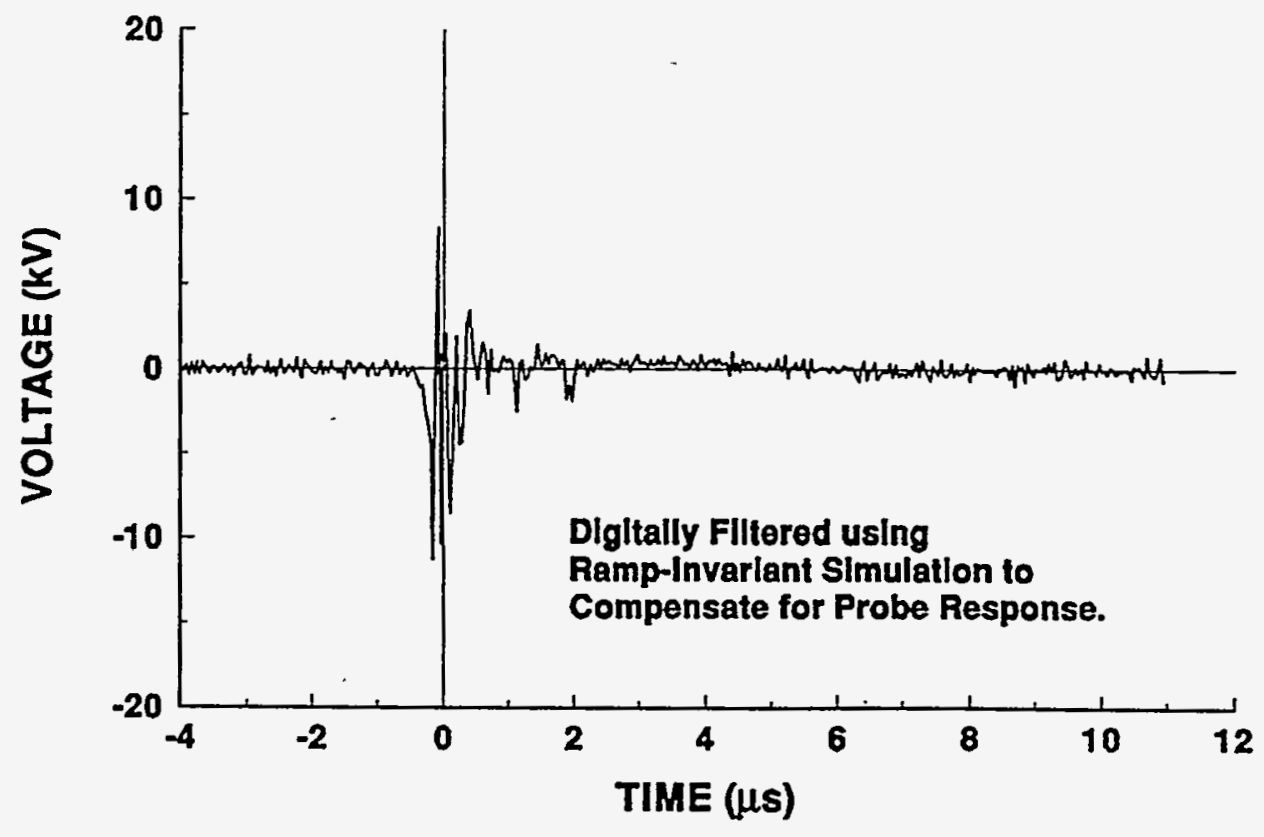




\section{4-04 STROKE 4}

TEST POINT 23
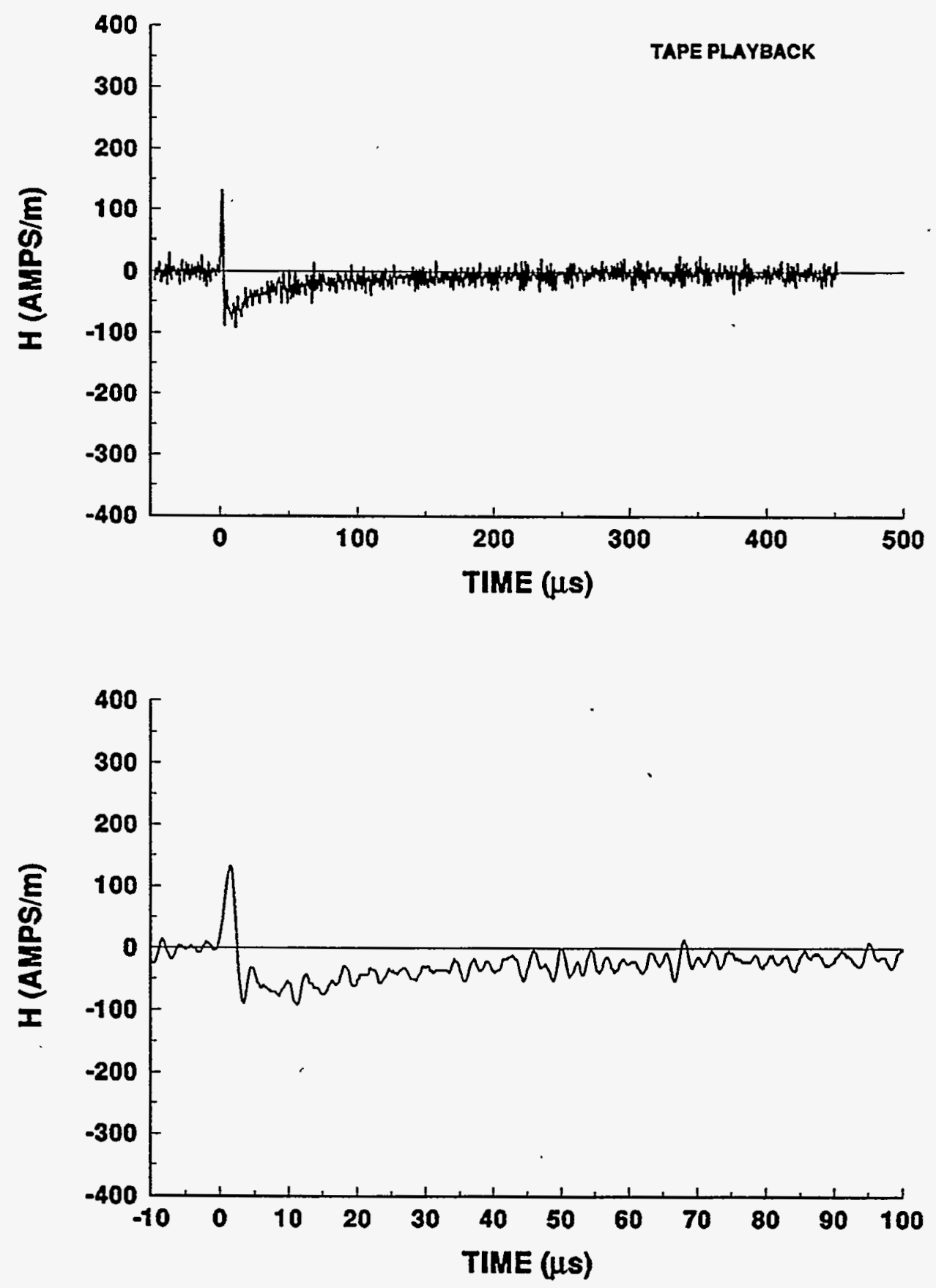


\section{4-06 STROKE 1}

INCIDENT CURRENT
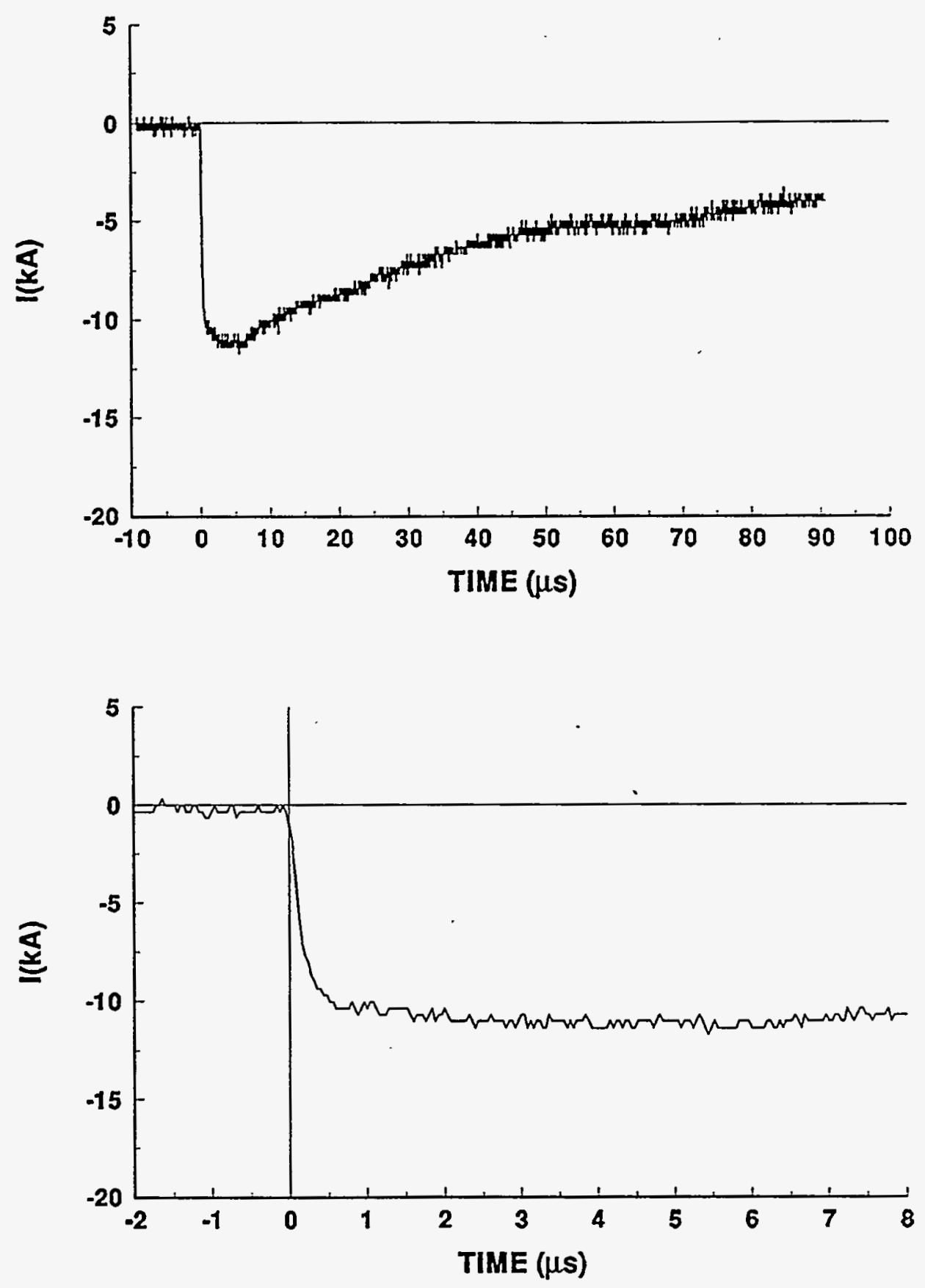


\section{4-06 STROKE 1}

TEST POINT 1

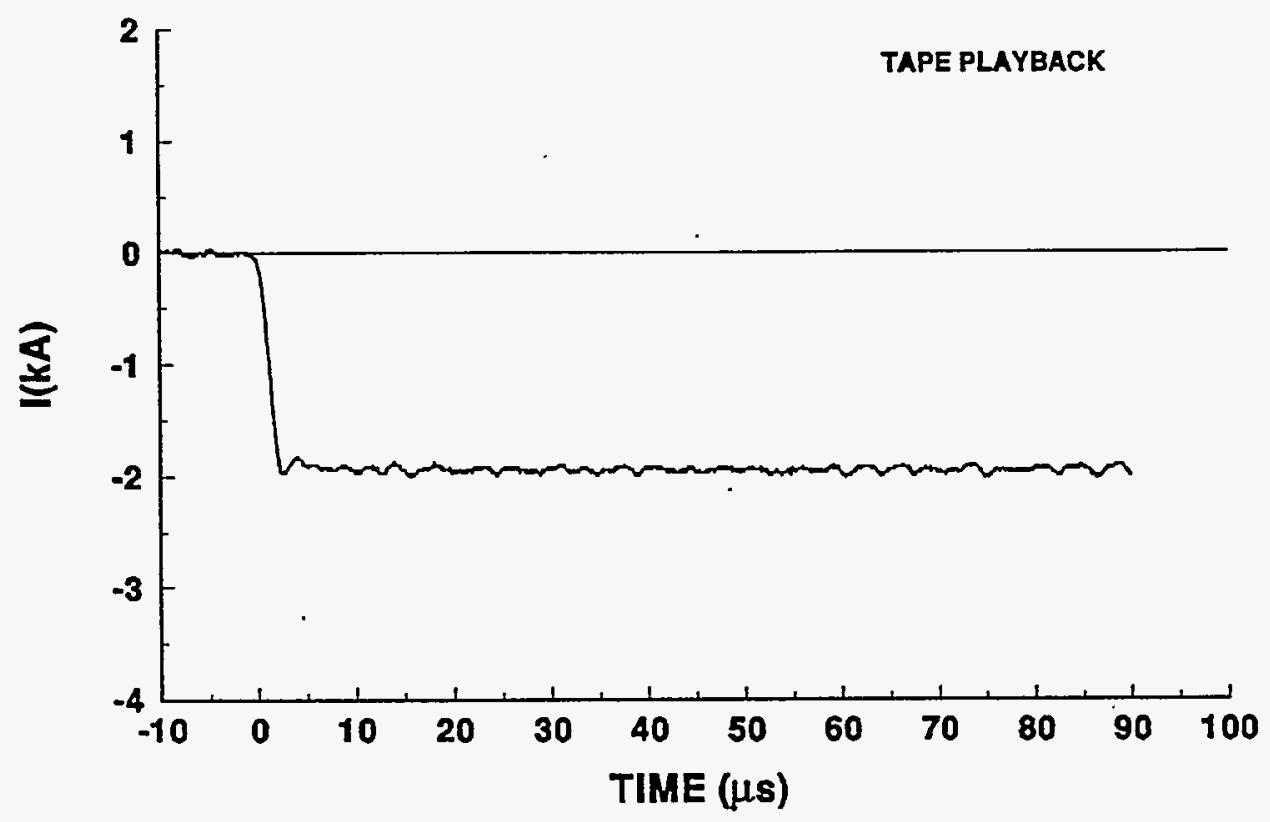

\section{4-02 STROKE 1}

TEST POINT 2

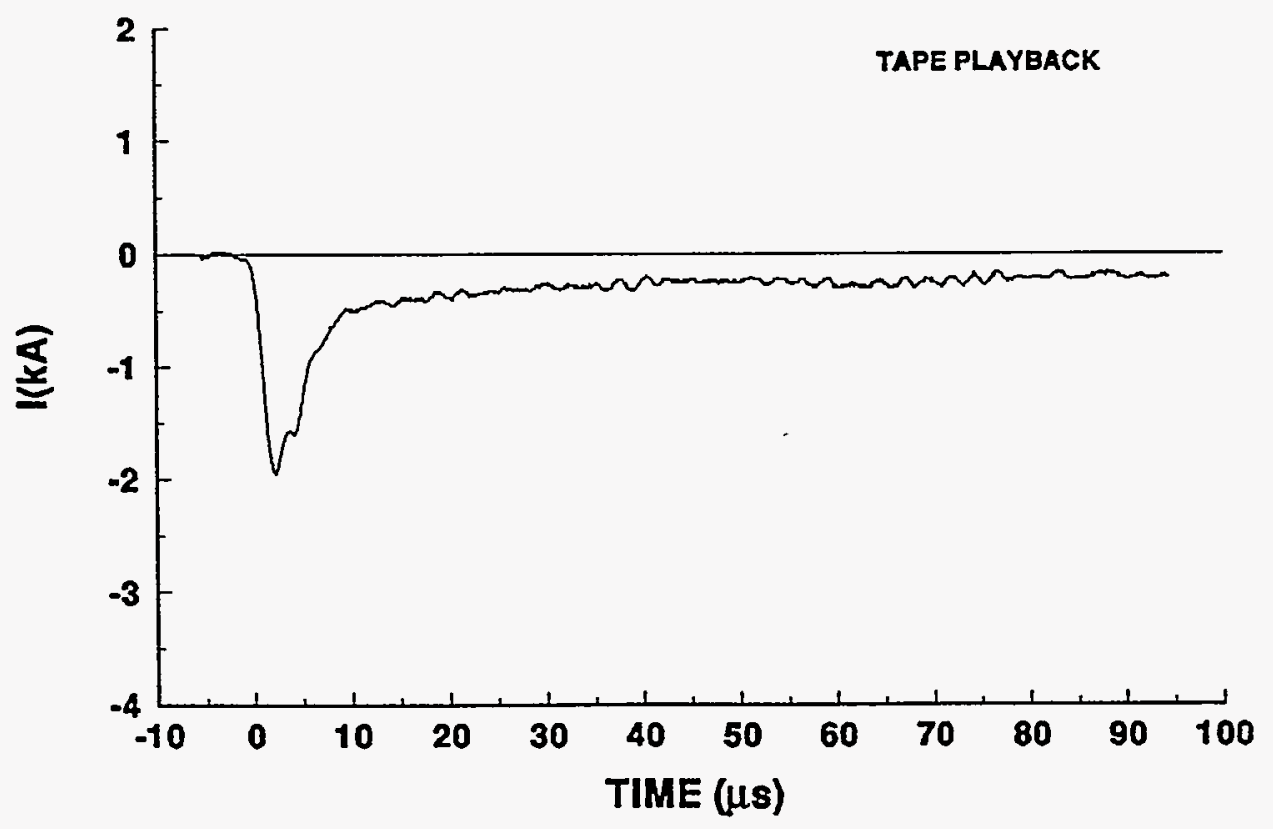


94-06 STROKE 1

TEST POINT 5
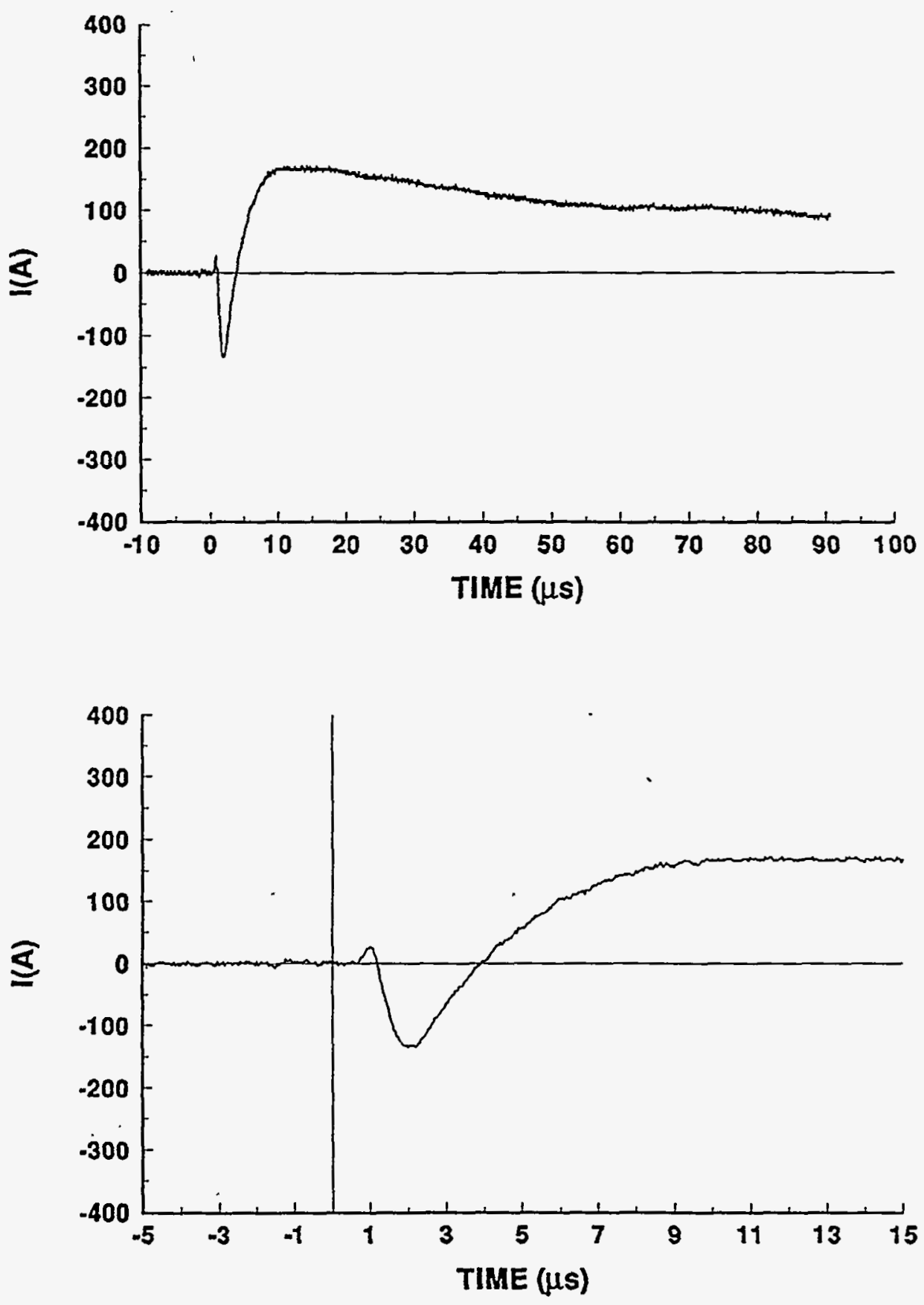


\section{4-06 STROKE 1}

TEST POINT 5'
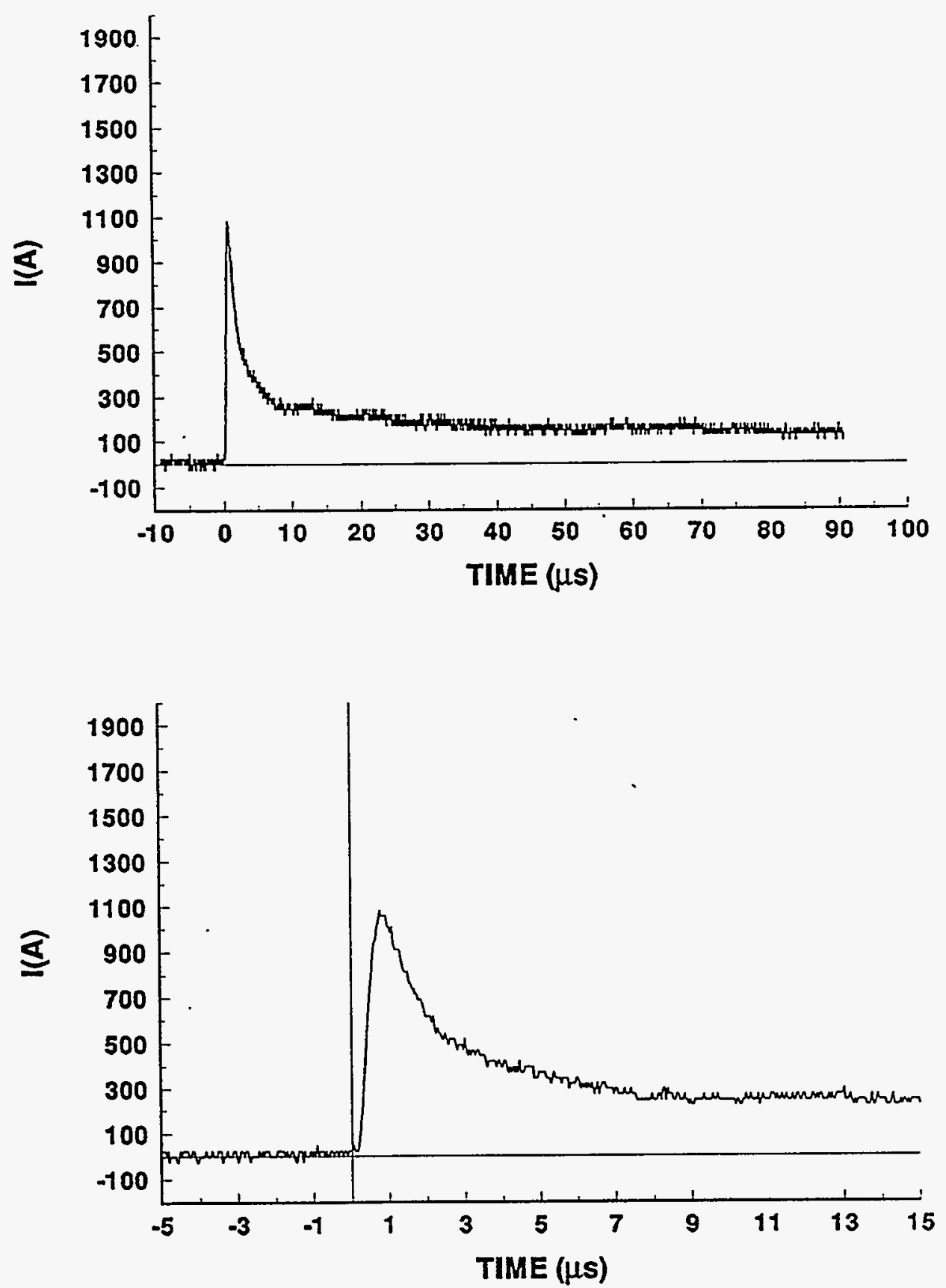


\section{4-06 STROKE 1}

TEST POINT 6'

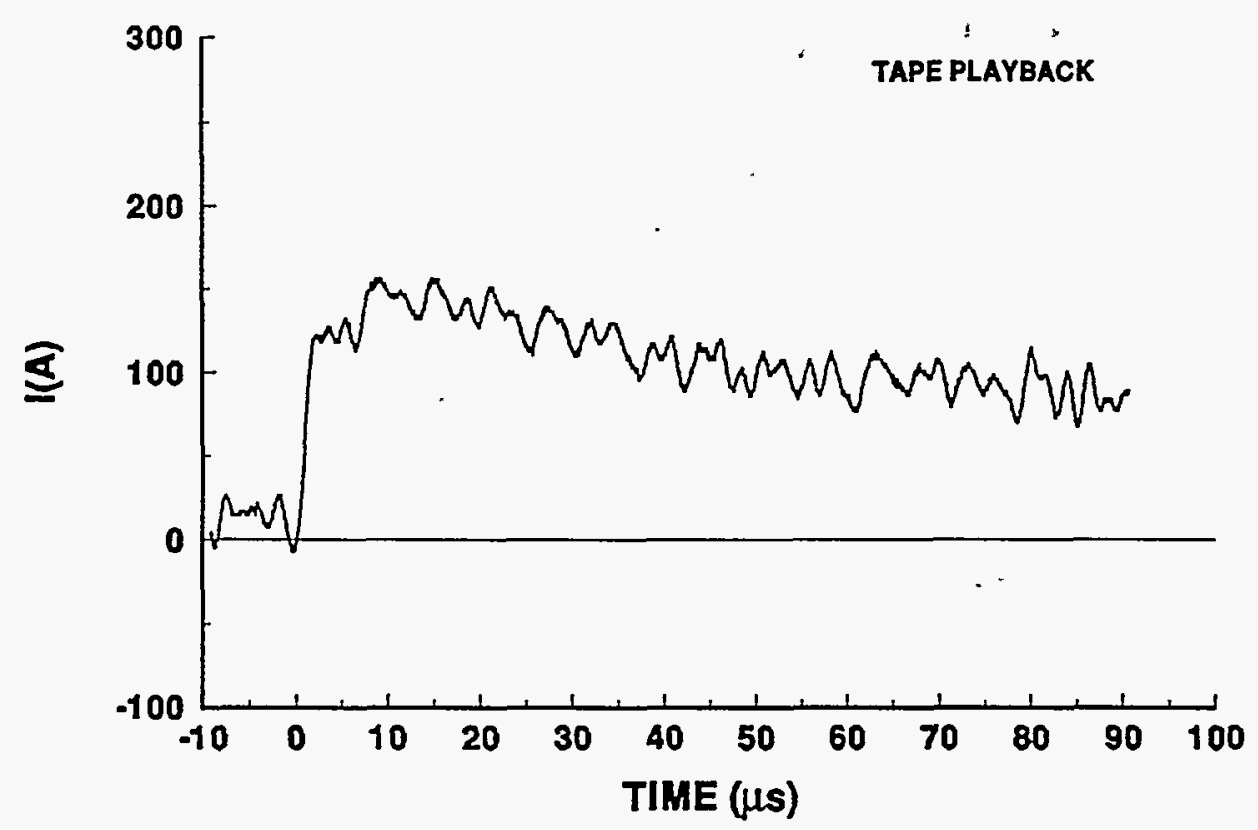


94-06 STROKE 1

TEST POINT 7
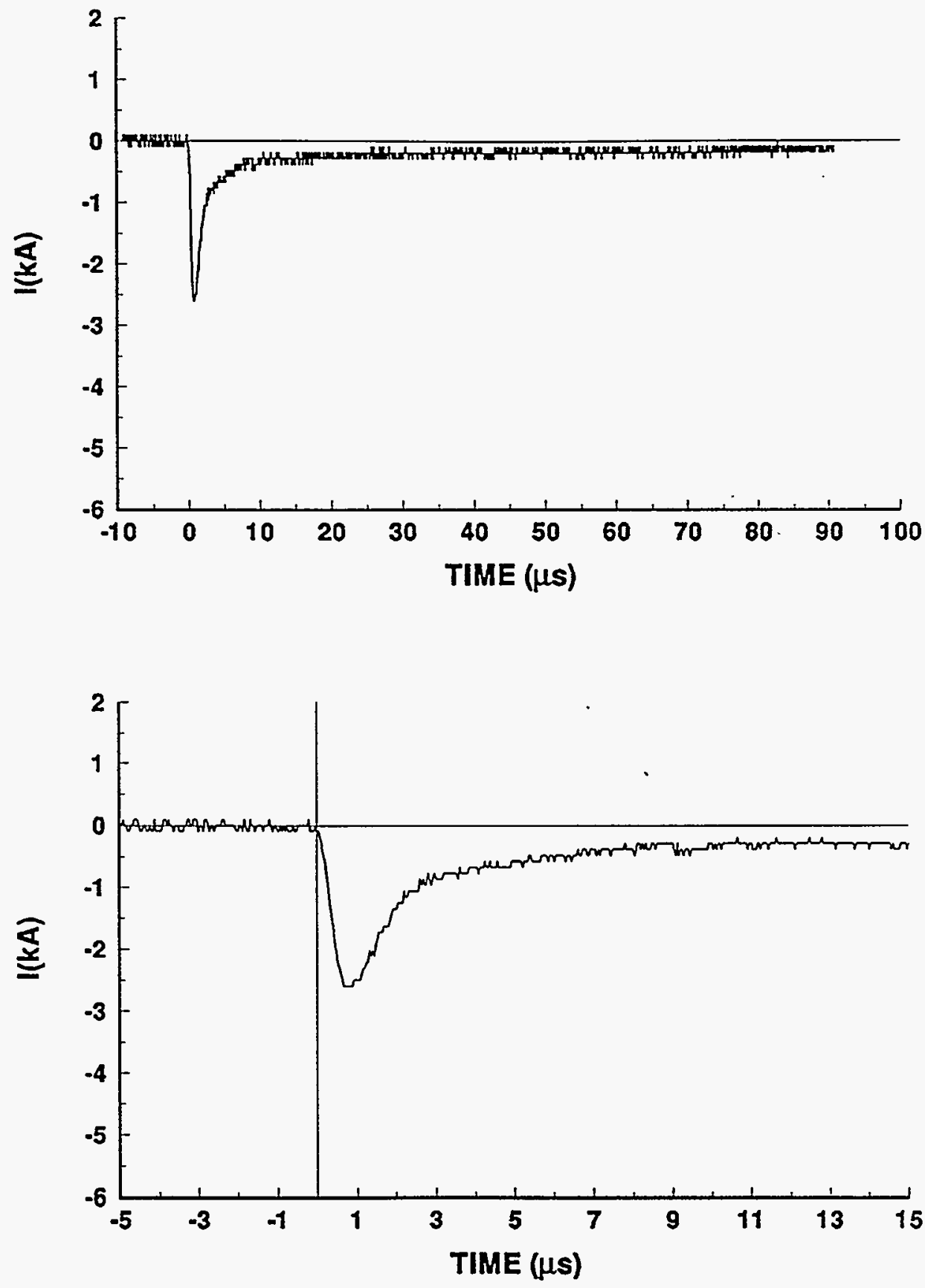


\section{4-06 STROKE 1}

TEST POINT 8
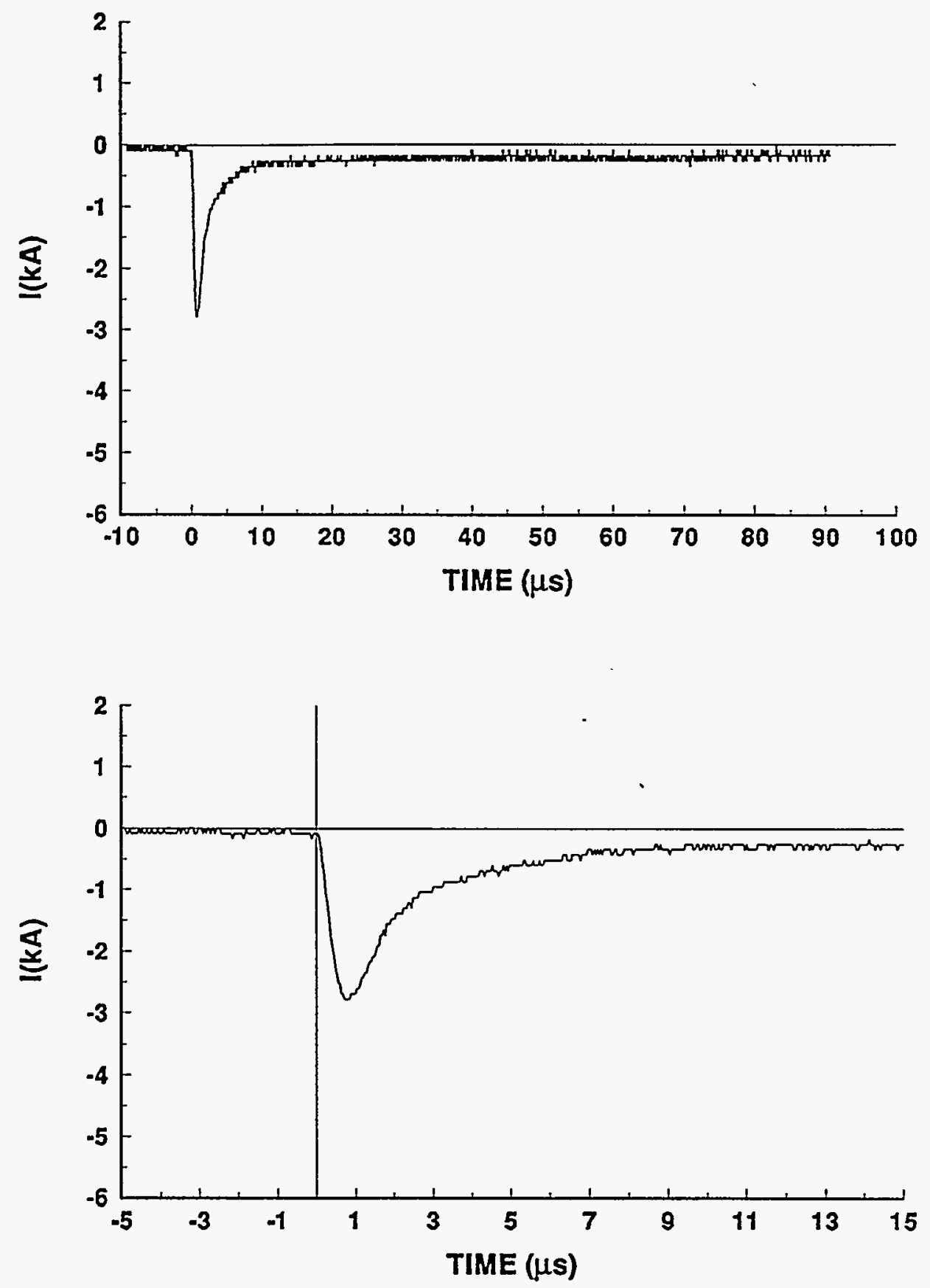
94-06 STROKE 1

TEST POINT 10

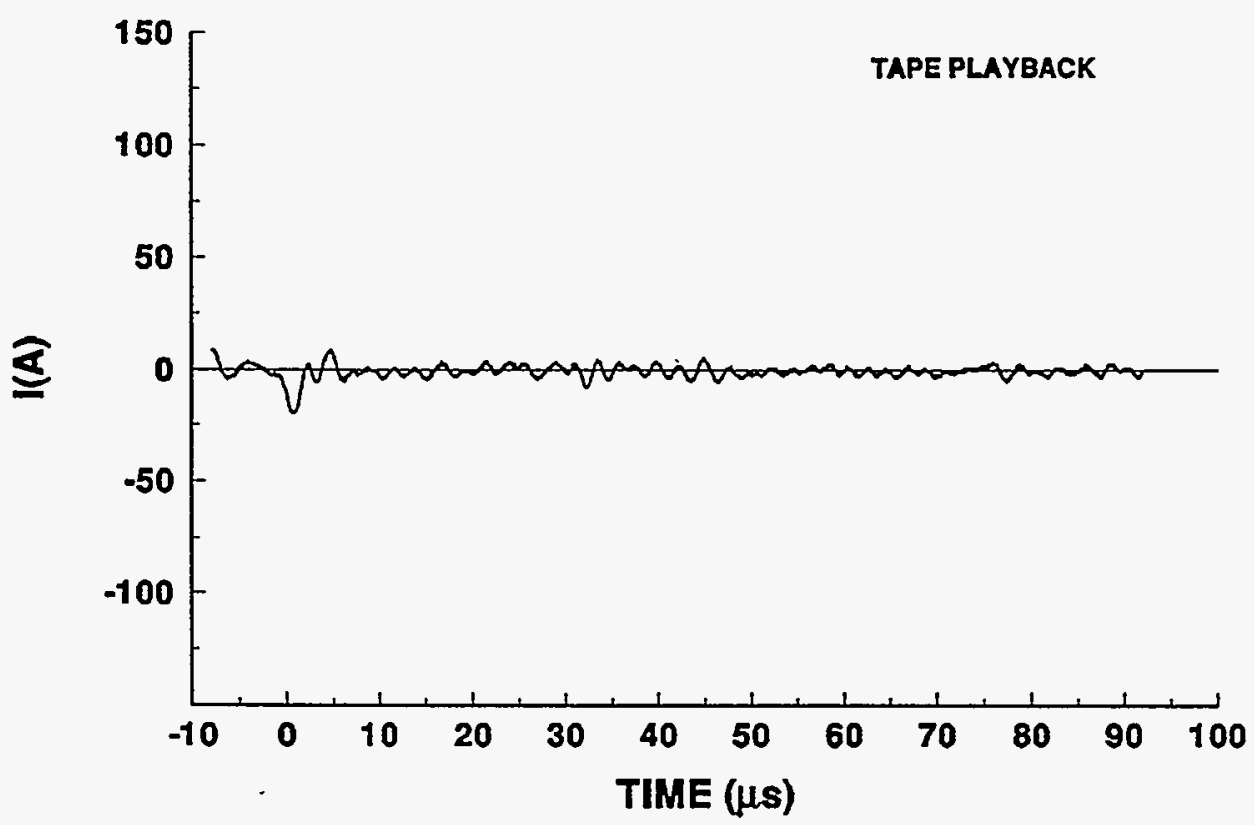

94-06 STROKE 1

TEST POINT 11

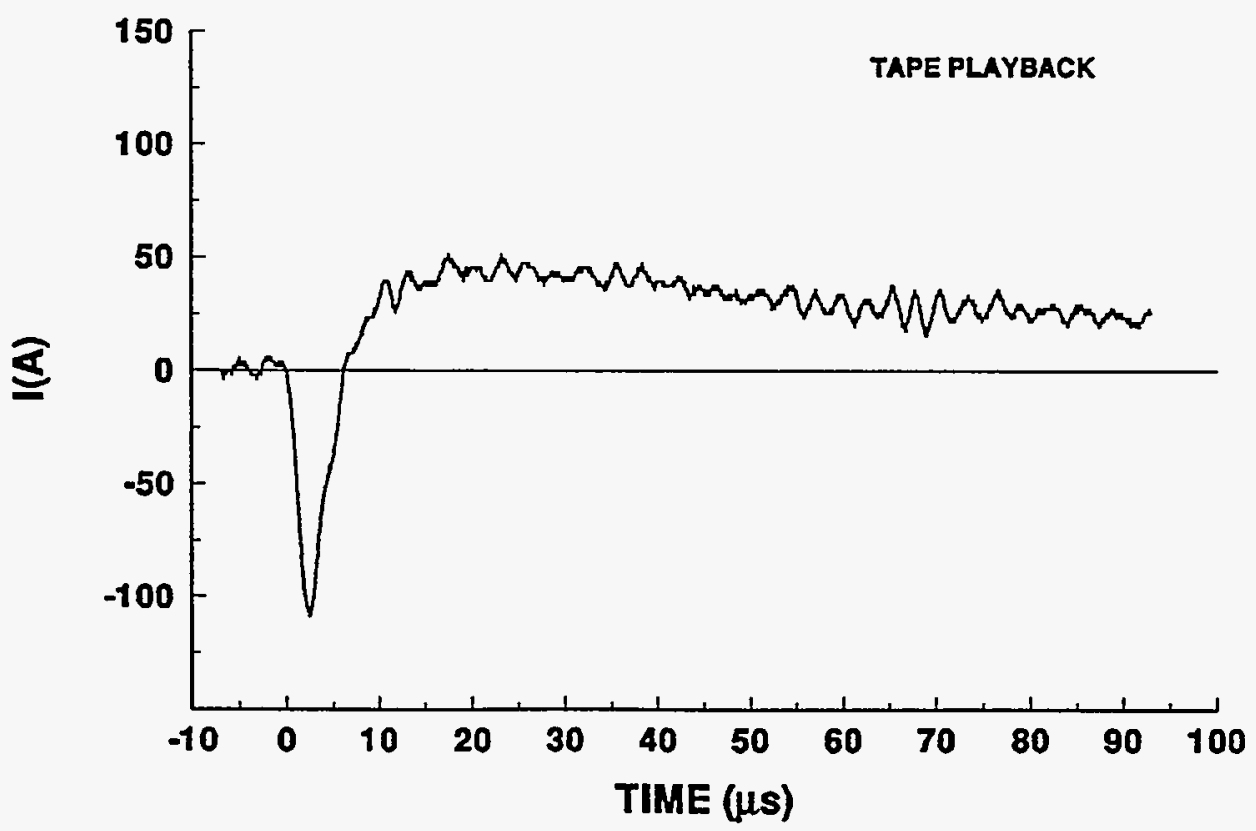




\section{4-06 STROKE 1}

TEST POINT 12

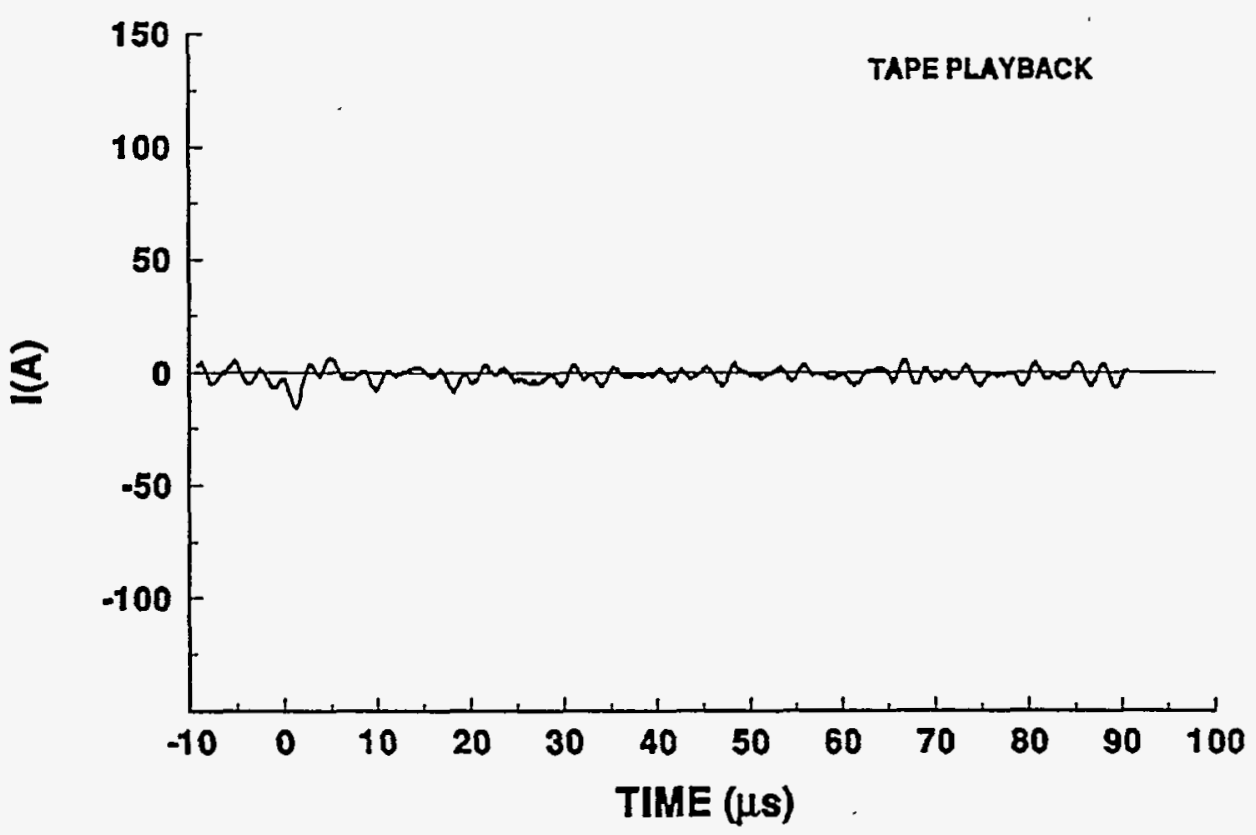

\section{4-06 STROKE 1}

TEST POINT 13

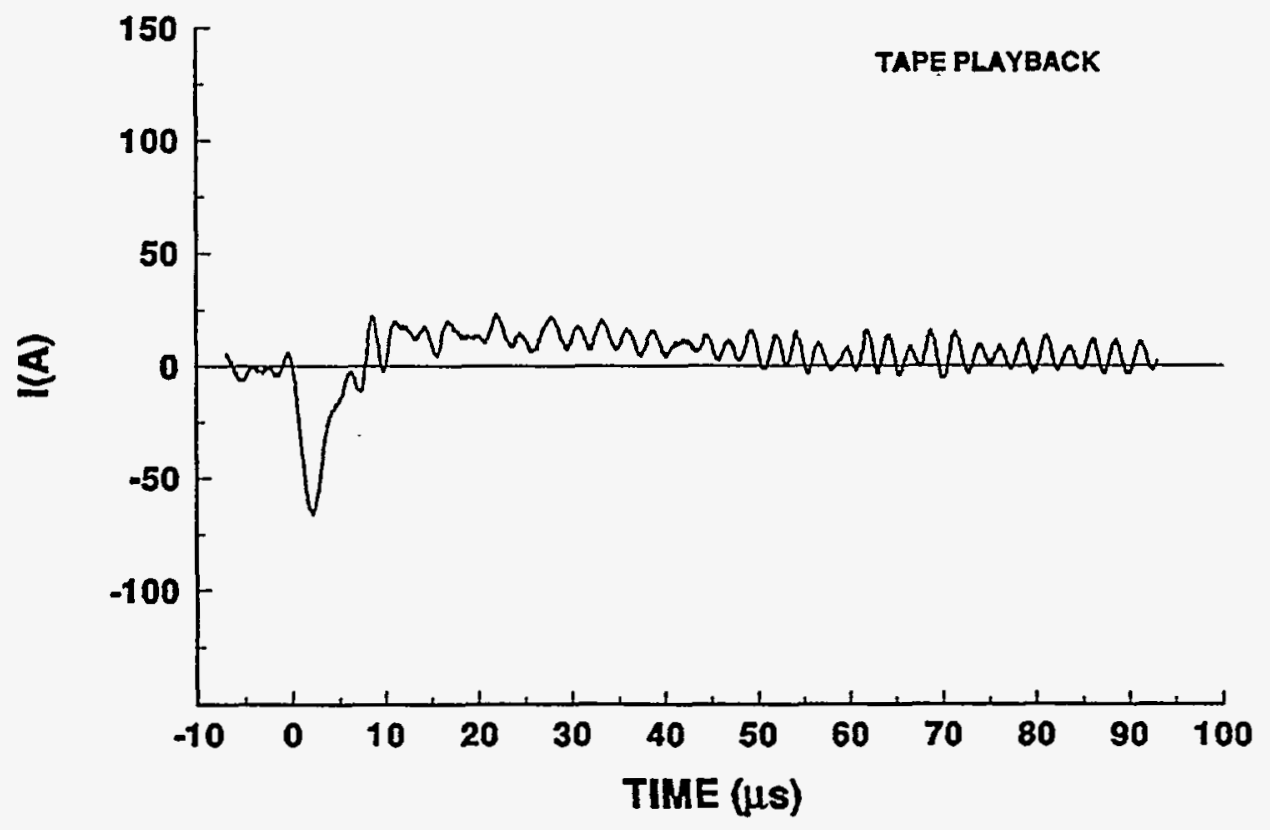




\section{4-06 STROKE 1}

TEST POINT 14
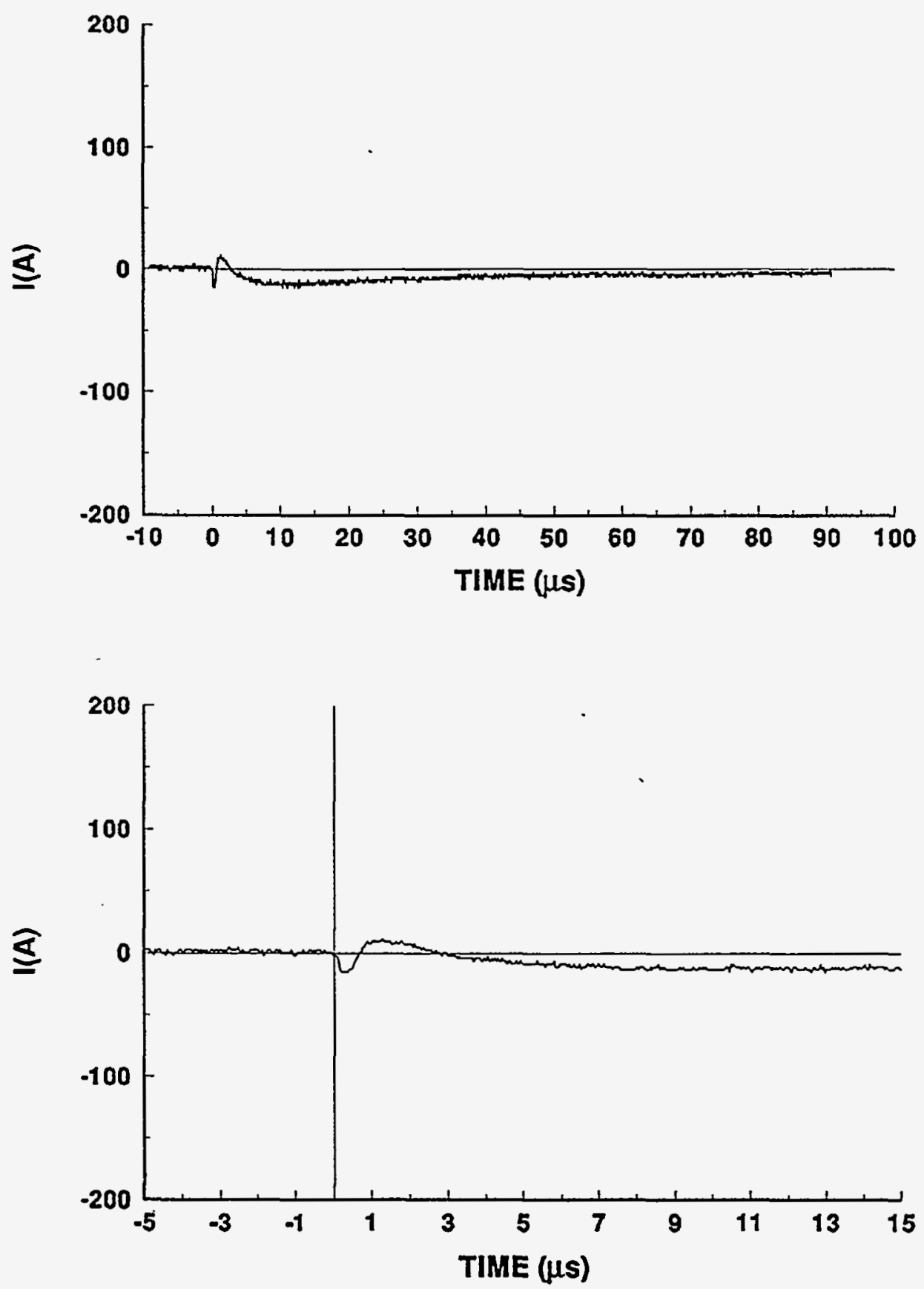


\section{4-06 STROKE 1}

\section{TEST POINT 15}
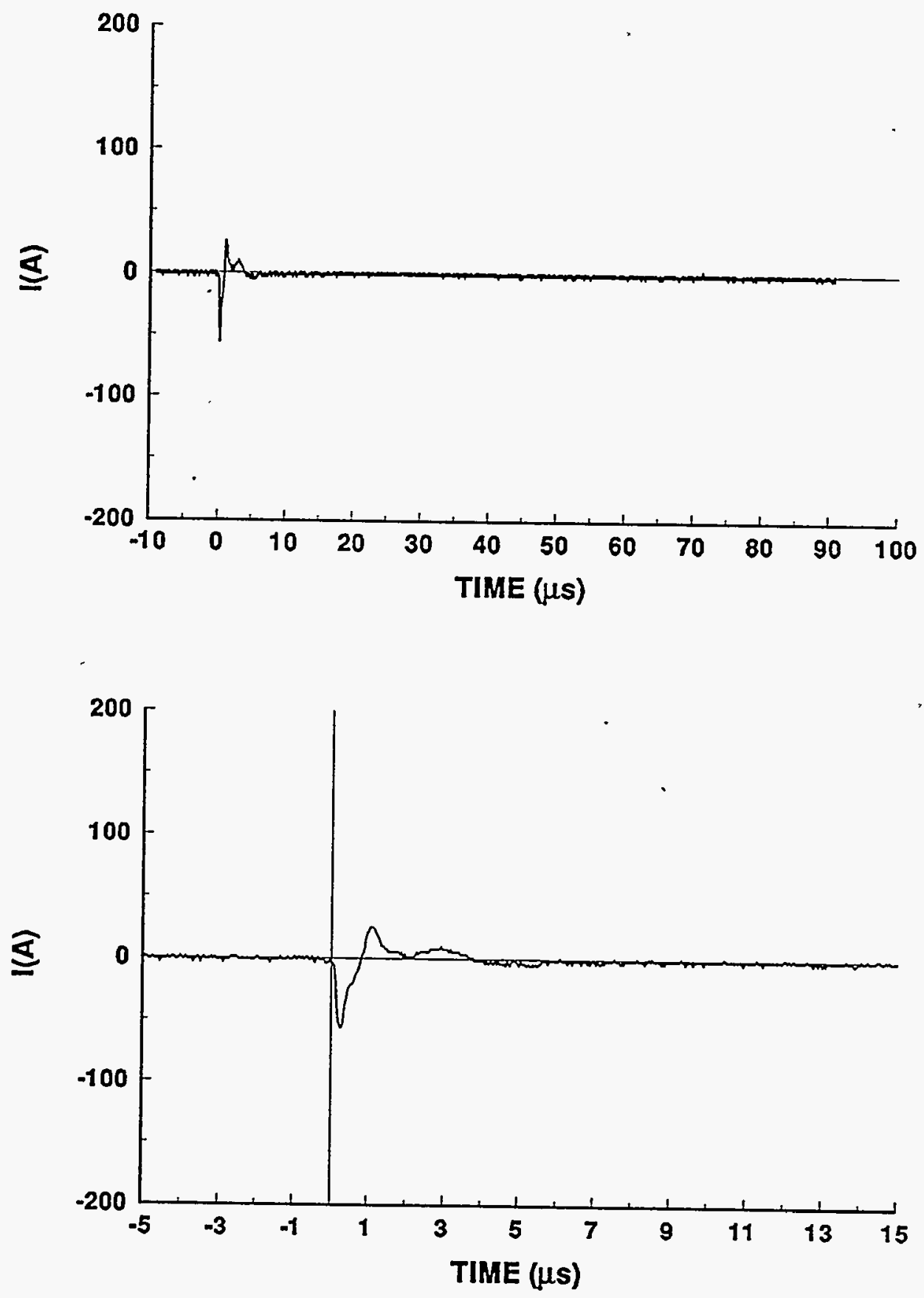
94-06 STROKE 1

TEST POINT 20

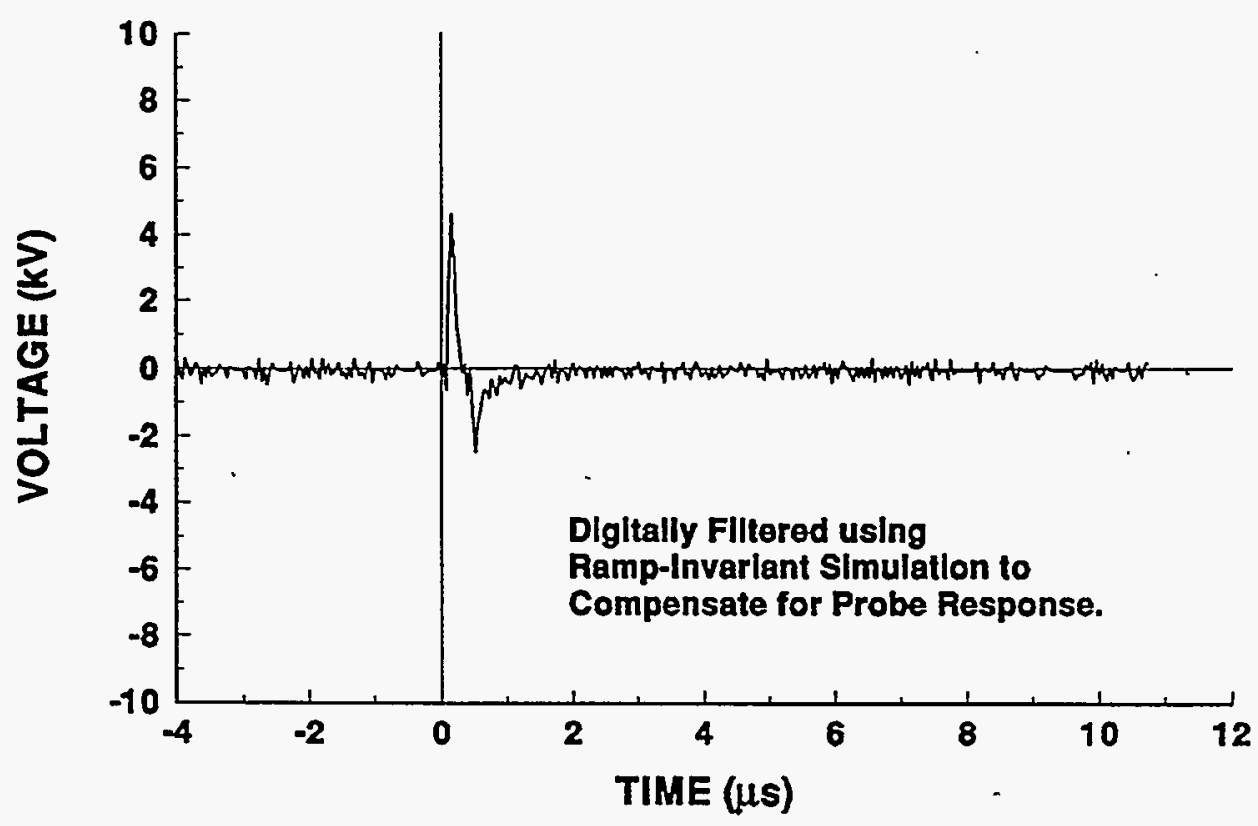

94-06 STROKE 1

TEST POINT 21

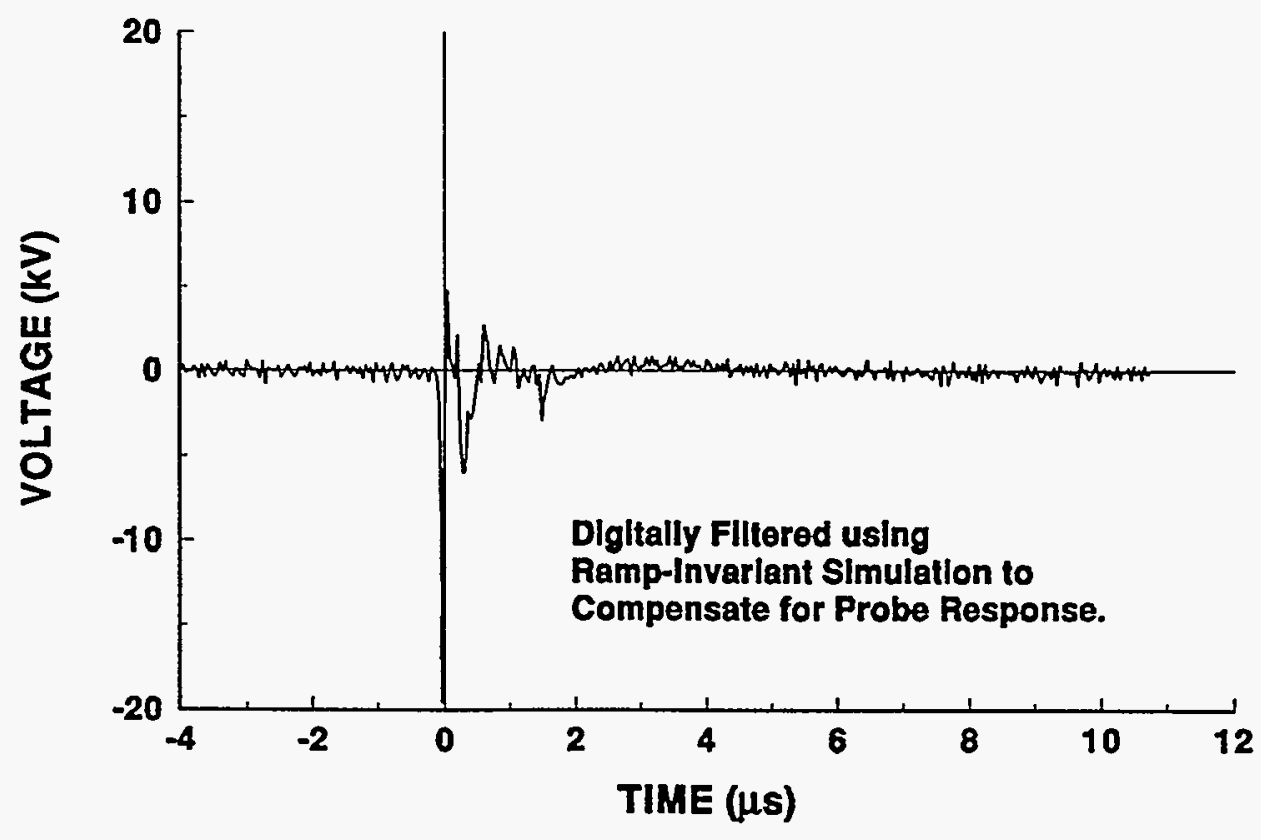




\section{4-06 STROKE 1}

TEST POINT 23

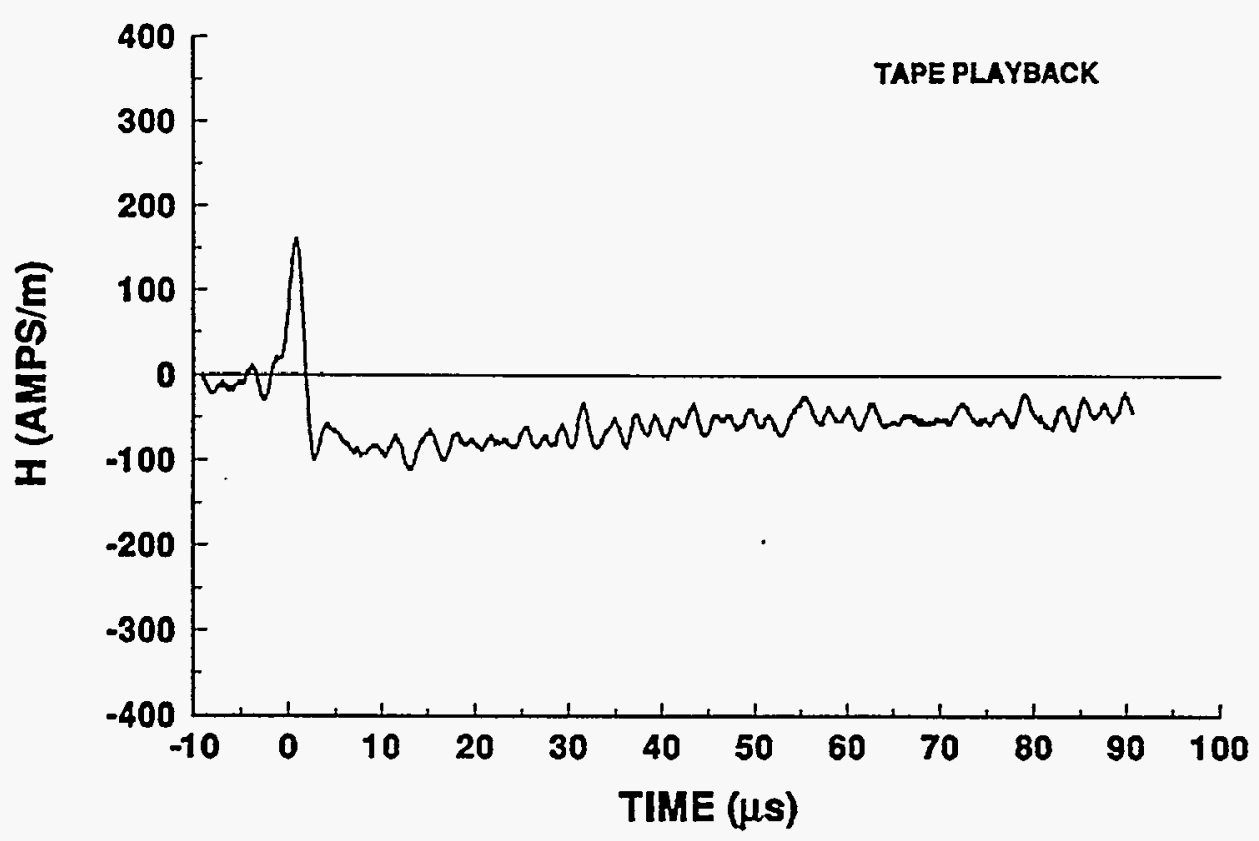




\section{4-06 STROKE 2 \\ INCIDENT CURRENT}
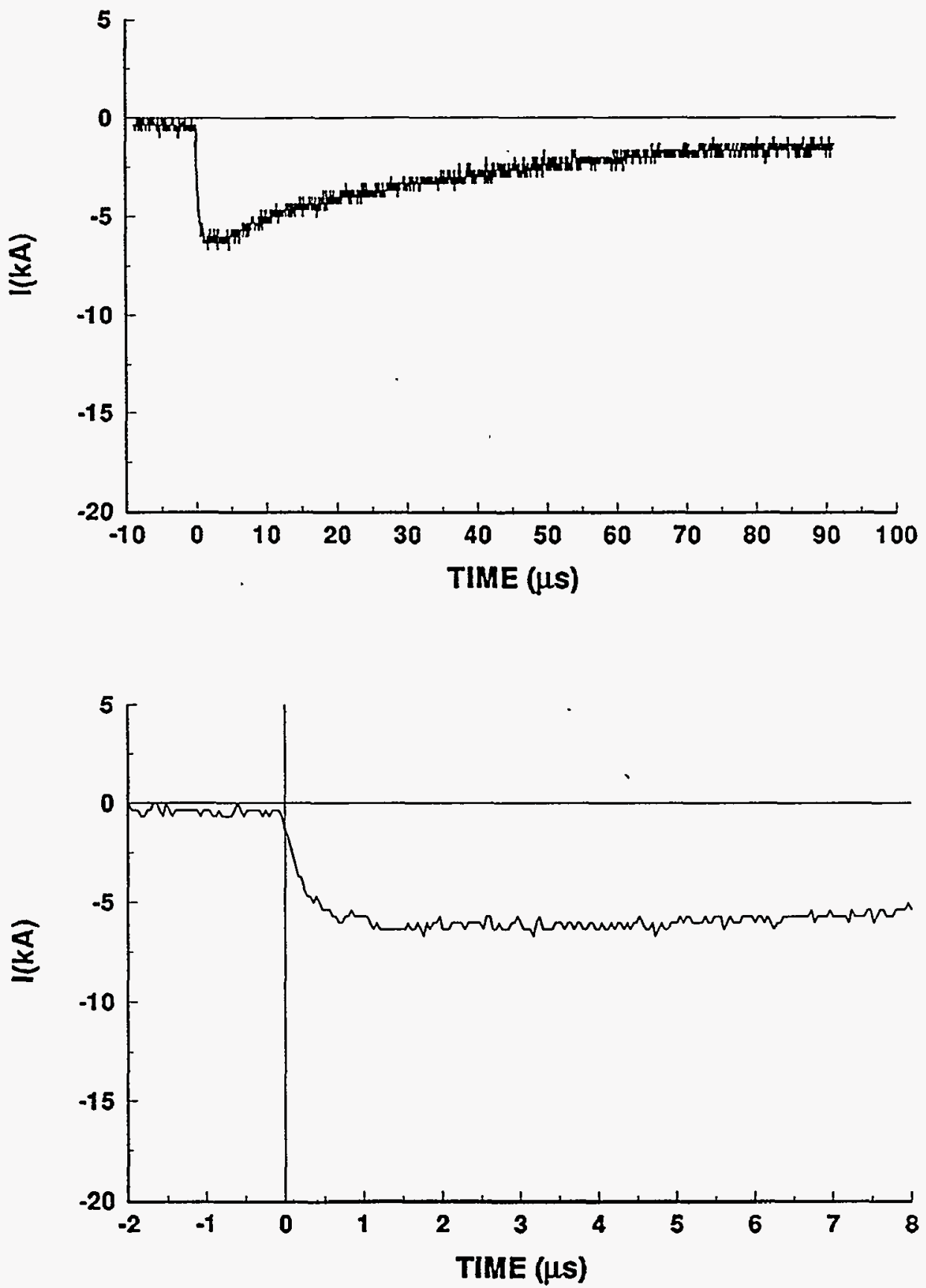


\section{4-06 STROKE 2}

TEST POINT 1

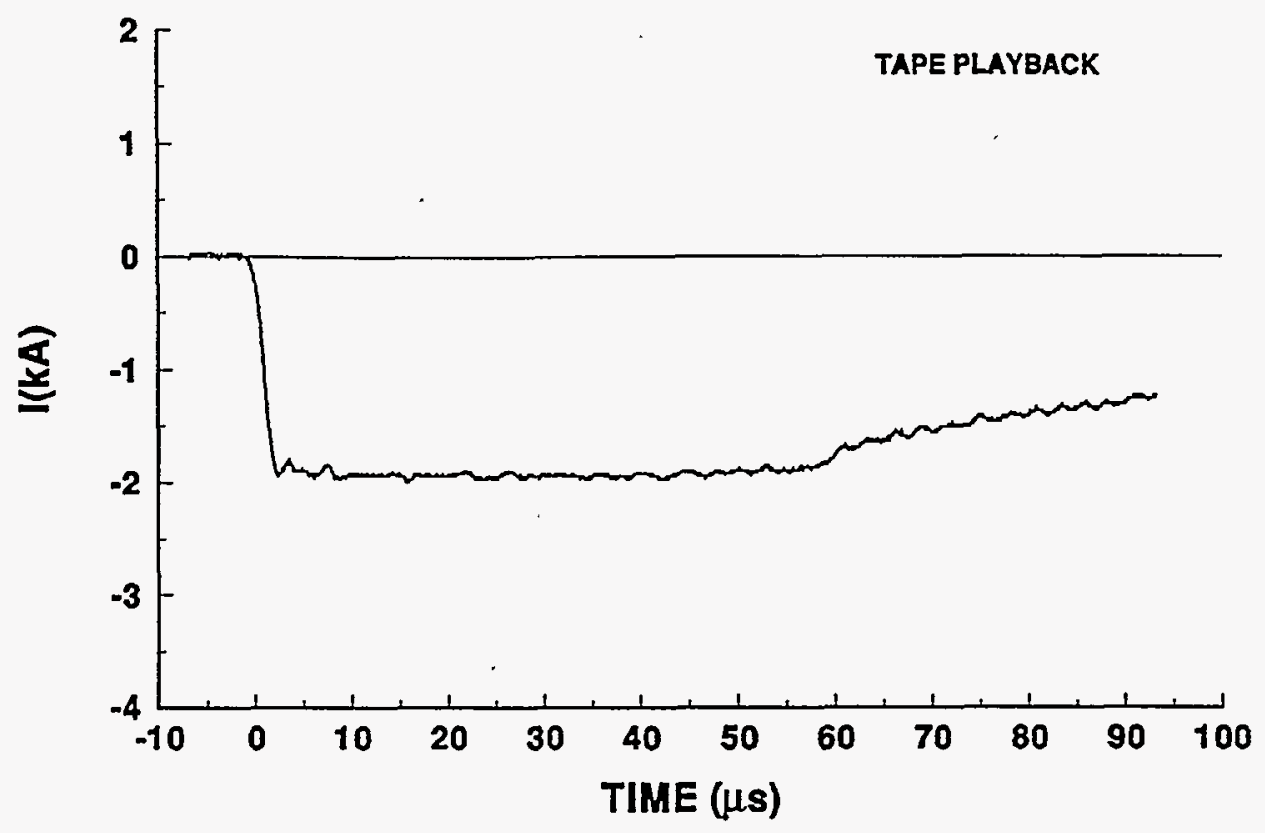

\section{4-02 STROKE 2 .}
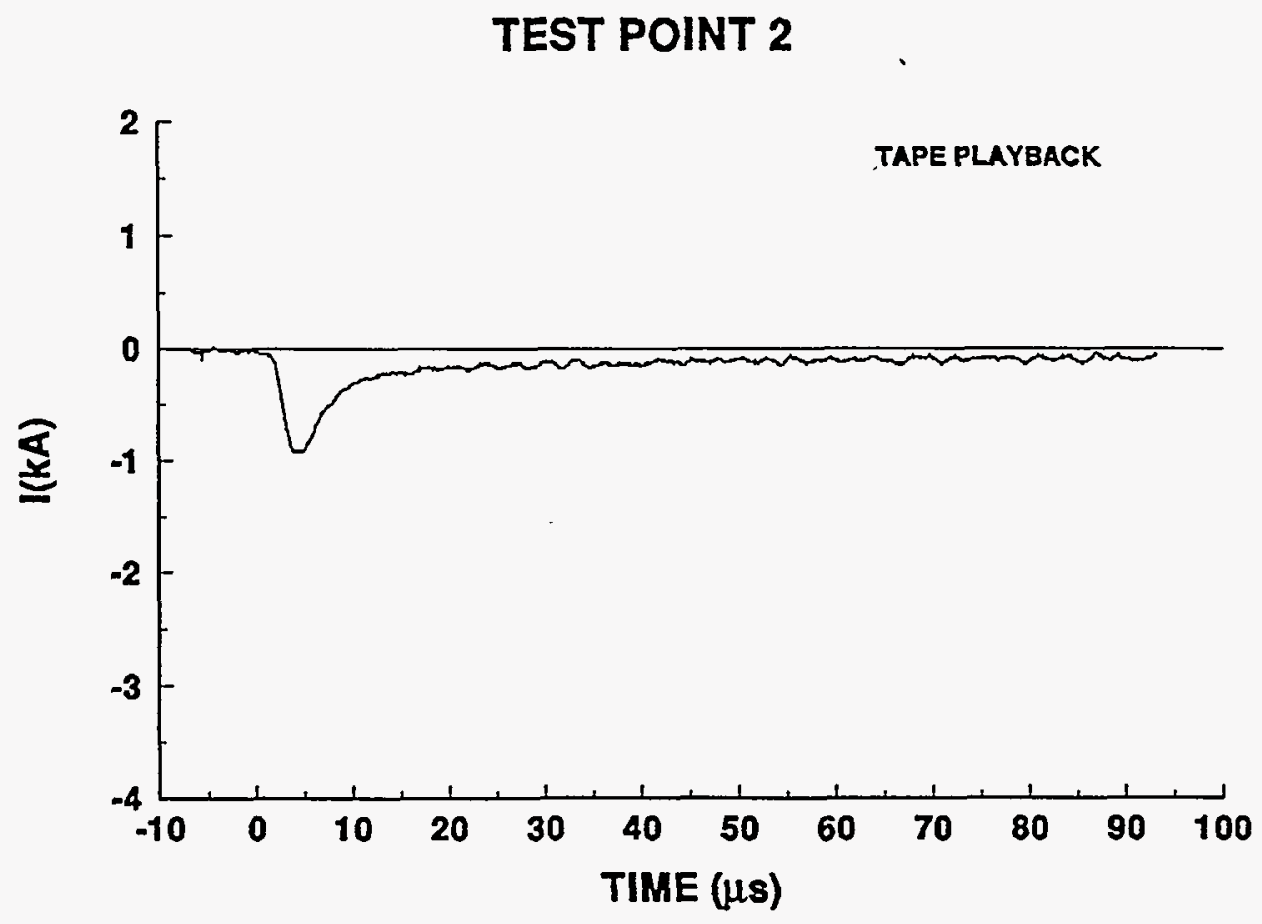
94-06 STROKE 2

TEST POINT 5
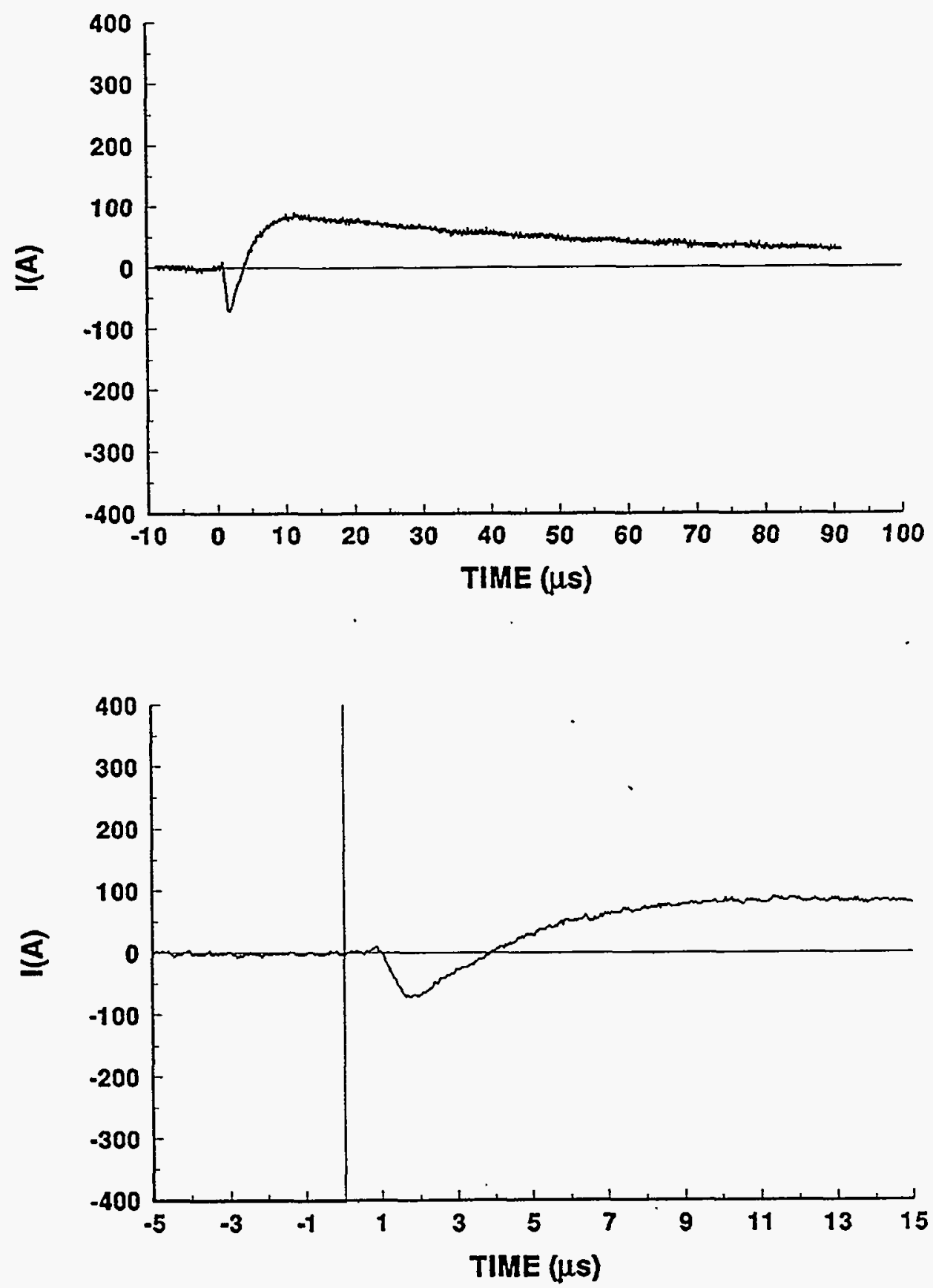


\section{4-06 STROKE 2}

\section{TEST POINT 5'}
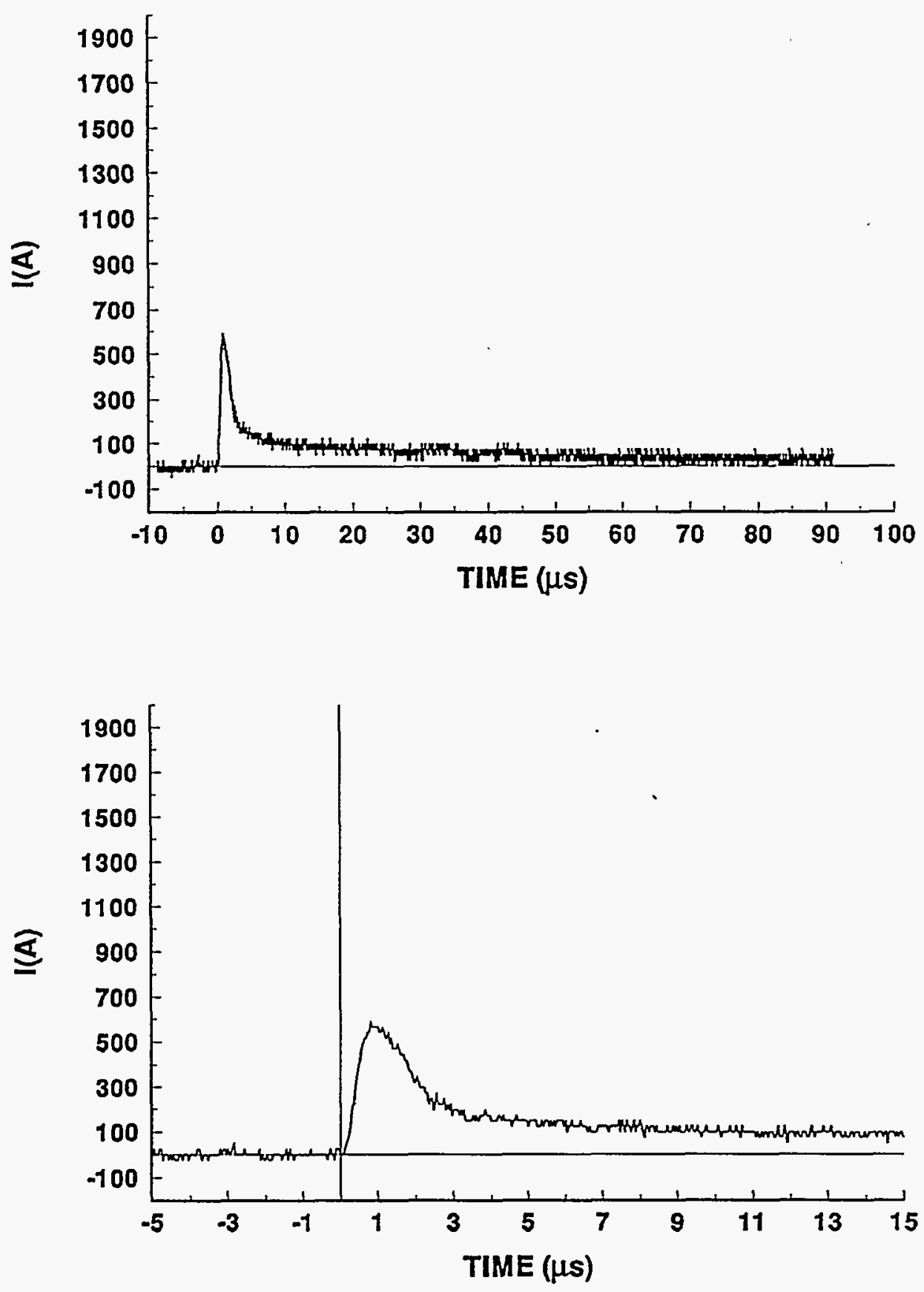


\section{4-06 STROKE 2}

TEST POINT 6'

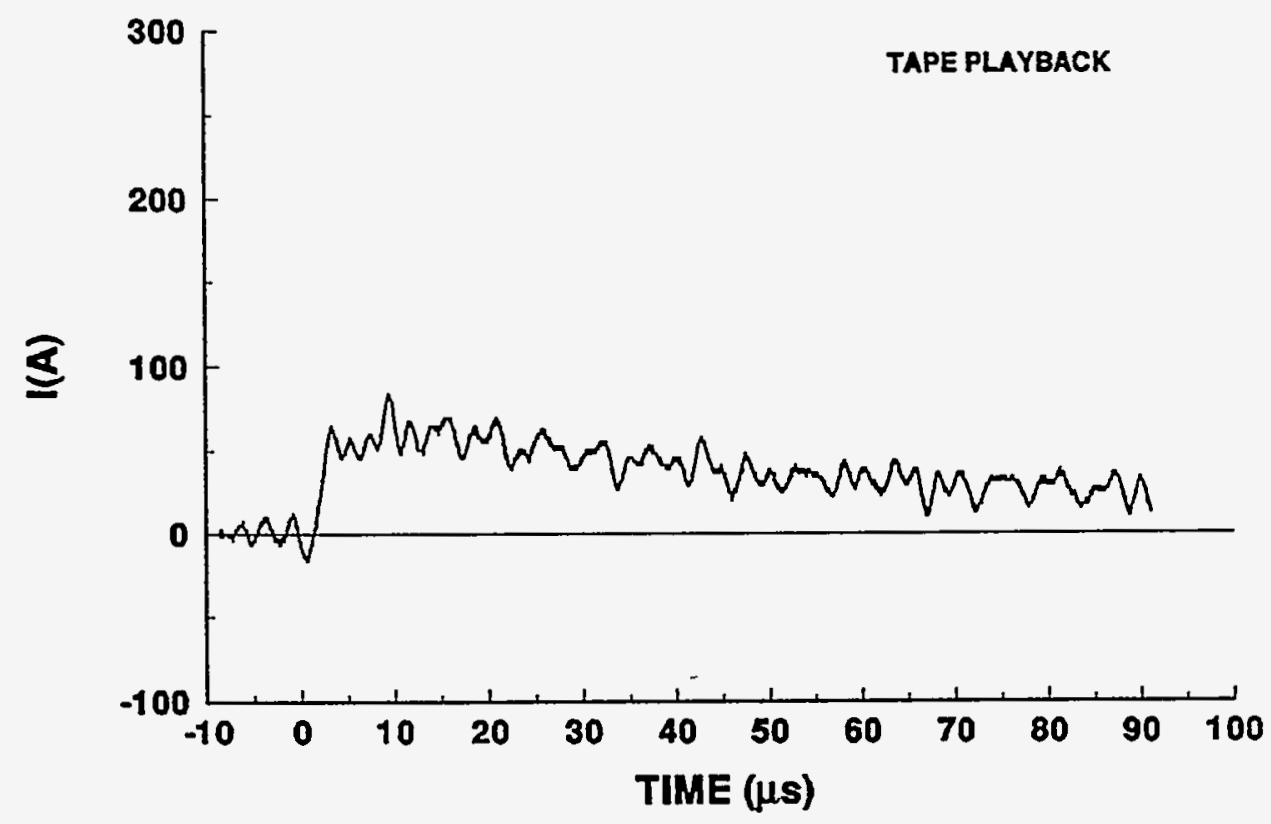




\section{4-06 STROKE 2}

TEST POINT 7
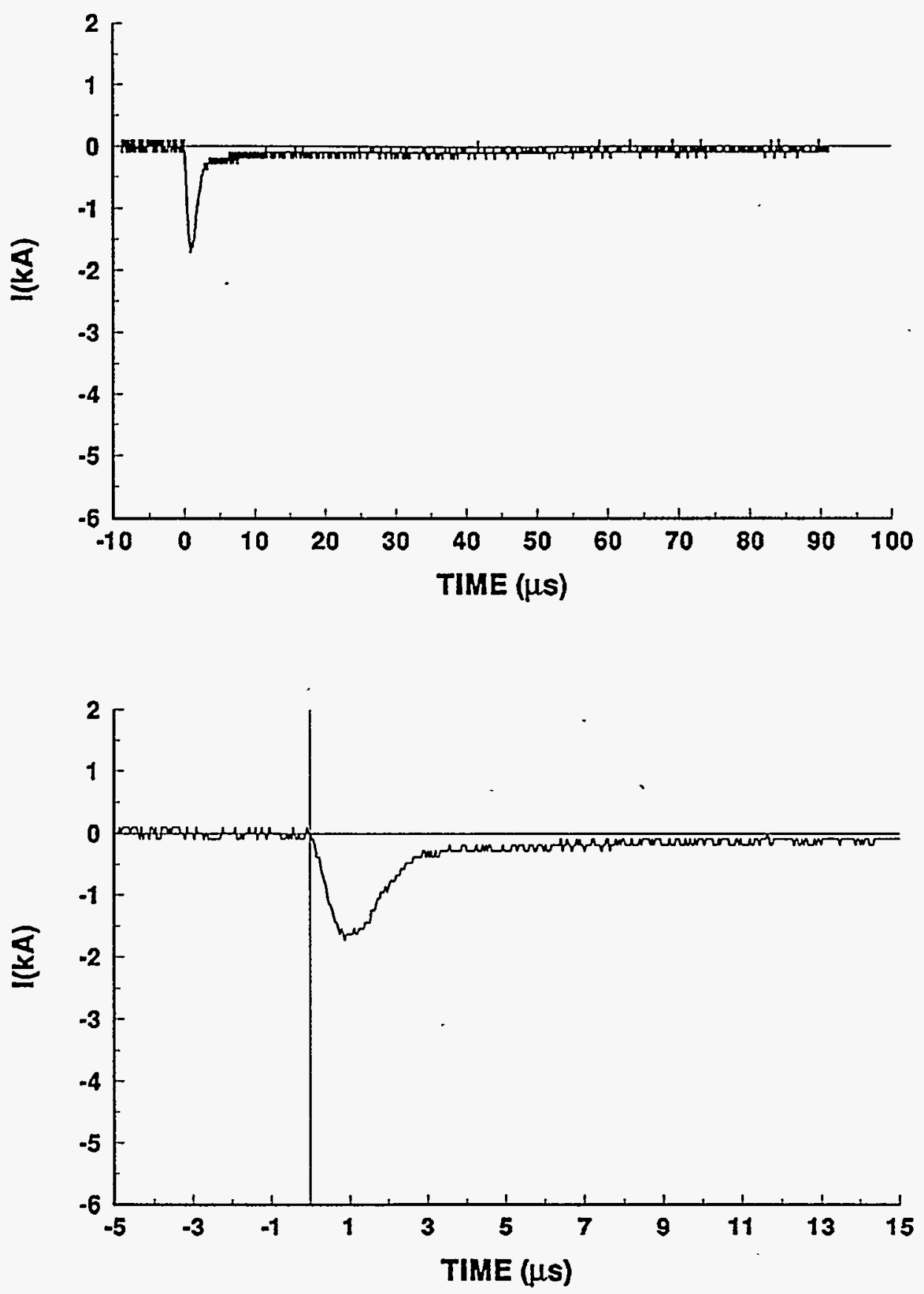


\section{4-06 STROKE 2}

TEST POINT 8
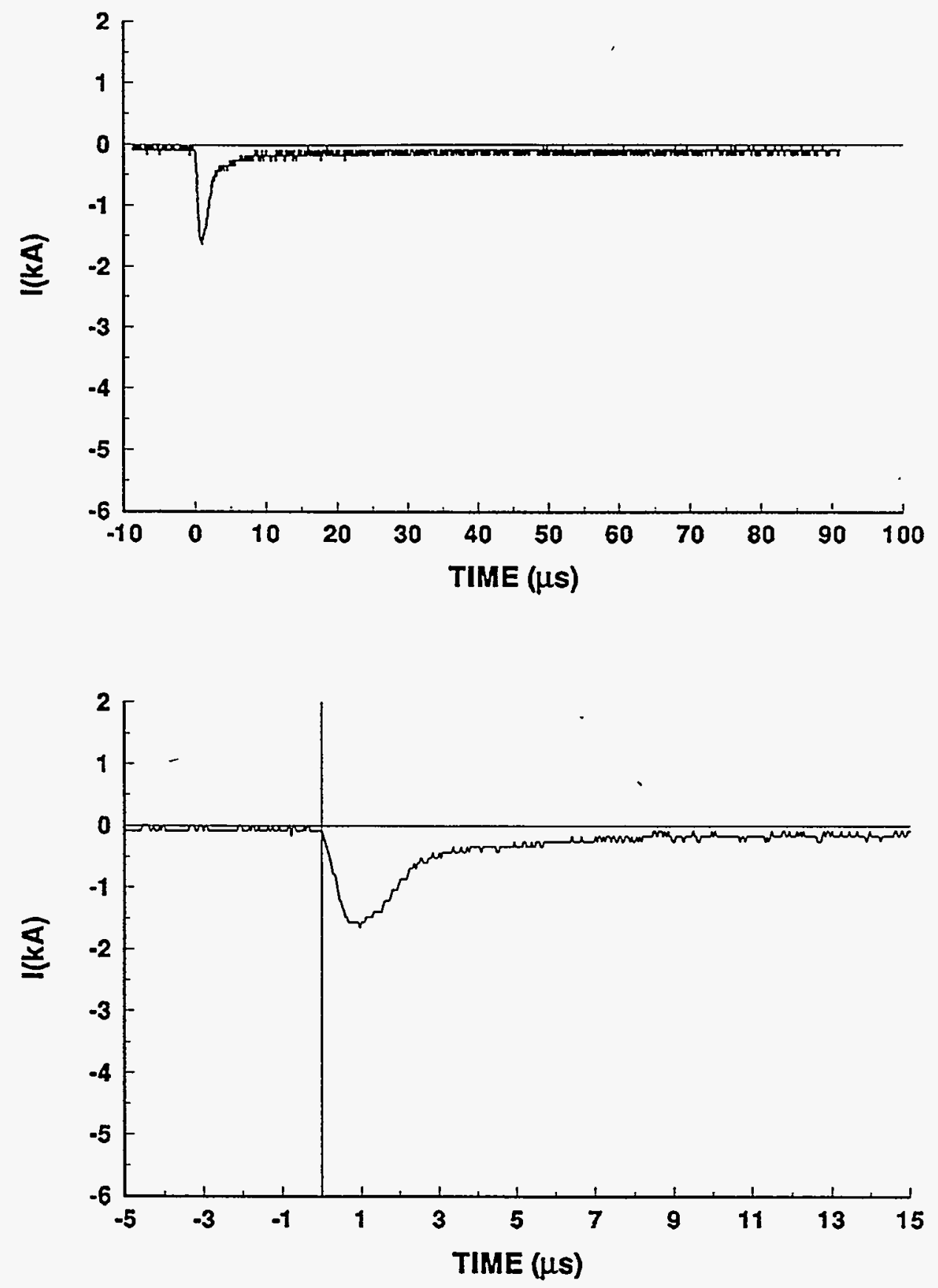


\section{4-06 STROKE 2}

\section{TEST POINT 10}

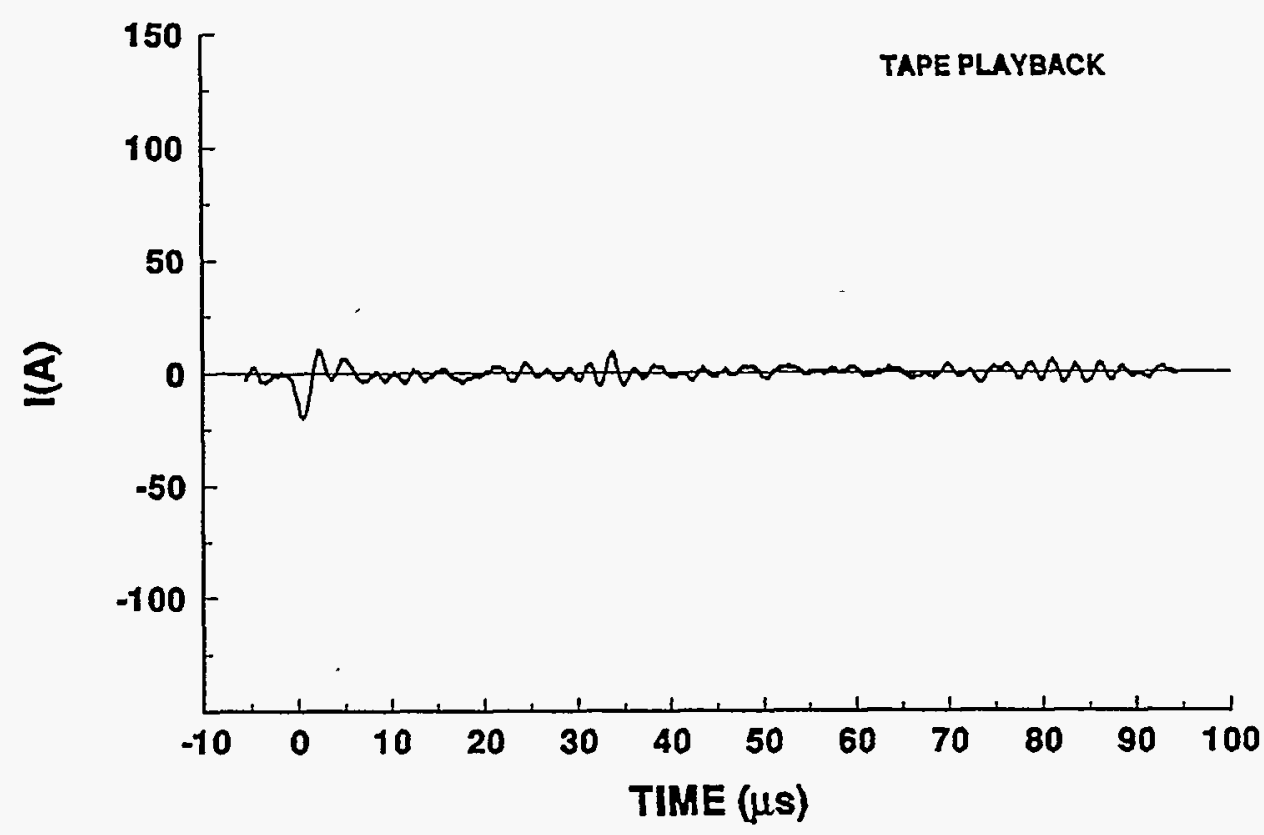

\section{4-06 STROKE 2}

\section{TEST POINT 11}

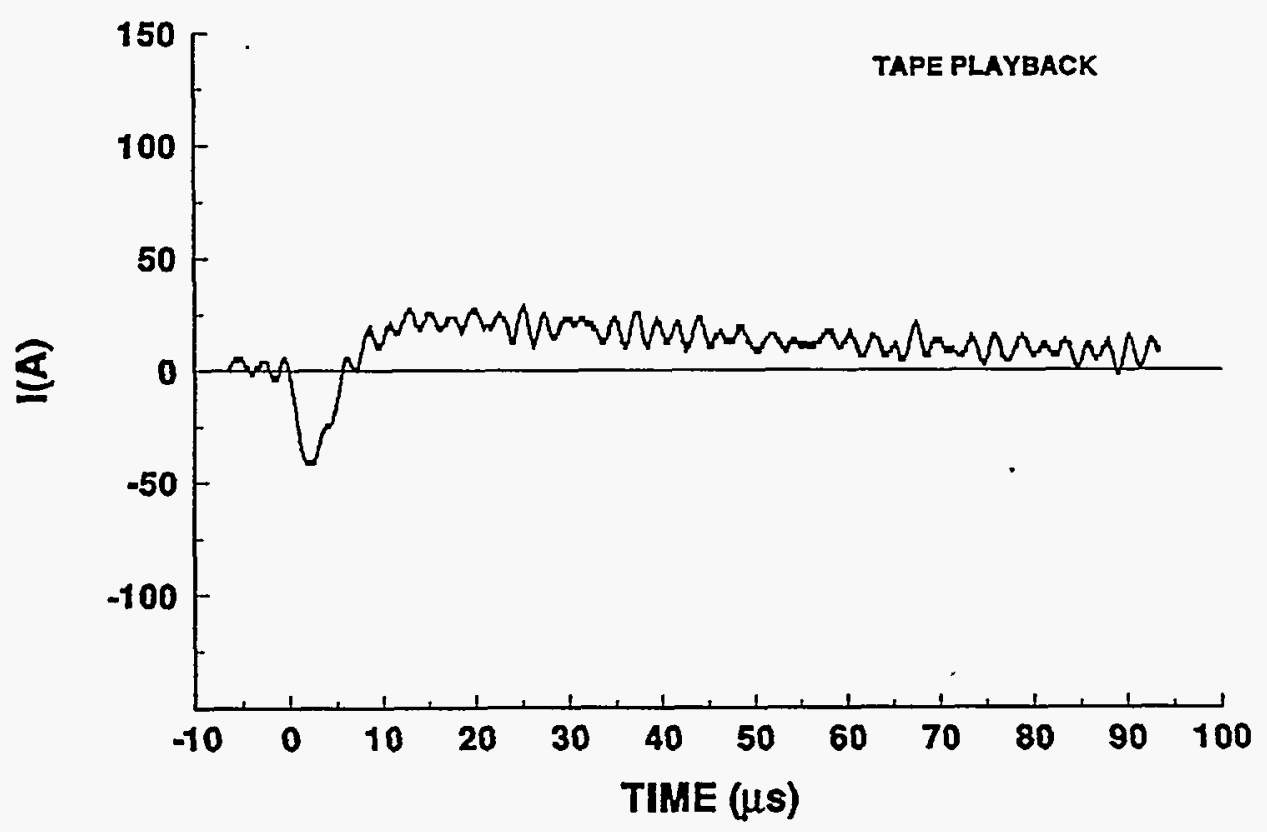




\section{4-06 STROKE 2}

TEST POINT 12

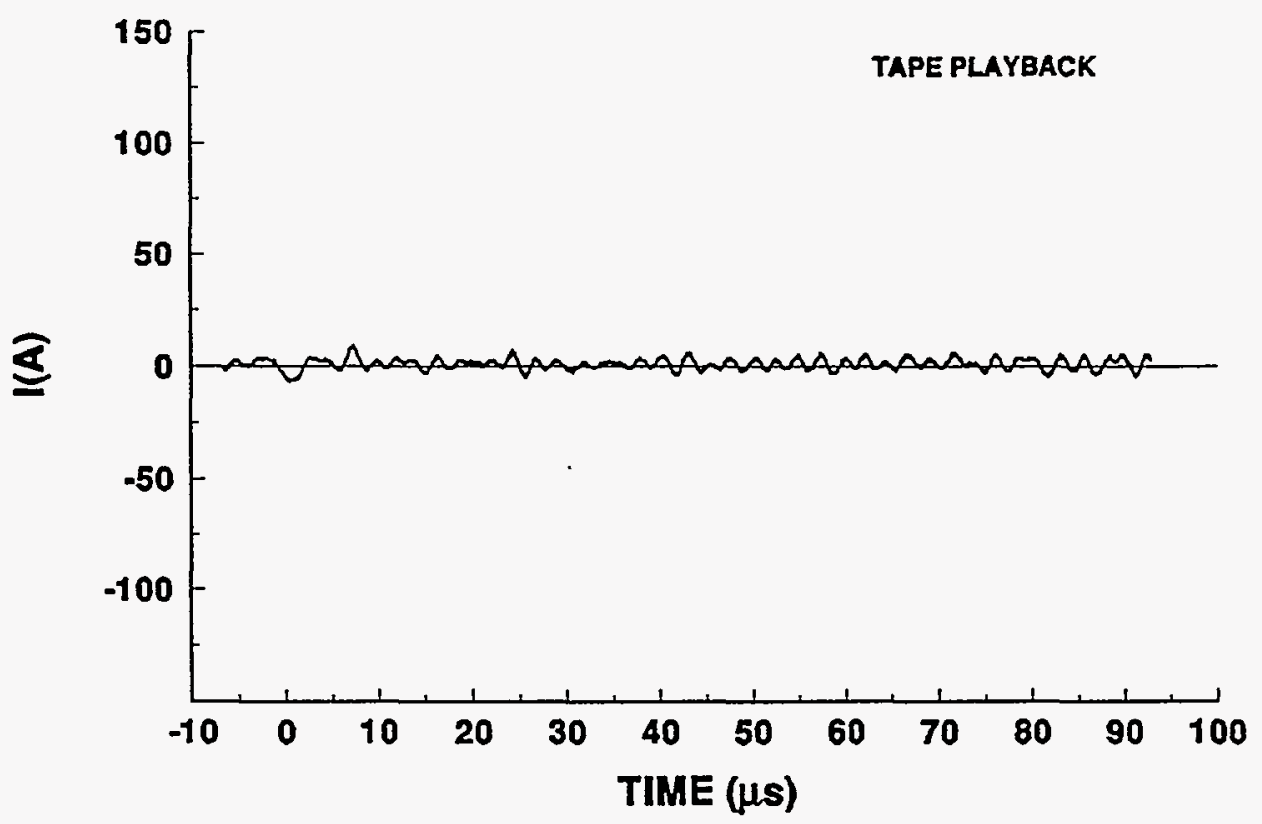

\section{4-06 STROKE 2}

TEST POINT 13

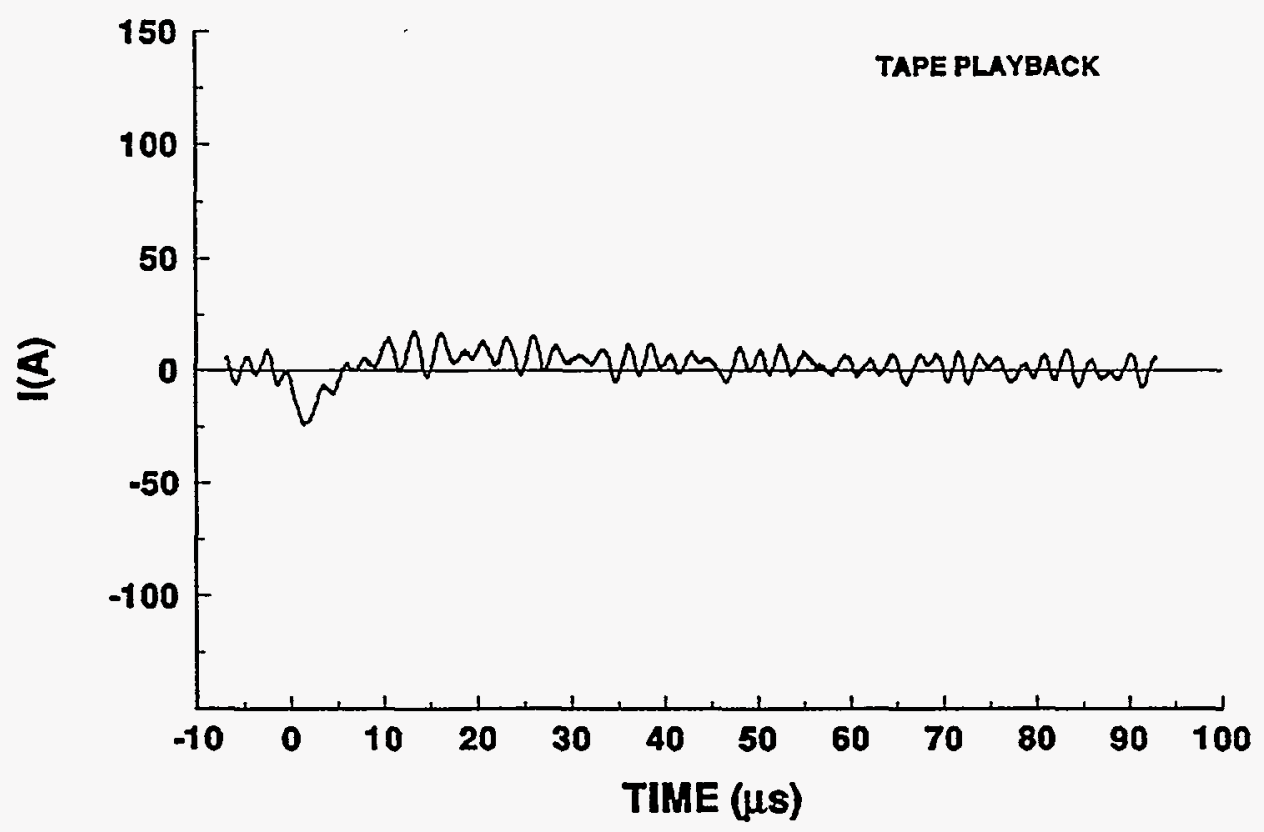




\section{4-06 STROKE 2}

TEST POINT 14
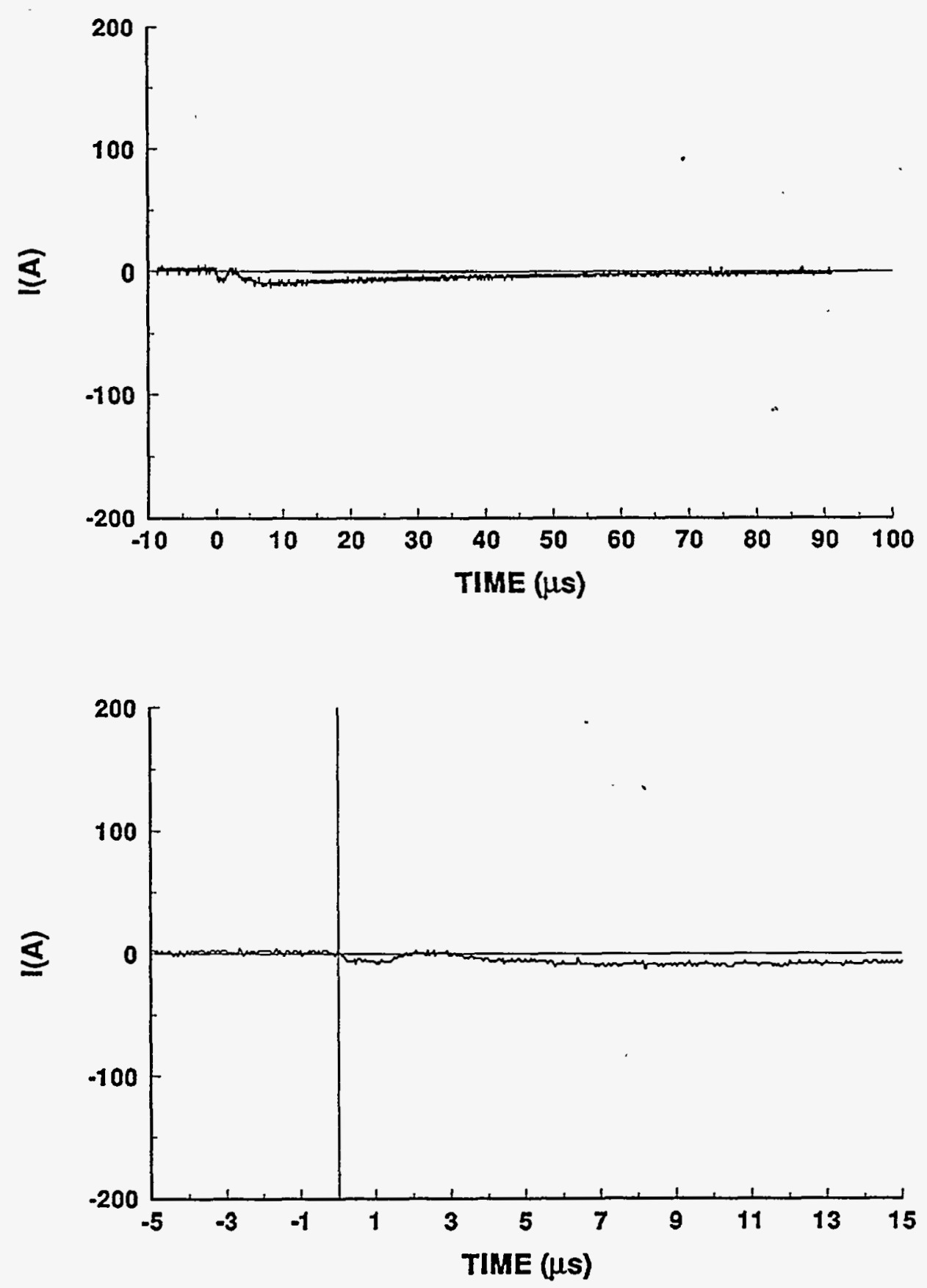
94-06 STROKE 2

TEST POINT 15
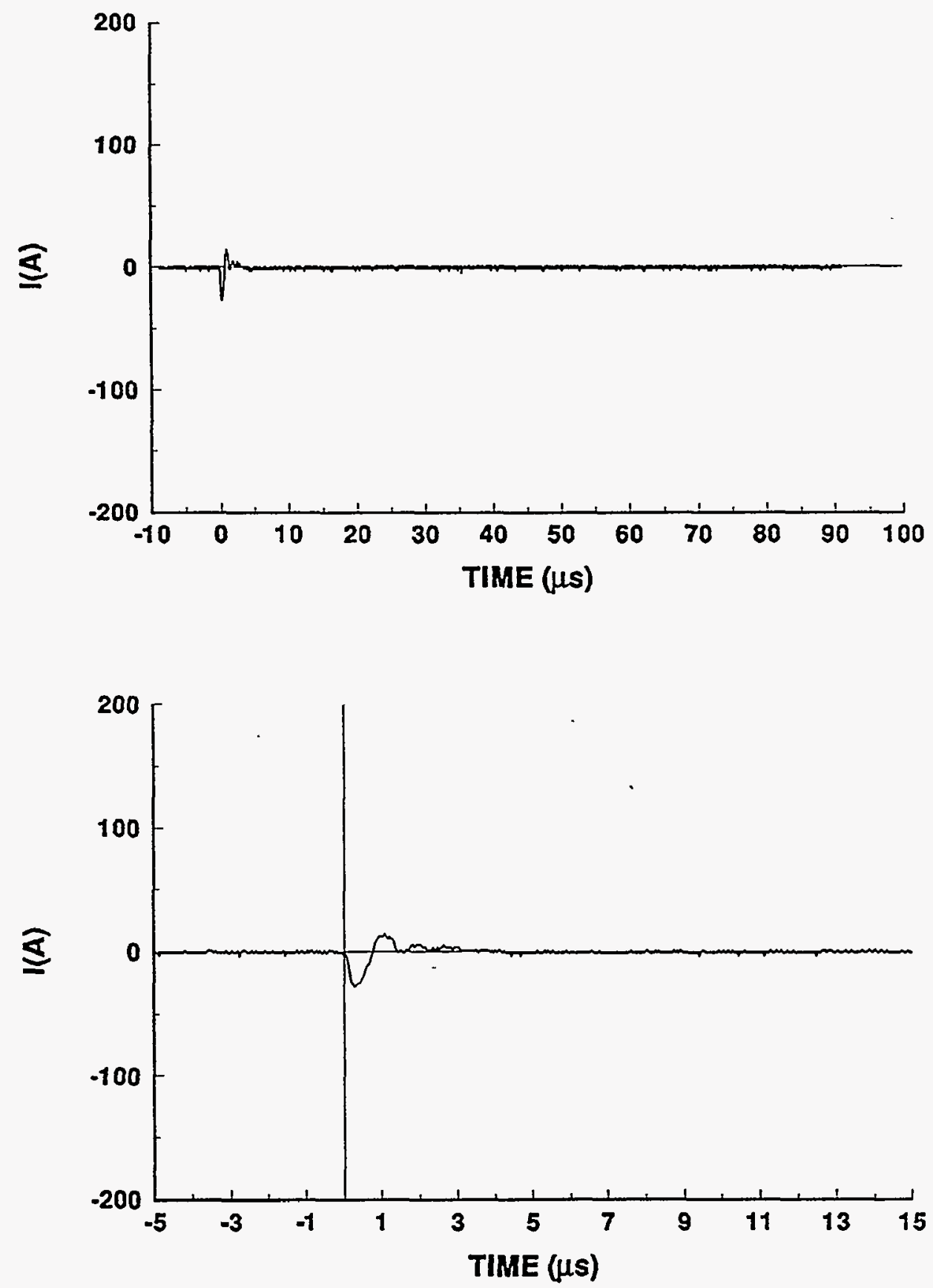


\section{4-06 STROKE 2}

TEST POINT 20

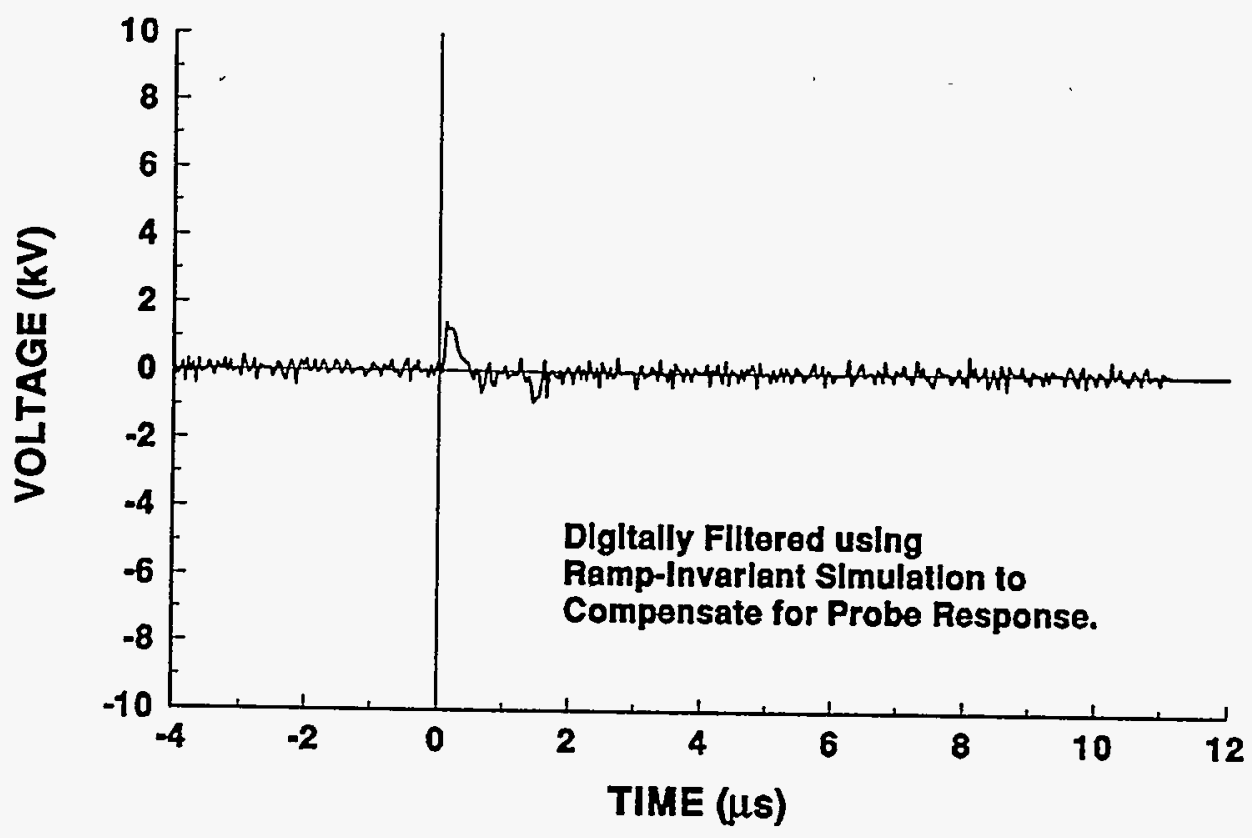

94-06 STROKE 2

TEST POINT 21

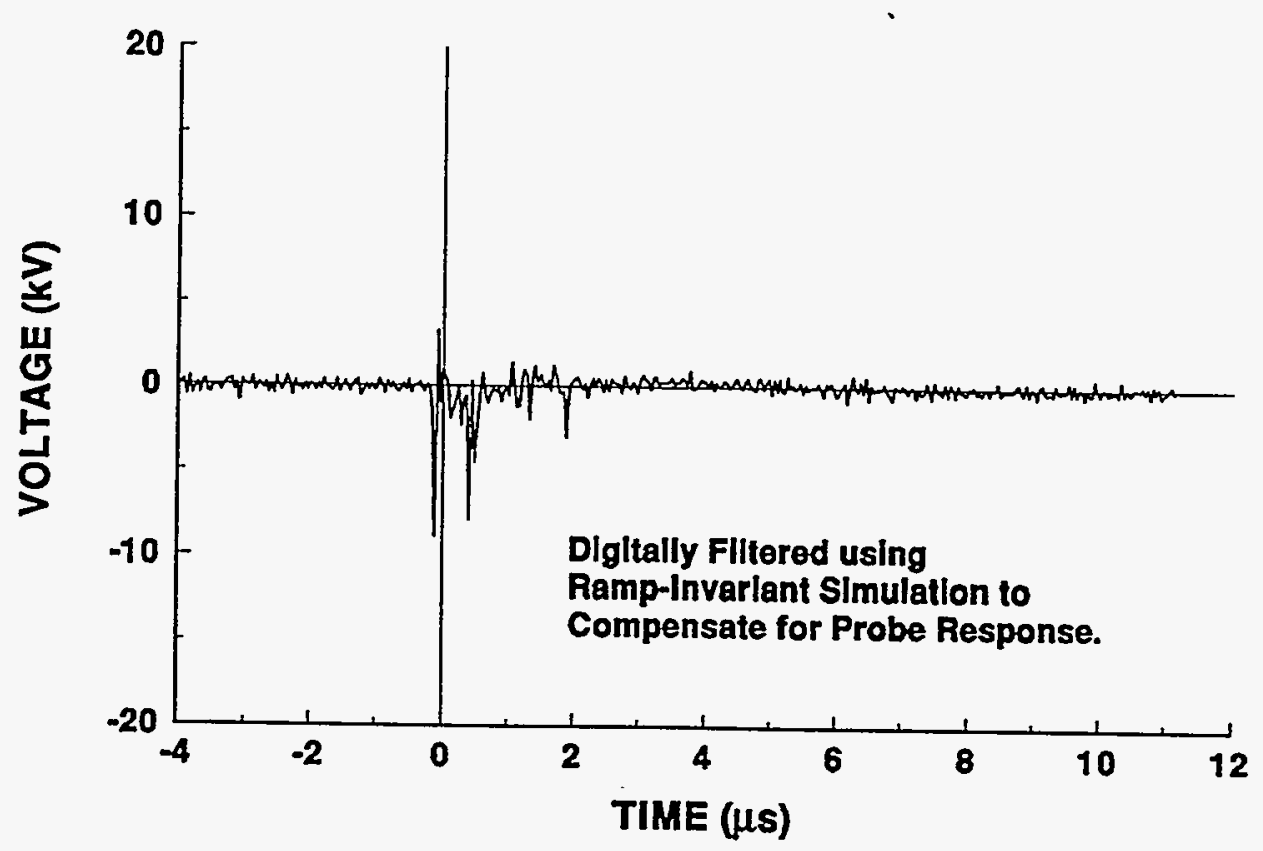




\section{4-06 STROKE 2}

TEST POINT 23

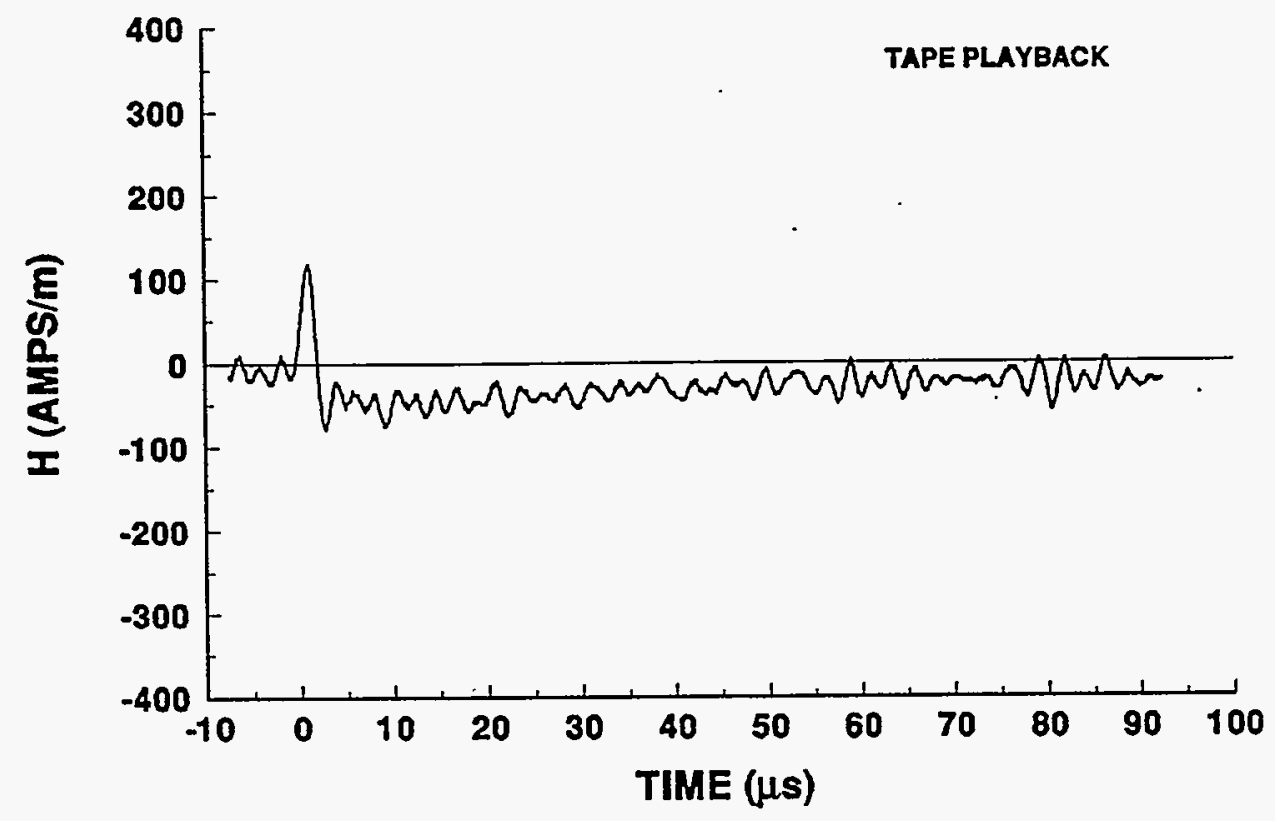




\section{4-06 STROKE 3 \\ INCIDENT CURRENT}
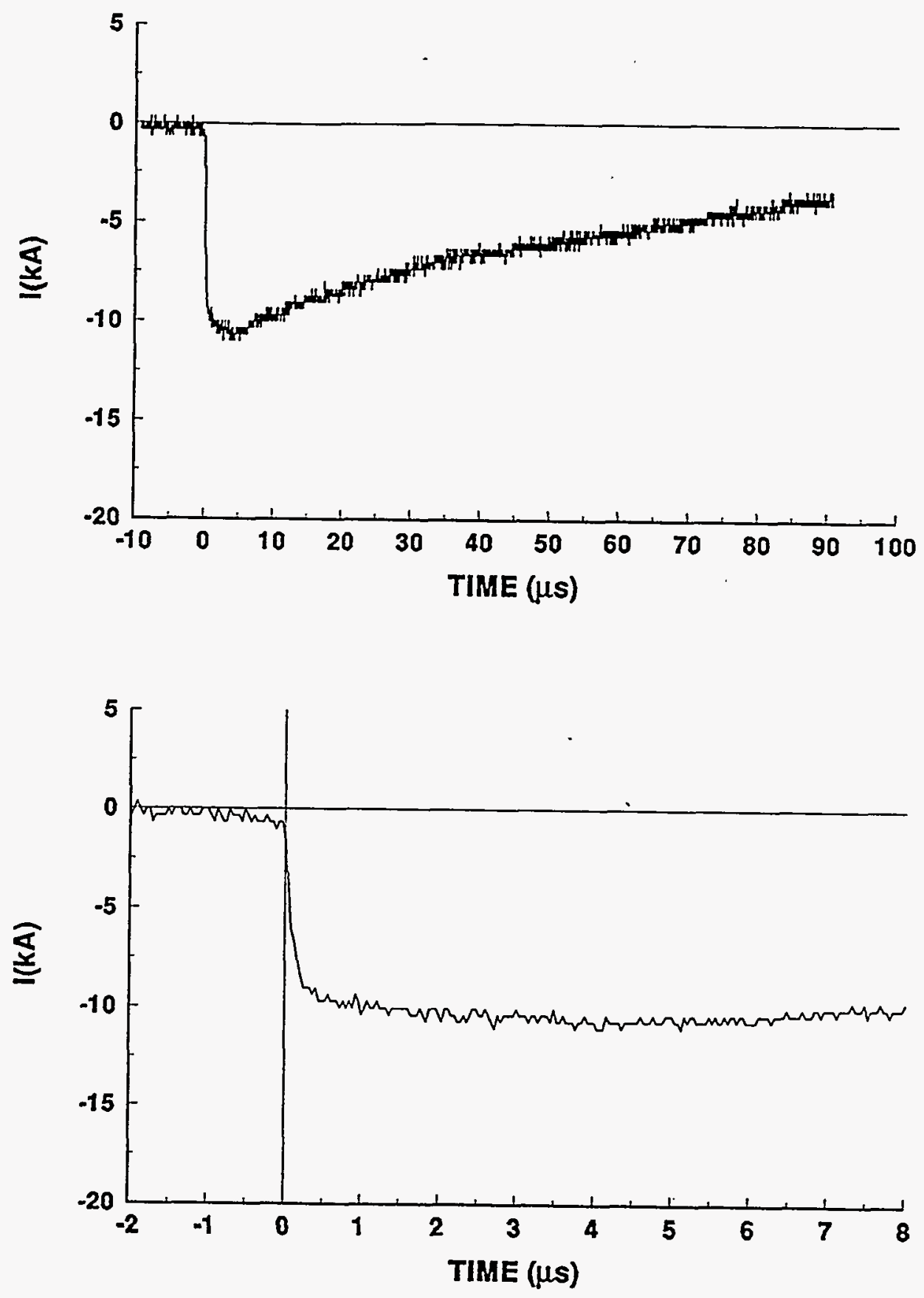


\section{4-06 STROKE 3}

TEST POINT 1

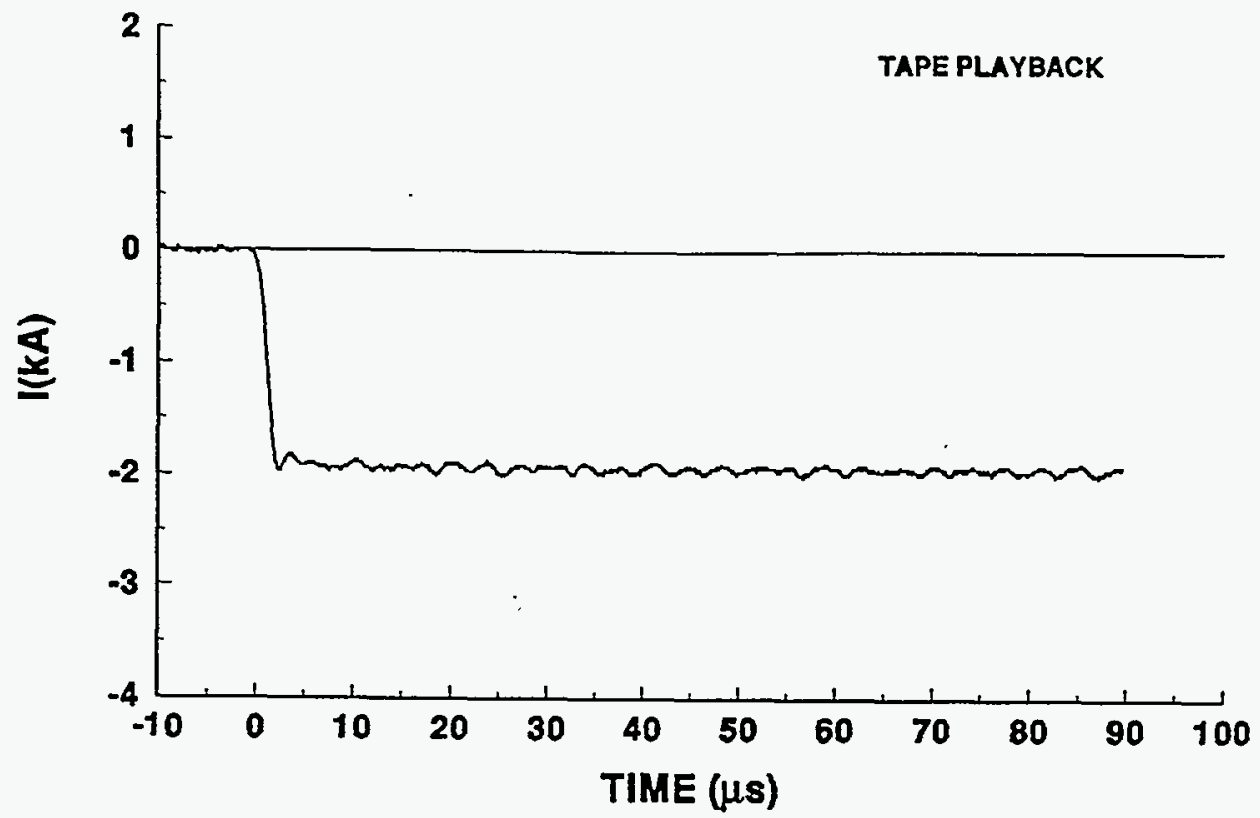

\section{4-02 STROKE 3}

TEST POINT 2

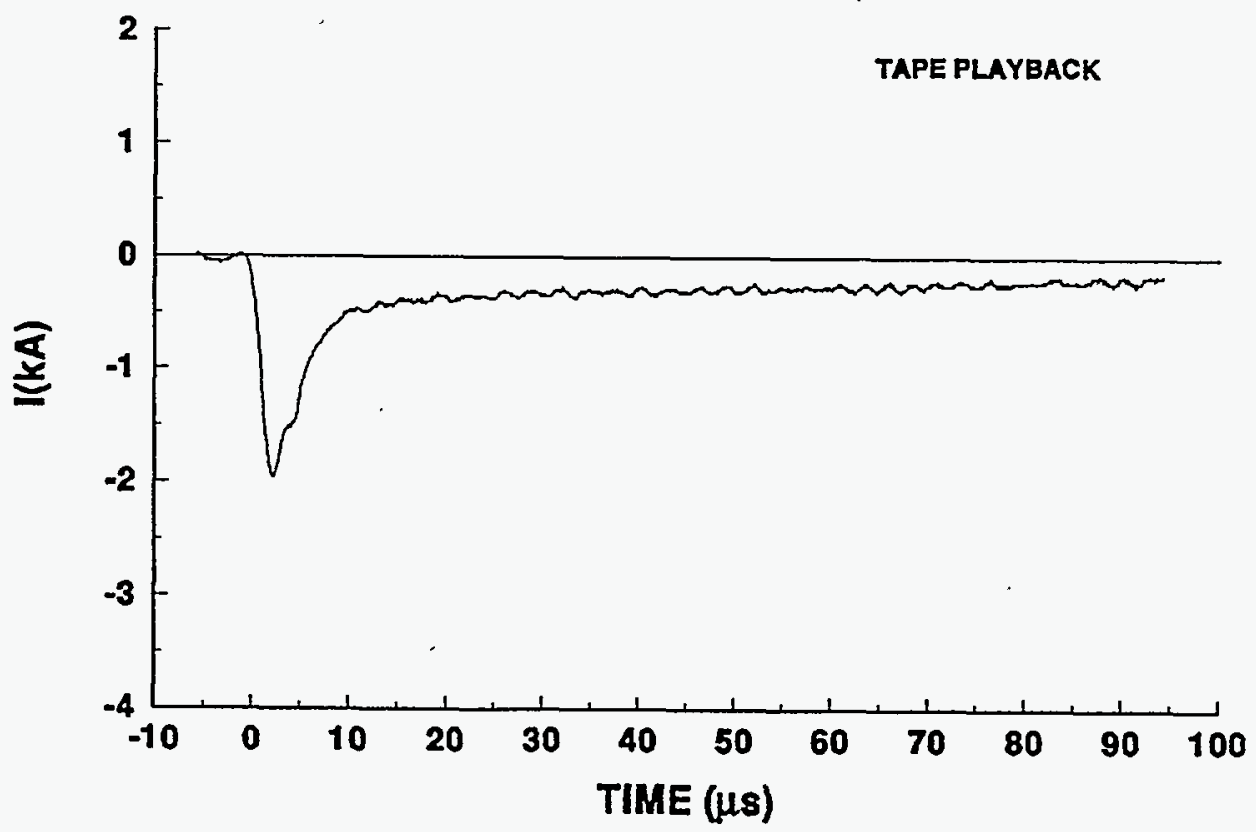




\section{4-06 STROKE 3}

TEST POINT 5
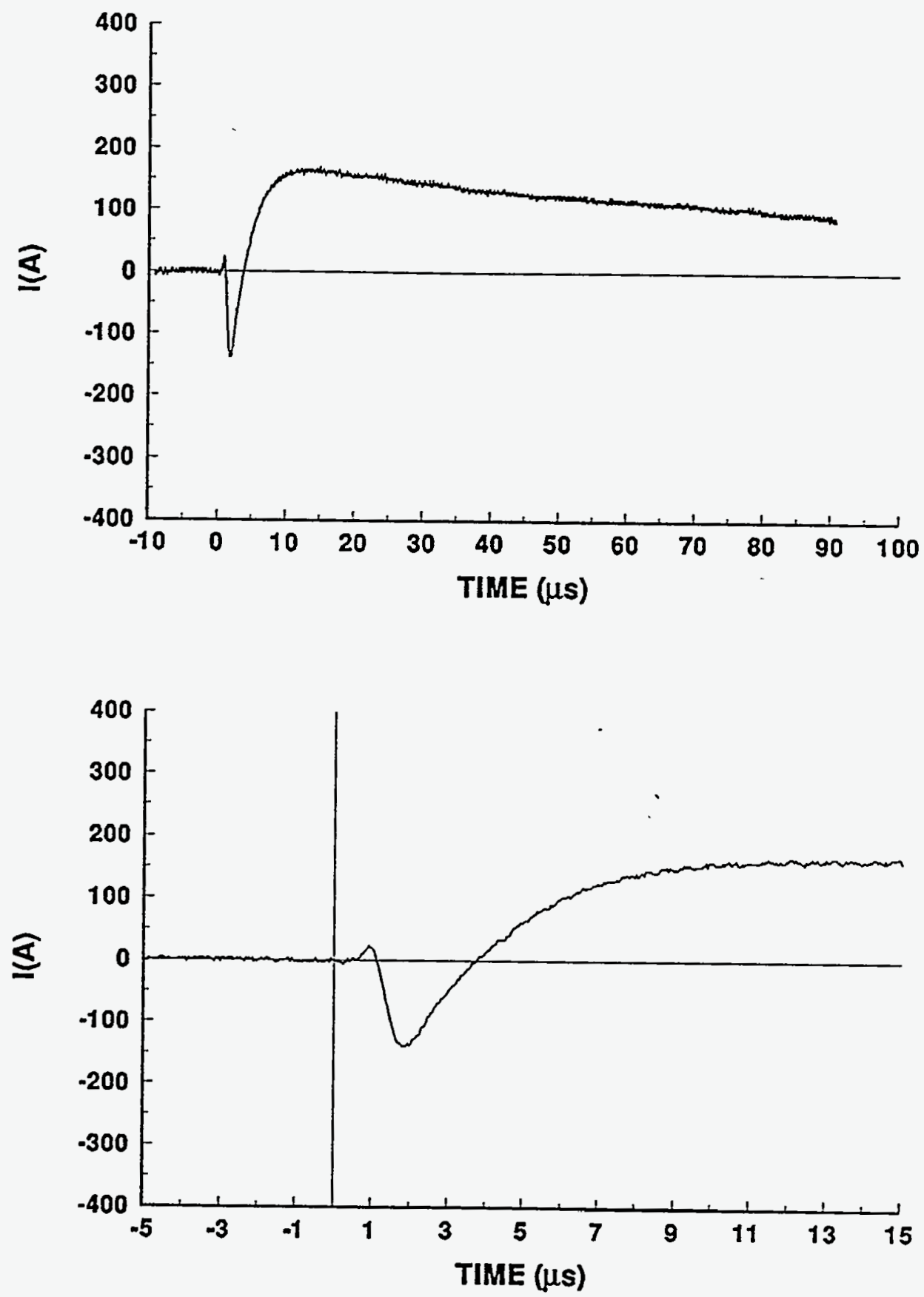
94-06 STROKE 3

TEST POINT 5'
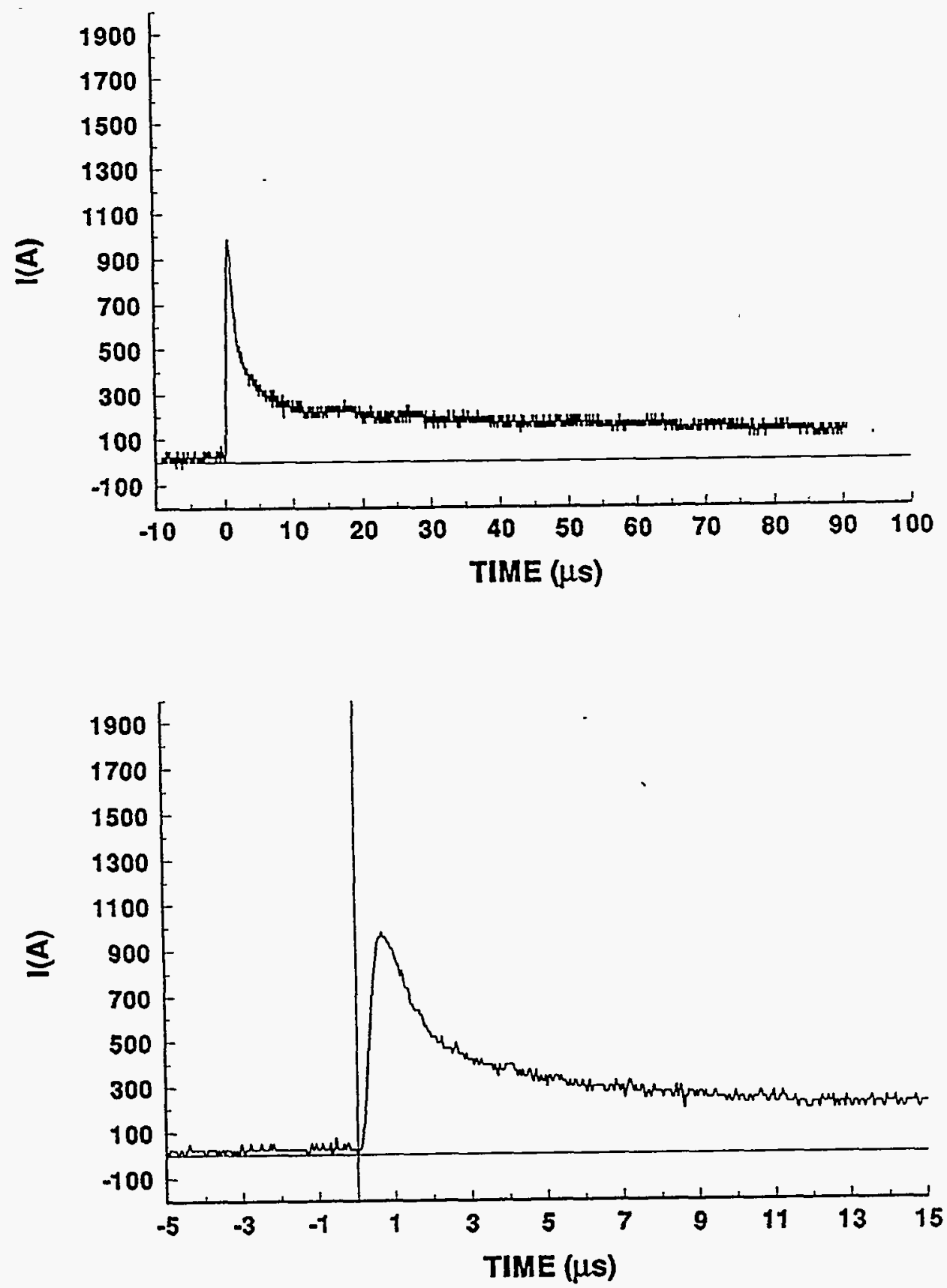


\section{4-06 STROKE 3}

TEST POINT 6'

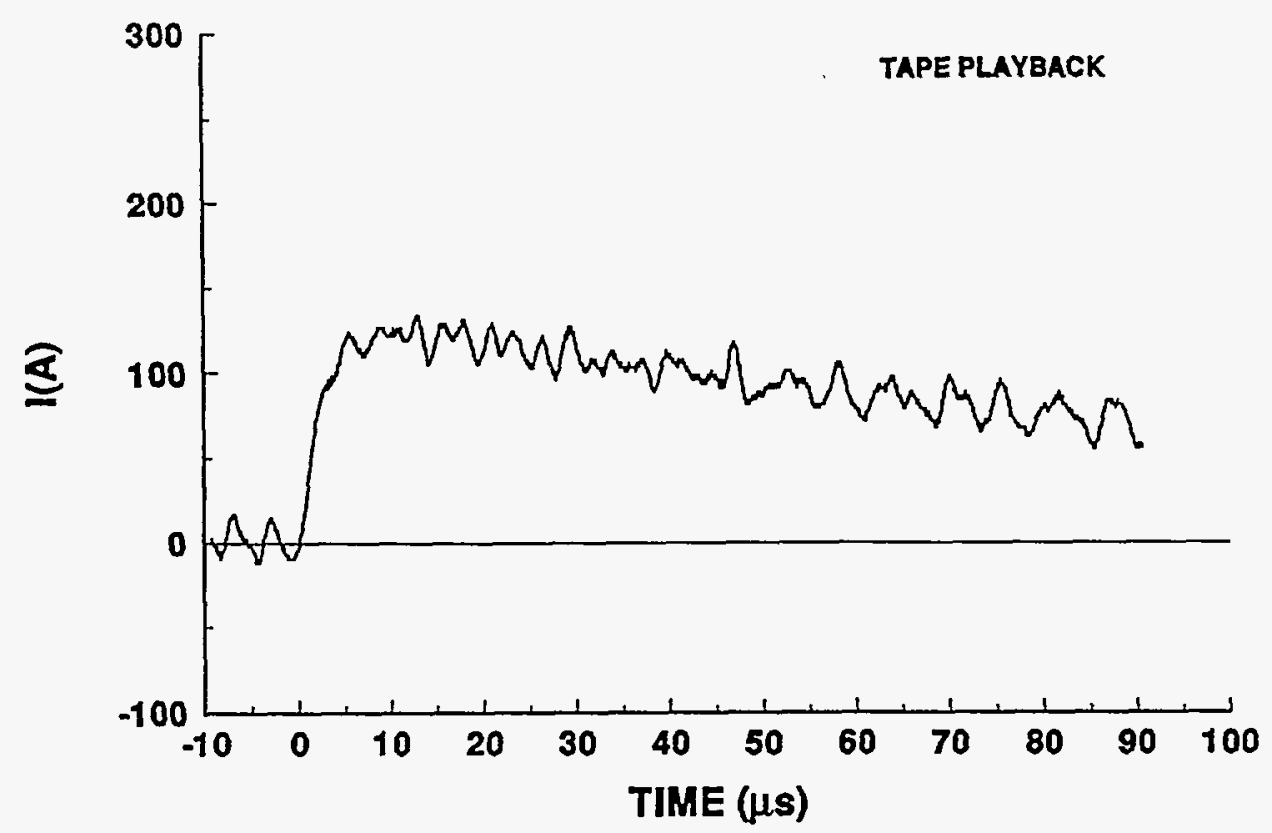




\section{4-06 STROKE 3}

TEST POINT 7
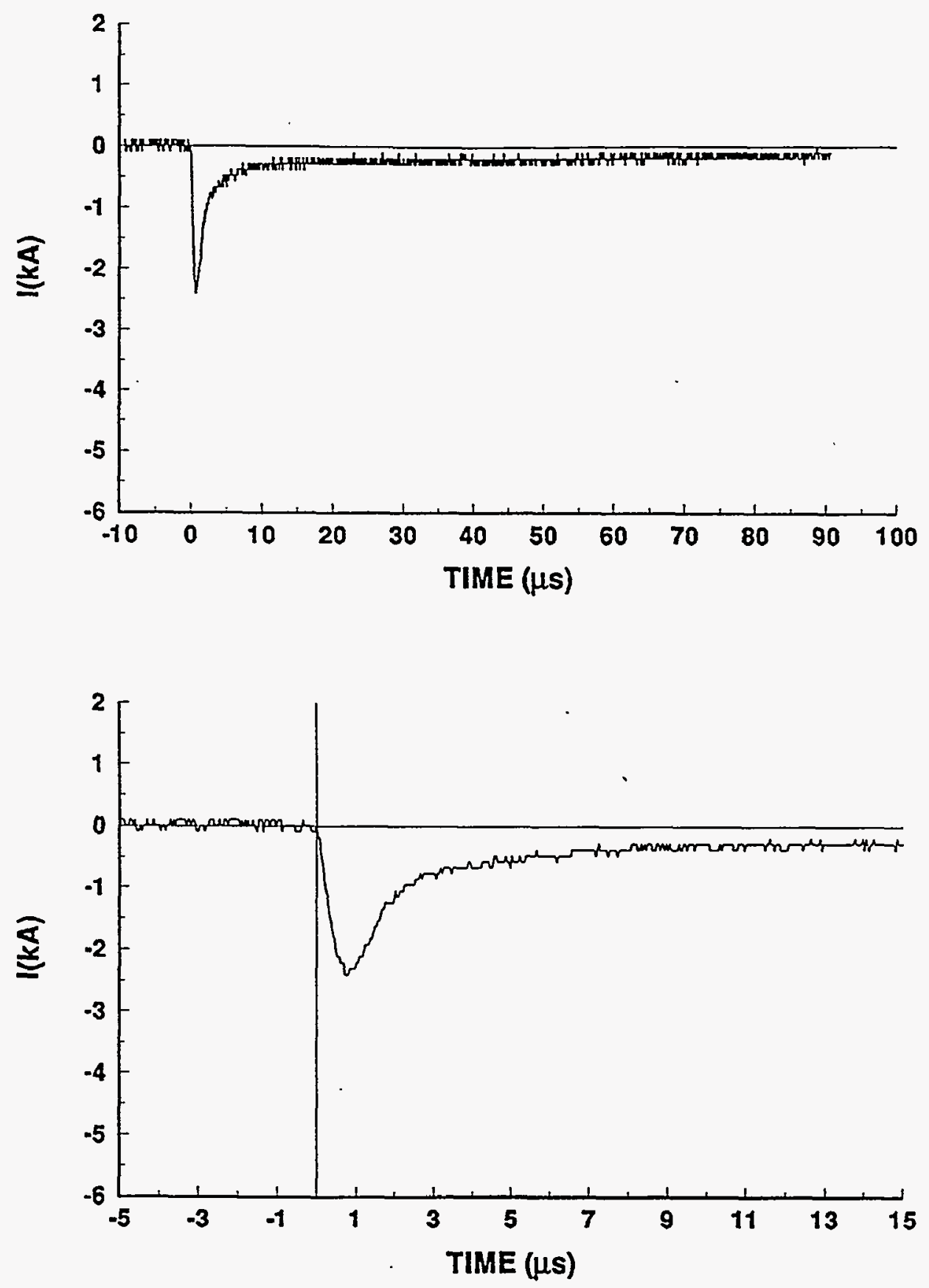
94-06 STROKE 3

TEST POINT 8
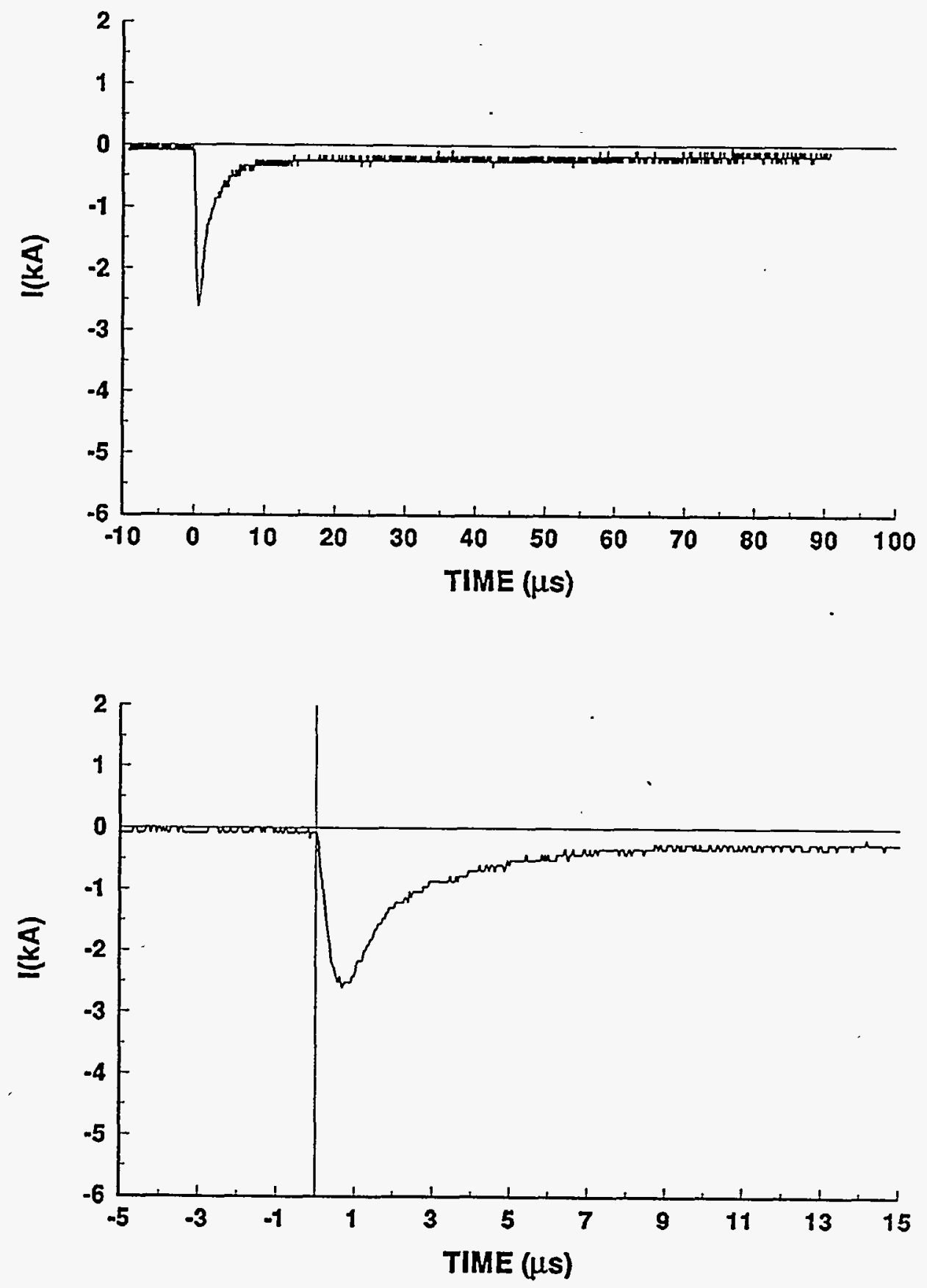
94-06 STROKE 3

TEST POINT 10

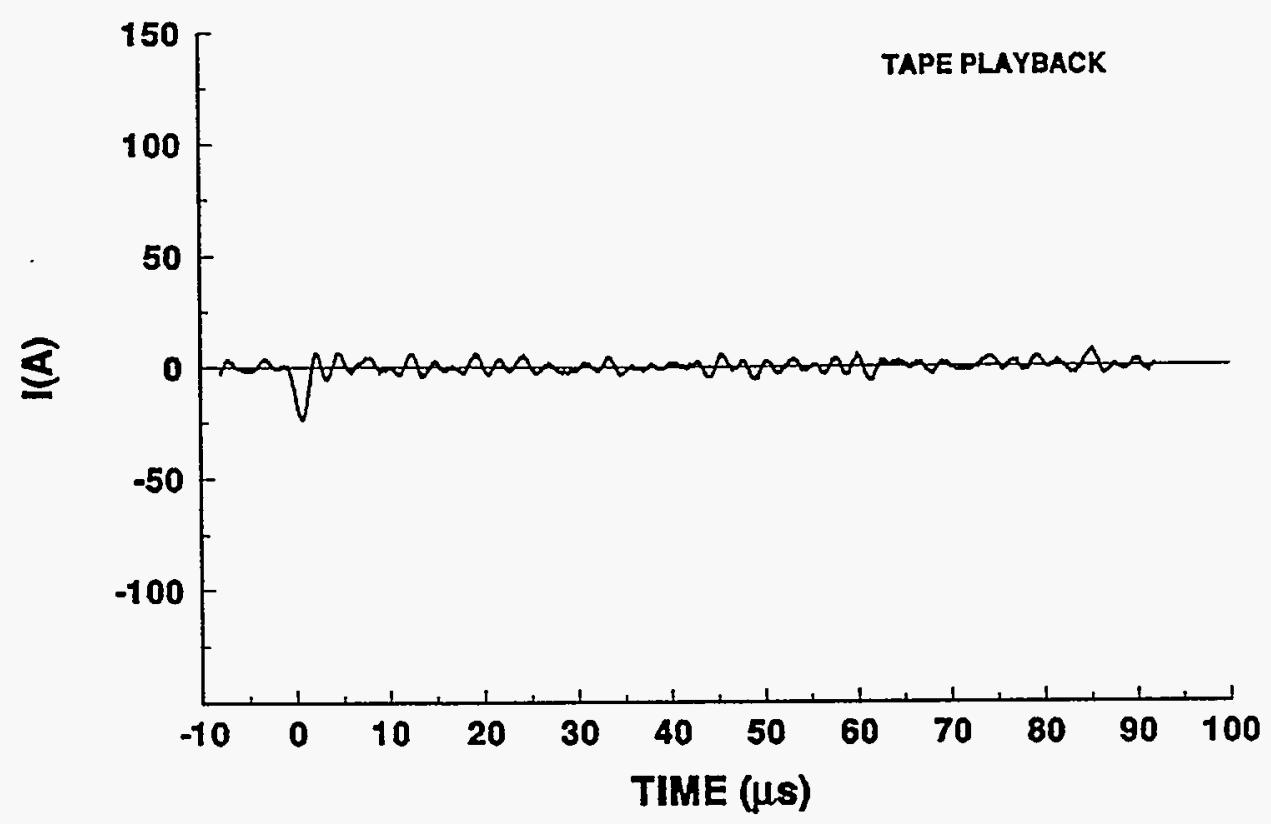

94-06 STROKE 3

TEST POINT 11

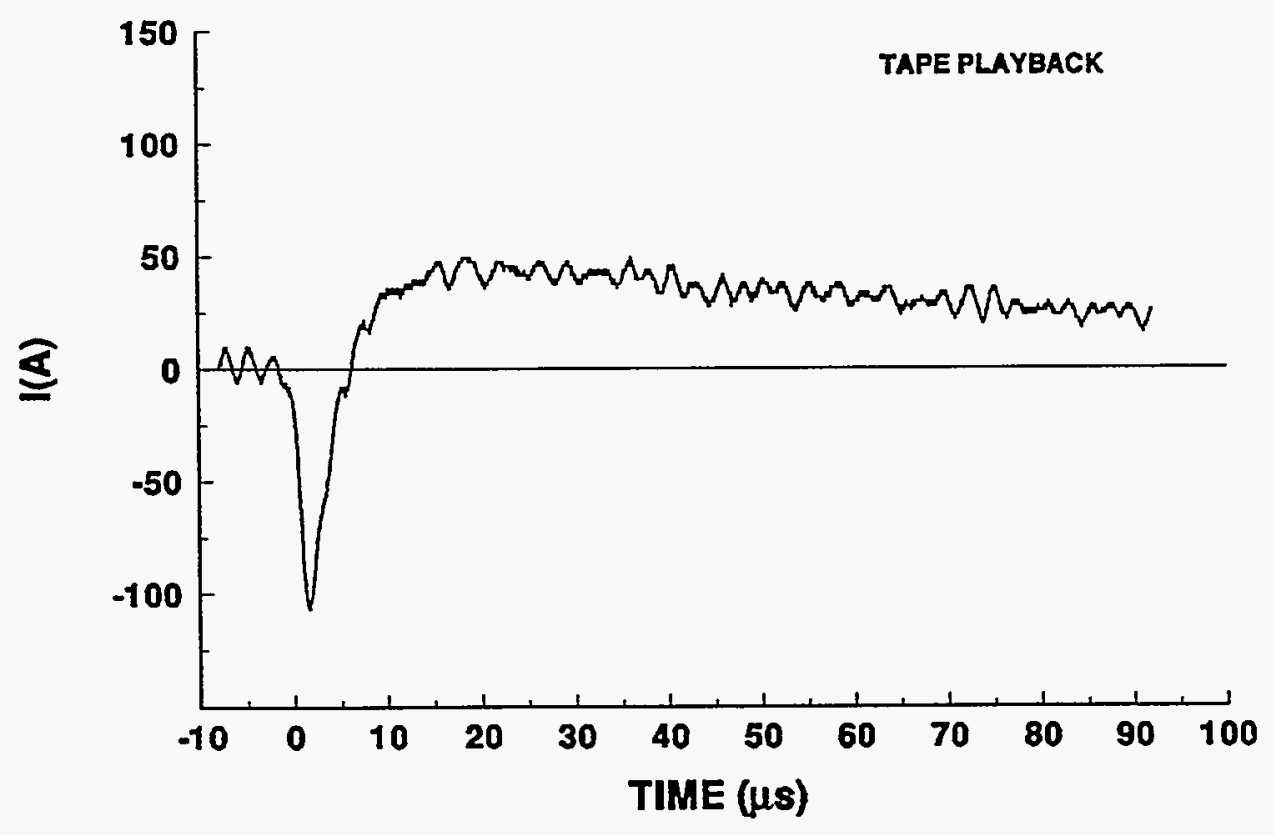




\section{4-06 STROKE 3}

\section{TEST POINT 12}

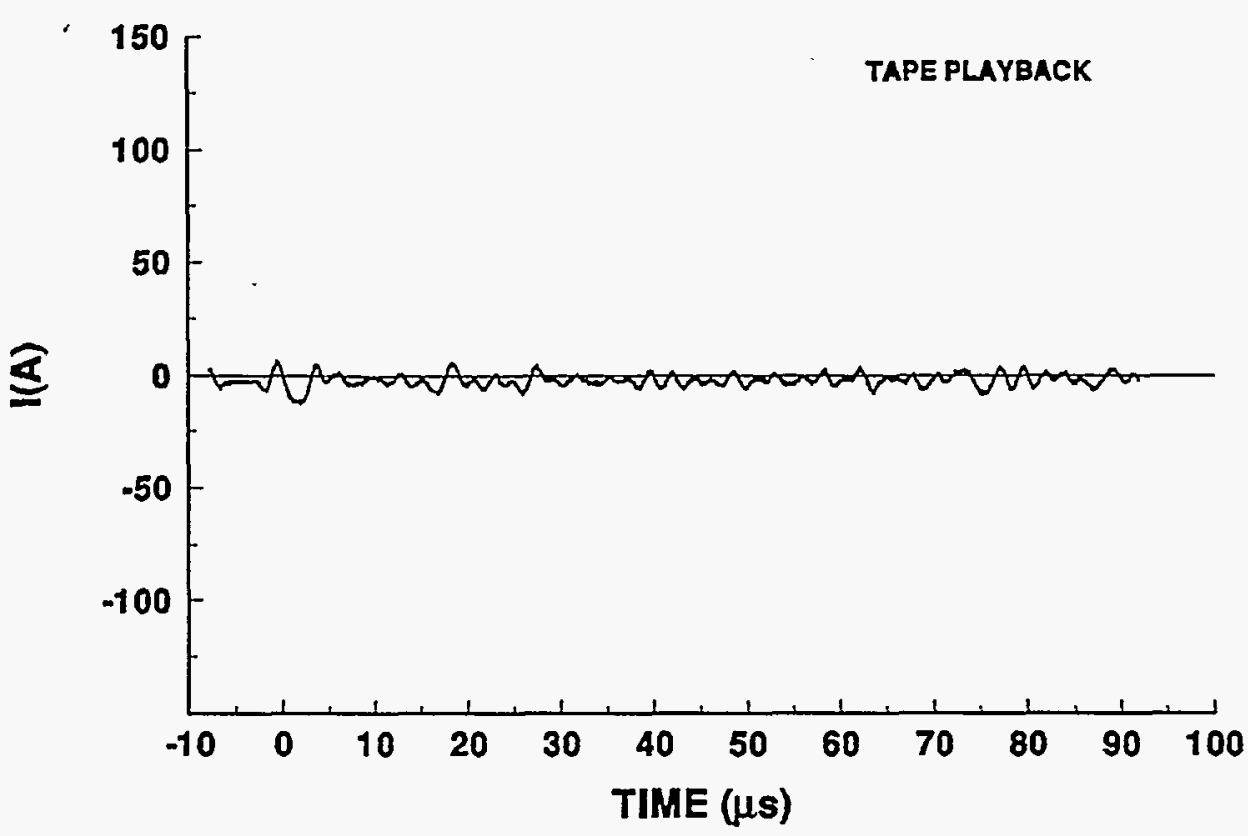

94-06 STROKE 3

TEST POINT 13

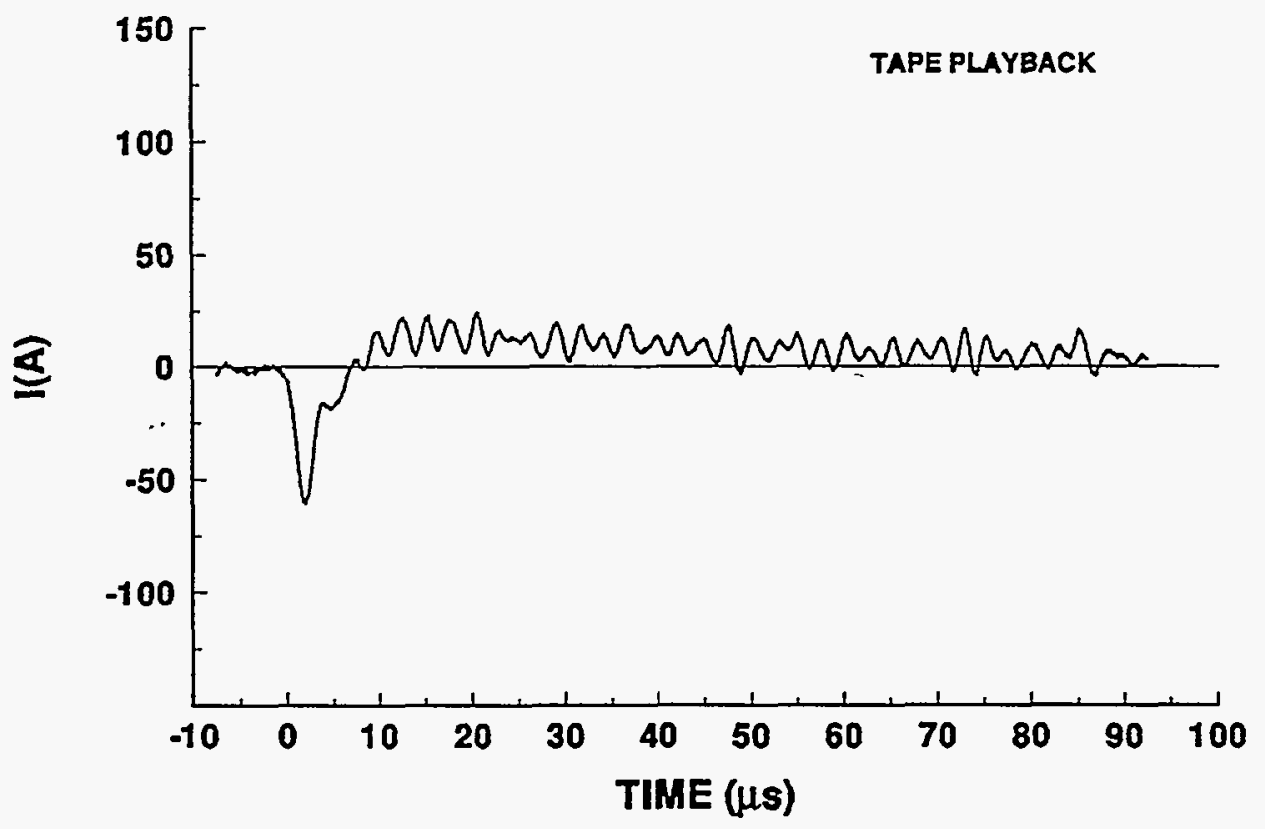




\section{4-06 STROKE 3}

TEST POINT 14
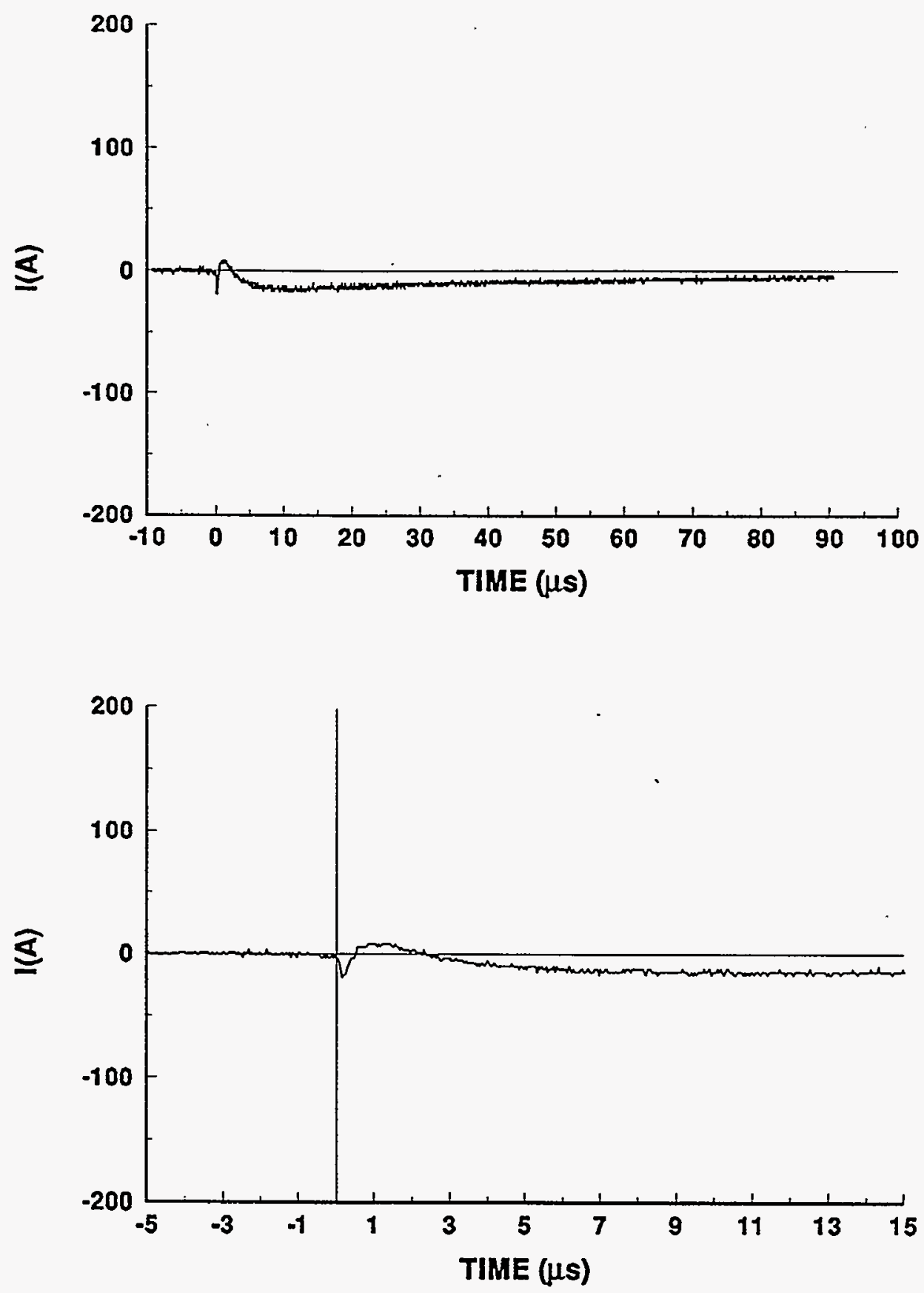


\section{4-06 STROKE 3}

TEST POINT 15
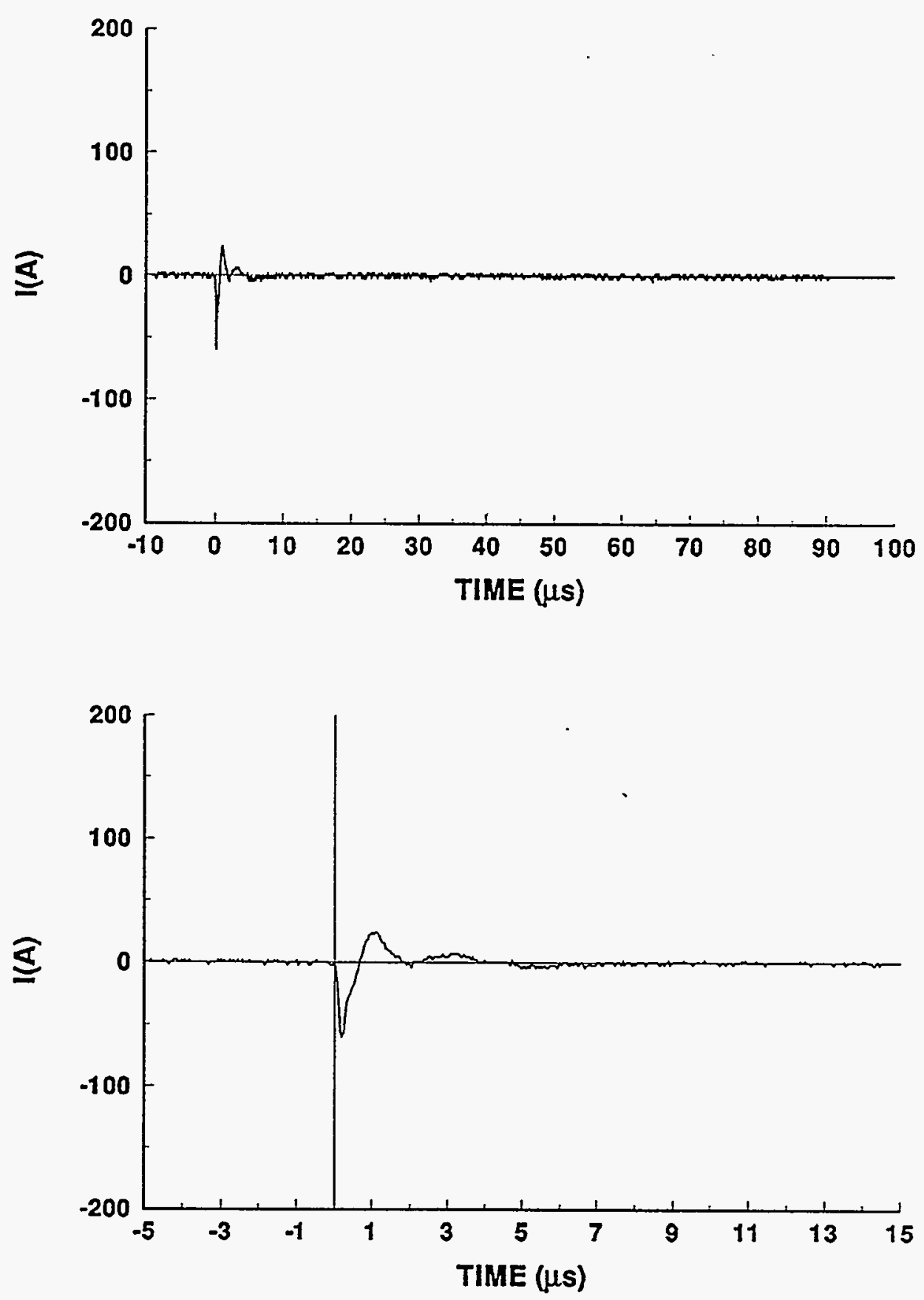


\section{4-06 STROKE 3}

TEST POINT 20

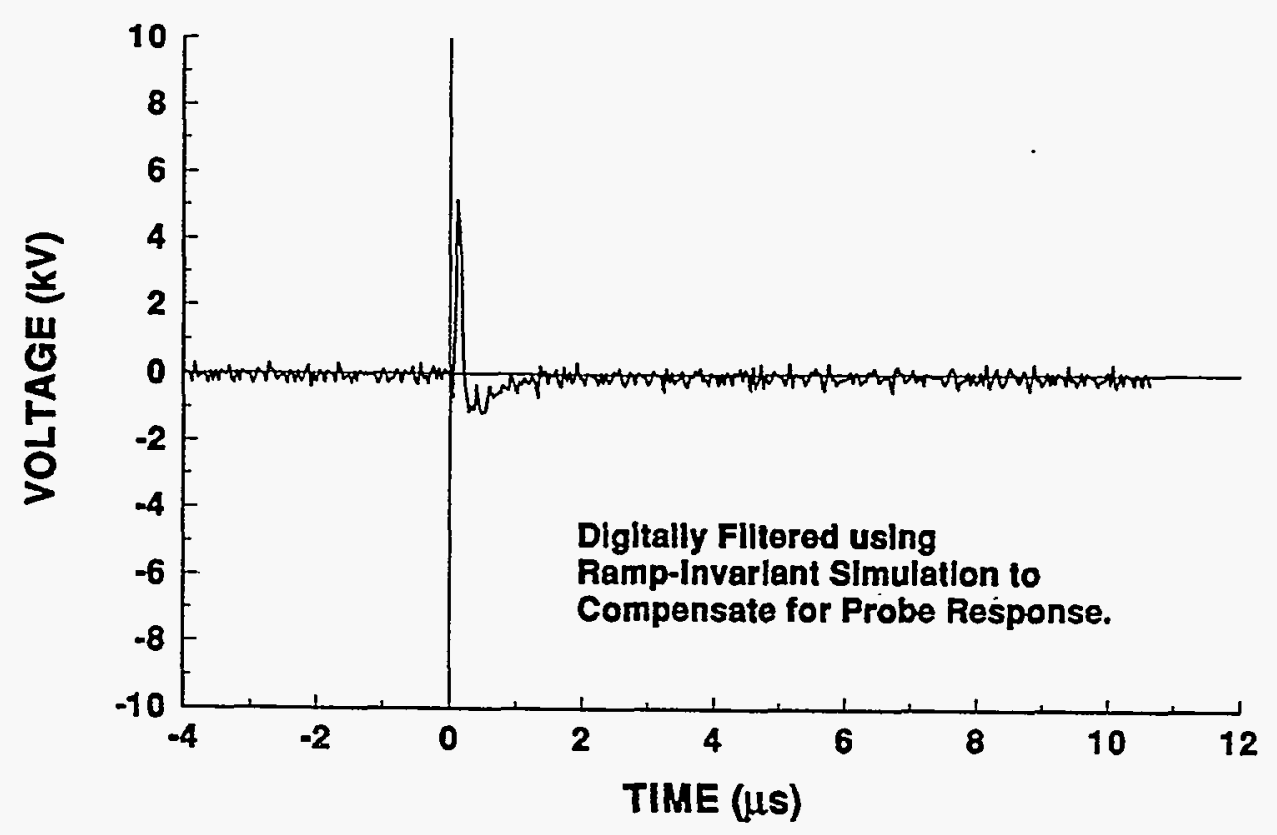

\section{4-06 STROKE 3}

TEST POINT 21

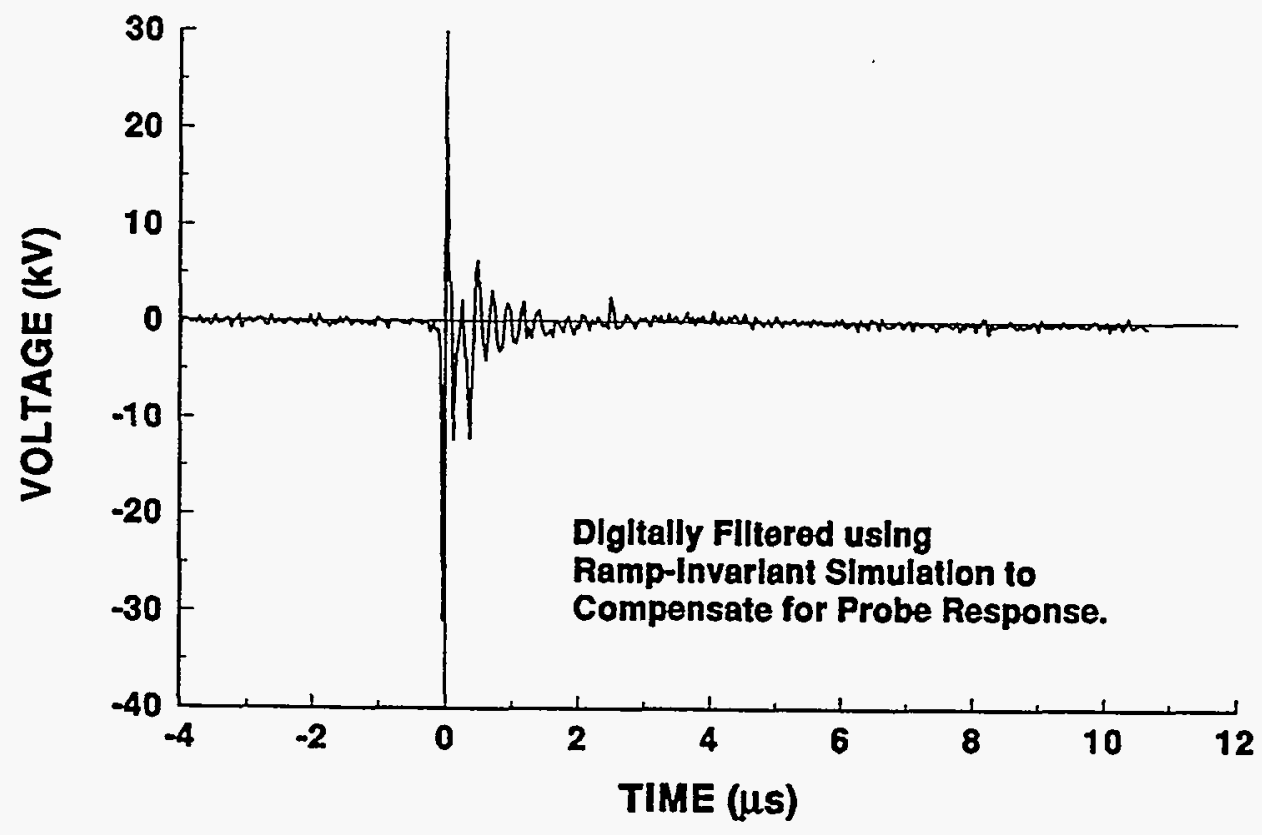




\section{4-06 STROKE 3}

TEST POINT 23

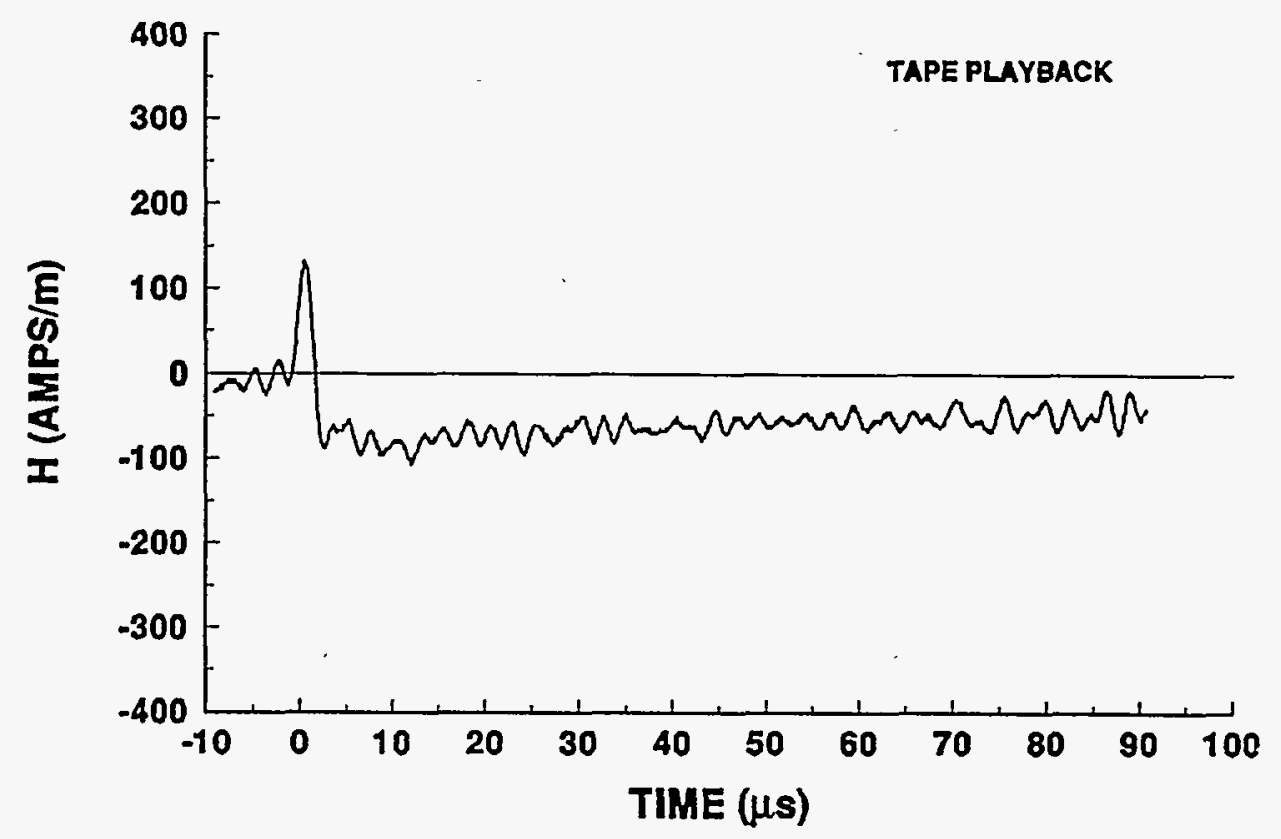




\section{4-06 STROKE 4 \\ INCIDENT CURRENT}
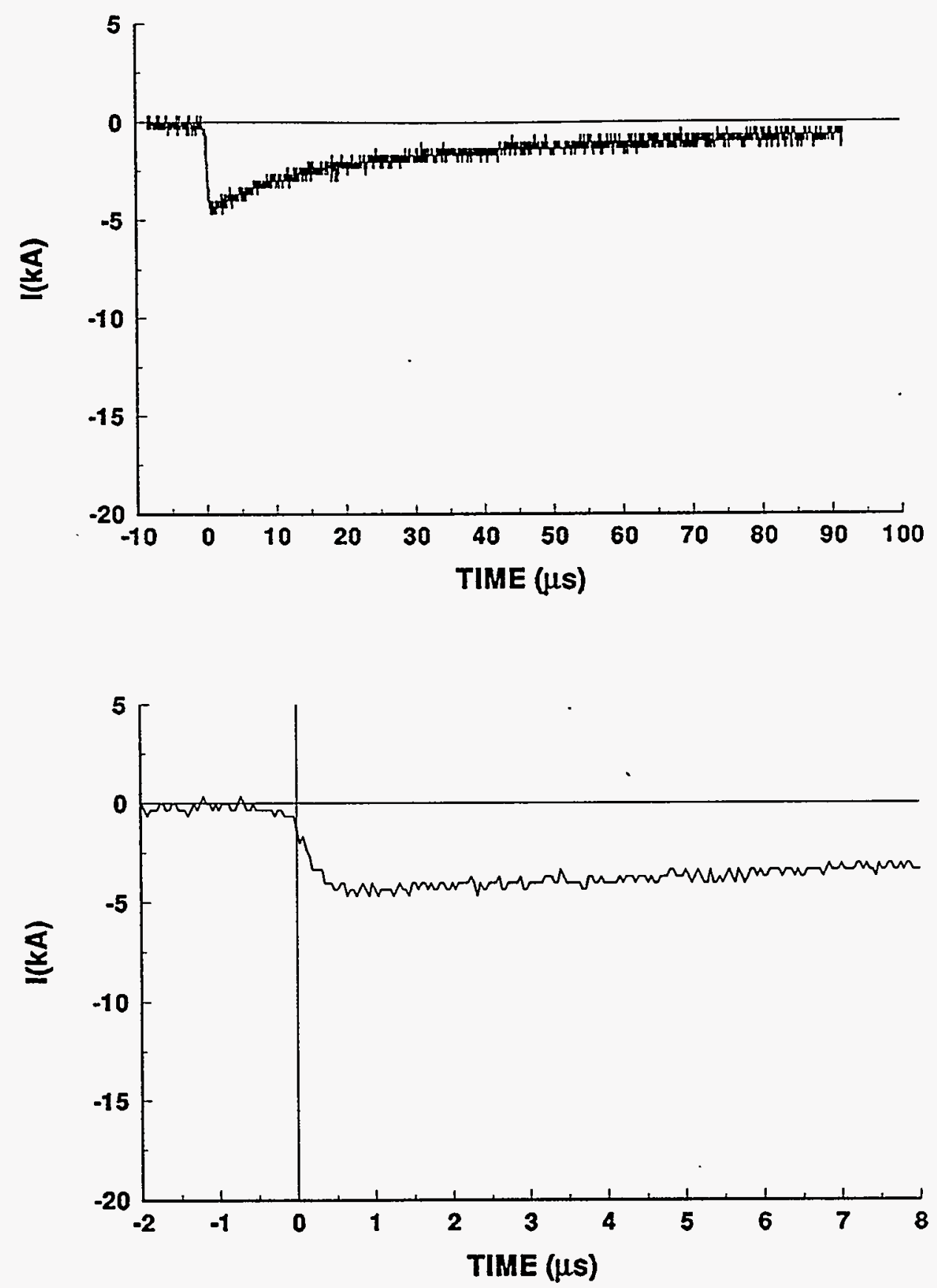


\section{4-06 STROKE 4}

TEST POINT 1

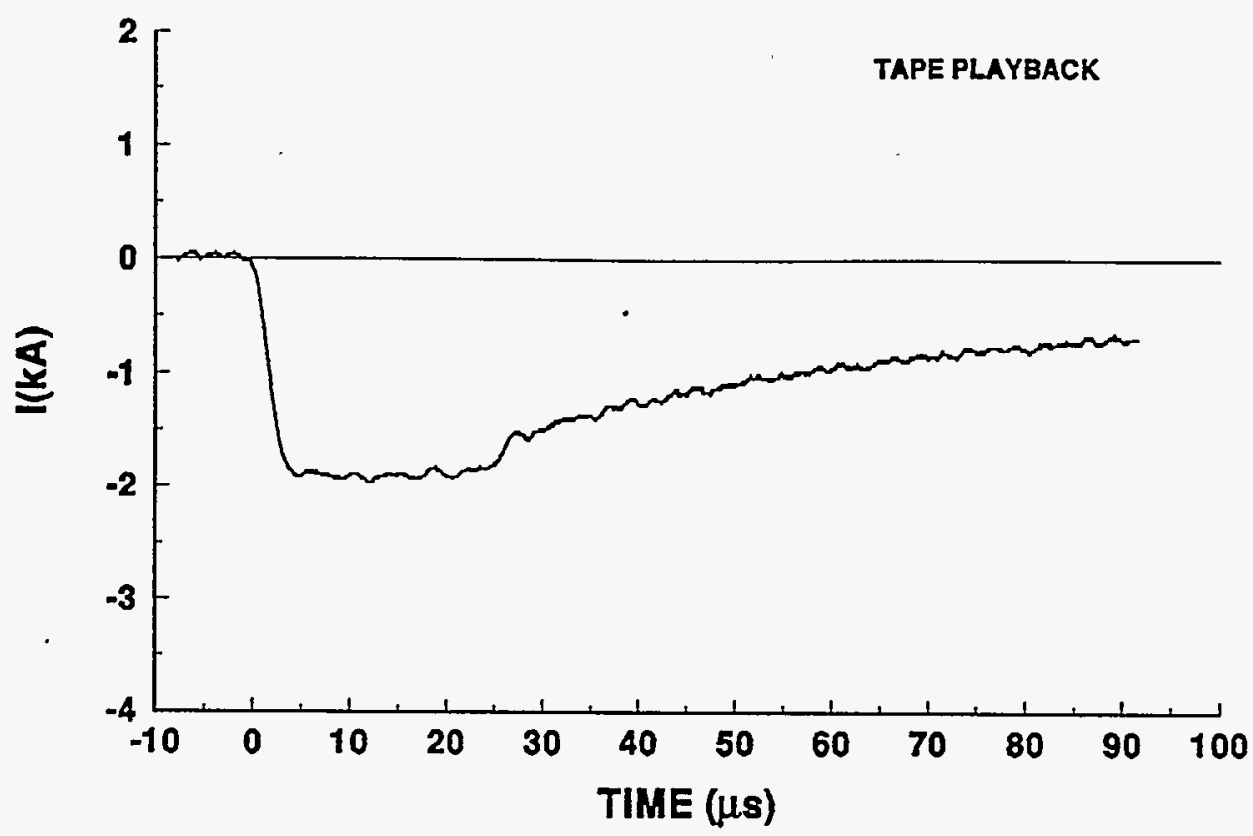

\section{4-02 STROKE.4}

\section{TEST POINT 2}

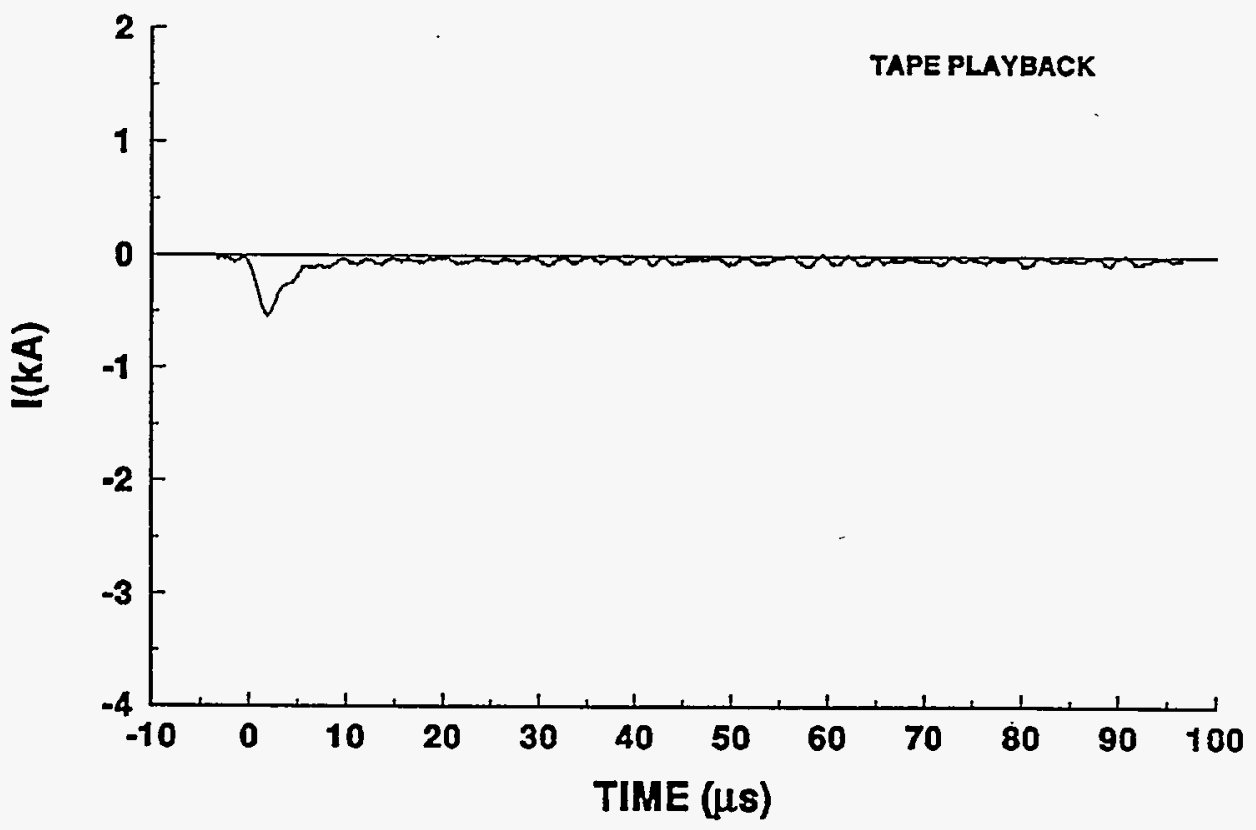




\section{4-06 STROKE 4 \\ TEST POINT 5}
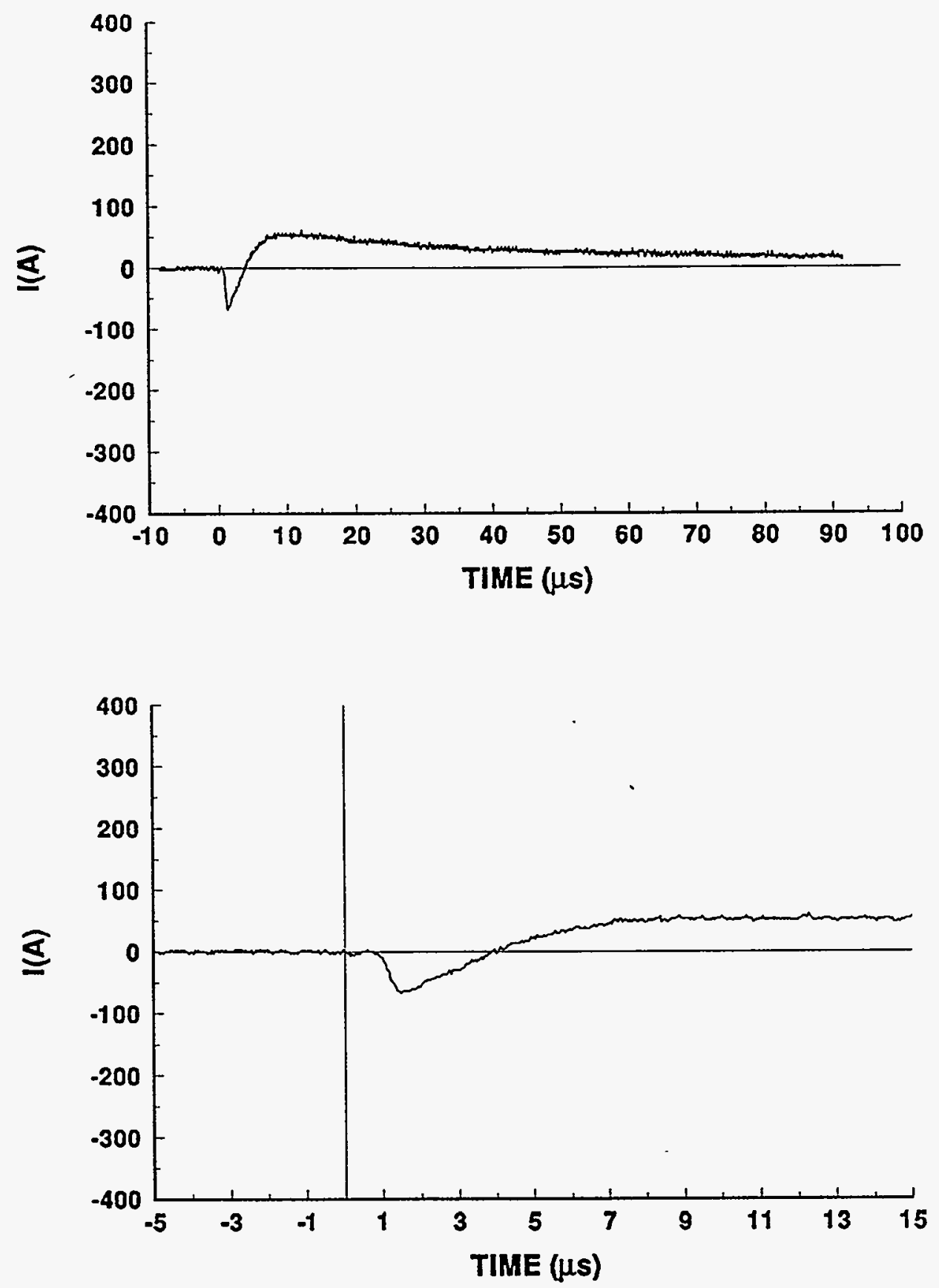


\section{4-06 STROKE 4}

TEST POINT 5'
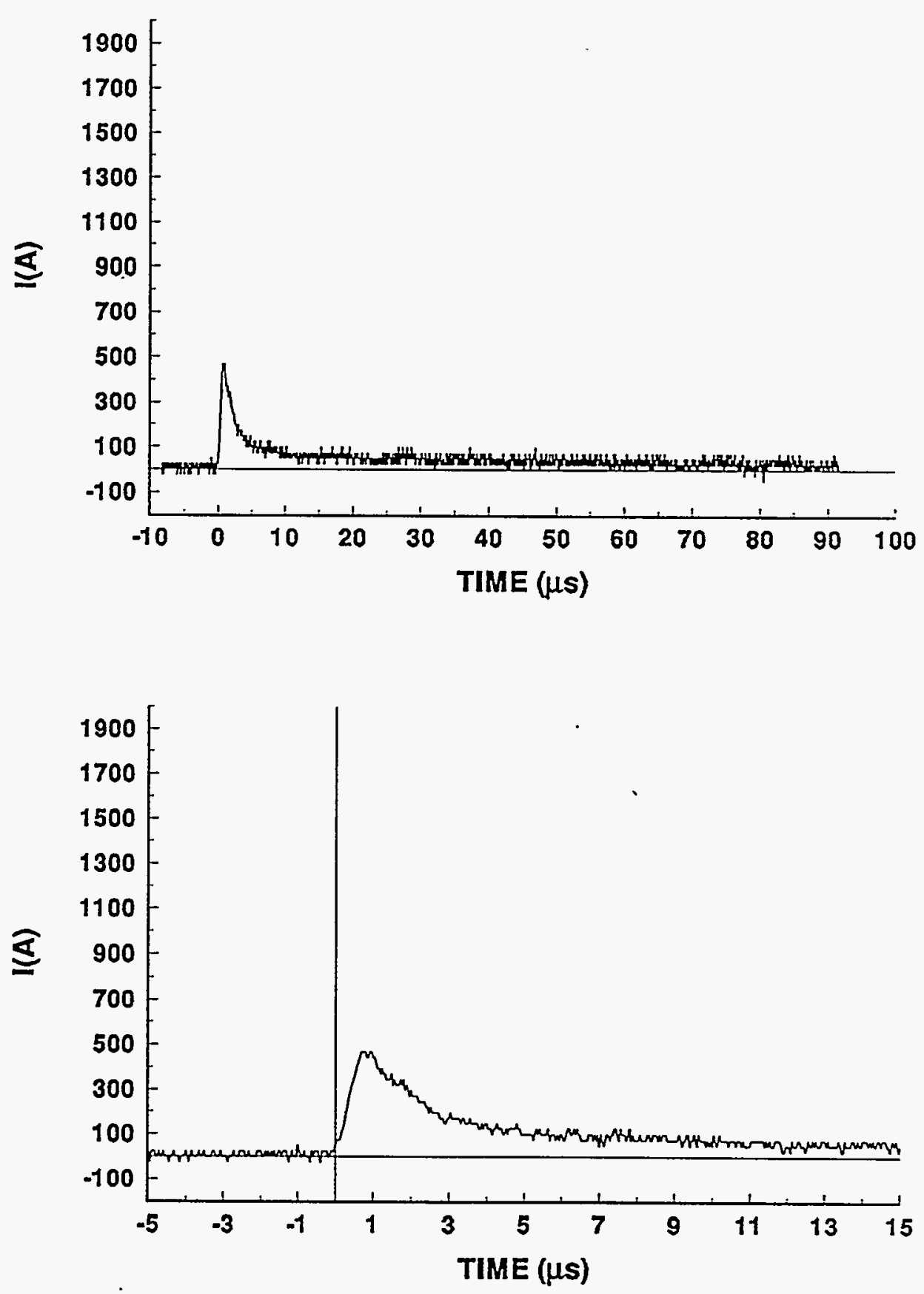


\section{4-06 STROKE 4}

TEST POINT 6'

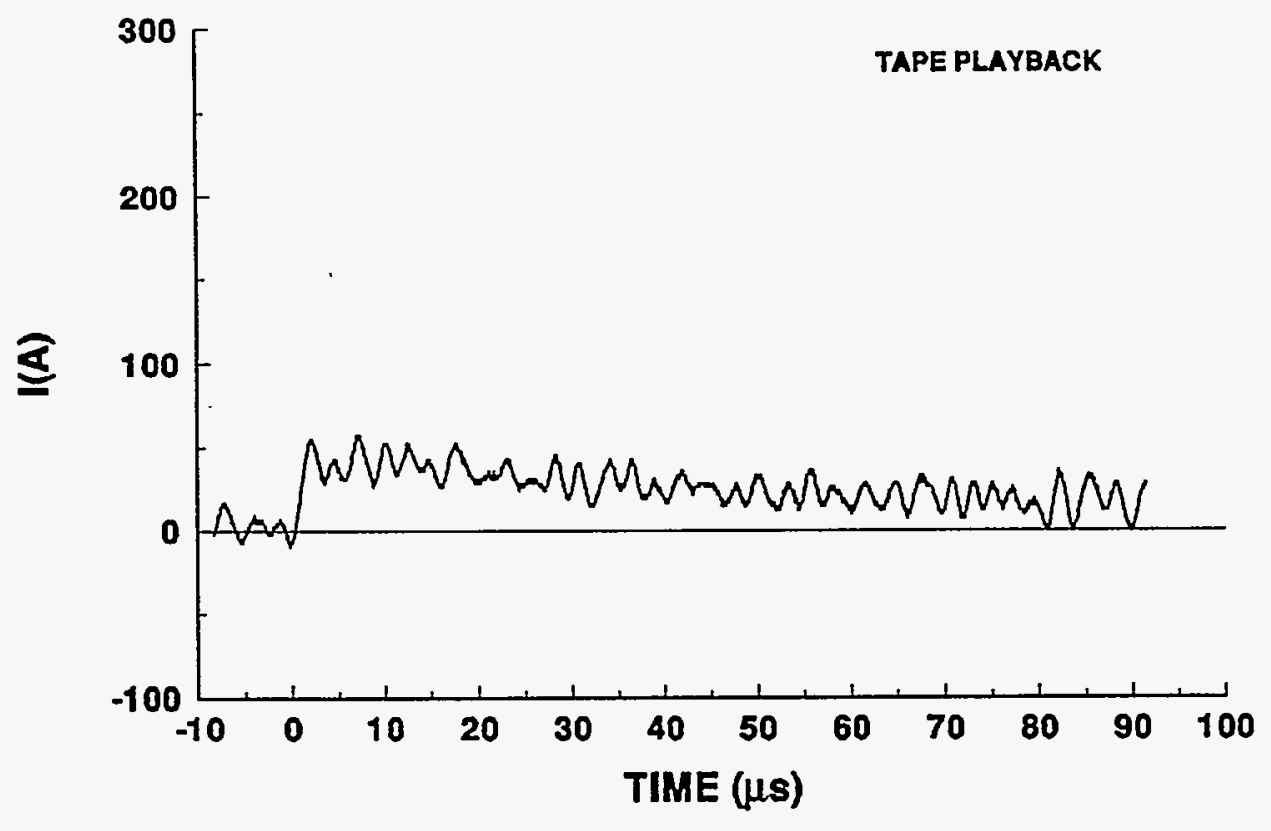




\section{4-06 STROKE 4}

TEST POINT 7
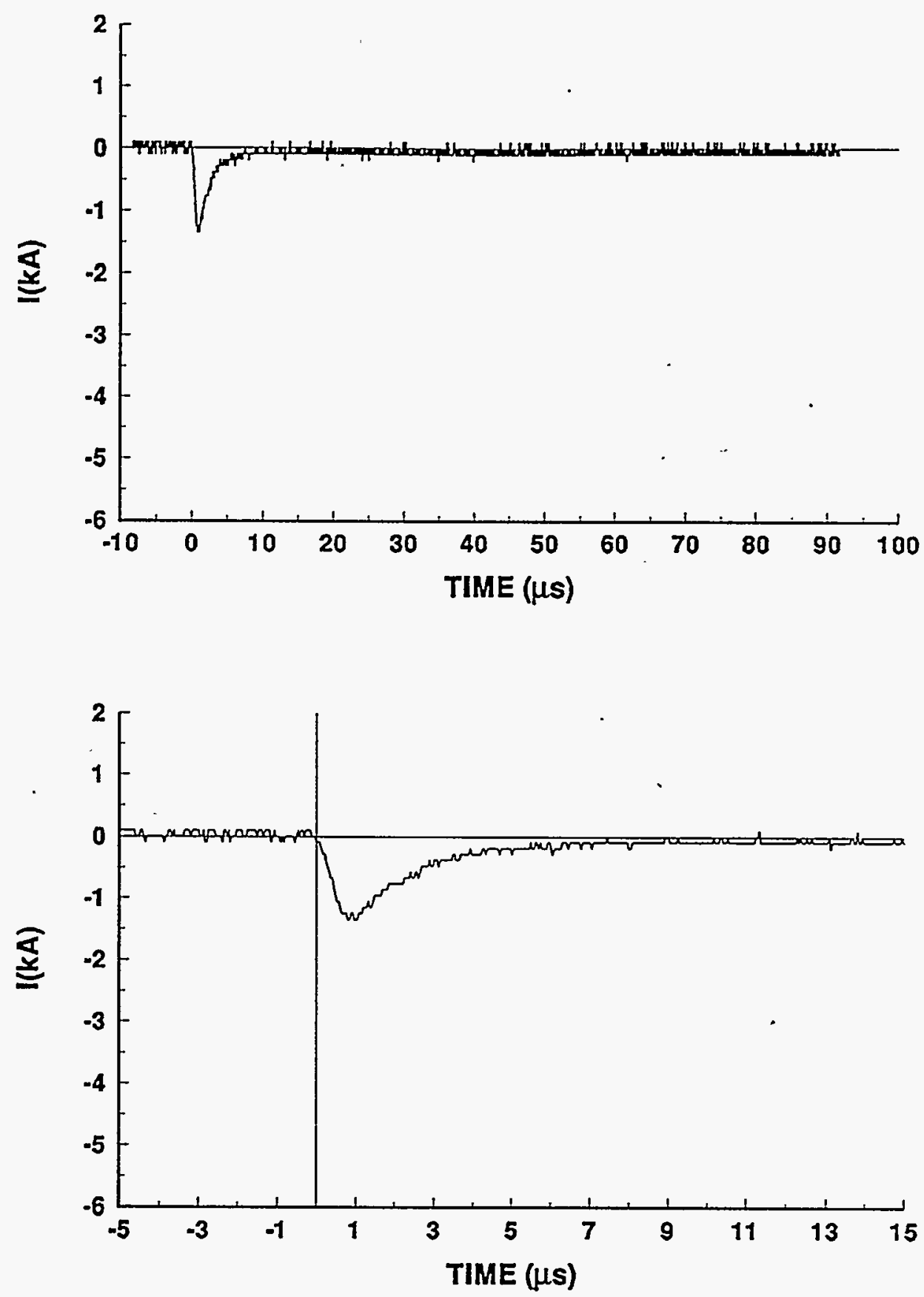


\section{4-06 STROKE 4}

TEST POINT 8
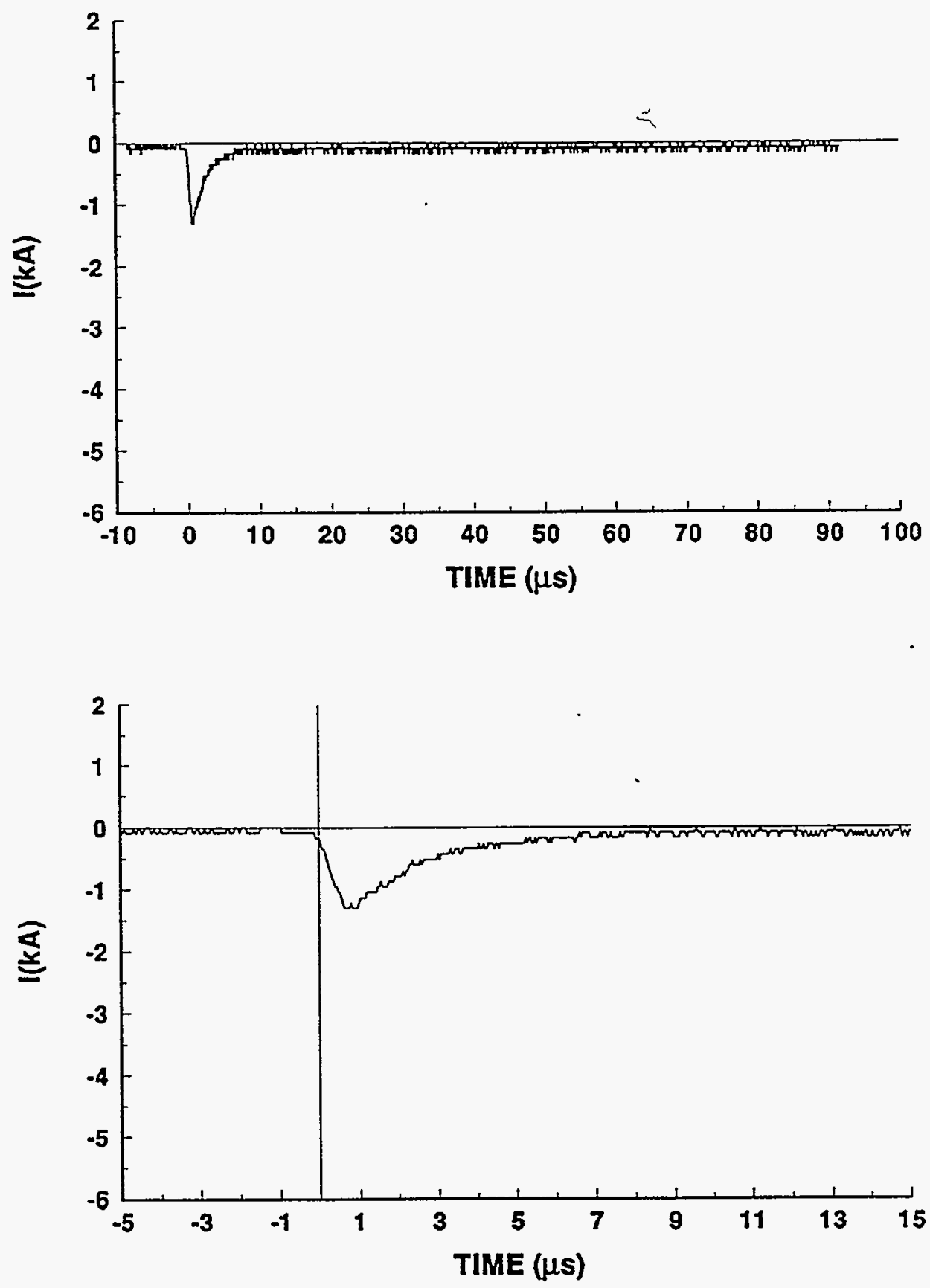


\section{4-06 STROKE 4}

TEST POINT 10

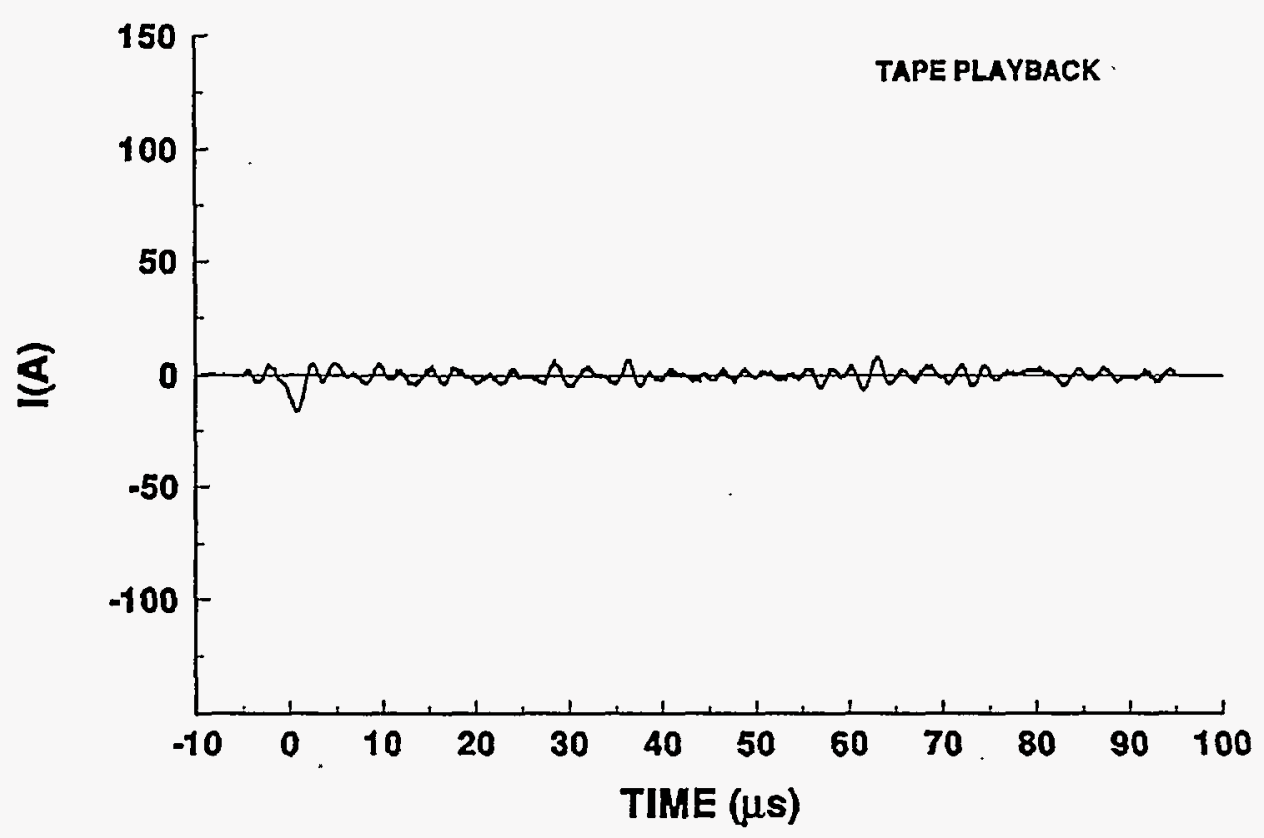

94-06 STROKE 4

TEST POINT 11

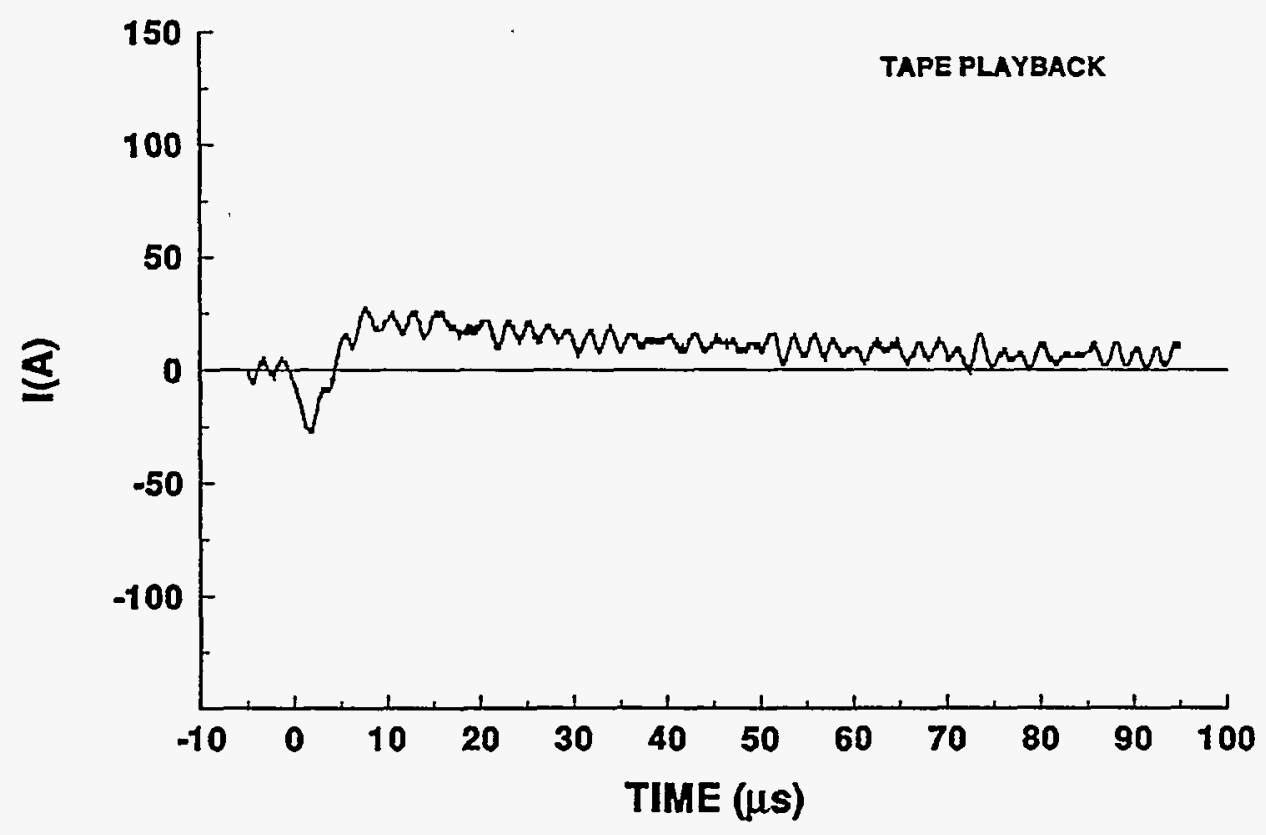




\section{4-06 STROKE 4}

TEST POINT 12

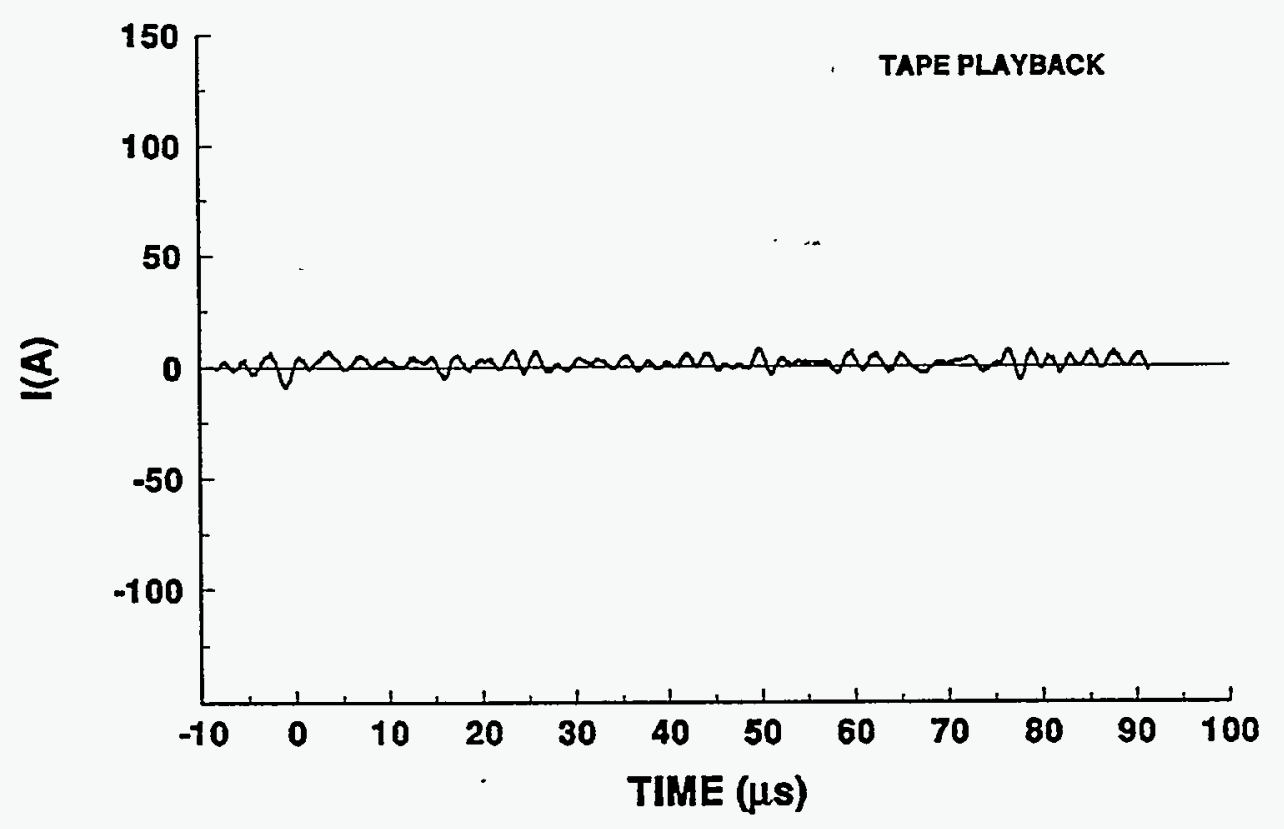

\section{4-06 STROKE 4}

TEST POINT 13

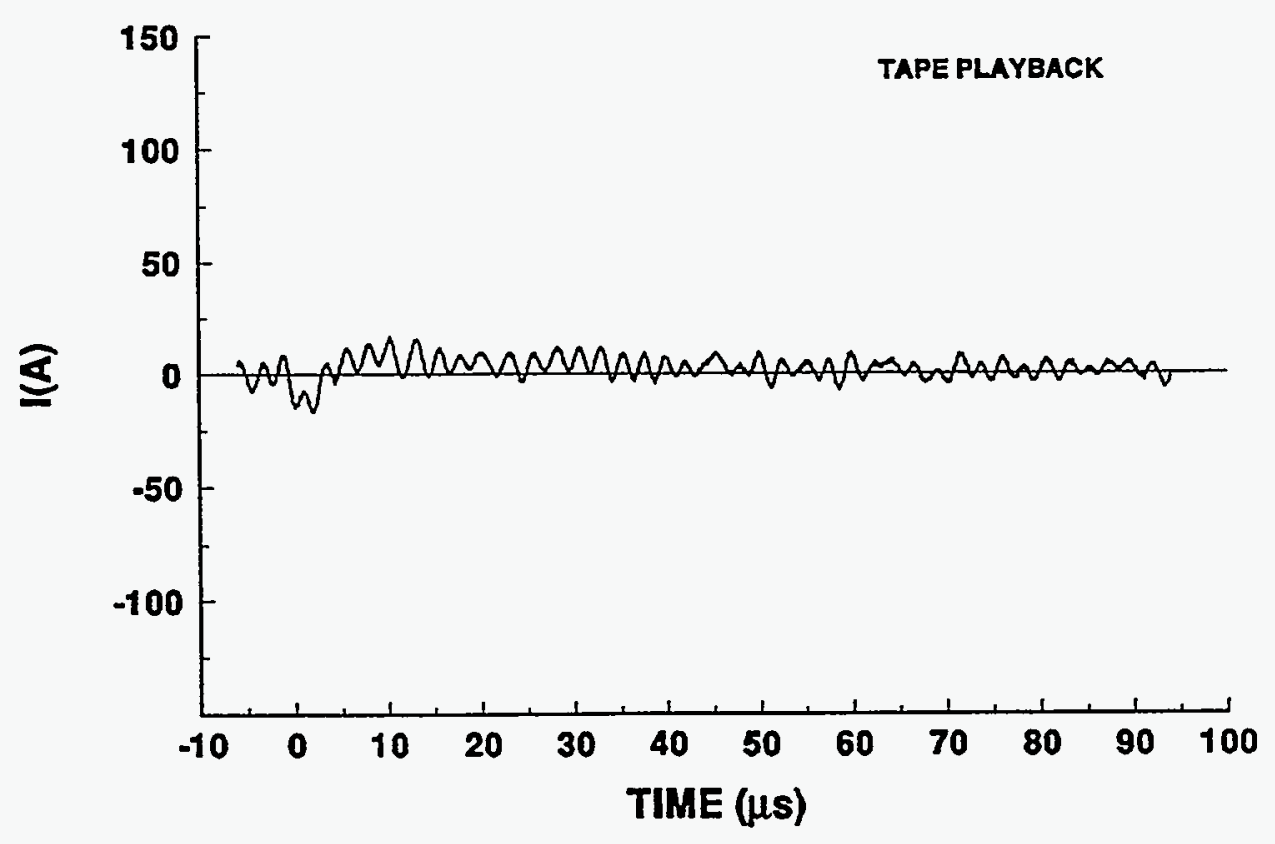




\section{4-06 STROKE 4}

\section{TEST POINT 14}
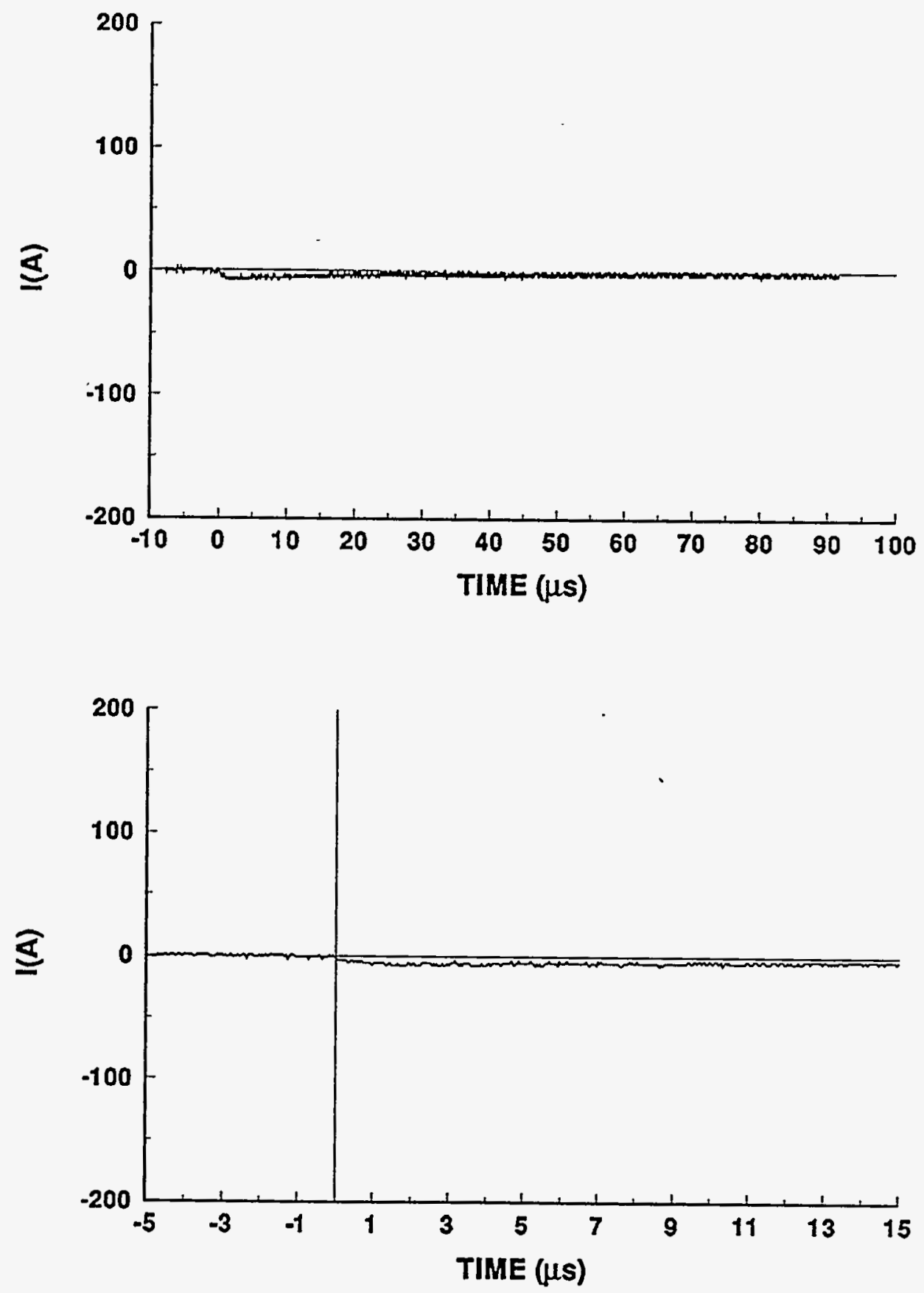
94-06 STROKE 4

TEST POINT 15
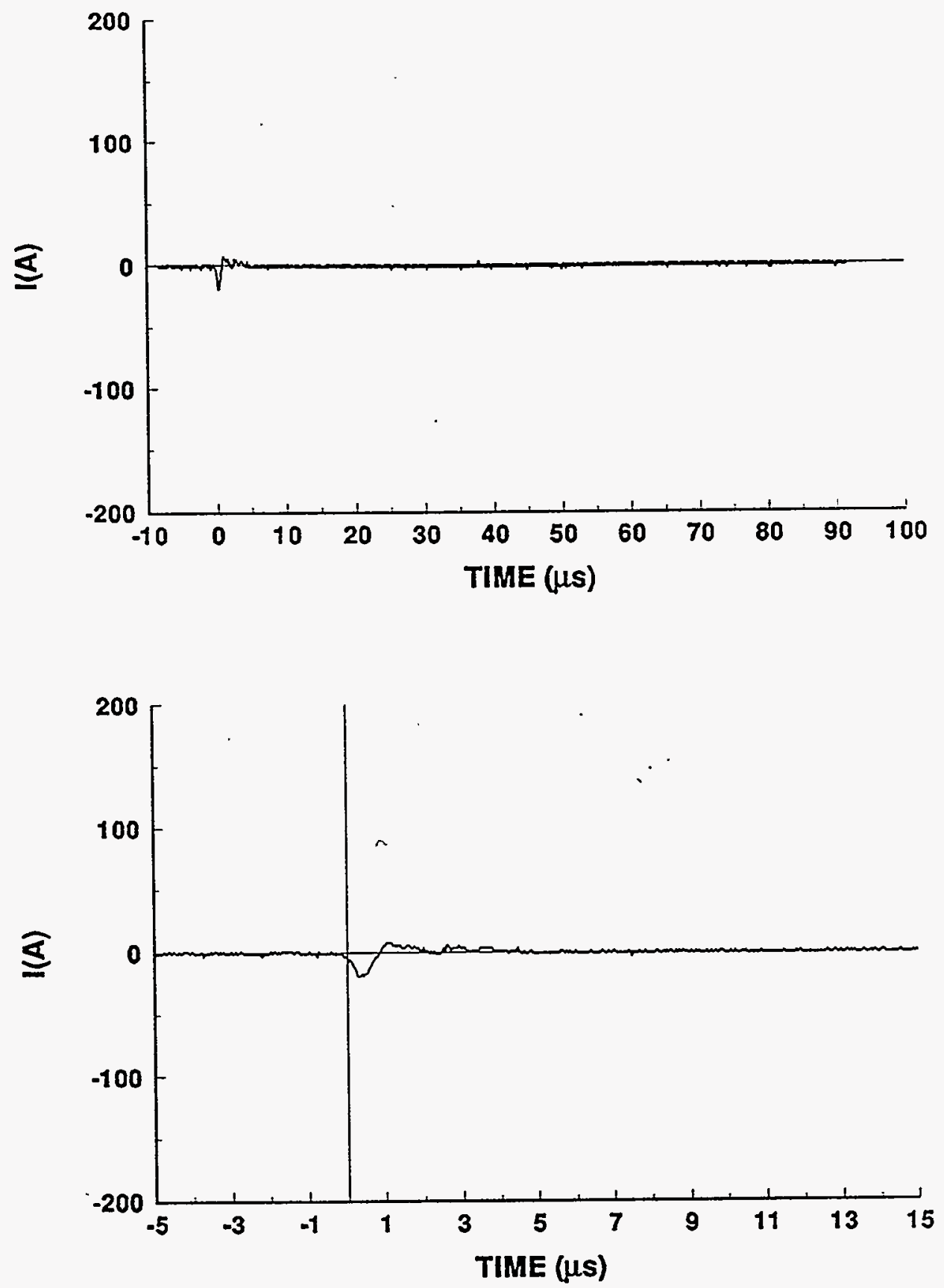


\section{4-06 STROKE 4}

TEST POINT 20

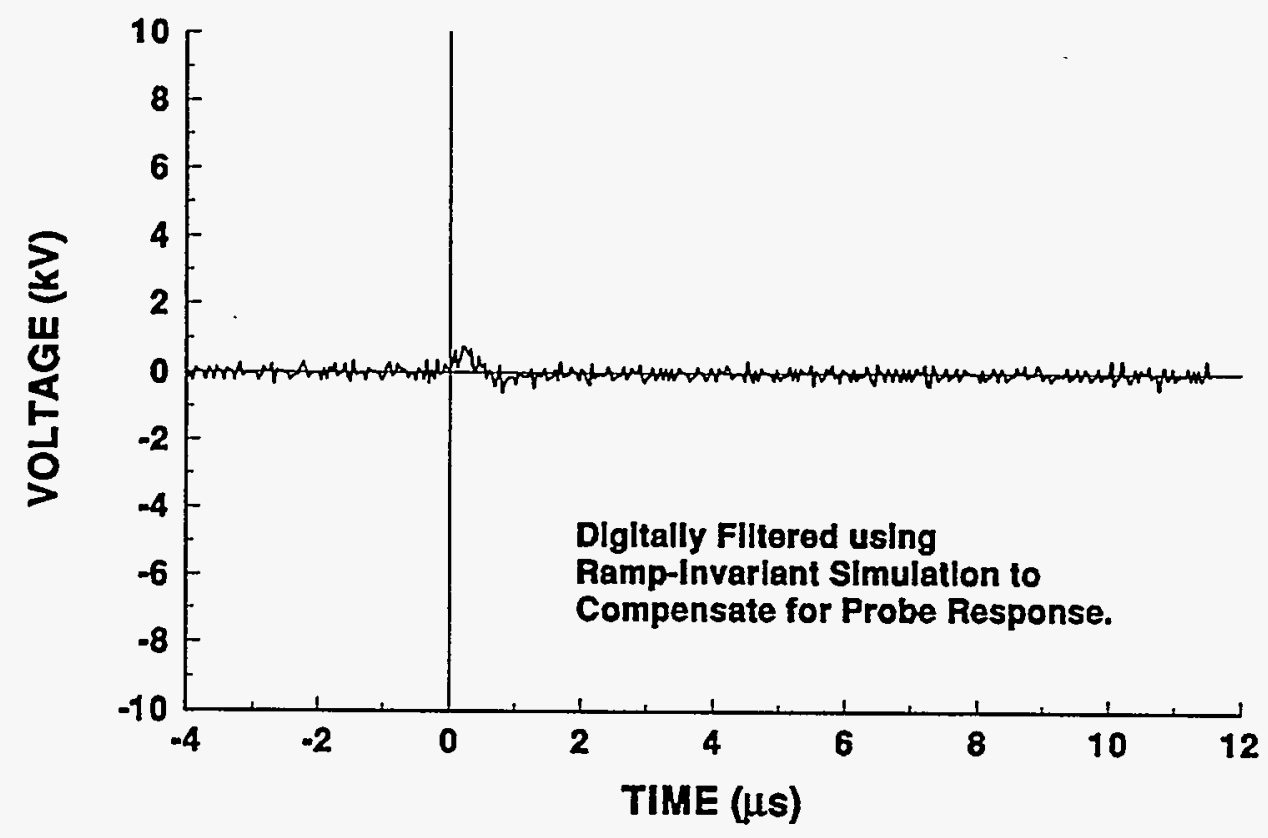

94-06 STROKE 4

TEST POINT 21

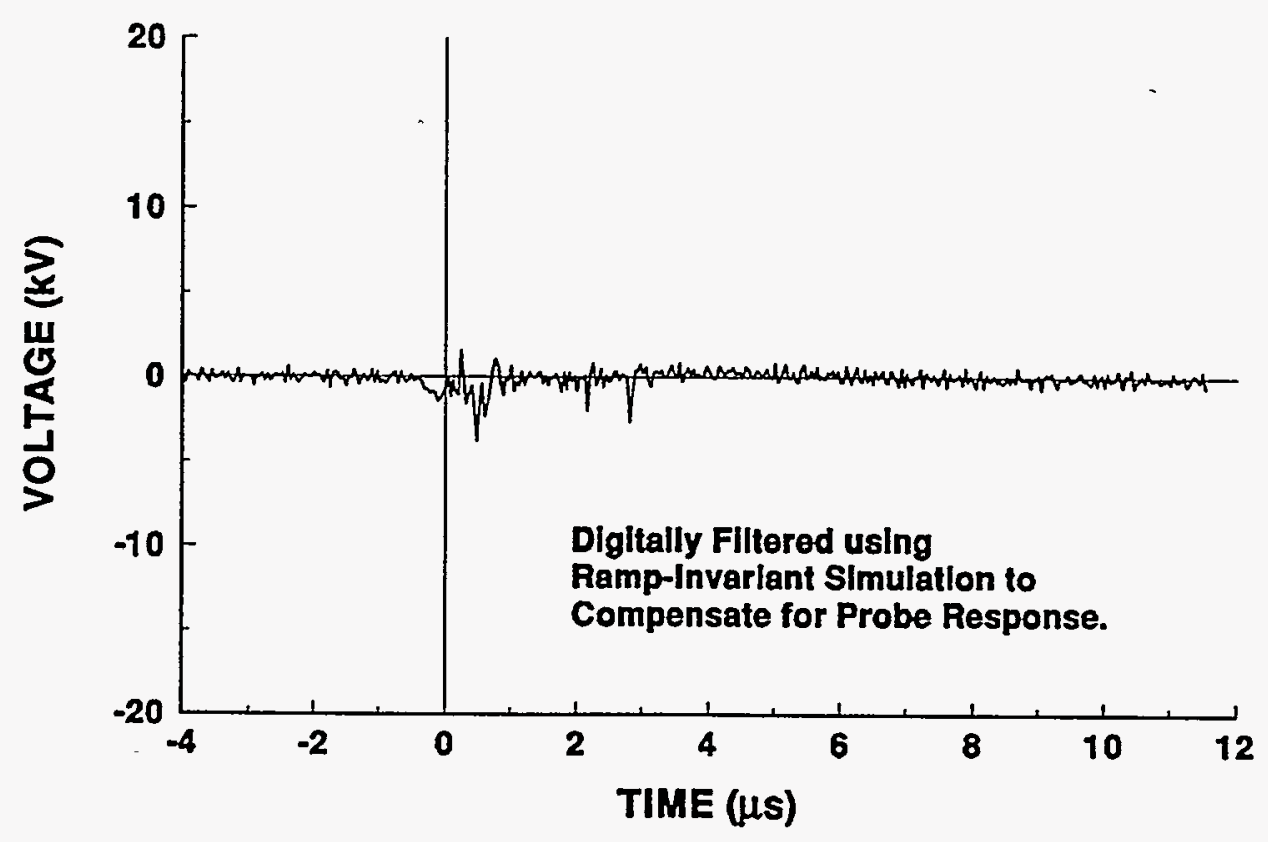




\section{4-06 STROKE 4}

TEST POINT 23

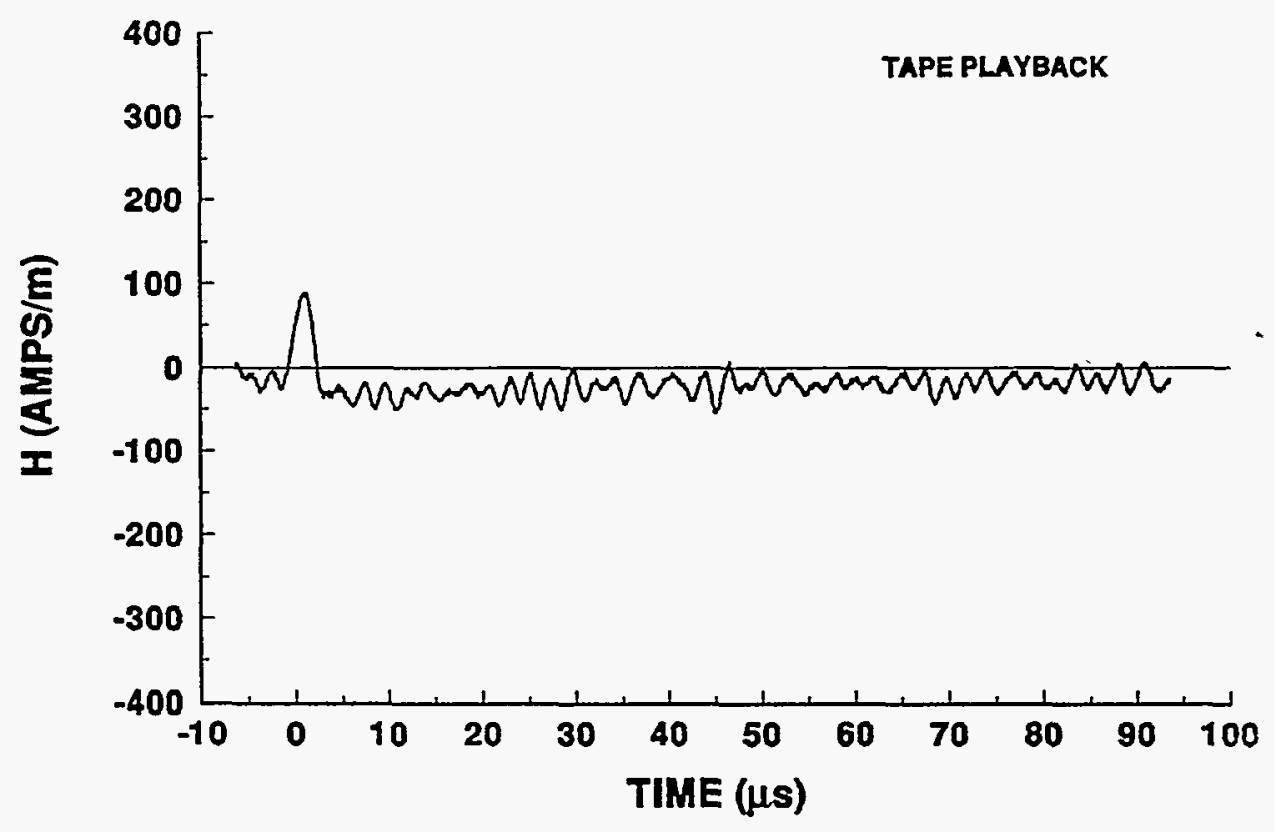




\section{4-06 STROKE 5 \\ INCIDENT CURRENT}
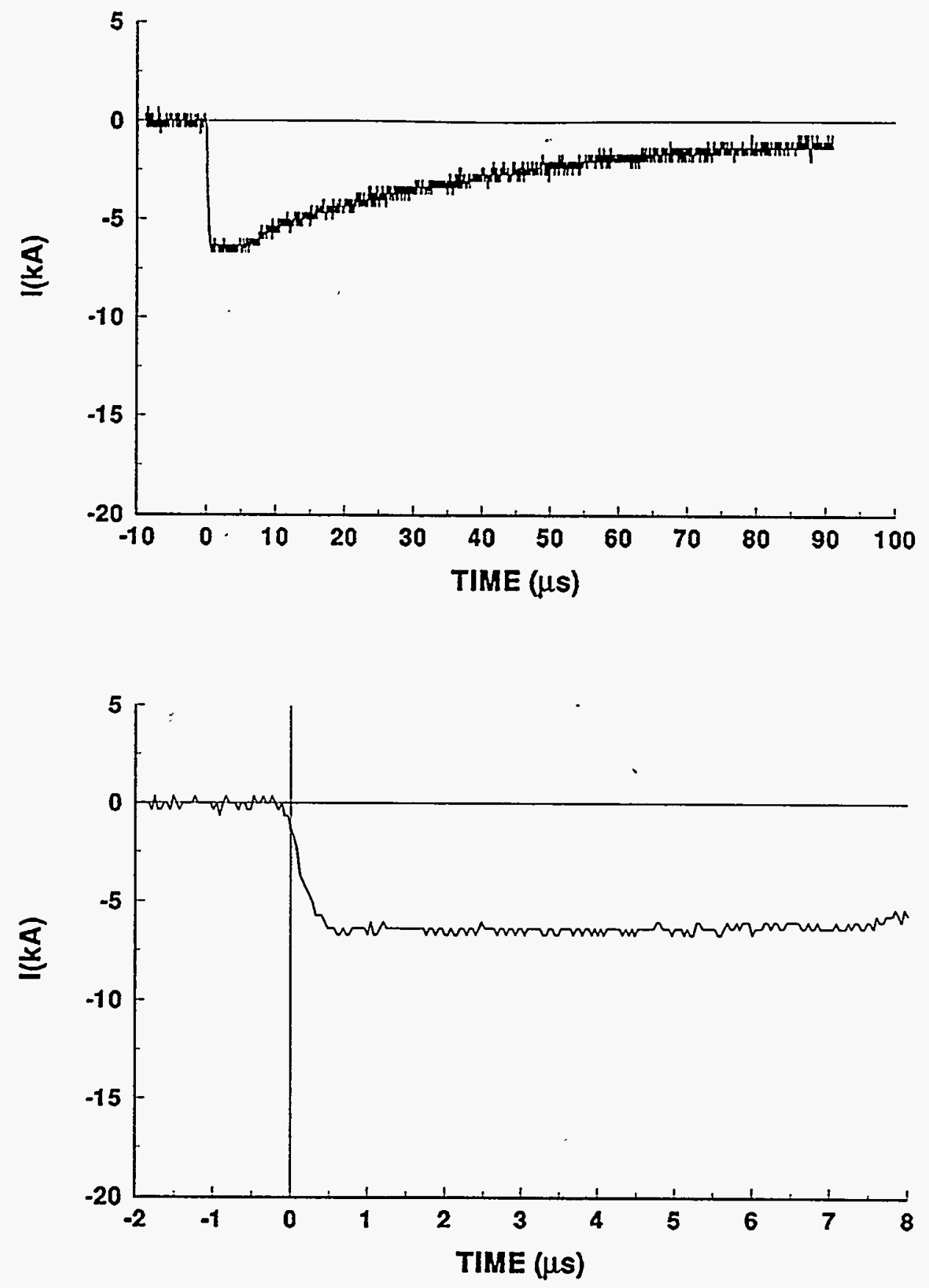


\section{4-06 STROKE 5}

TEST POINT 1

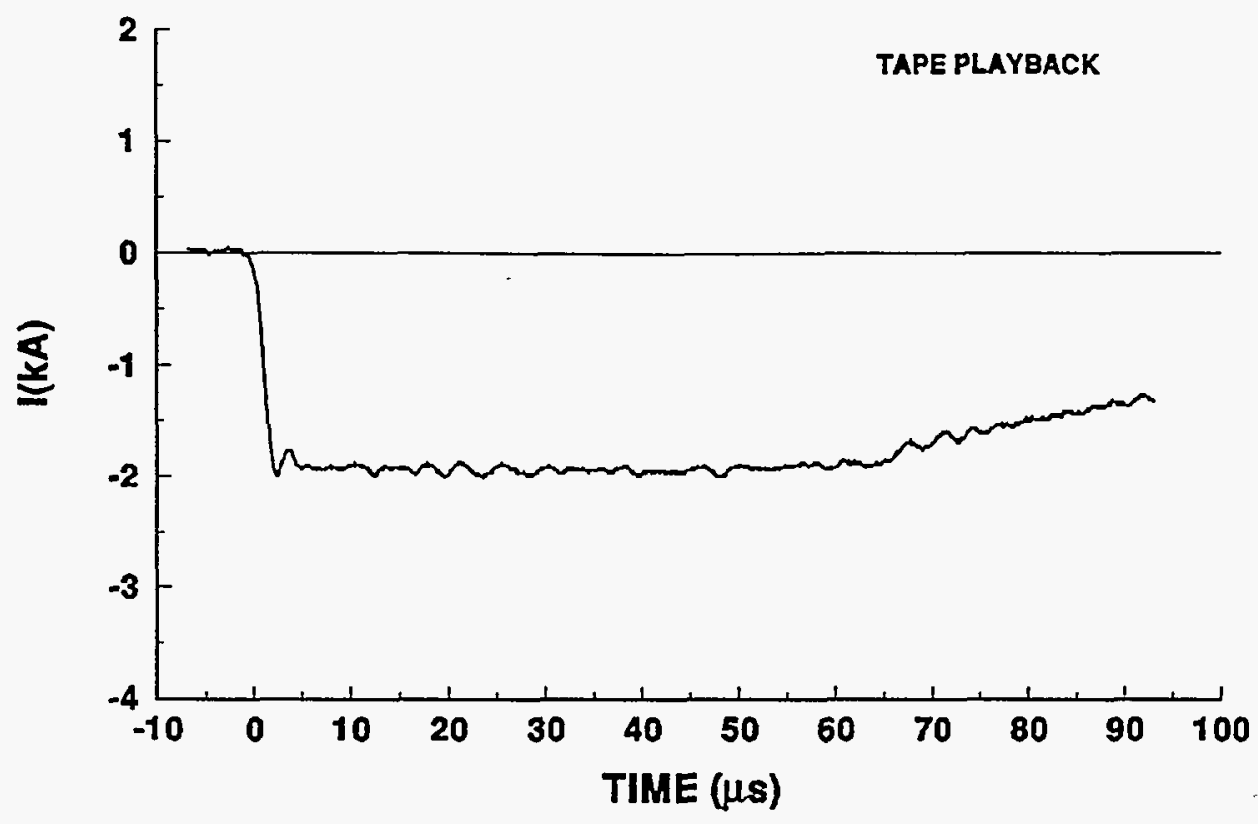

\section{4-06 STROKE 5}

TEST POINT 2

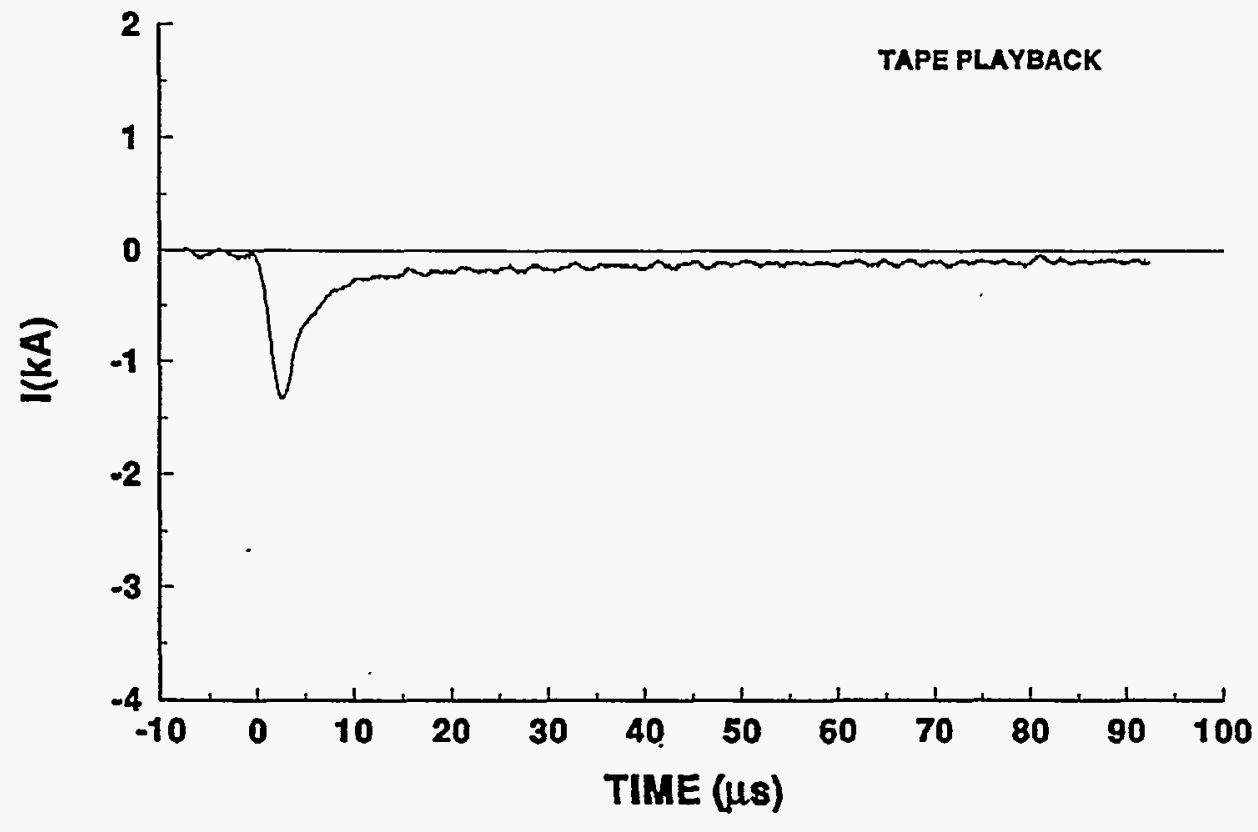




\section{4-06 STROKE 5}

TEST POINT 5
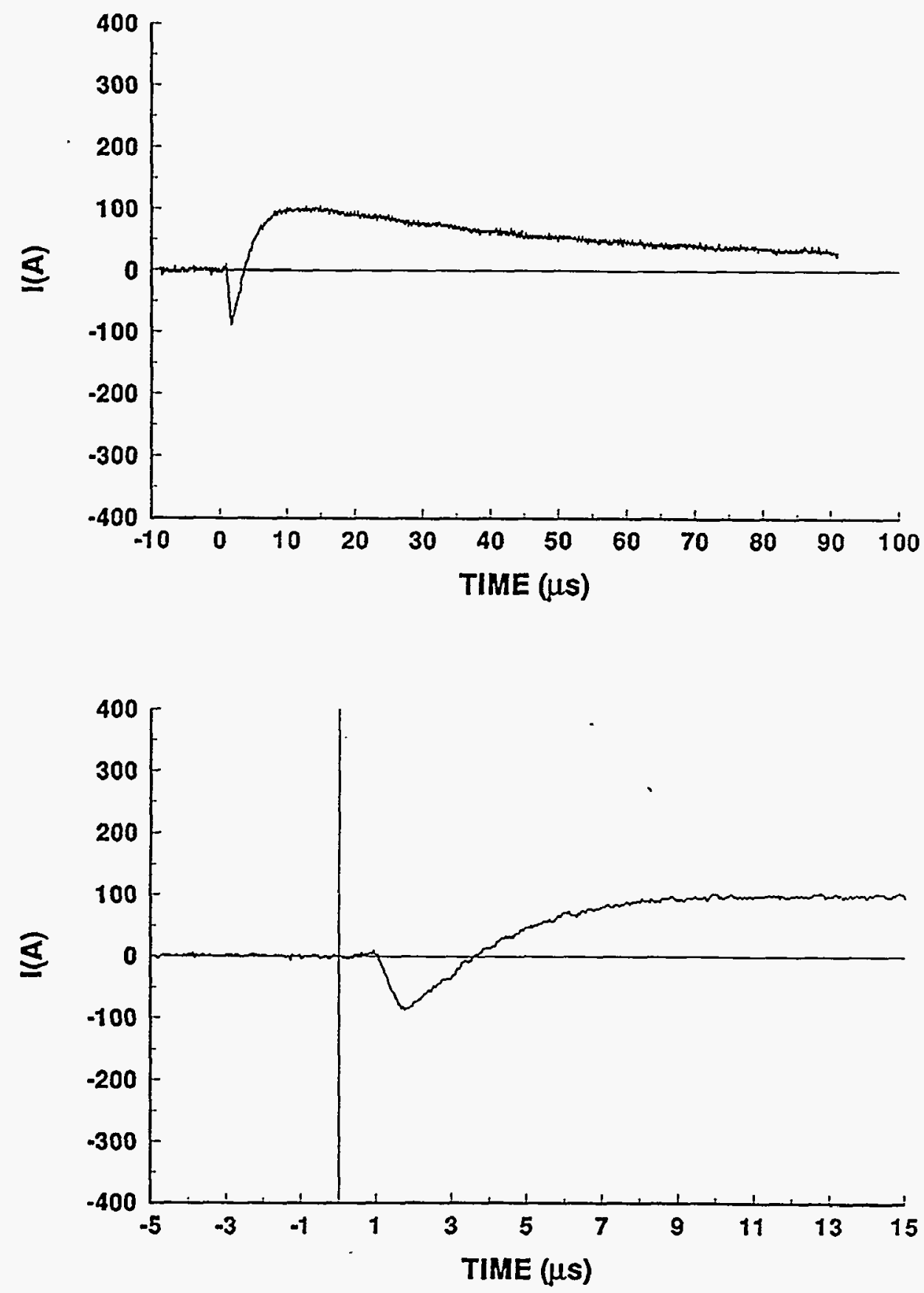


\section{4-06 STROKE 5 \\ TEST POINT 5'}
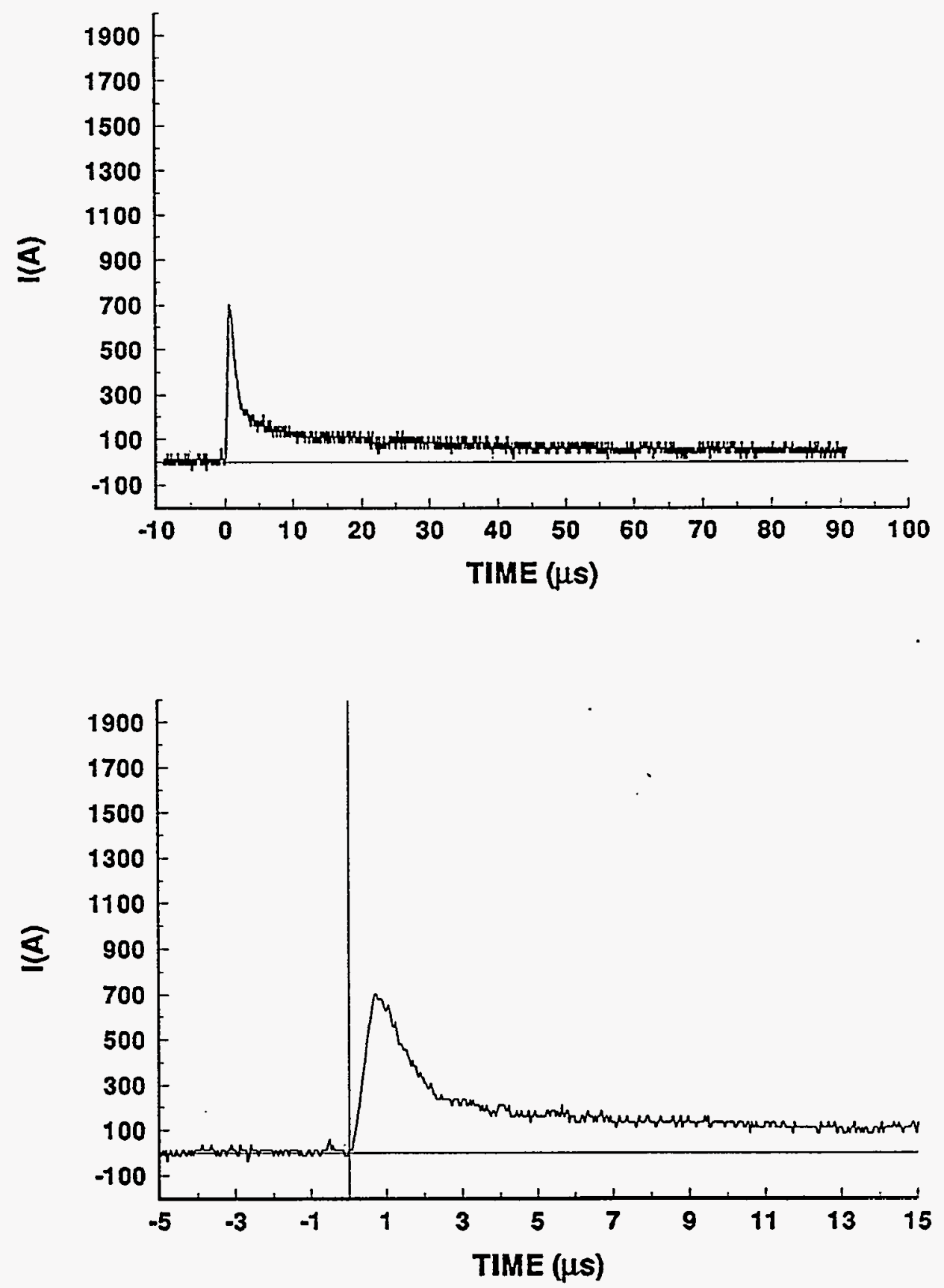


\section{4-06 STROKE 5} TEST POINT 6'

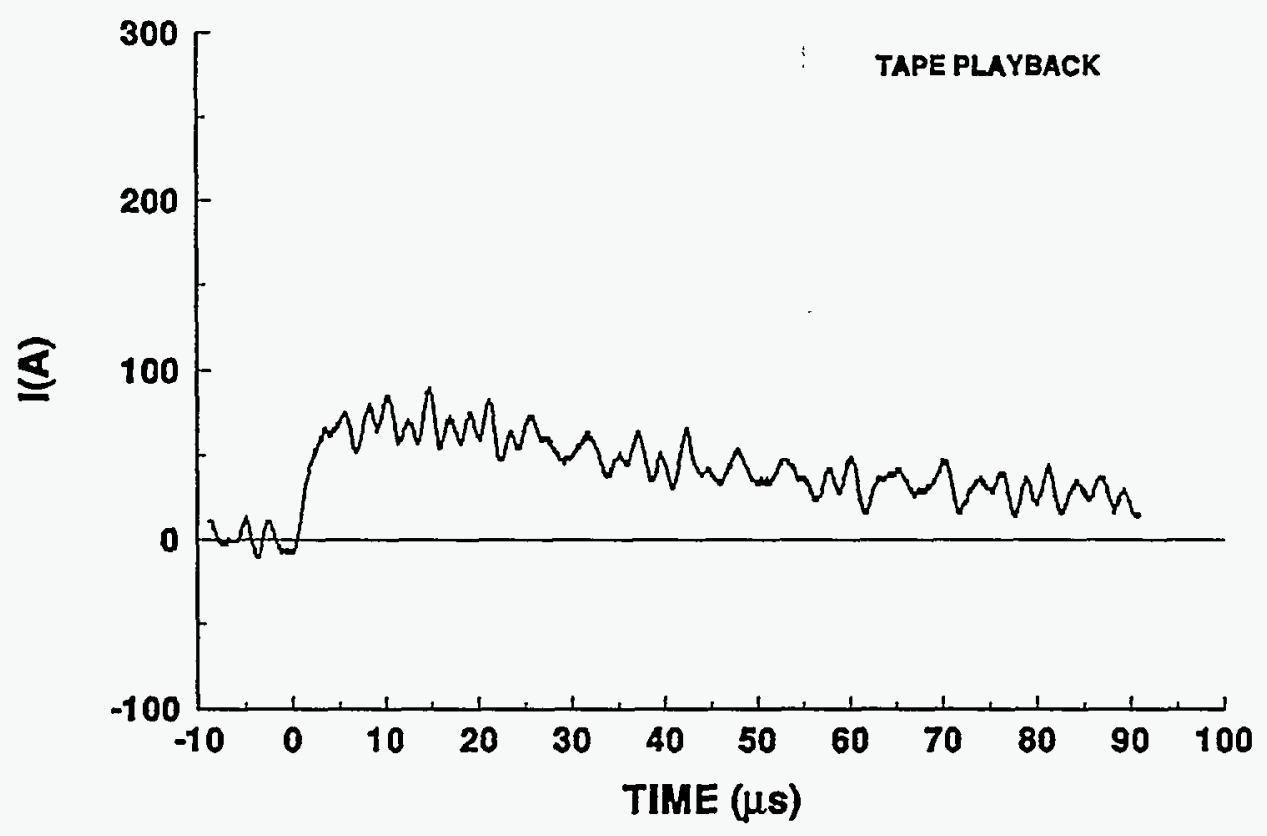




\section{4-06 STROKE 5}

TEST POINT 7
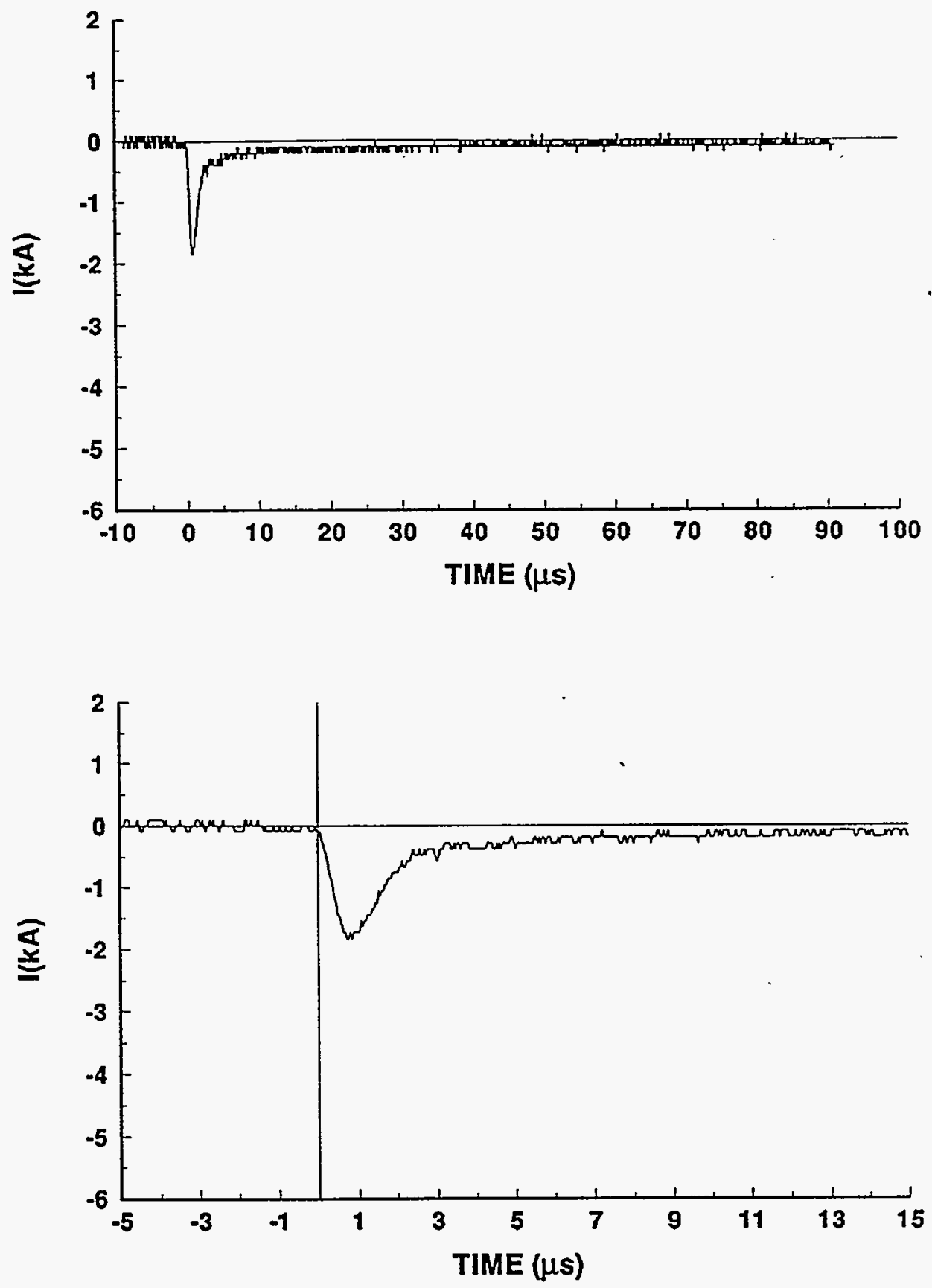


\section{4-06 STROKE 5 \\ TEST POINT 8}
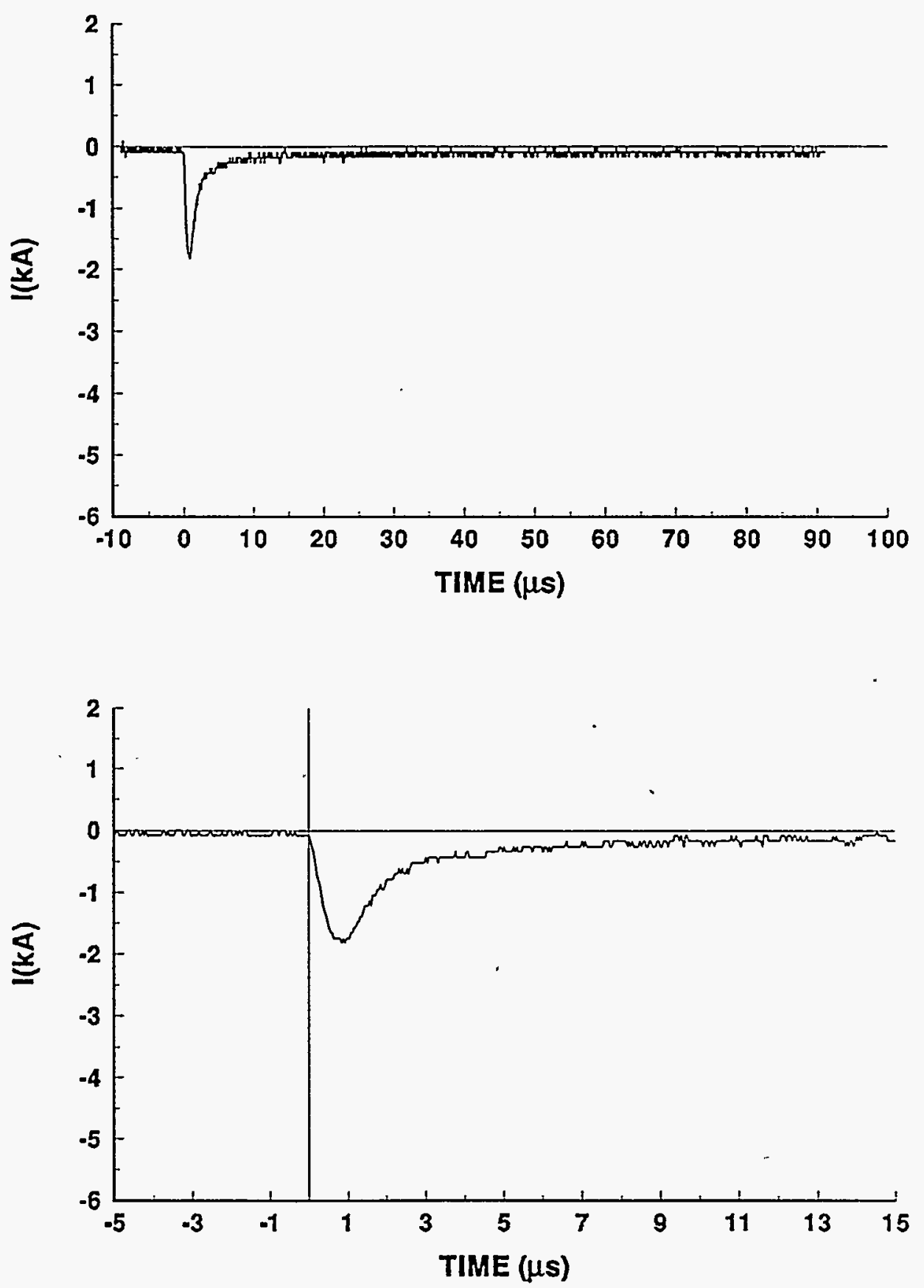


\section{4-06 STROKE 5}

TEST POINT 10

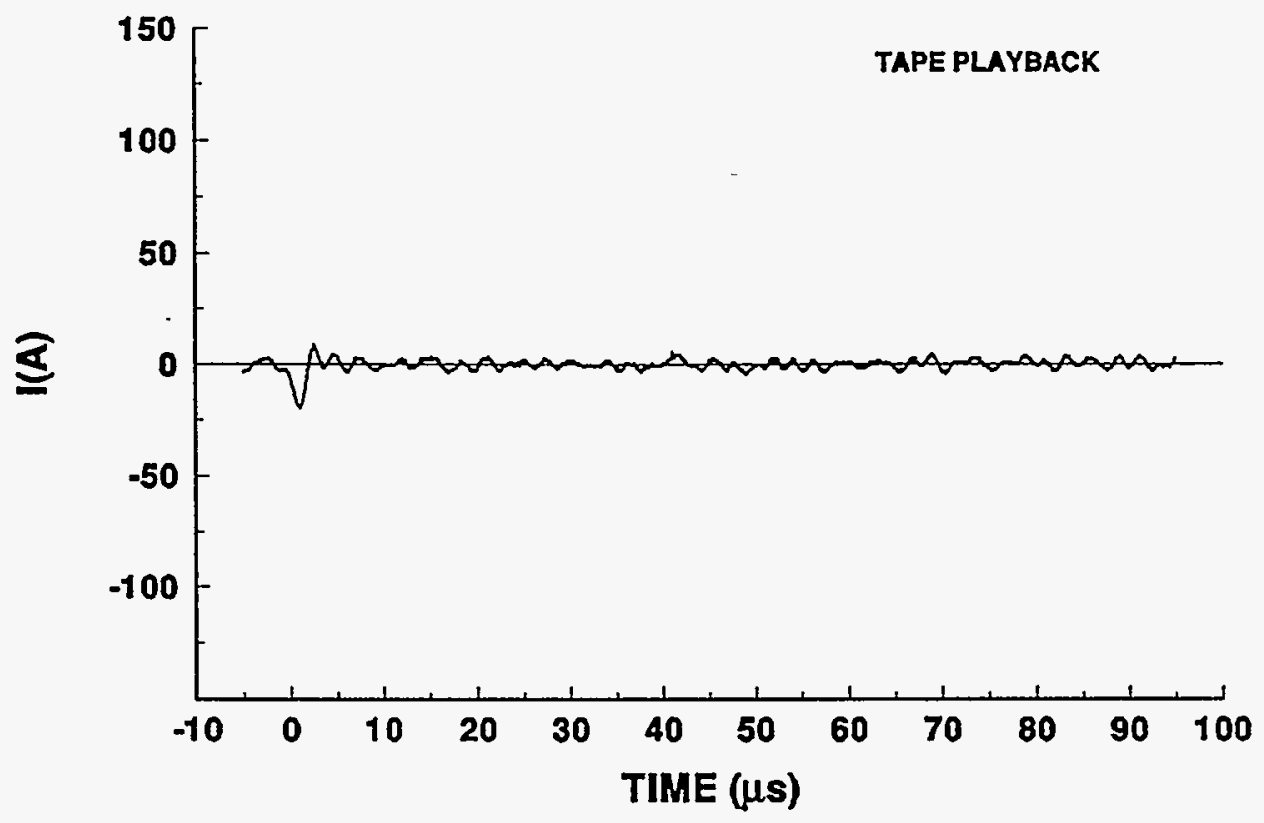

94-06 STROKE 5

TEST POINT 11

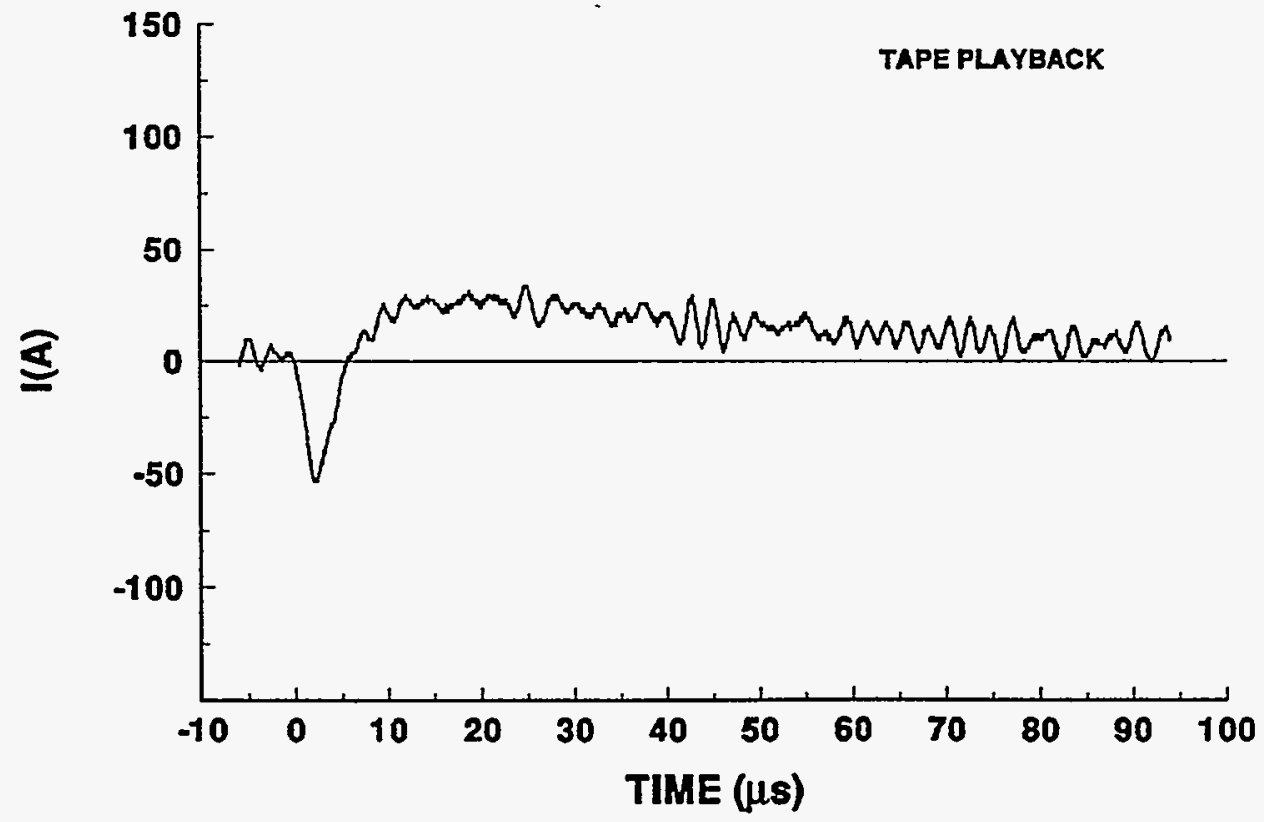




\section{4-06 STROKE 5}

TEST POINT 12

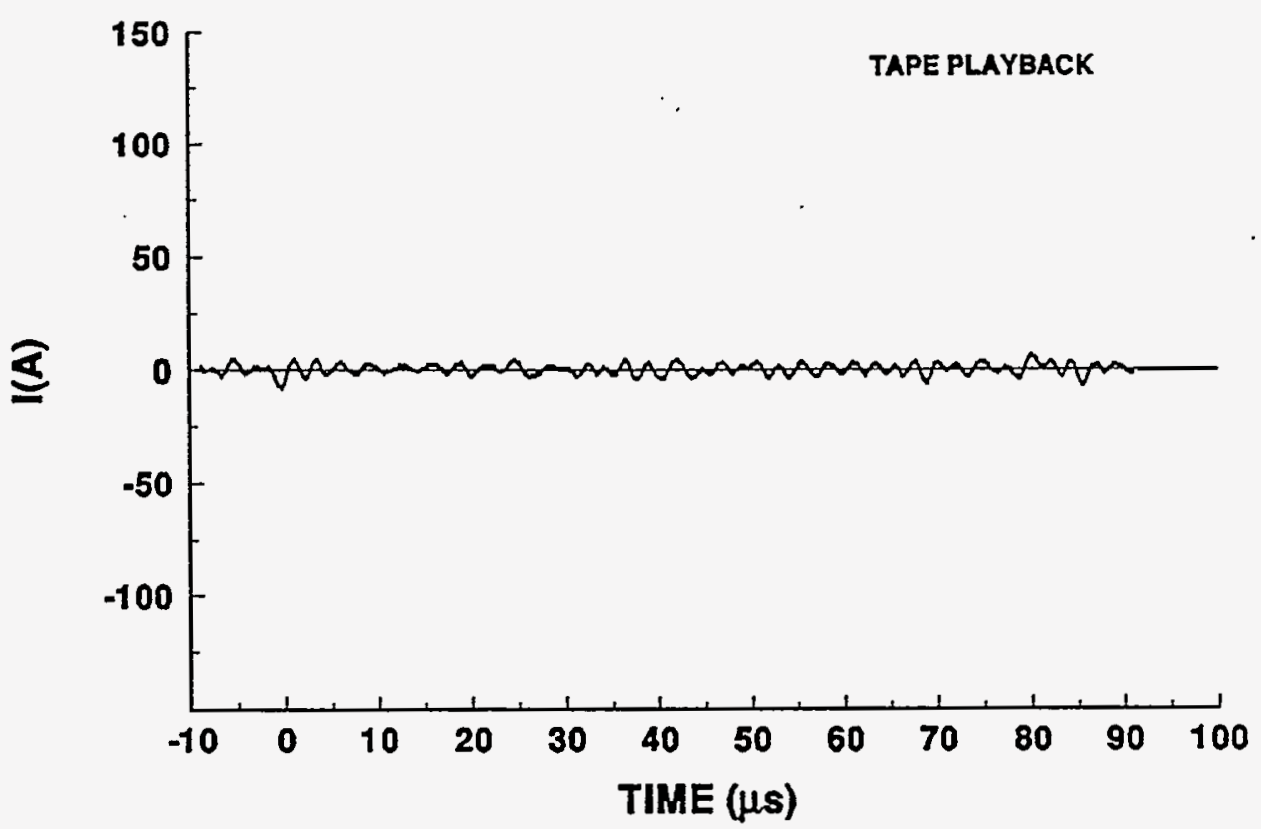

94-06 STROKE.5

TEST POINT 13

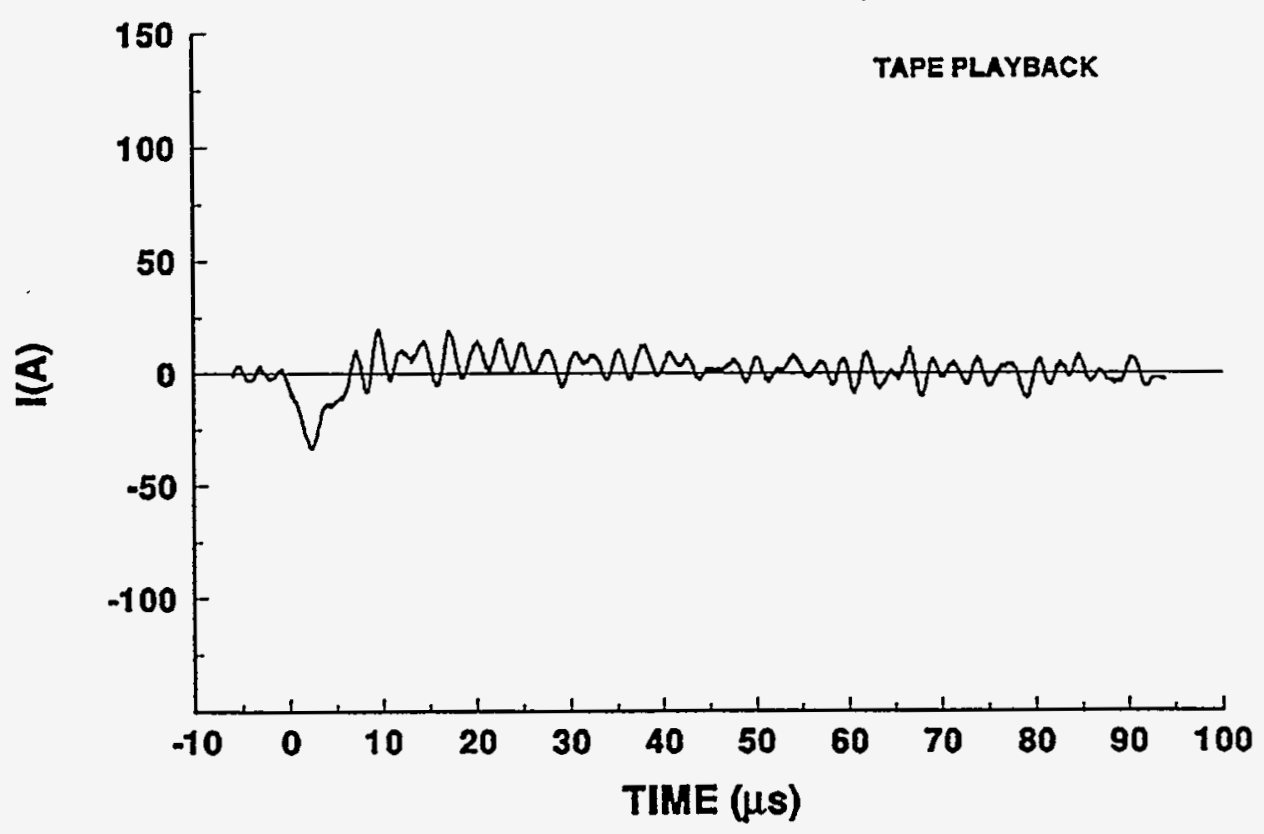




\section{4-06 STROKE 5}

TEST POINT 14
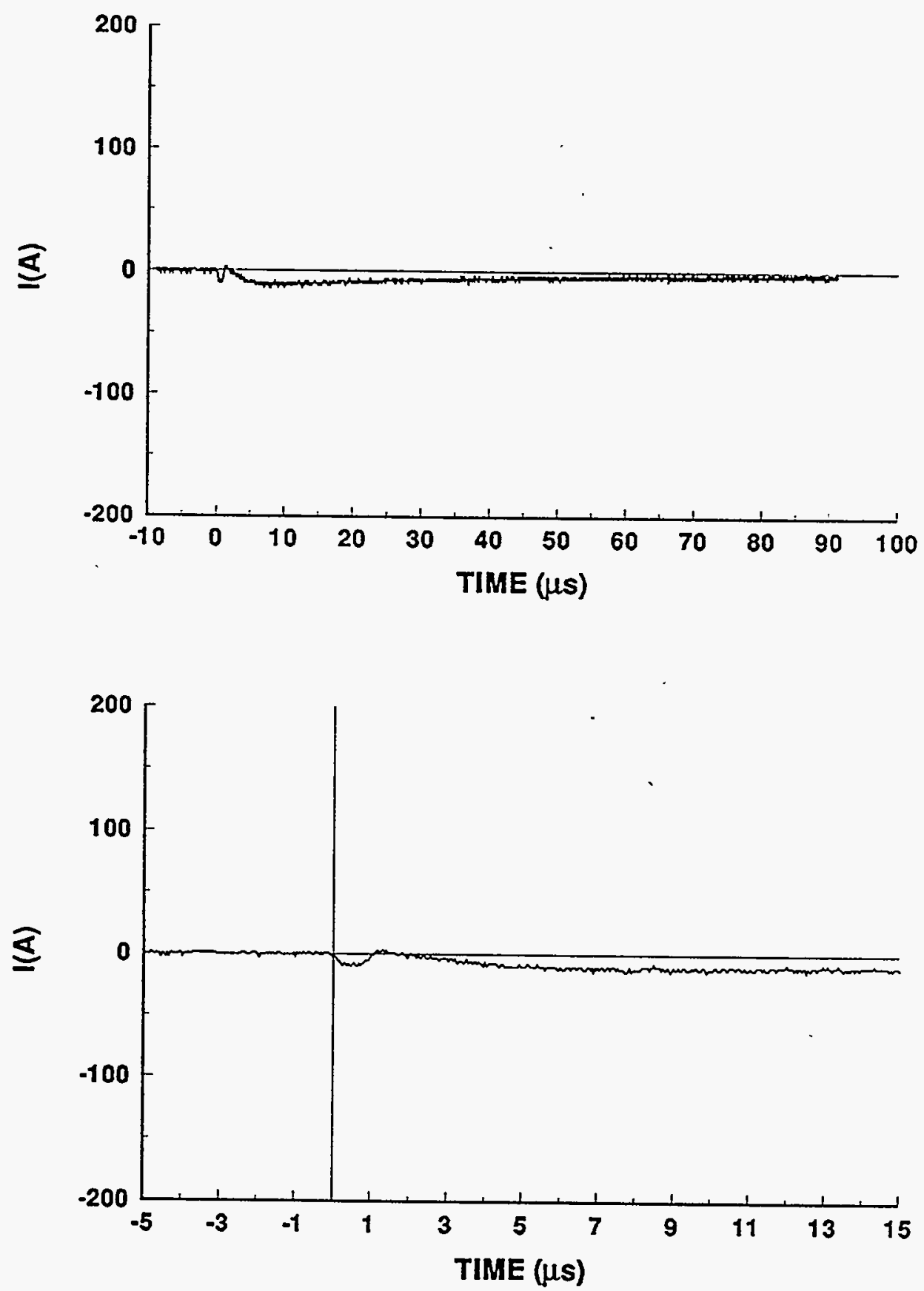


\section{4-06 STROKE 5}

TEST POINT 15
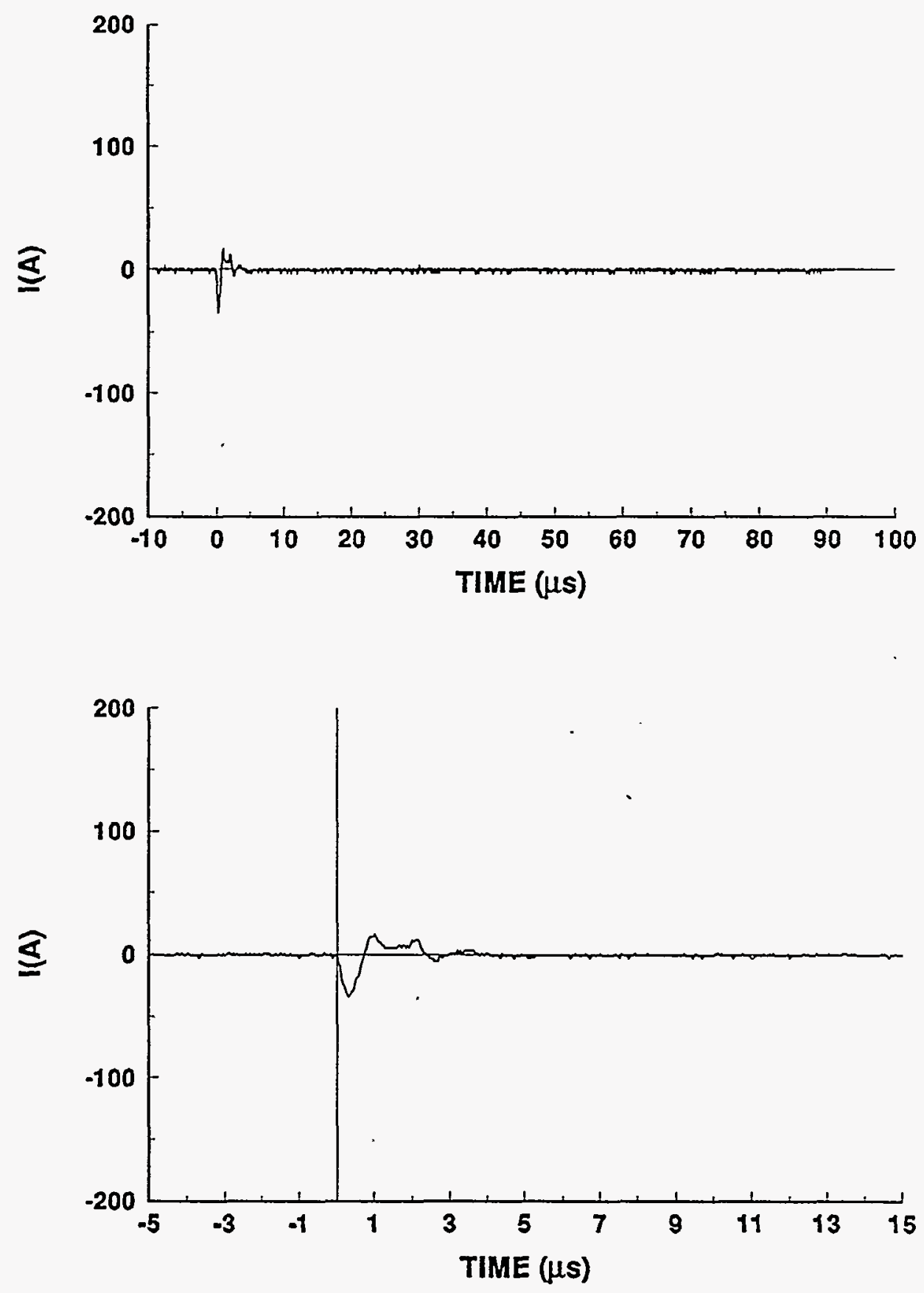


\section{4-06 STROKE 5}

TEST POINT 20

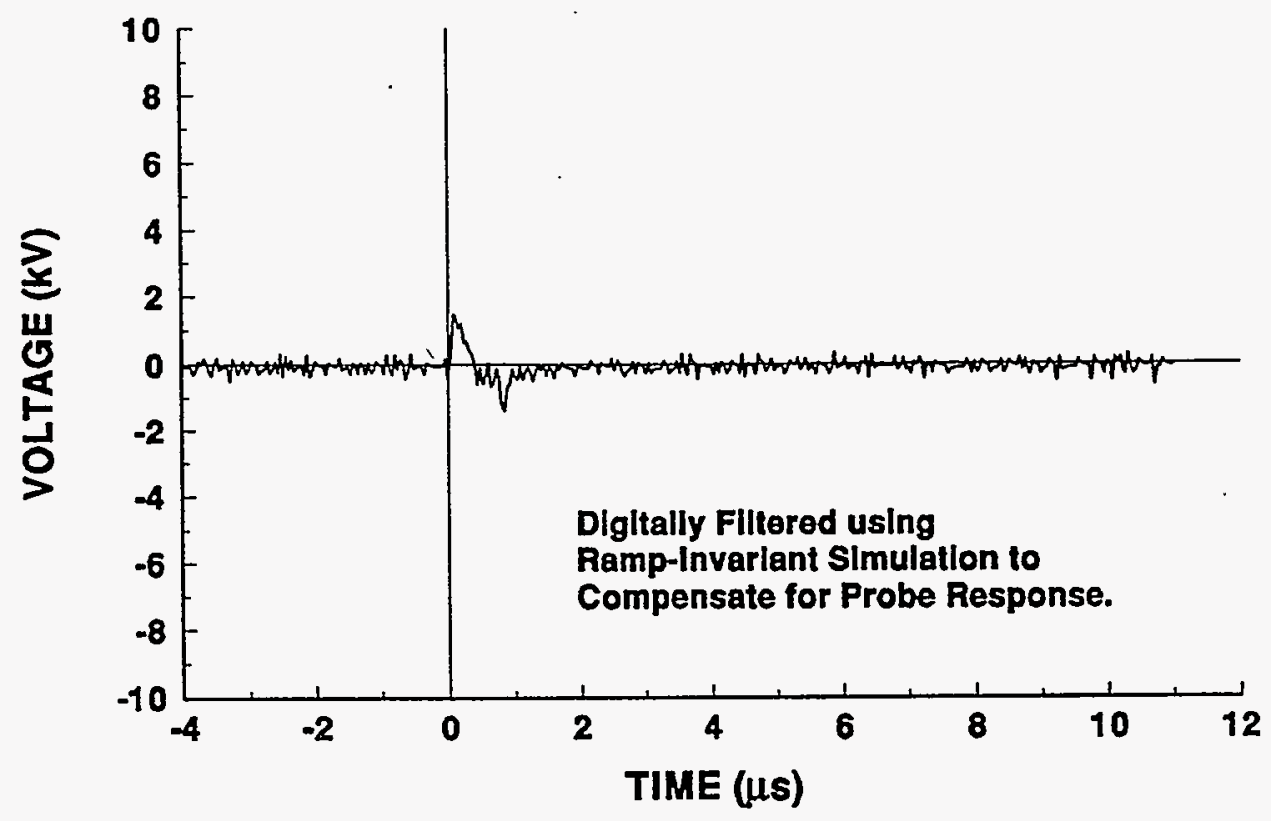

9,4-06 STROKE 5

TEST POINT 21

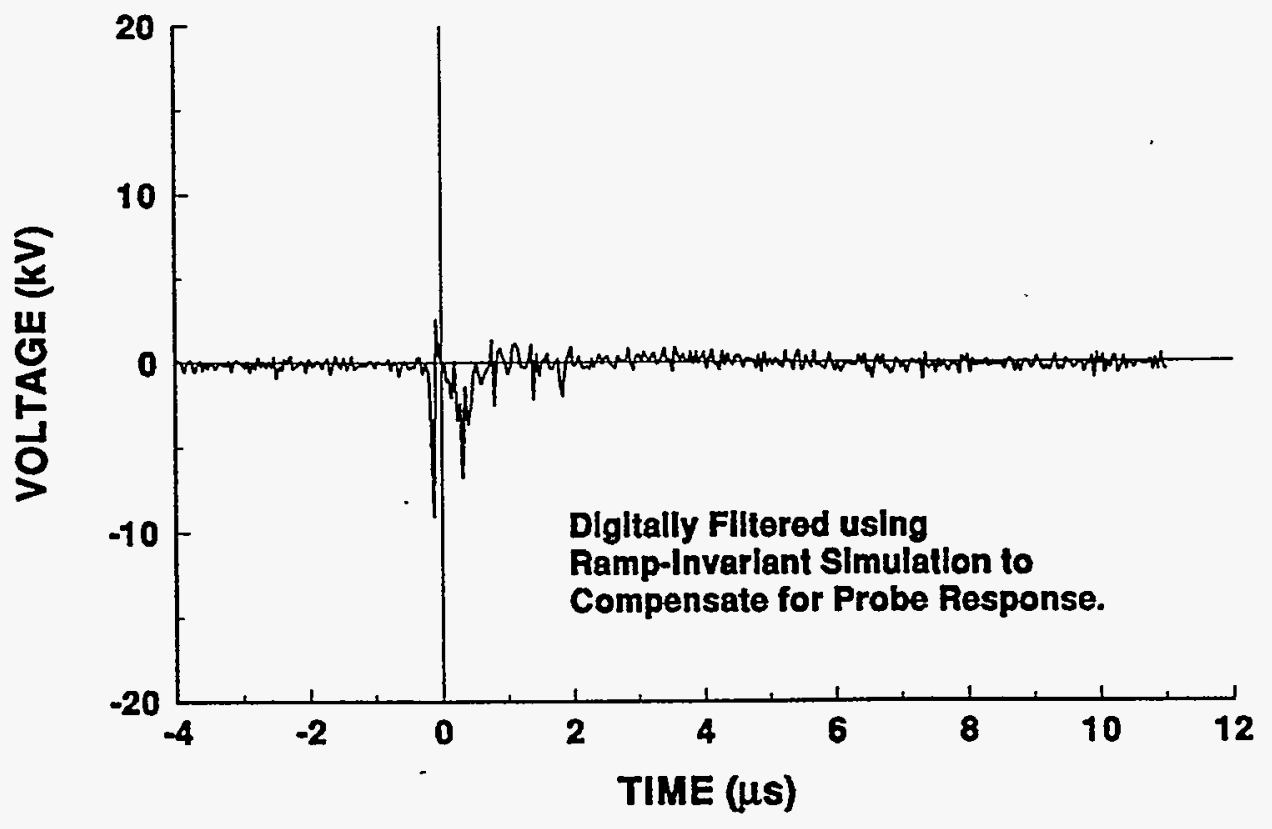




\section{4-06 STROKE 5}

TEST POINT 23

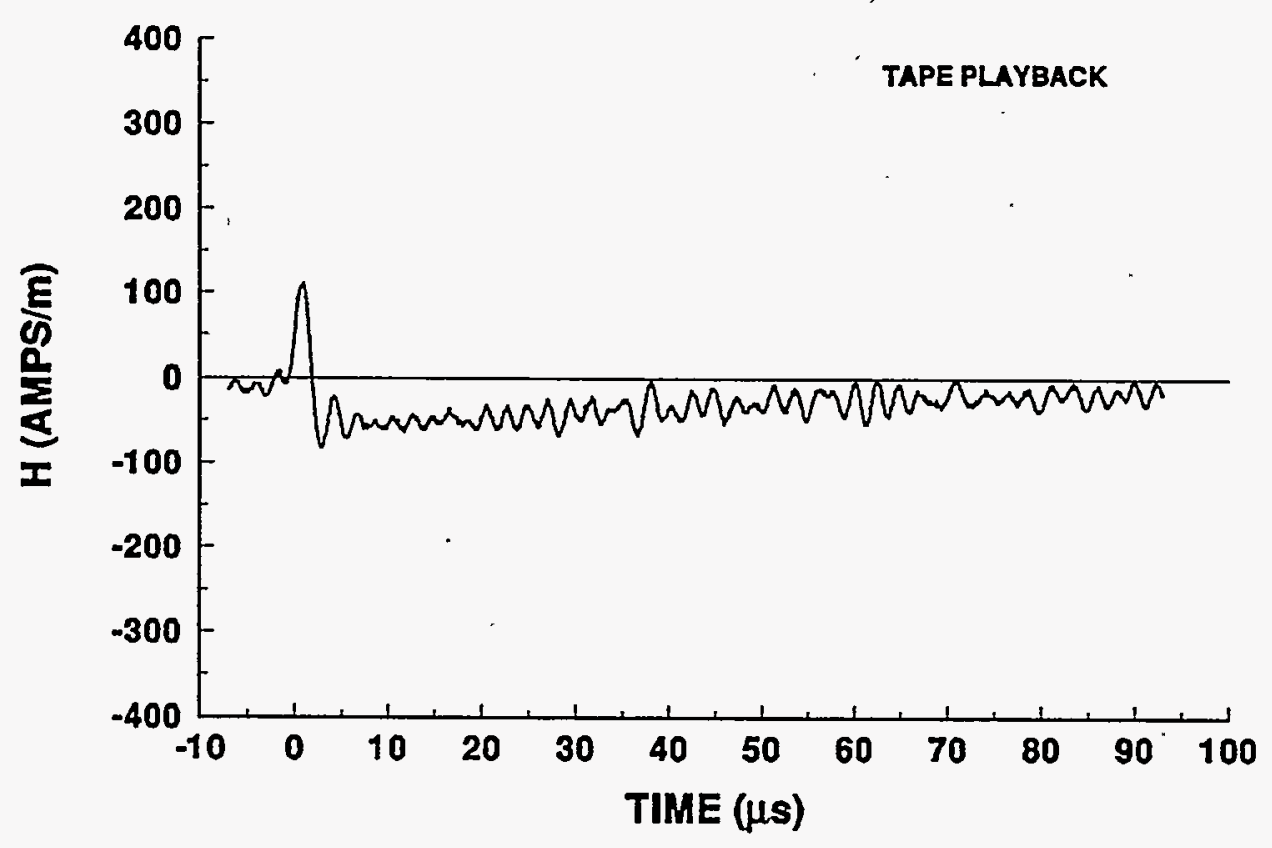




\section{4-06 STROKE 6 \\ INCIDENT CURRENT}
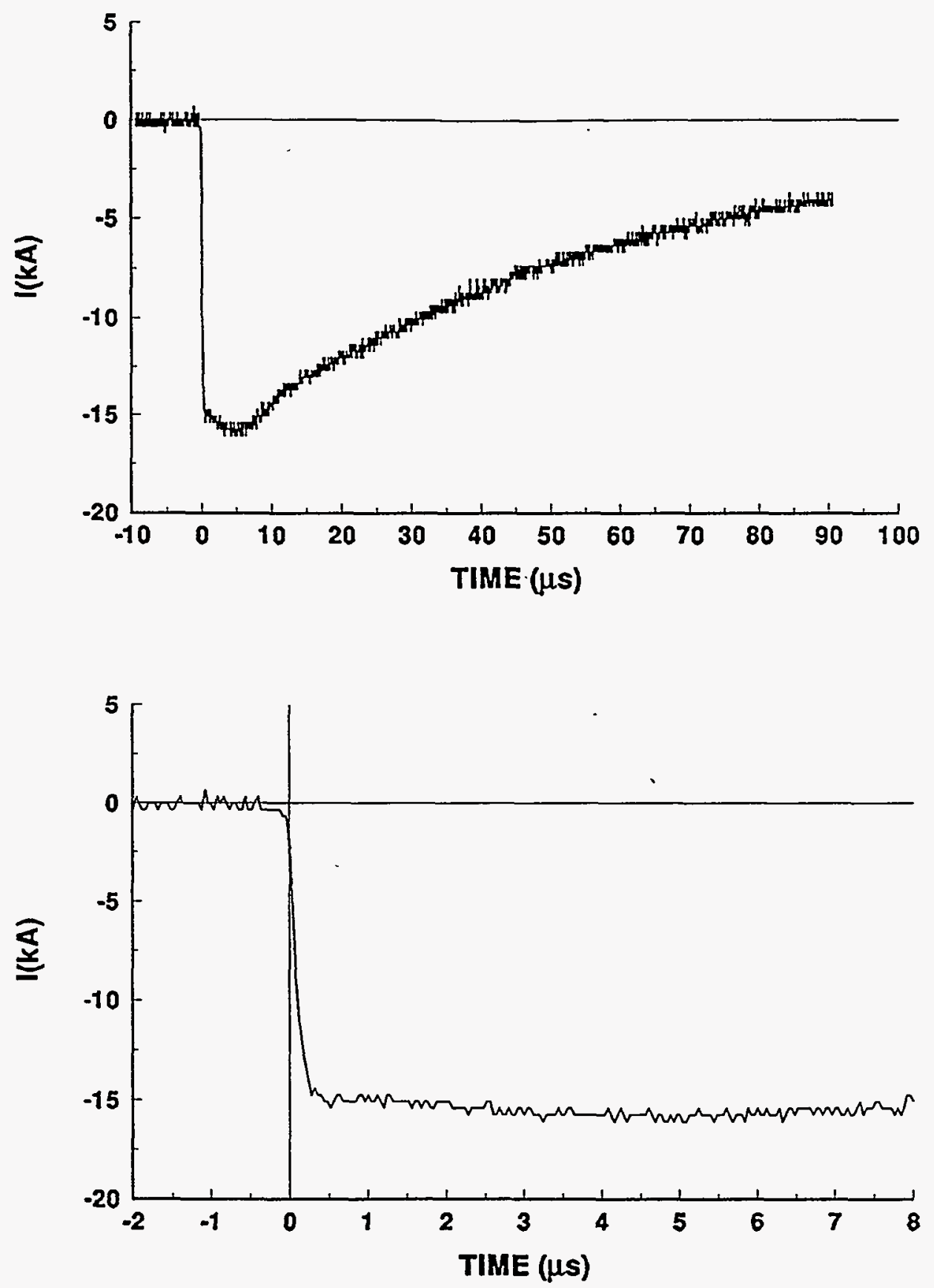


\section{4-06 STROKE 6}

TEST POINT 1

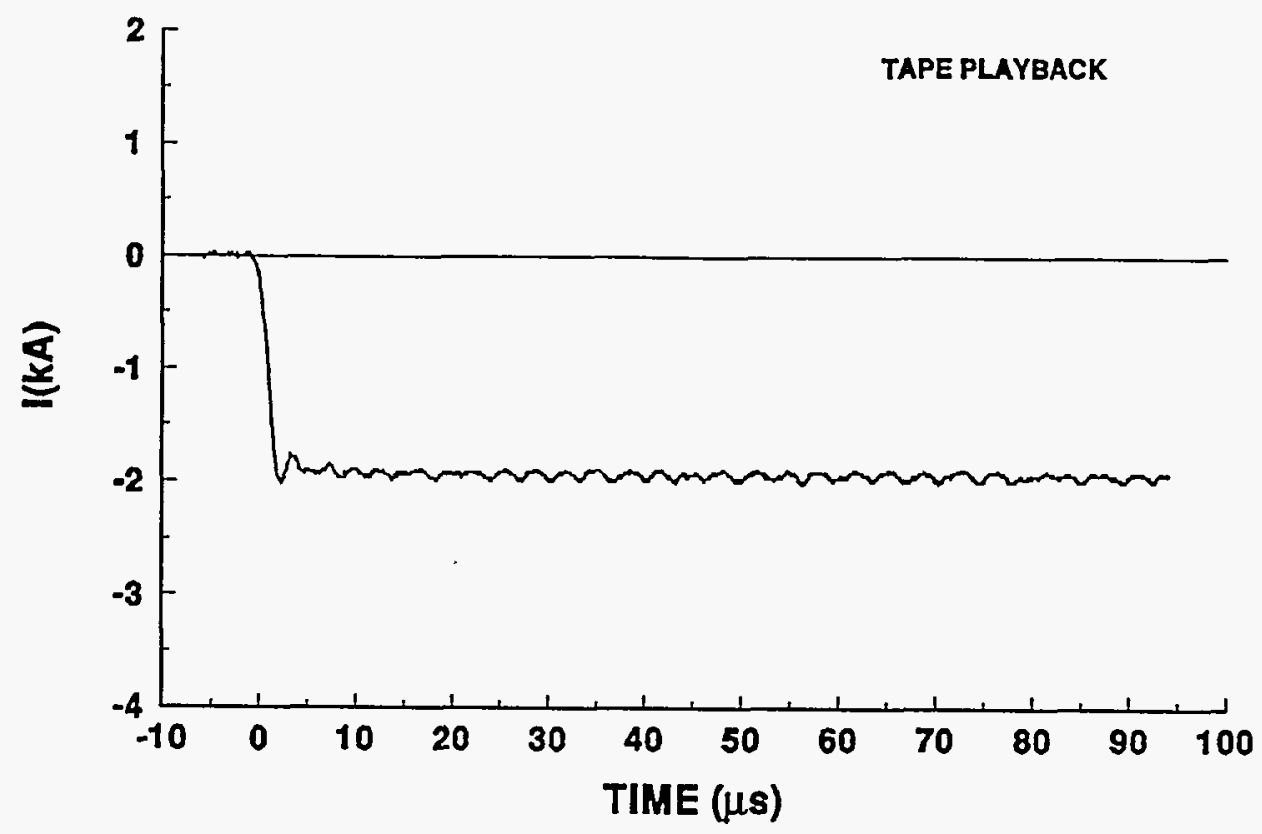

94-02 STROKE 6 .

TEST POINT 2

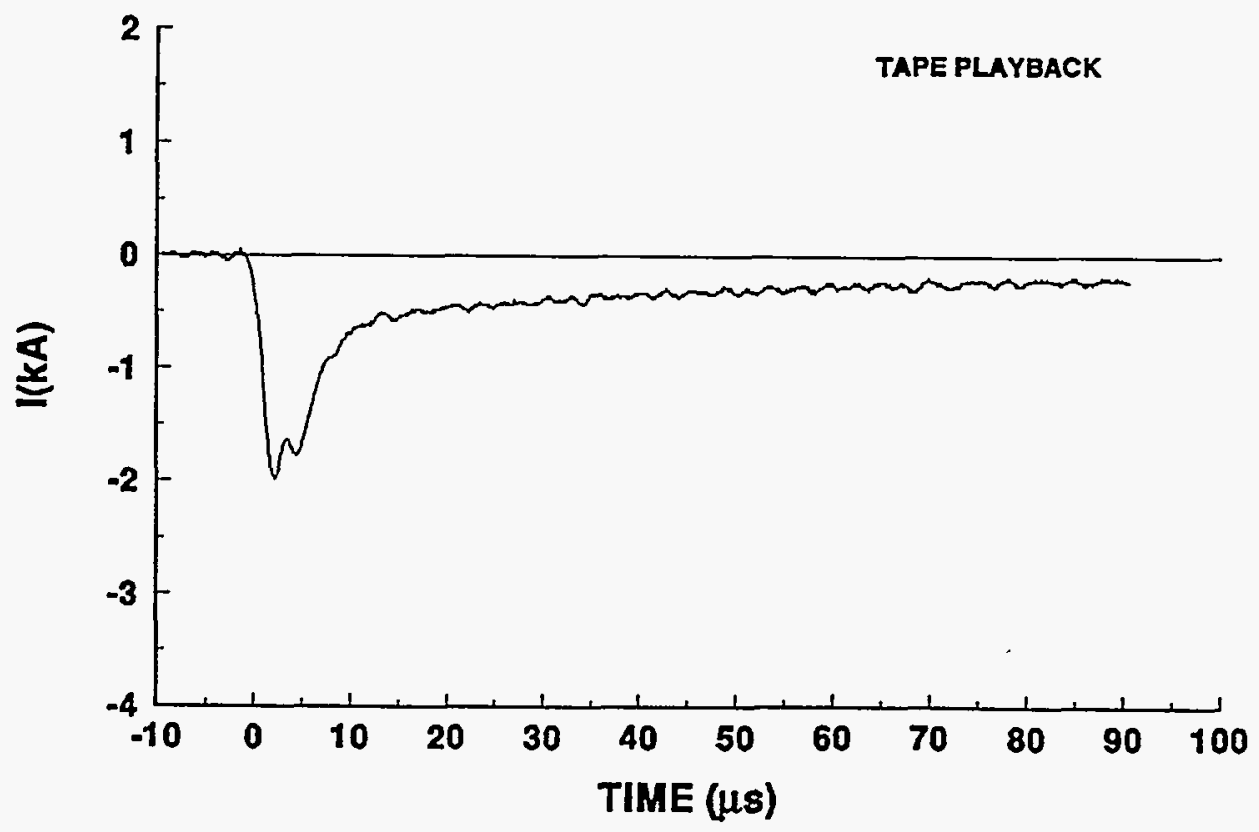




\section{4-06 STROKE 6 \\ TEST POINT 5}
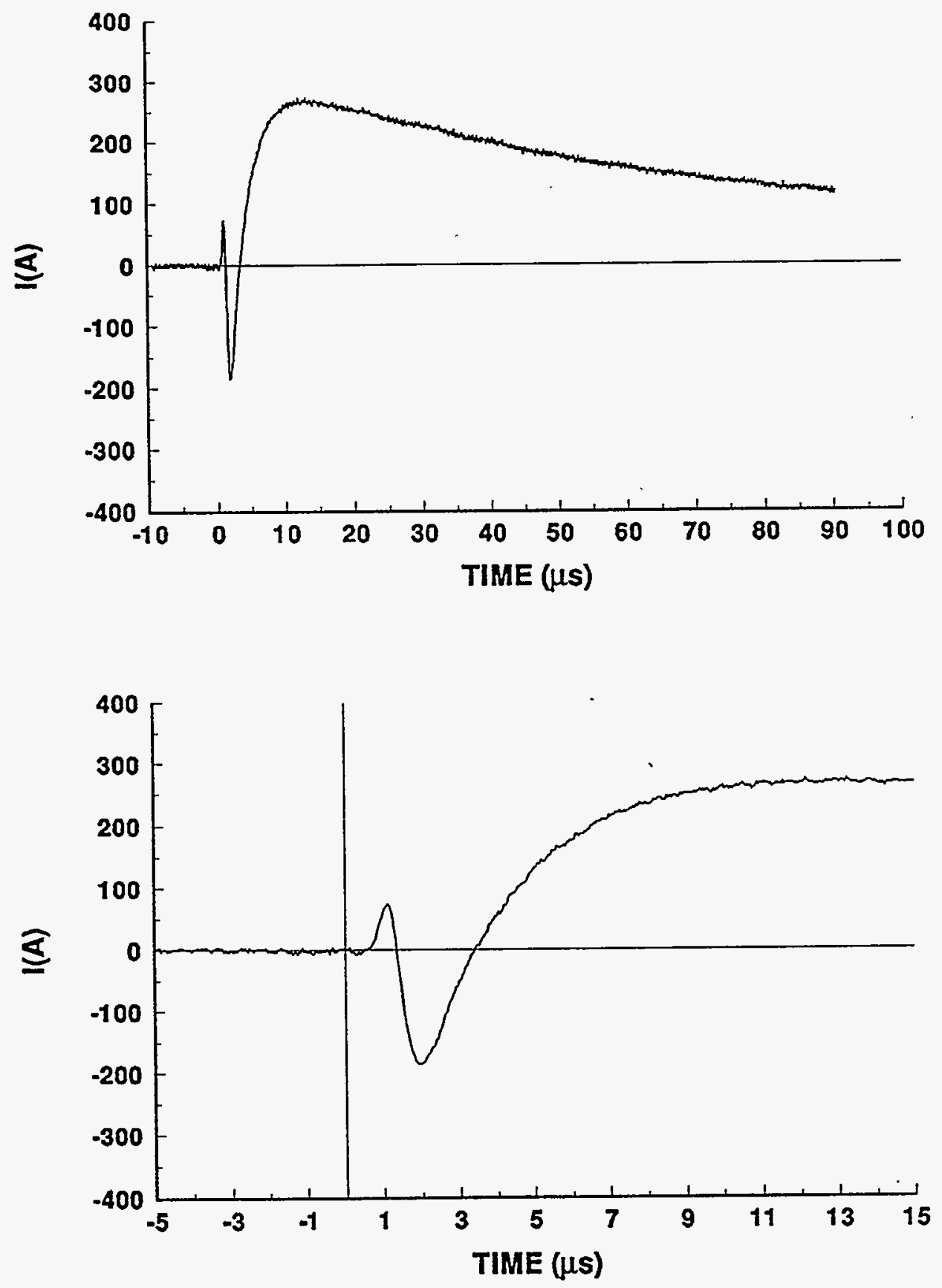


\section{4-06 STROKE 6}

\section{TEST POINT 5'}
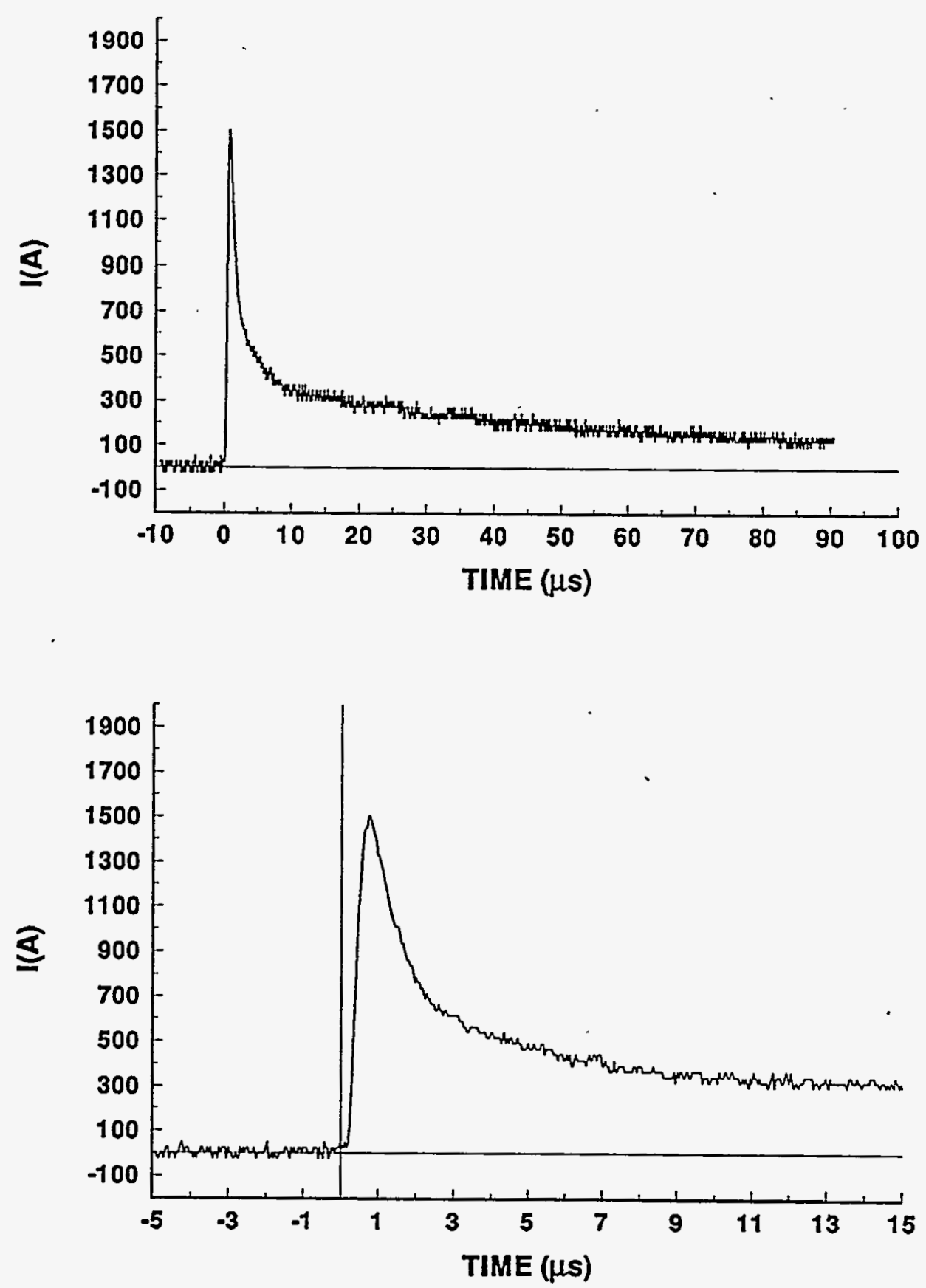


\section{4-06 STROKE 6}

TEST POINT 6'

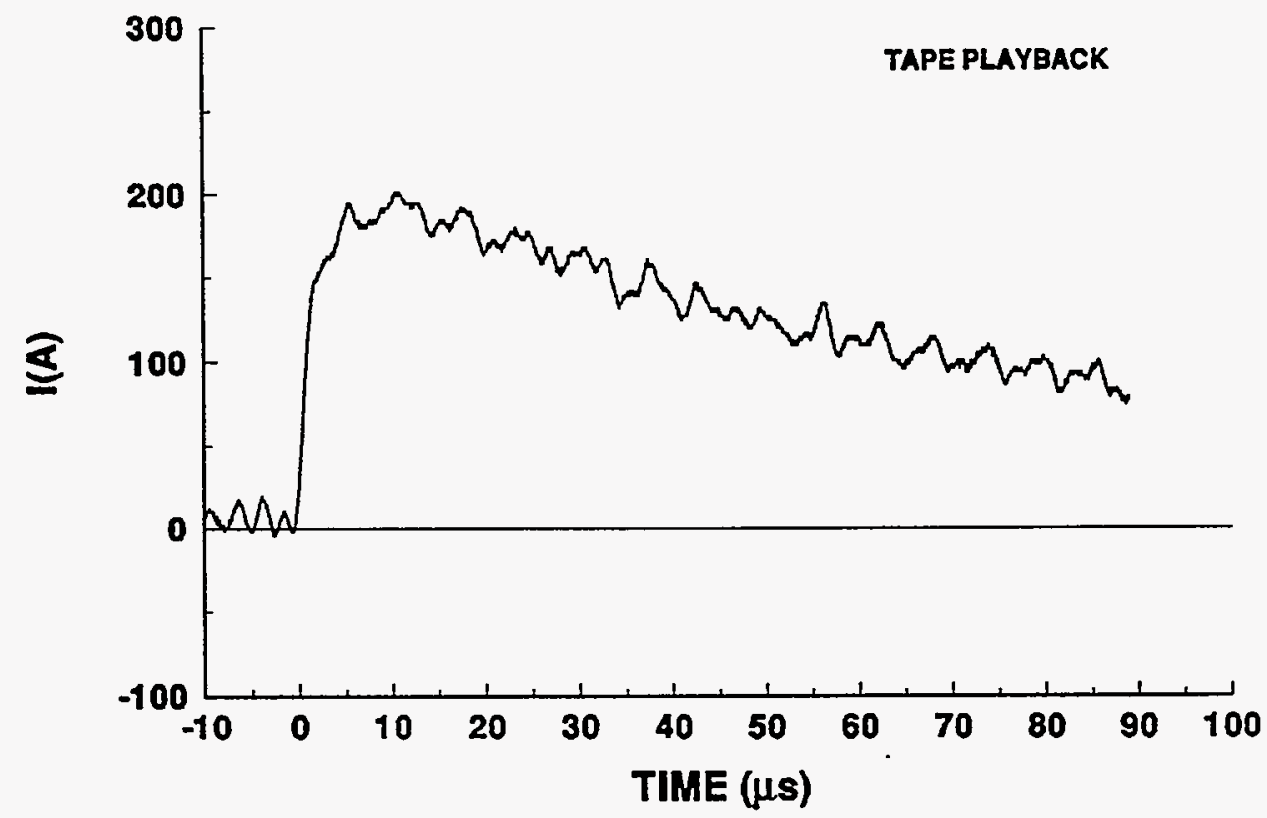




\section{4-06 STROKE 6 \\ TEST POINT 7}
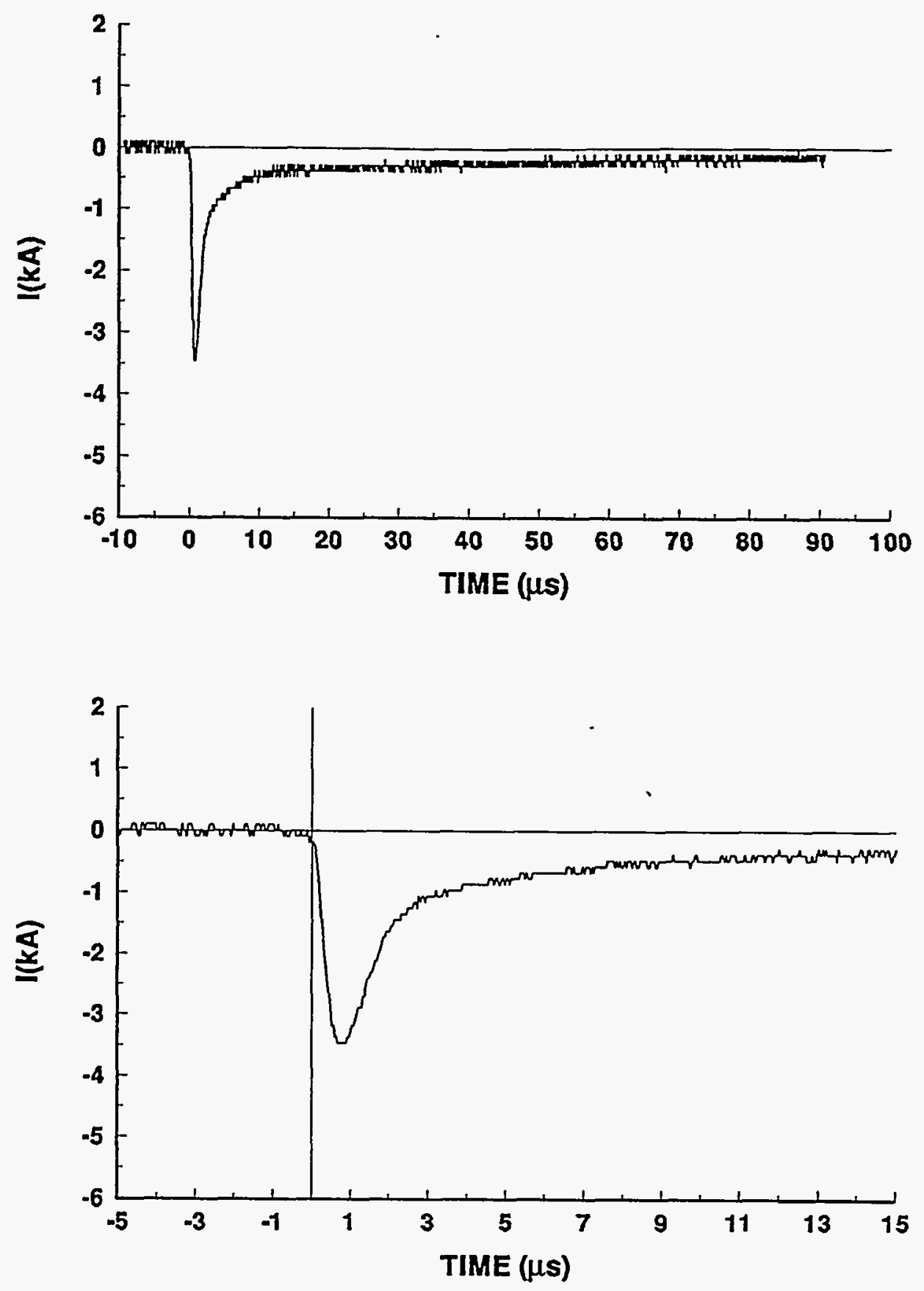


\section{4-06 STROKE 6}

\section{TEST POINT 8}
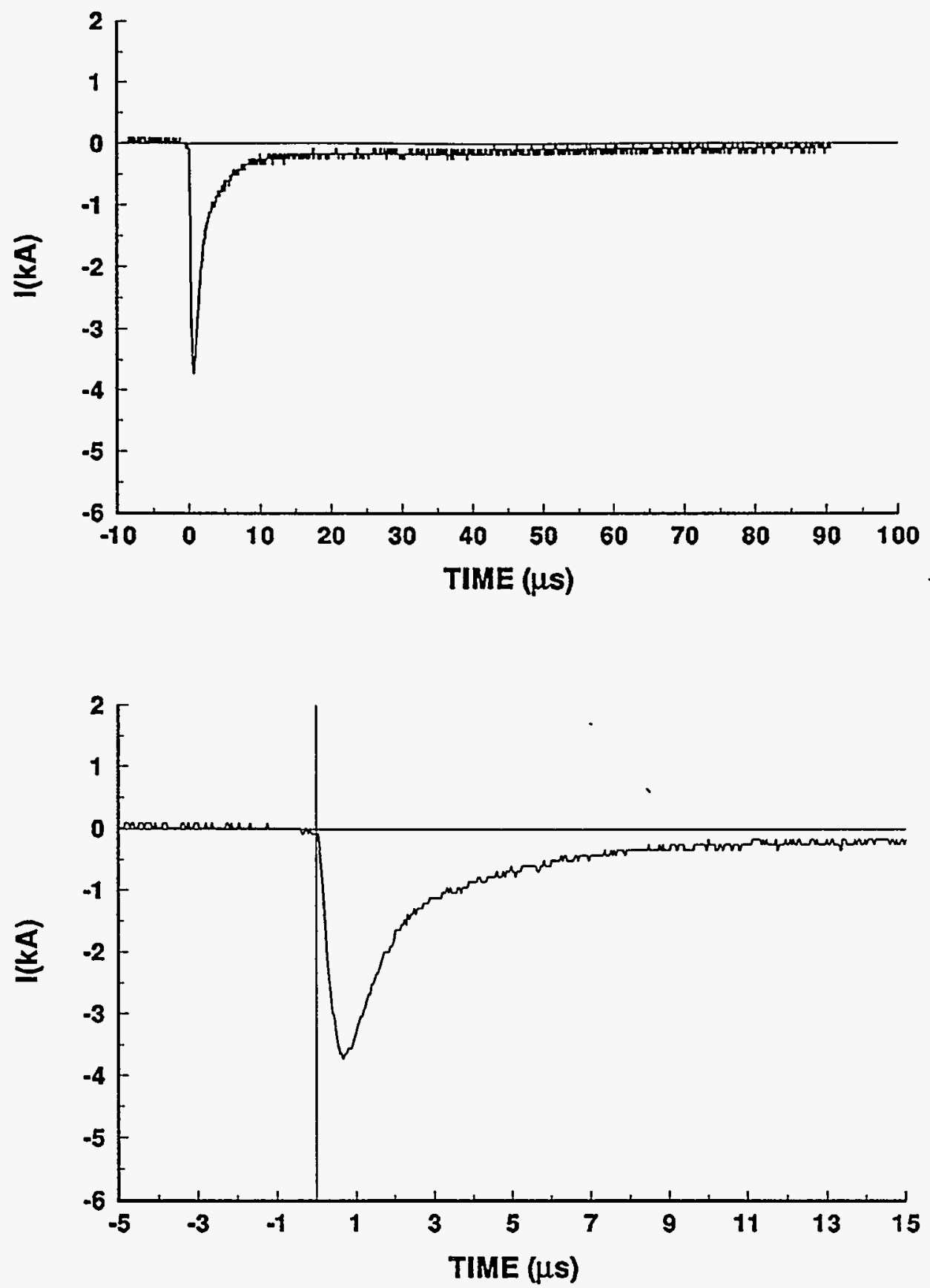


\section{4-06 STROKE 6}

TEST POINT 10

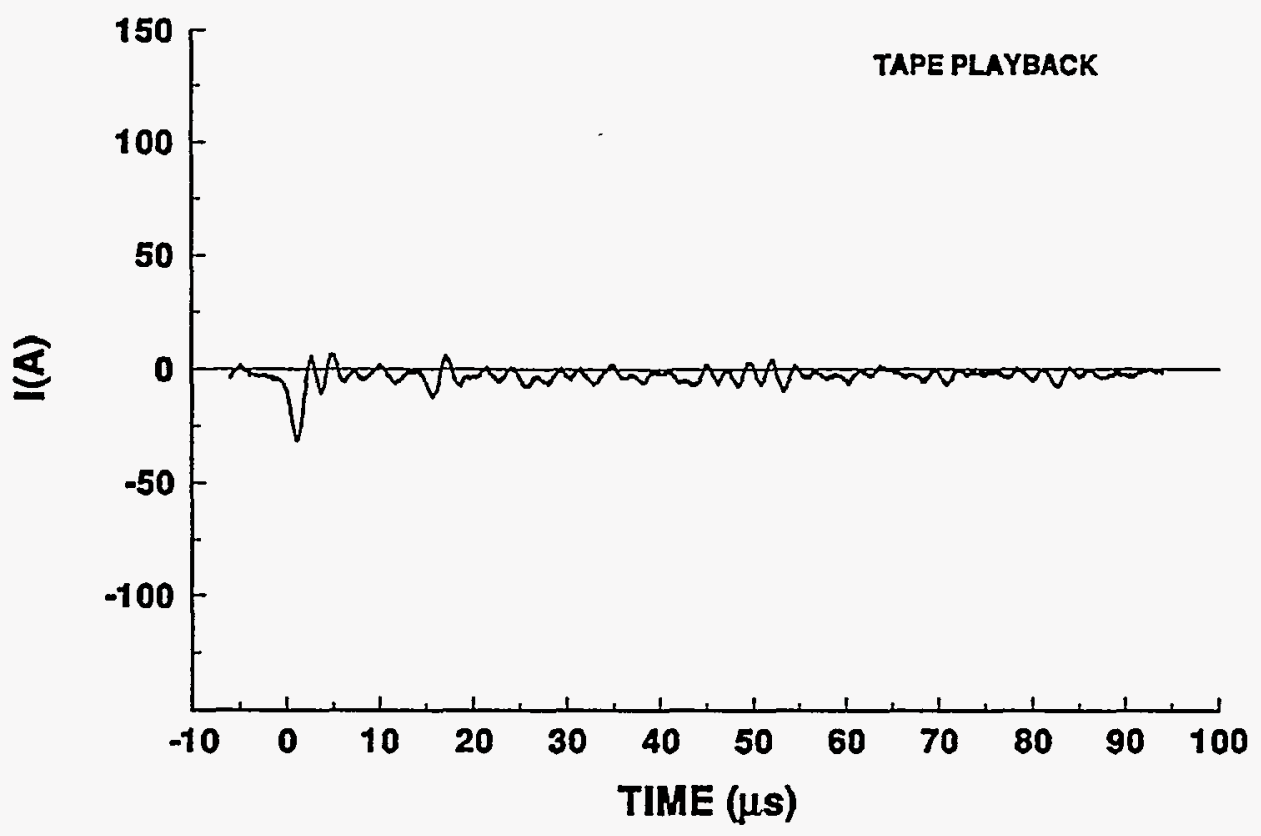

94-06 STROKE 6

TEST POINT 11

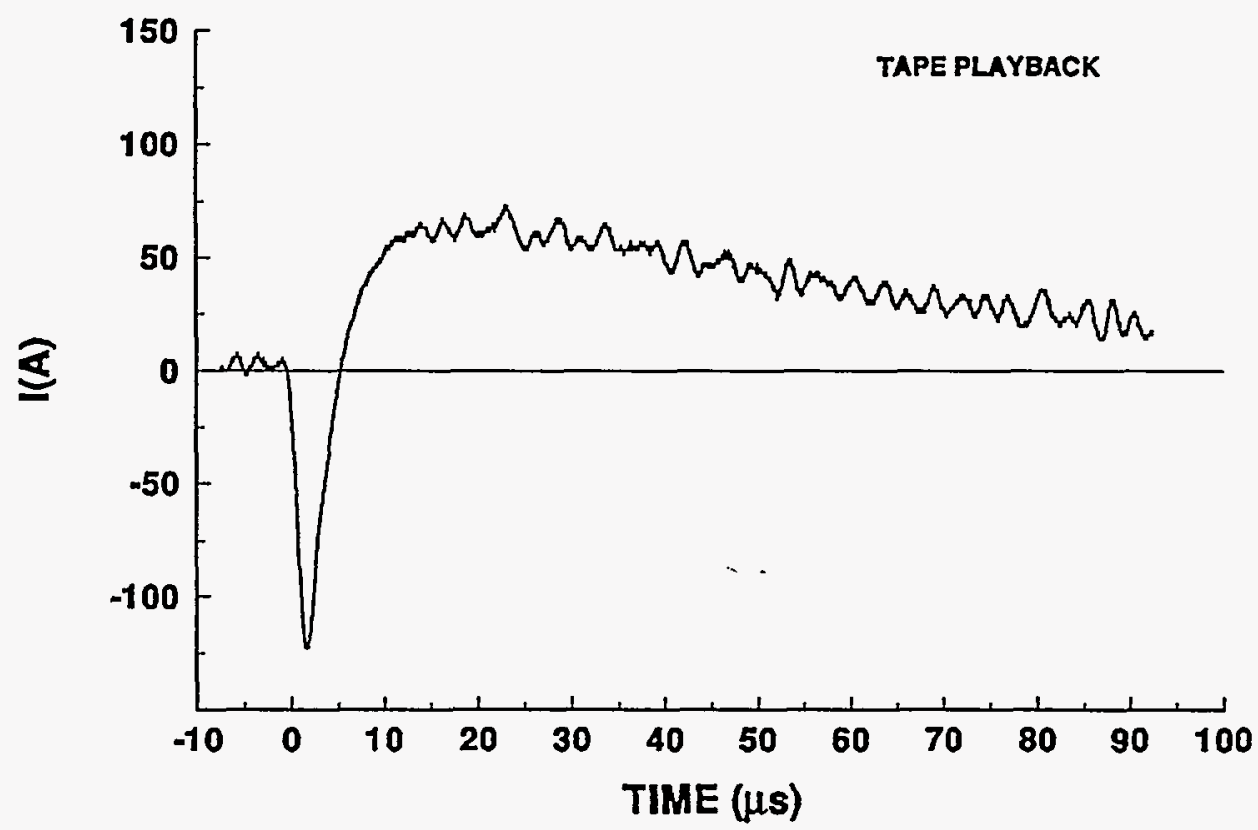




\section{4-06 STROKE 6}

TEST POINT 12

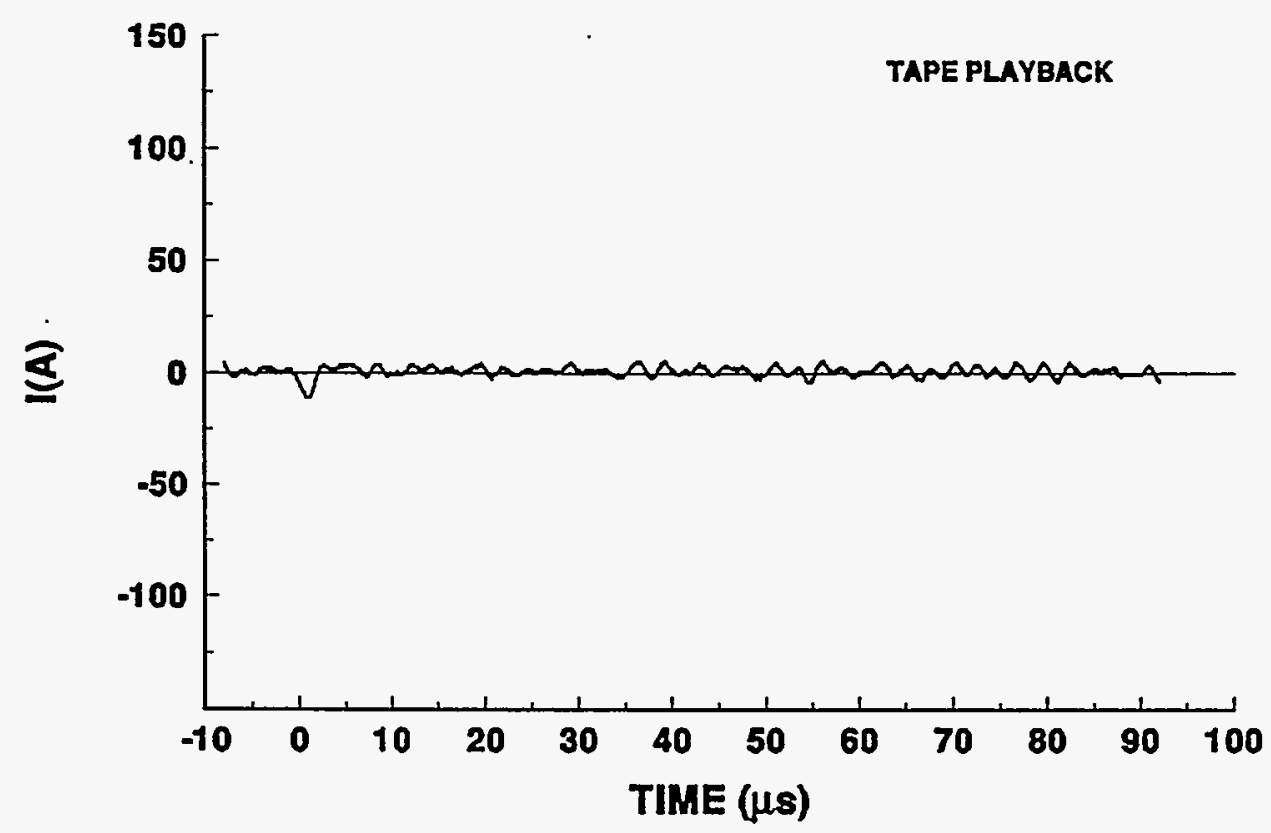

94-06 STROKE 6

TEST POINT 13

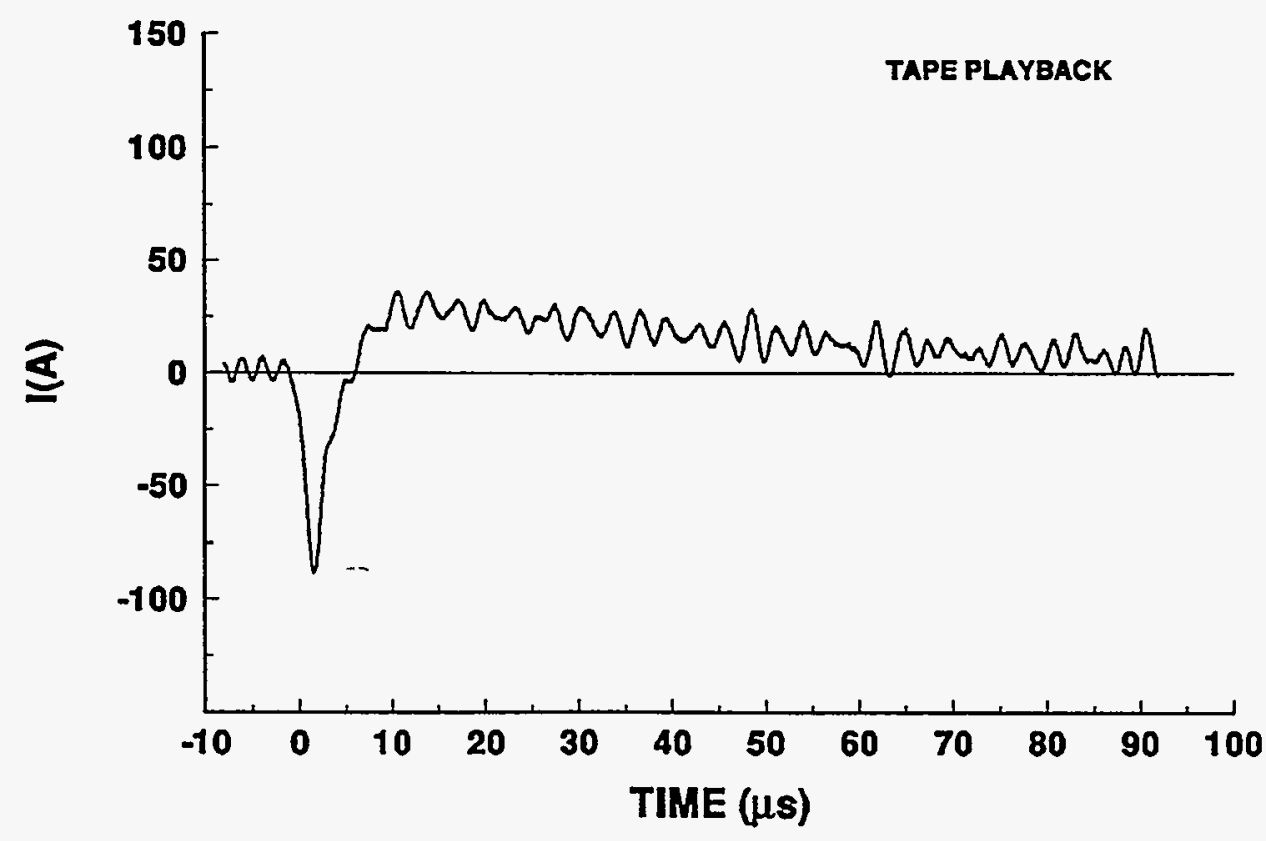




\section{4-06 STROKE 6}

\section{TEST POINT 14}
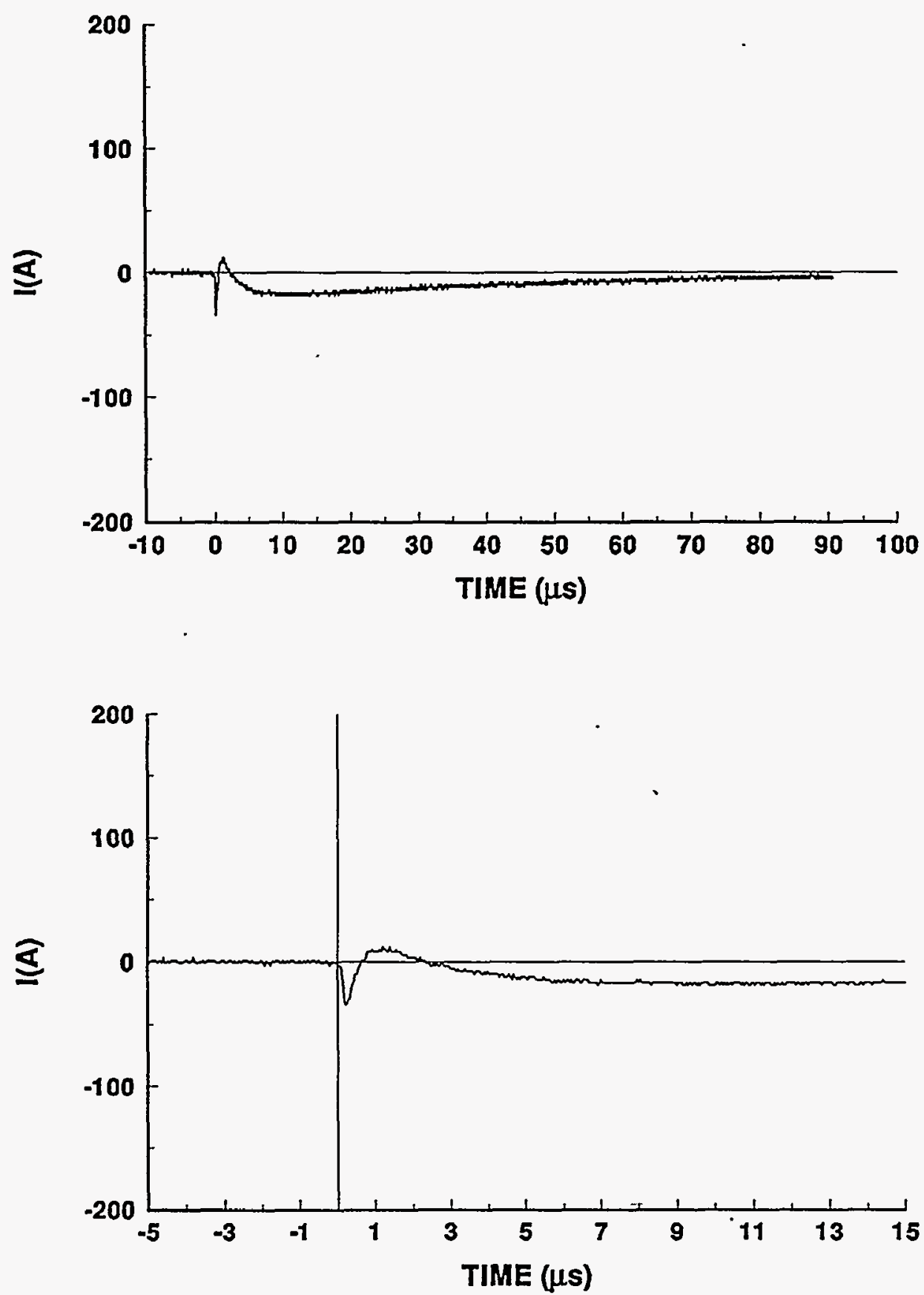


\section{4-06 STROKE 6}

TEST POINT 15
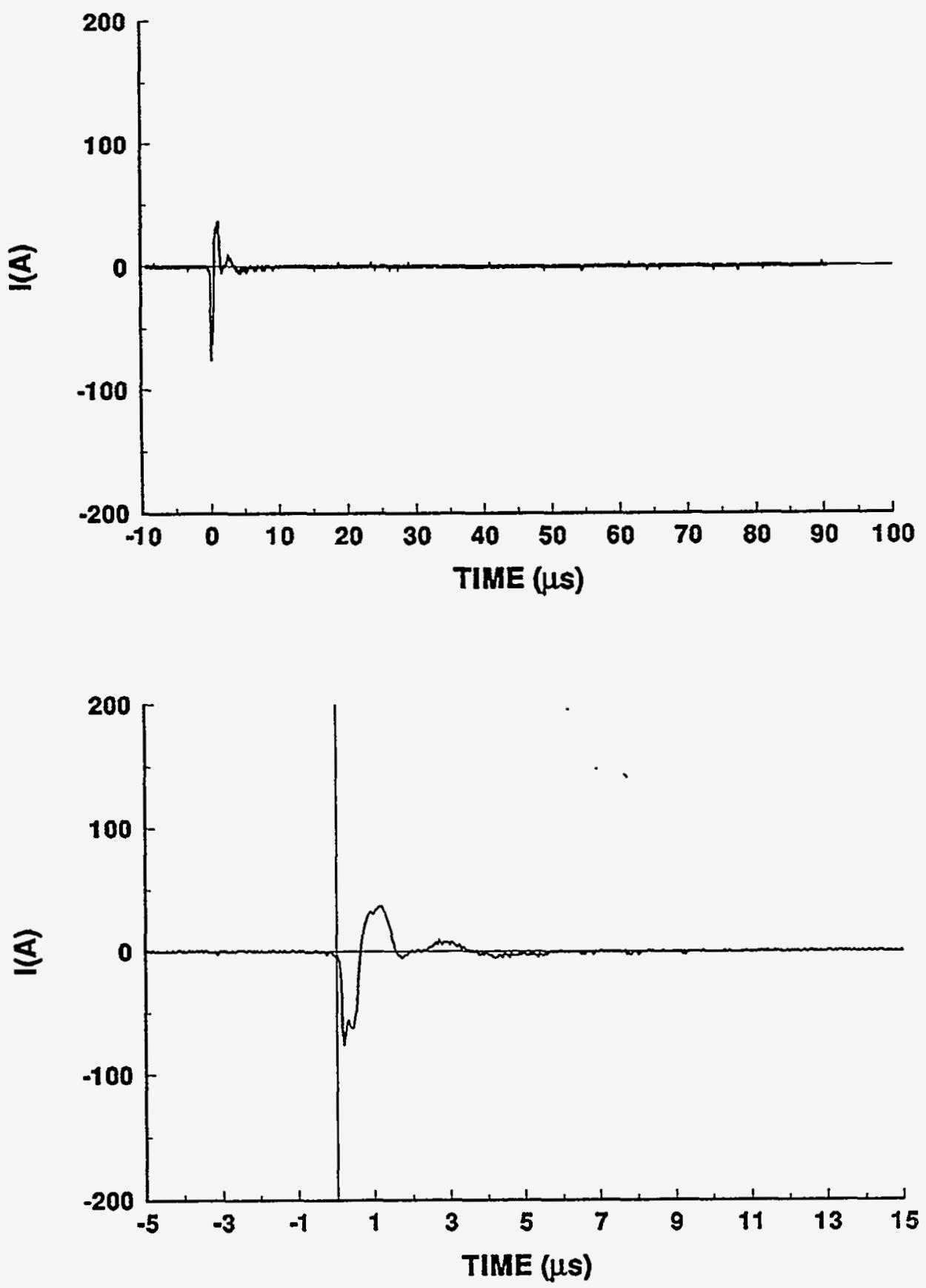


\section{4-06 STROKE 6}

TEST POINT 20

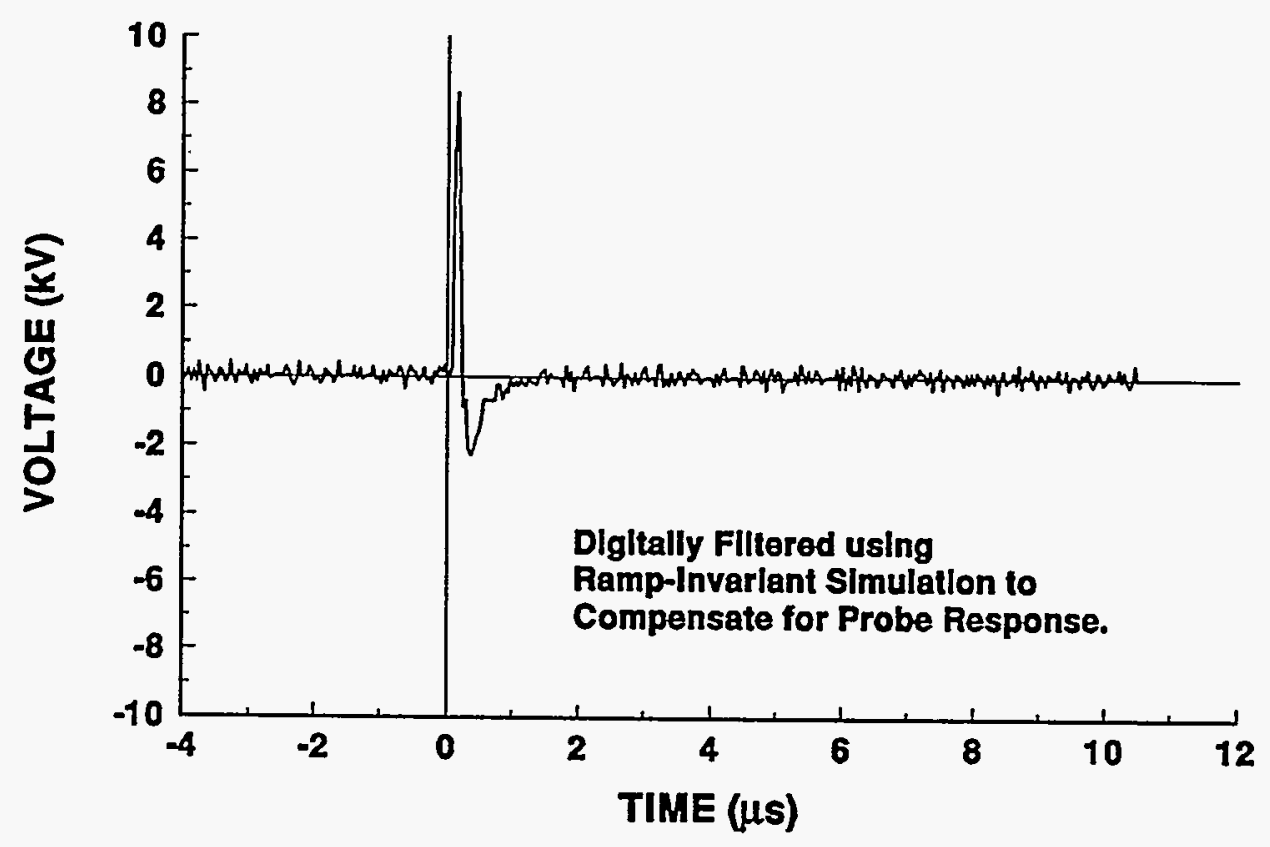

94-06 STROKE 6.

TEST POINT 21

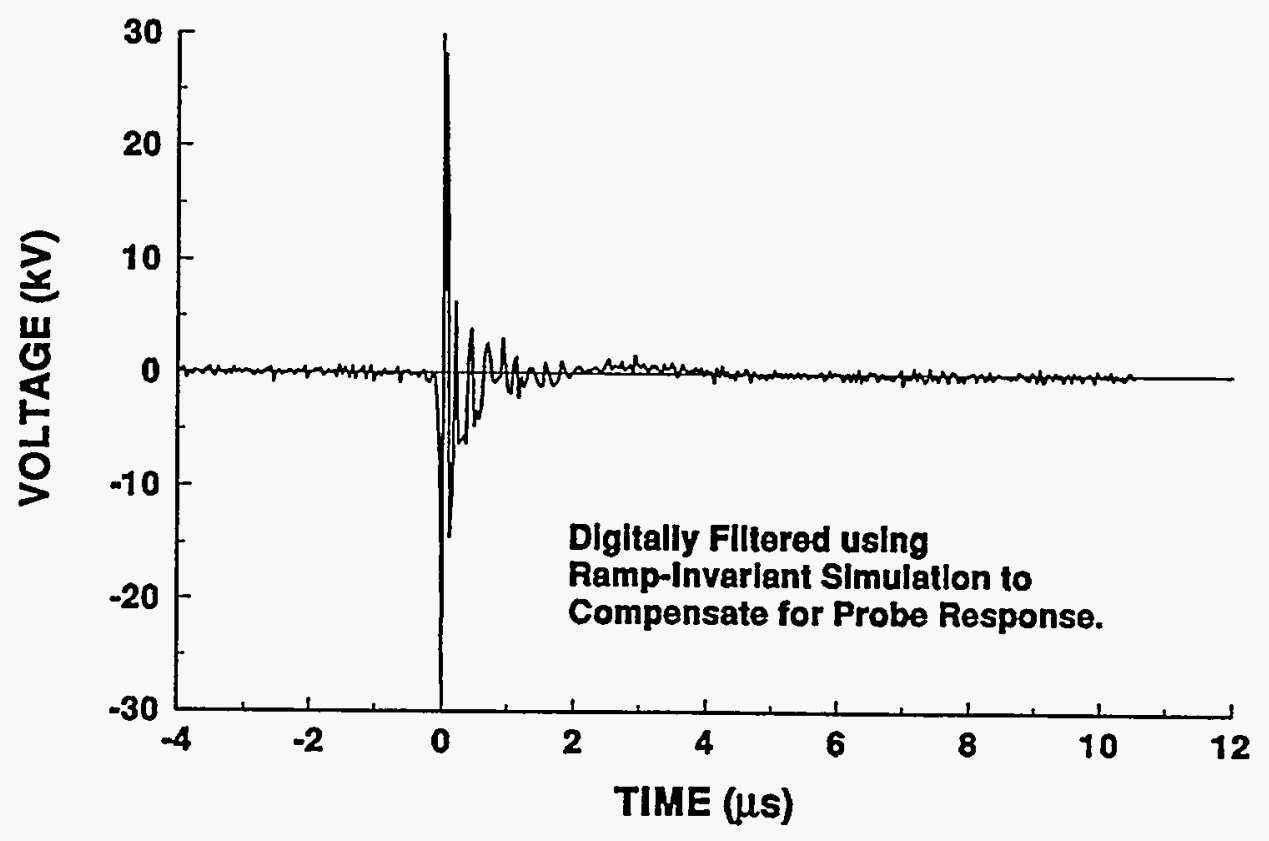




\section{4-06 STROKE 6}

TEST POINT 23

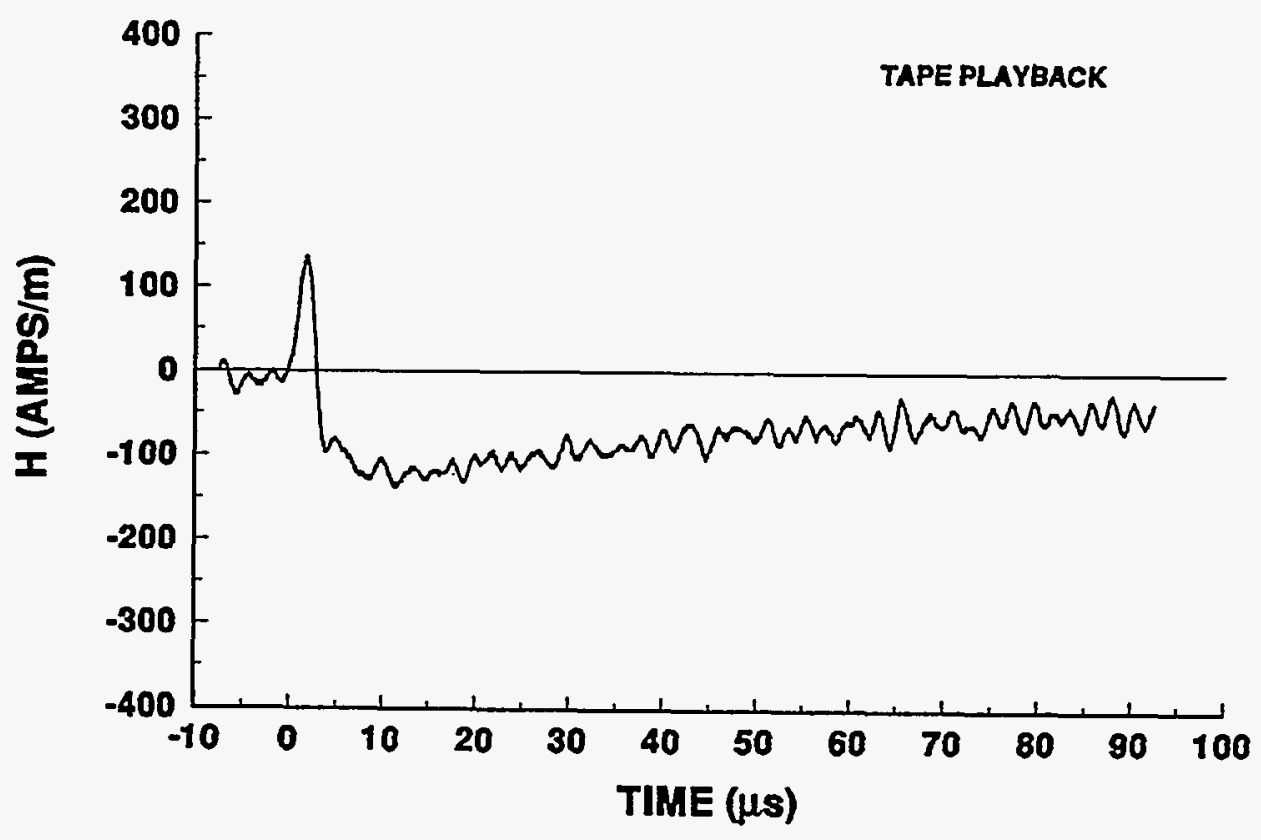




\section{4-06 STROKE 7 \\ INCIDENT CURRENT}
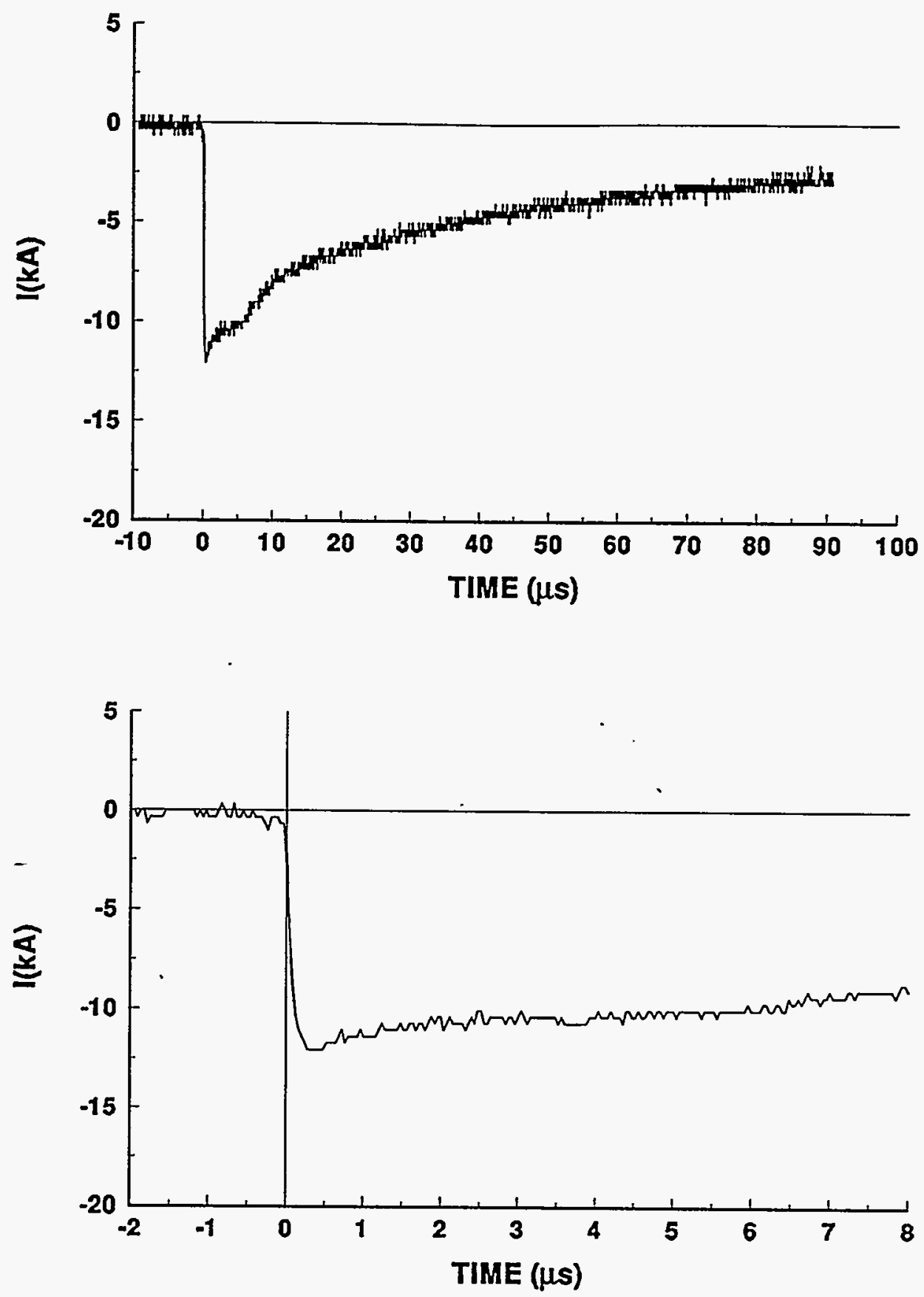


\section{4-06 STROKE 7}

TEST POINT 1

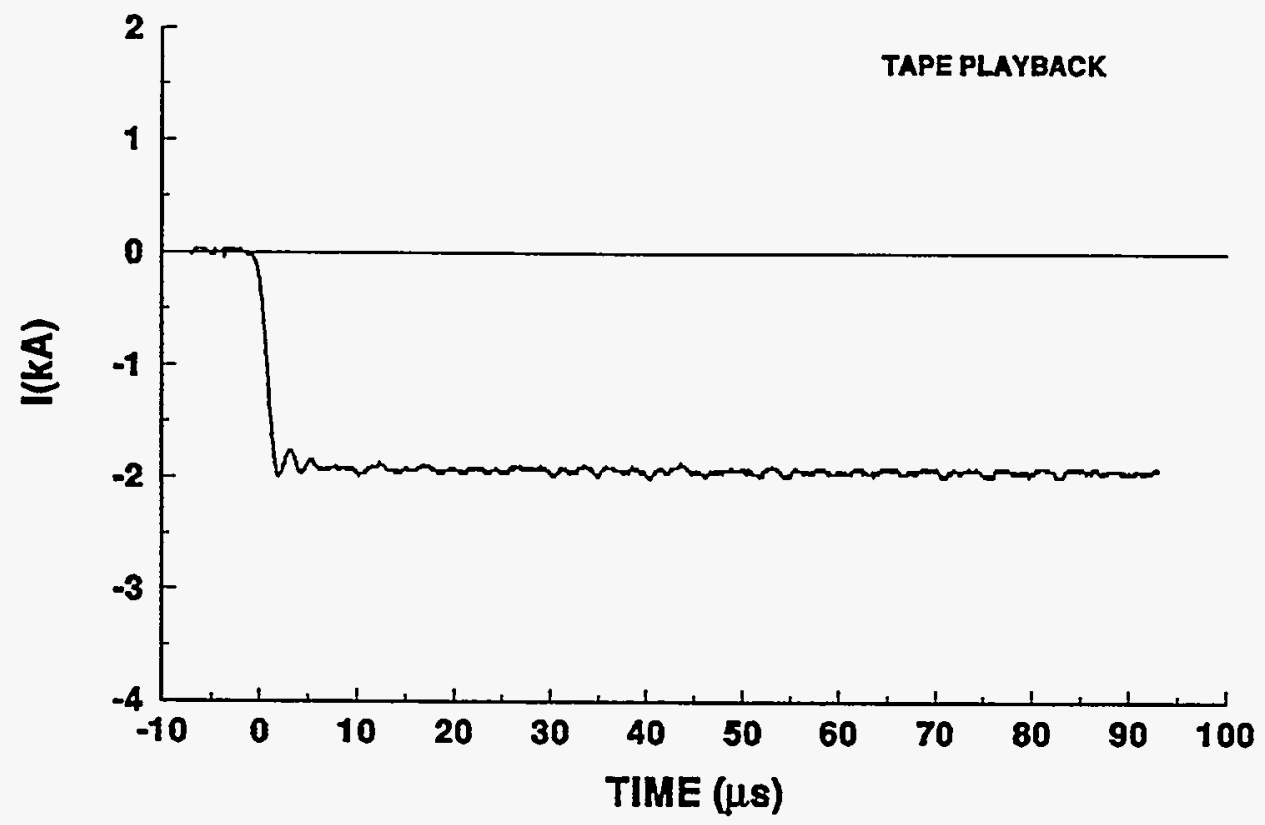

94-02 STROKE-7

TEST POINT 2

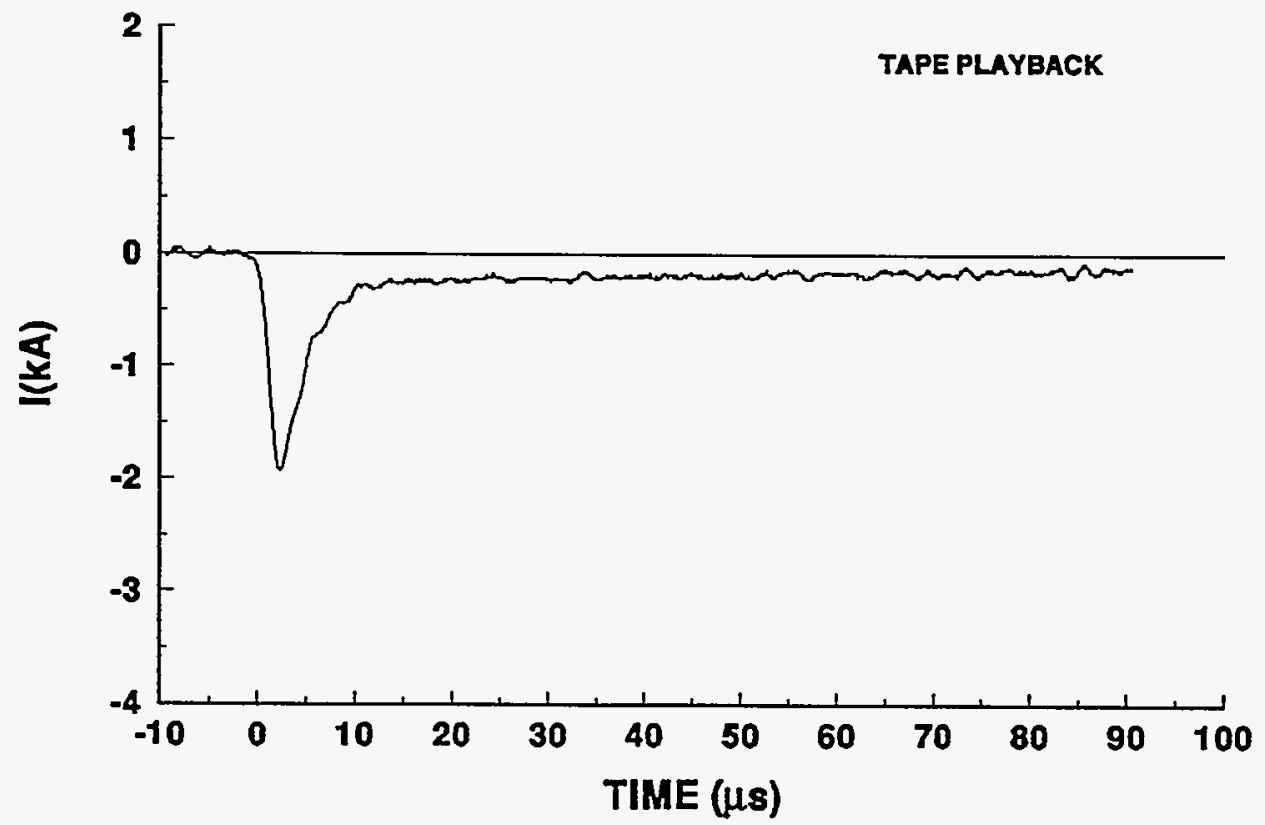




\section{4-06 STROKE 7}

TEST POINT 5
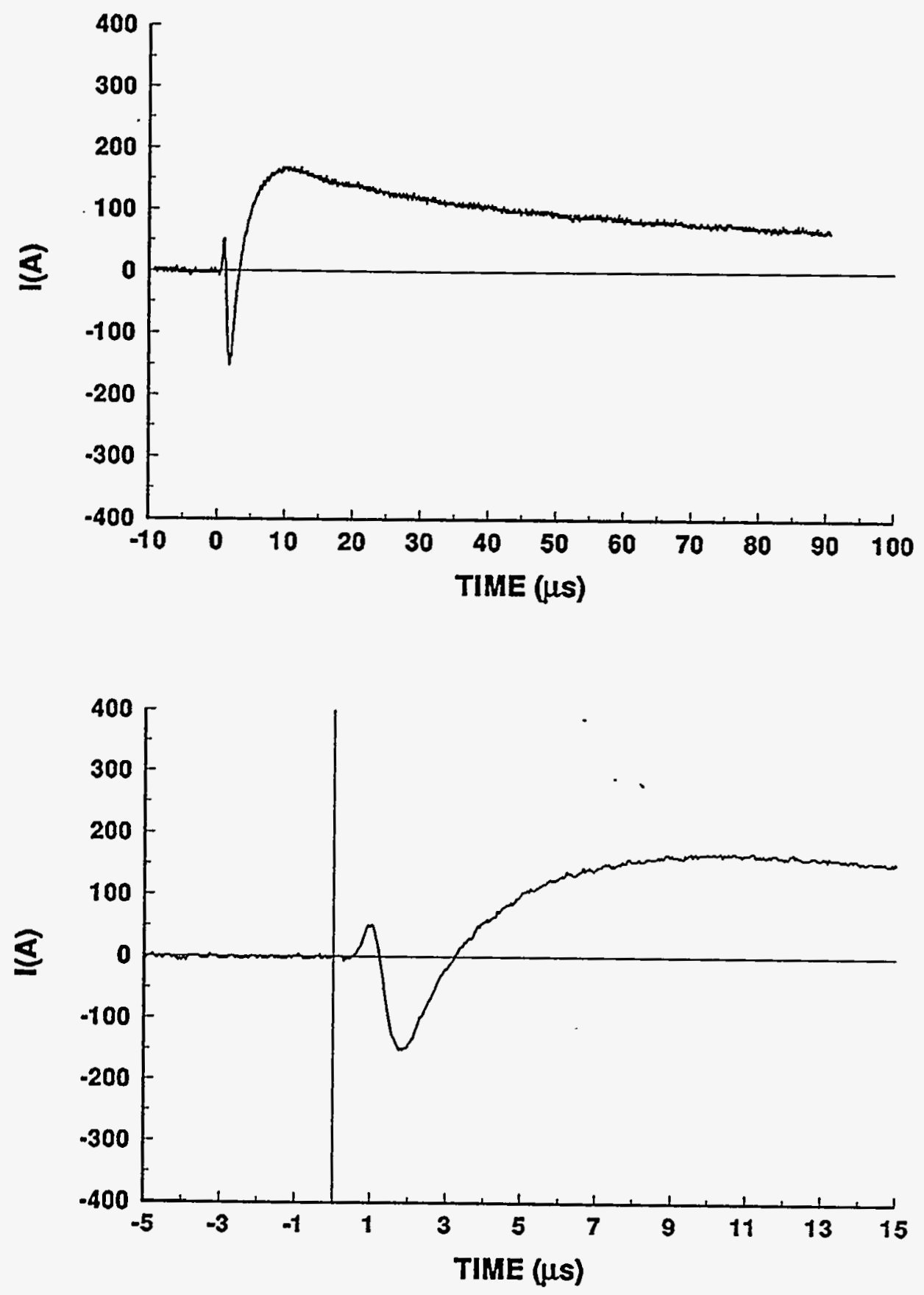


\section{4-06 STROKE 7}

TEST POINT 5'
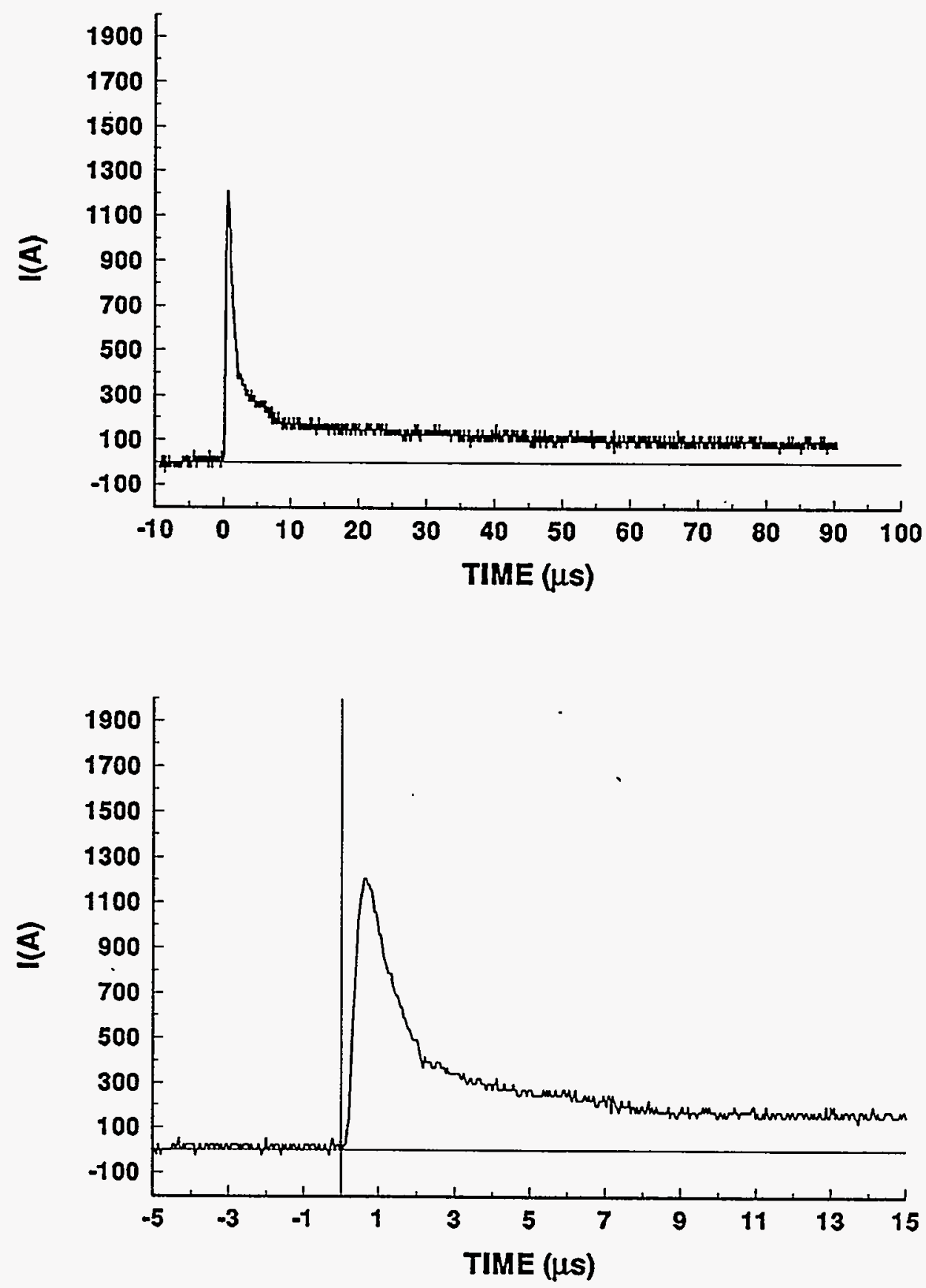


\section{4-06 STROKE 7}

TEST POINT 6'

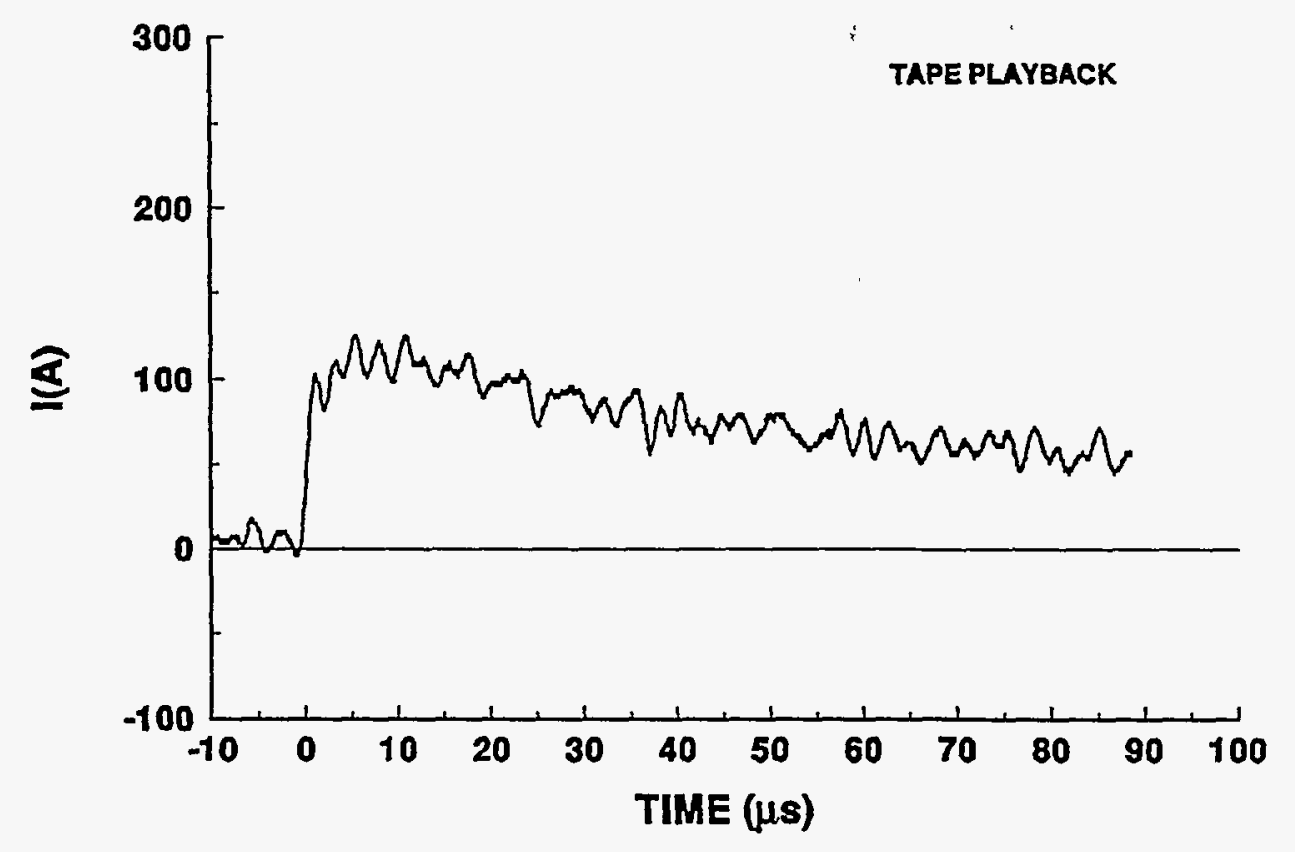




\section{4-06 STROKE 7}

TEST POINT 7
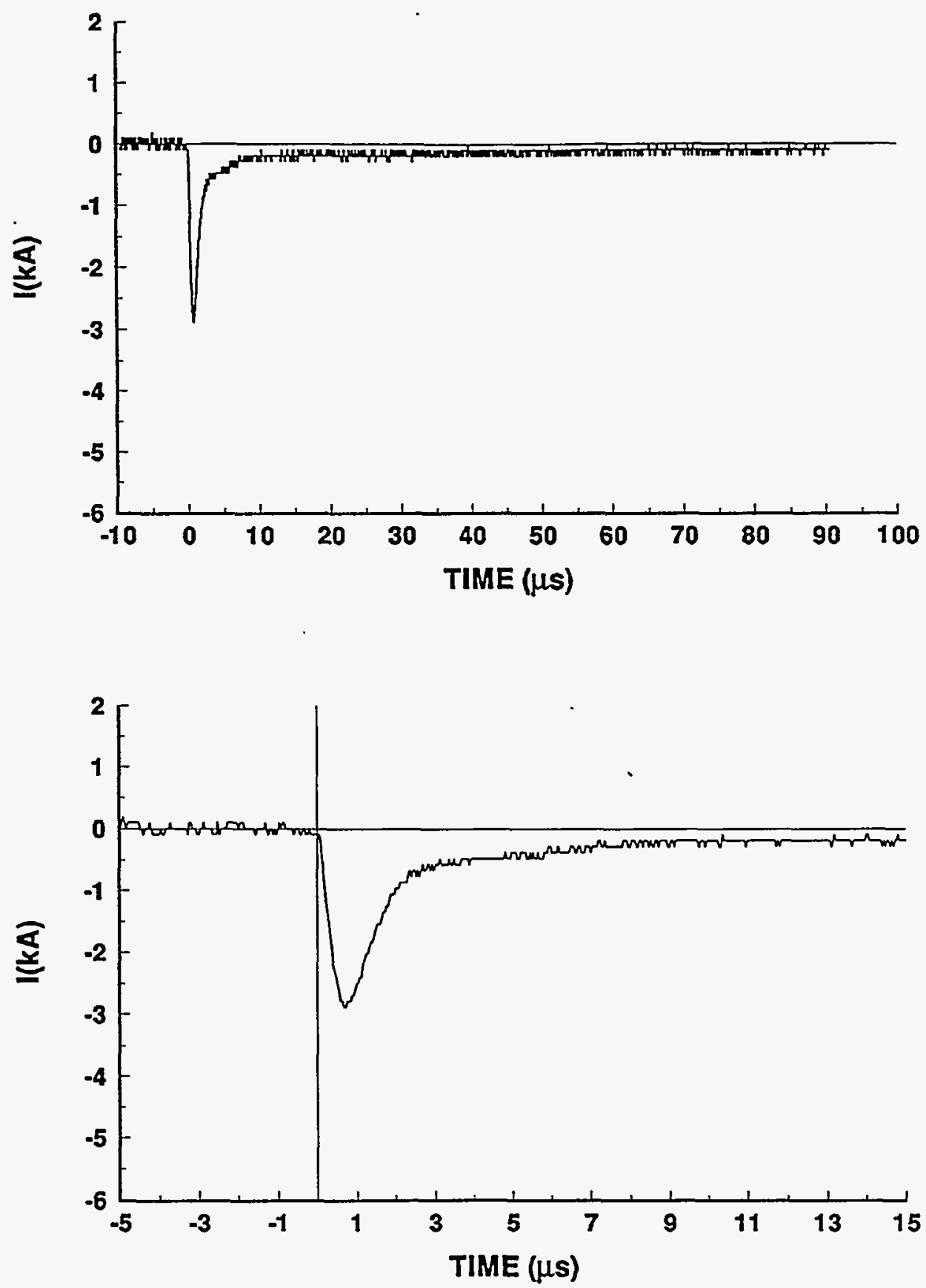


\section{4-06 STROKE 7}

TEST POINT 8
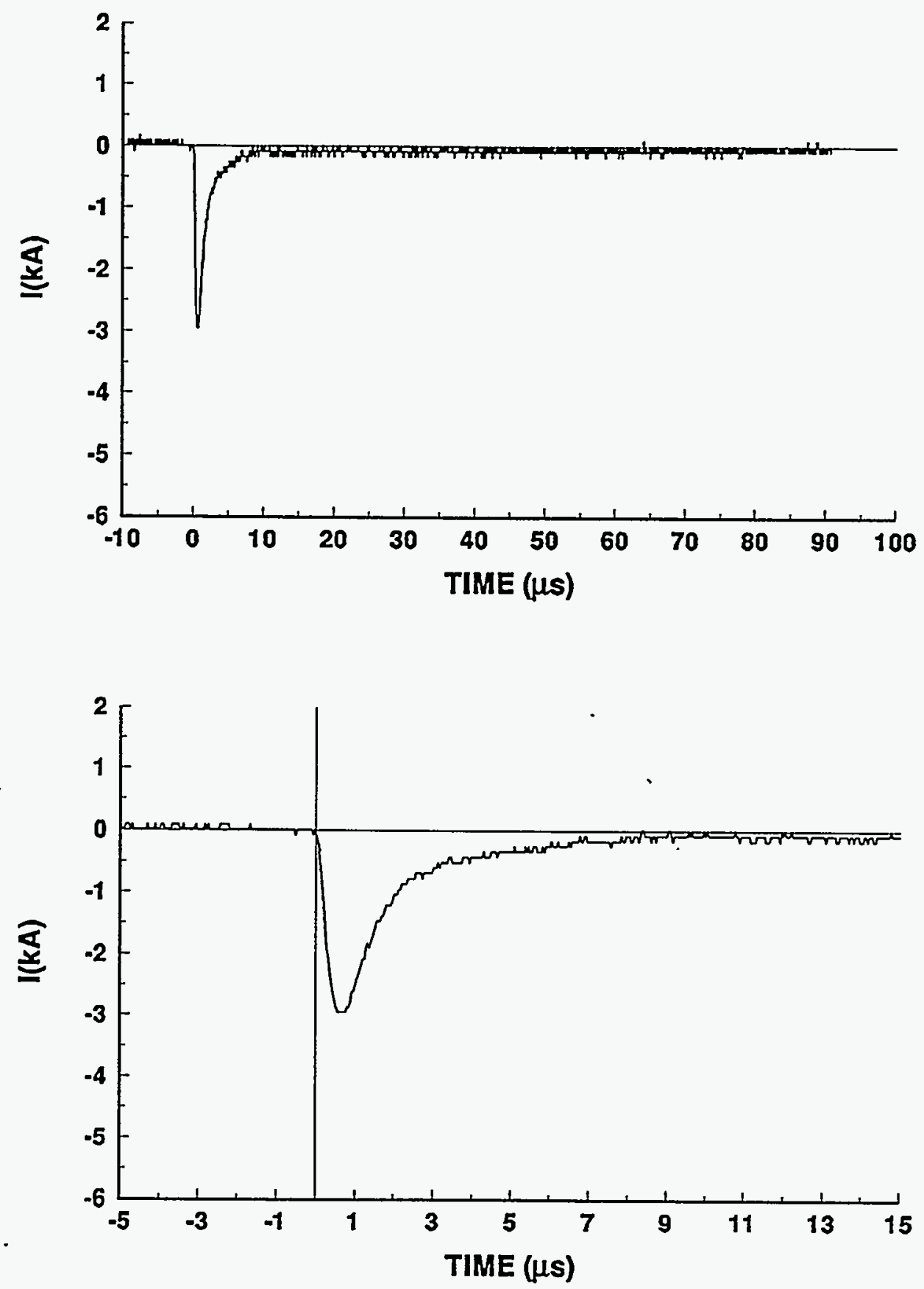


\section{4-06 STROKE 7}

TEST POINT 10

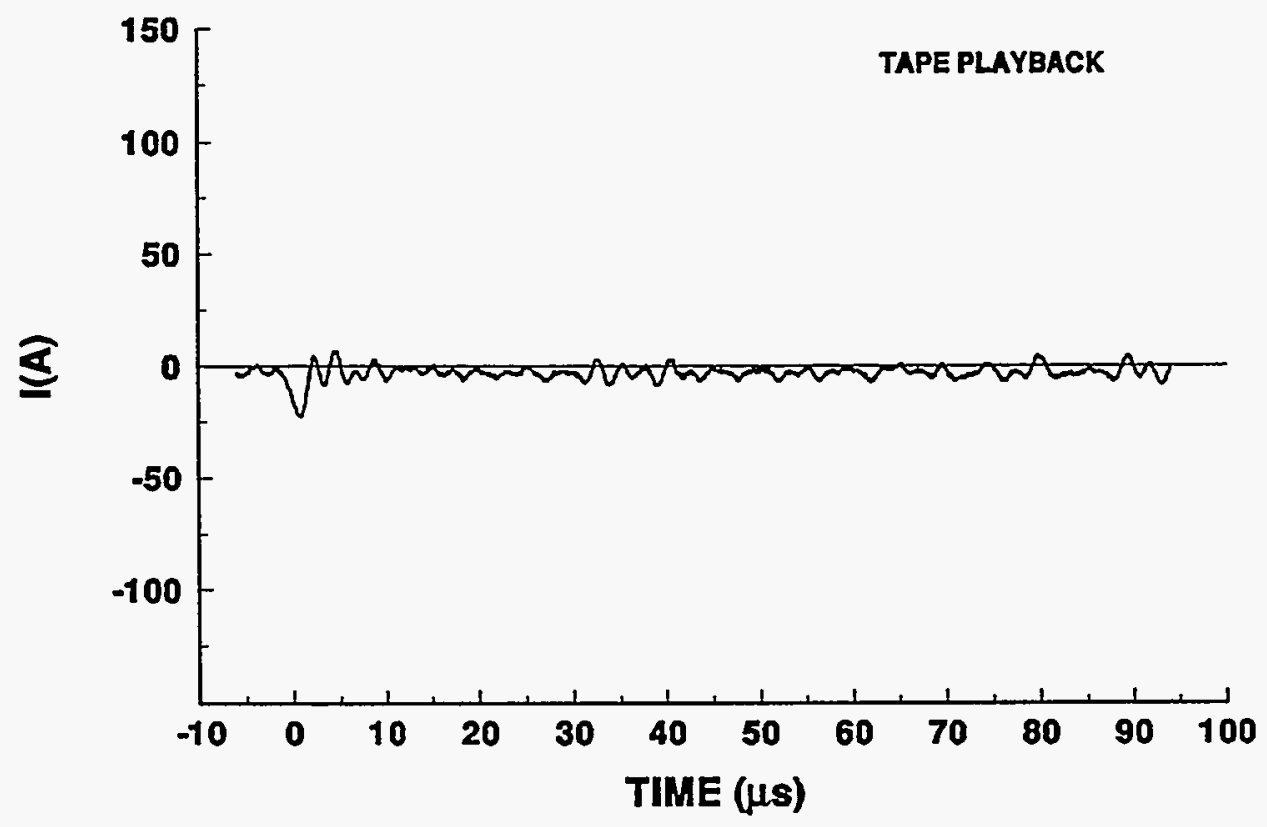

\section{4-06 STROKE.7}

TEST POINT 11

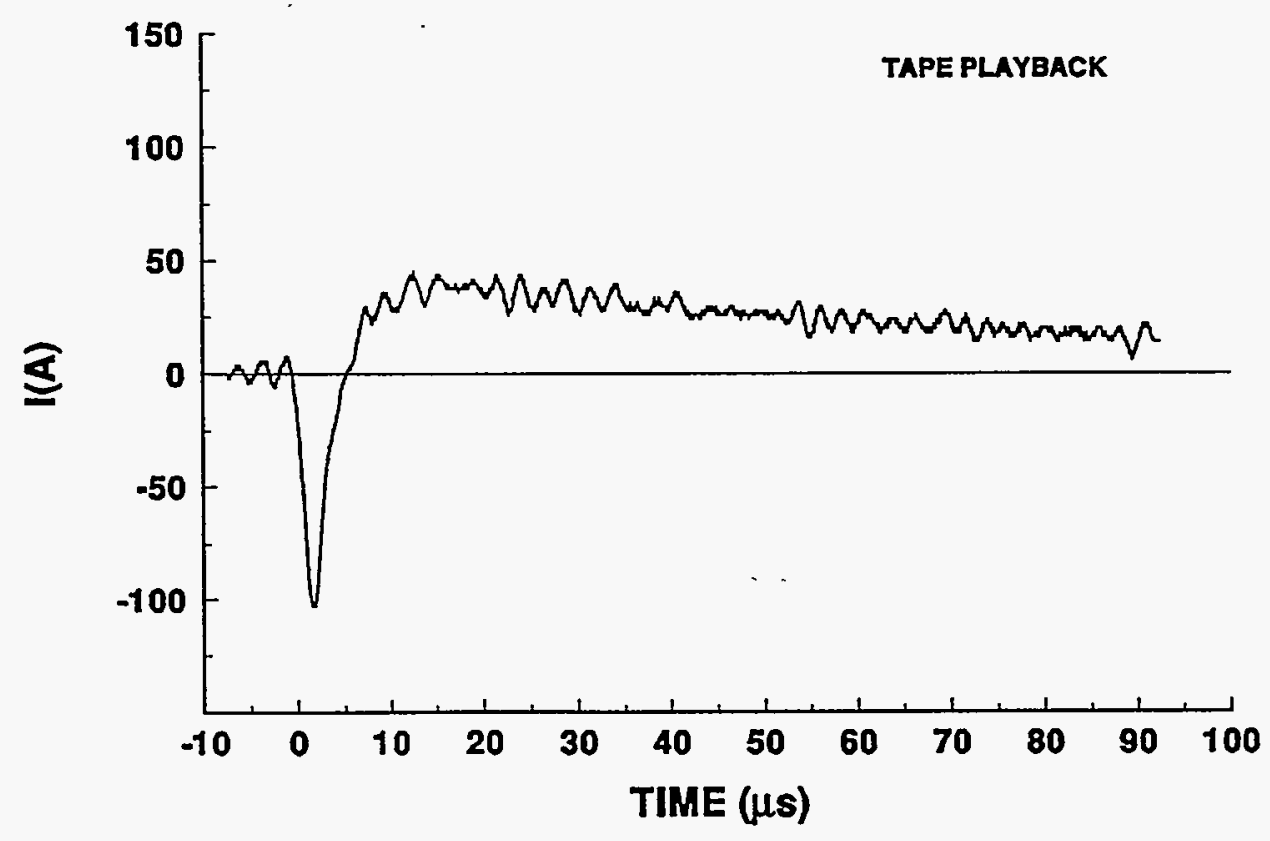




\section{4-06 STROKE 7}

TEST POINT 12

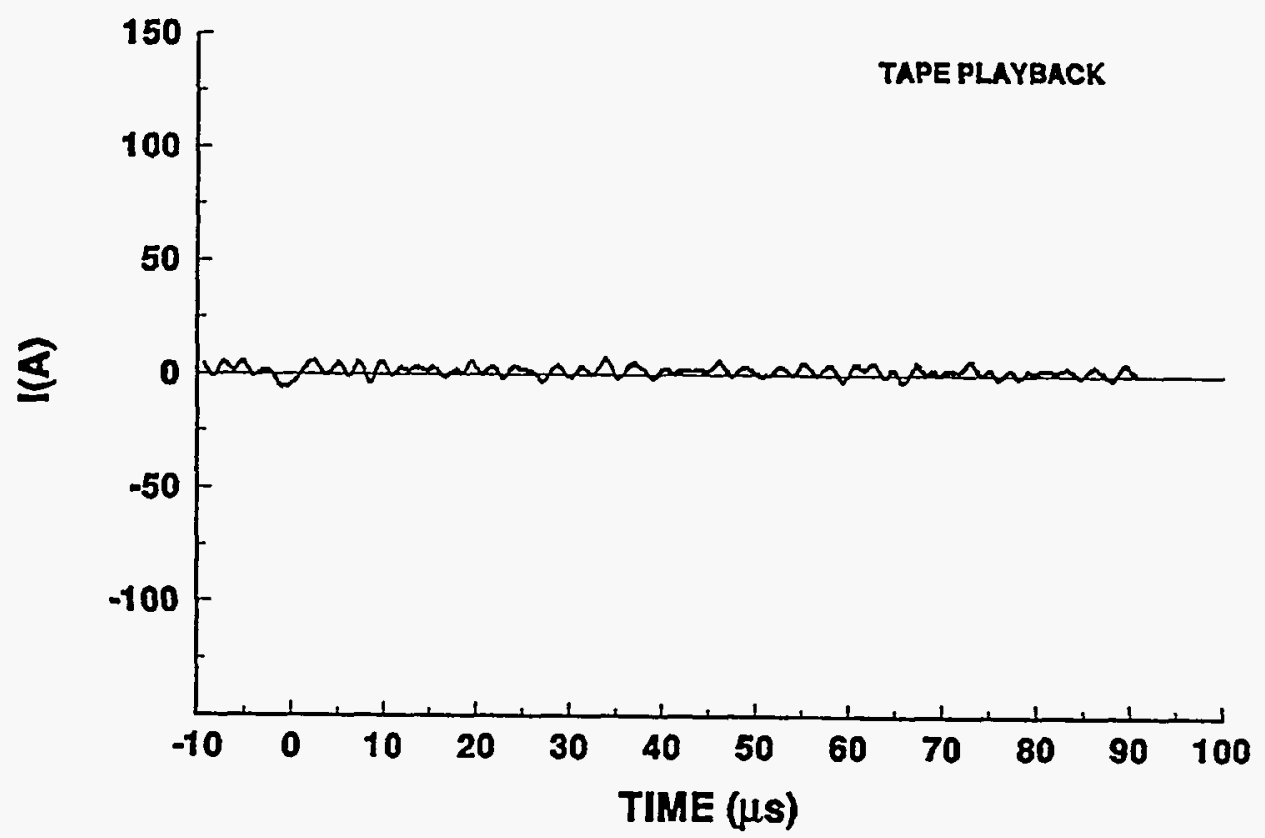

94-06 STROKE 7

TEST POINT 13

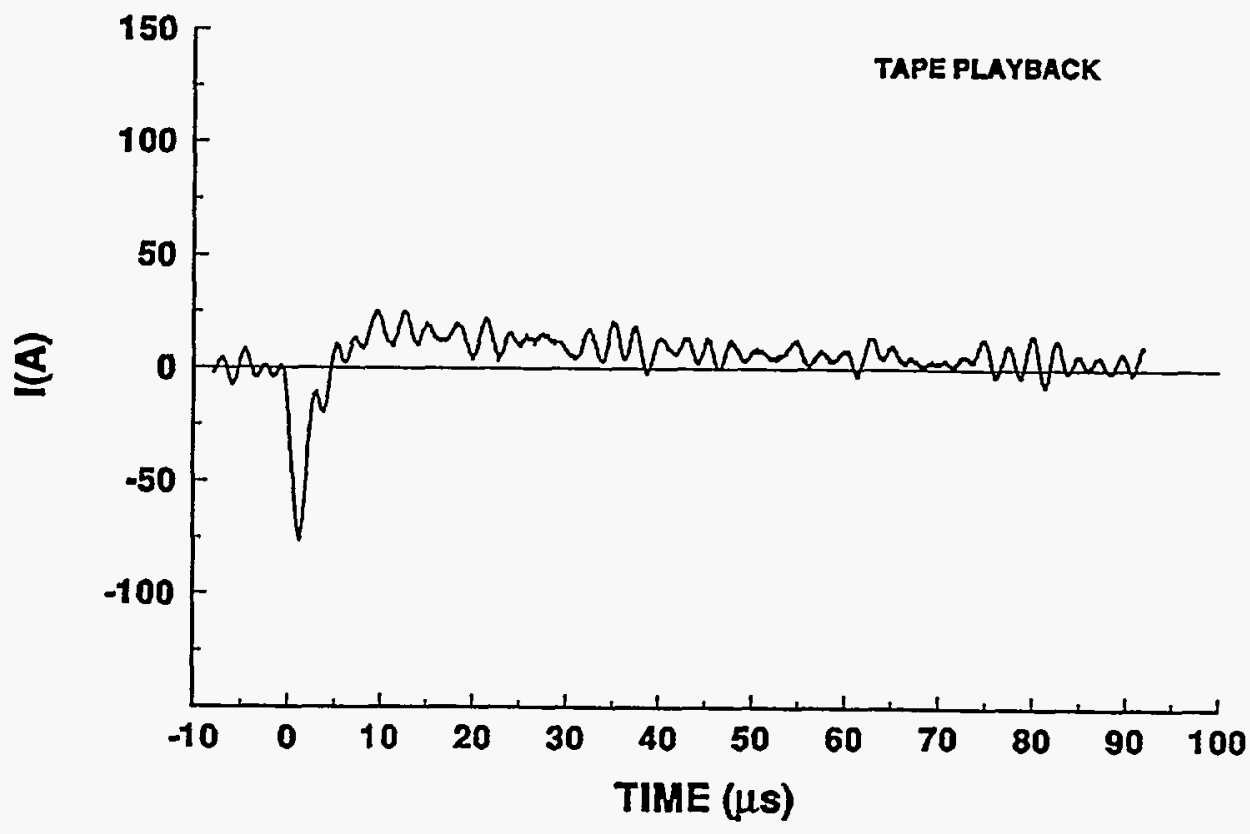




\section{4-06 STROKE 7 \\ TEST POINT 14}
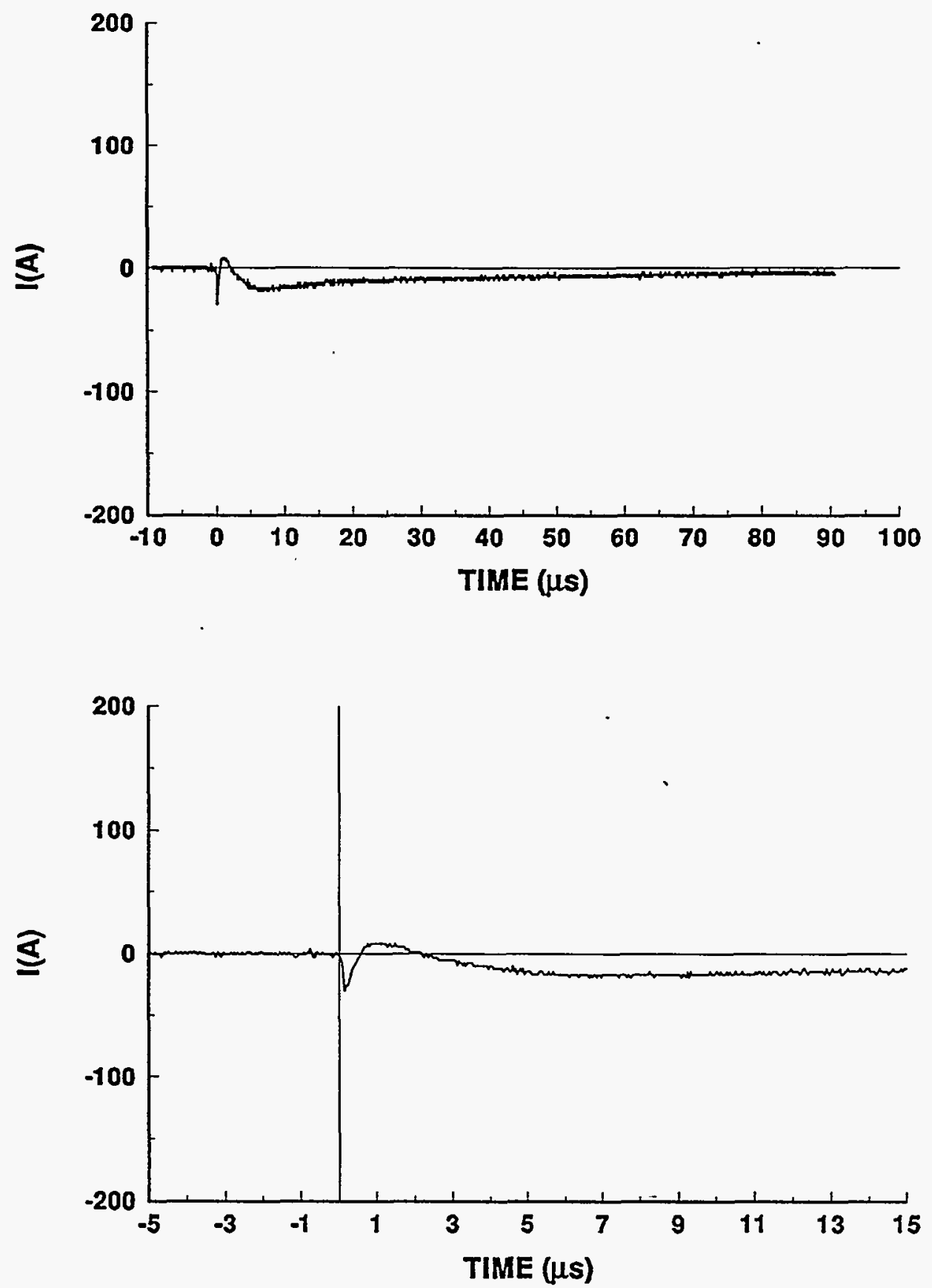


\section{4-06 STROKE 7}

TEST POINT 15
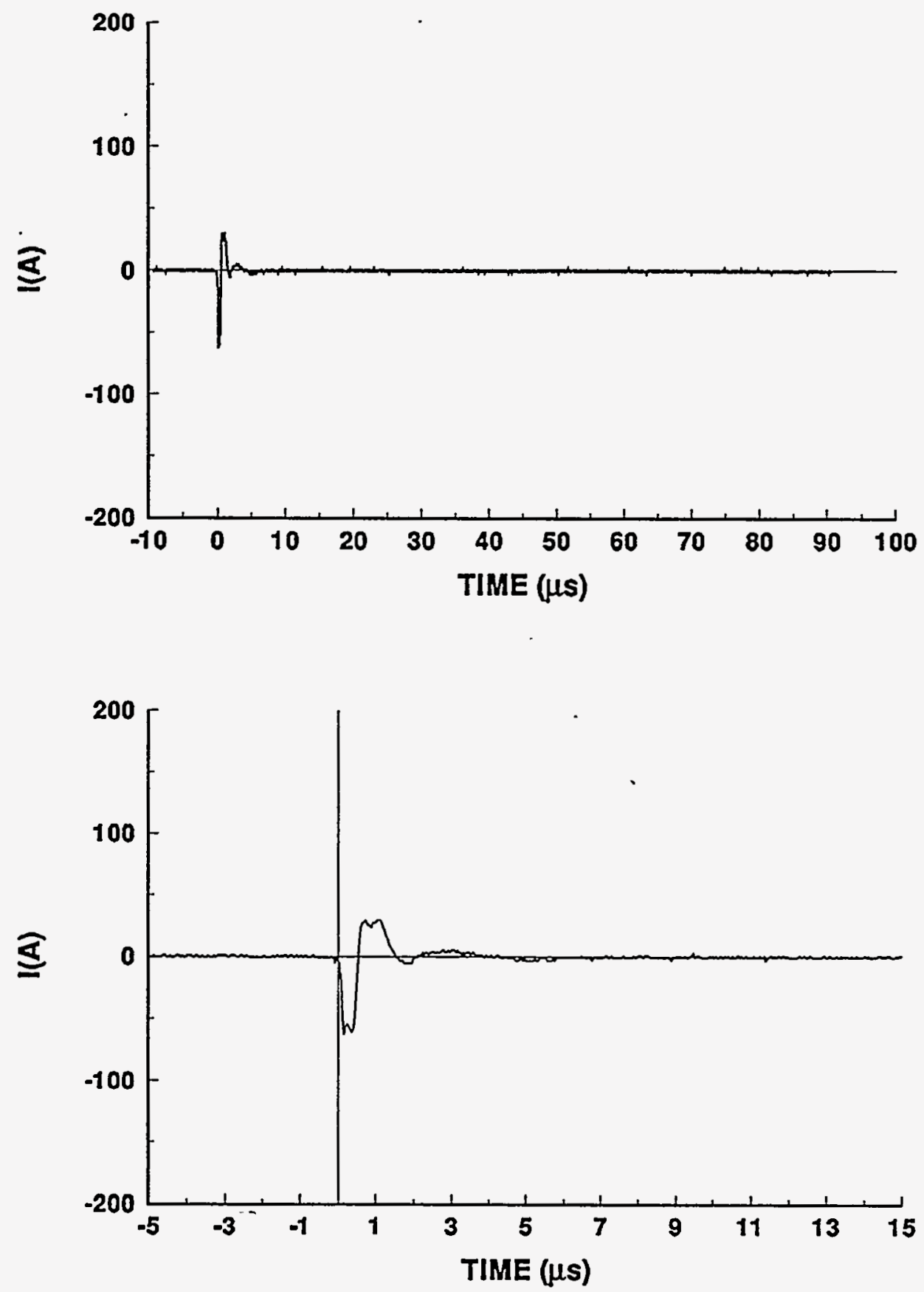


\section{4-06 STROKE 7}

TEST POINT 20

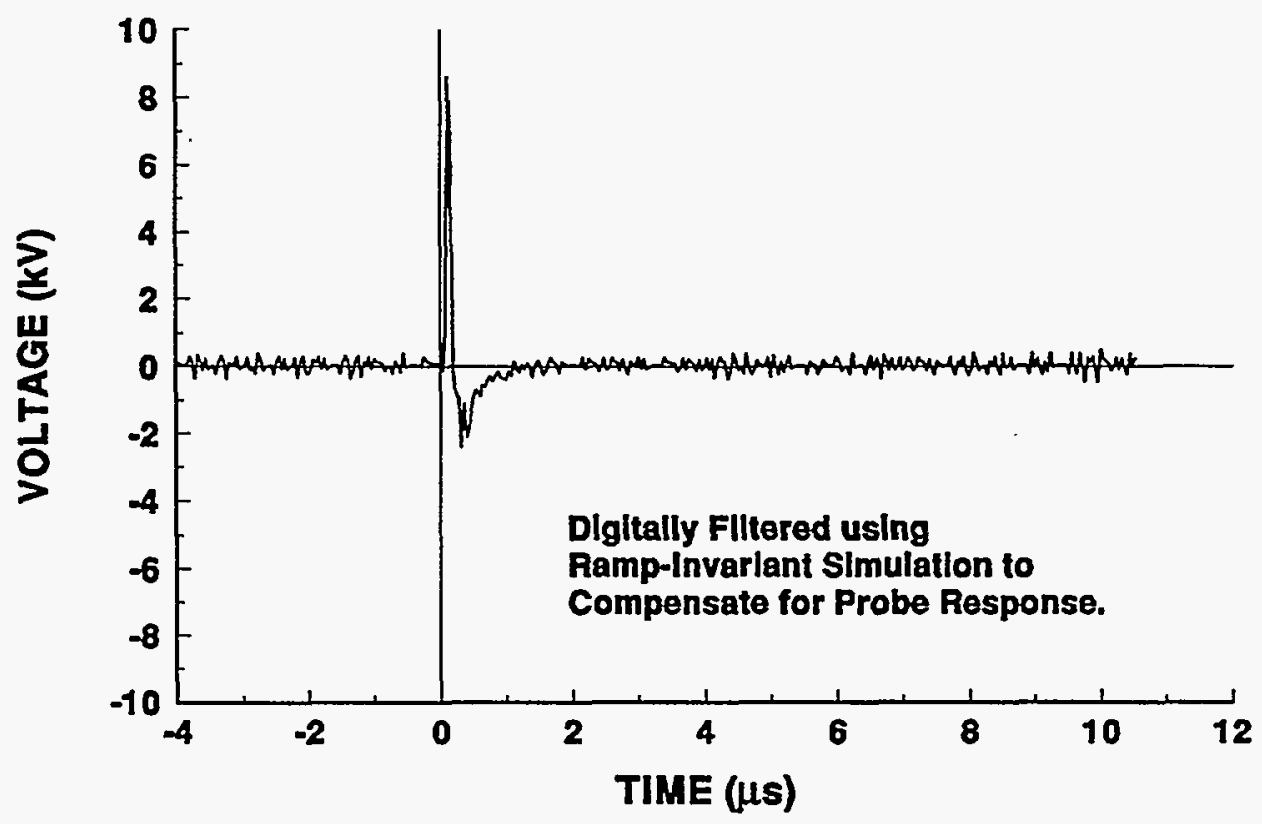

94-06 STROKE 7

TEST POINT 21

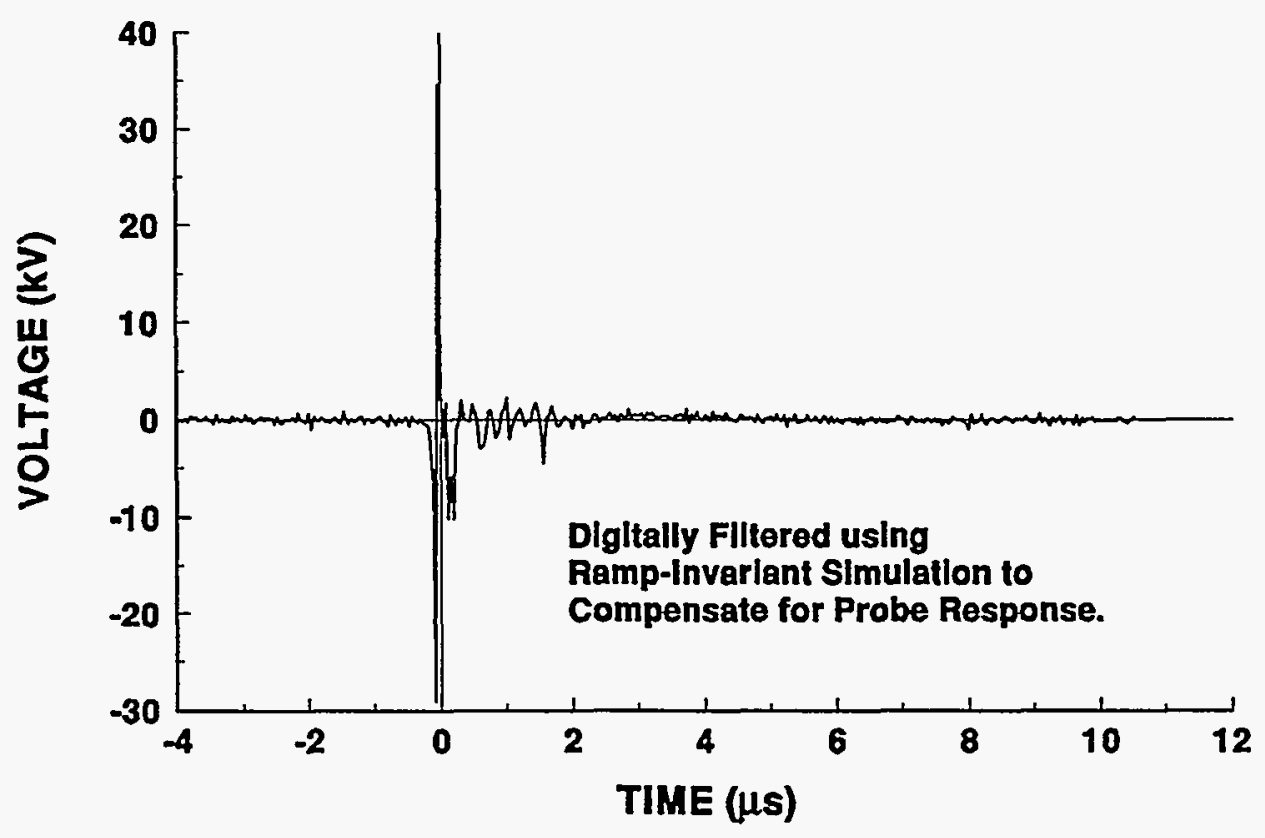




\section{4-06 STROKE 7}

\section{TEST POINT 23}

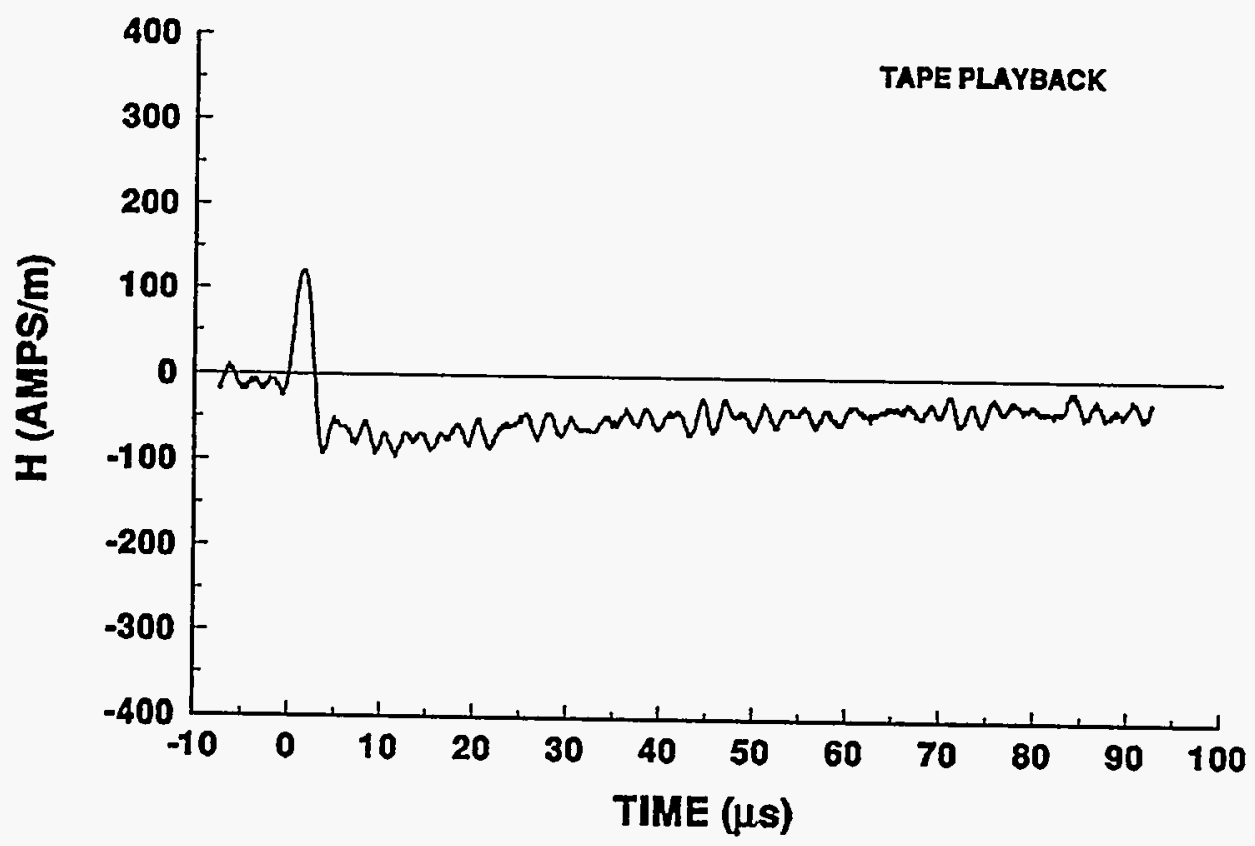




\section{4-06 STROKE 8 \\ INCIDENT CURRENT}
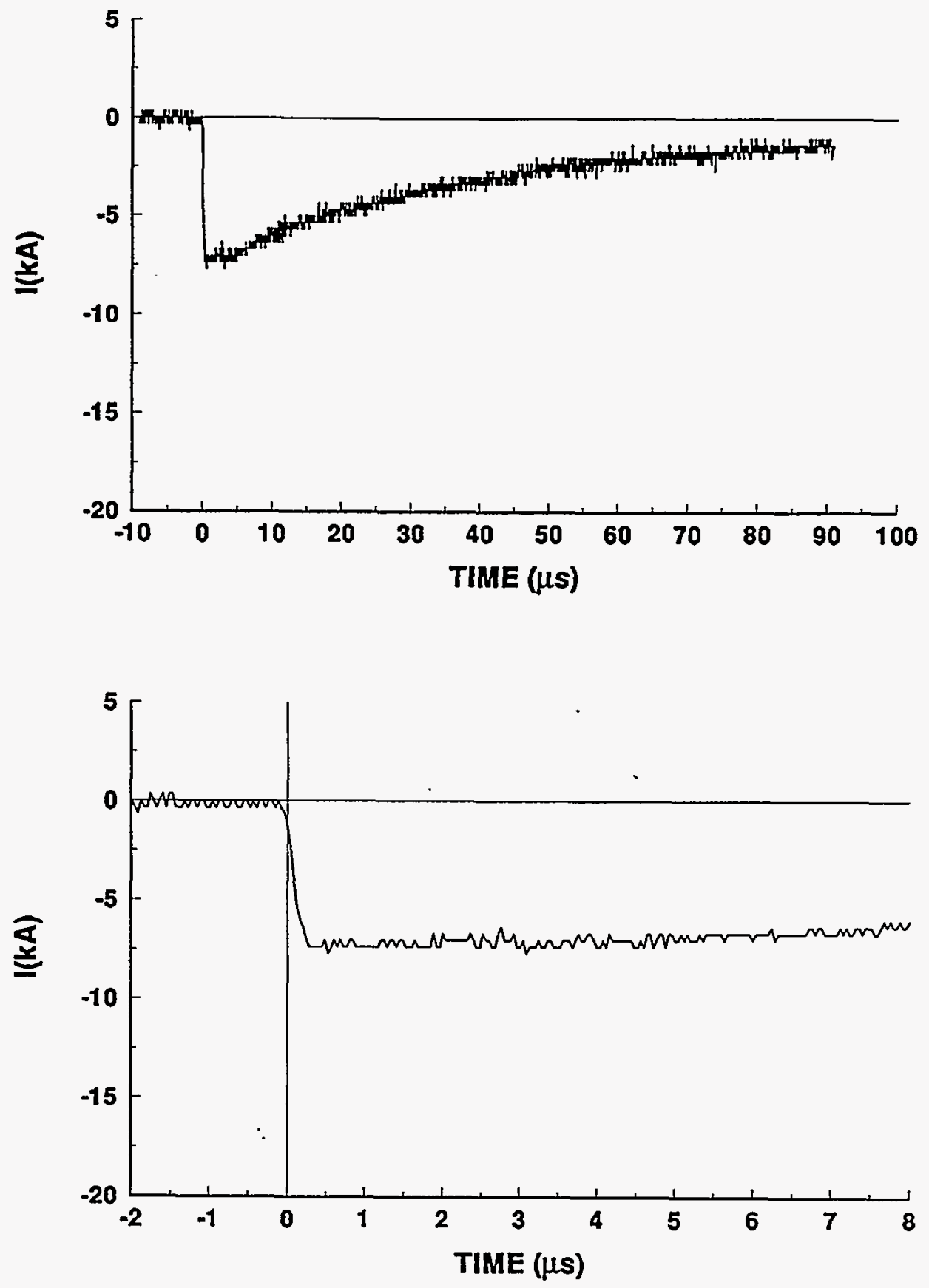


\section{4-06 STROKE 8}

TEST POINT 1

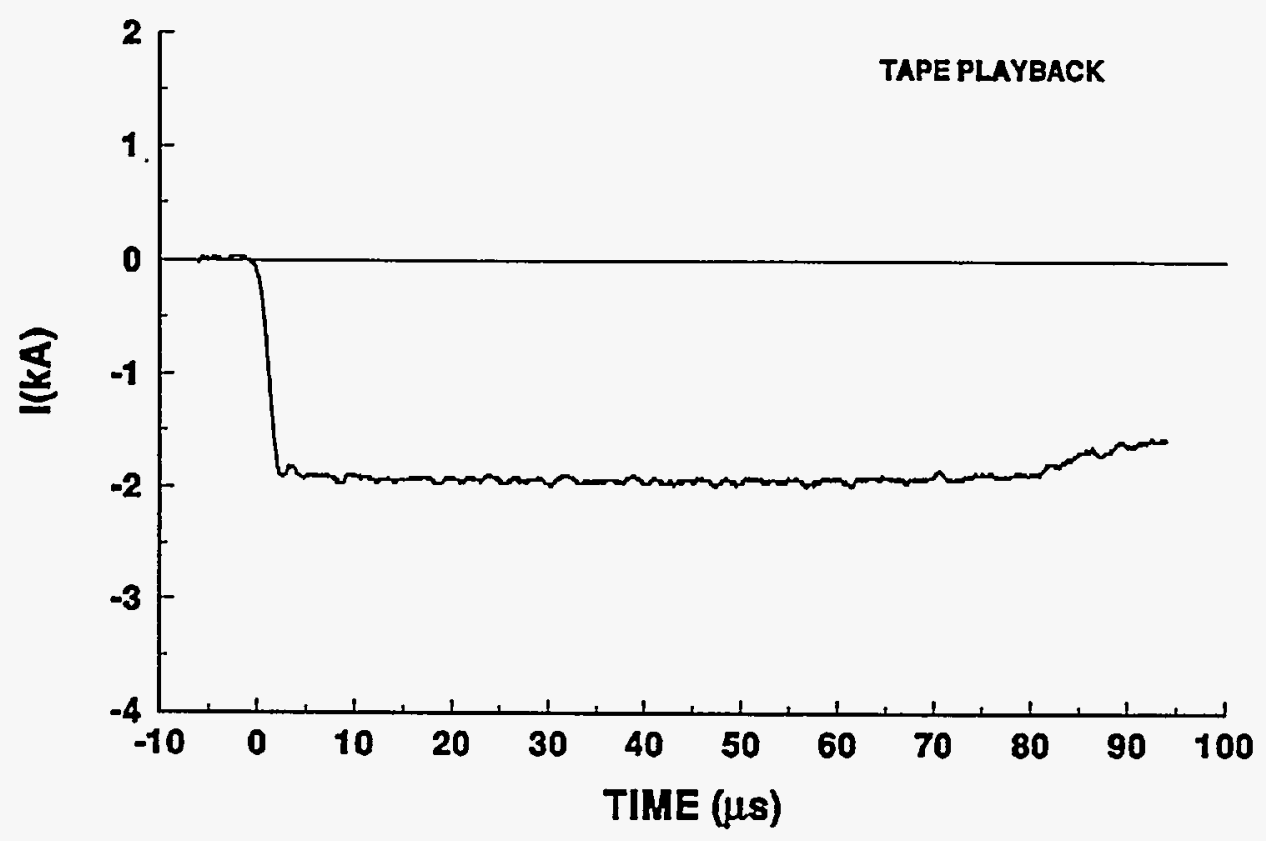

94-02 STROKE 8 TEST POINT 2

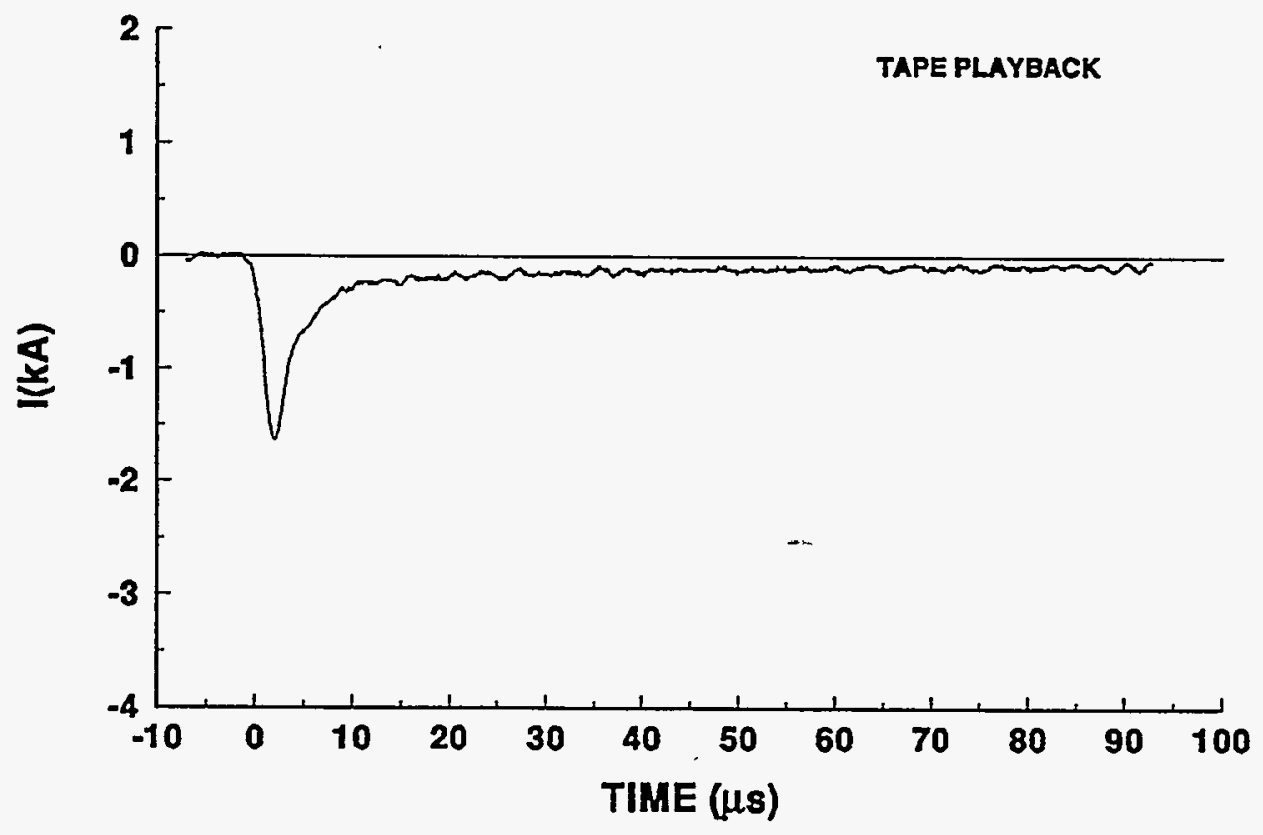


94-06 STROKE 8

TEST POINT 5
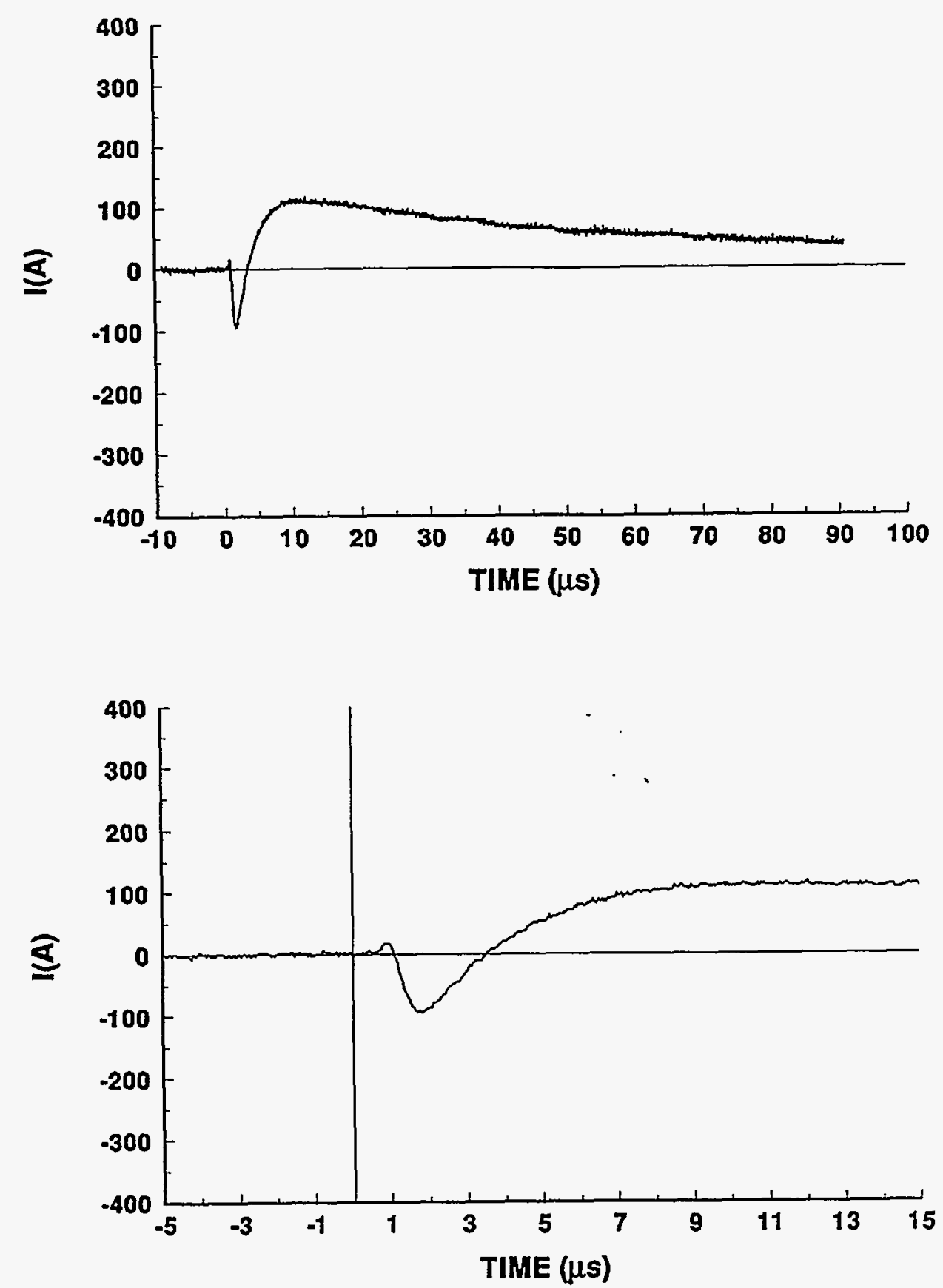


\section{4-06 STROKE 8} TEST POINT 5'
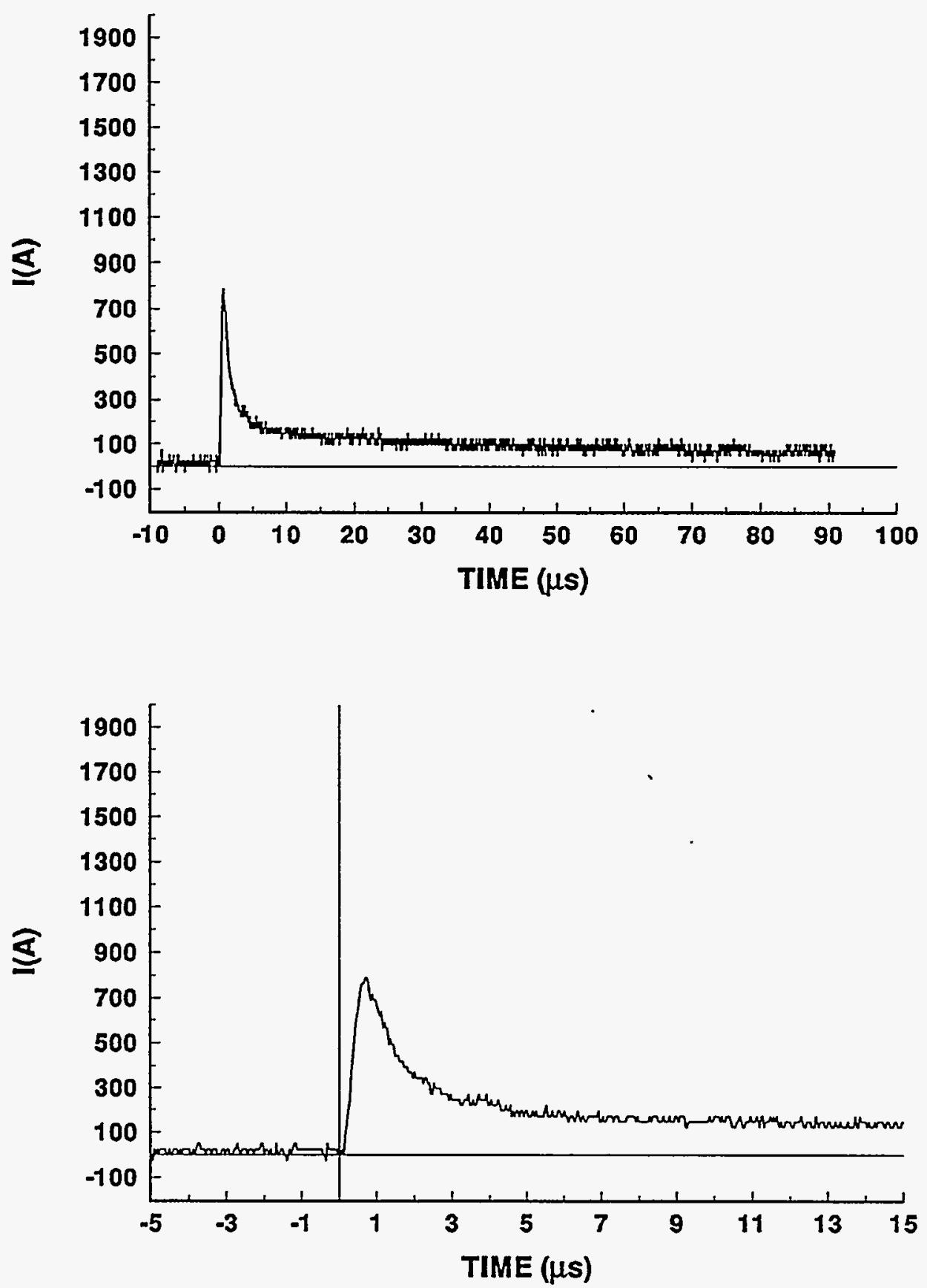


\section{4-06 STROKE 8}

TEST POINT 6'

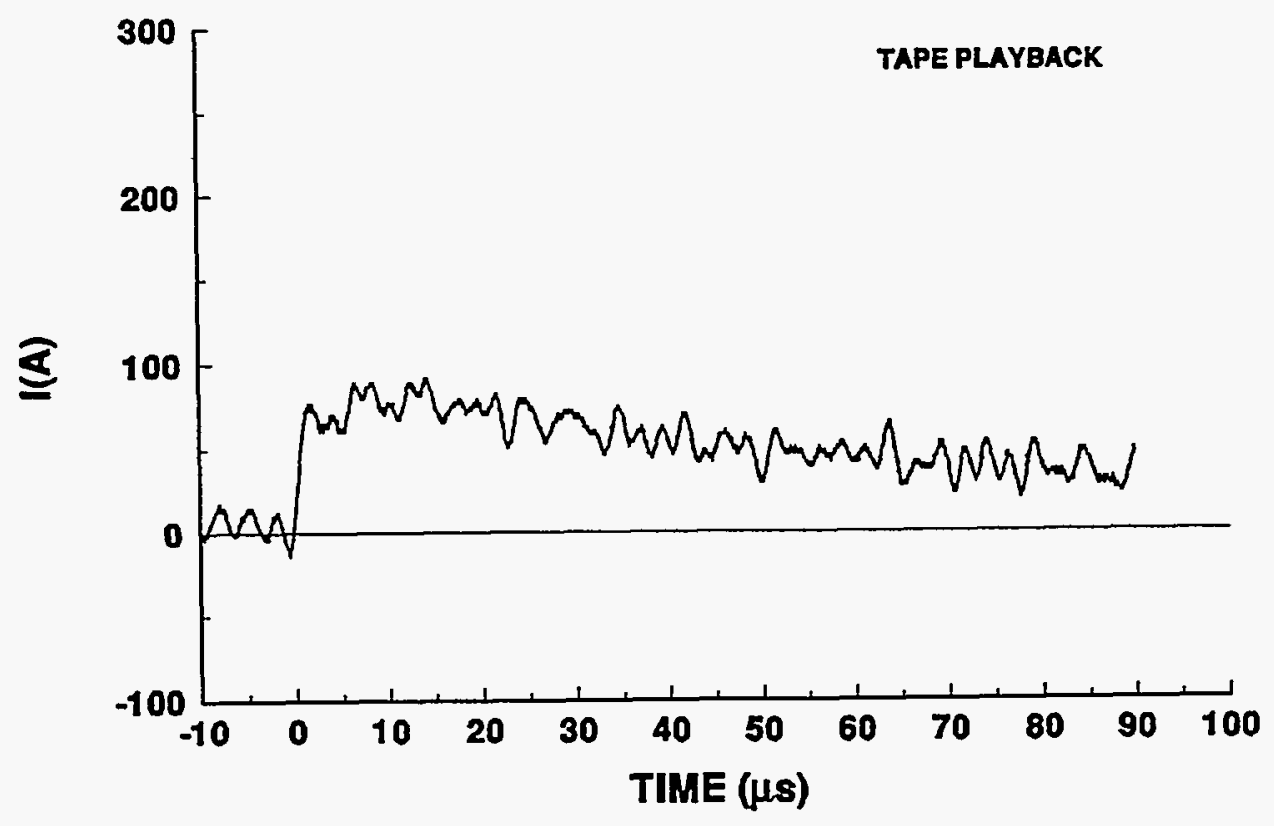




\section{4-06 STROKE 8}

TEST POINT 7
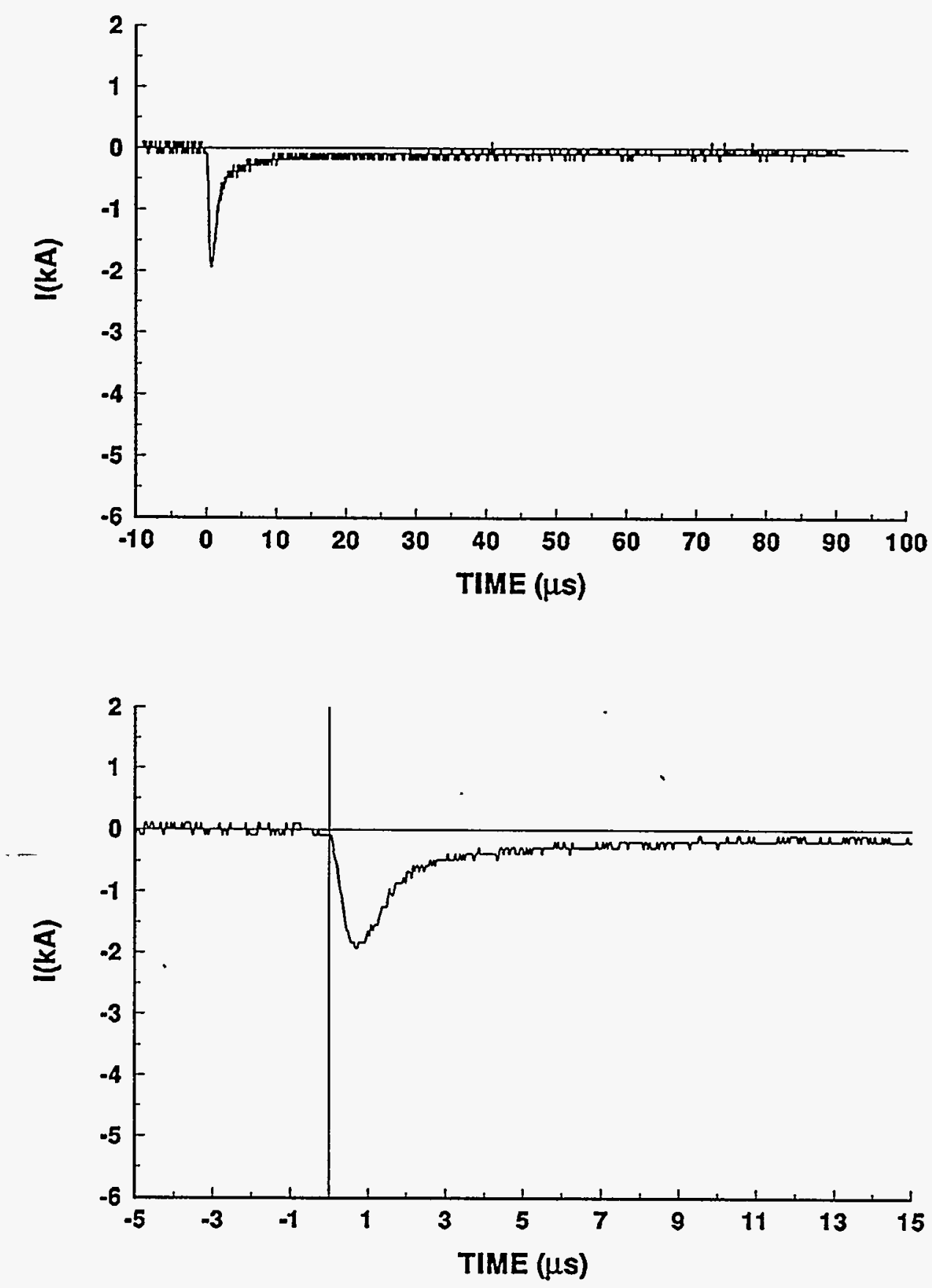


\section{4-06 STROKE 8 \\ TEST POINT 8}
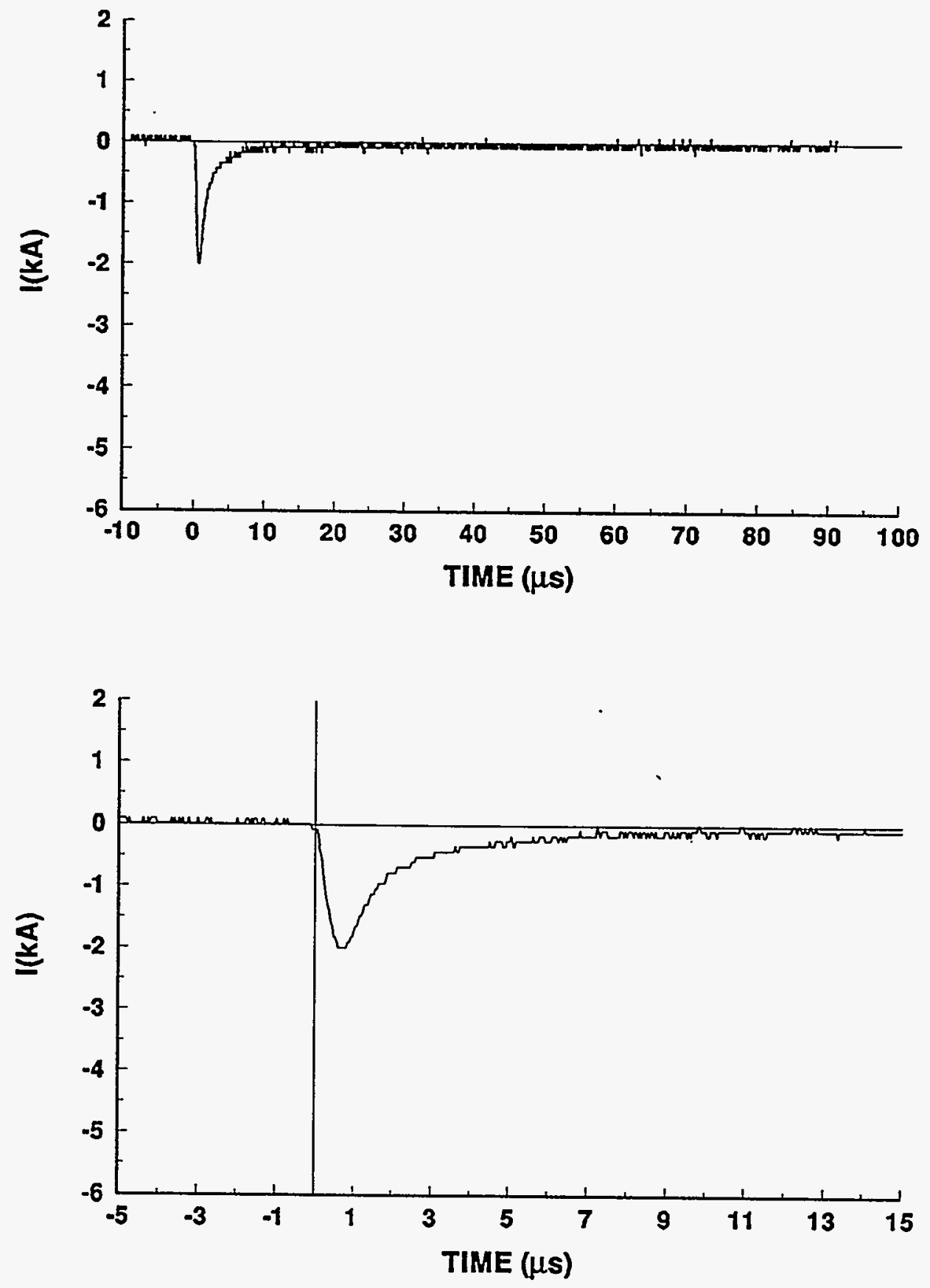


\section{4-06 STROKE 8}

TEST POINT 10

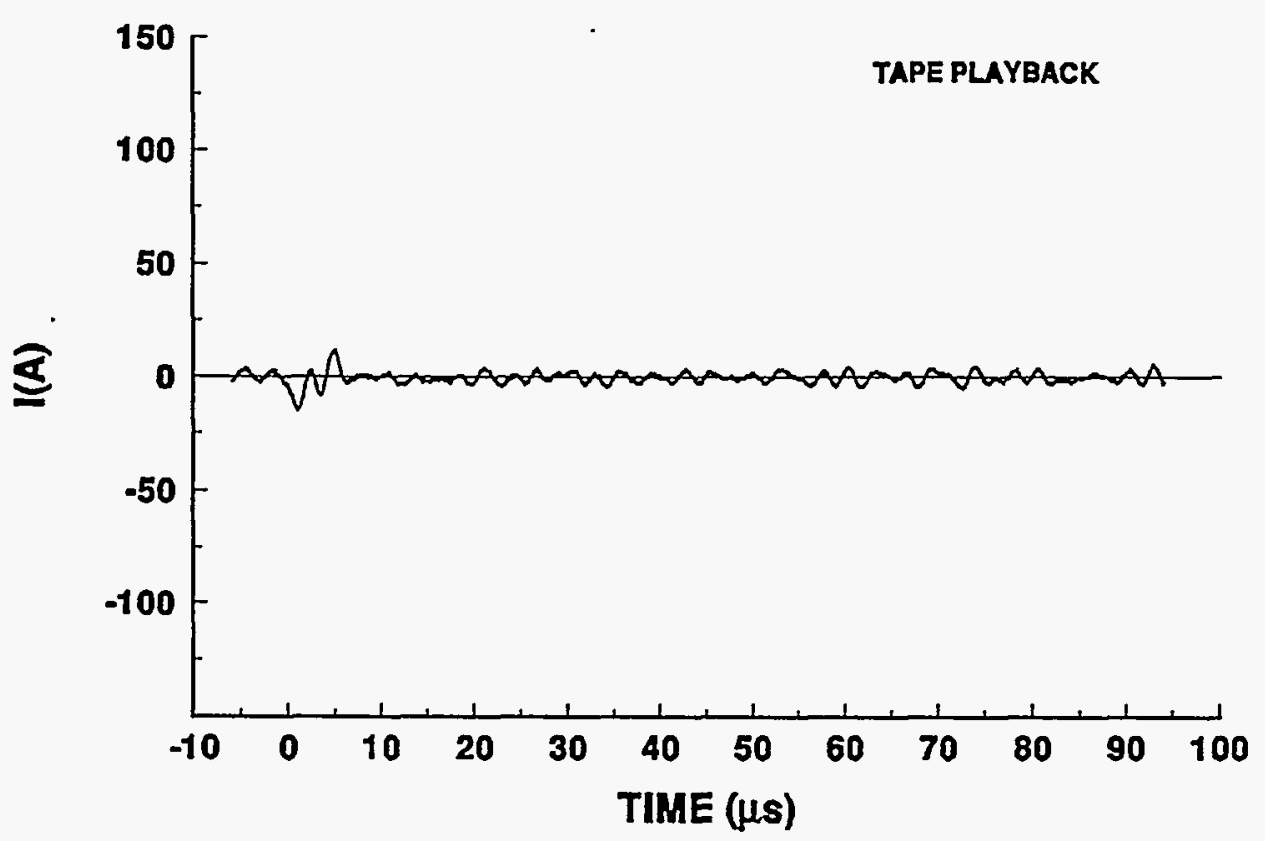

94-06 STROKE 8

TEST POINT 11

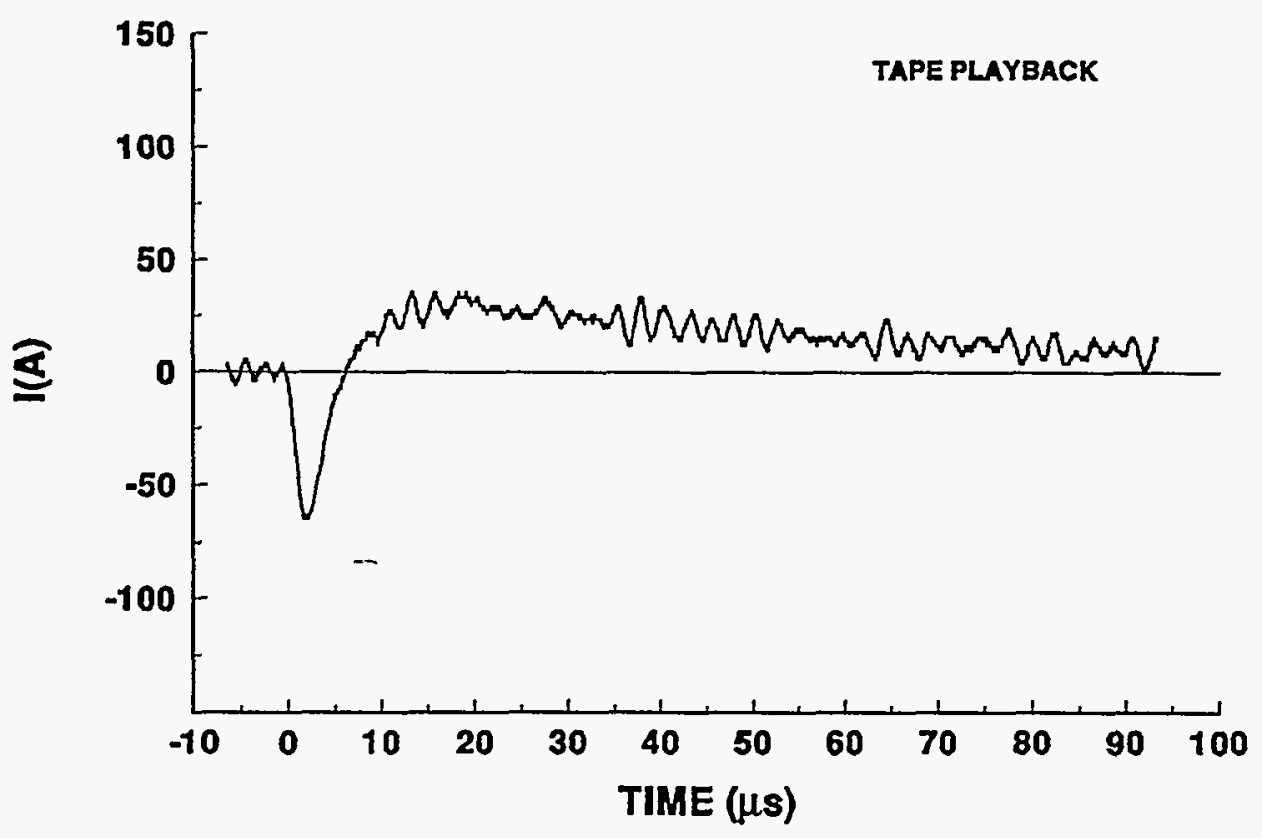




\section{4-06 STROKE 8}

TEST POINT 12

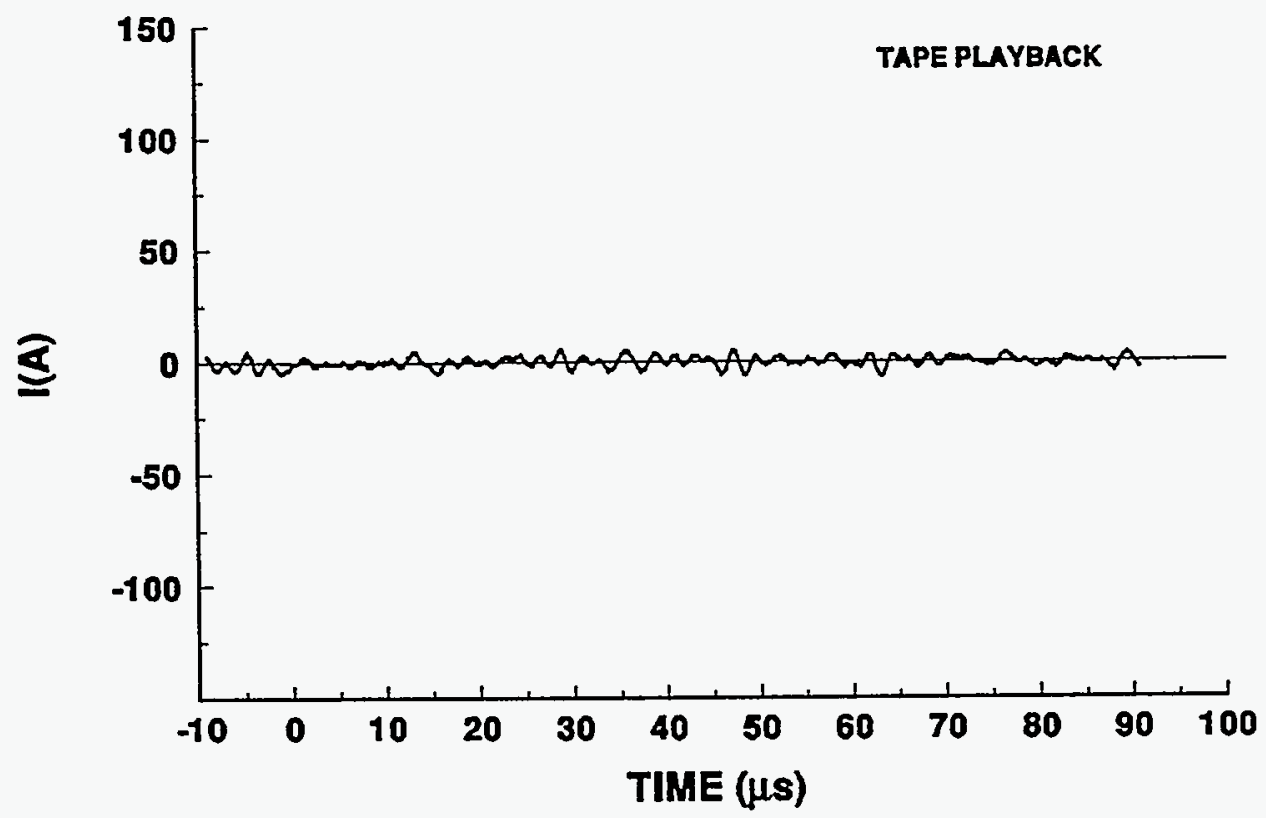

94-06 STROKE 8

TEST POINT 13

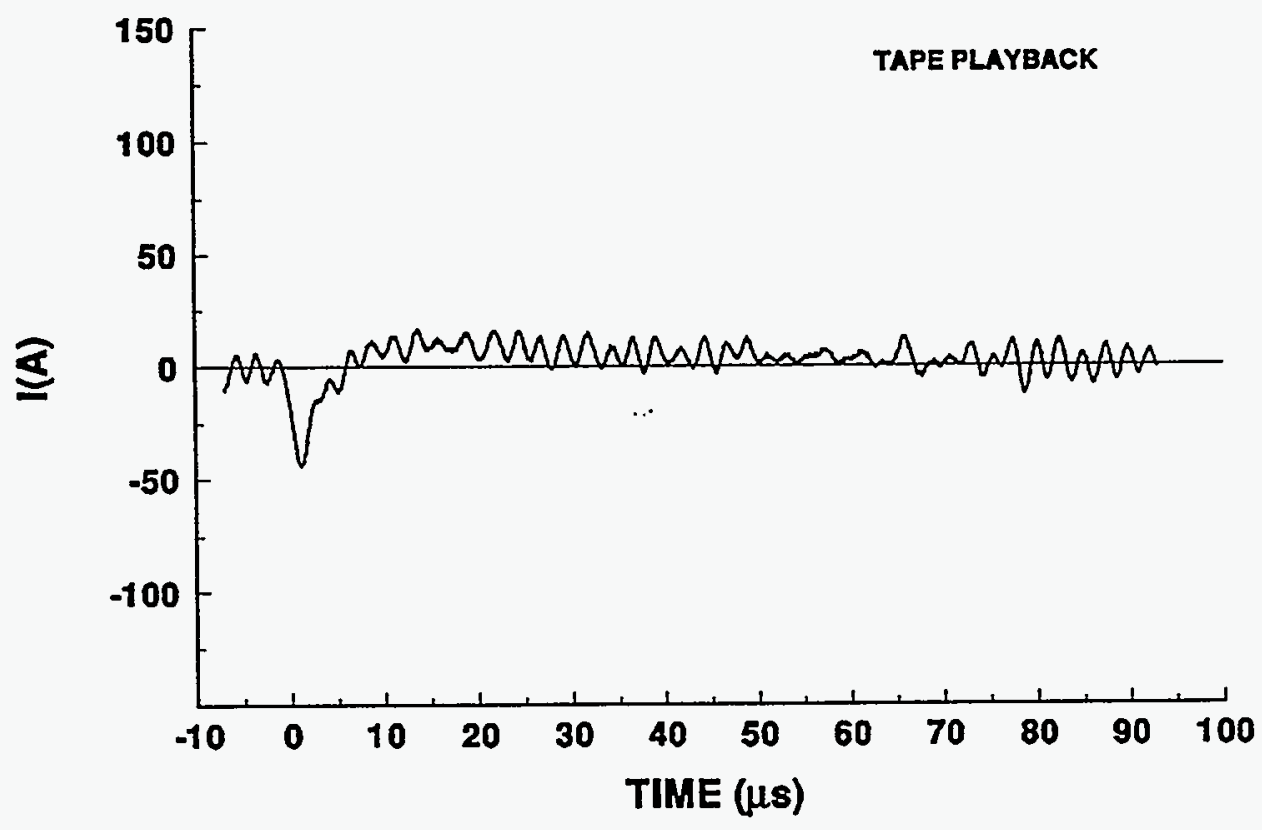




\section{4-06 STROKE 8}

TEST POINT 14
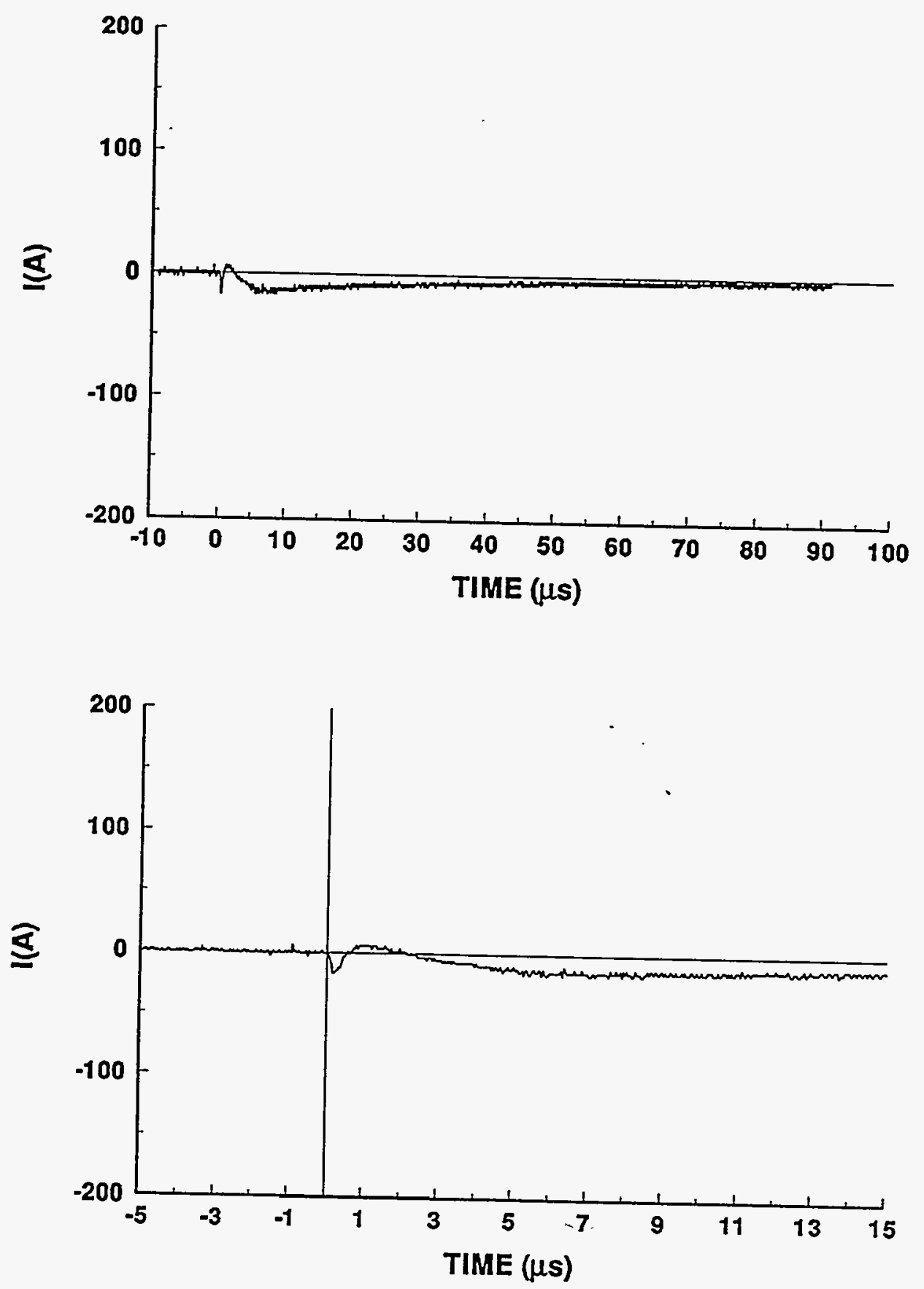


\section{4-06 STROKE 8}

TEST POINT 15
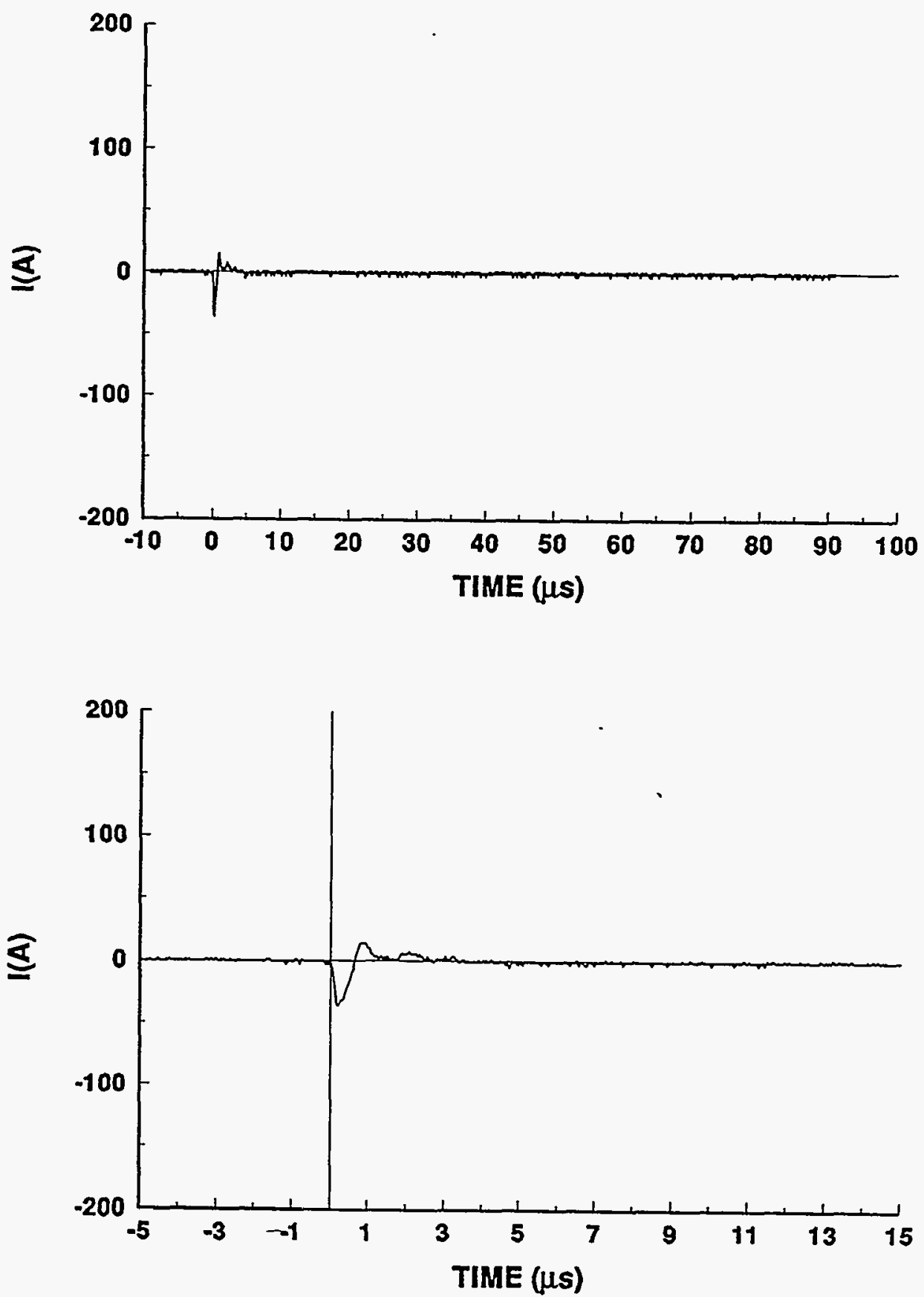


\section{4-06 STROKE 8}

TEST POINT 20

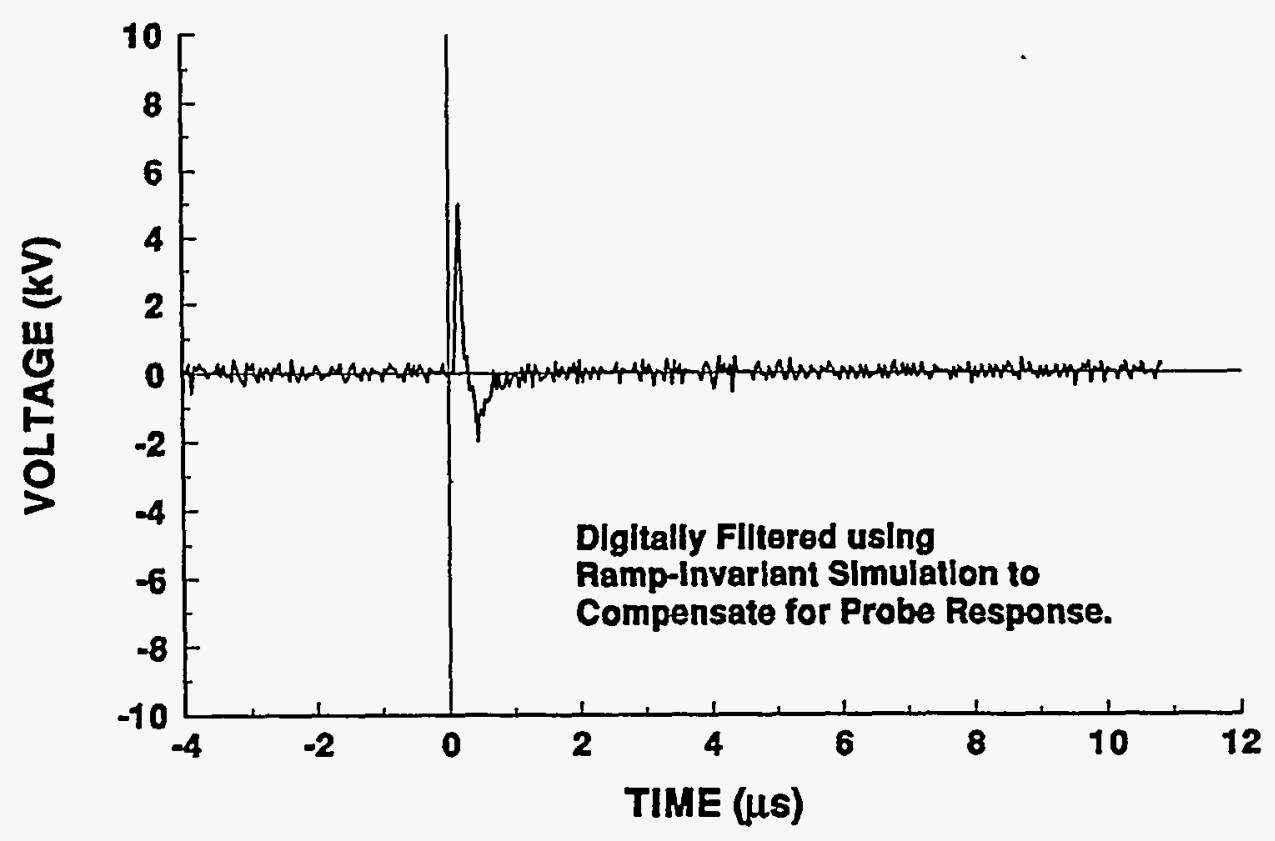

94-06 STROKE 8

TEST POINT 21

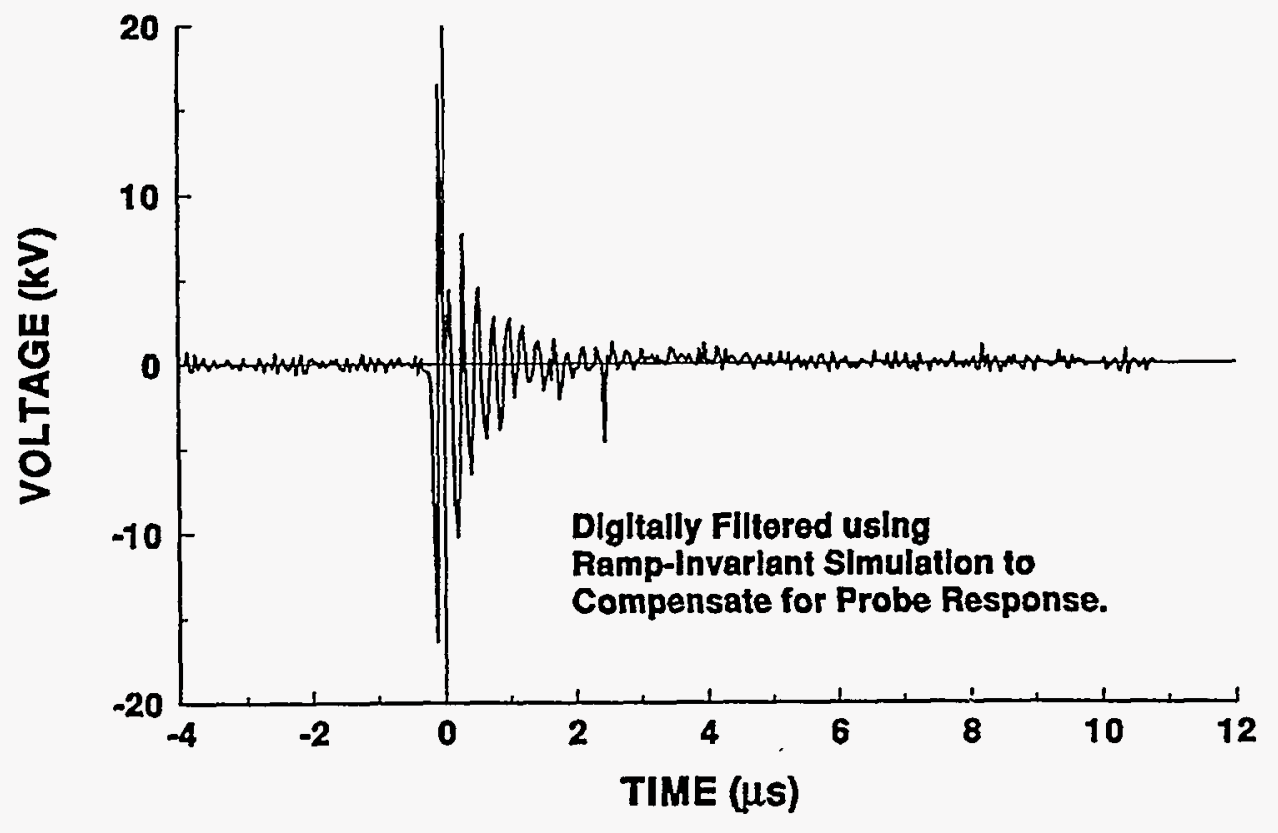




\section{4-06 STROKE 8}

TEST POINT 23

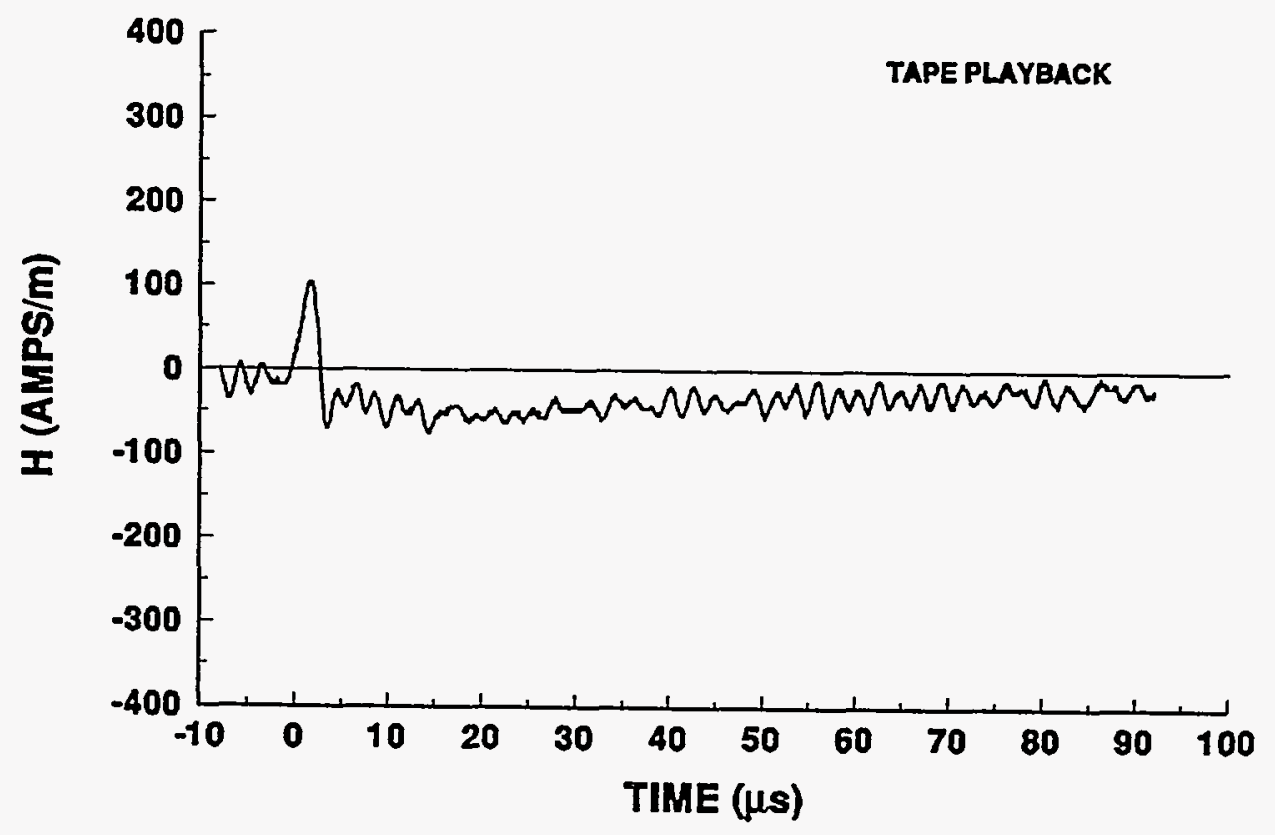




\section{Storm 2 Data Plots}

Flashes 94-07, 94-09, and 94-10 


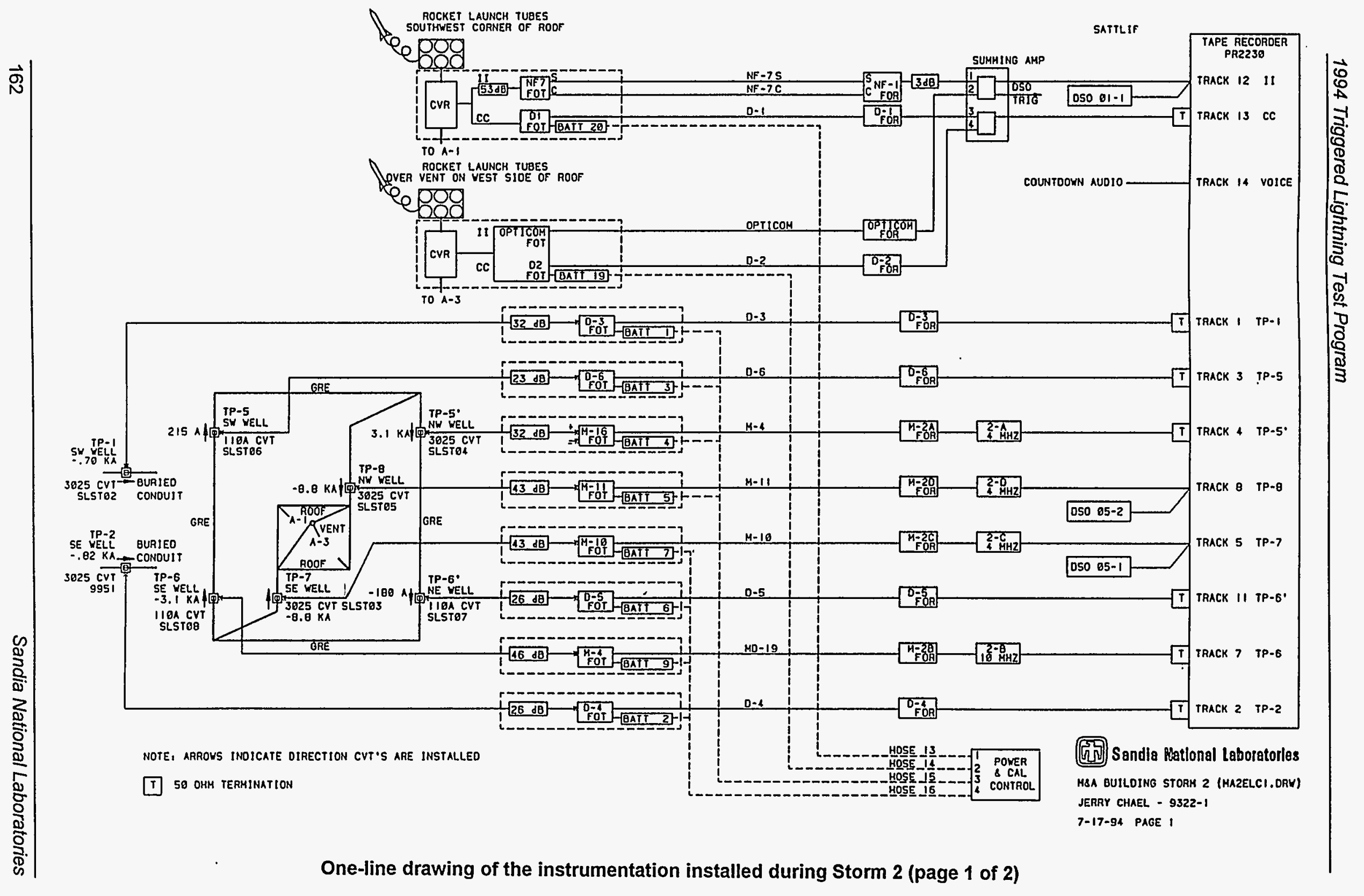




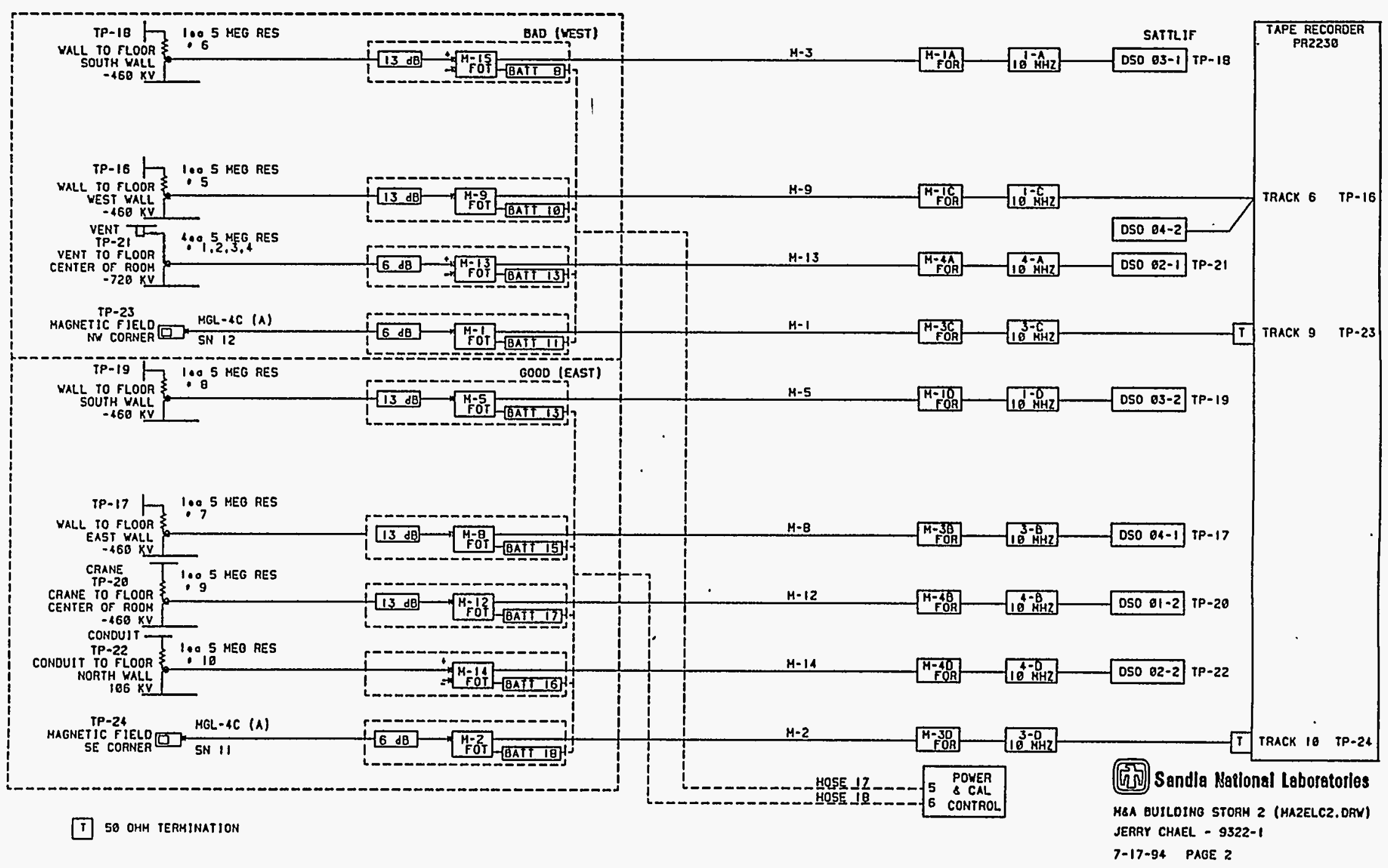

One-line drawing of the instrumentation installed during Storm 2 (page 2 of 2) 


\section{4-07 STROKE 1 \\ INCIDENT CURRENT}
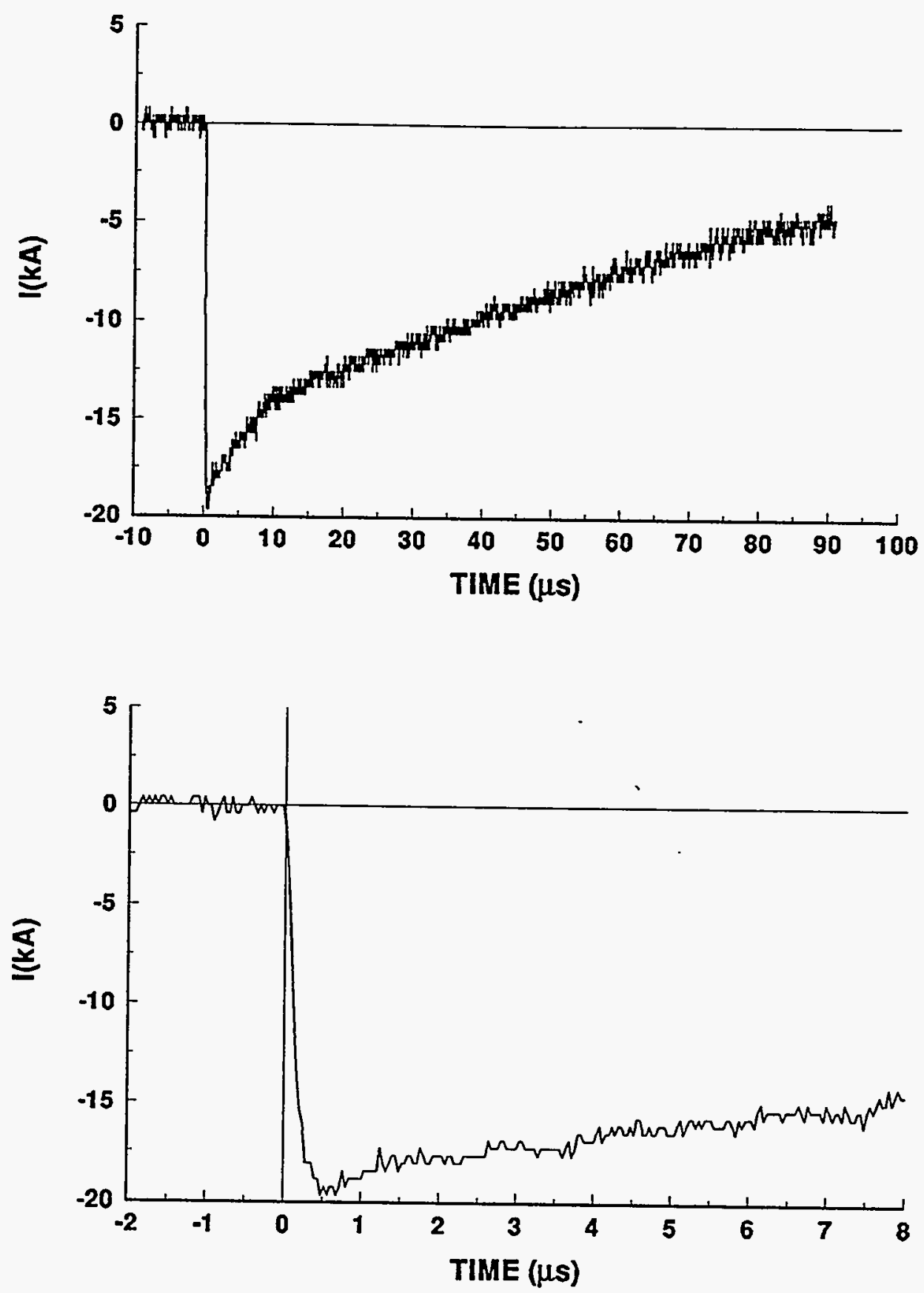


\section{4-07 STROKE 1}

TEST POINT 1

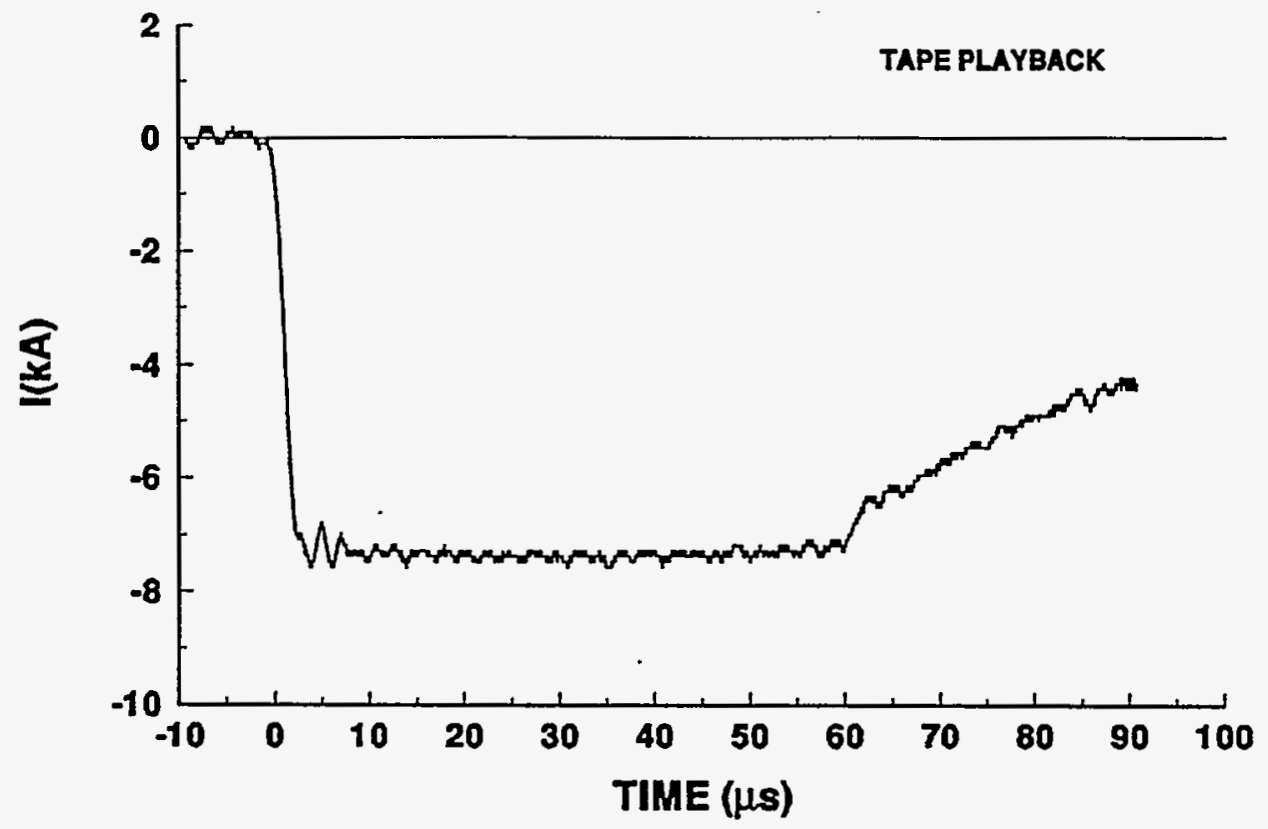

\section{4-07 STROKE.1}

\section{TEST POINT 2}

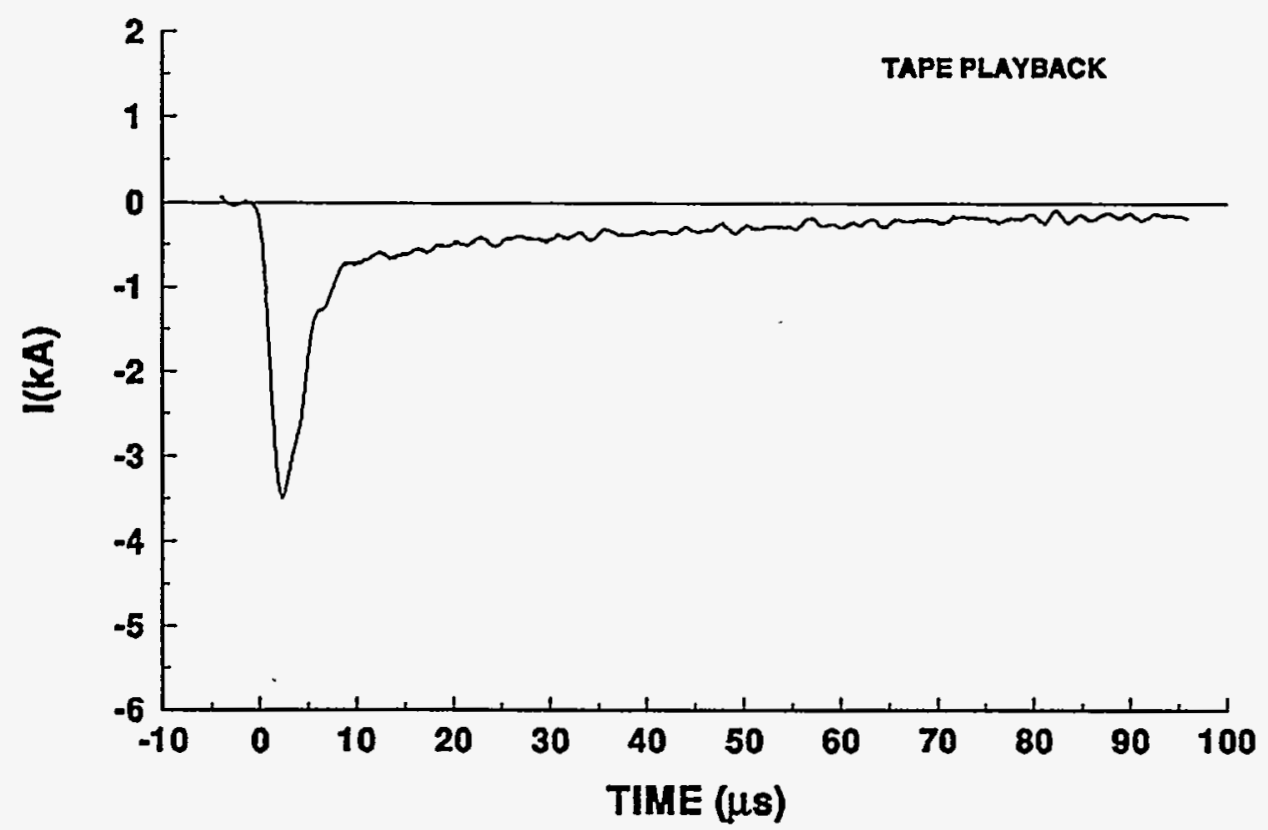


94-07 STROKE 1

TEST POINT 5

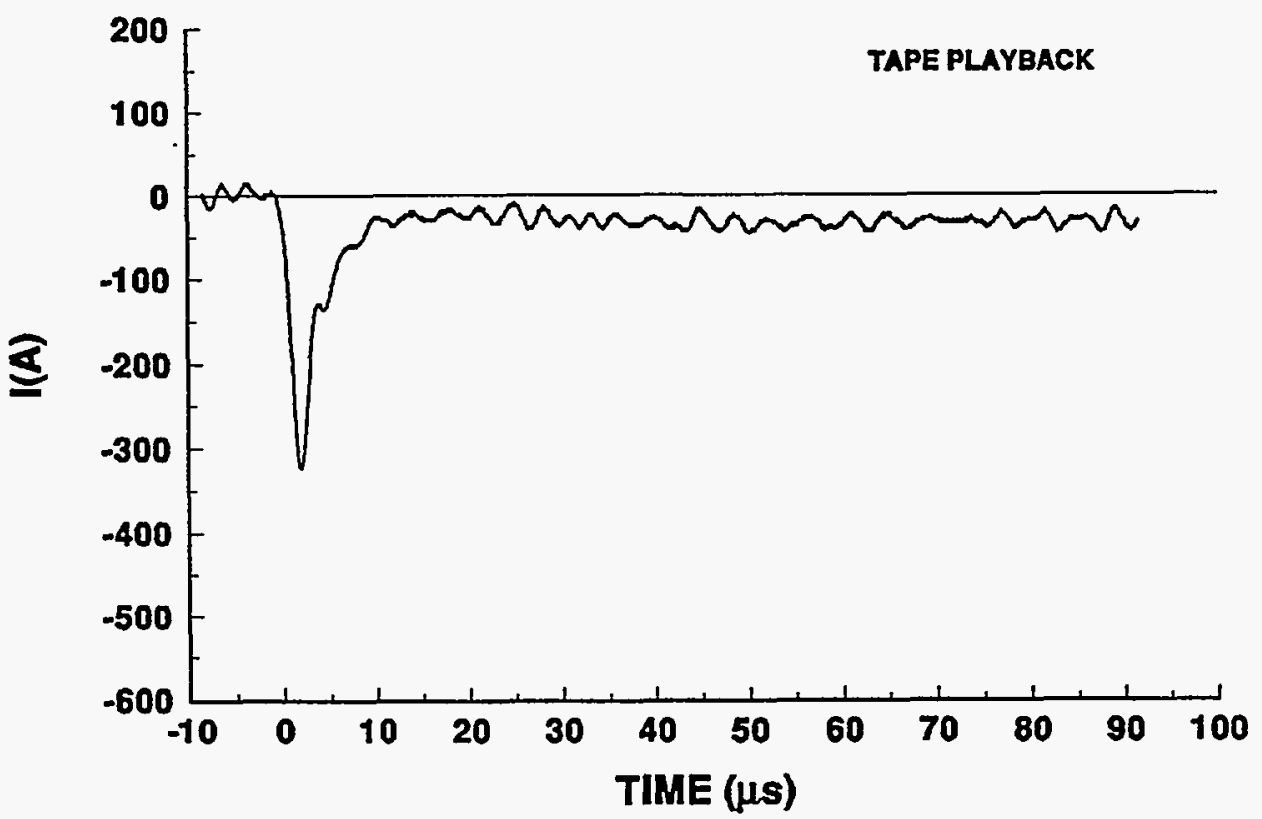

94-07 STROKE'1

TEST POINT 5'

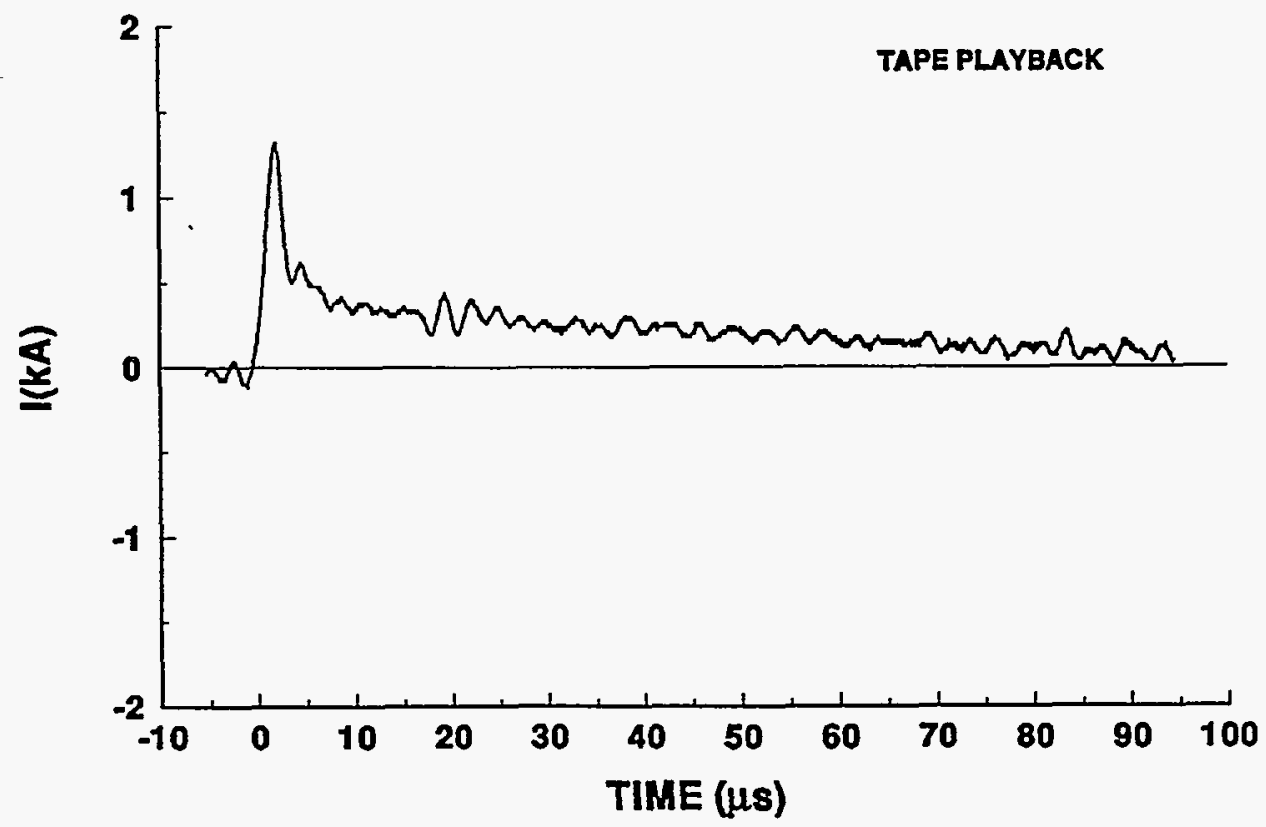




\section{4-07 STROKE 1}

TEST POINT 6
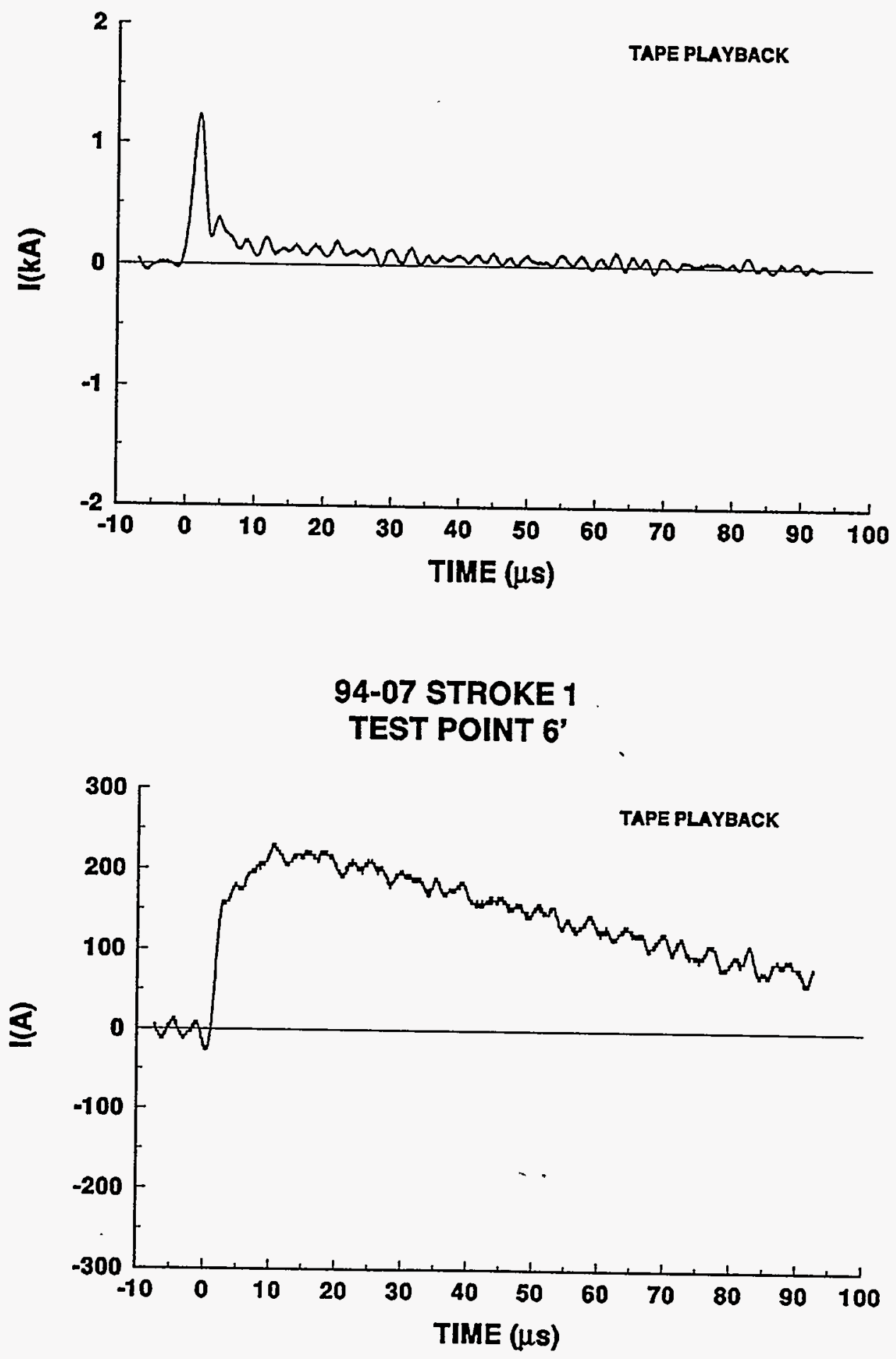
94-07 STROKE 1

TEST POINT 7
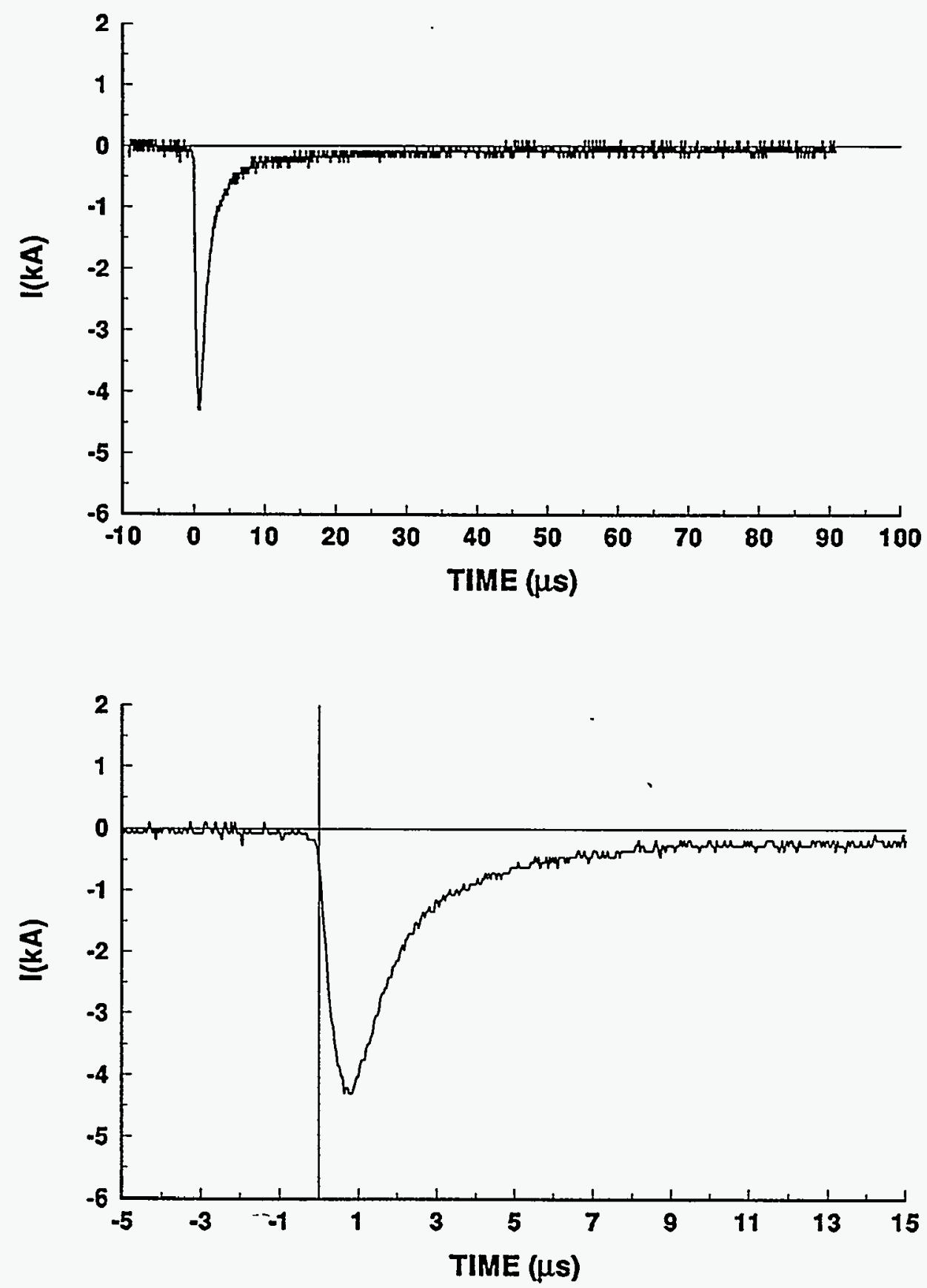


\section{4-07 STROKE 1}

\section{TEST POINT 8}
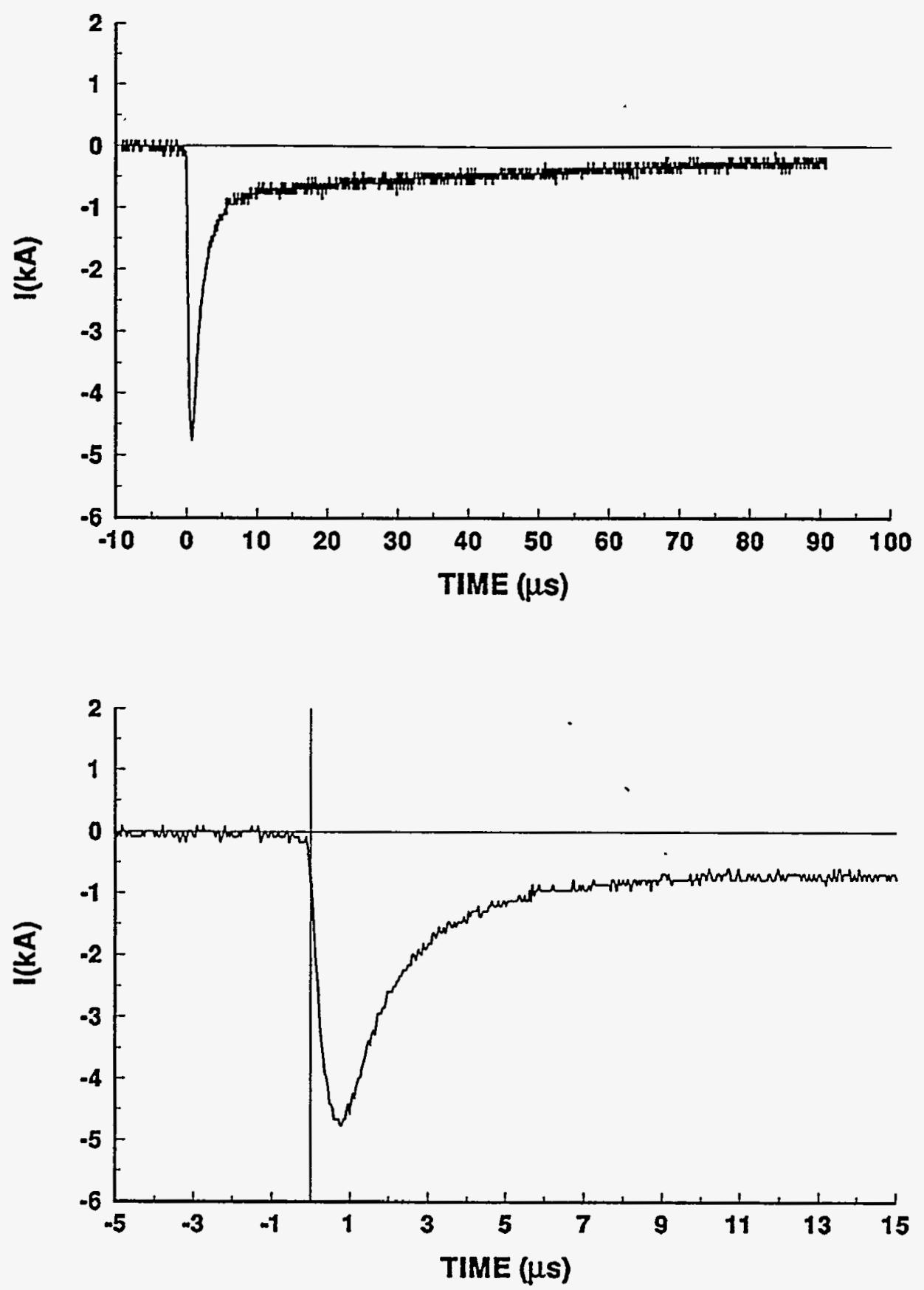


\section{4-07 STROKE 1}

TEST POINT 16

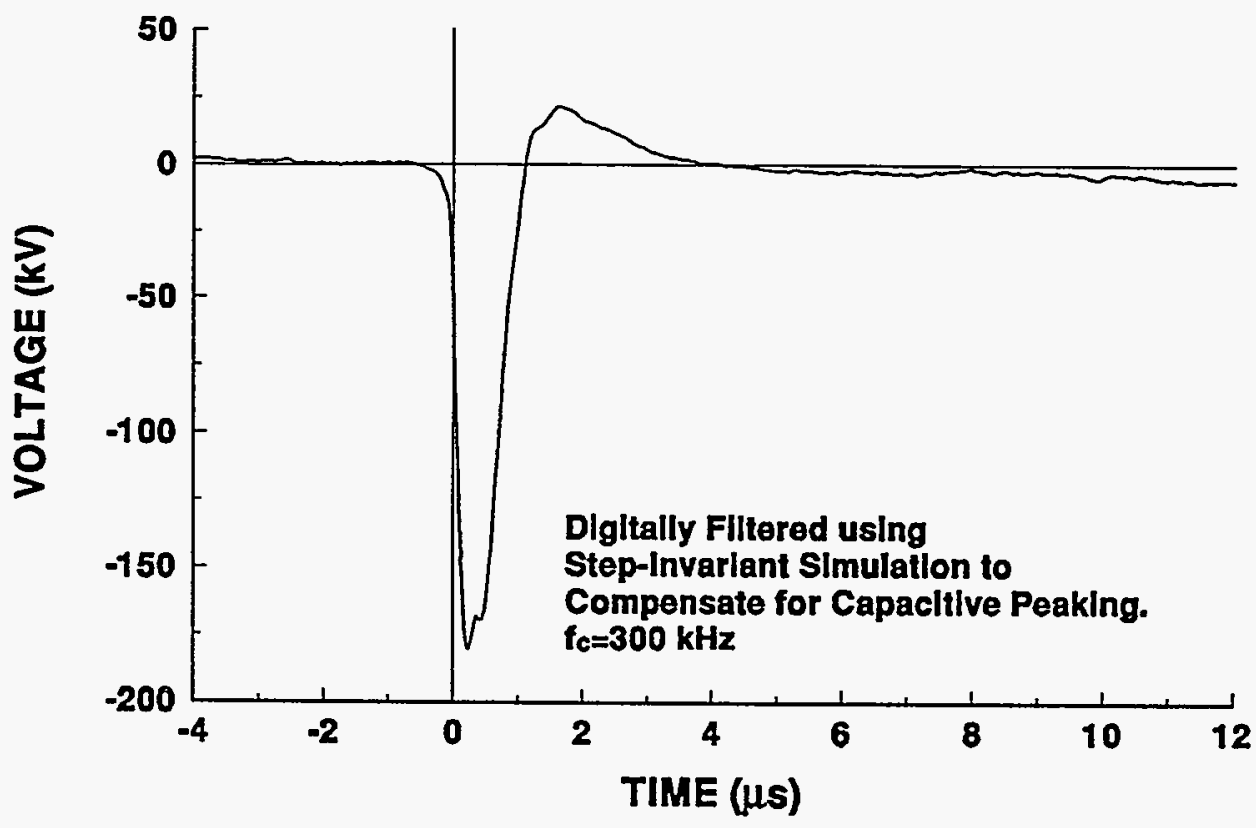

\section{4-07 STROKE 1} TEST POINT 17

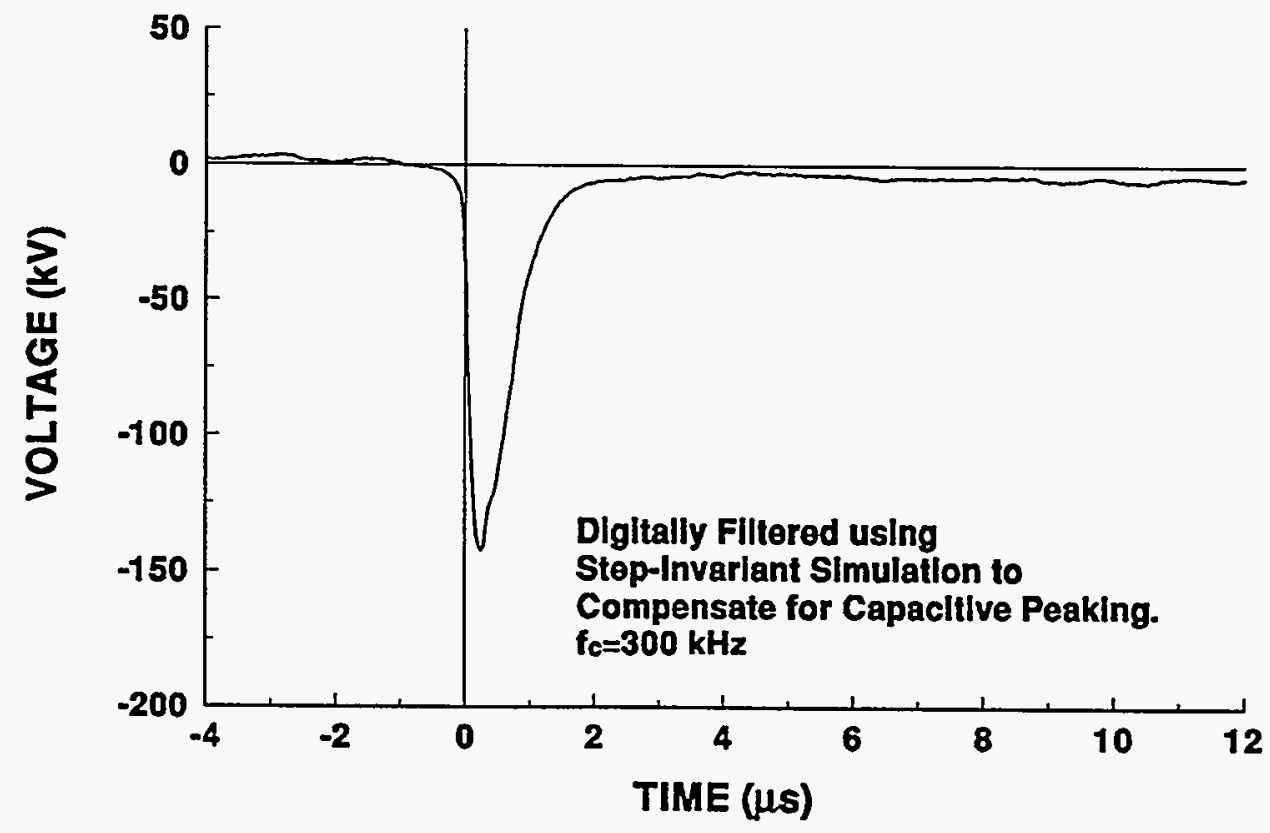




\section{4-07 STROKE 1}

\section{TEST POINT 18}

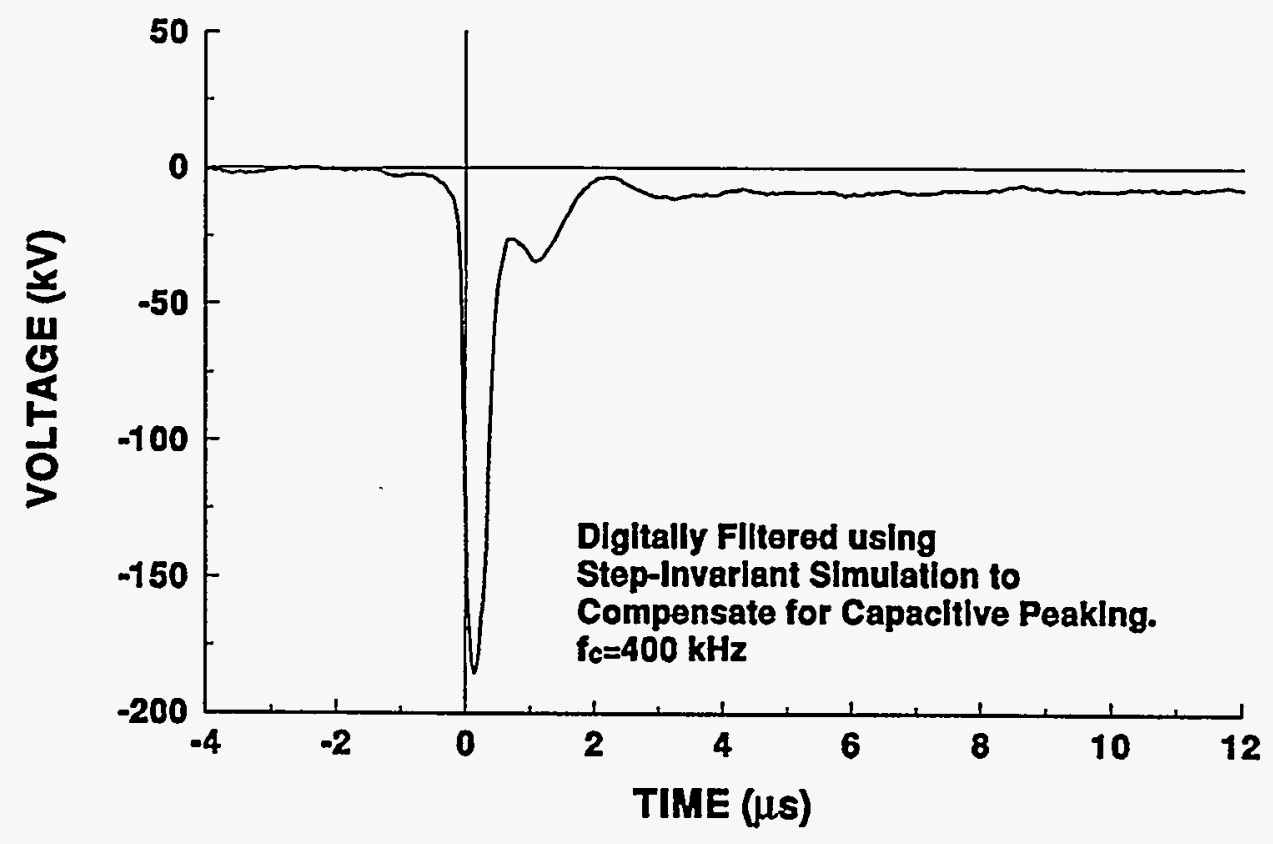

\section{4-07 STROKE-1}

TEST POINT 19

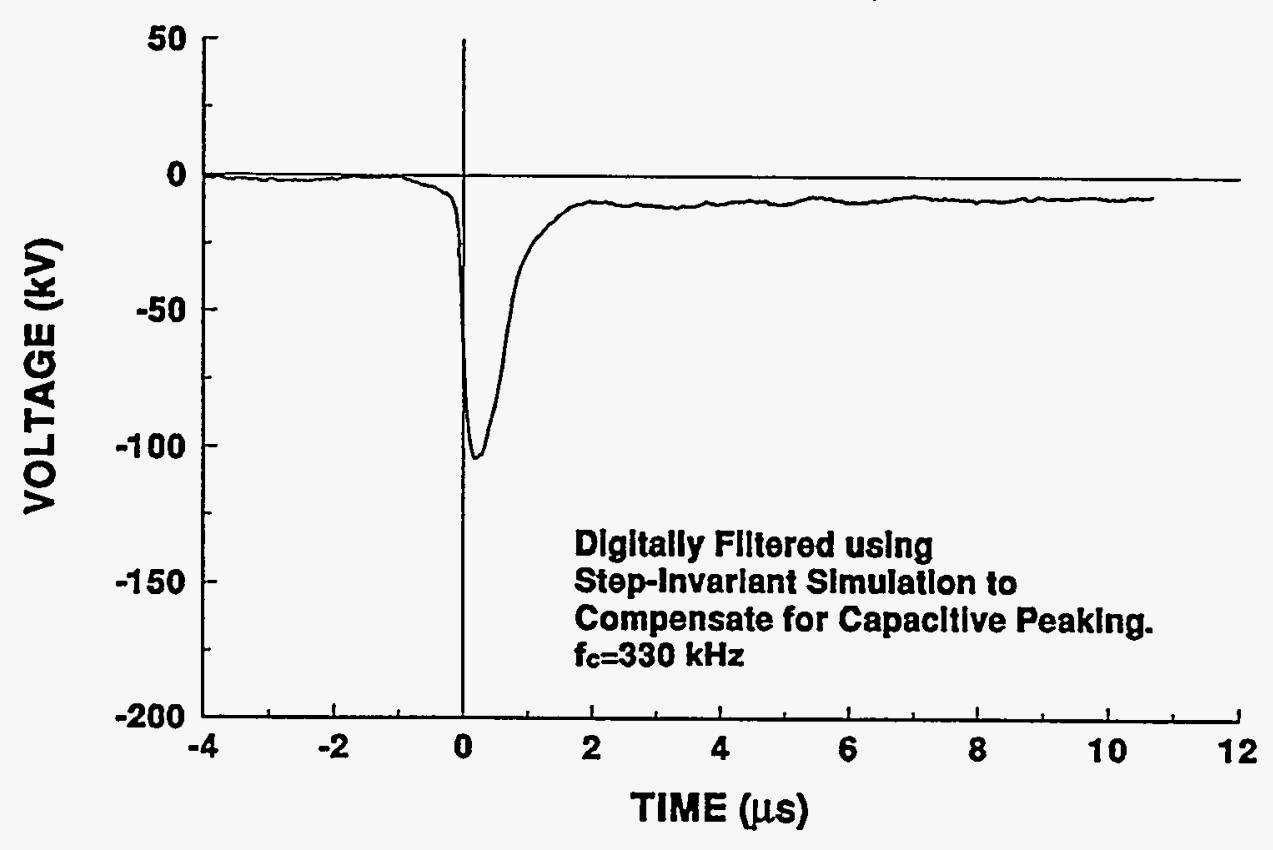




\section{4-07 STROKE 1}

TEST POINT 20

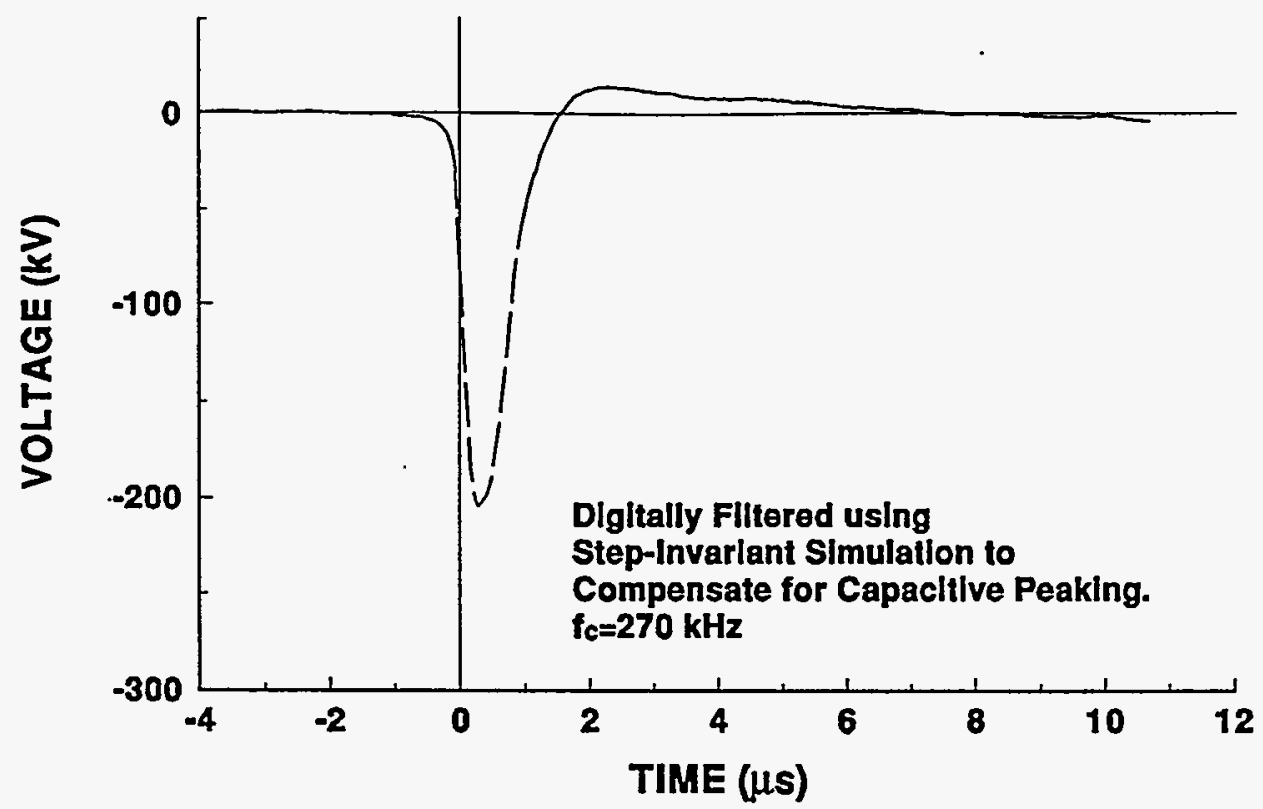

94-07 STROKE 1

TEST POINT 22

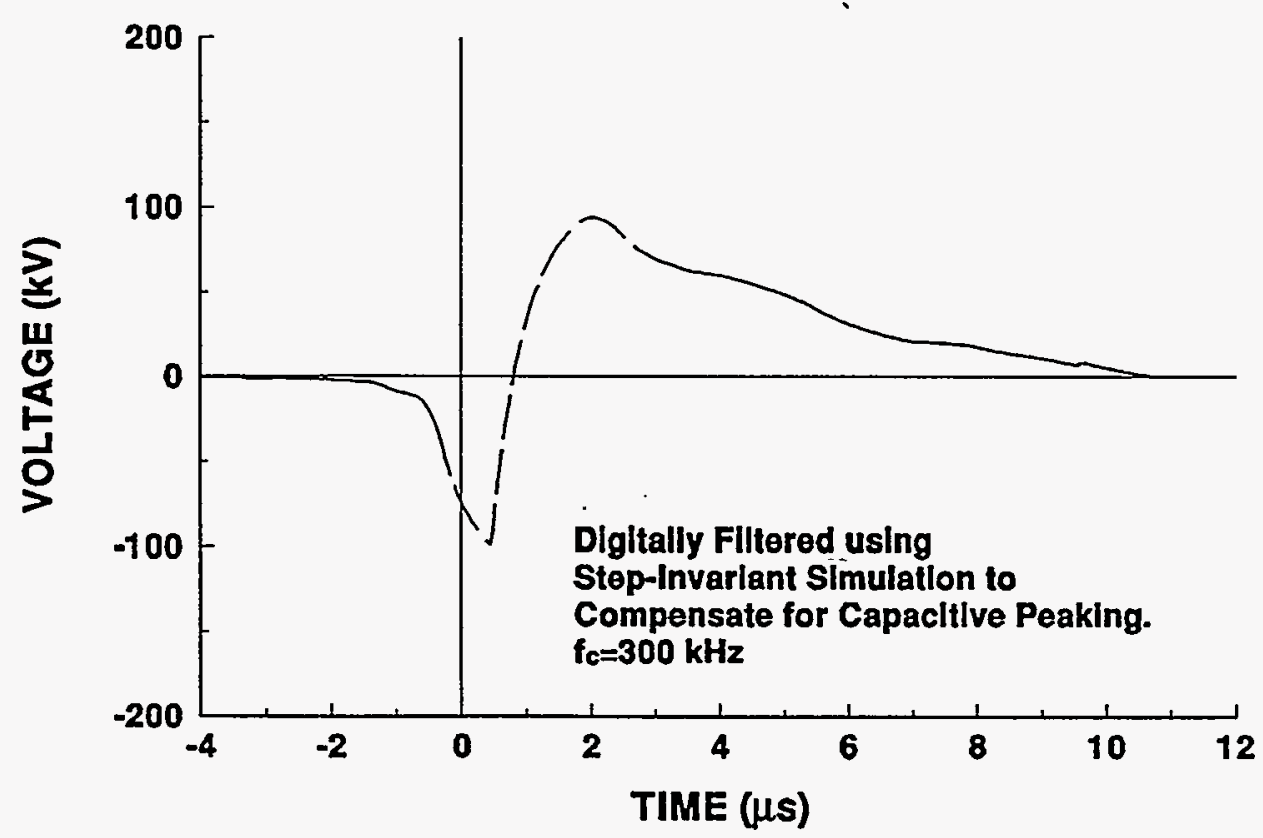




\section{4-07 STROKE 1}

\section{TEST POINT 23}

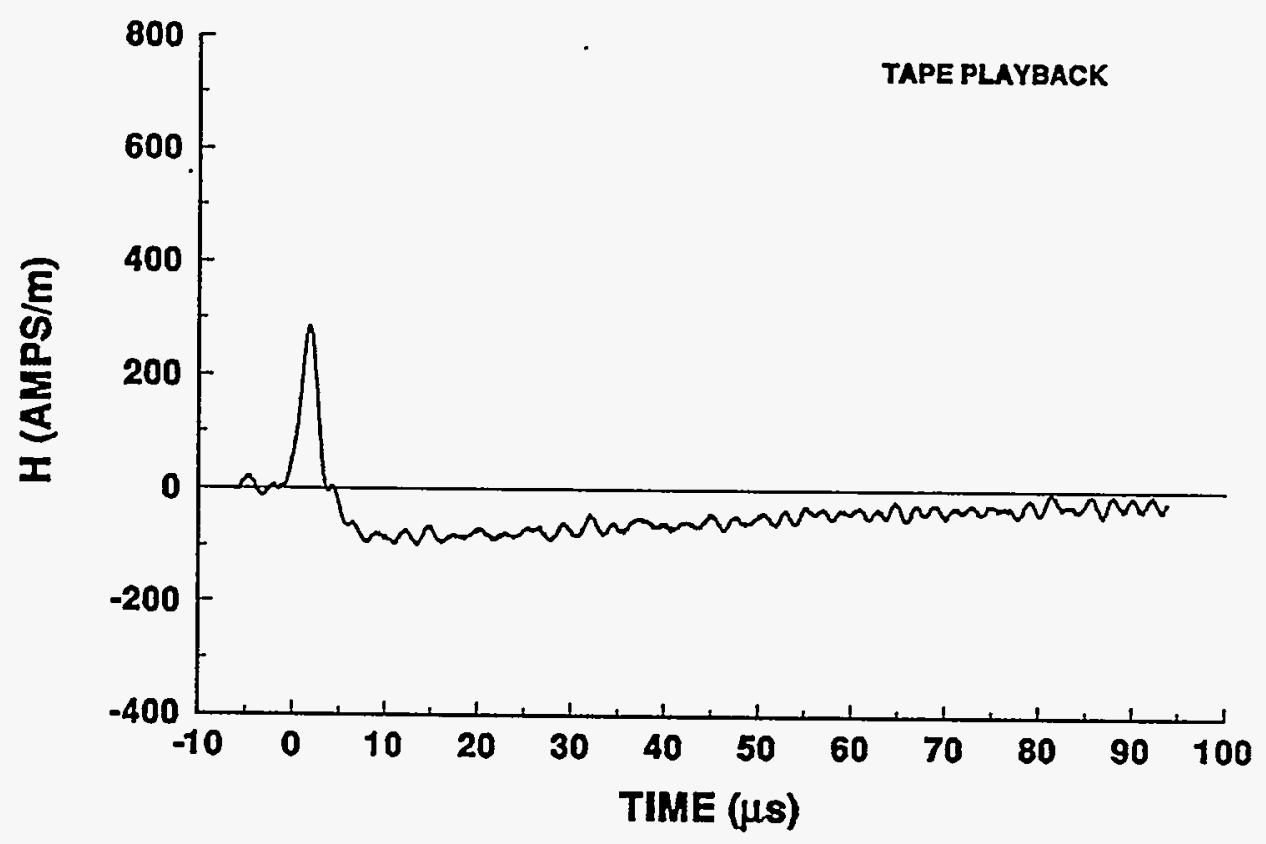

94-07 STROKE.1

TEST POINT 24

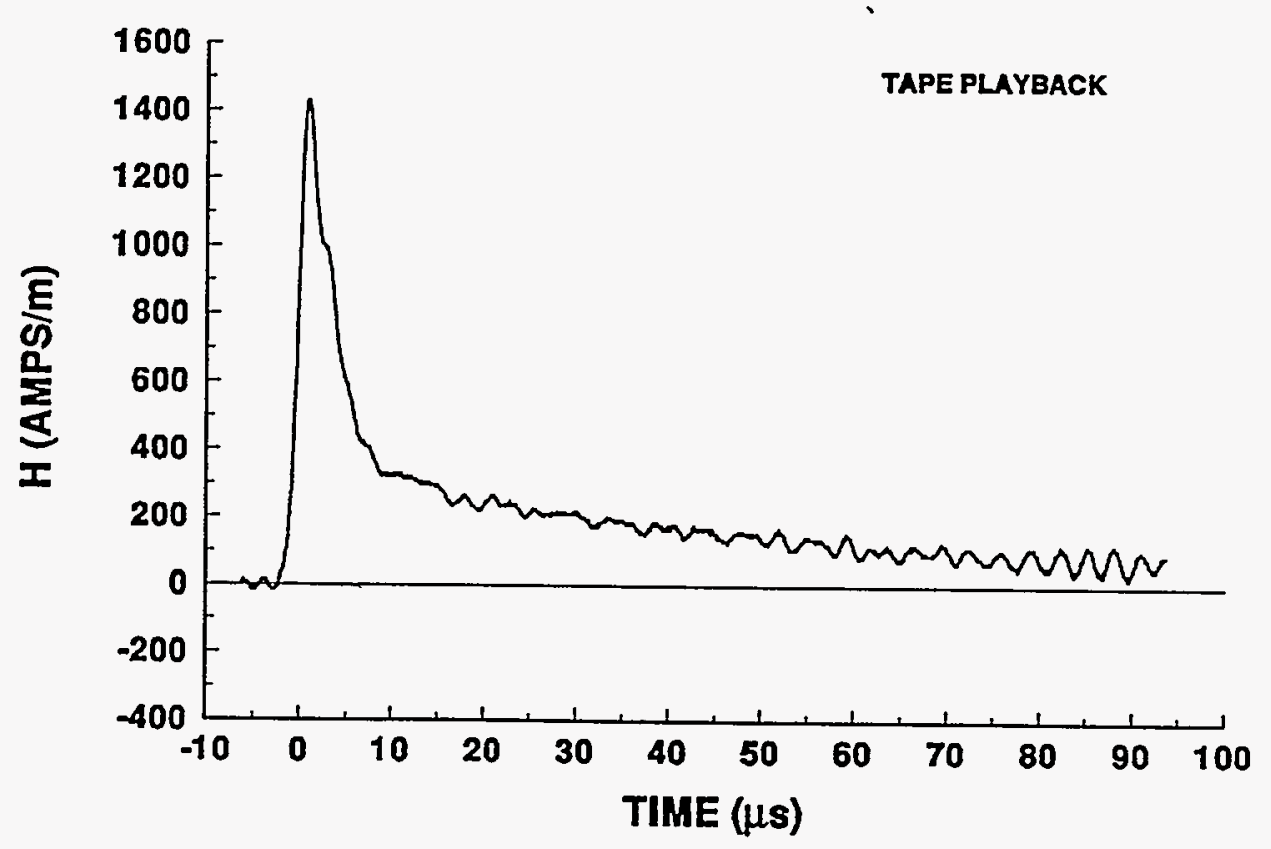




\section{4-07 STROKE 2 \\ INCIDENT CURRENT}
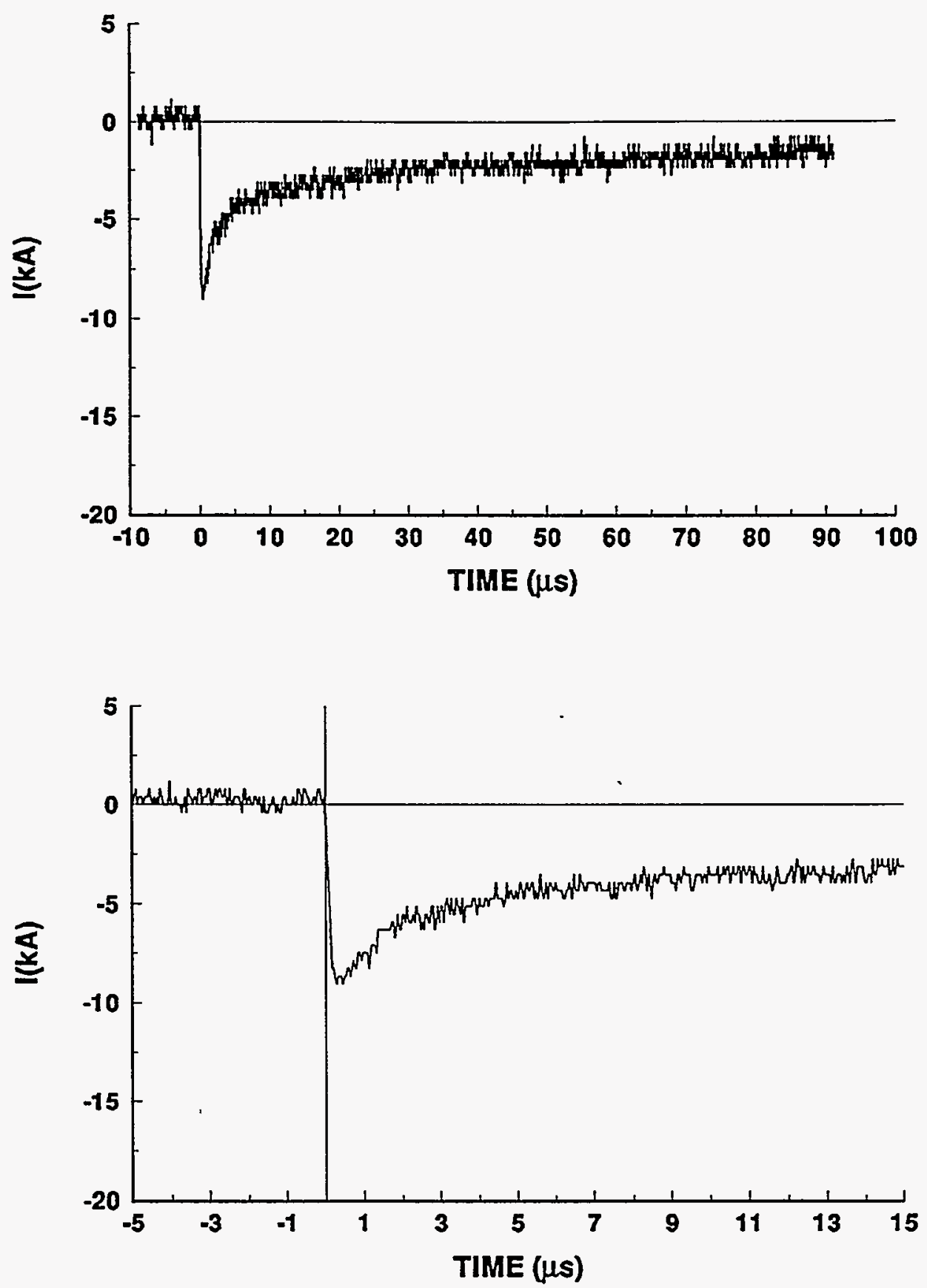


\section{4-07 STROKE 2}

\section{TEST POINT 1}

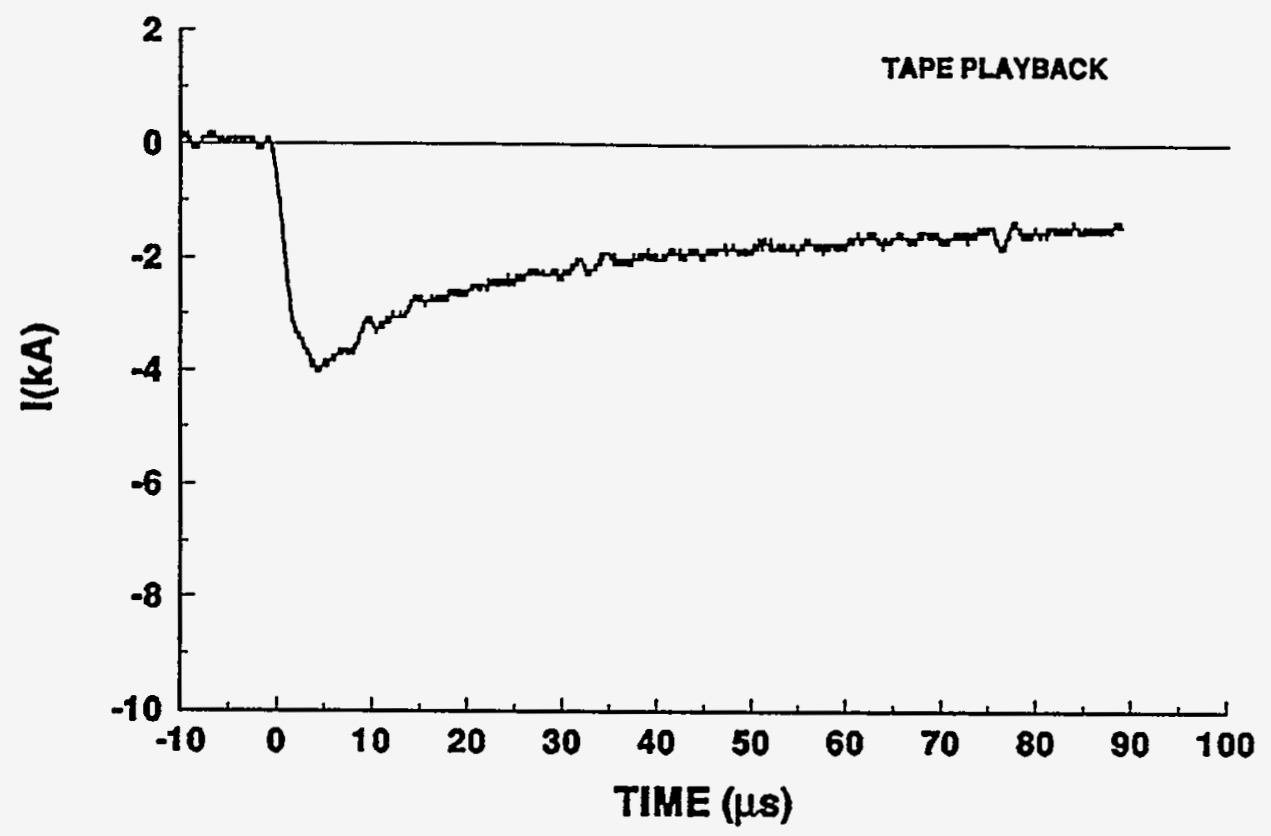

94-07 STROKE 2

TEST POINT 2

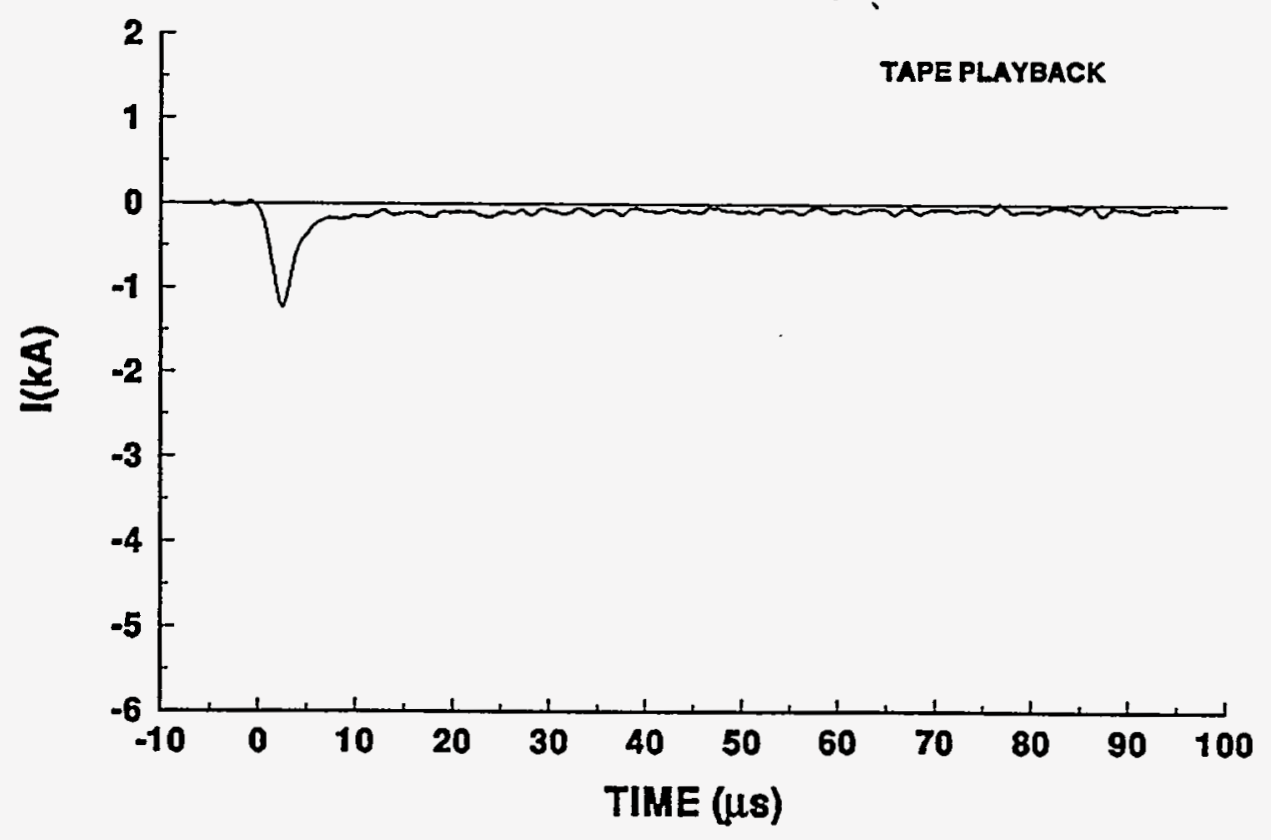




\section{4-07 STROKE 2 \\ TEST POINT 5}

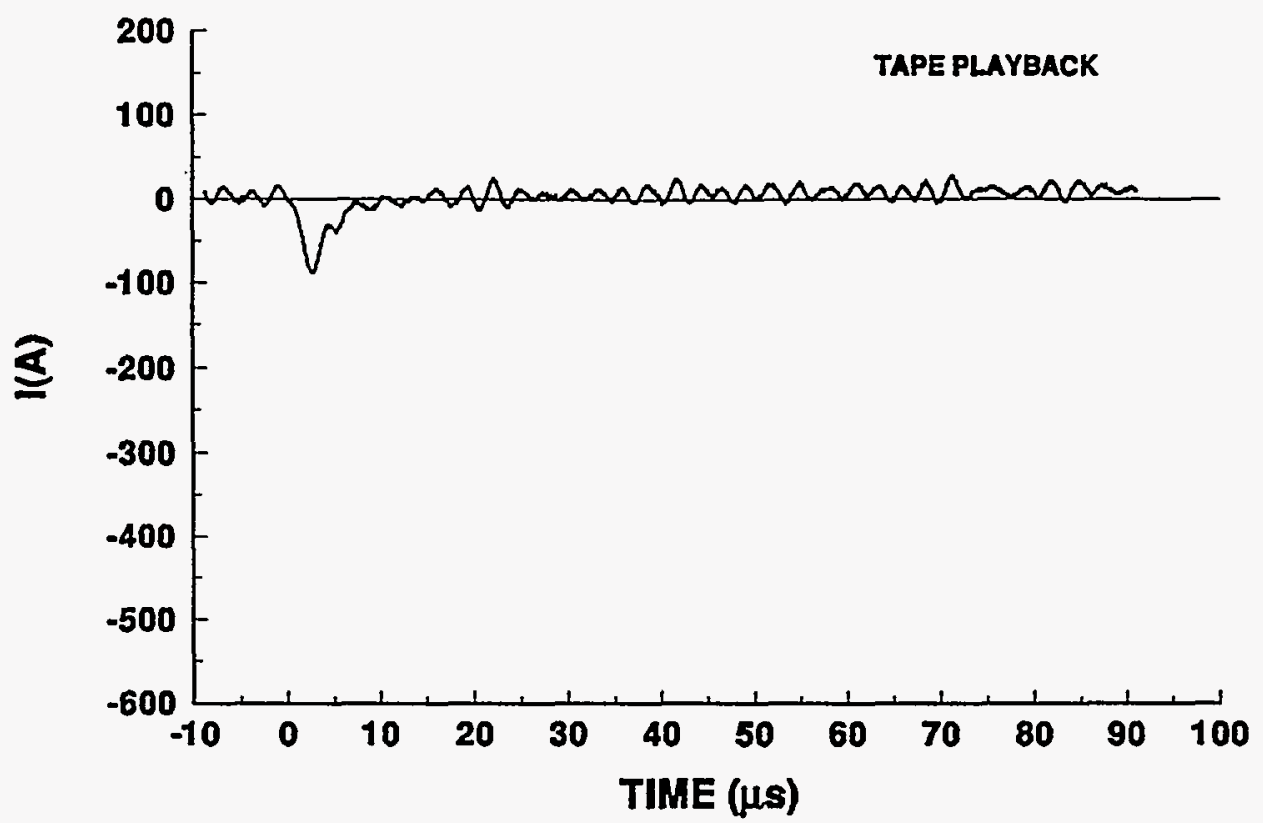

\section{4-07 STROKE 2}

TEST POINT 5'

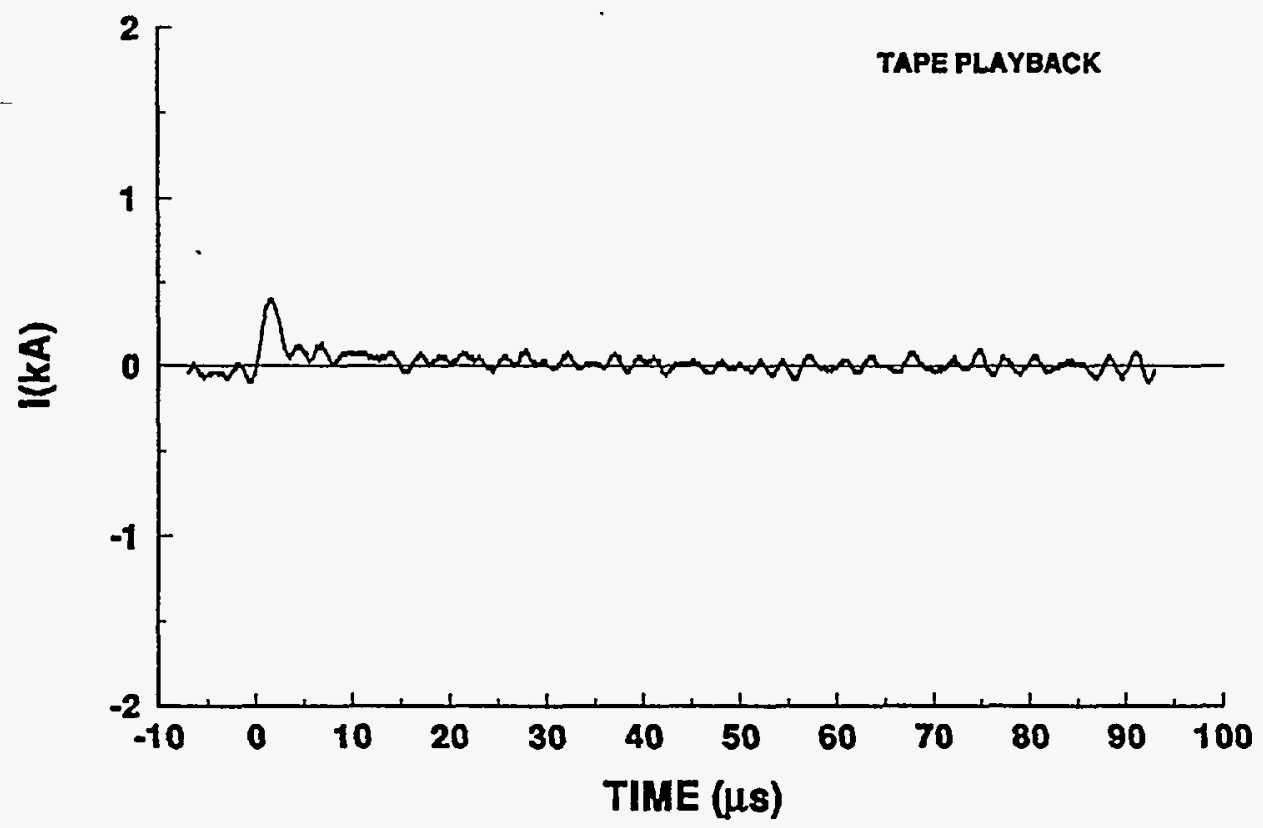




\section{4-07 STROKE 2}

\section{TEST POINT 6}

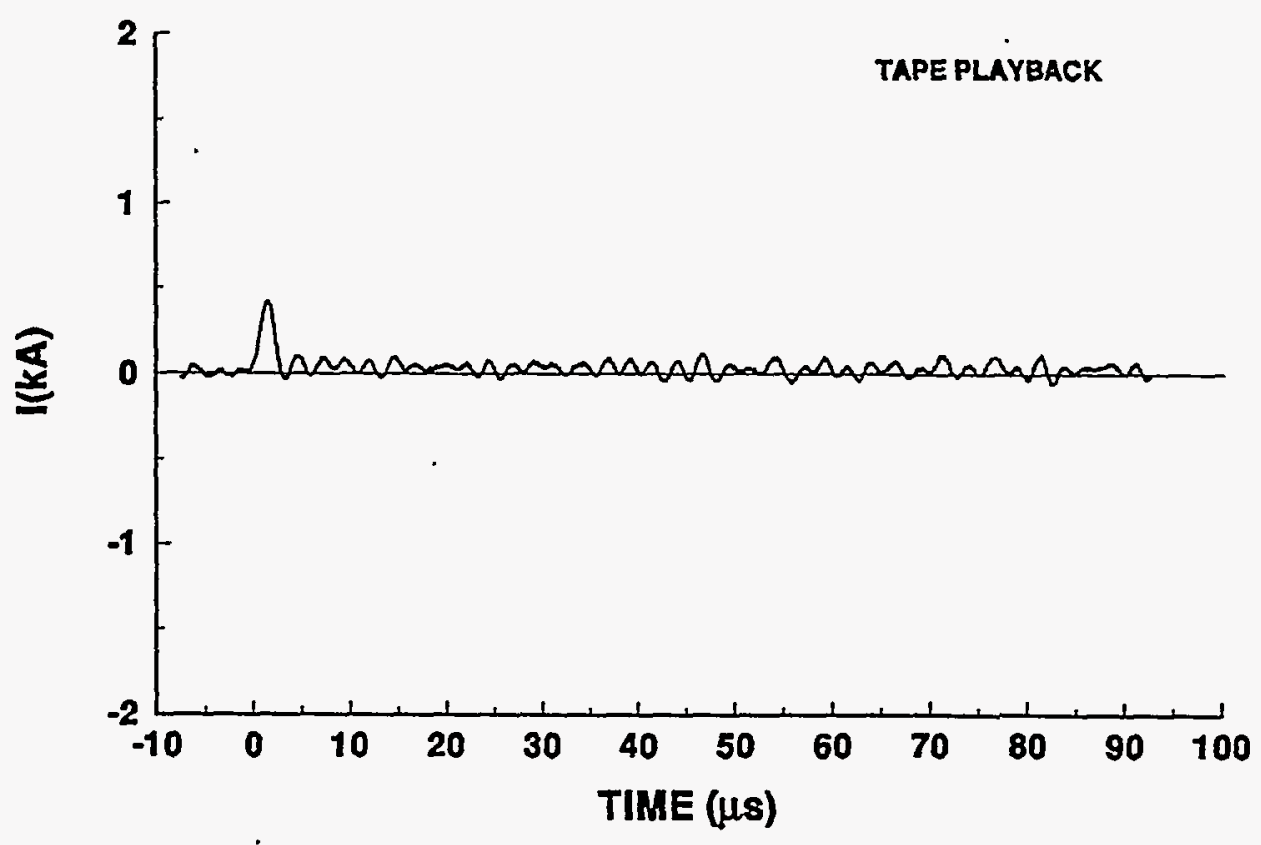

\section{4-07 STROKE 2 TEST POINT 6'}

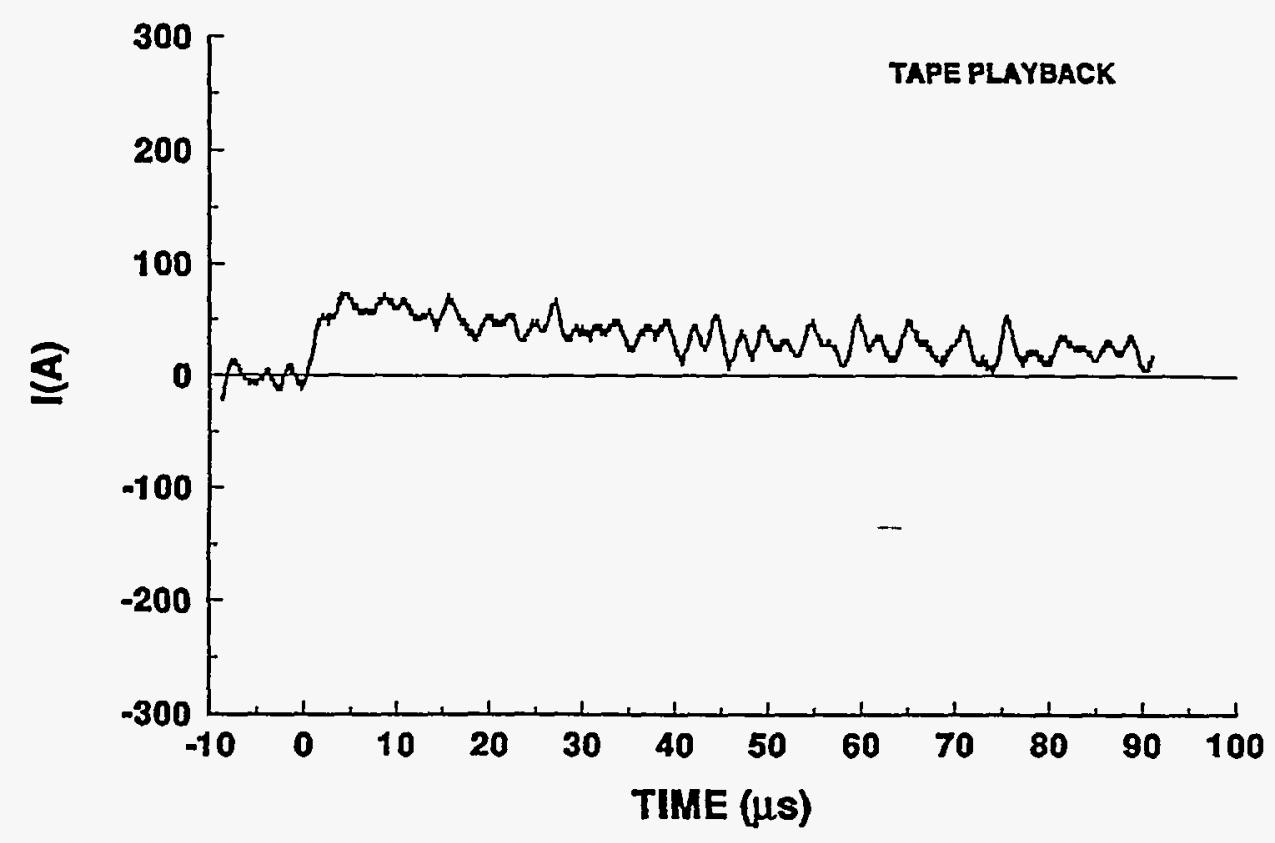




\section{4-07 STROKE 2}

TEST POINT 7
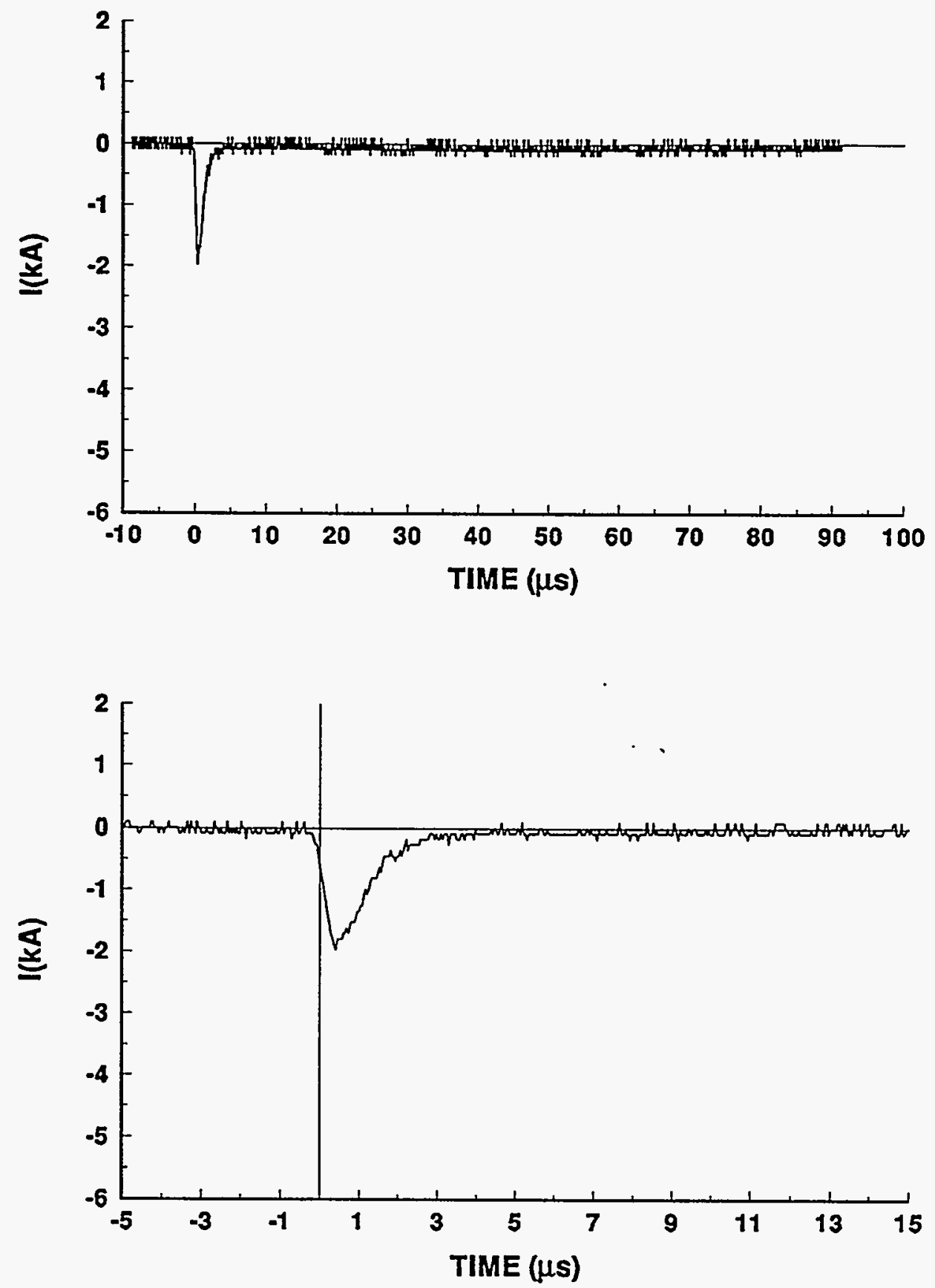


\section{4-07 STROKE 2}

TEST POINT 8
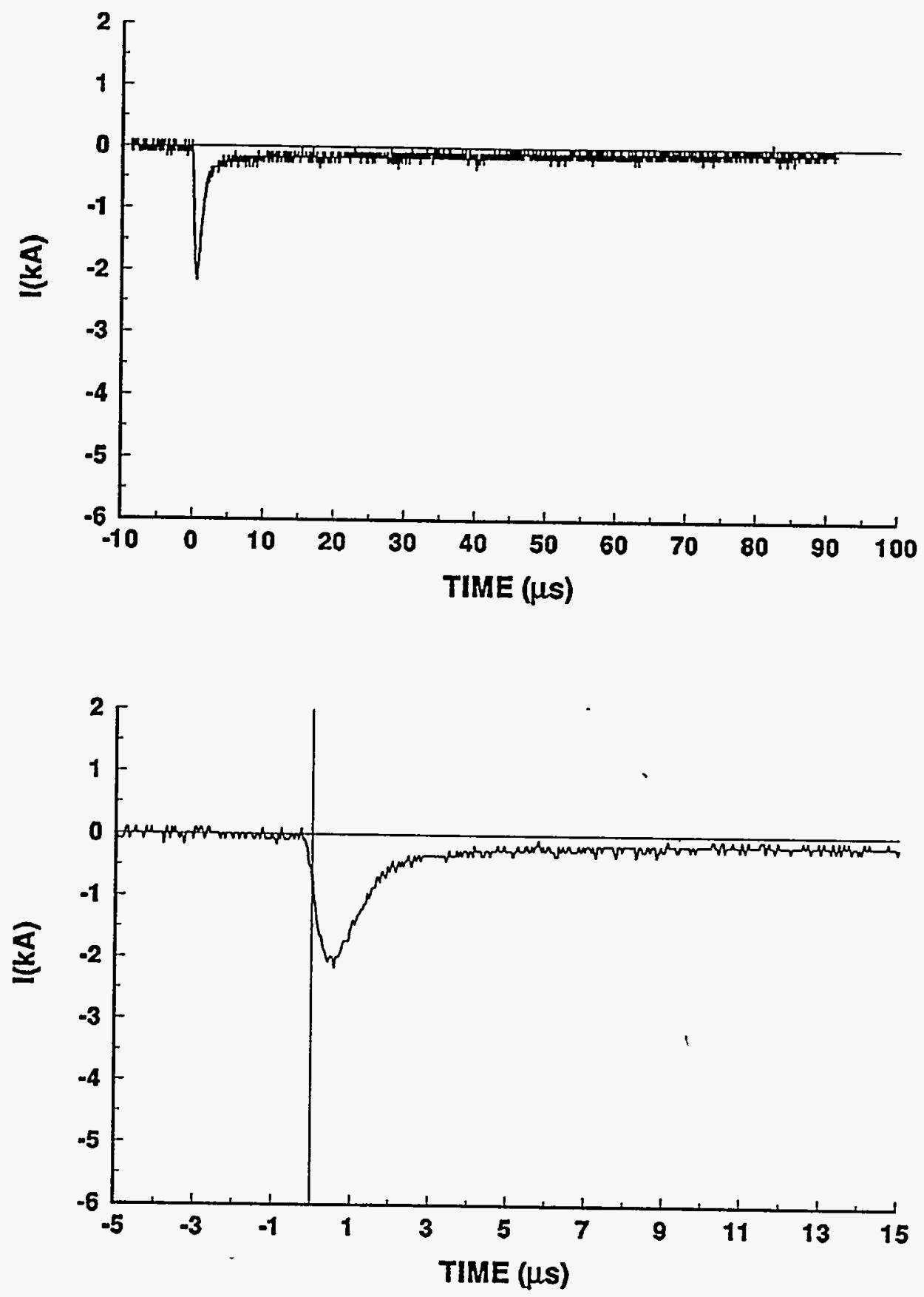


\section{4-07 STROKE 2}

TEST POINT 16

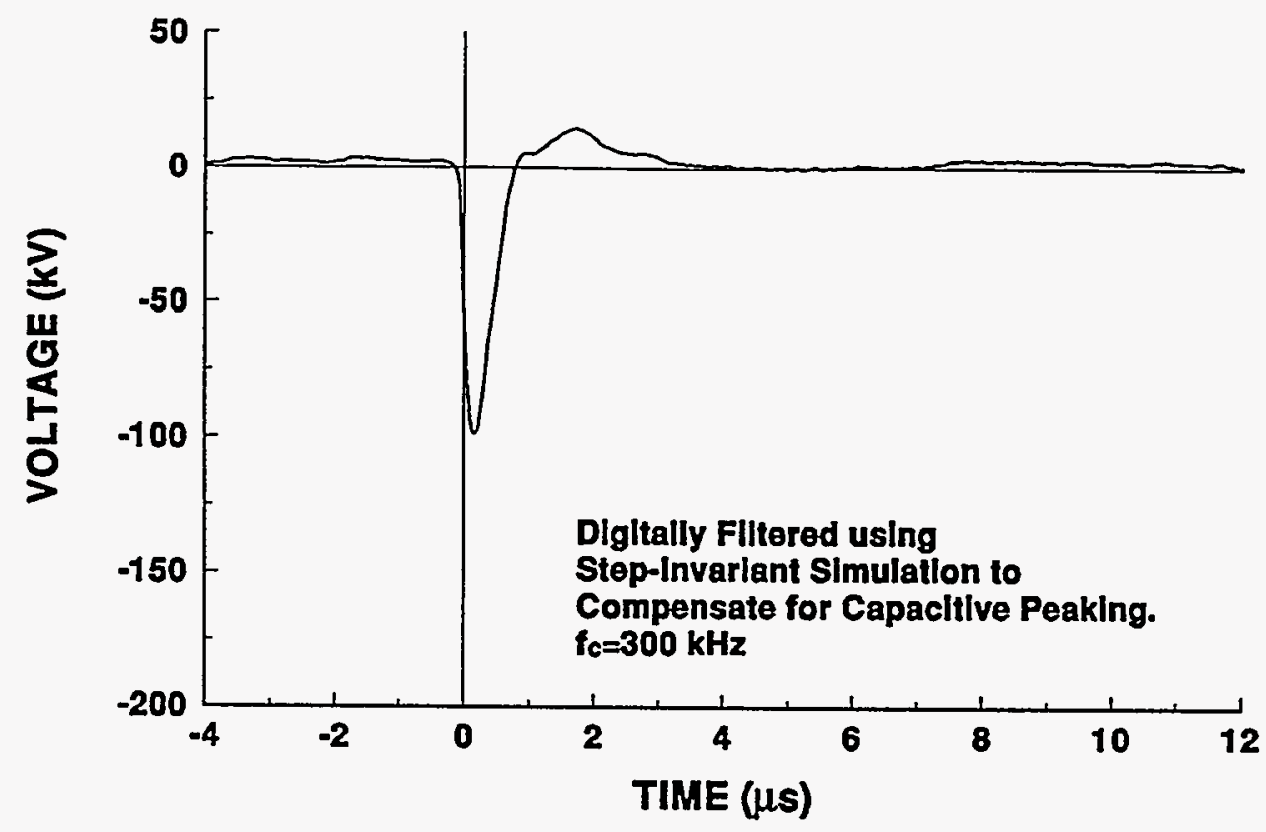

94-07 STROKE 2

TEST POINT 17

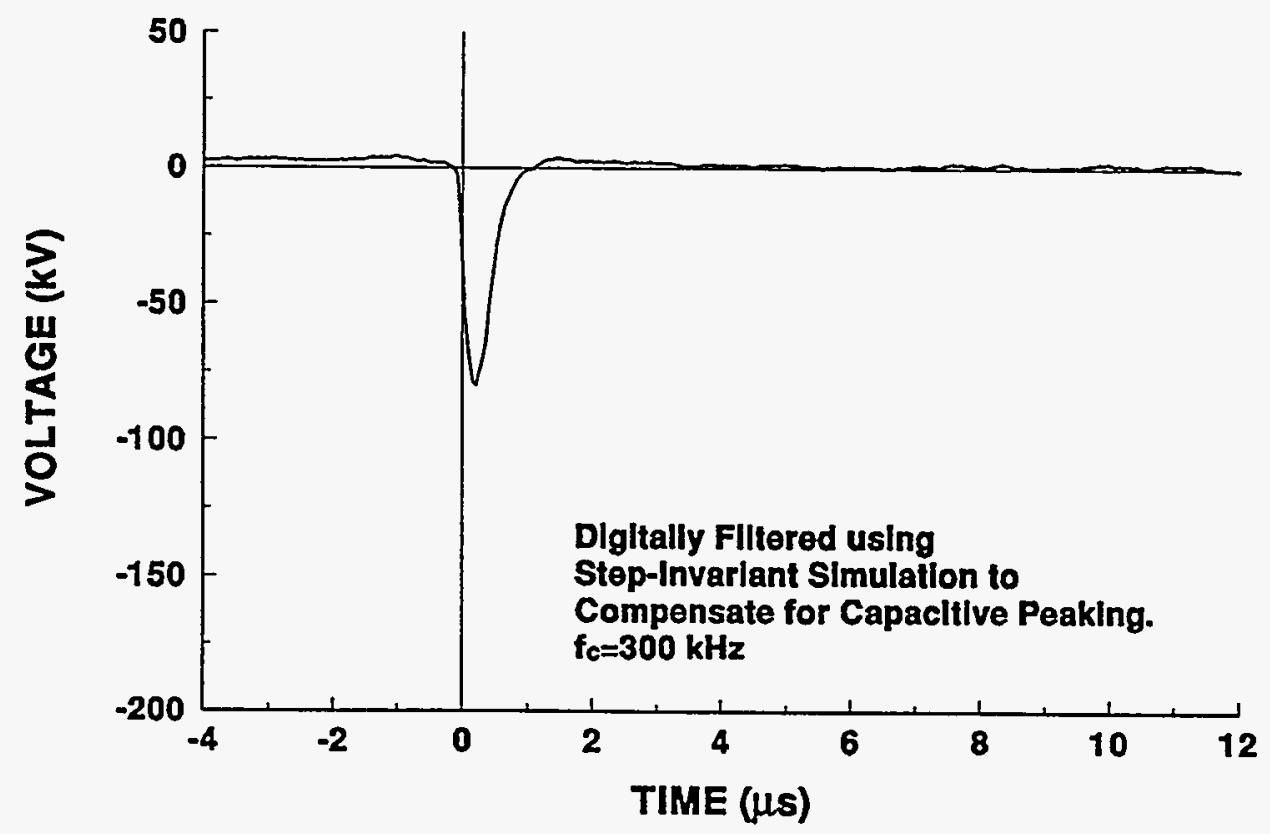




\section{4-07 STROKE 2}

TEST POINT 18

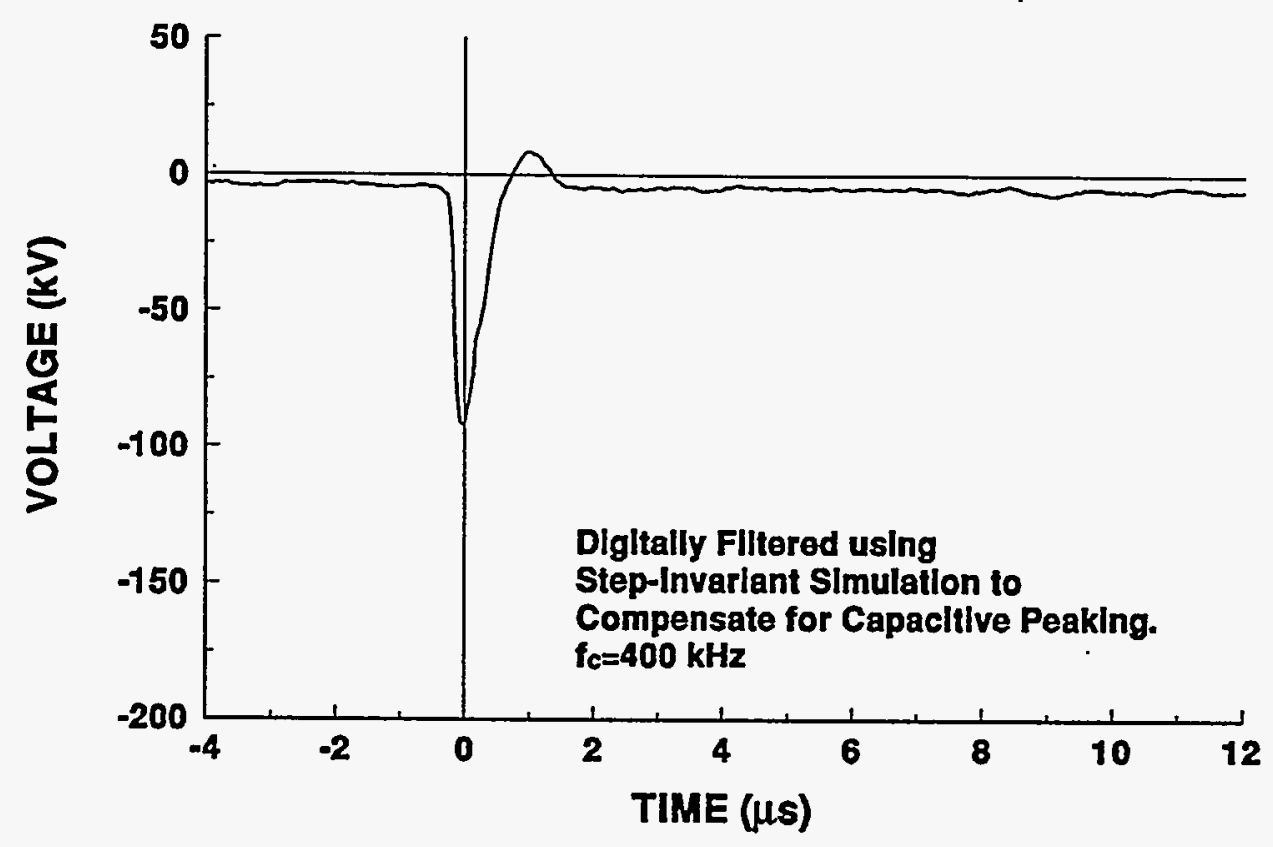

\section{4-07 STROKE 2}

TEST POINT 19

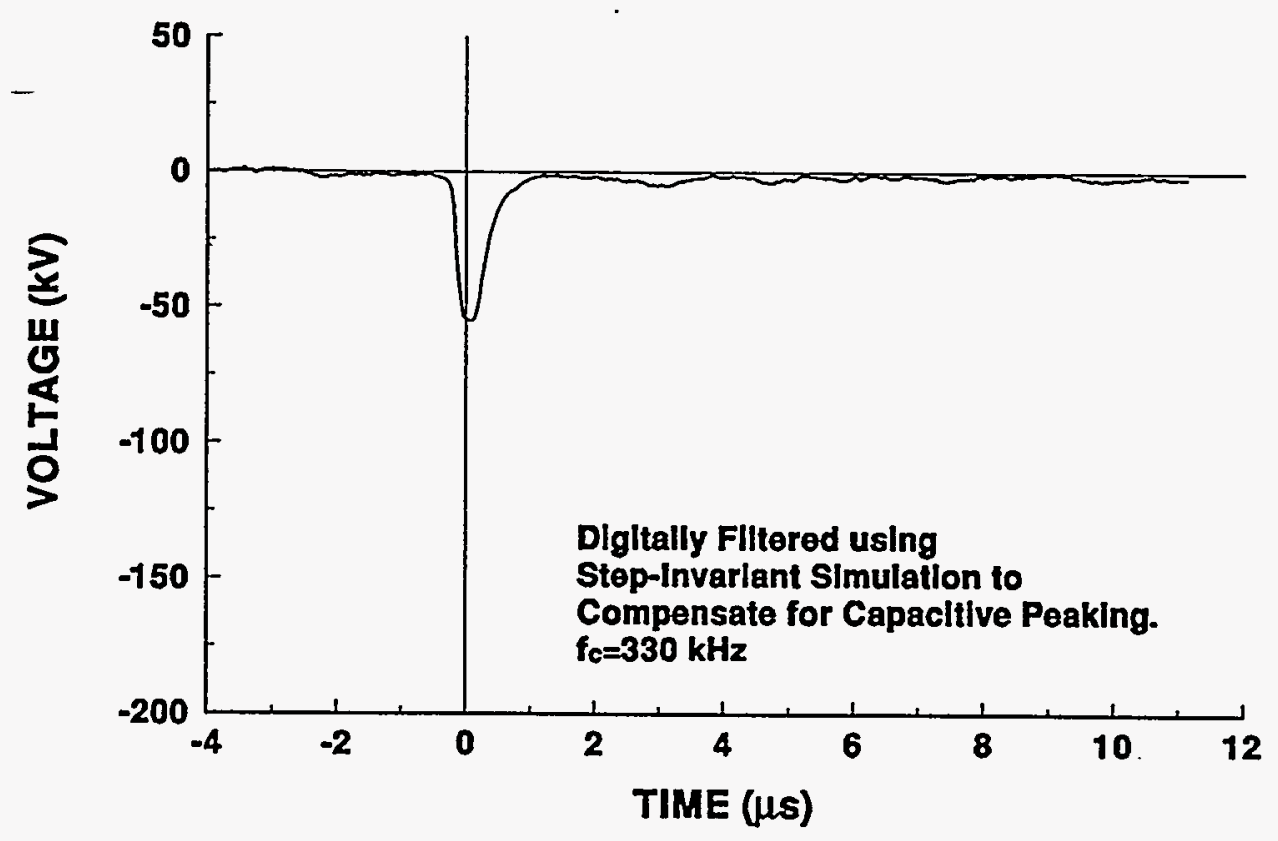




\section{4-07 STROKE 2}

TEST POINT 20

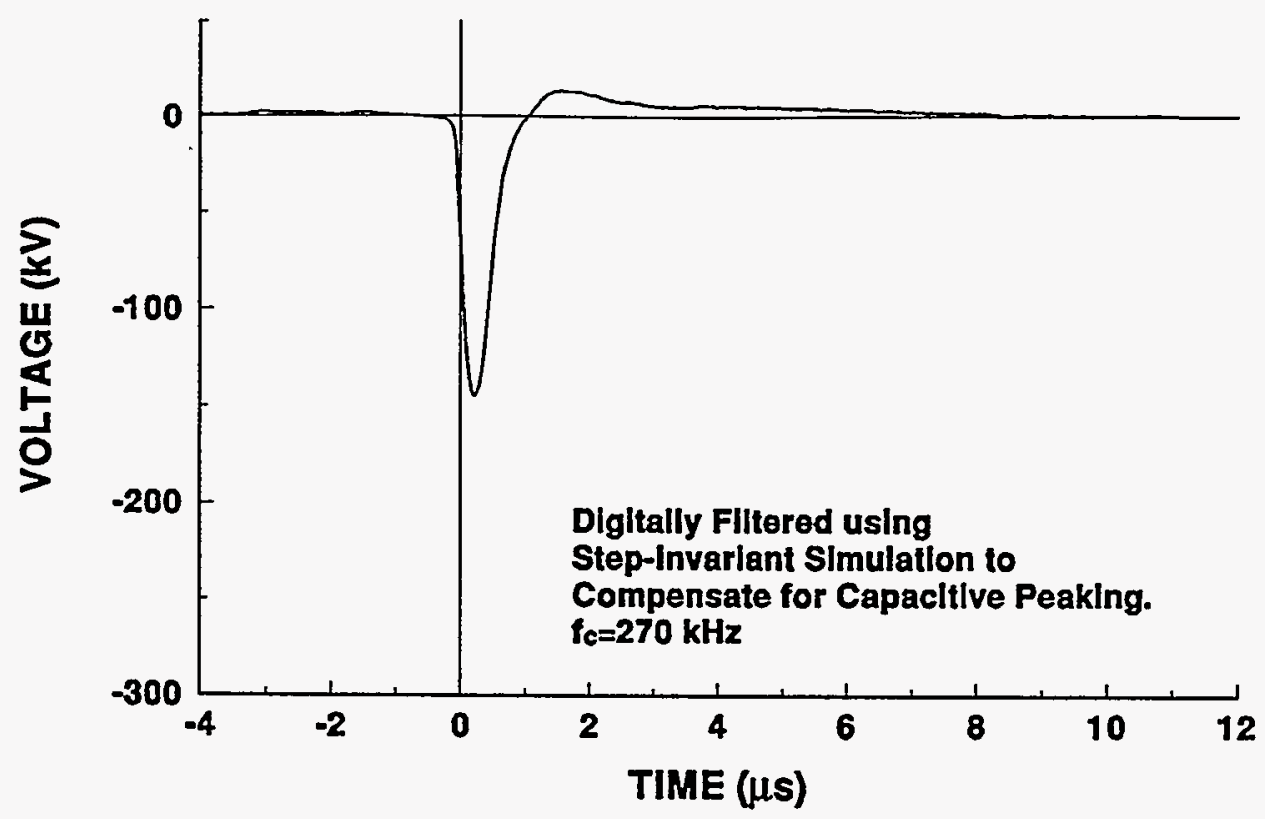

\section{4-07 STROKE-2}

TEST POINT 22

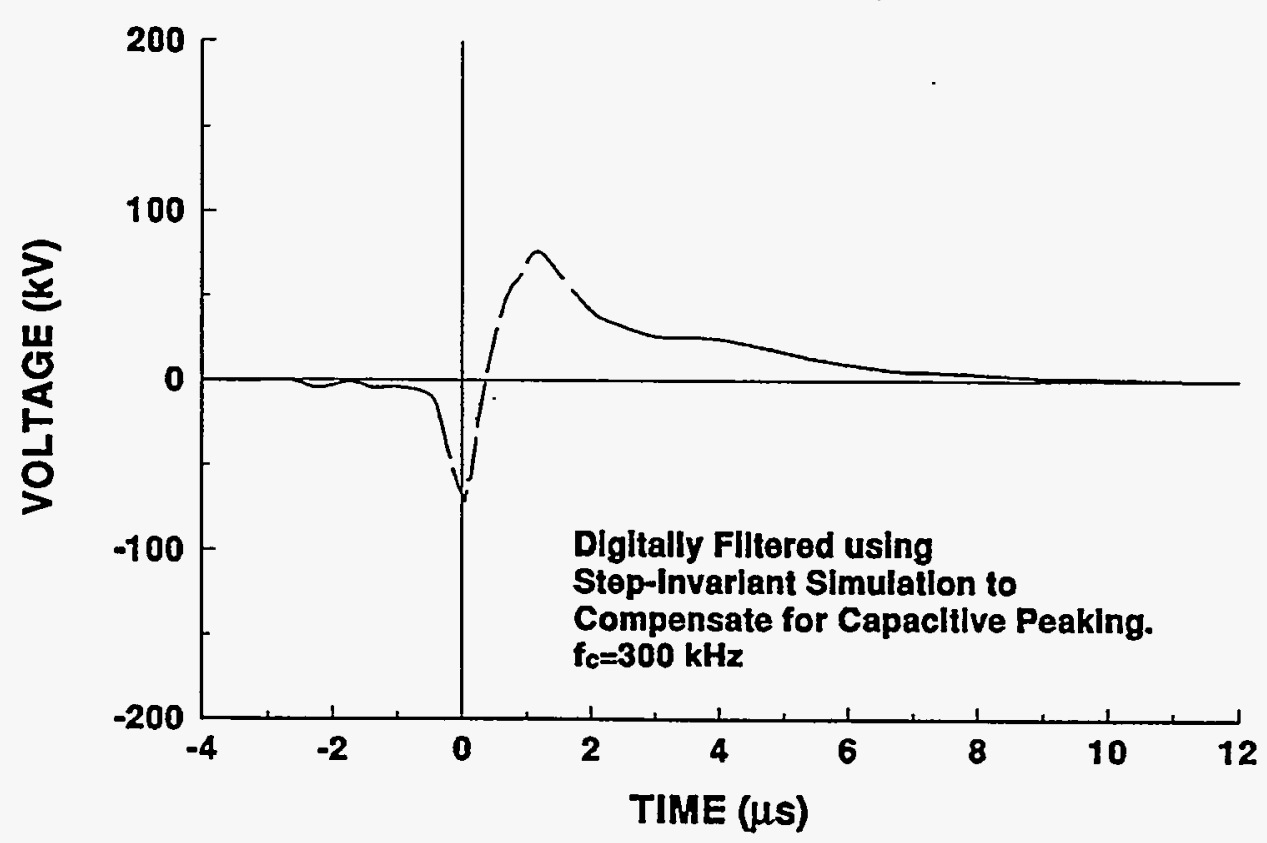




\section{4-07 STROKE 2}

TEST POINT 23

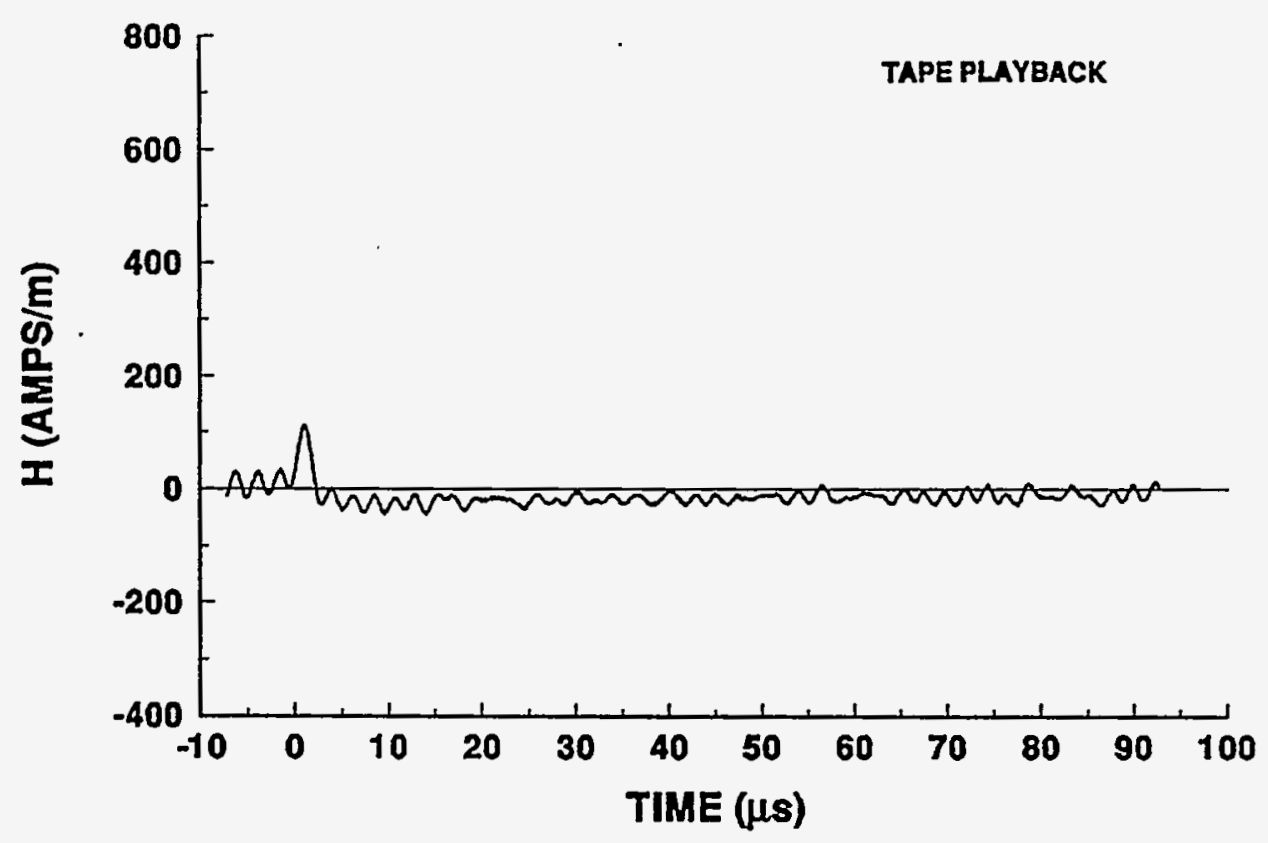

\section{4-07 STROKE 2}

\section{TEST POINT 24}

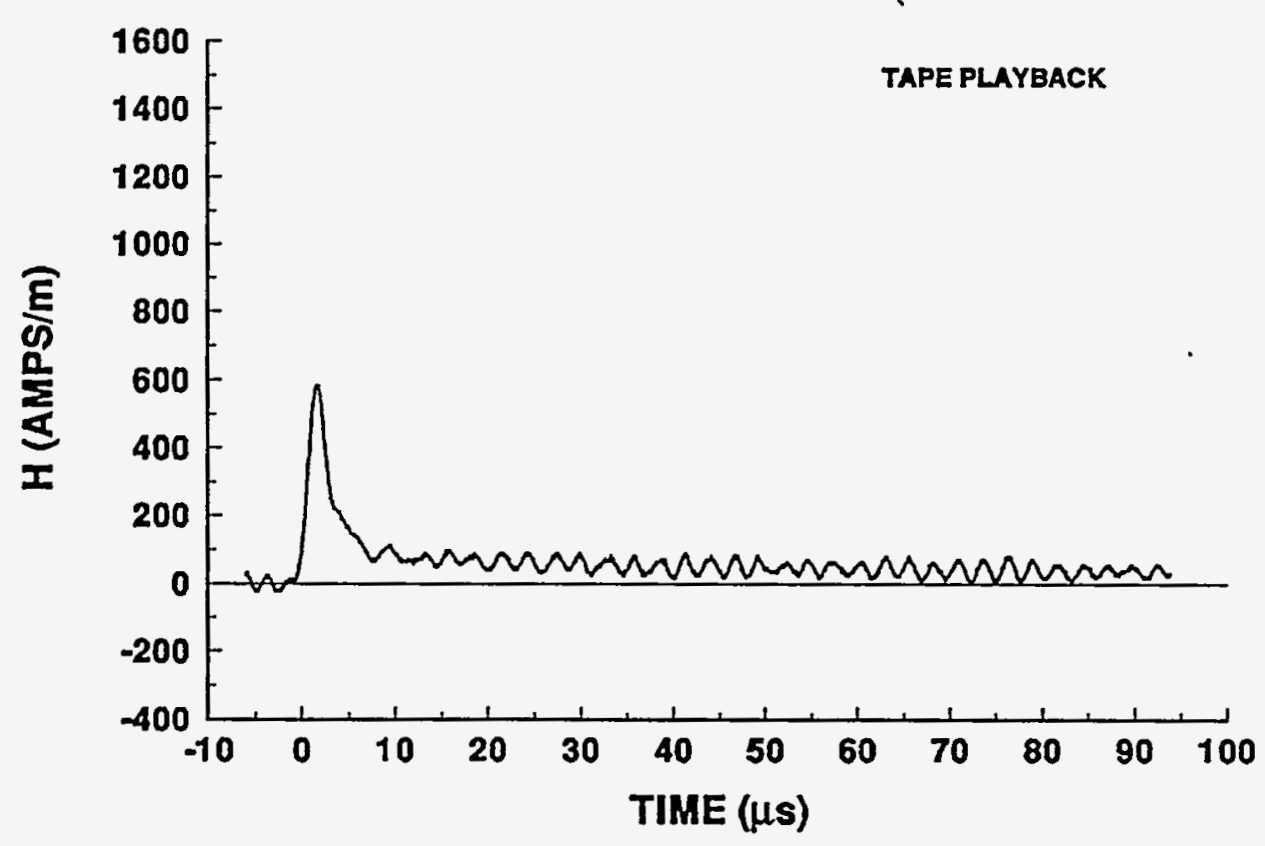




\section{4-07 STROKE 3 \\ INCIDENT CURRENT}
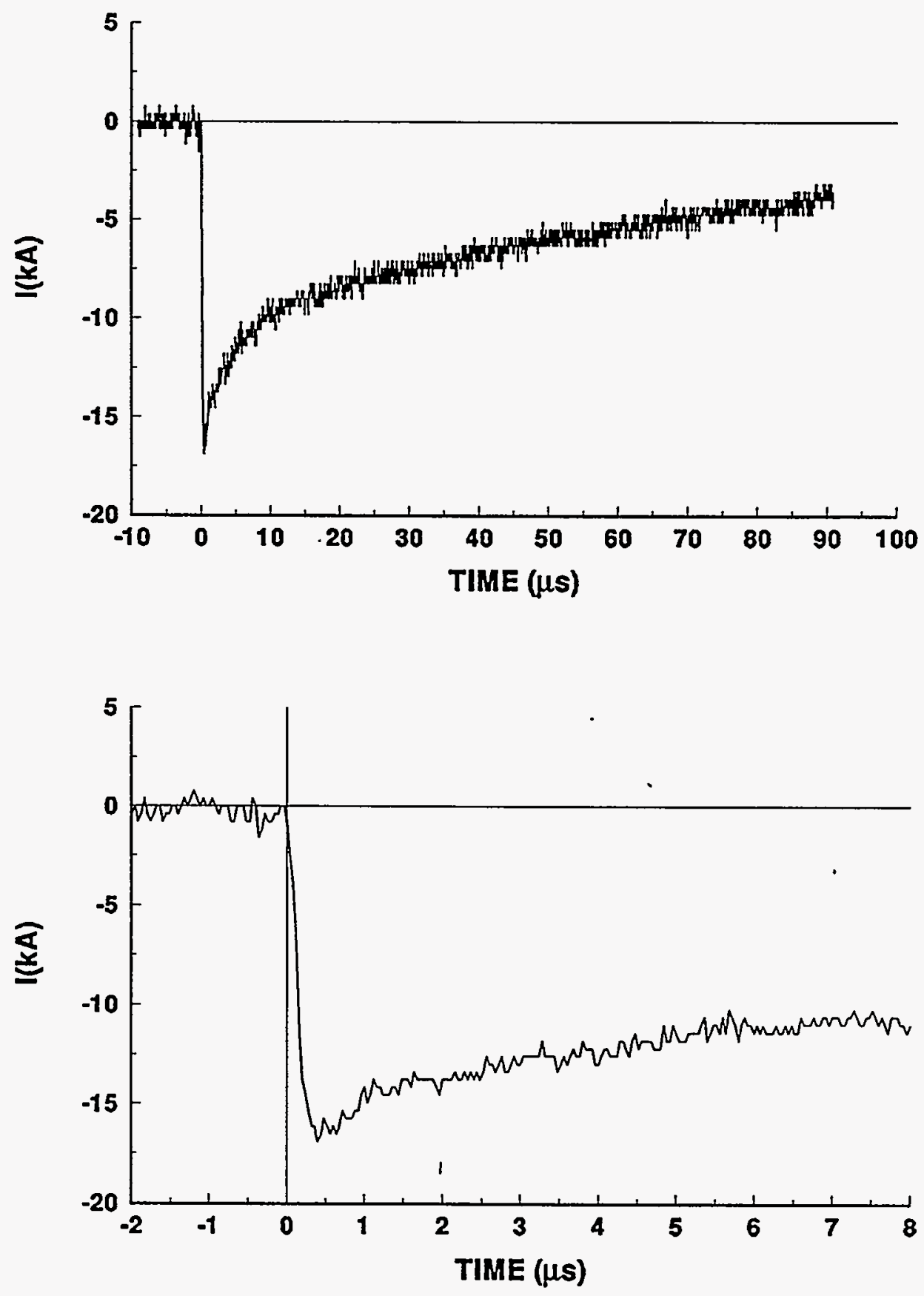


\section{4-07 STROKE 3}

TEST POINT 1

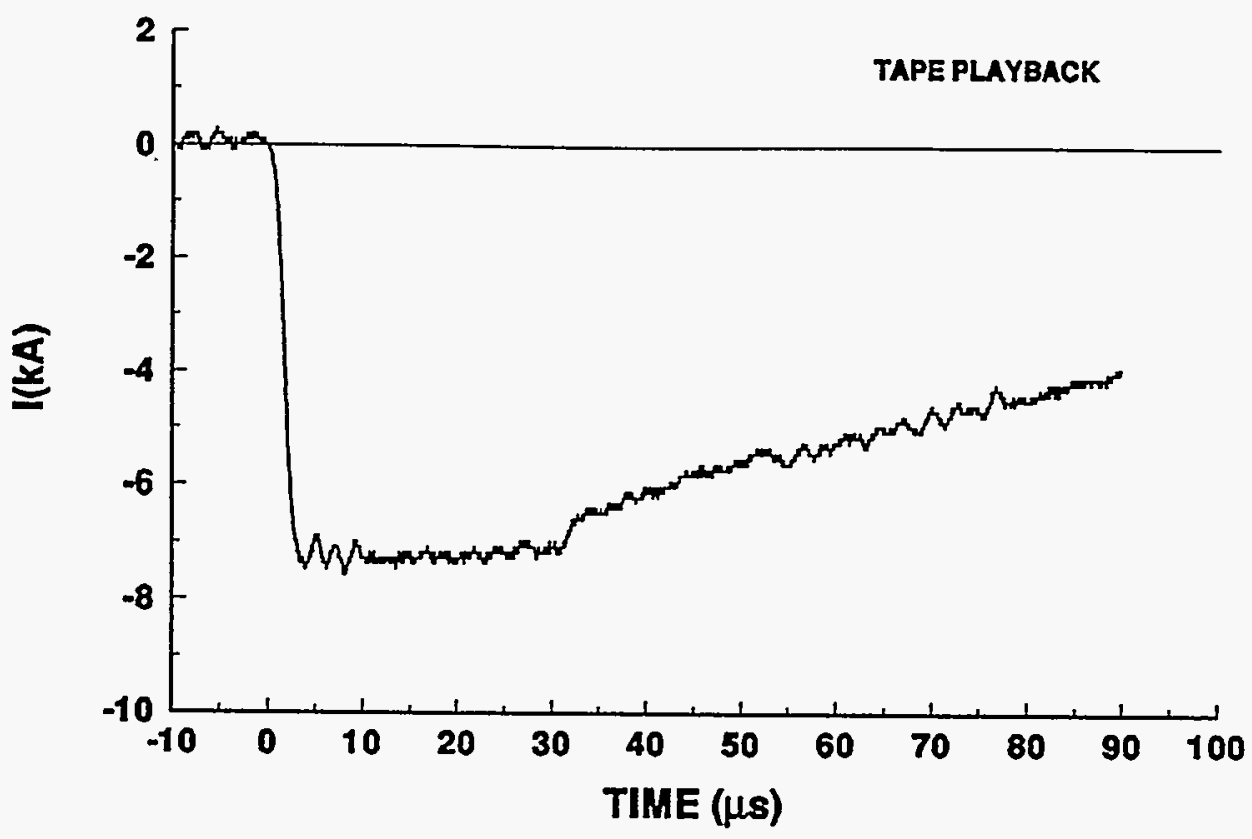

\section{4-07 STROKE 3}

TEST POINT 2

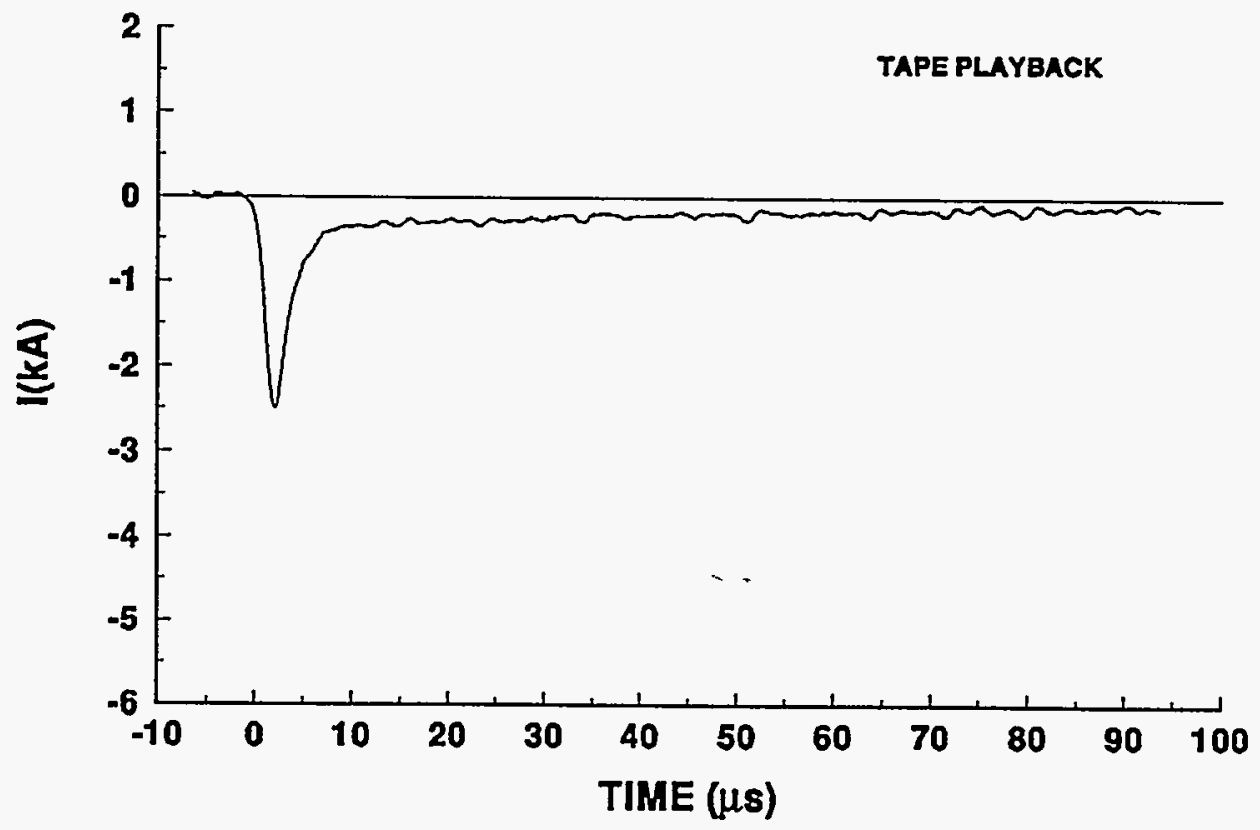




\section{4-07 STROKE 3}

TEST POINT 5

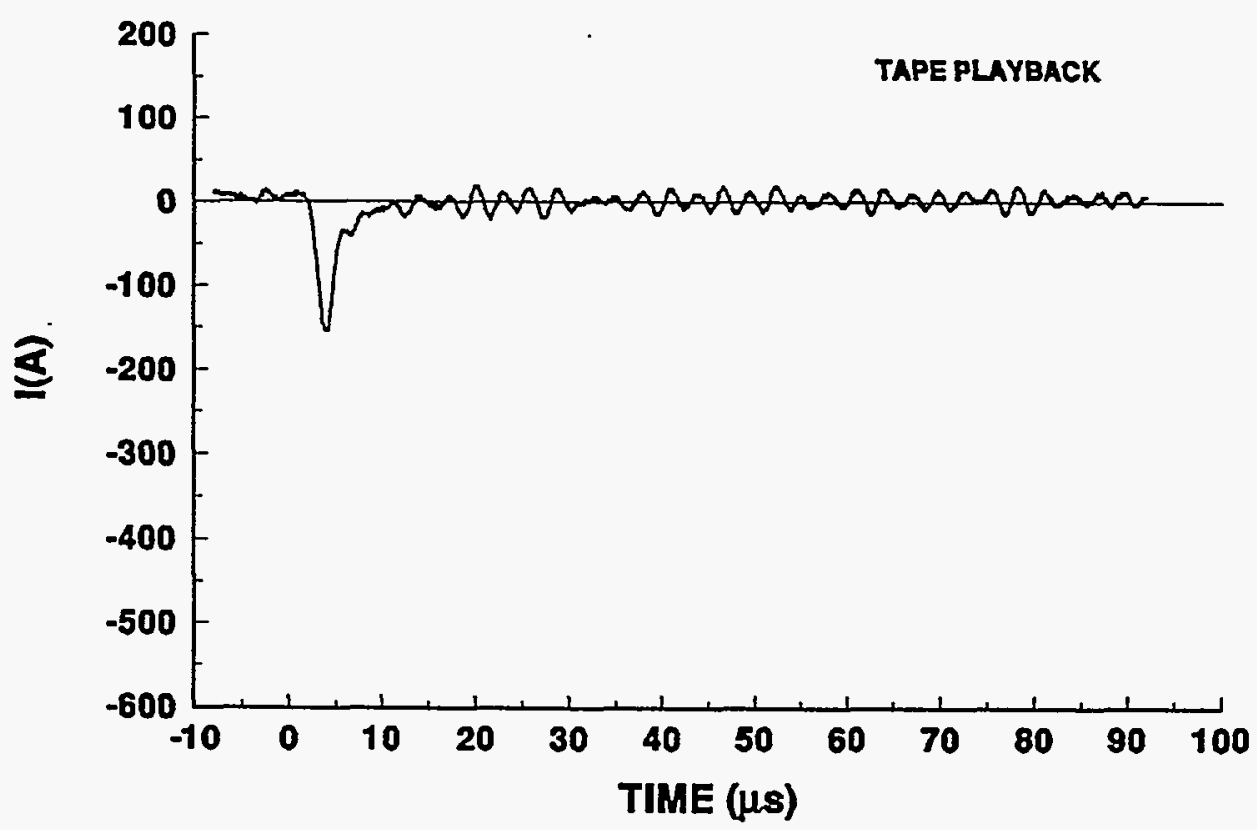

\section{4-07 STROKE 3}

TEST POINT 5'

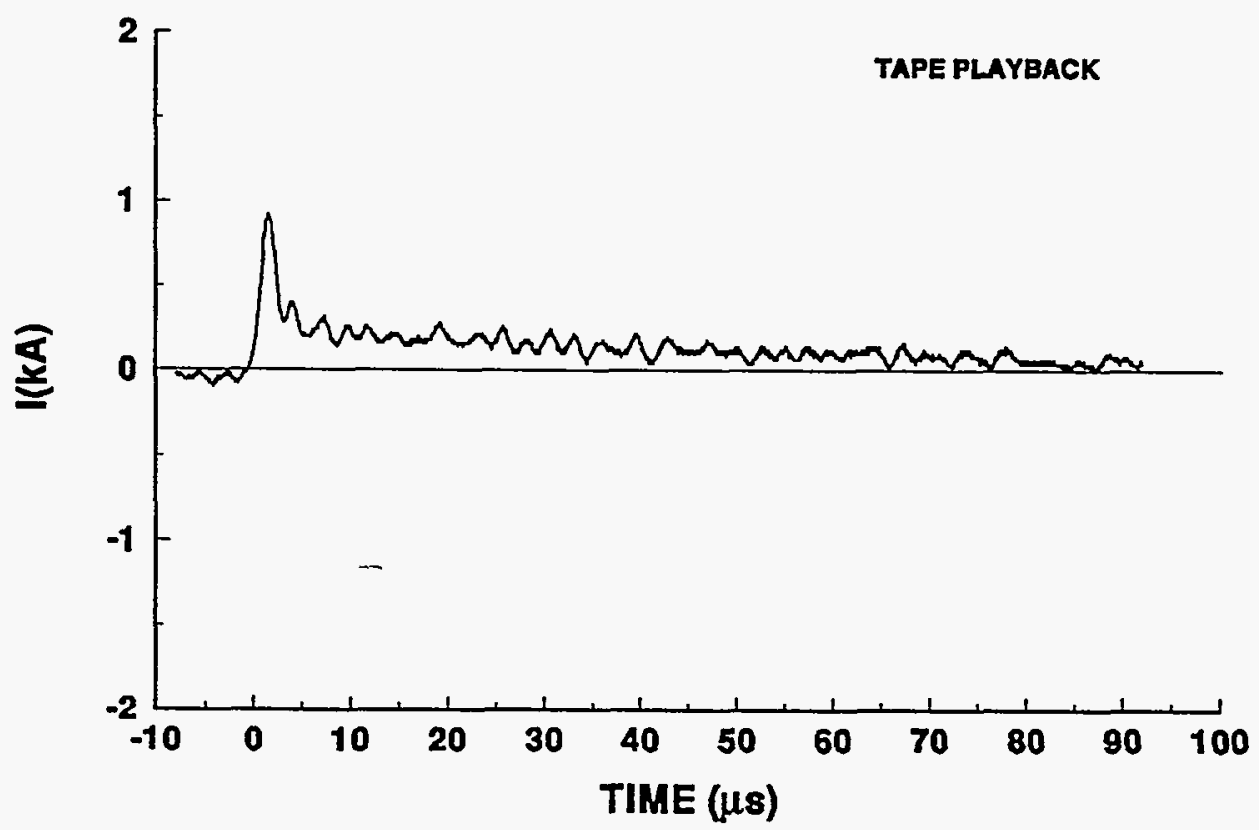




\section{4-07 STROKE 3}

TEST POINT 6

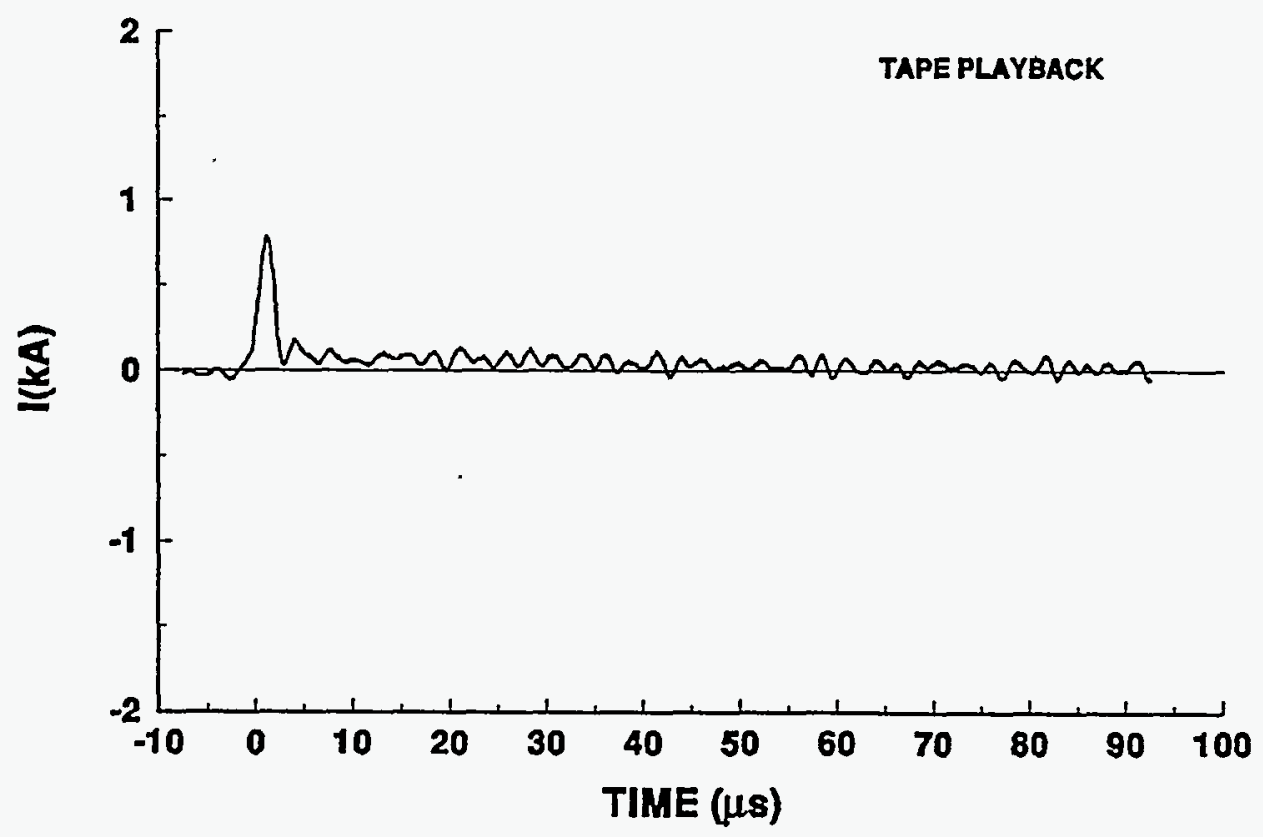

\section{4-07 STROKE 3}

TEST POINT 6'

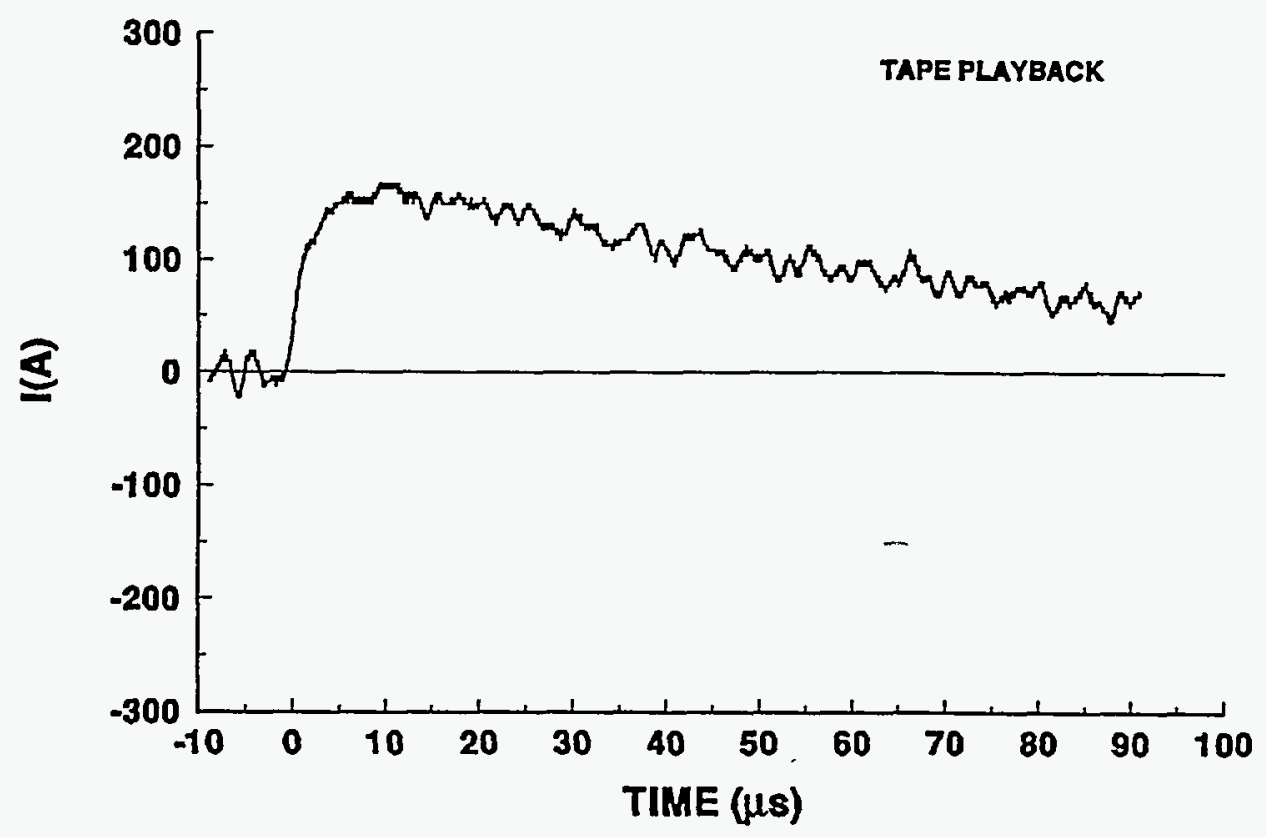




\section{4-07 STROKE 3 \\ TEST POINT 7}
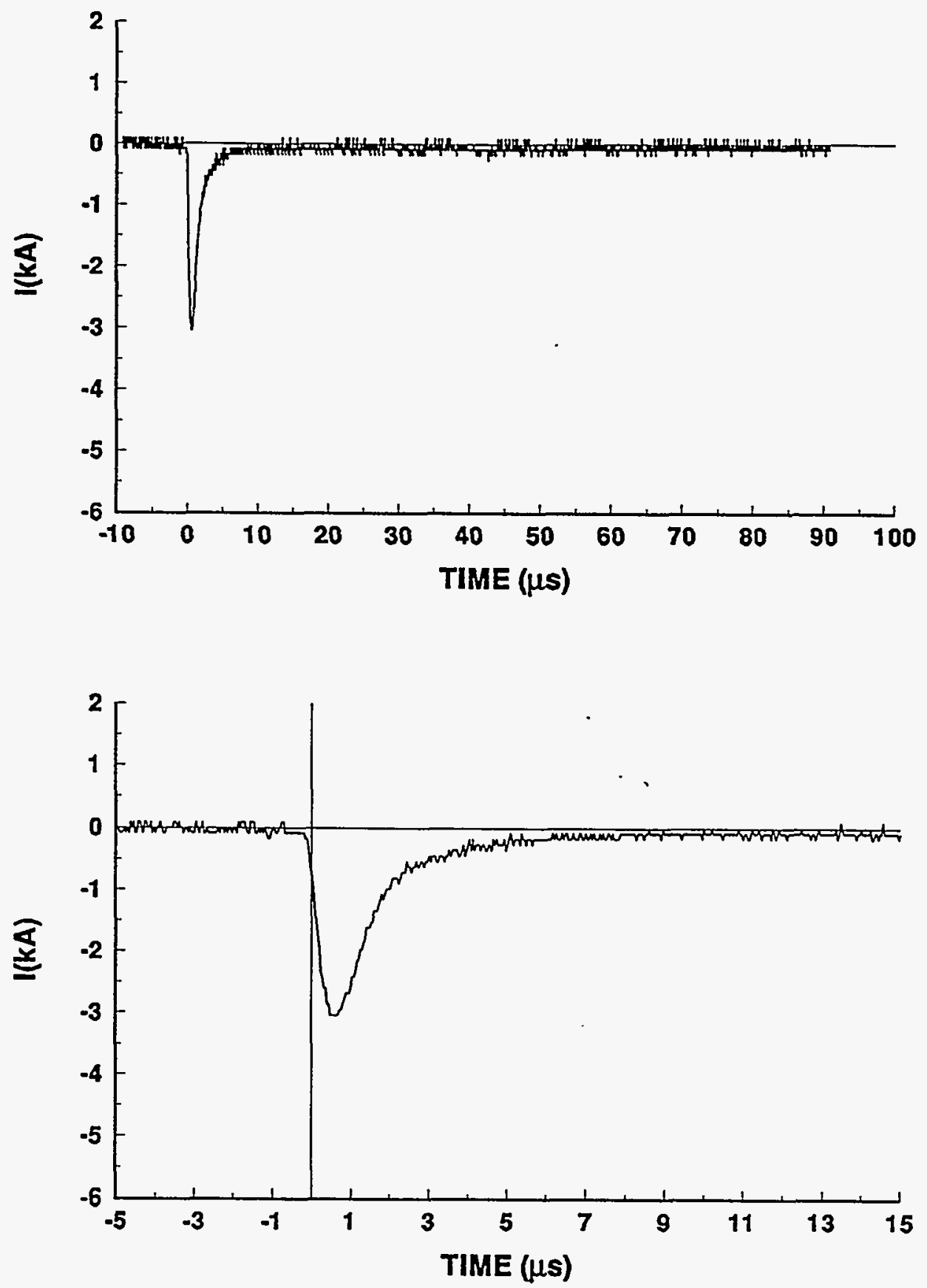


\section{4-07 STROKE 3}

TEST POINT 8
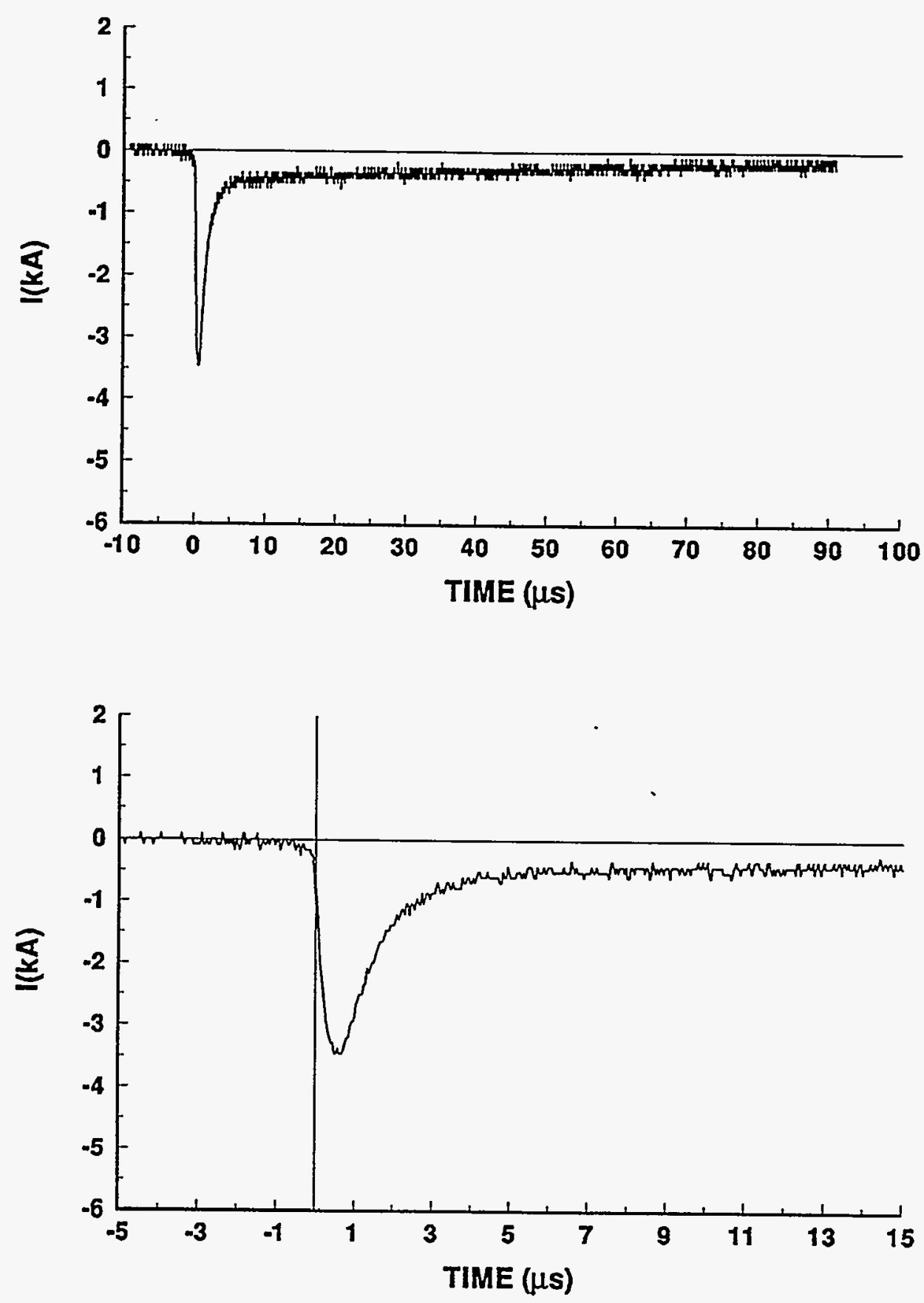


\section{4-07 STROKE 3}

\section{TEST POINT 16}

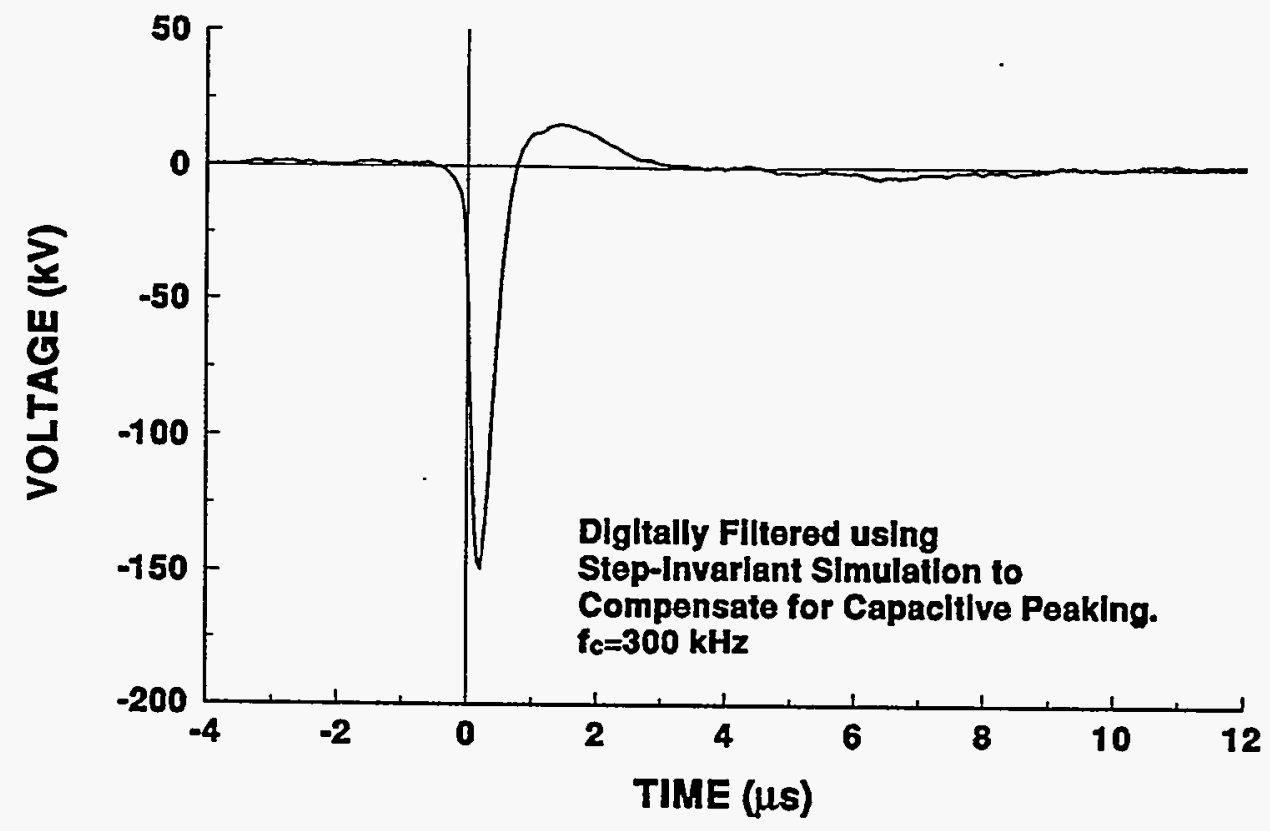

94-07 STROKE 3

TEST POINT 17

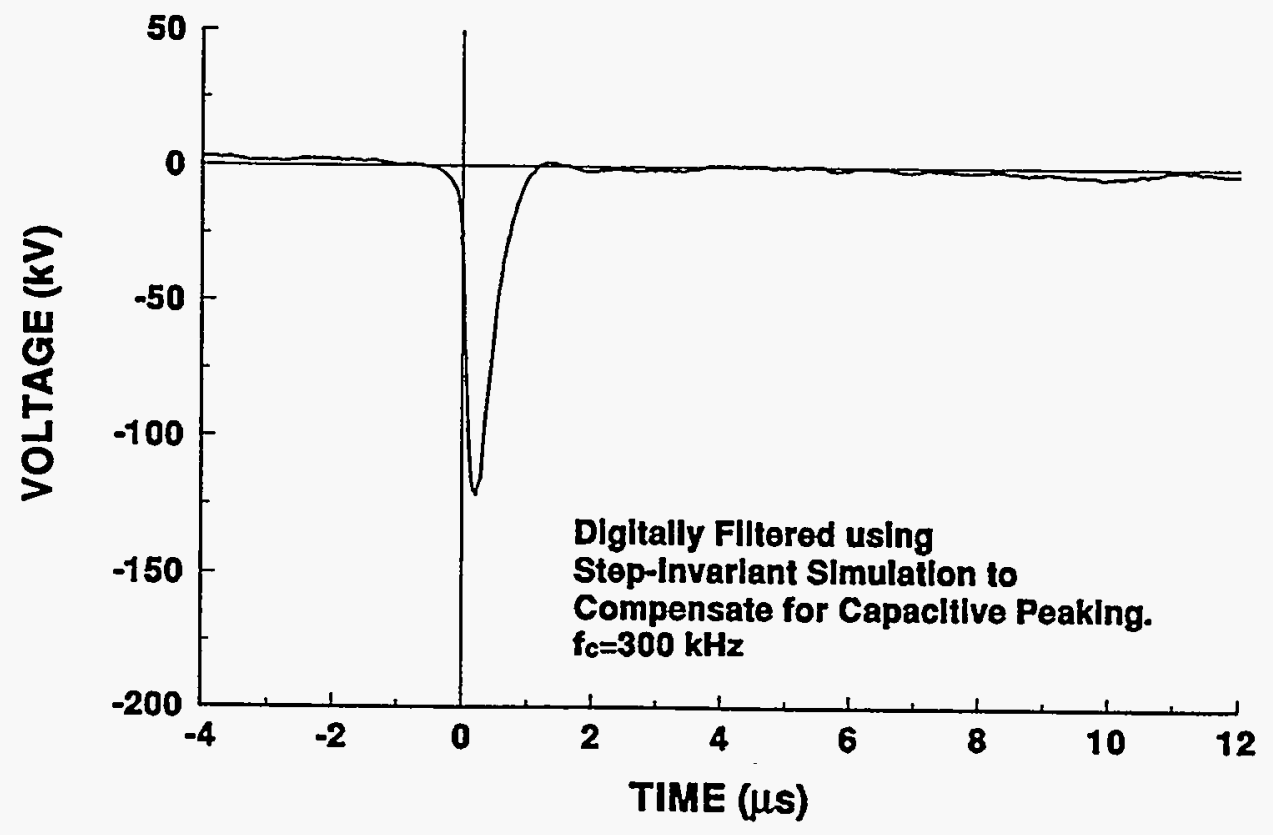




\section{4-07 STROKE 3}

TEST POINT 18

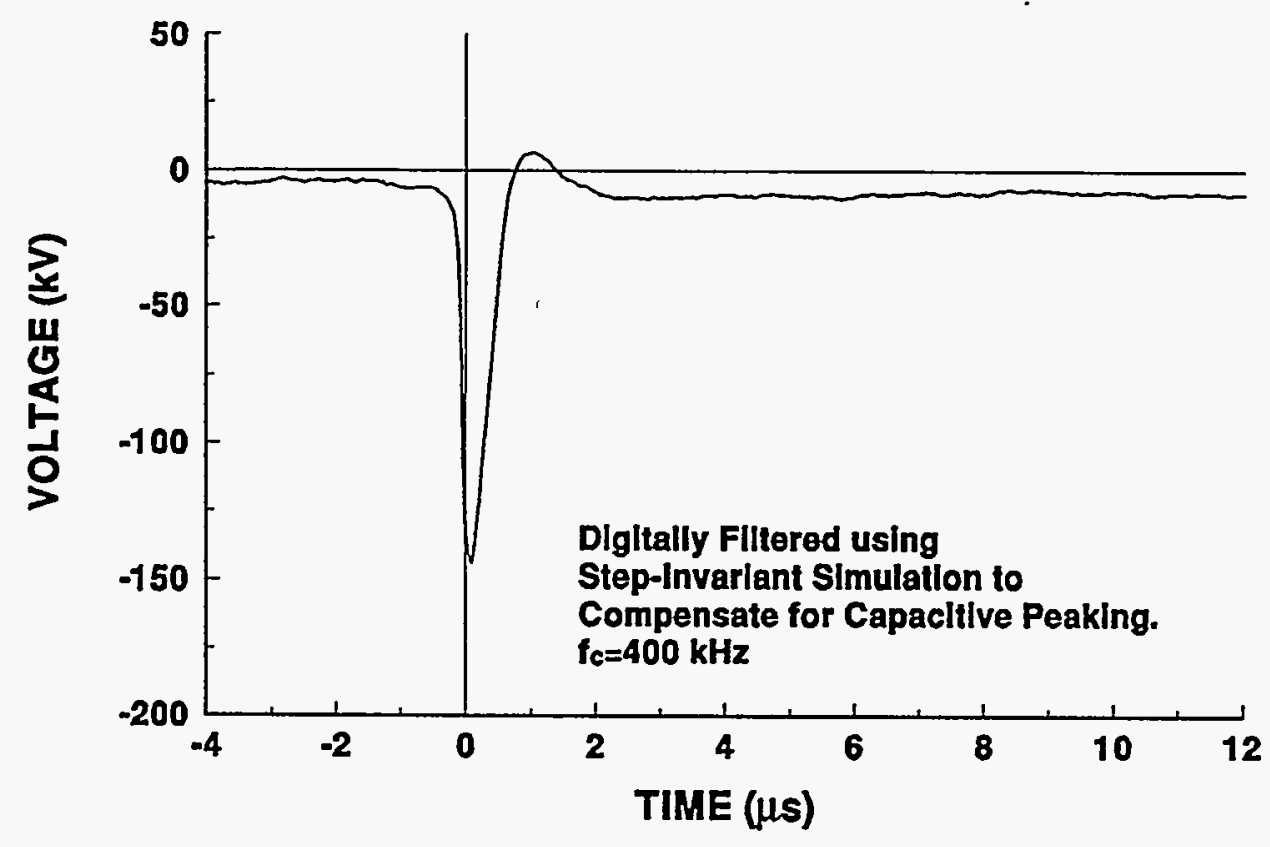

\section{4-07 STROKE 3}

TEST POINT 19

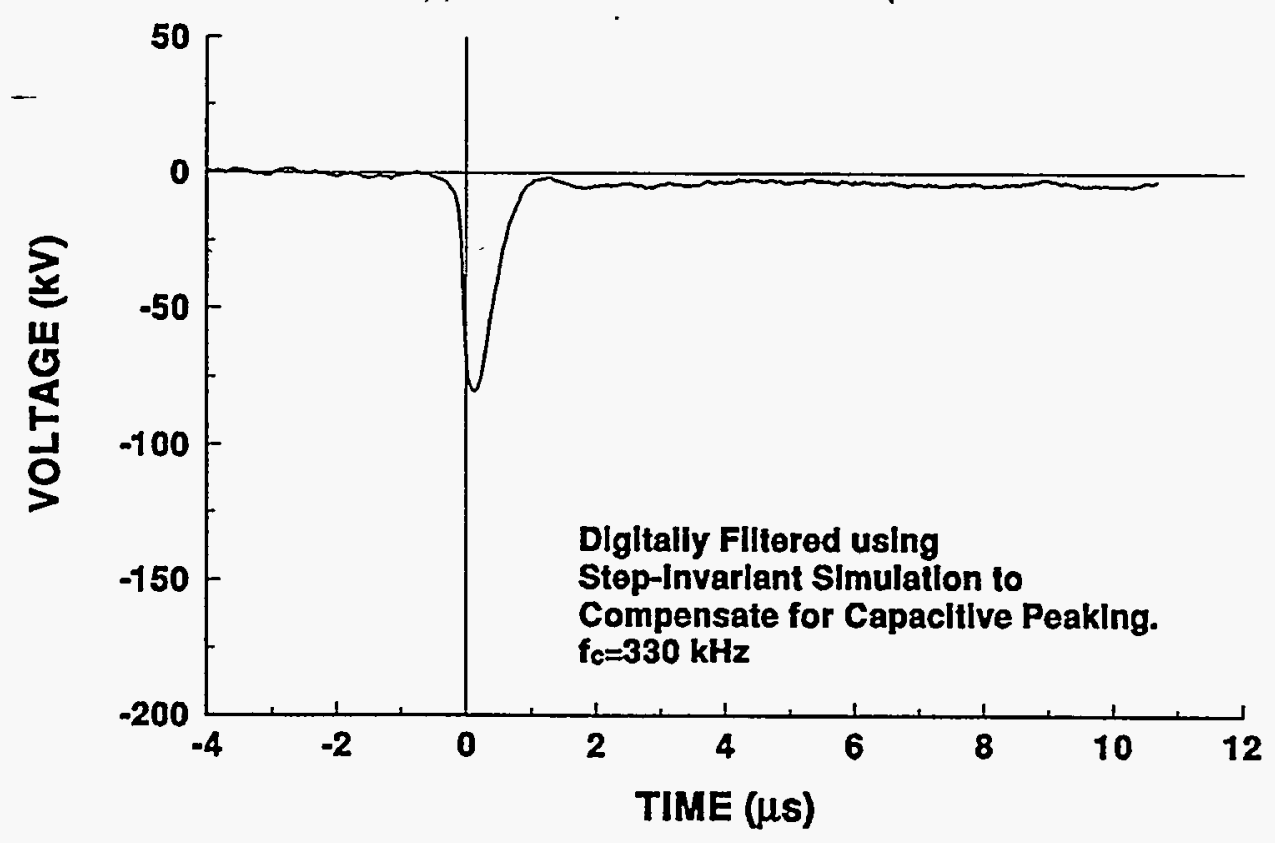




\section{4-07 STROKE 3}

TEST POINT 20

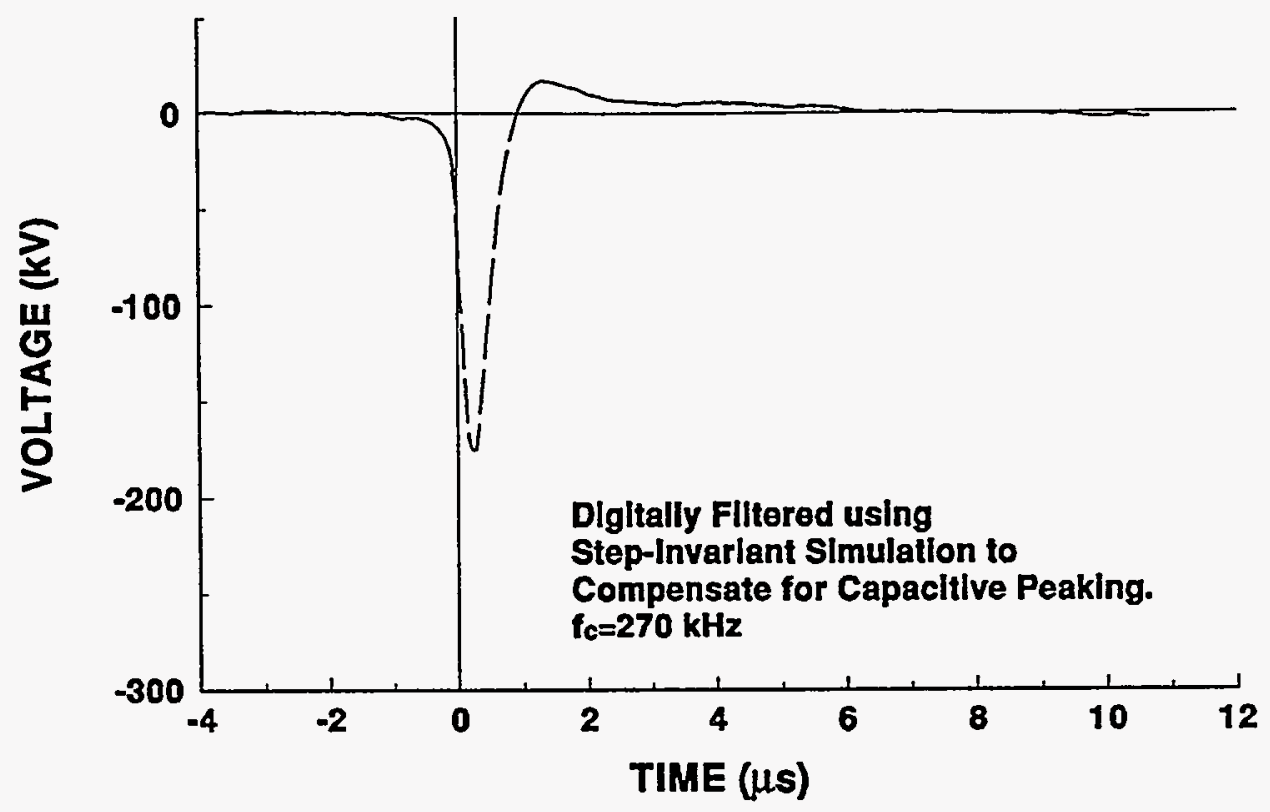

94-07 STROKE 3

TEST POINT 22

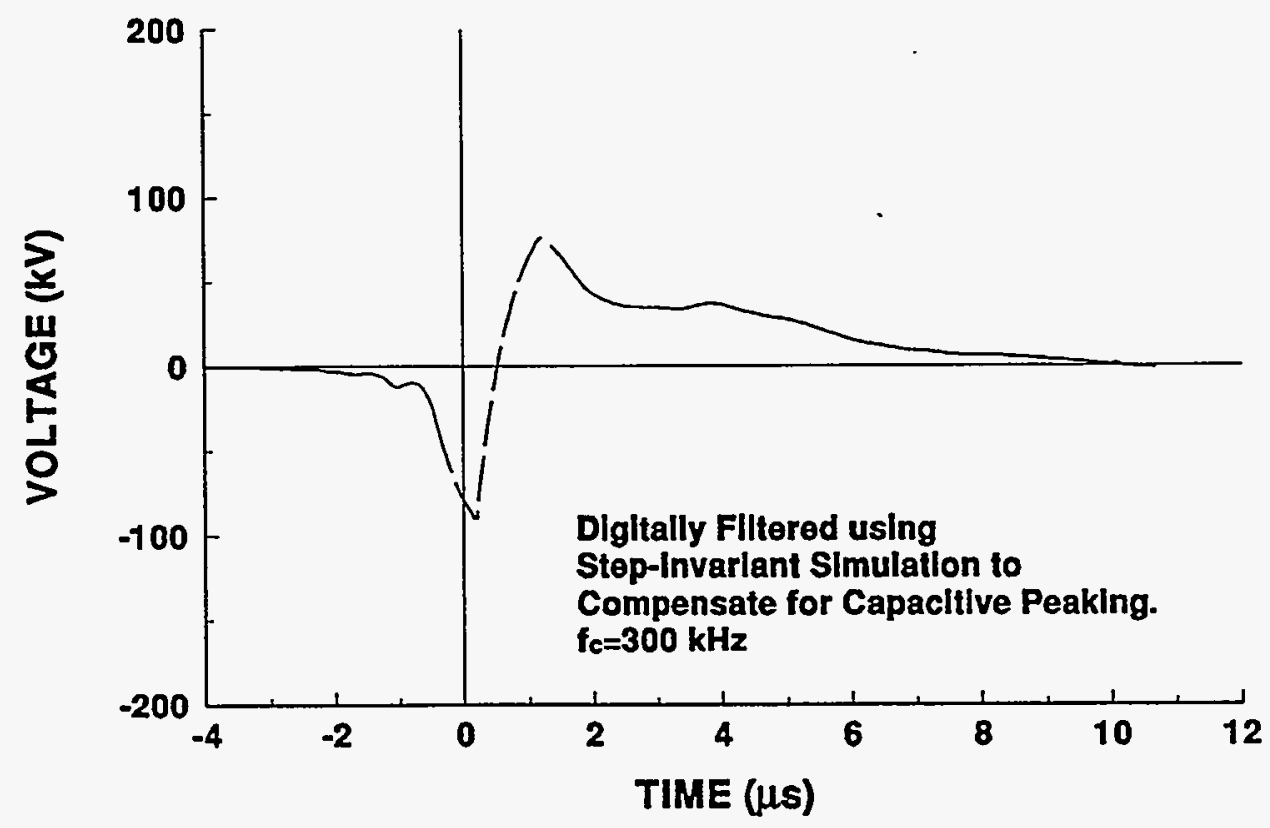


94-07 STROKE 3

TEST POINT 23

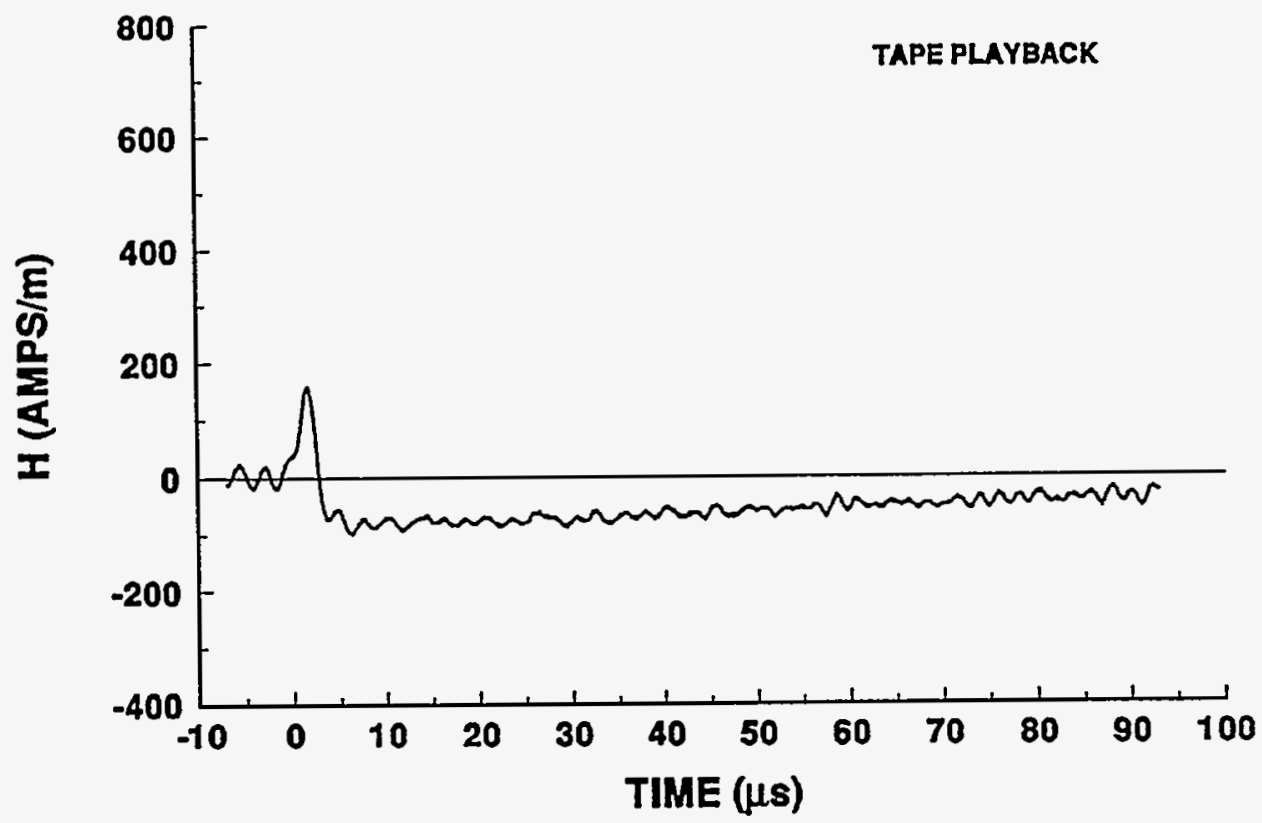

94-07 STROKE 3

TEST POINT 24

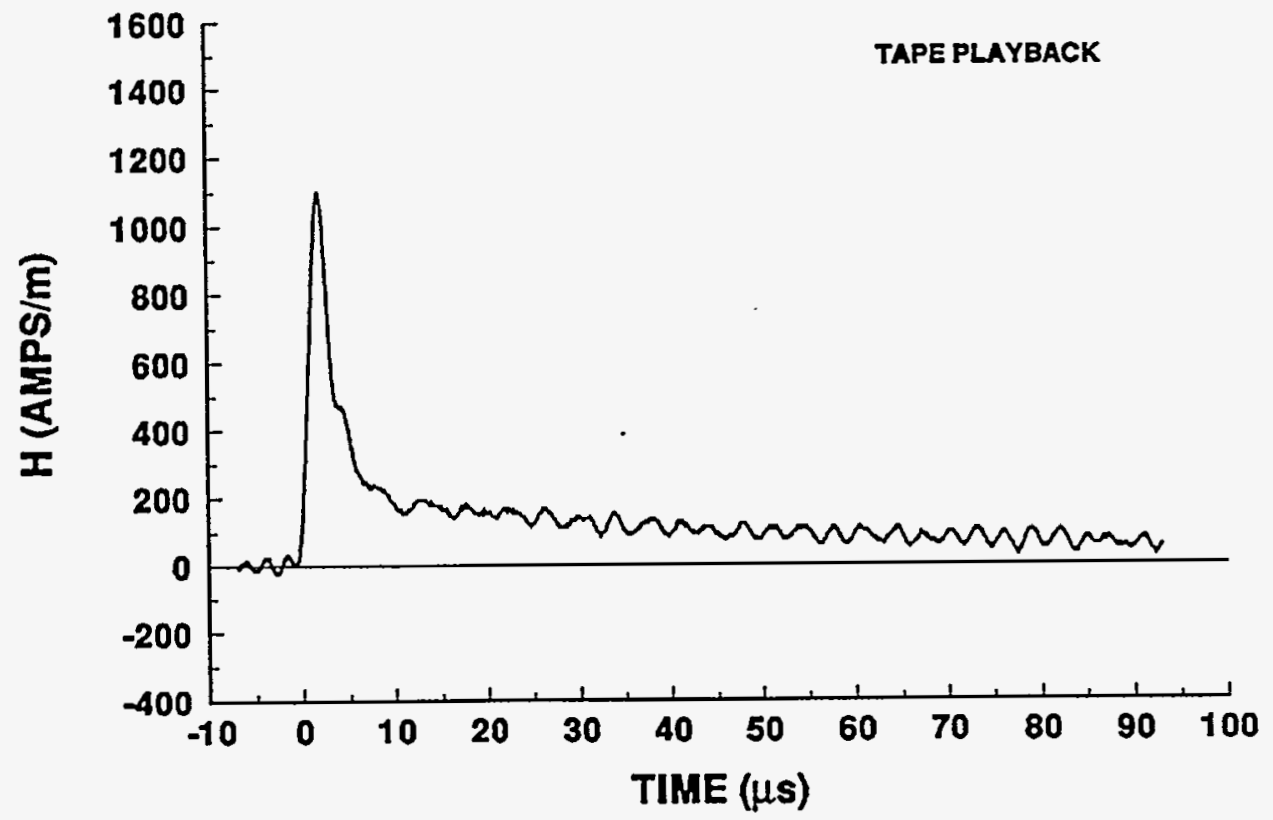




\section{4-07 STROKE 4 INCIDENT CURRENT}
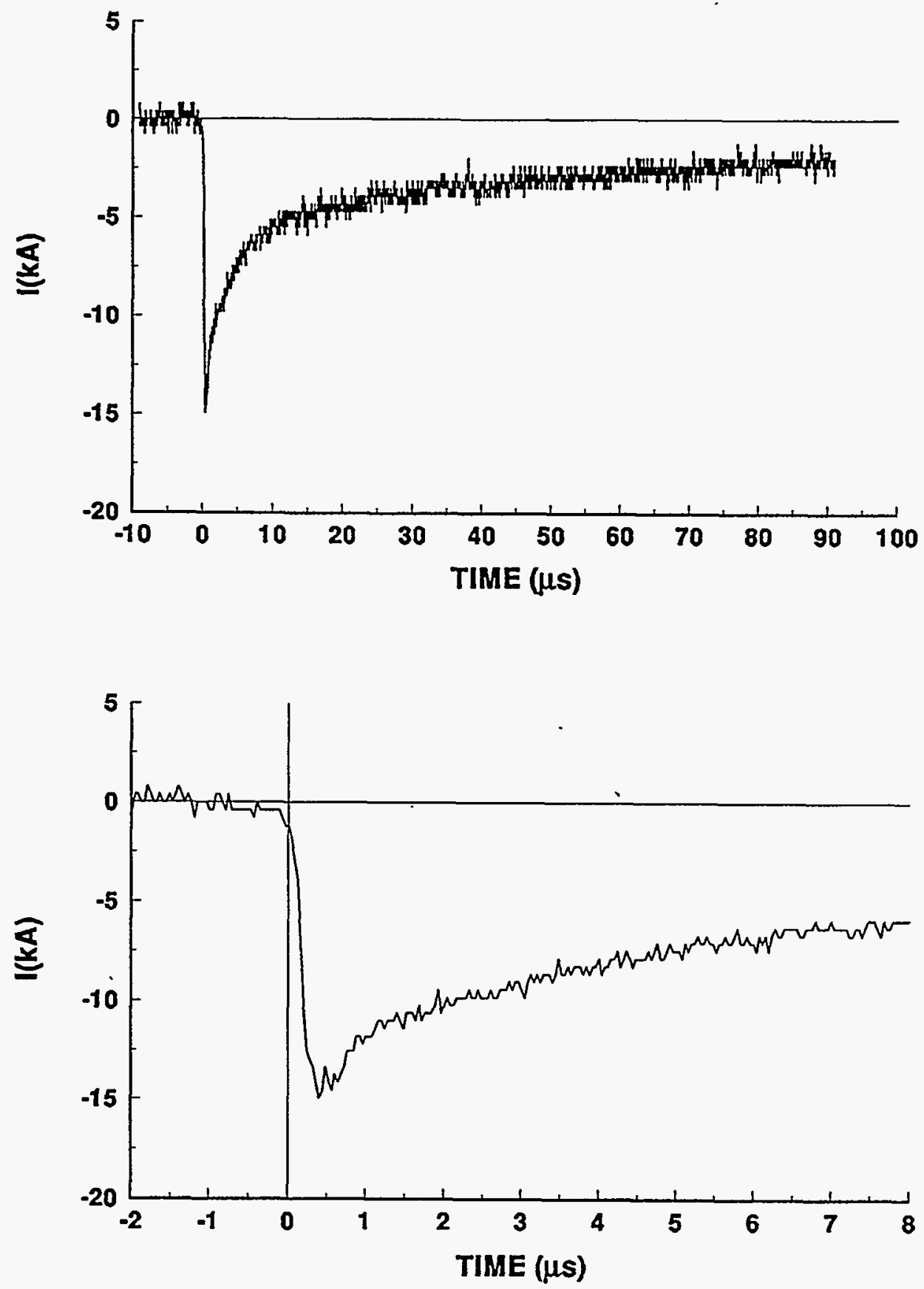


\section{4-07 STROKE 4}

TEST POINT 1

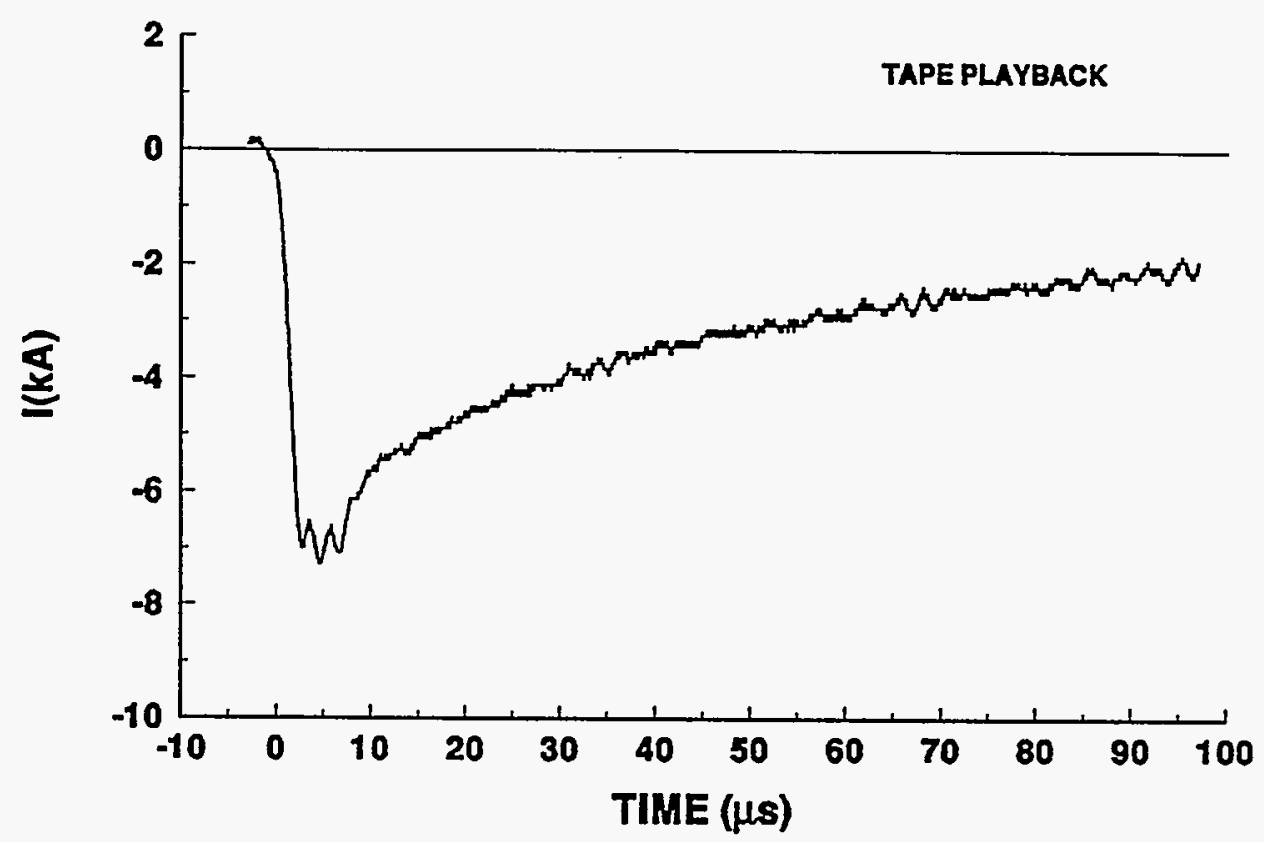

94-07 STROKE 4

TEST POINT 2

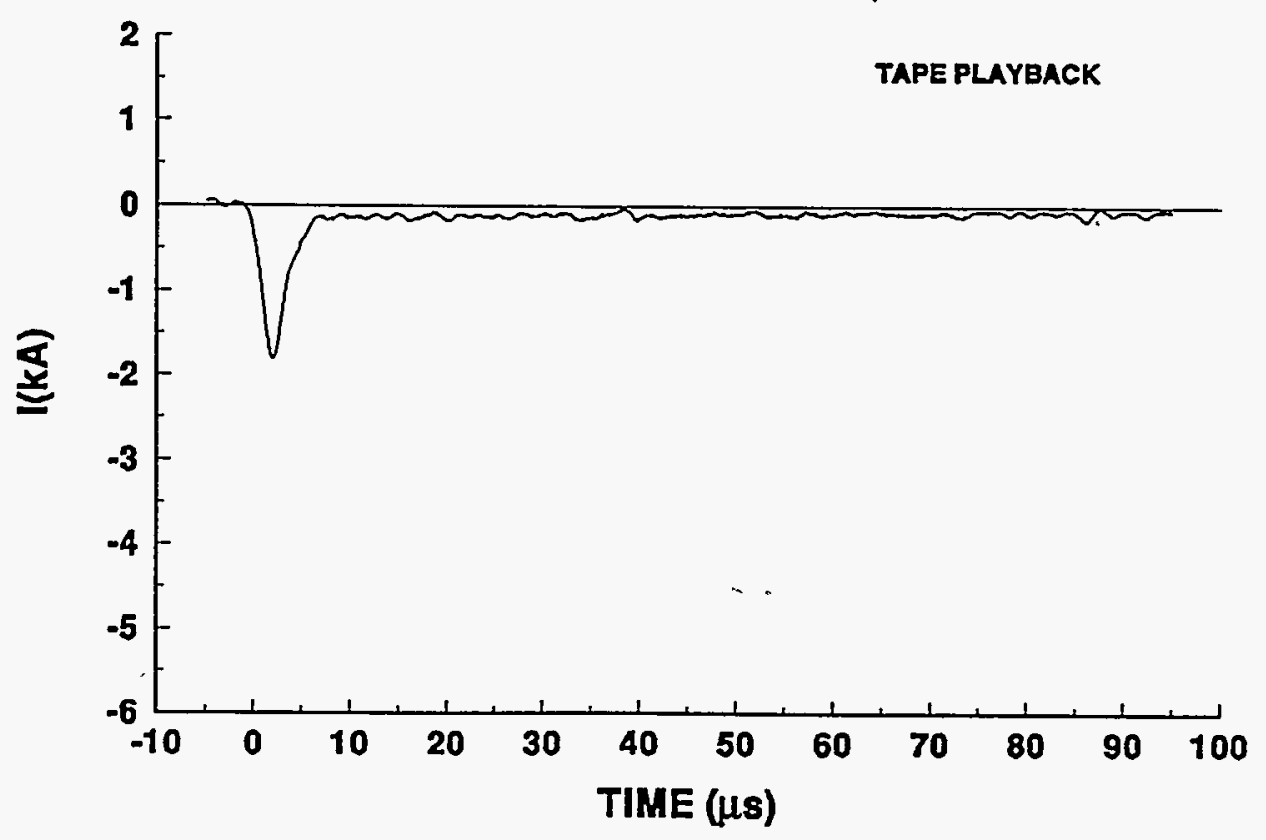




\section{4-07 STROKE 4}

TEST POINT 5

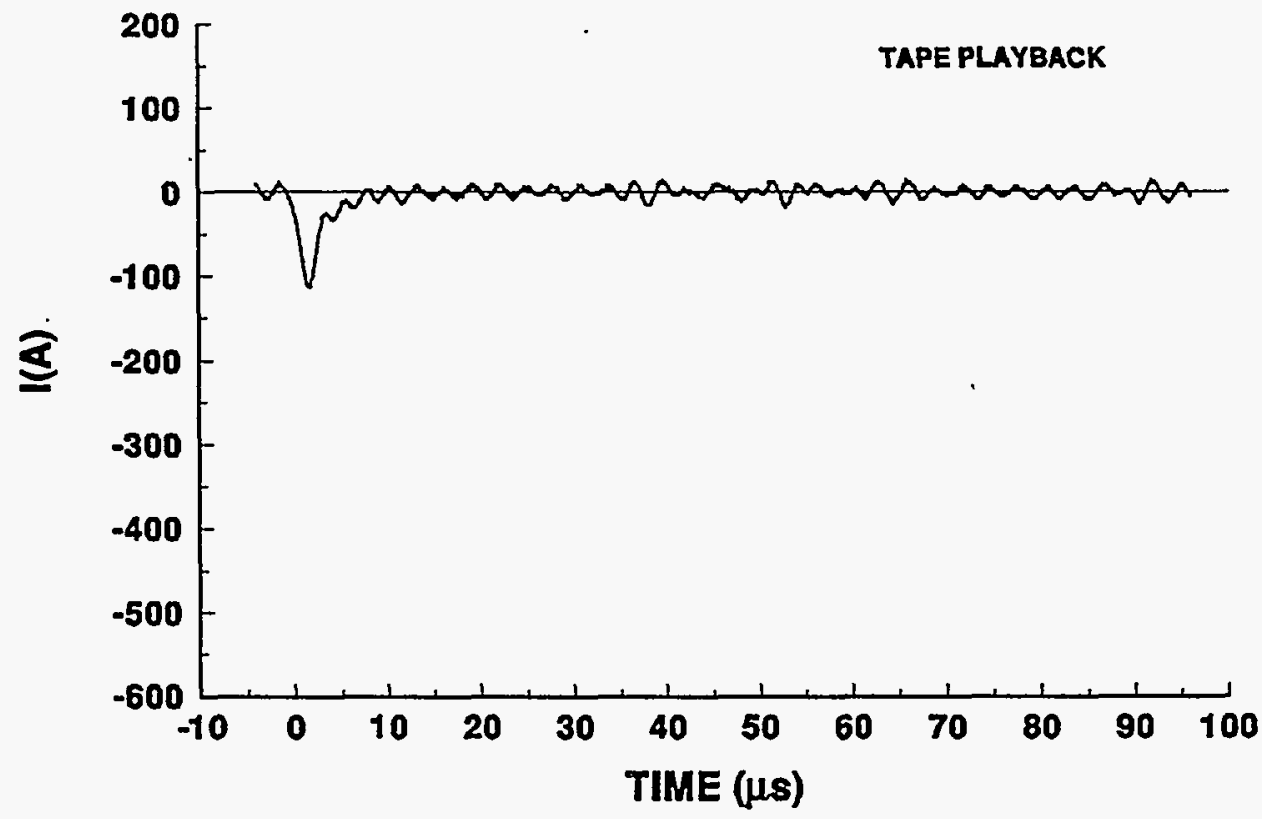

94-07 STROKE 4

TEST POINT 5'

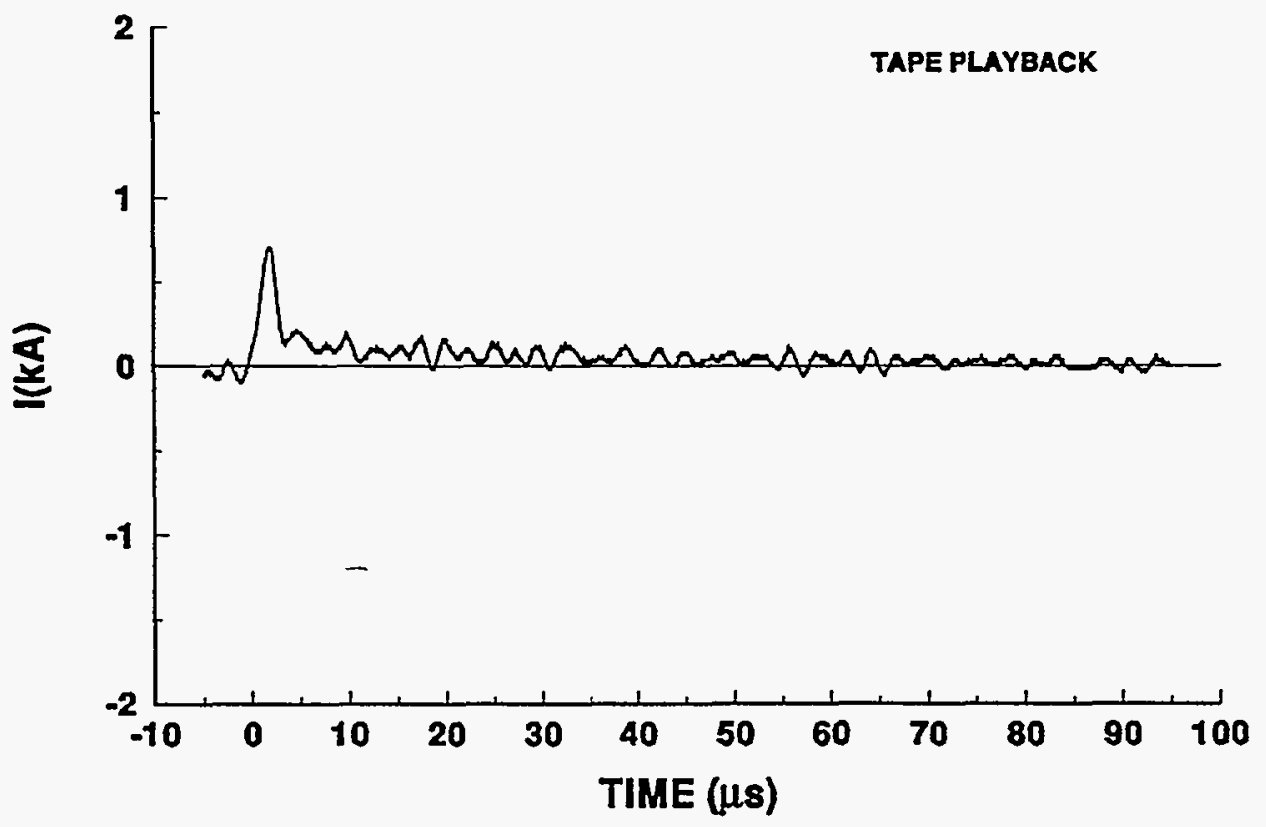




\section{4-07 STROKE 4}

TEST POINT 6

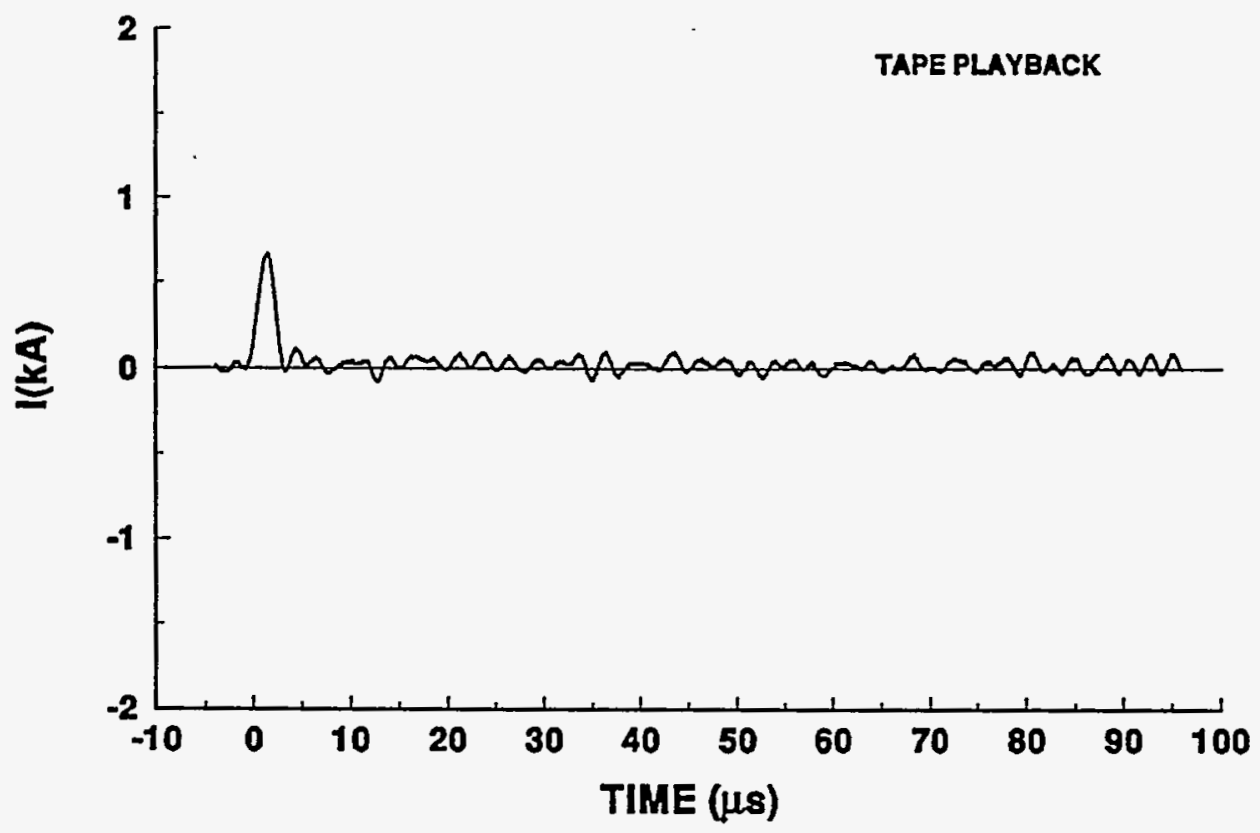

\section{4-07 STROKE 4}

TEST POINT 6'

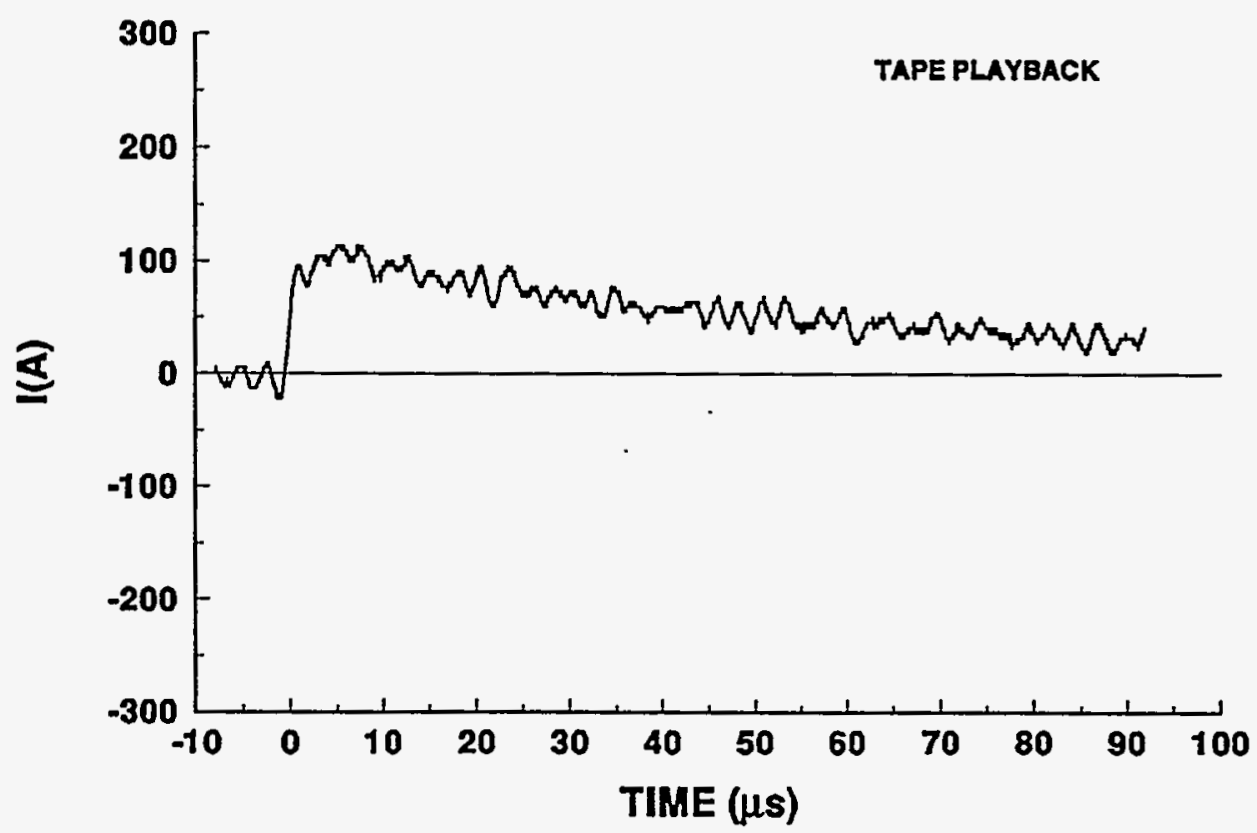




\section{4-07 STROKE 4}

TEST POINT 7
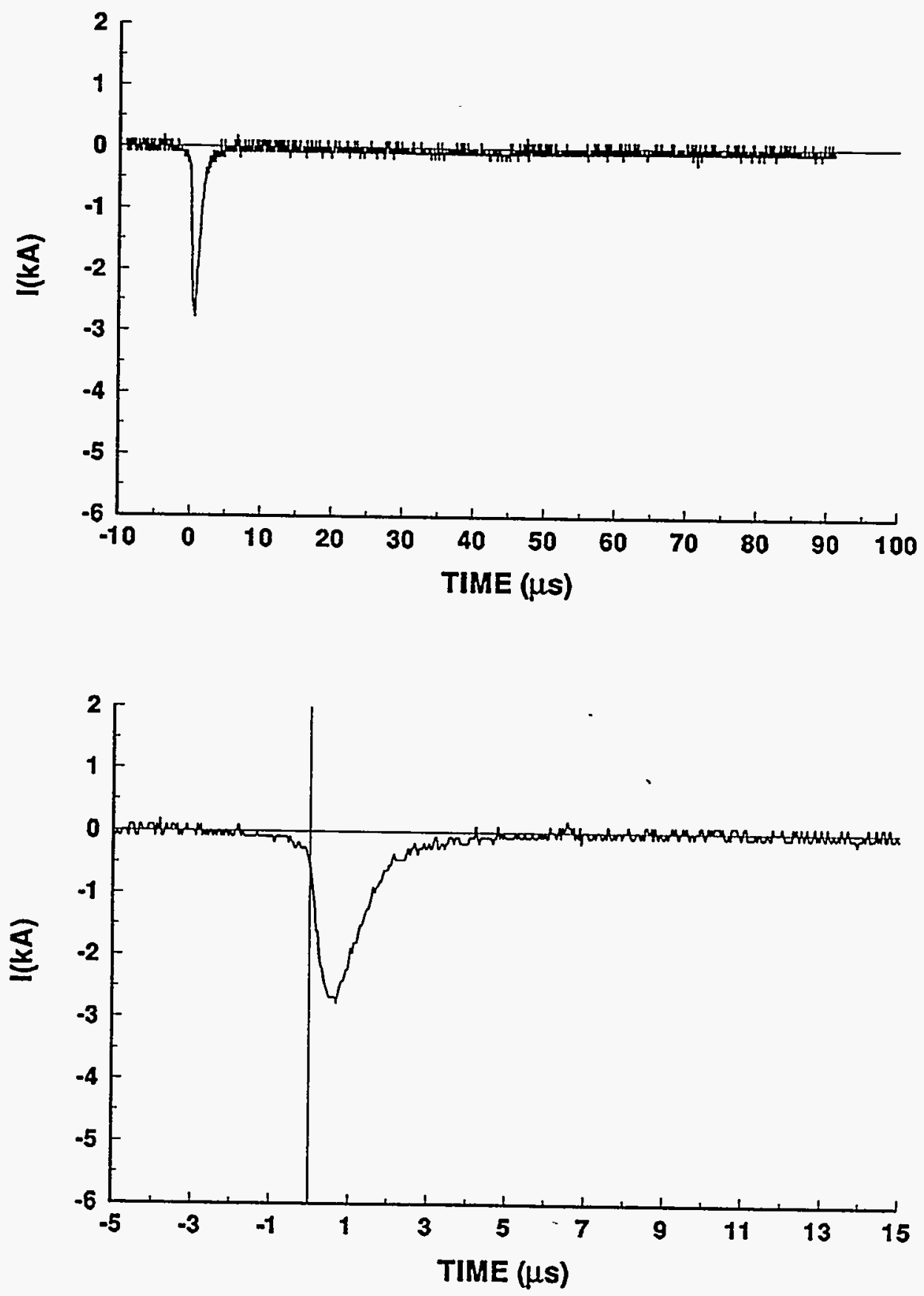


\section{4-07 STROKE 4}

TEST POINT 8
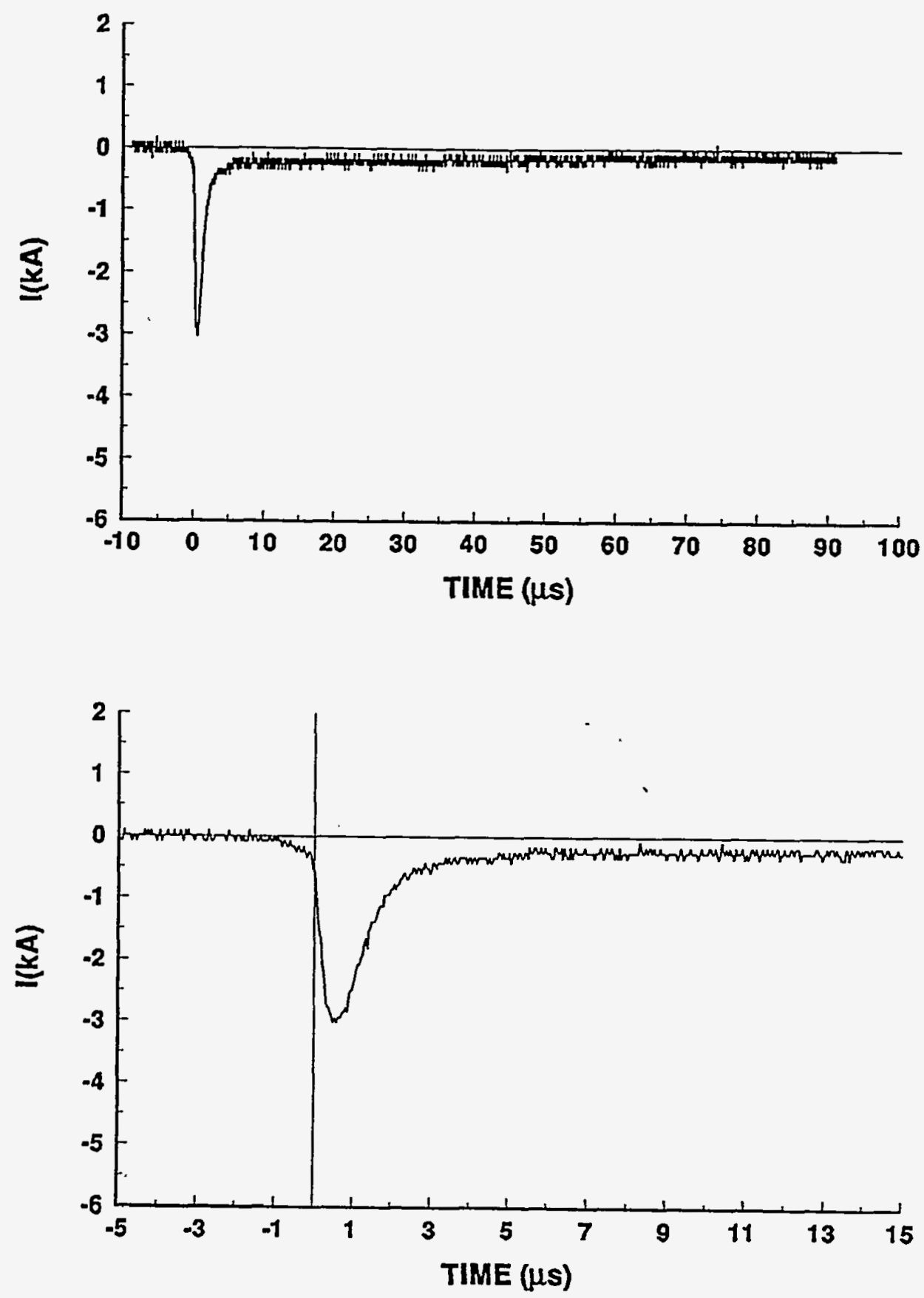
94-07 STROKE 4

TEST POINT 16

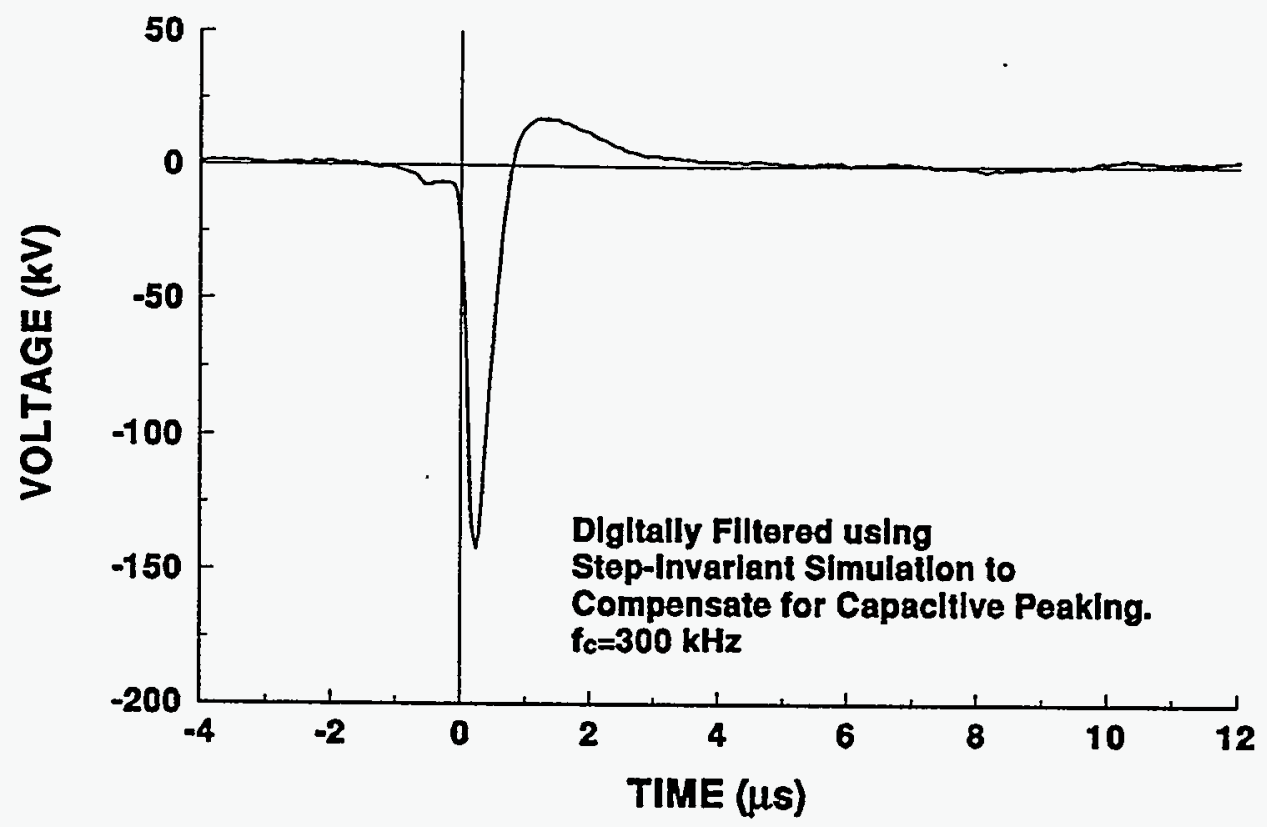

94-07 STROKE 4

TEST POINT 17

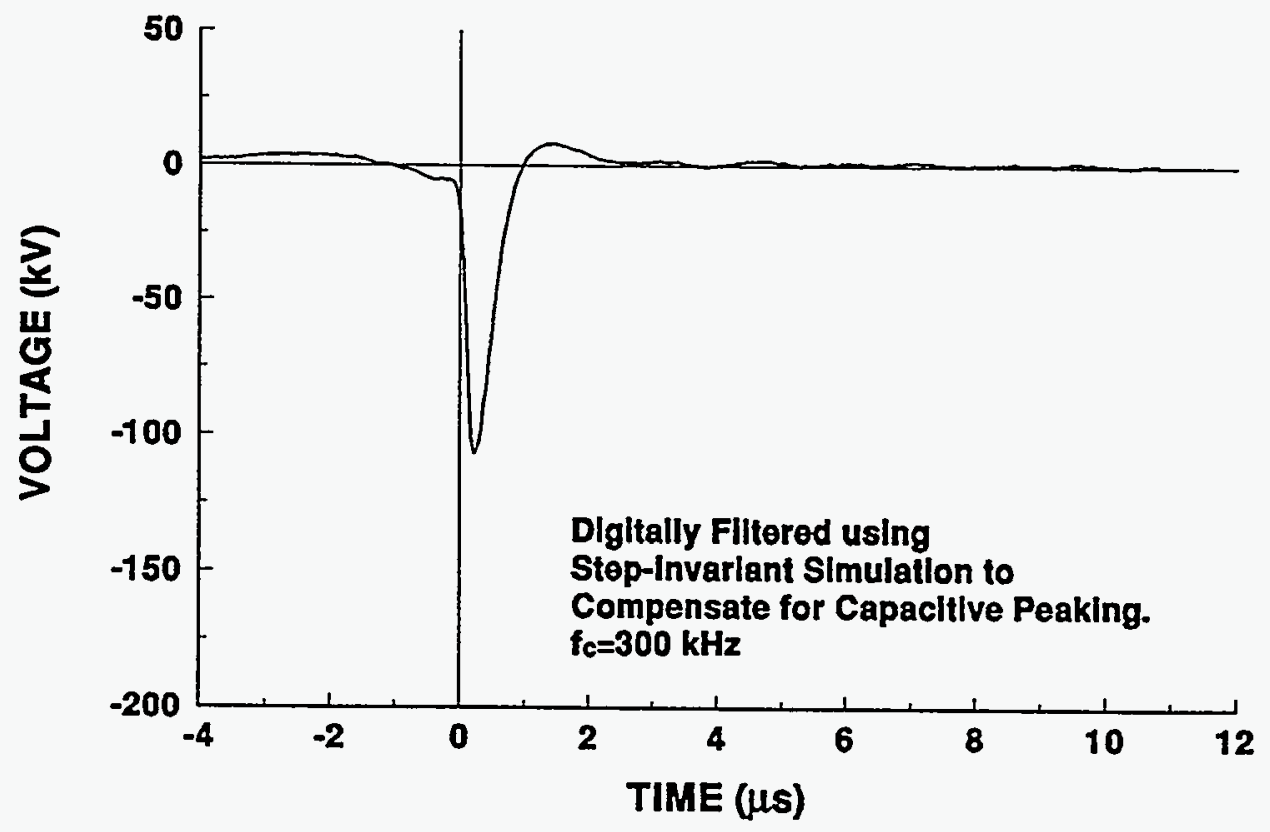




\section{4-07 STROKE 4}

\section{TEST POINT 18}

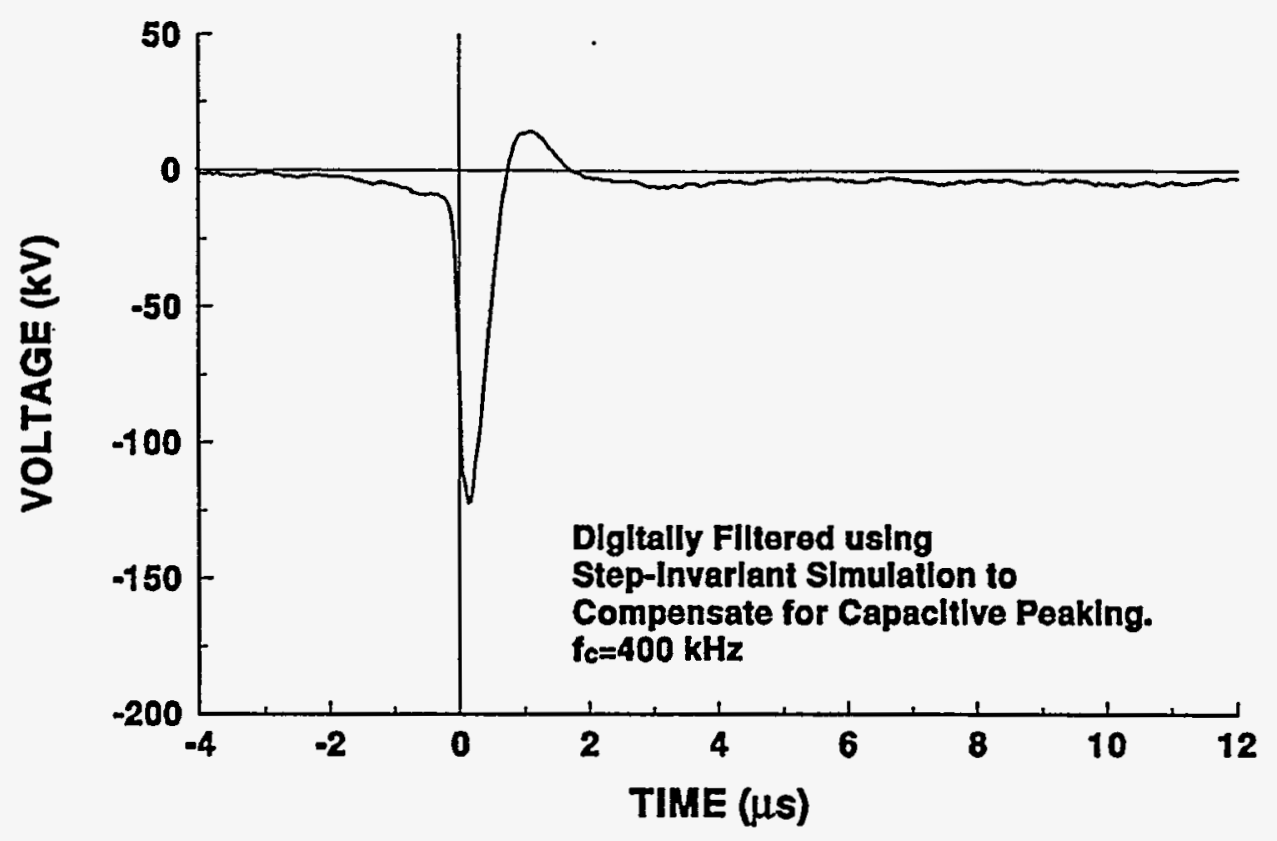

94-07 STROKE 4

TEST POINT 19

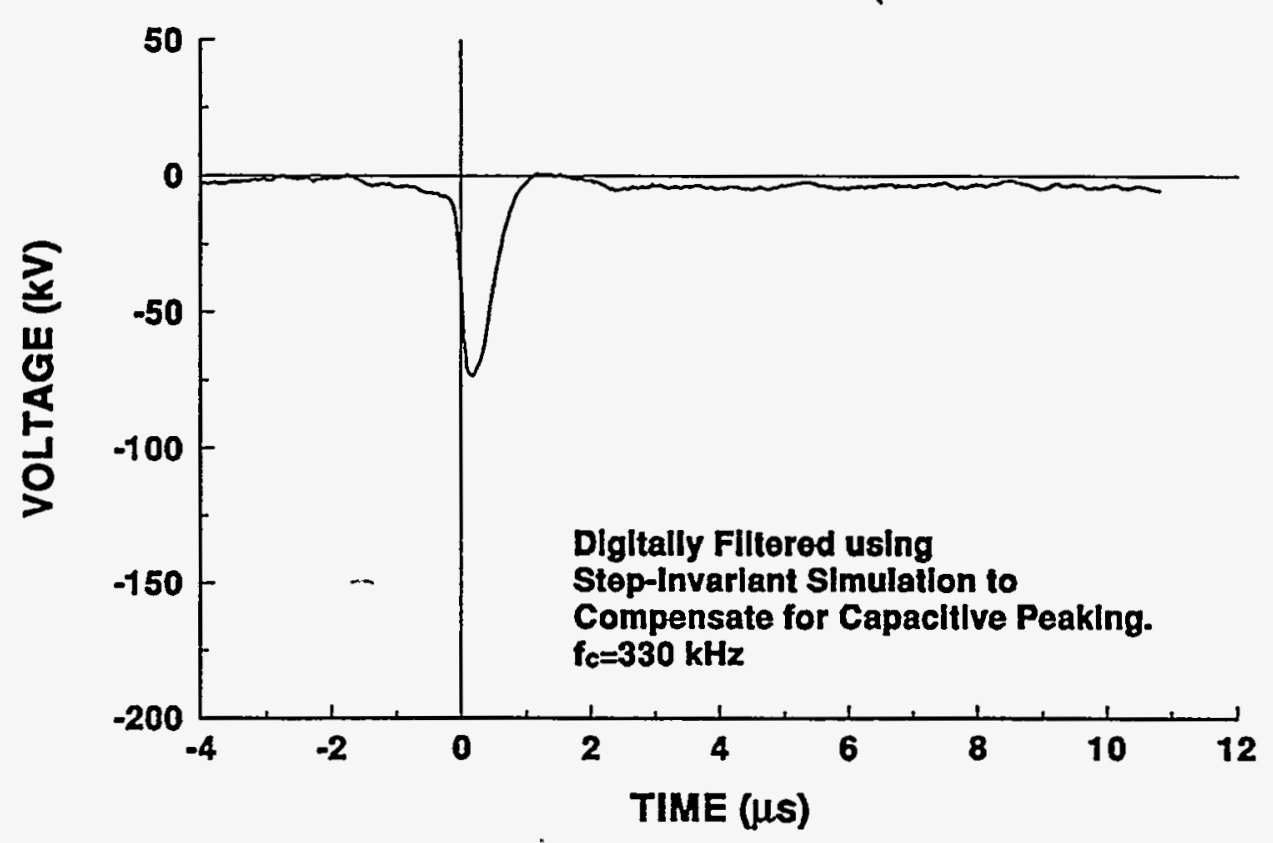


94-07 STROKE 4

TEST POINT 20

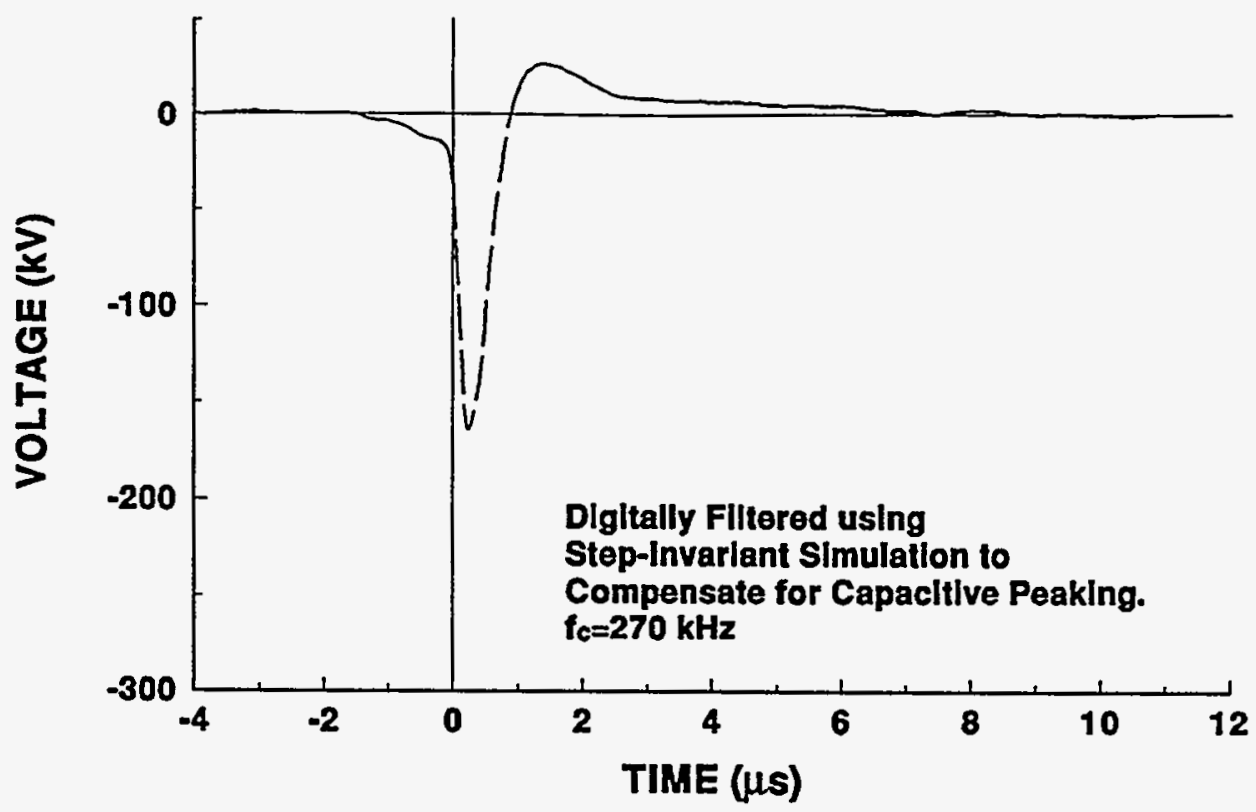

94-07 STROKE 4

TEST POINT 22

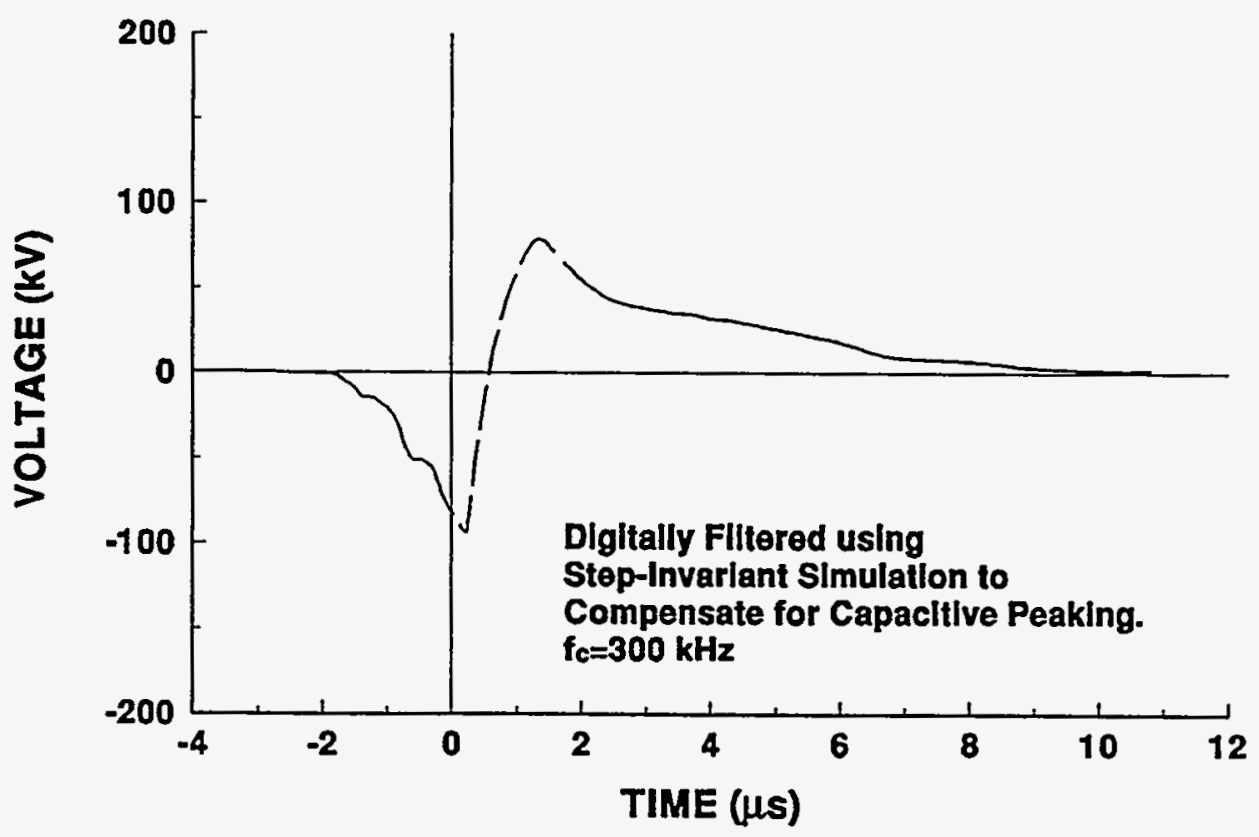




\section{4-07 STROKE 4}

\section{TEST POINT 23}

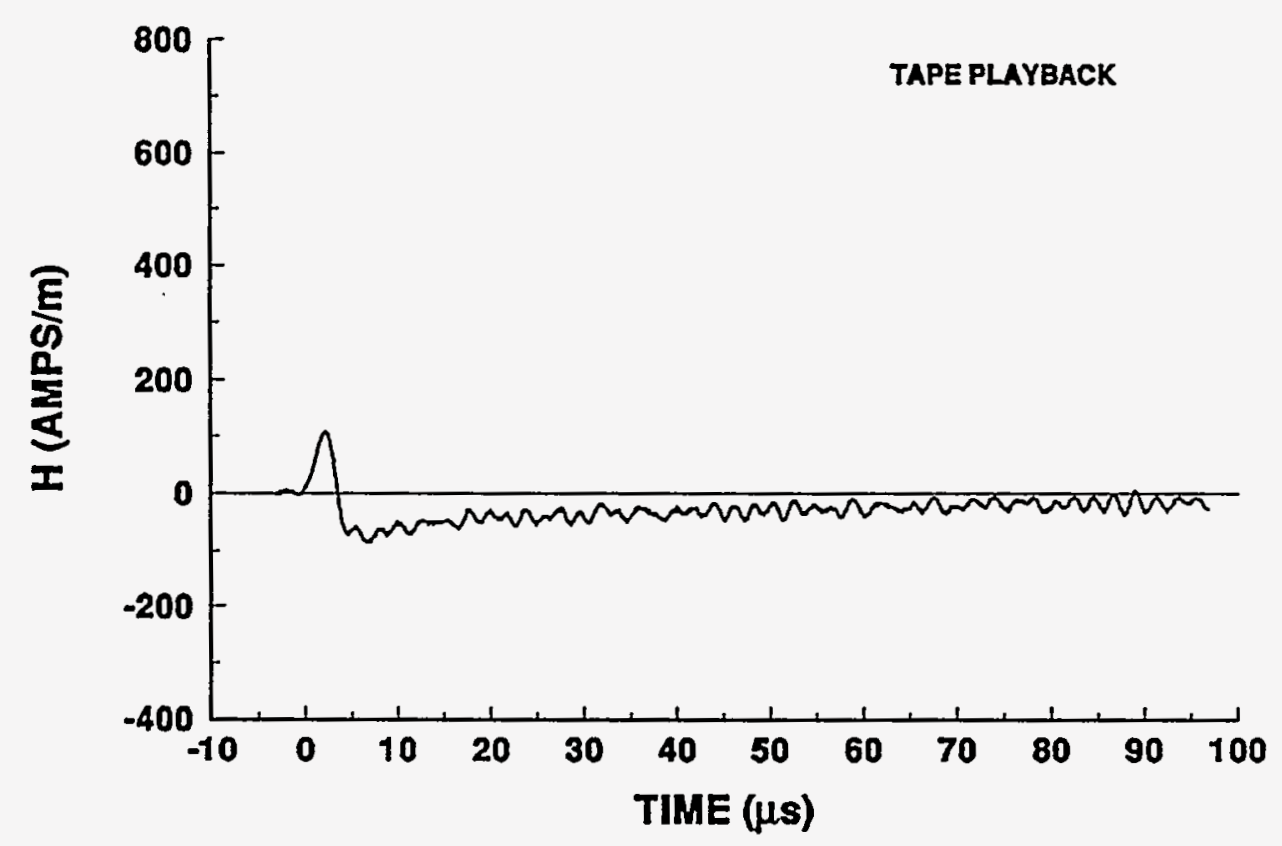

94-07 STROKE 4.

TEST POINT 24

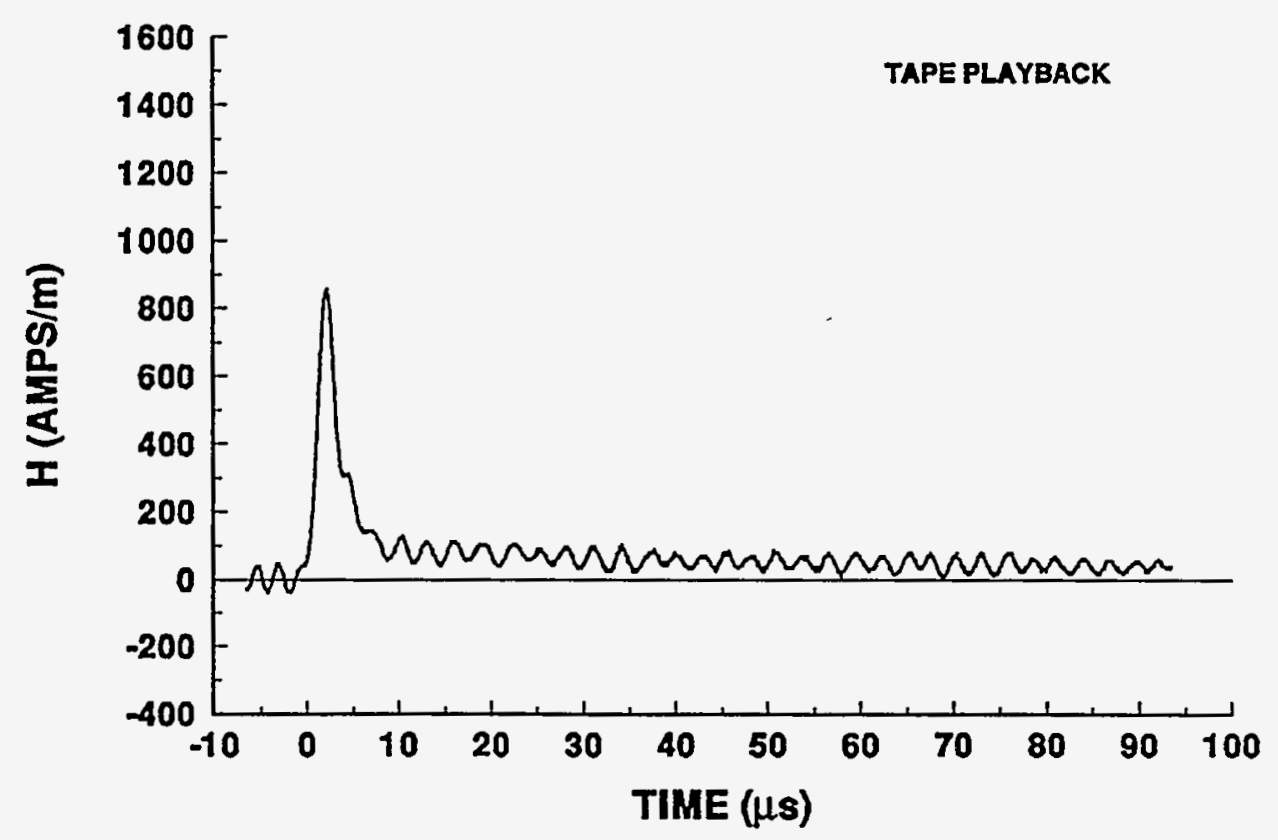




\section{4-09 STROKE 1 \\ INCIDENT CURRENT}
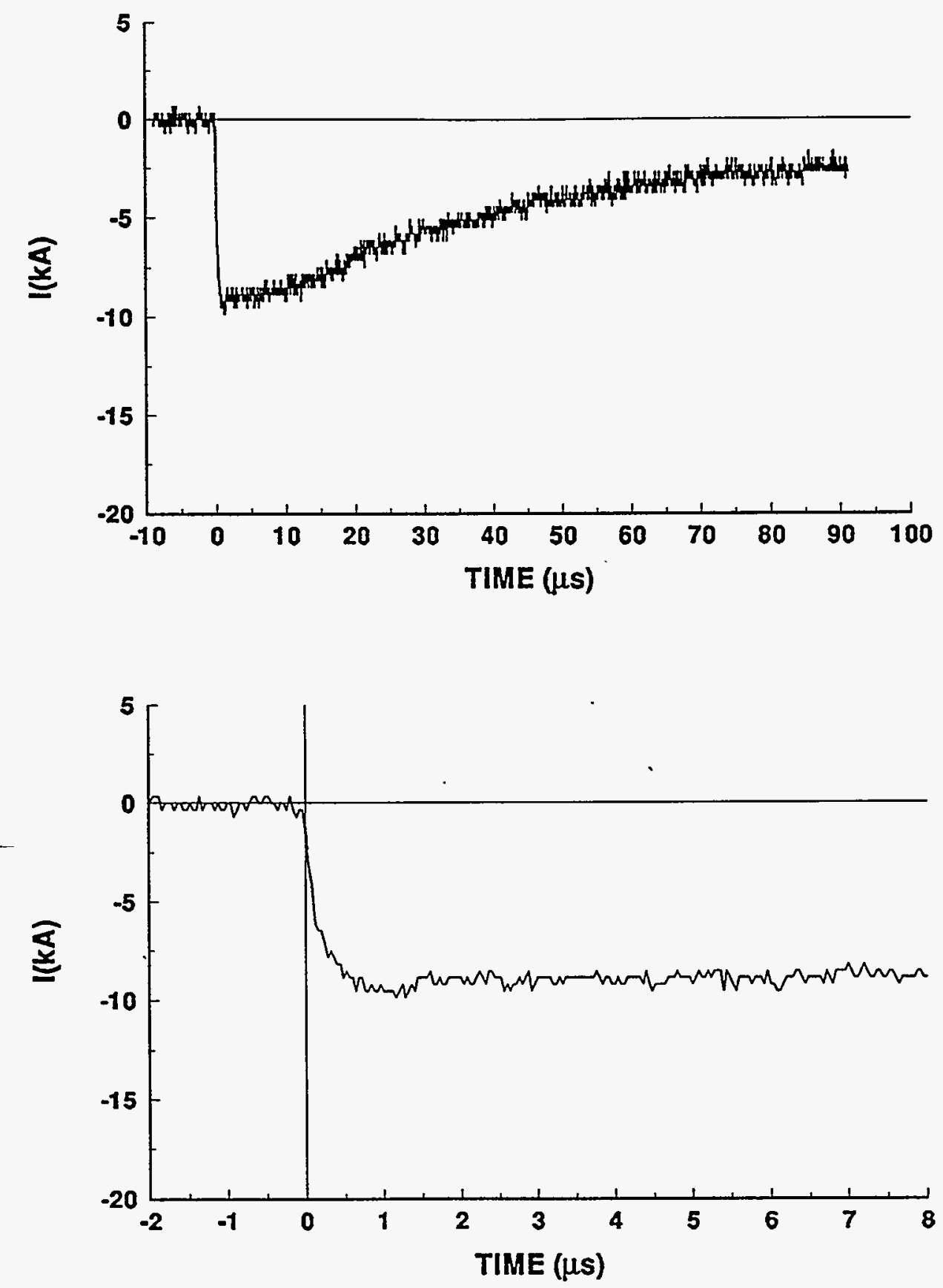


\section{4-09 STROKE 1}

TEST POINT 1

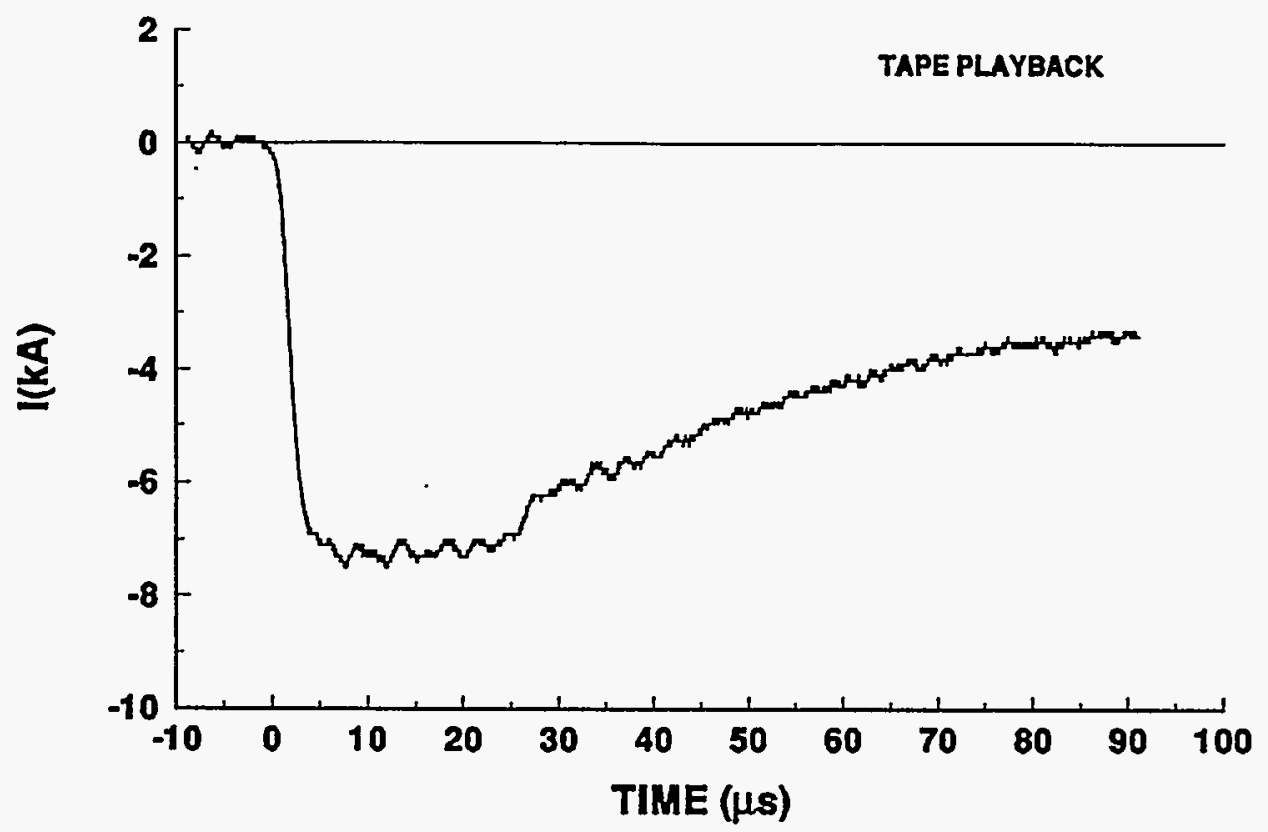

\section{4-09 STROKE 1}

TEST POINT 2

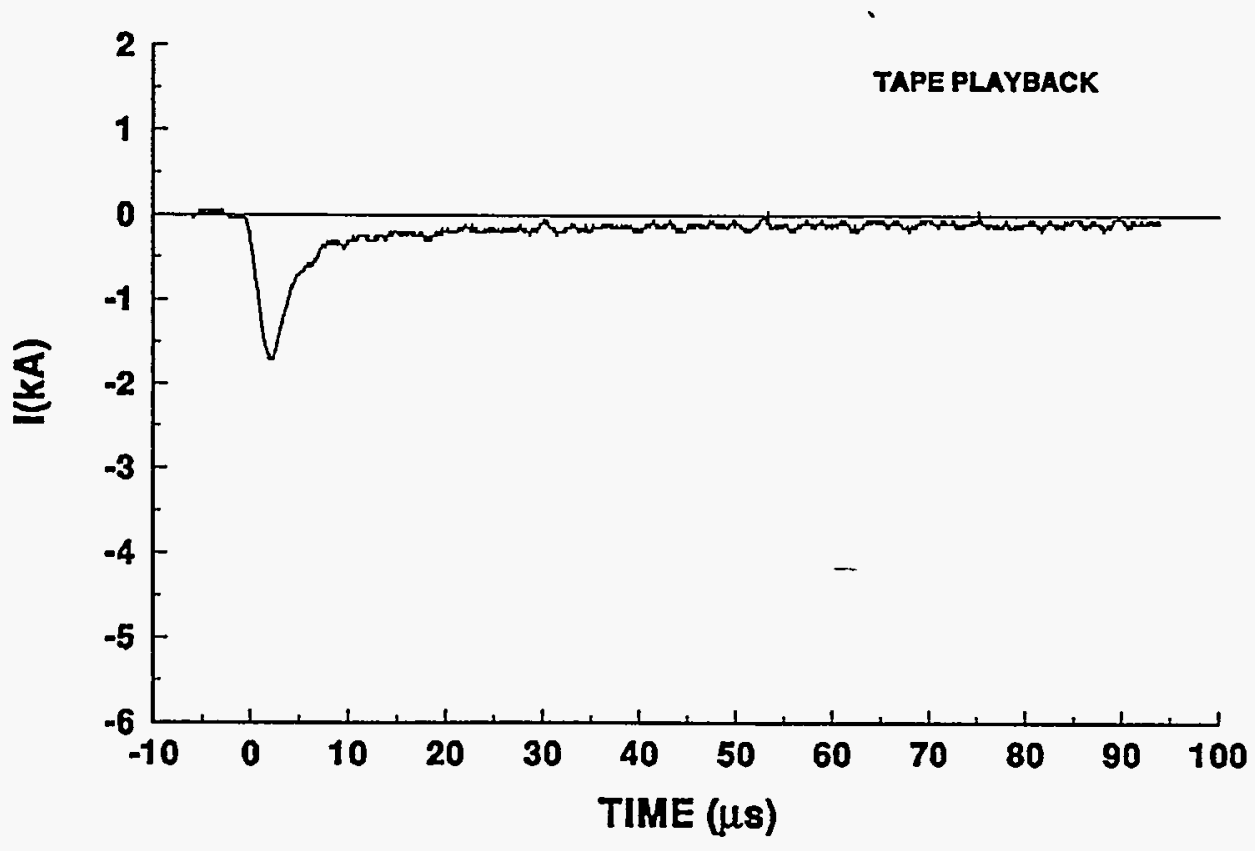


94-09 STROKE 1

TEST POINT 5

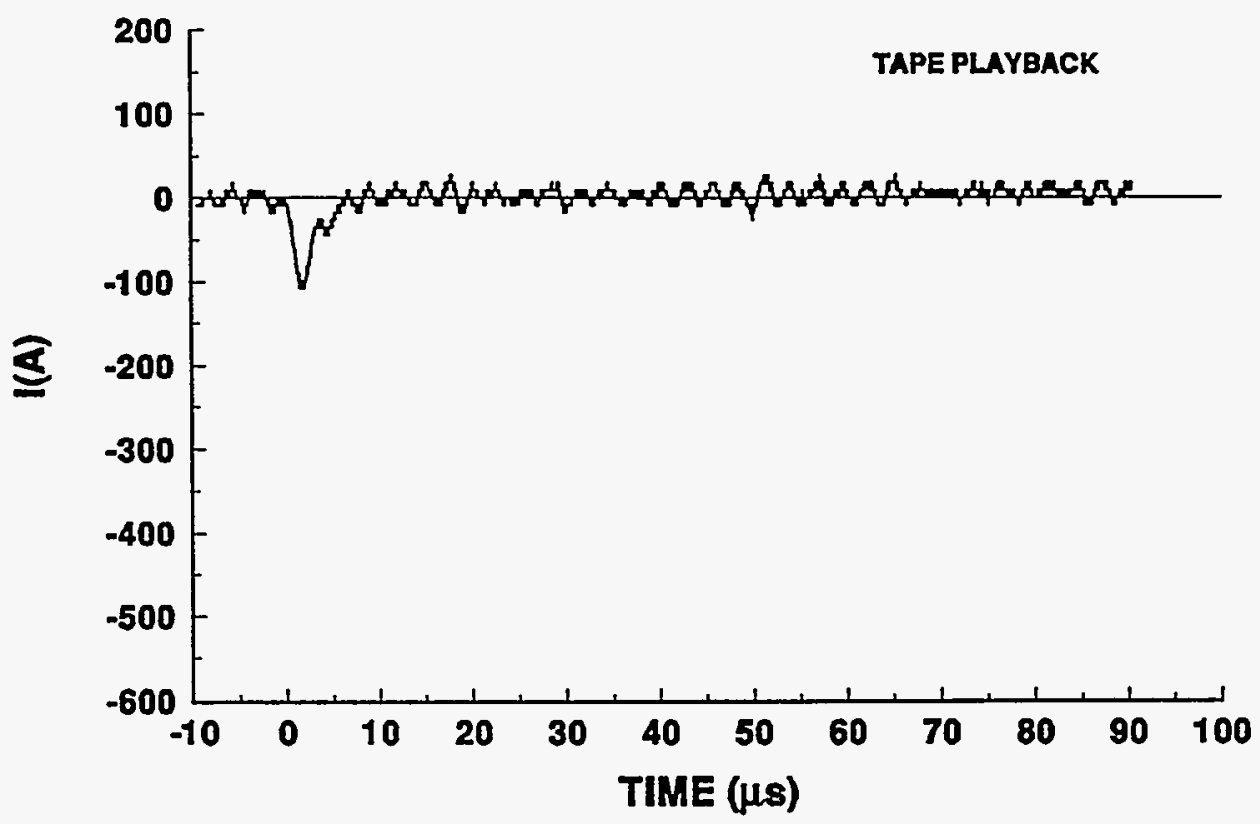

94-09 STROKE 1

TEST POINT 5'

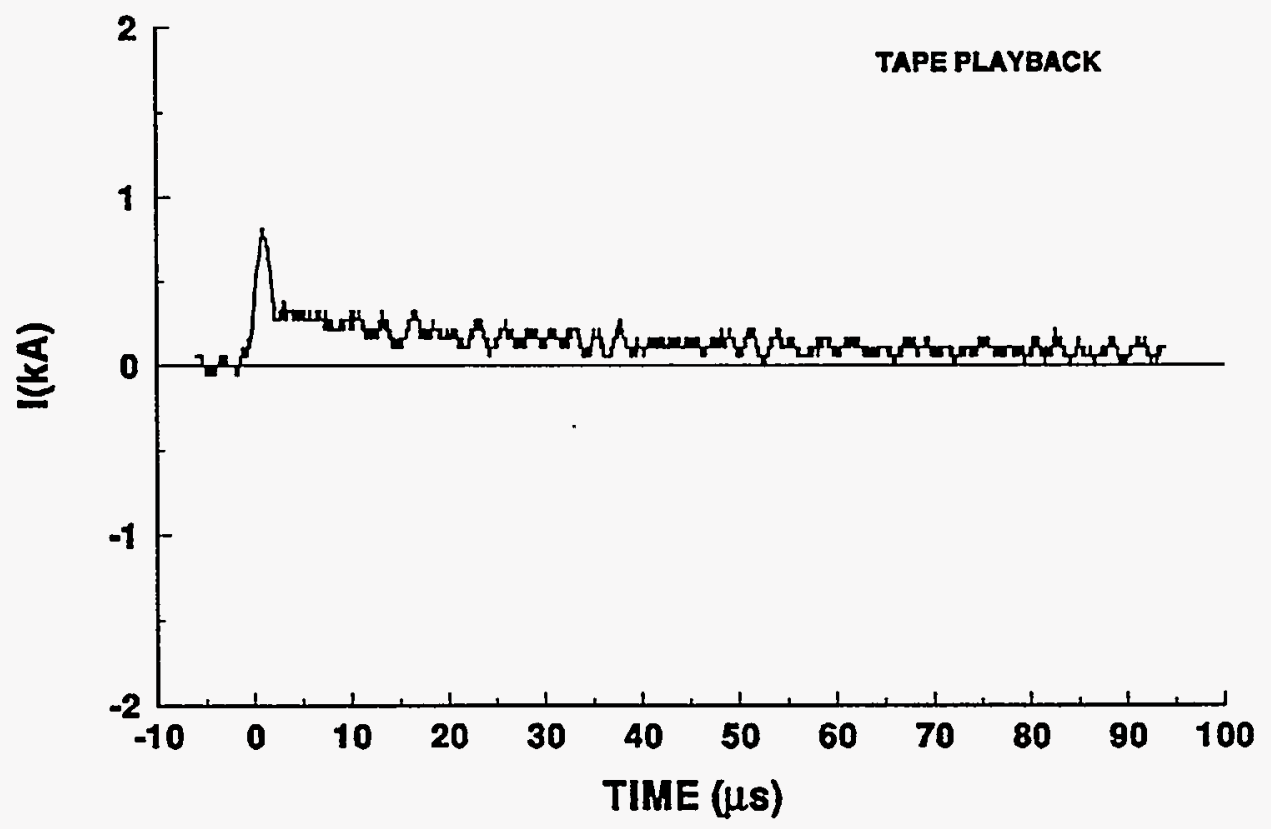




\section{4-09 STROKE 1}

TEST POINT 6

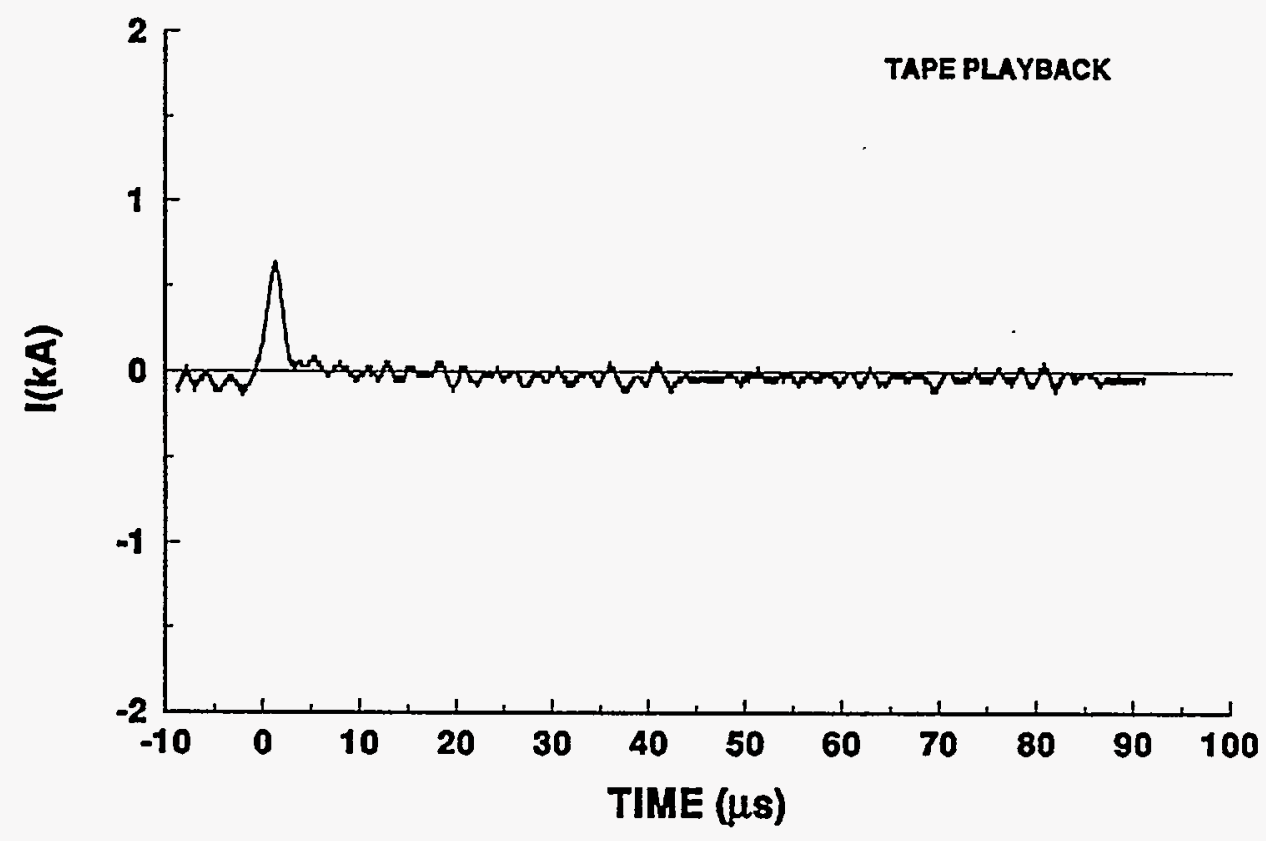

\section{4-09 STROKE.1}

TEST POINT 6'

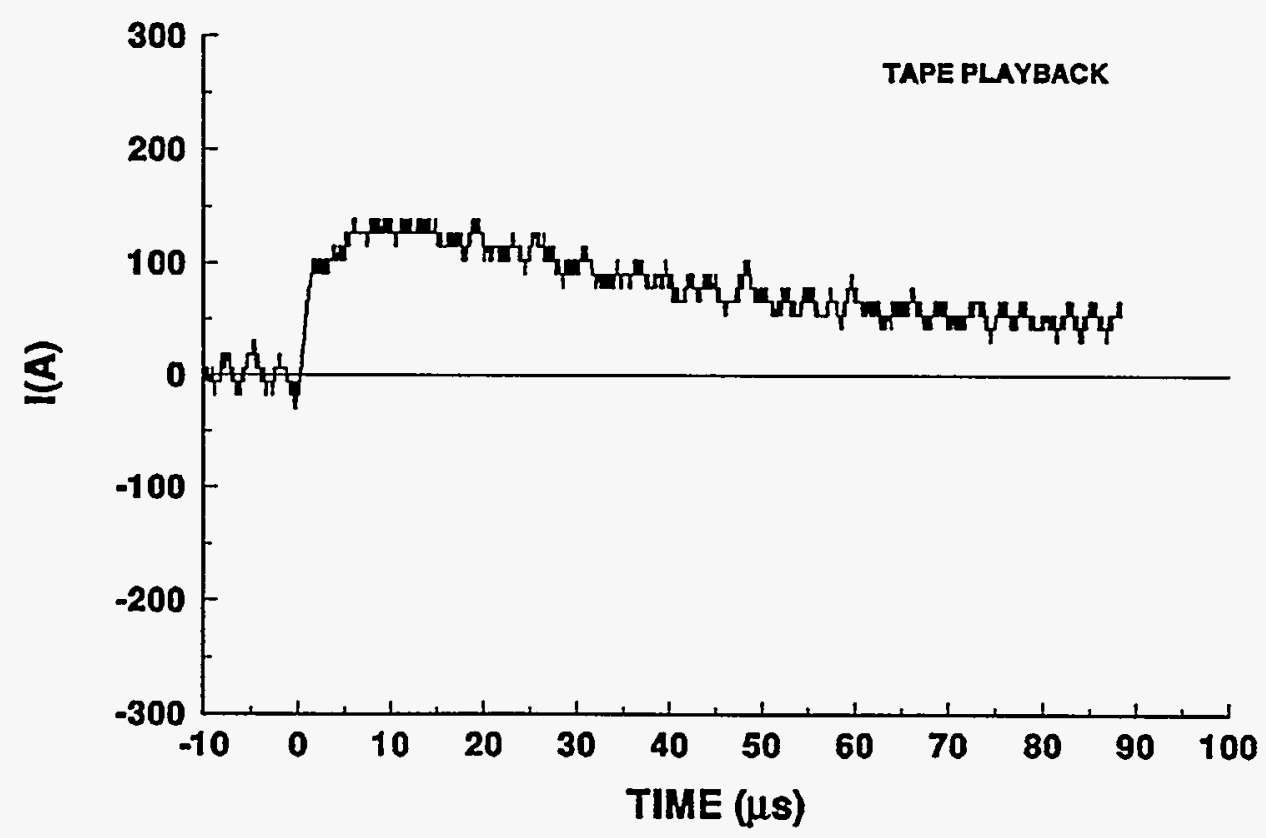




\section{4-09 STROKE 1 \\ TEST POINT 7}
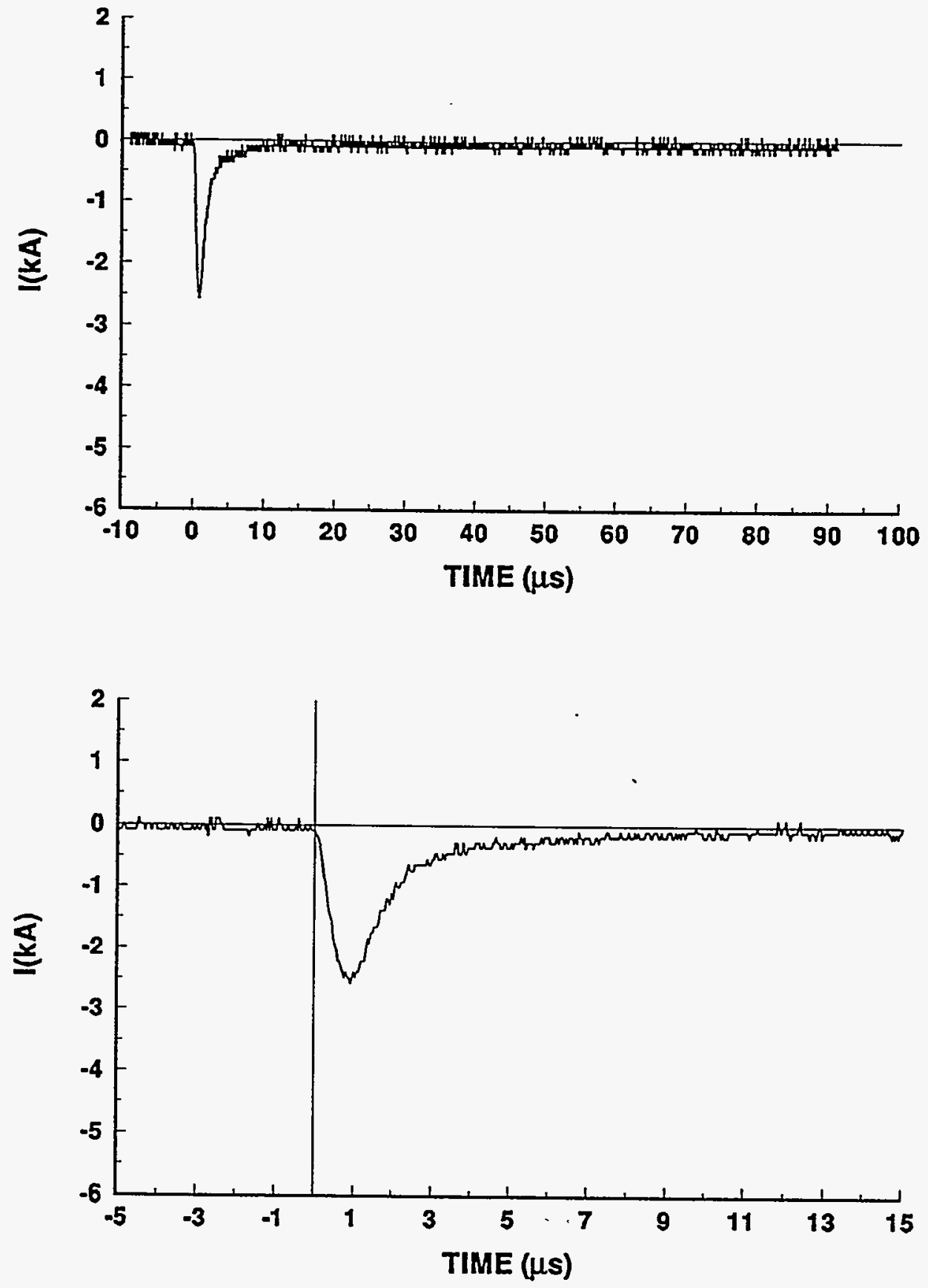


\section{4-09 STROKE 1 \\ TEST POINT 8}
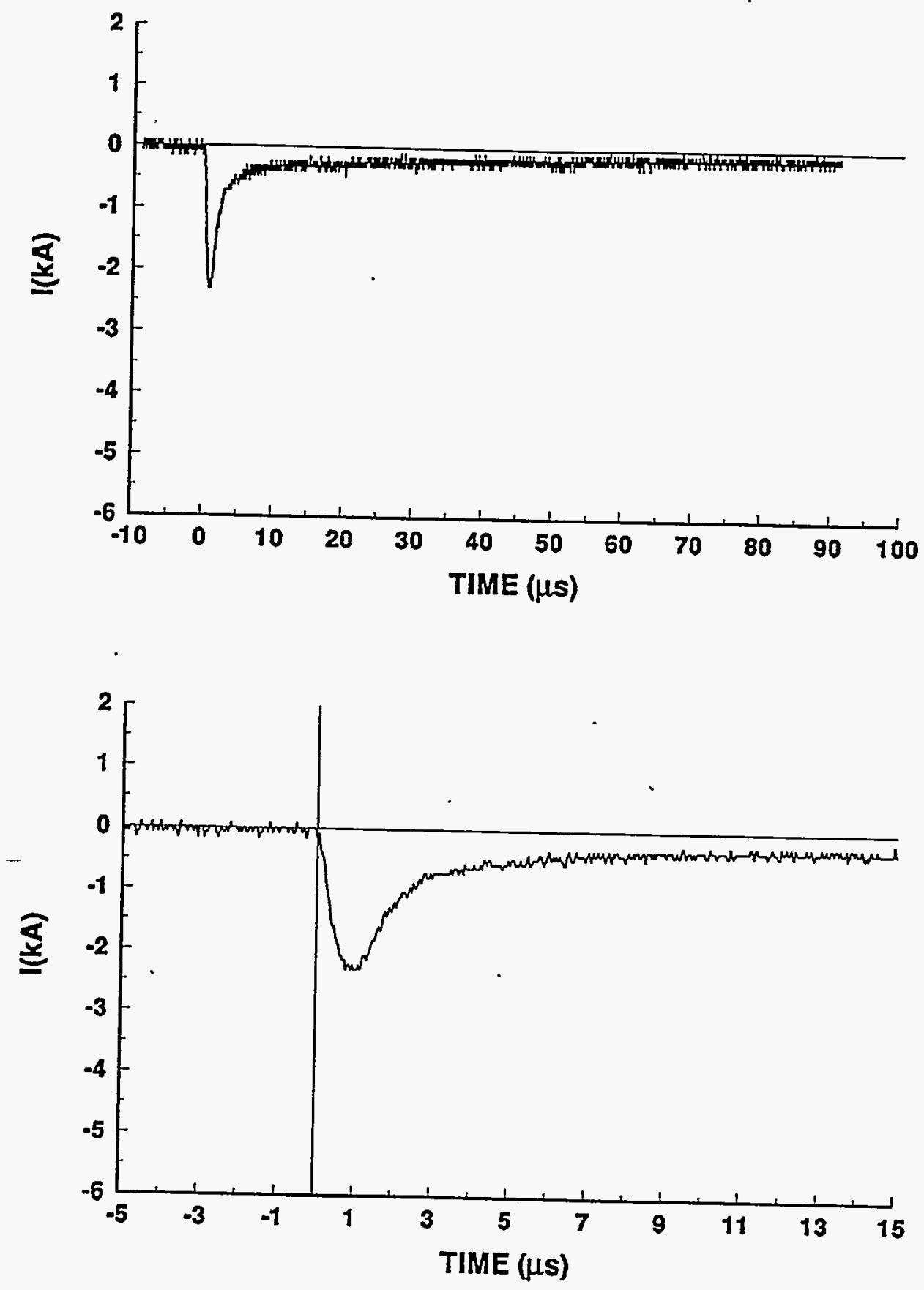


\section{4-09 STROKE 1}

TEST POINT 16

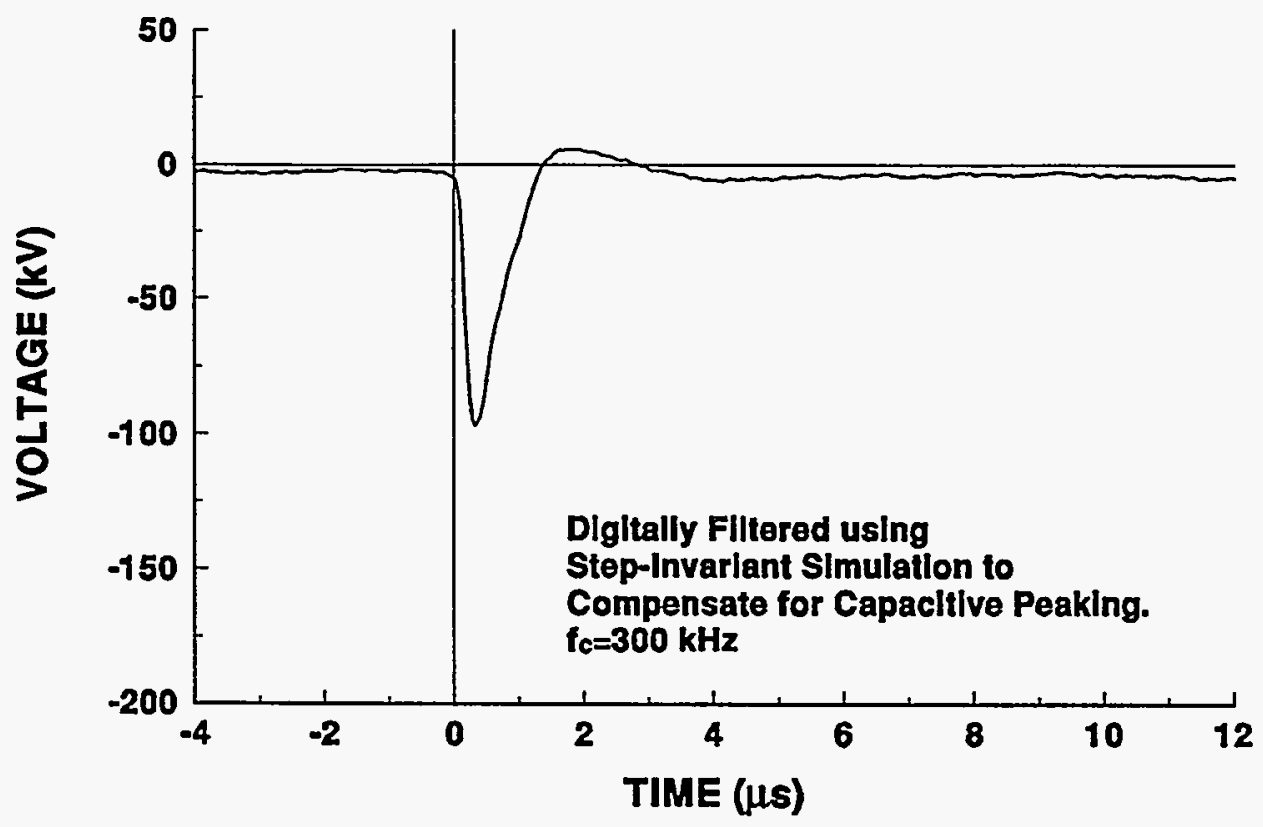

\section{4-09 STROKE 1} TEST POINT 17

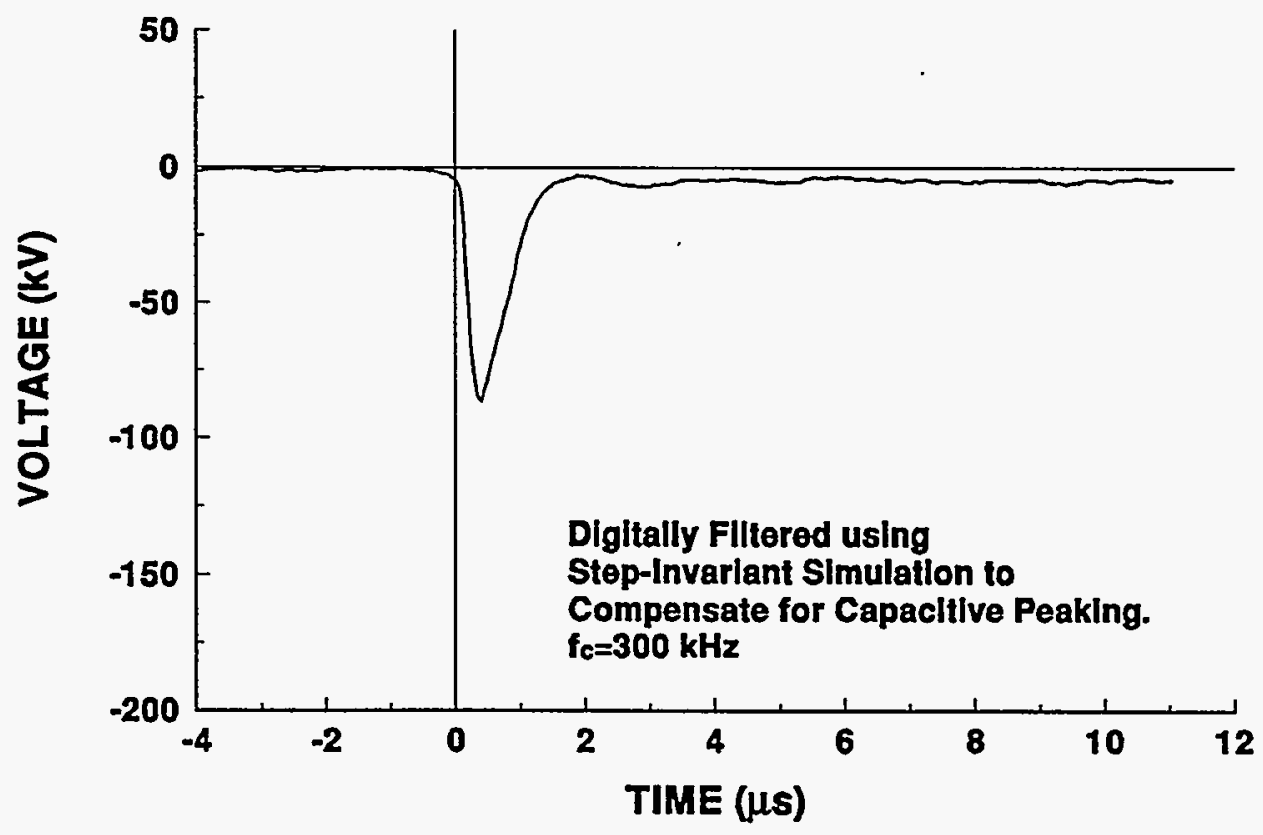




\section{4-09 STROKE 1}

TEST POINT 18

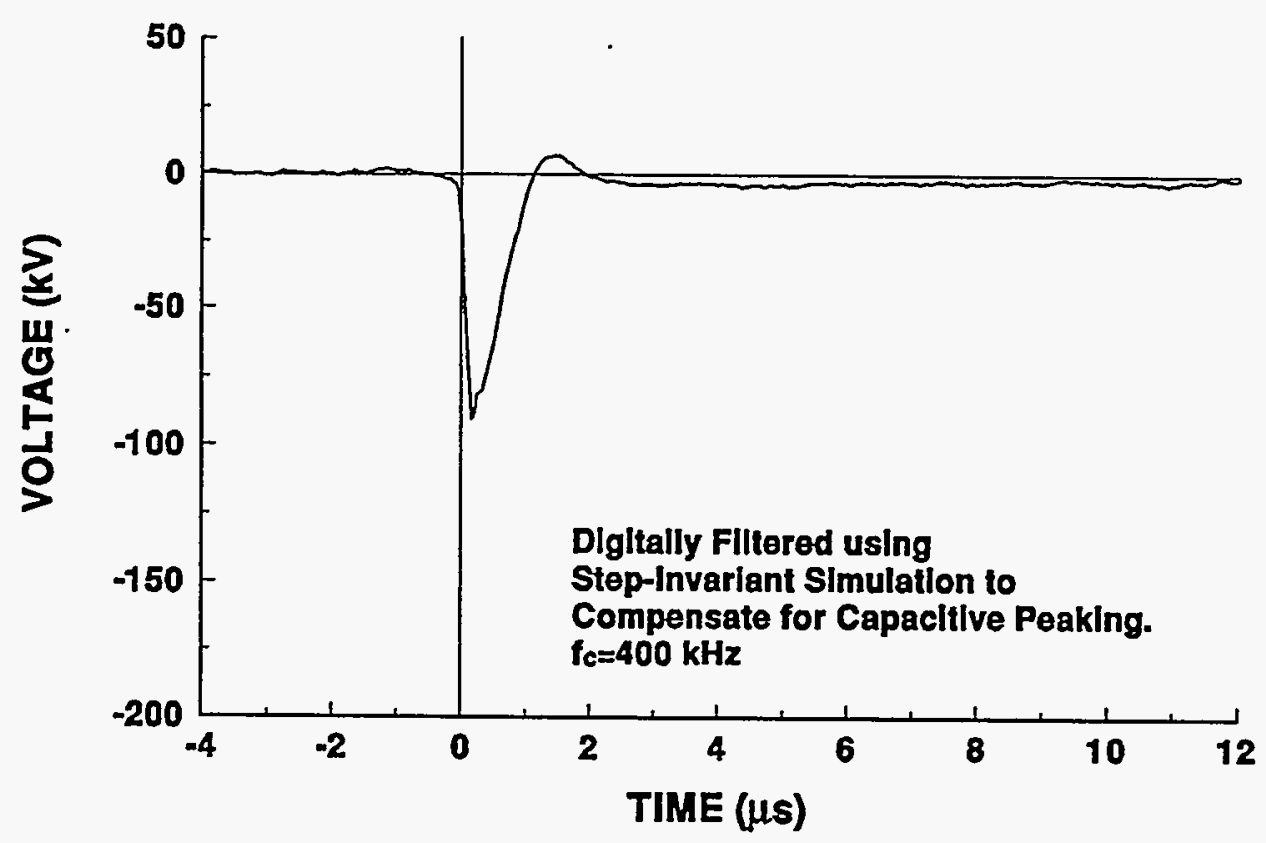

\section{4-09 STROKE 1 .}

\section{TEST POINT 19}

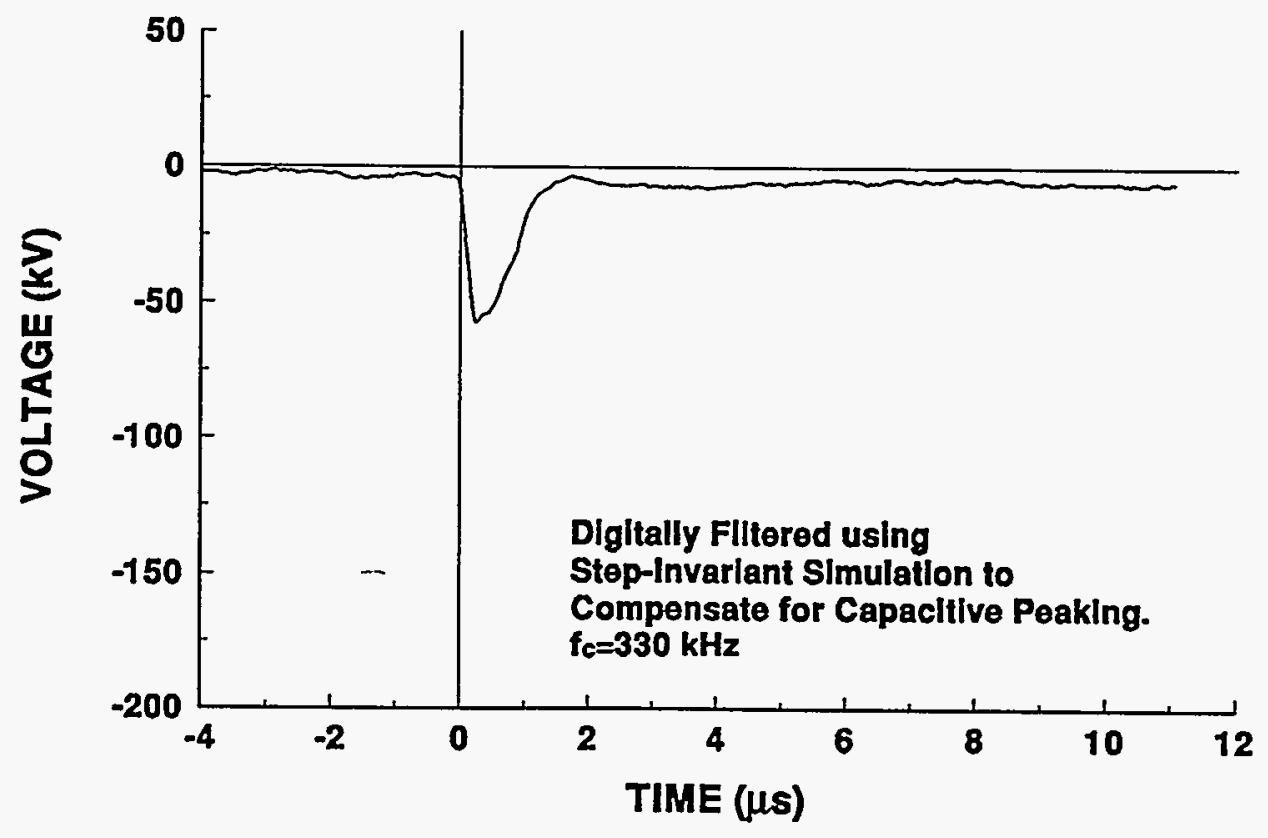




\section{4-09 STROKE 1}

TEST POINT 20

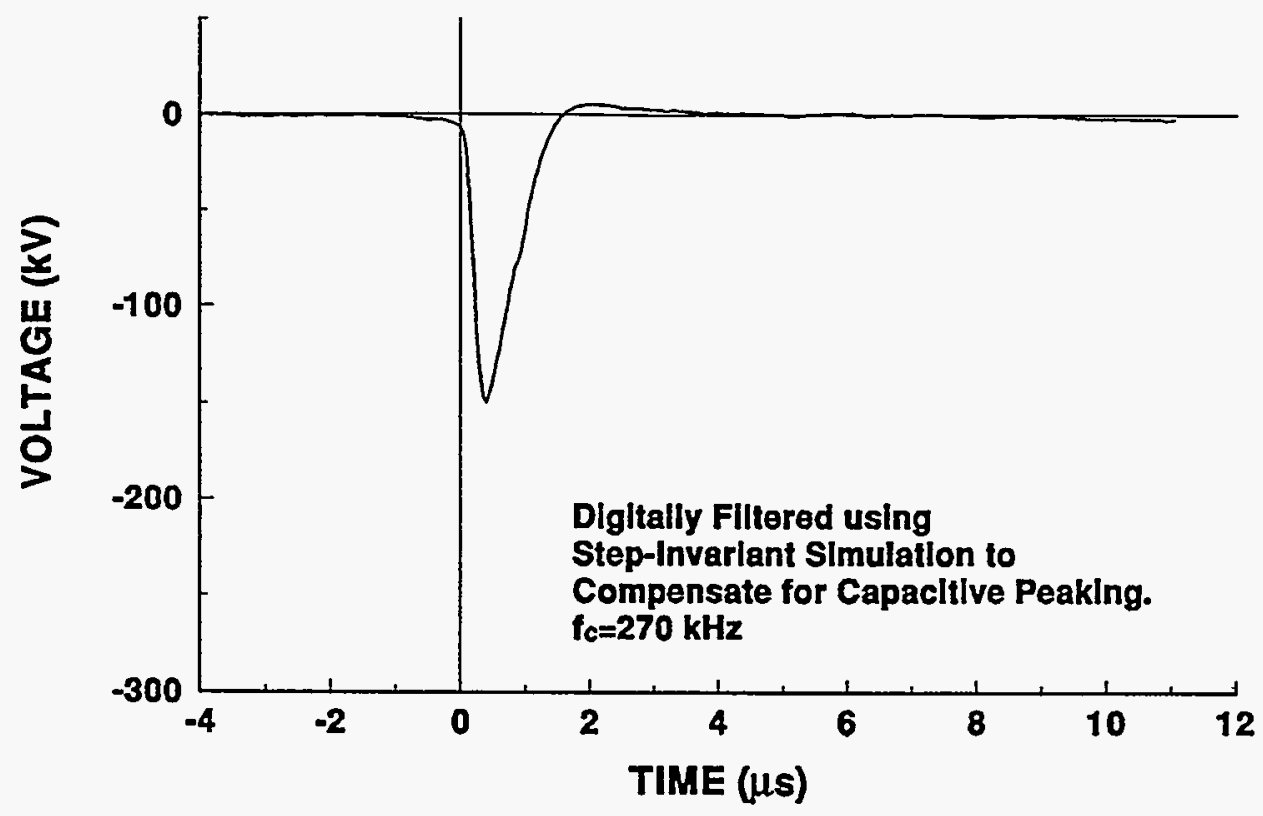

\section{4-09 STROKE 1} TEST POINT $2 \dot{2}$

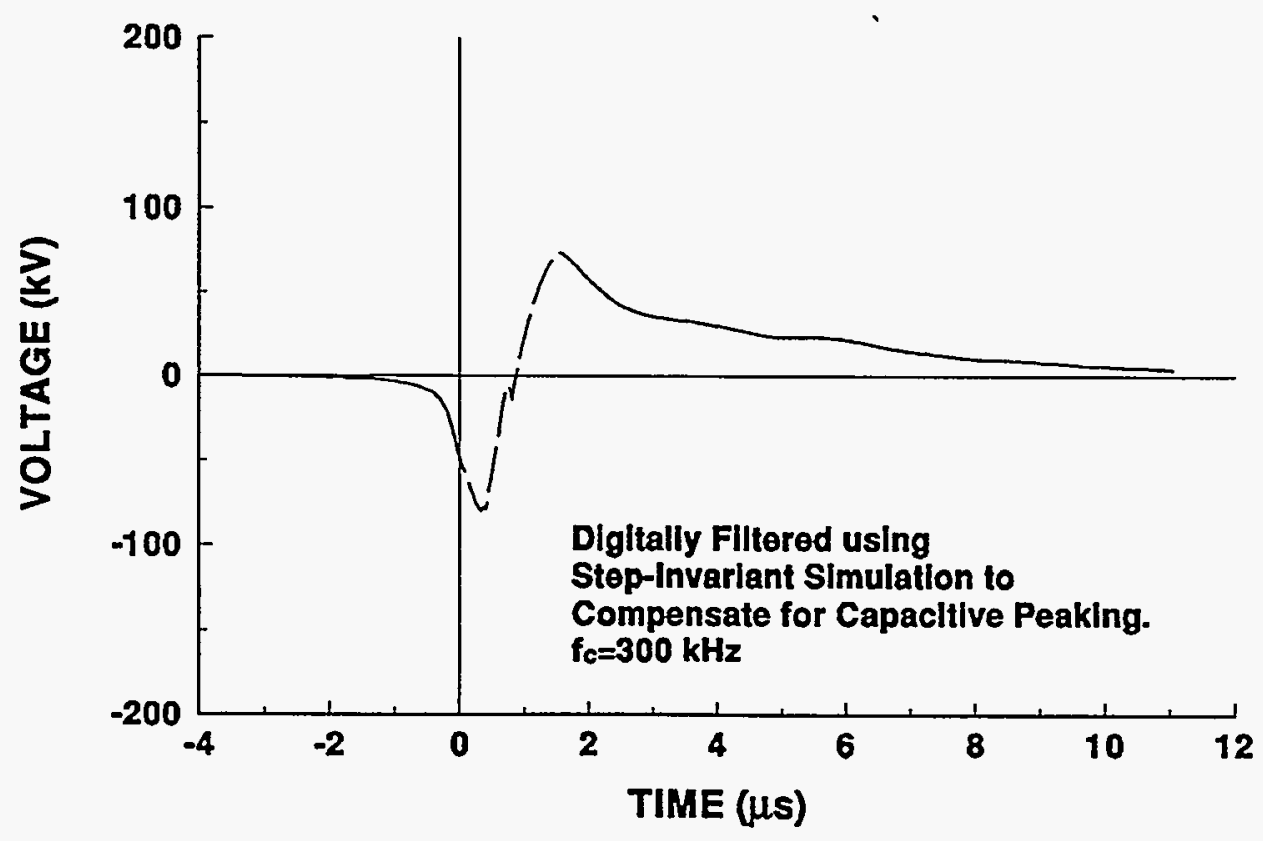




\section{4-09 STROKE 1}

TEST POINT 23

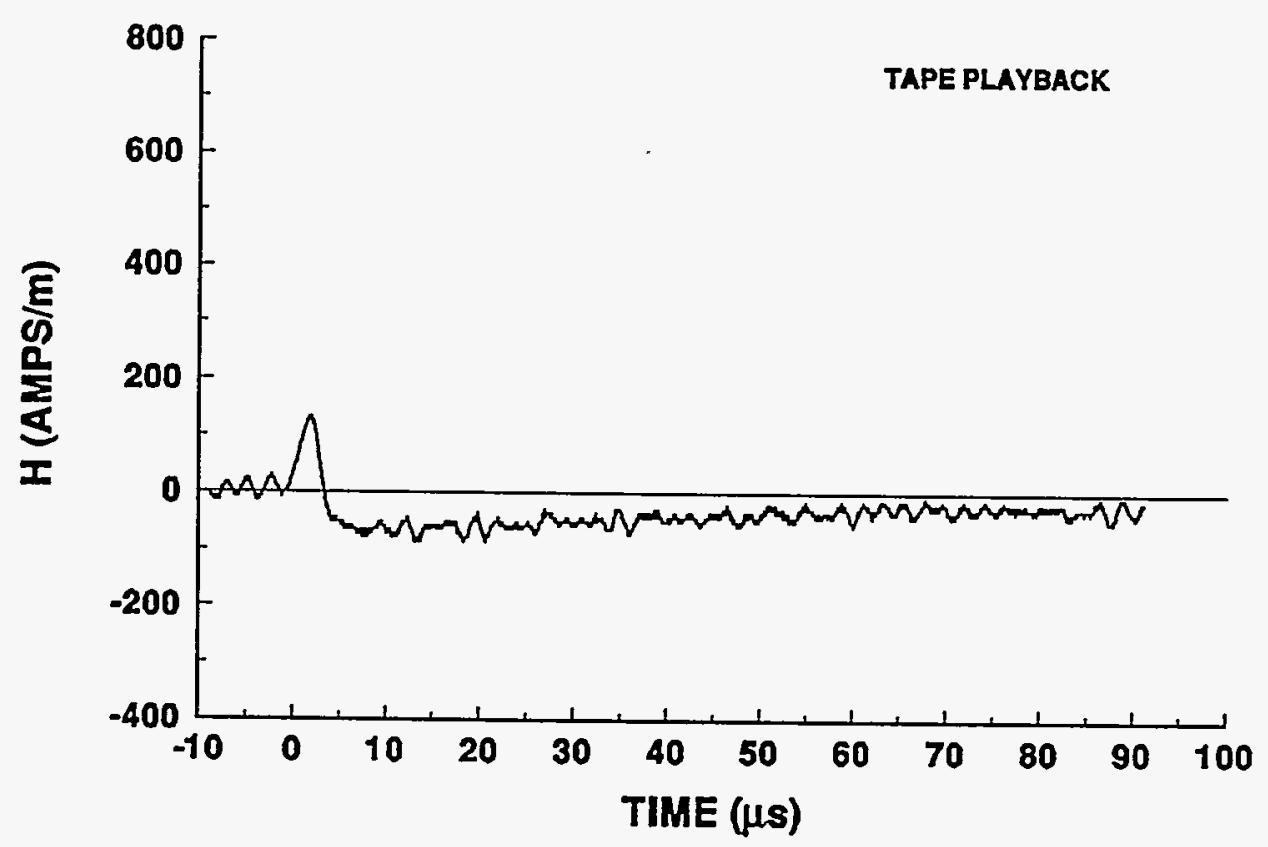

\section{4-09 STROKE 1}

TEST POINT 24

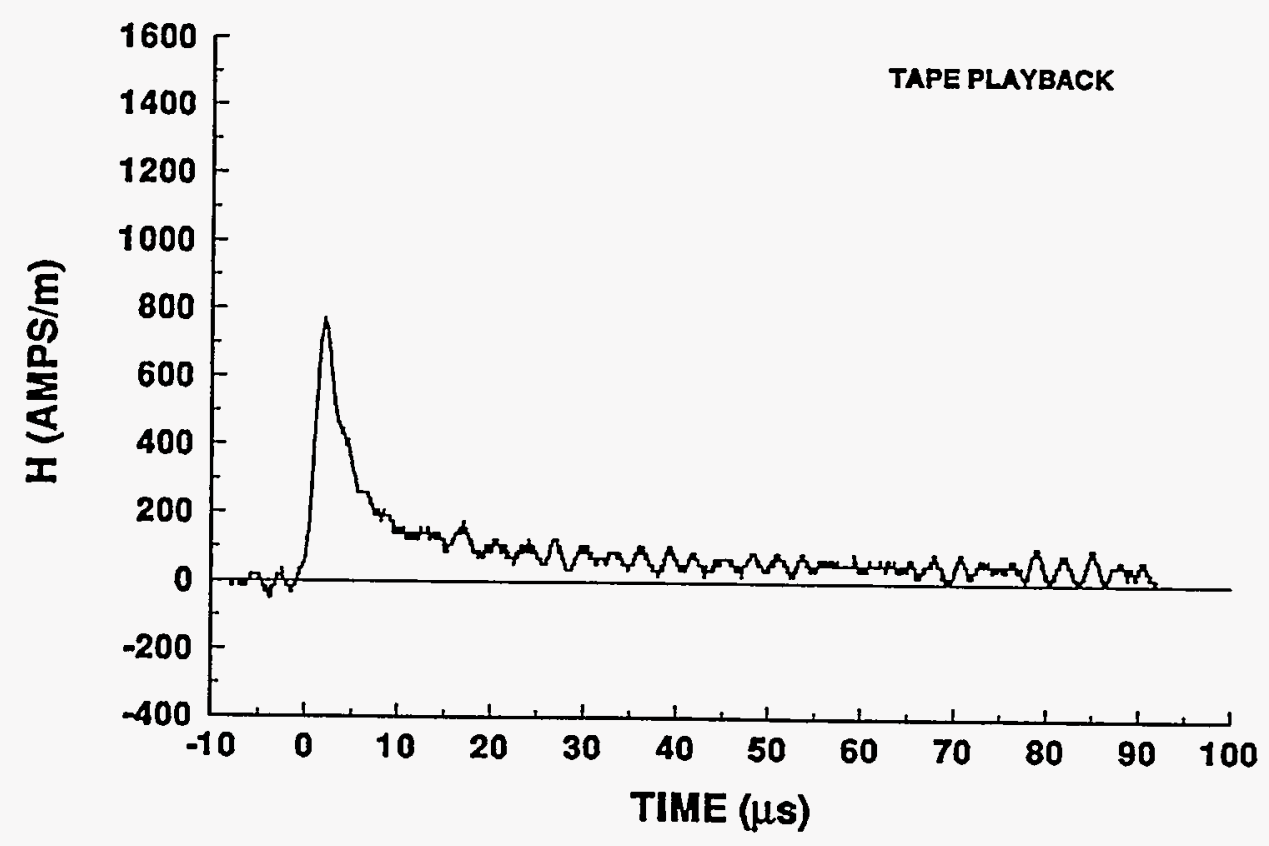




\section{4-09 STROKE 2 \\ INCIDENT CURRENT}
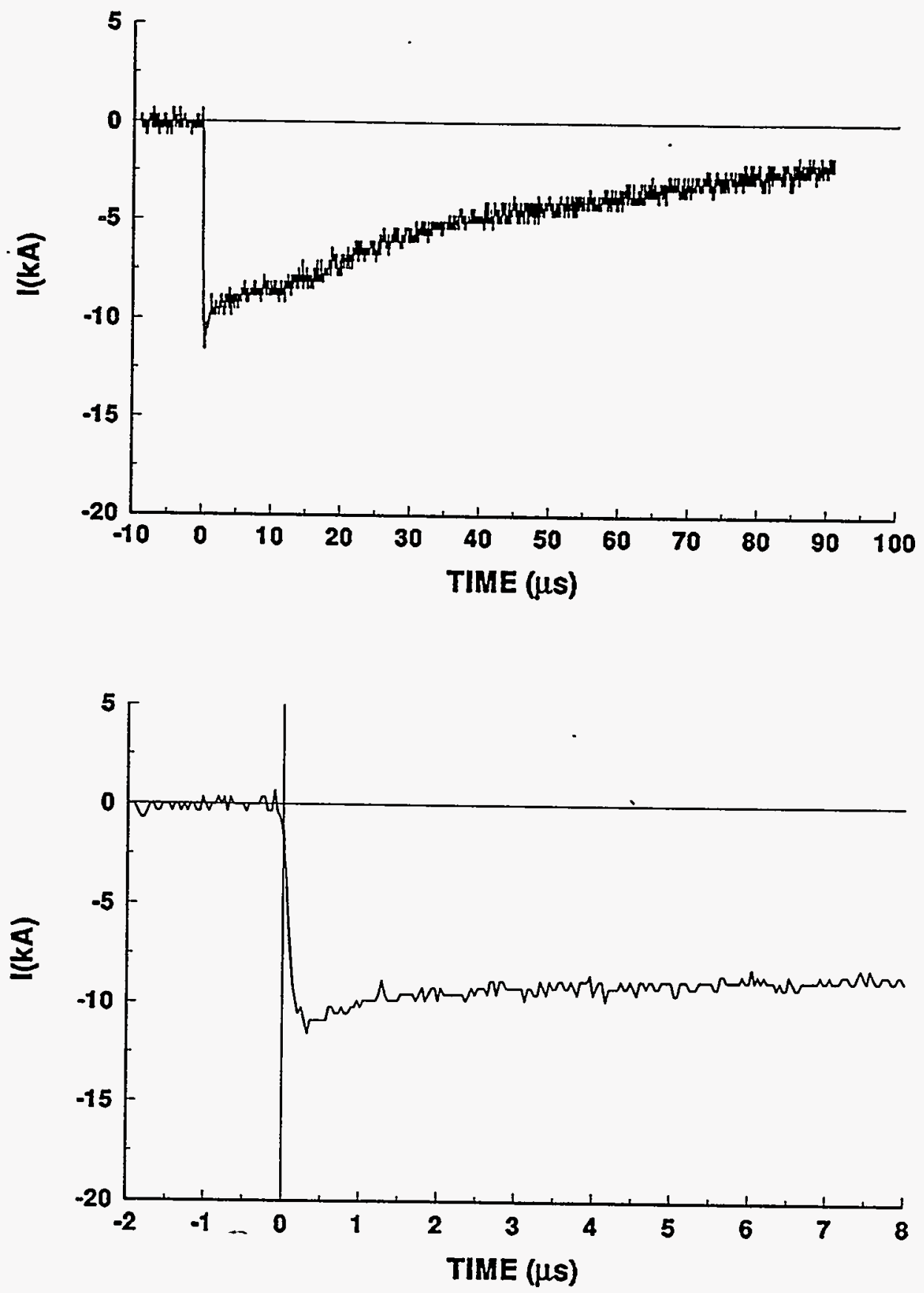


\section{4-09 STROKE 2}

TEST POINT 1

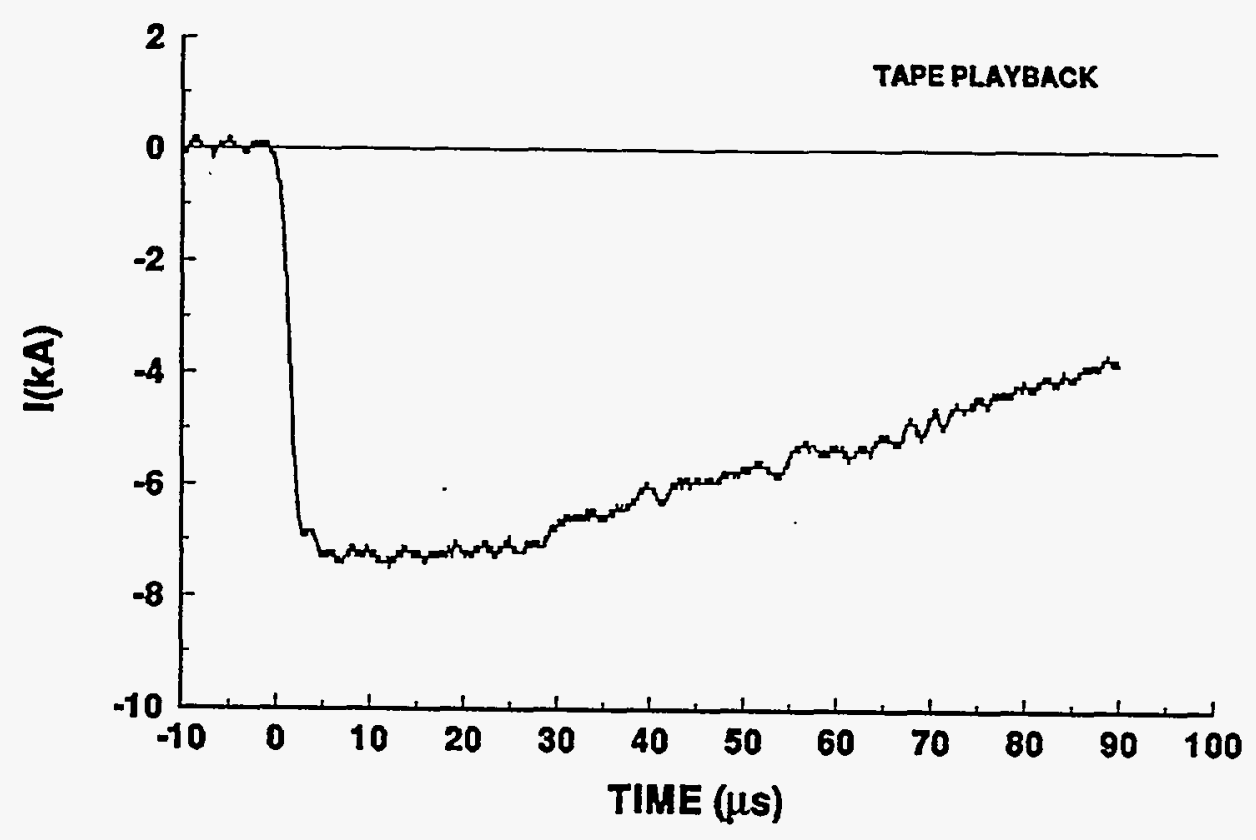

\section{4-09 STROKE 2}
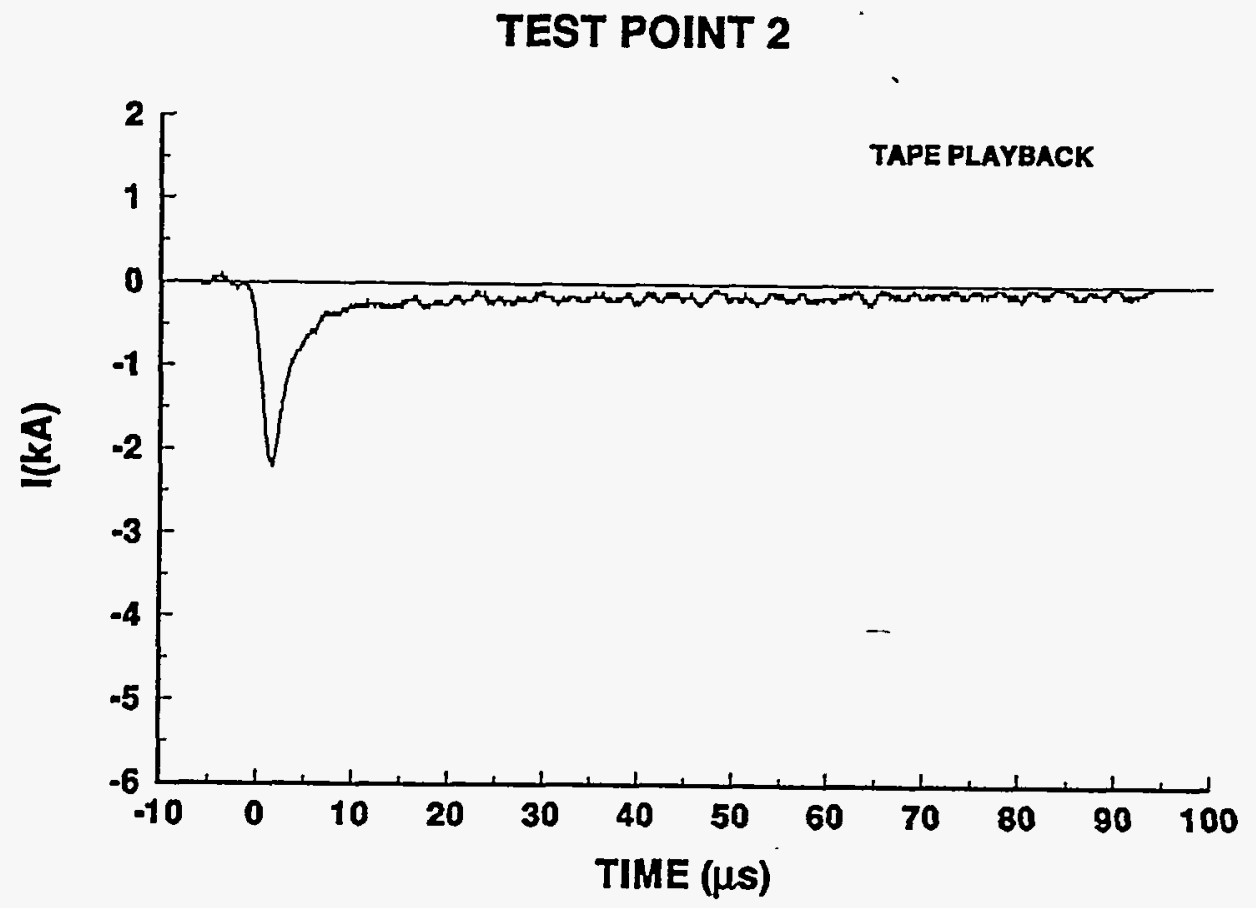
94-09 STROKE 2

TEST POINT 5

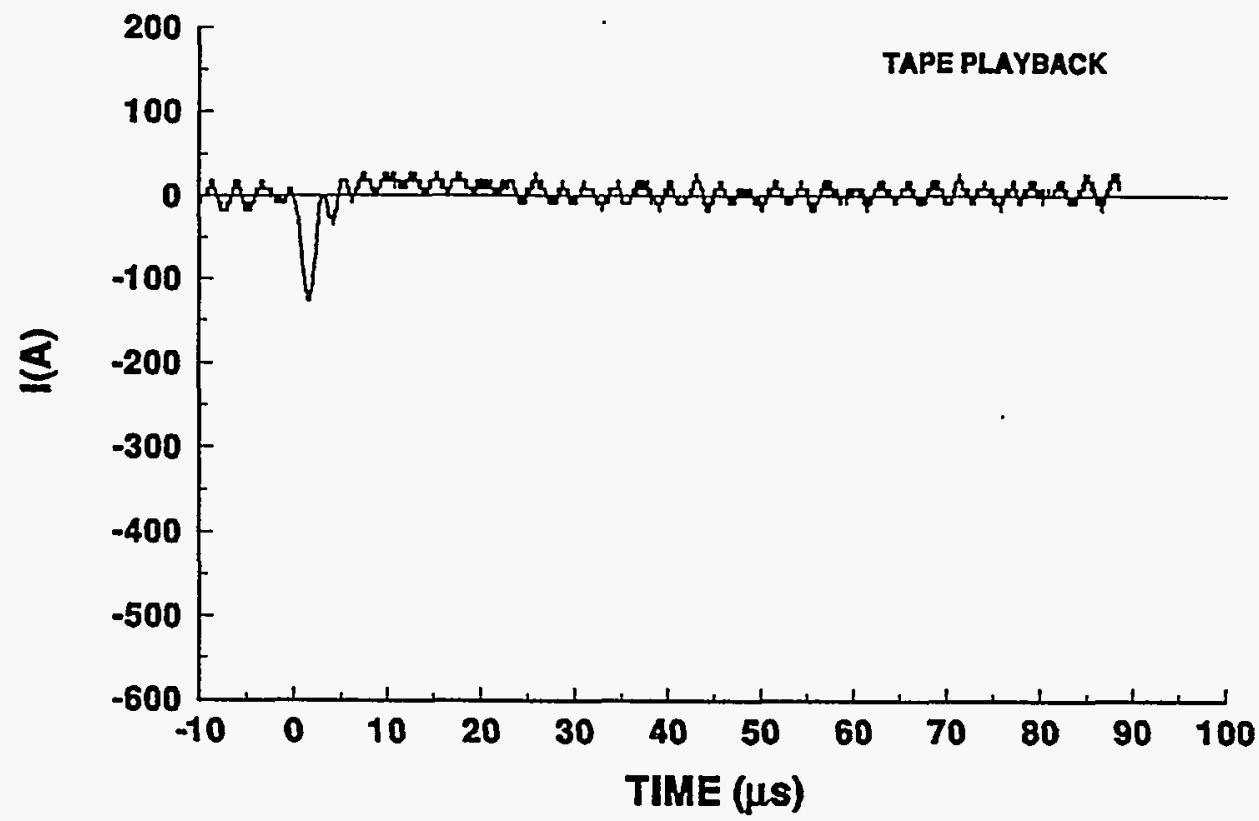

\section{4-09 STROKE 2}

TEST POINT 5'

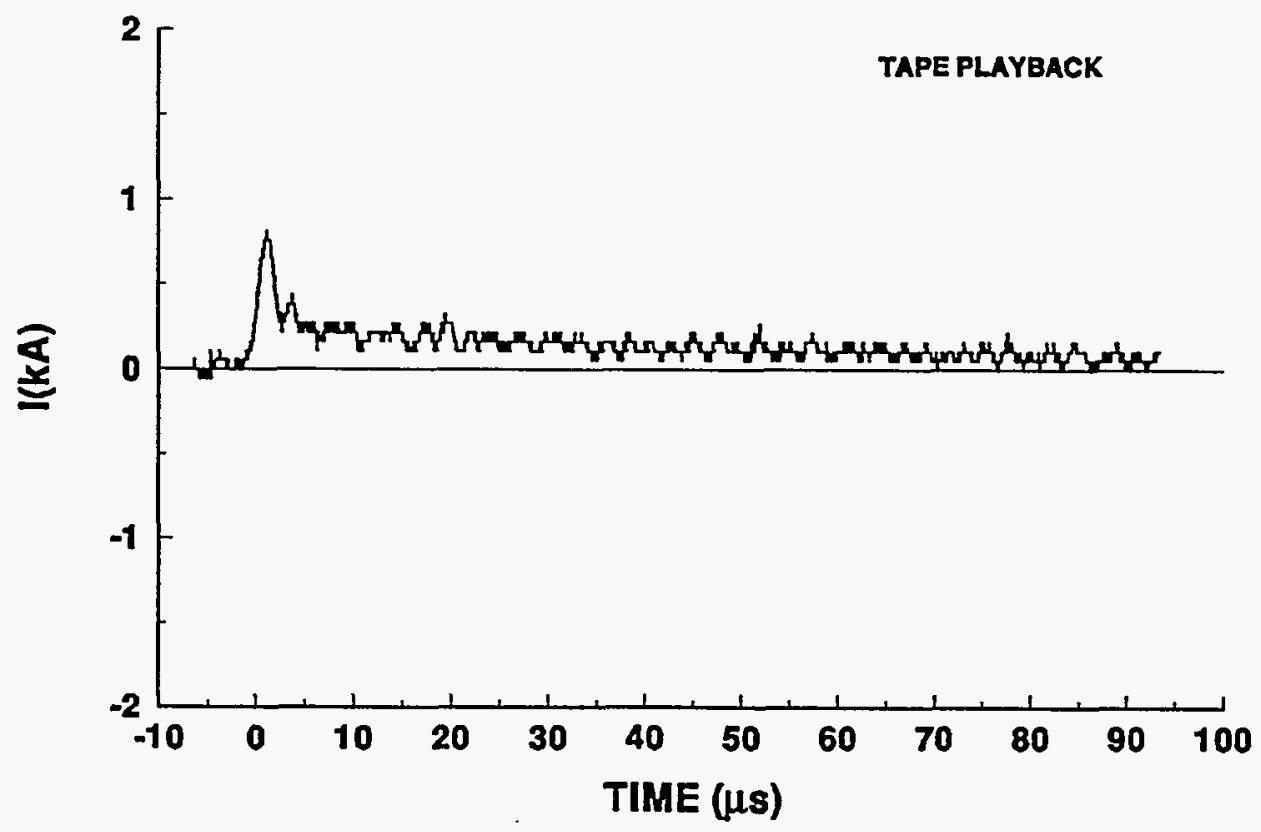




\section{4-09 STROKE 2}

TEST POINT 6

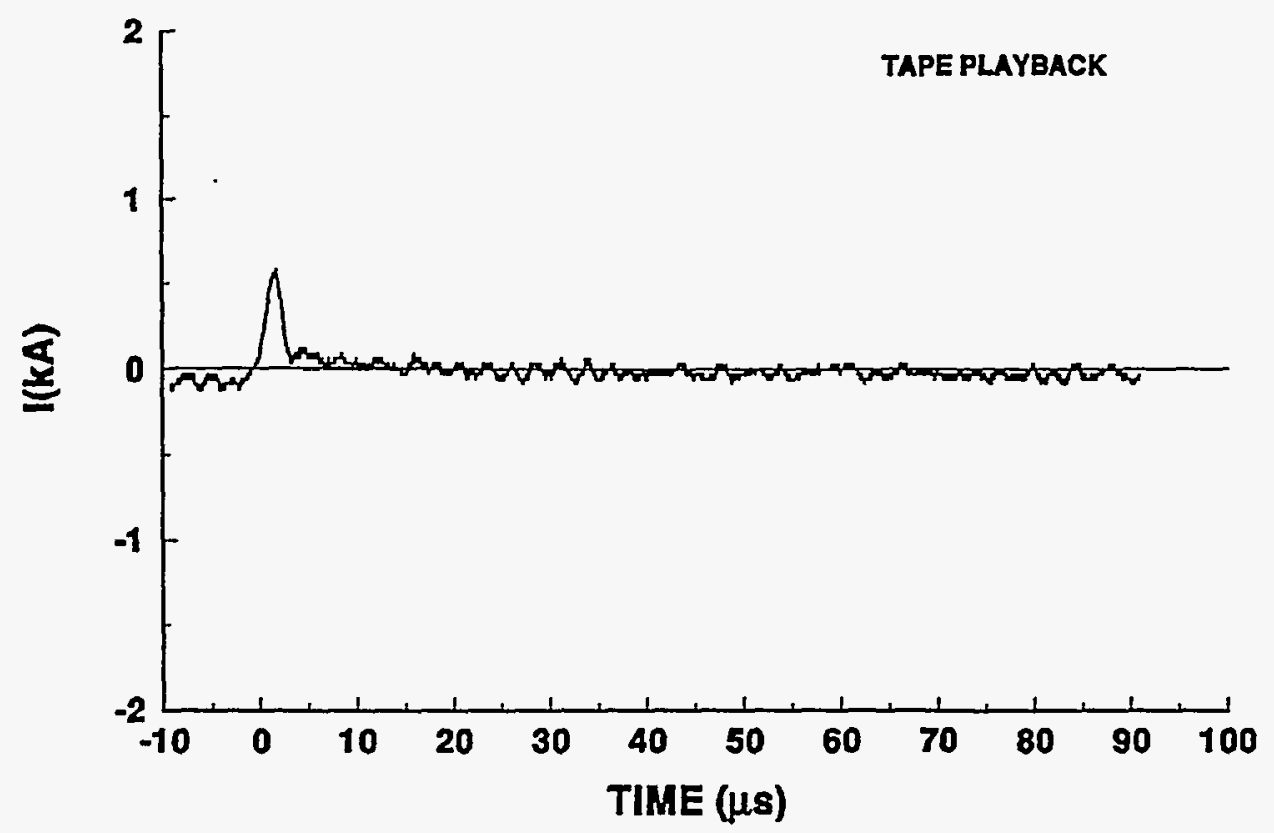

94-09 STROKE 2.

TEST POINT 6'

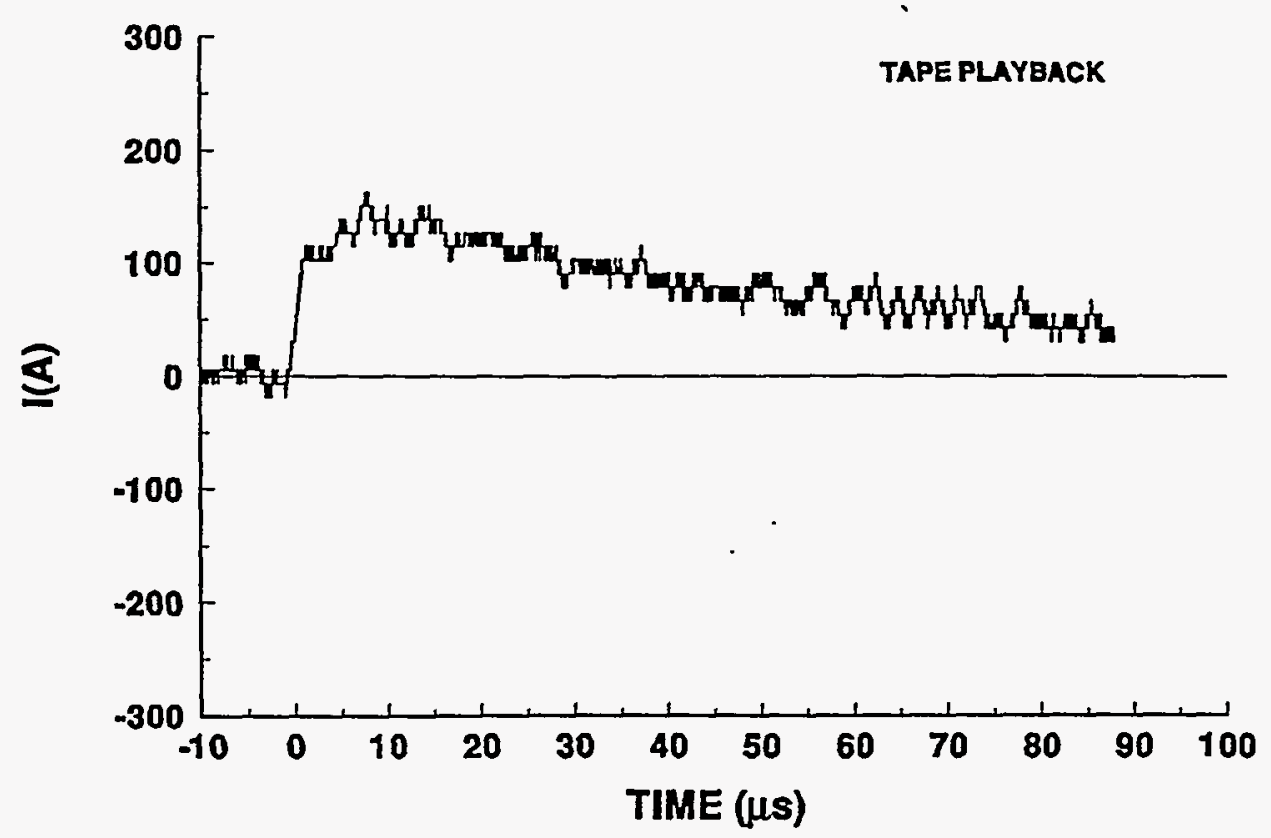




\section{4-09 STROKE 2 \\ TEST POINT 7}
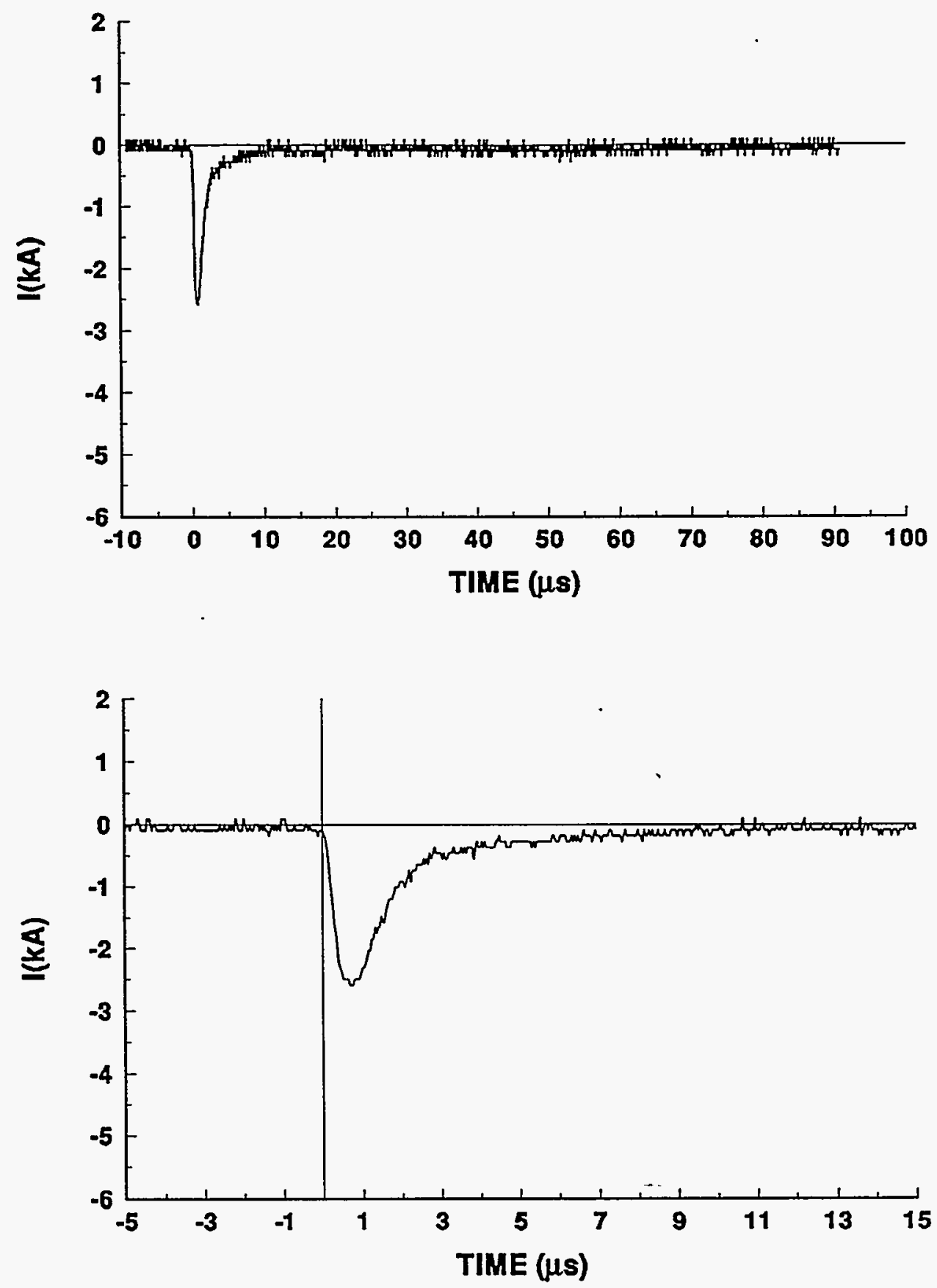


\section{4-09 STROKE 2}

TEST POINT 8
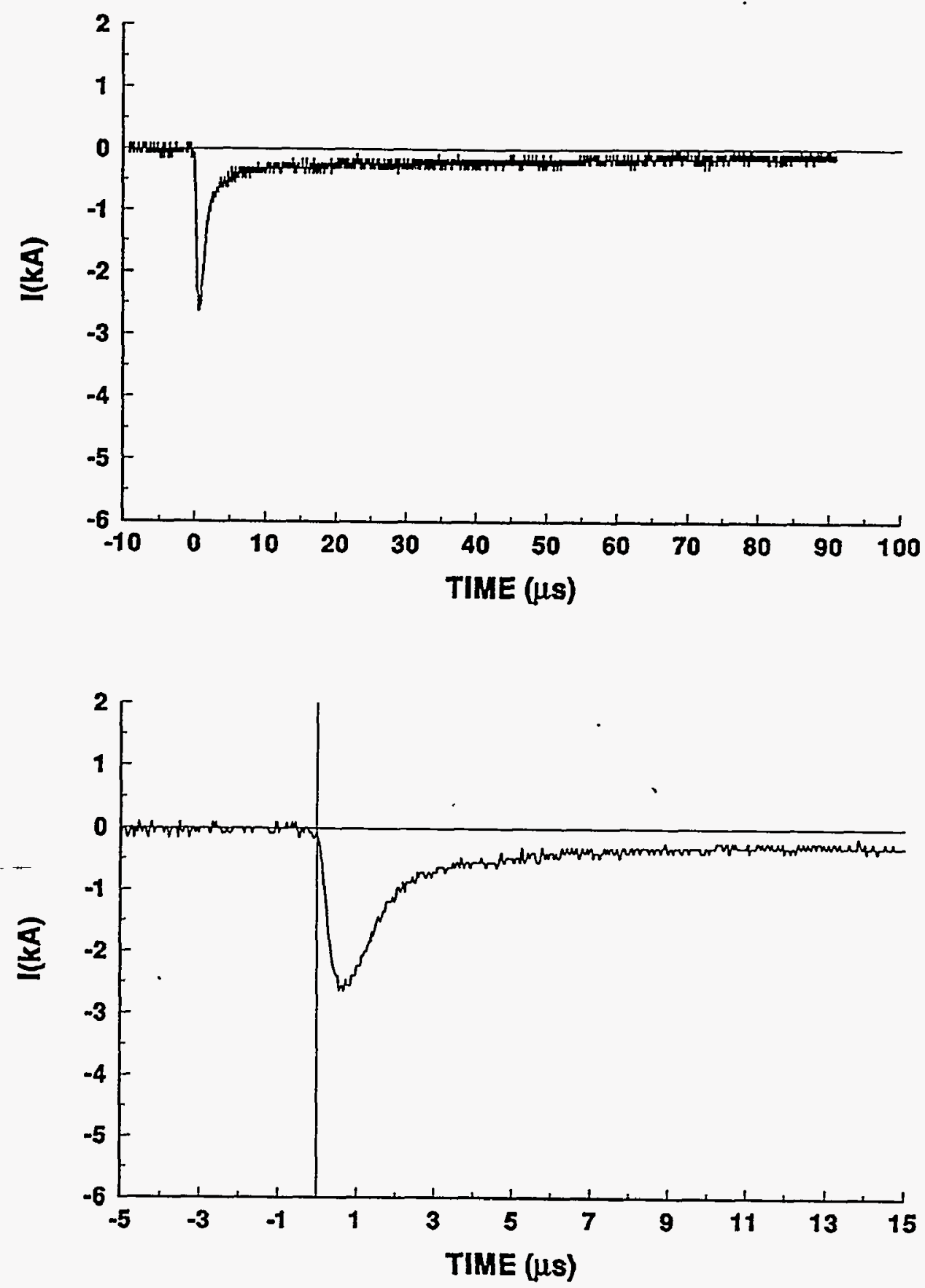


\section{4-09 STROKE 2}

TEST POINT 16

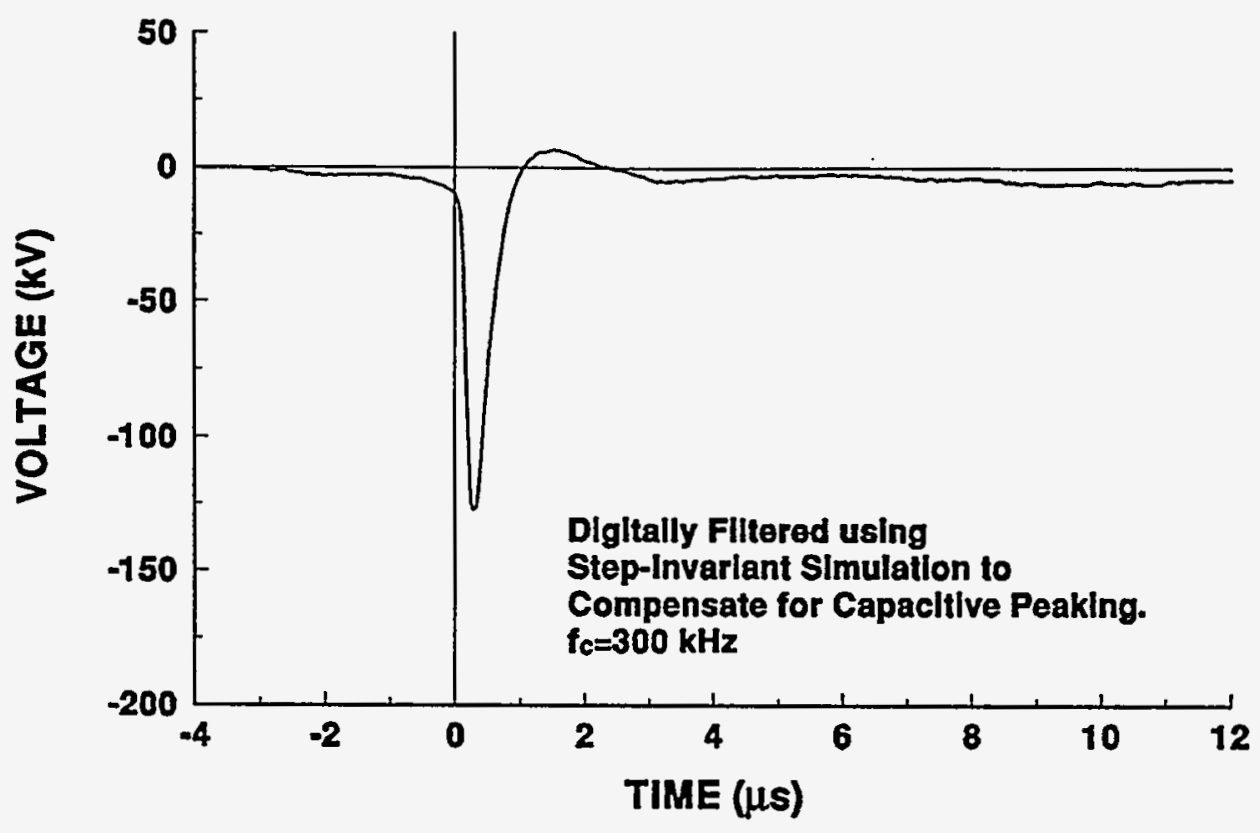

94-09 STROKE 2

TEST POINT 17

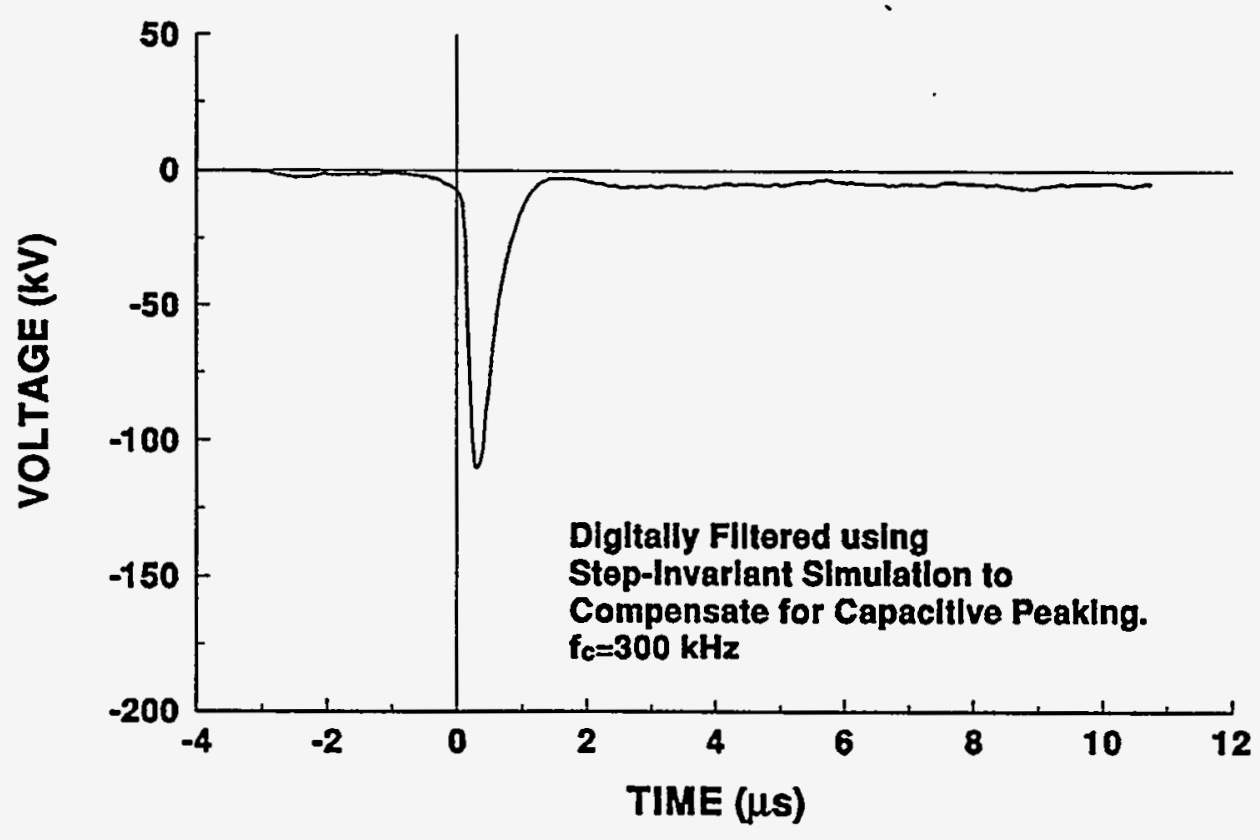




\section{4-09 STROKE 2}

TEST POINT 18

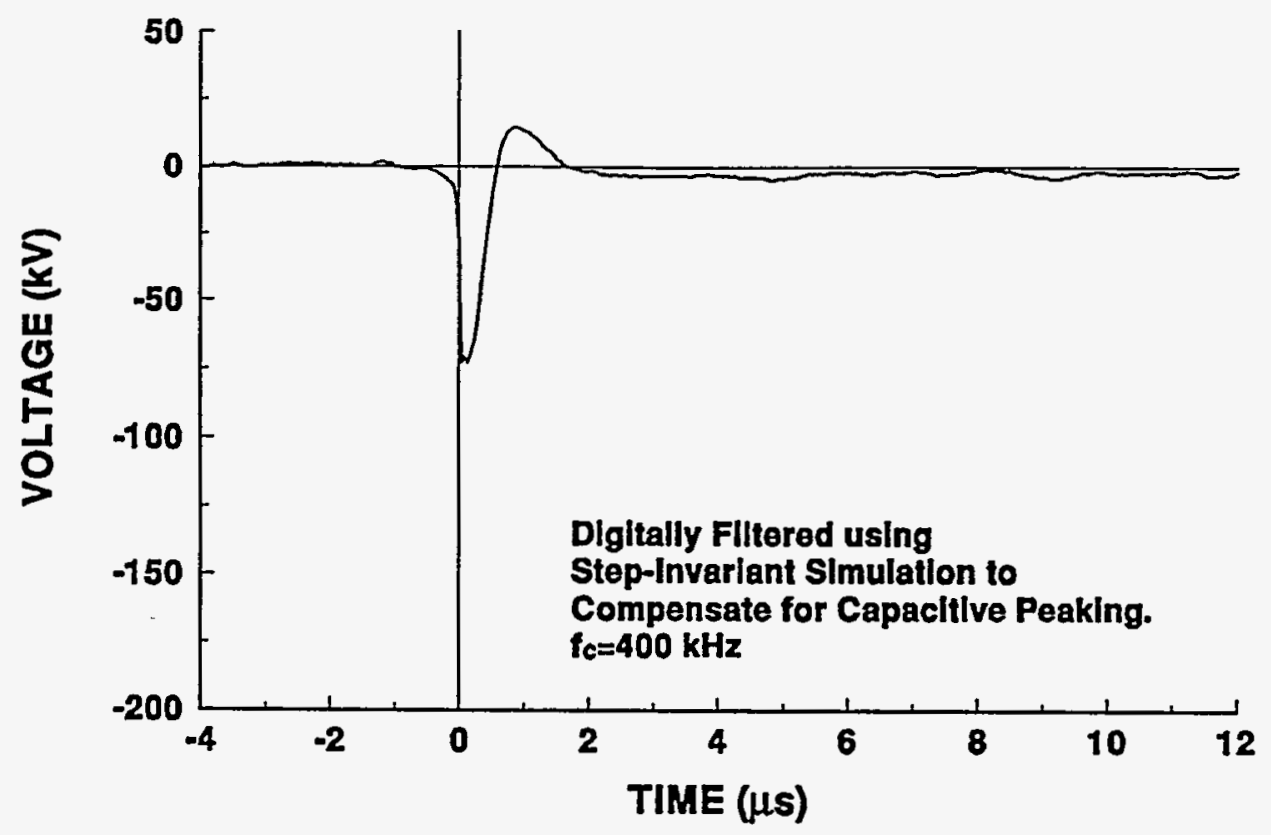

\section{4-09 STROKE 2}

TEST POINT 19

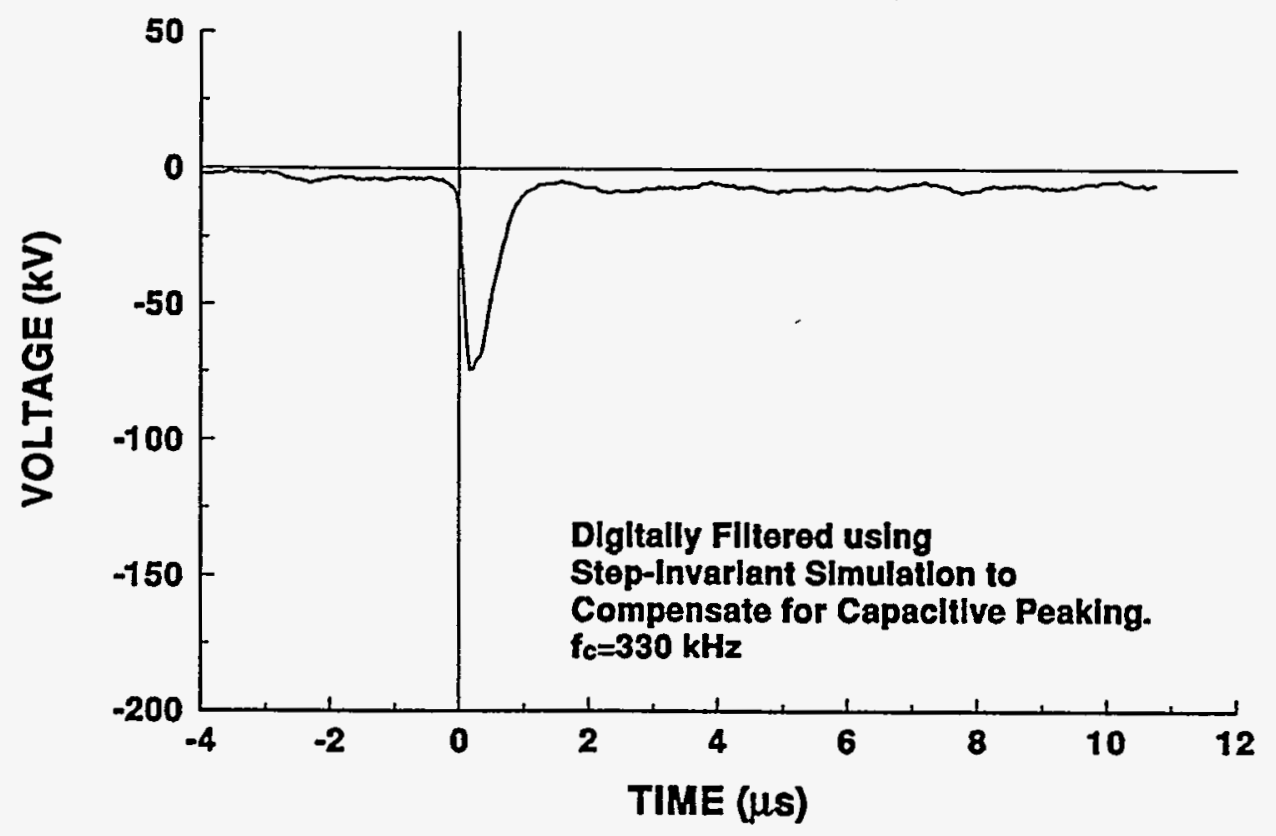




\section{4-07 STROKE 2}

TEST POINT 20

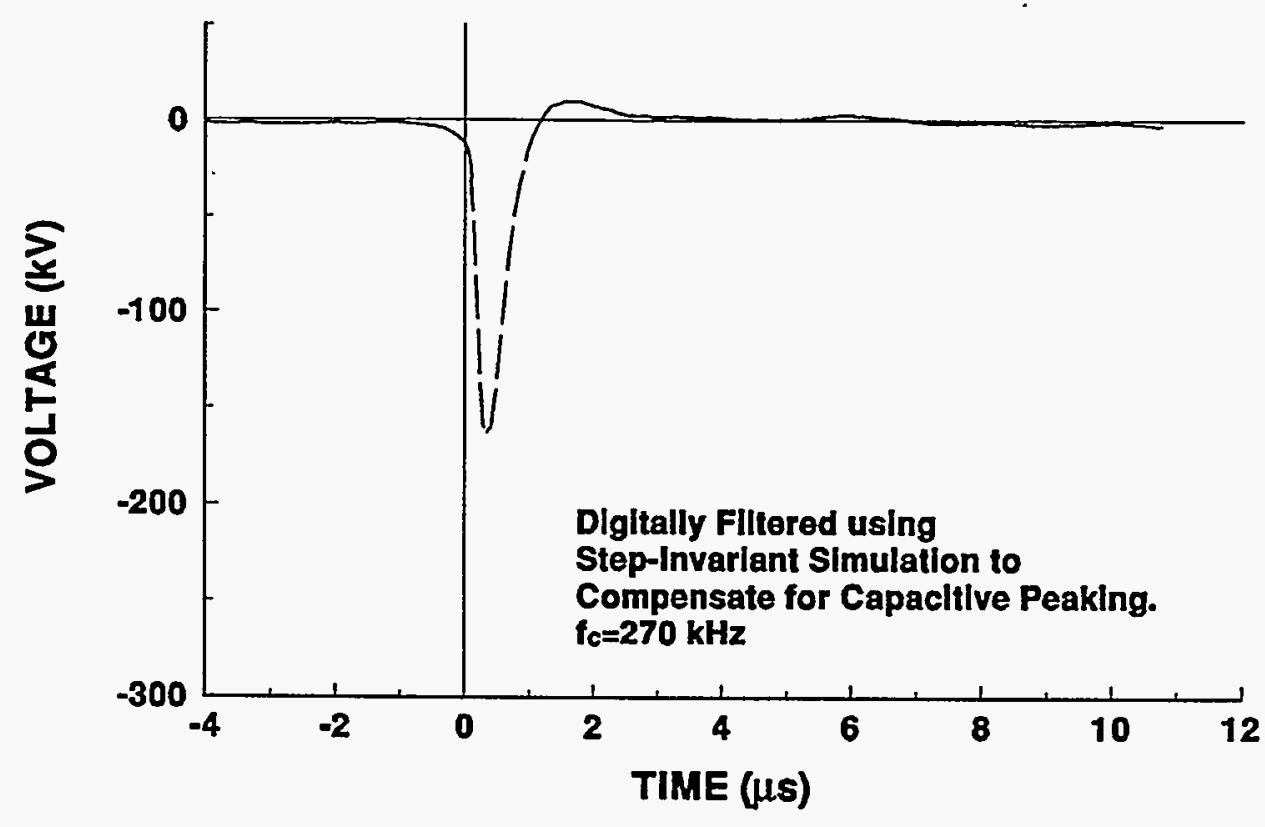

\section{4-07 STROKE 2}

TEST POINT 22

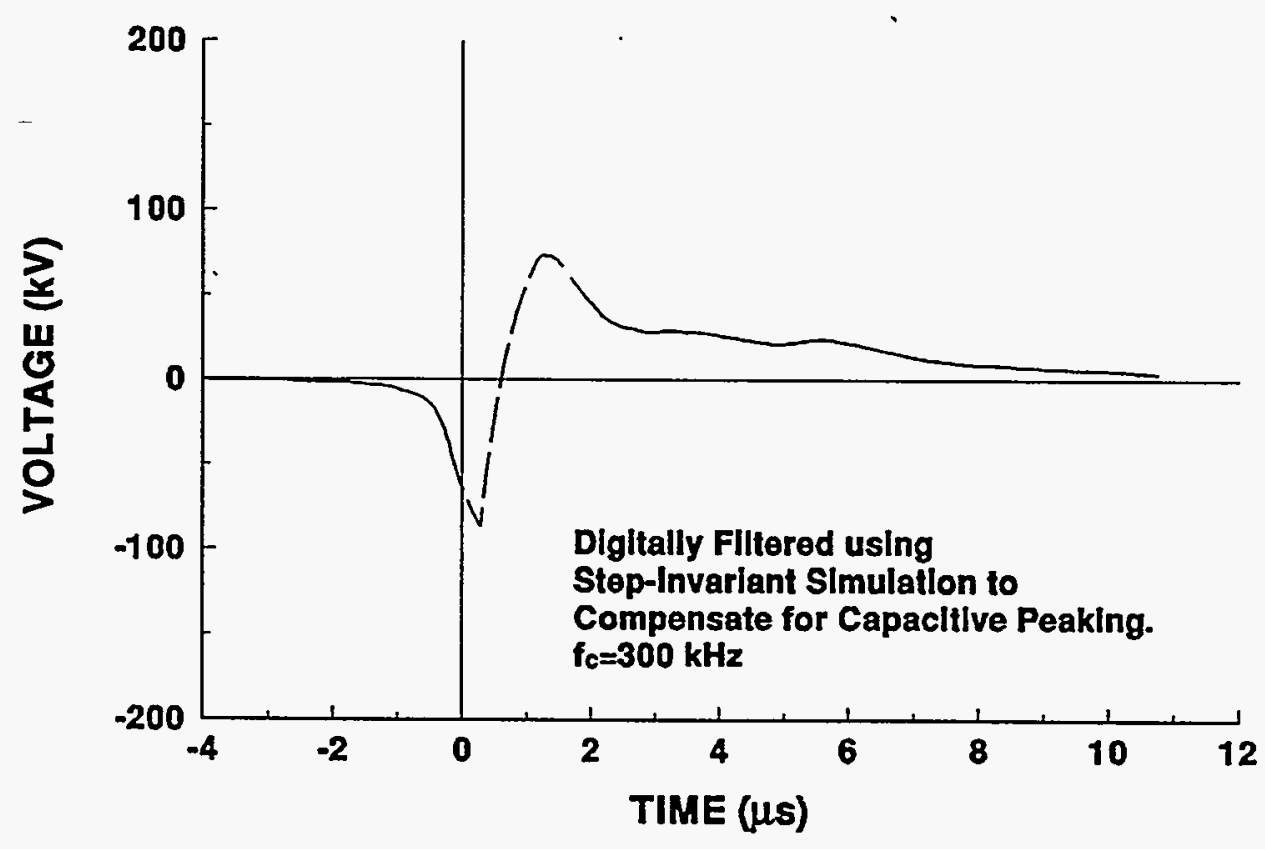




\section{4-09 STROKE 2}

\section{TEST POINT 23}

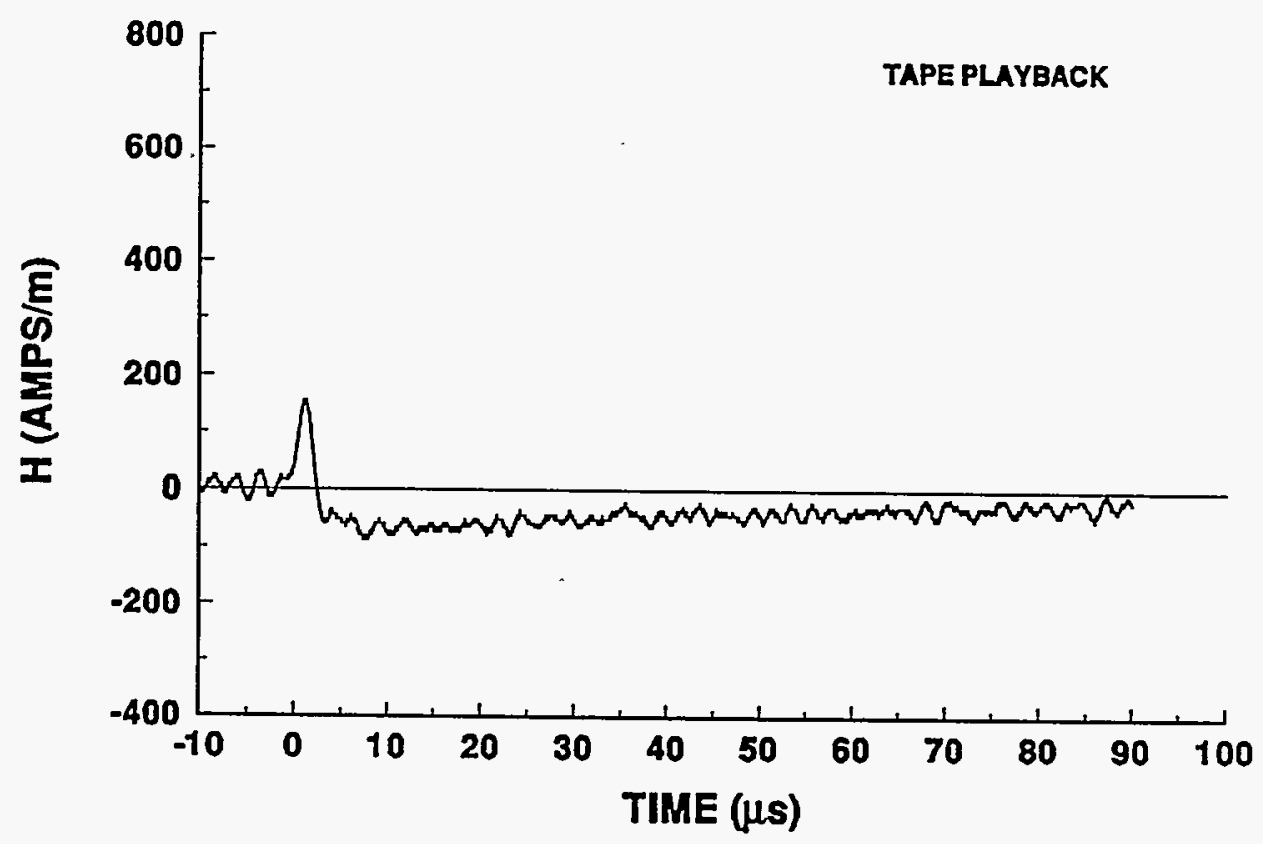

94-09 STROKE 2

TEST POINT 24

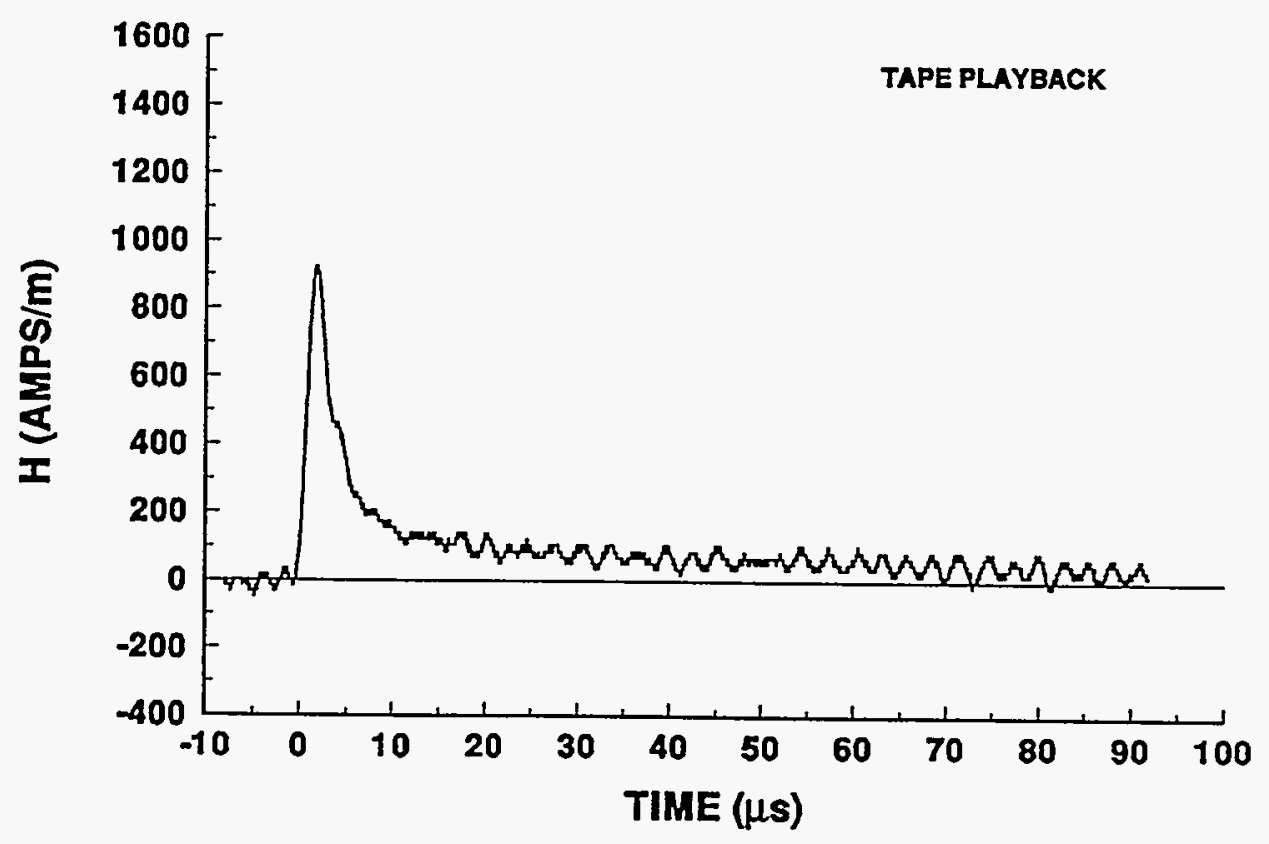




\section{4-10 STROKE 1 \\ INCIDENT CURRENT}
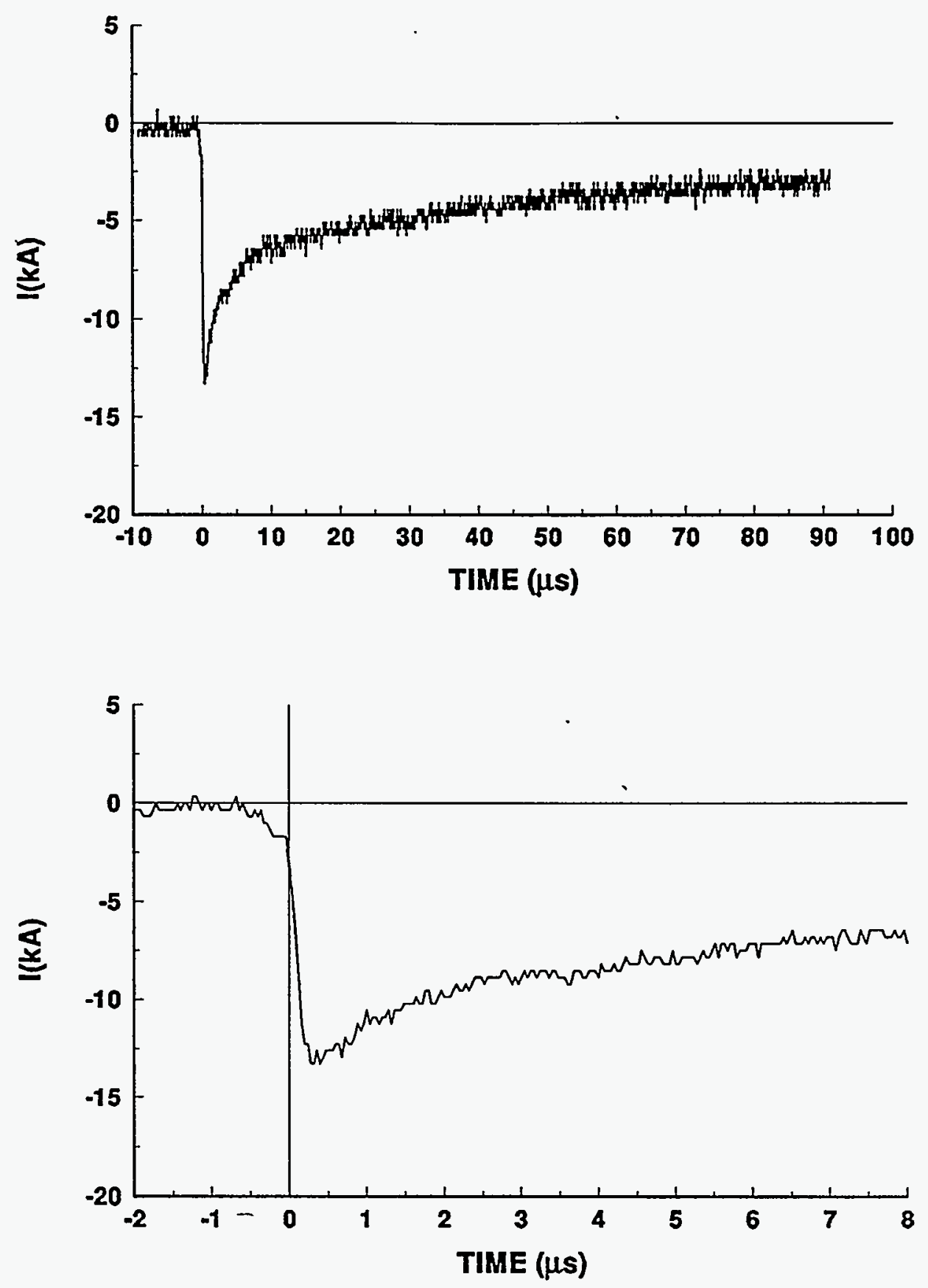


\section{4-10 STROKE 1}

TEST POINT 1

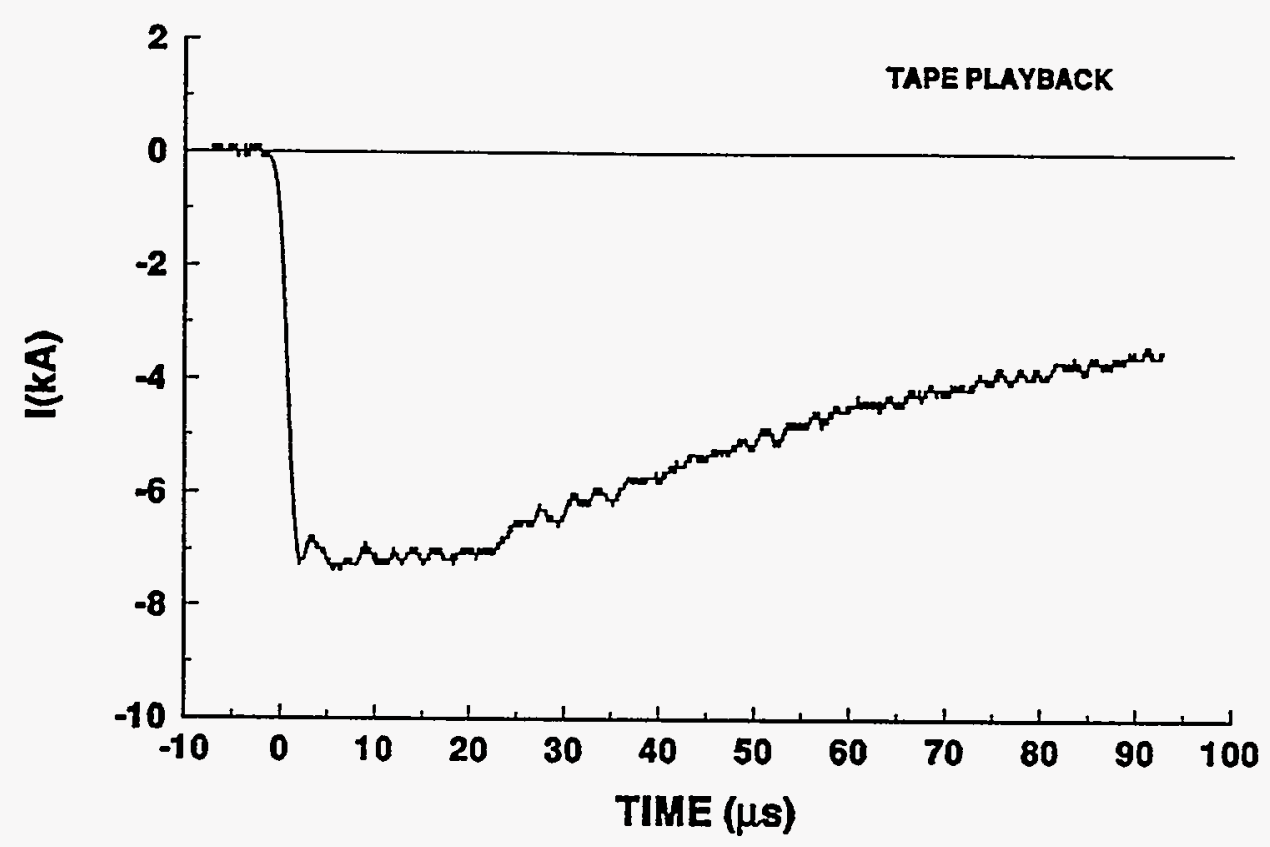

\section{4-10 STROKE.1}

\section{TEST POINT 2}

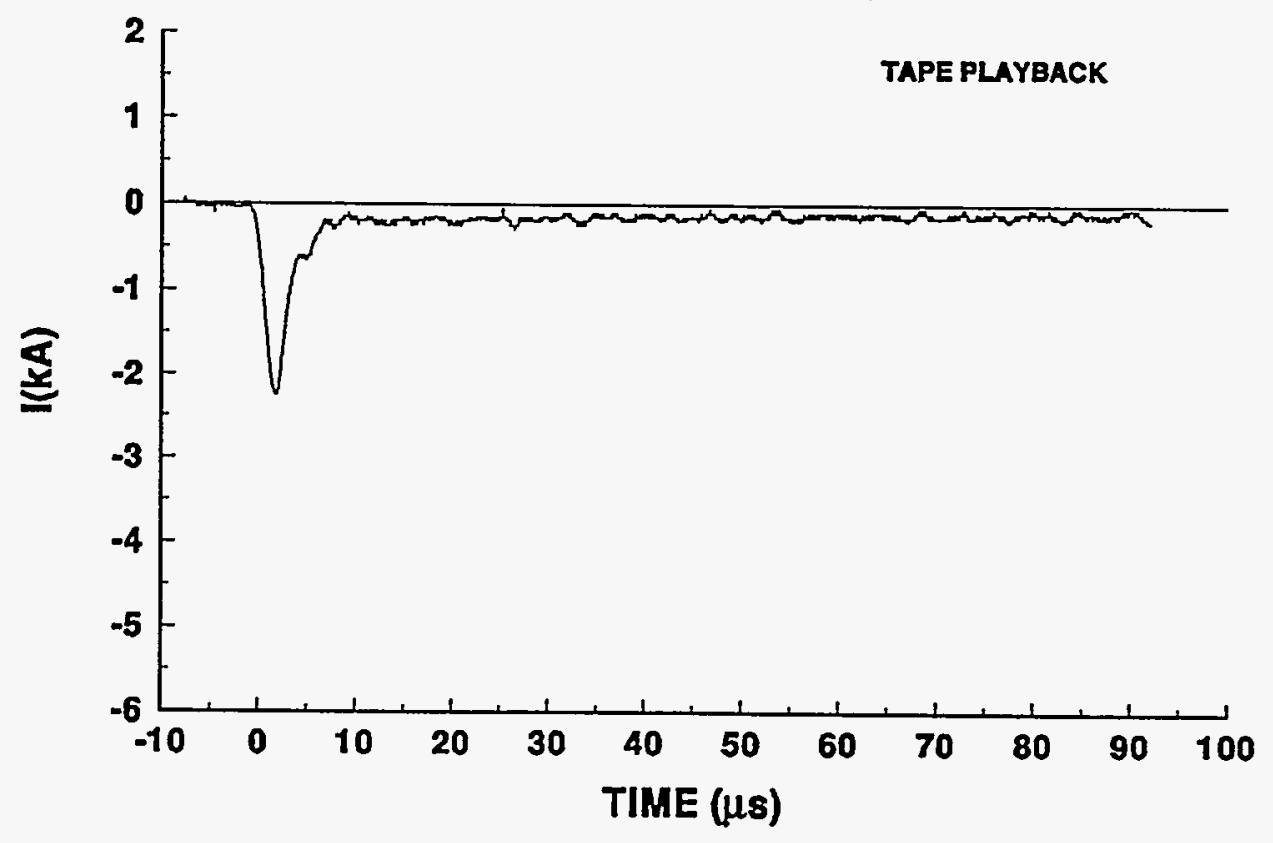


94-10 STROKE 1

TEST POINT 5

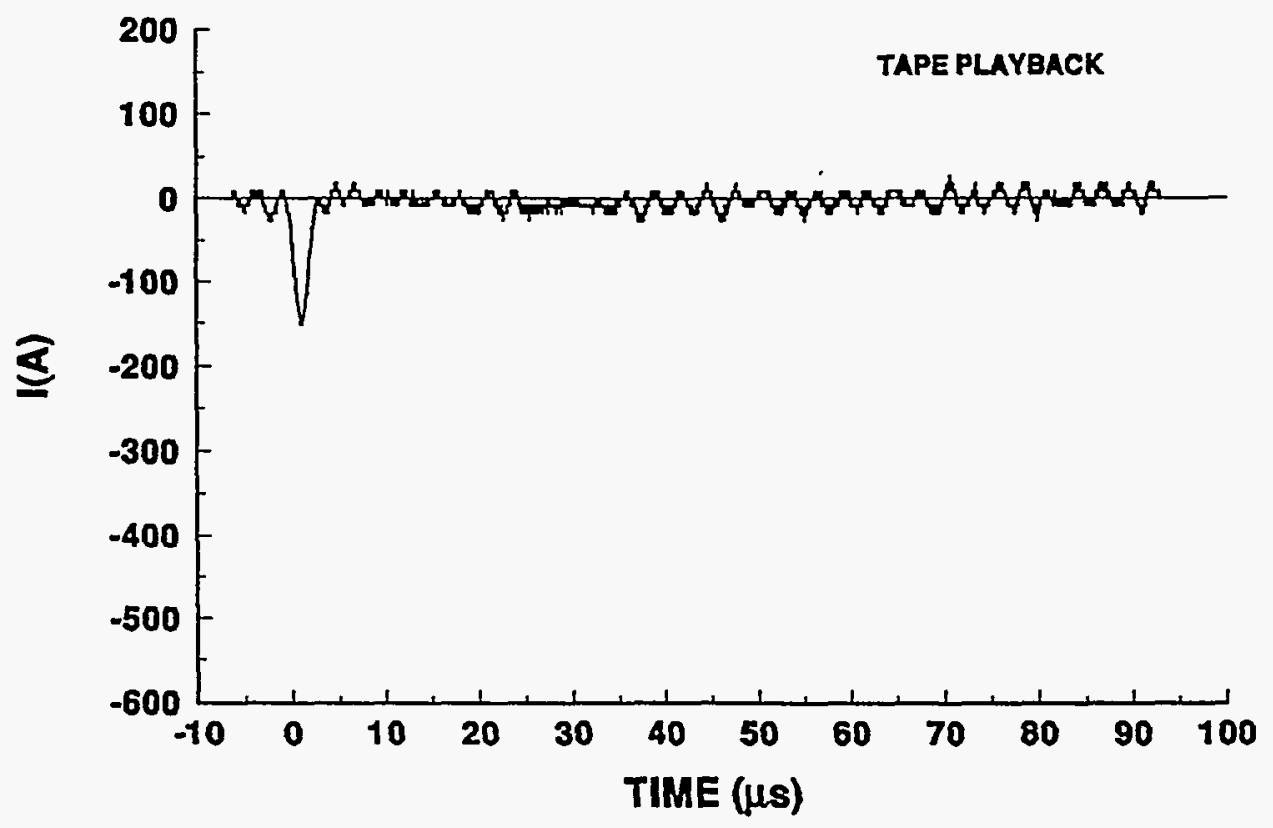

\section{4-10 STROKE 1}

TEST POINT 5'

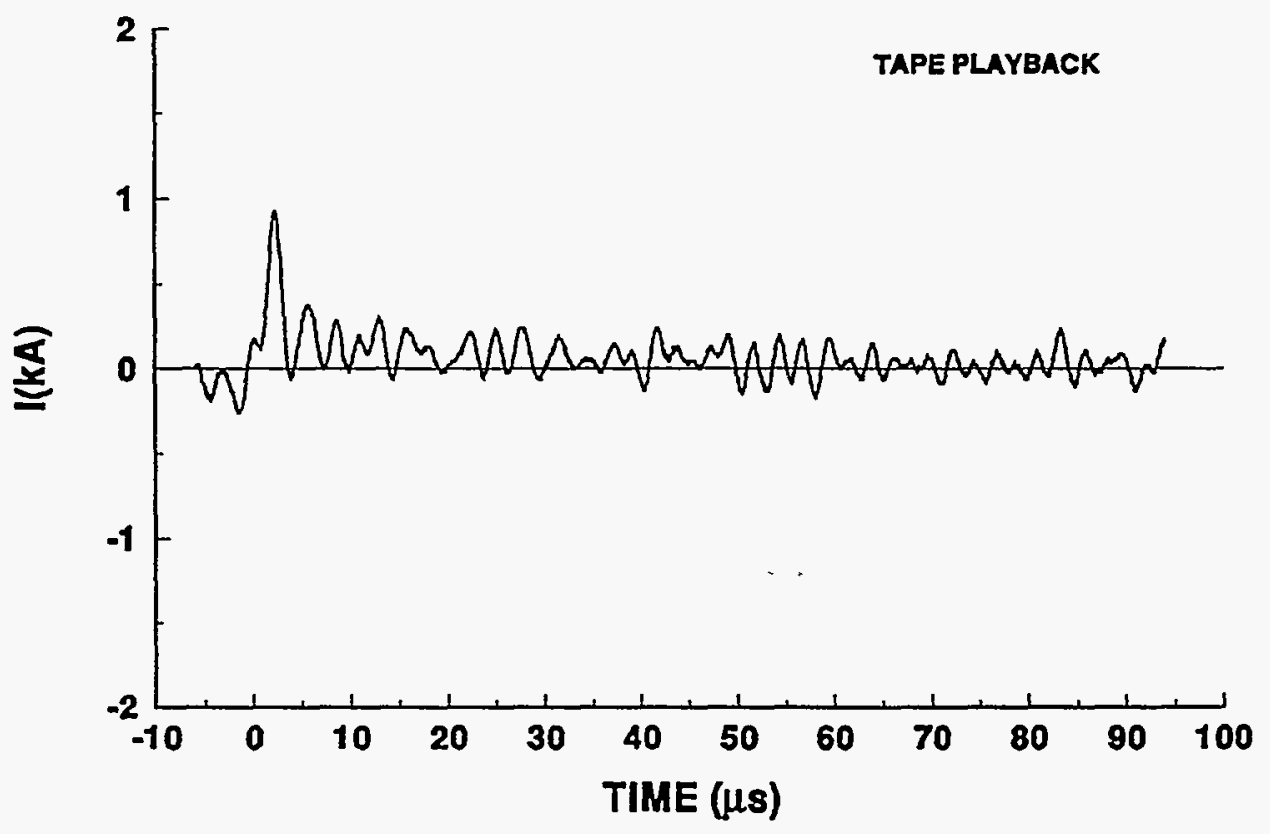




\section{4-10 STROKE 1}

TEST POINT 6

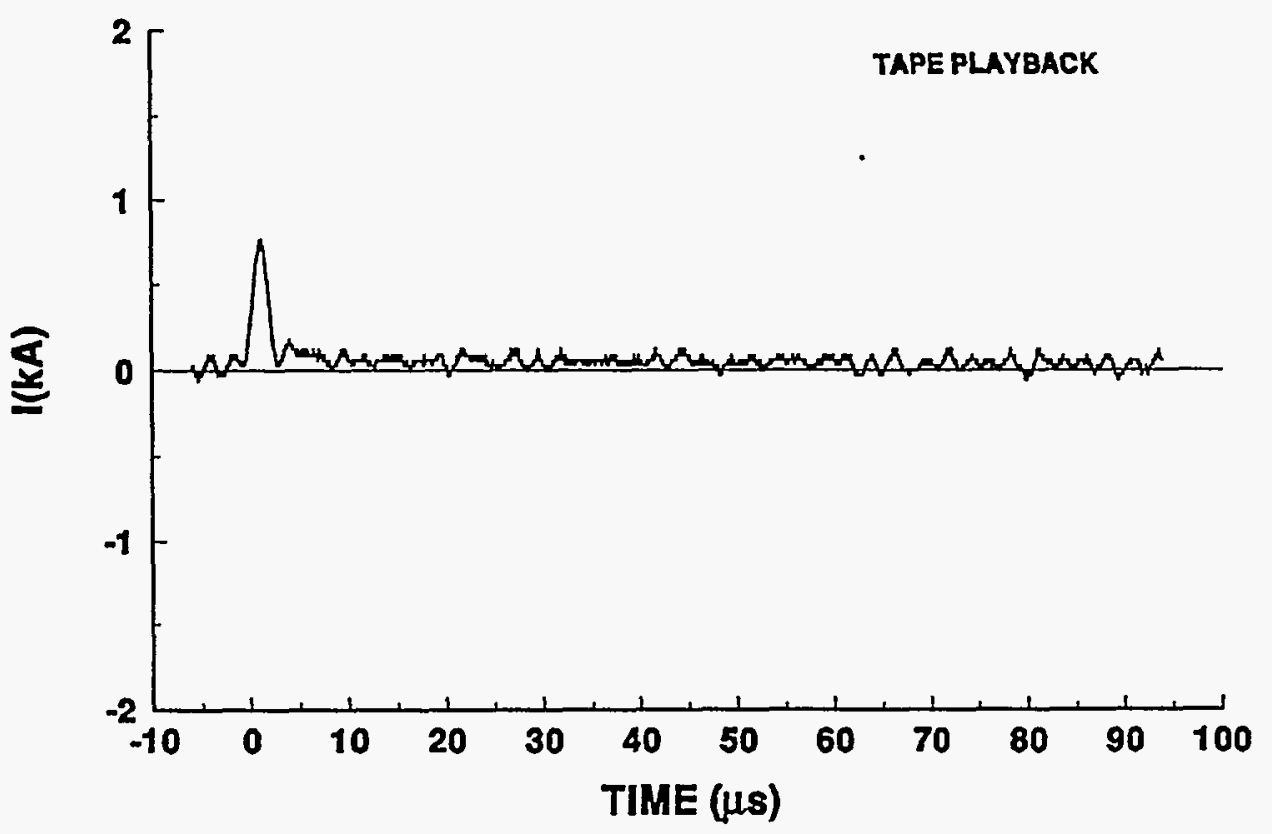

94-10 STROKE.1

TEST POINT 6'

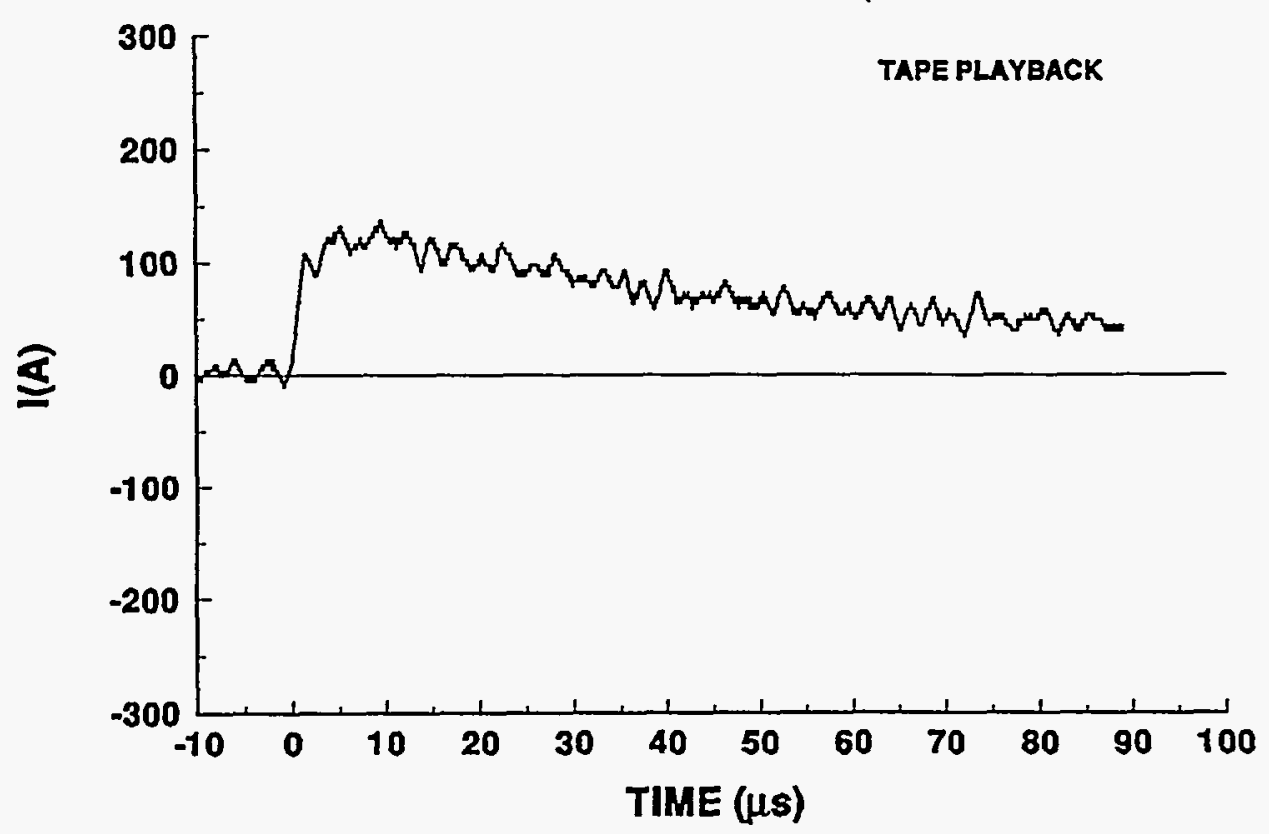




\section{4-10 STROKE 1}

\section{TEST POINT 7}
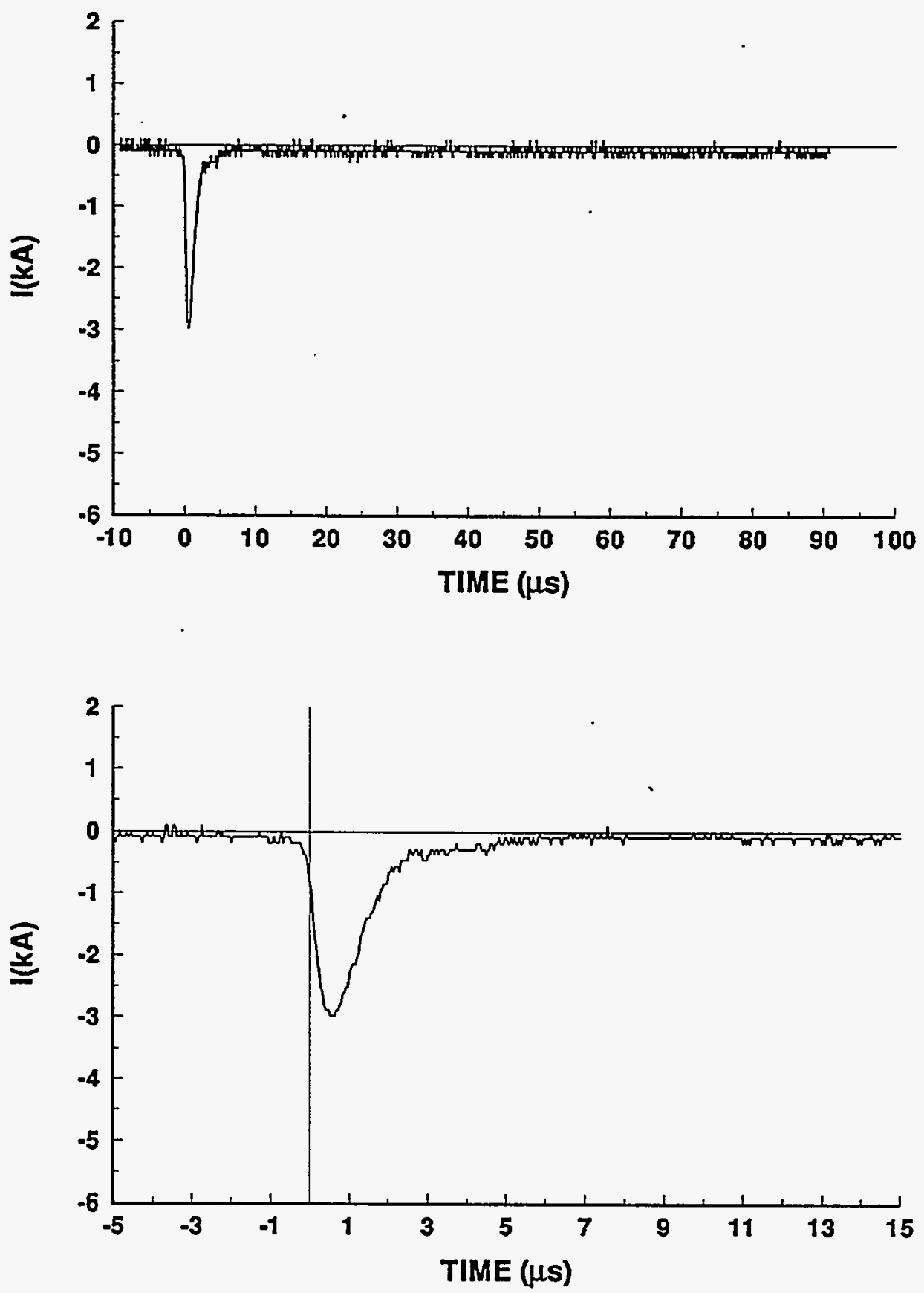


\section{4-10 STROKE 1}

\section{TEST POINT 8}
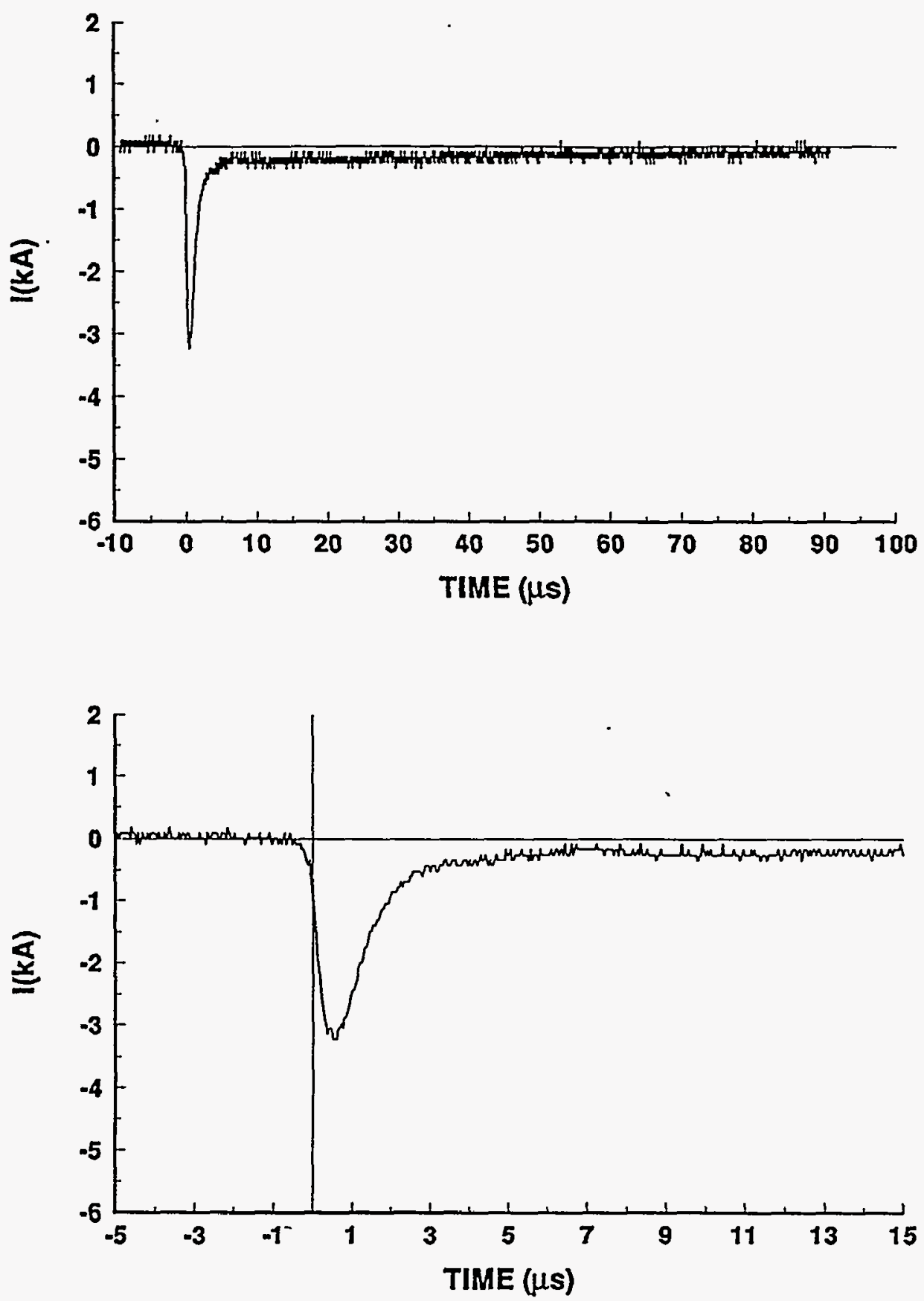


\section{4-10 STROKE 1}

TEST POINT 16

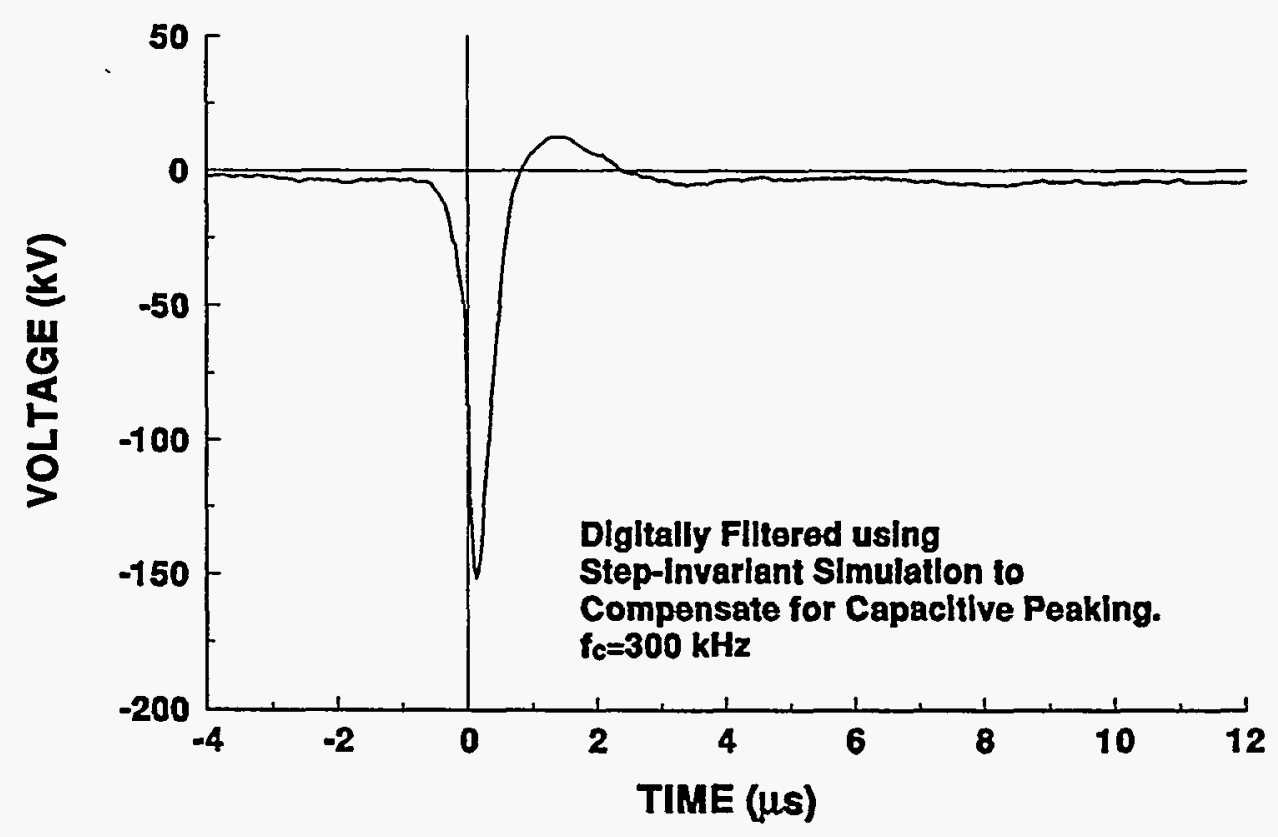

94-10 STROKE 1

TEST POINT 17

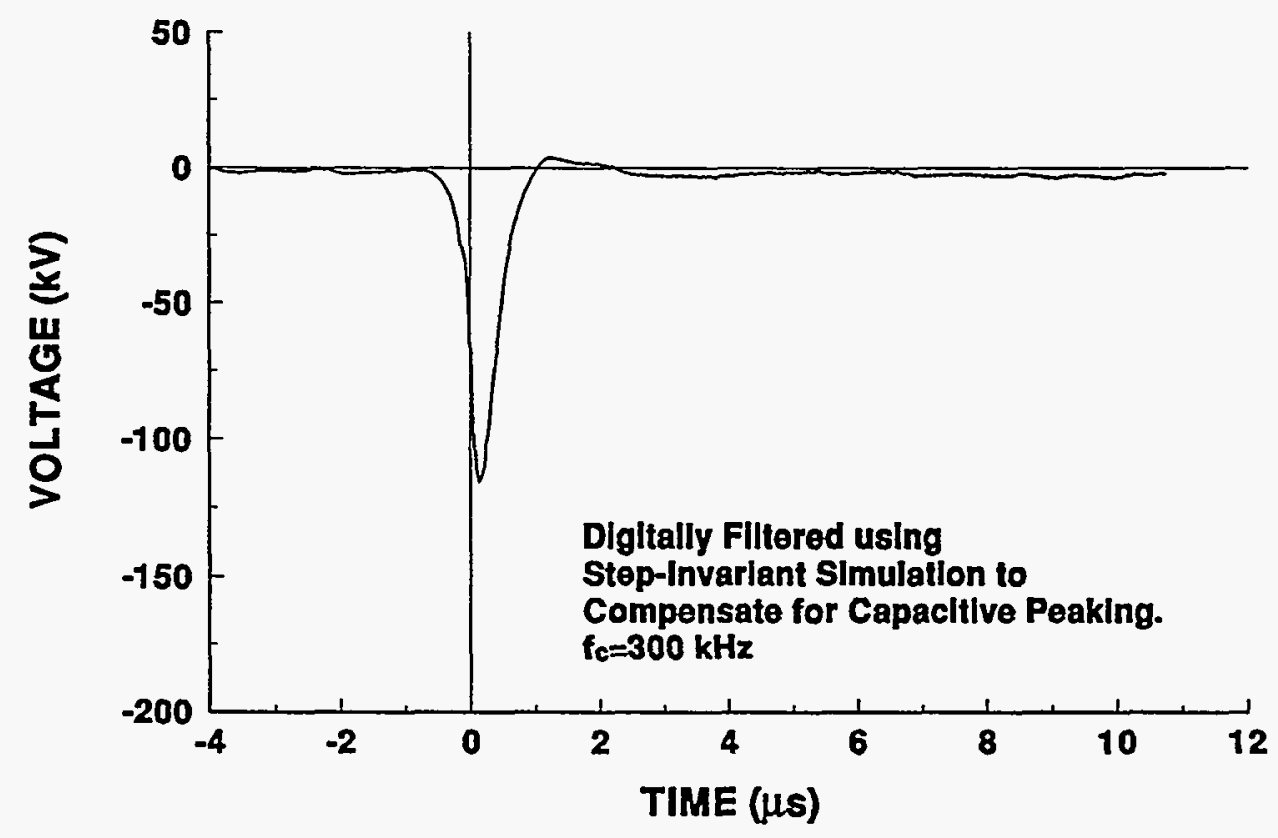




\section{4-10 STROKE 1}

TEST POINT 18

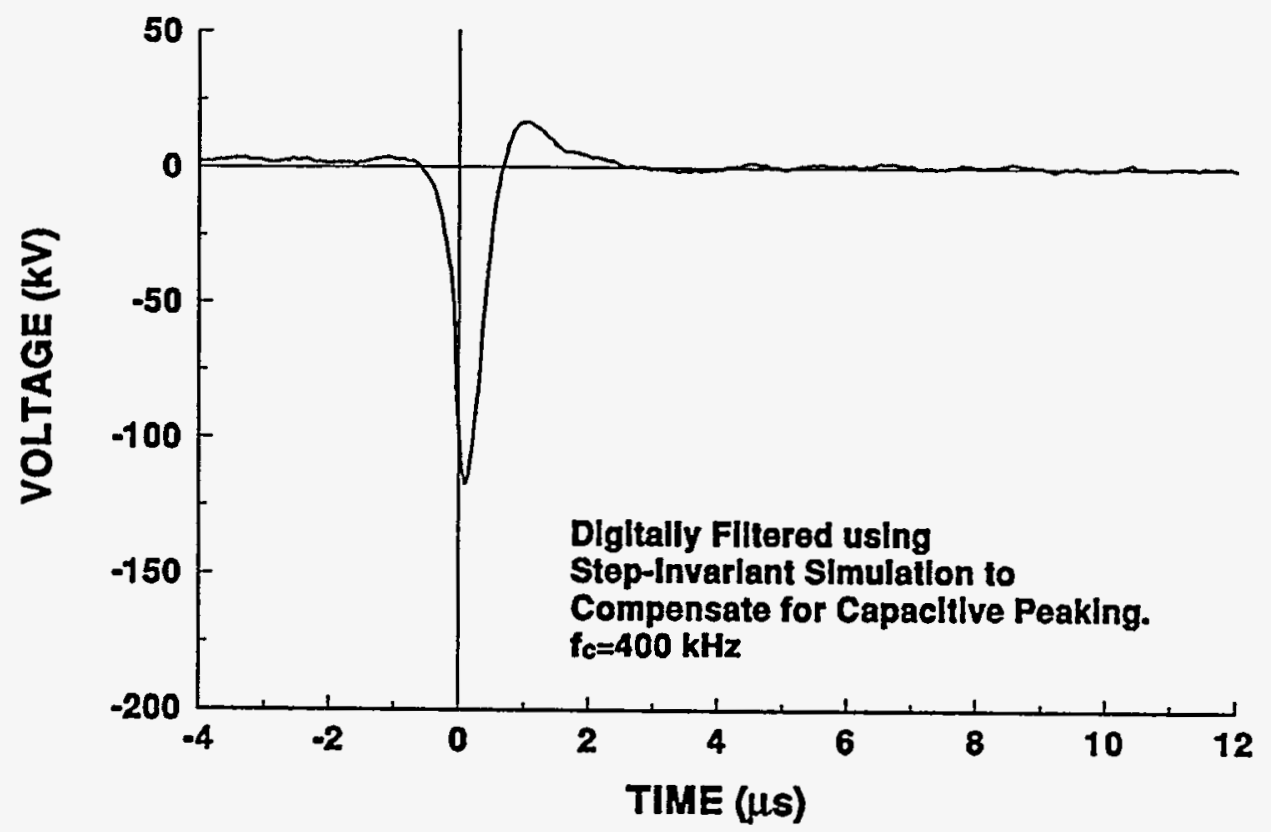

94-10 STROKE 1

TEST POINT 19

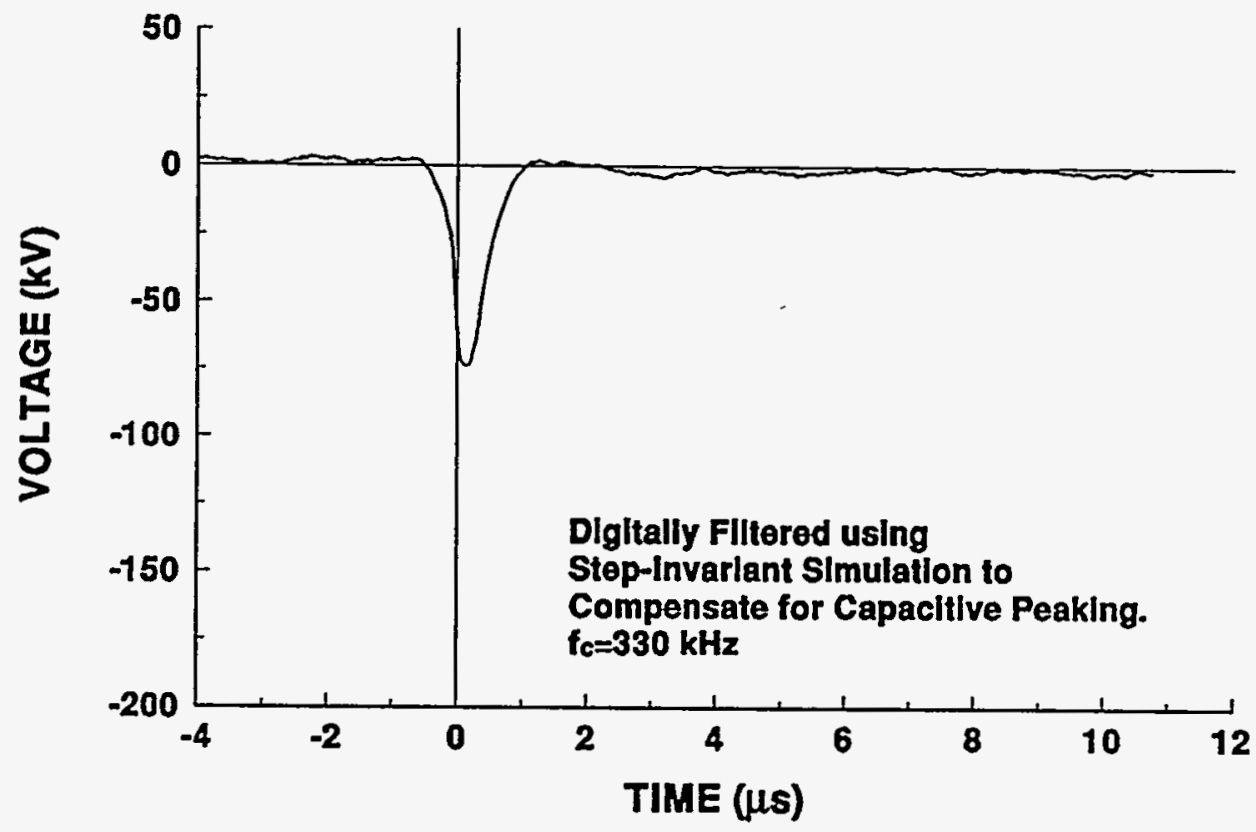




\section{4-10 STROKE 1}

TEST POINT 20

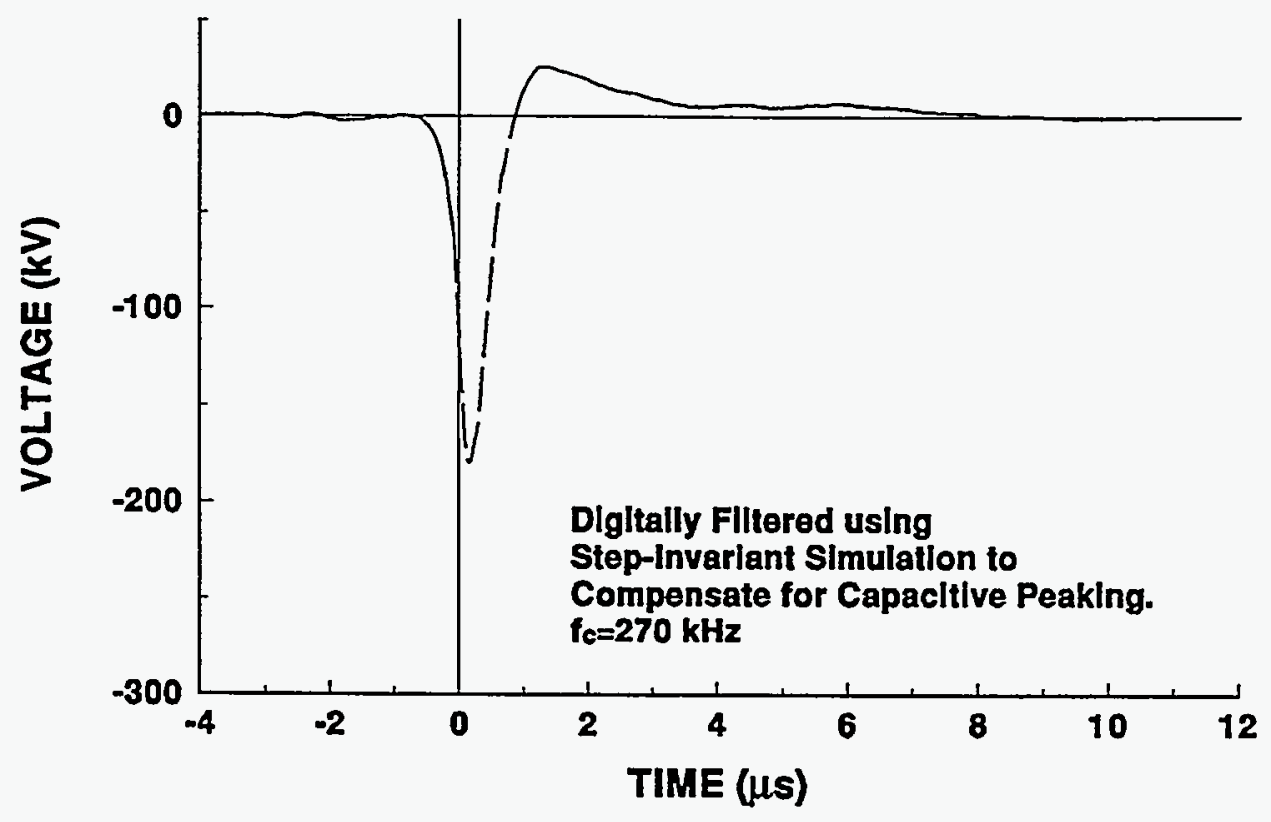

94-10 STROKE.1

TEST POINT 22

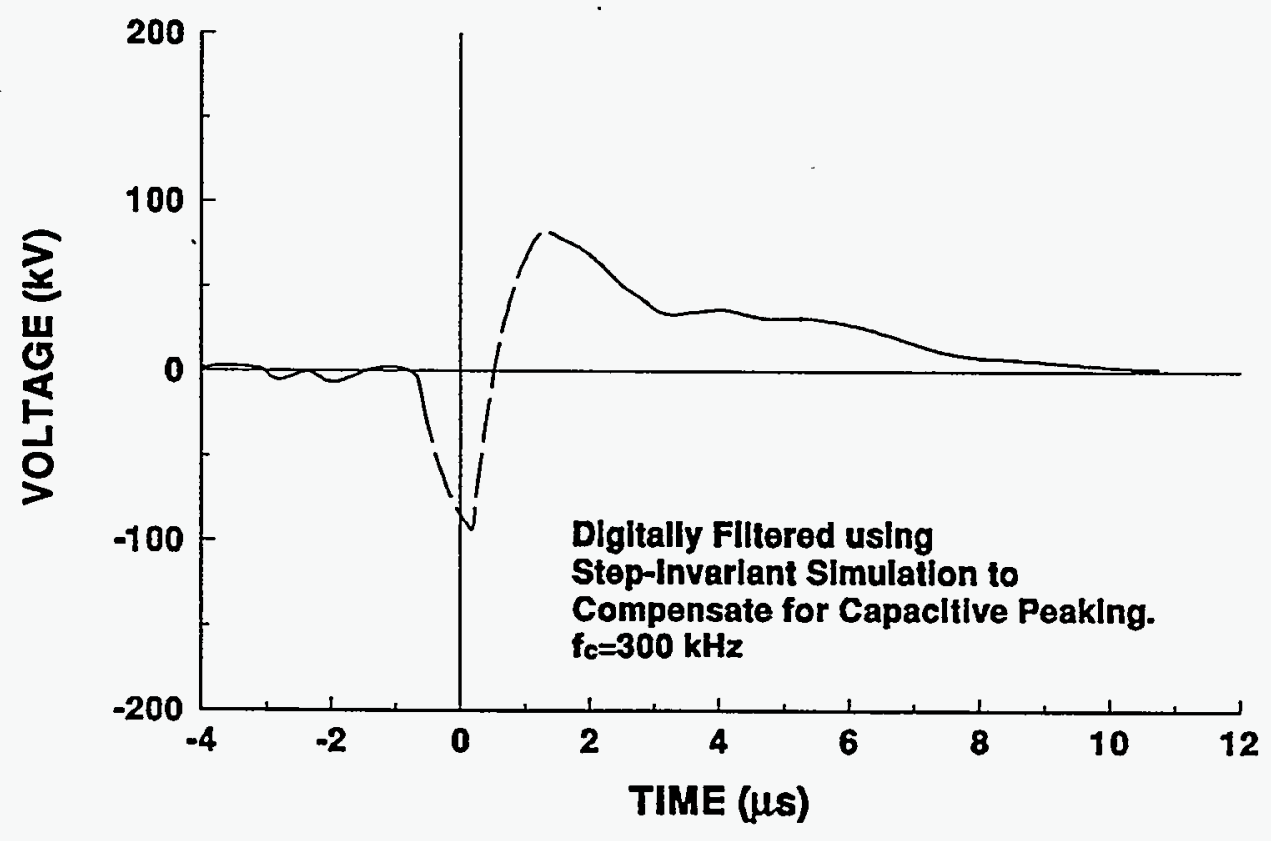




\section{4-10 STROKE 1}

\section{TEST POINT 23}

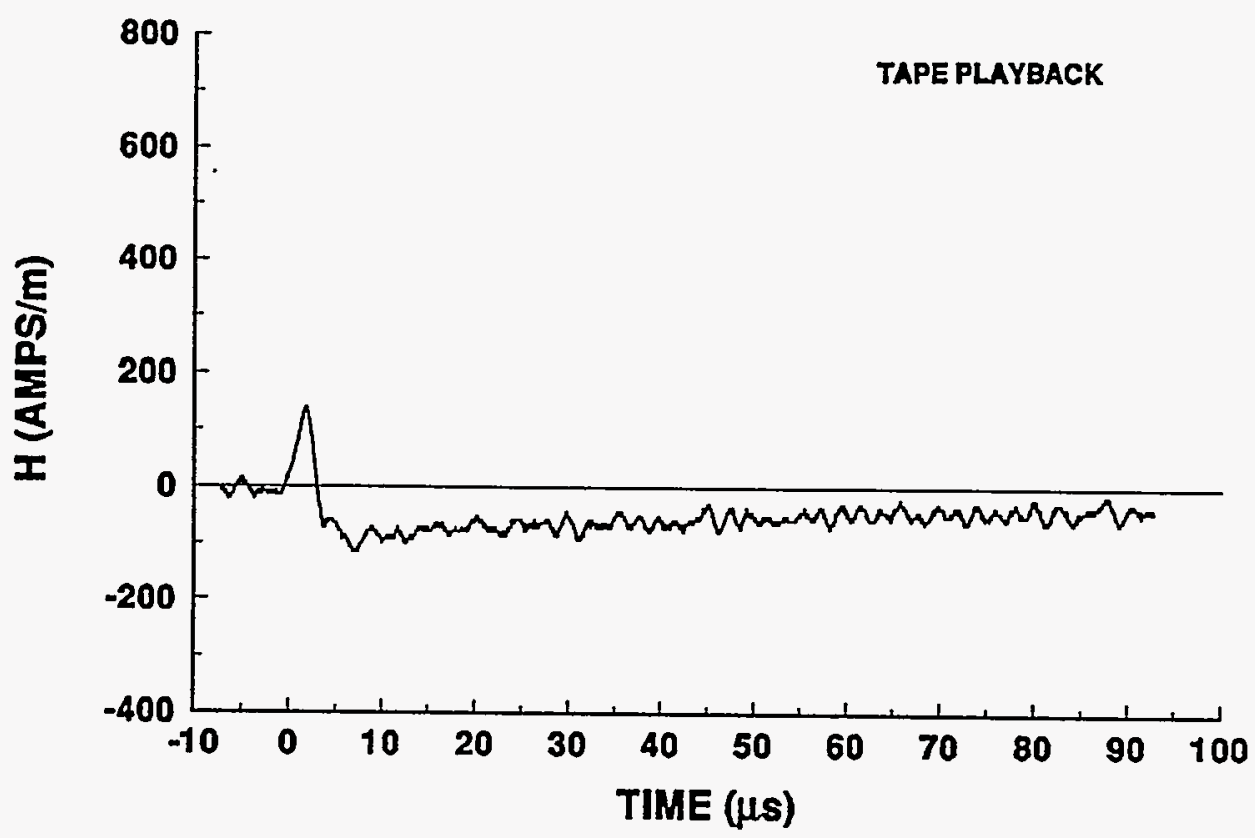

94-10 STROKE 1

TEST POINT 24

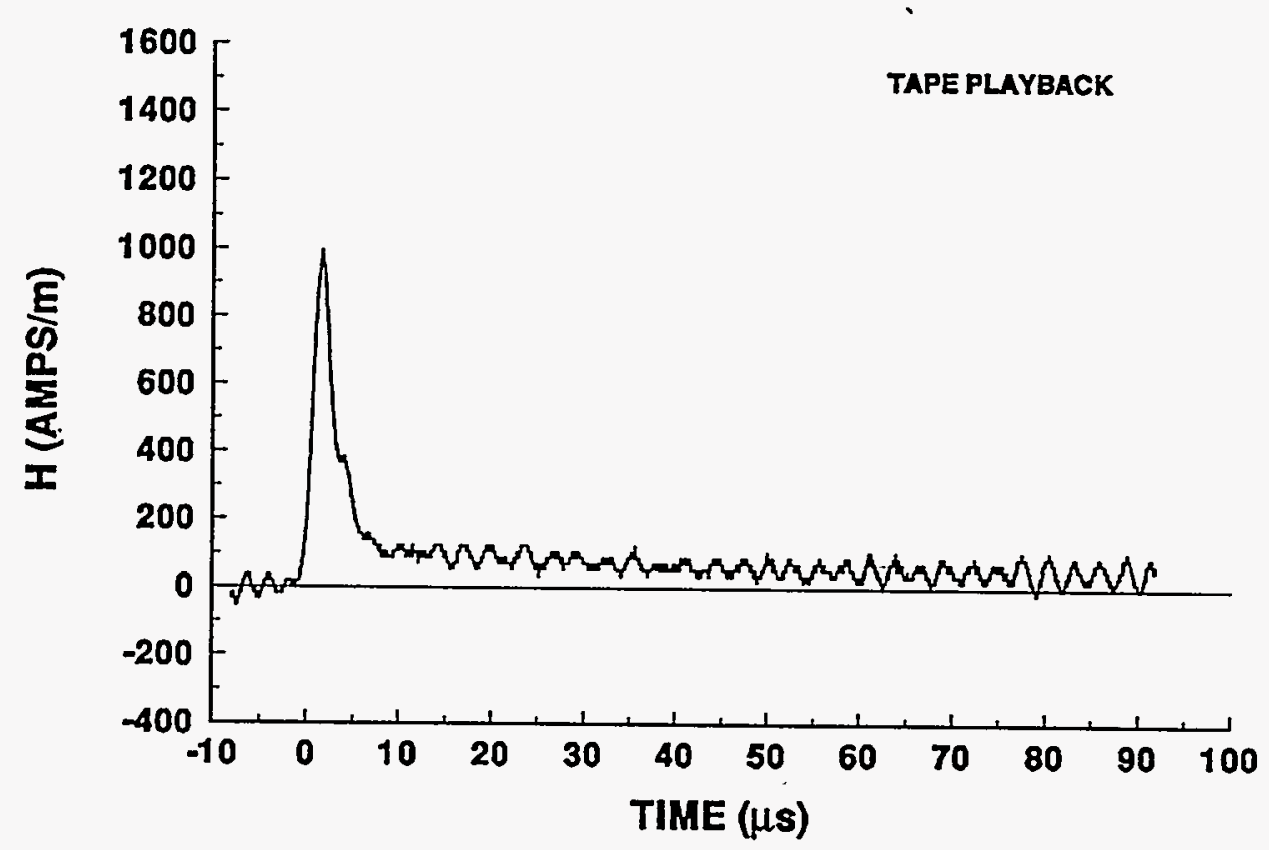




\section{Storm 3 Data Plots}

\section{Flashes 94-14 and 94-15}




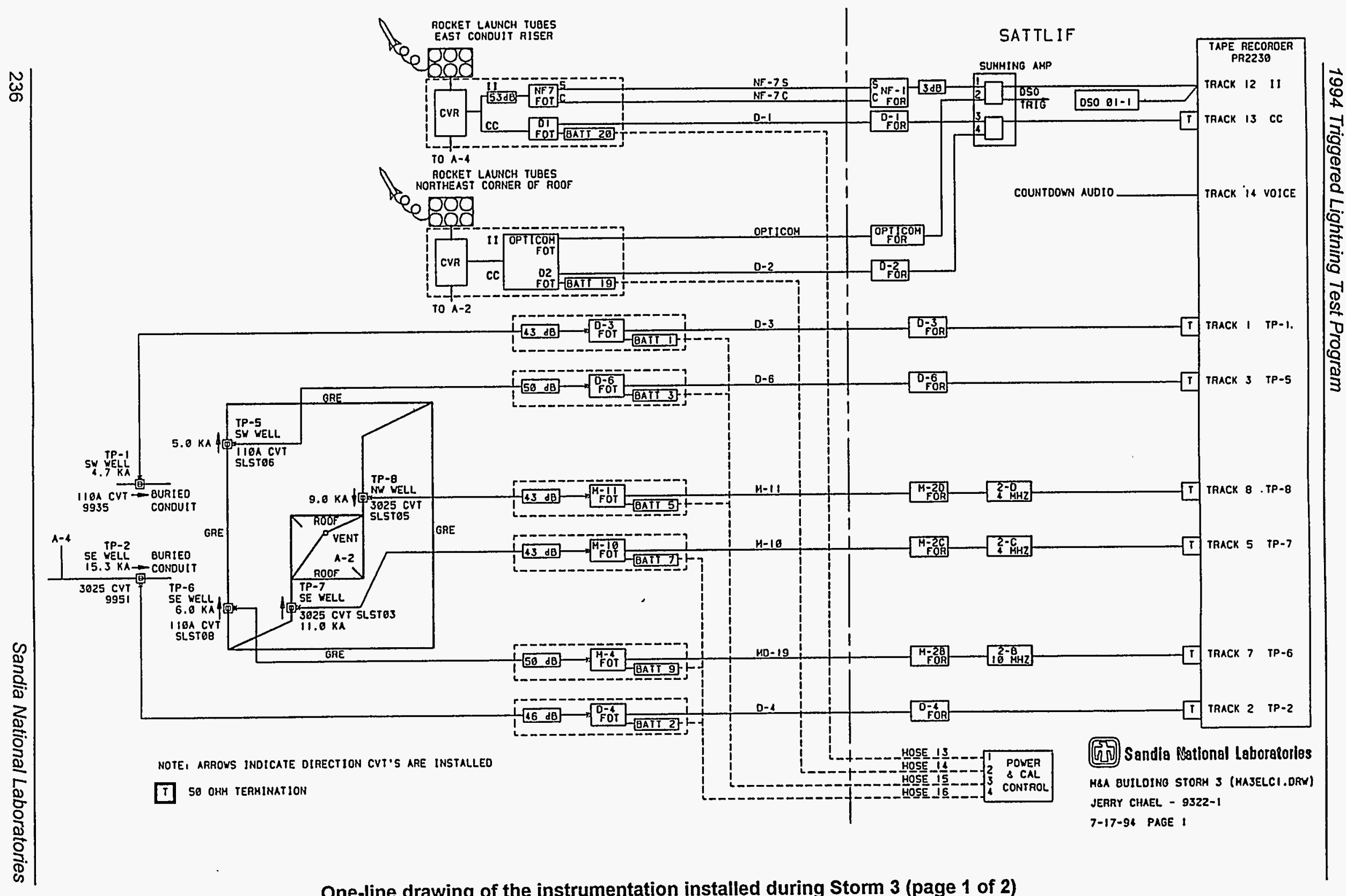

One-line drawing of the instrumentation installed during Storm 3 (page 1 of 2) 


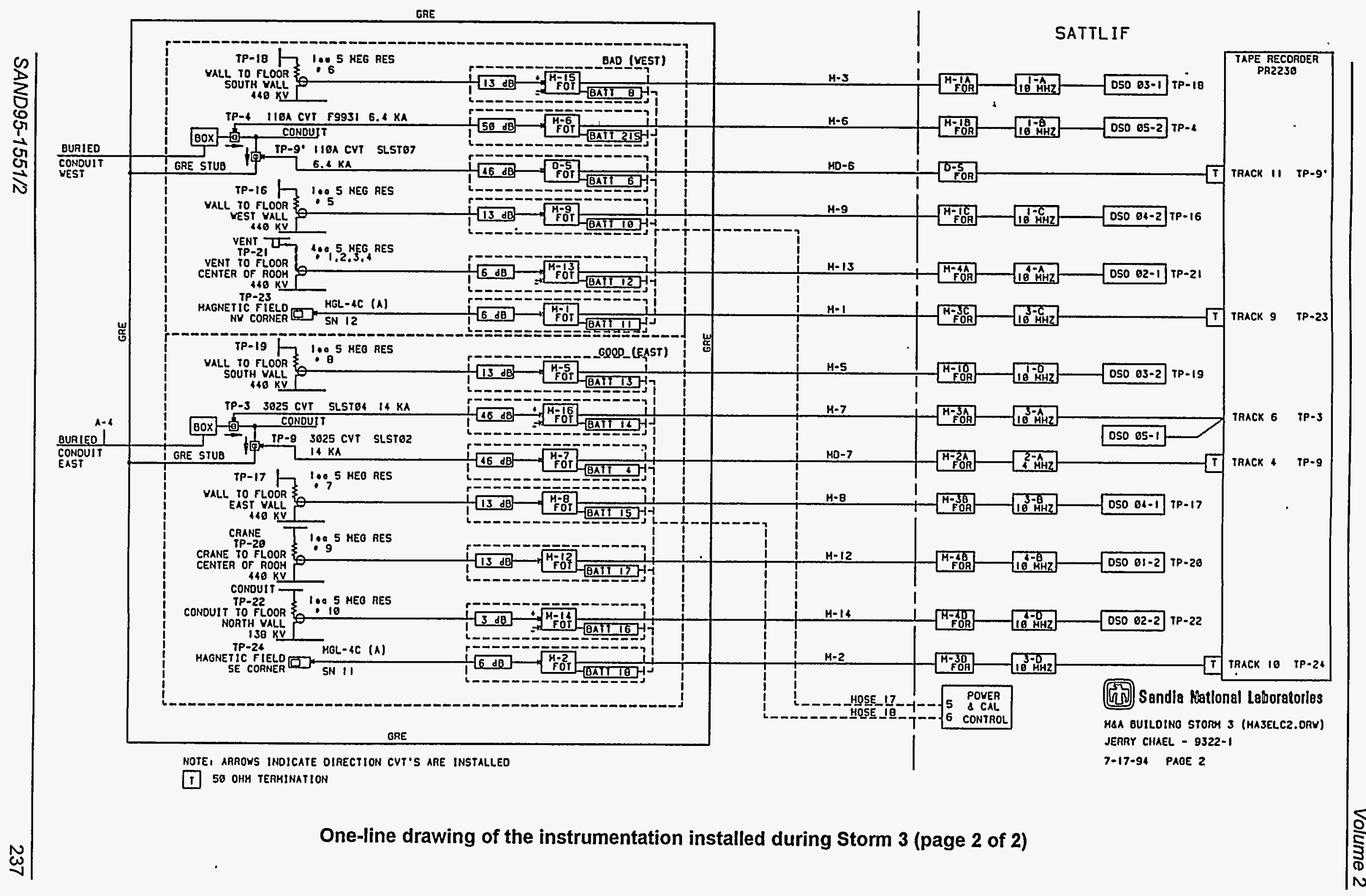




\section{4-14 STROKE 1}

\section{INCIDENT CURRENT}
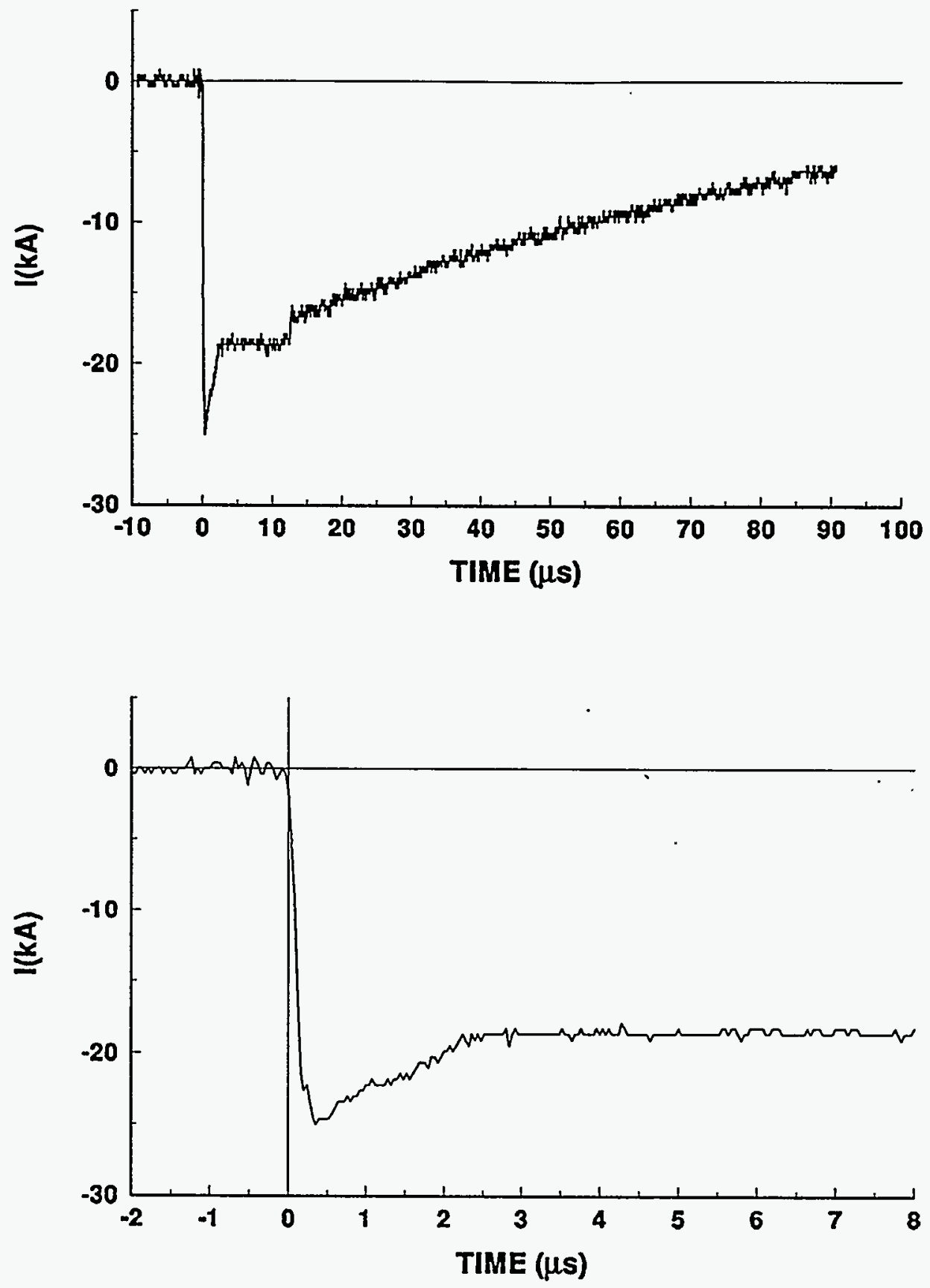


\section{4-14 STROKE 1}

\section{TEST POINT 4}
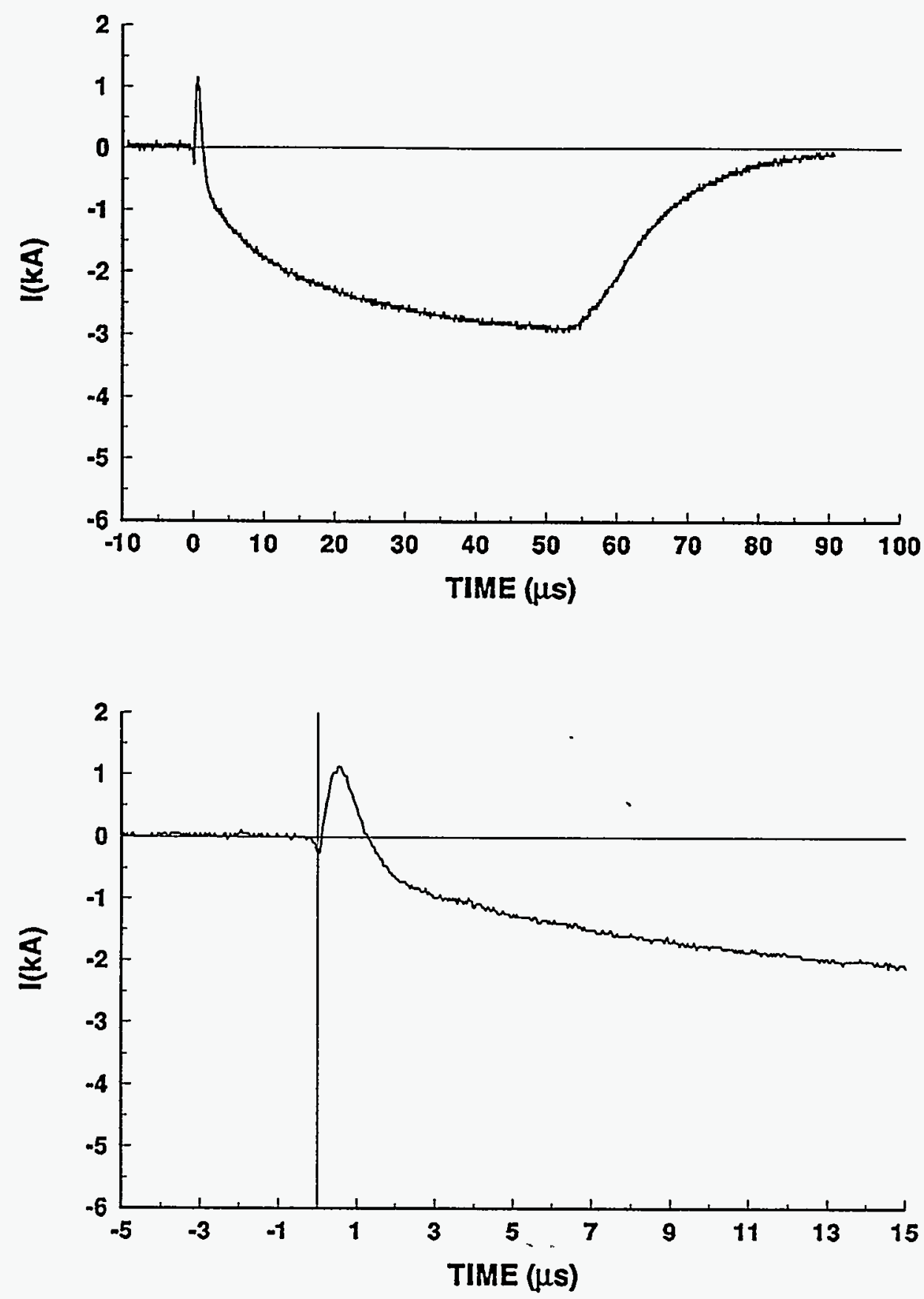


\section{4-14 STROKE 1}

\section{TEST POINT 5}

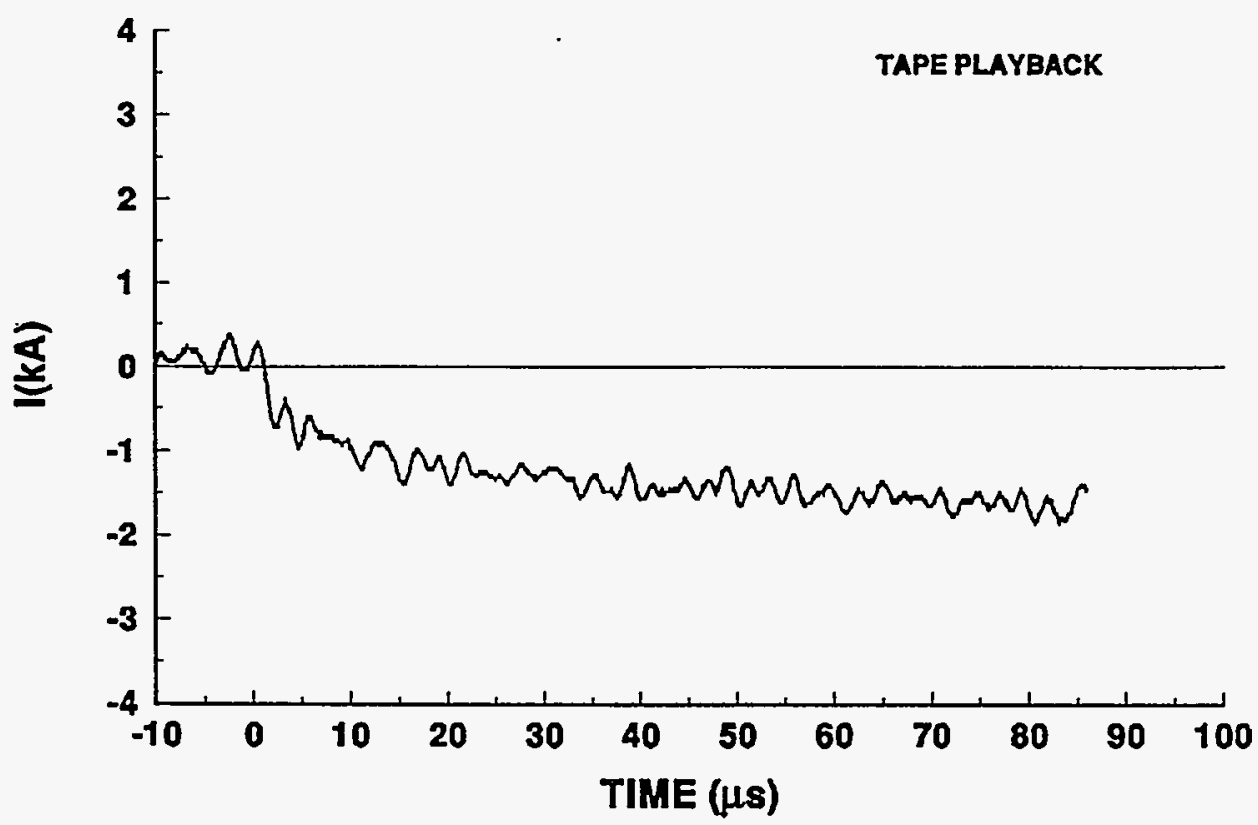

\section{4-14 STROKE 1}

TEST POINT 6

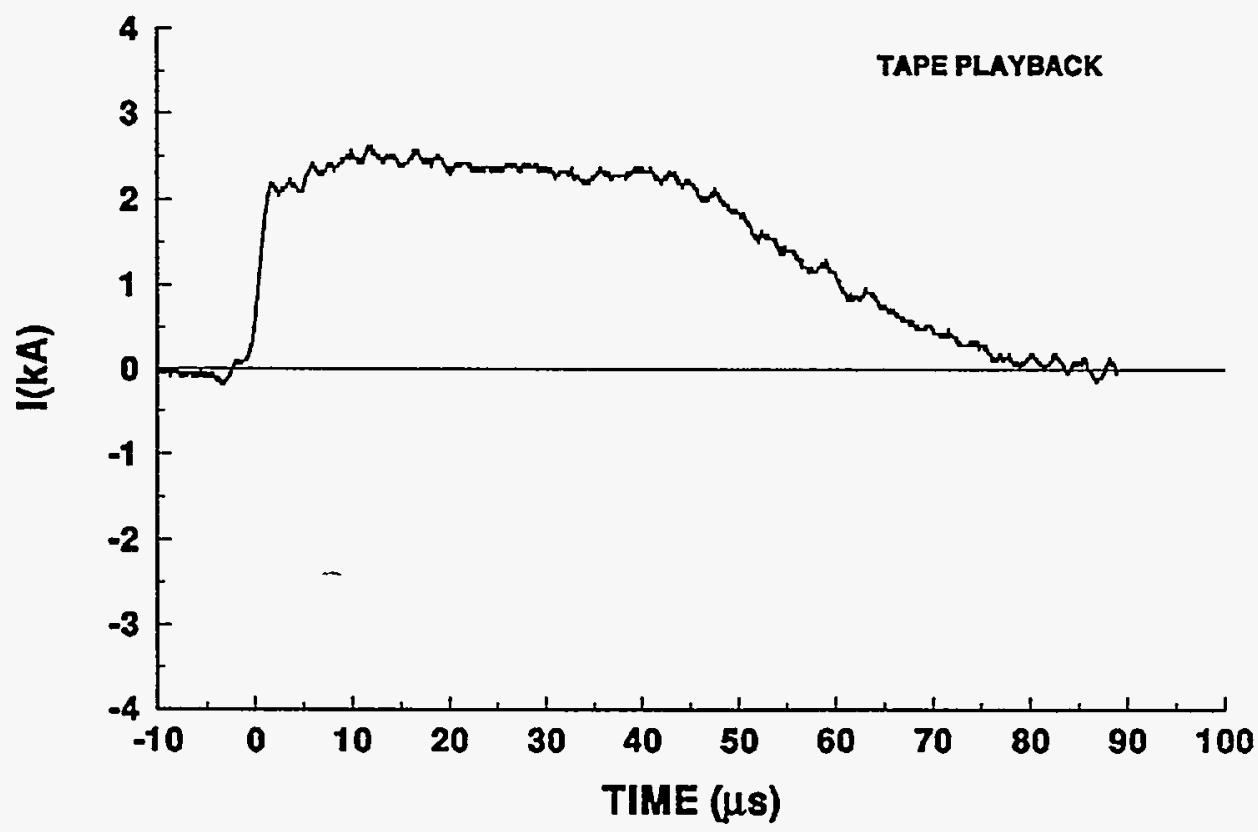




\section{4-14 STROKE 1}

TEST POINT 7

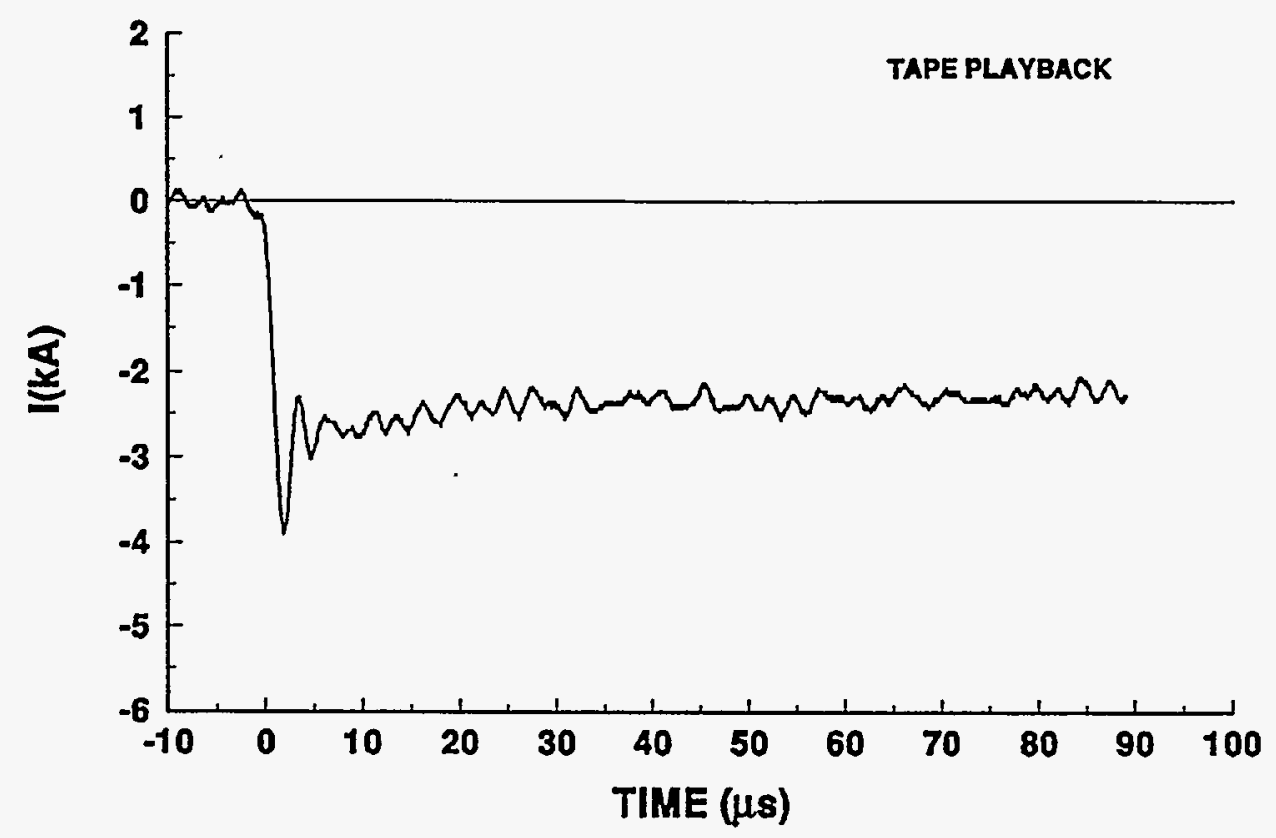

94-14 STROKE 1

TEST POINT 8

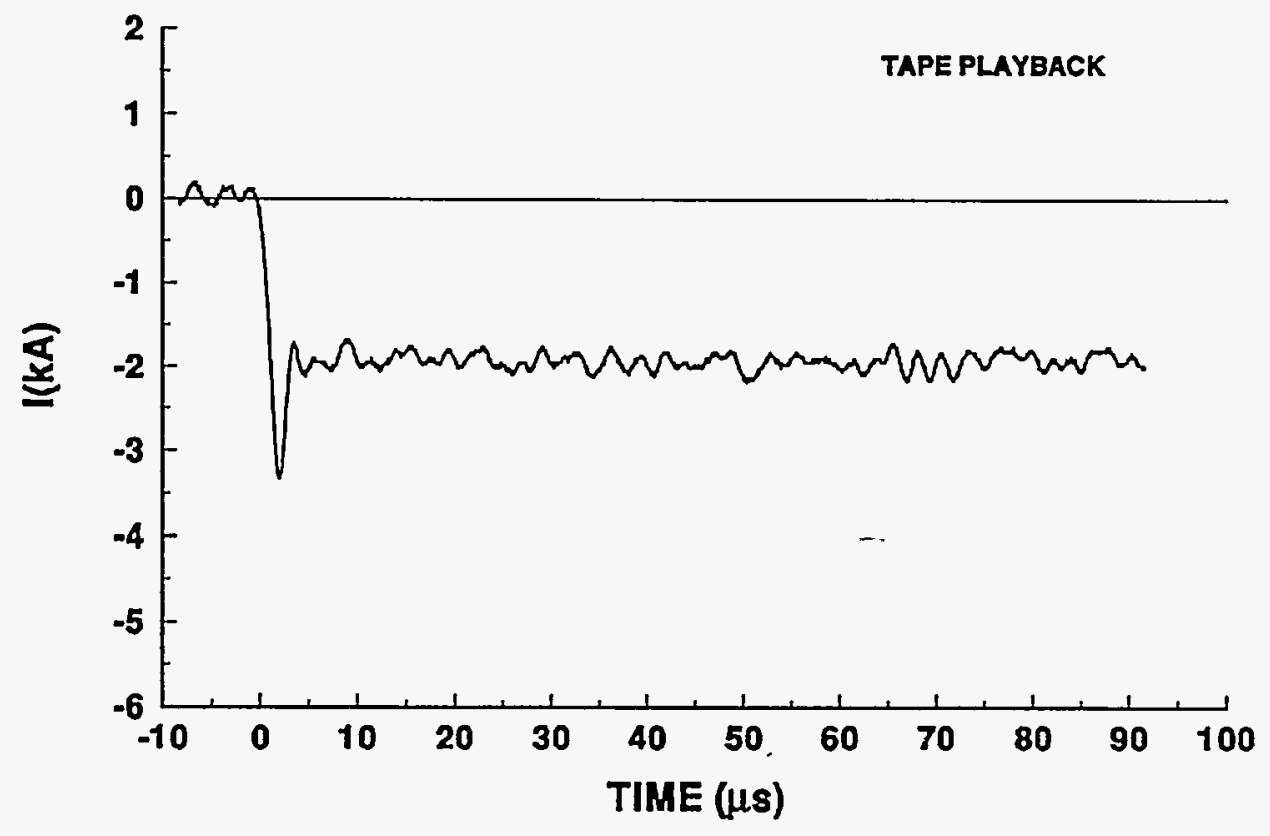


94-14 STROKE 1

TEST POINT 9

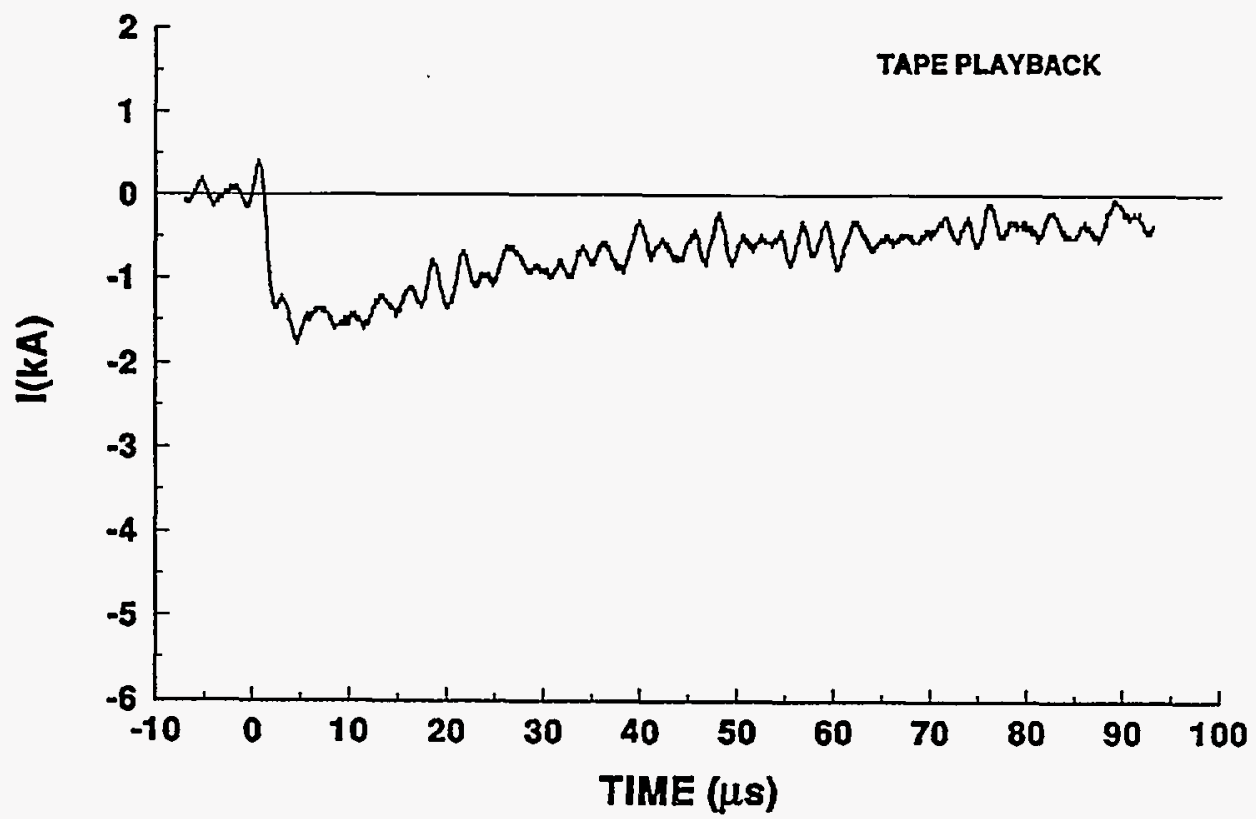

94-14 STROKE 1

TEST POINT 9'

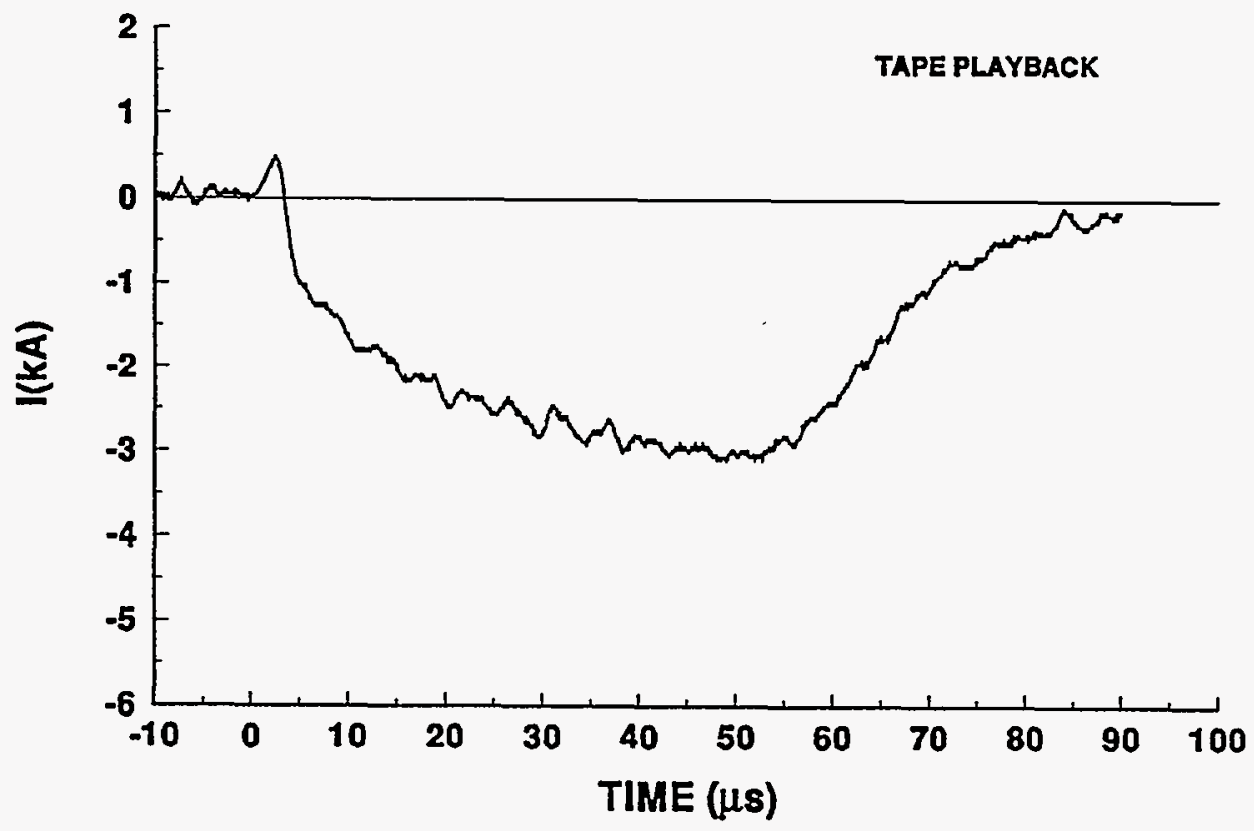




\section{4-14 STROKE 1}

TEST POINT 16

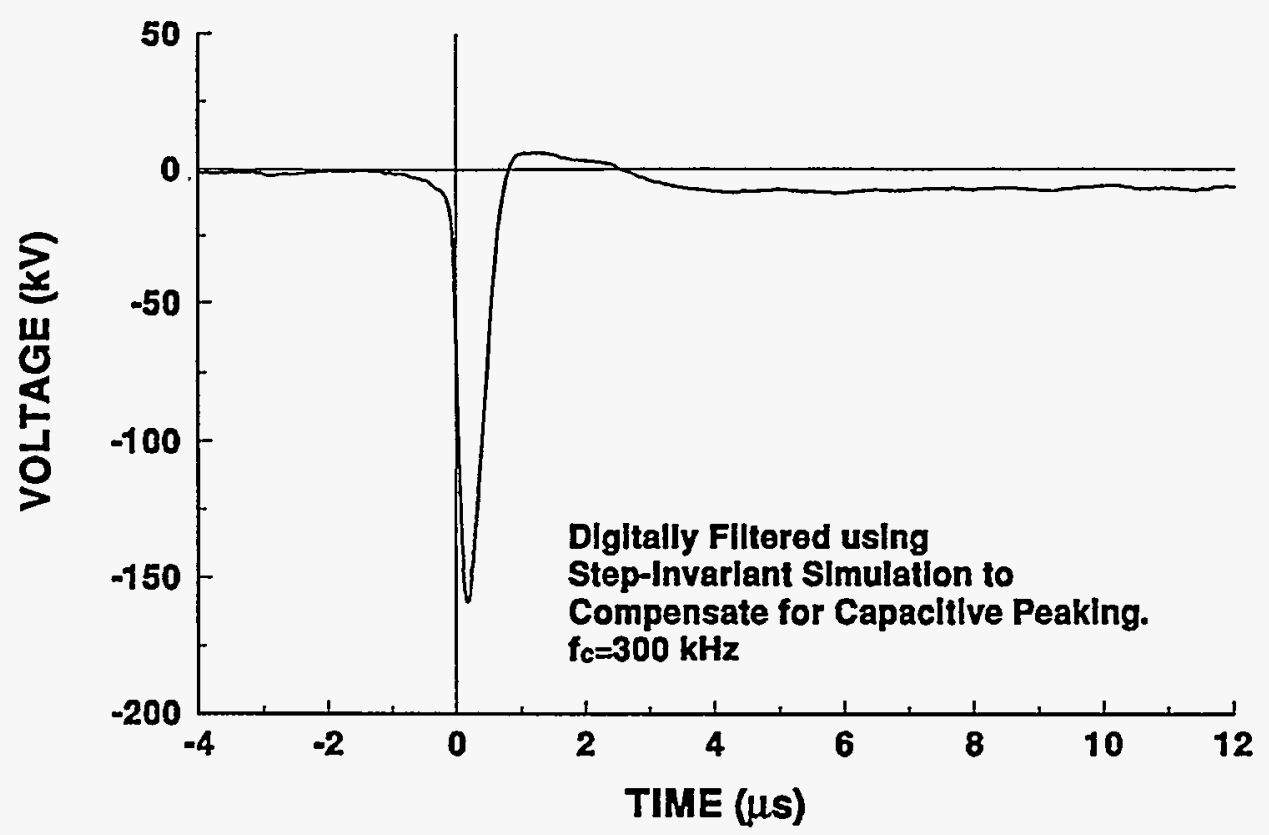

94-14 STROKE.1

TEST POINT 17

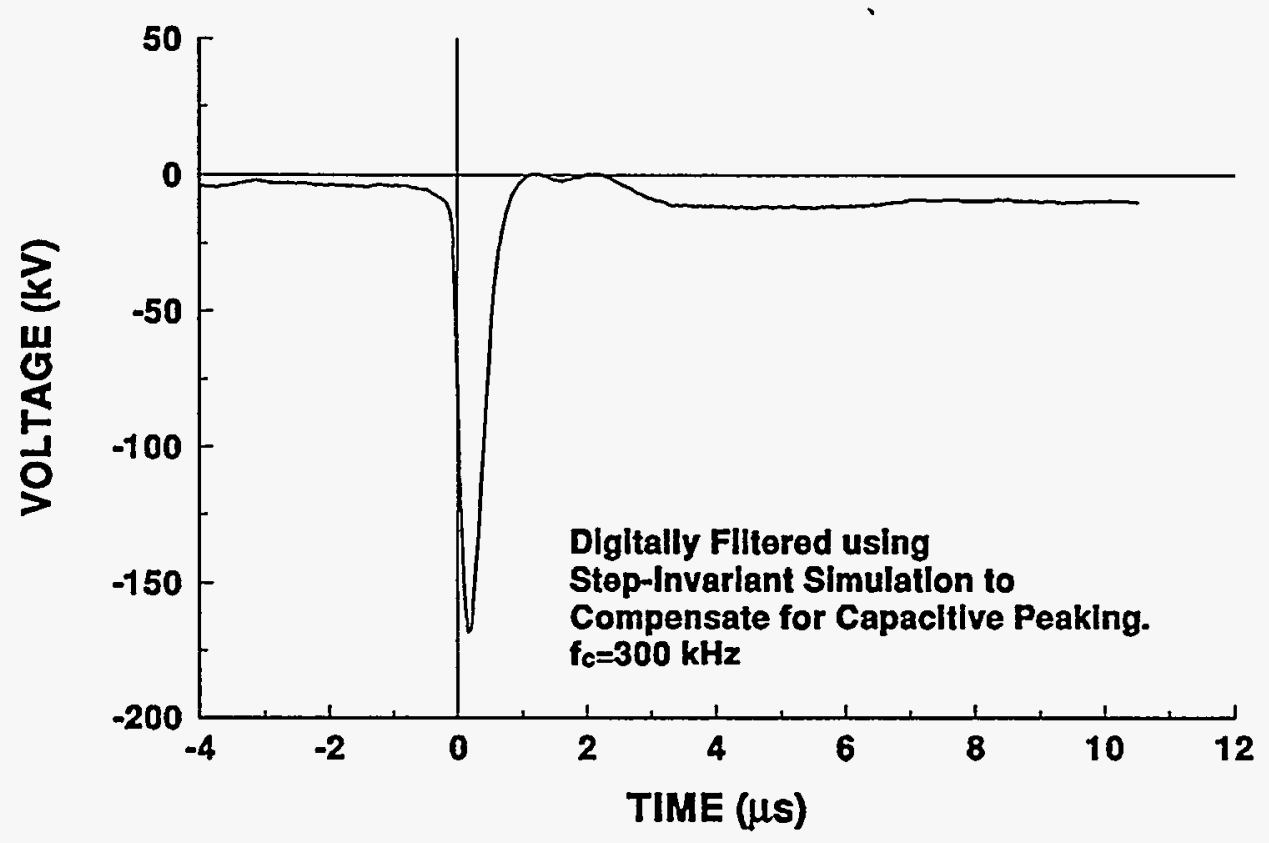




\section{4-14 STROKE 1}

\section{TEST POINT 18}

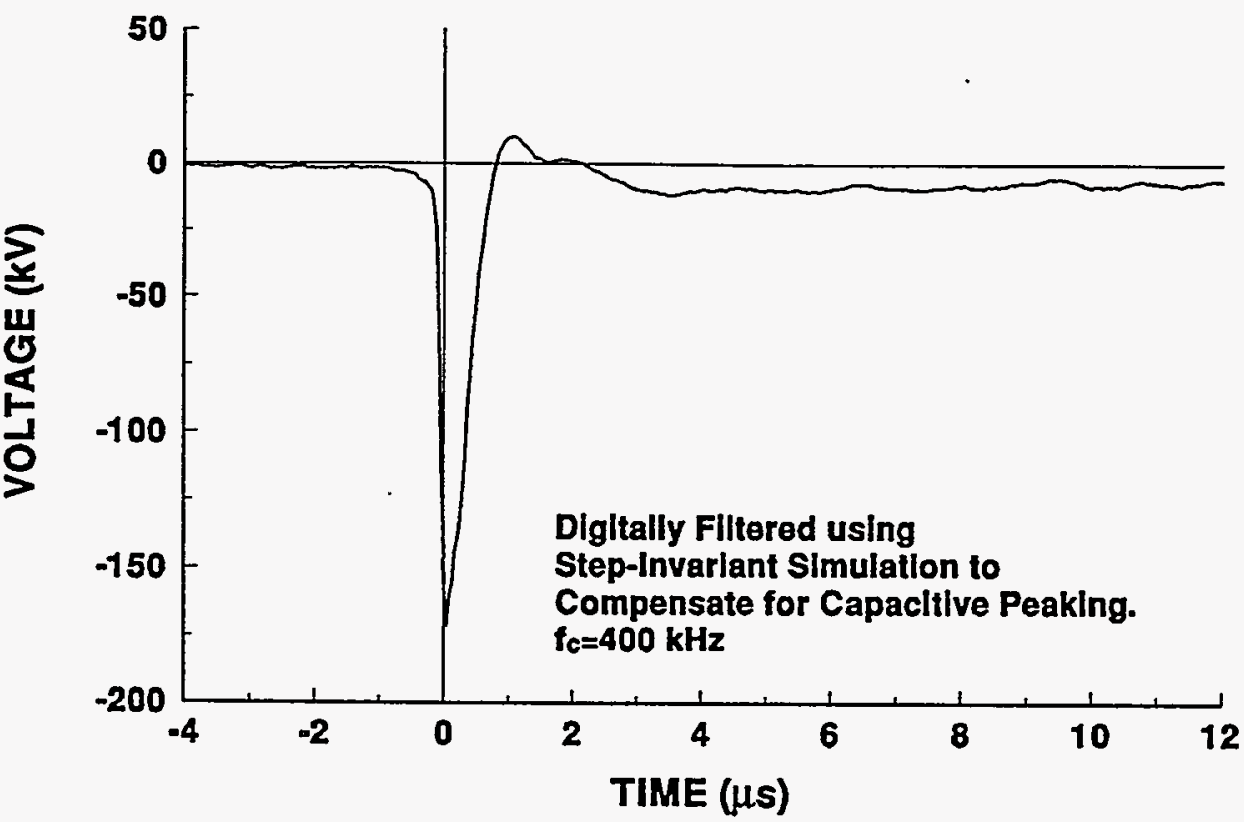

\section{4-14 STROKE 1}

TEST POINT 19

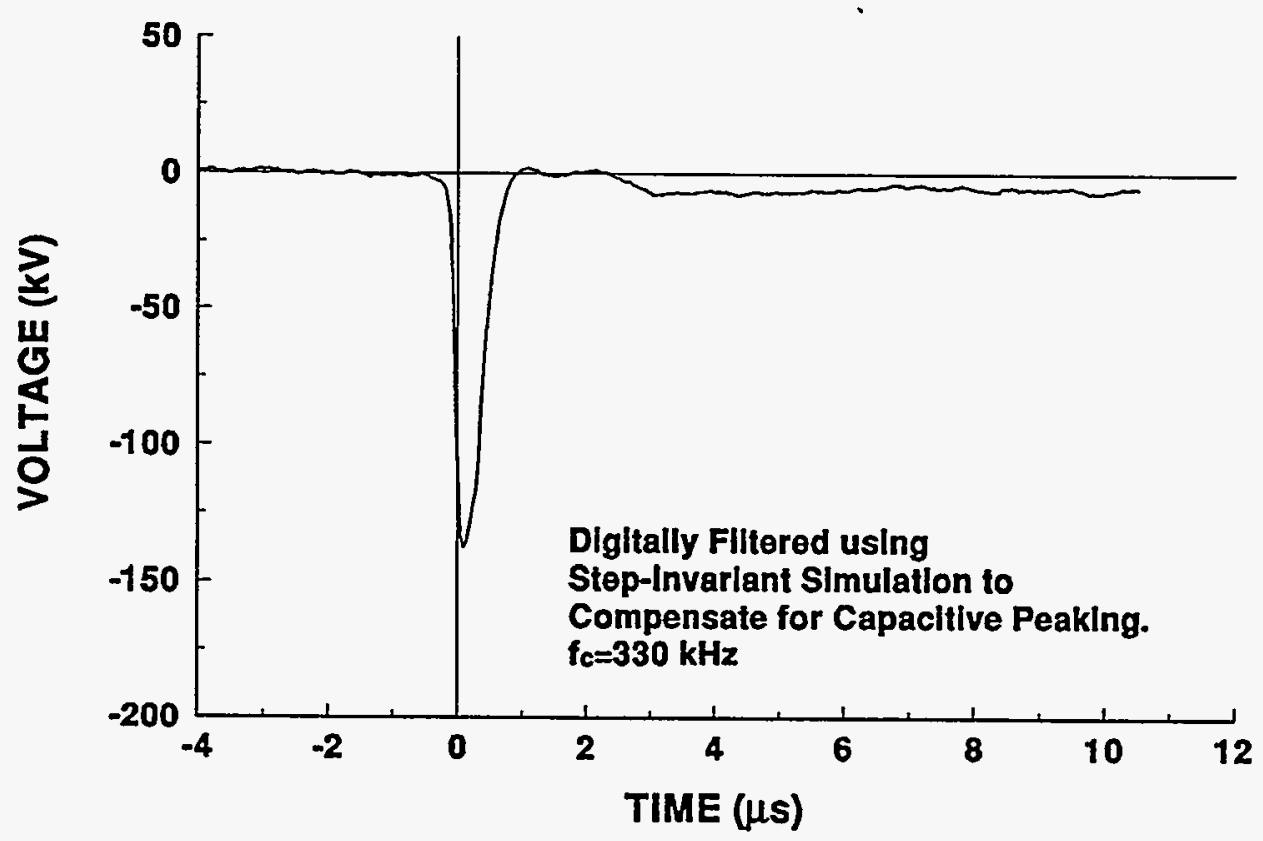




\section{4-14 STROKE 1}

\section{TEST POINT 20}

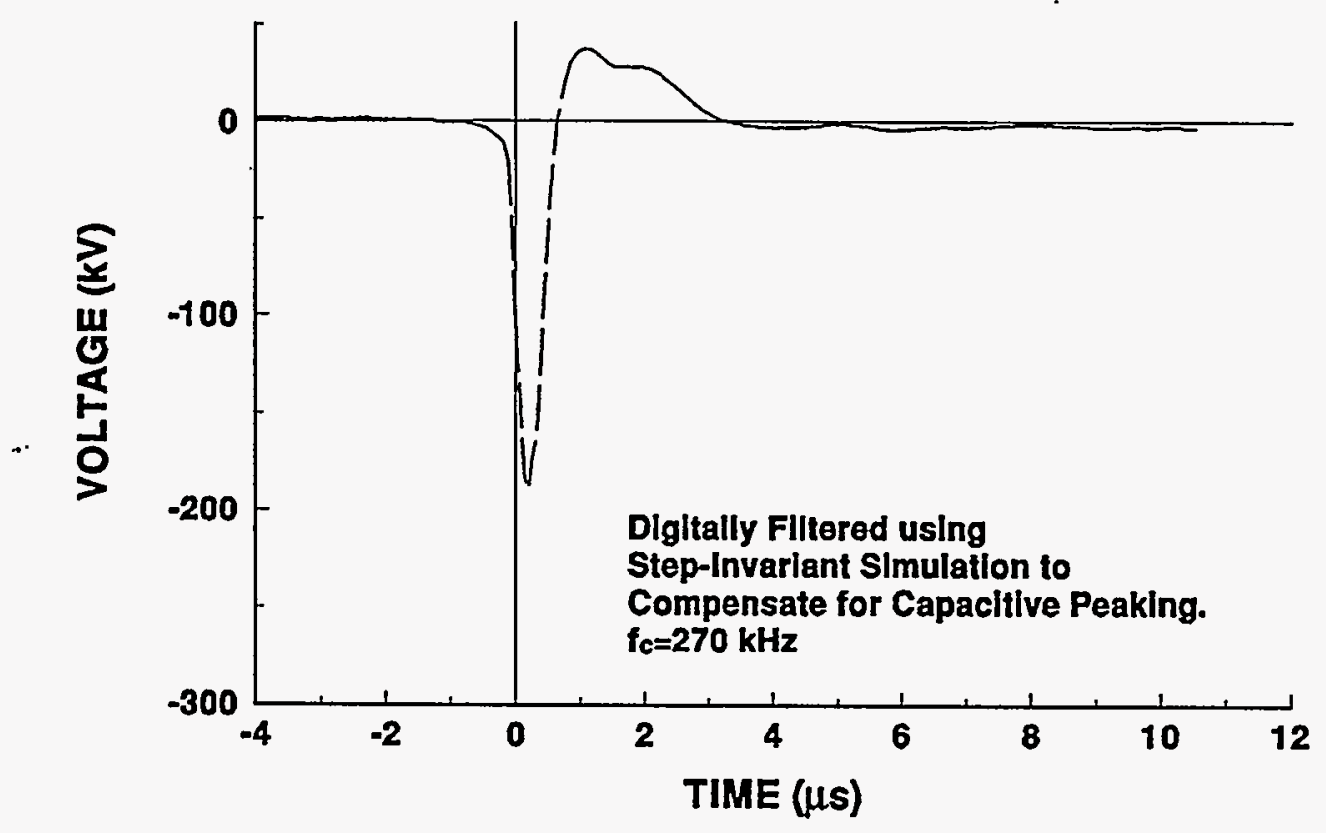

94-14 STROKE.1

TEST POINT 22

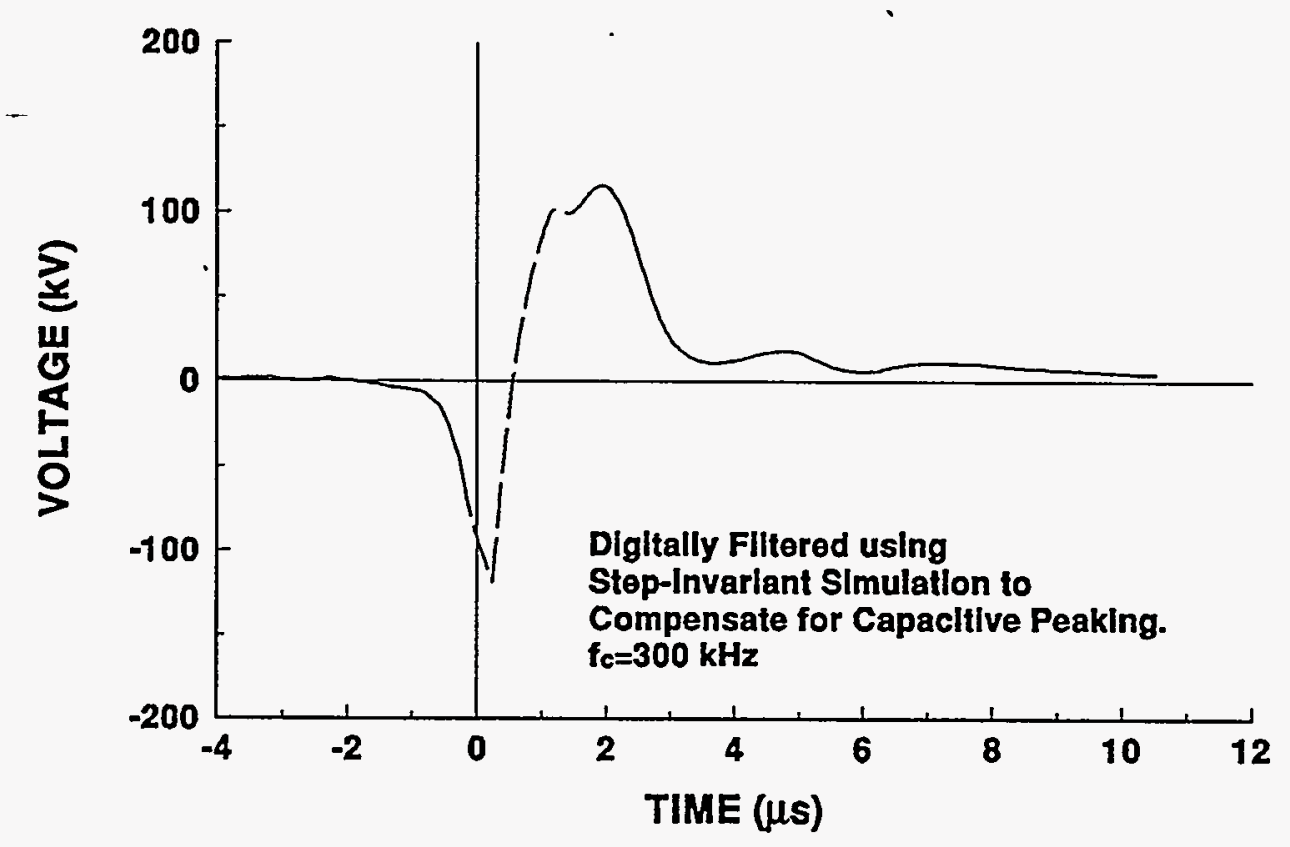




\section{4-14 STROKE 1}

TEST POINT 23

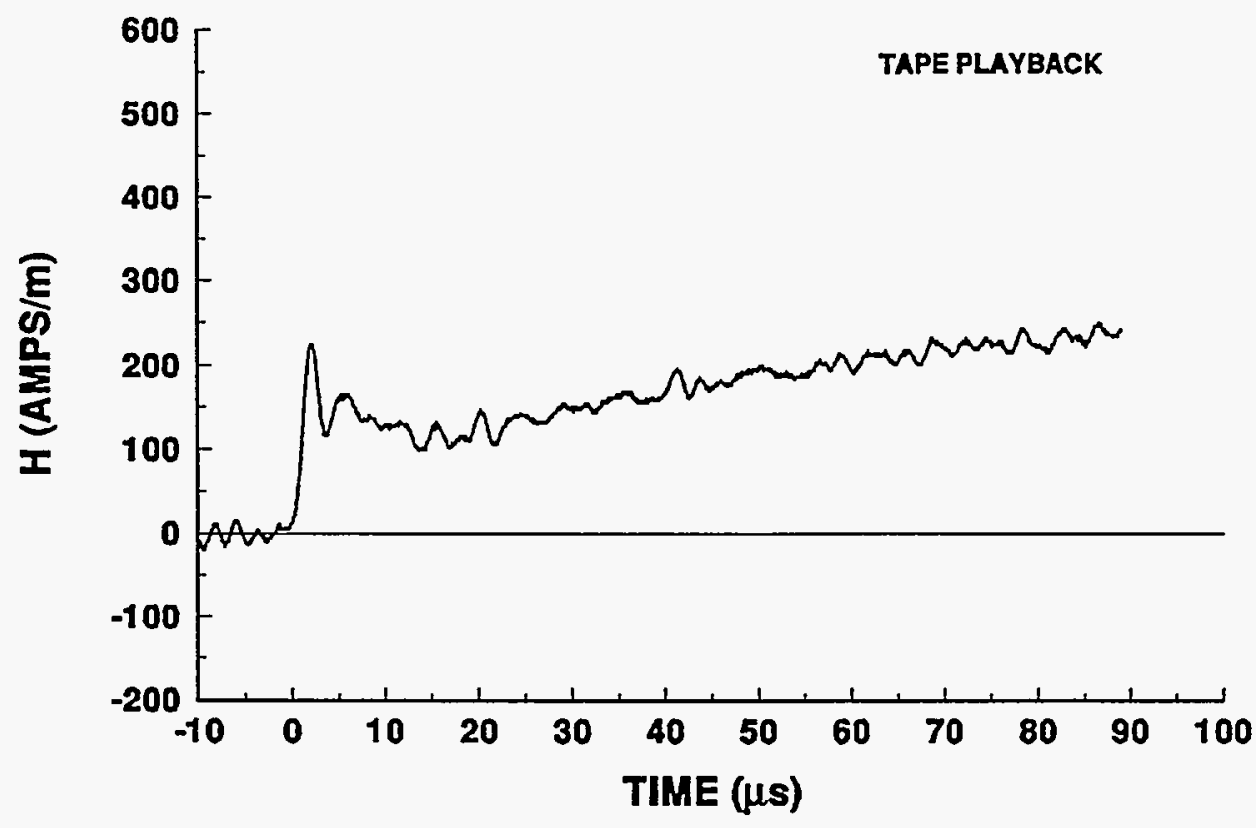

94-14 STROKE 1

TEST POINT 24

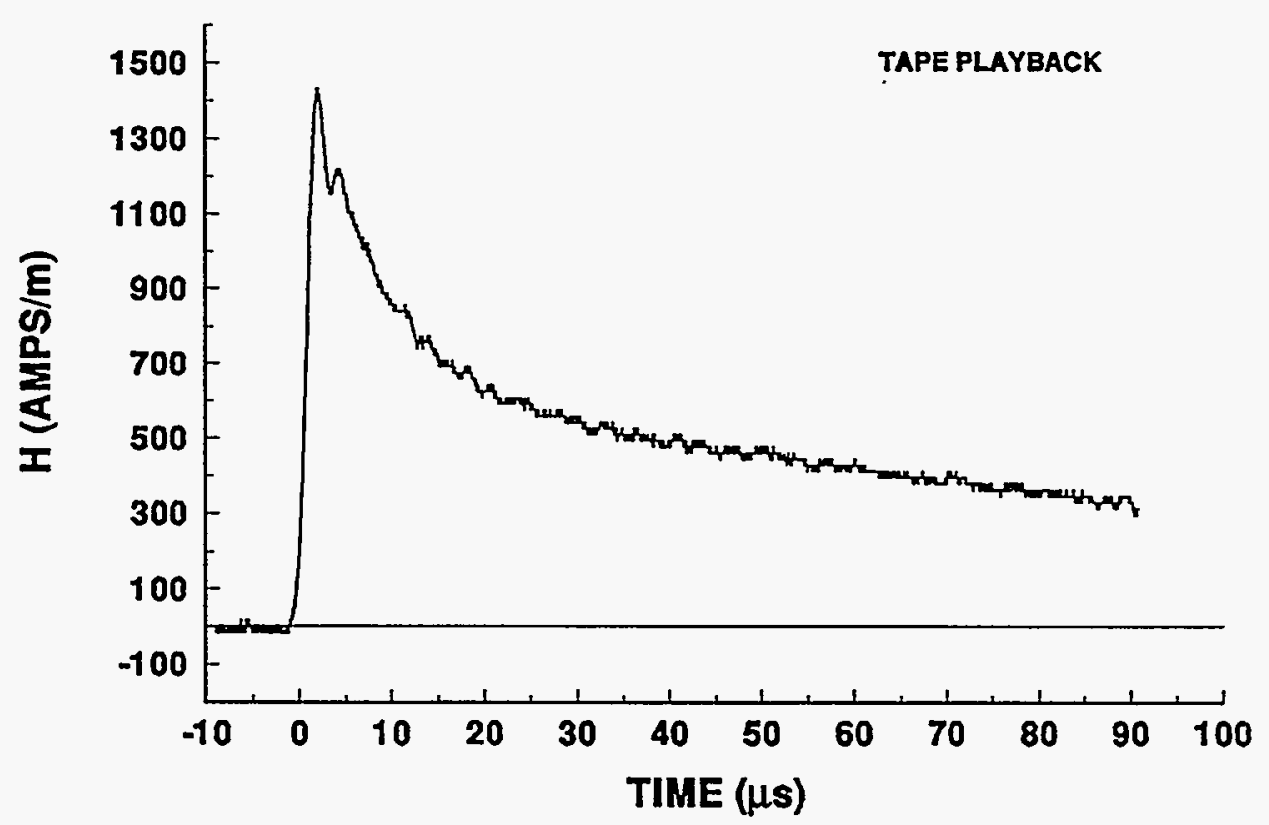




\section{4-14 STROKE 2}

\section{INCIDENT CURRENT}
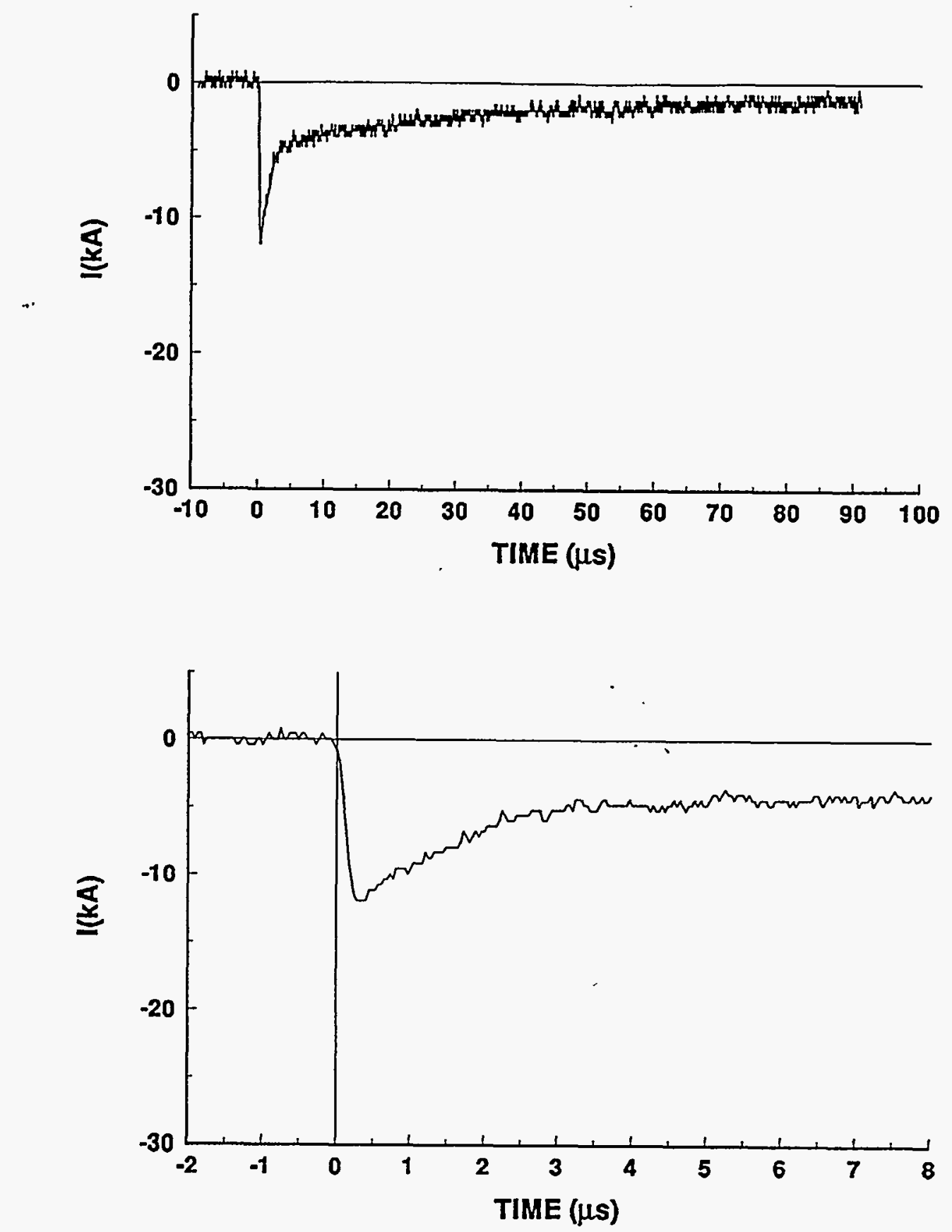


\section{4-14 STROKE 2}

\section{TEST POINT 1}

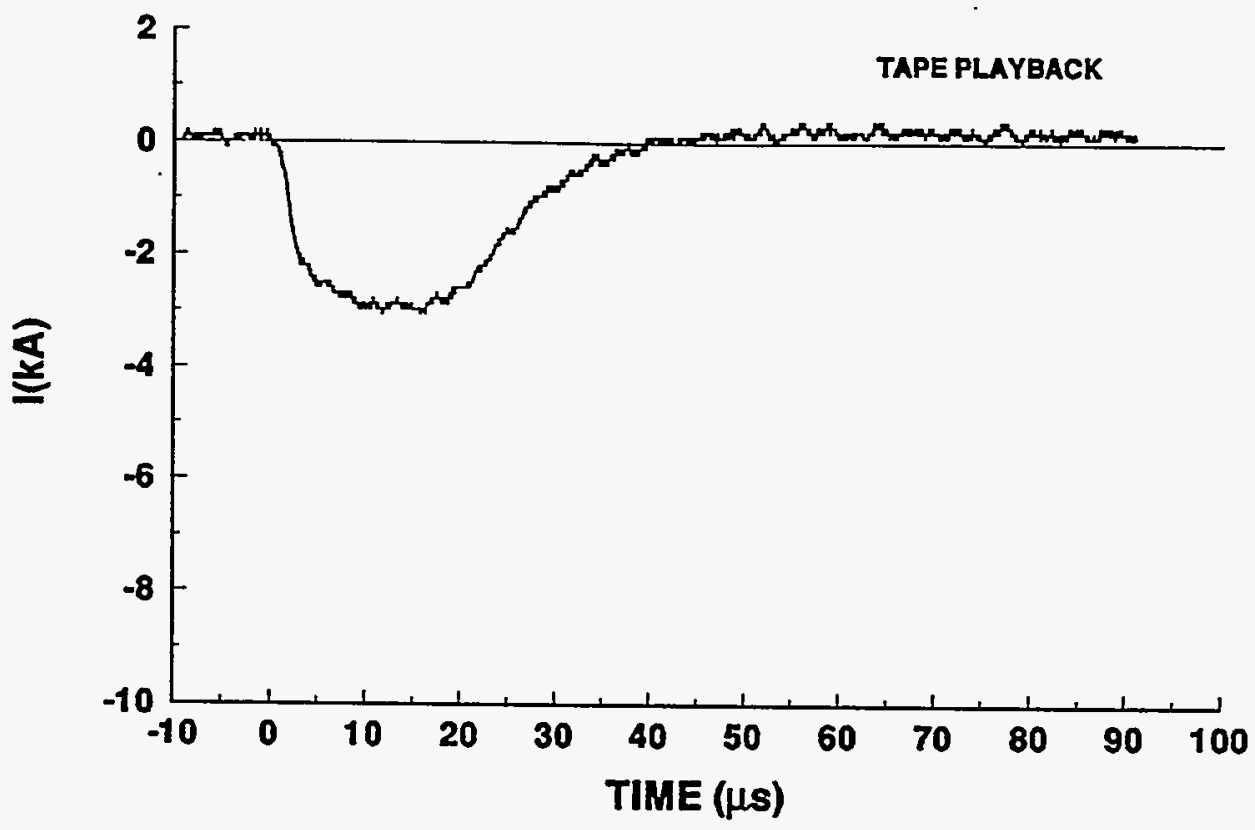

94-14 STROKE 2

TEST POINT 2

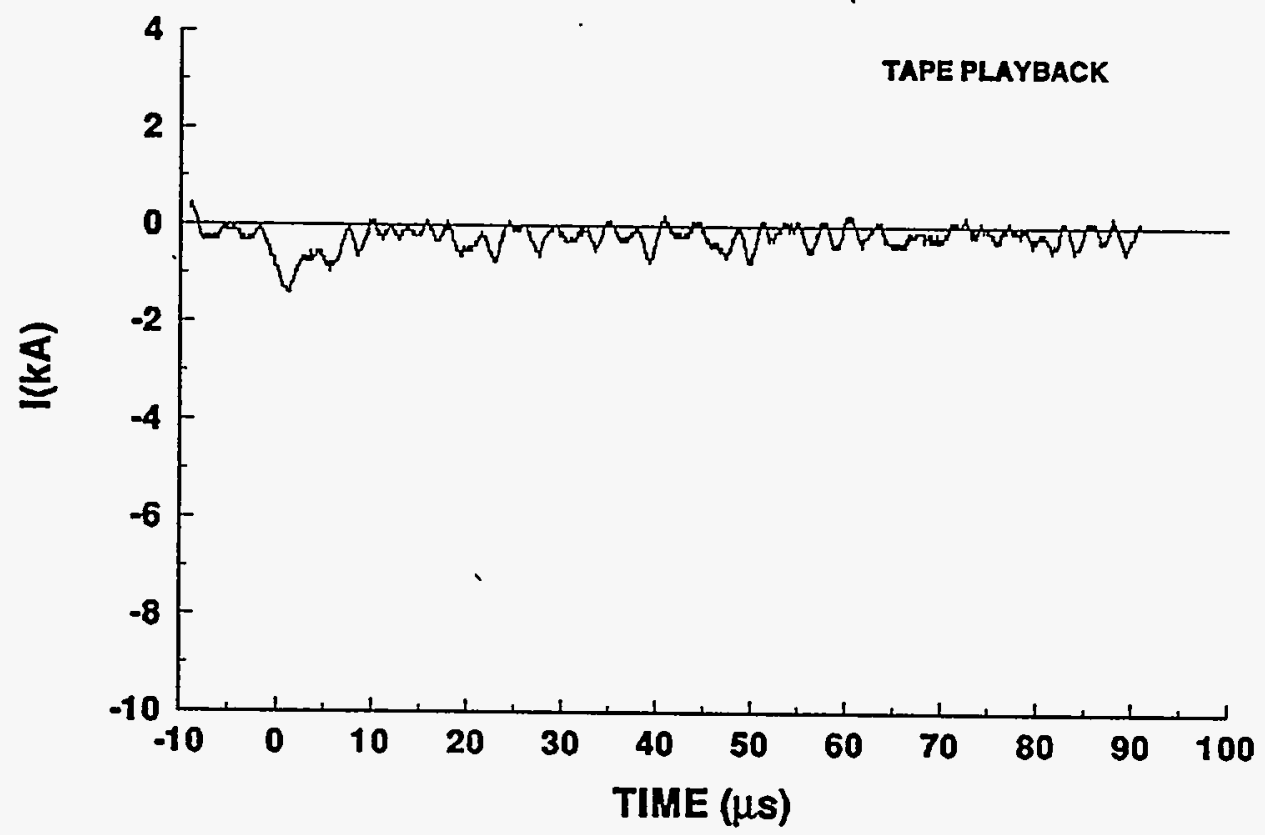




\section{4-14 STROKE 2}

TEST POINT 3
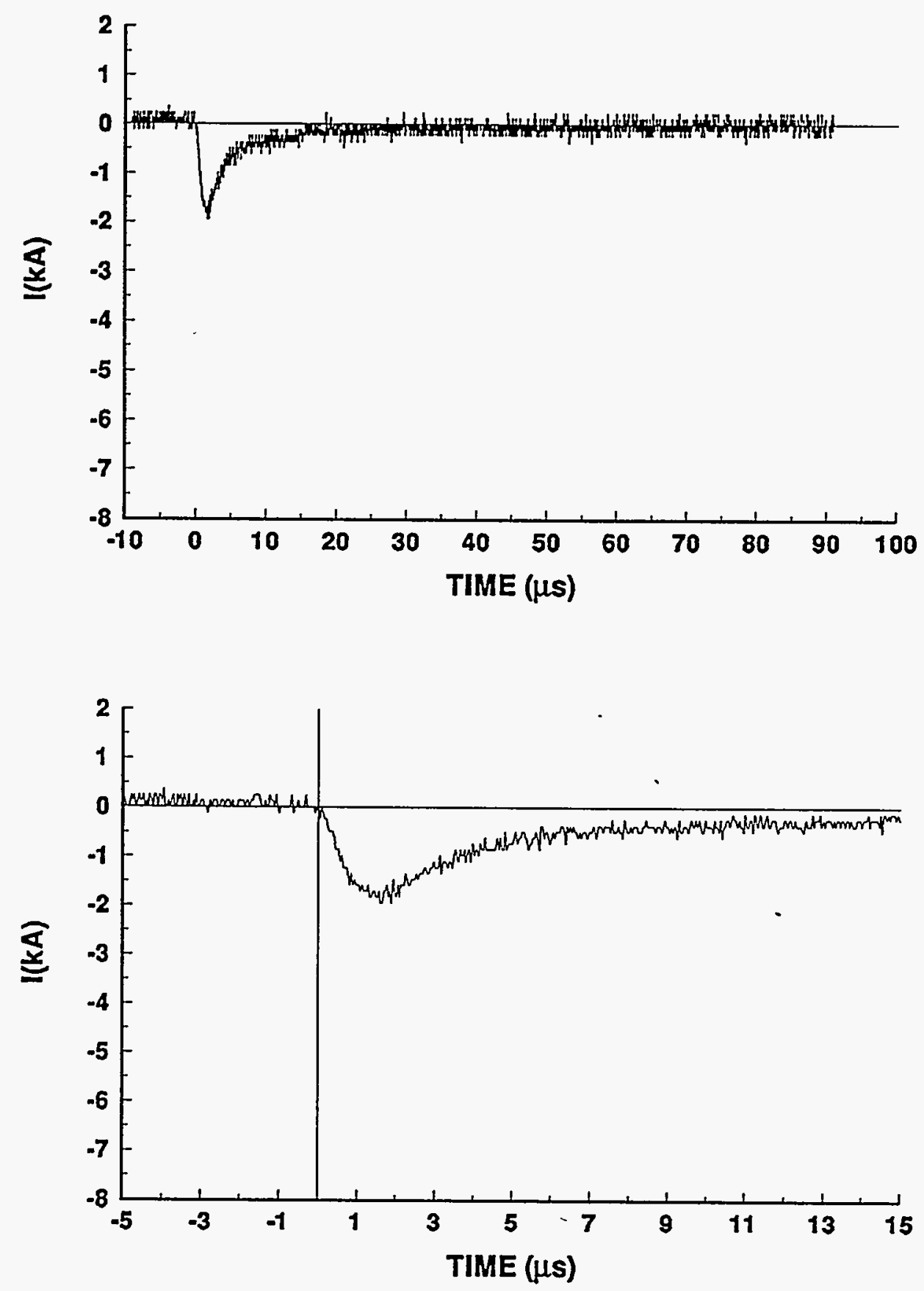


\section{4-14 STROKE 2 \\ TEST POINT 4}
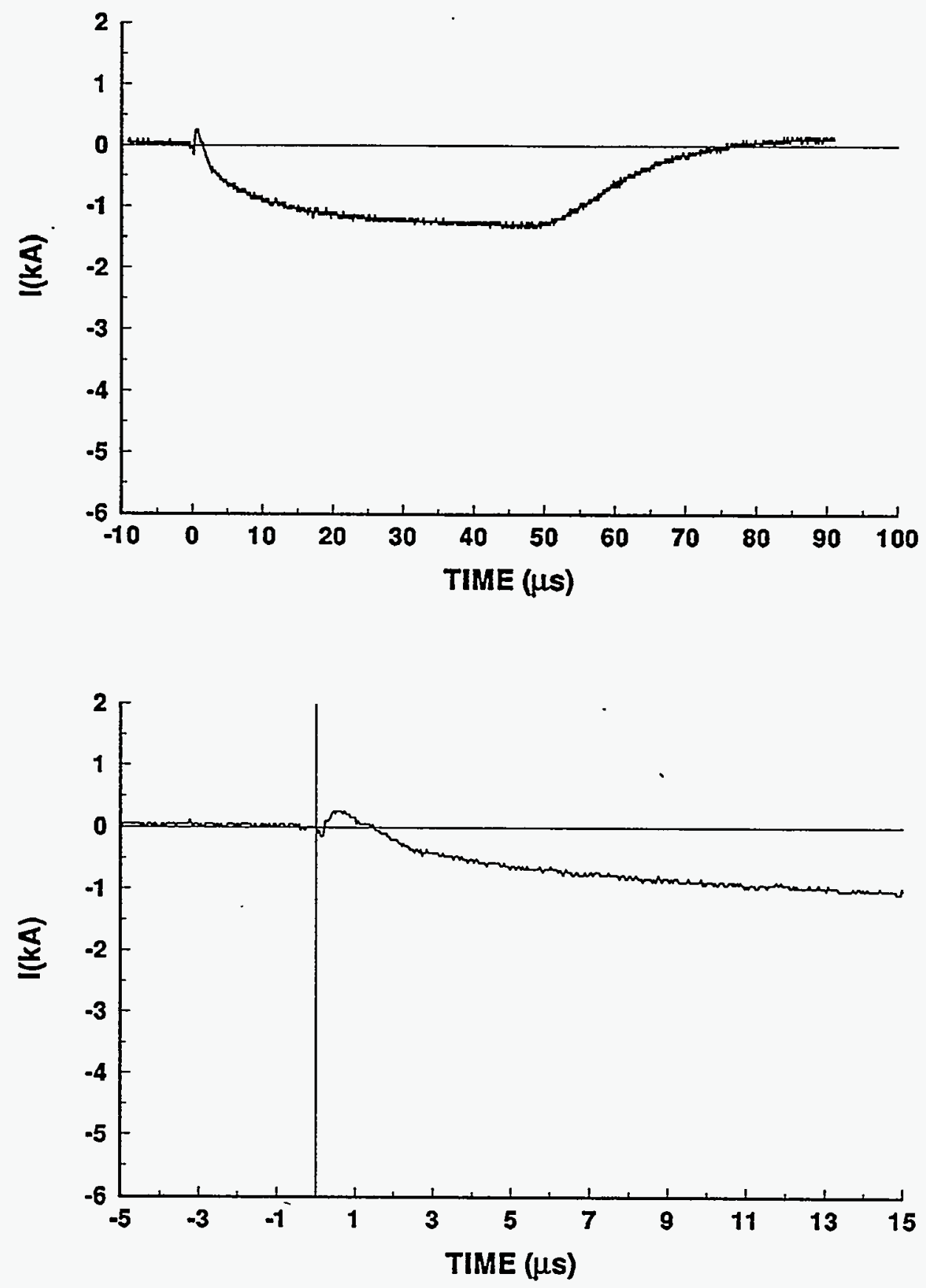


\section{4-14 STROKE 2}

TEST POINT 5

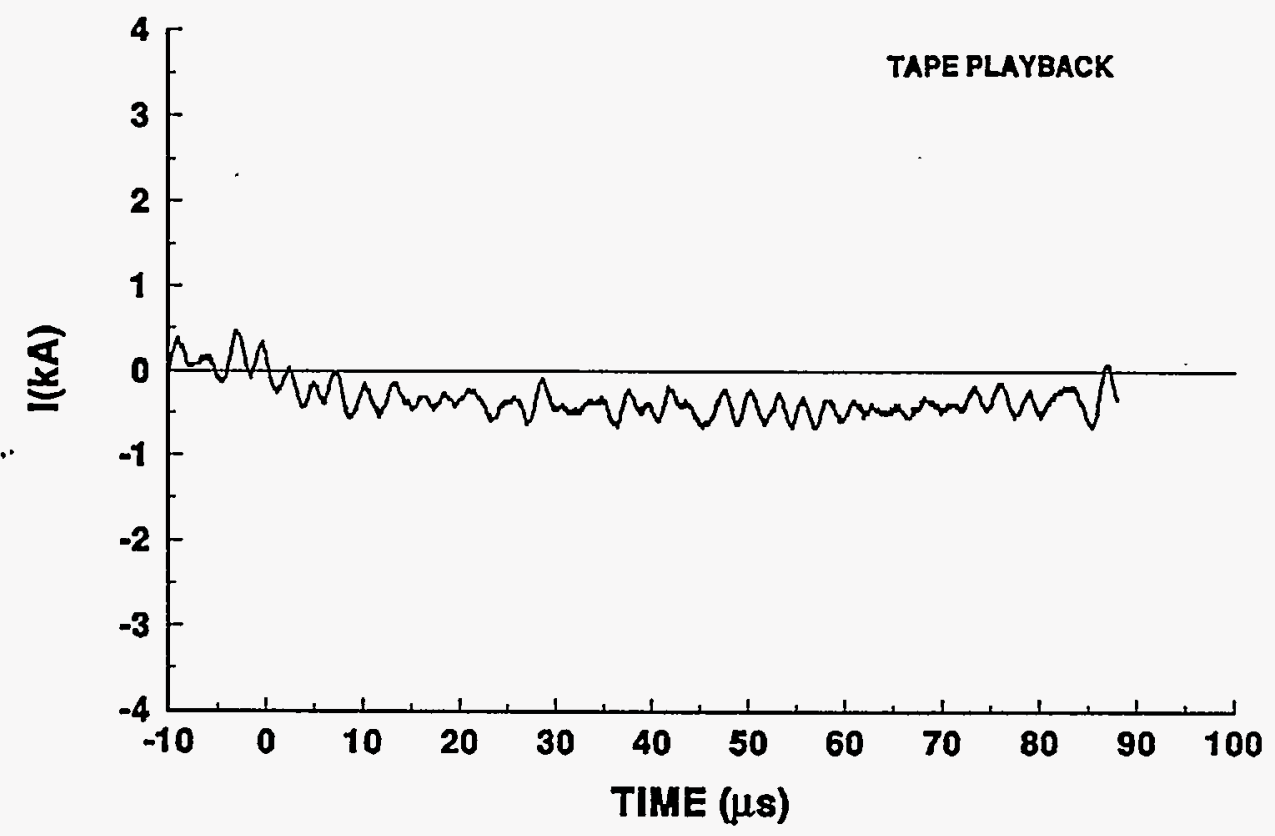

94-14 STROKE 2.

TEST POINT 6

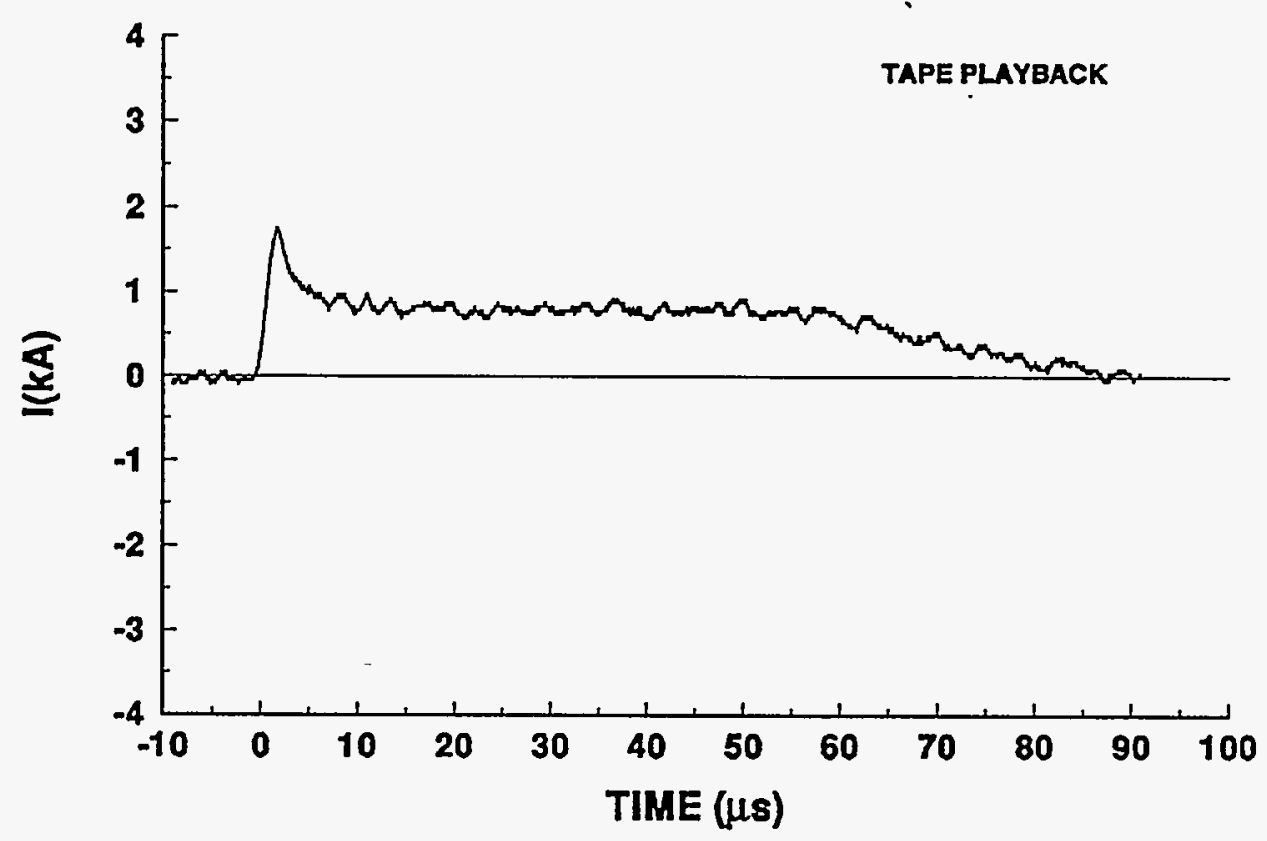


94-14 STROKE 2

TEST POINT 7

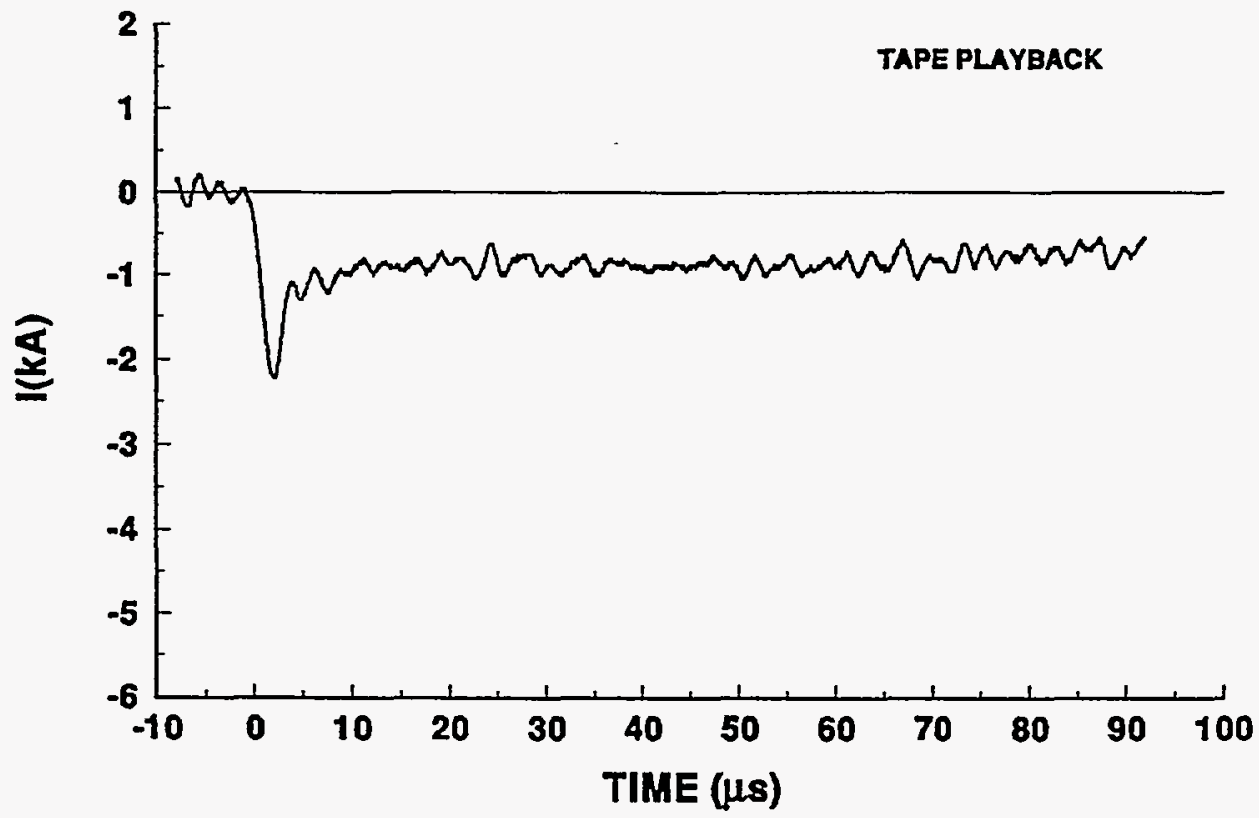

94-14 STROKE. 2

TEST POINT 8

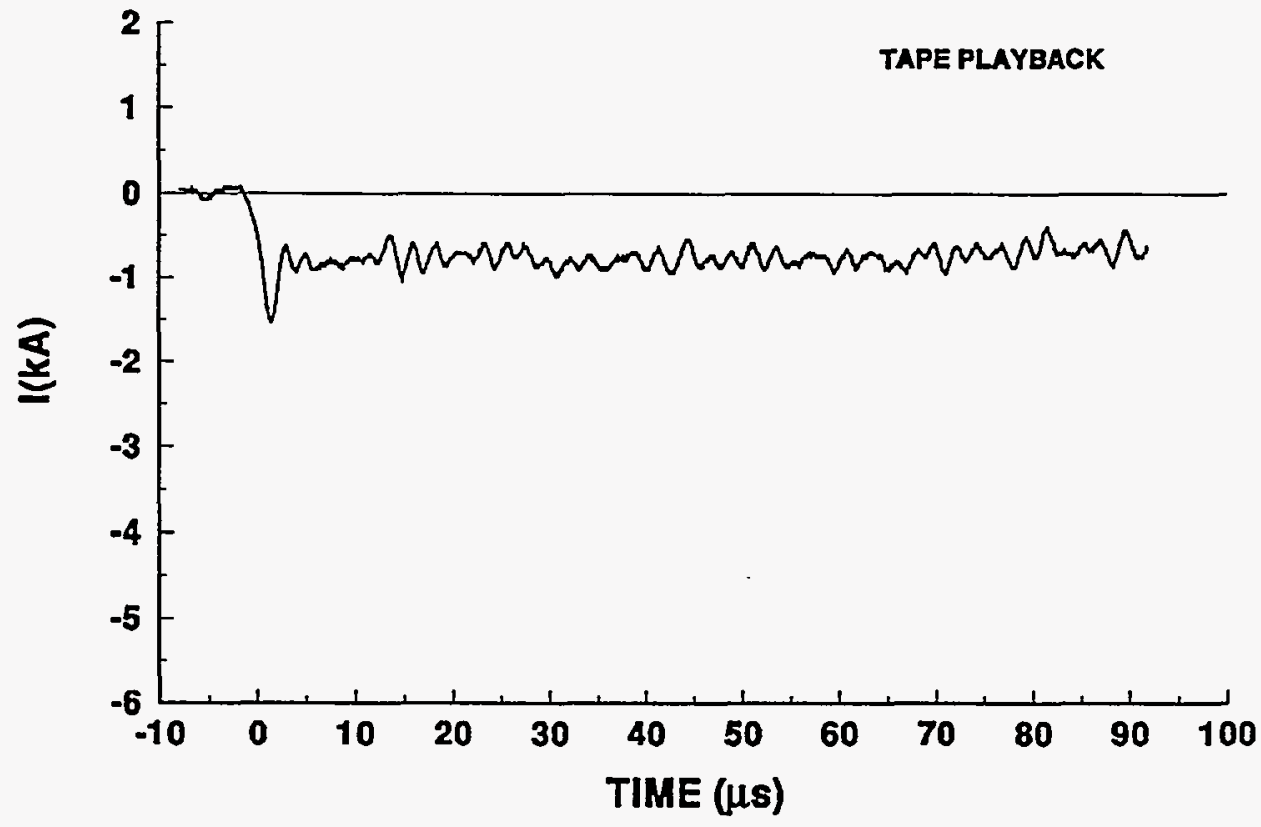




\section{4-14 STROKE 2}

TEST POINT 9

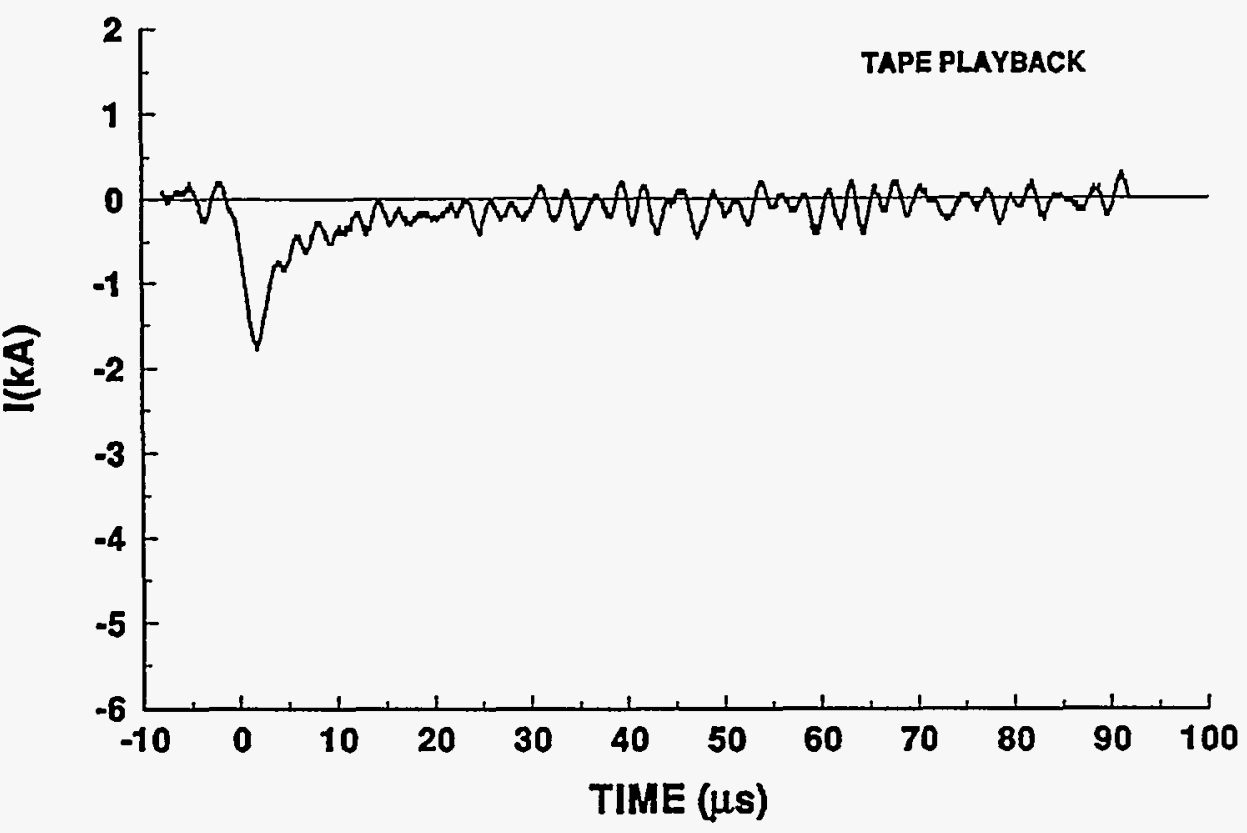

\section{4-14 STROKE 2}

TEST POINT 9'

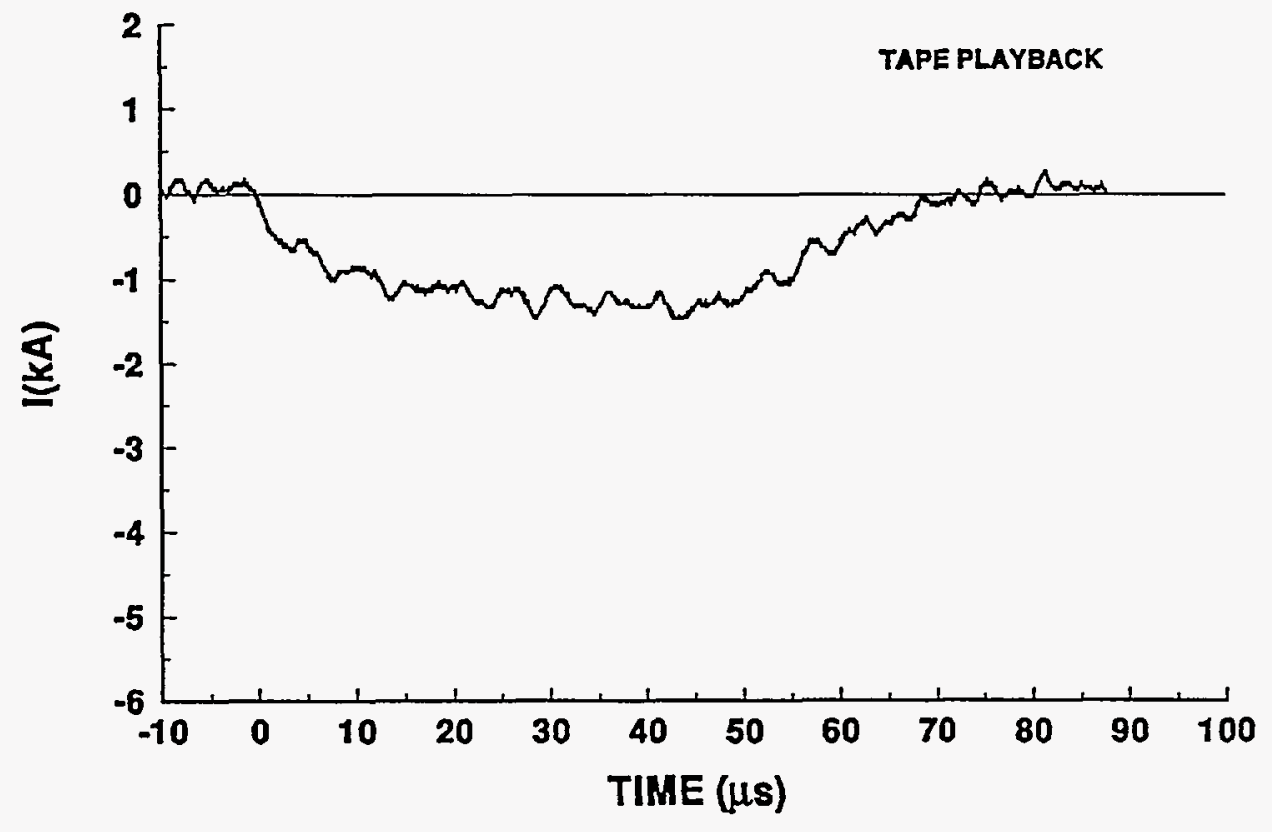




\section{4-14 STROKE 2}

\section{TEST POINT 16}

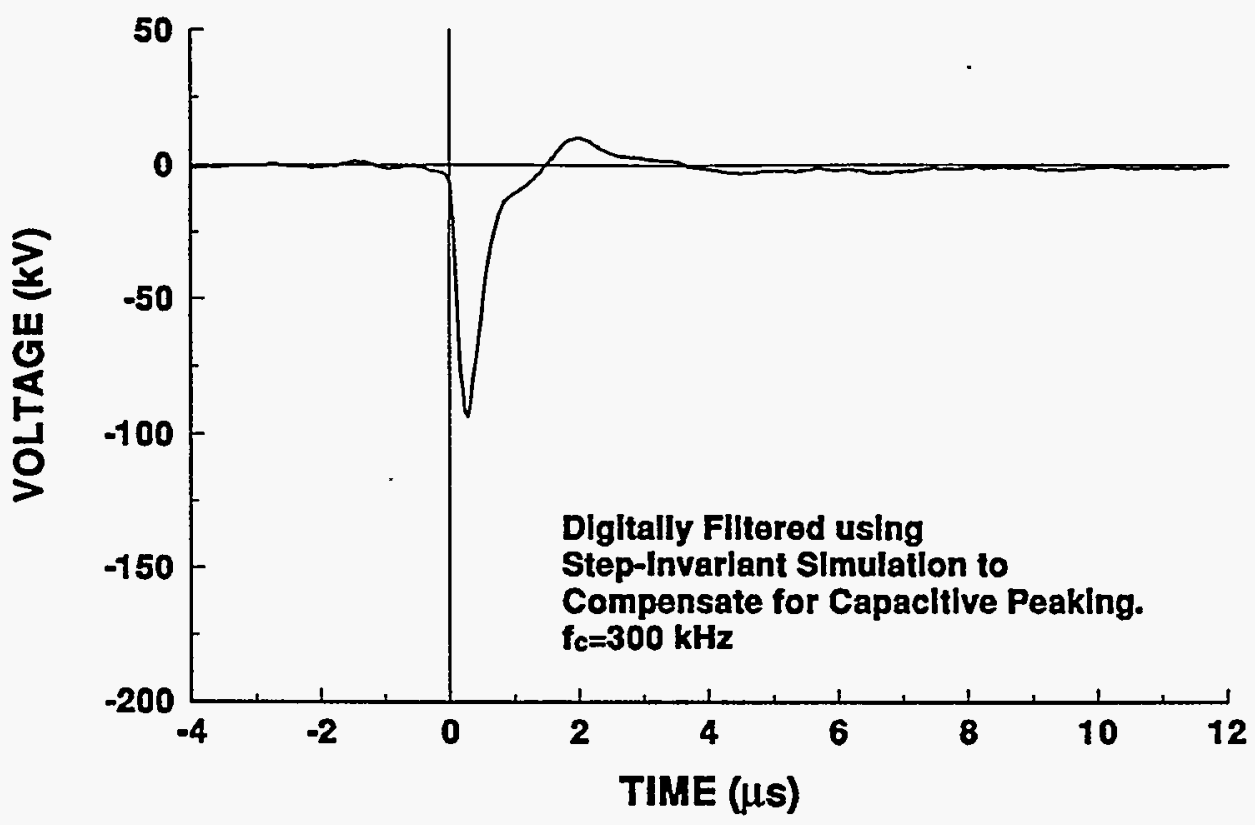

94-14 STROKE 2

TEST POINT 17

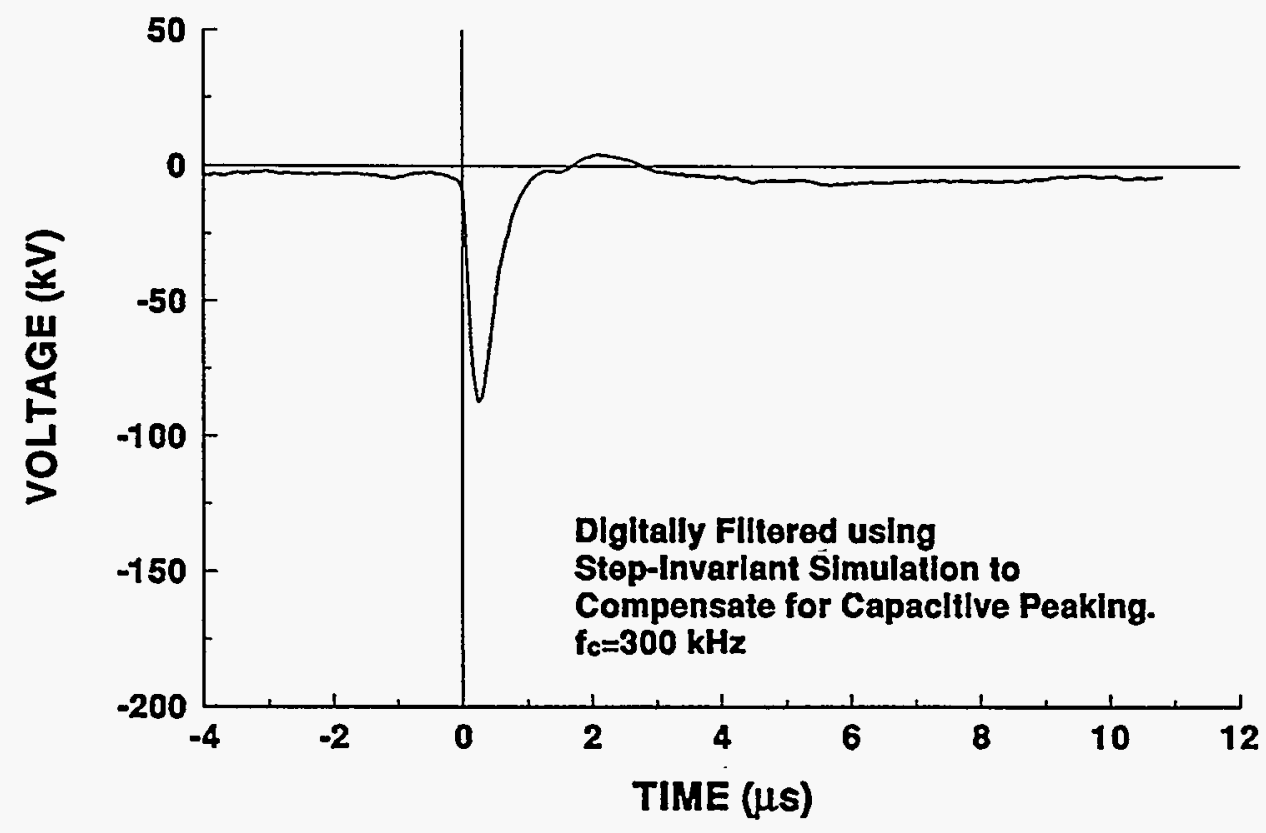




\section{4-14 STROKE 2}

\section{TEST POINT 18}

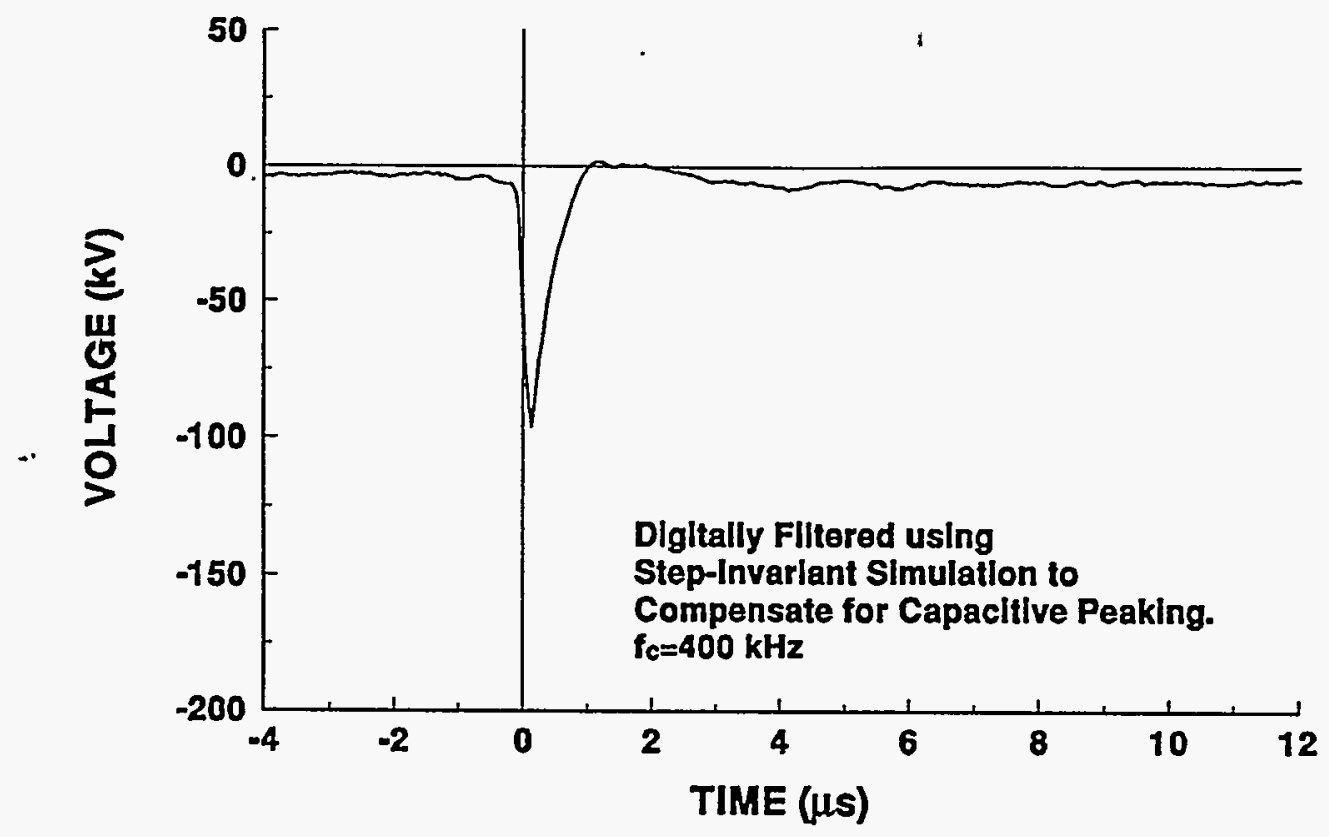

\section{4-14 STROKE 2}

TEST POINT 19

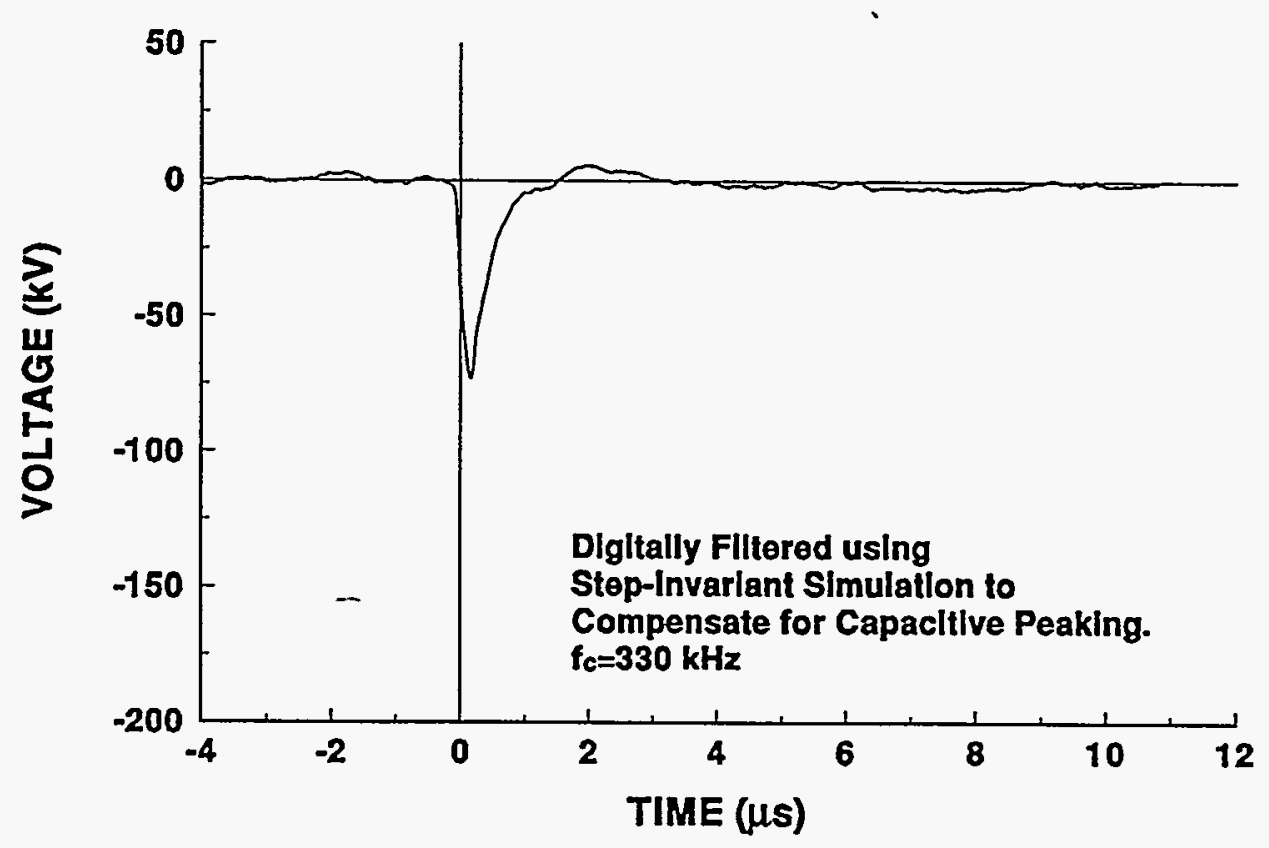




\section{4-14 STROKE 2}

TEST POINT 20

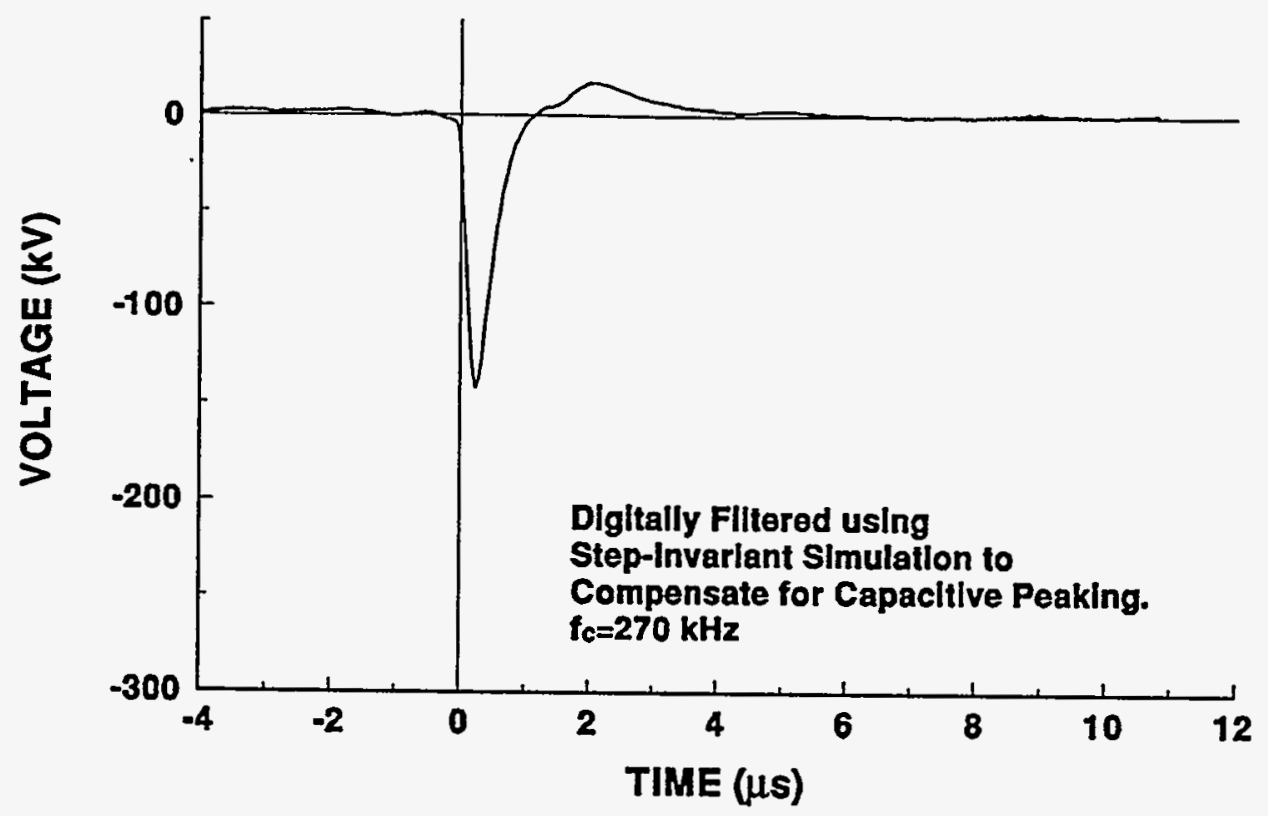

94-14 STROKE 2

TEST POINT 22

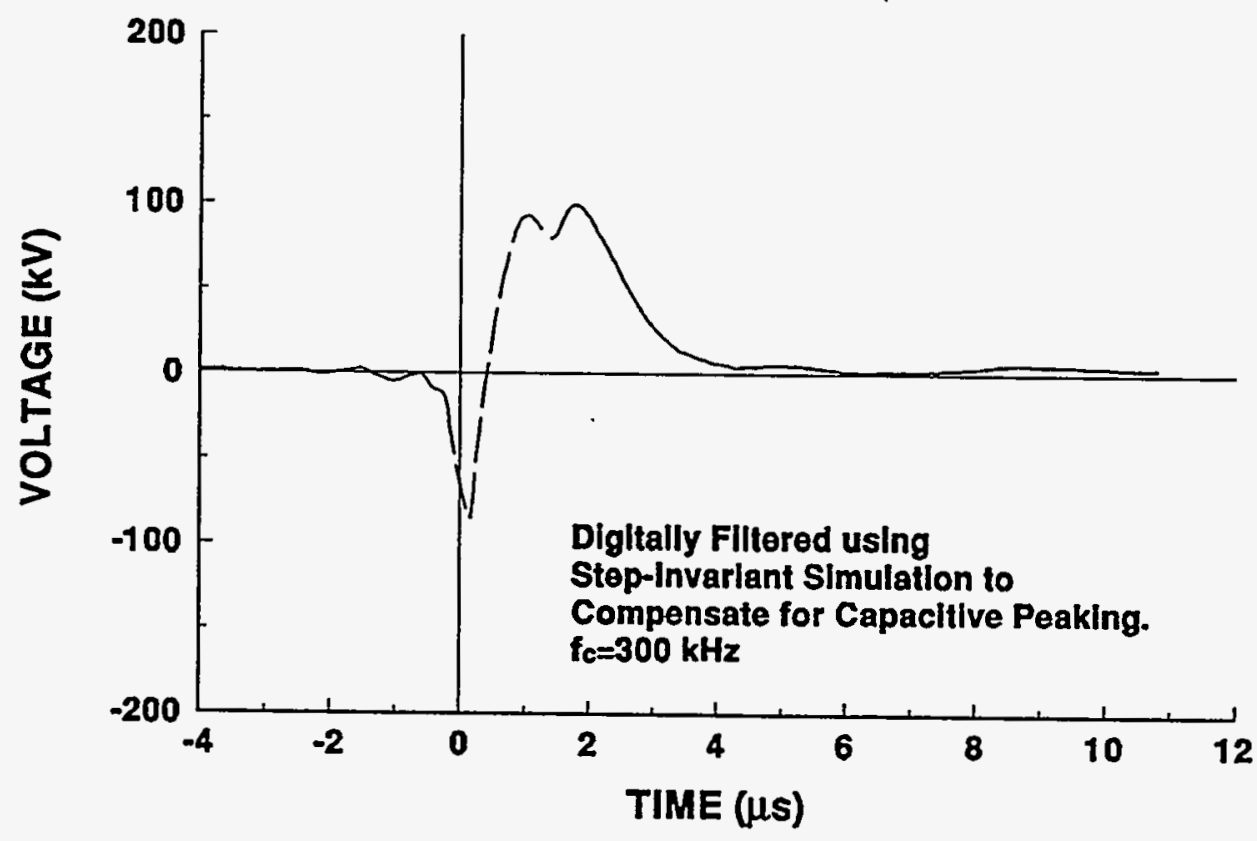




\section{4-14 STROKE 2}

\section{TEST POINT 23}

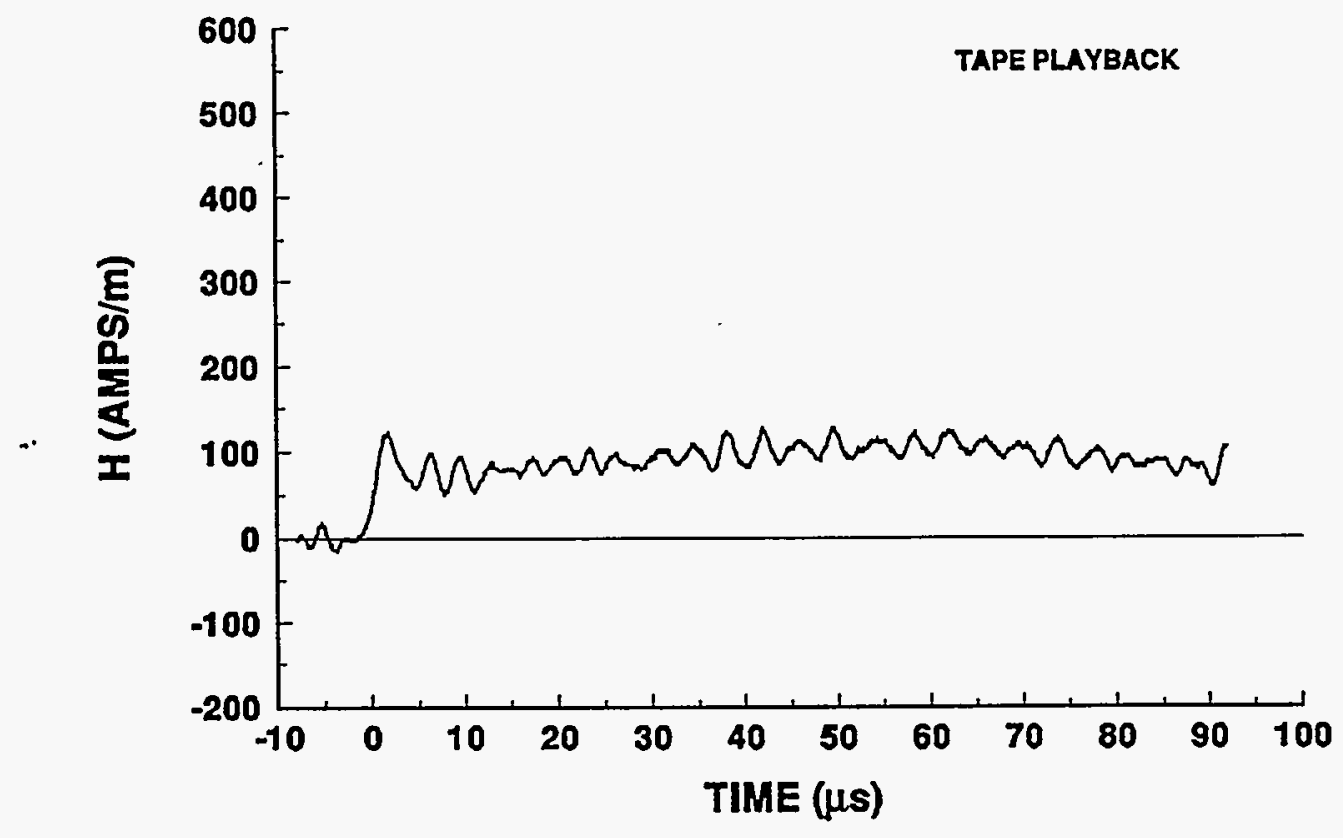

94-14 STROKE 2

TEST POINT 24

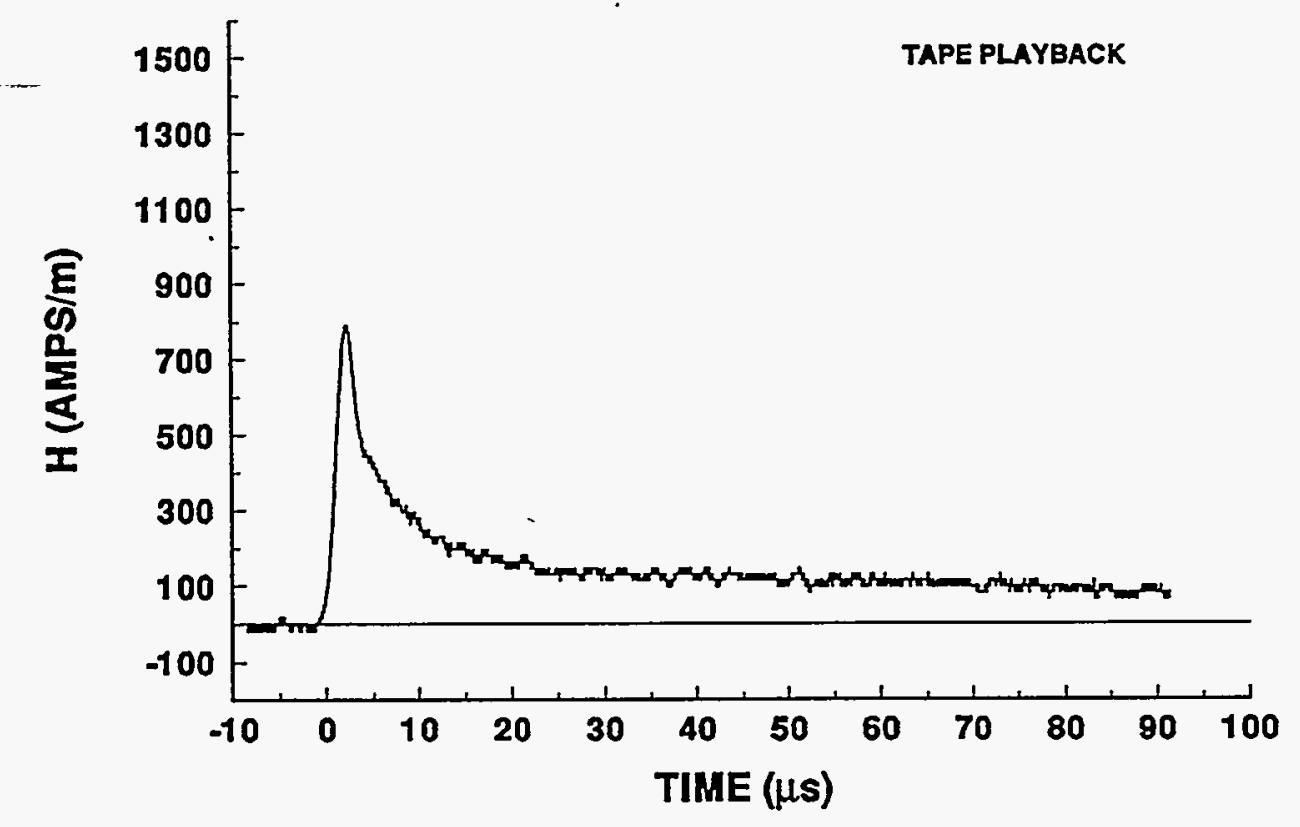




\section{4-14 STROKE 3 \\ INCIDENT CURRENT}
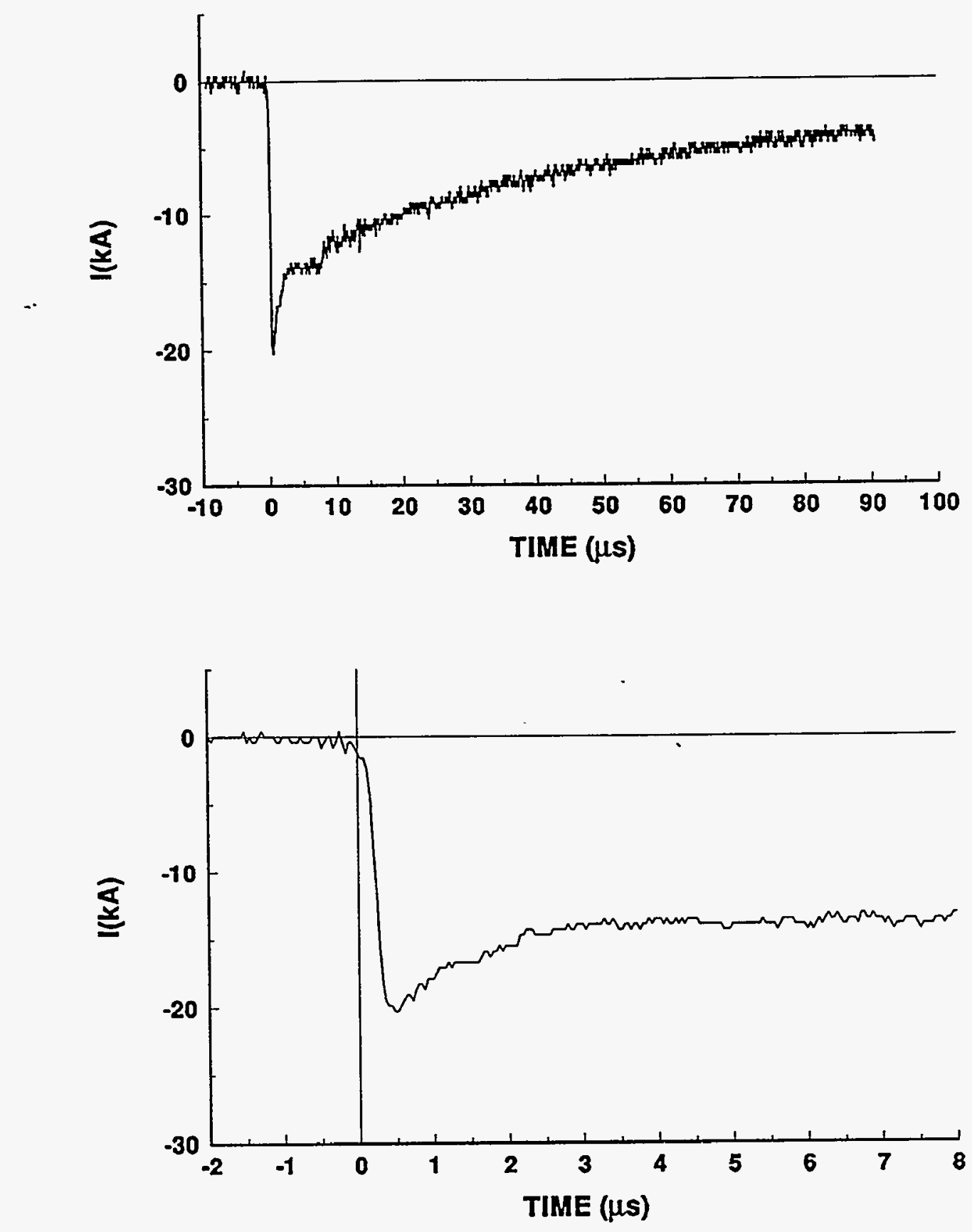


\section{4-14 STROKE 3}

TEST POINT 1

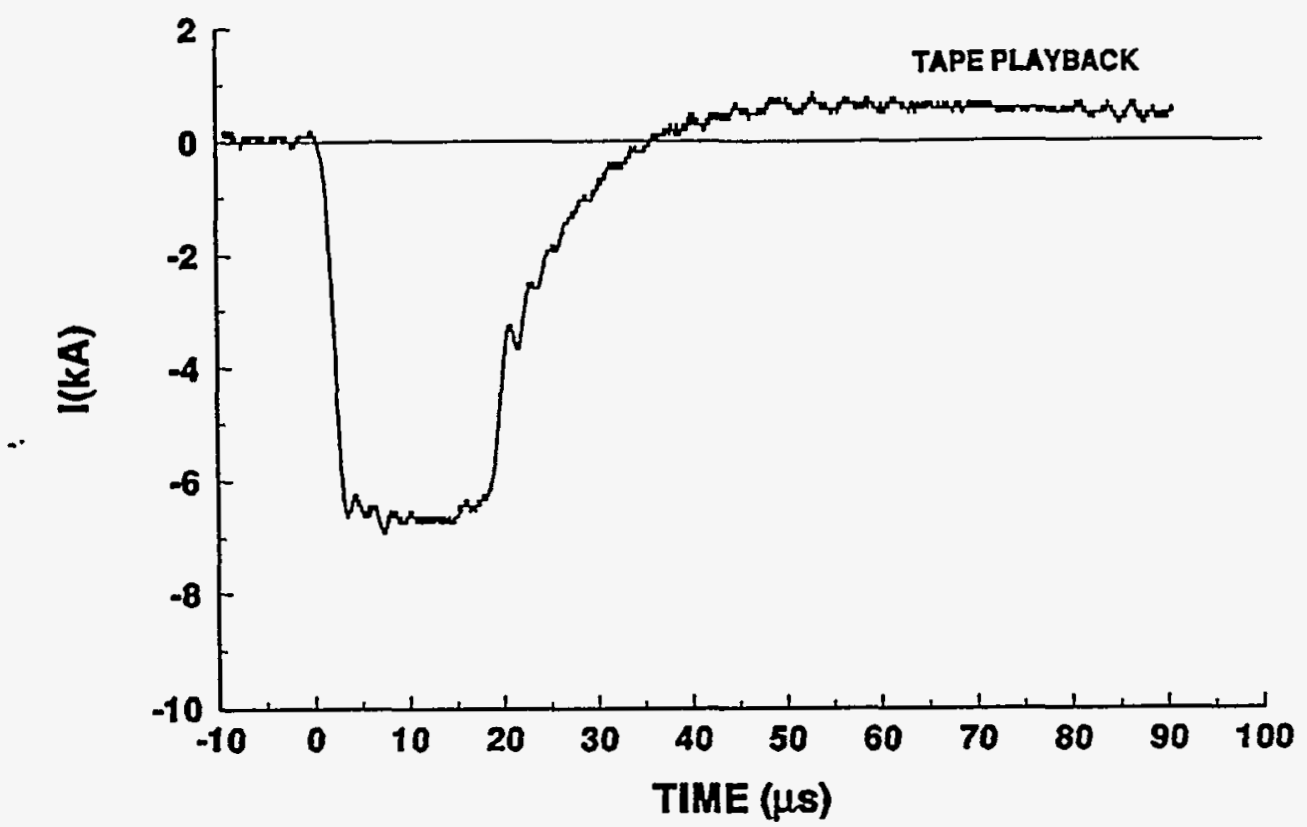

\section{4-14 STROKE 3}

TEST POINT 2

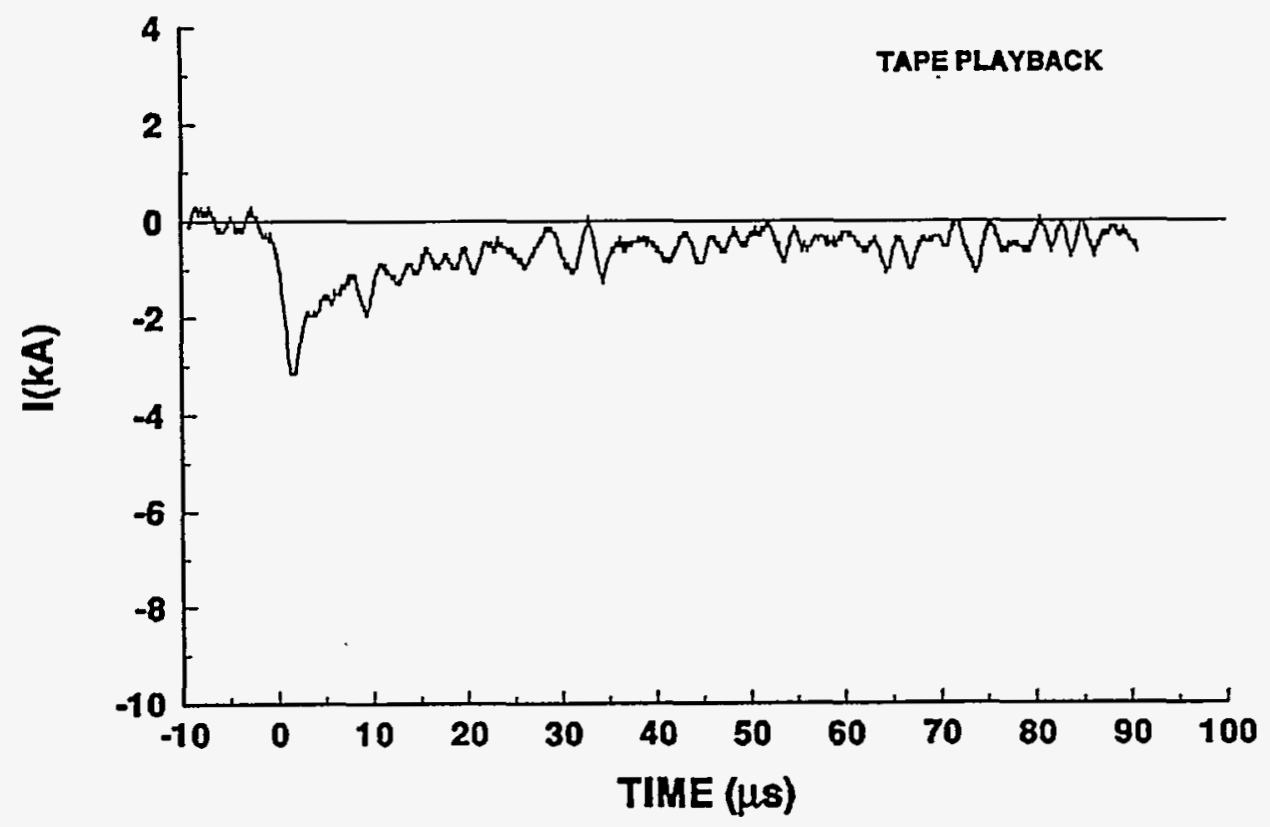


94-14 STROKE 3

TEST POINT 3
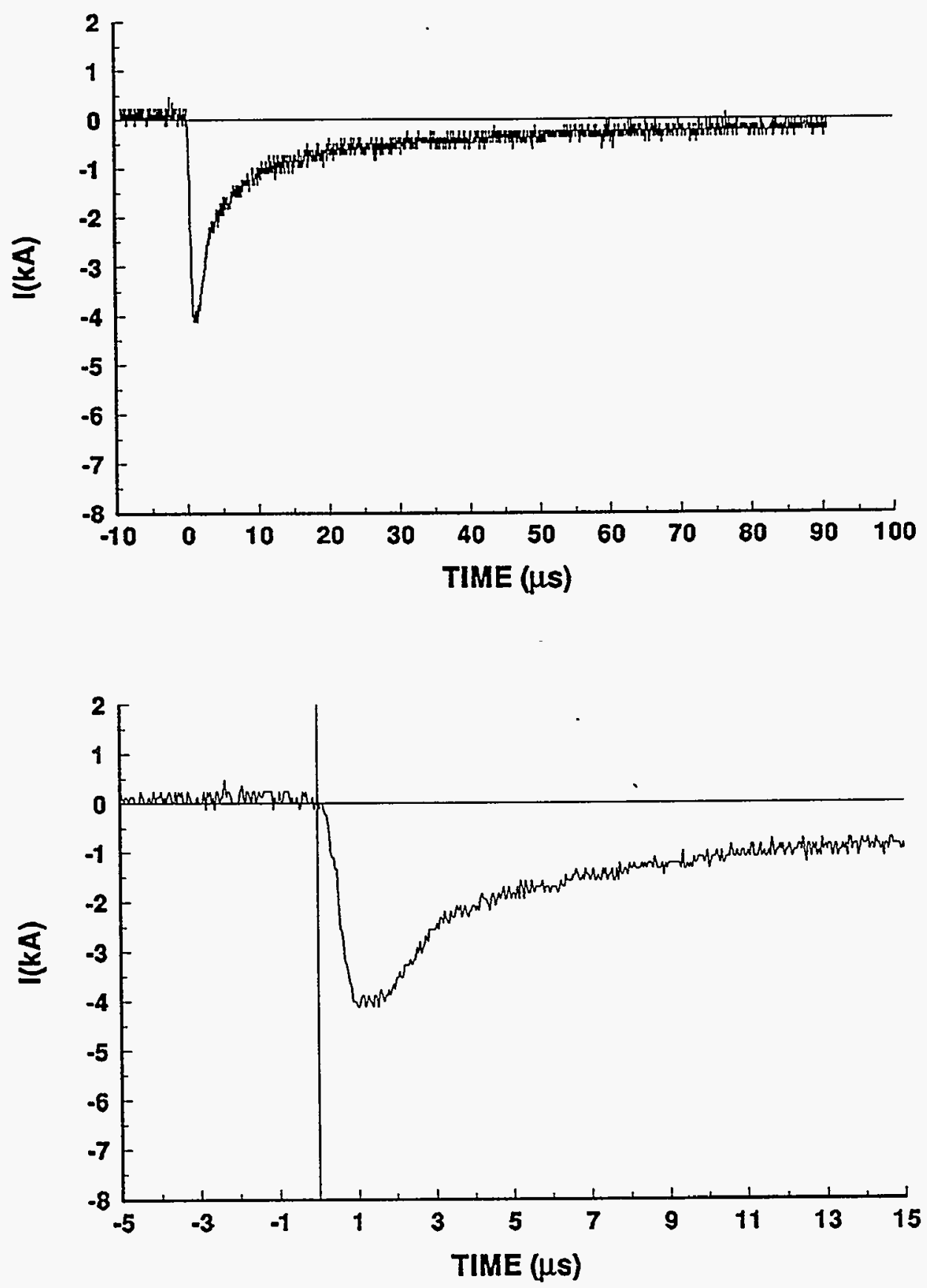


\section{4-14 STROKE 3}

TEST POINT 4
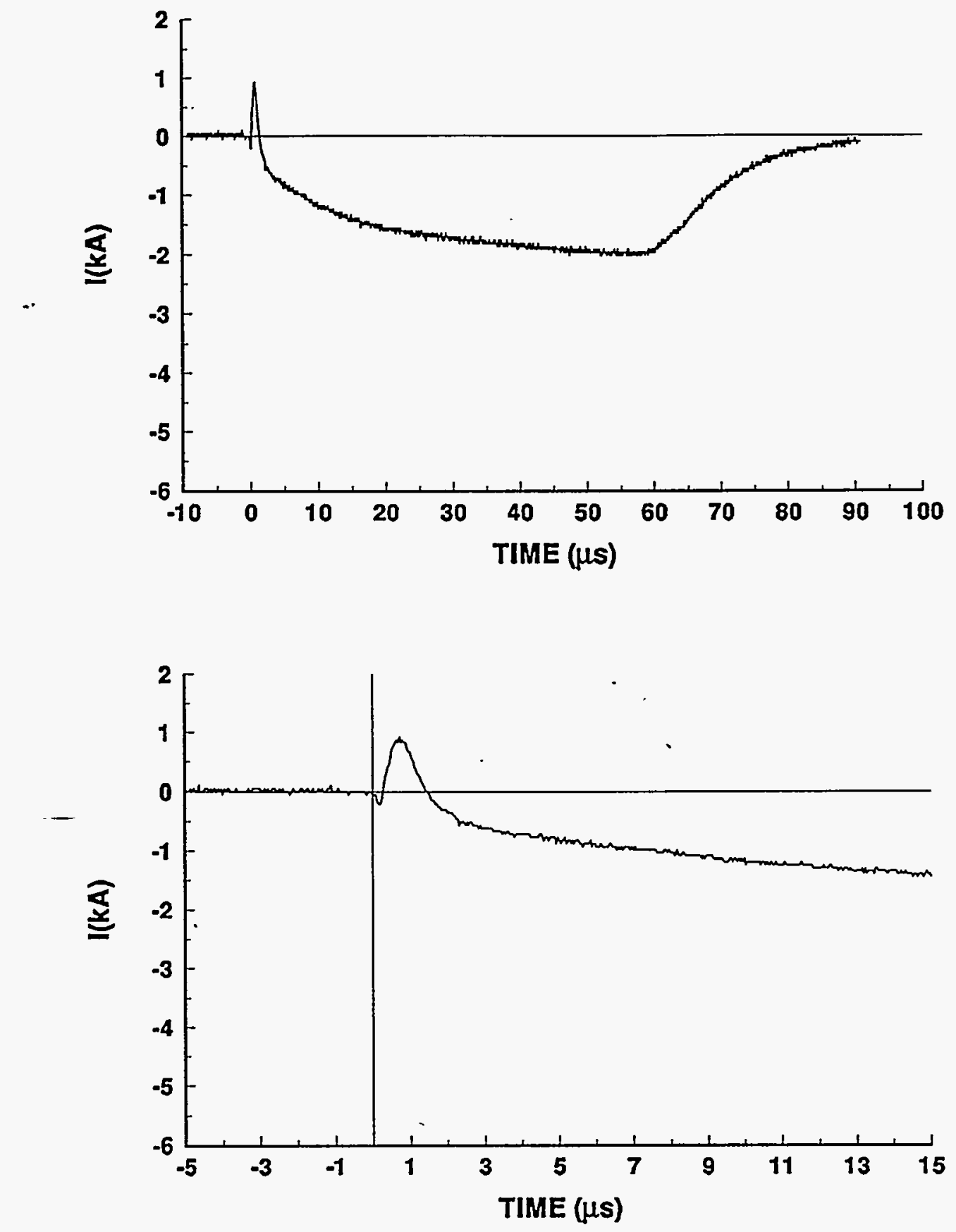


\section{4-14 STROKE 3}

\section{TEST POINT 5}

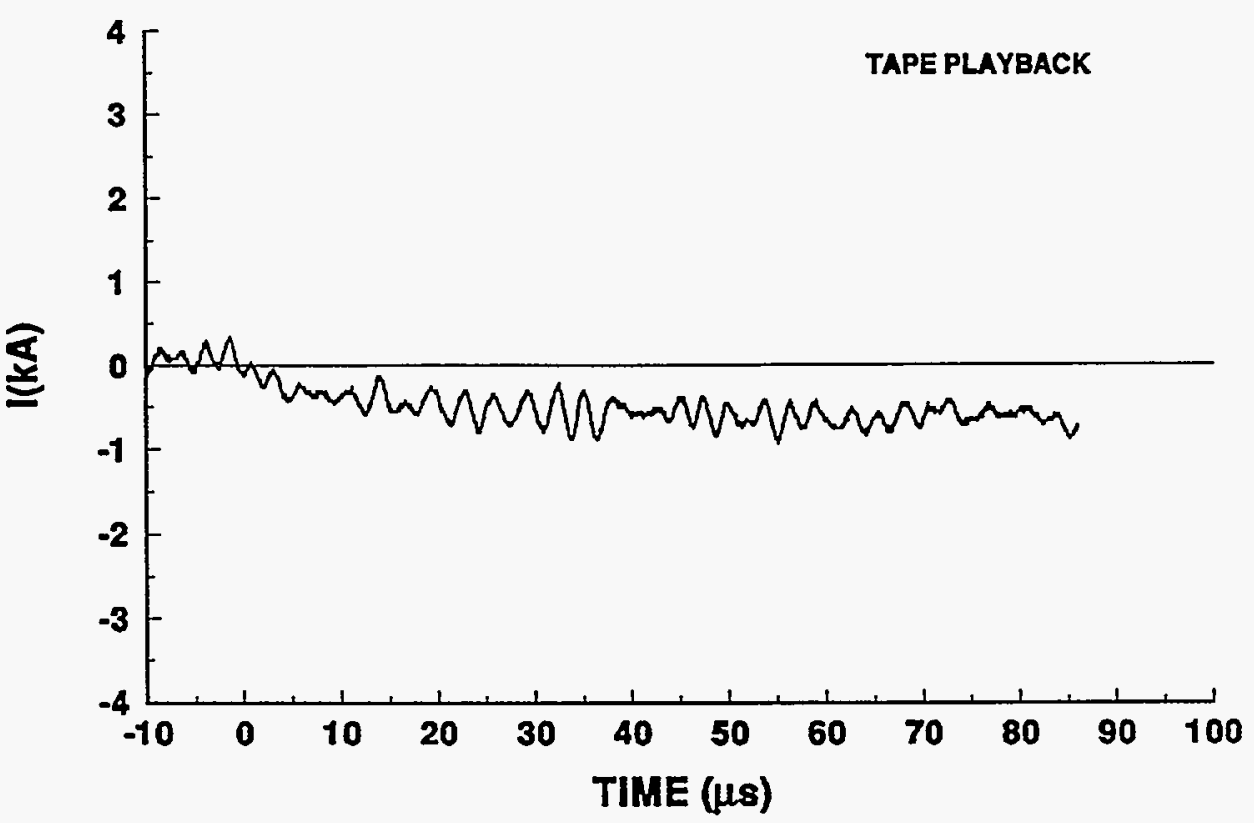

\section{4-14 STROKE 3}
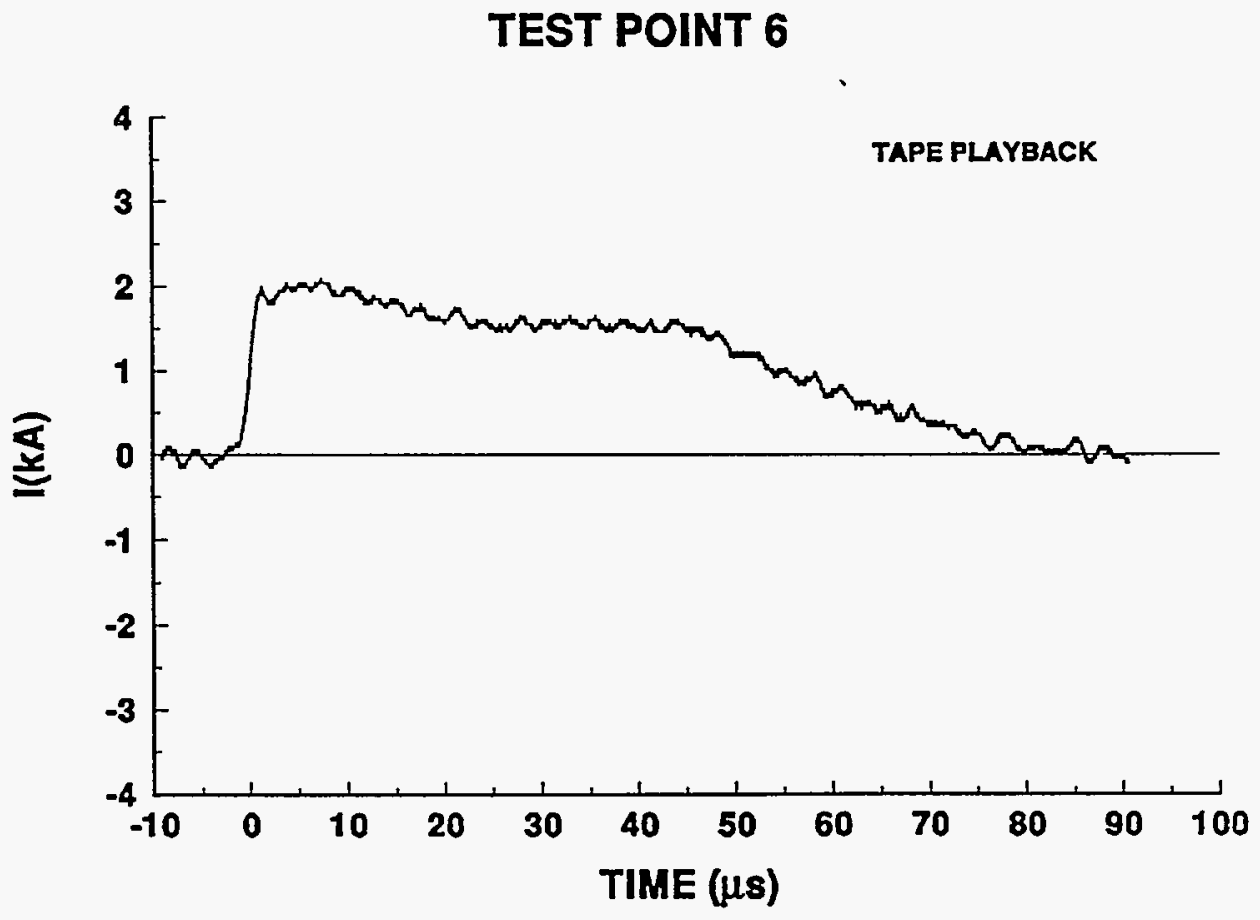
94-14 STROKE 3

TEST POINT 7

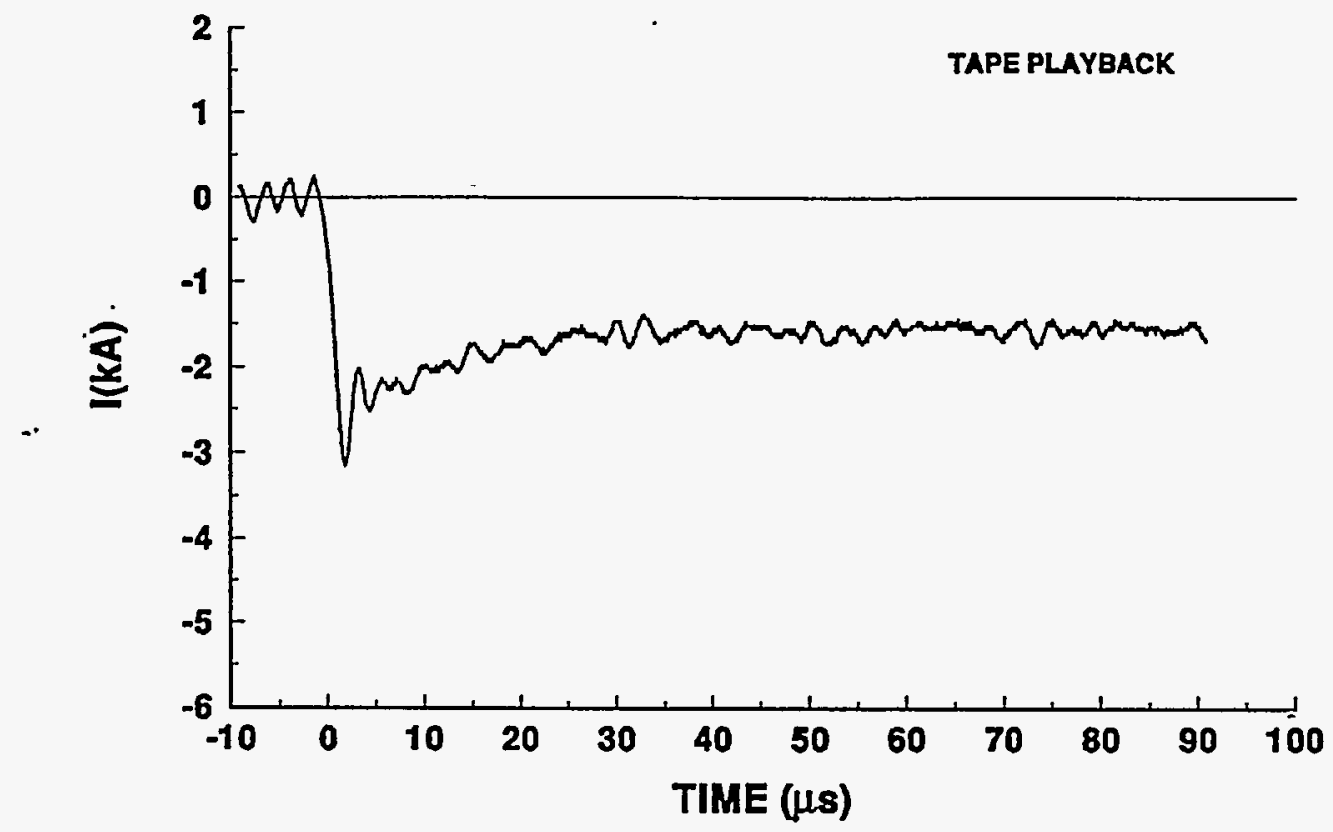

94-14 STROKE-3

TEST POINT 8

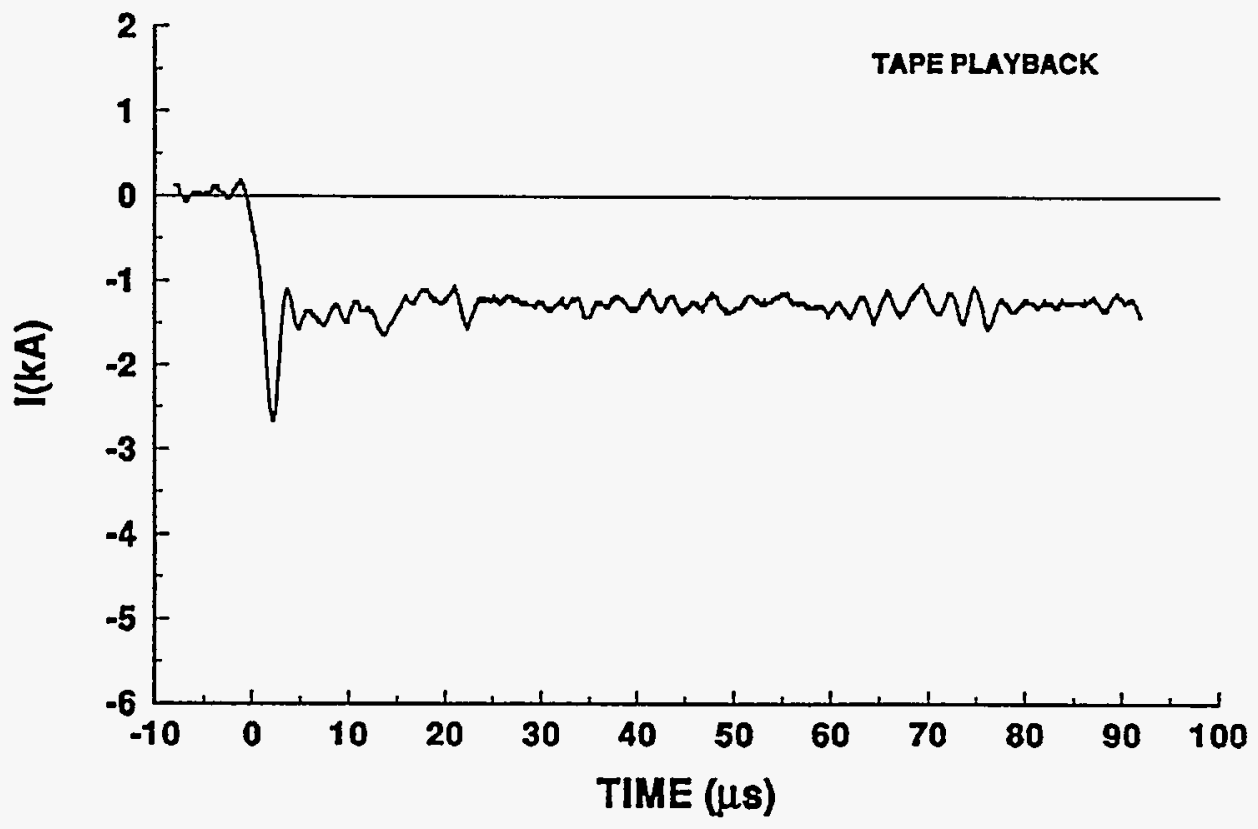




\section{4-14 STROKE 3}

TEST POINT 9

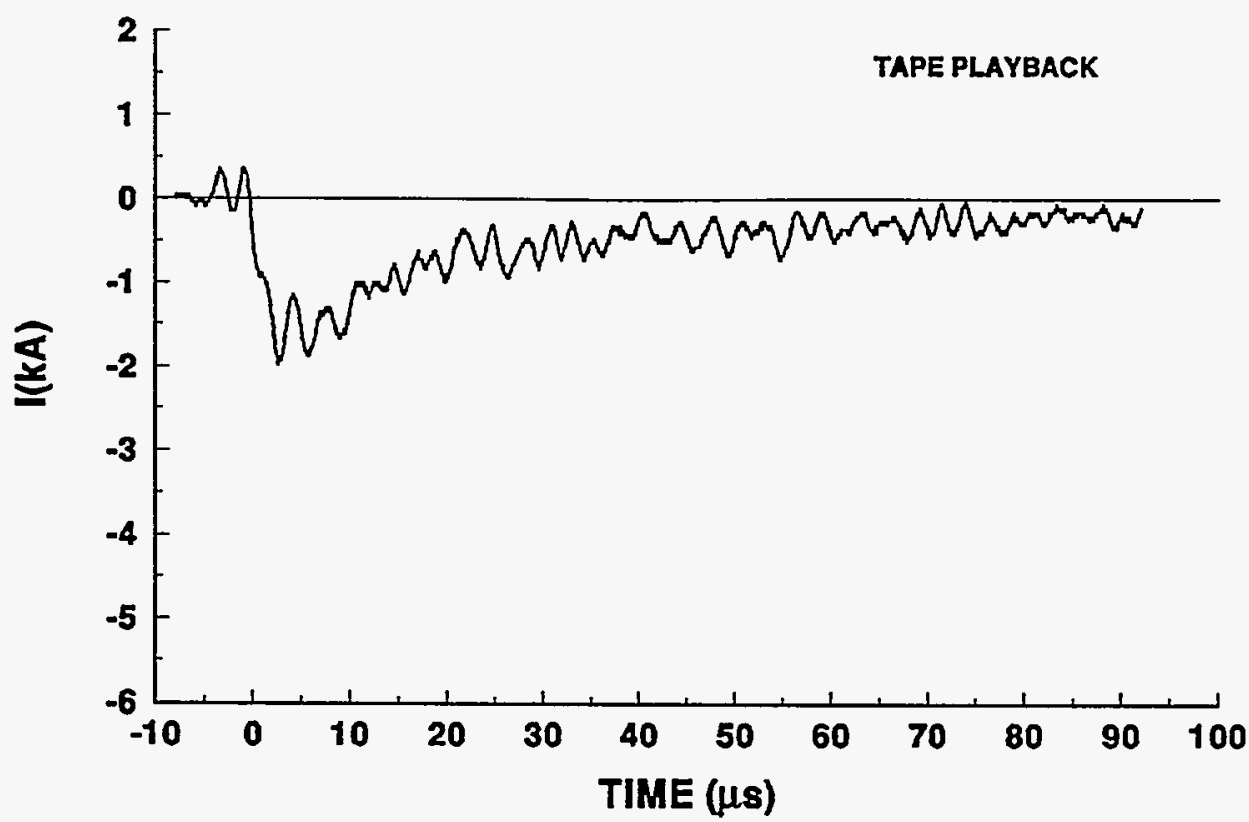

\section{4-14 STROKE 3}

TEST POINT 9'

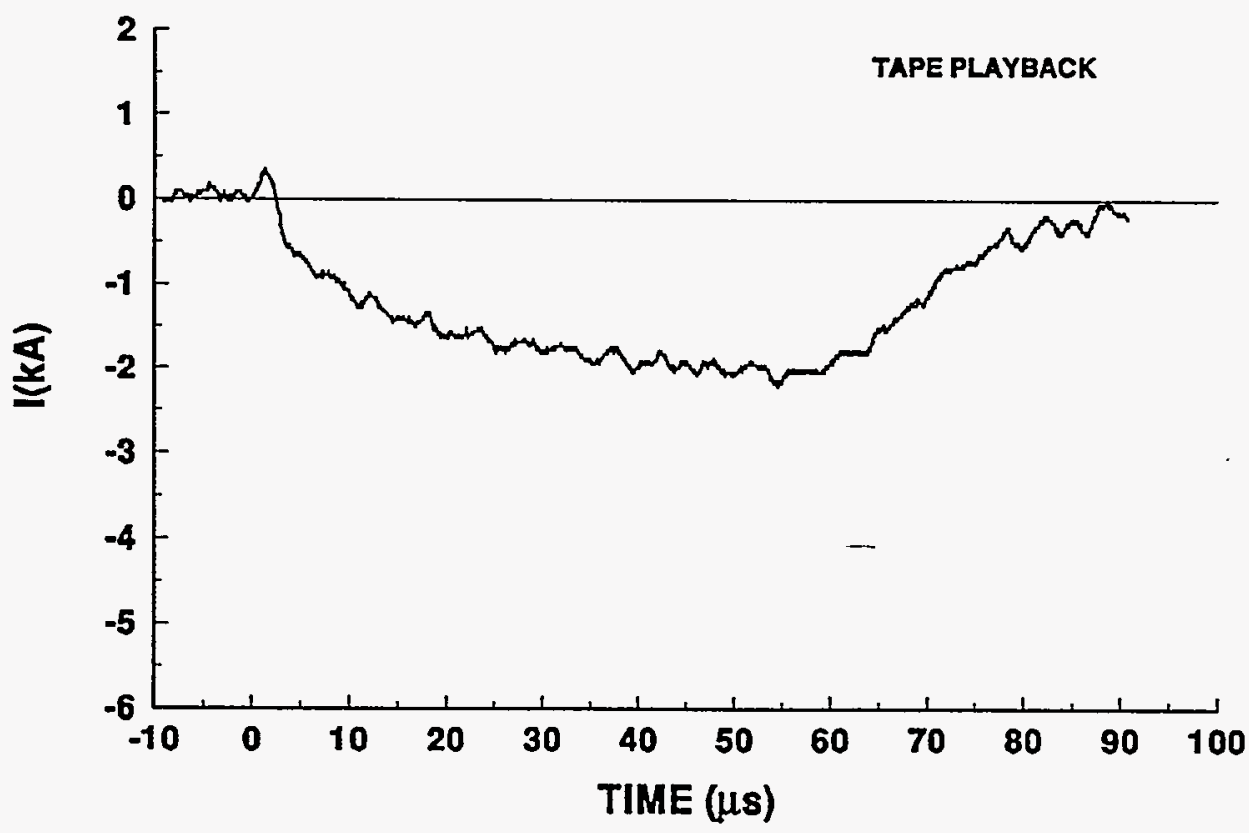




\section{4-14 STROKE 3}

TEST POINT 16

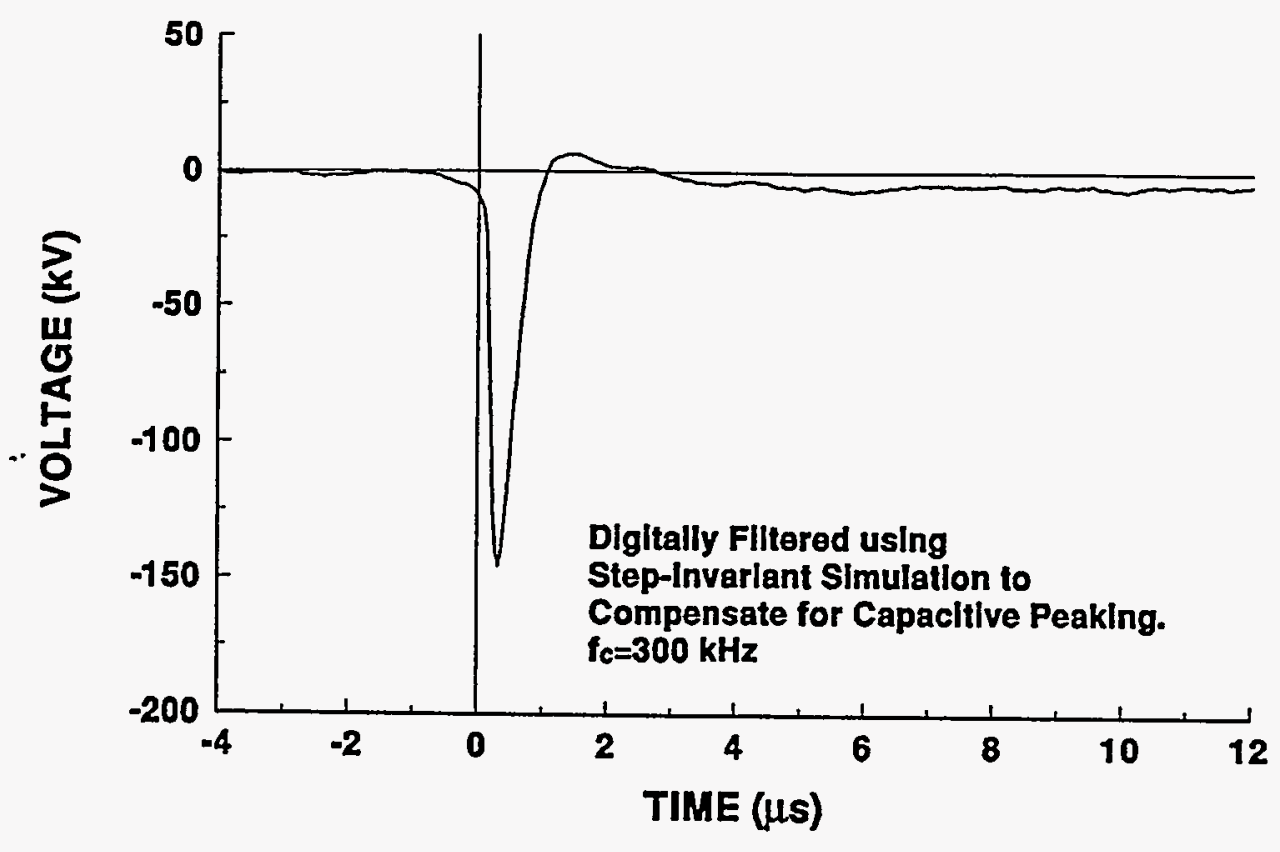

\section{4-14 STROKE 3.} TEST POINT 17

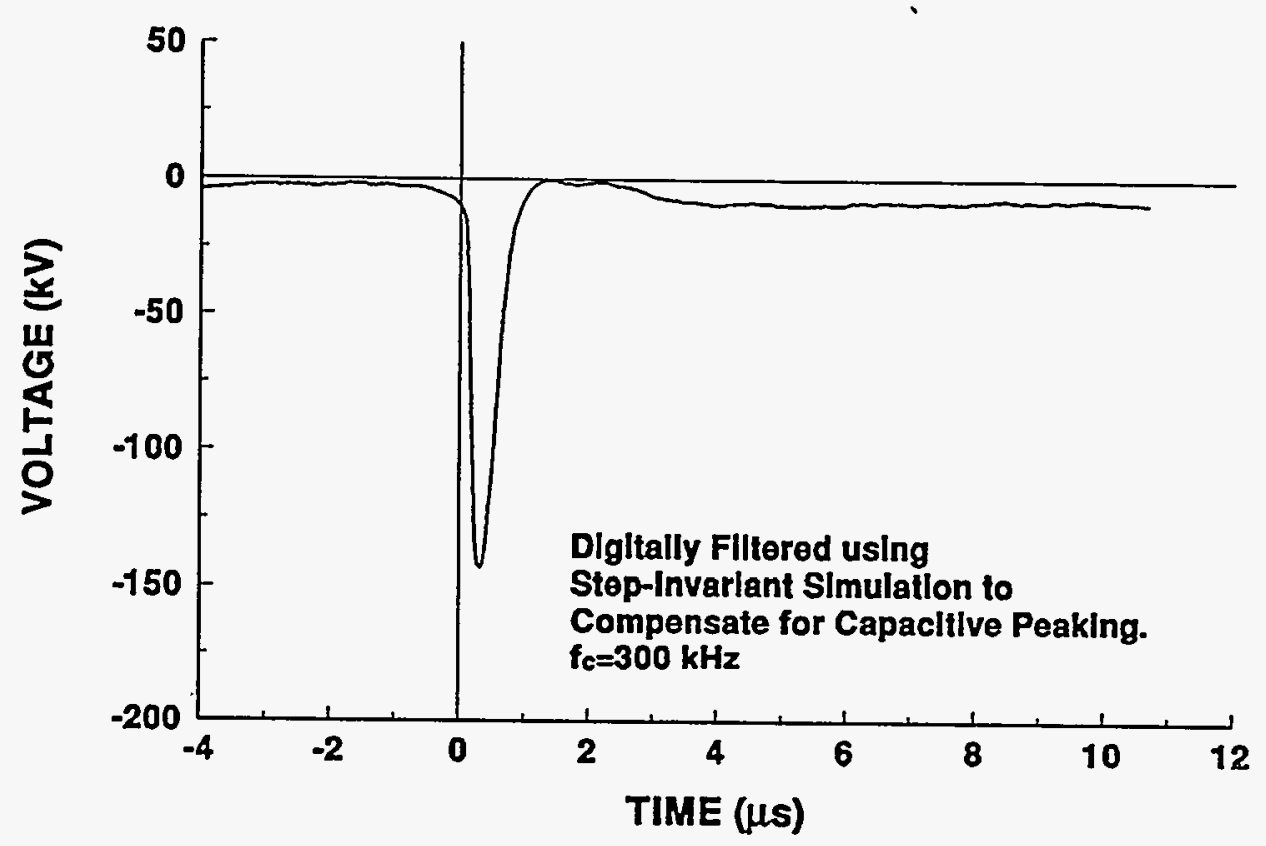




\section{4-14 STROKE 3}

TEST POINT 18

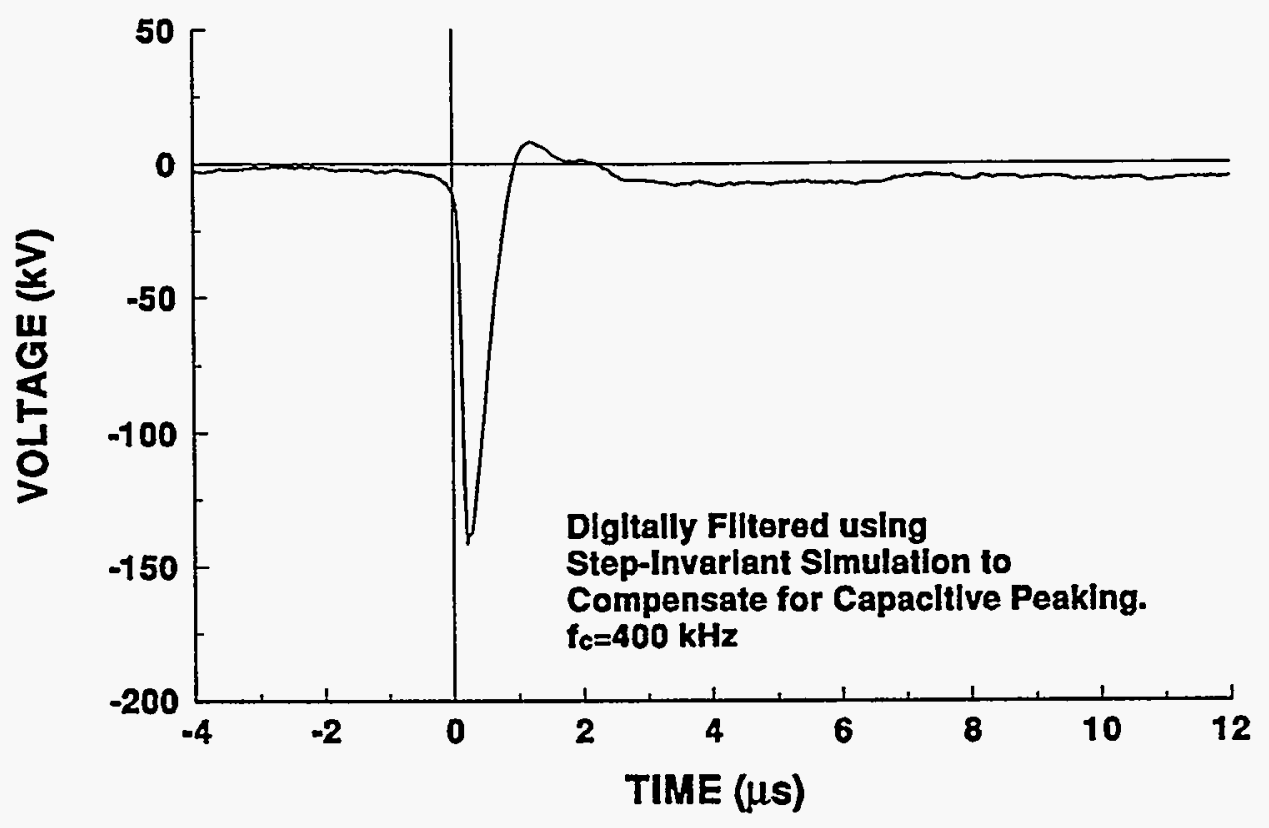

94-14 STROKE 3

TEST POINT 19

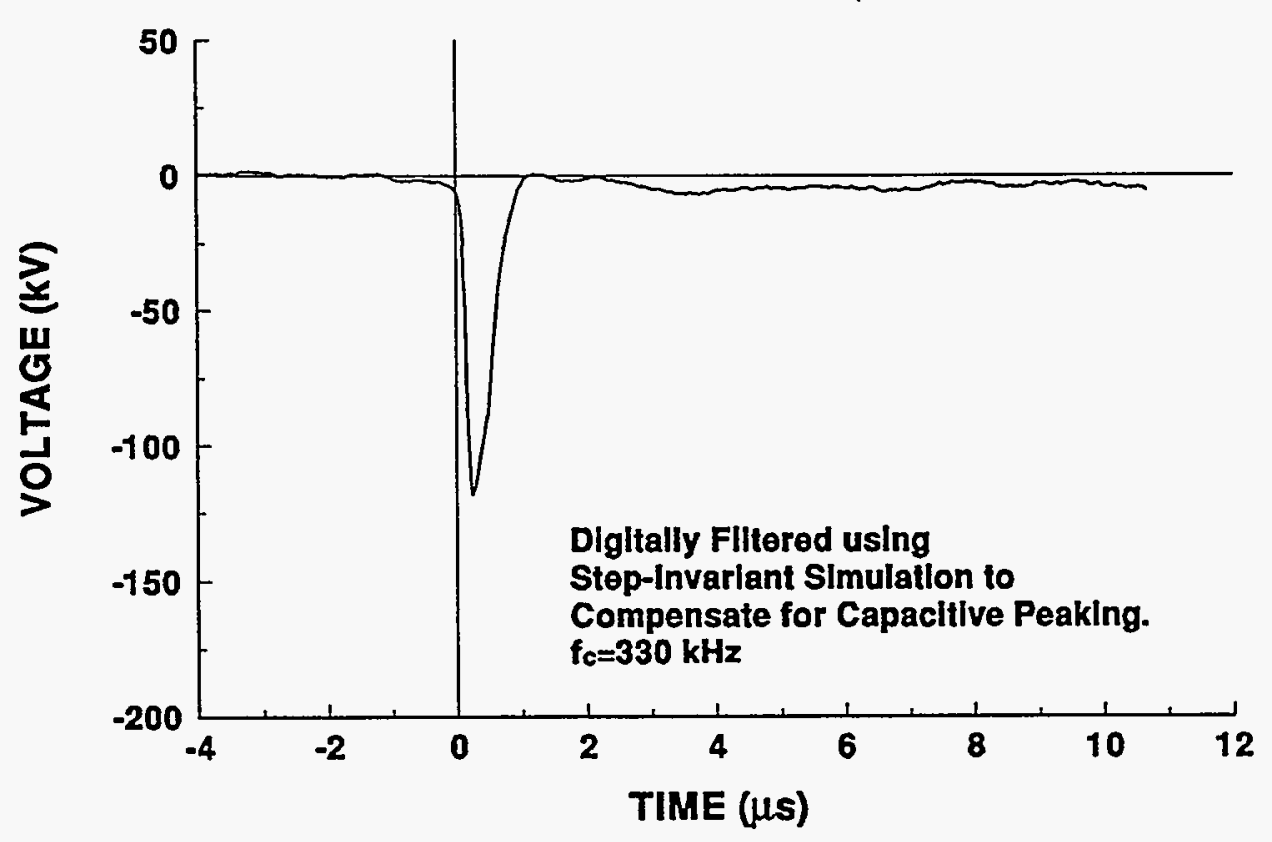




\section{4-14 STROKE 3}

\section{TEST POINT 20}

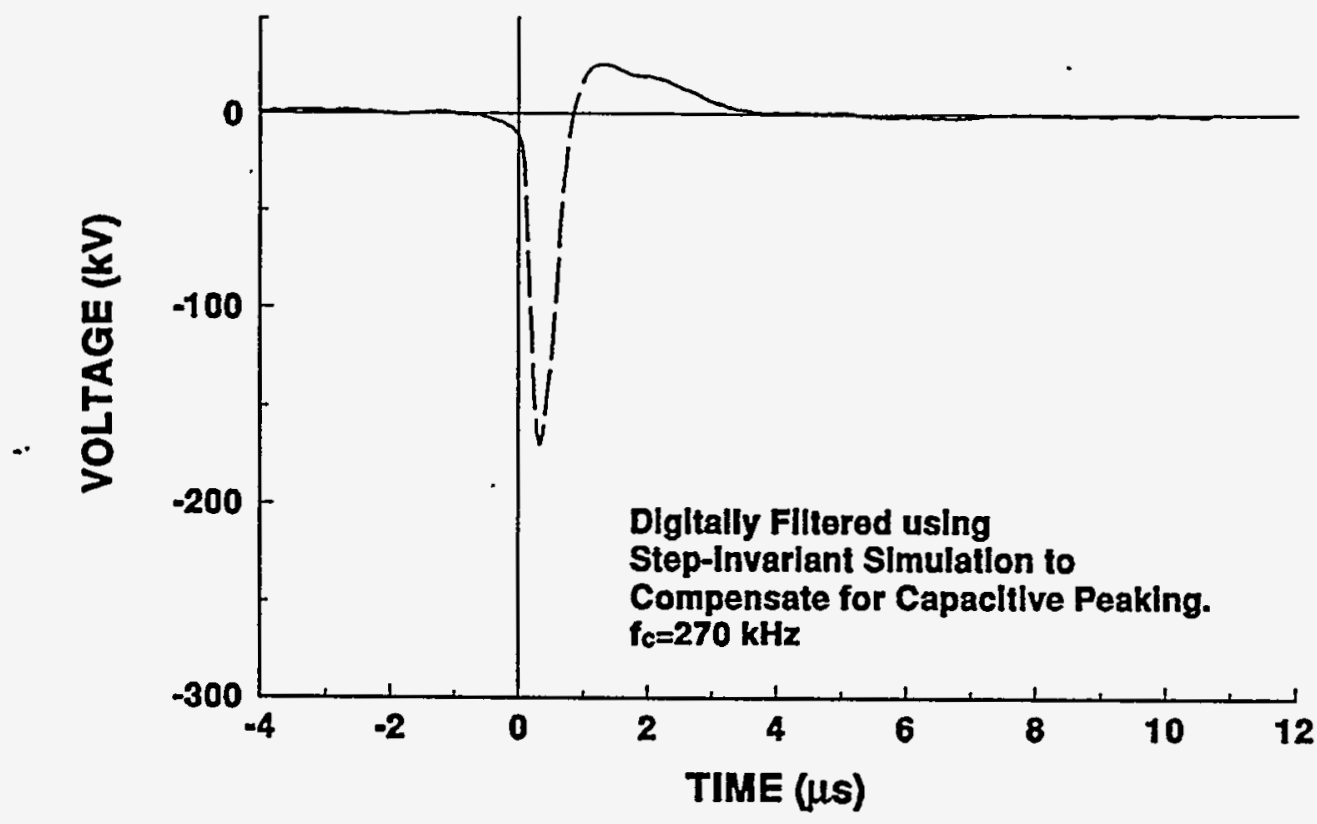

94-1 4 STROKE 3

TEST POINT 22

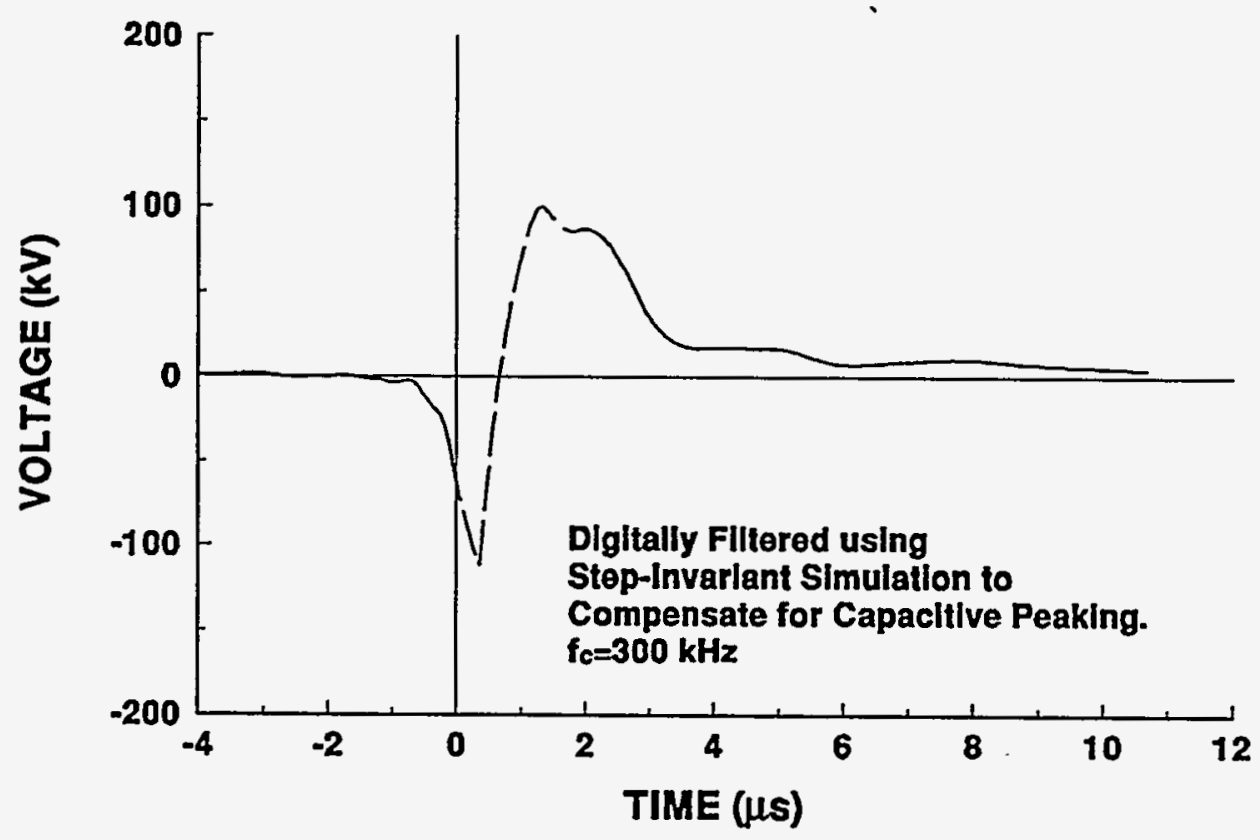




\section{4-14 STROKE 3}

TEST POINT 23

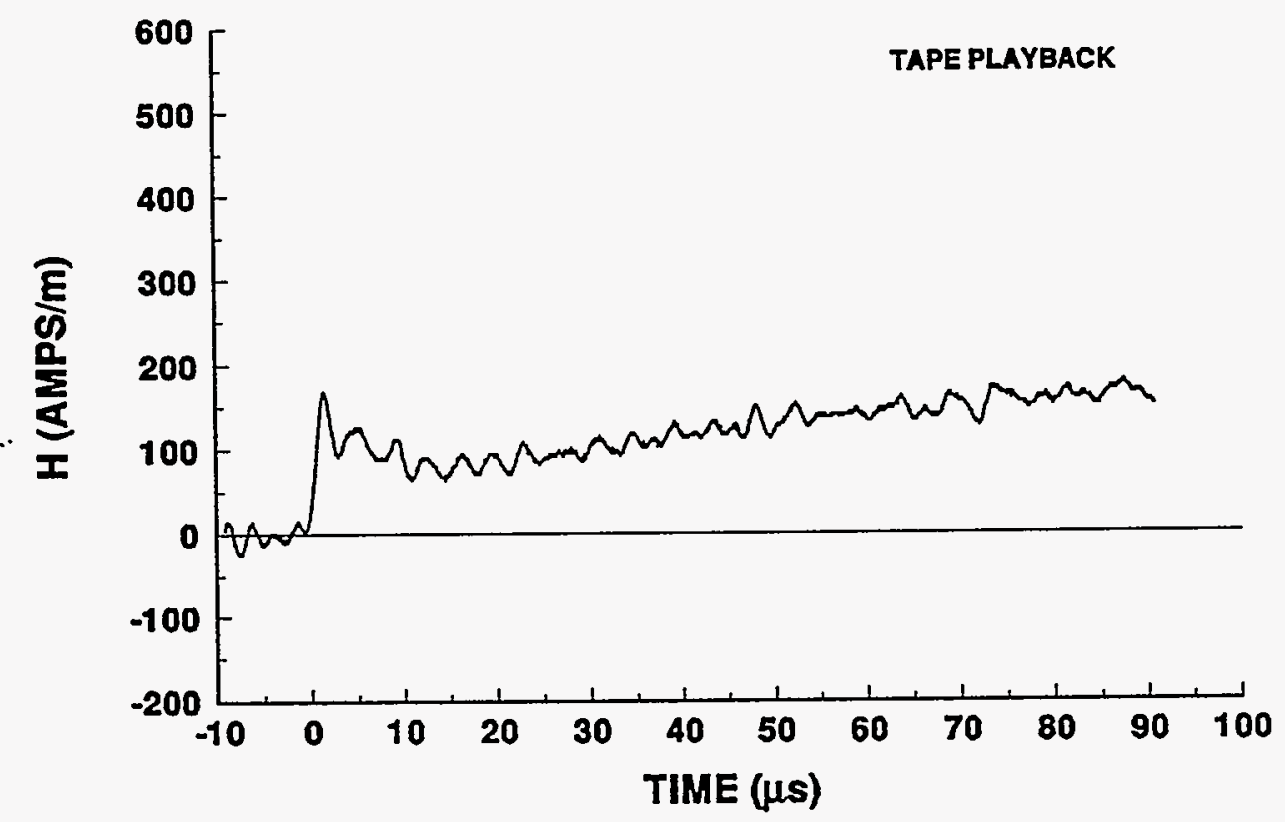

94-14 STROKE 3

TEST POINT 24

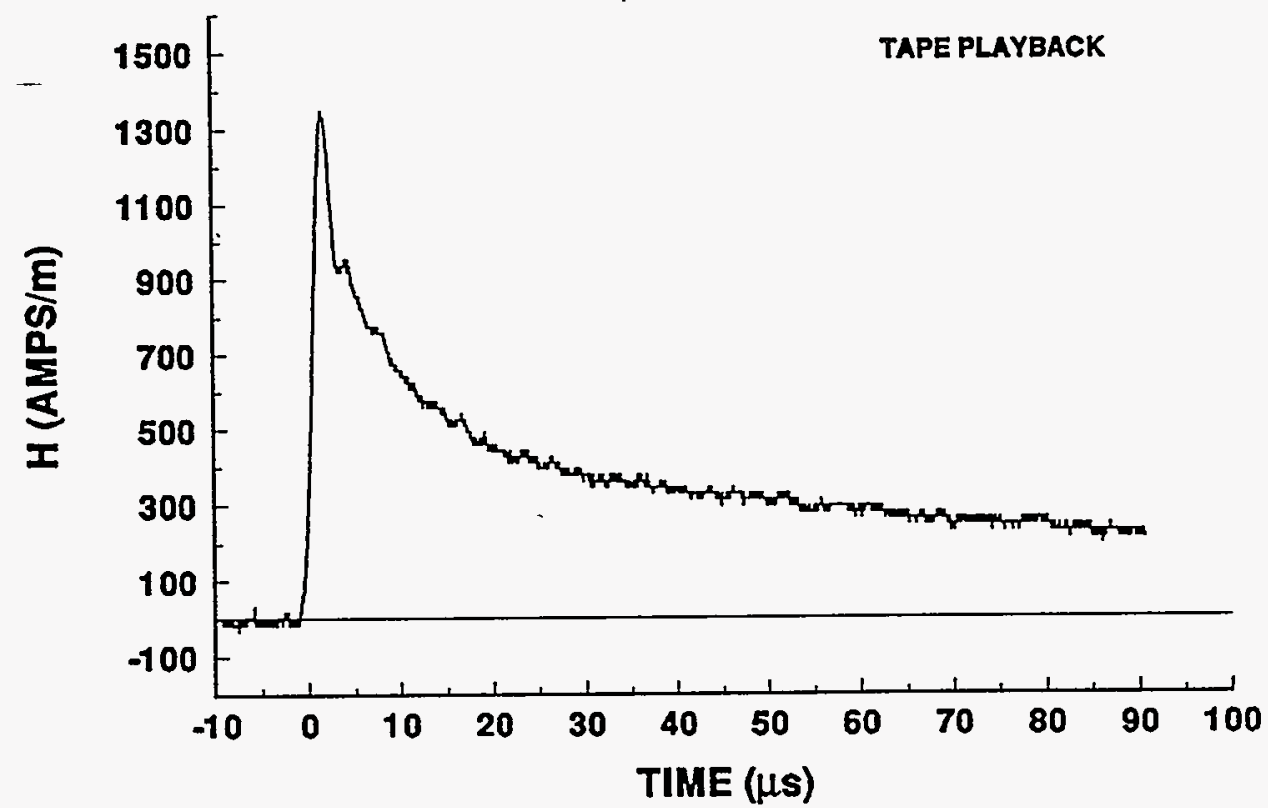


94-14 STROKE 4

INCIDENT CURRENT
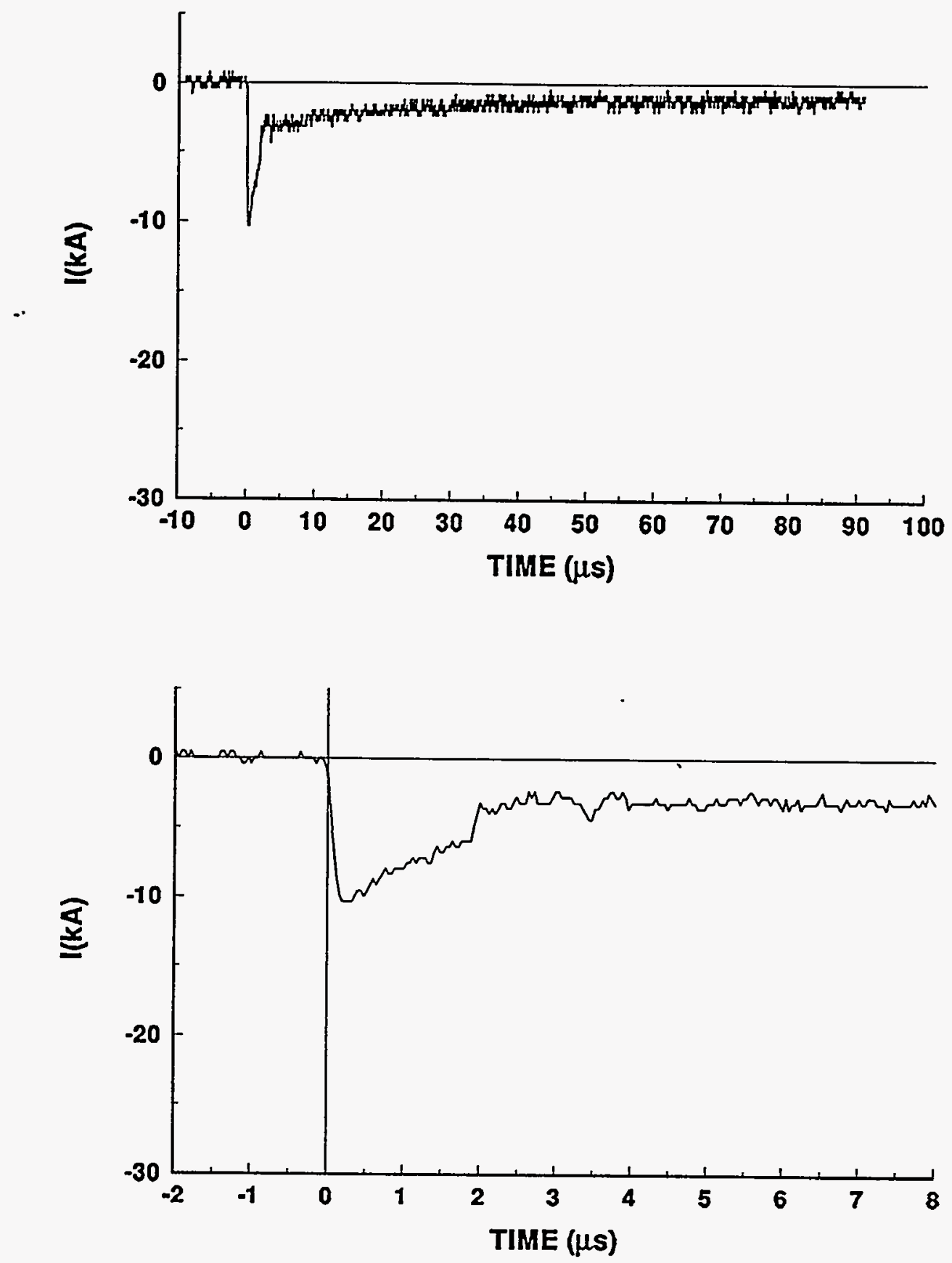


\section{4-14 STROKE 4 \\ TEST POINT 1}

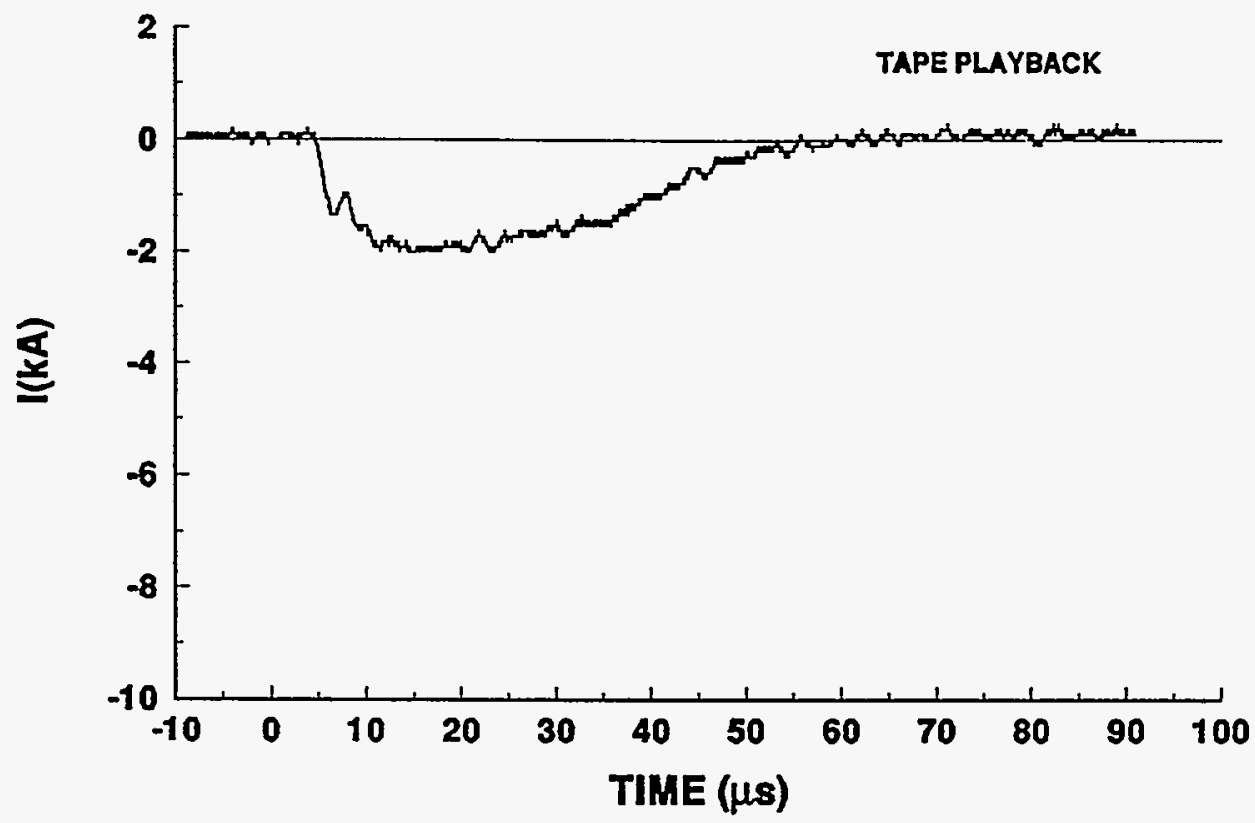

\section{4-14 STROKE 4}

TEST POINT 2

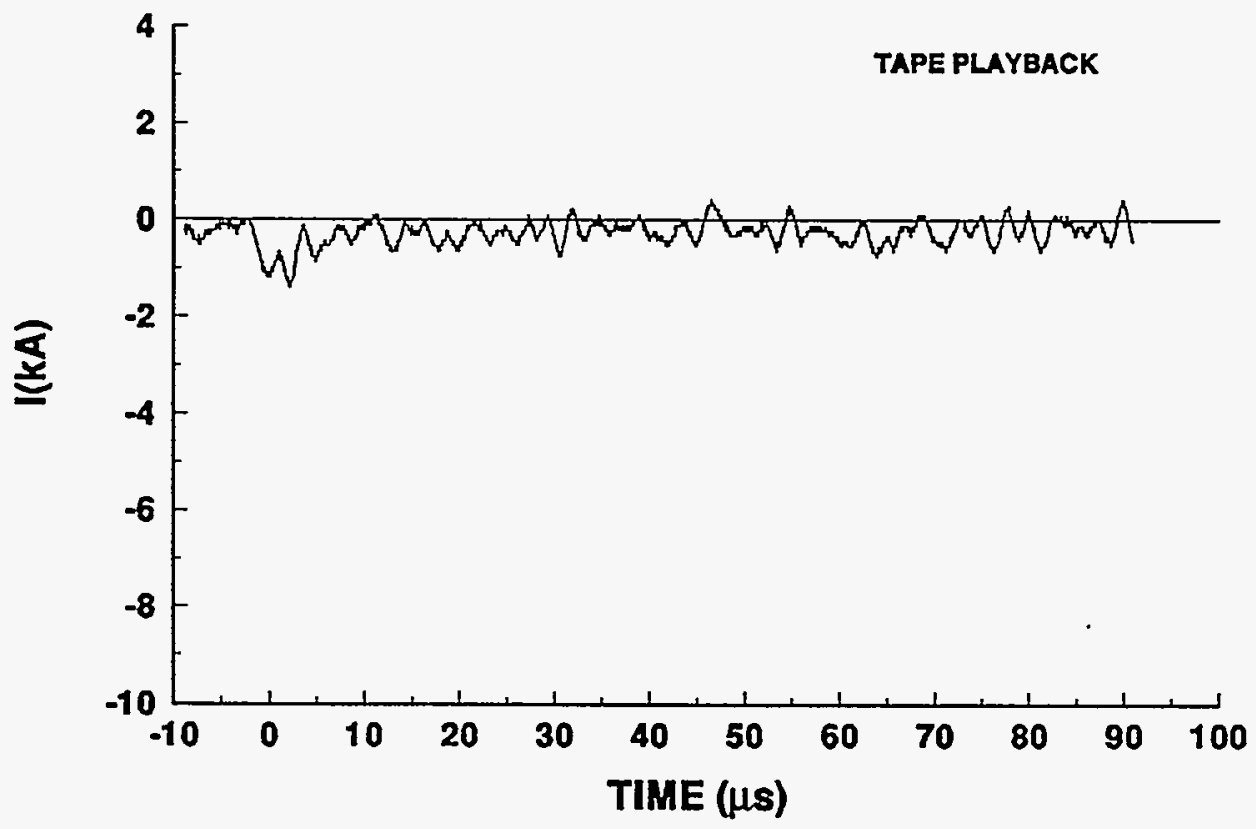




\section{4-14 STROKE 4 \\ TEST POINT 3}
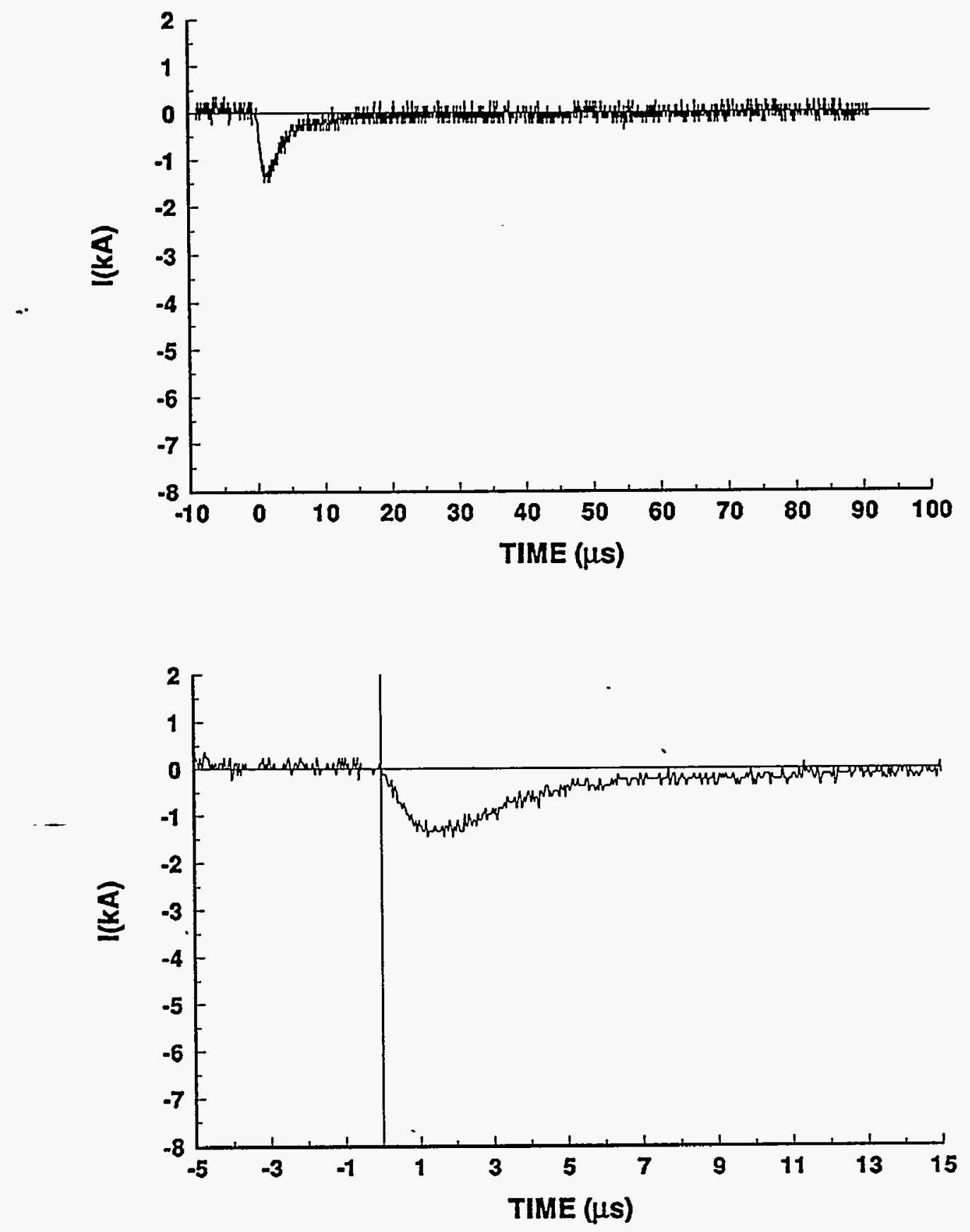


\section{4-14 STROKE 4 \\ TEST POINT 4}
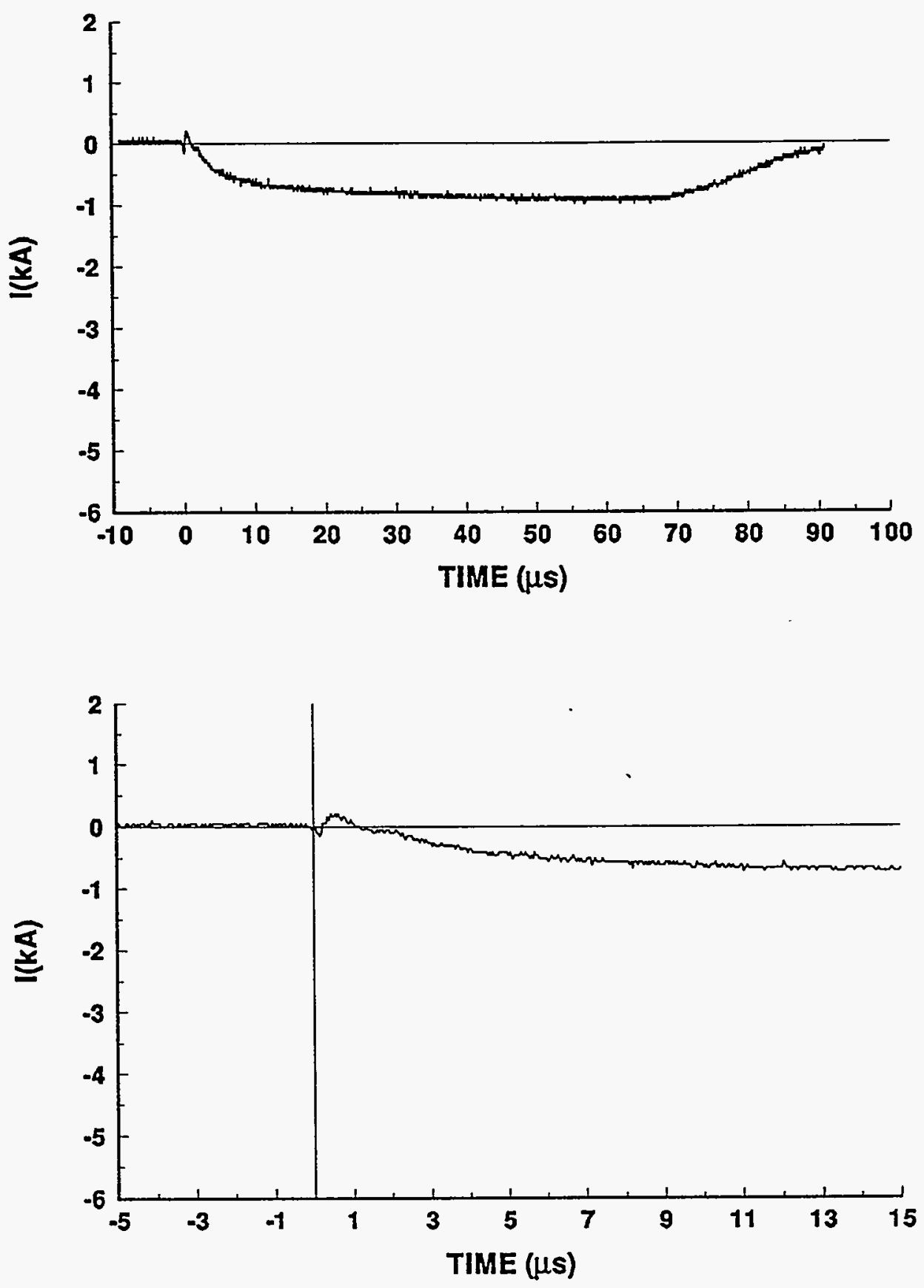


\section{4-14 STROKE 4}

\section{TEST POINT 5}

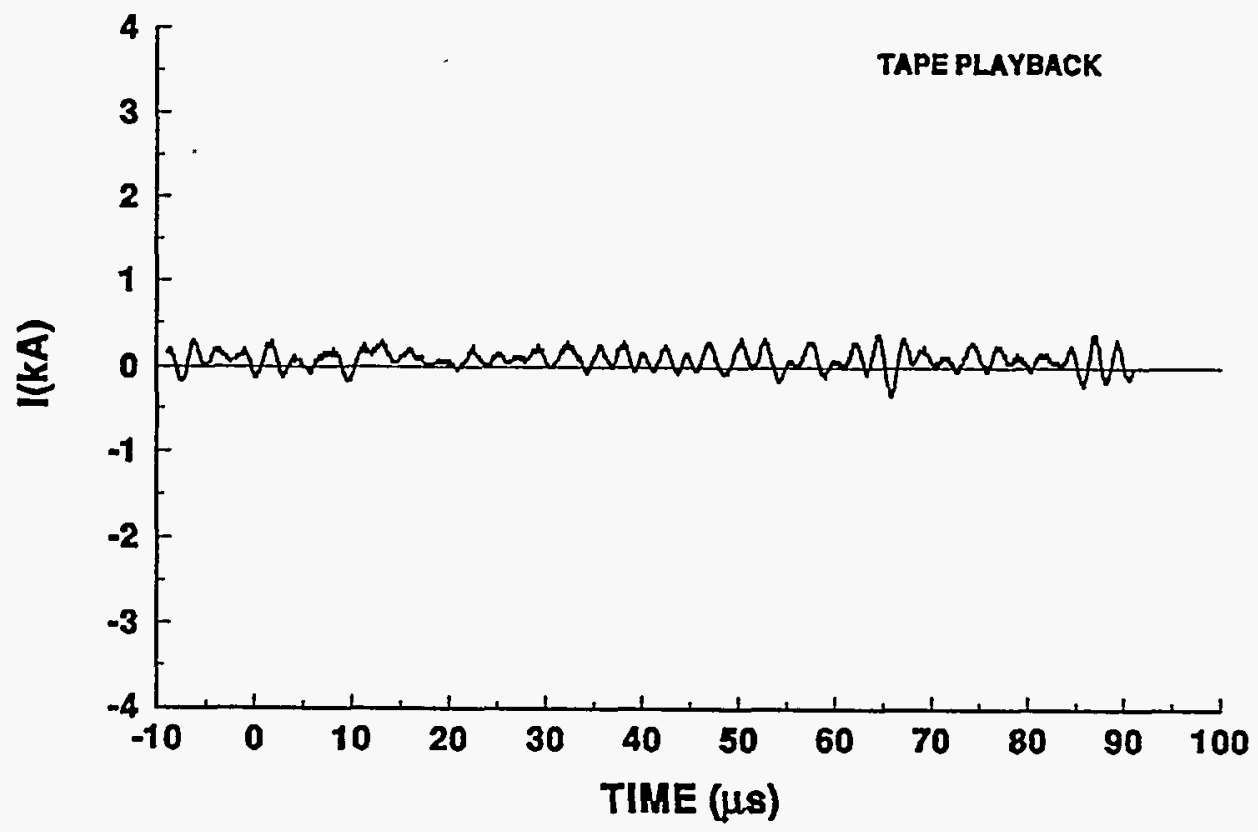

94-14 STROKE 4

TEST POINT 6

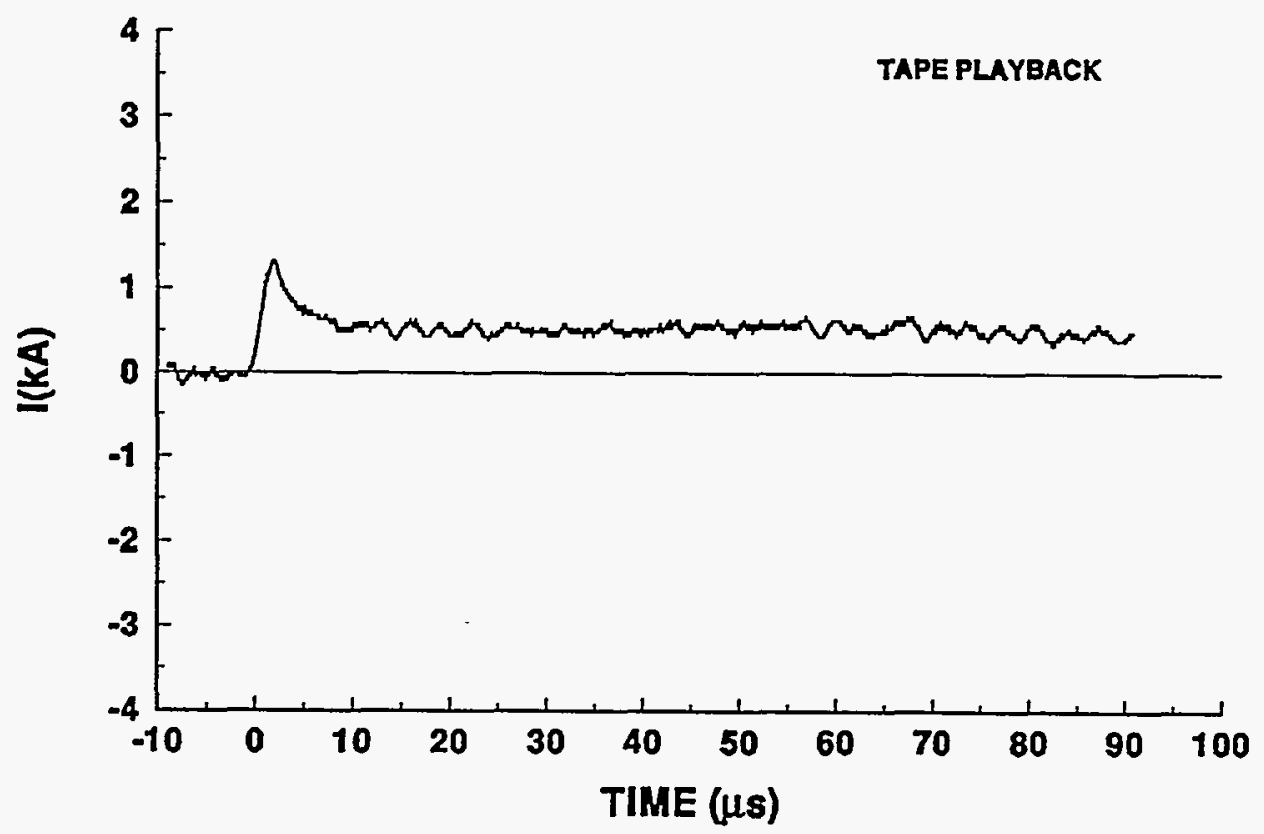




\section{4-14 STROKE 4}

TEST POINT 7

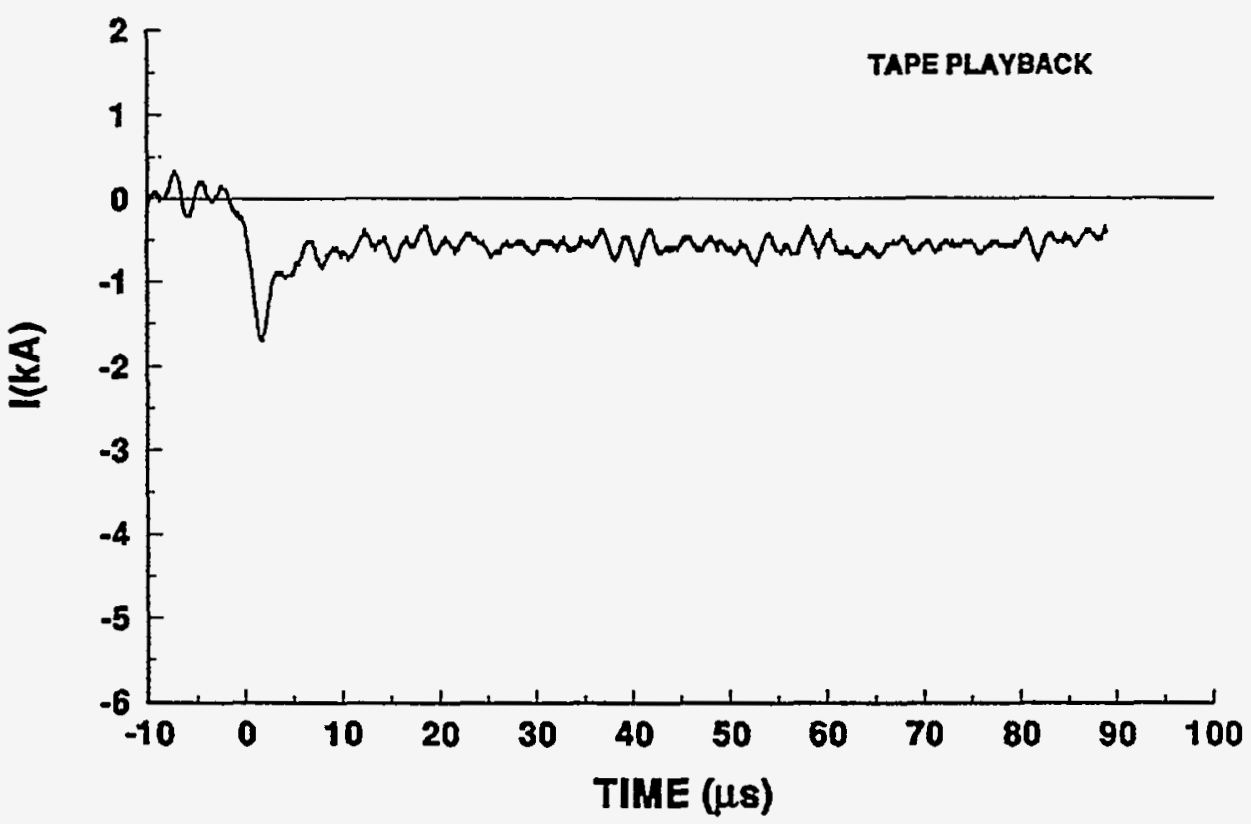

\section{4-14 STROKE 4}

TEST POINT 8

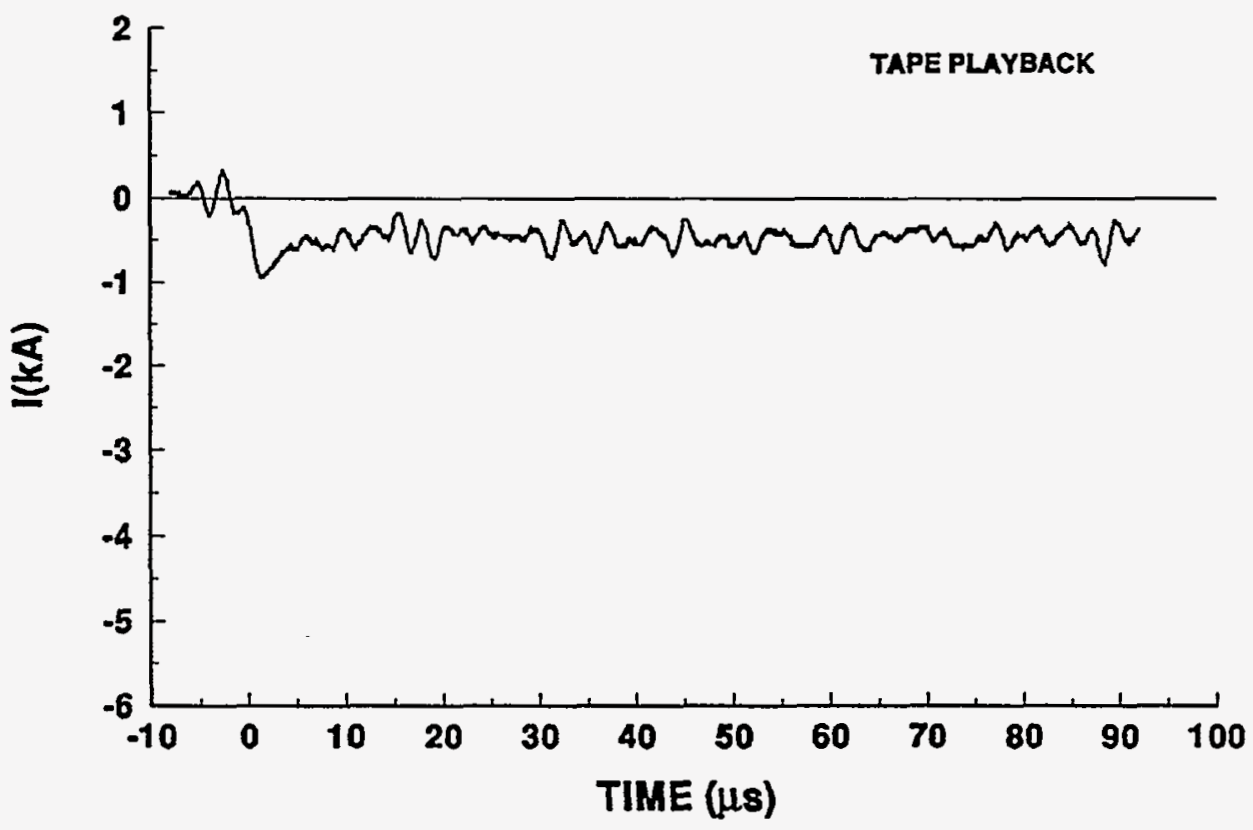




\section{4-14 STROKE 4}

\section{TEST POINT 9}

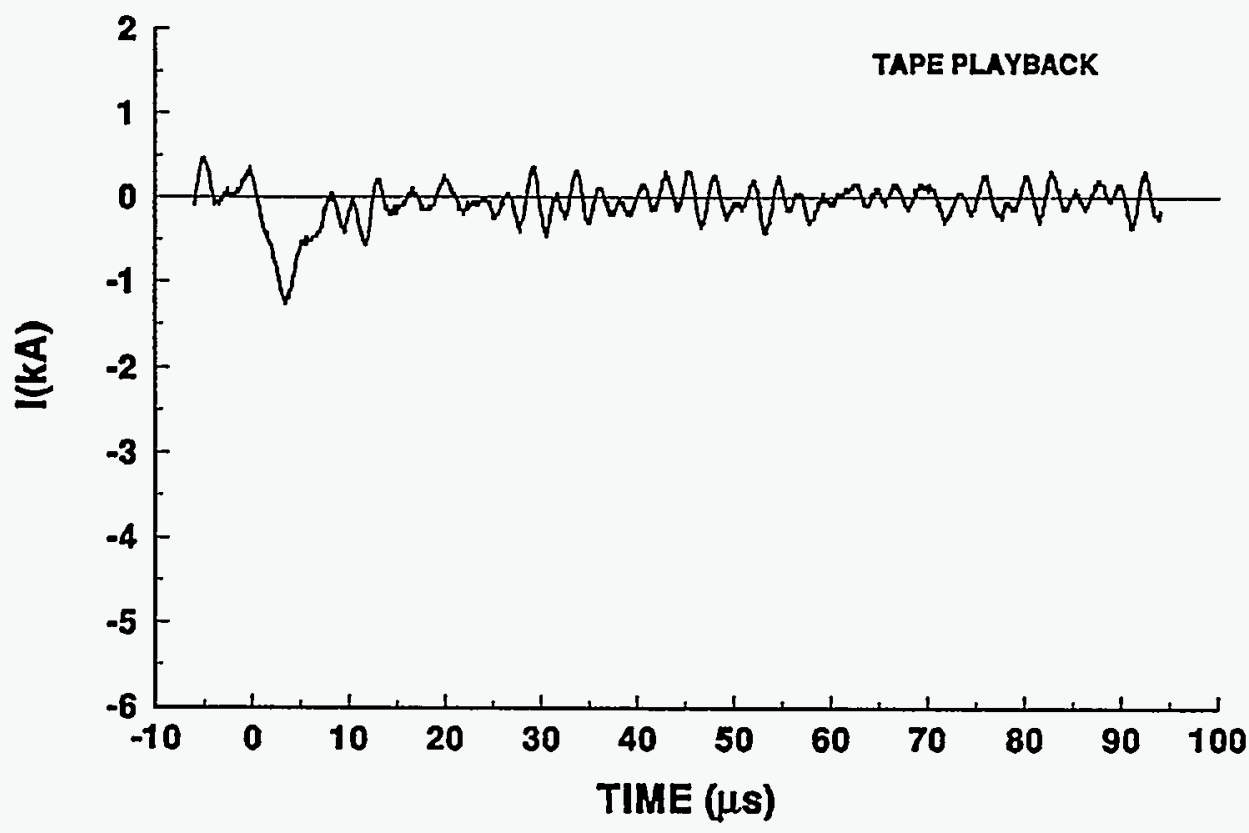

\section{4-14 STROKE 4 .}

TEST POINT 9'

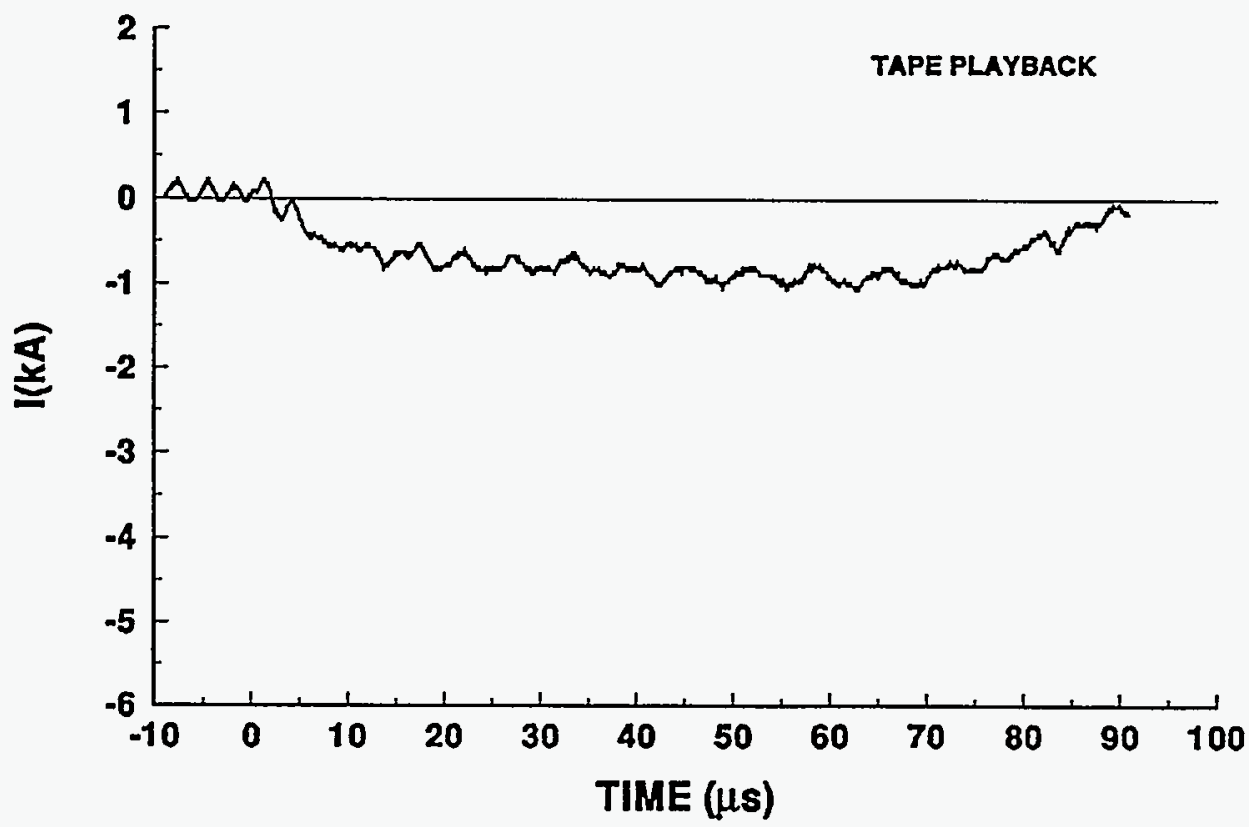




\section{4-14 STROKE 4}

TEST POINT 16

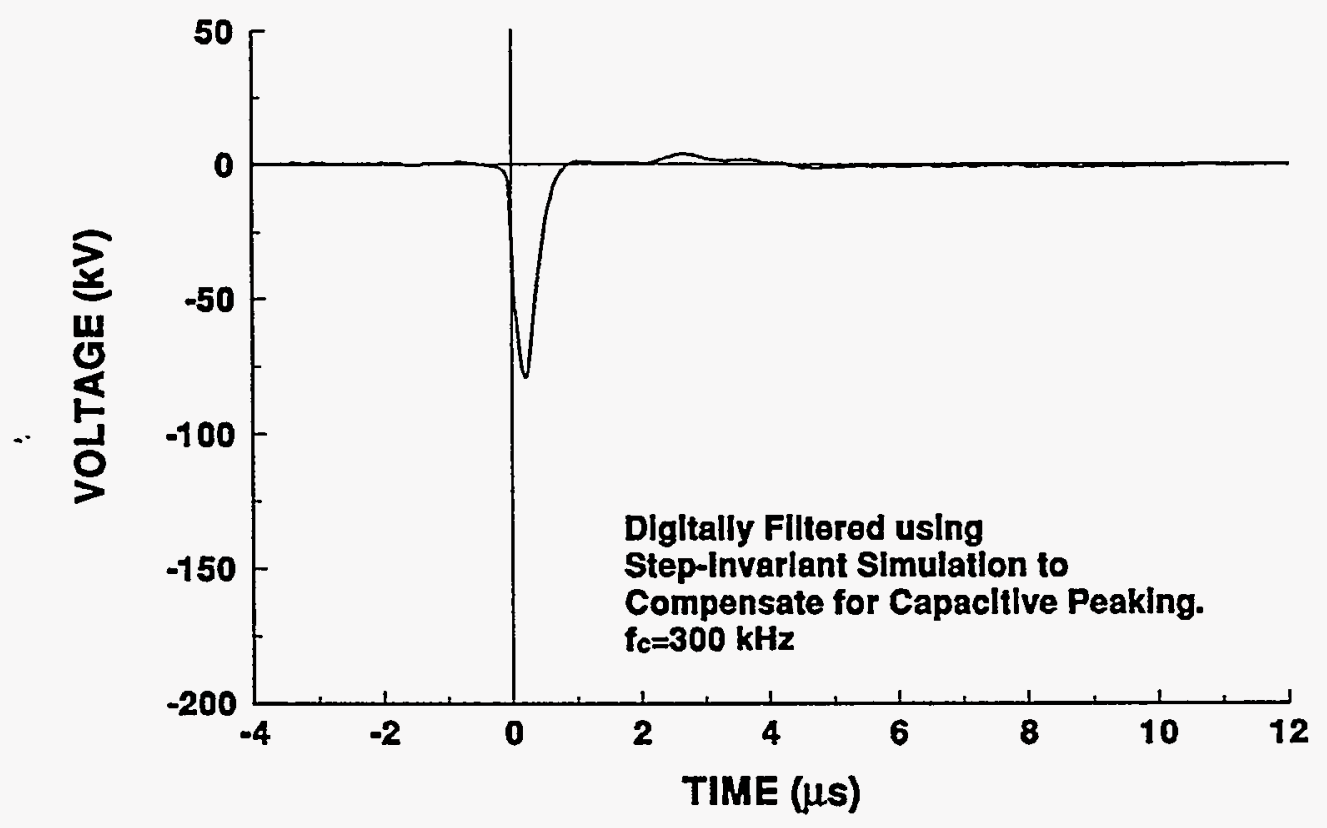

\section{4-14 STROKE 4}

TEST POINT 17

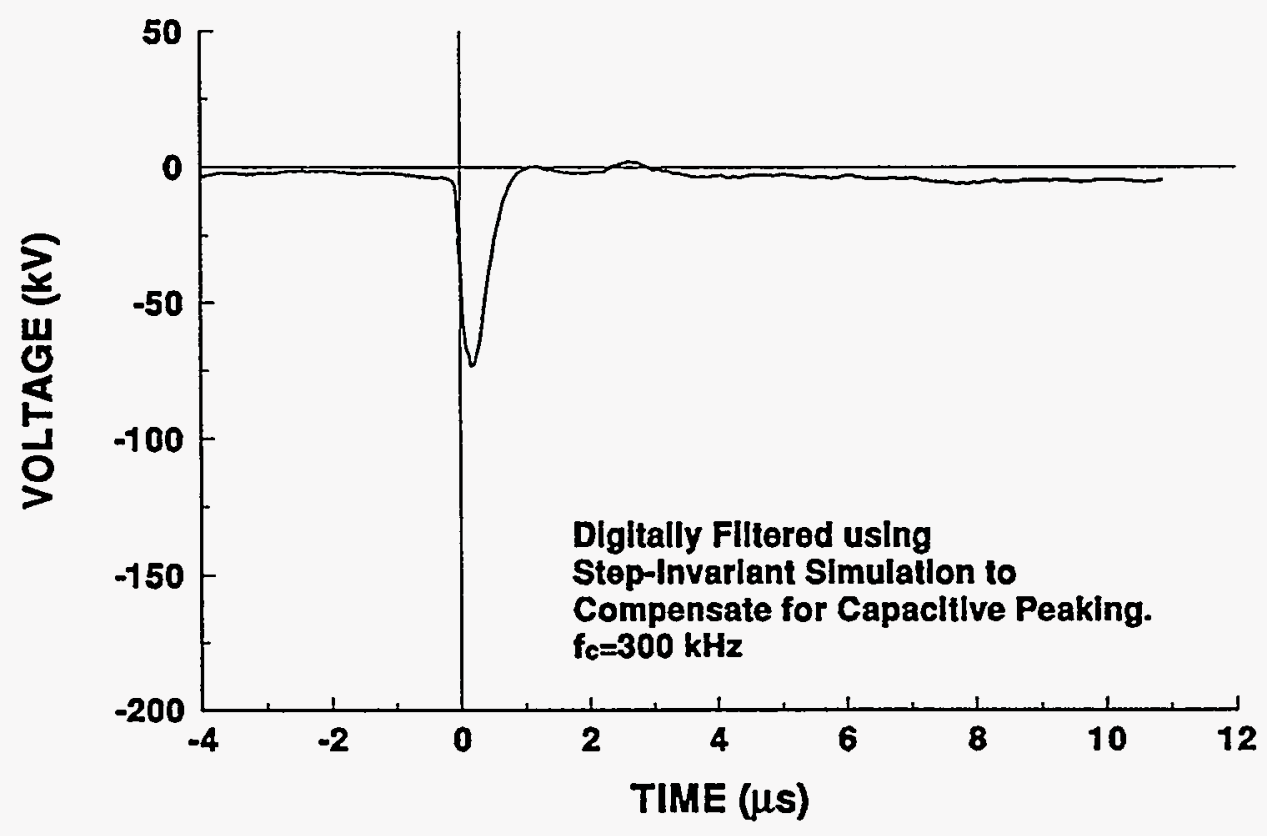




\section{4-14 STROKE 4}

\section{TEST POINT 18}

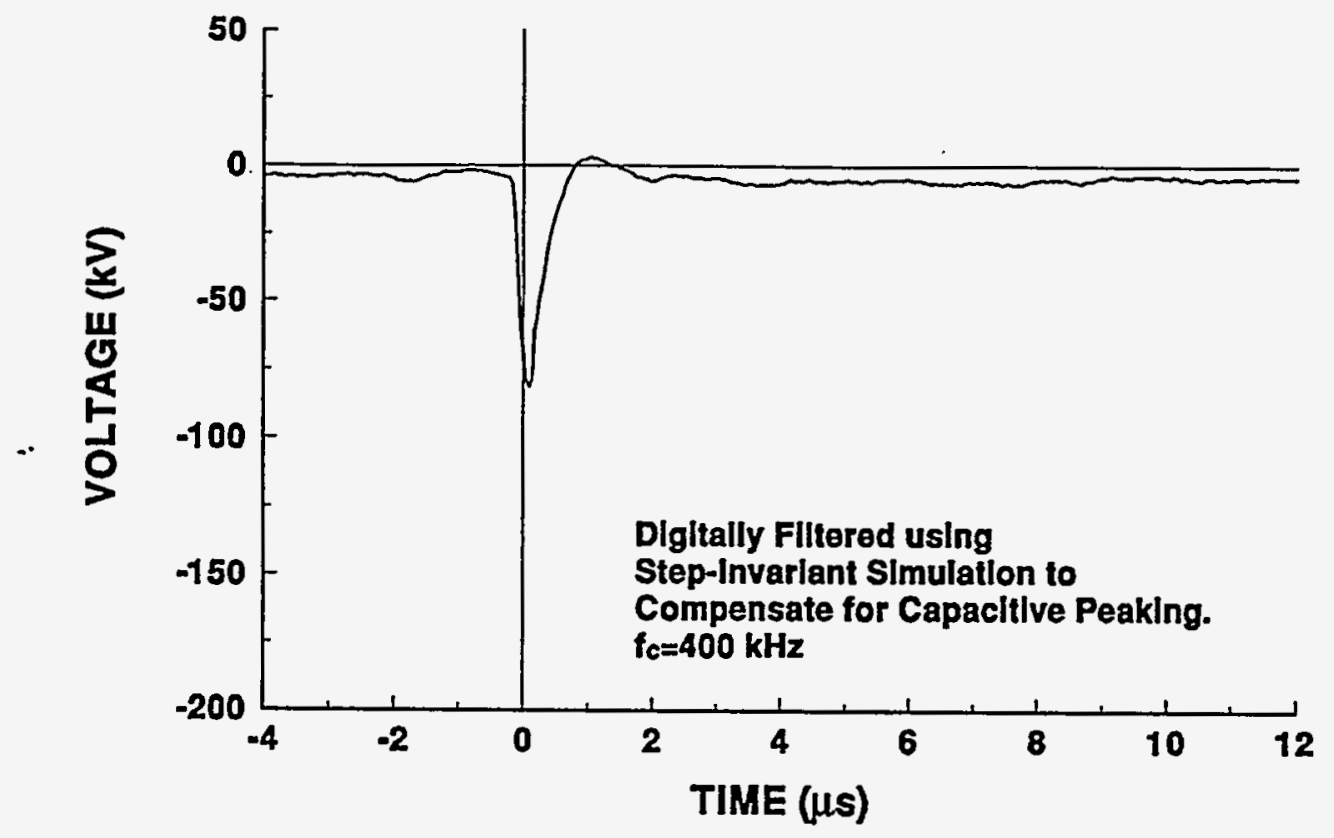

\section{4-14 STROKE.4}

TEST POINT 19

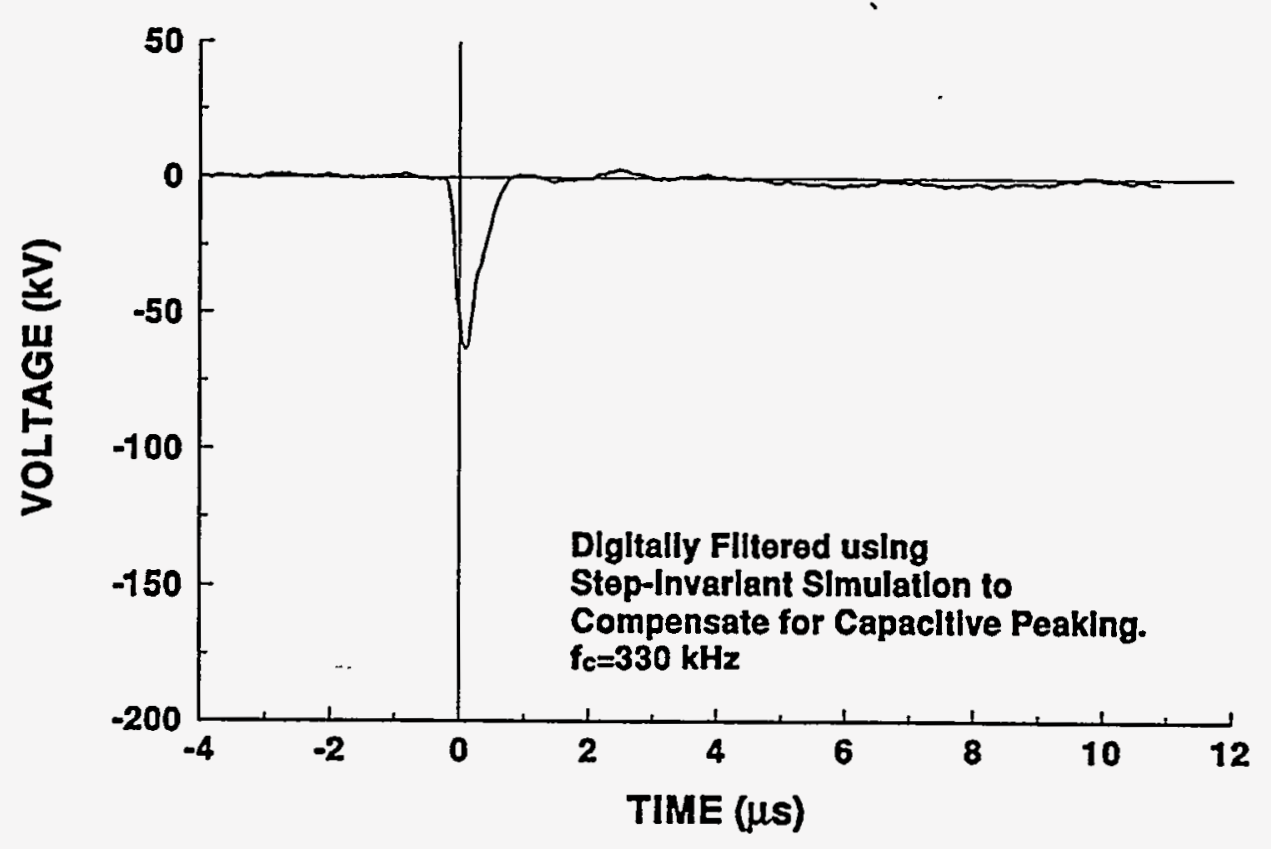




\section{4-14 STROKE 4}

TEST POINT 20

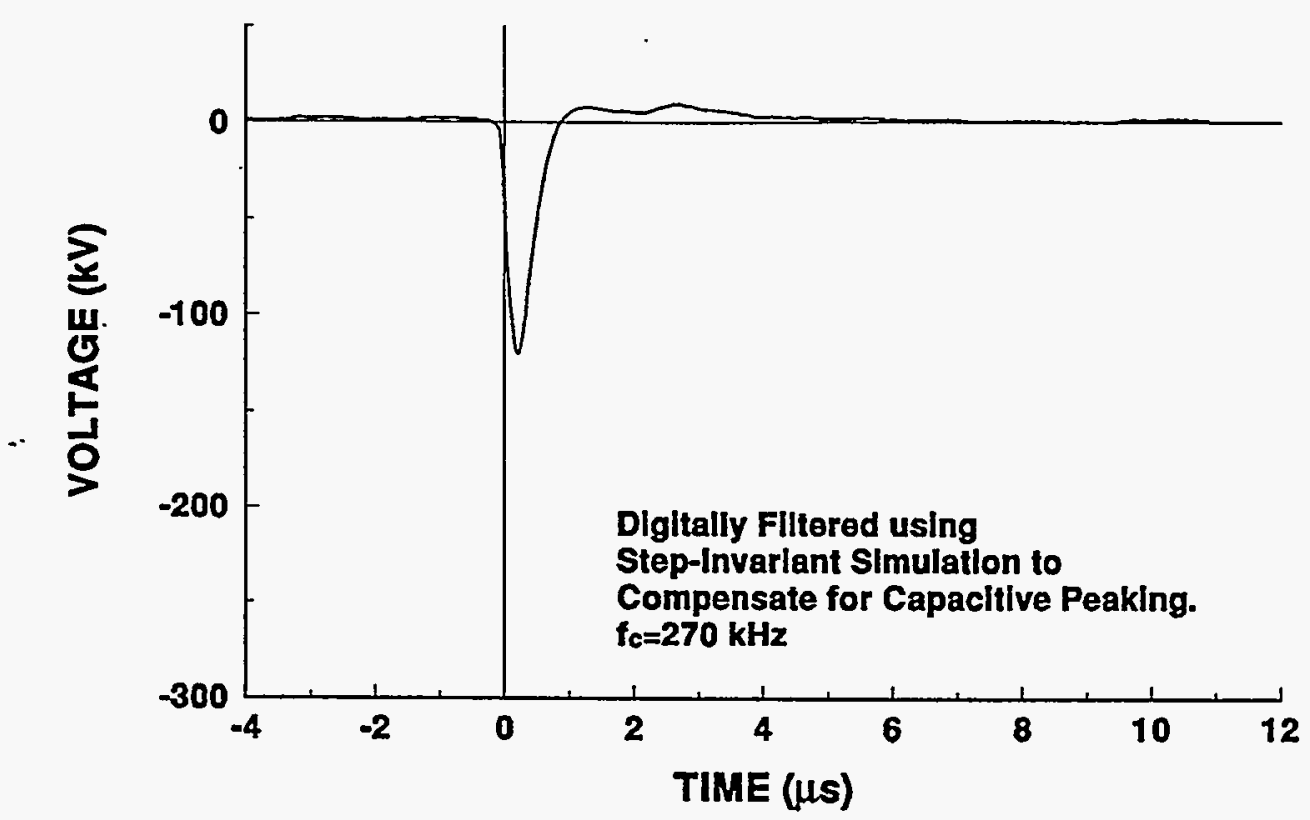

\section{4-14 STROKE 4}

TEST POINT 22

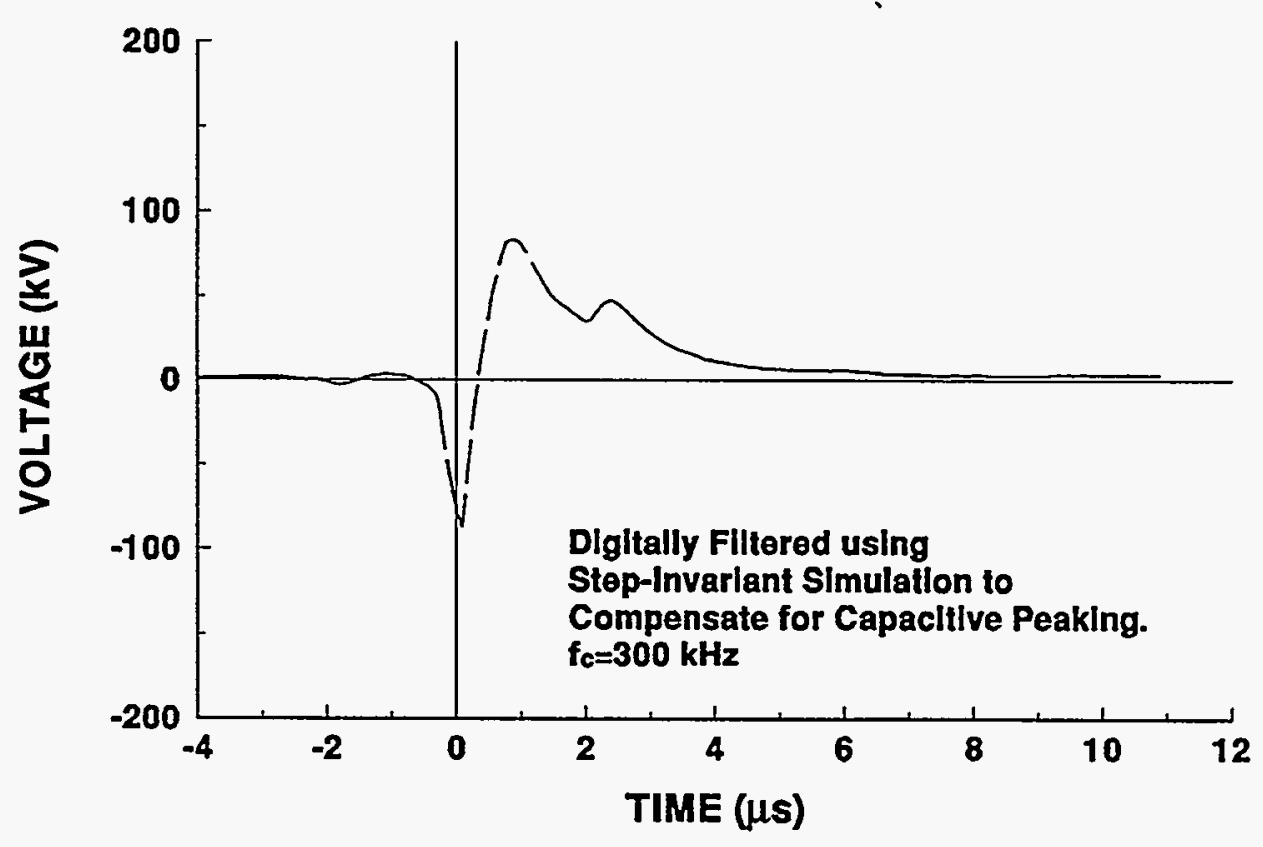




\section{4-14 STROKE 4}

TEST POINT 23

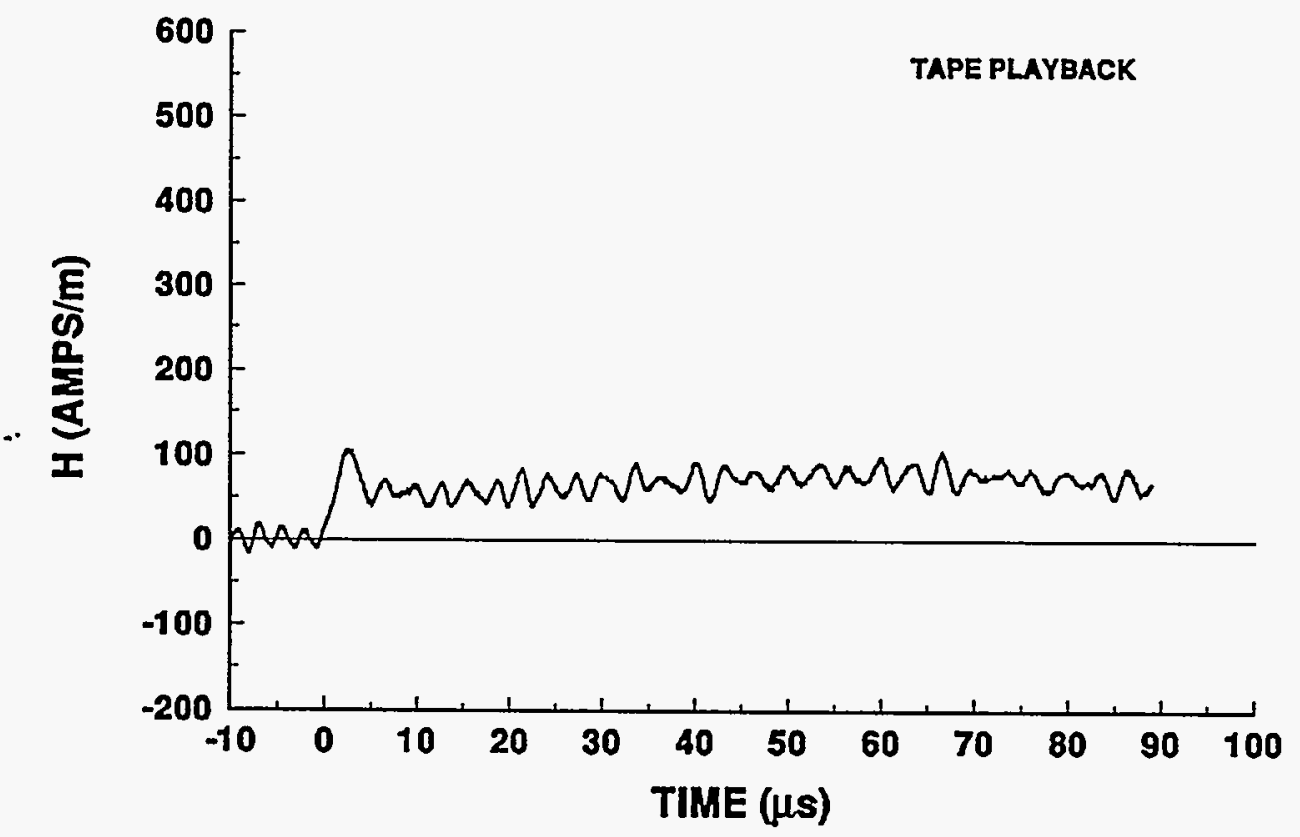

94-14 STROKE 4

TEST POINT 24

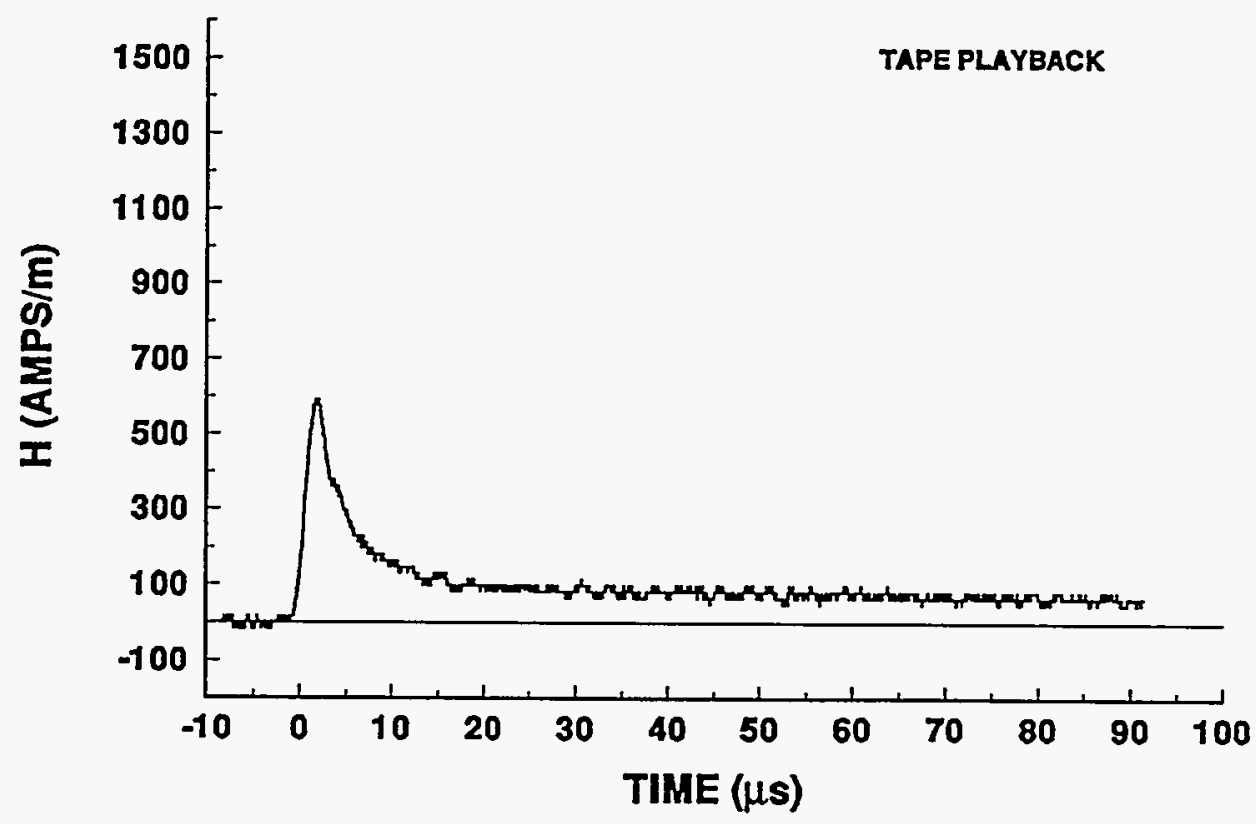




\section{4-15 STROKE 1 \\ INCIDENT CURRENT}
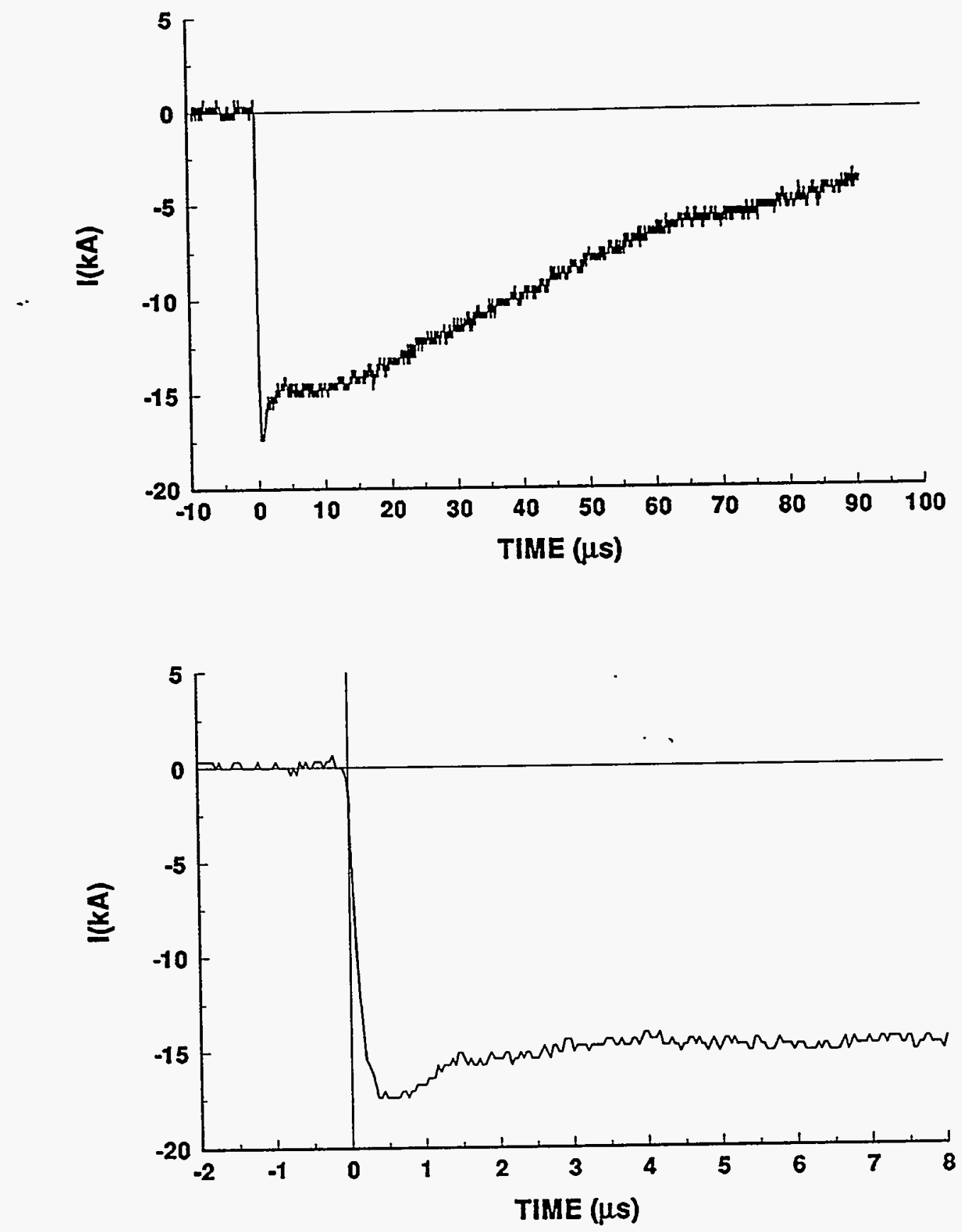


\section{4-15 STROKE 1}

TEST POINT 1

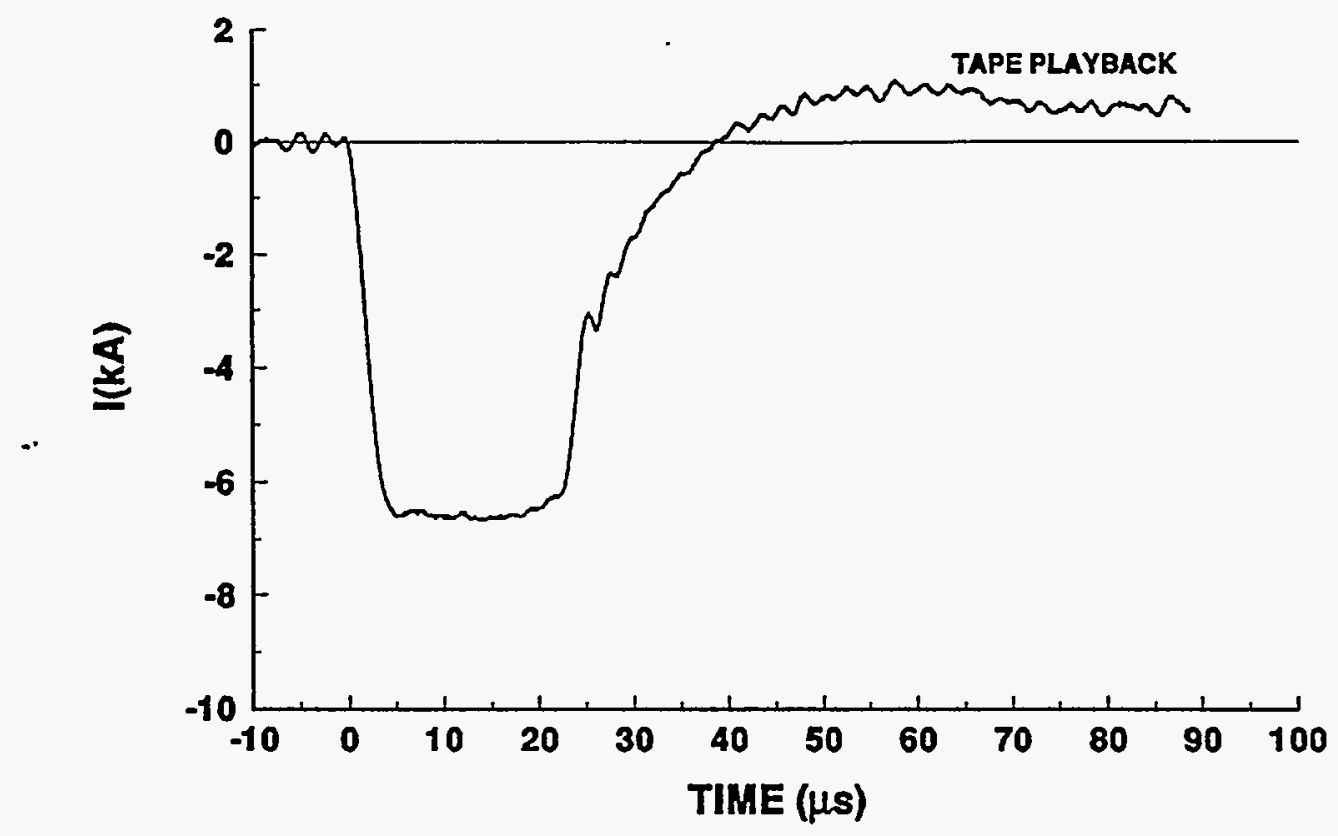

\section{4-15 STROKE 1}

TEST POINT 2

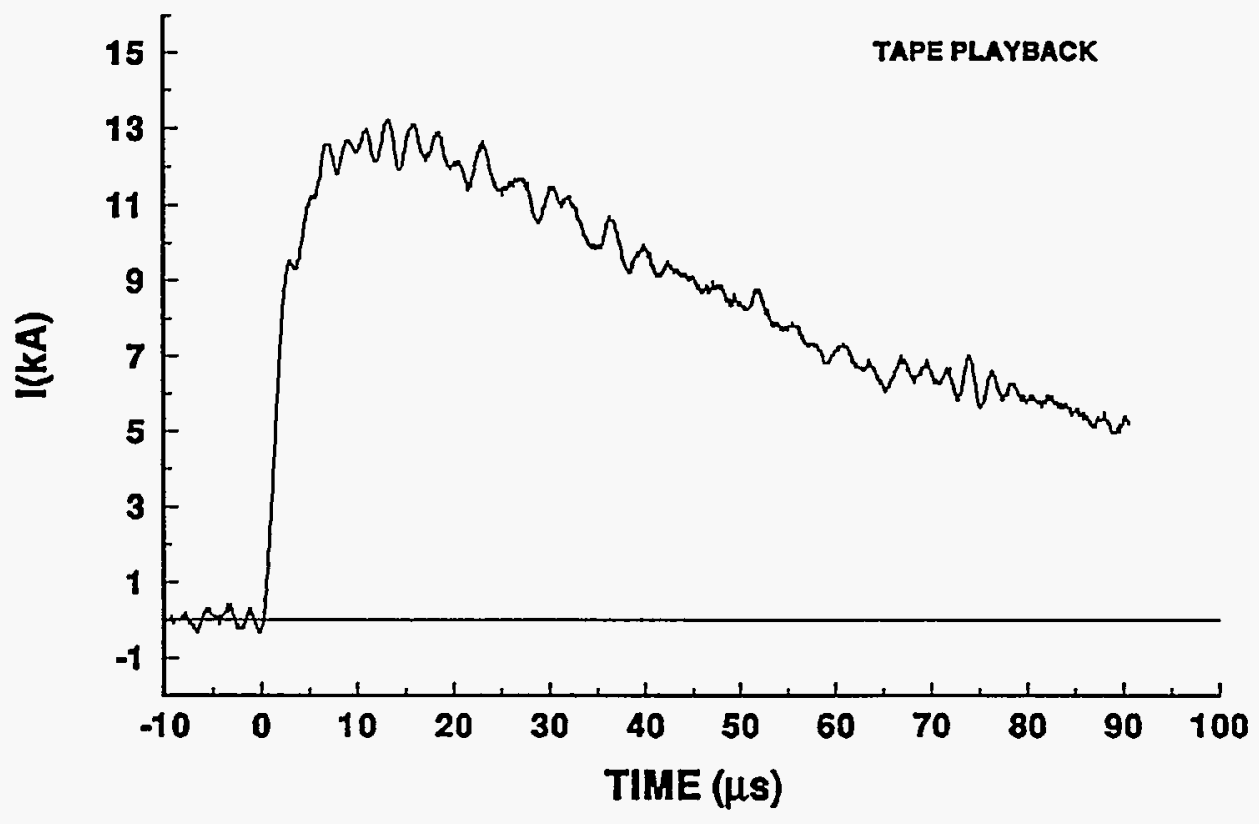




\section{4-15 STROKE 1}

TEST POINT 3
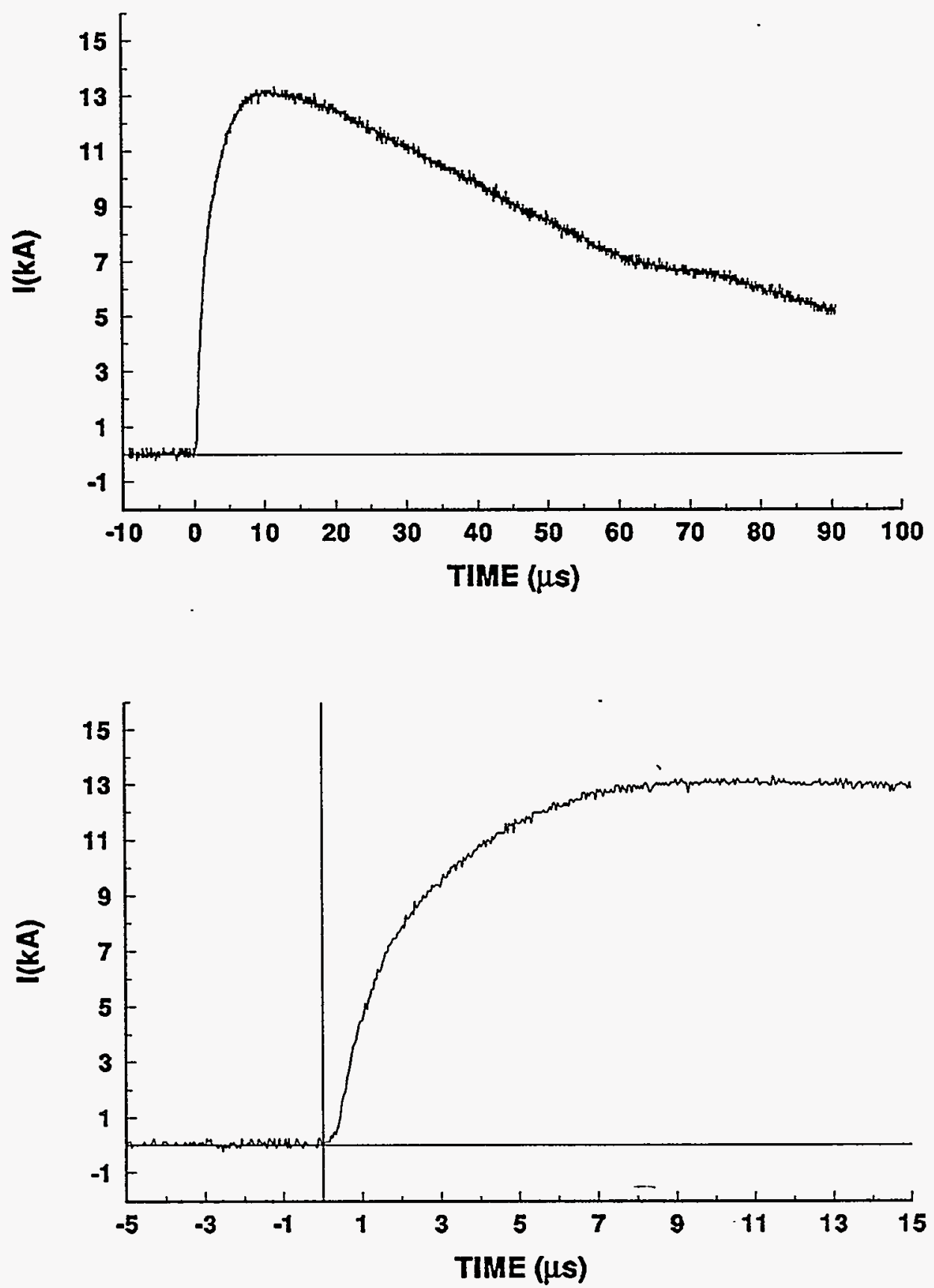


\section{4-15 STROKE 1}

TEST POINT 4
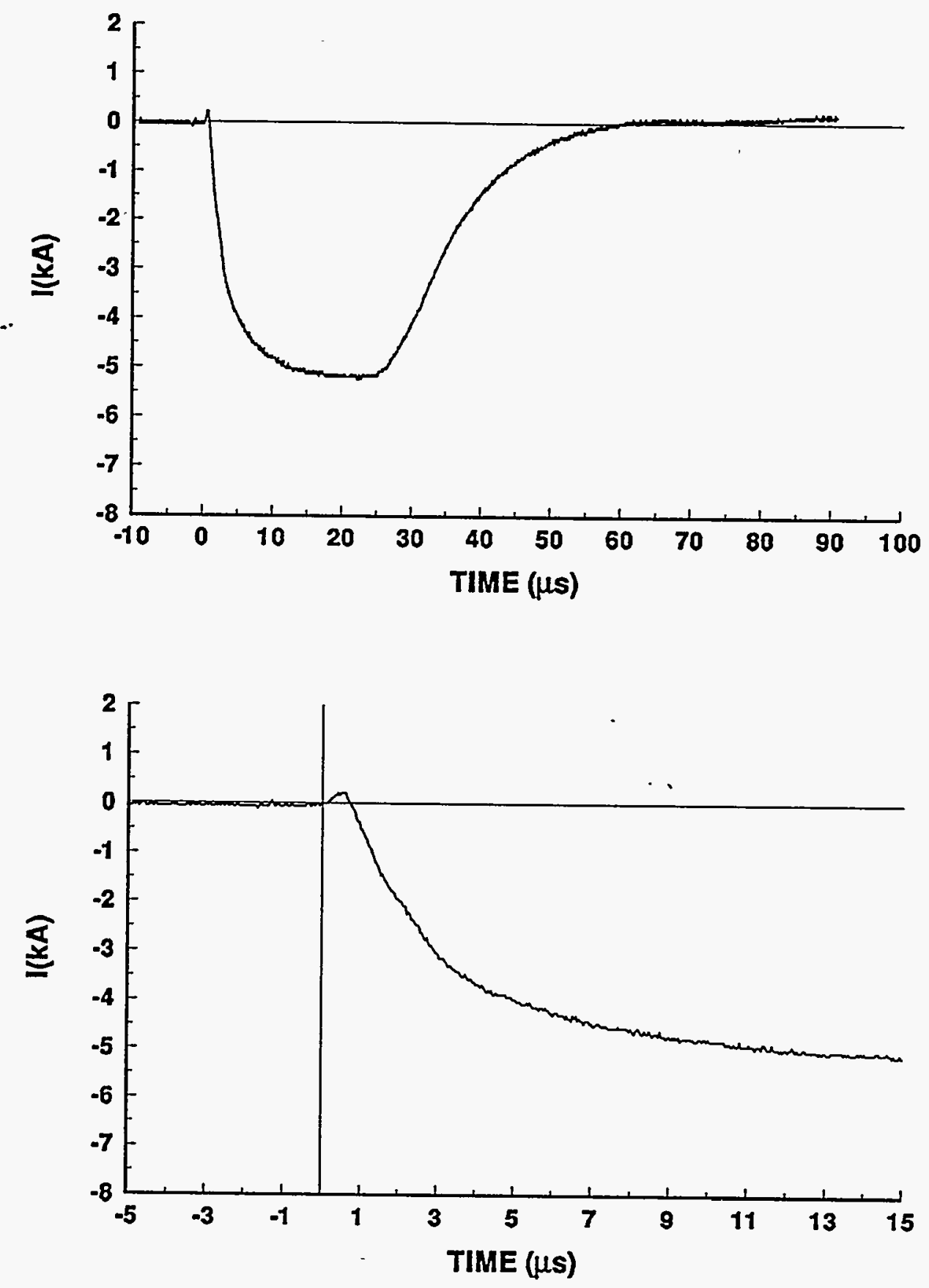


\section{4-15 STROKE 1}

TEST POINT 5

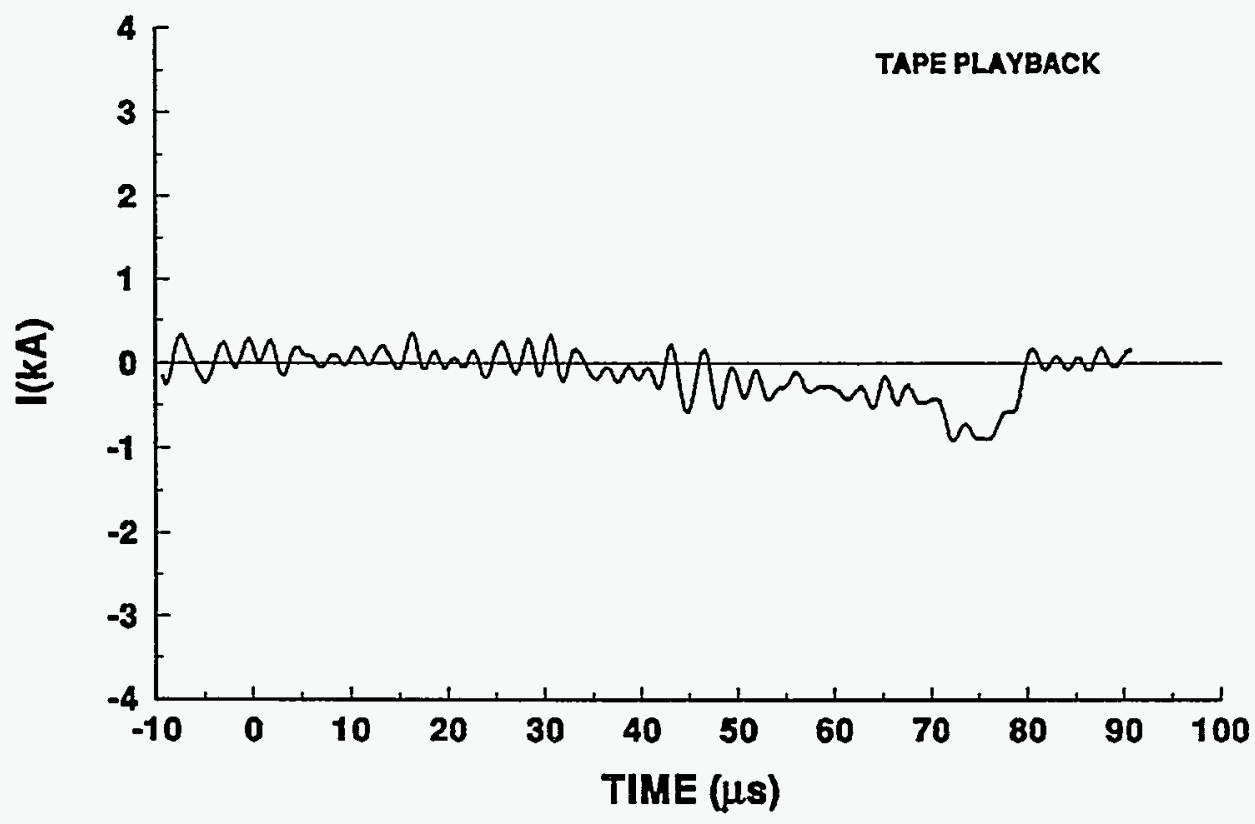

\section{4-15 STROKE 1 \\ TEST POINT 6}

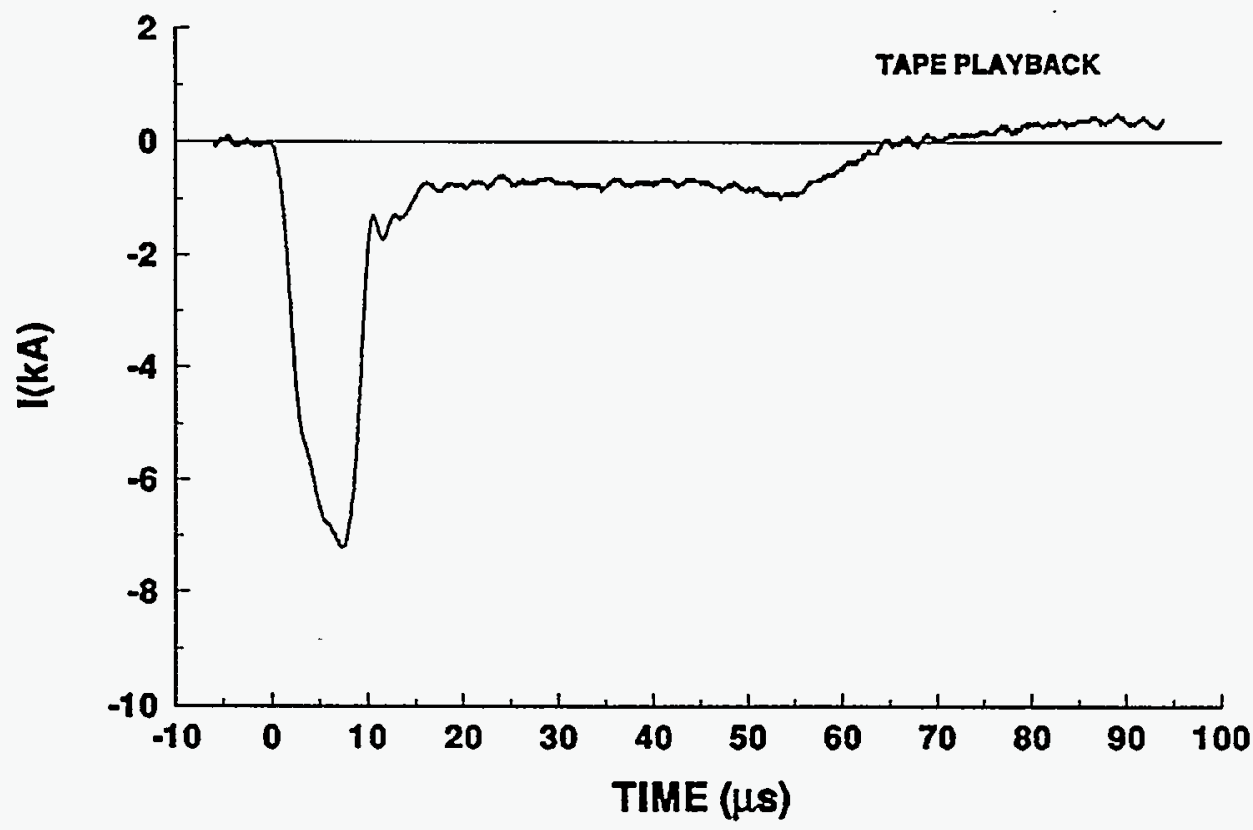




\section{4-15 STROKE 1}

TEST POINT 7

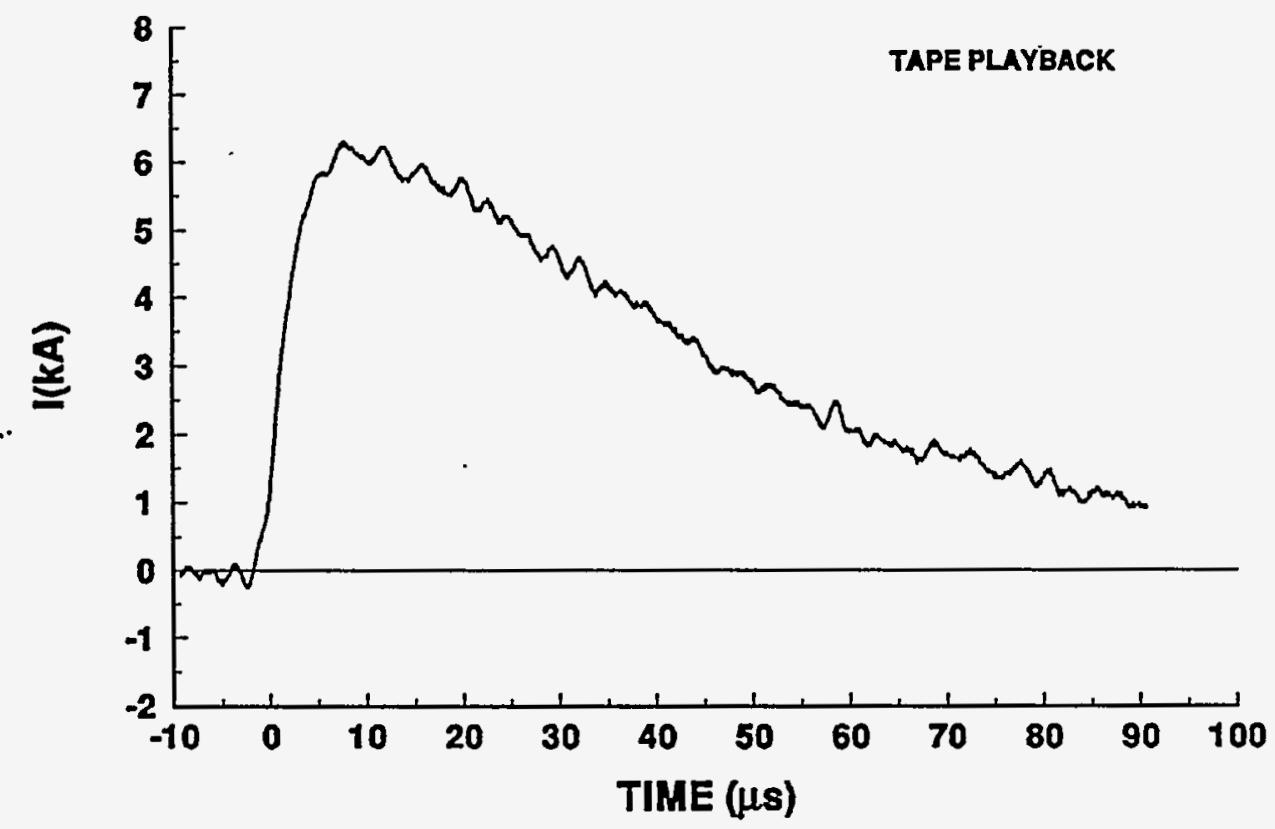

94-15 STROKE 1.

TEST POINT 8

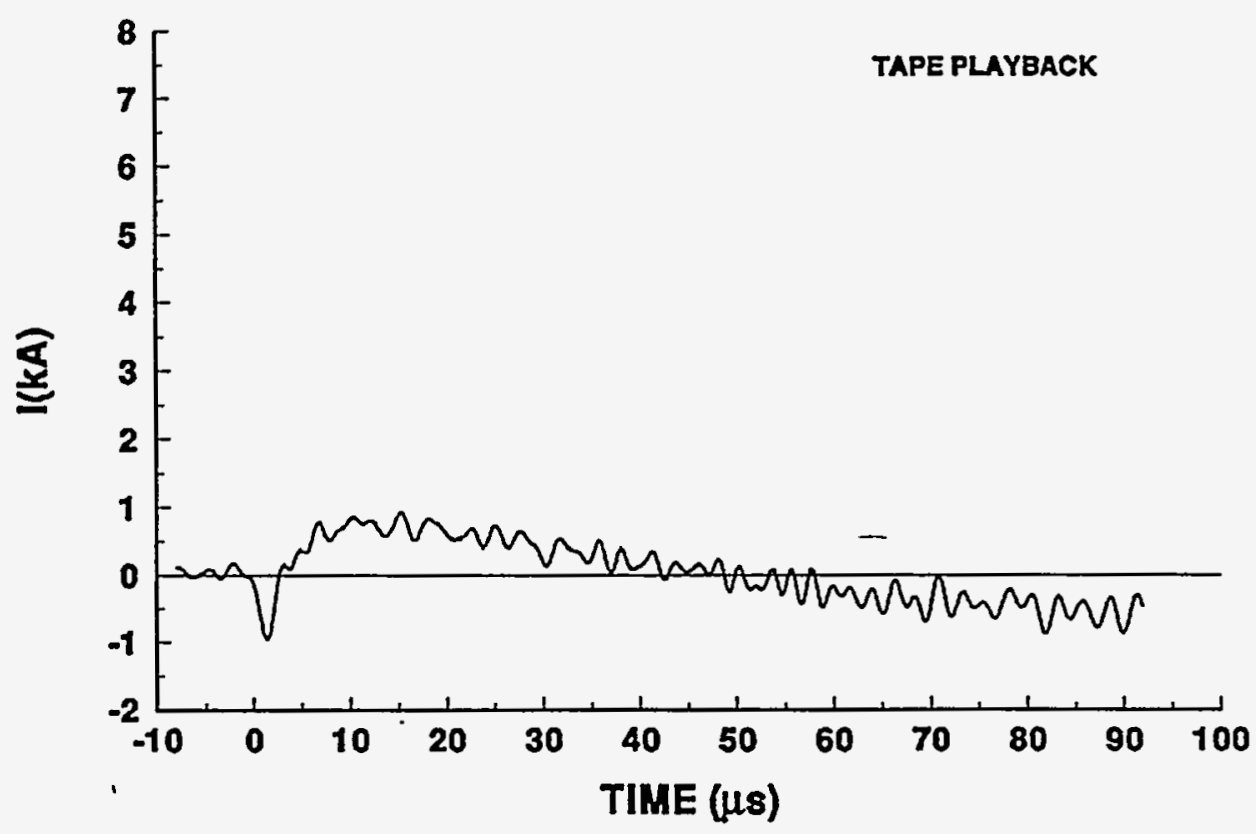


94-15 STROKE 1

TEST POINT 9

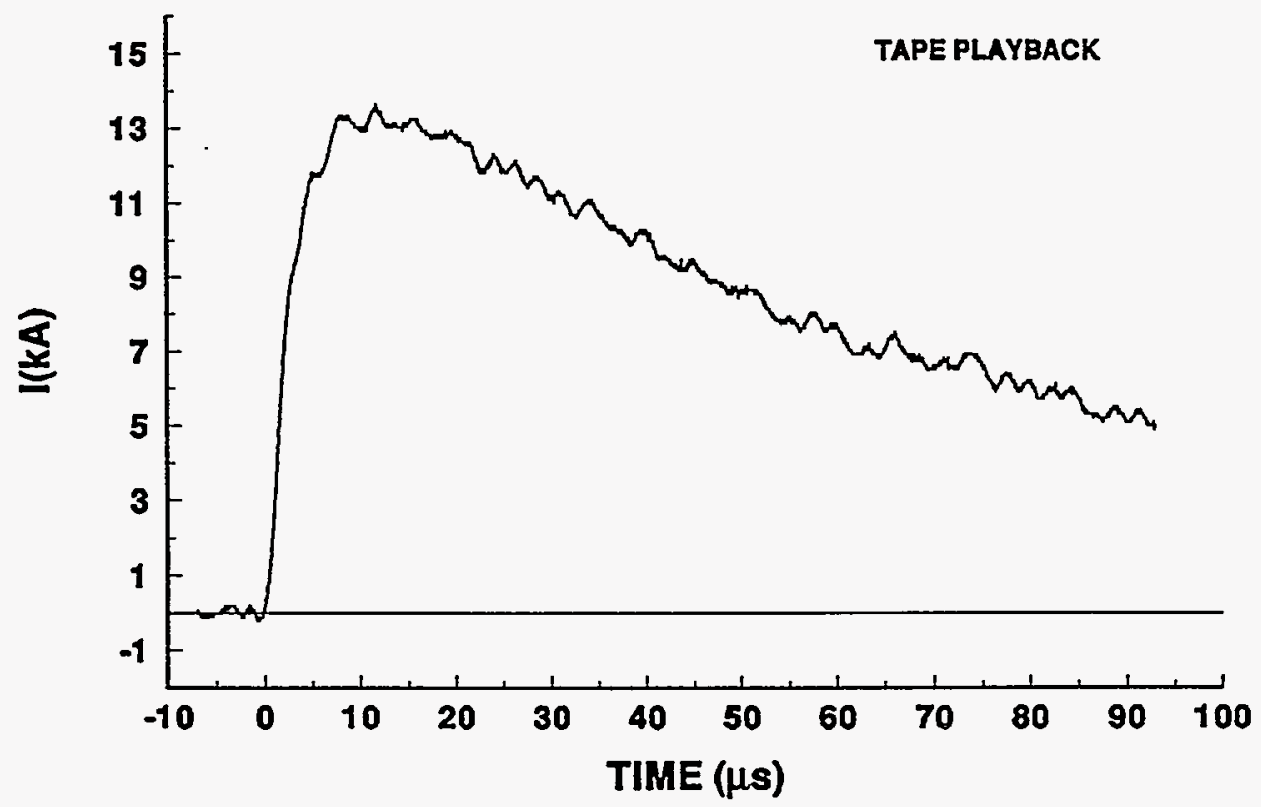

\section{4-15 STROKE 1}

TEST POINT 9'

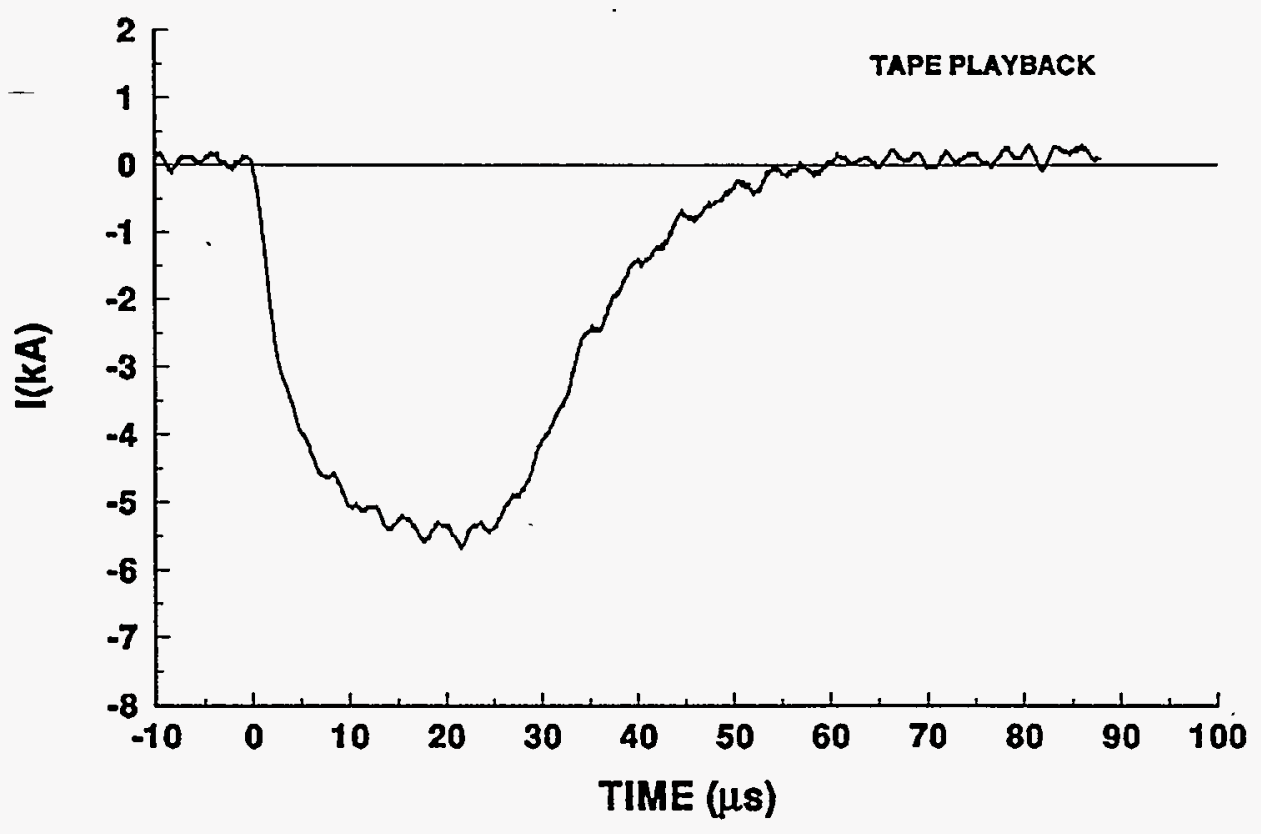




\section{4-15 STROKE 1}

TEST POINT 16

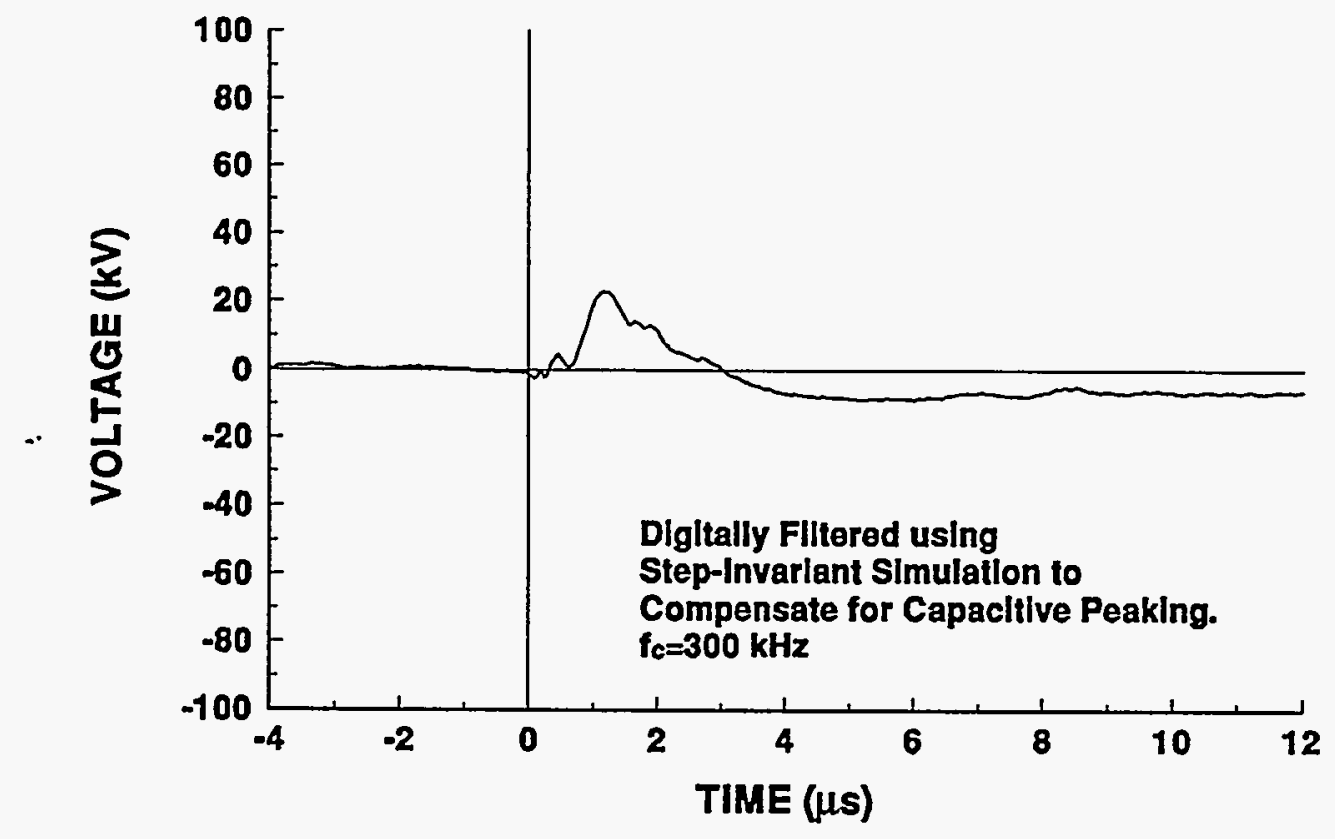

94-15 STROKE-1

TEST POINT 17

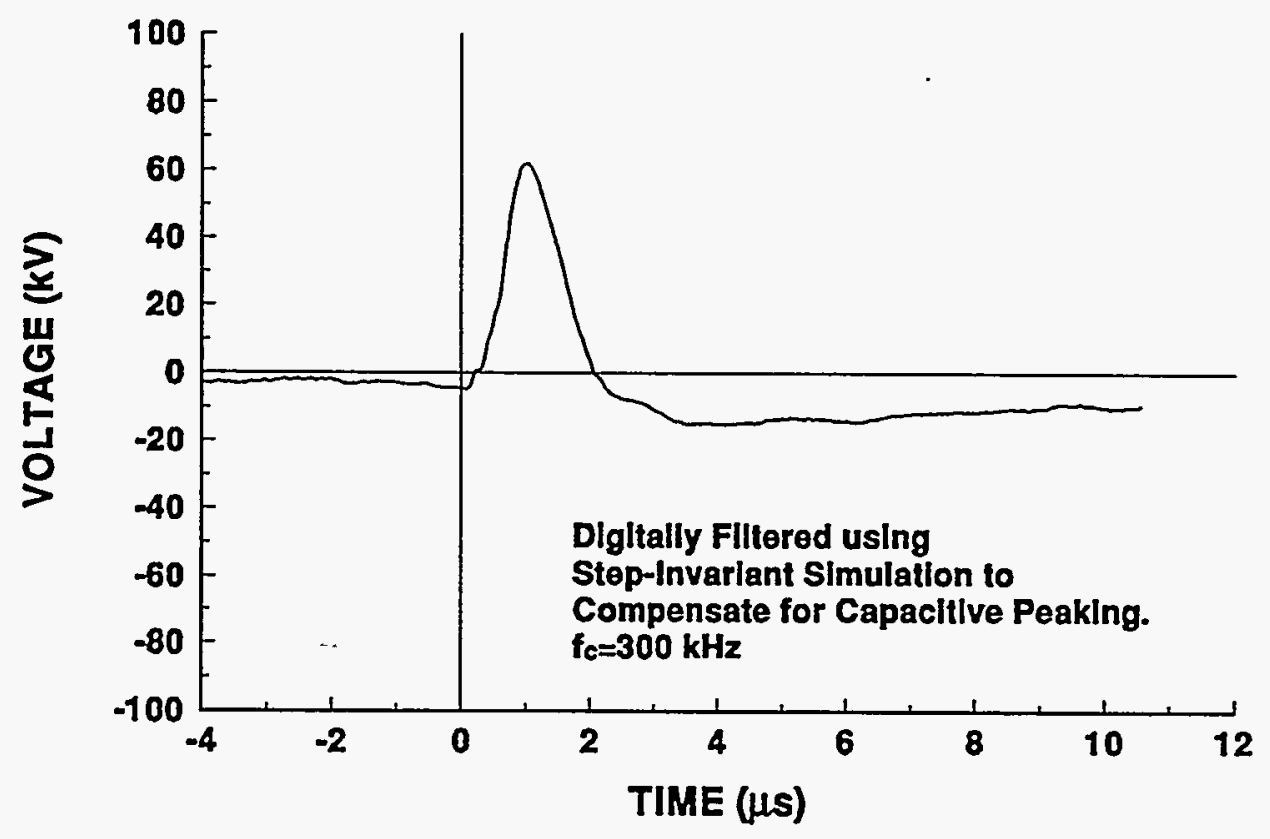




\section{4-15 STROKE 1}

\section{TEST POINT 18}

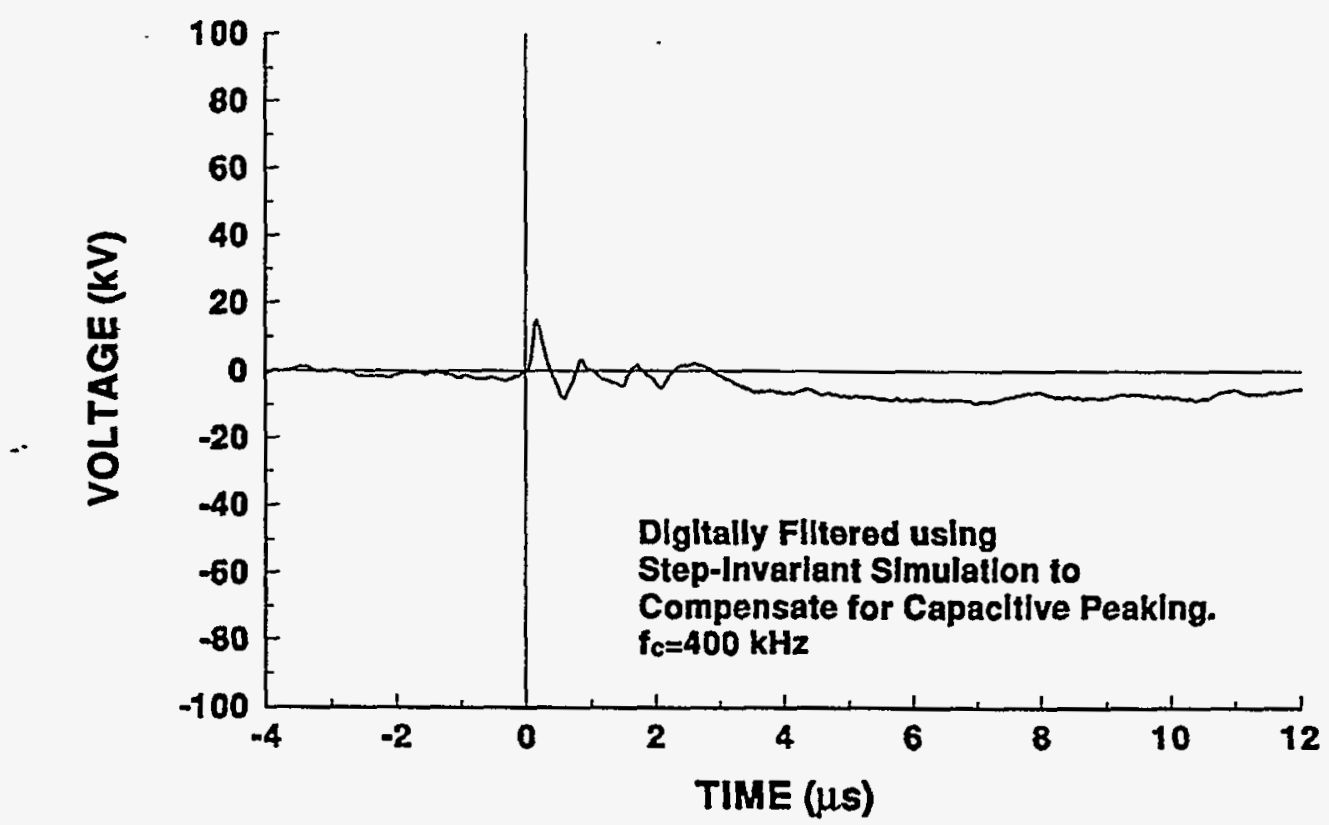

\section{4-15 STROKE 1}

TEST POINT 19

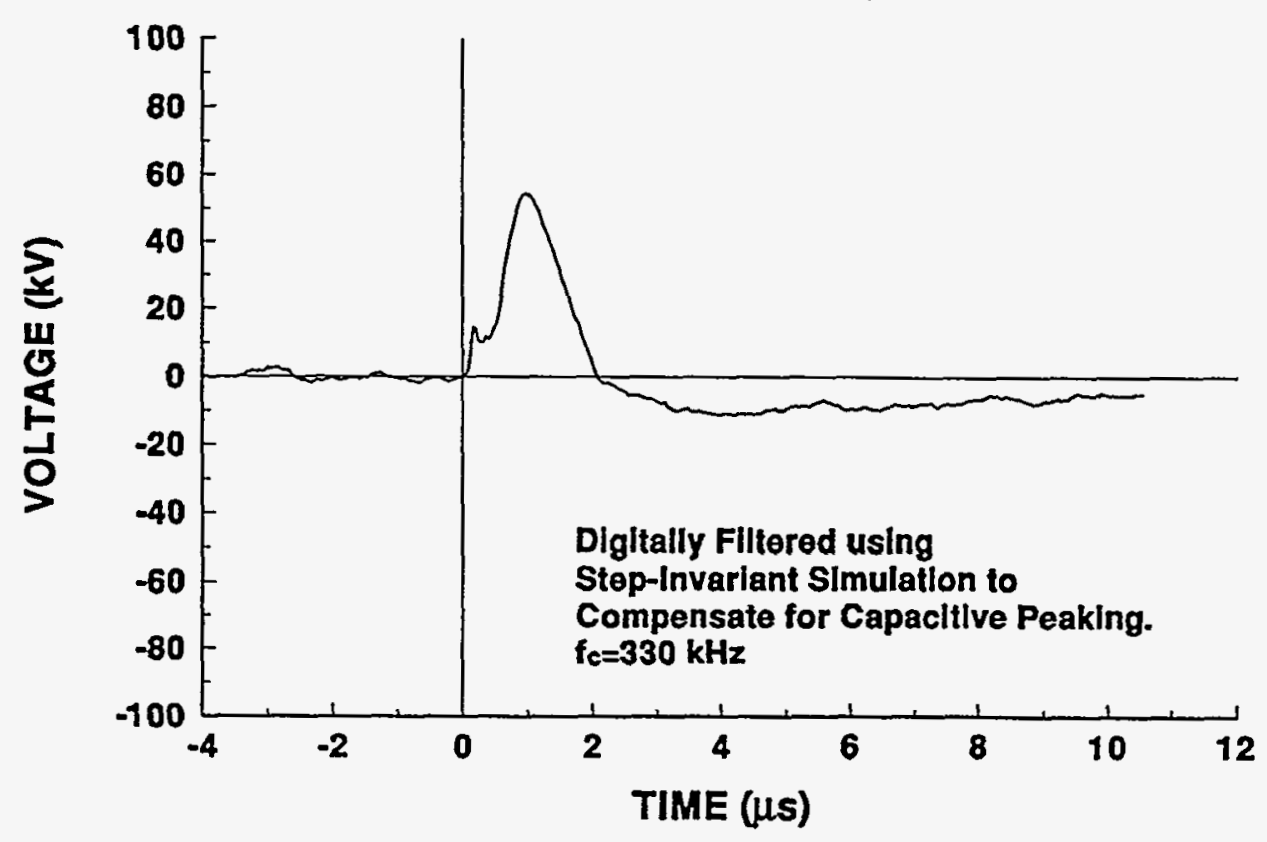




\section{4-15 STROKE 1}

TEST POINT 20

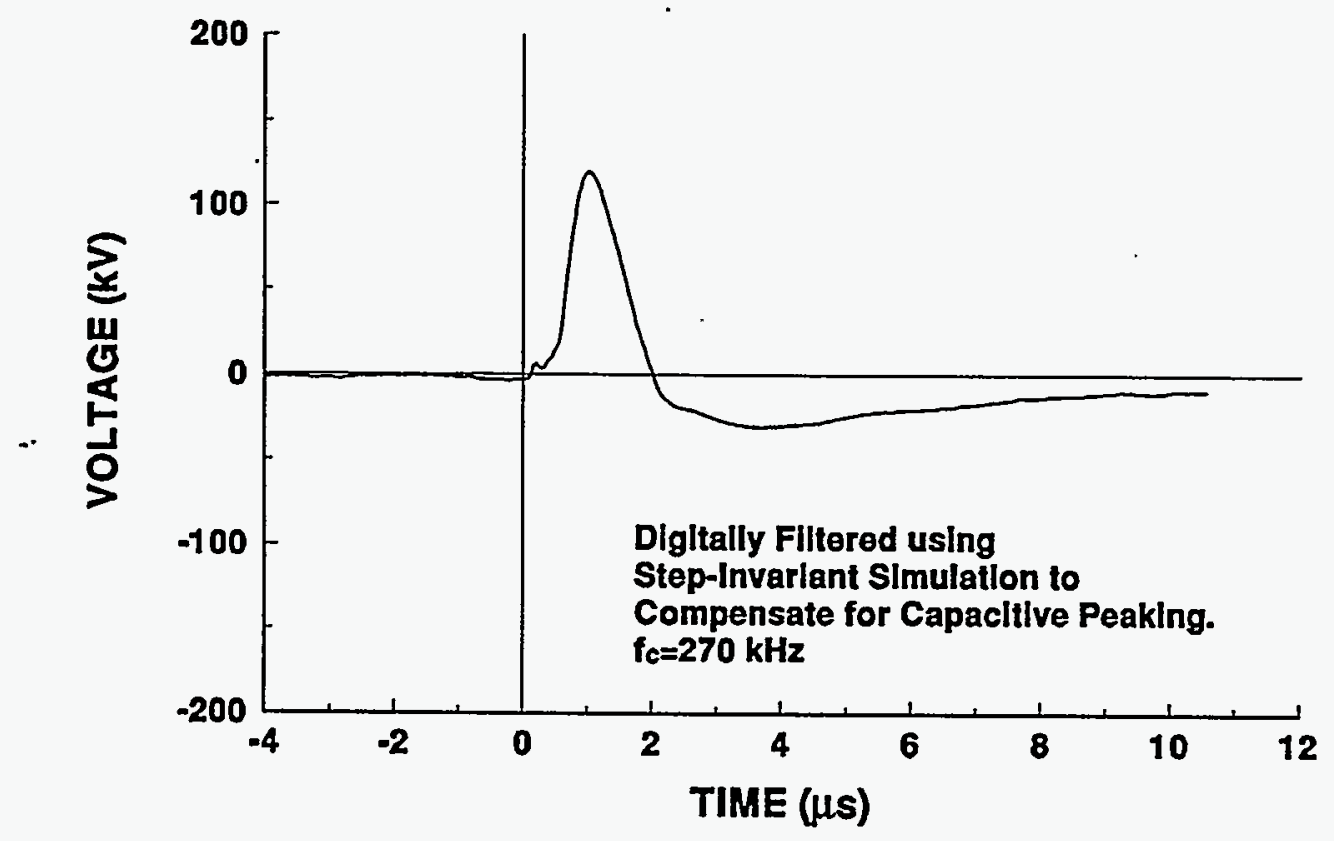

\section{4-15 STROKE-1}

\section{TEST POINT 22}

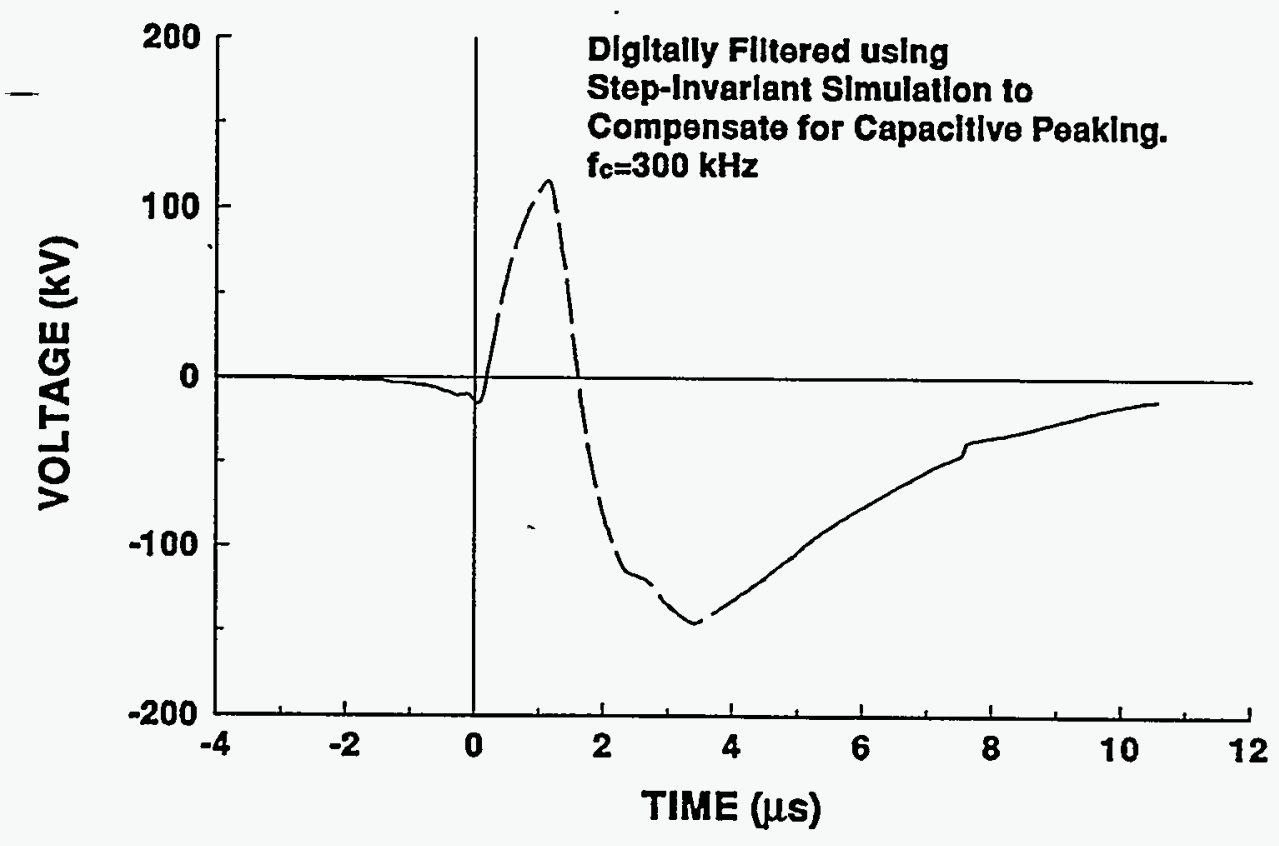




\section{4-15 STROKE 1}

TEST POINT 23

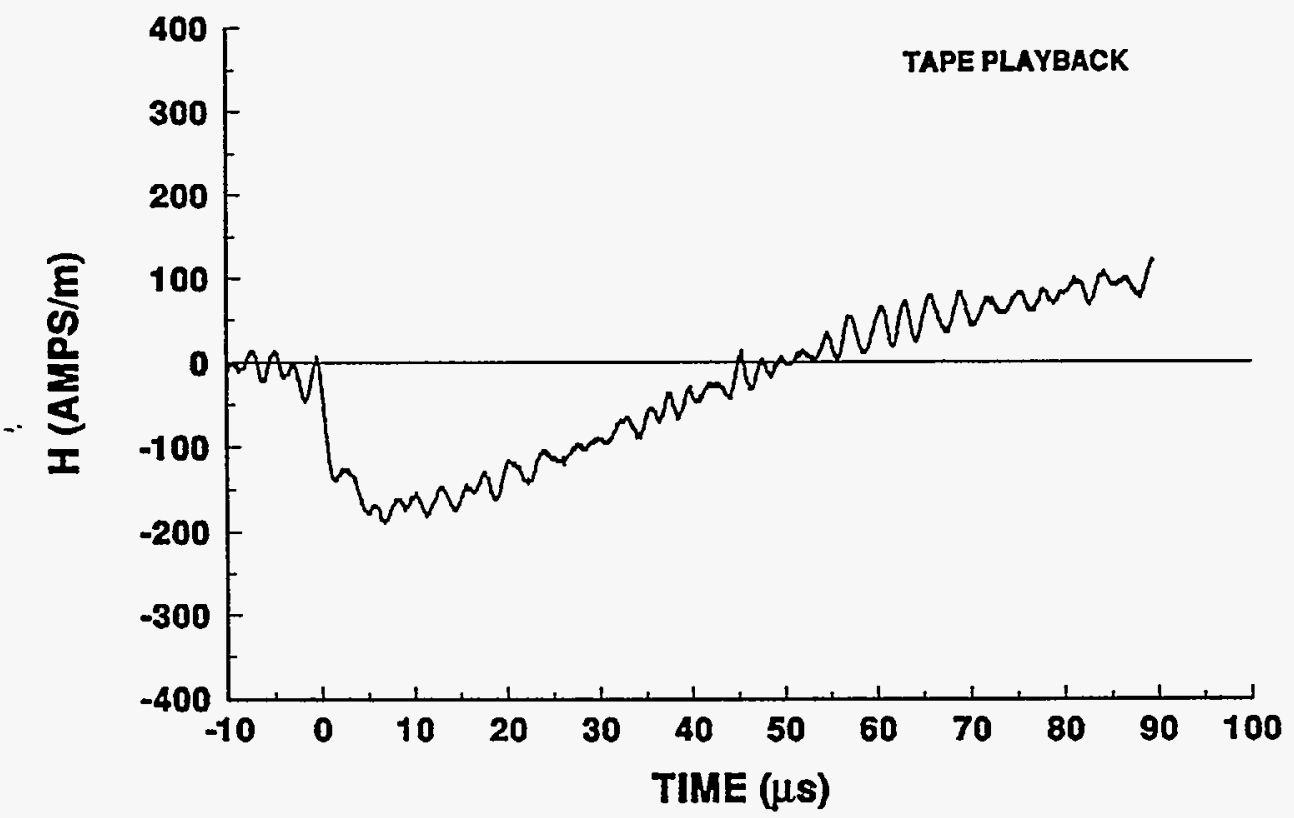

94-15 STROKE 1

TEST POINT 24

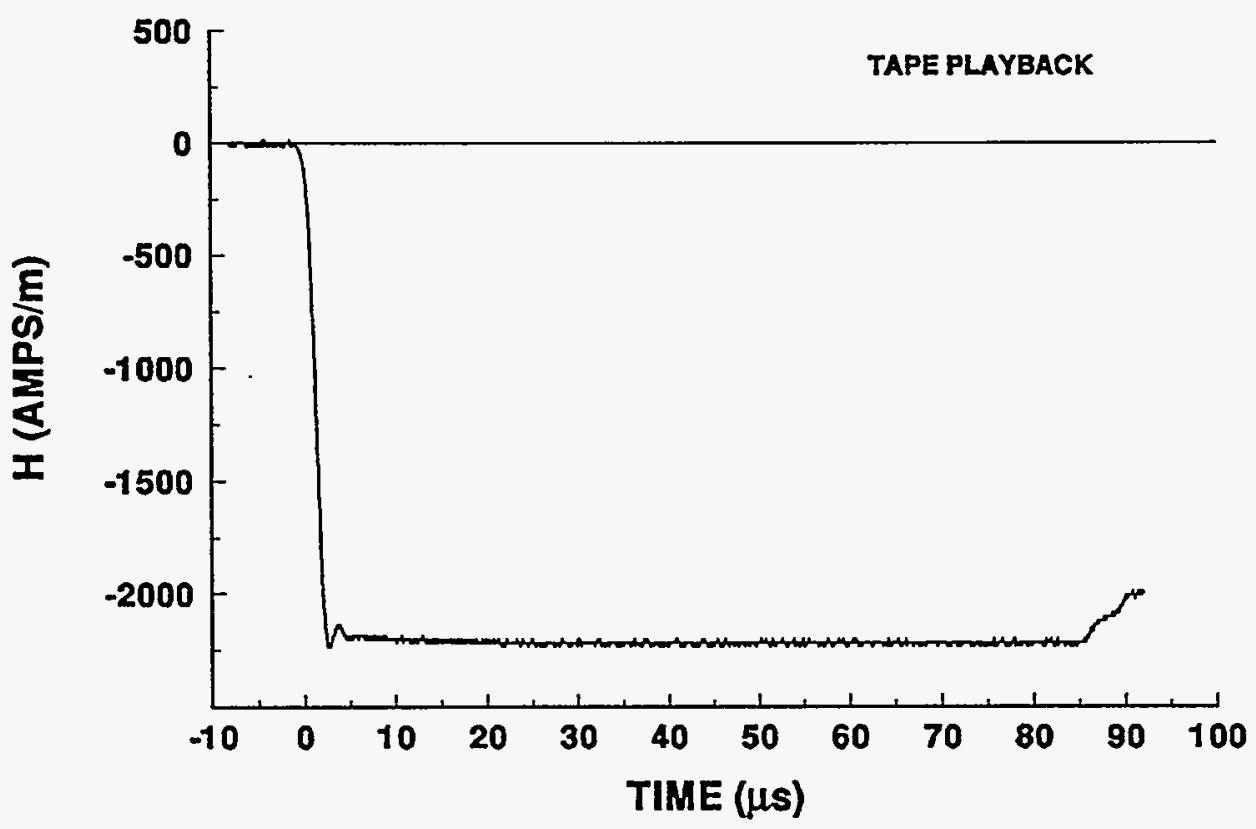




\section{4-15 STROKE 2}

\section{INCIDENT CURRENT}
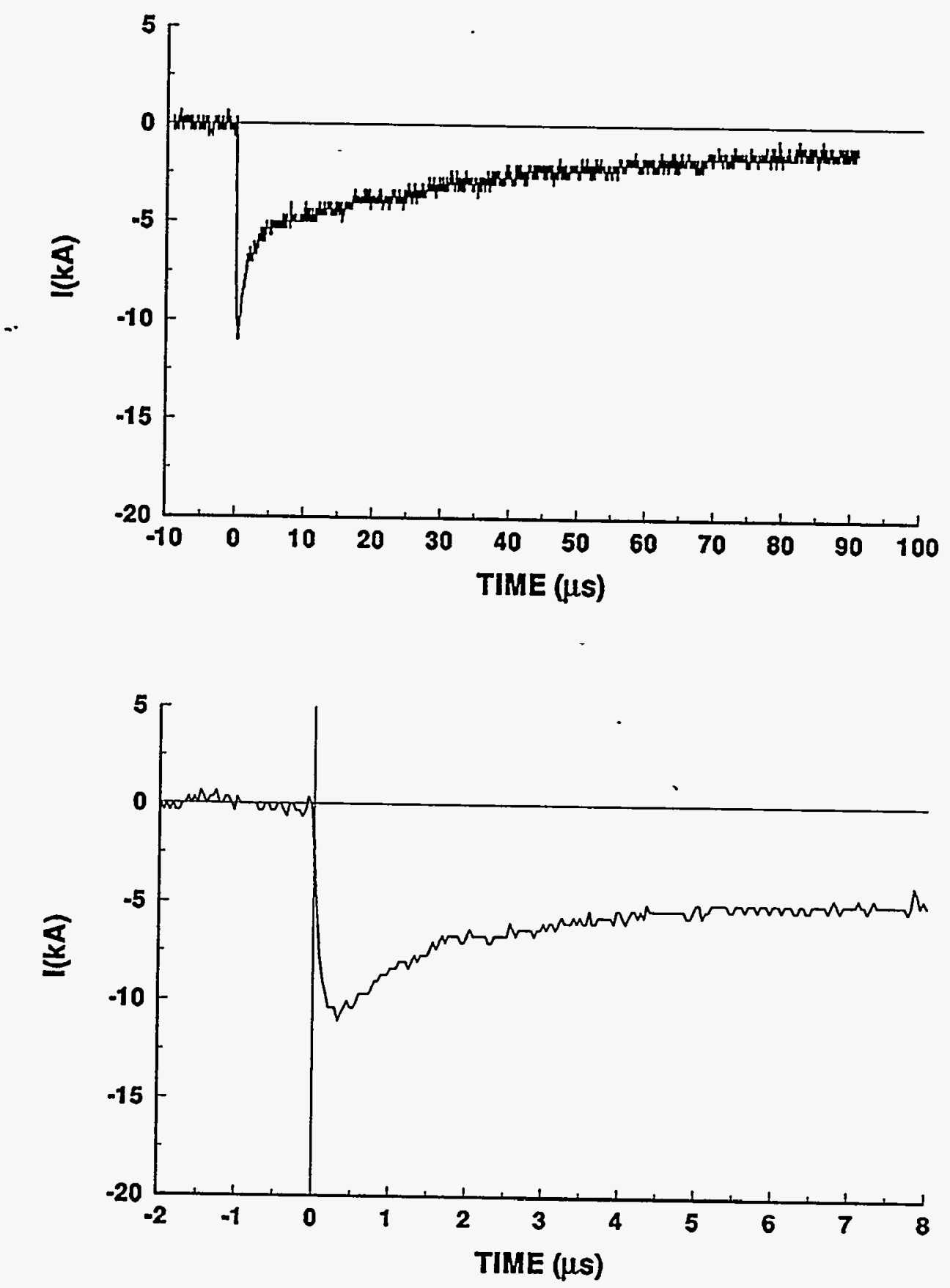


\section{4-15 STROKE 2}

TEST POINT 1

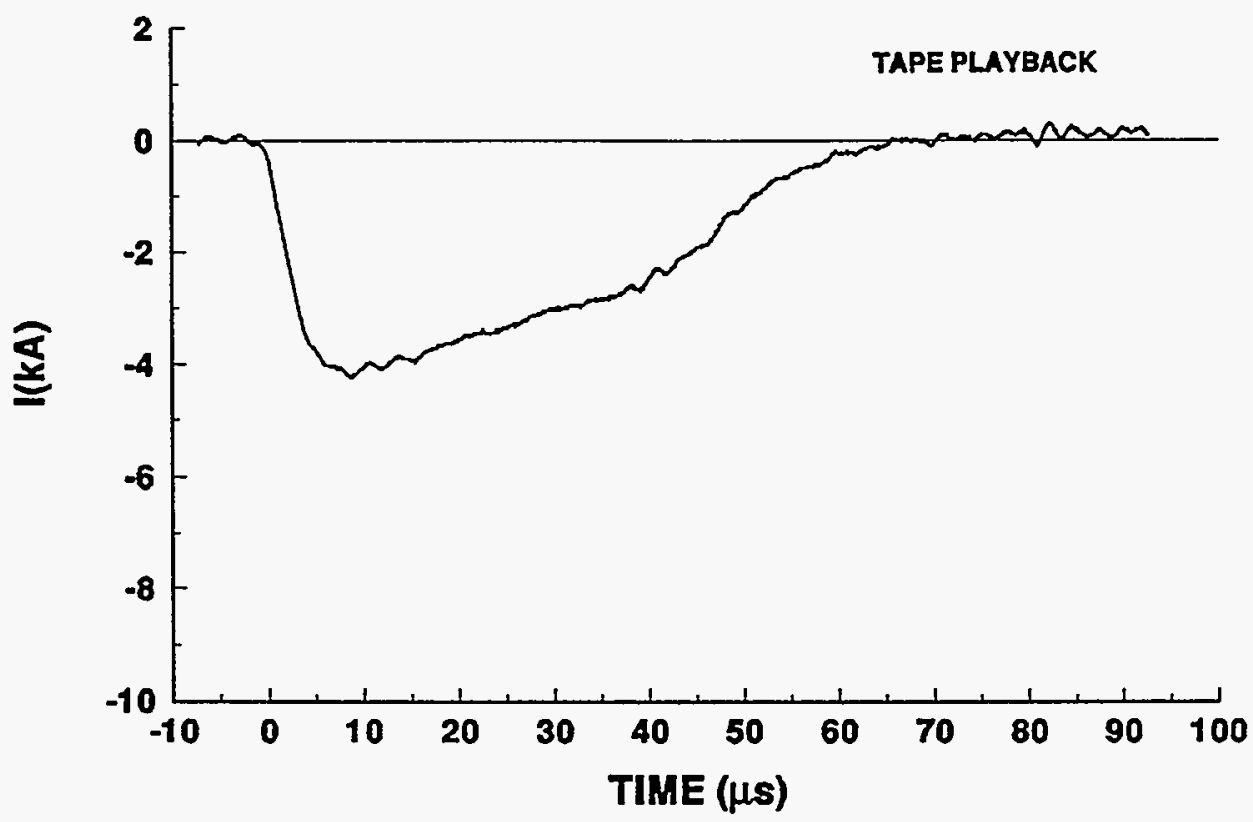

\section{4-15 STROKE 2}

TEST POINT 2

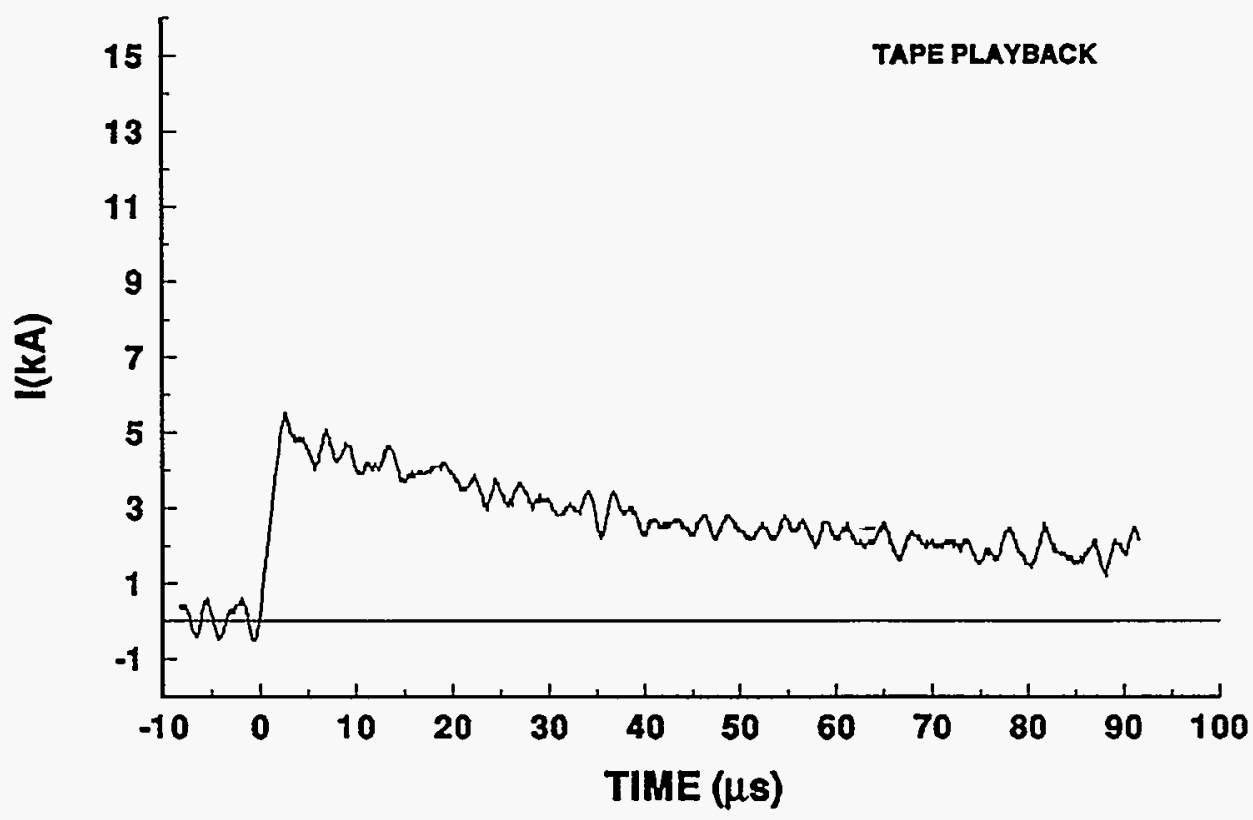




\section{4-15 STROKE 2}

TEST POINT 3
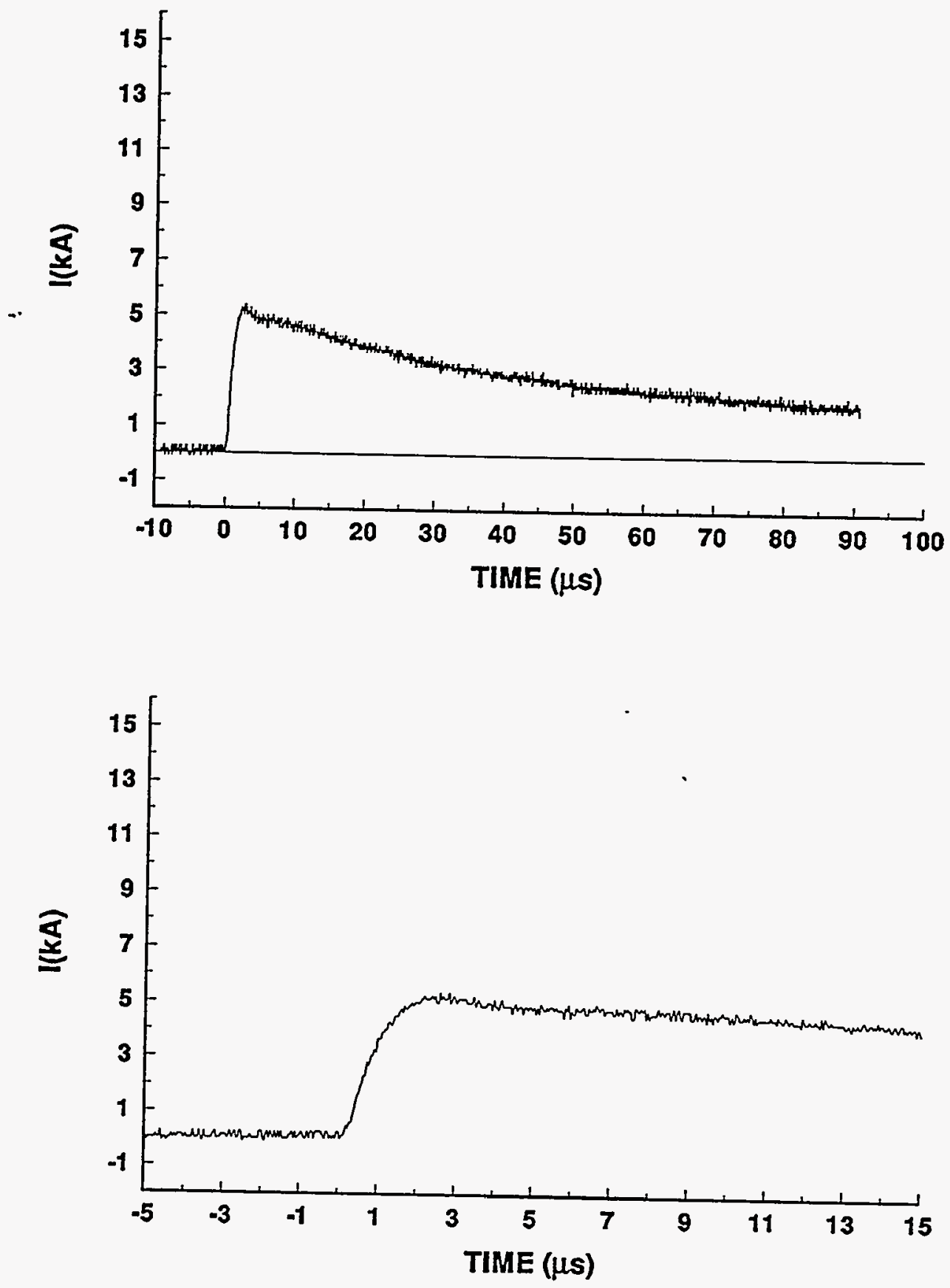


\section{4-15 STROKE 2}

TEST POINT 4
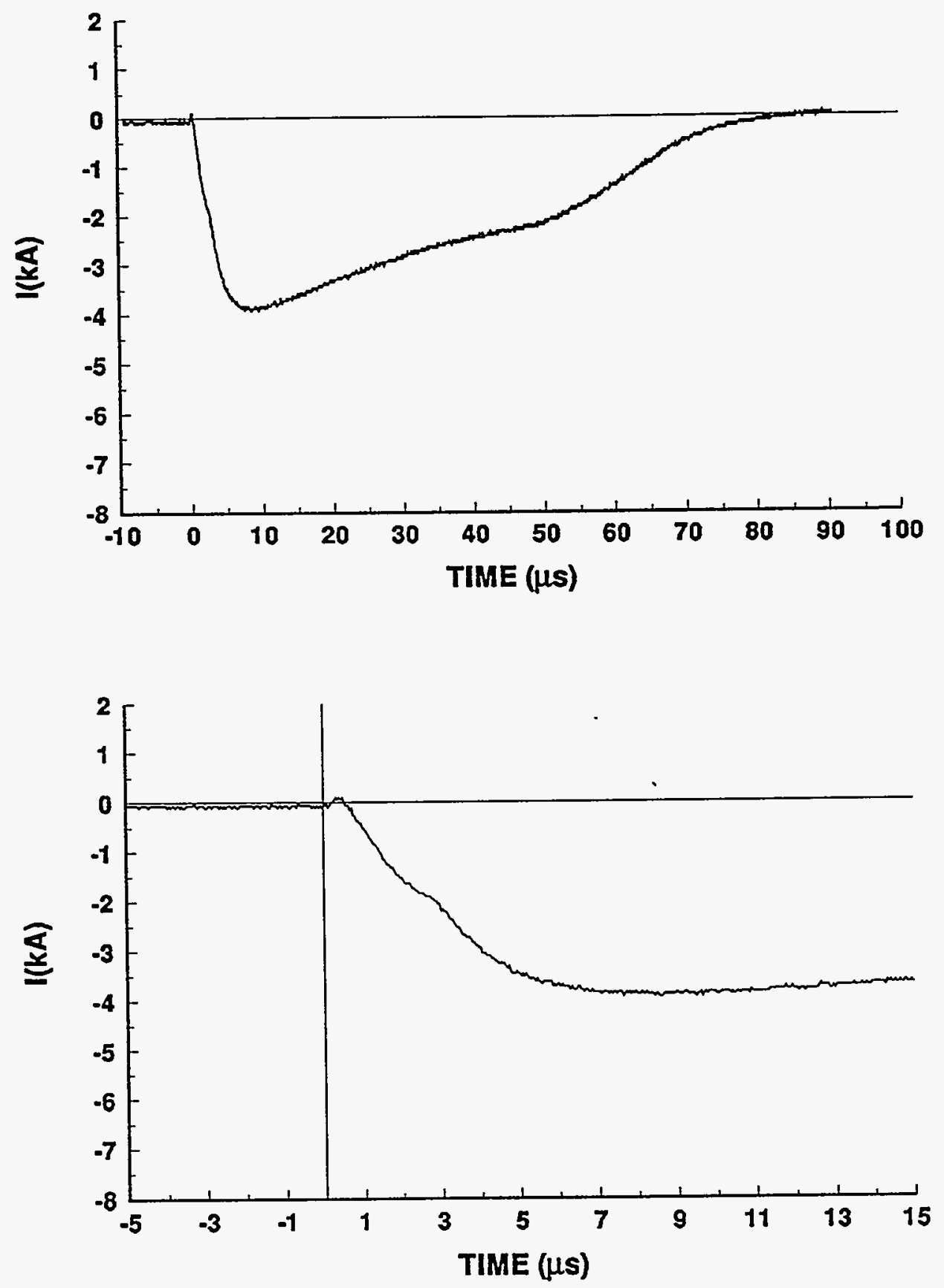


\section{4-15 STROKE 2}

\section{TEST POINT 5}

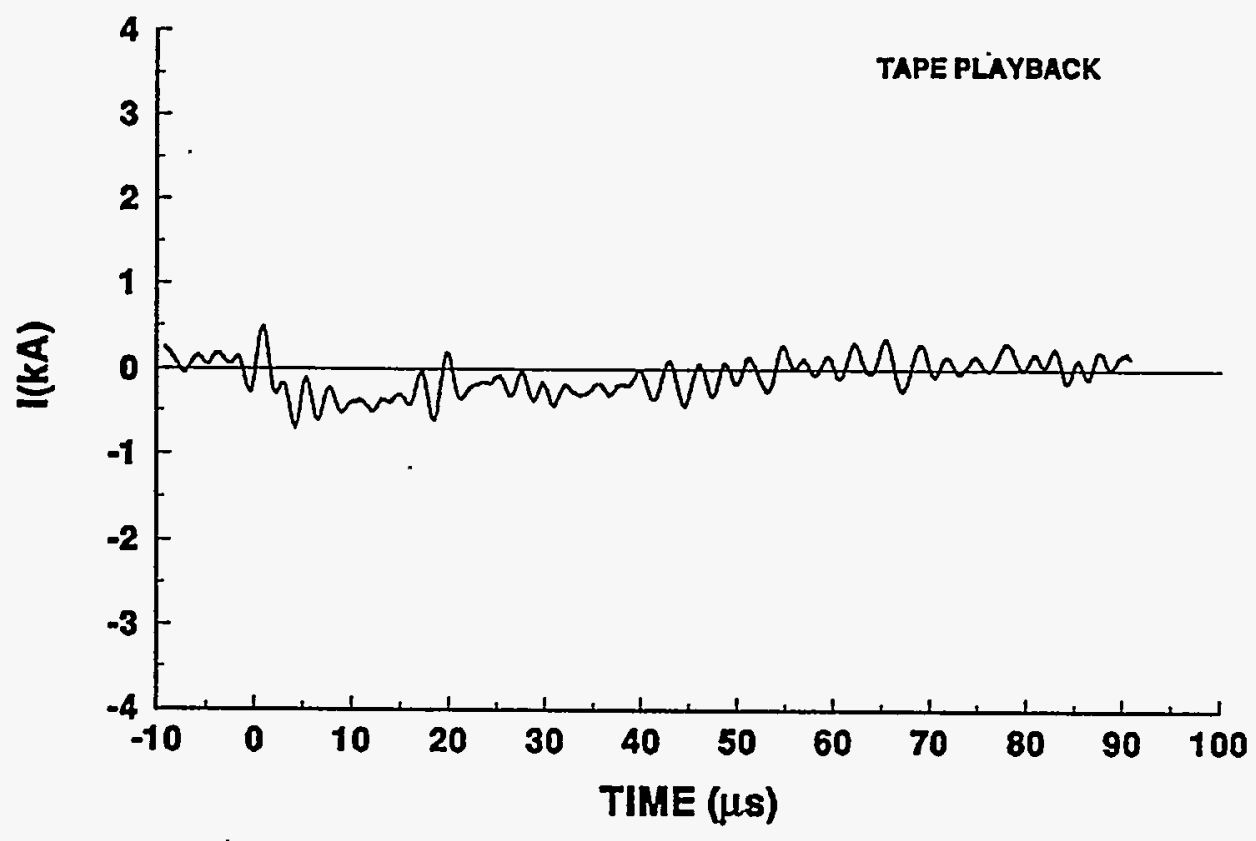

\section{4-15 STROKE 2}

TEST POINT 6

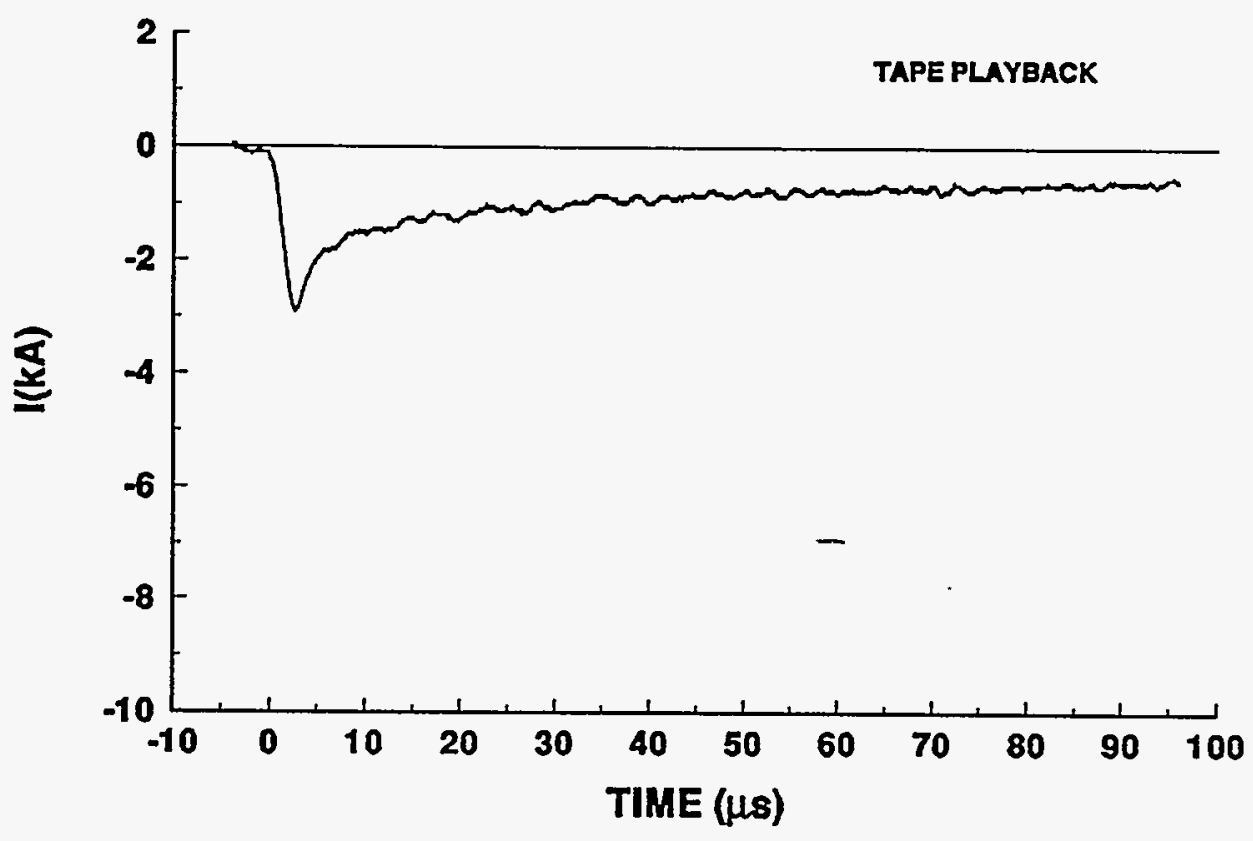


94-15 STROKE 2

TEST POINT 7

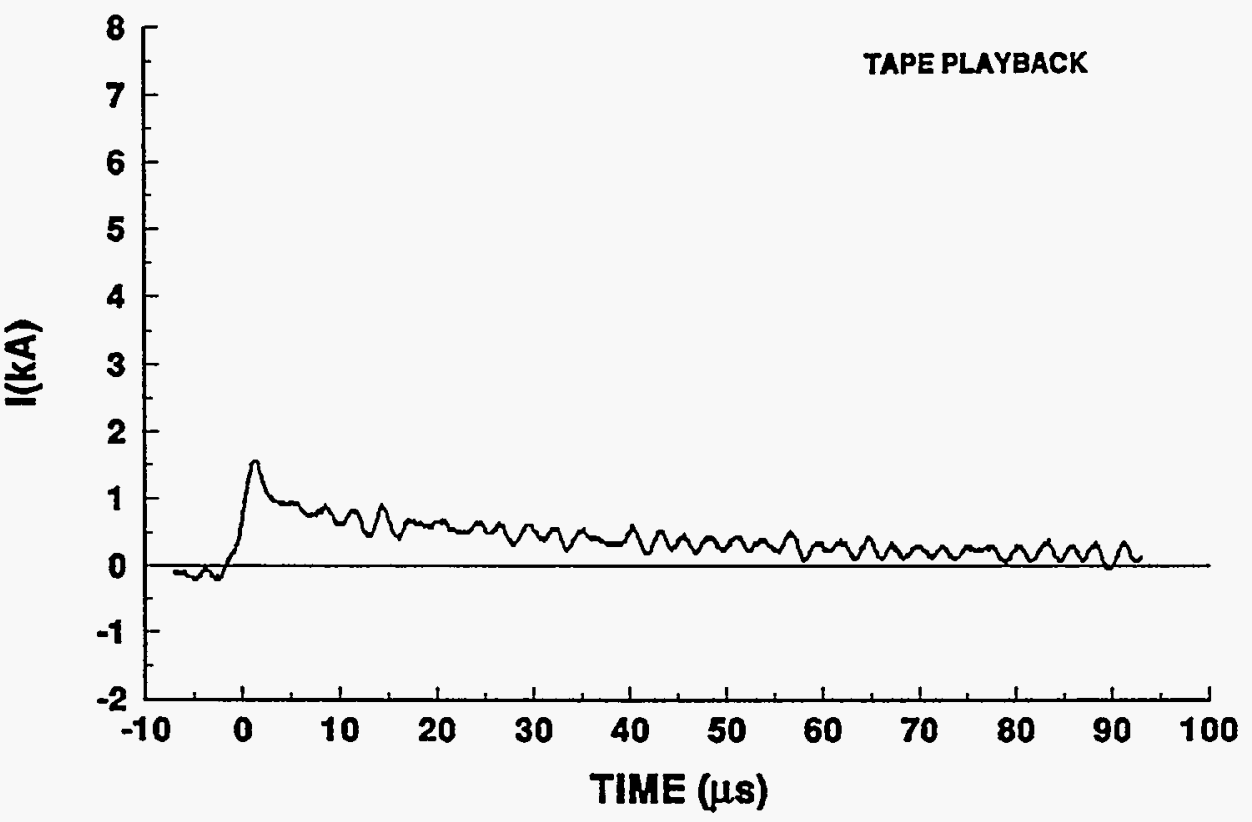

94-15 STROKE 2

TEST POINT 8

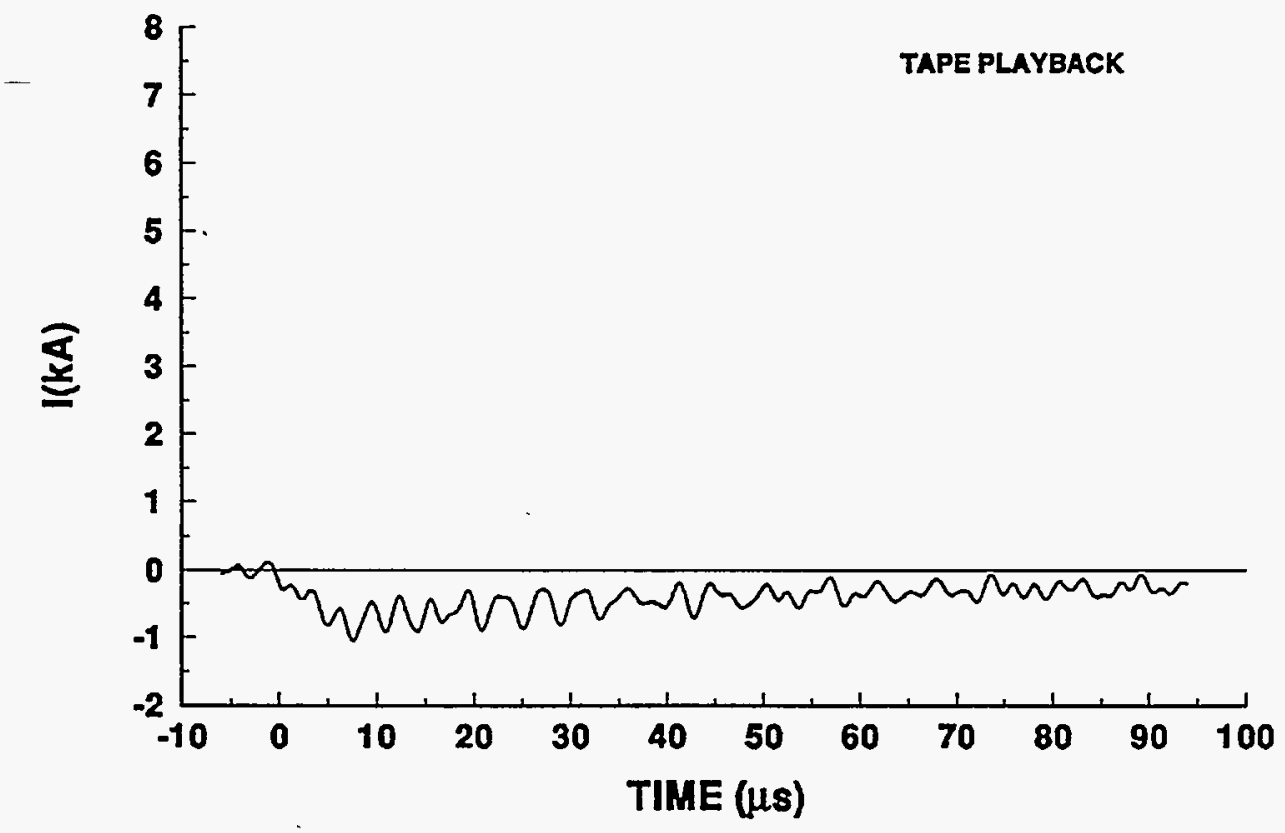


94-15 STROKE 2

\section{TEST POINT 9}

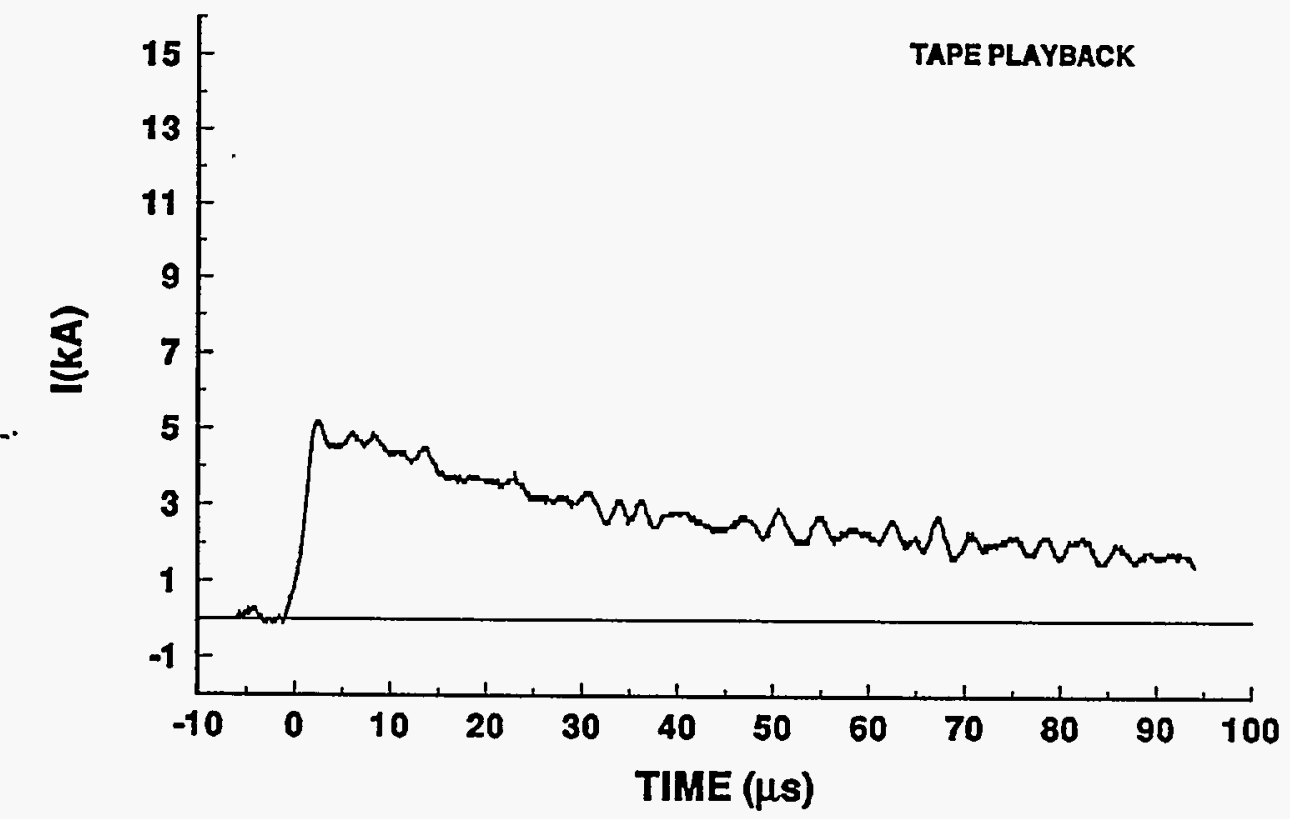

\section{4-15 STROKE 2} TEST POINT 9'

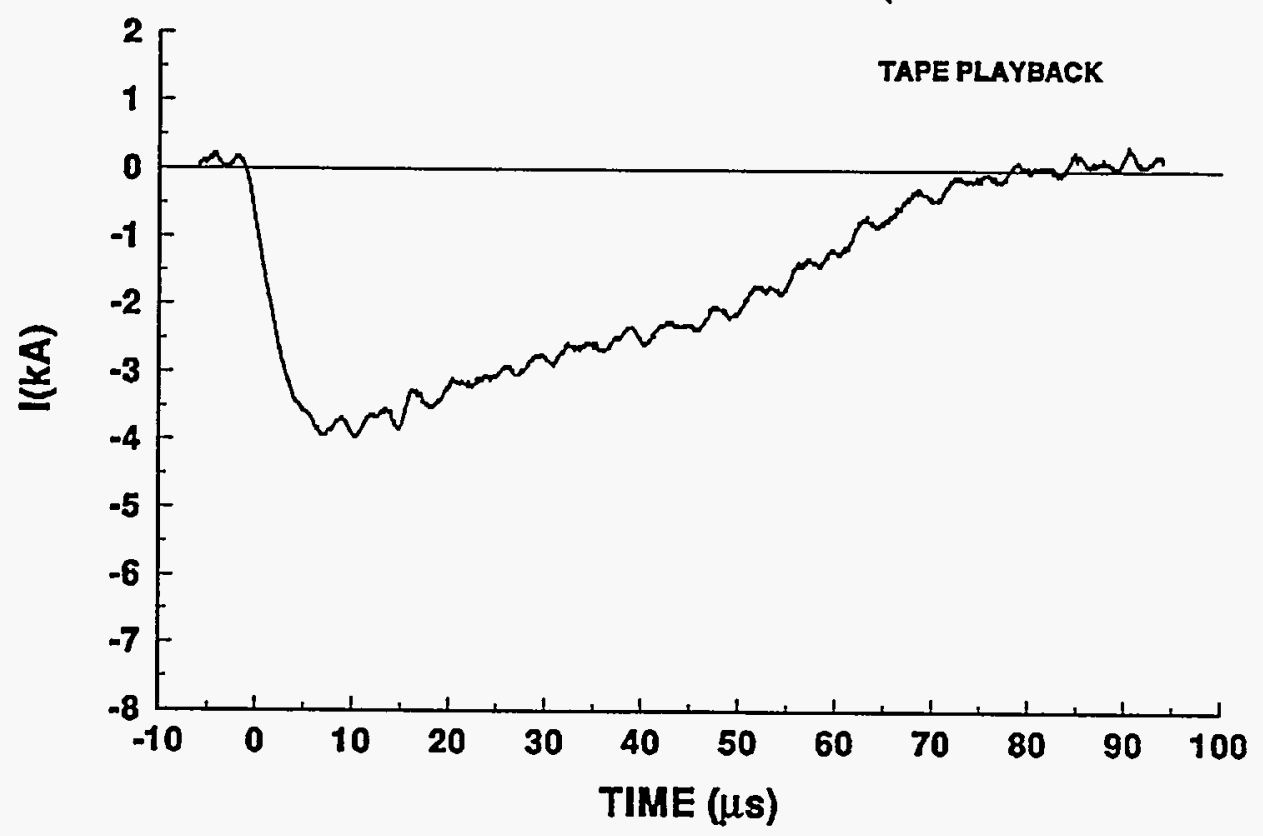




\section{4-15 STROKE 2}

TEST POINT 16

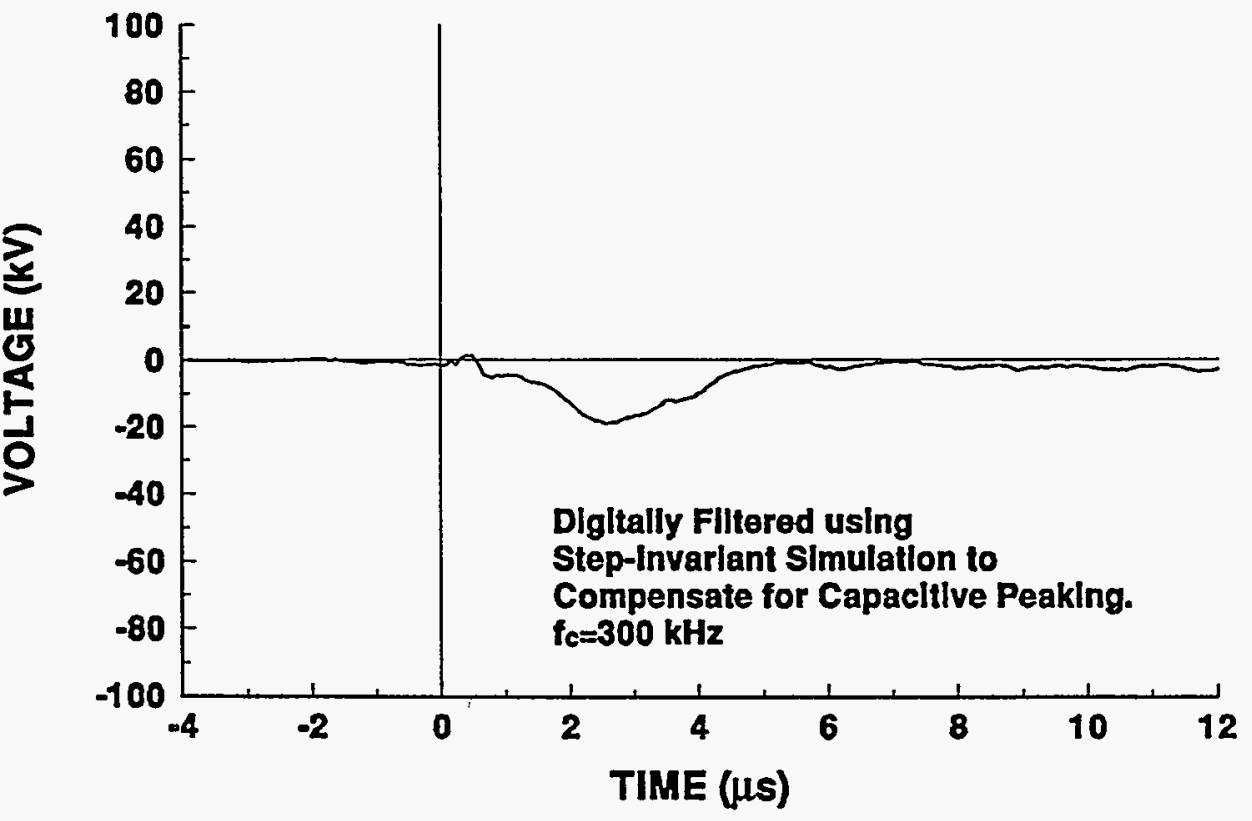

94-15 STROKE 2

TEST POINT 17

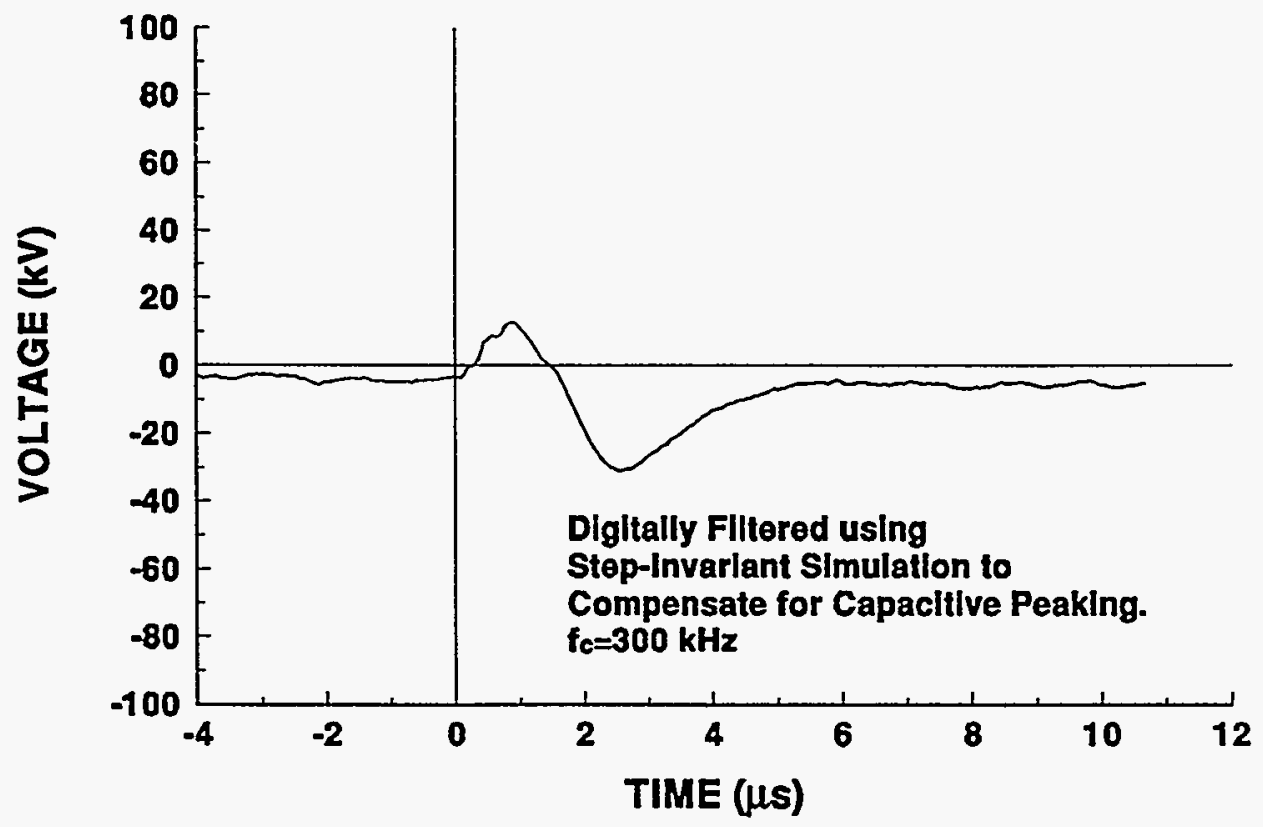




\section{4-15 STROKE 2}

\section{TEST POINT 18}

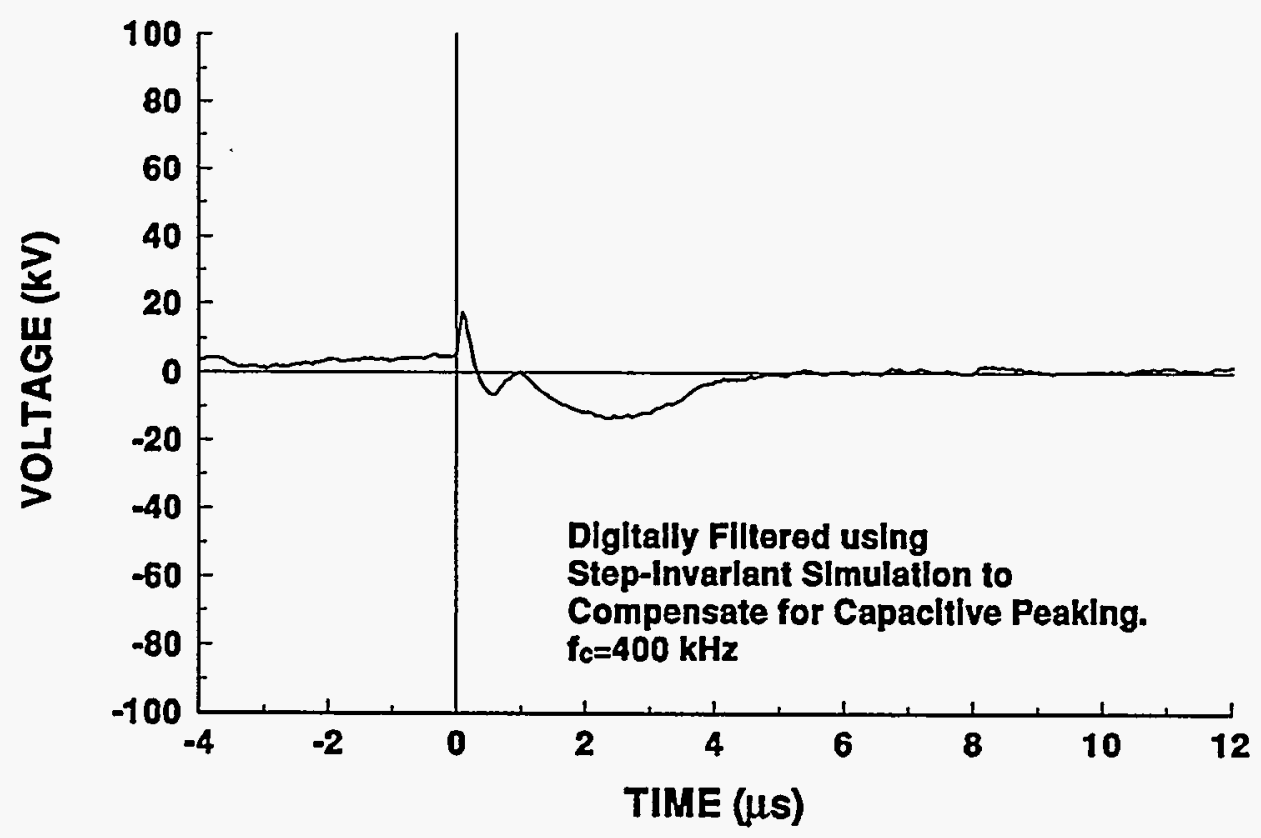

94-15 STROKE 2

TEST POINT 19

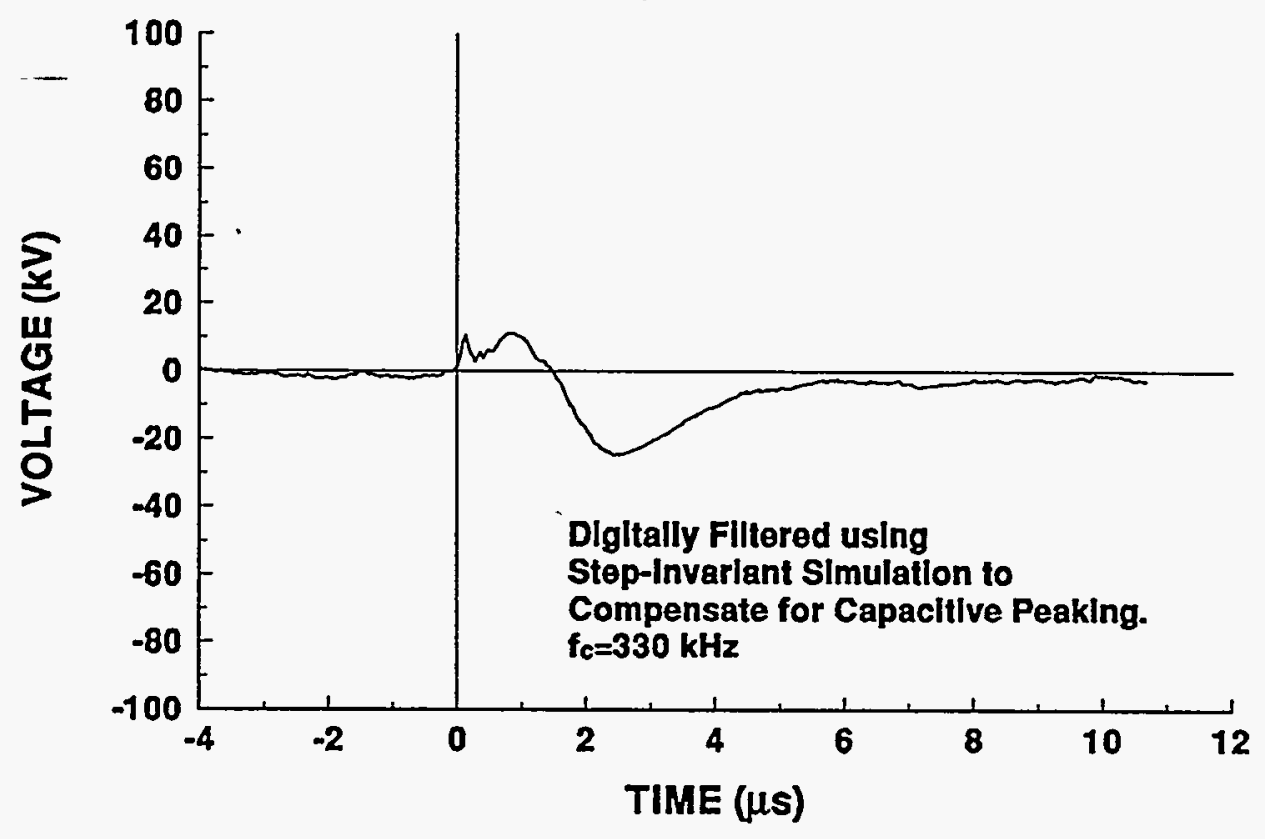


94-15 STROKE 2

TEST POINT 20

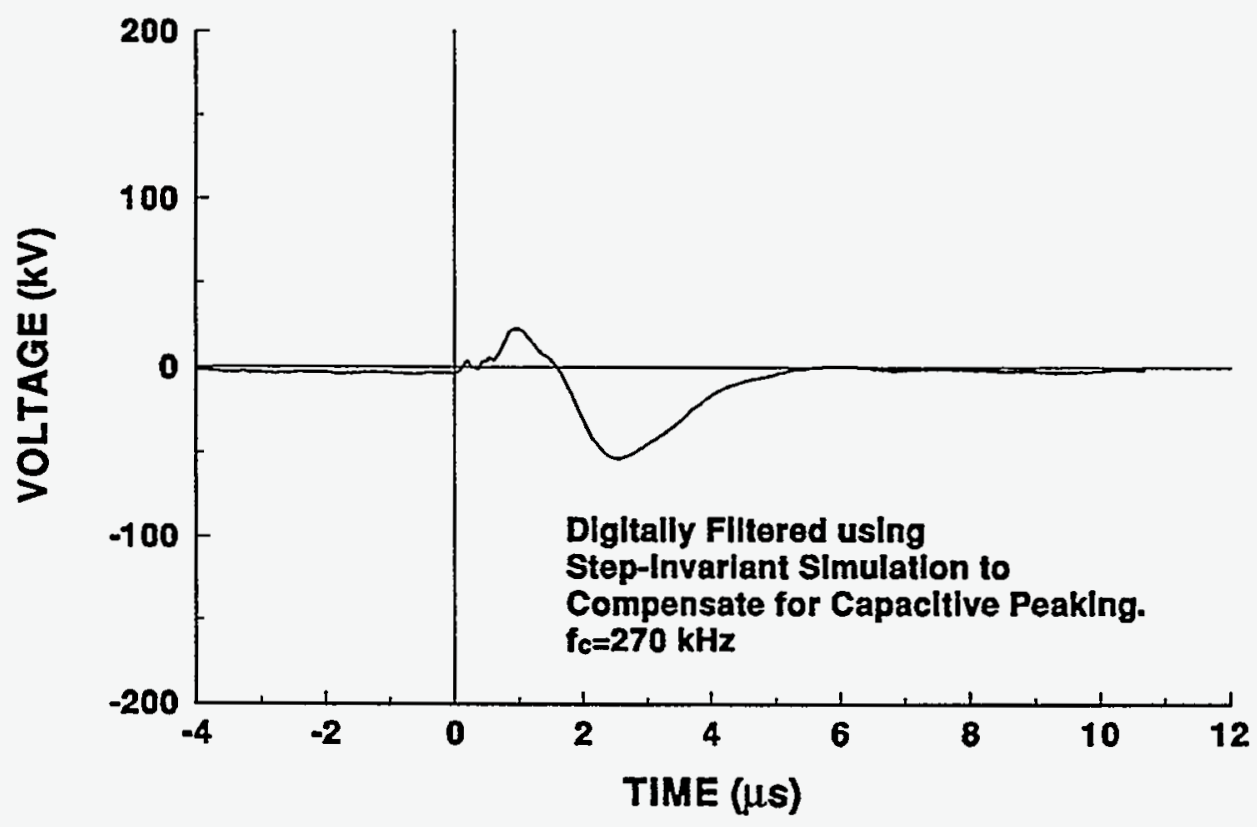

94-15 STROKE 2

TEST POINT 22

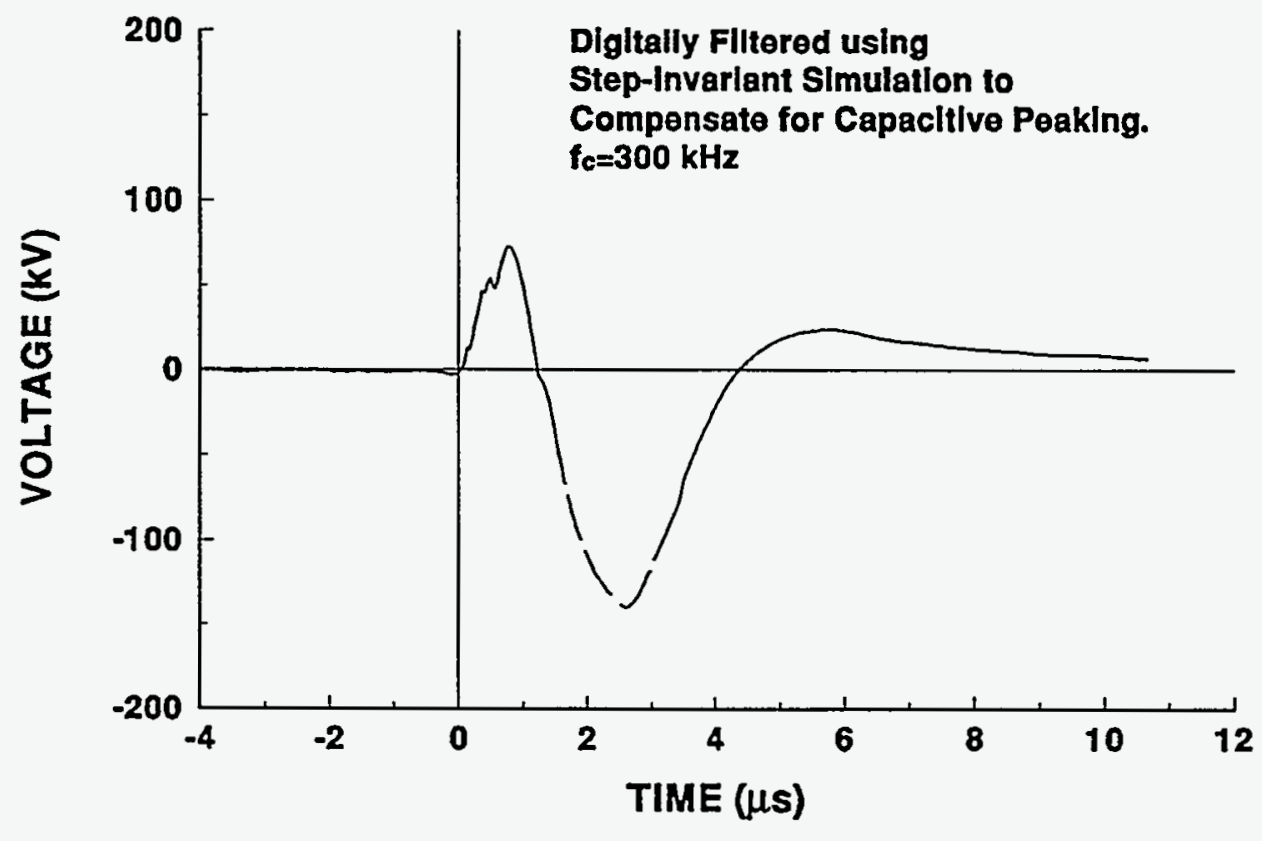




\section{4-15 STROKE 2}

TEST POINT 23

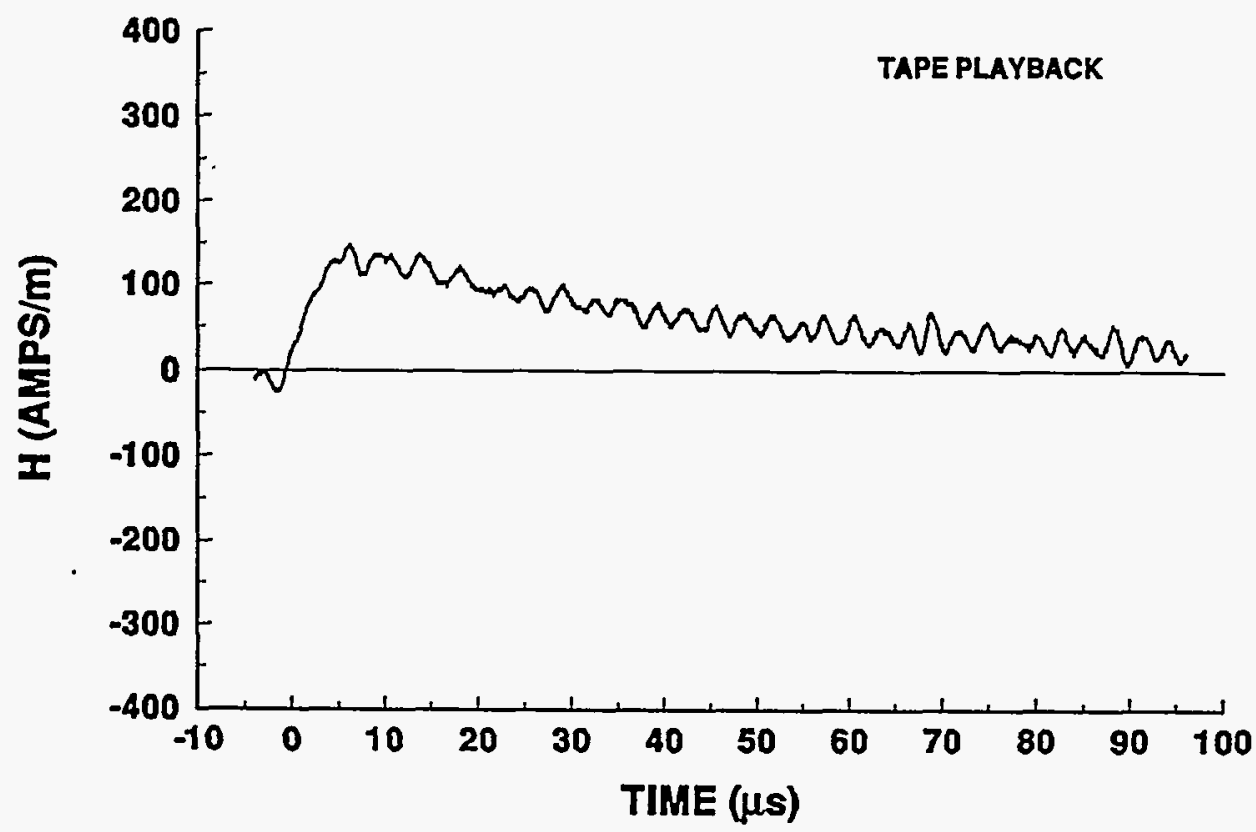

94-15 STROKE 2

TEST POINT 24

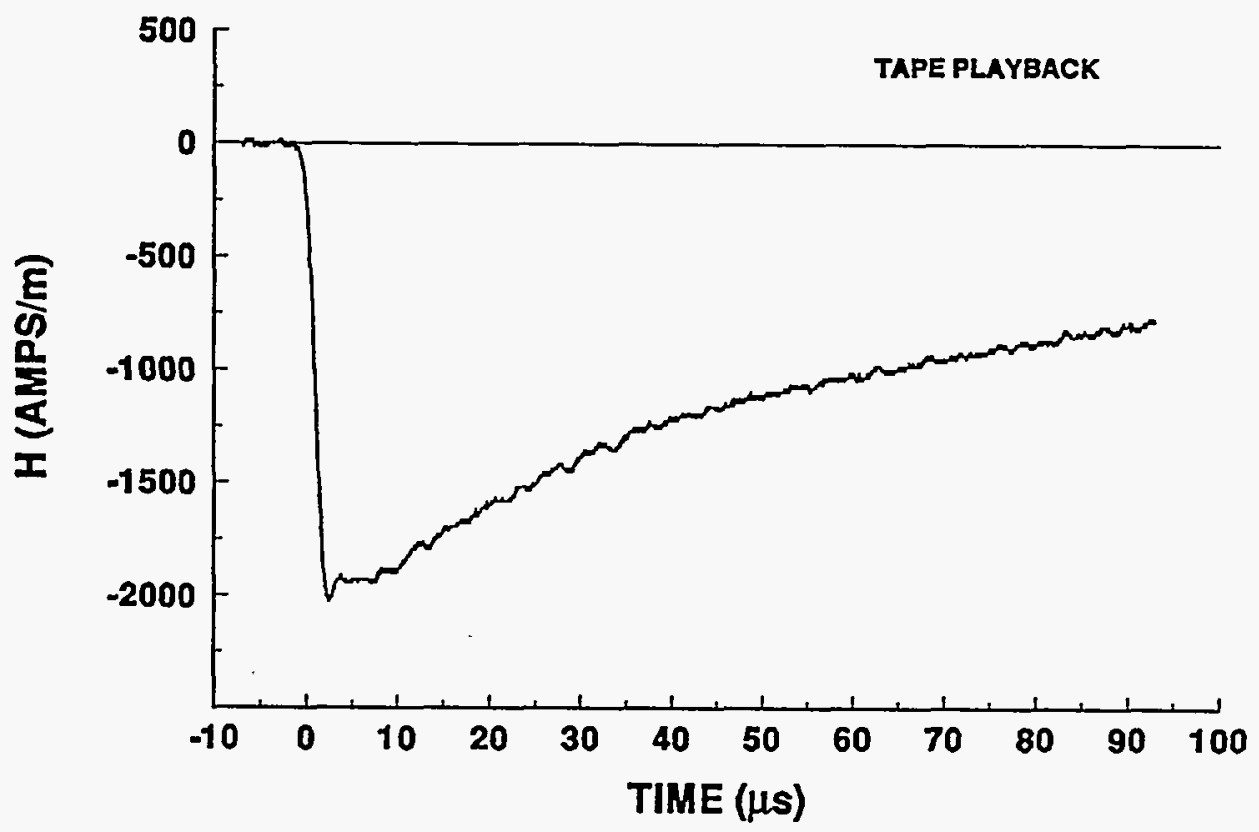




\section{4-15 STROKE 3 INCIDENT CURRENT}
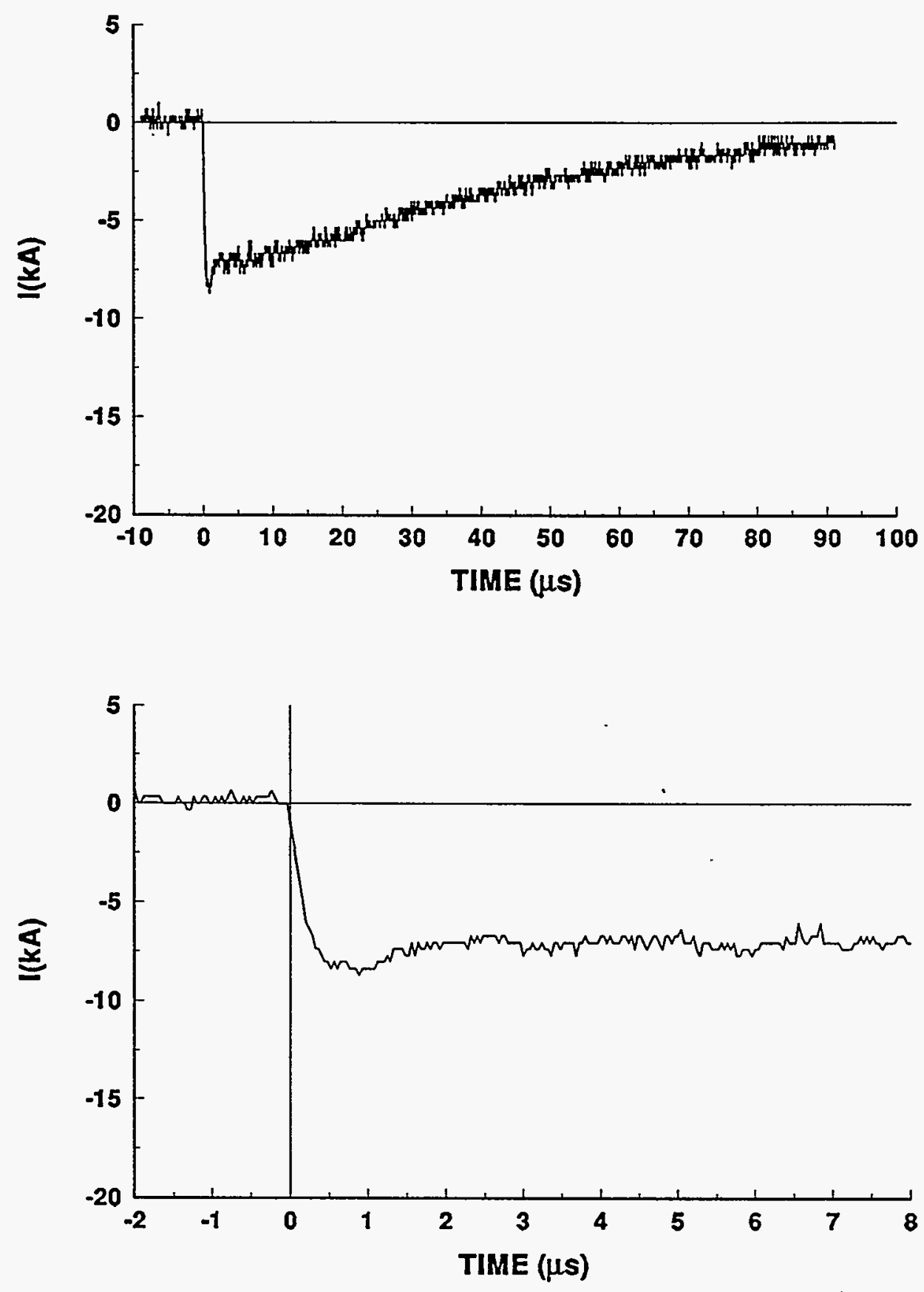


\section{4-15 STROKE 3}

TEST POINT 1

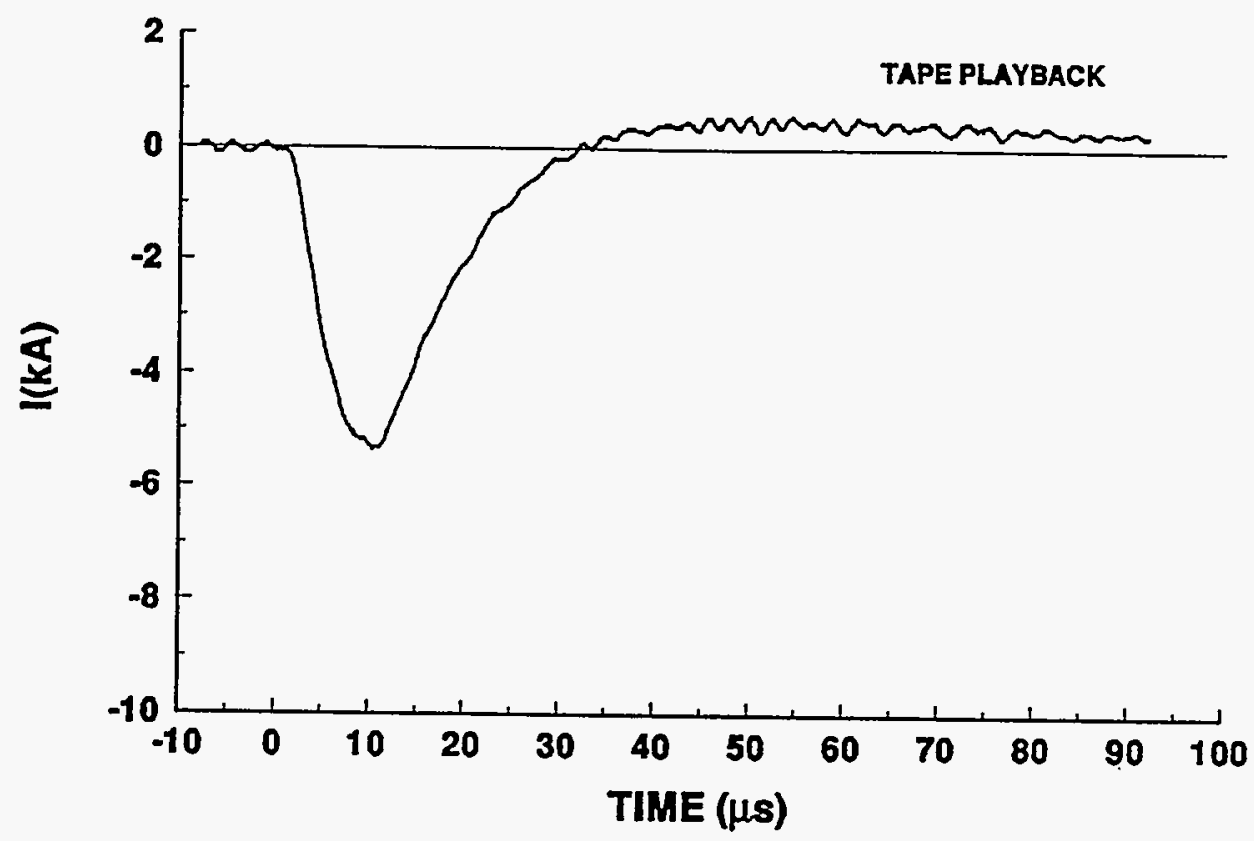

\section{4-15 STROKE 3 .}

\section{TEST POINT 2}

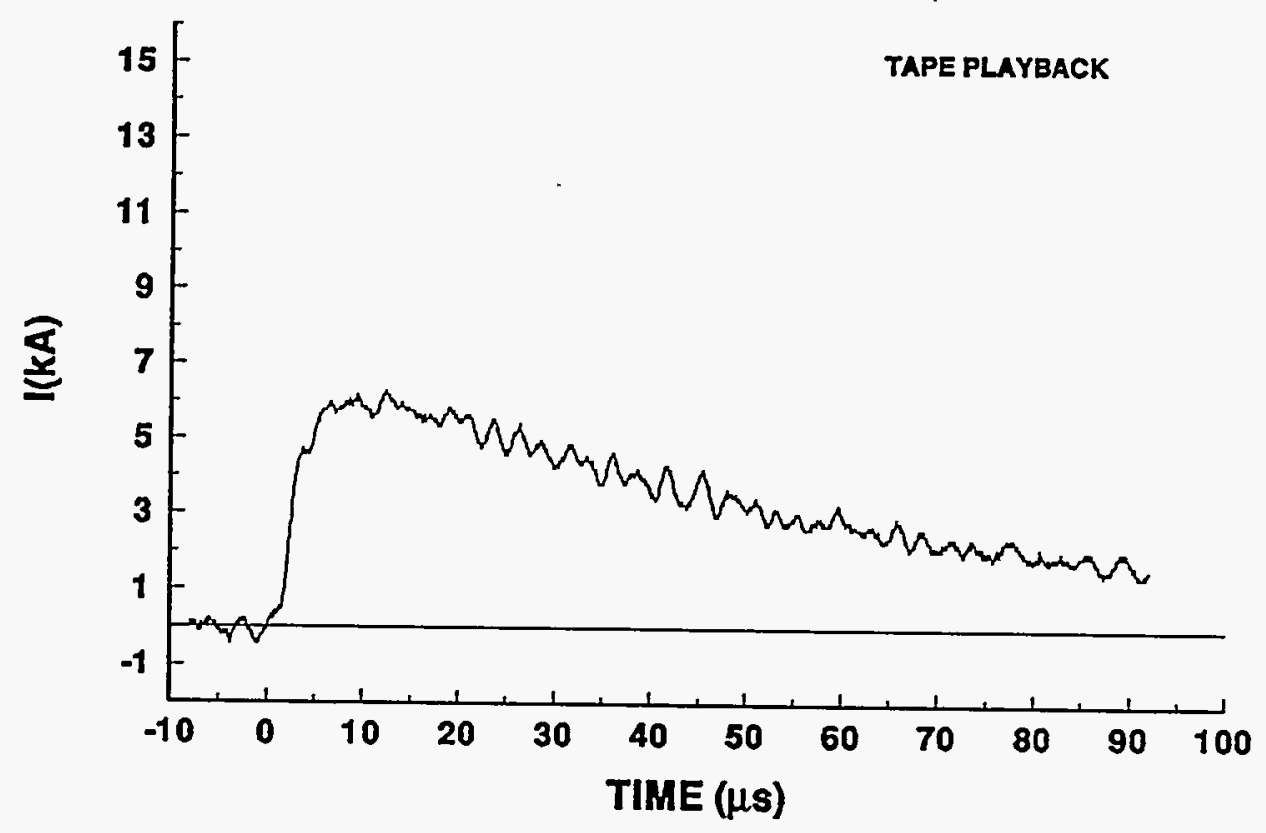




\section{4-15 STROKE 3}

TEST POINT 3
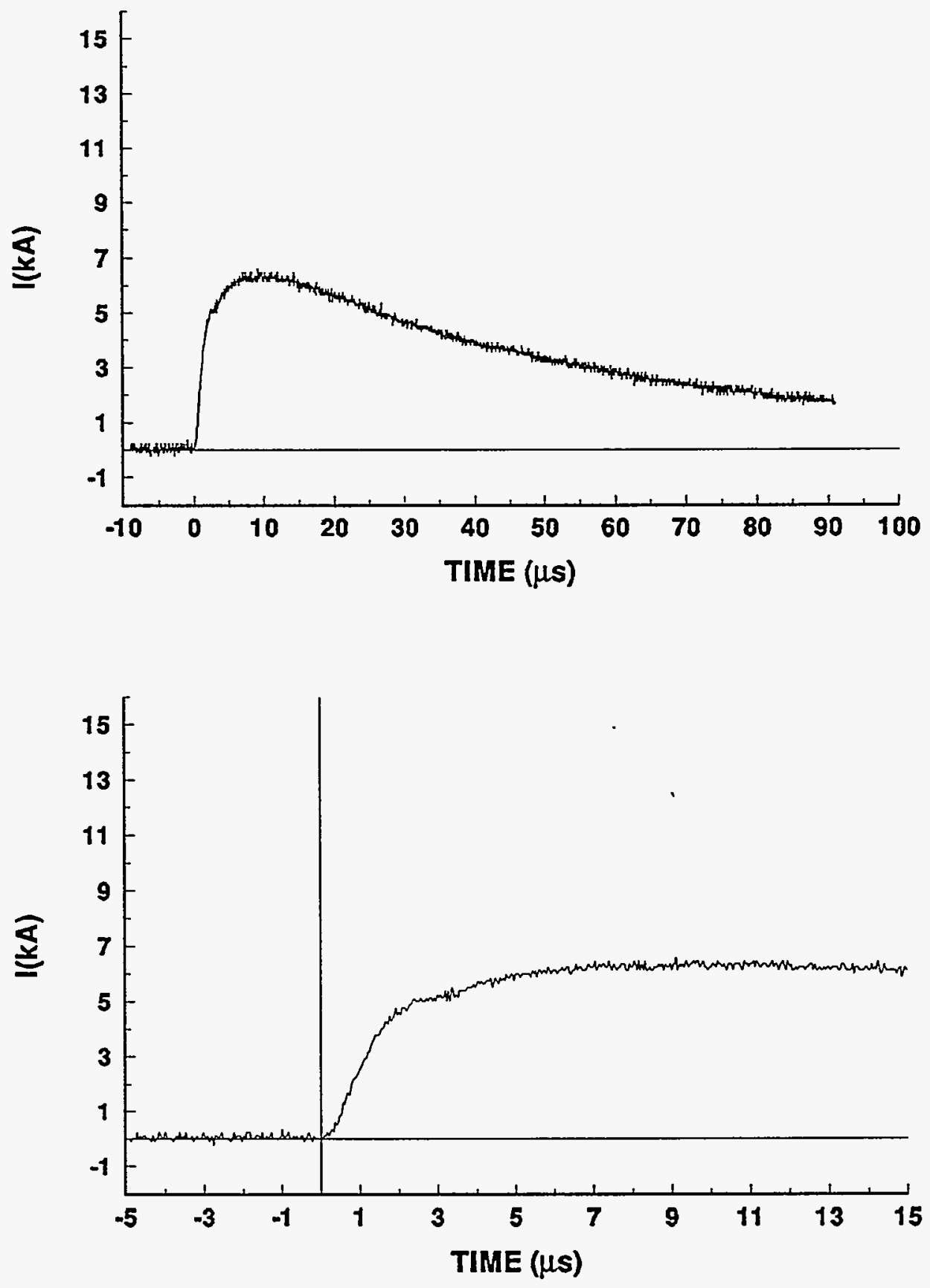


\section{4-15 STROKE 3}

\section{TEST POINT 4}
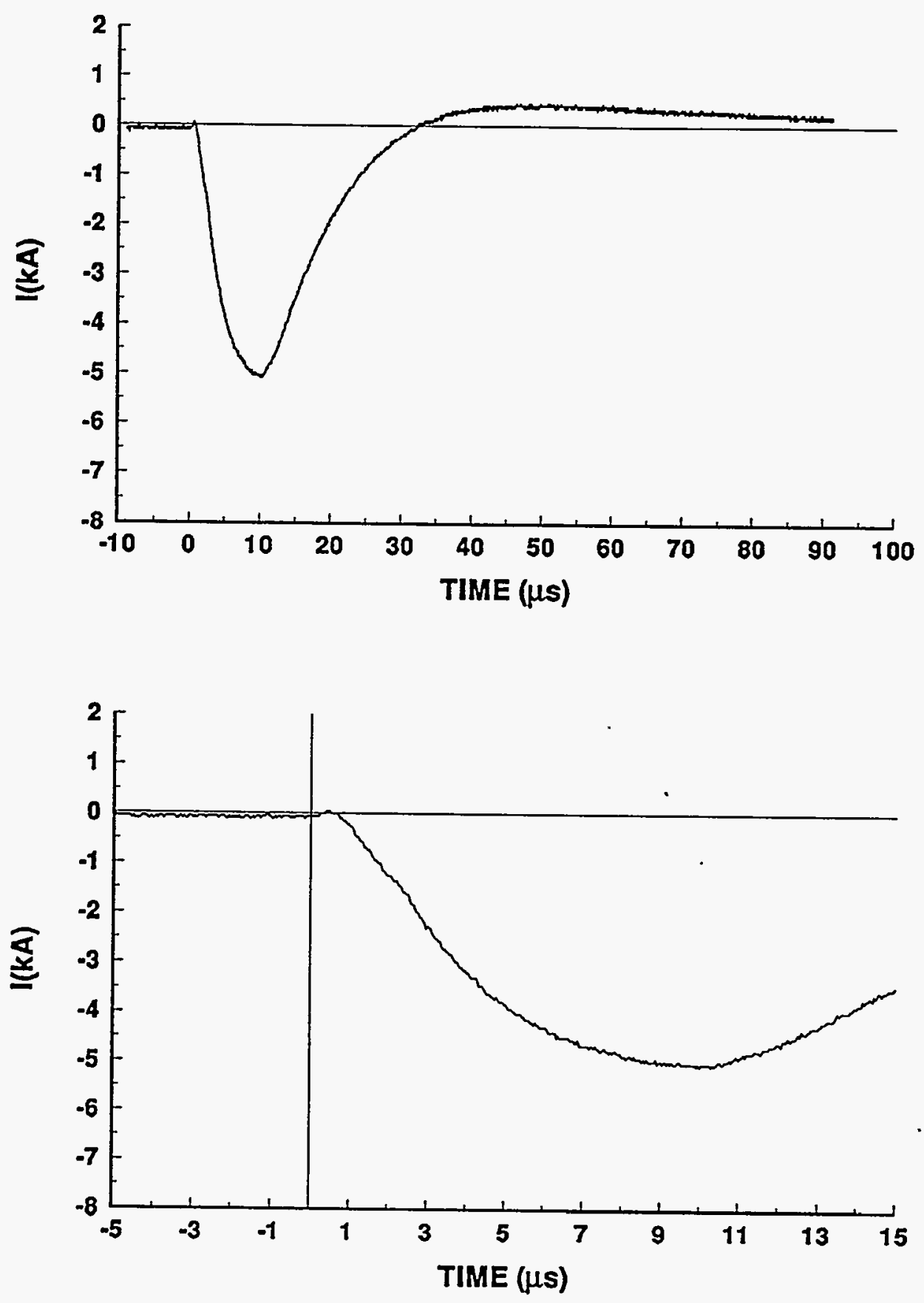


\section{4-15 STROKE 3}

TEST POINT 5

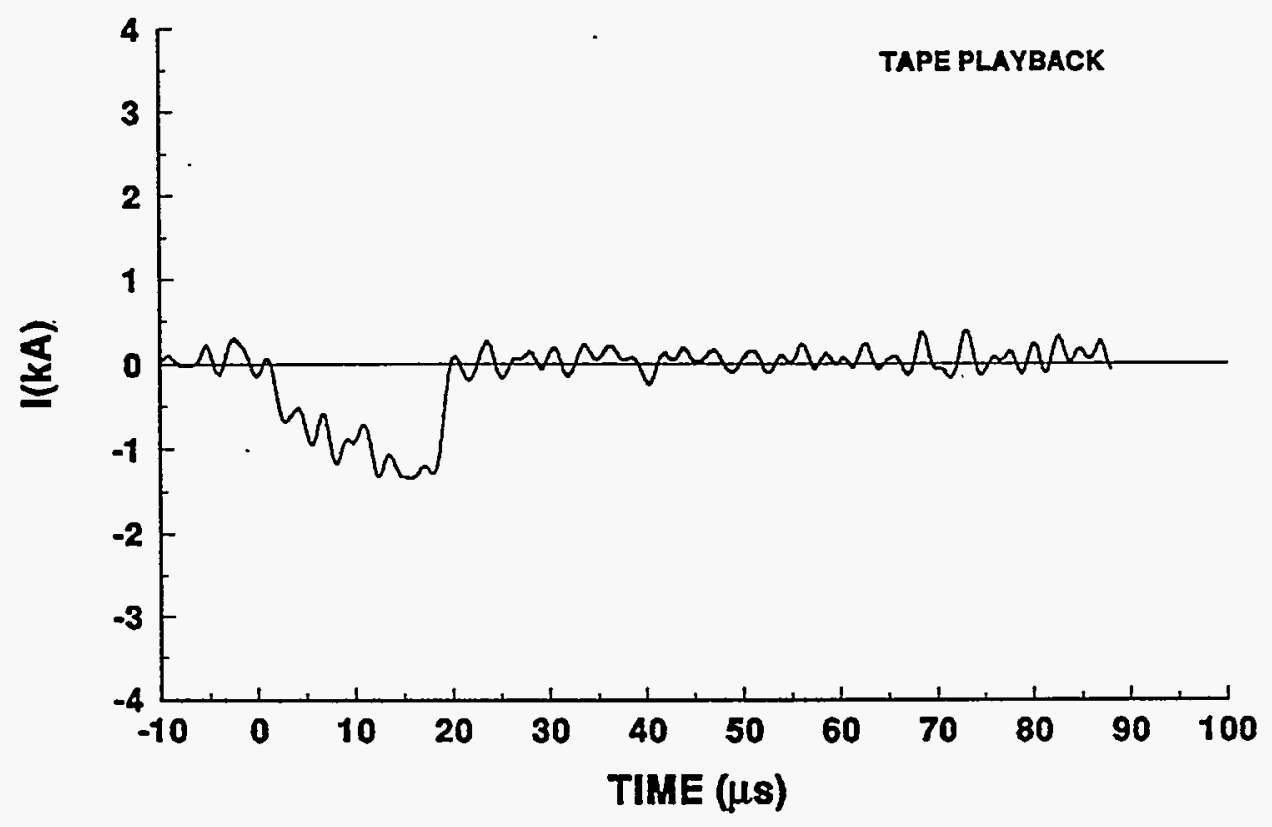

\section{4-15 STROKE 3}

TEST POINT 6

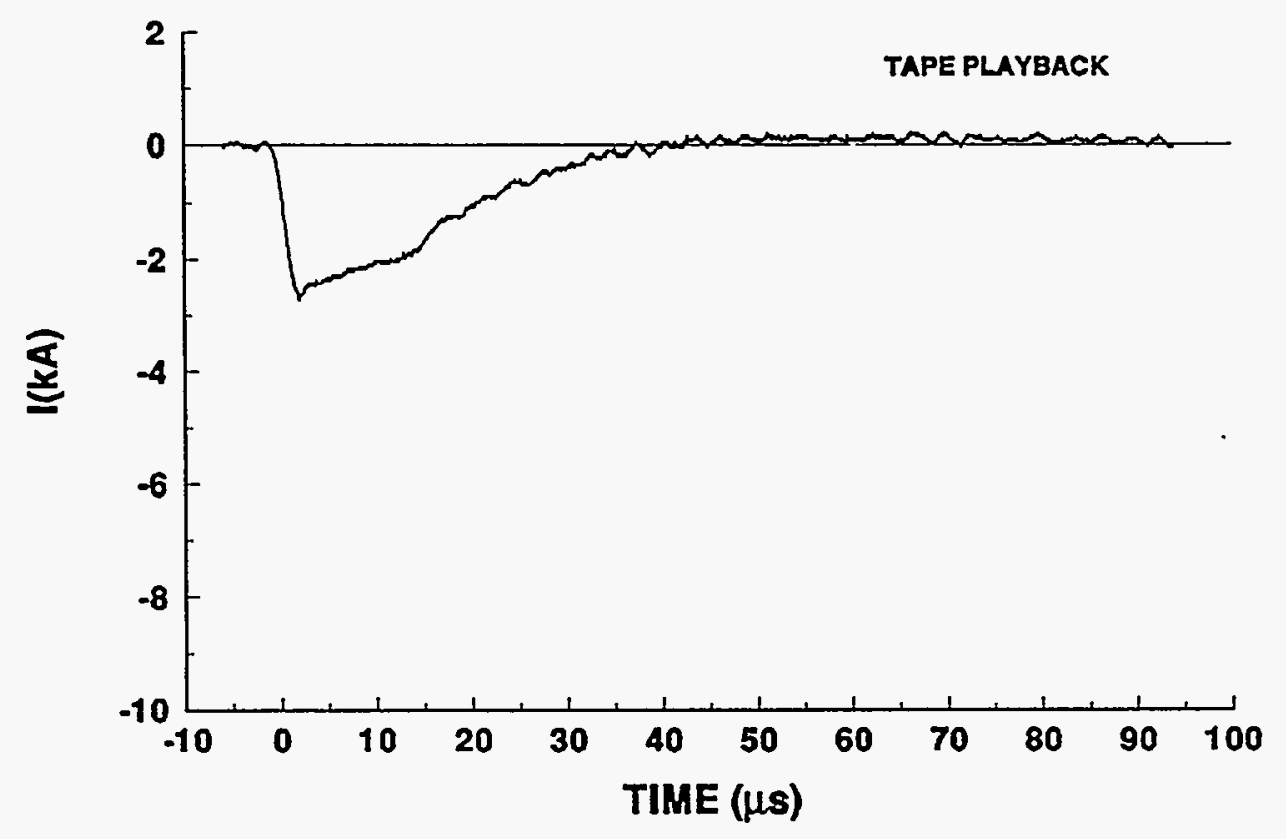




\section{4-15 STROKE 3}

TEST POINT 7

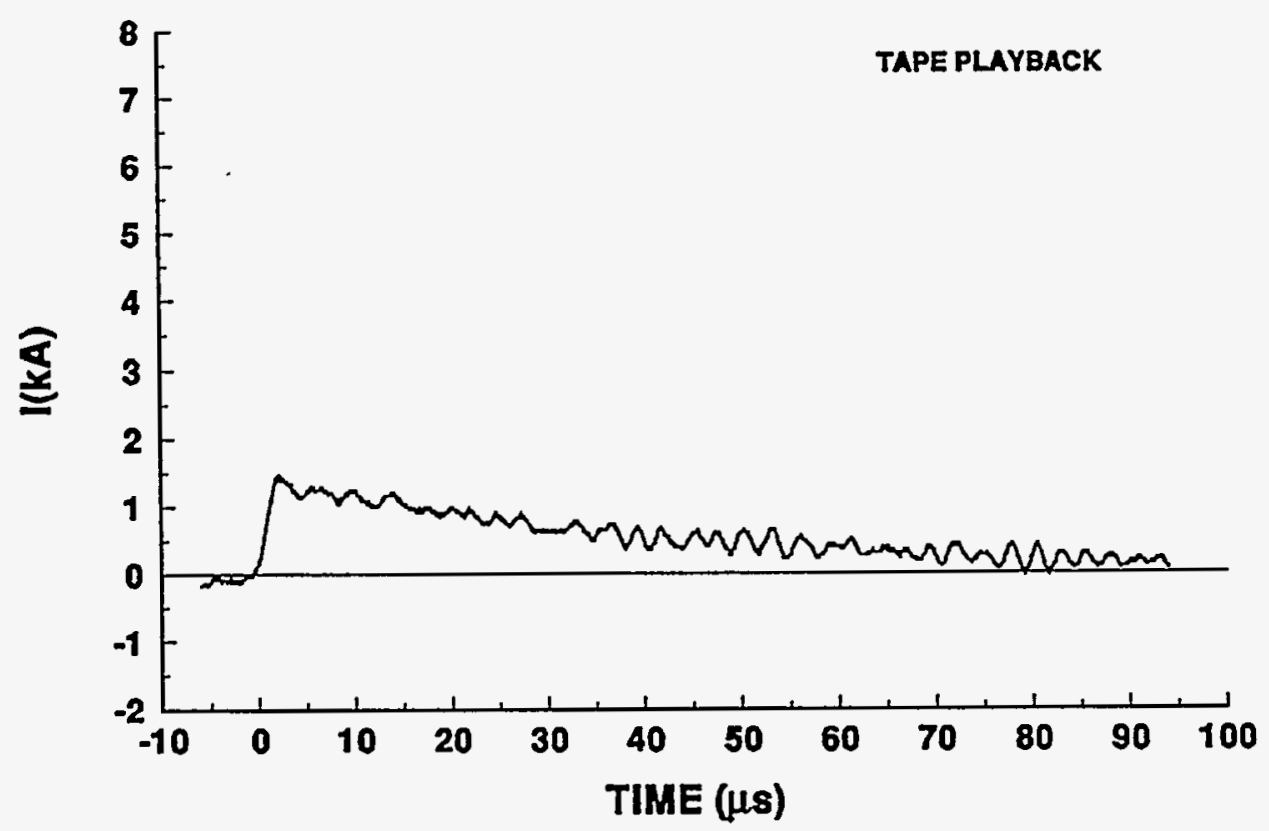

94-15 STROKE 3.

TEST POINT 8

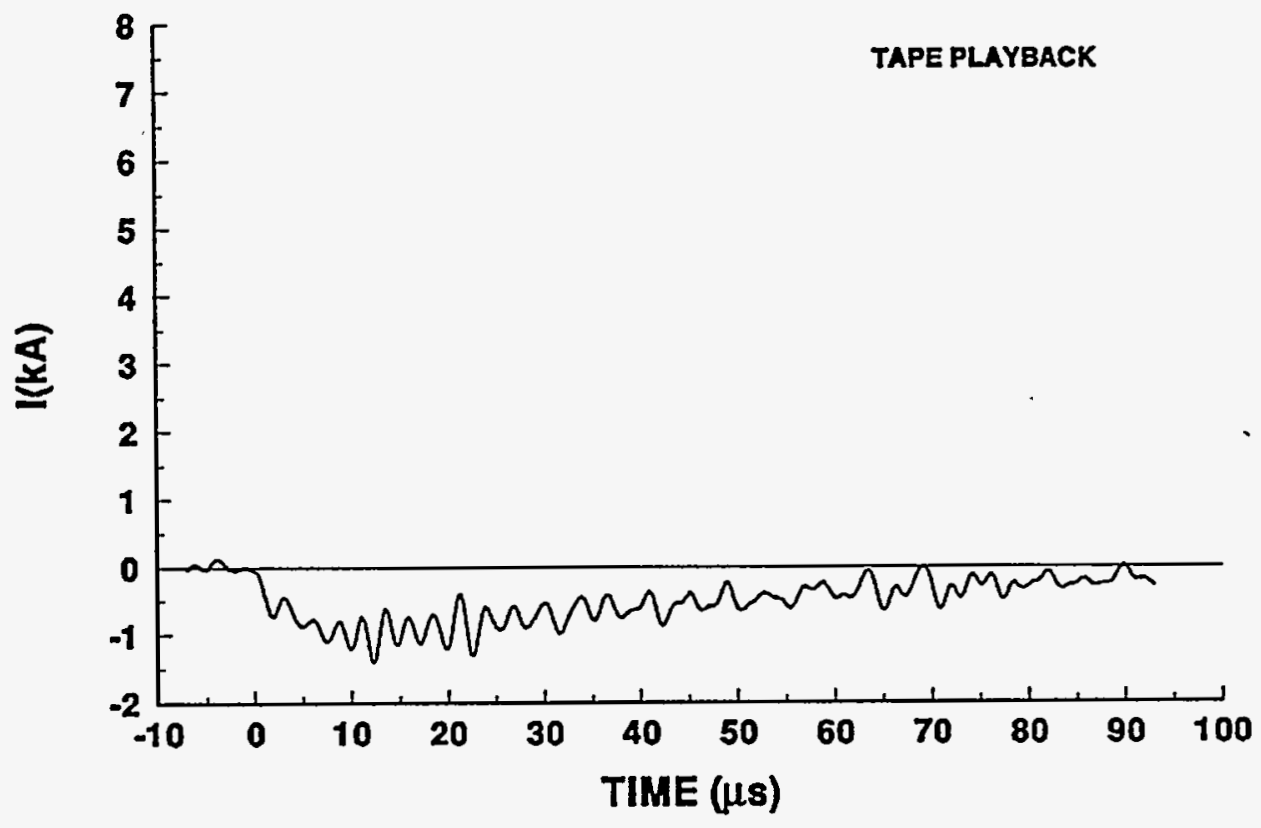




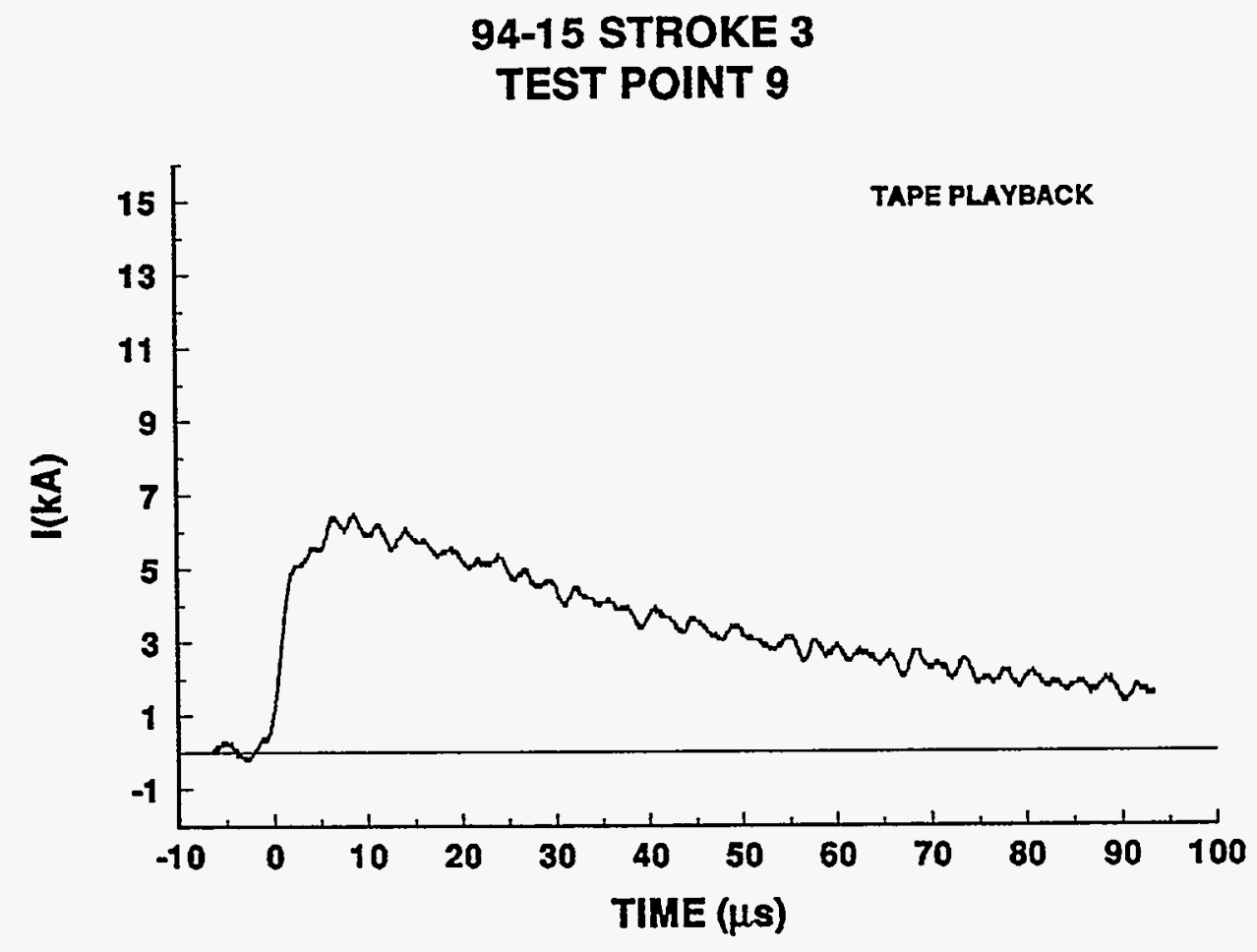

\section{4-15 STROKE 3}

TEST POINT 9'

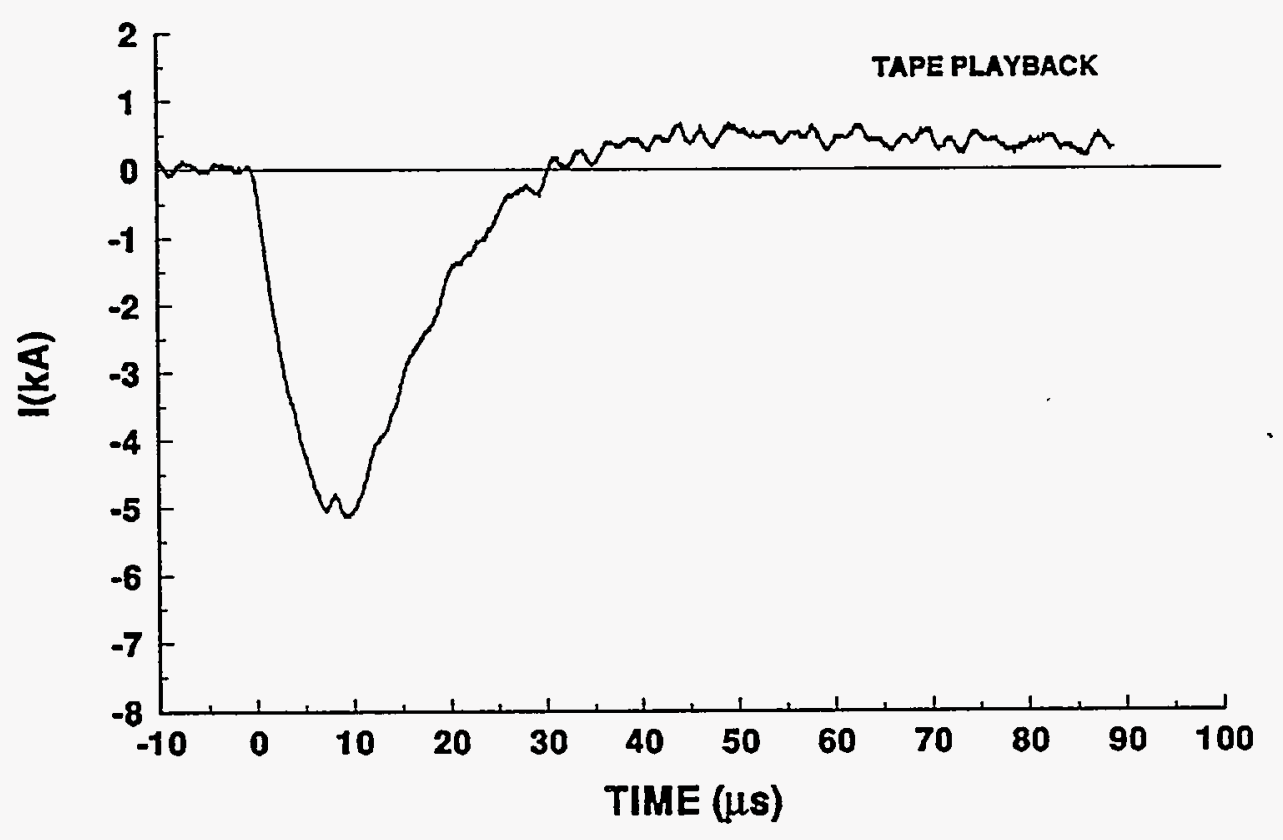




\section{4-15 STROKE 3}

\section{TEST POINT 16}

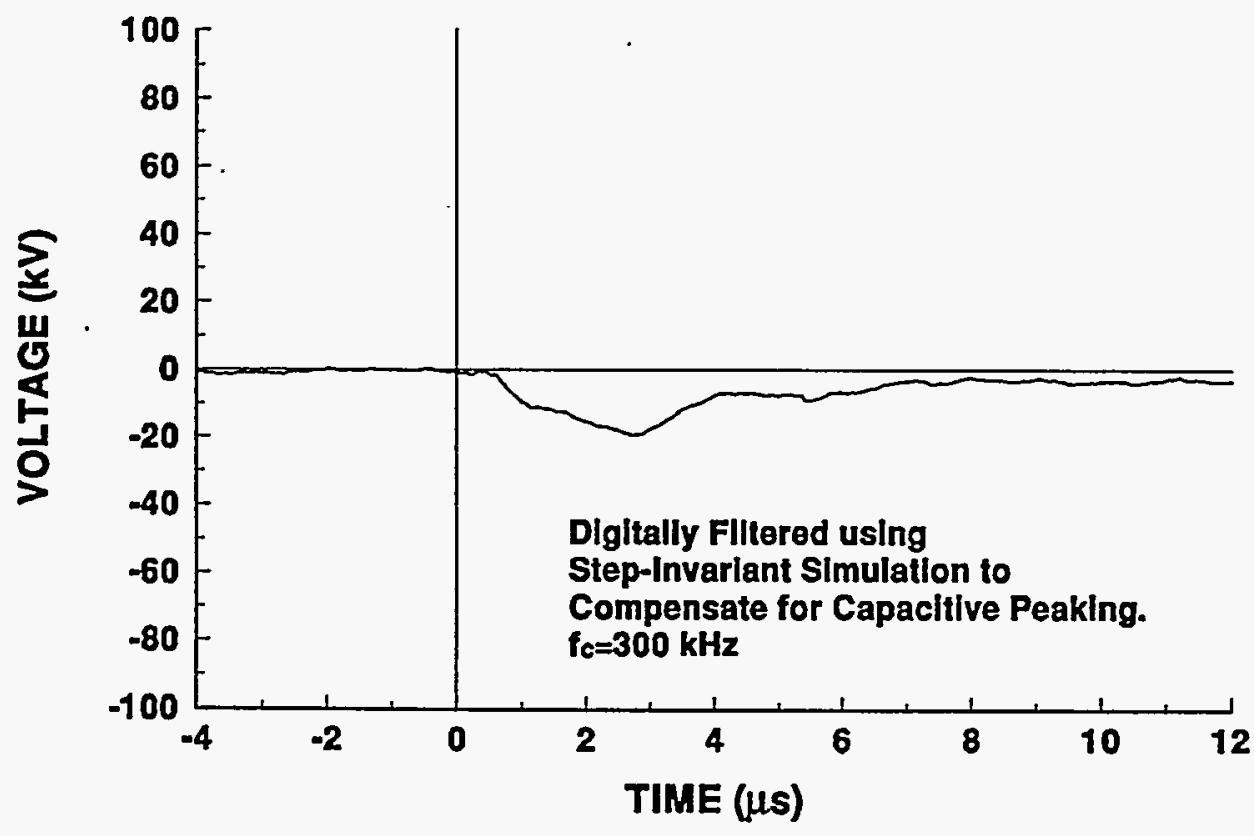

94-15 STROKE 3. TEST POINT 17

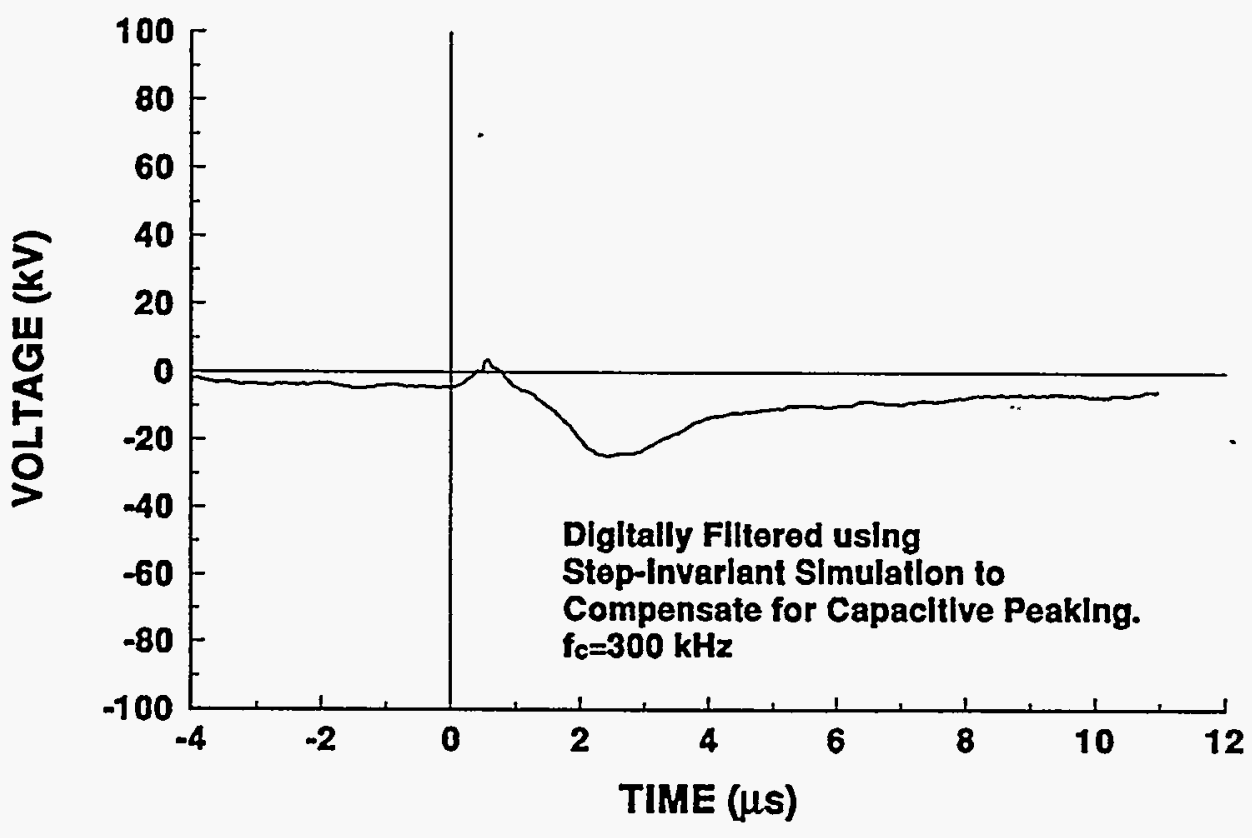


94-15 STROKE 3

TEST POINT 18

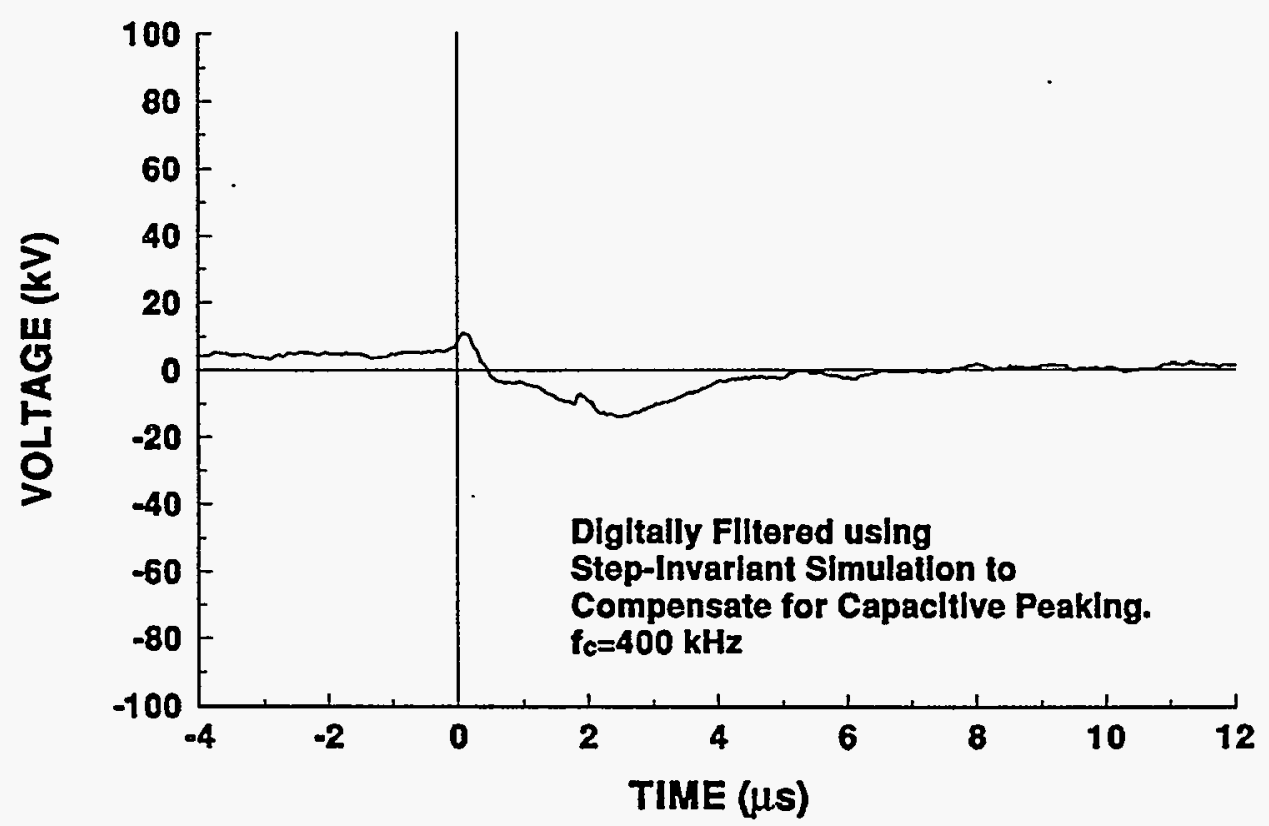

94-15 STROKE 3.

TEST POINT 19

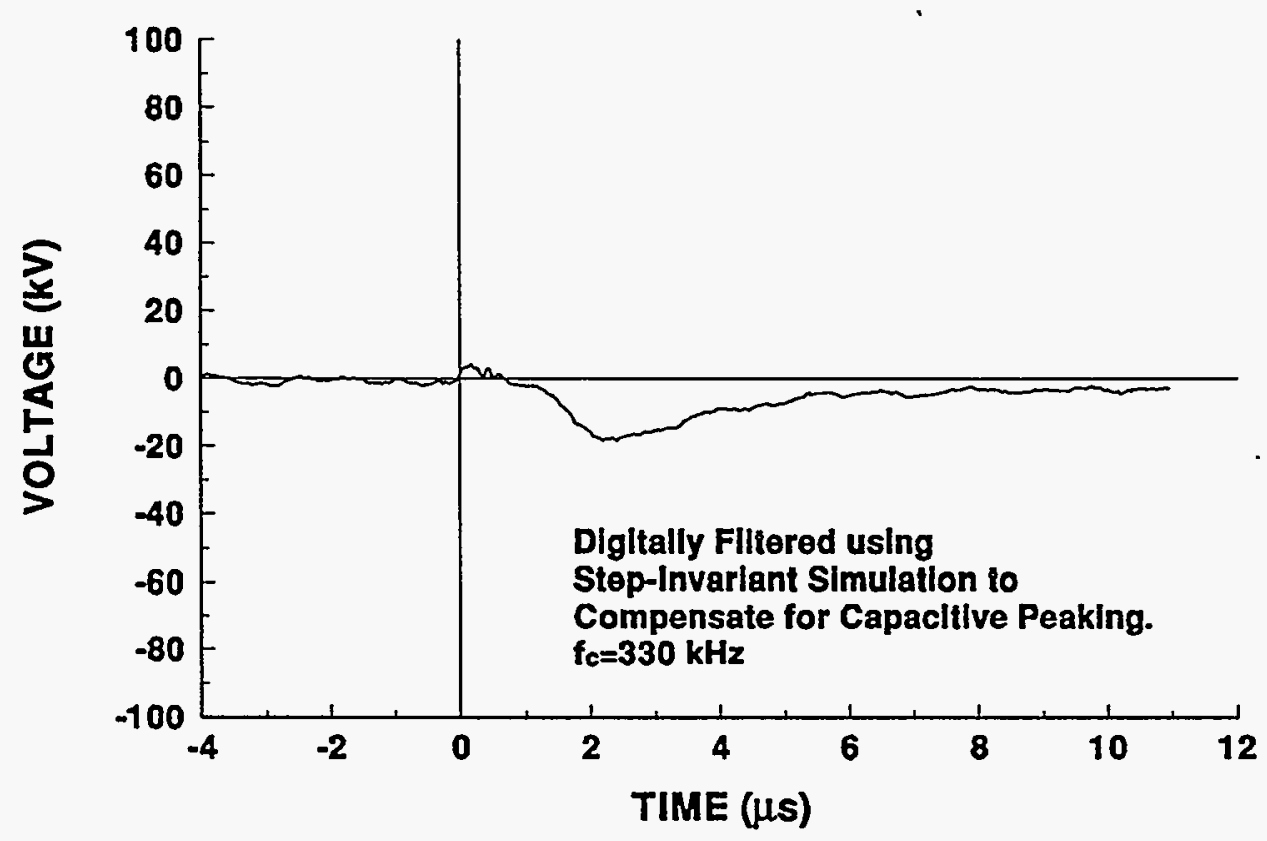




\section{4-15 STROKE 3}

TEST POINT 20

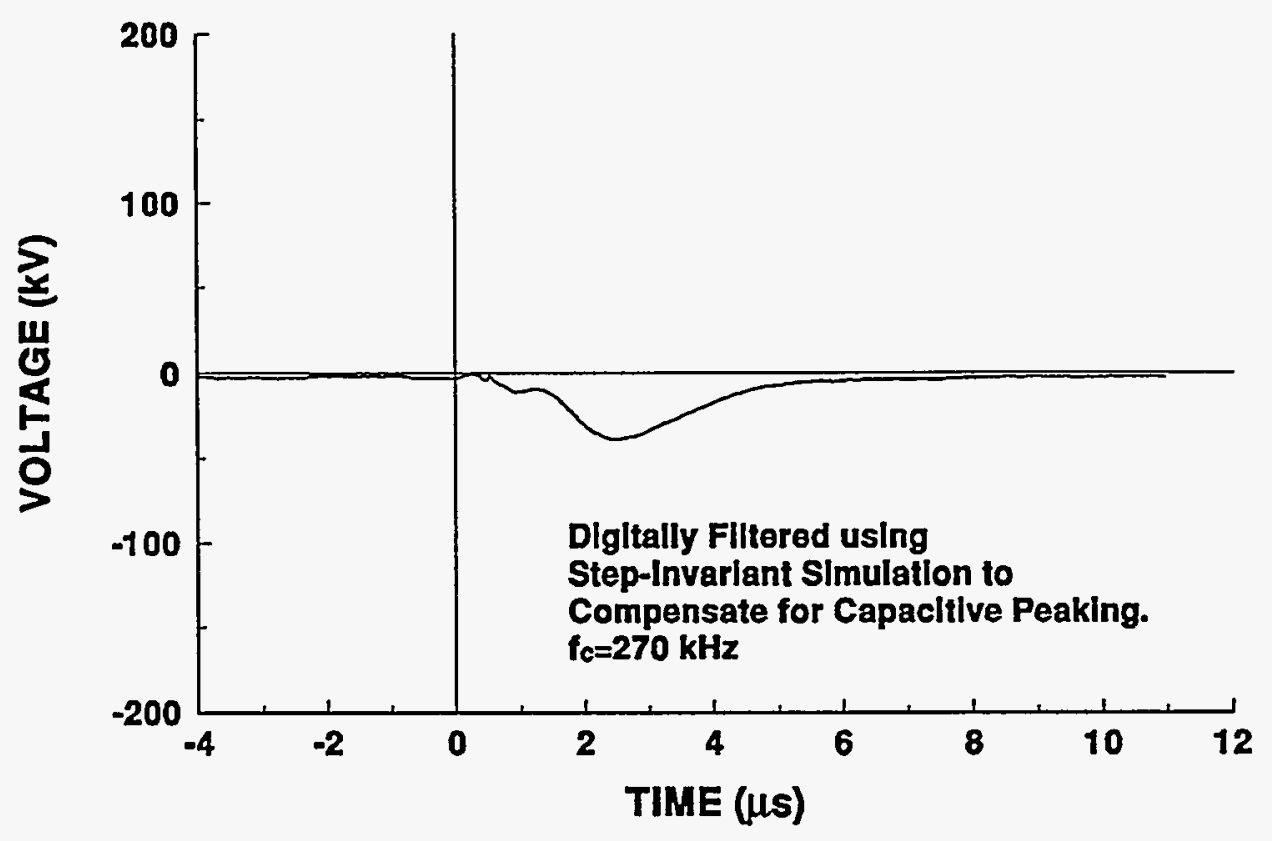

\section{4-15 STROKE 3}

TEST POINT 22

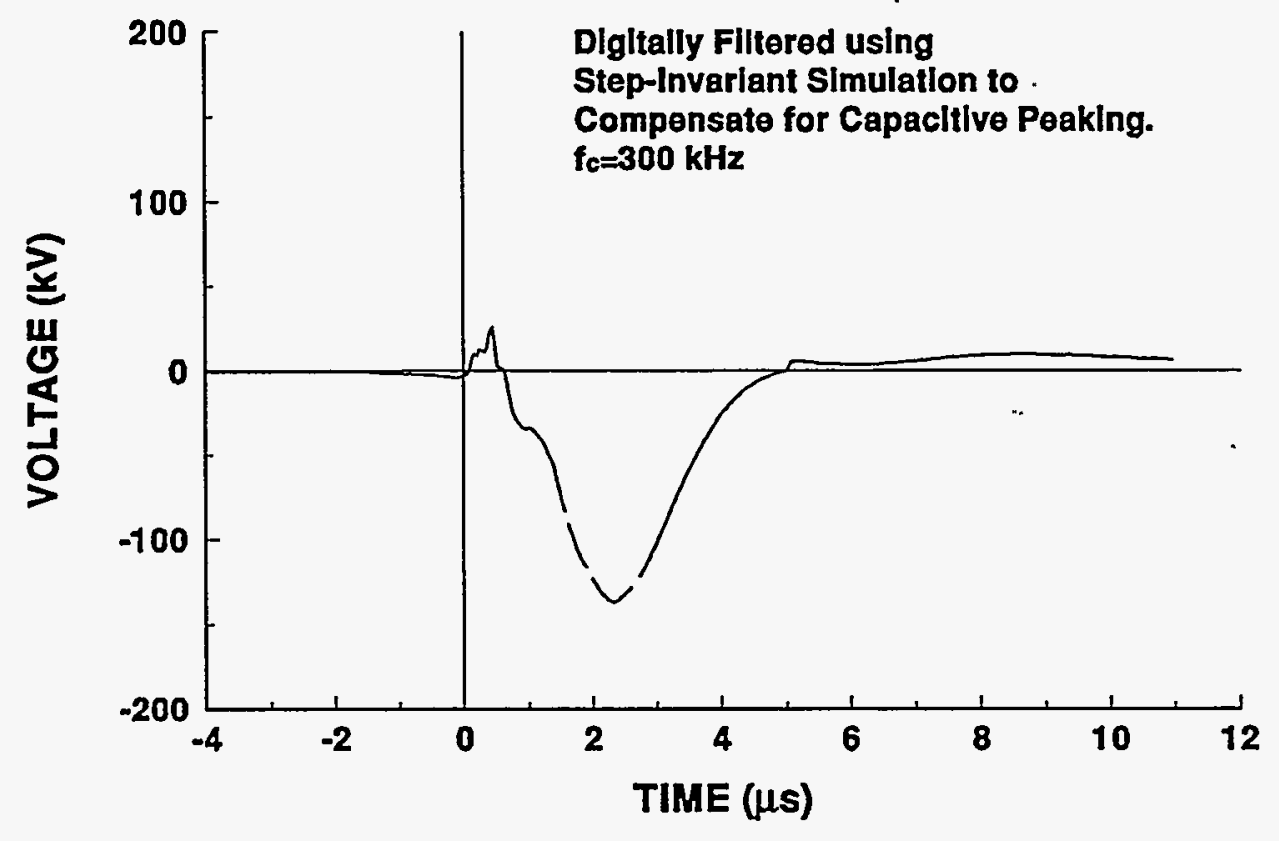




\section{4-15 STROKE 3}

TEST POINT 23

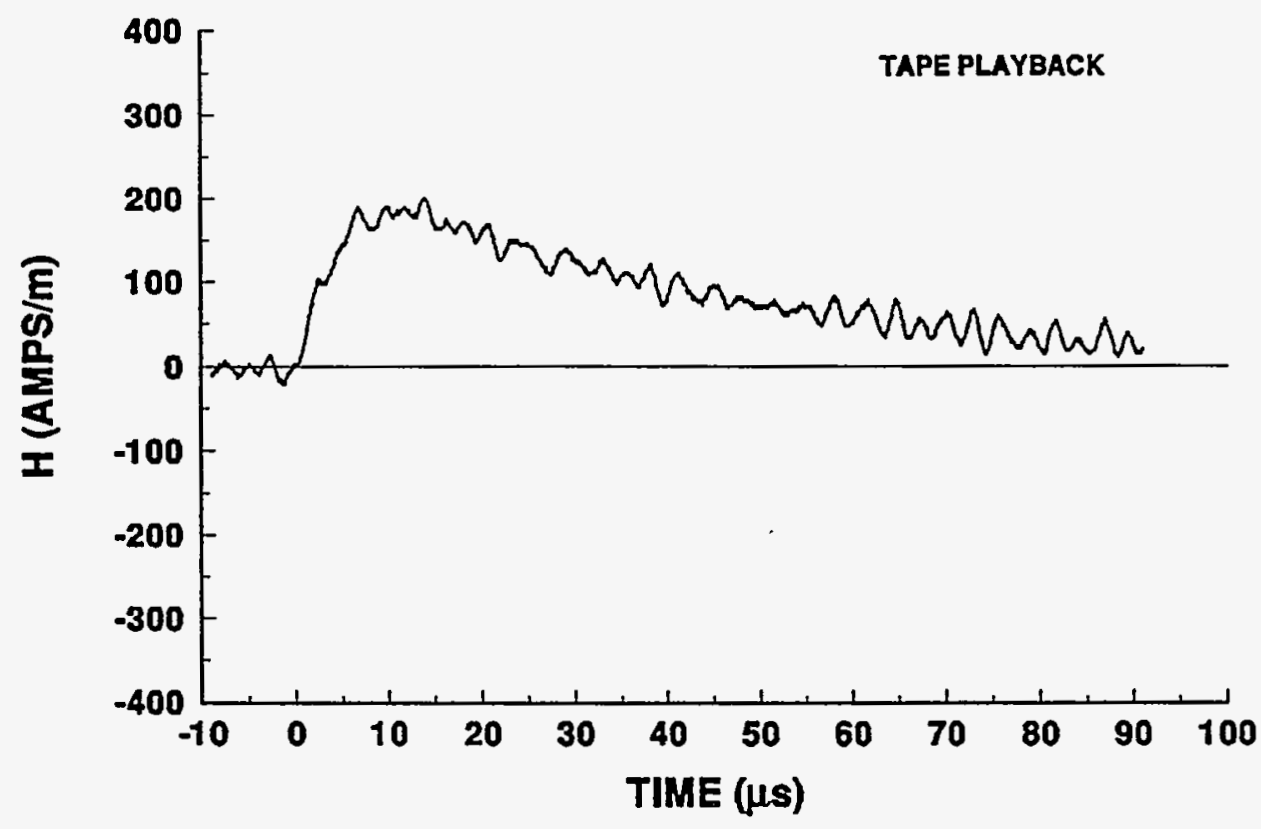

94-15 STROKE 3

TEST POINT 24

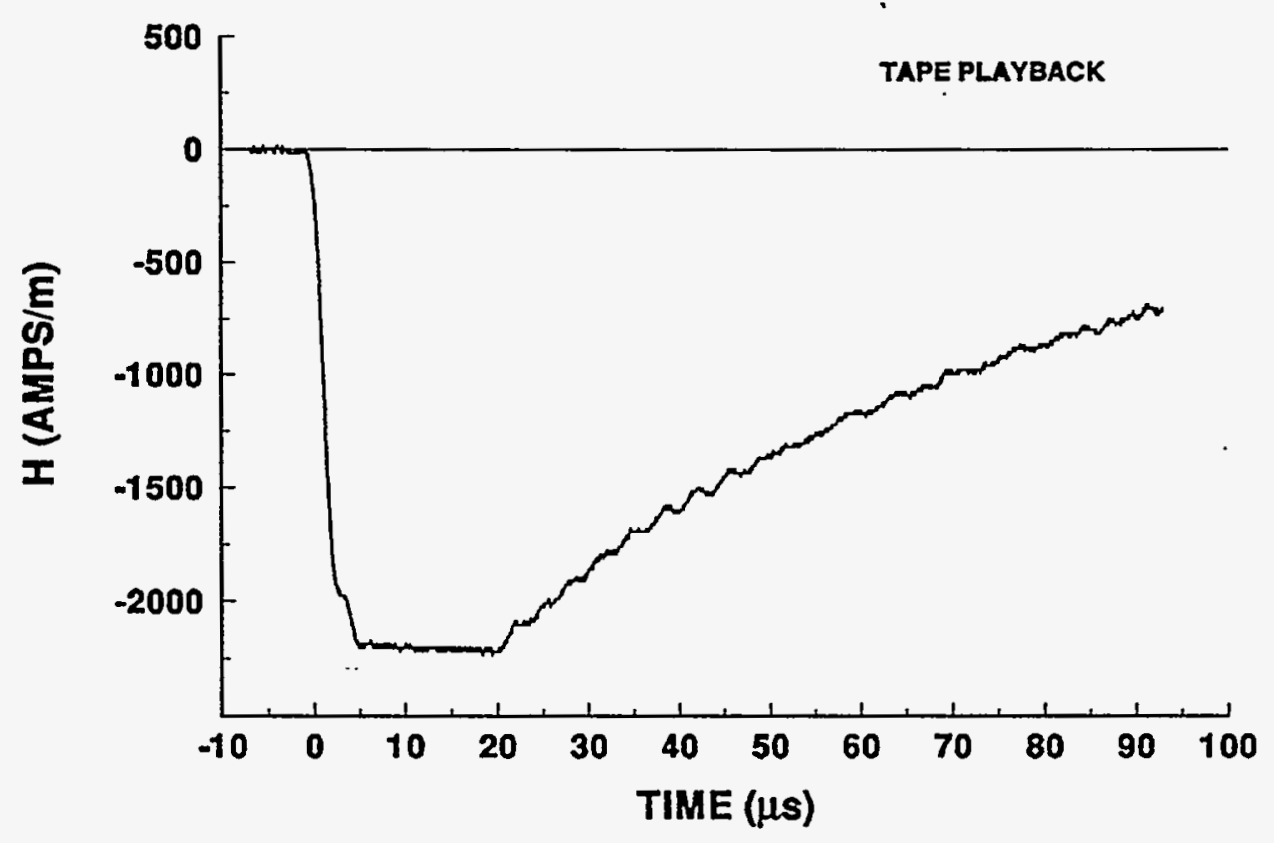




\section{Storm 4 Data Plots}

Flashes 94-21, 94-22, and 94-24 


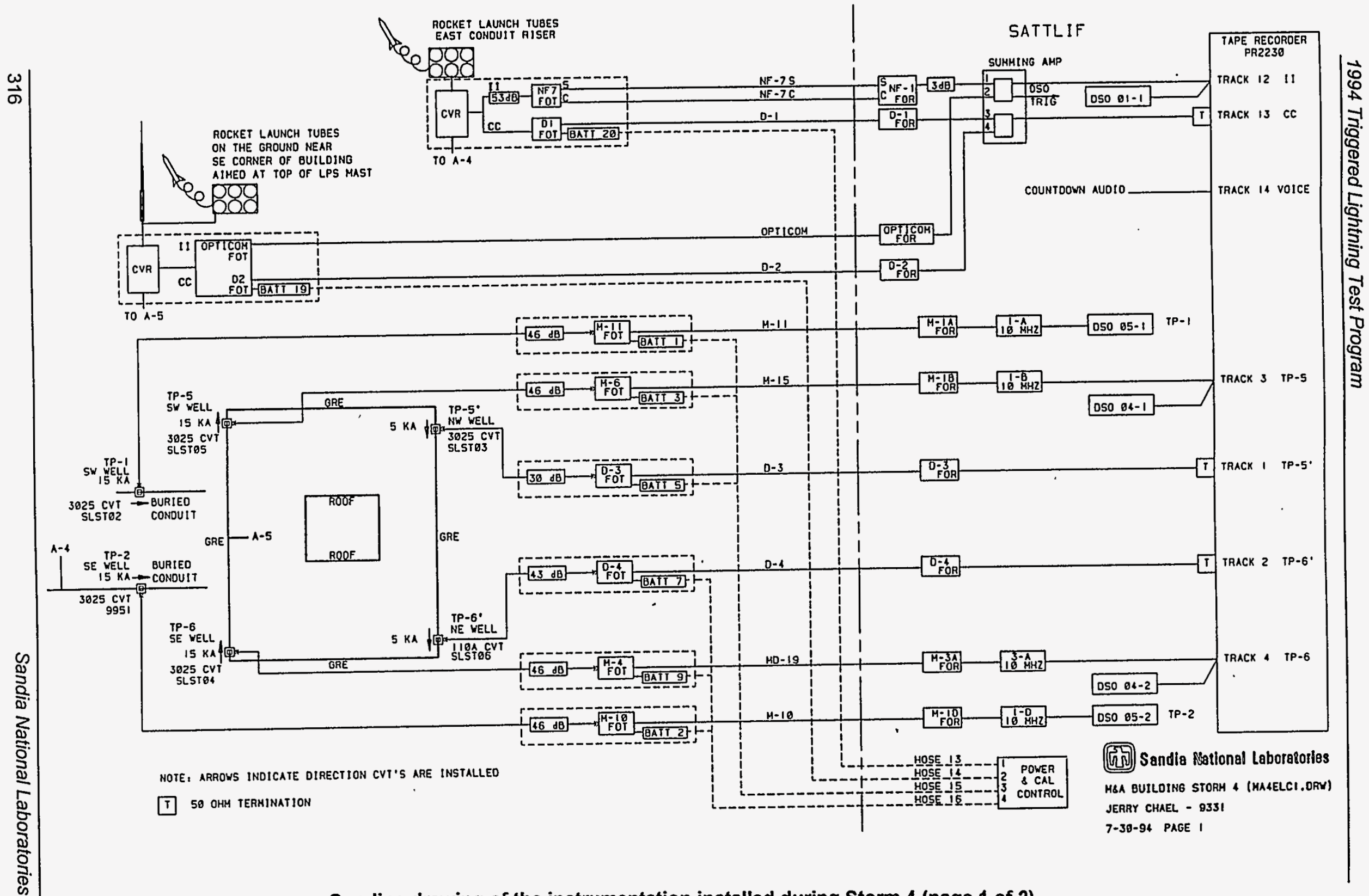

One-line drawing of the instrumentation installed during Storm 4 (page 1 of 2) 


\section{4-21 STROKE 1 \\ INCIDENT CURRENT}
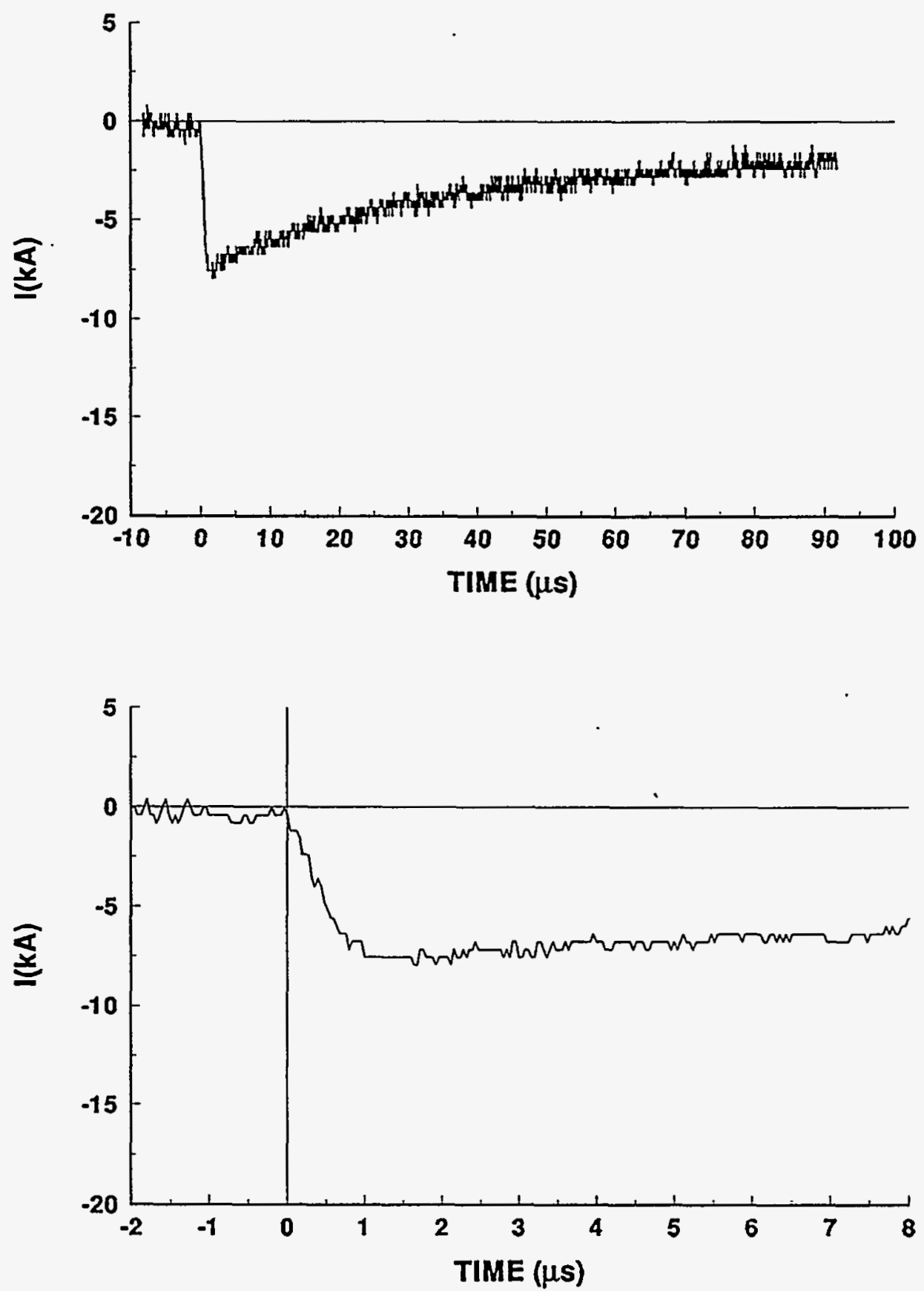


\section{4-21 STROKE 1}

TEST POINT 1
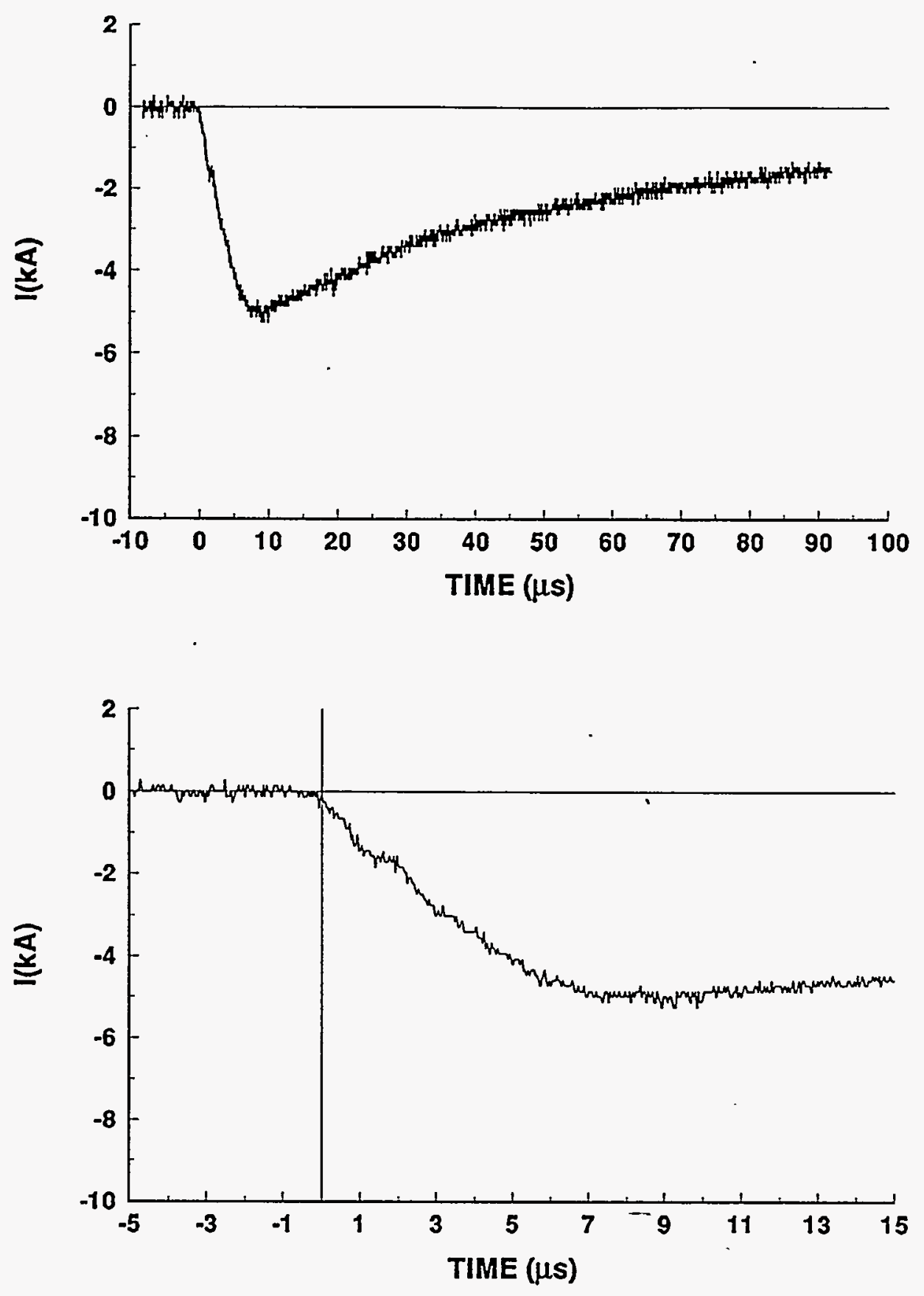


\section{4-21 STROKE 1}

TEST POINT 2
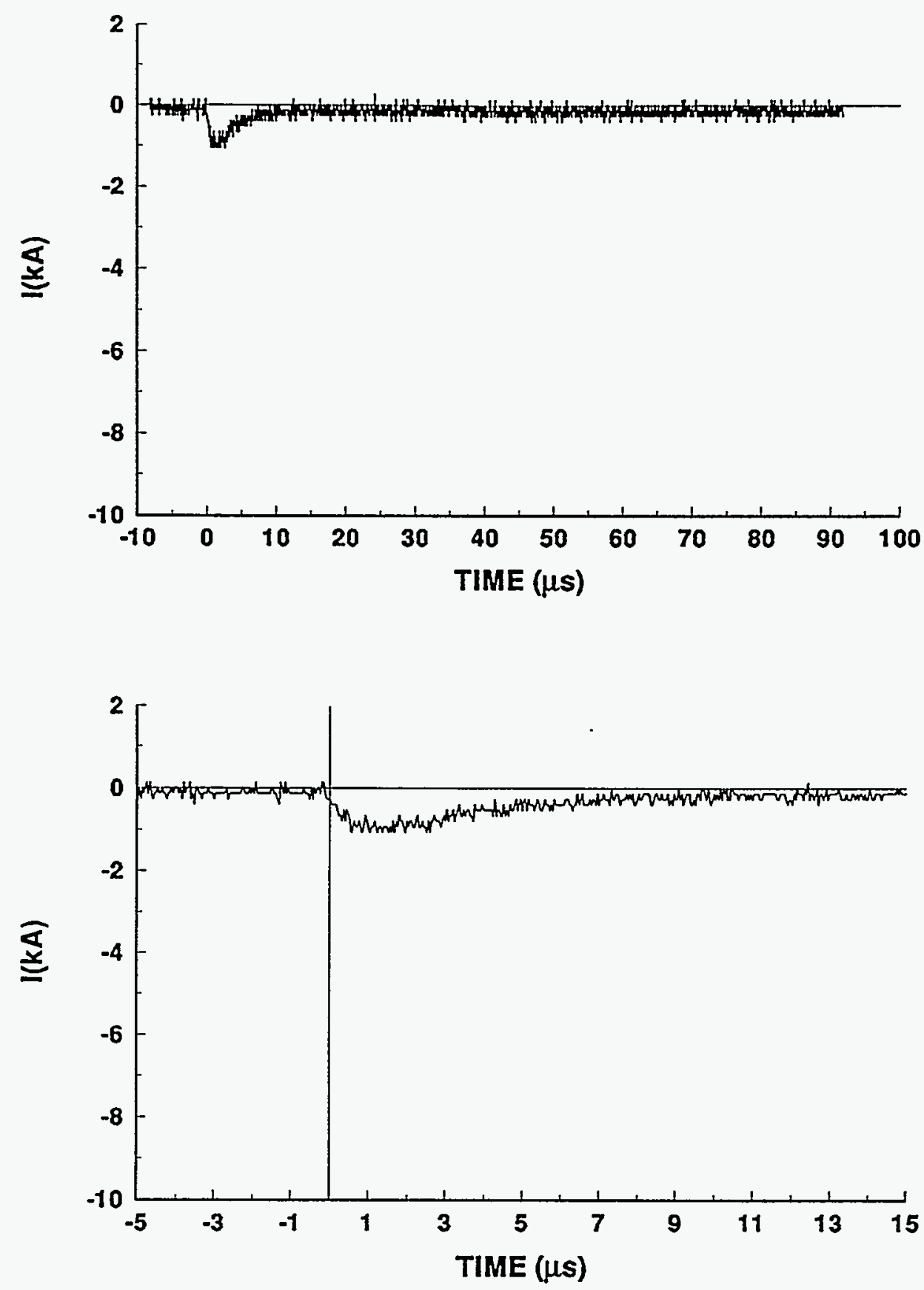


\section{4-21 STROKE 1}

TEST POINT 5
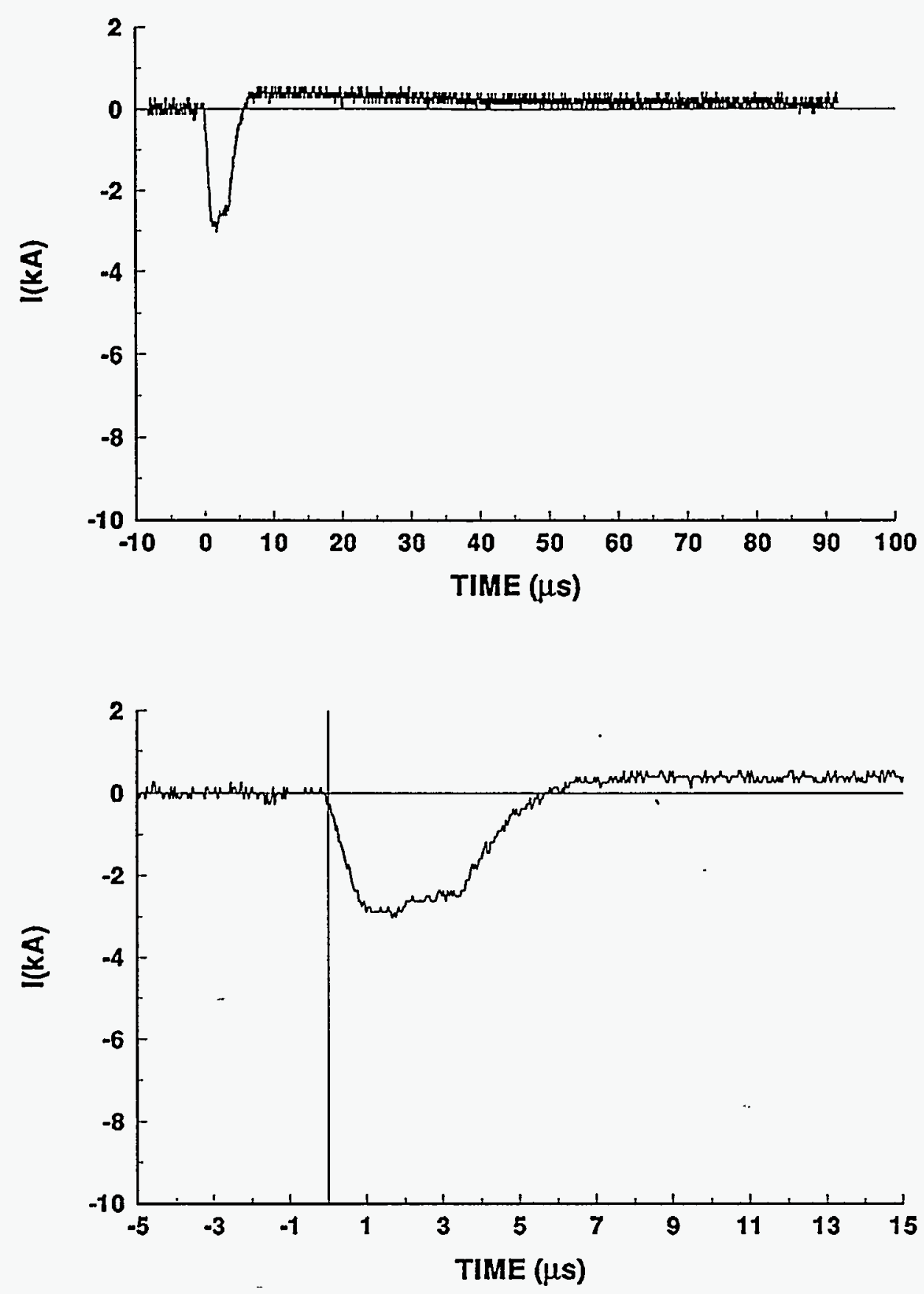


\section{4-21 STROKE 1 \\ TEST POINT 6}
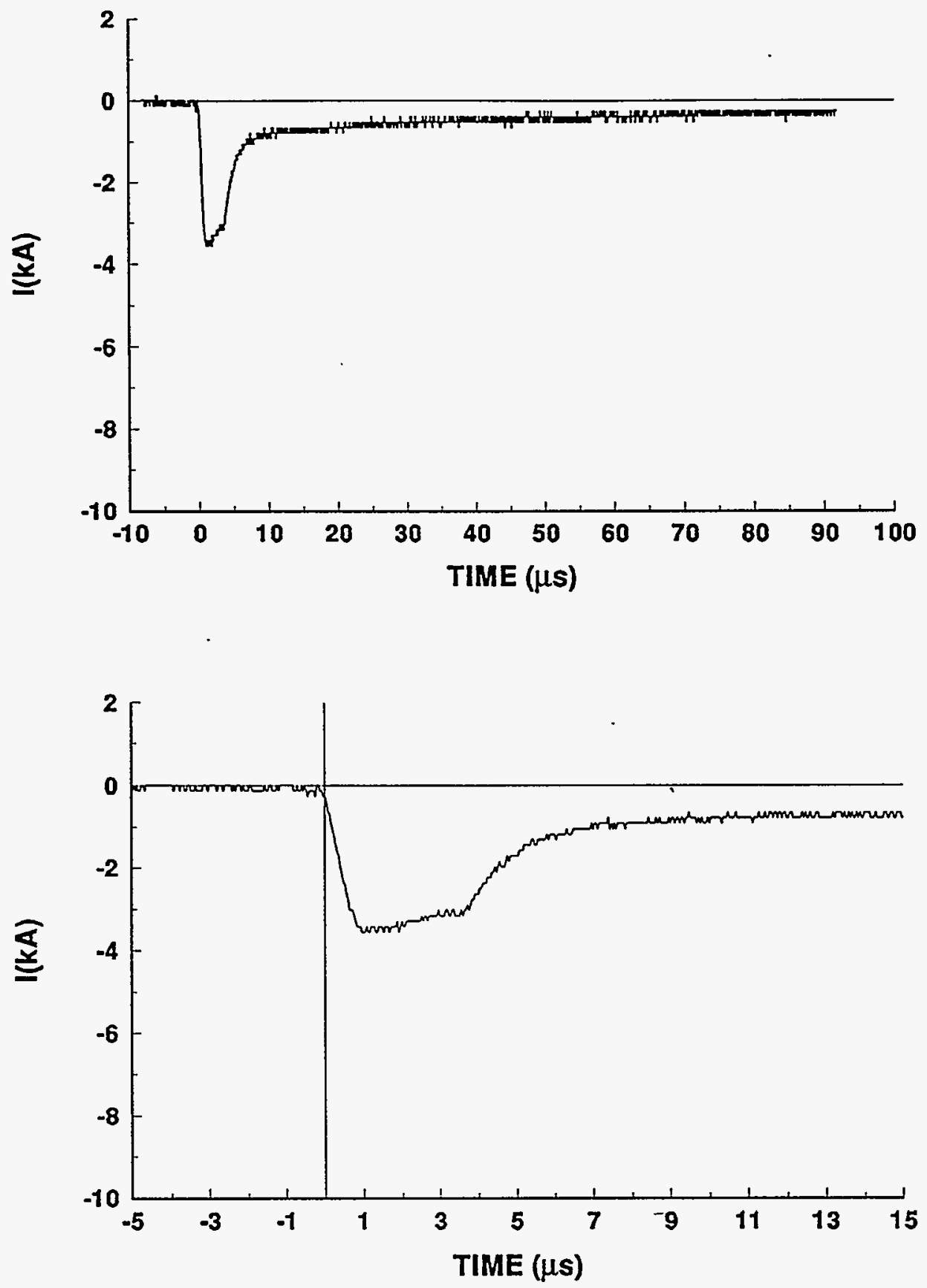


\section{4-21 STROKE 1}

TEST POINT 5'

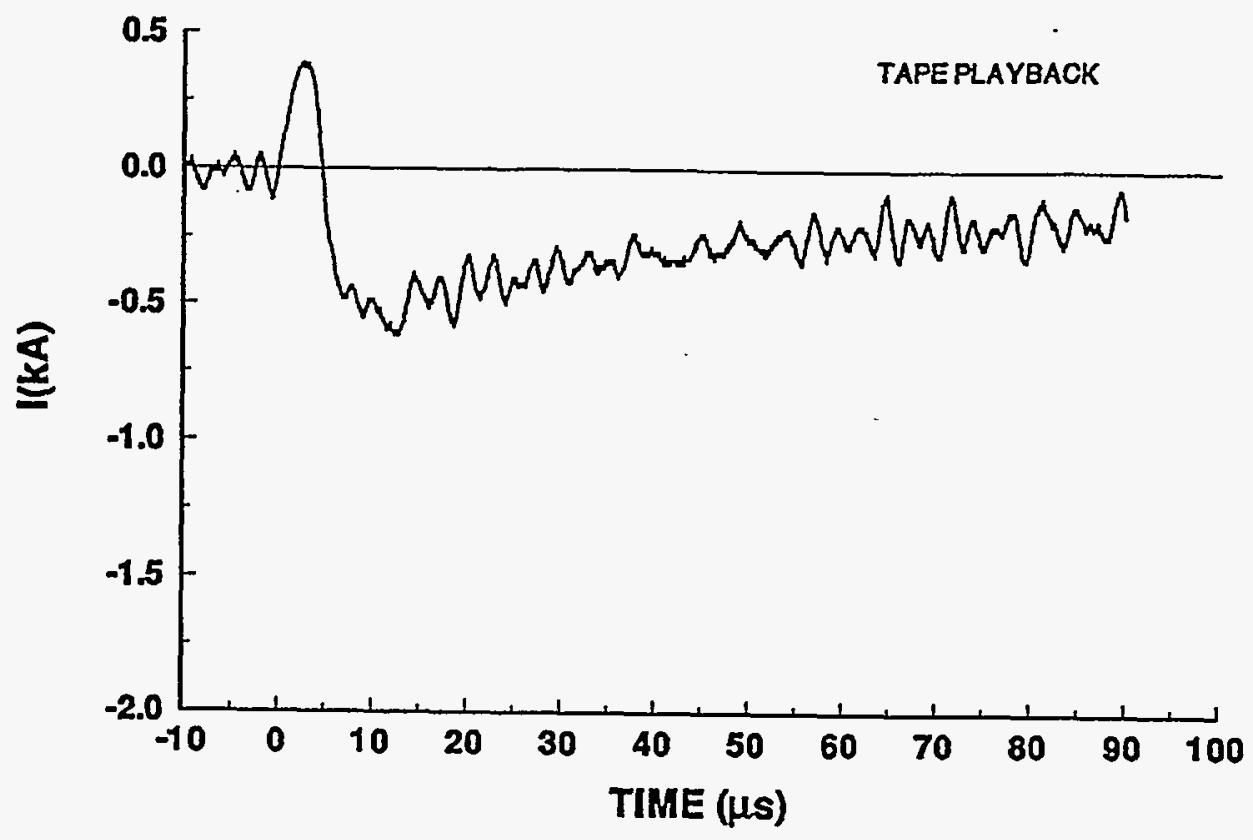

\section{4-21 STROKE 1}

\section{TEST POINT 6'}

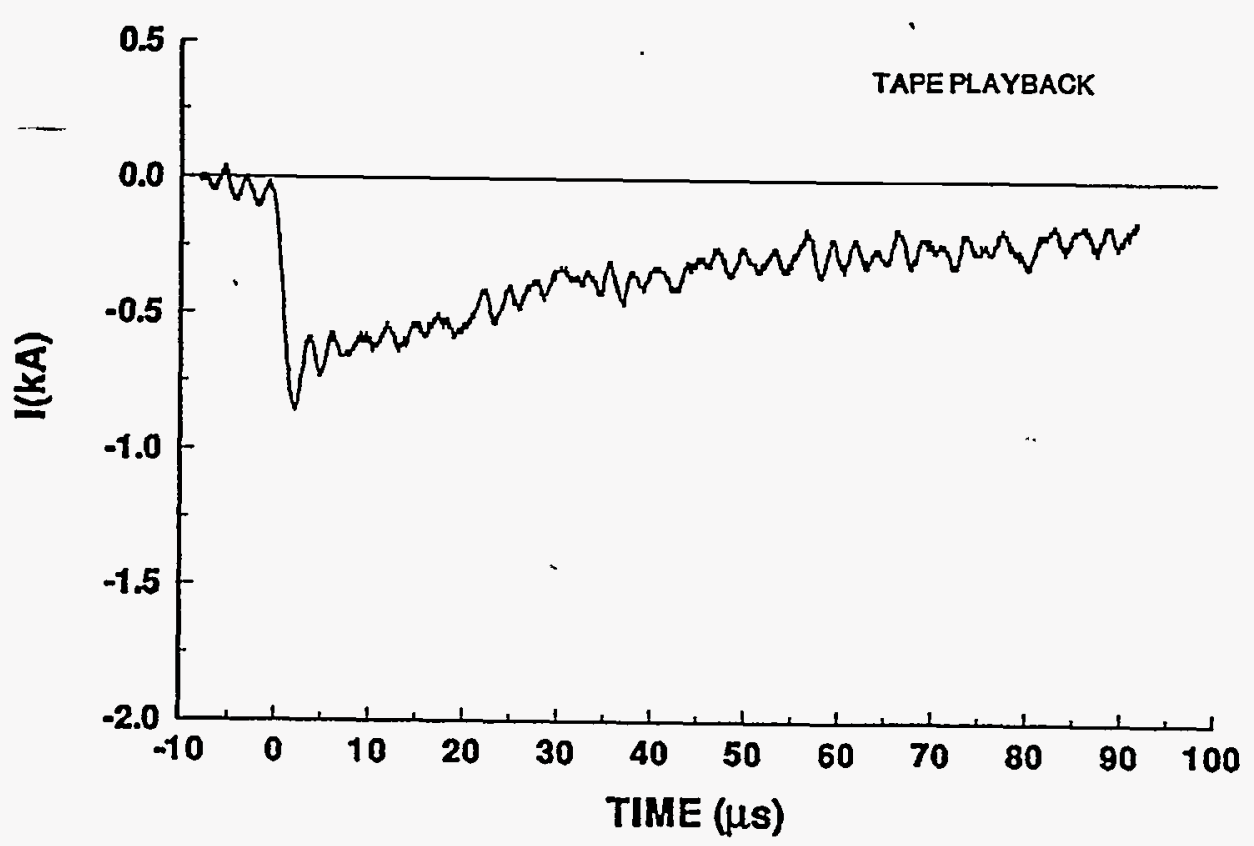


94-21 STROKE 1

TEST POINT 10

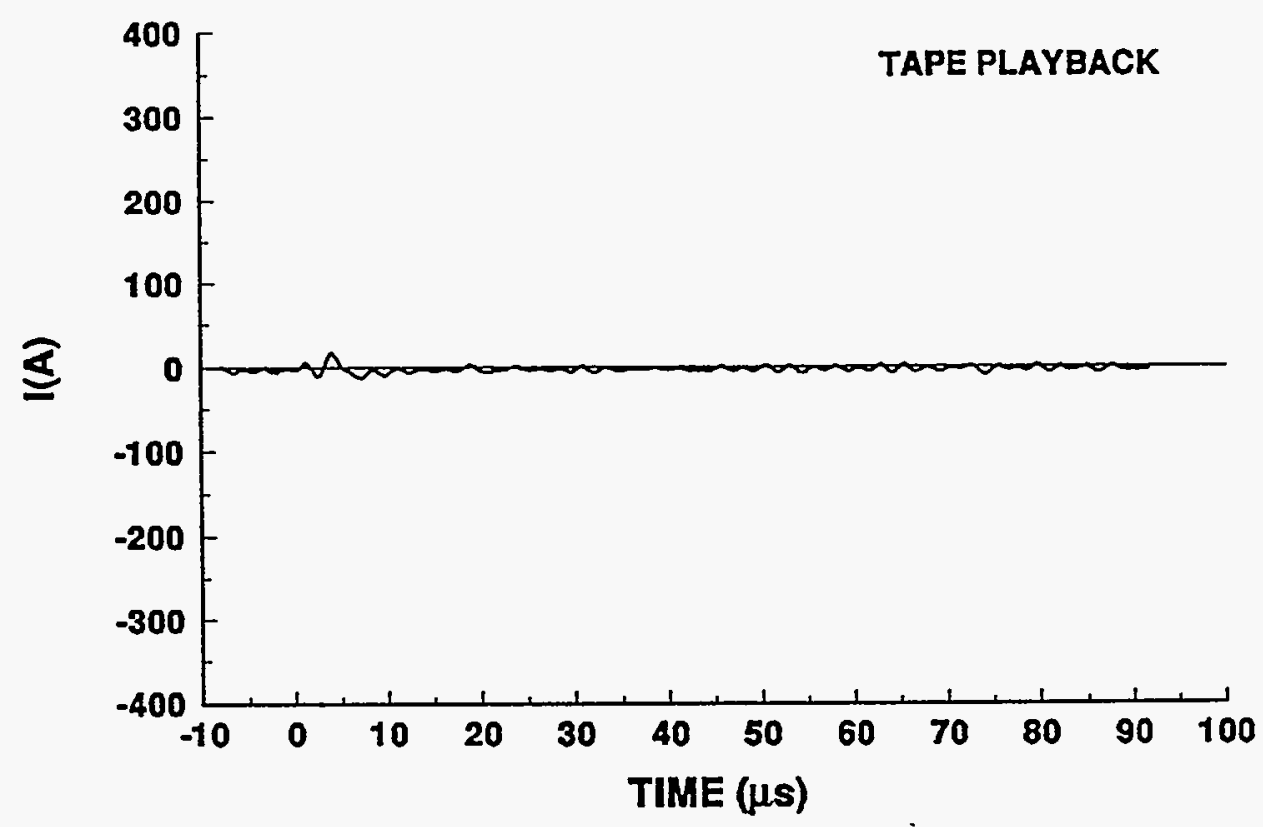

94-21 STROKE 1

TEST POINT 11

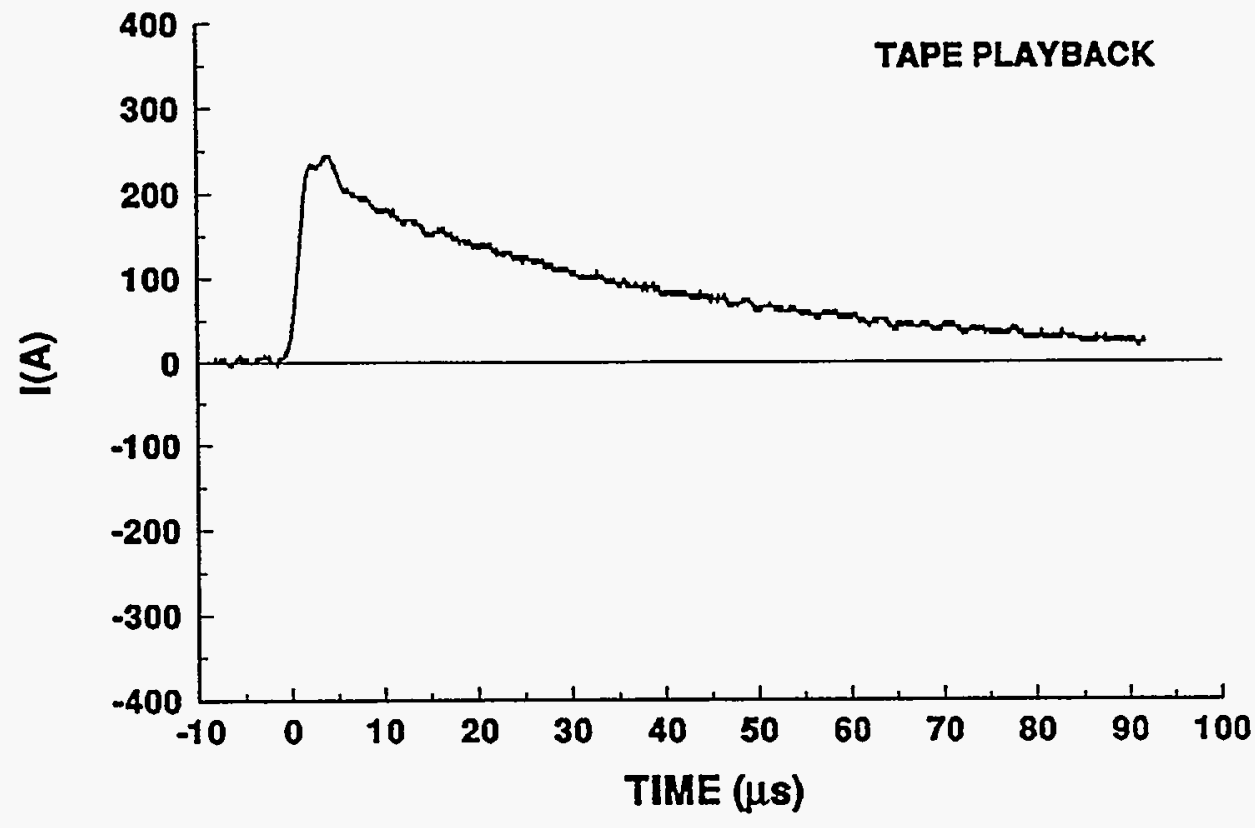




\section{4-21 STROKE 1}

TEST POINT 12

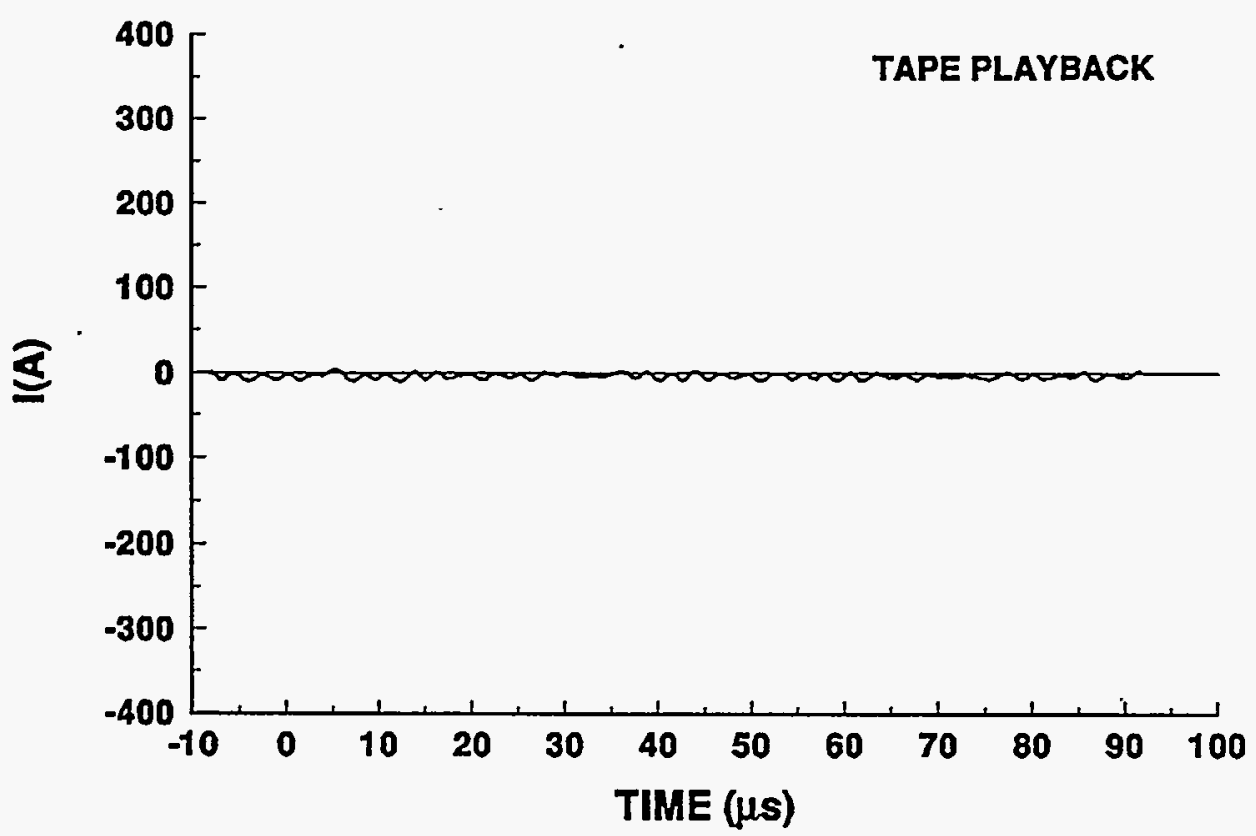

94-21 STROKE 1.

TEST POINT 13

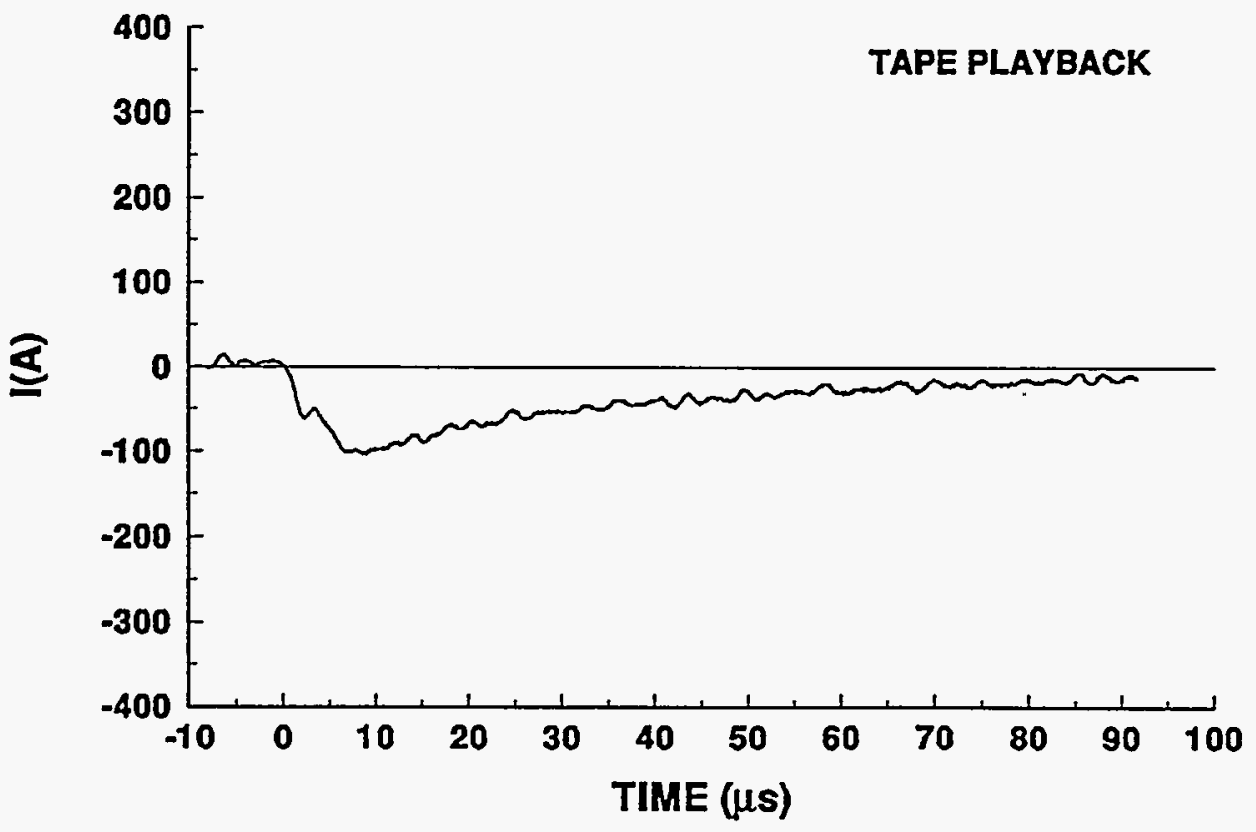




\section{4-21 STROKE 1}

TEST POINT 14
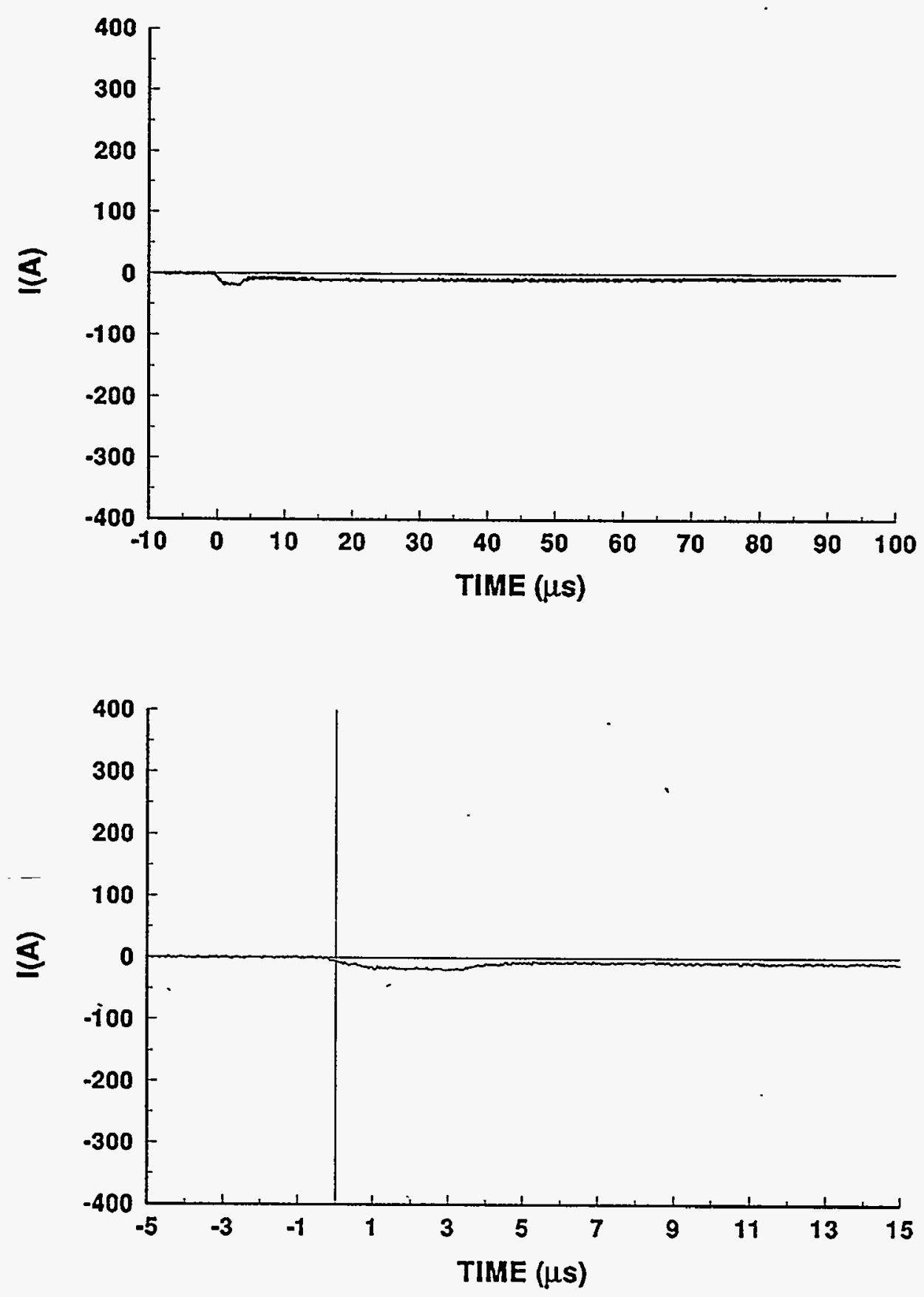


\section{4-21 STROKE 1}

TEST POINT 15
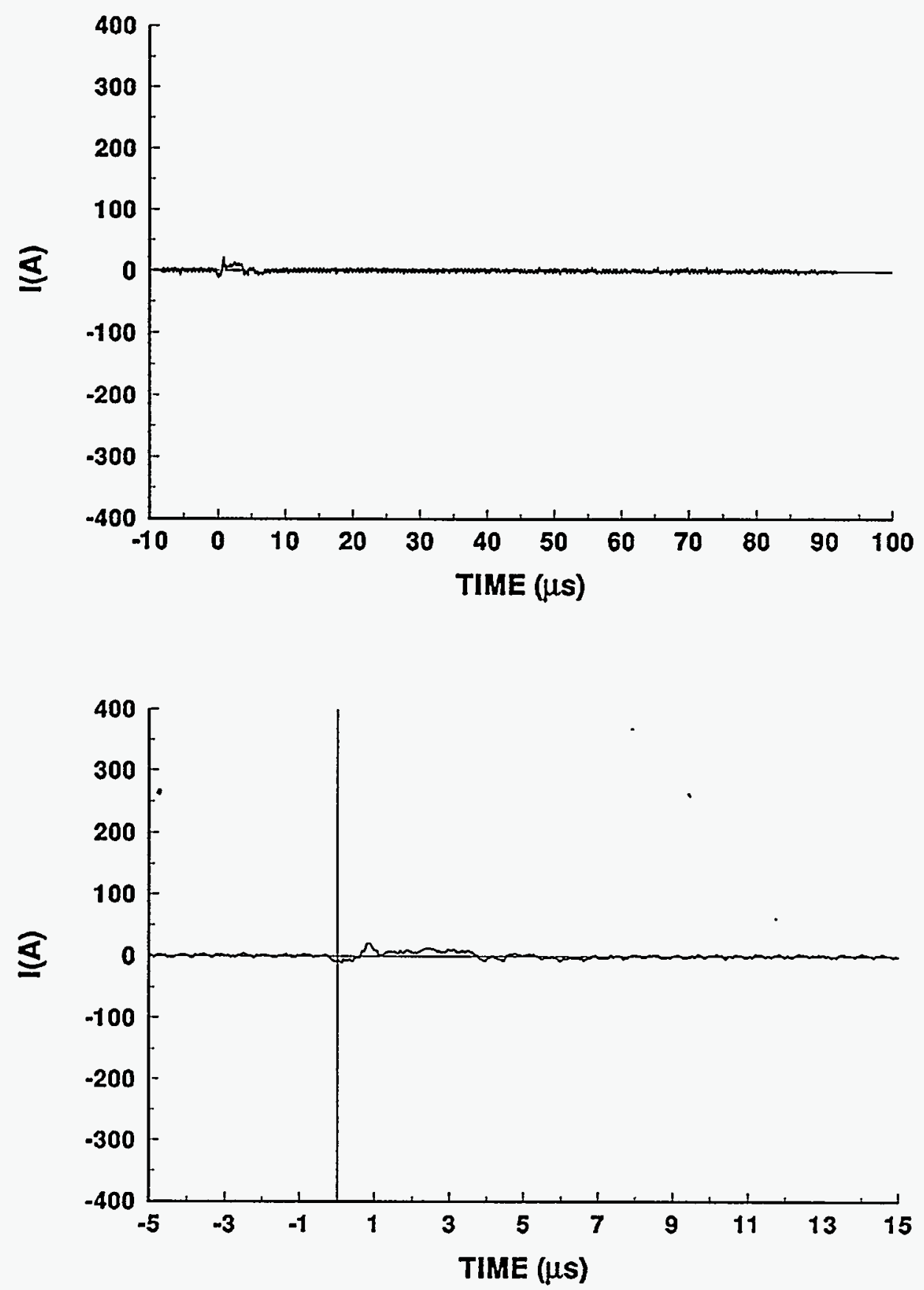


\section{4-21 STROKE 1}

TEST POINT 20

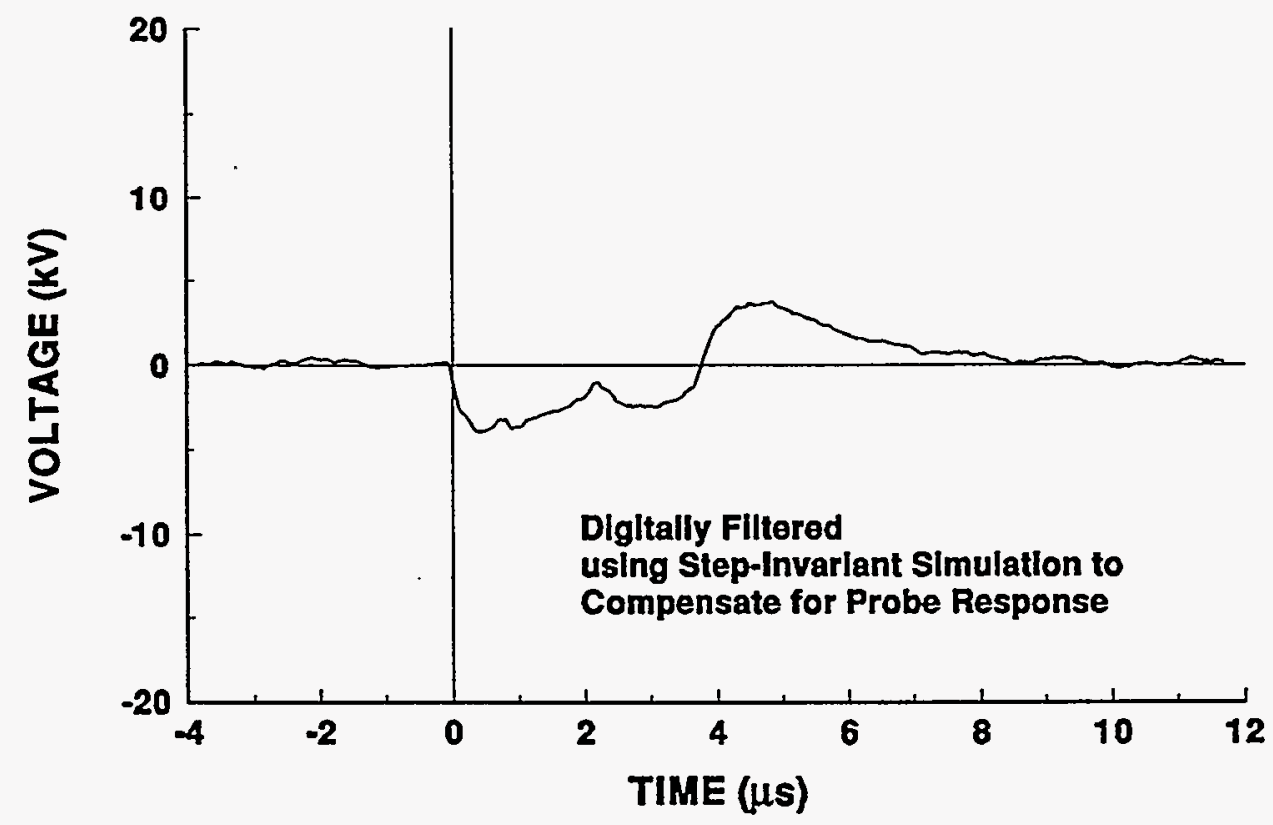

94-21 STROKE 1 .

TEST POINT 21

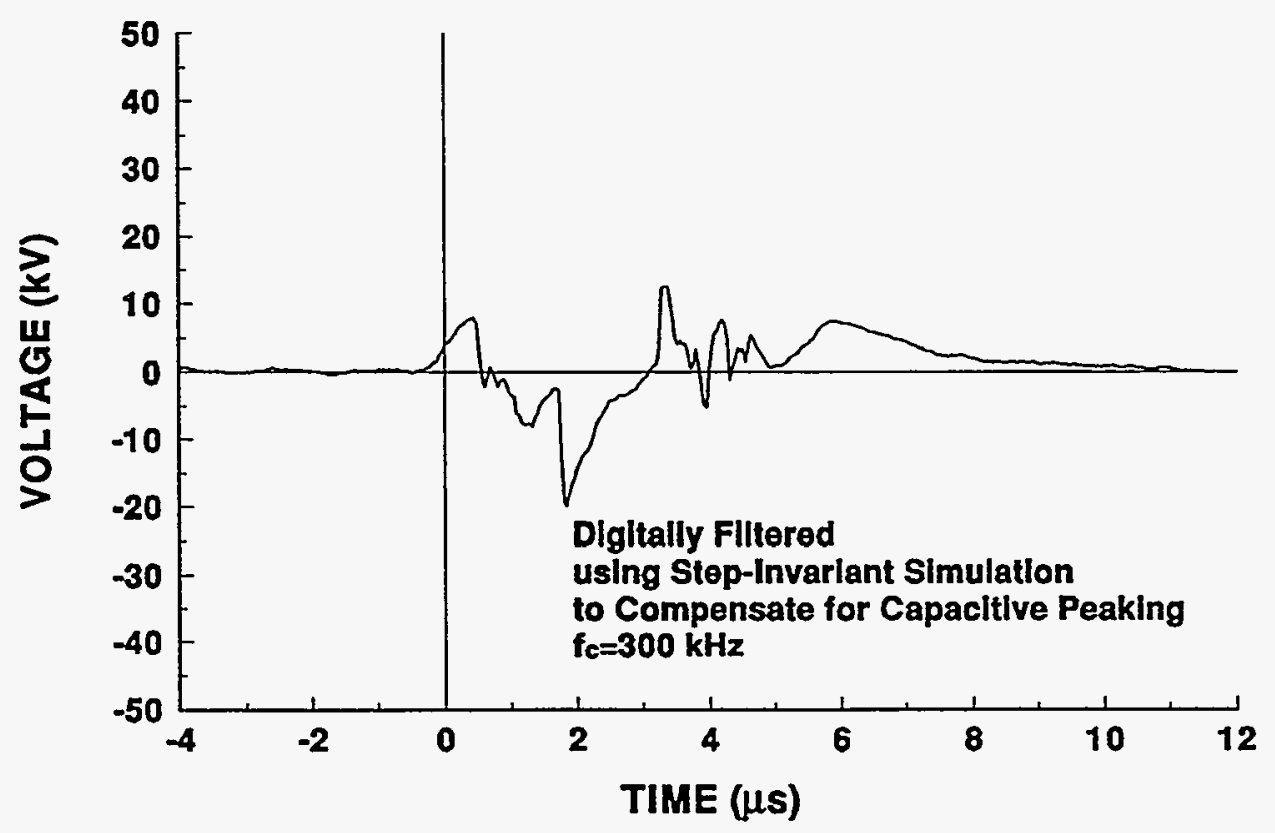




\section{4-21 STROKE 1}

TEST POINT 22

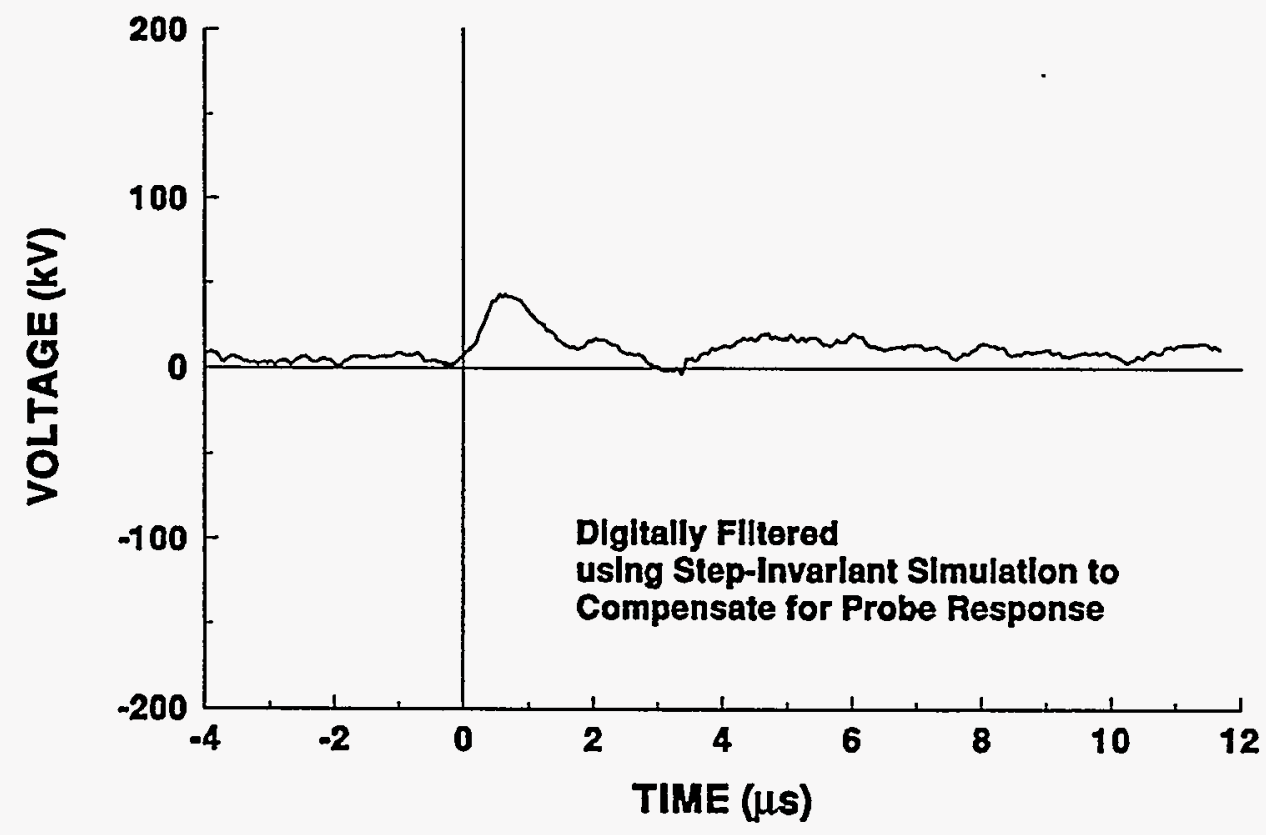




\section{4-21 STROKE 1}

TEST POINT 23

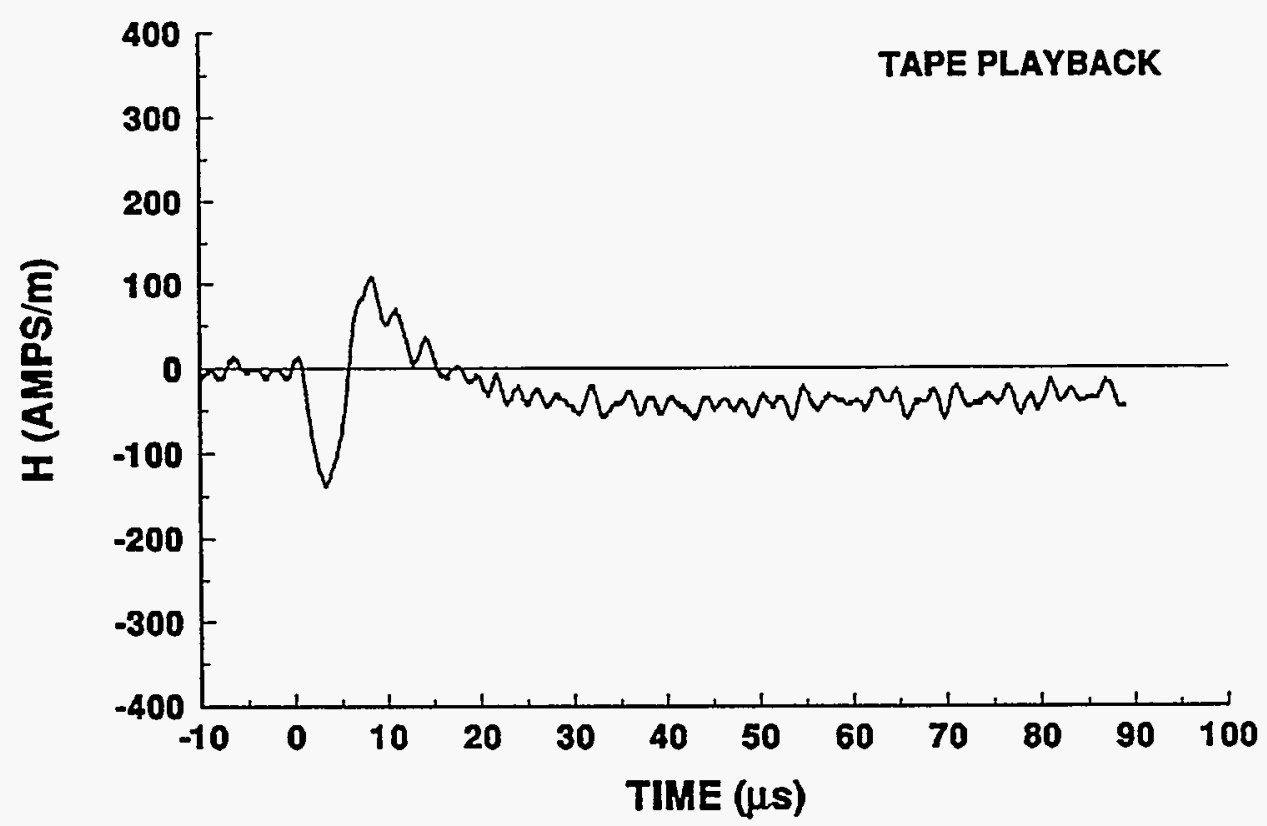

\section{4-21 STROKE 1}

TEST POINT 24

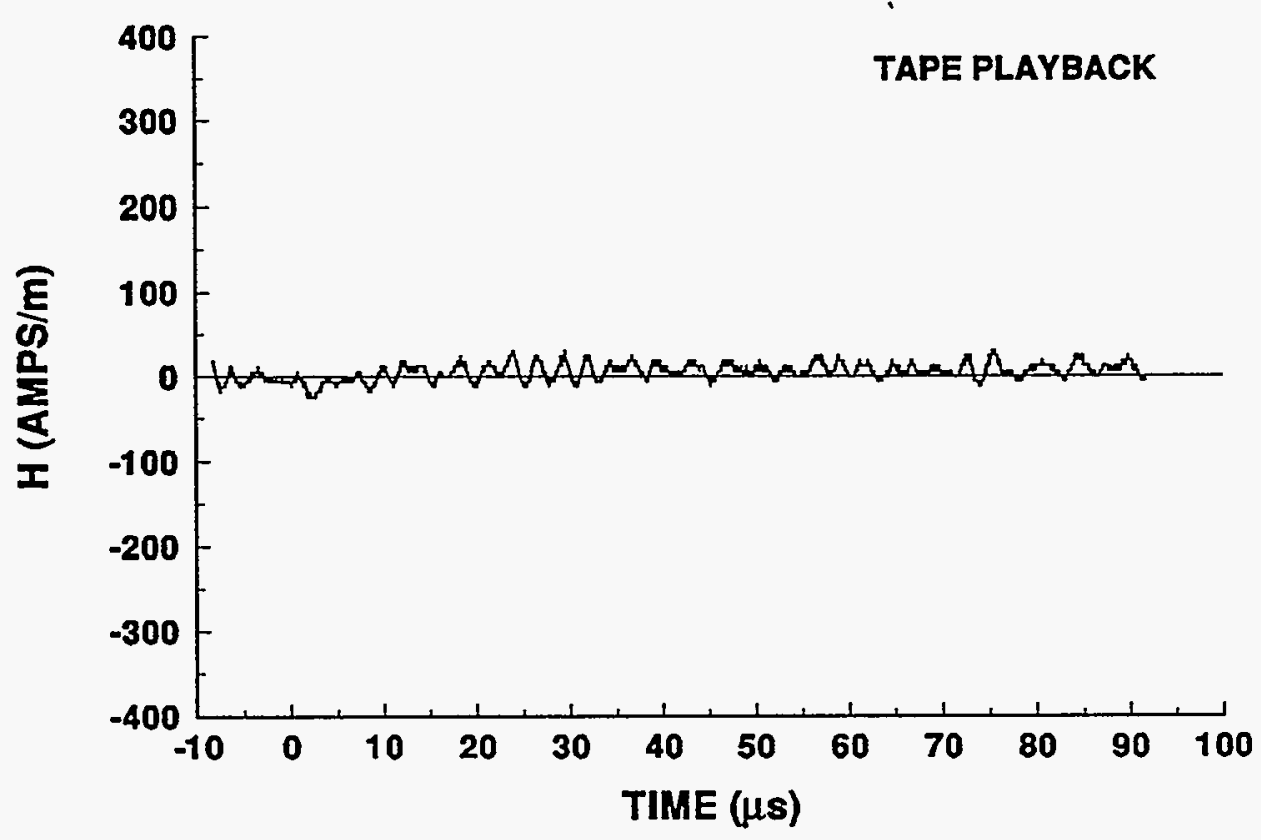




\section{4-21 STROKE 2 \\ INCIDENT CURRENT}
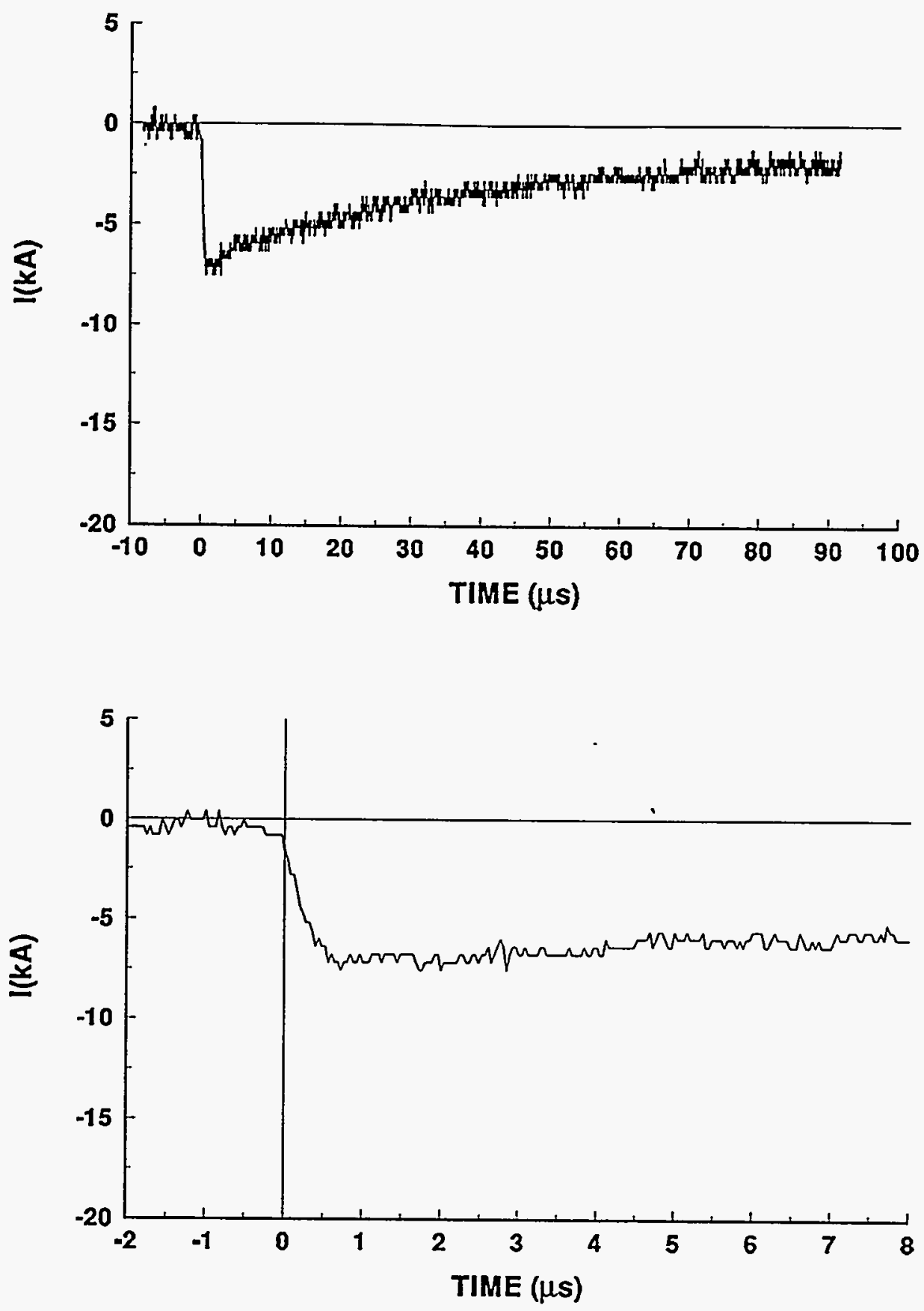


\section{4-21 STROKE 2}

TEST POINT 1
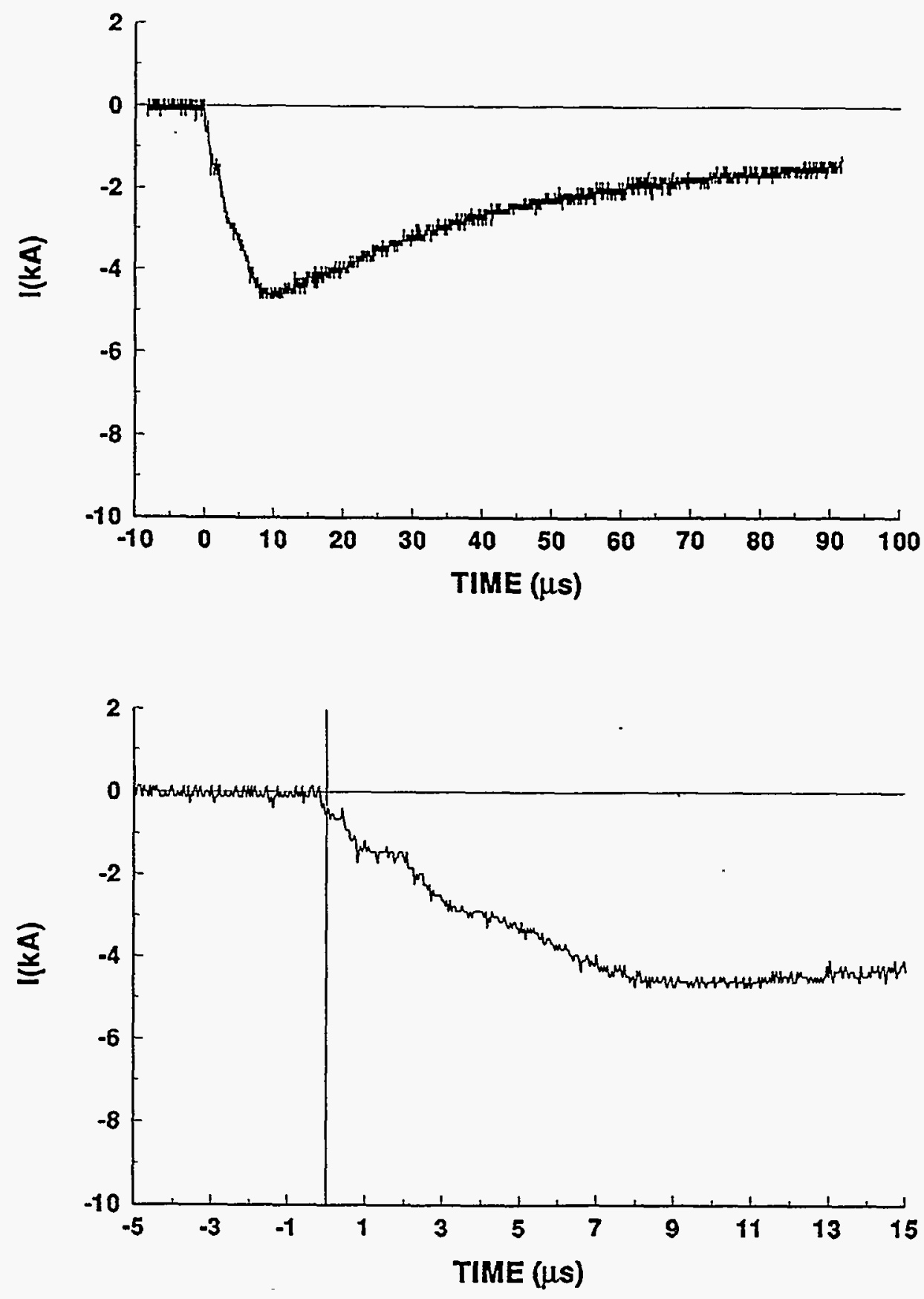


\section{4-21 STROKE 2}

\section{TEST POINT 2}
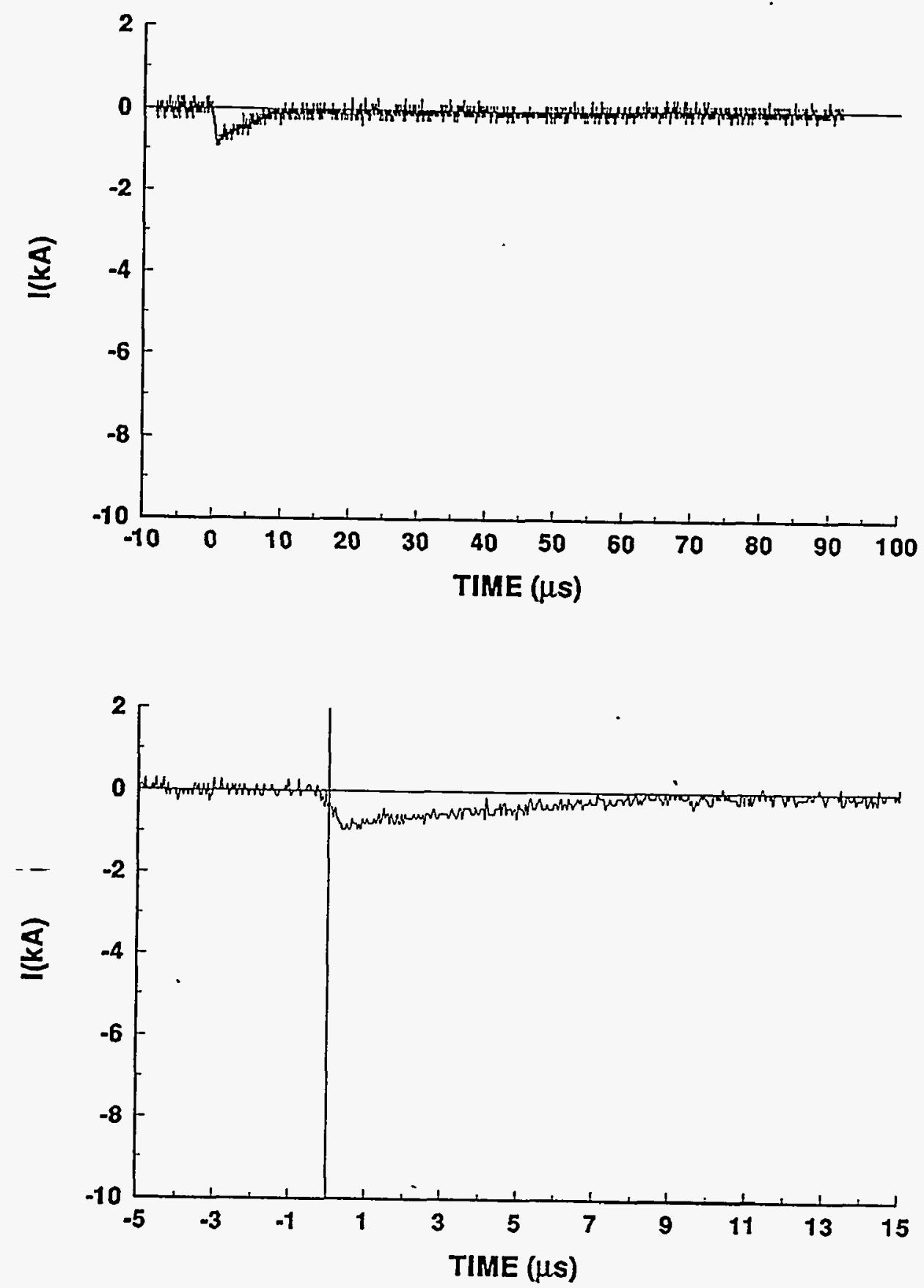


\section{4-21 STROKE 2 \\ TEST POINT 5}
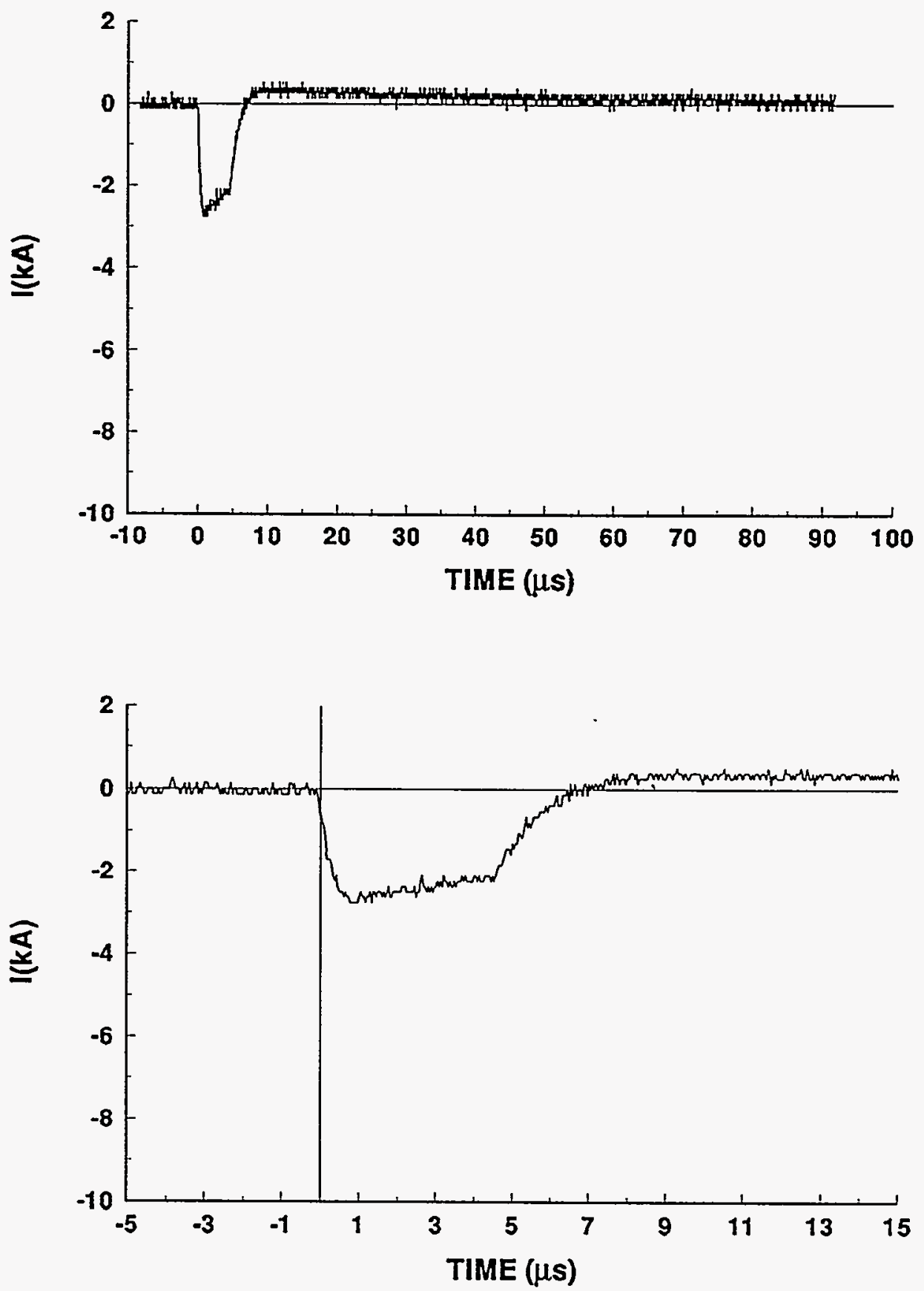


\section{4-21 STROKE 2}

TEST POINT 6
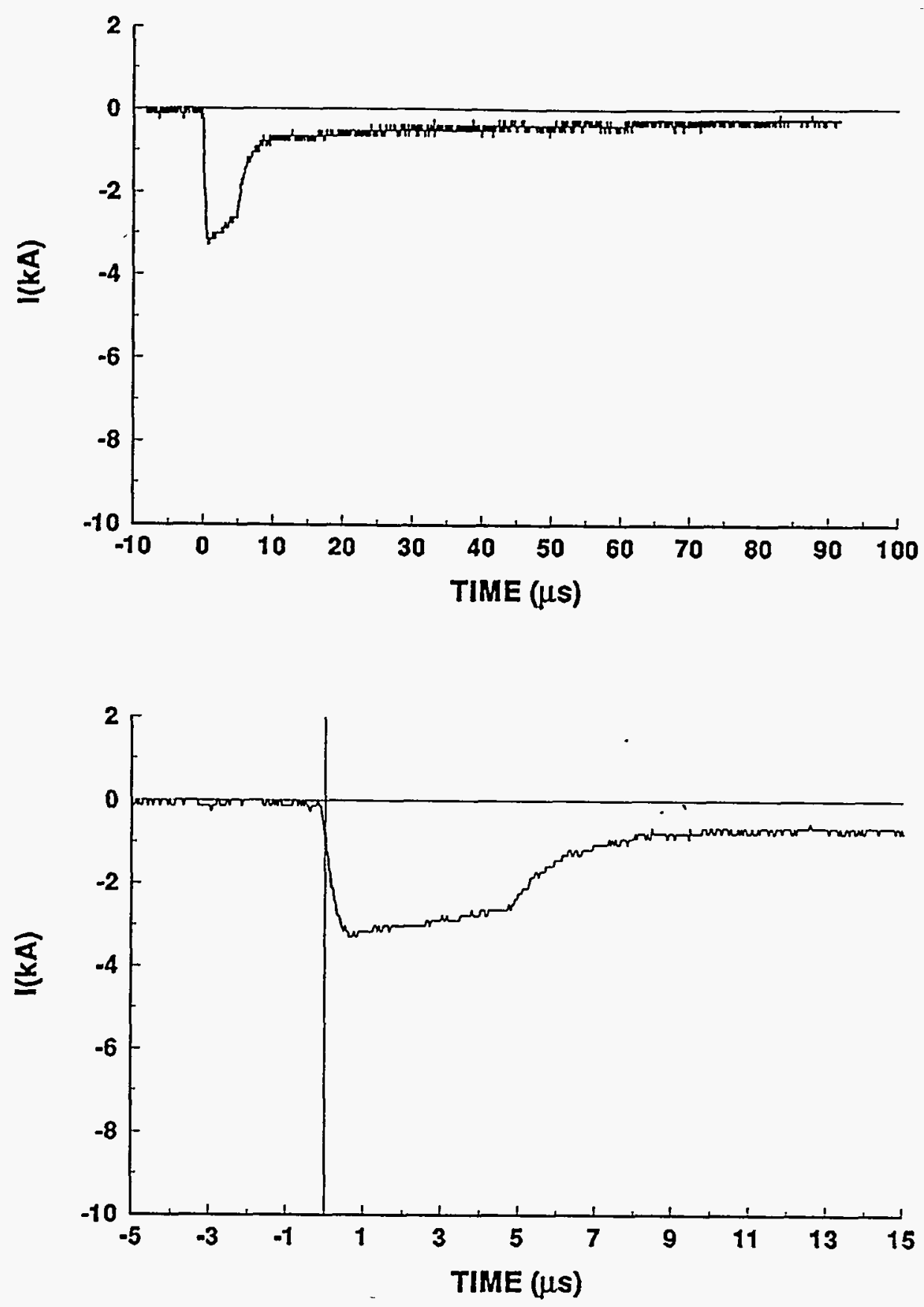


\section{4-21 STROKE 2}

TEST POINT 5'

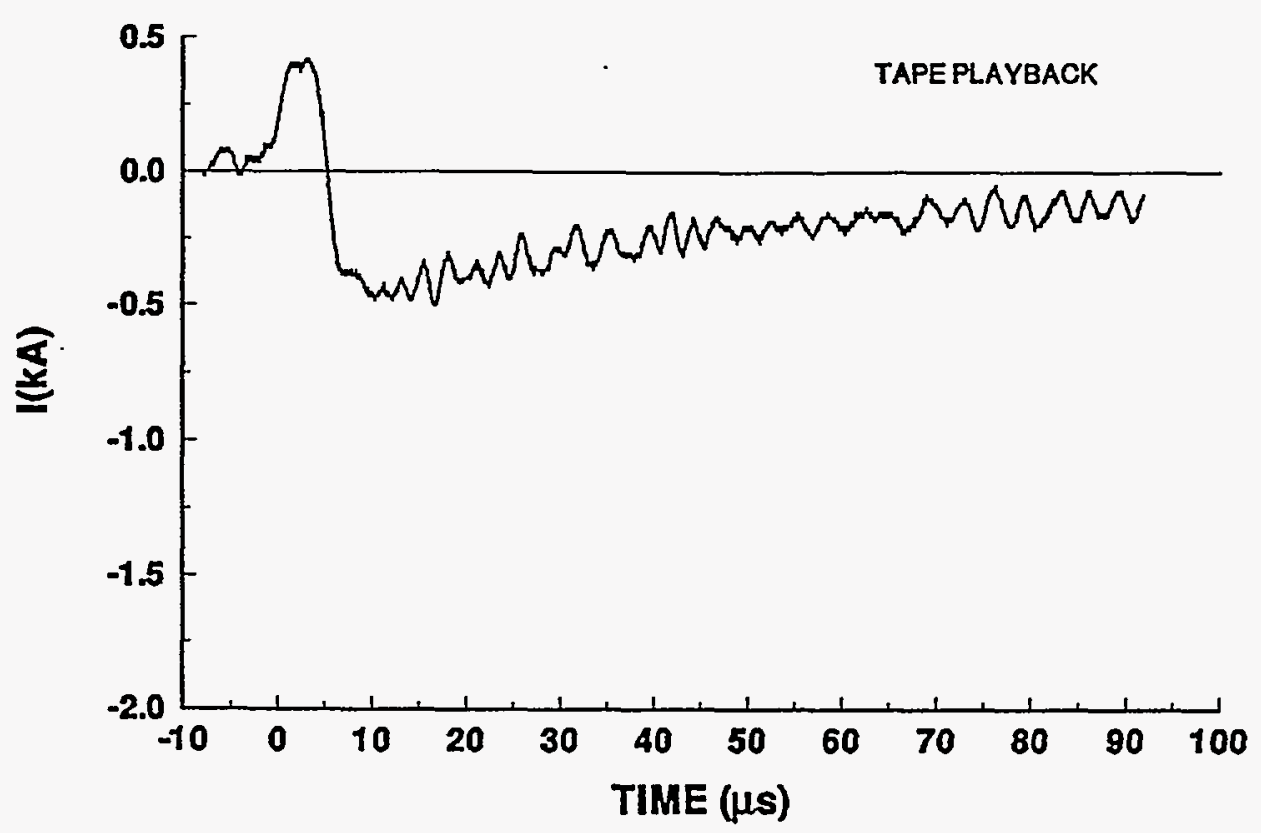

\section{4-21 STROKE 2}

TEST POINT 6'

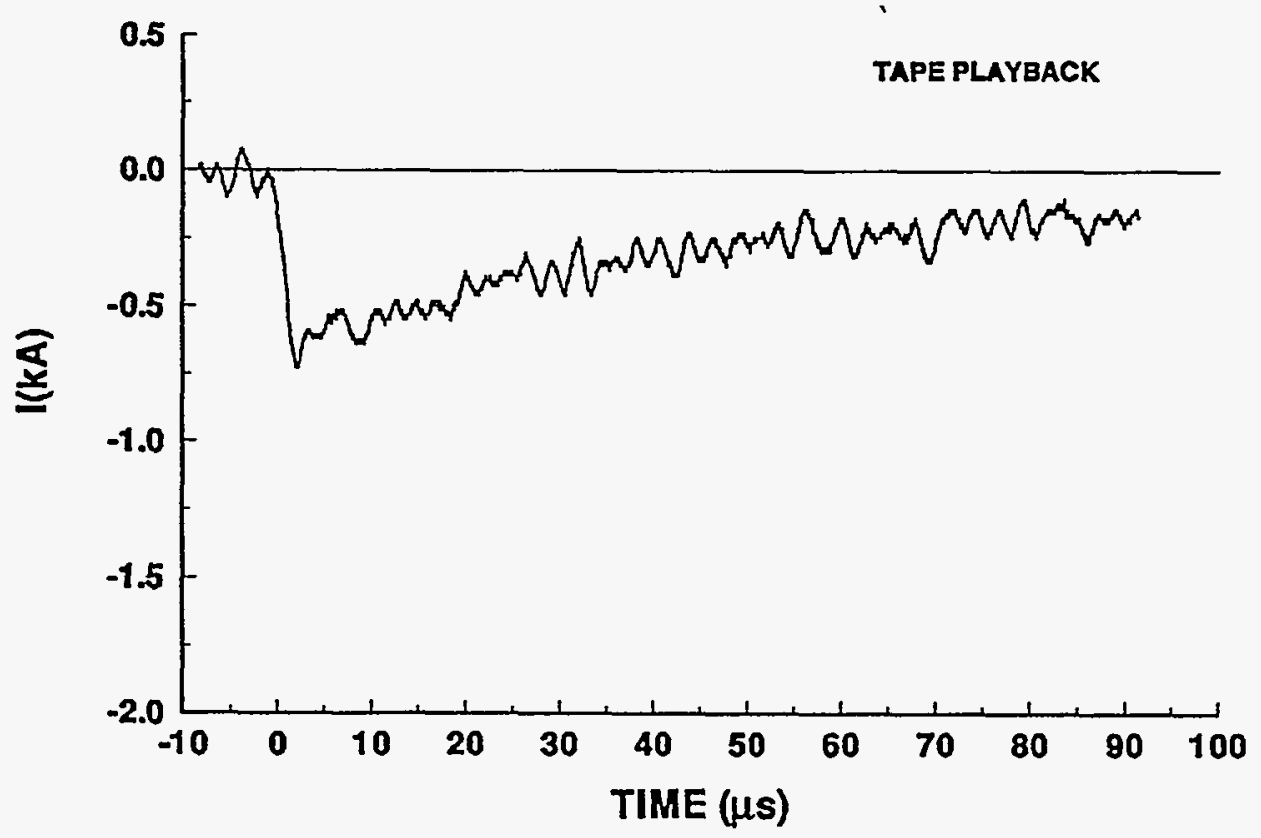




\section{4-21 STROKE 2}

TEST POINT 10

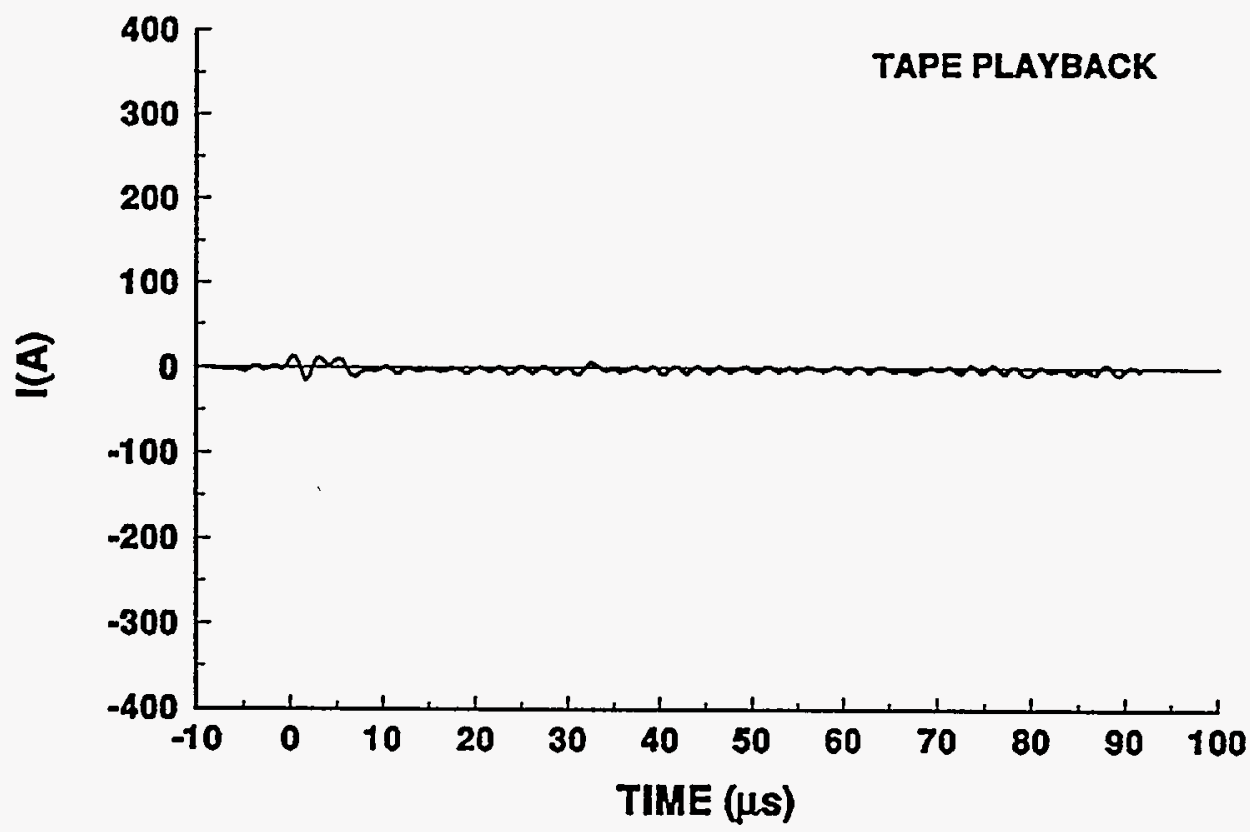

94-21 STROKE 2

TEST POINT 11

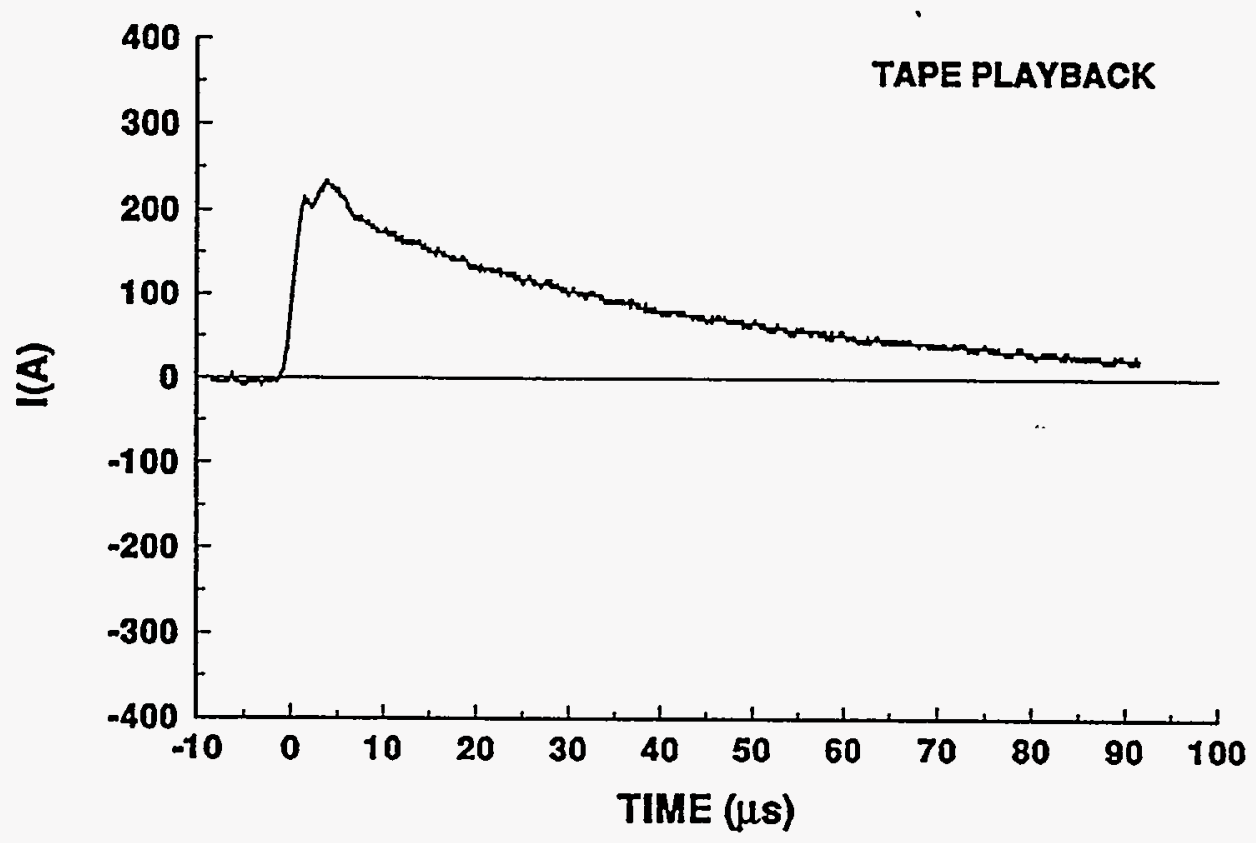


94-21 STROKE 2

TEST POINT 12

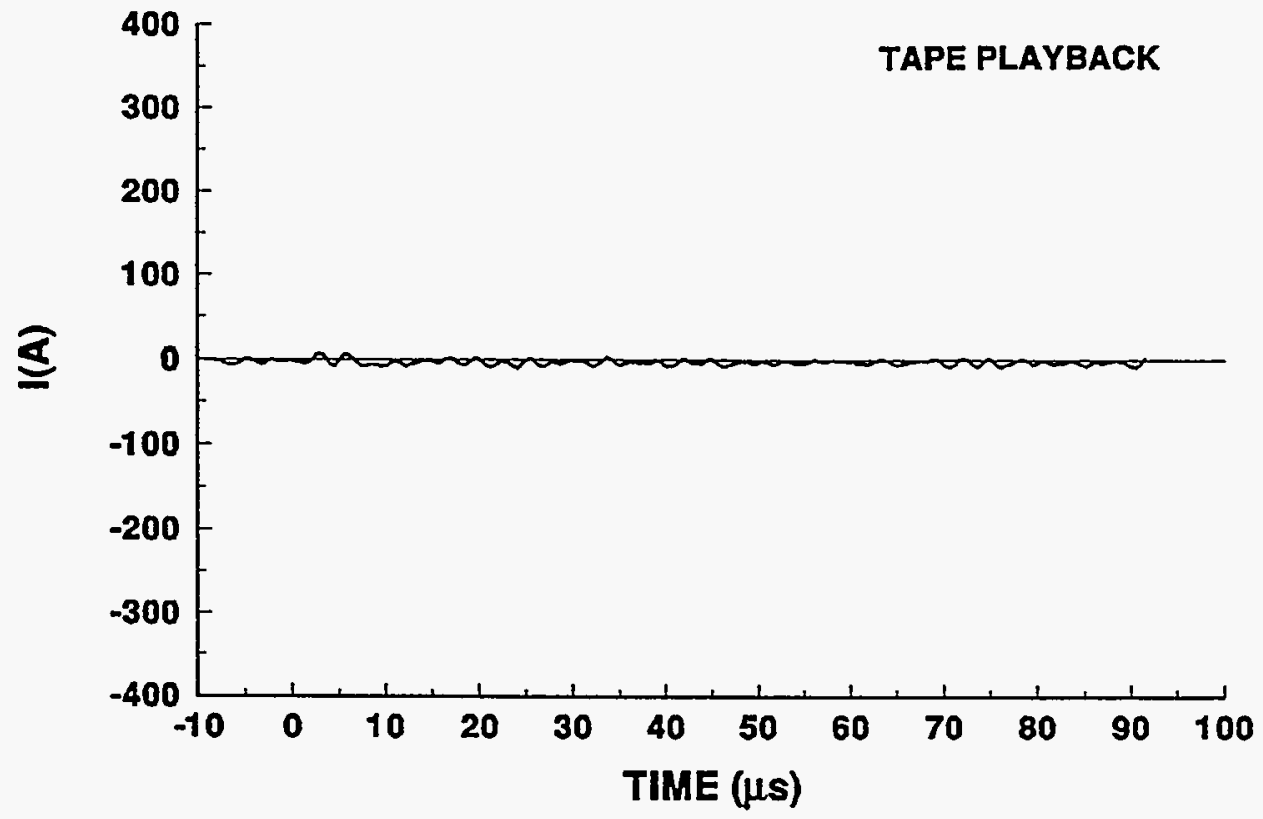

94-21 STROKE 2

TEST POINT 13

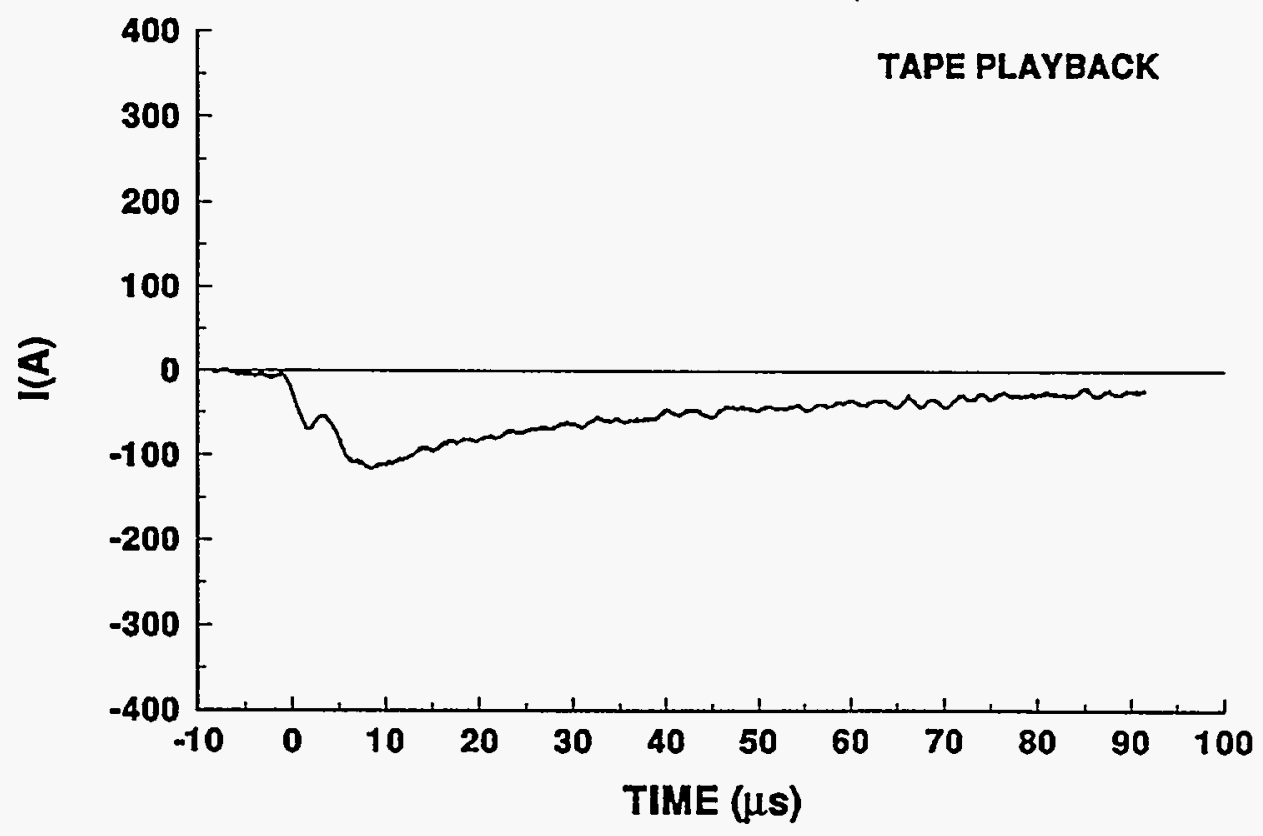




\section{4-21 STROKE 2}

TEST POINT 14
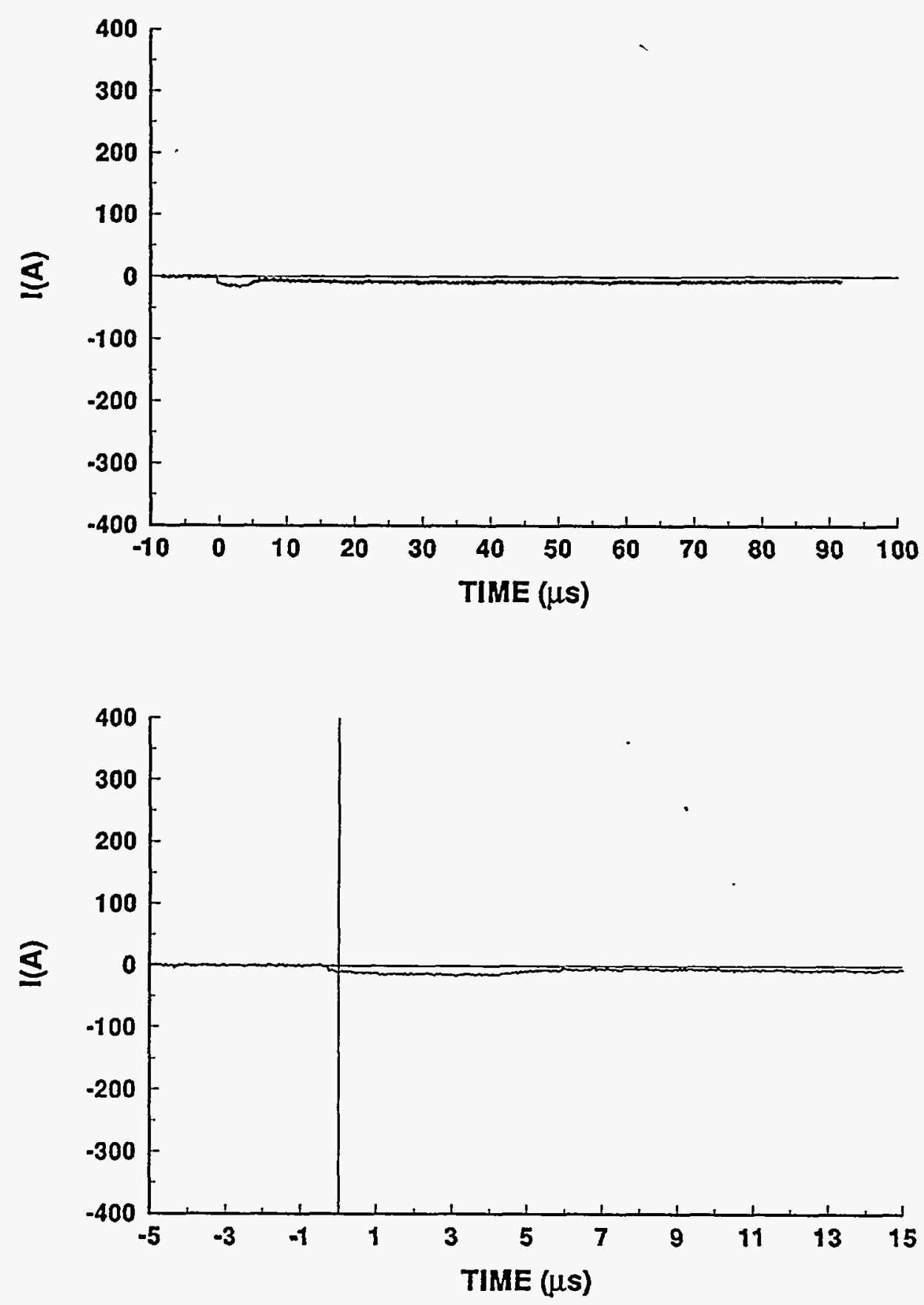
94-21 STROKE 2

TEST POINT 15
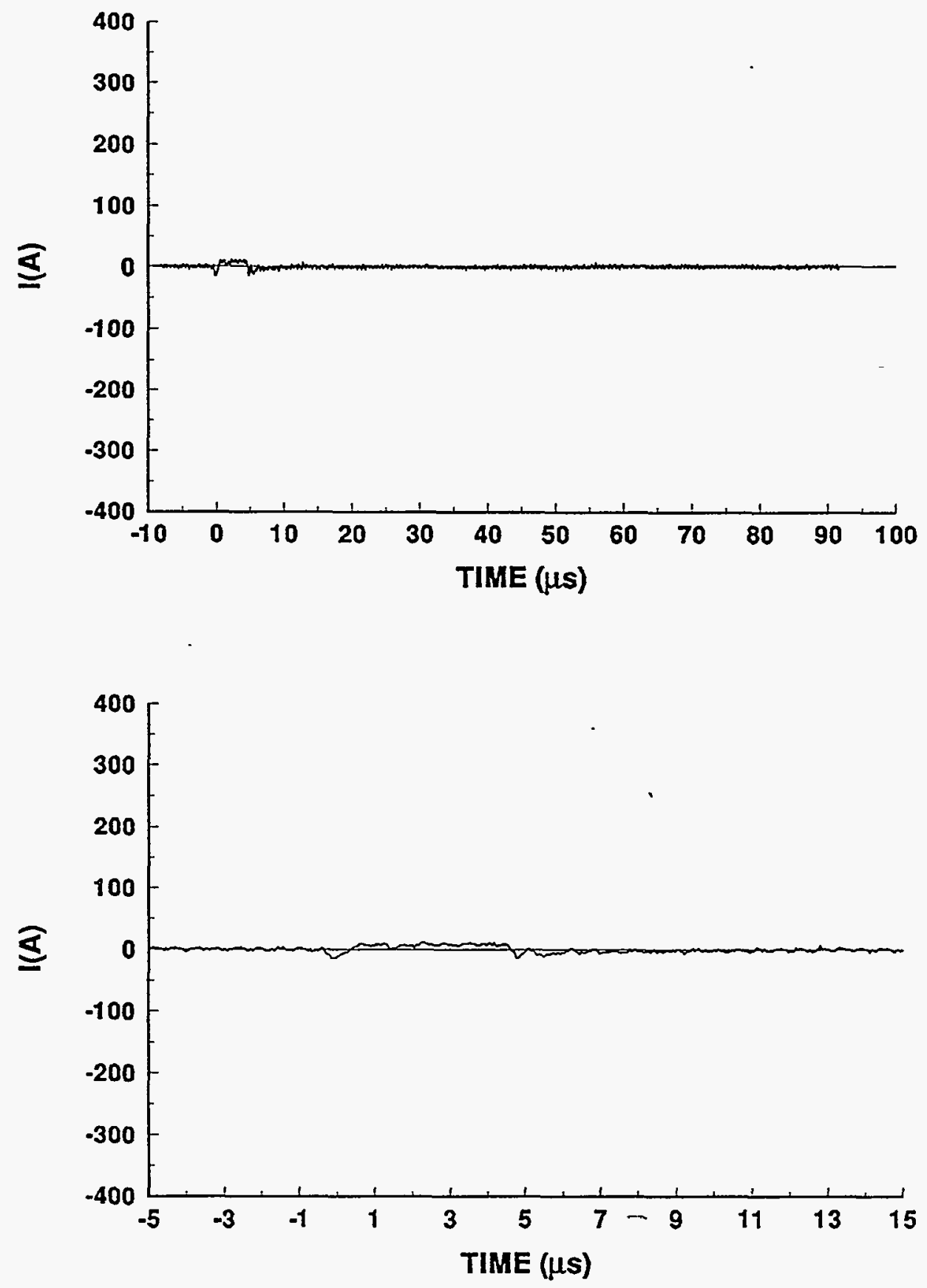


\section{4-21 STROKE 2}

TEST POINT 20

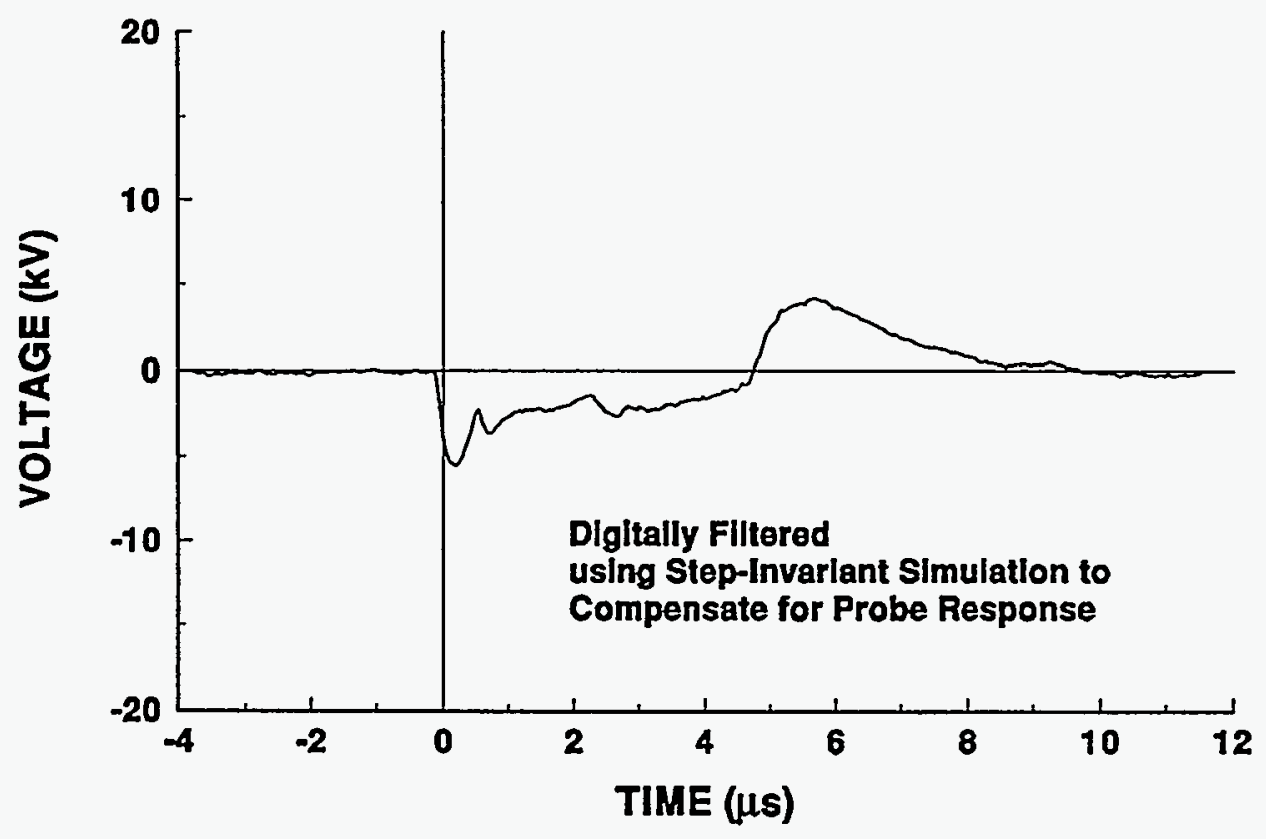

94-21 STROKE 2.

TEST POINT 21

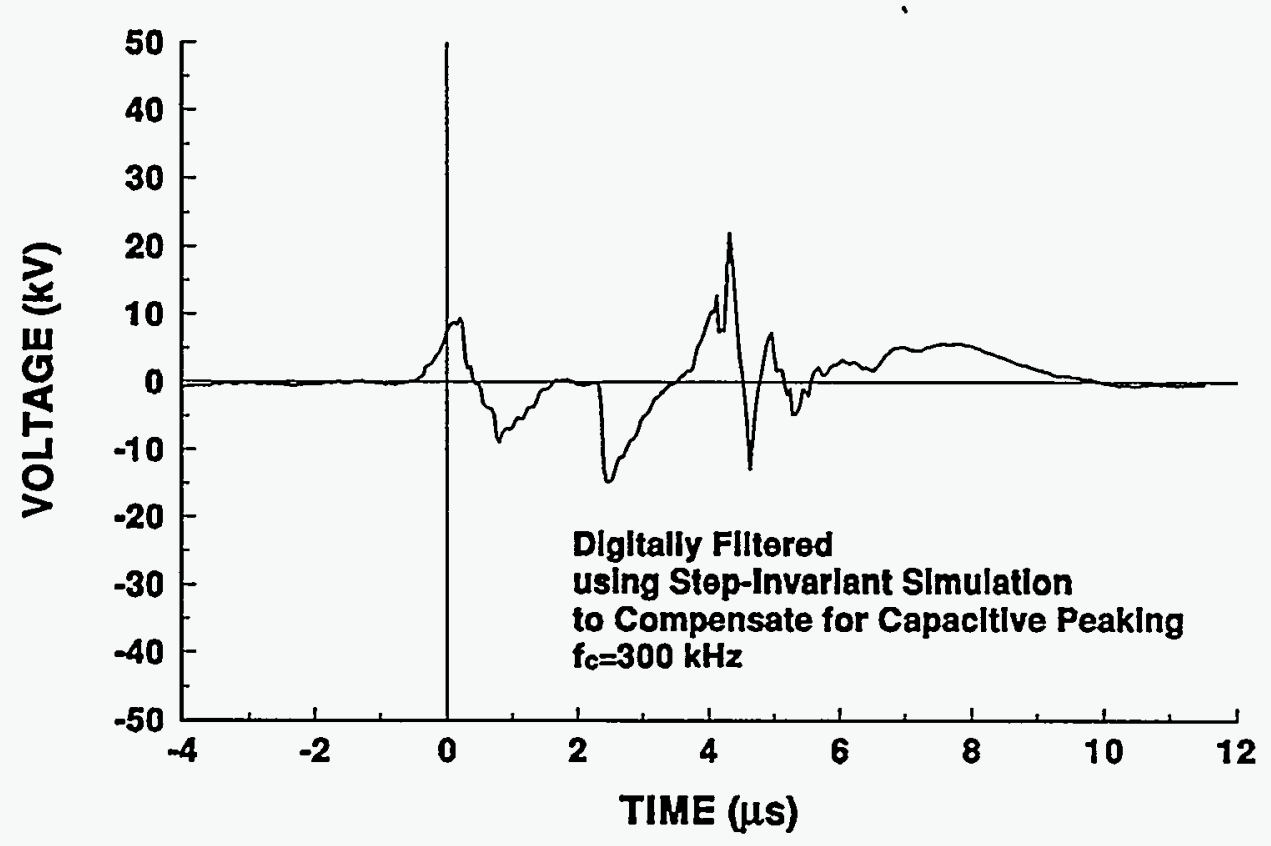




\section{4-21 STROKE 2}

TEST POINT 22

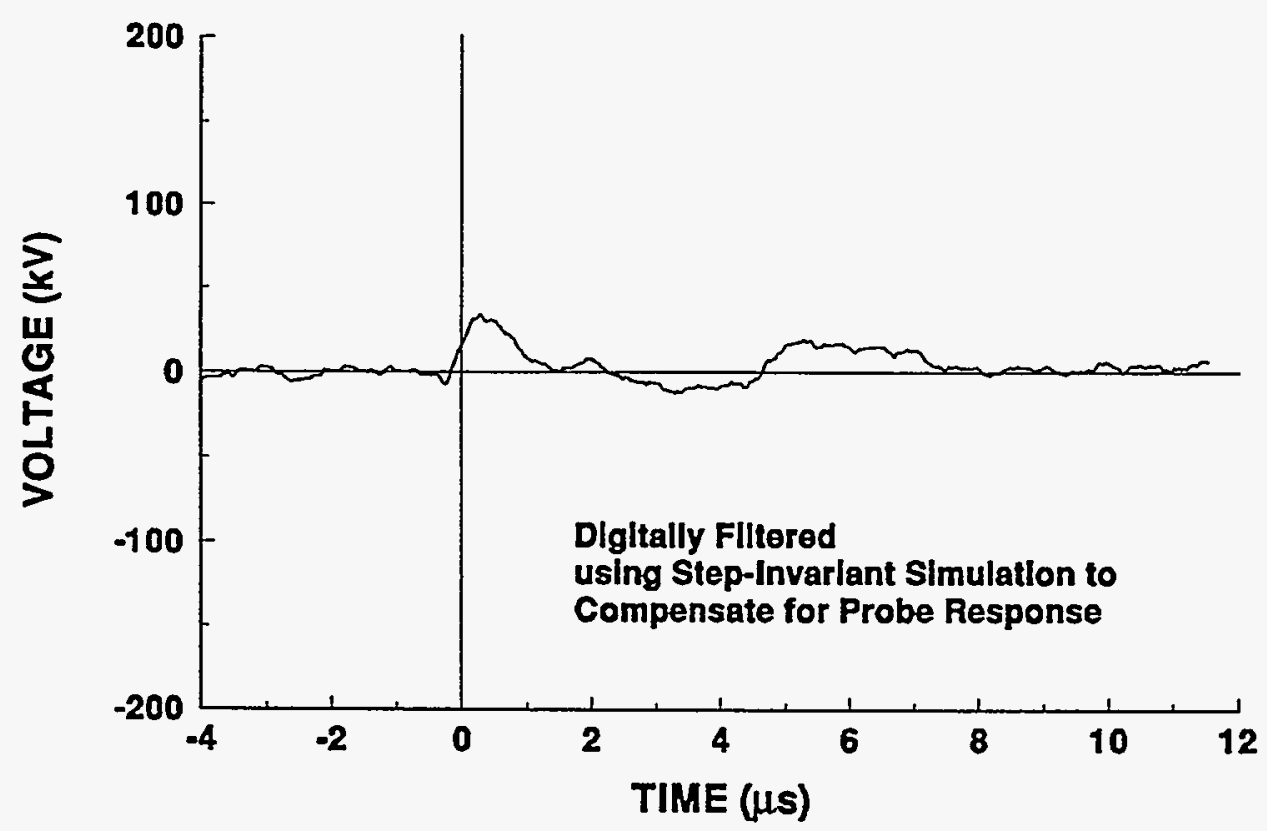




\section{4-21 STROKE 2}

TEST POINT 23

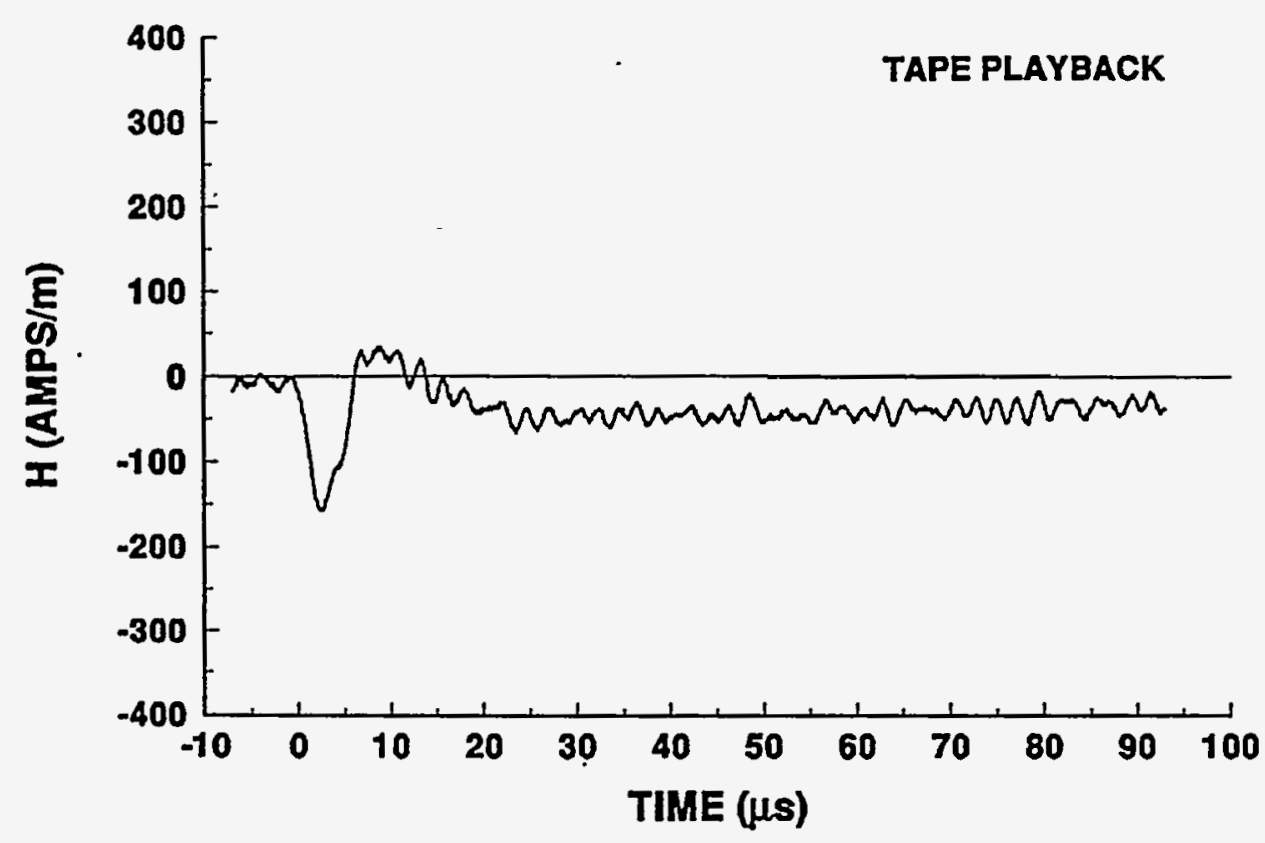

\section{4-21 STROKE 2.}

TEST POINT 24

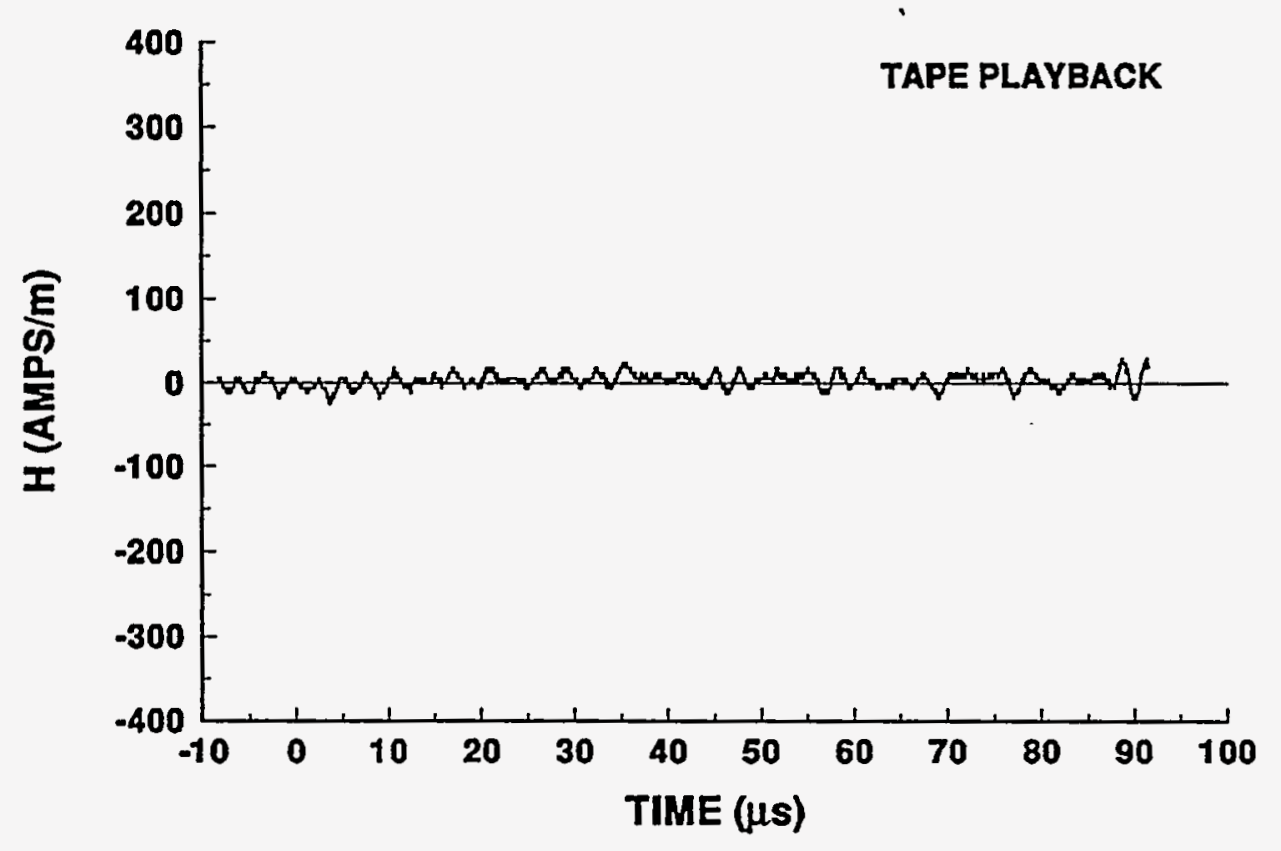




\section{4-21 STROKE 3 INCIDENT CURRENT}
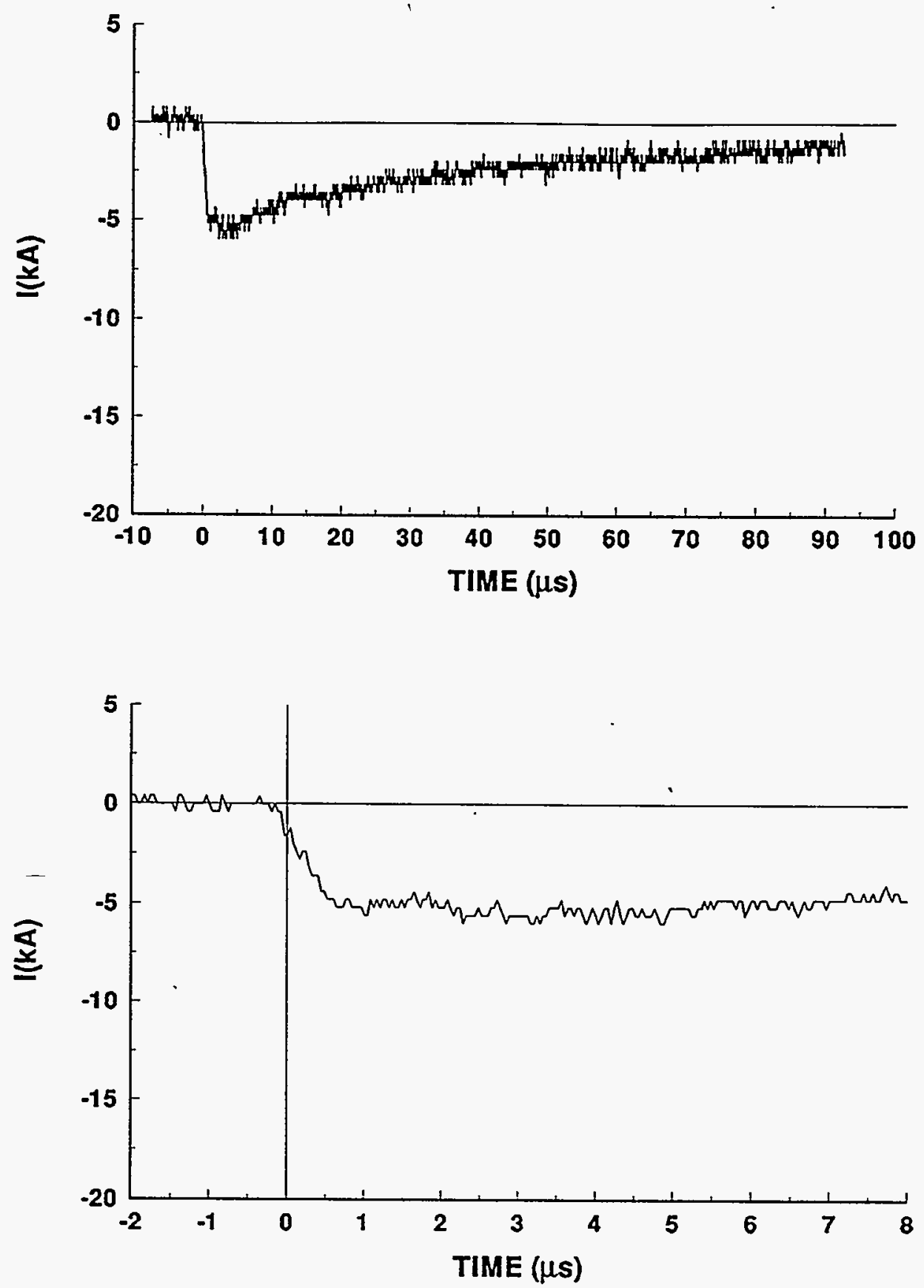


\section{4-21 STROKE 3 \\ TEST POINT 1}
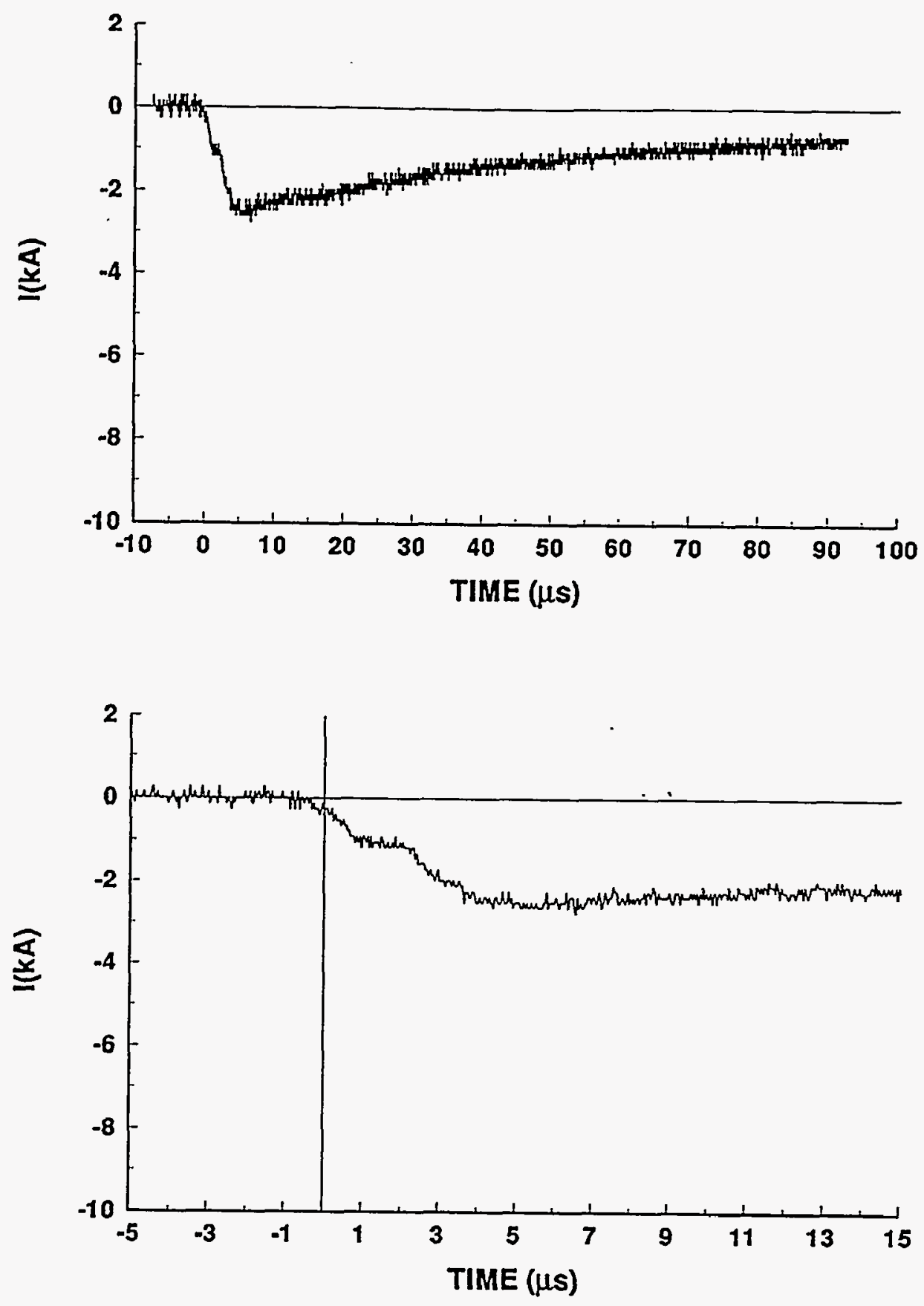


\section{4-21 STROKE 3}

TEST POINT 2
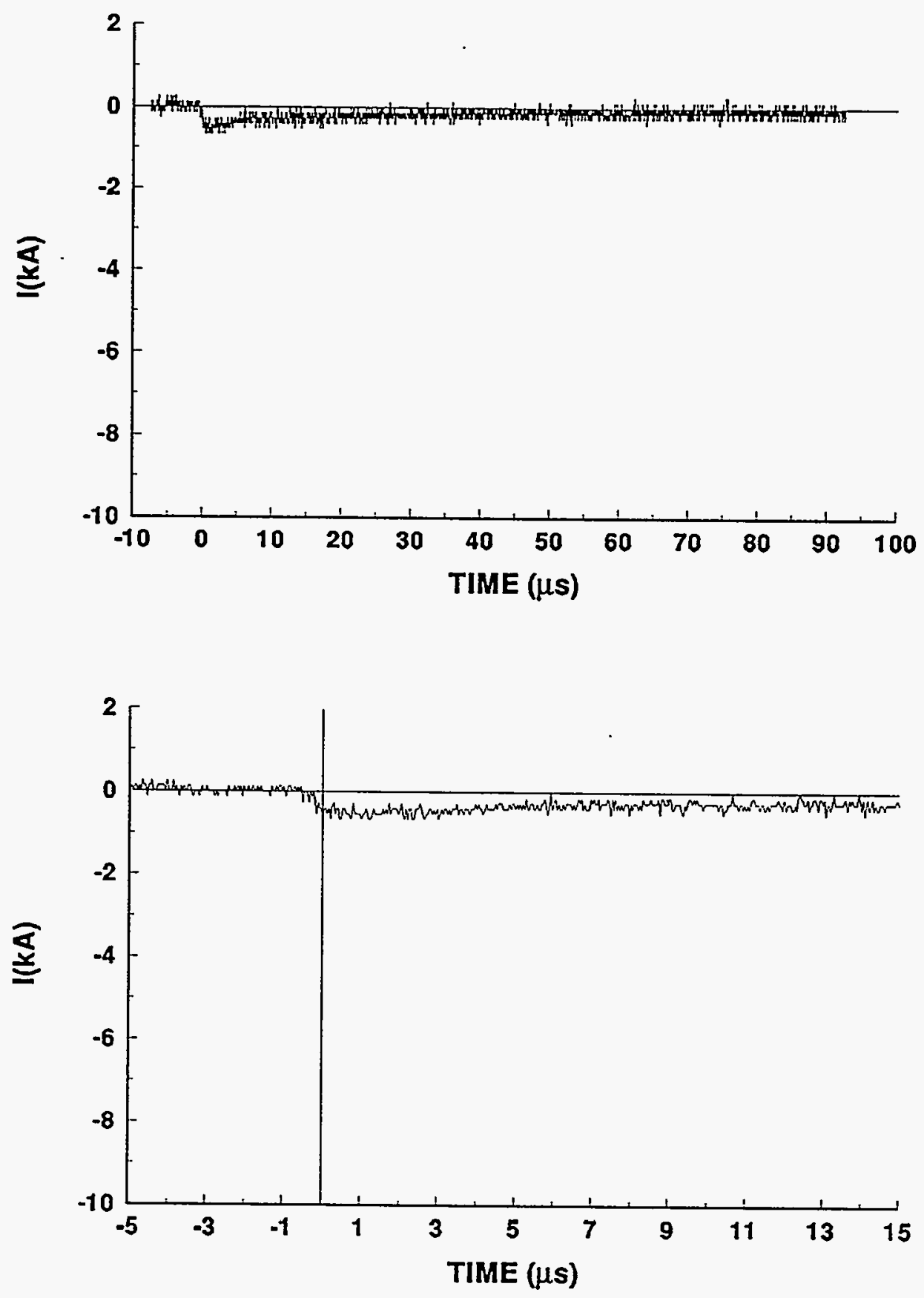


\section{4-21 STROKE 3}

TEST POINT 5
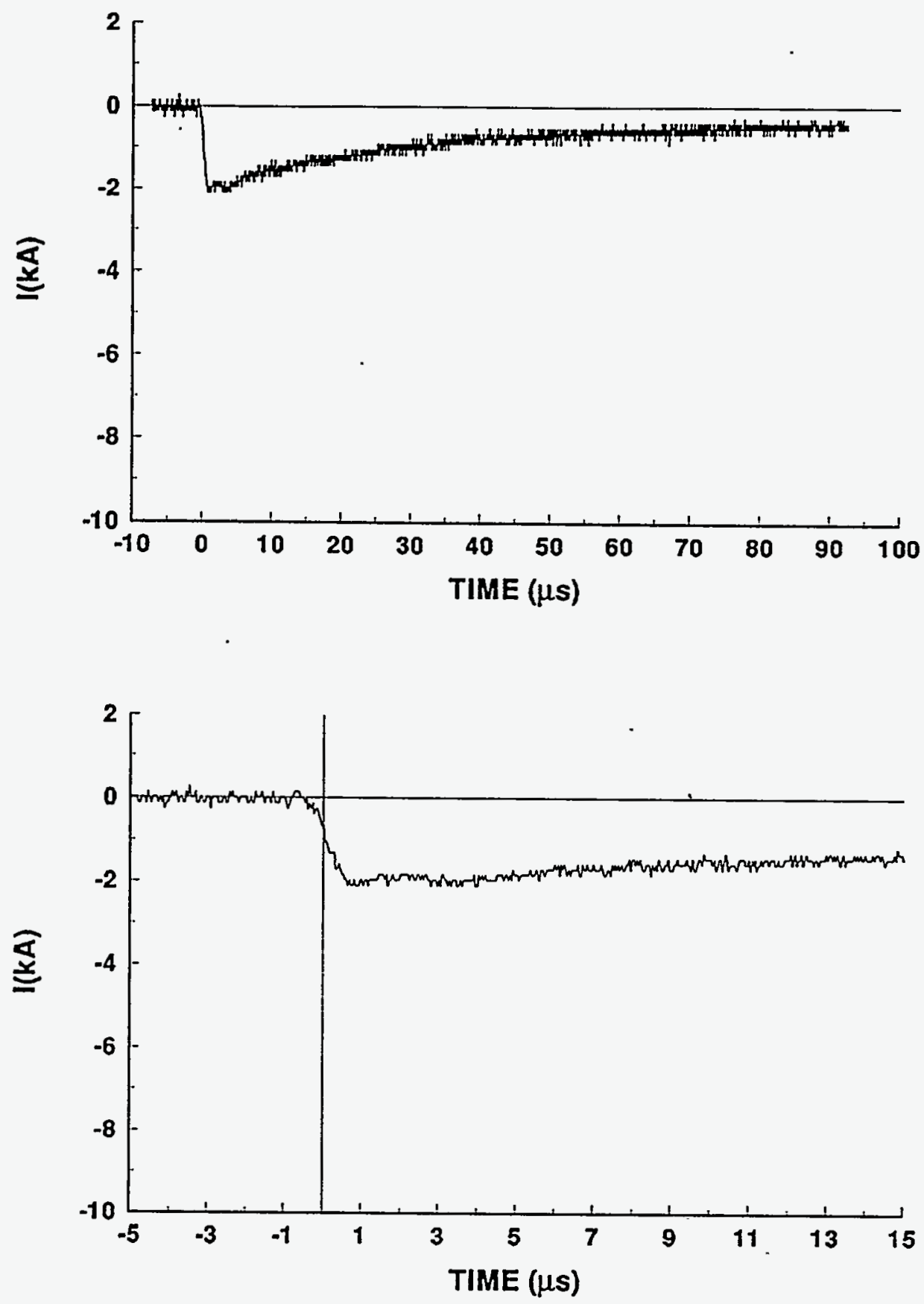


\section{4-21 STROKE 3}

TEST POINT 6
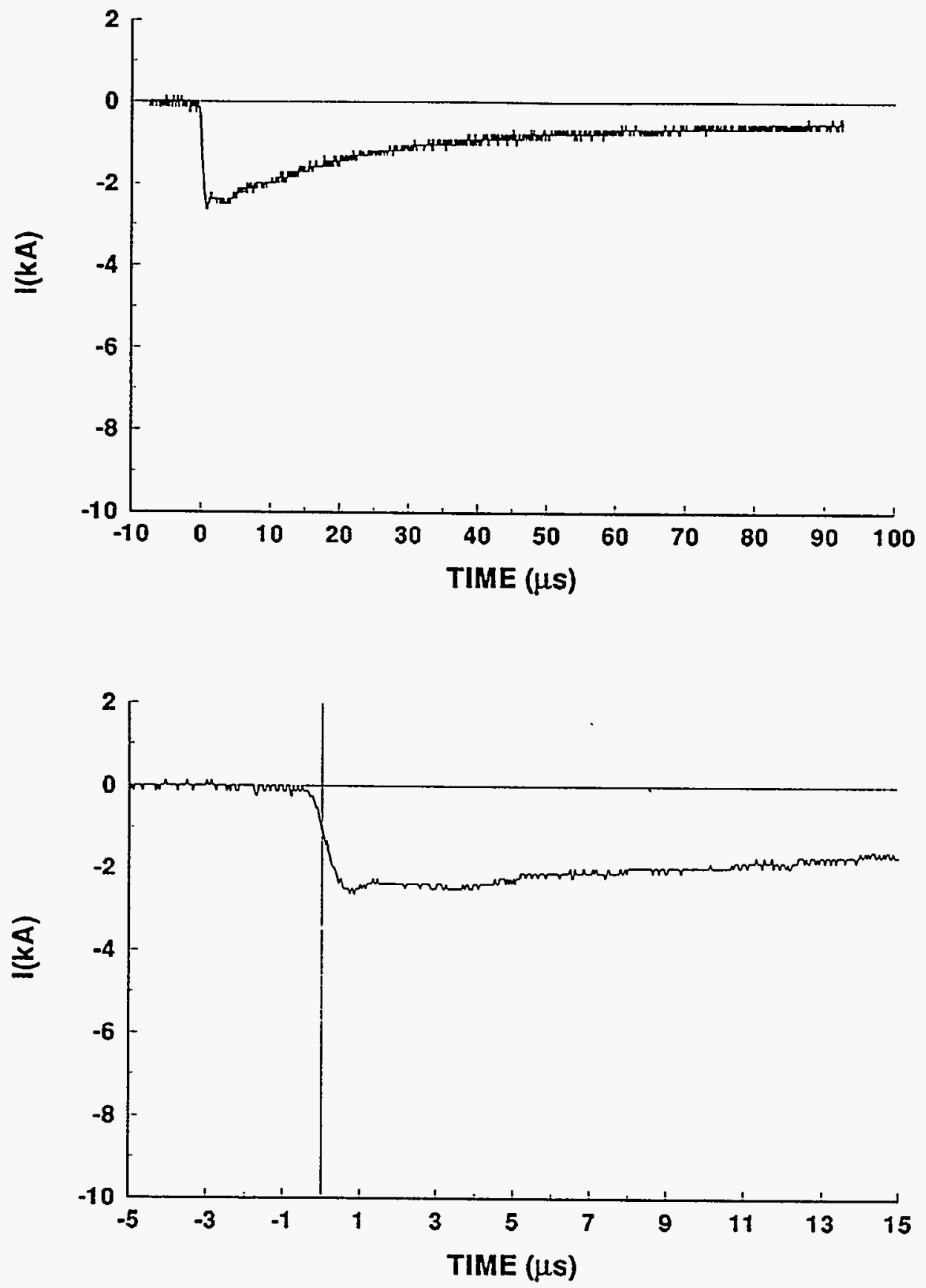


\section{4-21 STROKE 3}

TEST POINT 5'

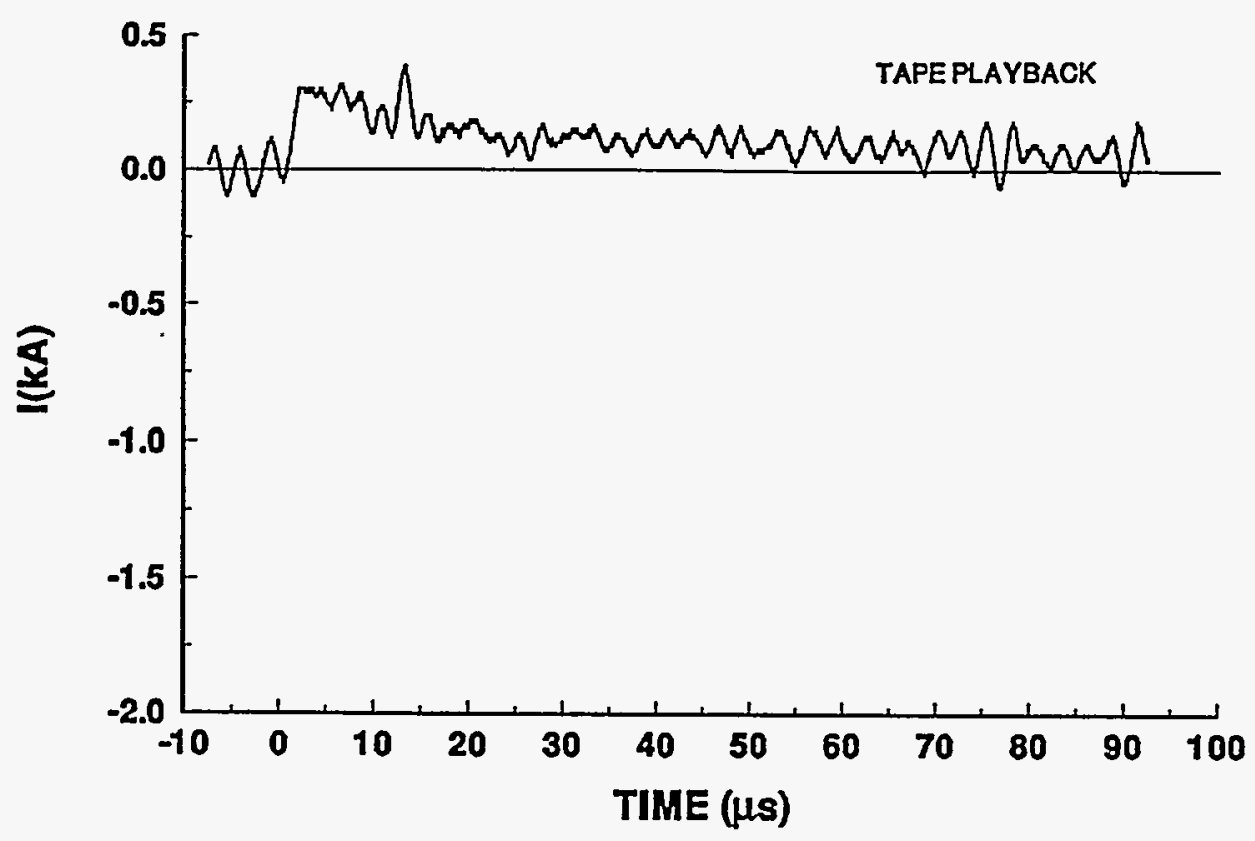

94-21 STROKE 3.

TEST POINT 6'

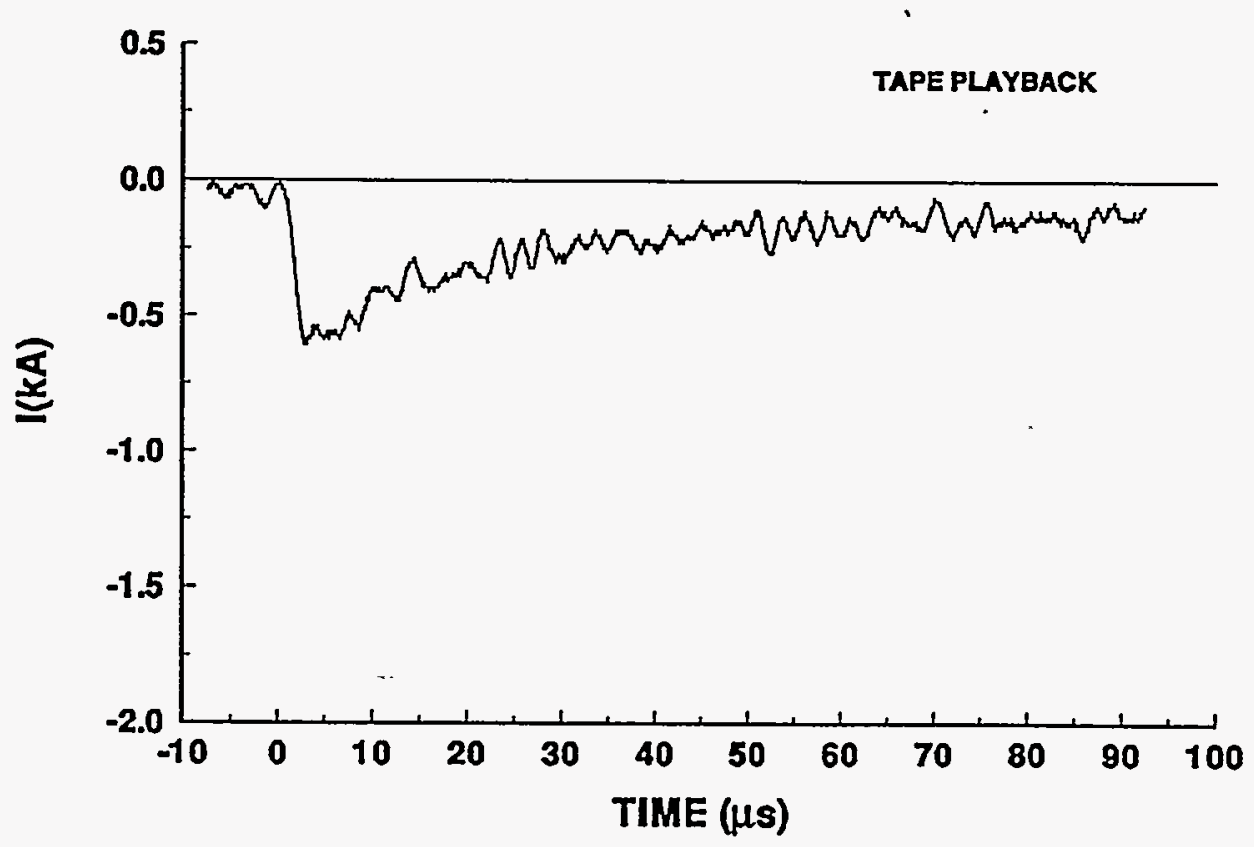


94-21 STROKE 3

TEST POINT 10

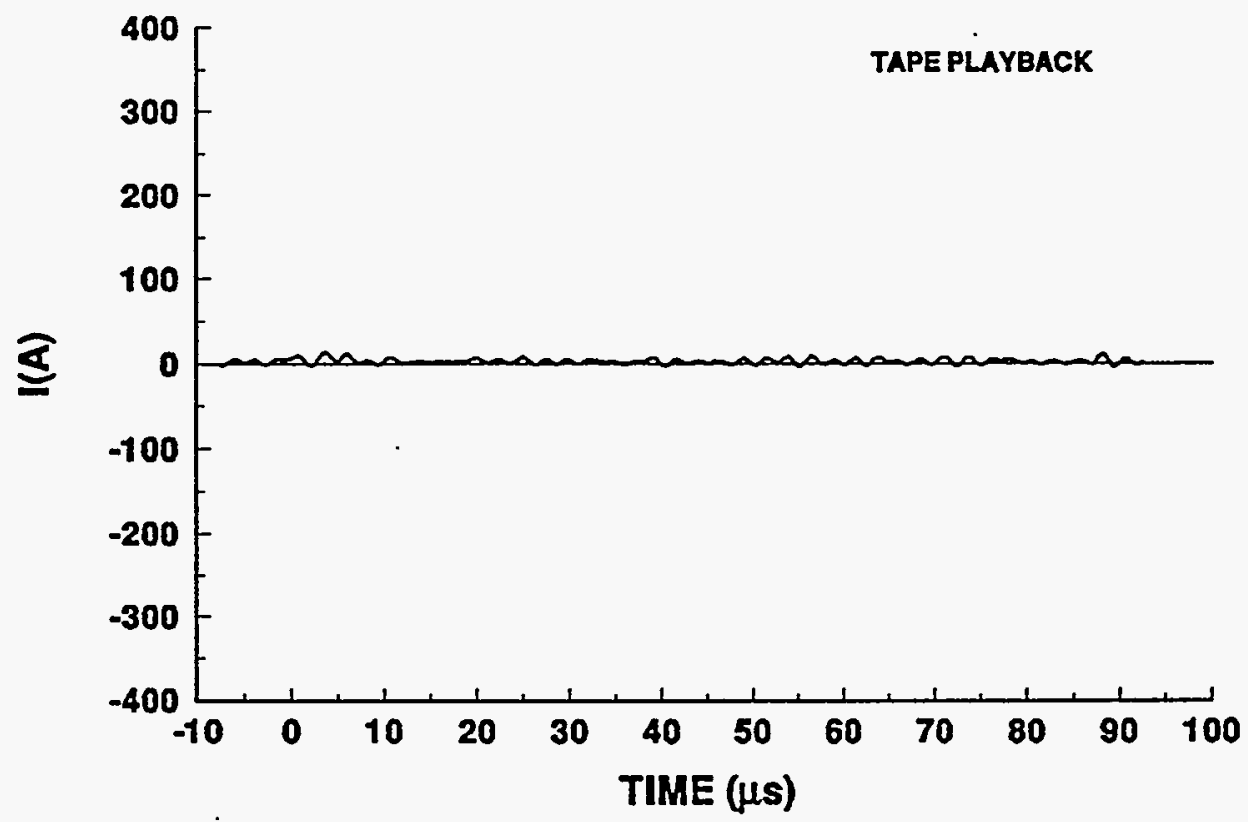

94-21 STROKE 3

TEST POINT 11

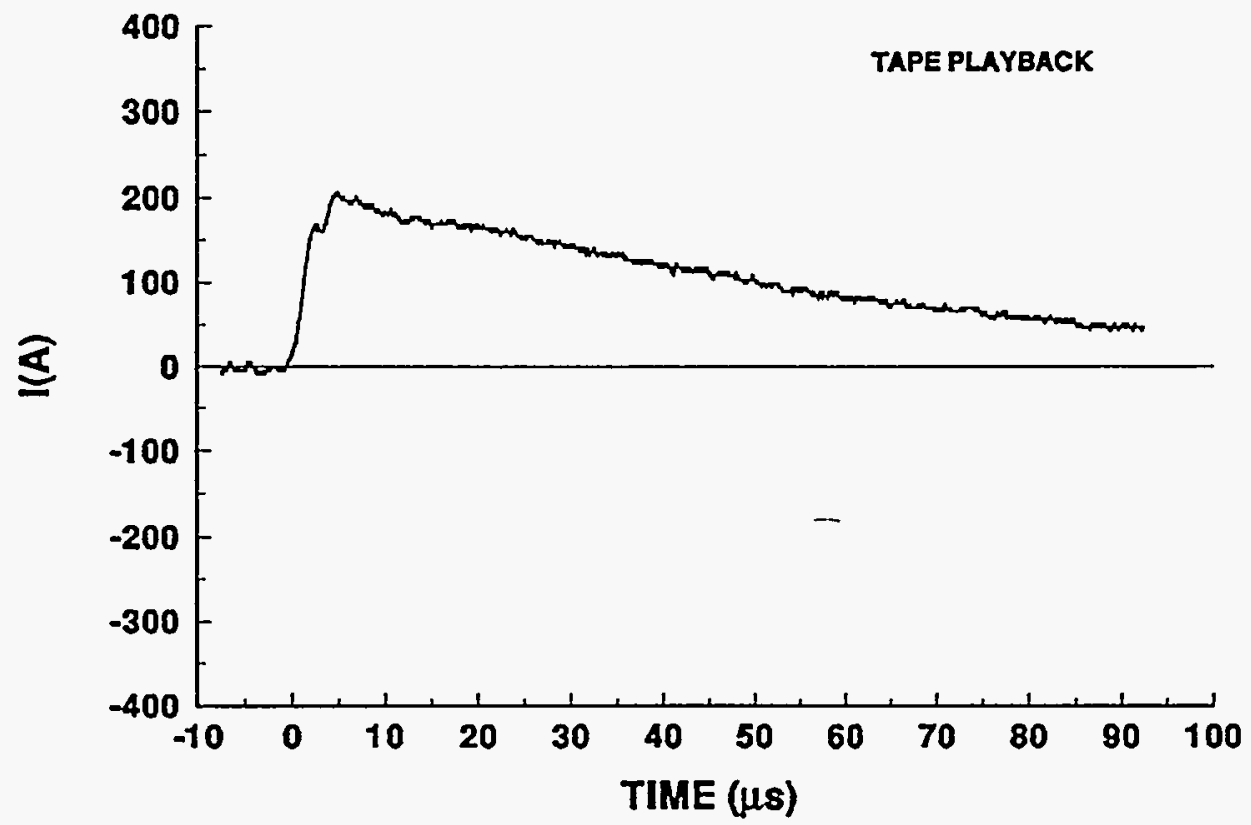




\section{4-21 STROKE 3}

\section{TEST POINT 12}

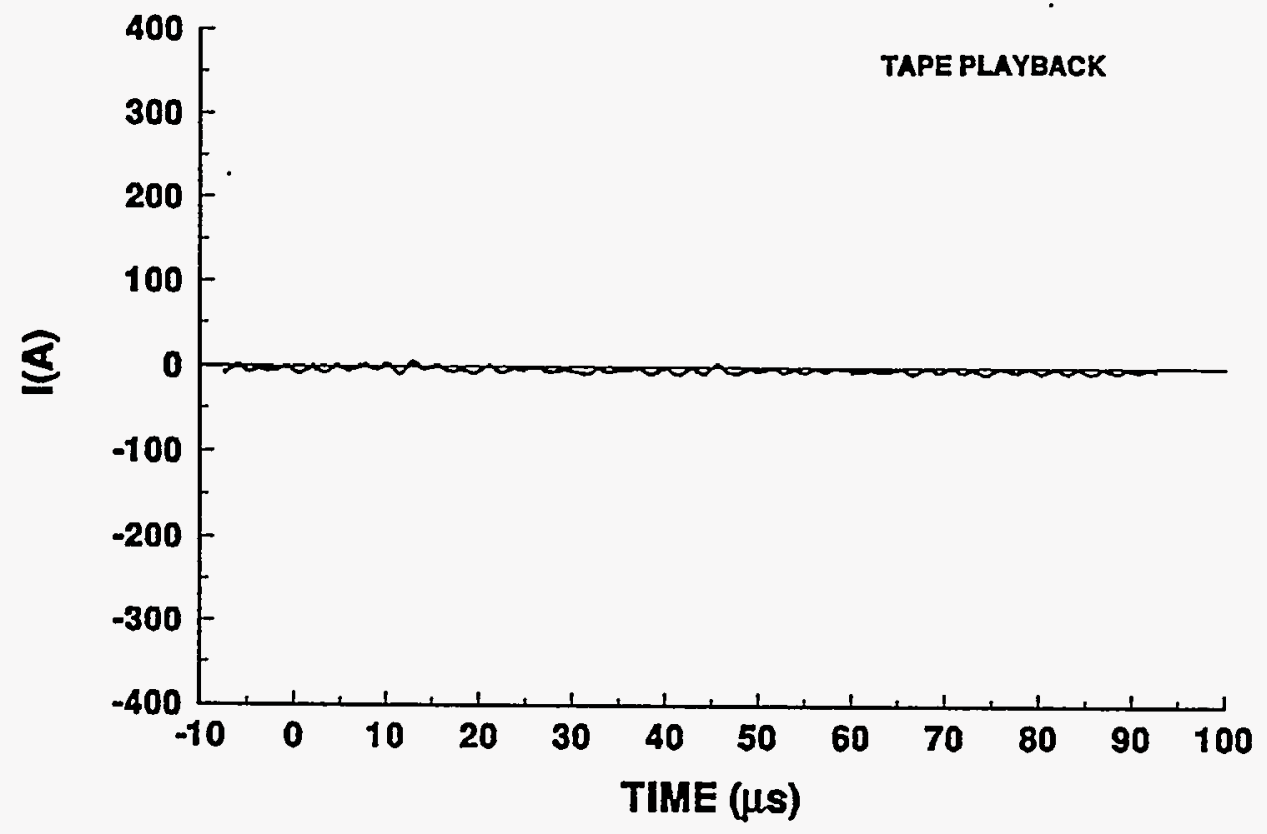

94-21 STROKE 3.

TEST POINT 13

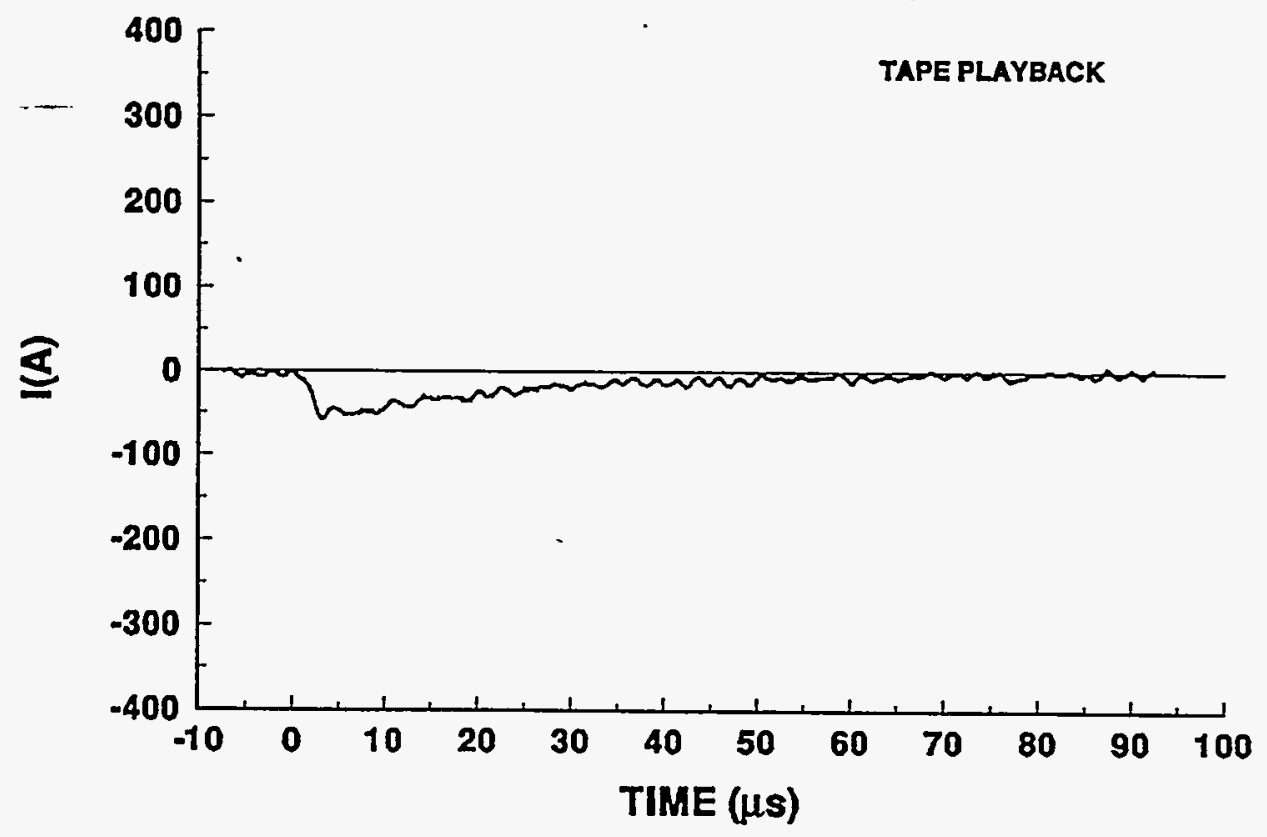




\section{4-21 STROKE 3}

TEST POINT 14
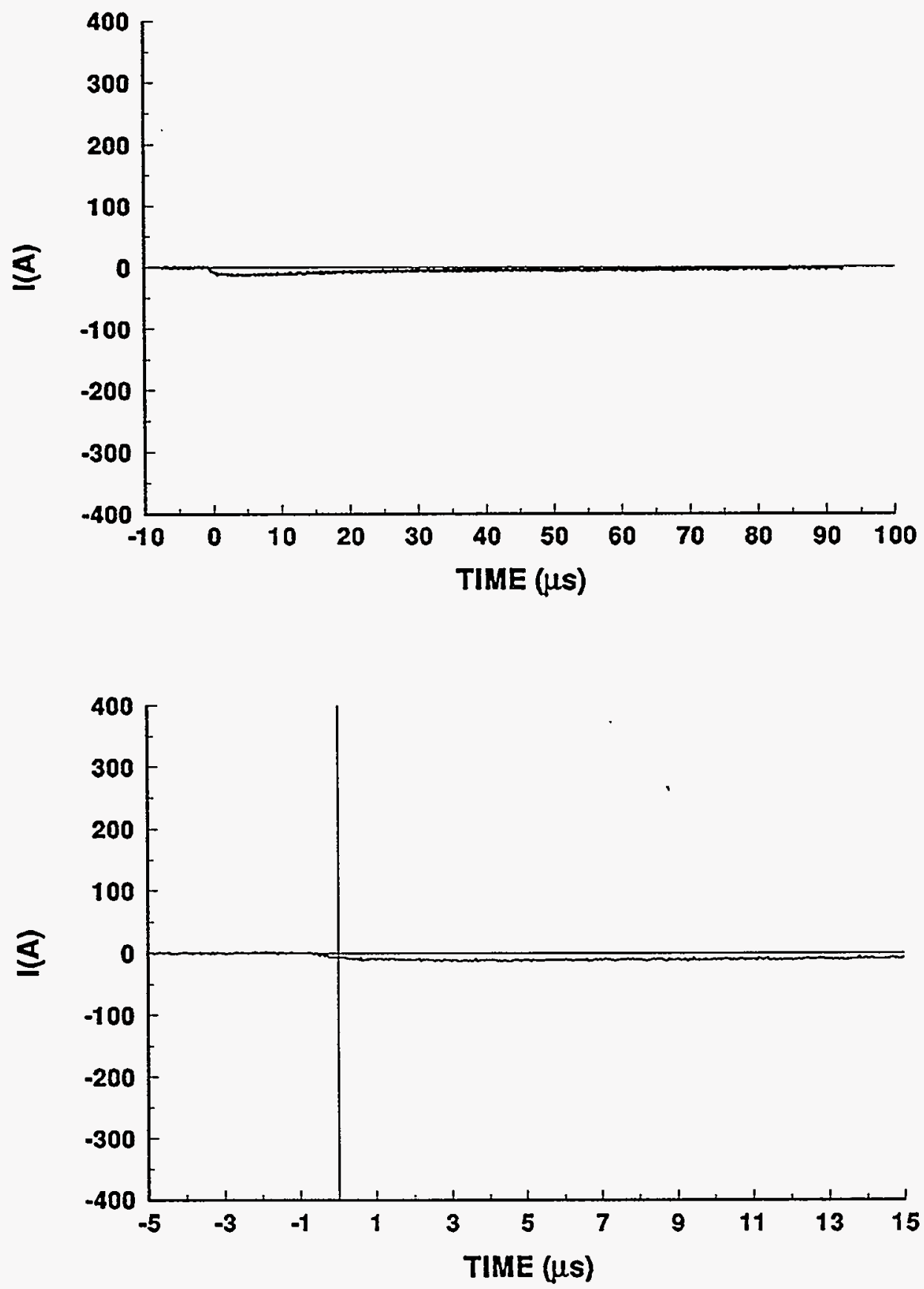


\section{4-21 STROKE 3}

TEST POINT 15
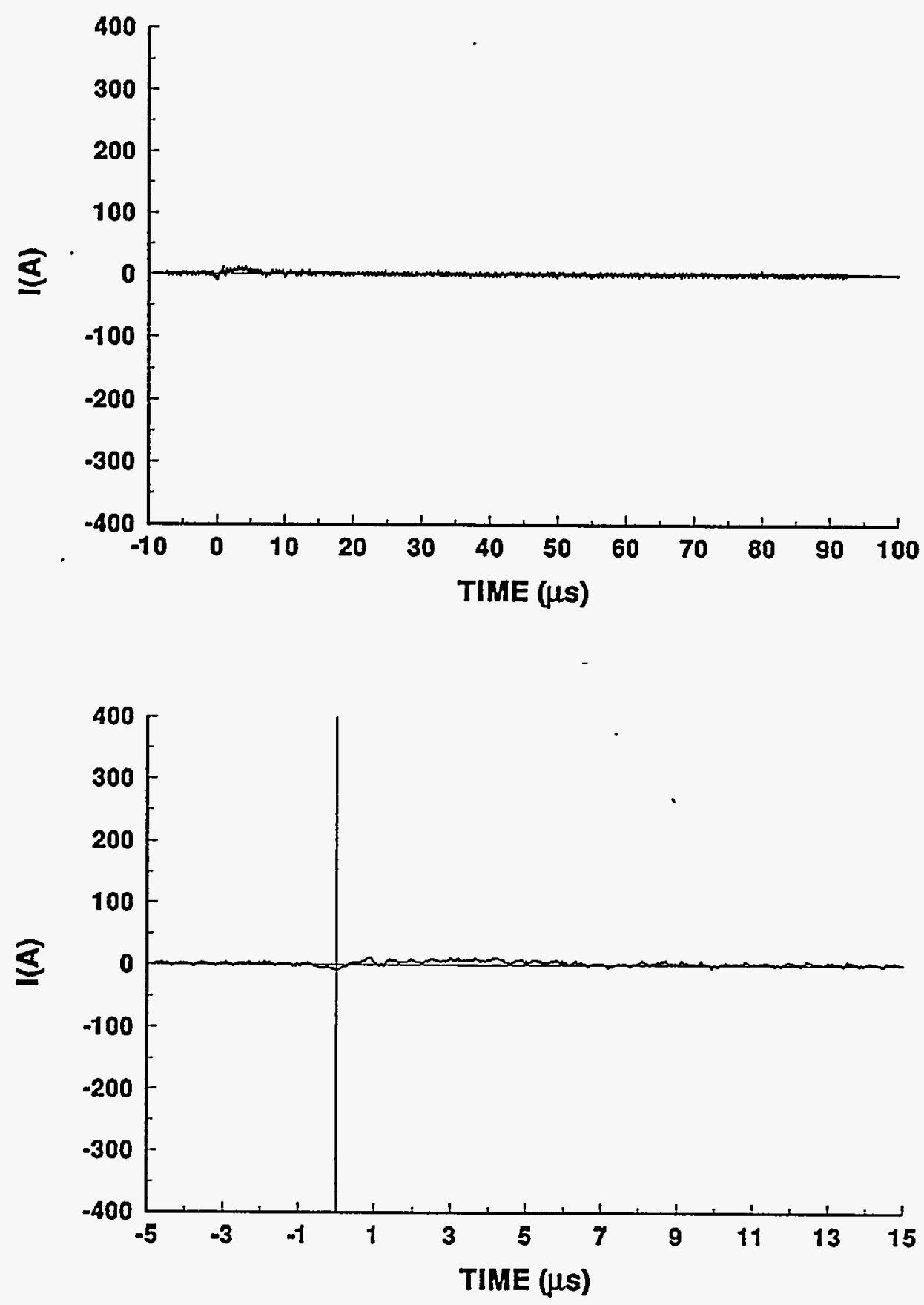


\section{4-21 STROKE 3}

TEST POINT 20

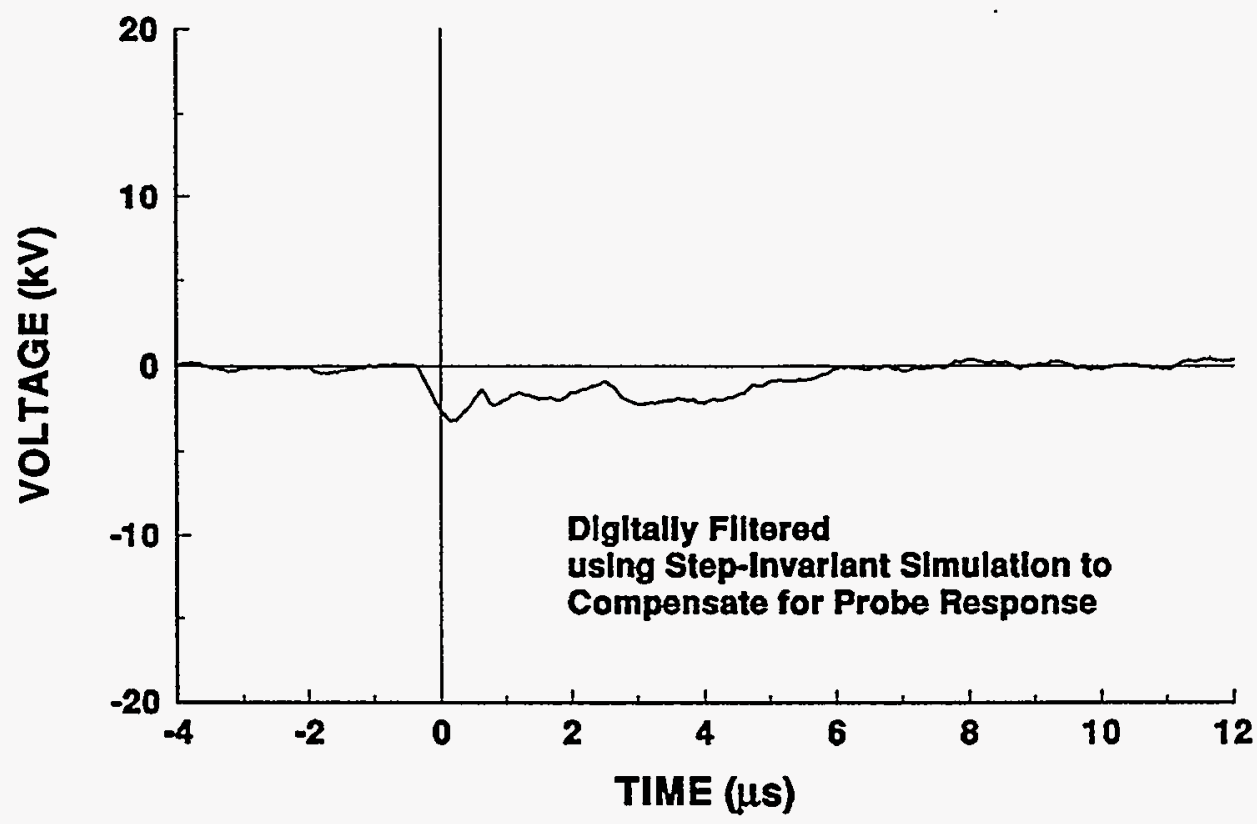

94-21 STROKE 3

TEST POINT 21

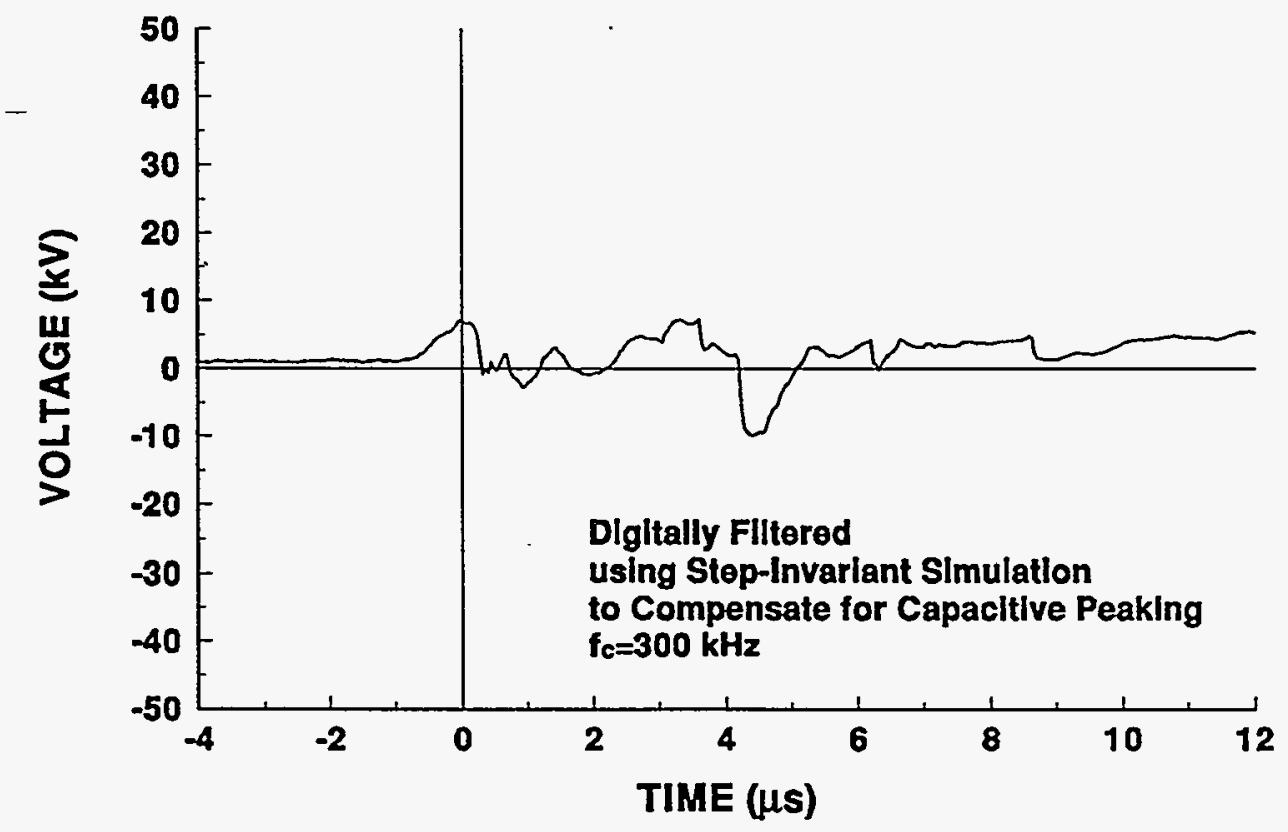




\section{4-21 STROKE 3}

TEST POINT 22

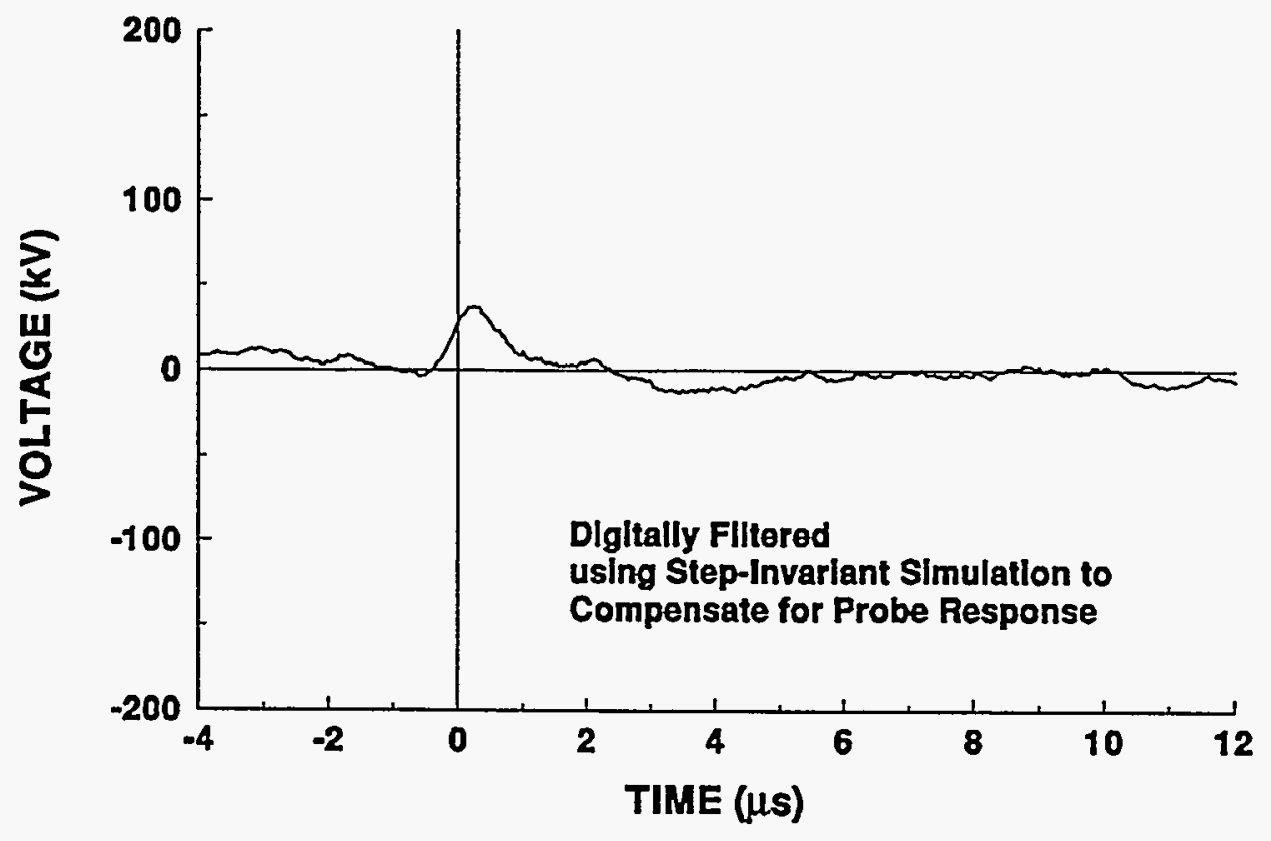




\section{4-21 STROKE.3}

TEST POINT 23

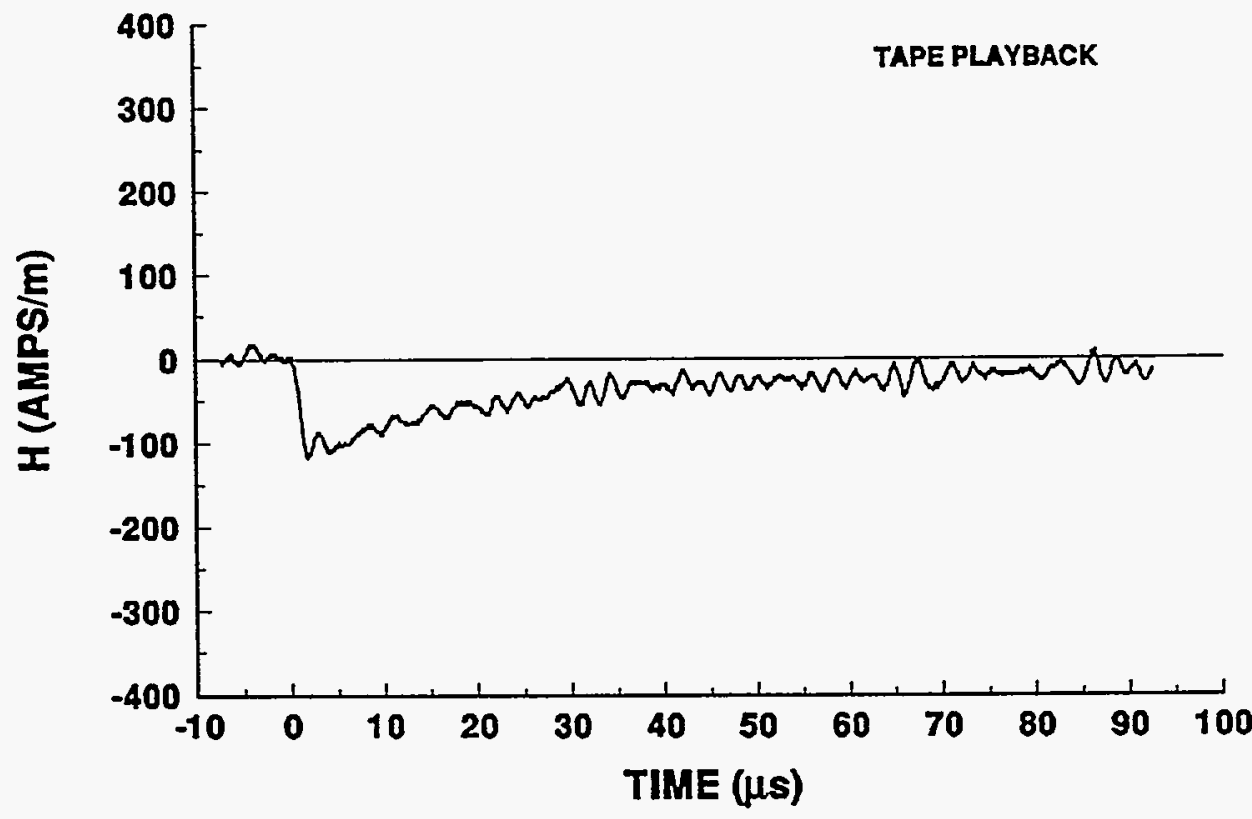

94-21 STROKE 3 .

TEST POINT 24

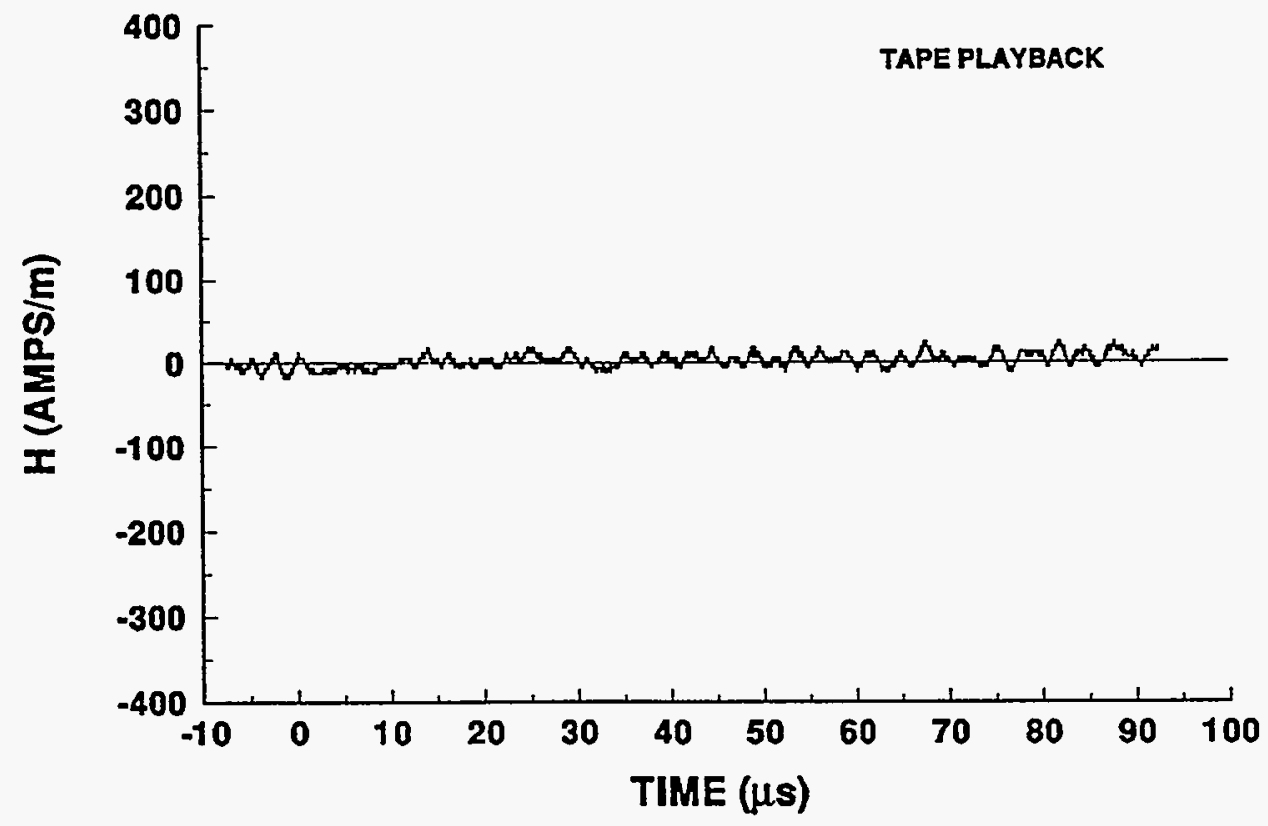




\section{4-21 STROKE 4}

TEST POINT 24
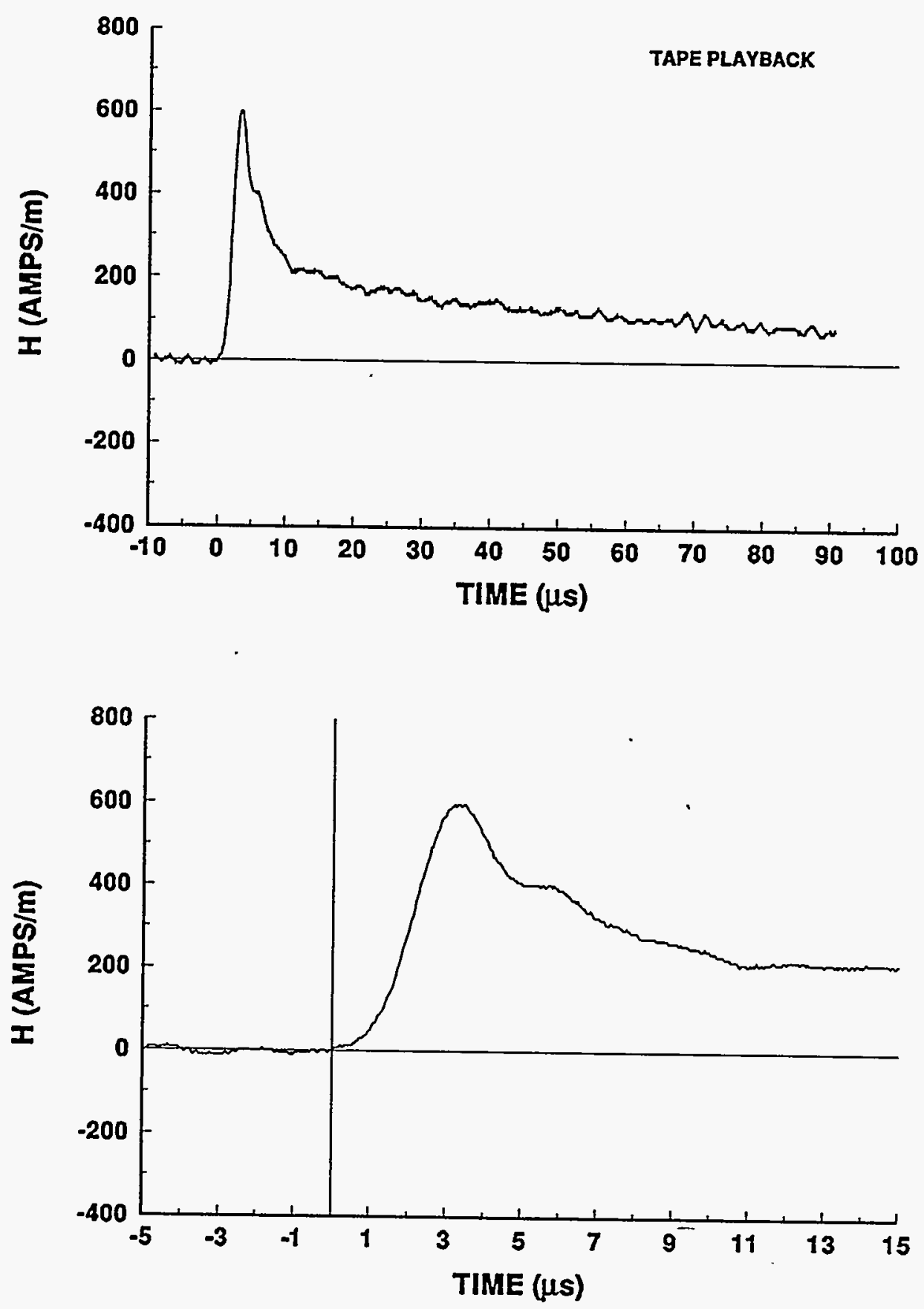
94-21 STROKE 4

INCIDENT CURRENT
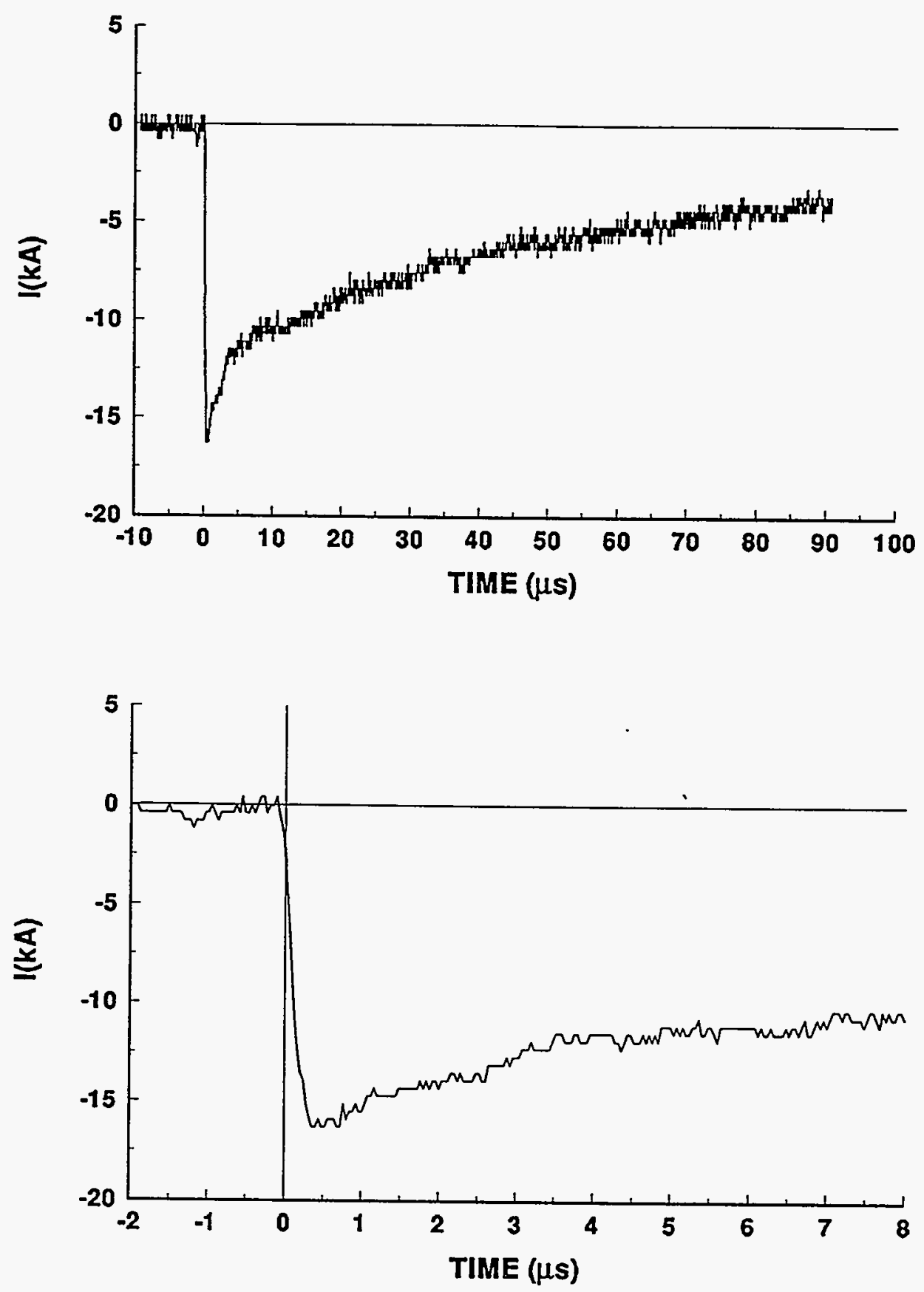


\section{4-21 STROKE 4}

TEST POINT 1
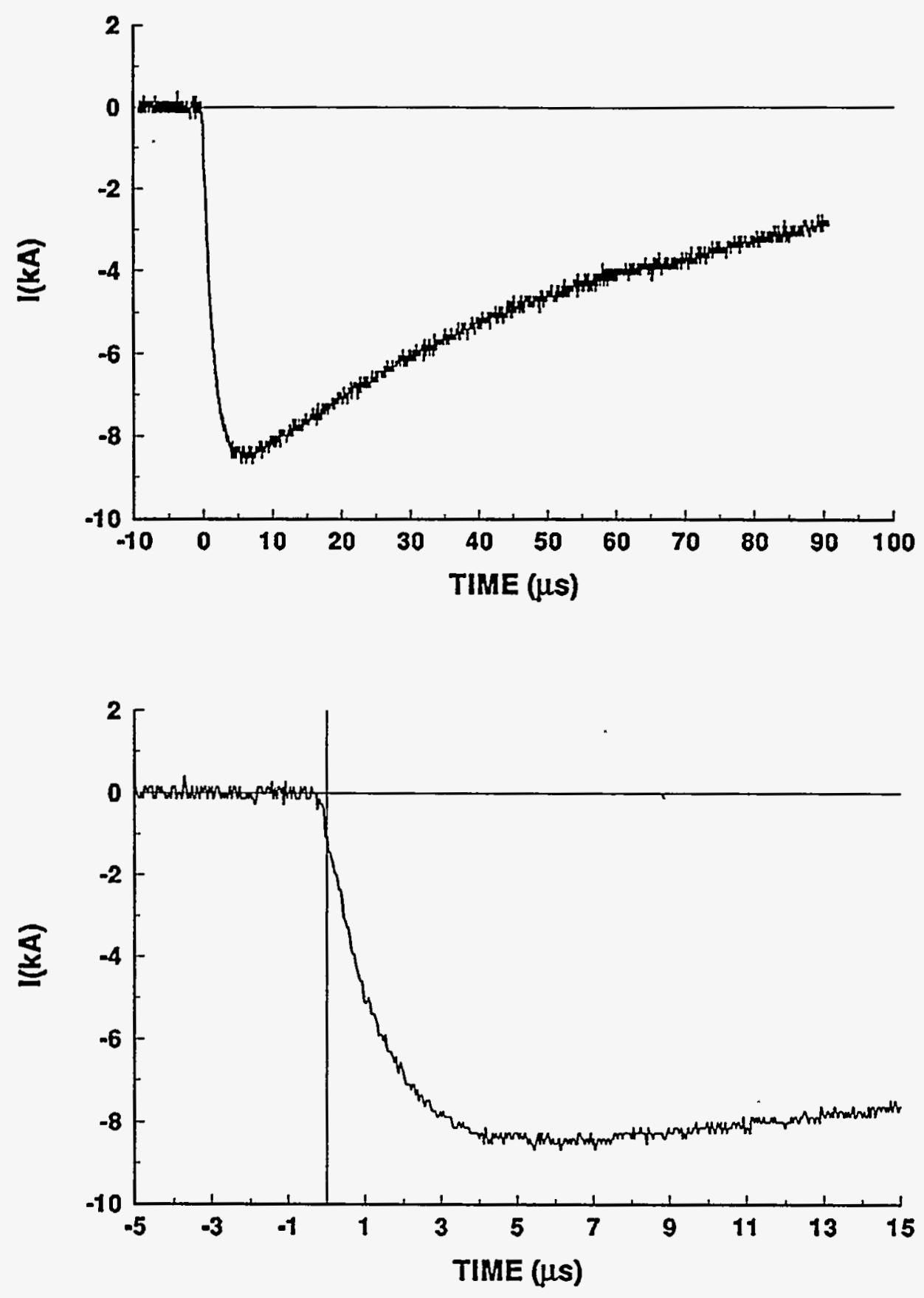


\section{4-21 STROKE 4 \\ TEST POINT 2}
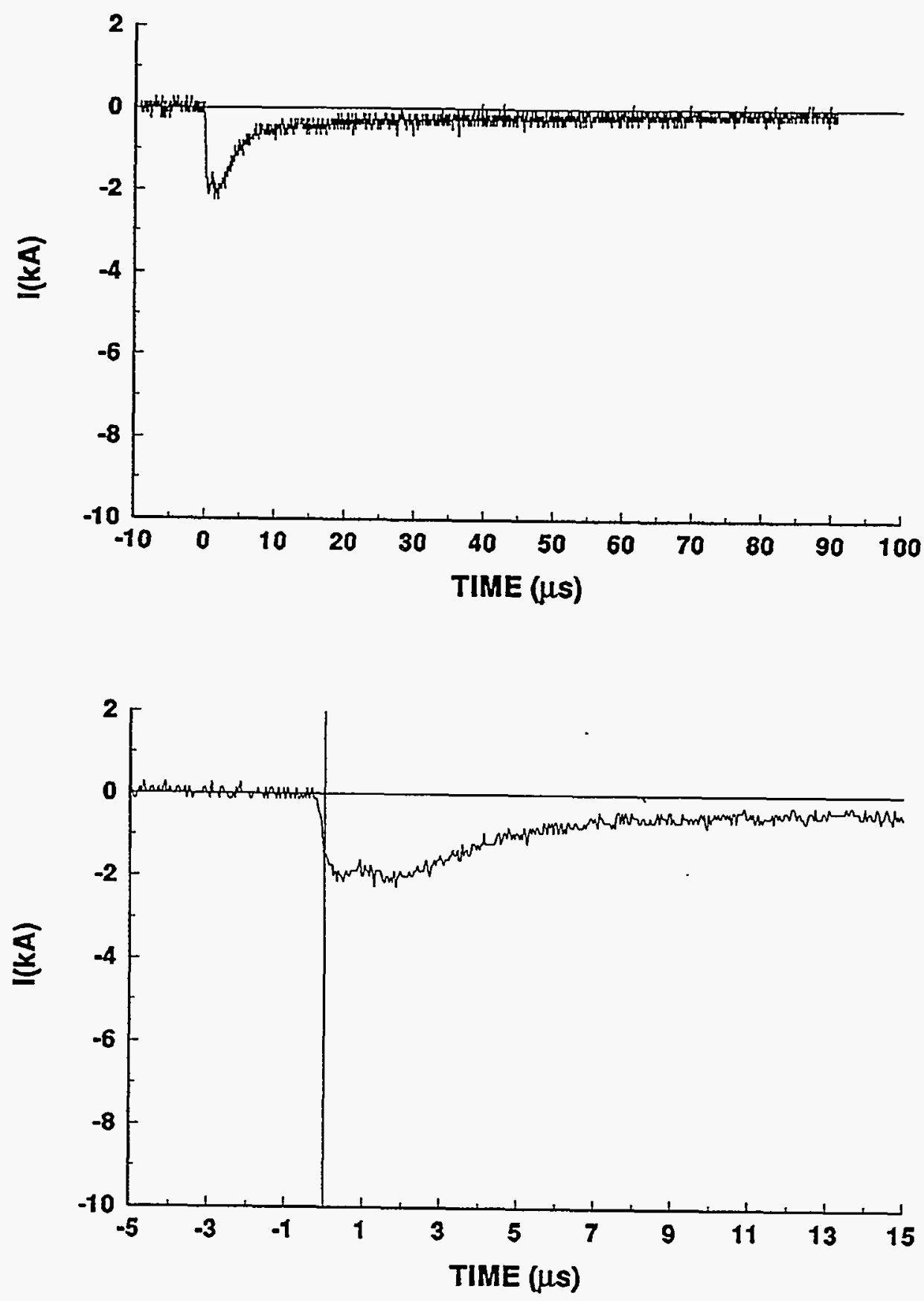


\section{4-21 STROKE 4}

TEST POINT 5
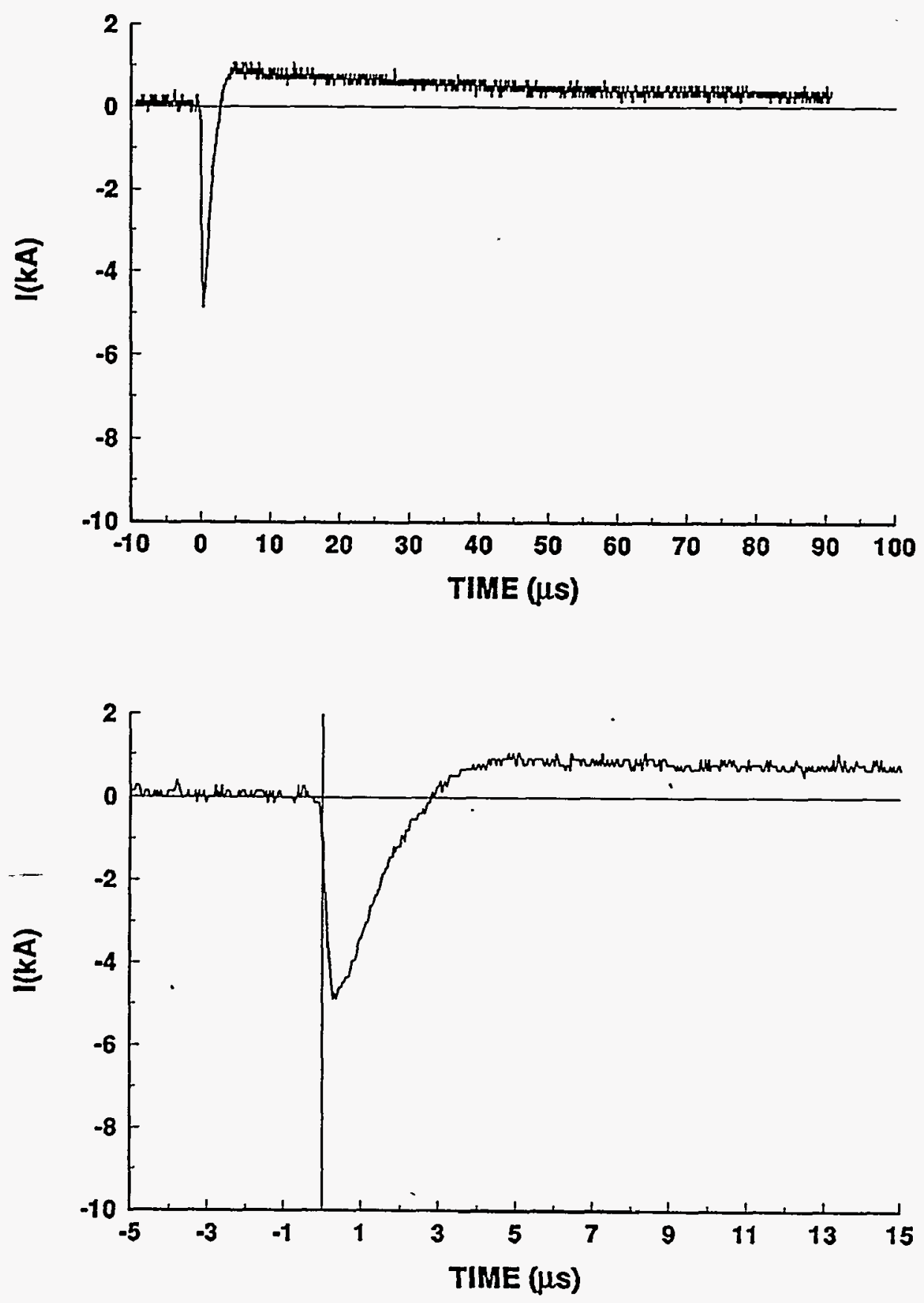


\section{4-21 STROKE 4 \\ TEST POINT 6}
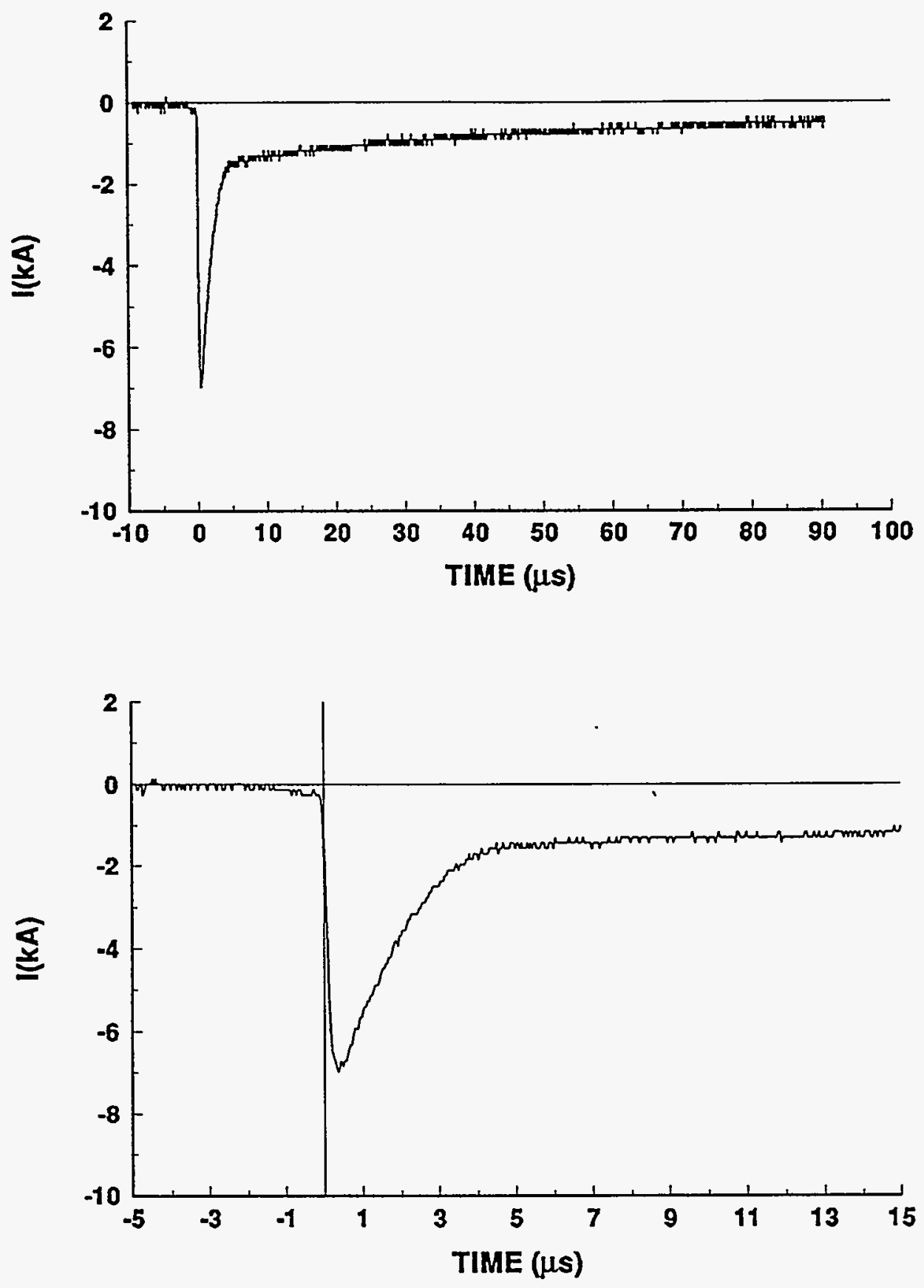


\section{4-21 STROKE 4}

TEST POINT 5;

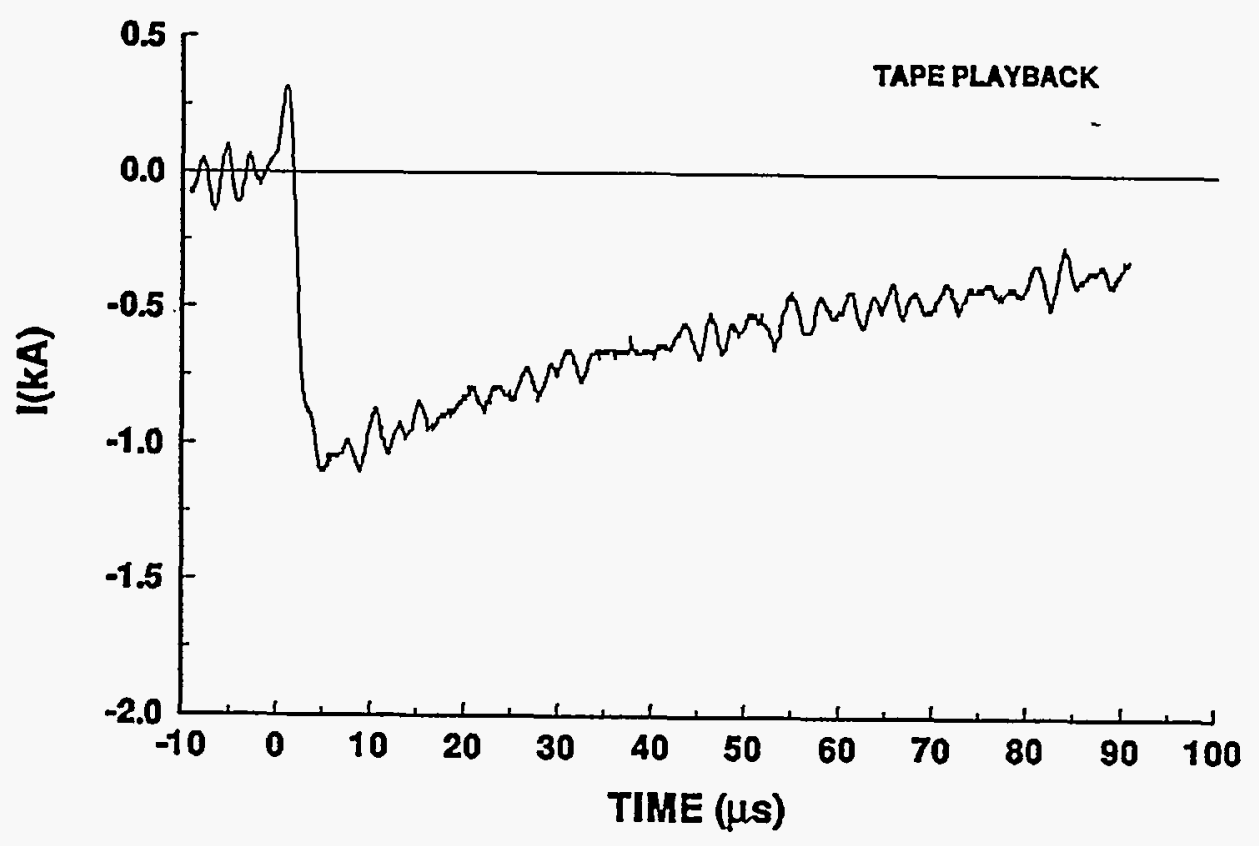

94-21 STROKE 4

TEST POINT 6'

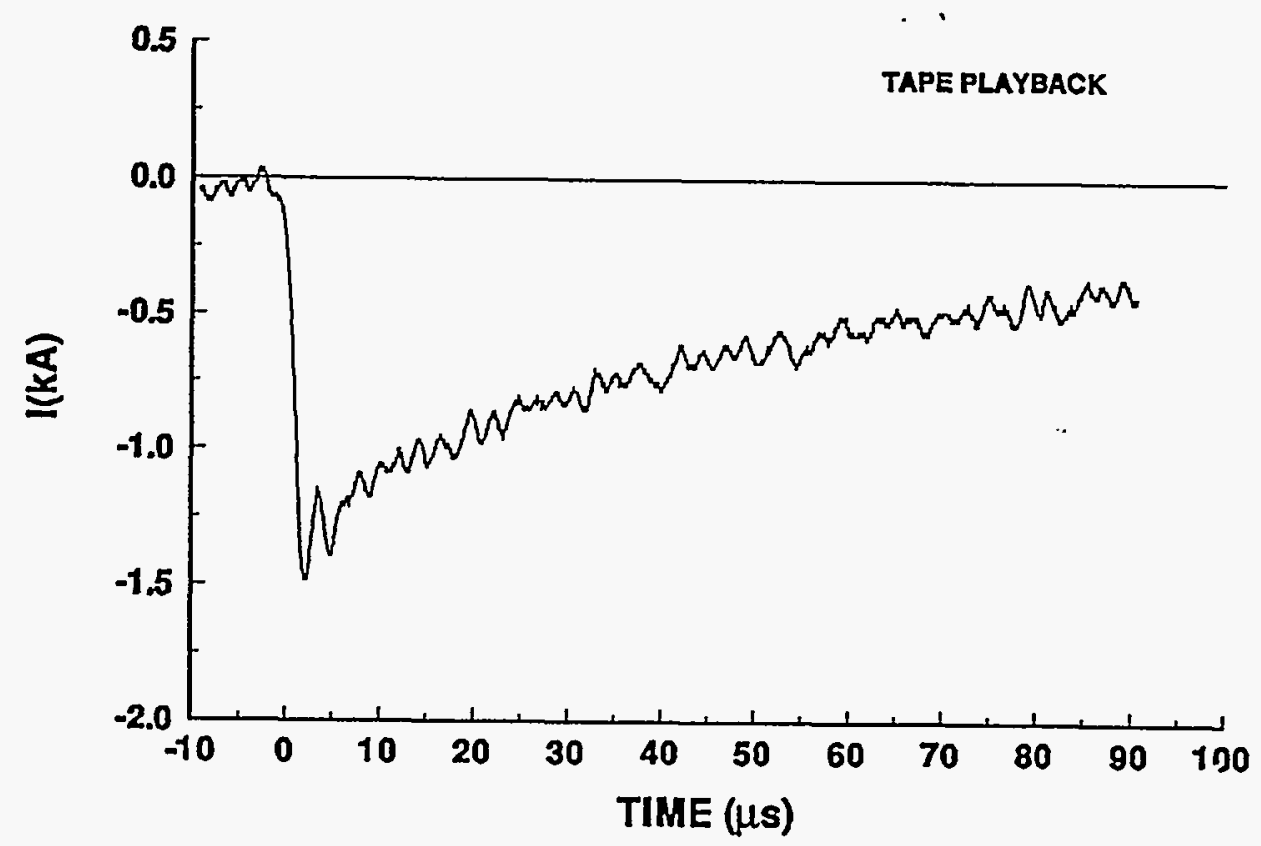


94-21 STROKE 4

TEST POINT 10

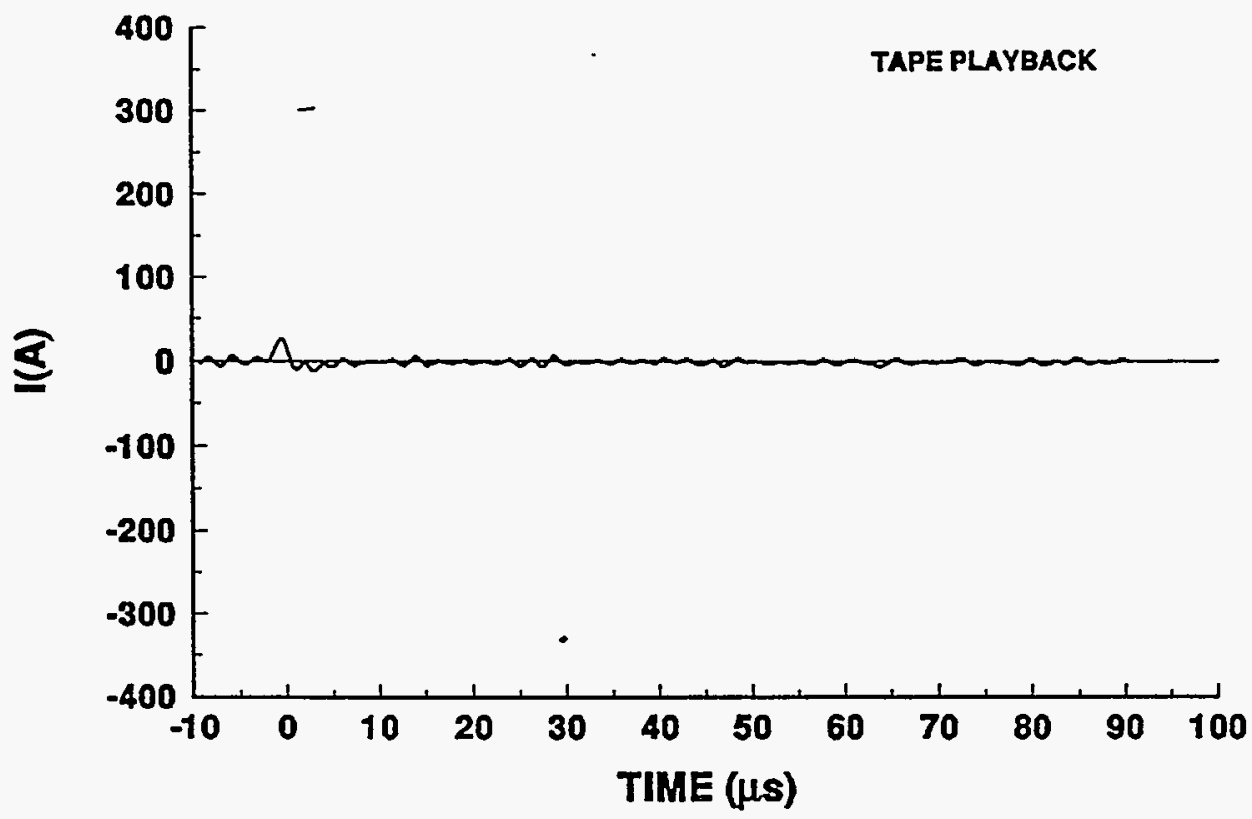

94-21 STROKE 4

TEST POINT 11

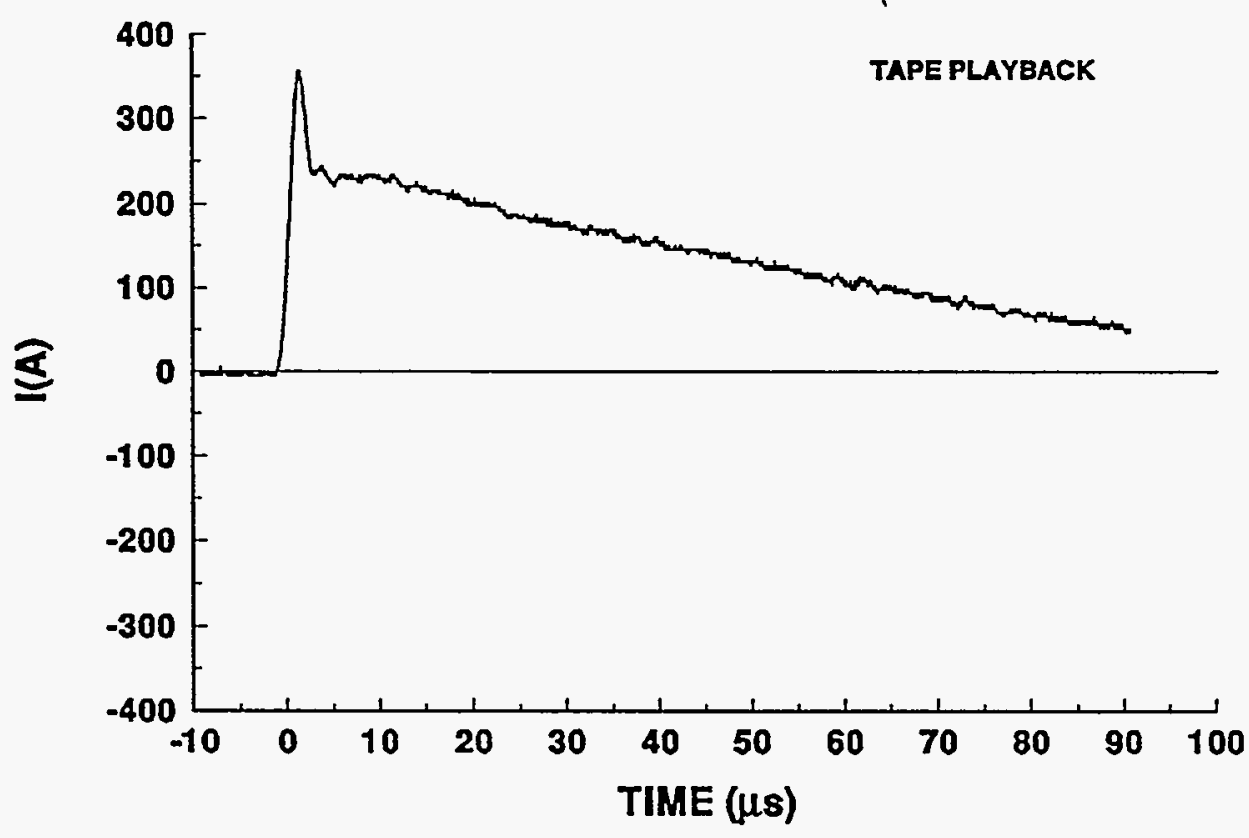


94-21 STROKE 4

TEST POINT 12

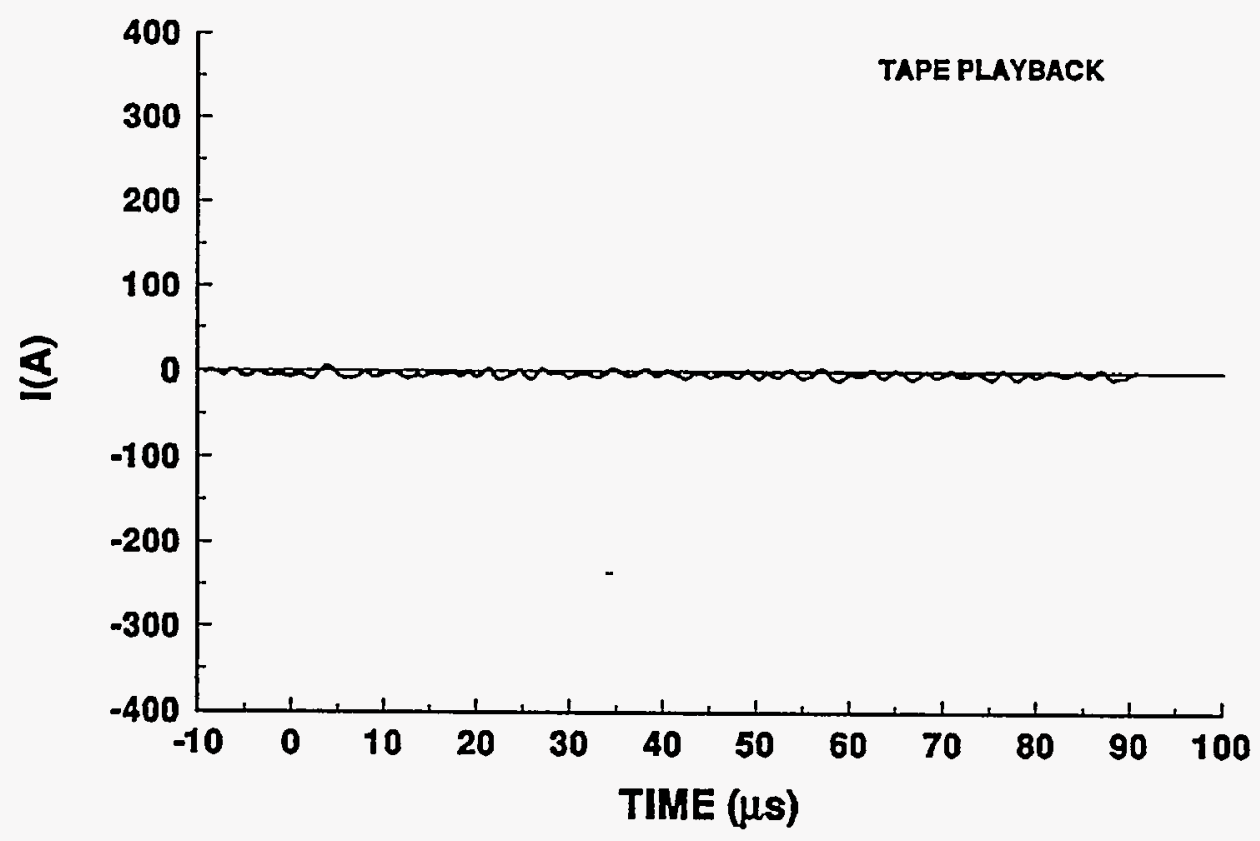

\section{4-21 STROKE 4}

TEST POINT 13

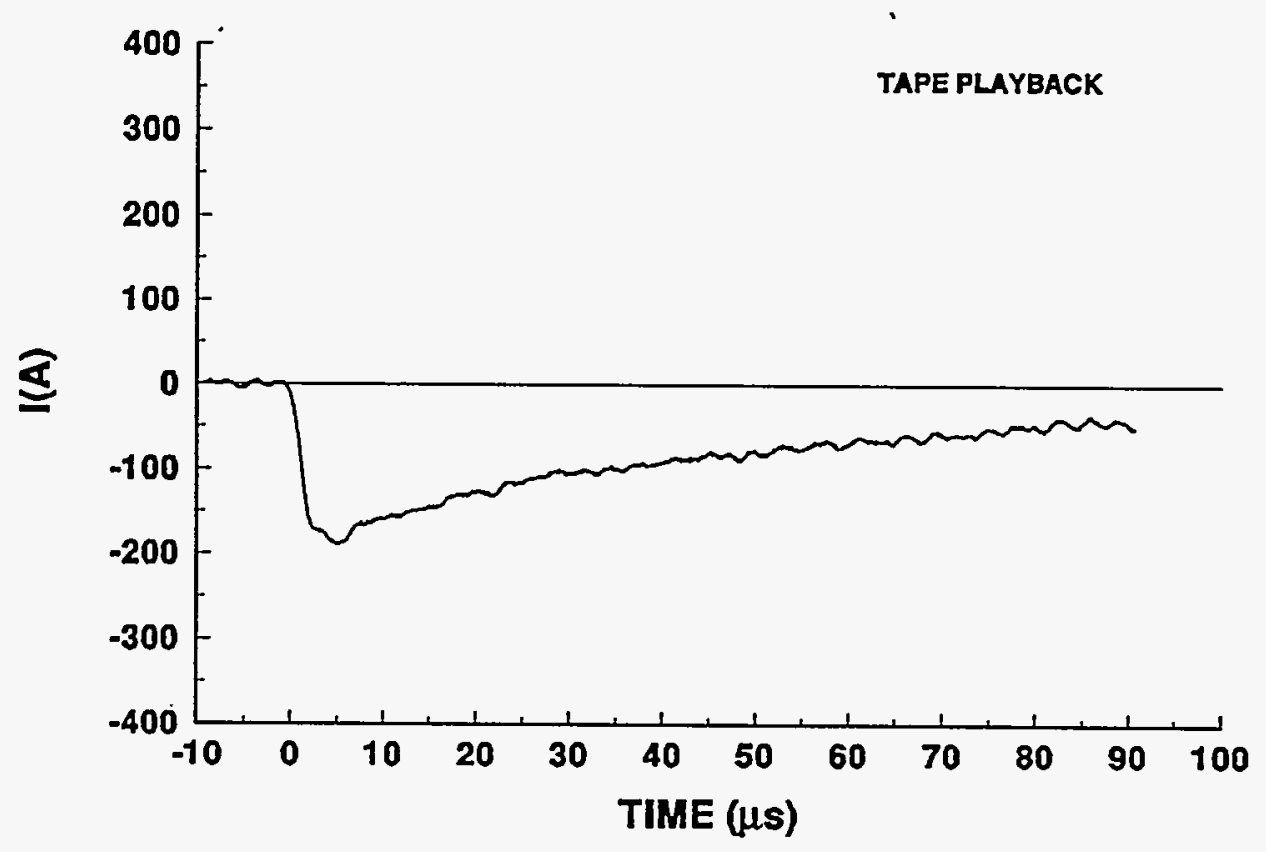




\section{4-21 STROKE 4}

TEST POINT 14
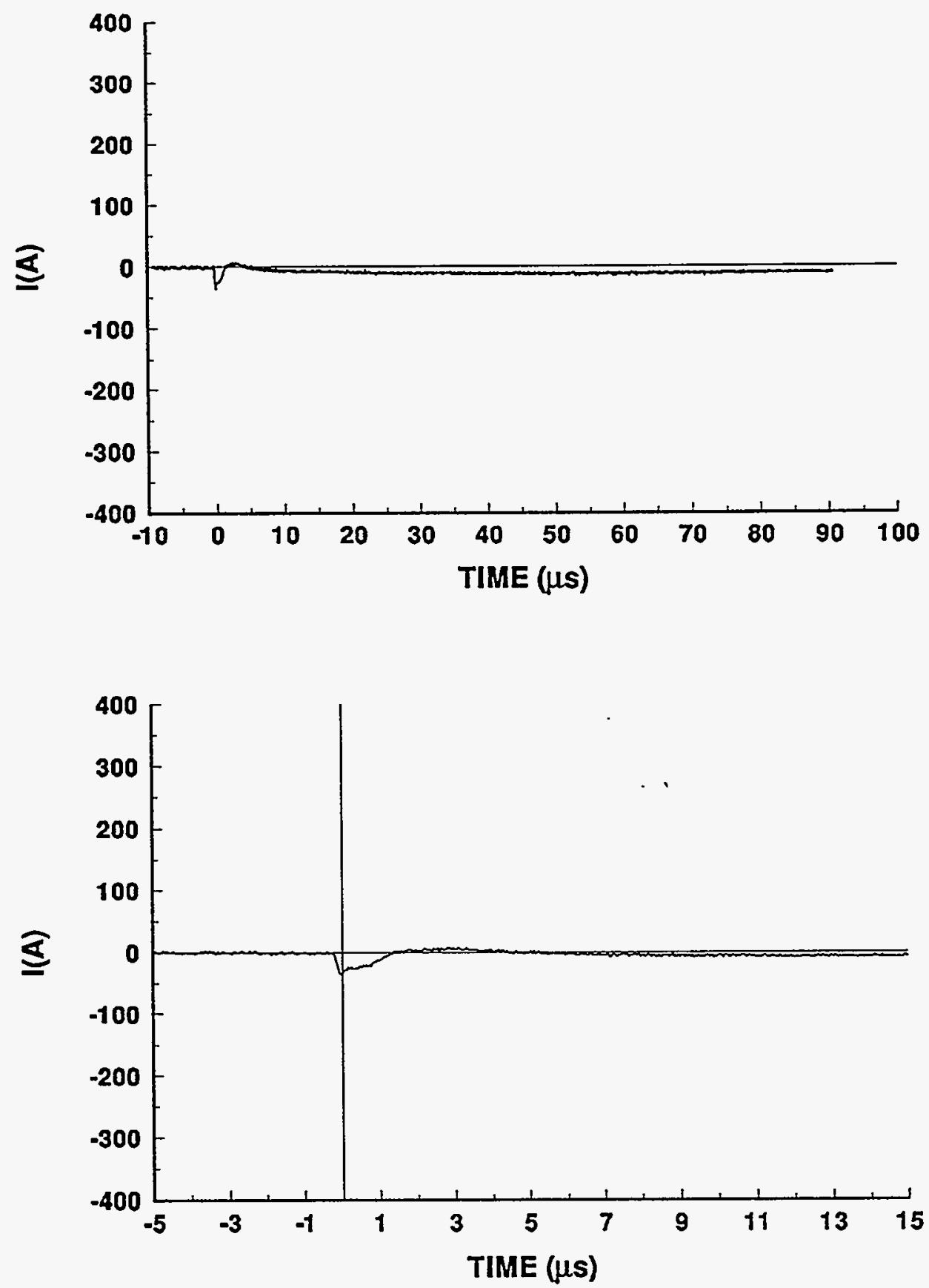


\section{4-21 STROKE 4}

TEST POINT 15
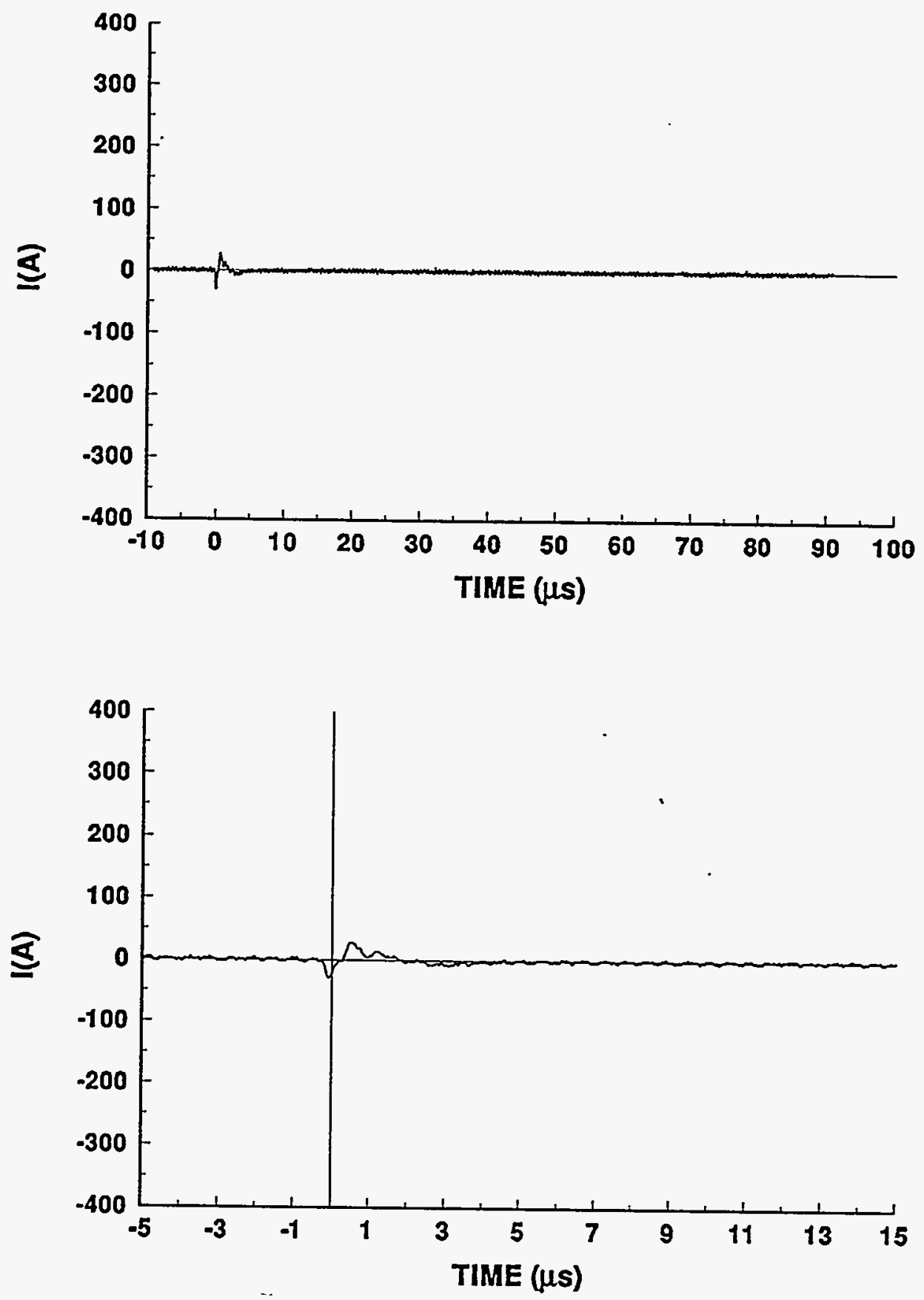
94-21 STROKE 4

TEST POINT 20

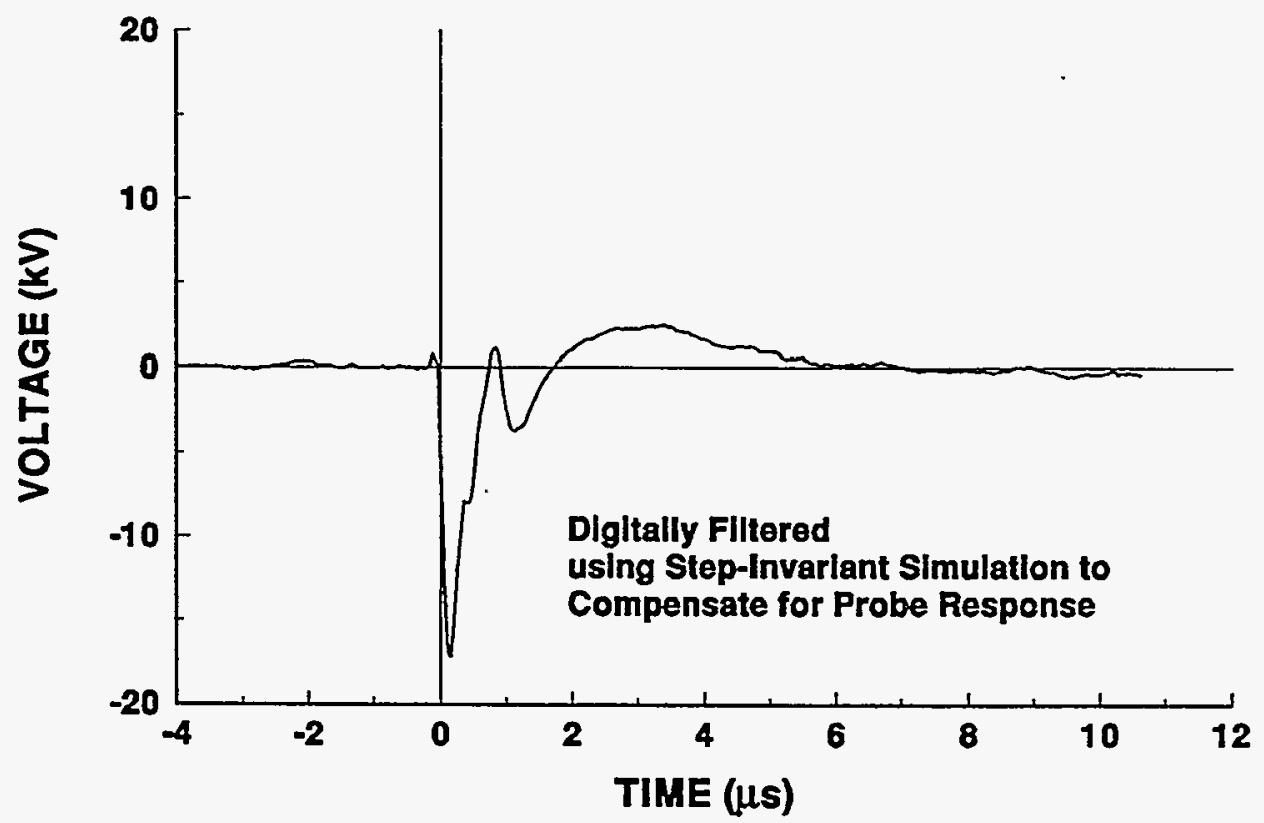

94-21 STROKE 4.

TEST POINT 21

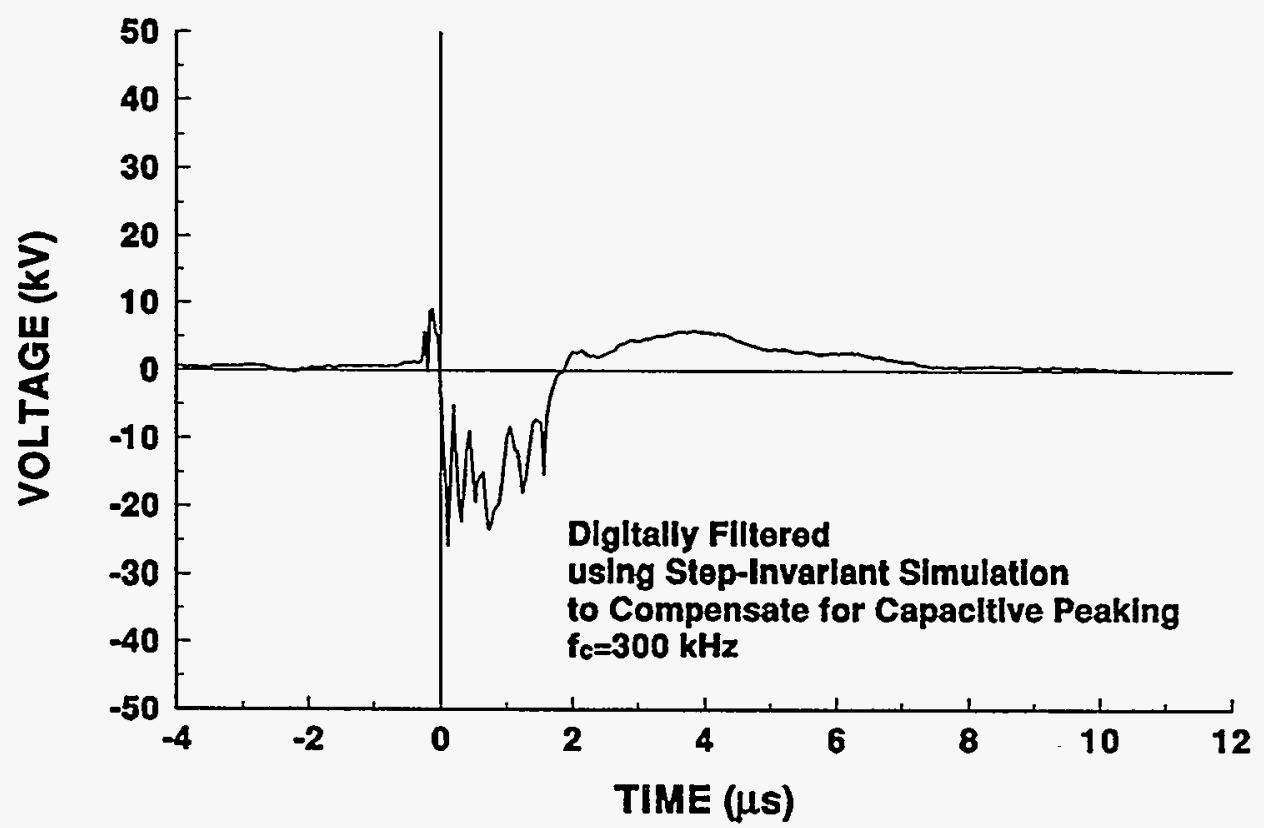




\section{4-21 STROKE 4}

TEST POINT 22

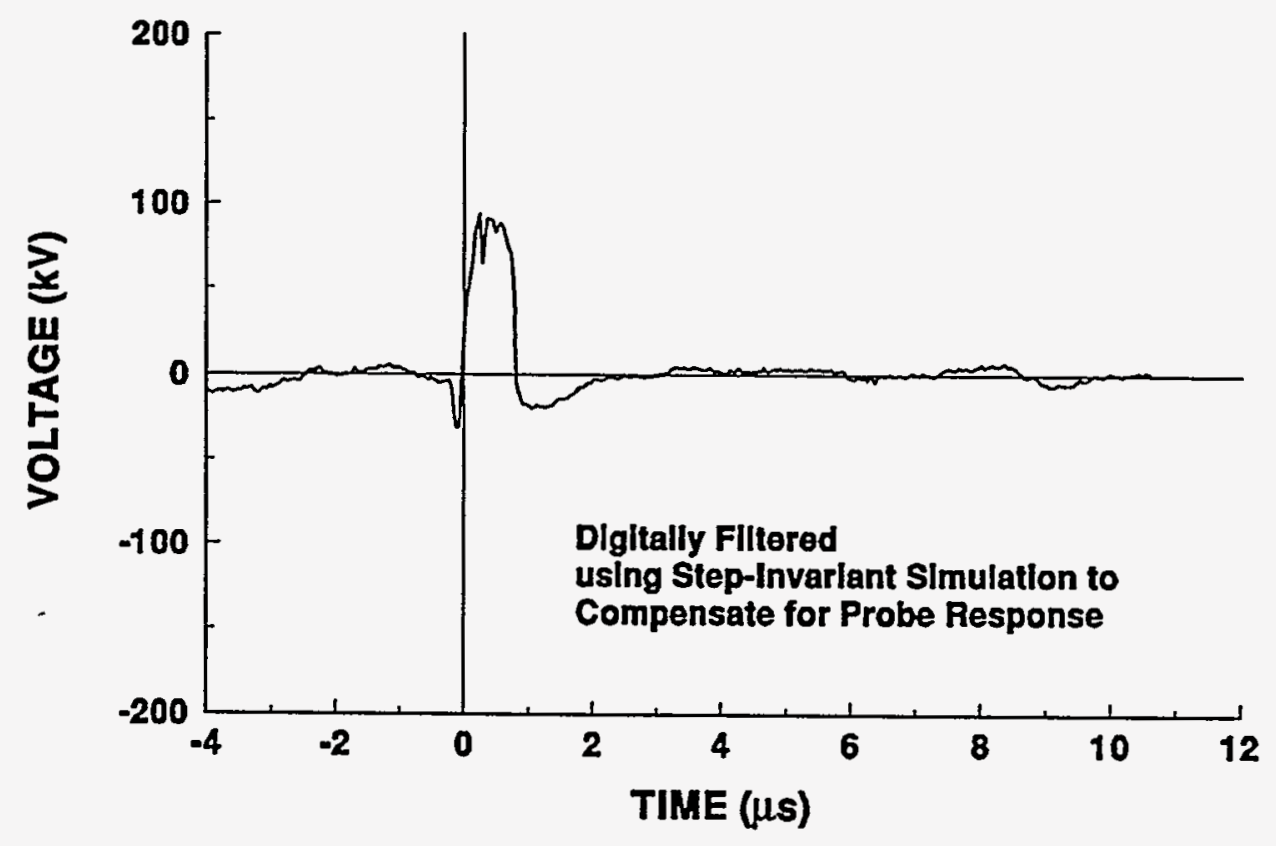


94-21 STROKE 4

TEST POINT 23

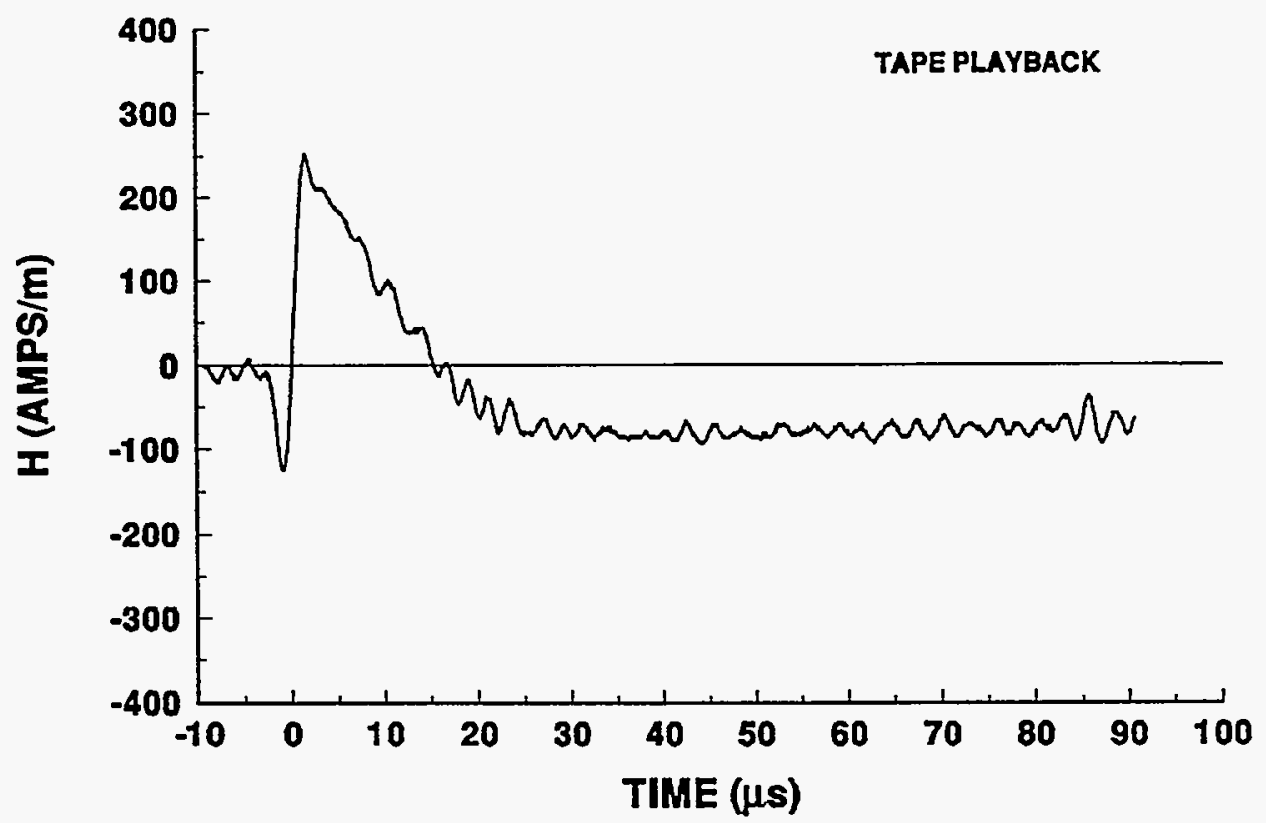

94-21 STROKE 4.

TEST POINT 24

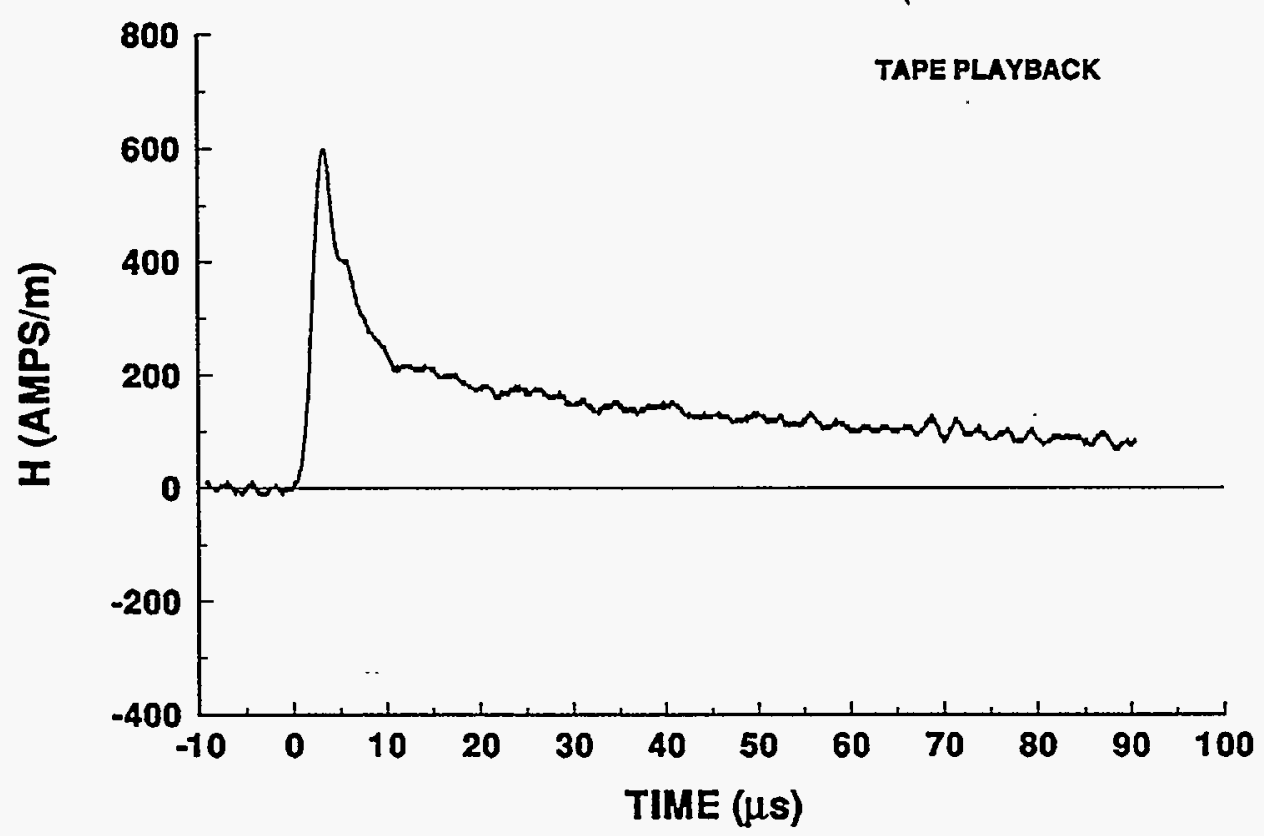




\section{4-21 STROKE 6}

TEST POINT 5'

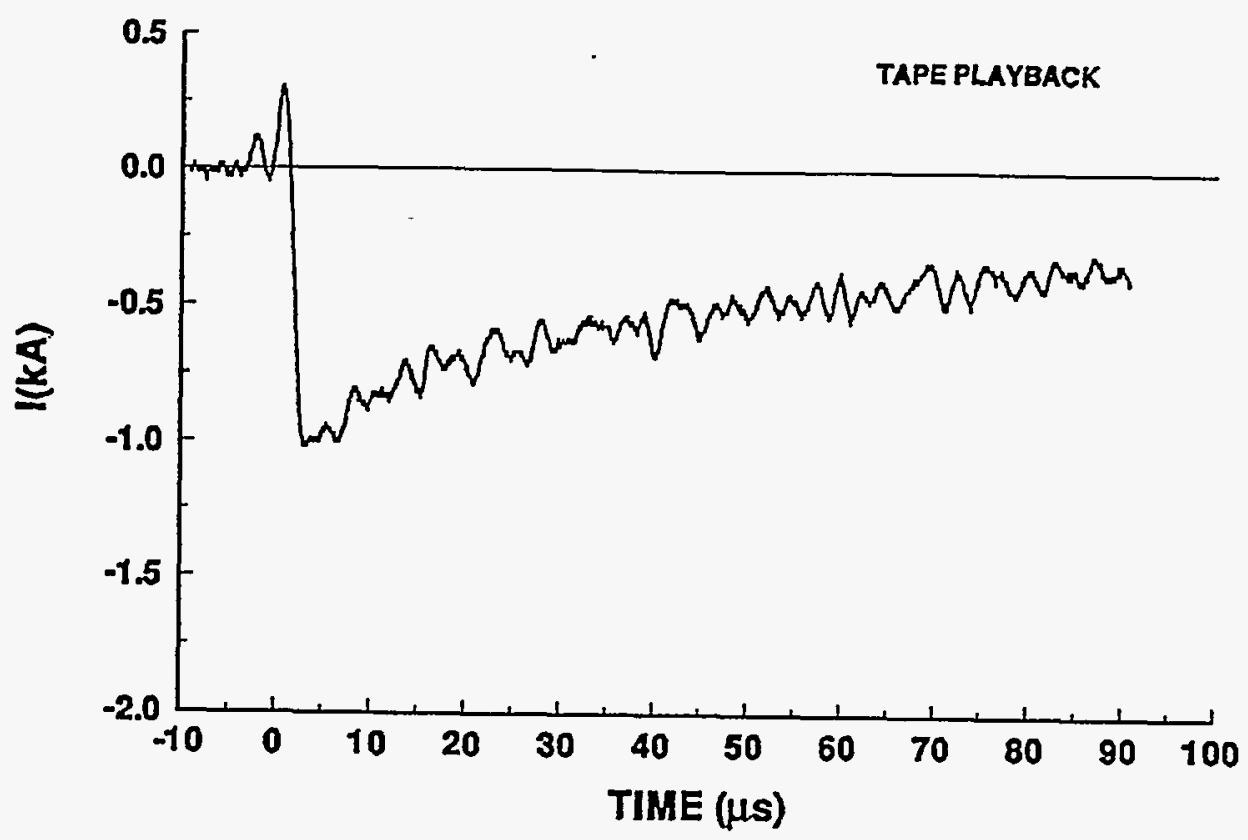

\section{4-21 STROKE 6}

TEST POINT 6'

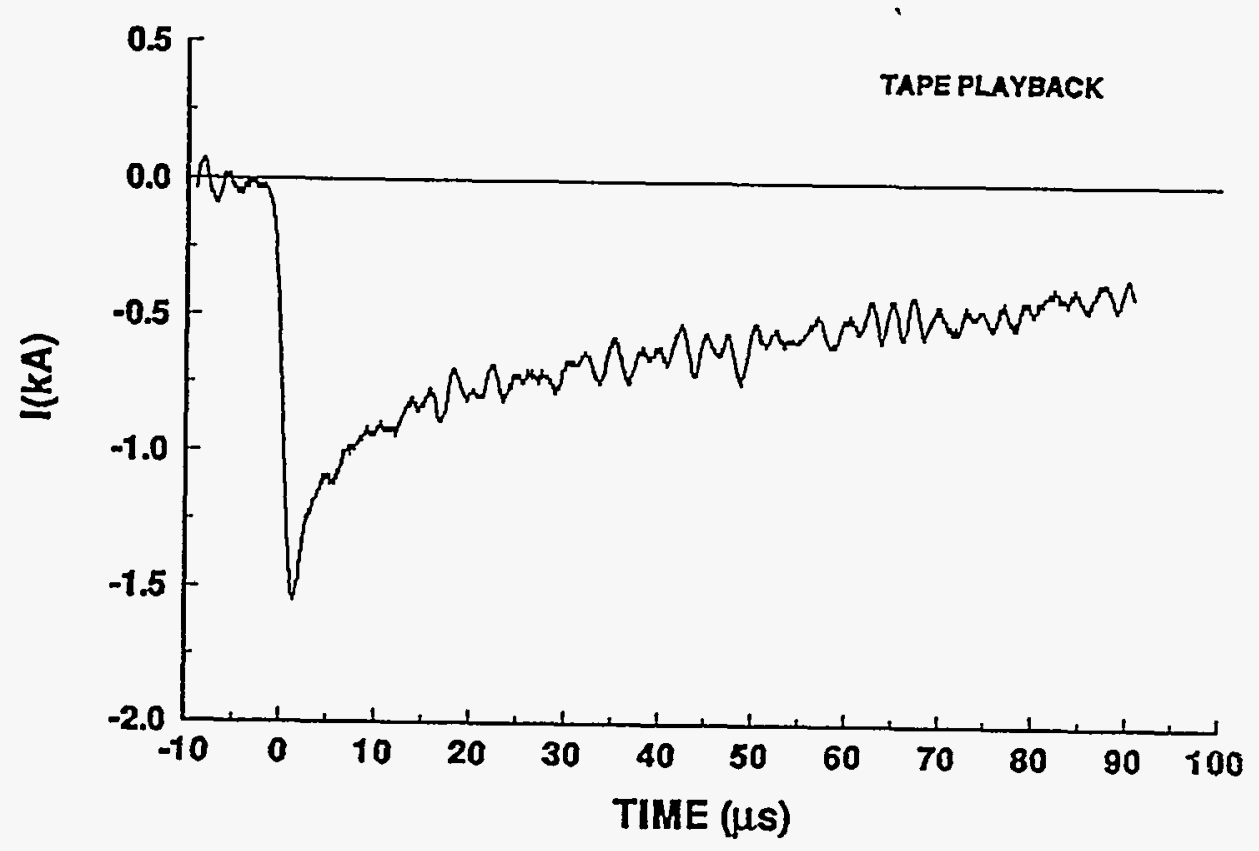




\section{4-21 STROKE 5 \\ INCIDENT CURRENT}
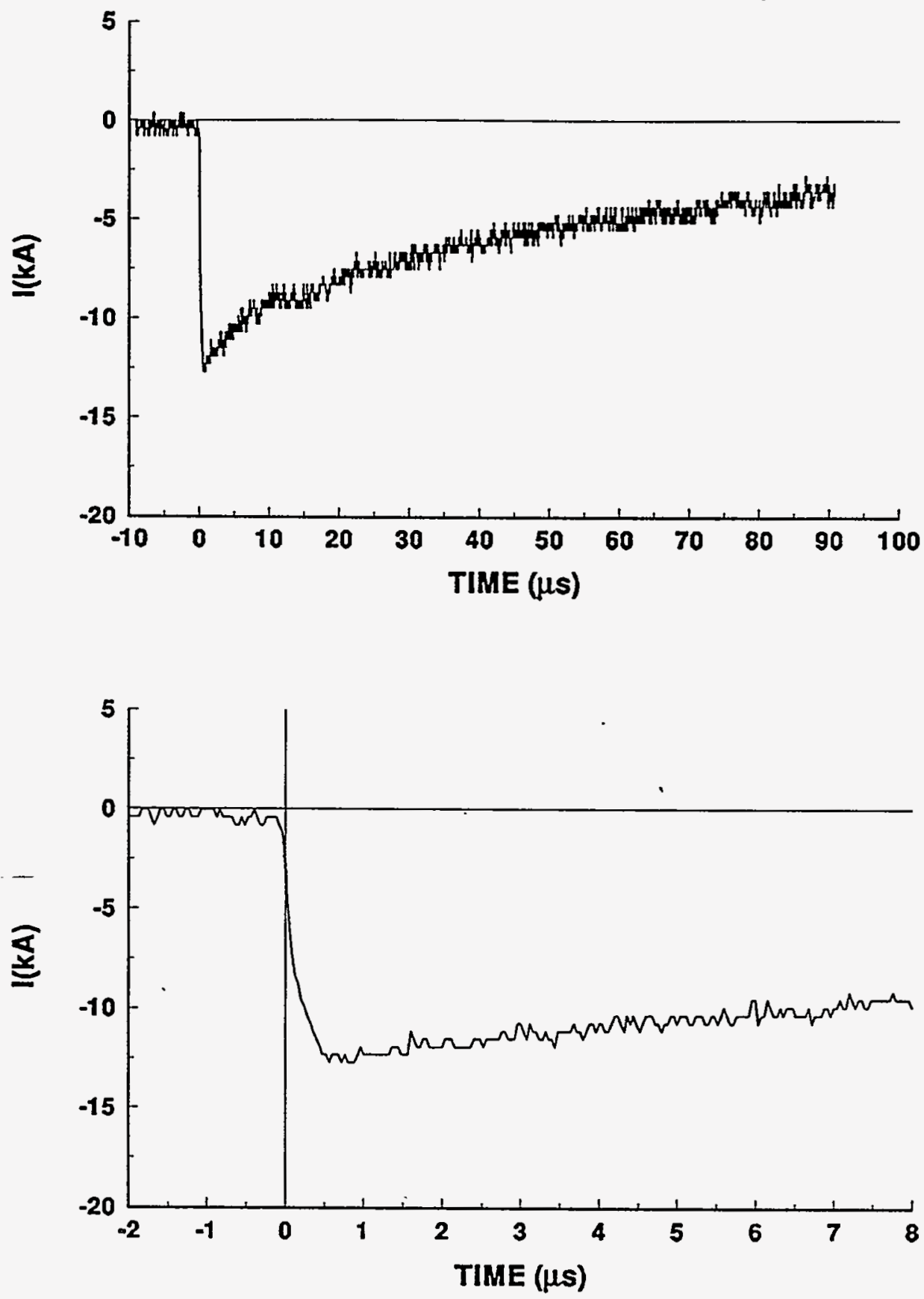


\section{4-21 STROKE 5}

TEST POINT 1
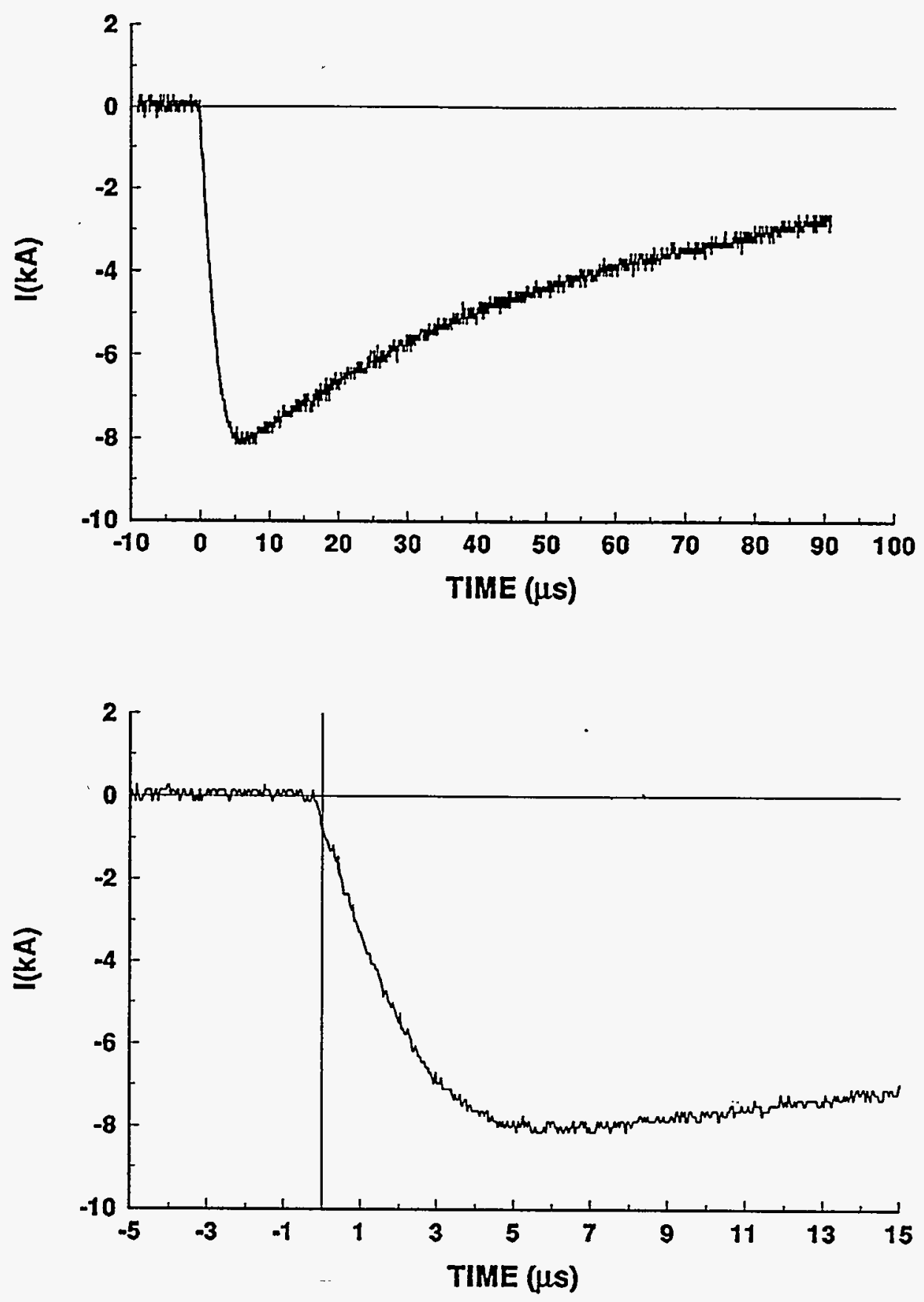


\section{4-21 STROKE 5 \\ TEST POINT 2}
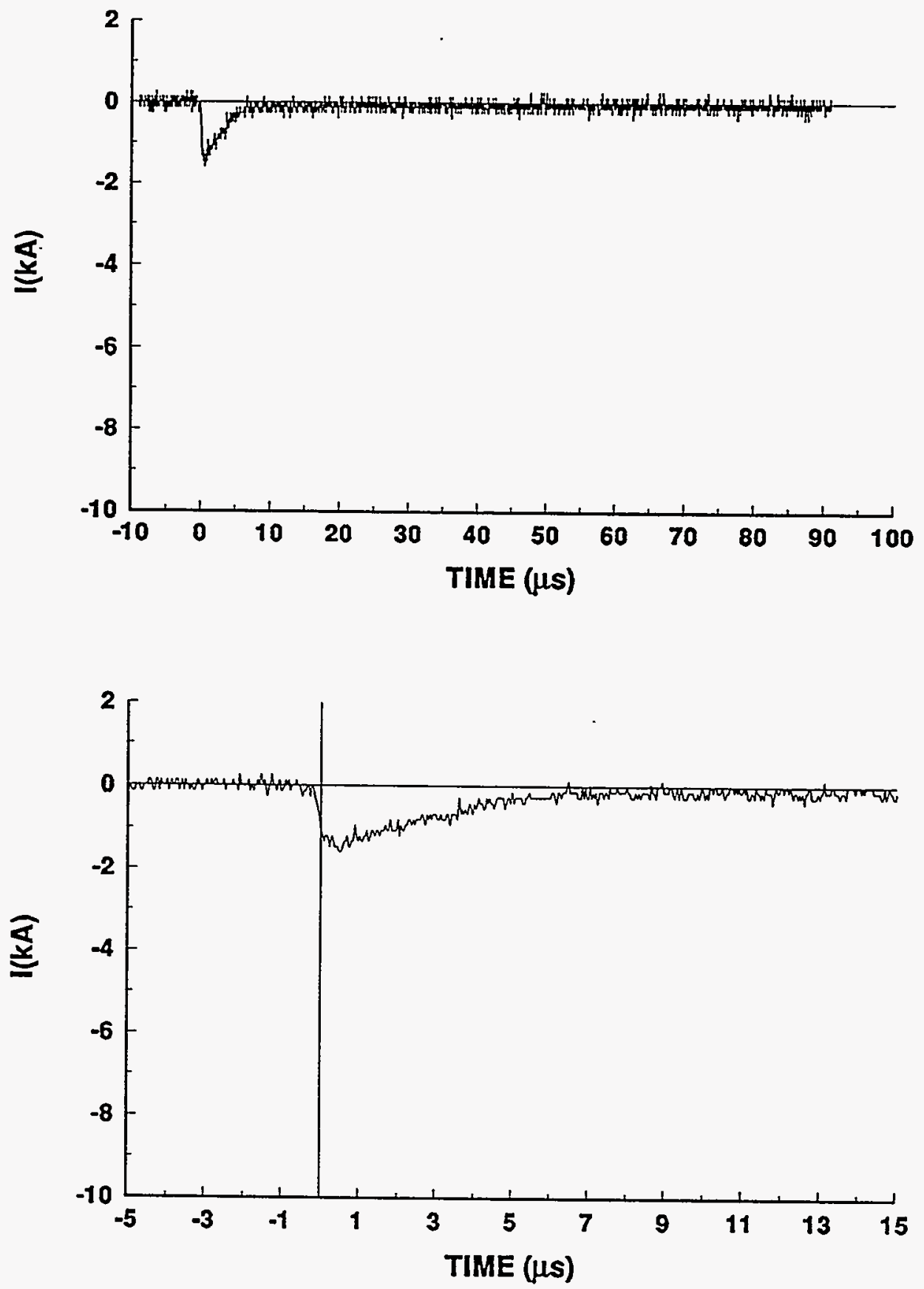


\section{4-21 STROKE 5}

TEST POINT 5
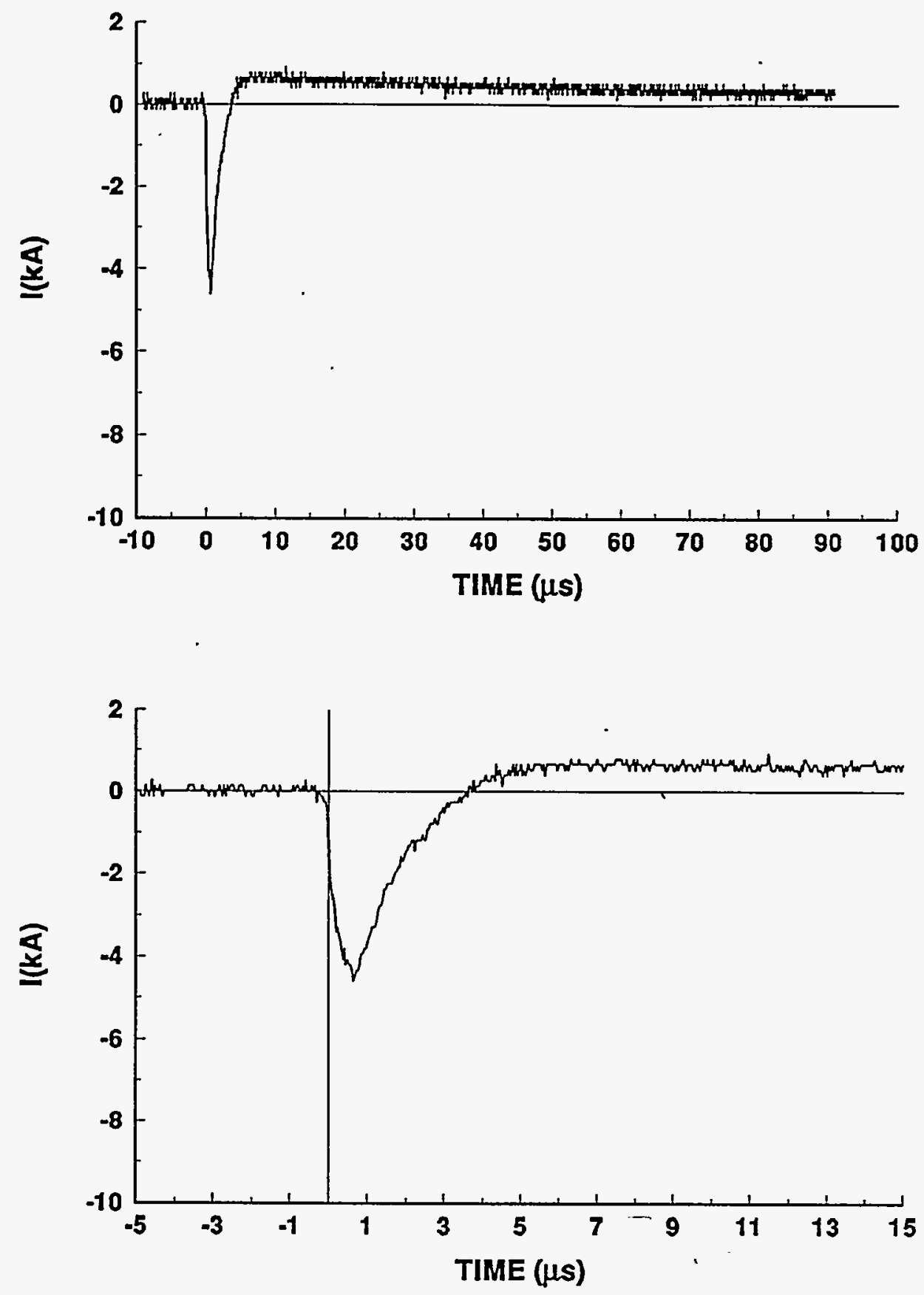


\section{4-21 STROKE 5 \\ TEST POINT 6}
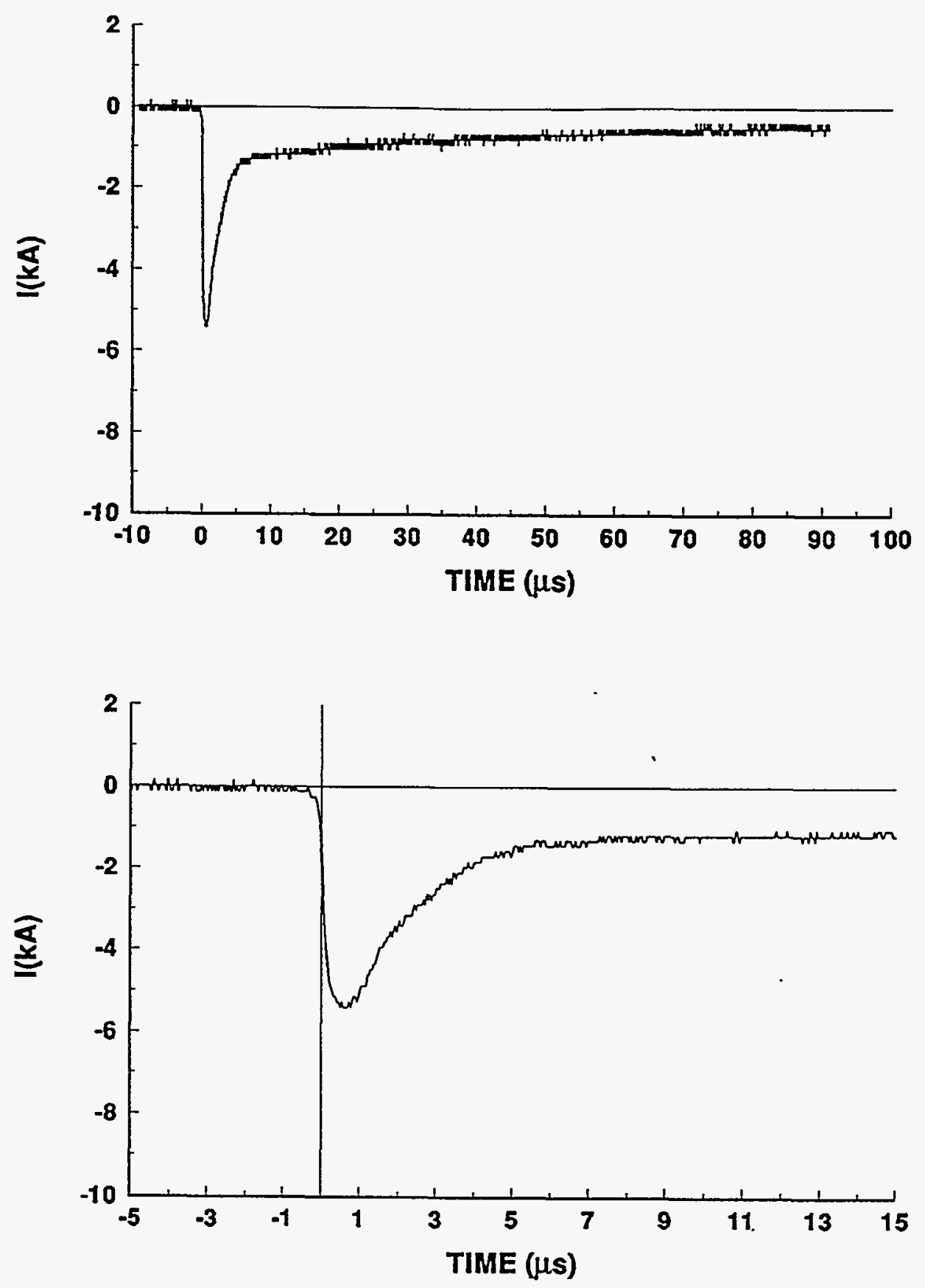


\section{4-21 STROKE 5}

TEST POINT 5'

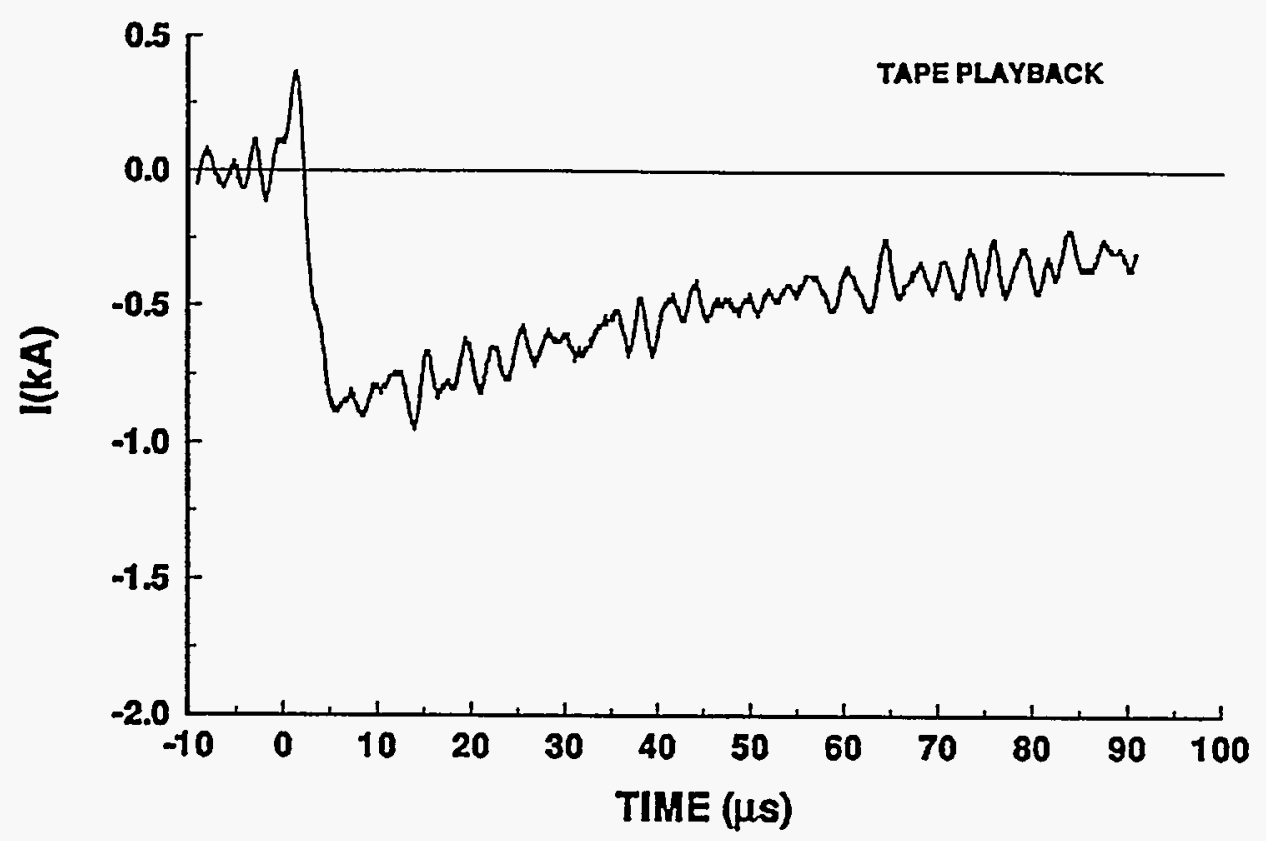

94-21 STROKE 5 .

TEST POINT 6'

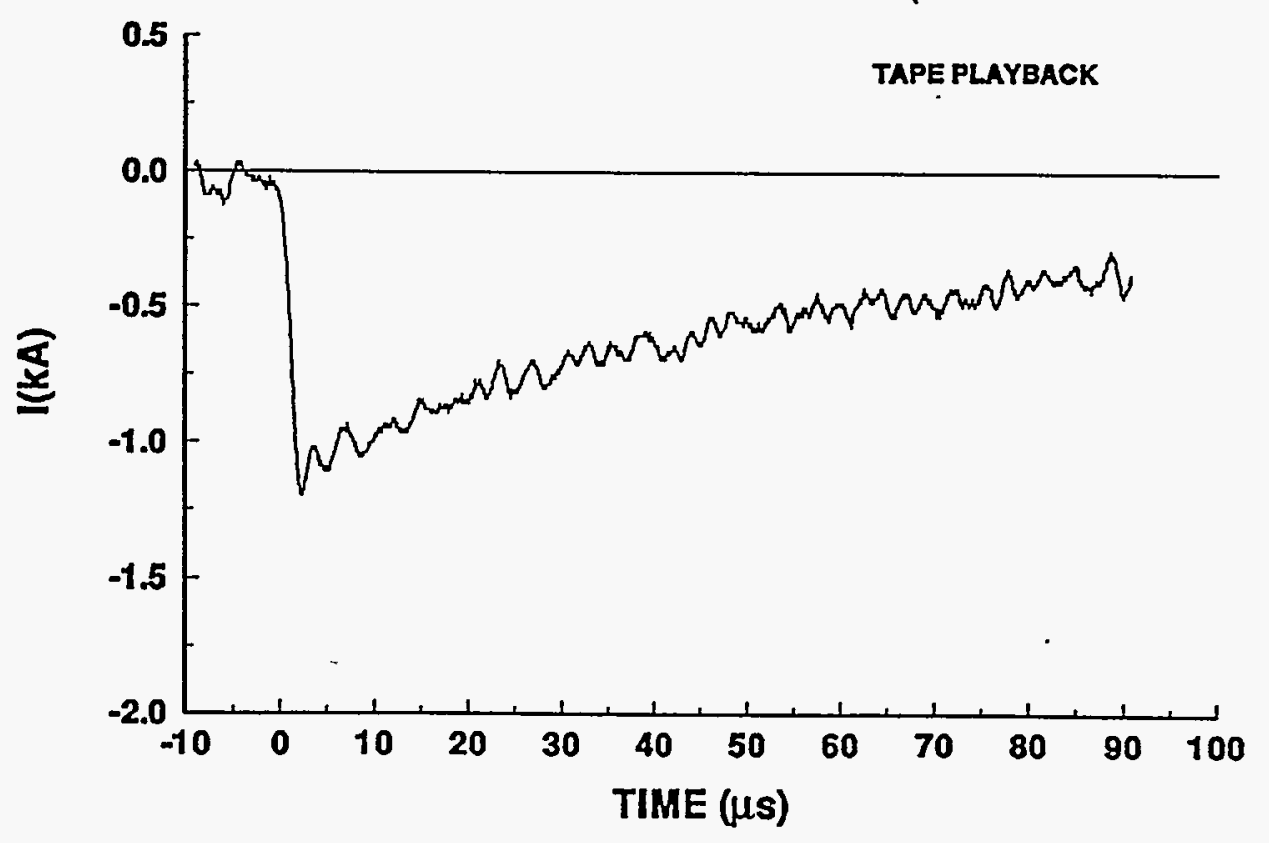


94-21 STROKE 5

TEST POINT 10

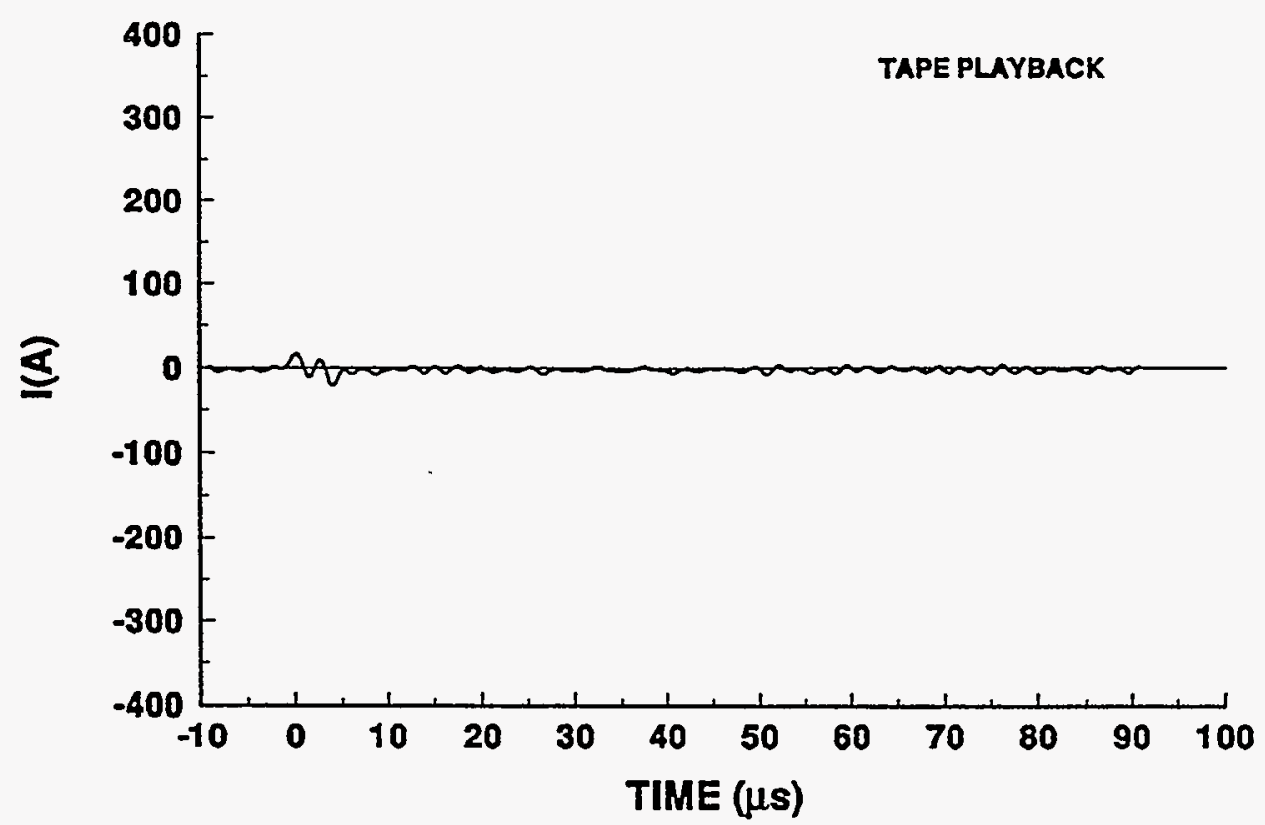

94-21 STROKE 5

TEST POINT 11

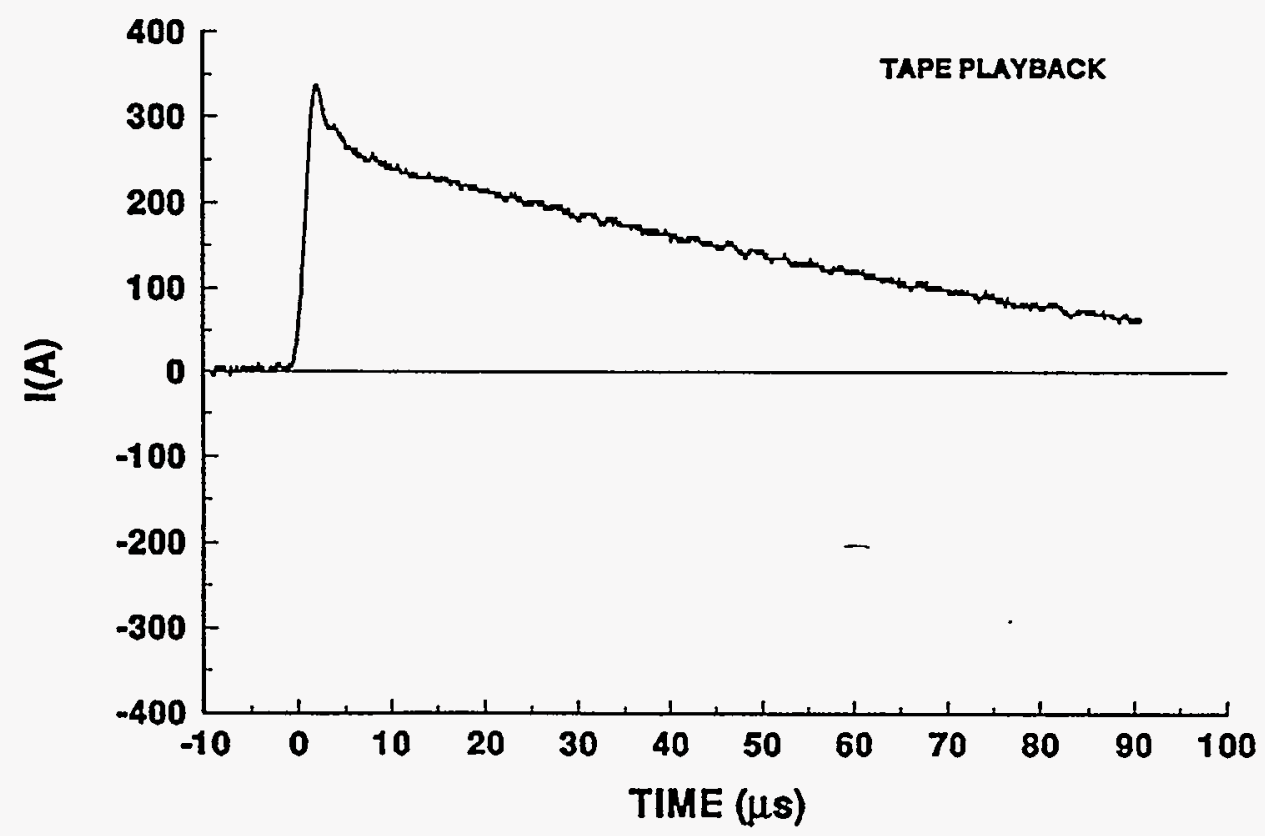




\section{4-21 STROKE 5}

TEST POINT 12

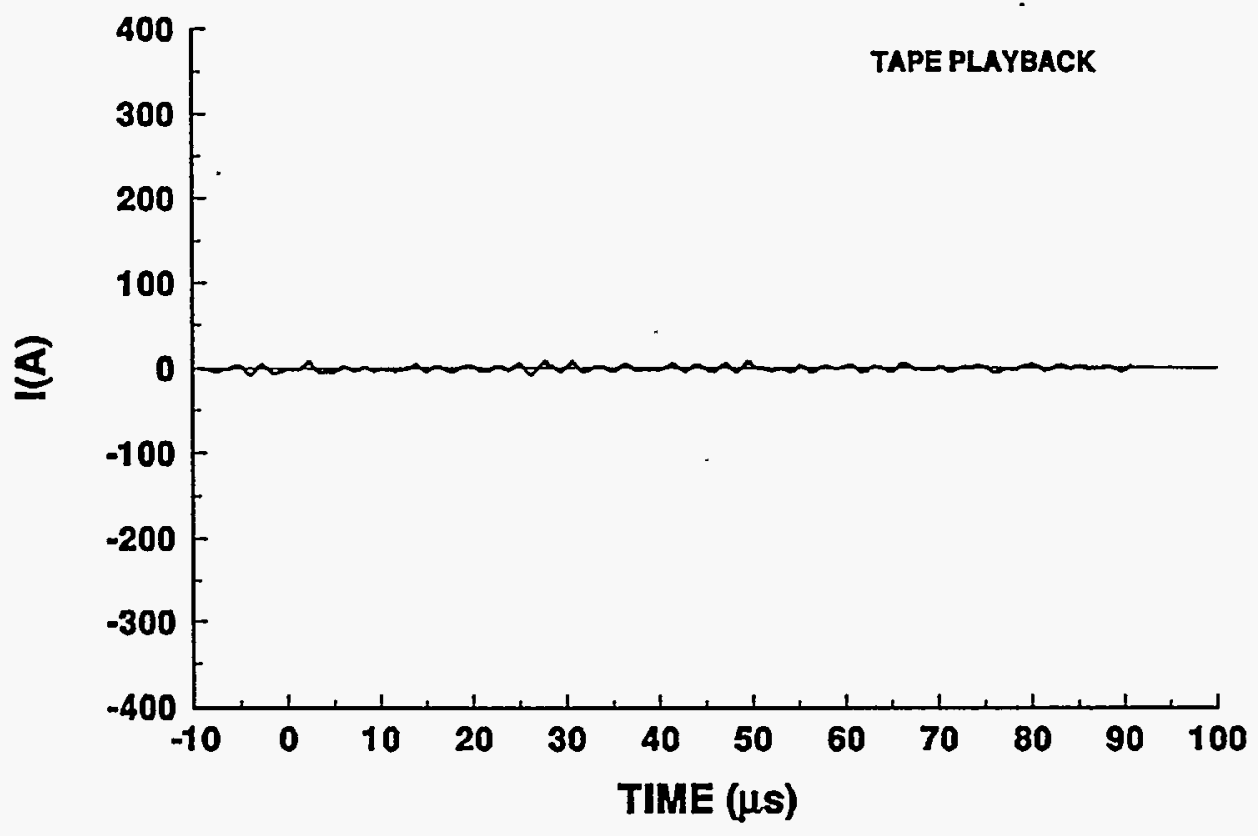

94-21 STROKE 5.

TEST POINT 13

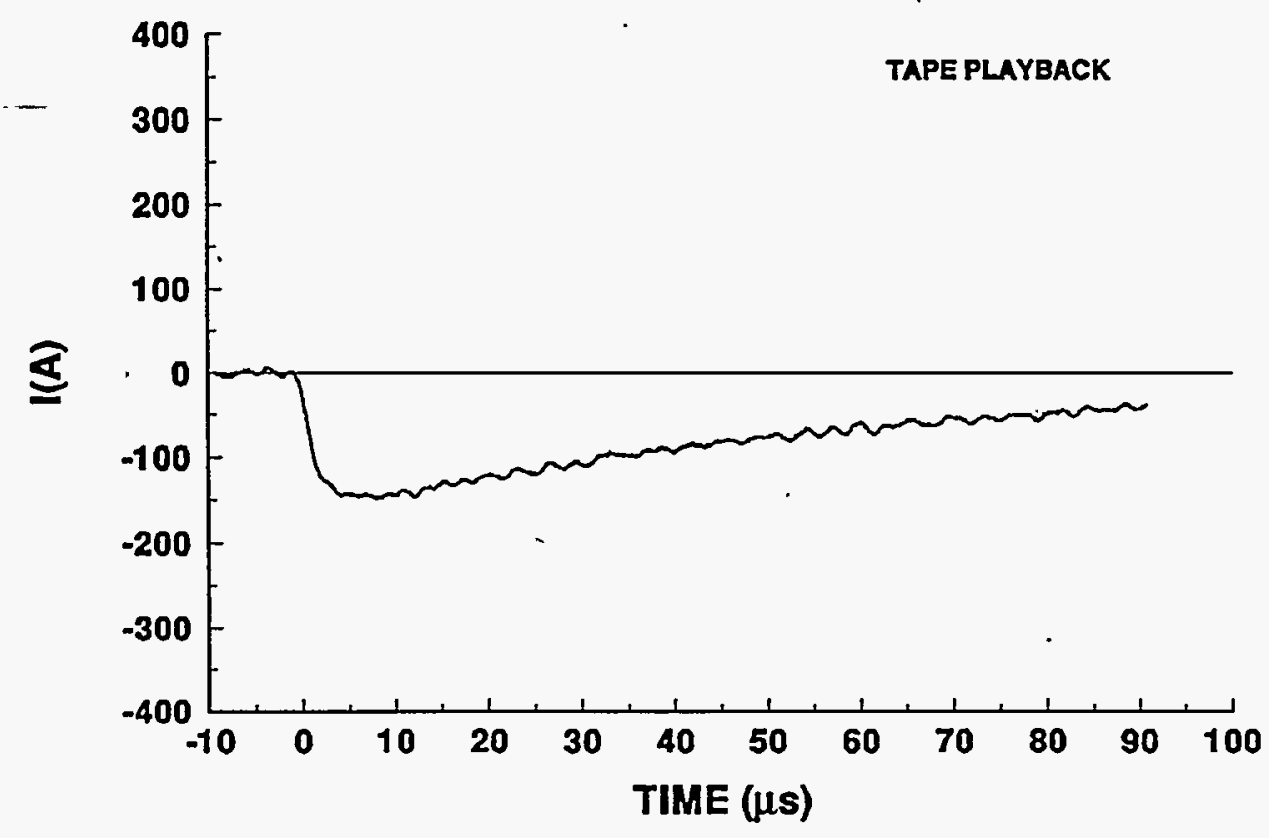


94-21 STROKE 5

TEST POINT 14
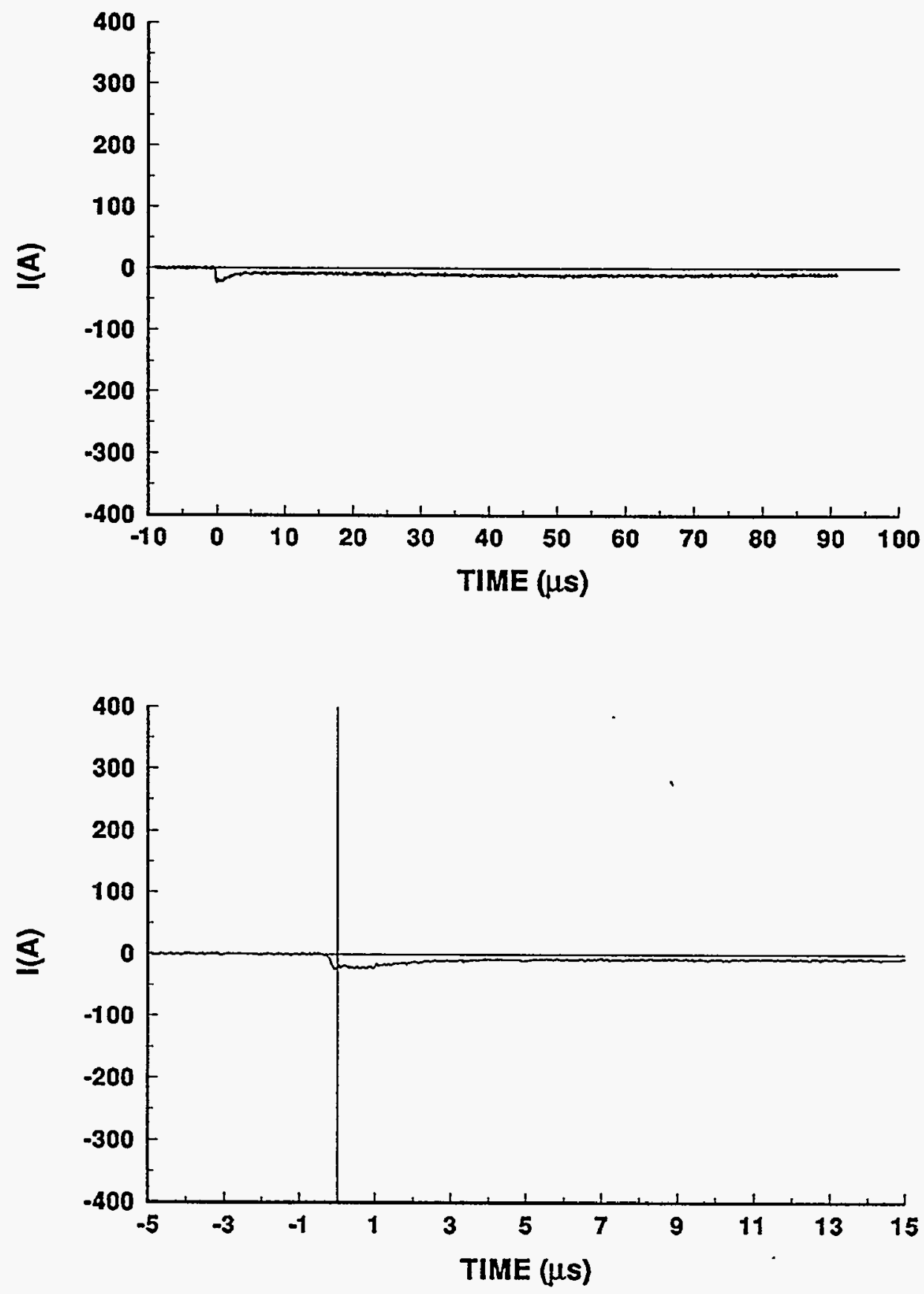


\section{4-21 STROKE 5}

\section{TEST POINT 15}
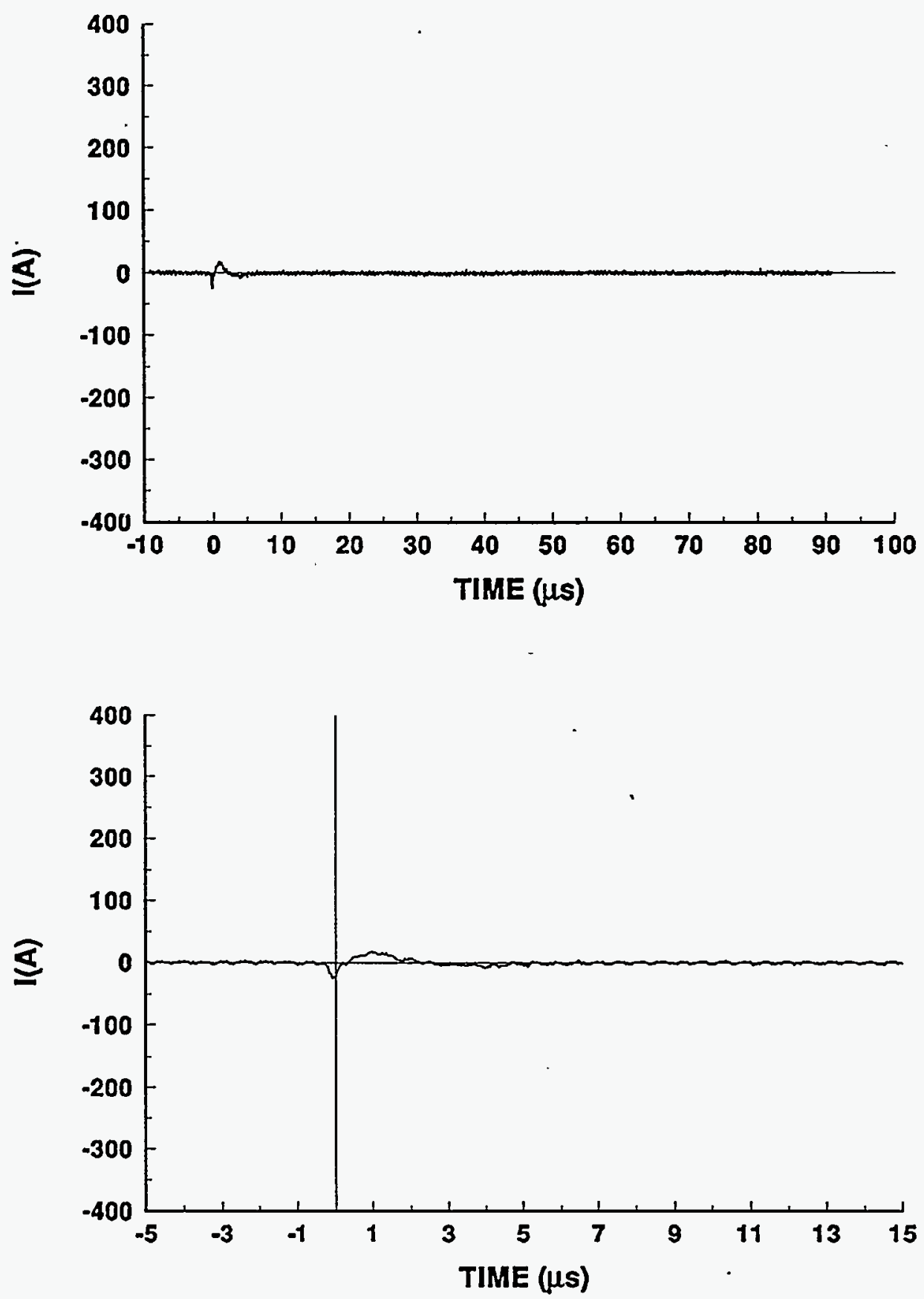


\section{4-21 STROKE 5}

TEST POINT 20

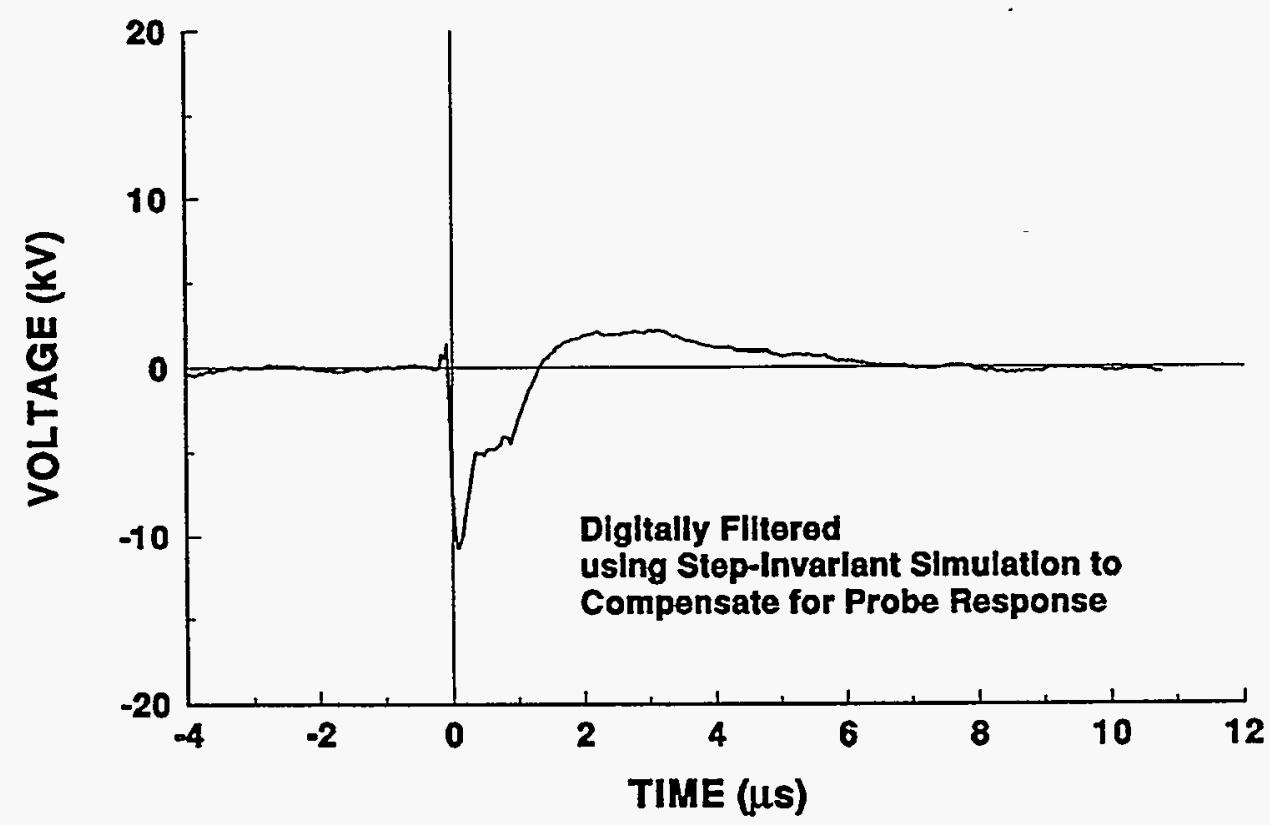

94-21 STROKE 5

TEST POINT 21

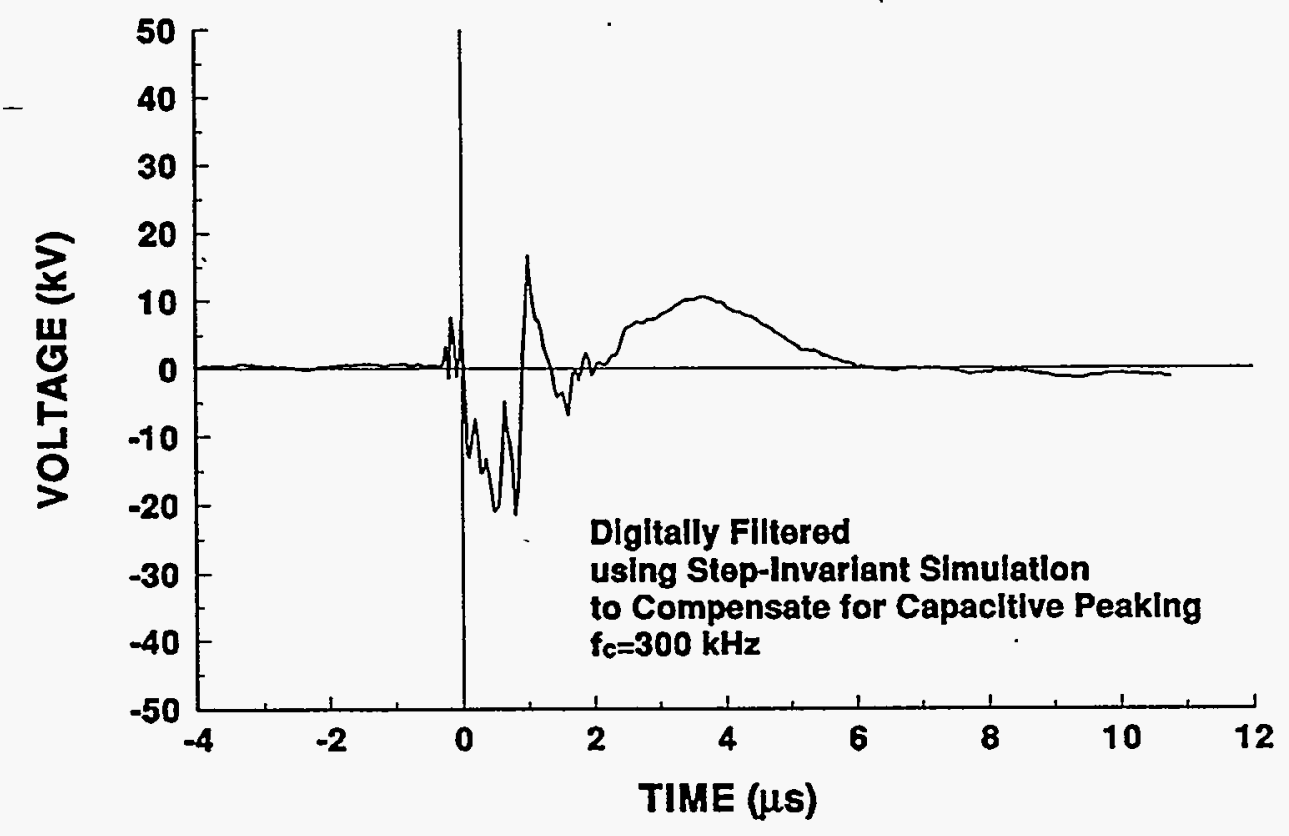




\section{4-21 STROKE 5}

TEST POINT 22

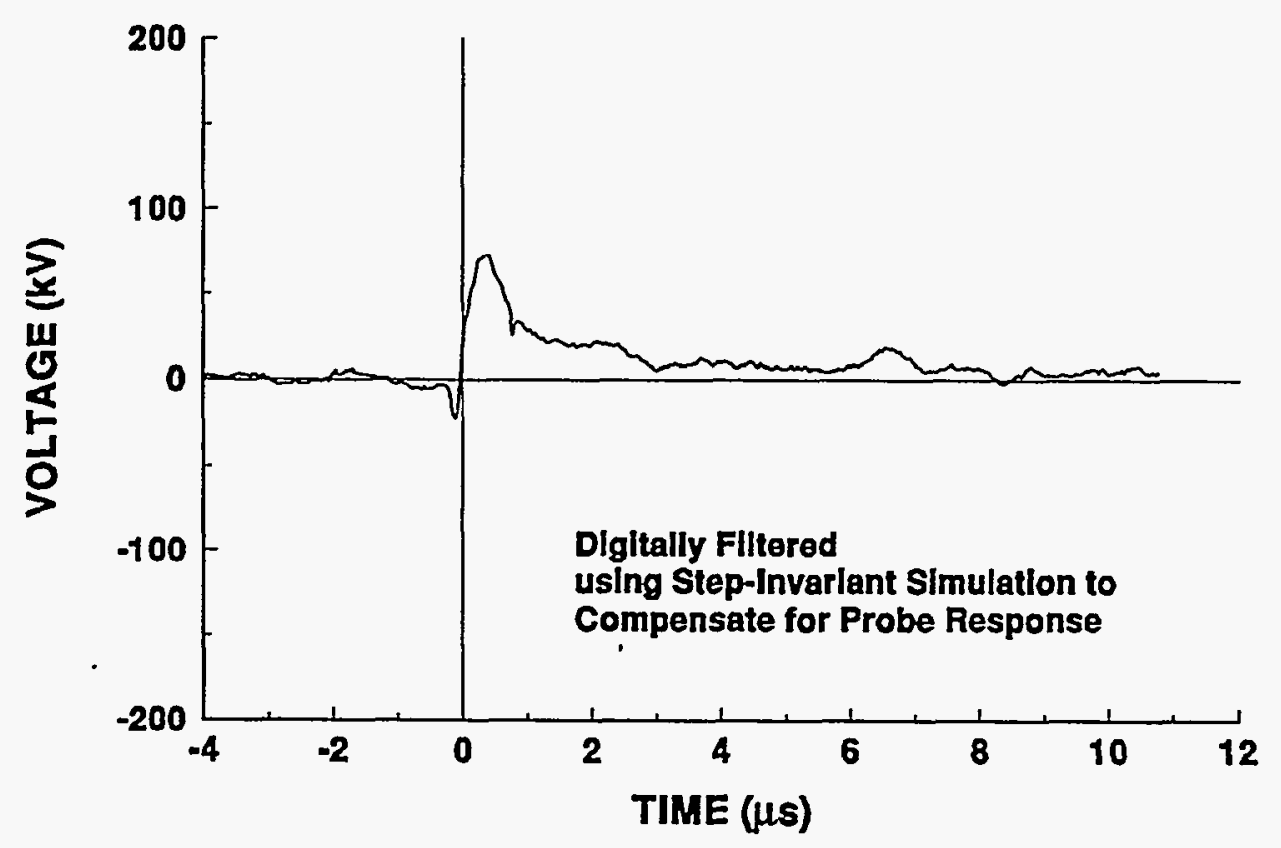




\section{4-21 STROKE 5}

TEST POINT 23

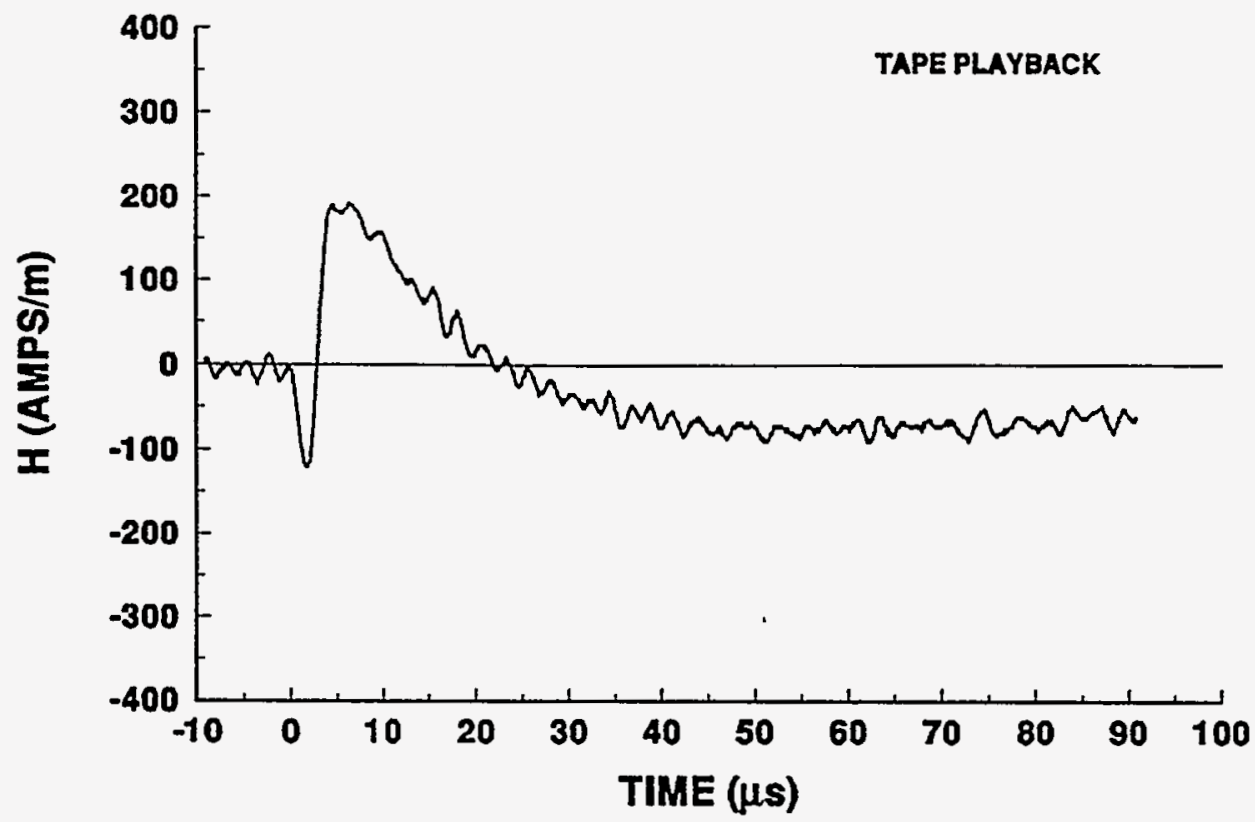

\section{4-21 STROKE 5.}

TEST POINT 24

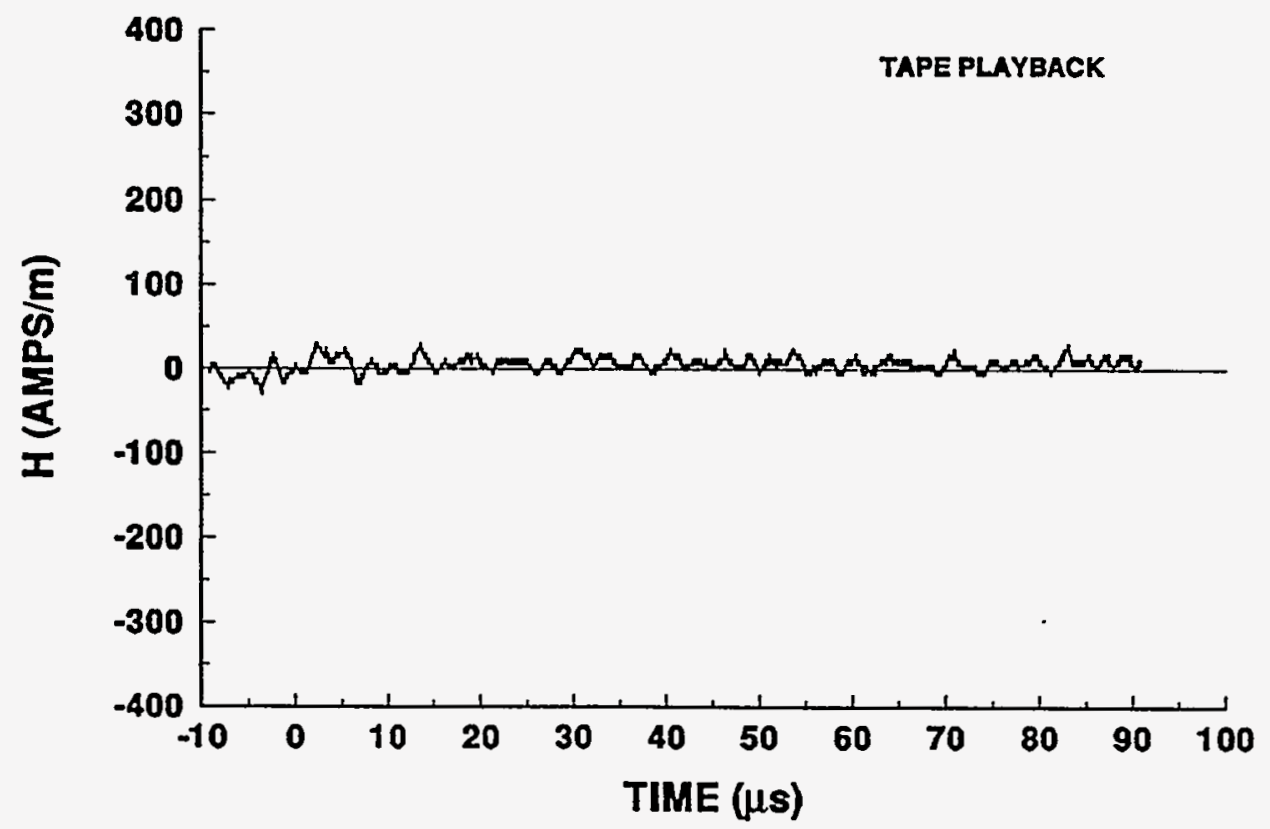




\section{4-21 STROKE 6 \\ INCIDENT CURRENT}
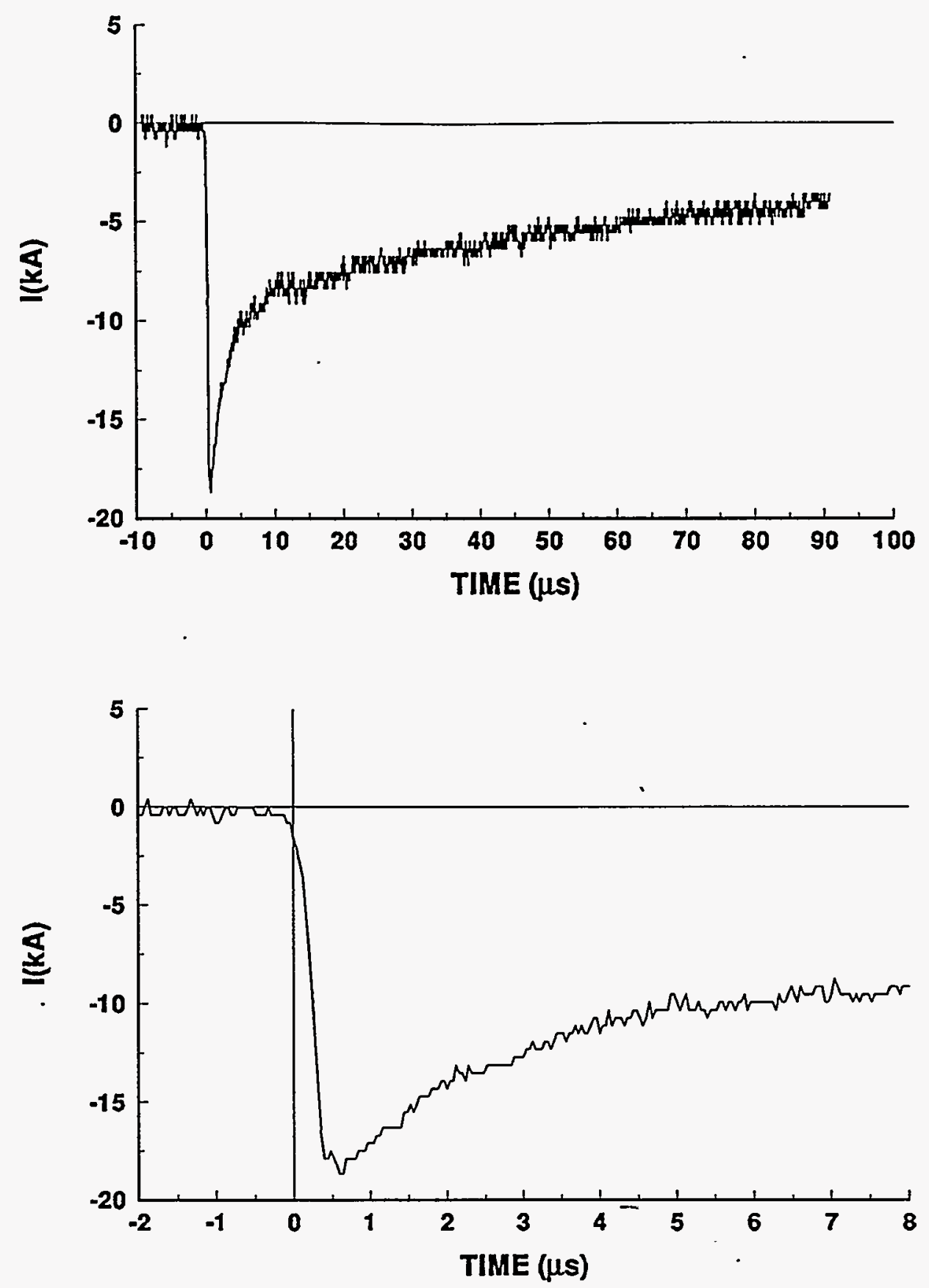


\section{4-21 STROKE 6}

\section{TEST POINT 1}
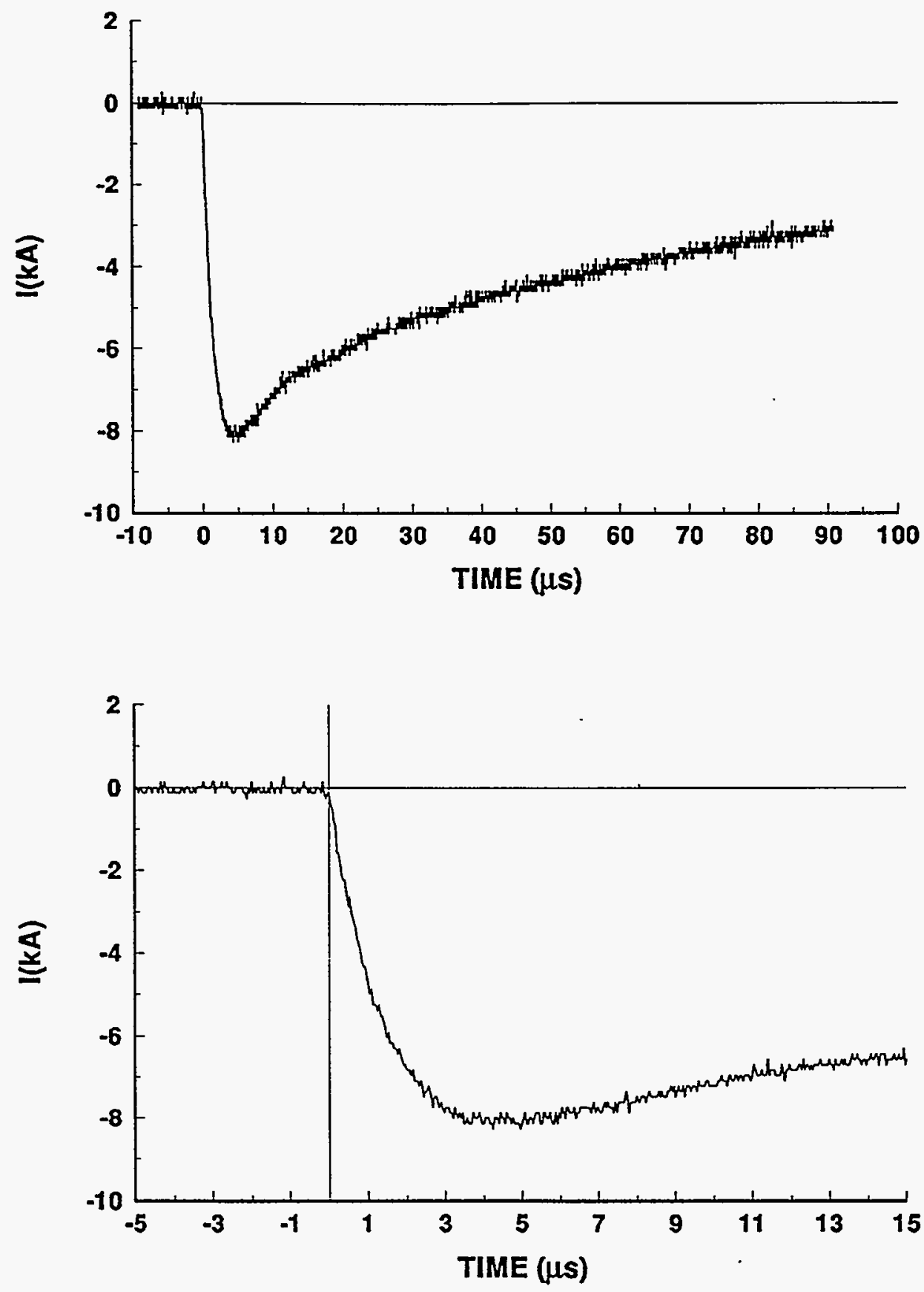


\section{4-21 STROKE 6}

\section{TEST POINT 2}
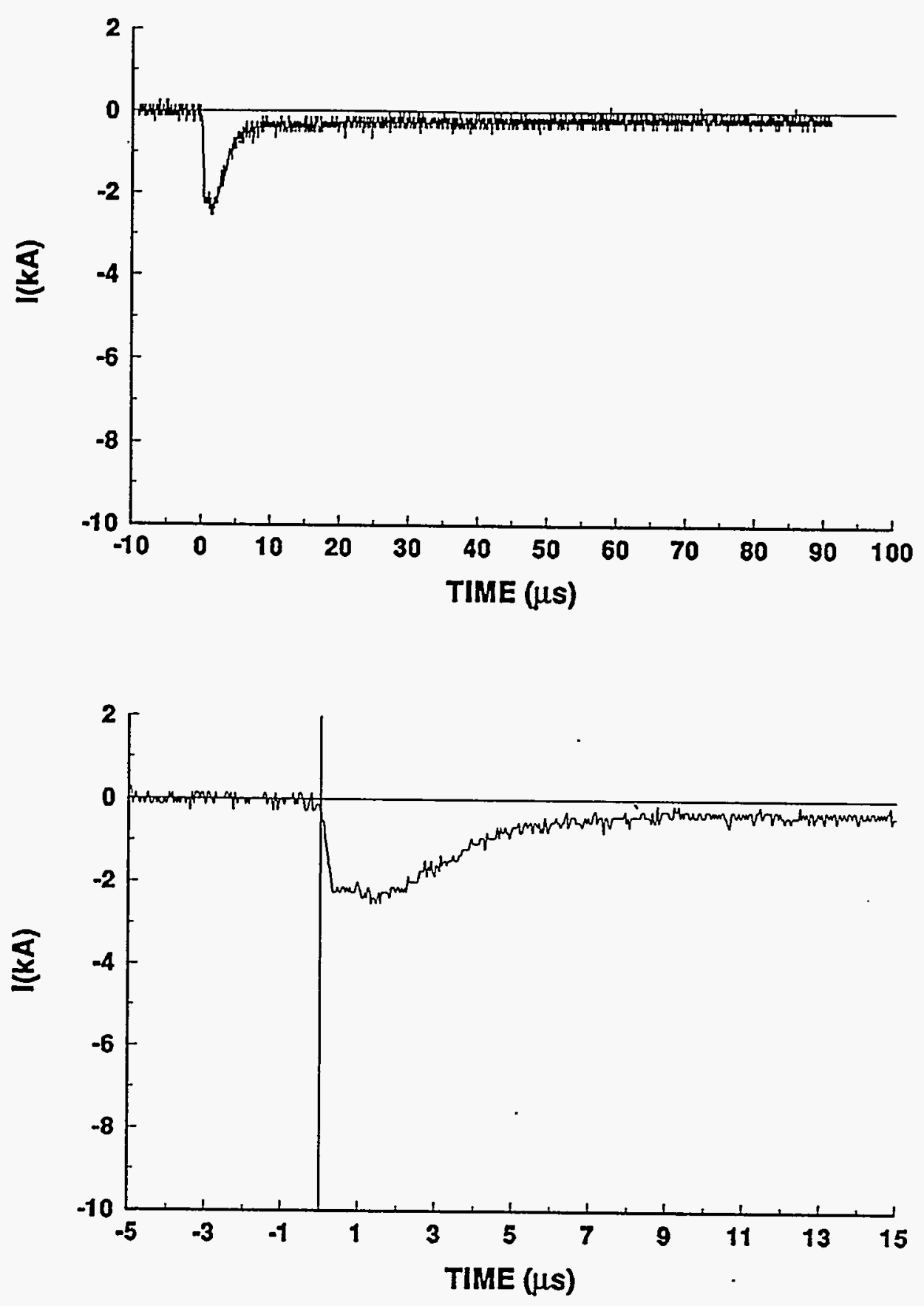


\section{4-21 STROKE 6 TEST POINT 5}
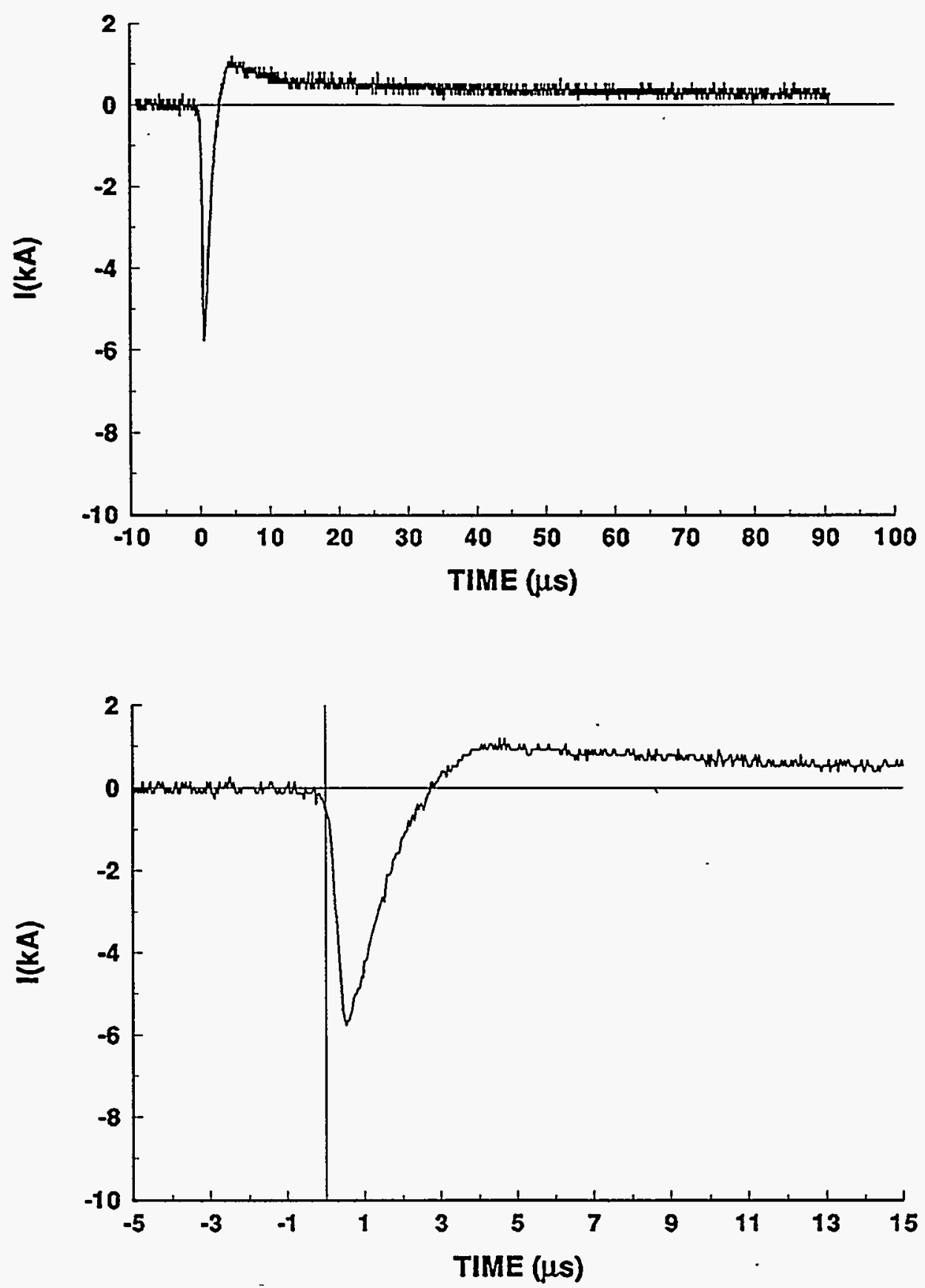


\section{4-21 STROKE 6}

\section{TEST POINT 6}
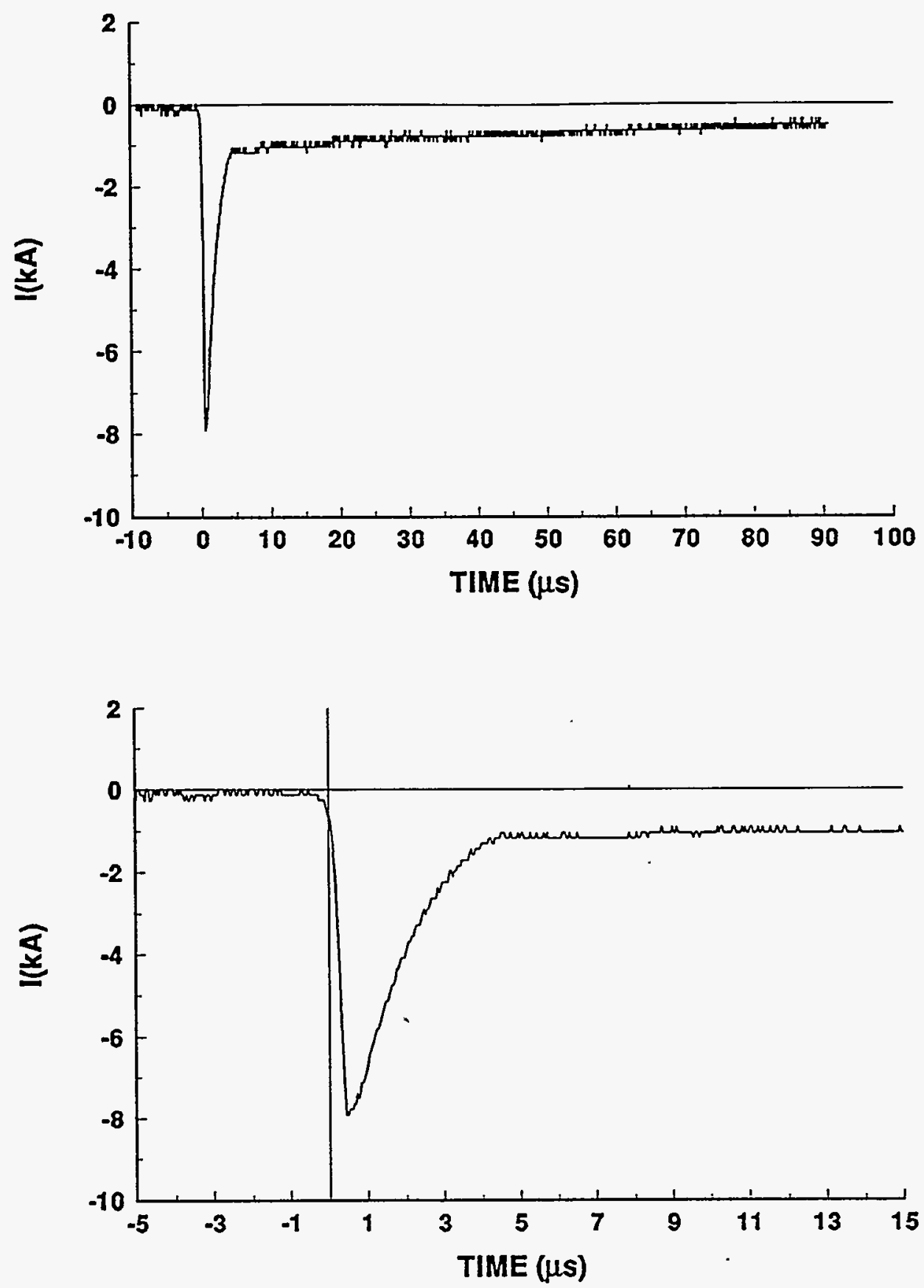
94-21 STROKE 6

TEST POINT 10

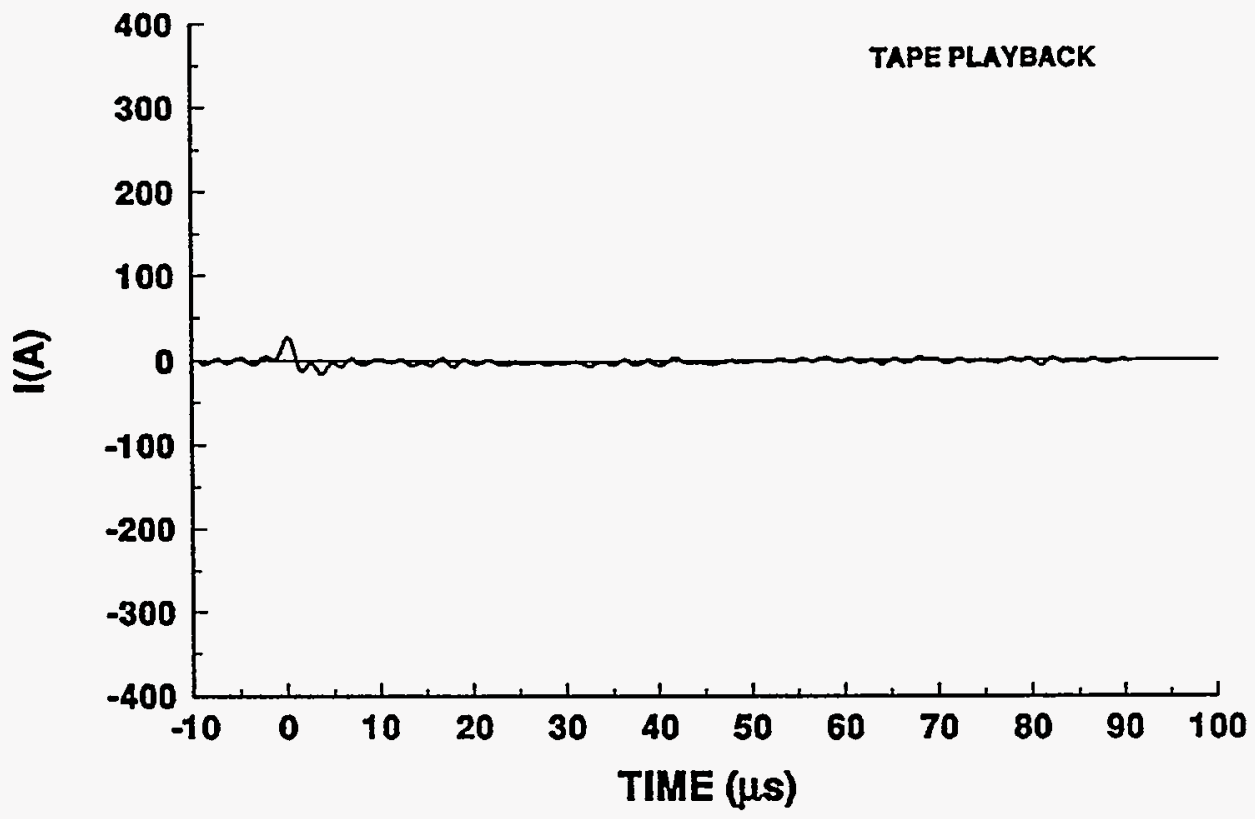

94-21 STROKE 6

TEST POINT 11

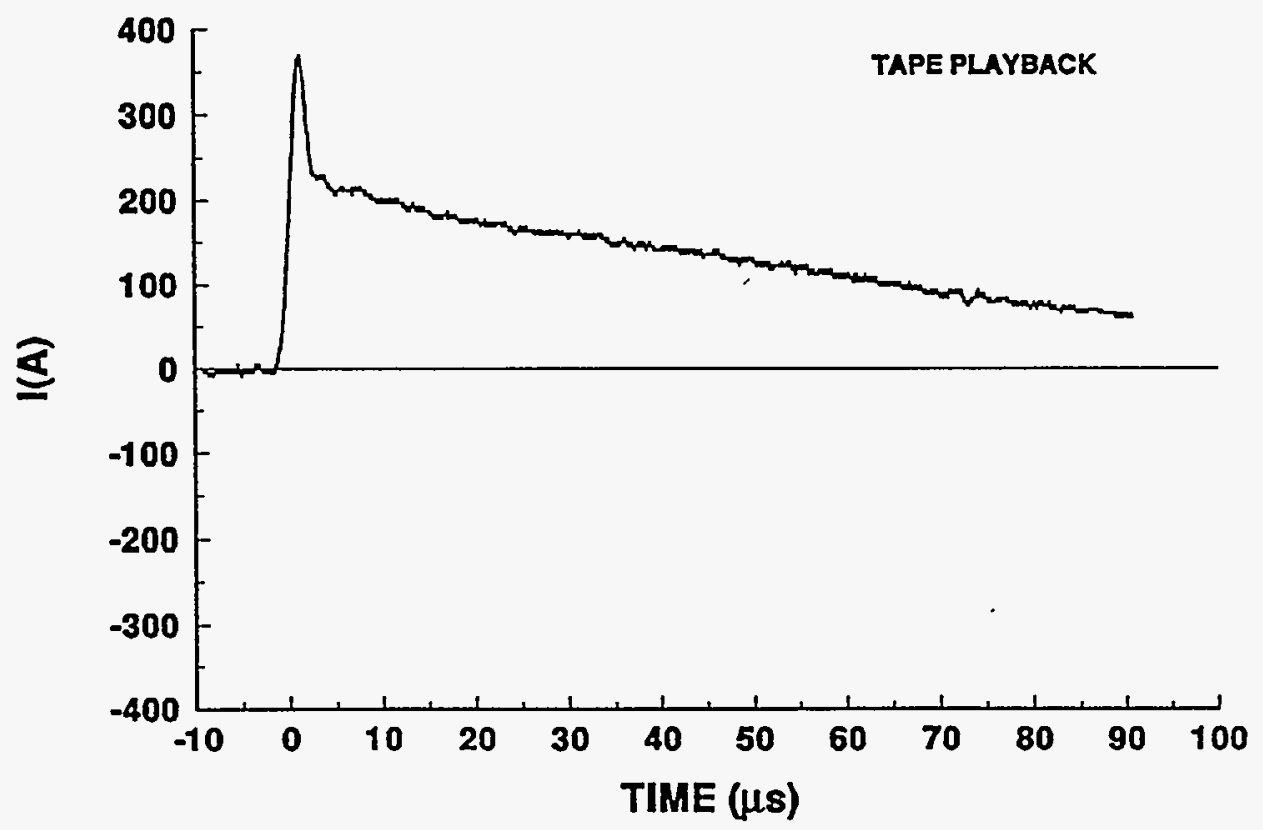




\section{4-21 STROKE 6}

TEST POINT 12

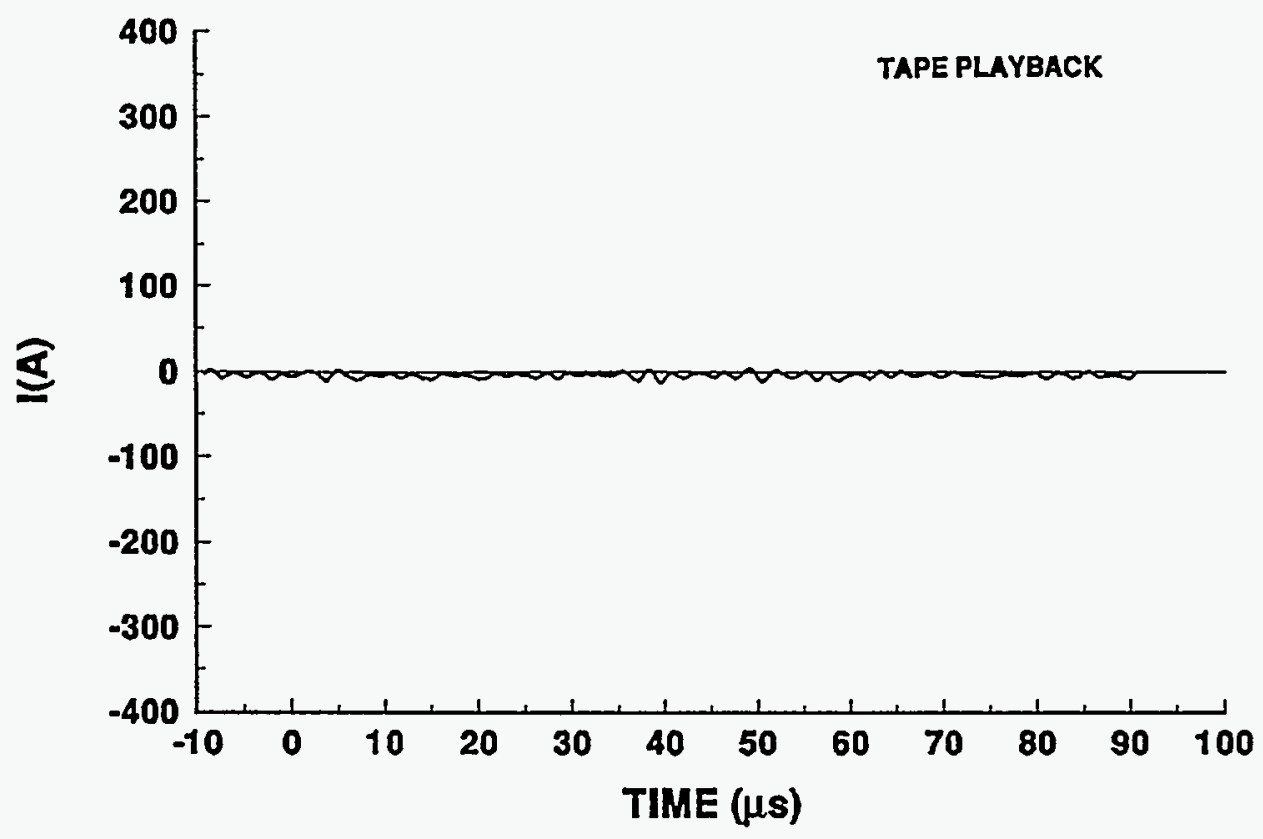

94-21 STROKE 6

TEST POINT 13

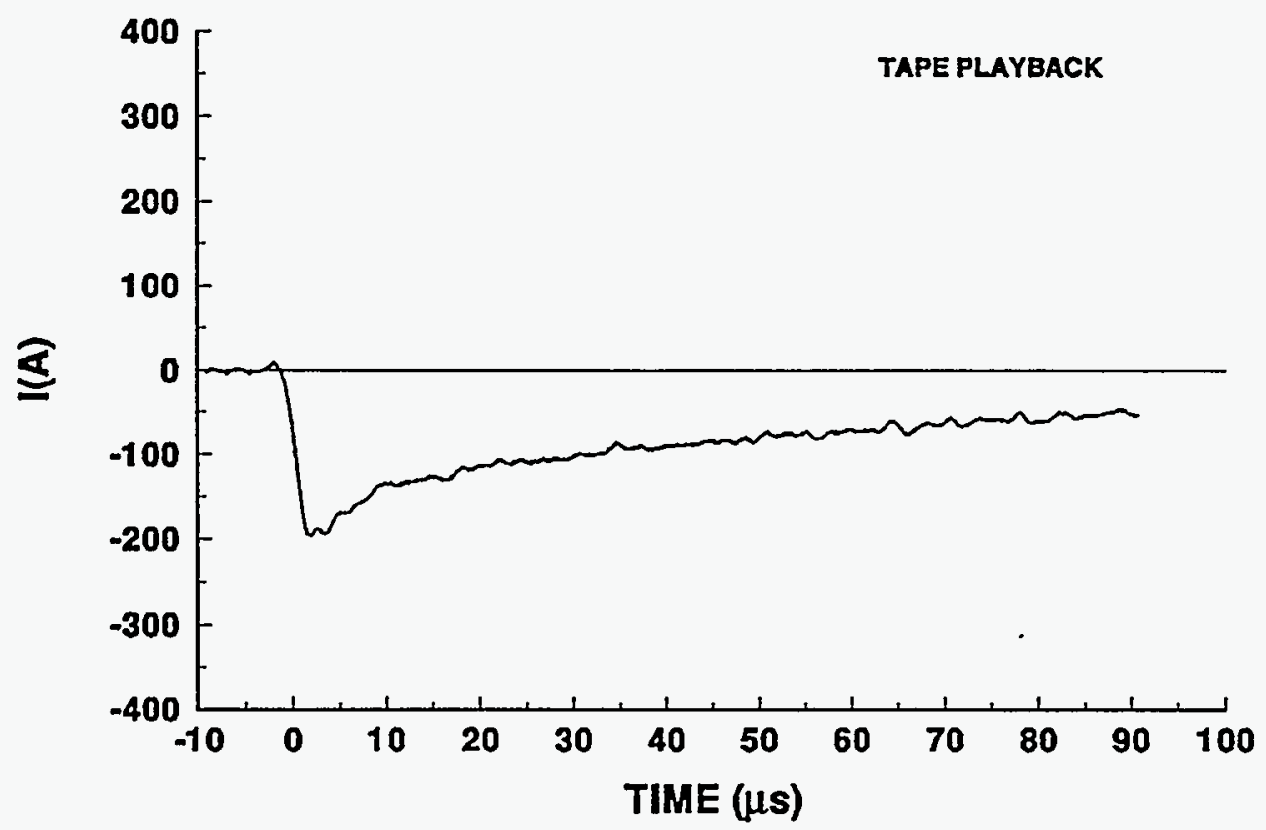




\section{4-21 STROKE 6}

TEST POINT 14
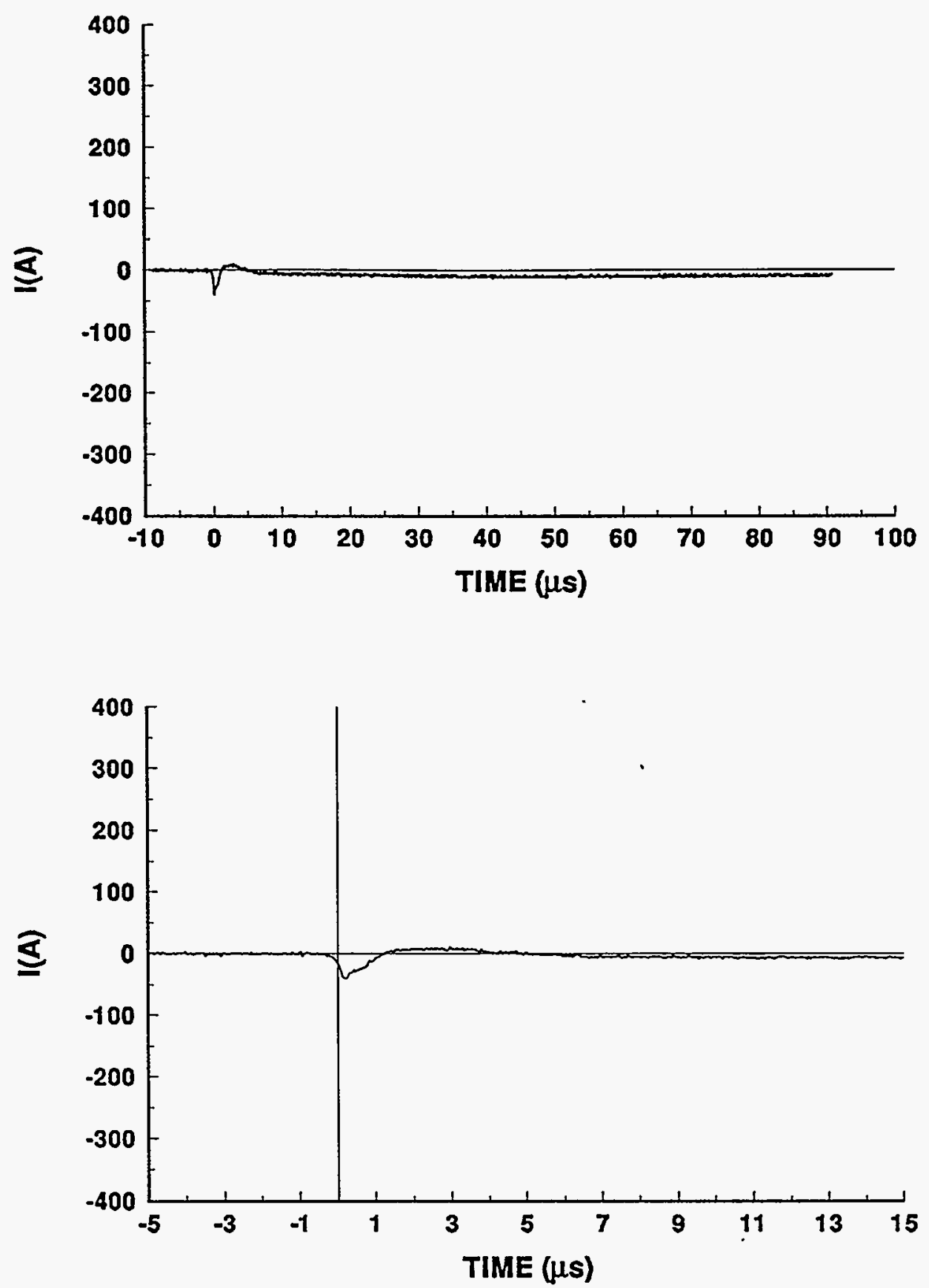


\section{4-21 STROKE 6}

TEST POINT 15
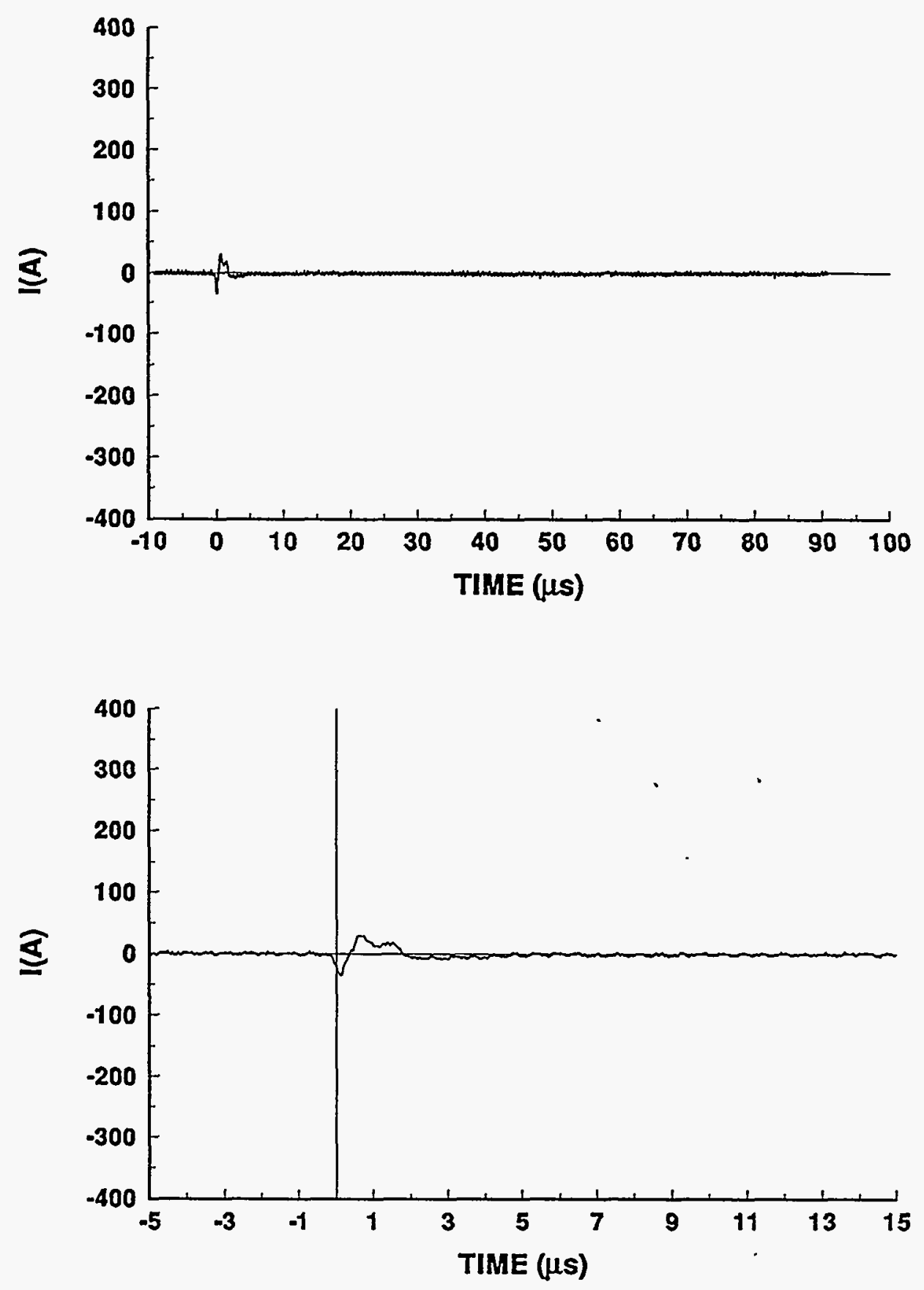

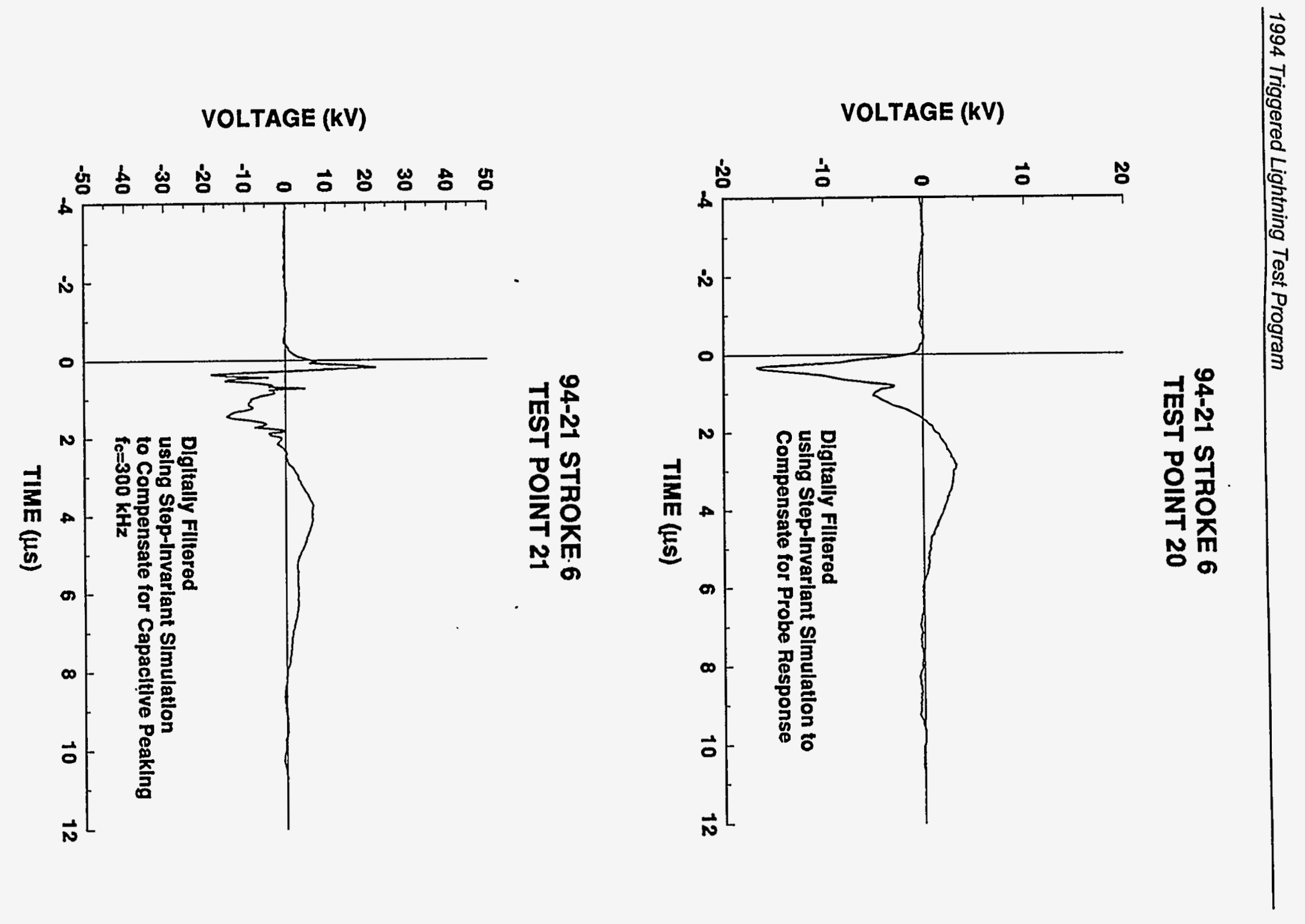


\section{4-21 STROKE 6}

TEST POINT 22

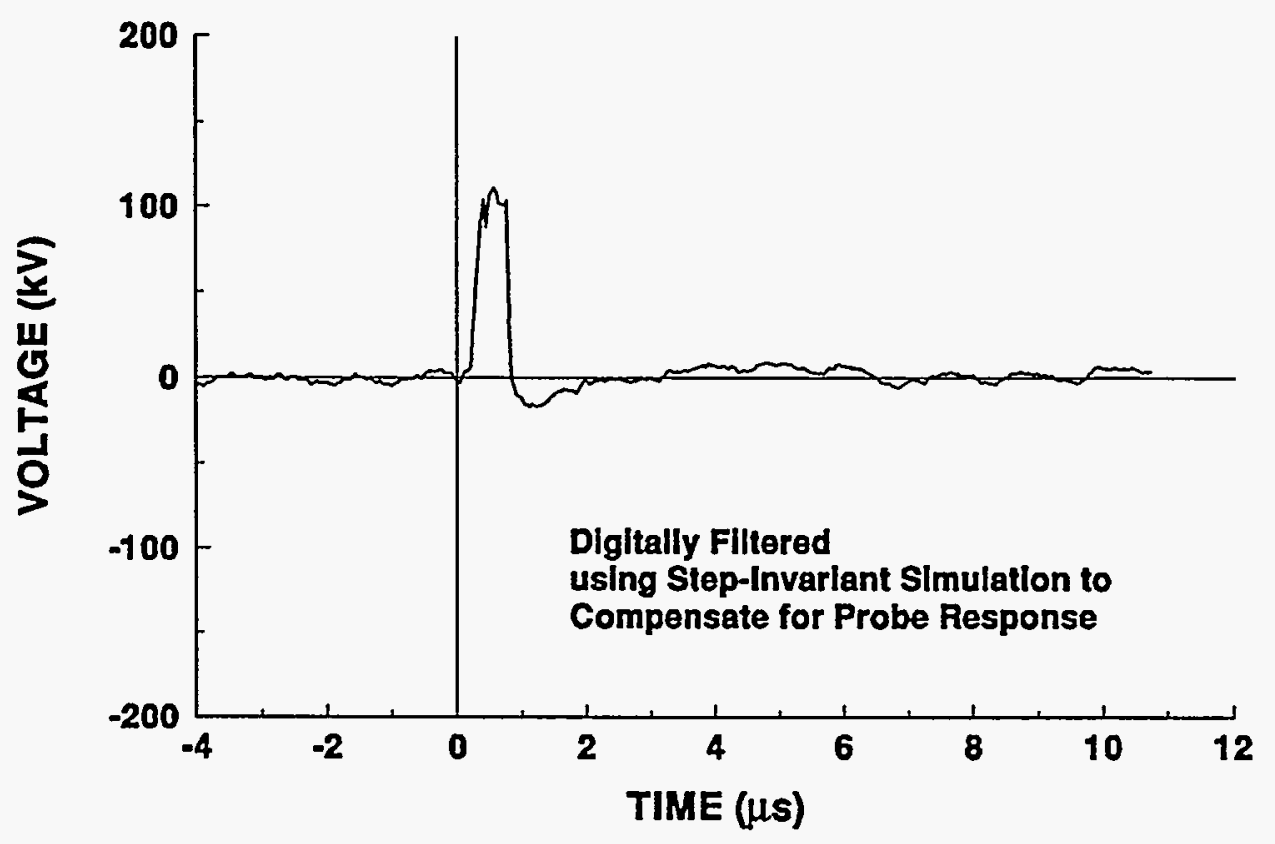




\section{4-21 STROKE 6}

TEST POINT 23

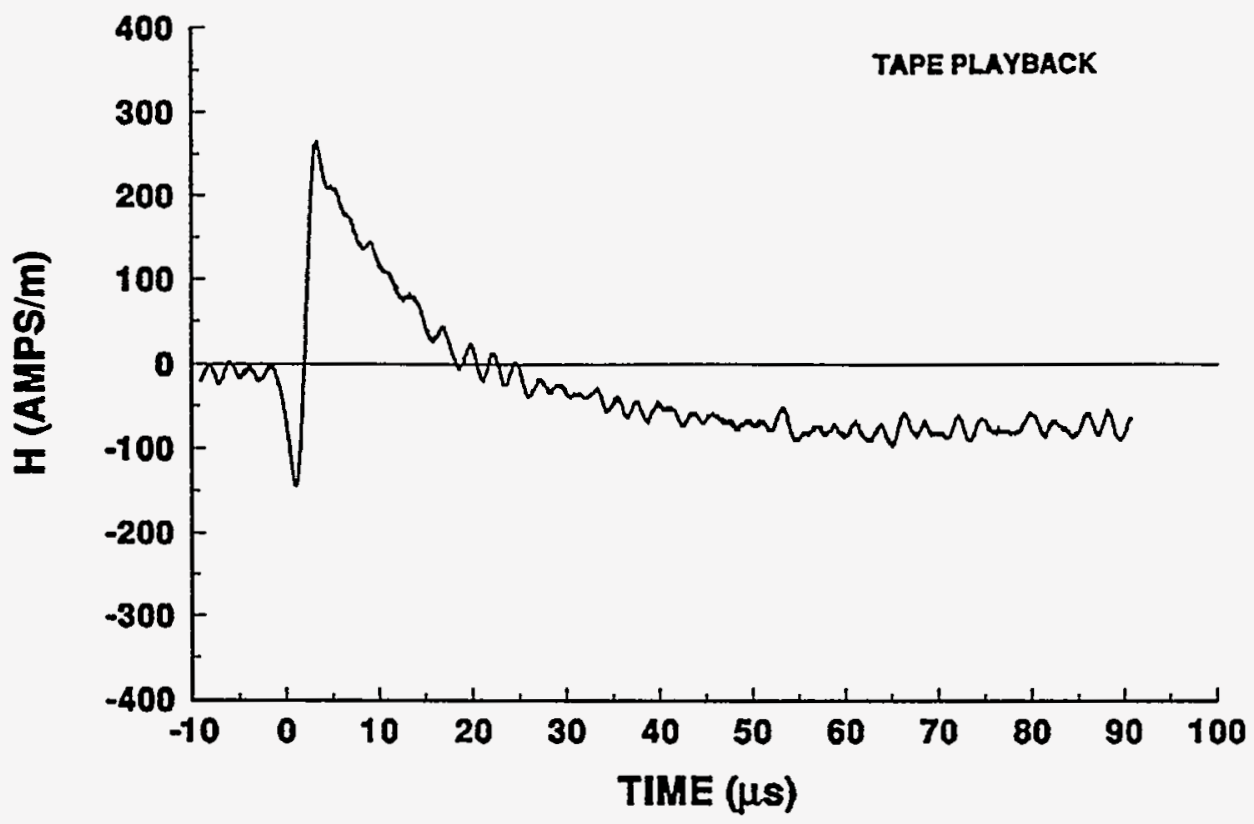

94-21 STROKE· 6

TEST POINT 24

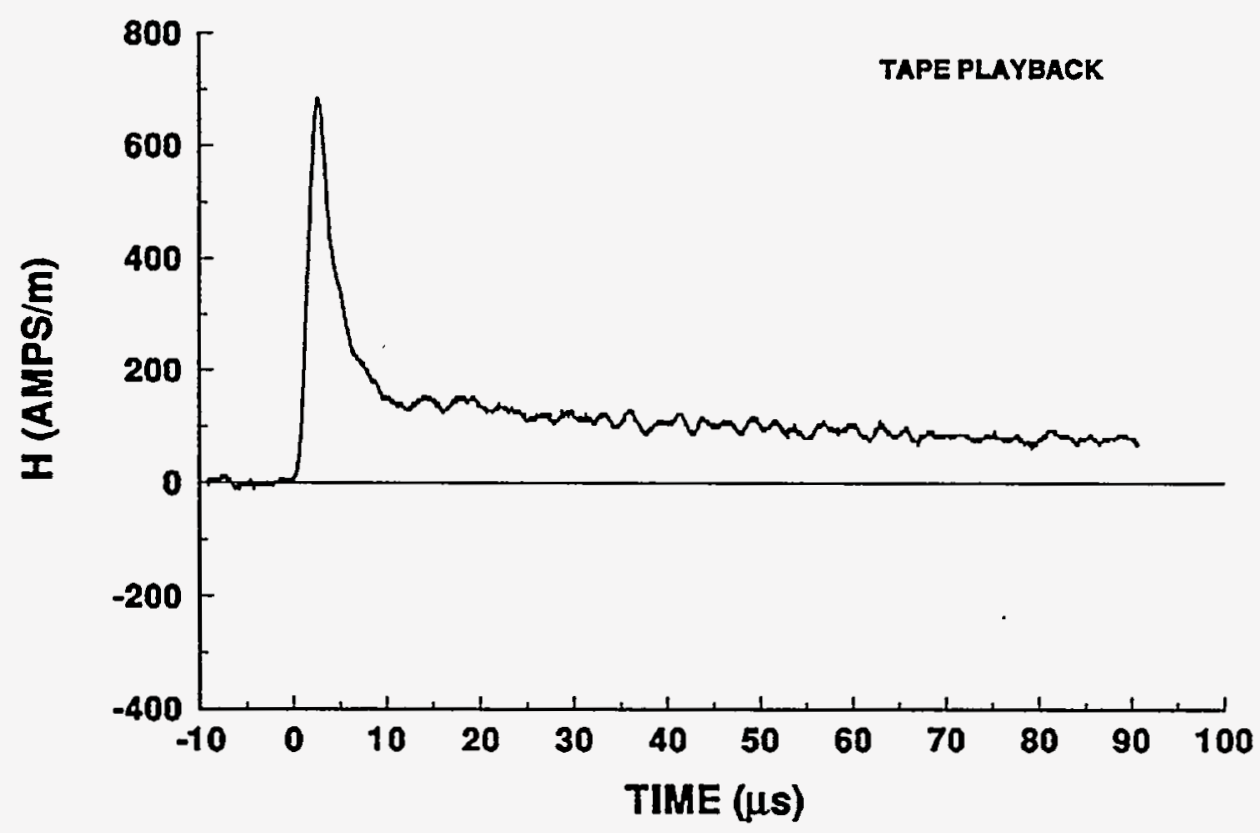




\section{4-21 STROKE 7}

\section{INCIDENT CURRENT}
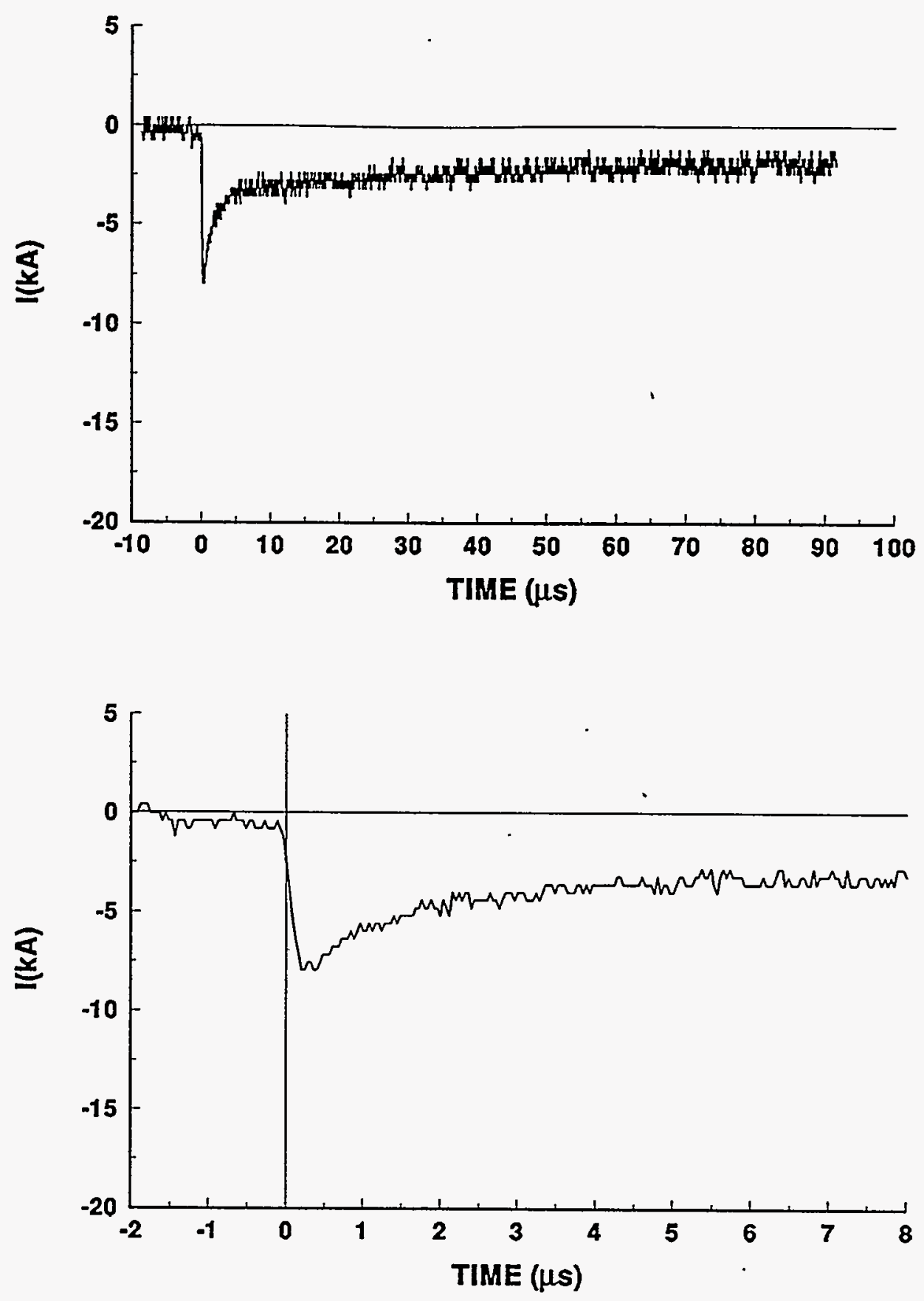


\section{4-21 STROKE 7}

TEST POINT 1
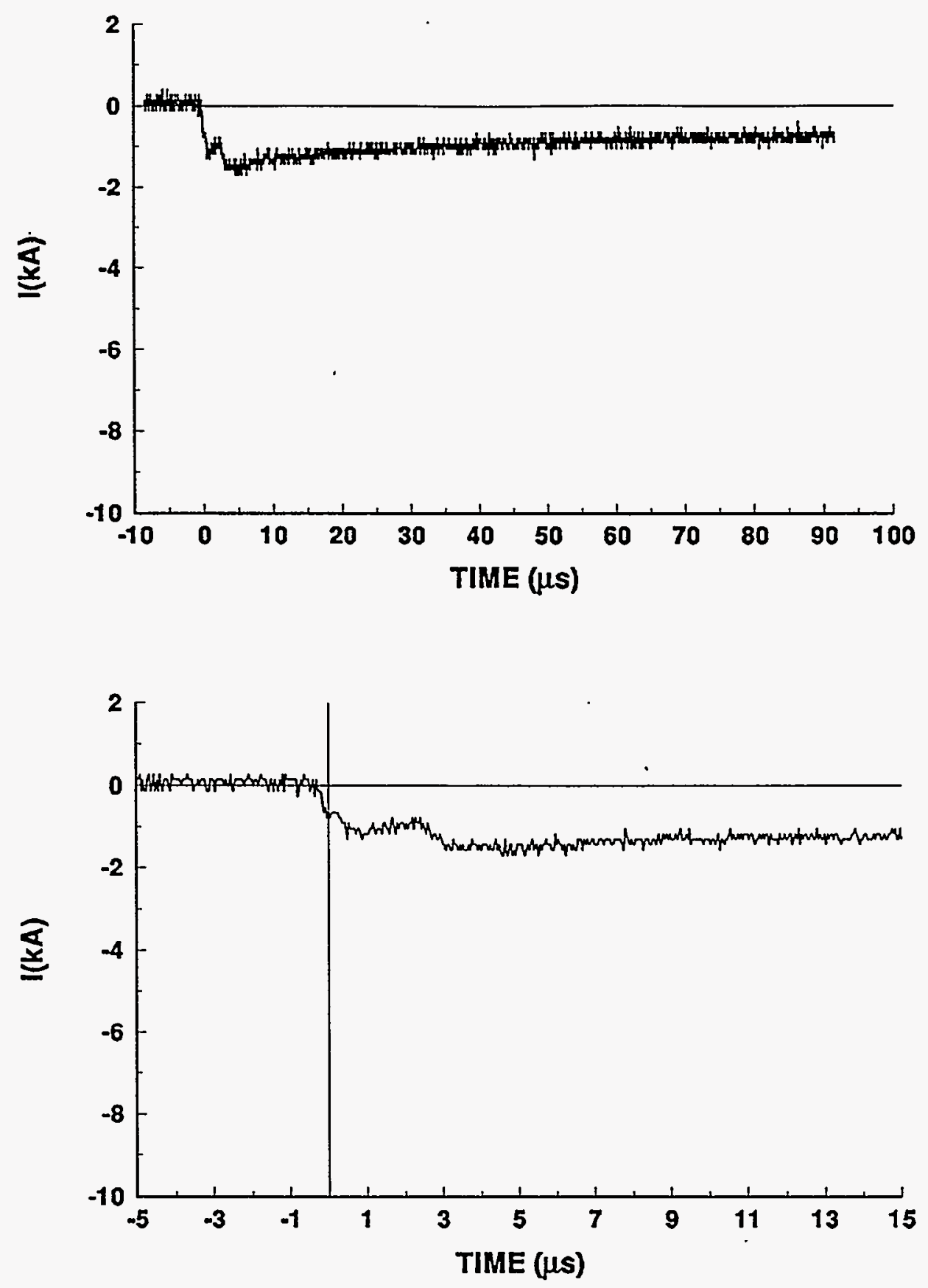


\section{4-21 STROKE 7 \\ TEST POINT 2}
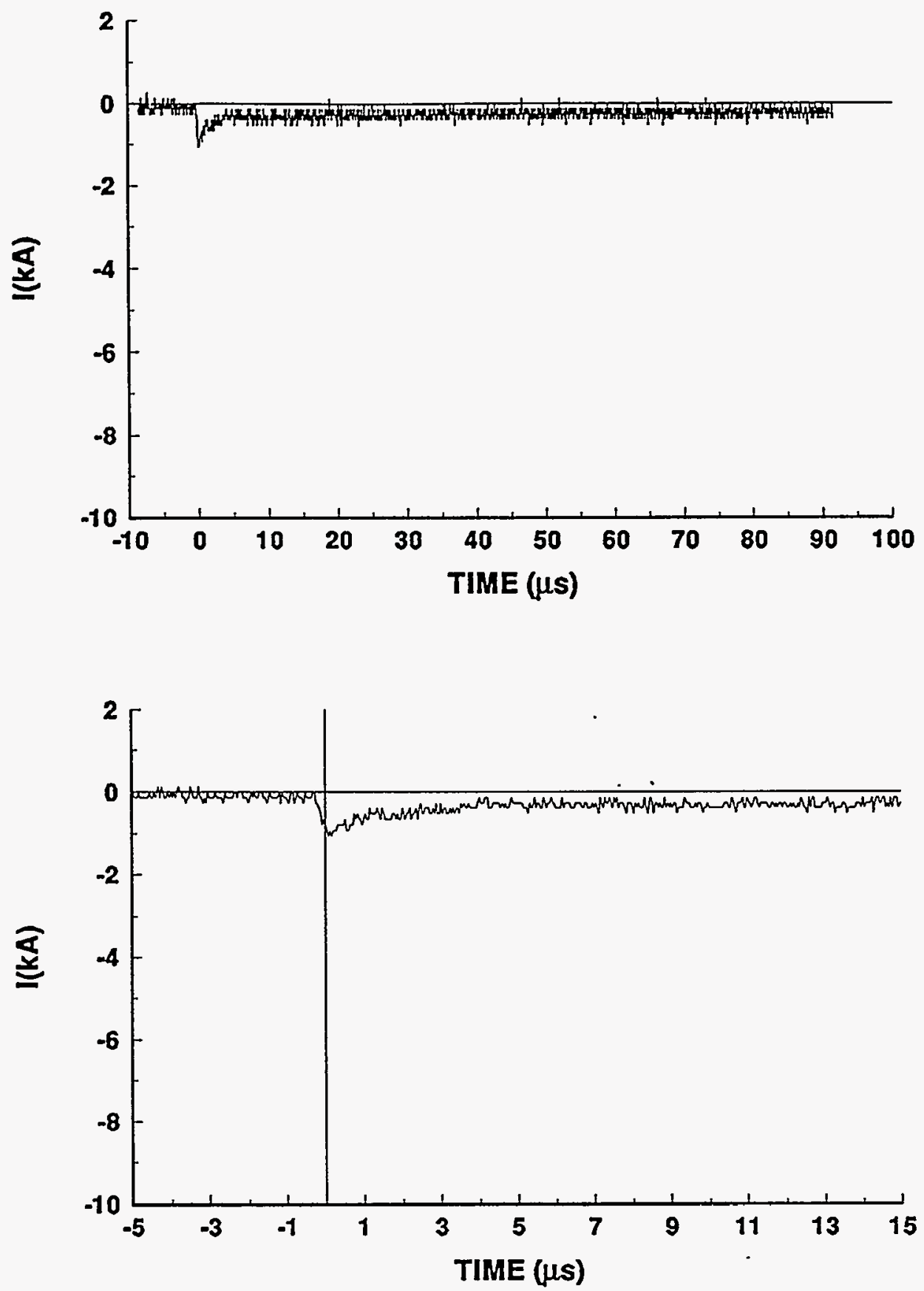


\section{4-21 STROKE 7}

TEST POINT 5
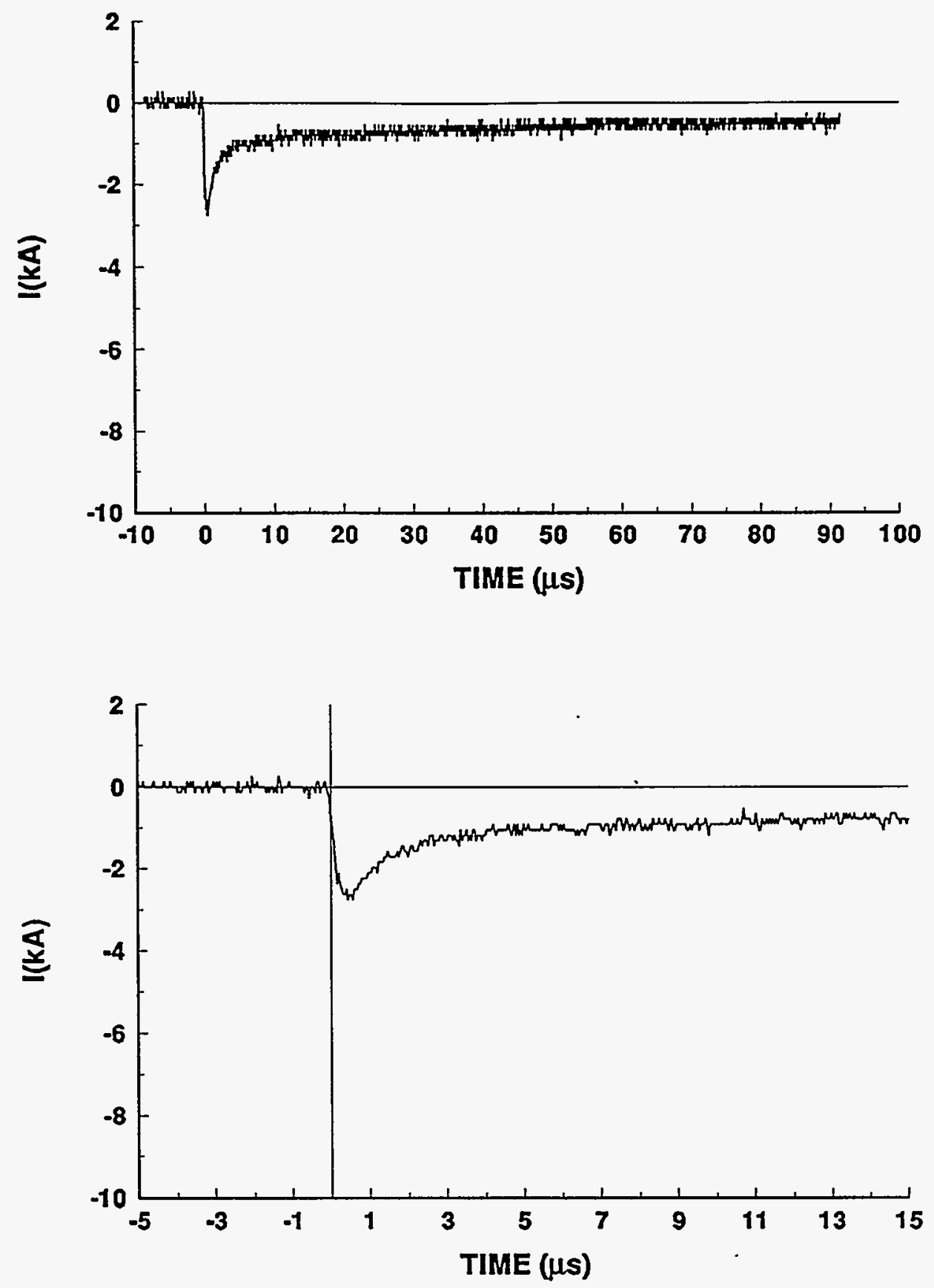


\section{4-21 STROKE 7}

TEST POINT 6
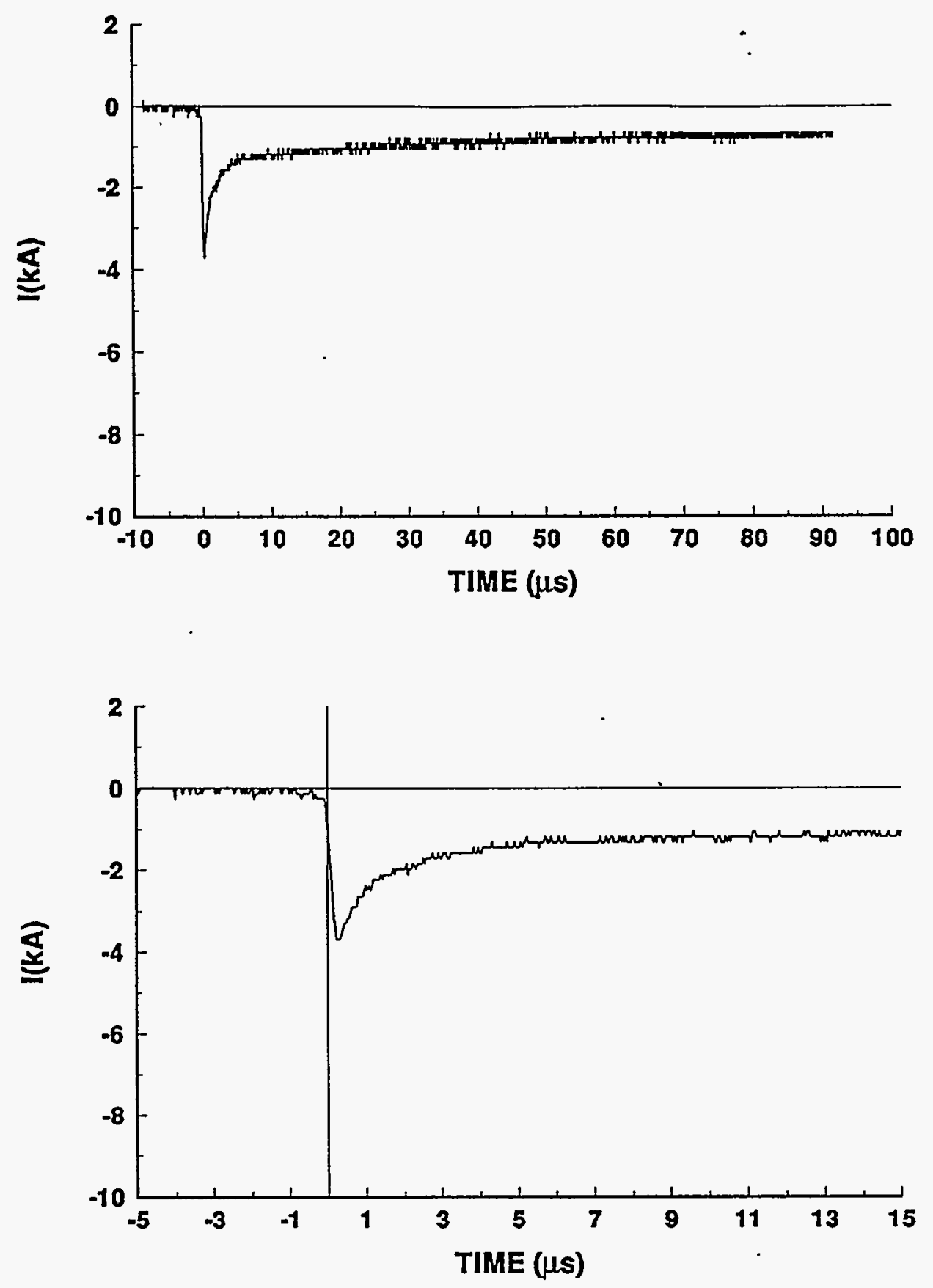


\section{4-21 STROKE 7}

TEST POINT 5'

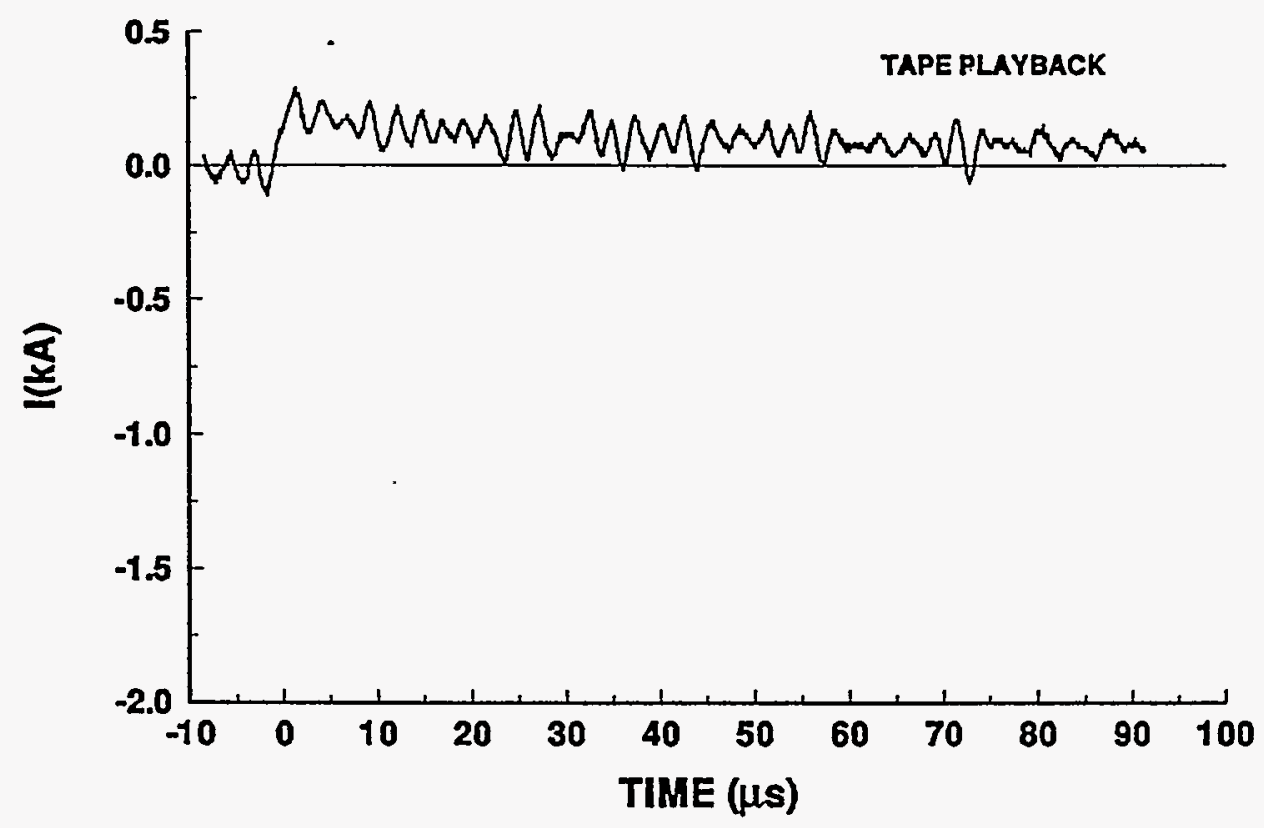

94-21 STROKE 7

TEST POINT 6'

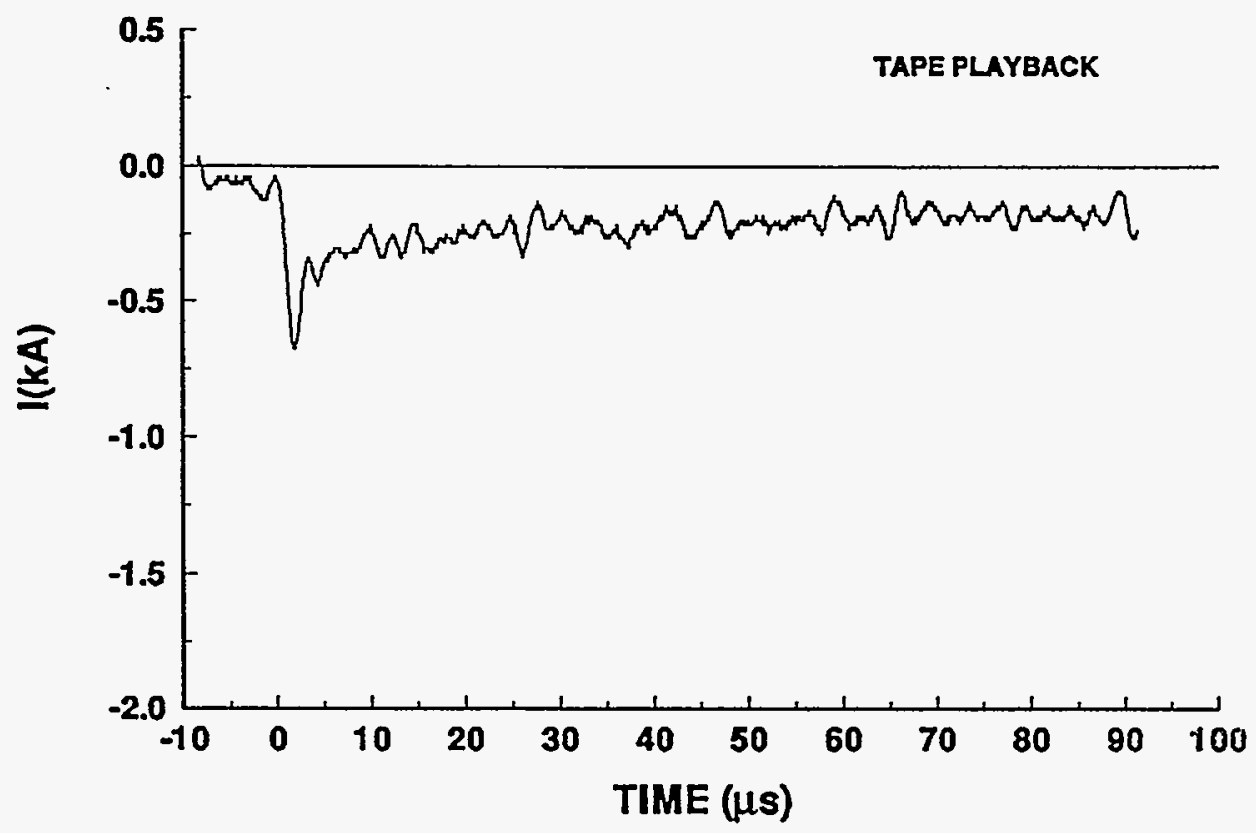




\section{4-21 STROKE 7}

TEST POINT 10

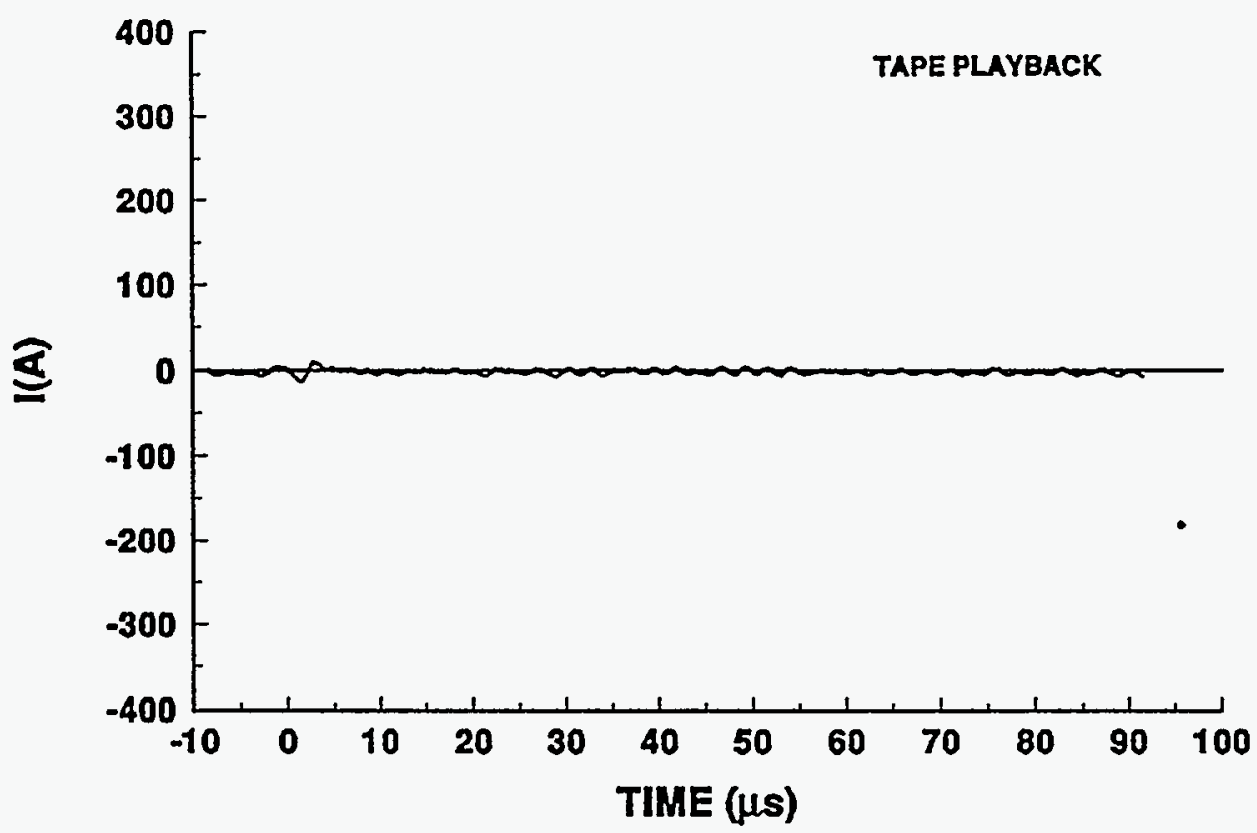

\section{4-21 STROKE.7}

TEST POINT 11

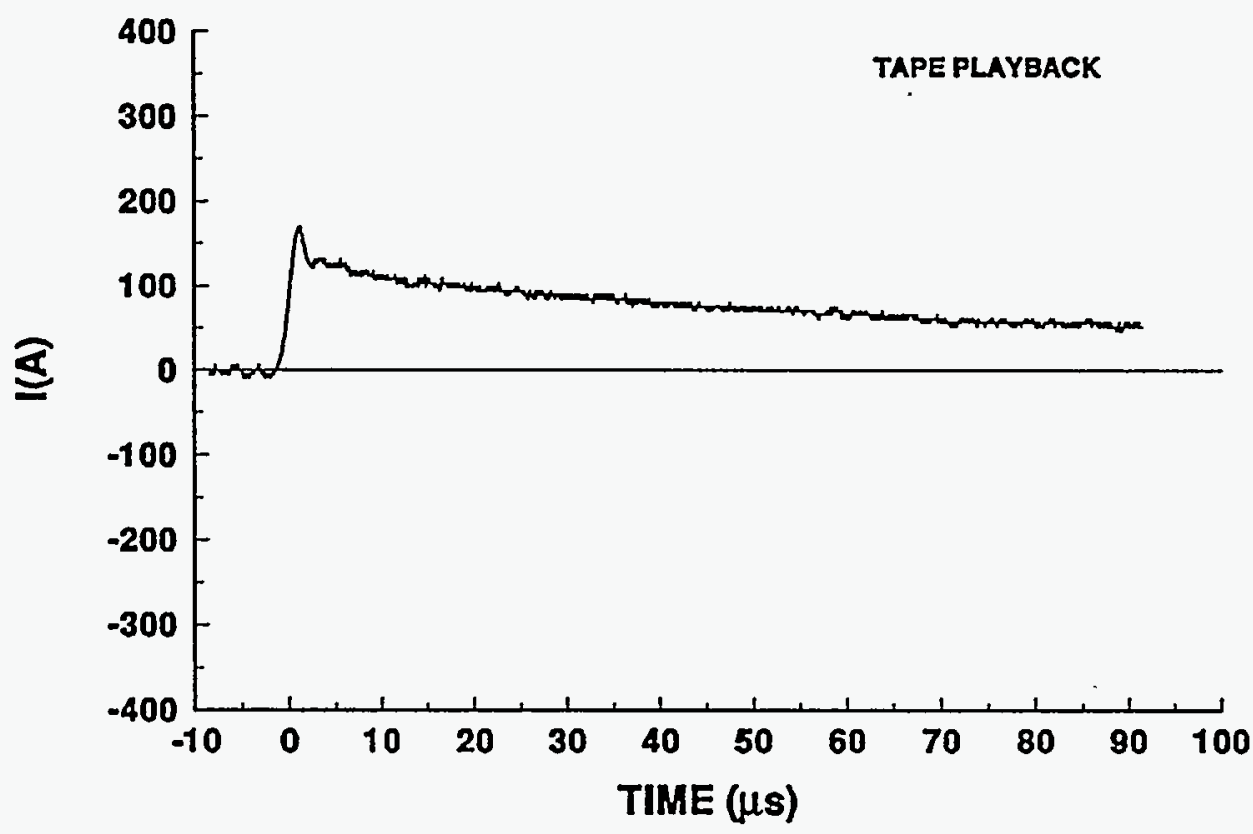




\section{4-21 STROKE 7}

TEST POINT 12

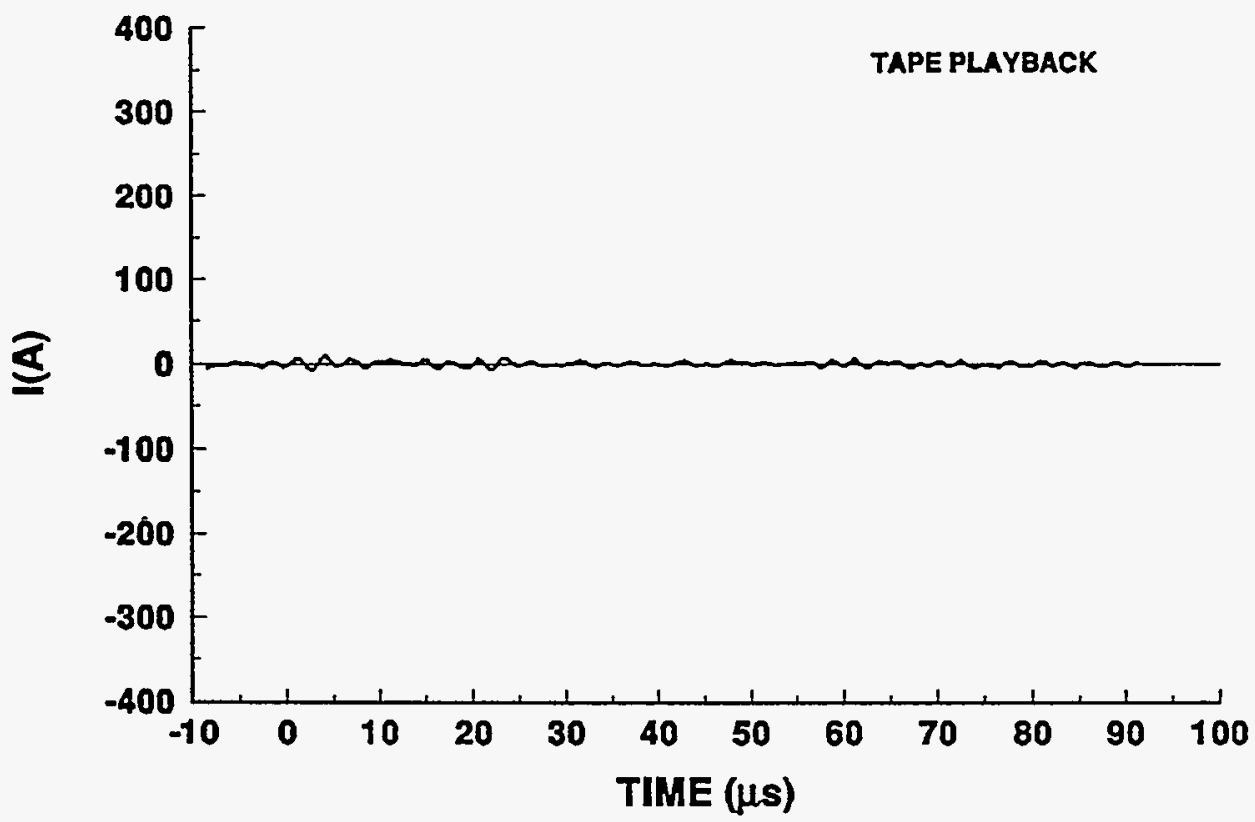

94-21 STROKE.7

TEST POINT 13

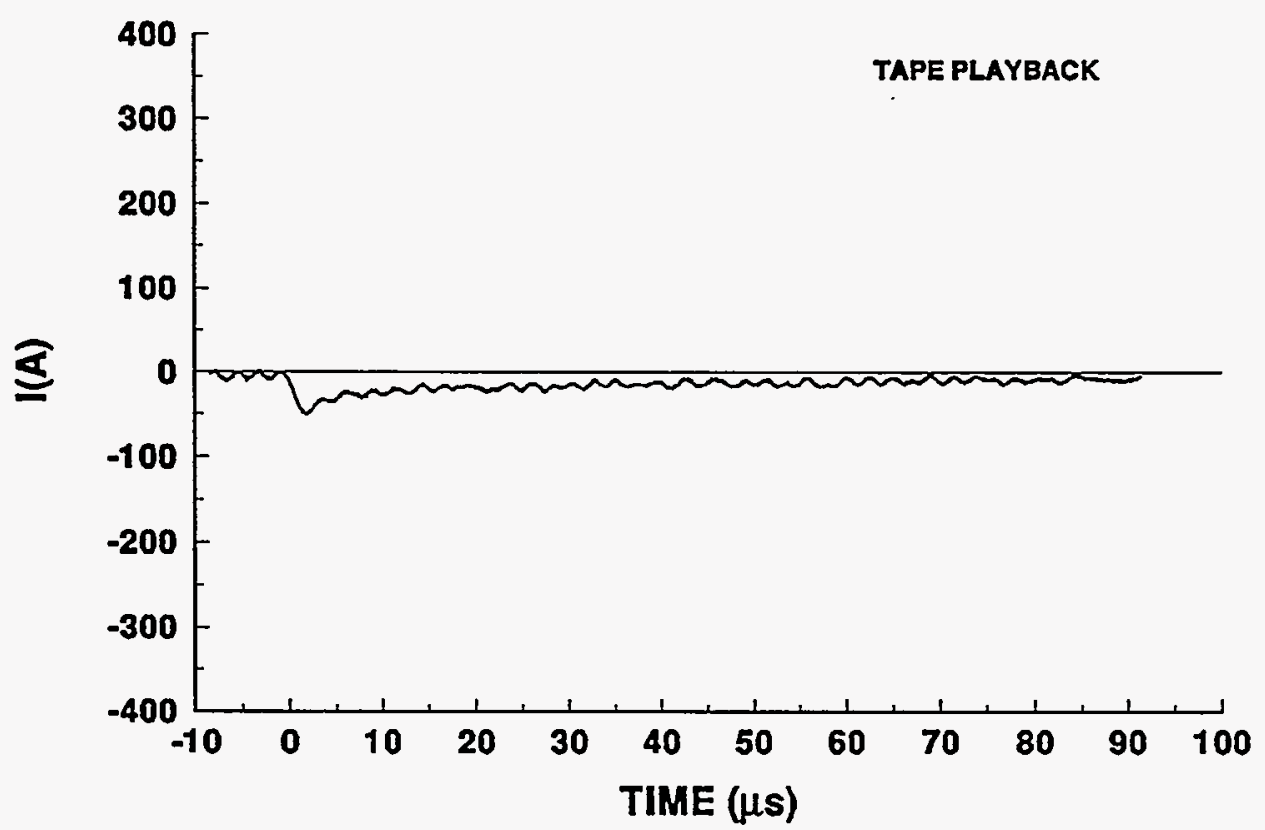




\section{4-21 STROKE 7}

TEST POINT' 14
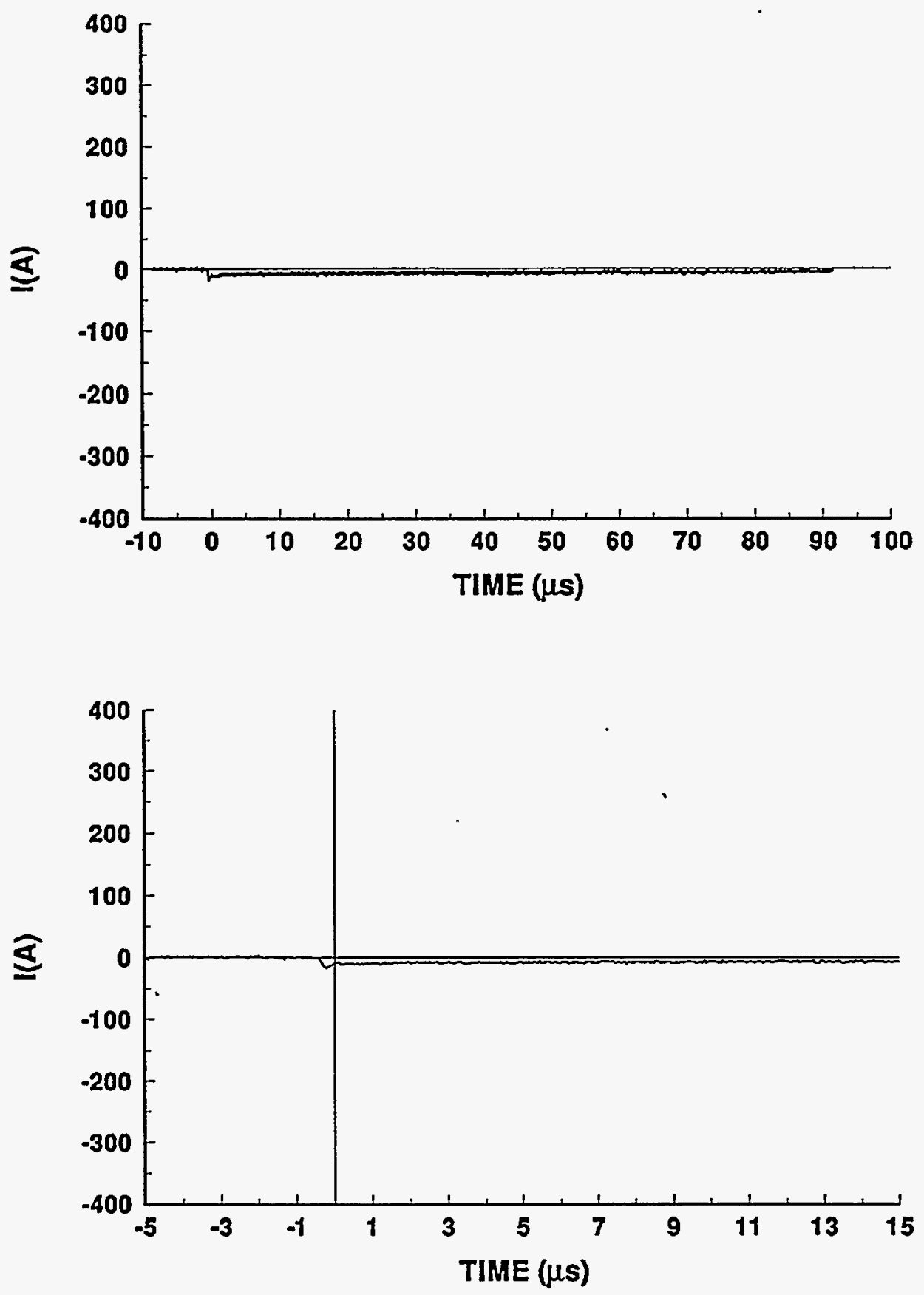


\section{4-21 STROKE 7}

TEST POINT 15
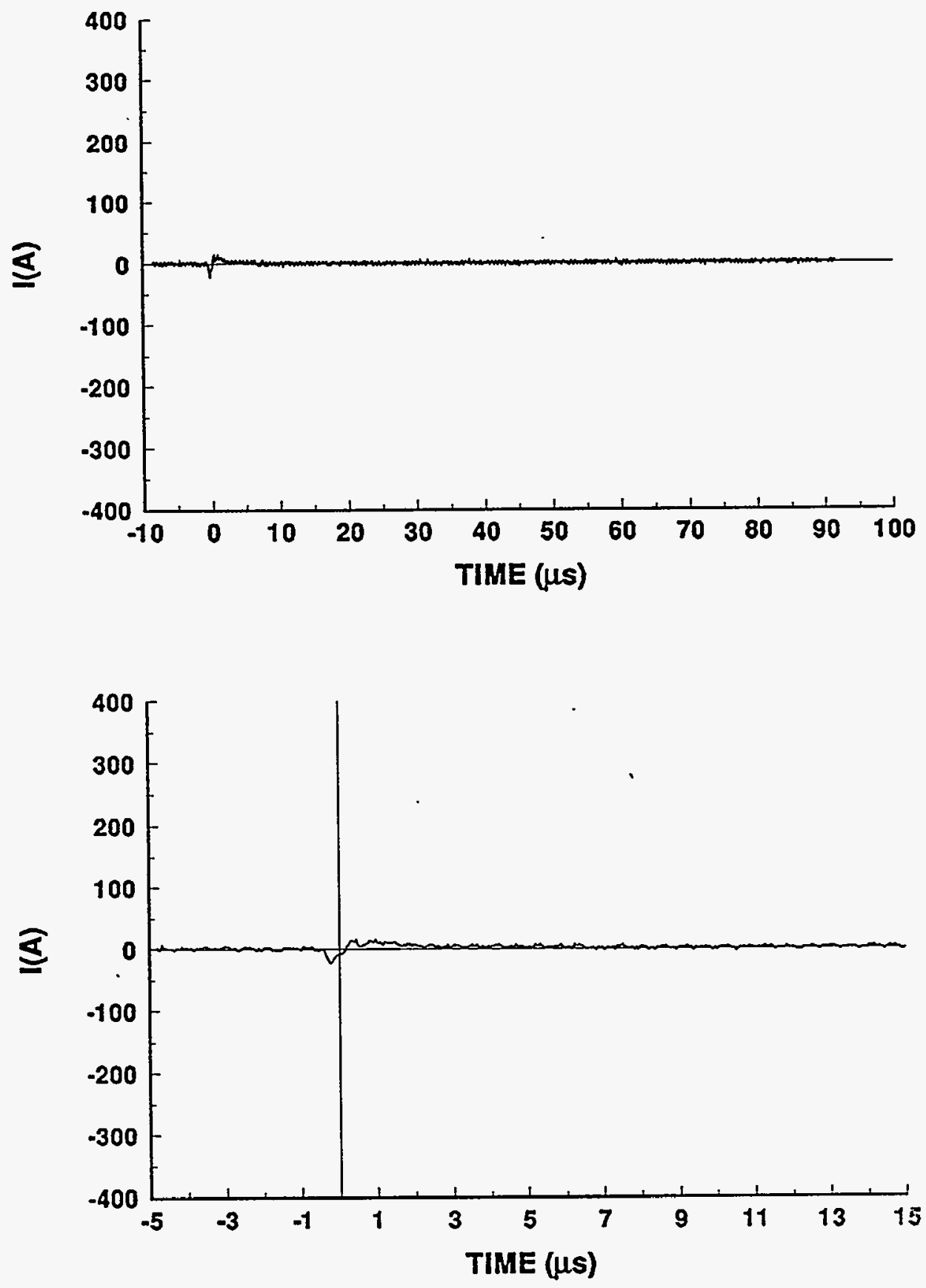


\section{4-21 STROKE 7}

\section{TEST POINT 20}

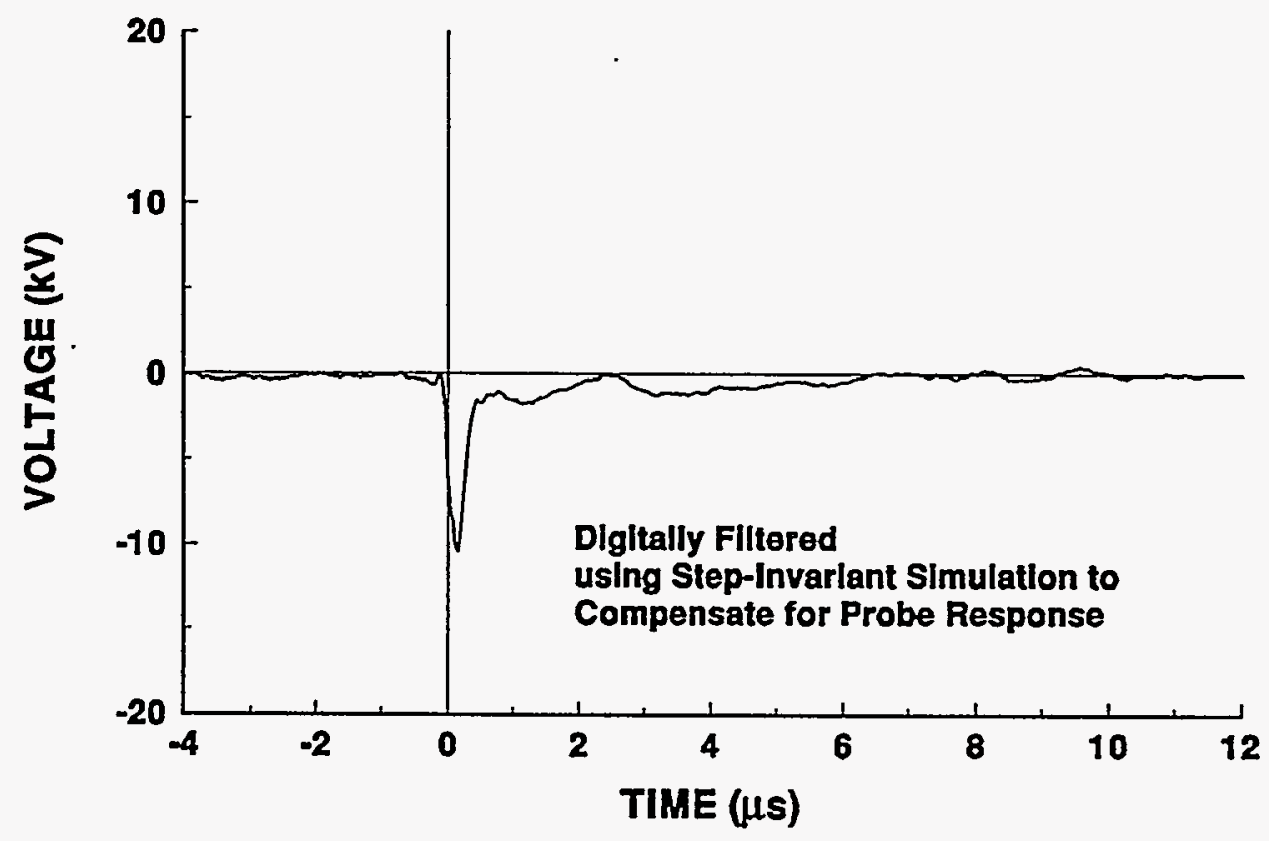

\section{4-21 STROKE 7.}

\section{TEST POINT 21}

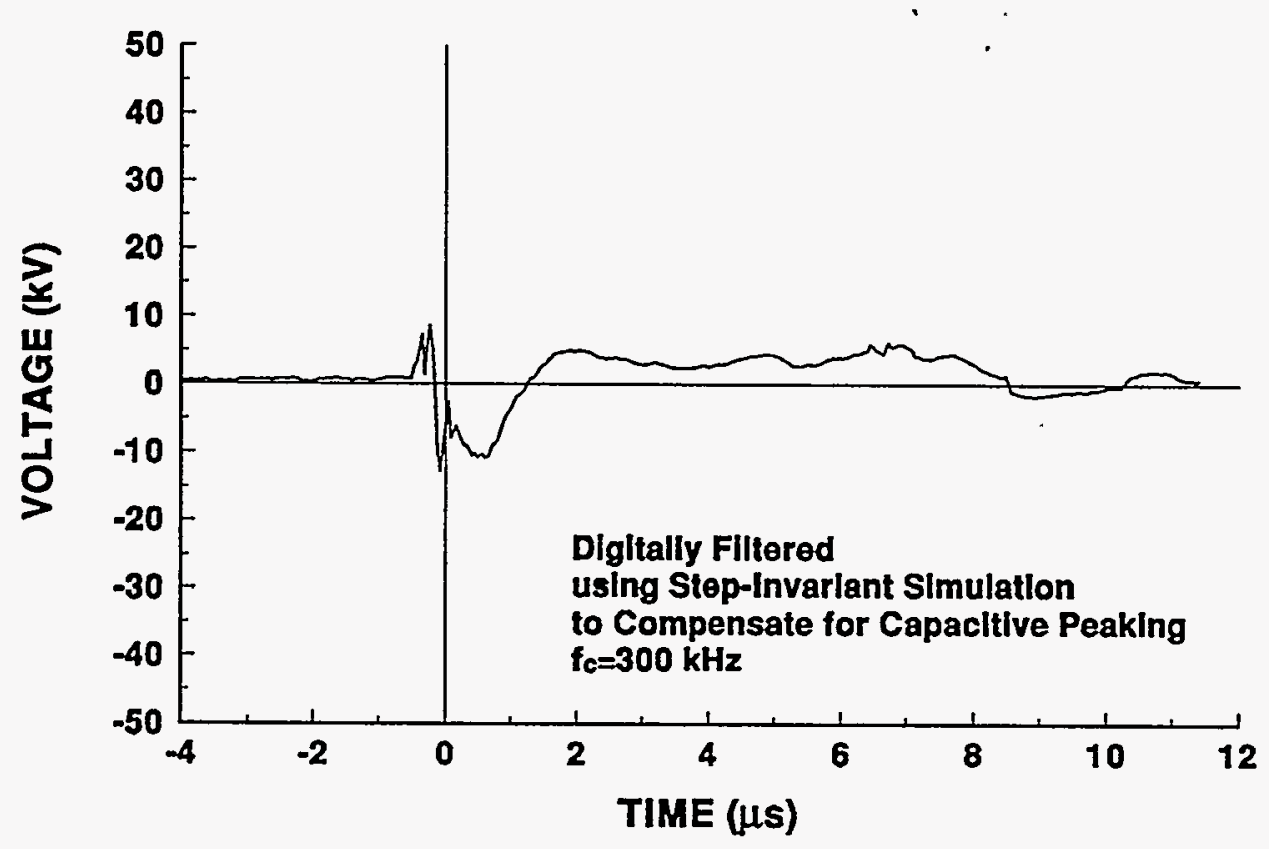




\section{4-21 STROKE 7}

TEST POINT 22

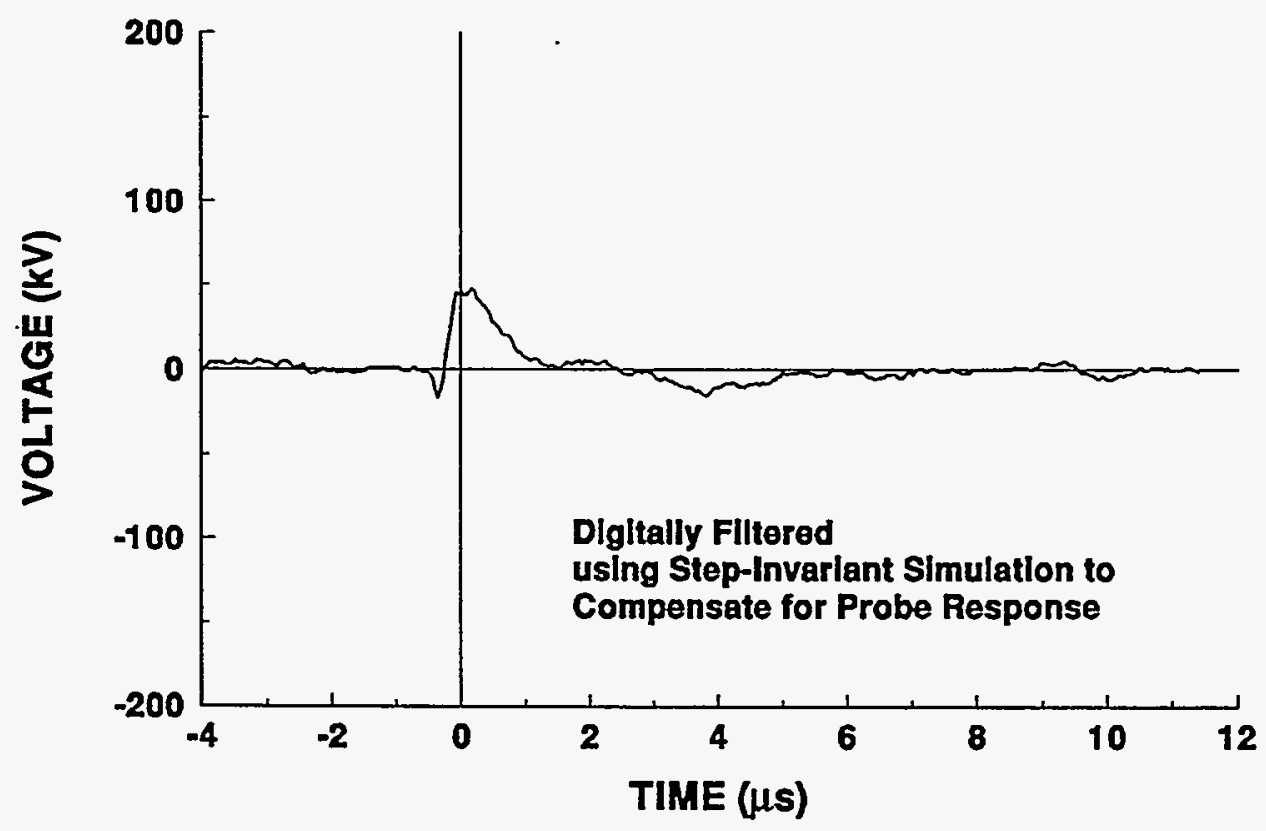




\section{4-21 STROKE 7}

TEST POINT 23

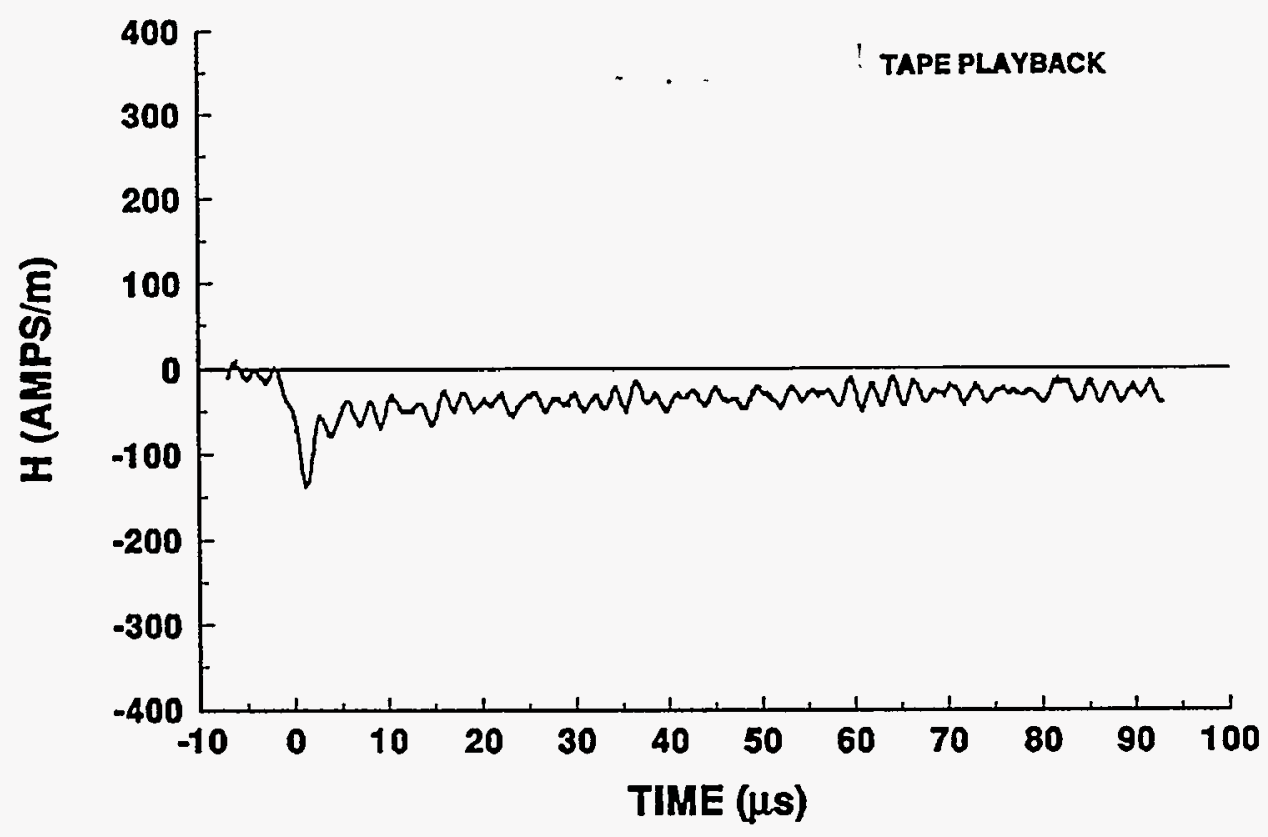

\section{4-21 STROKE.7}

TEST POINT 24

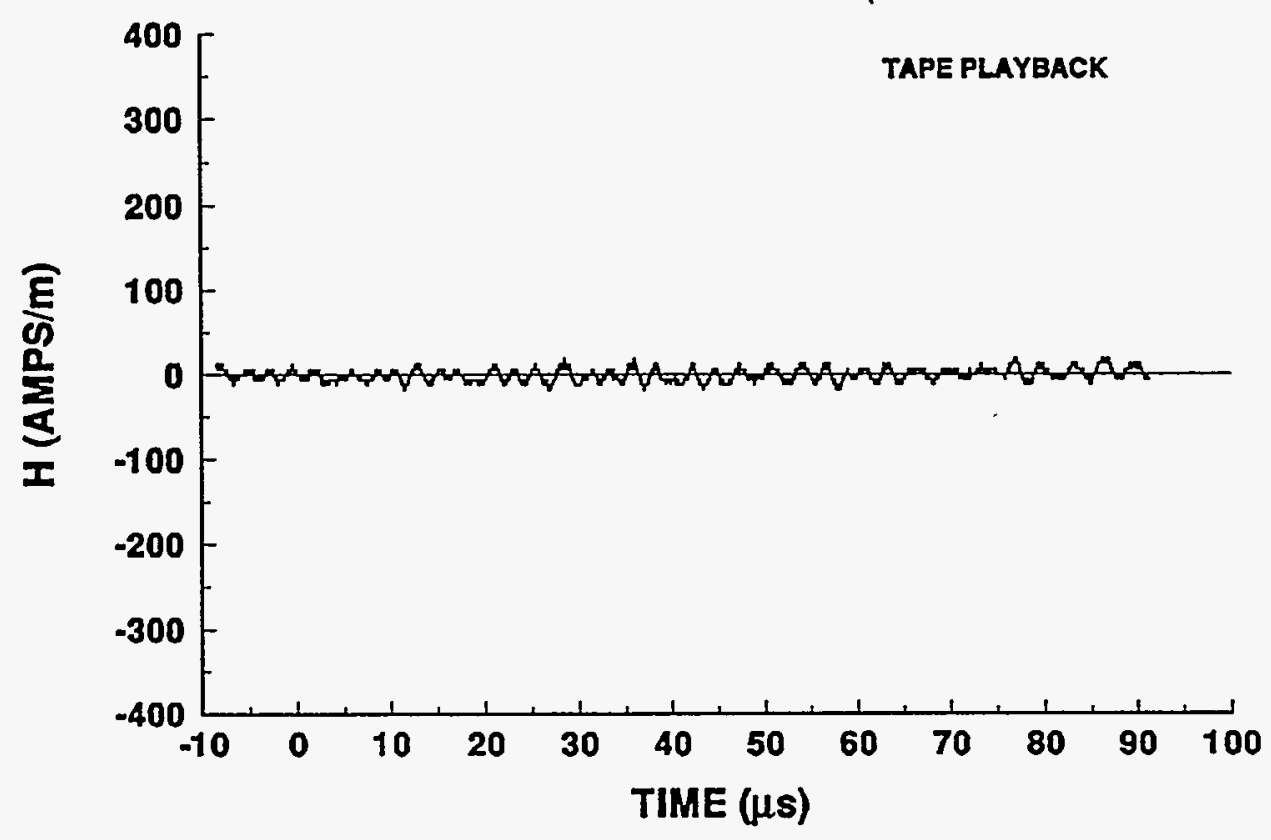




\section{4-22 STROKE 1 \\ INCIDENT CURRENT}
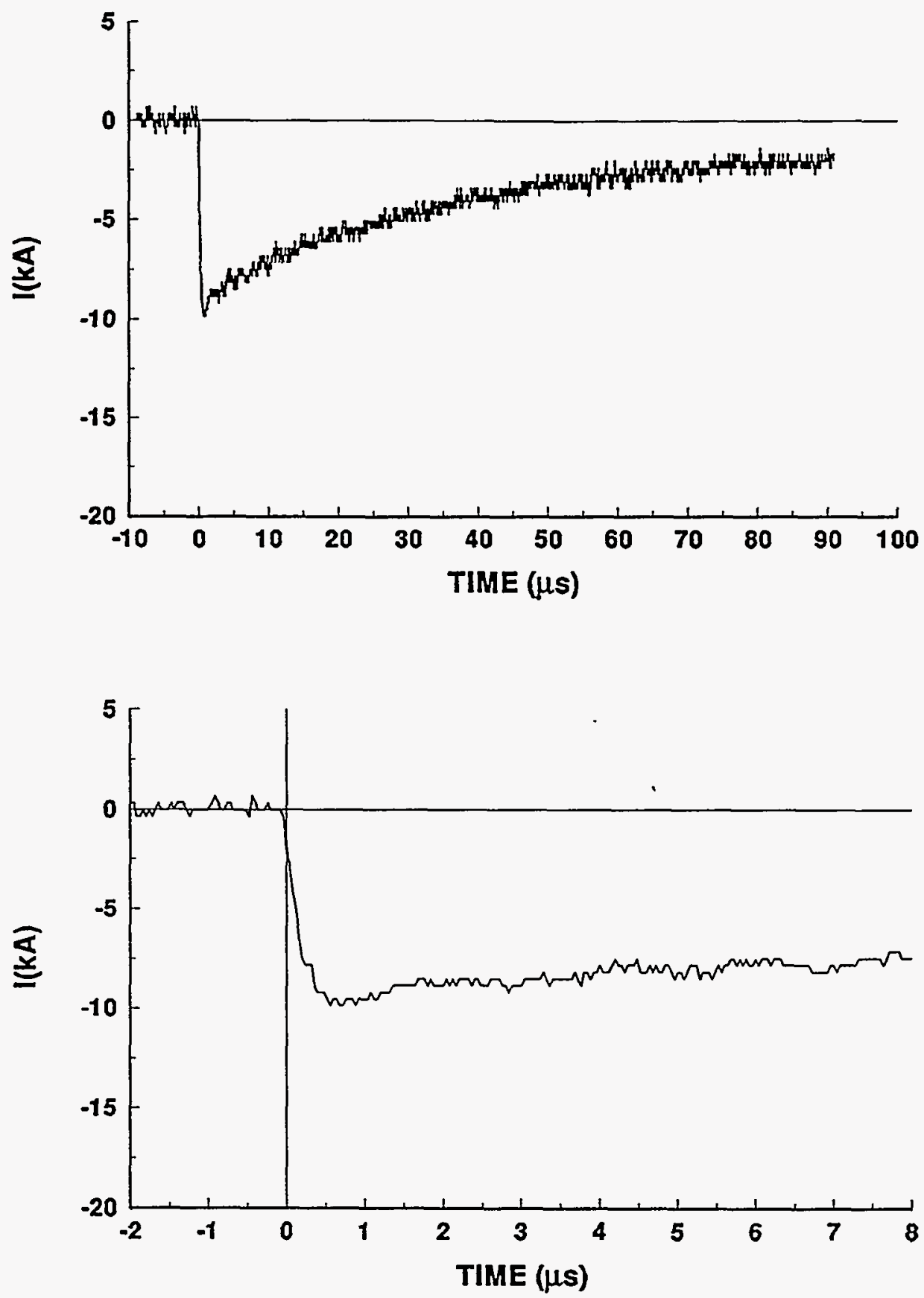


\section{4-22 STROKE 1}

\section{TEST POINT 1}
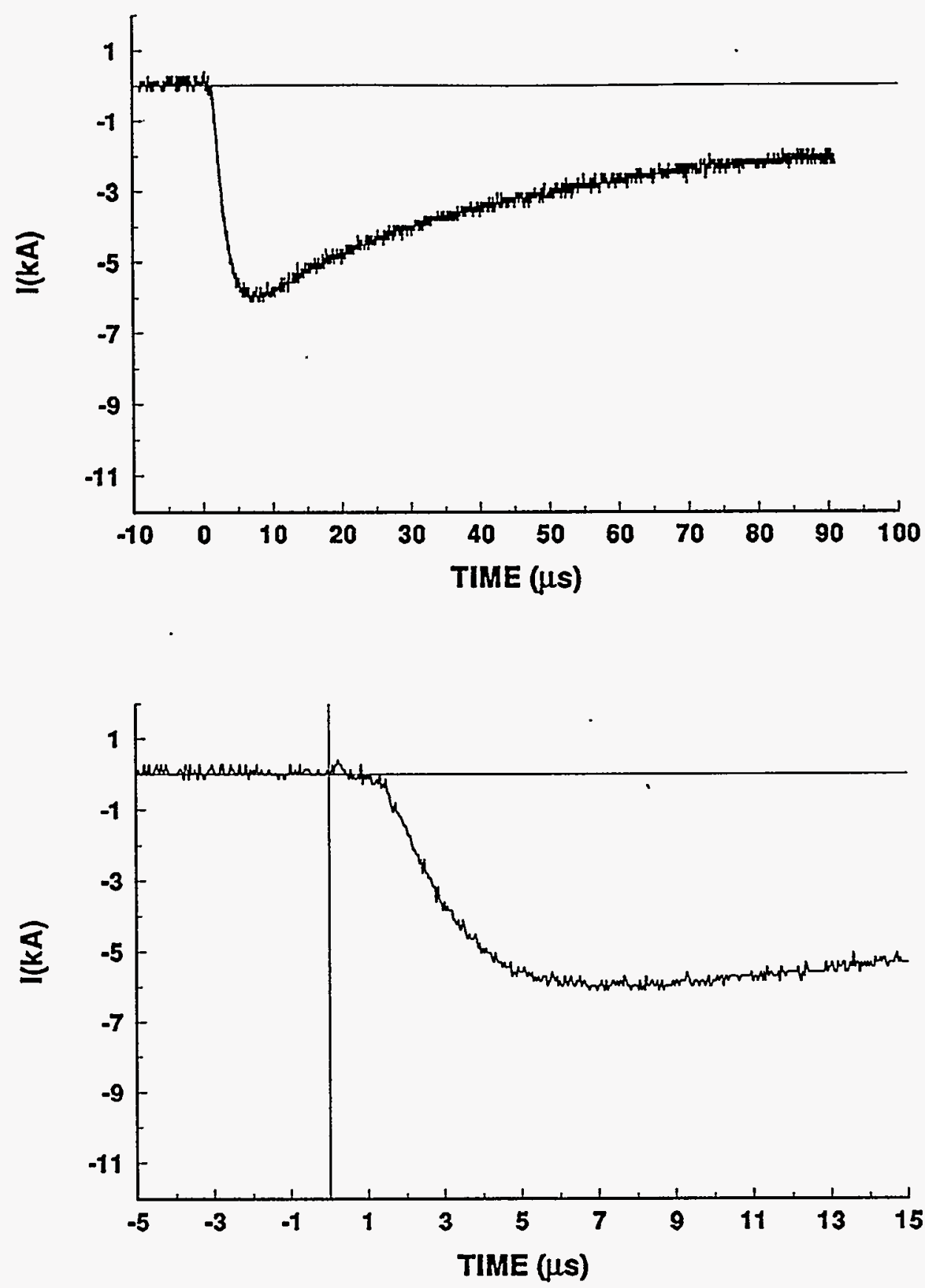


\section{4-22 STROKE 1}

\section{TEST POINT 2}
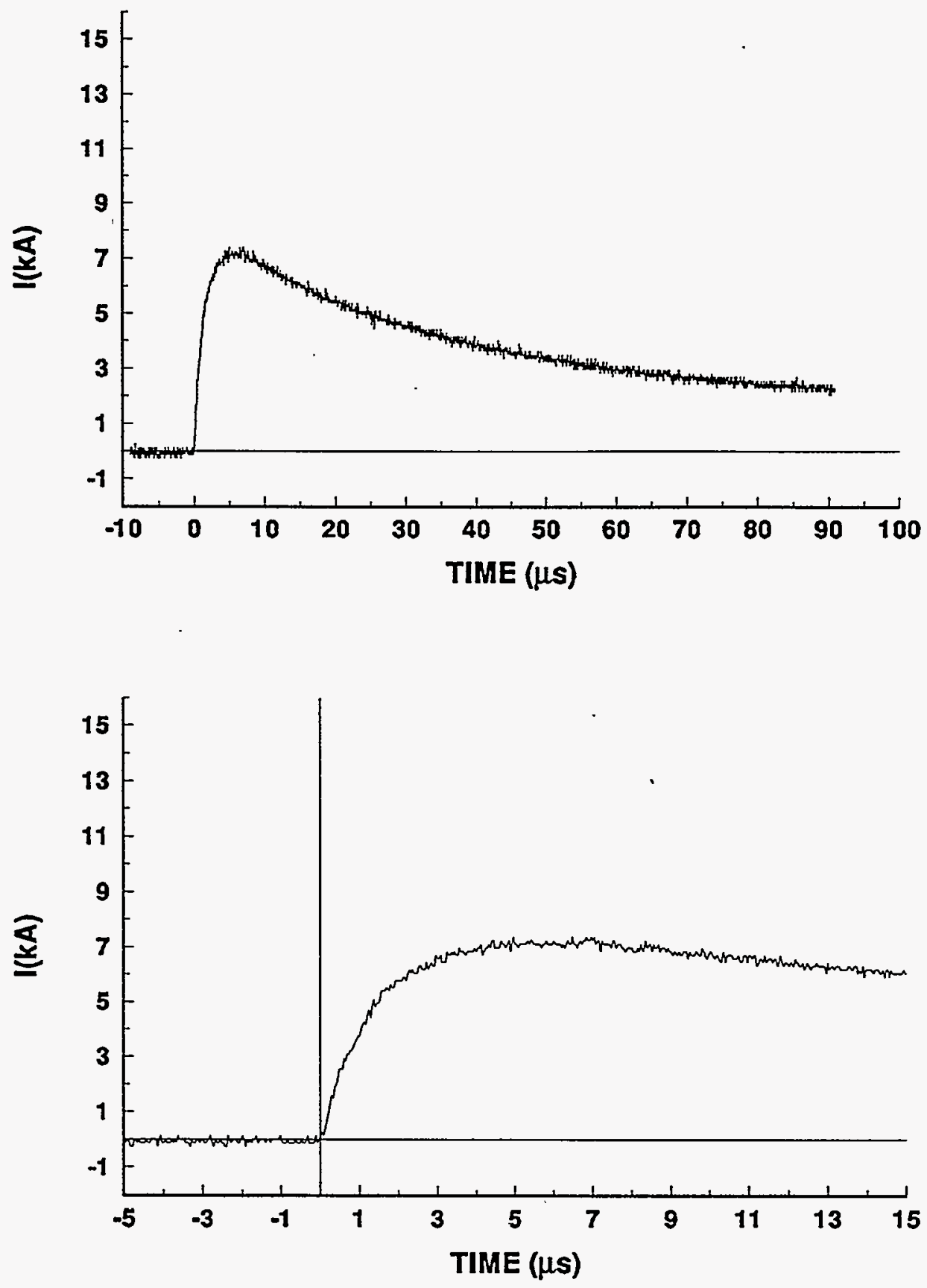


\section{4-22 STROKE 1}

TEST POINT 5
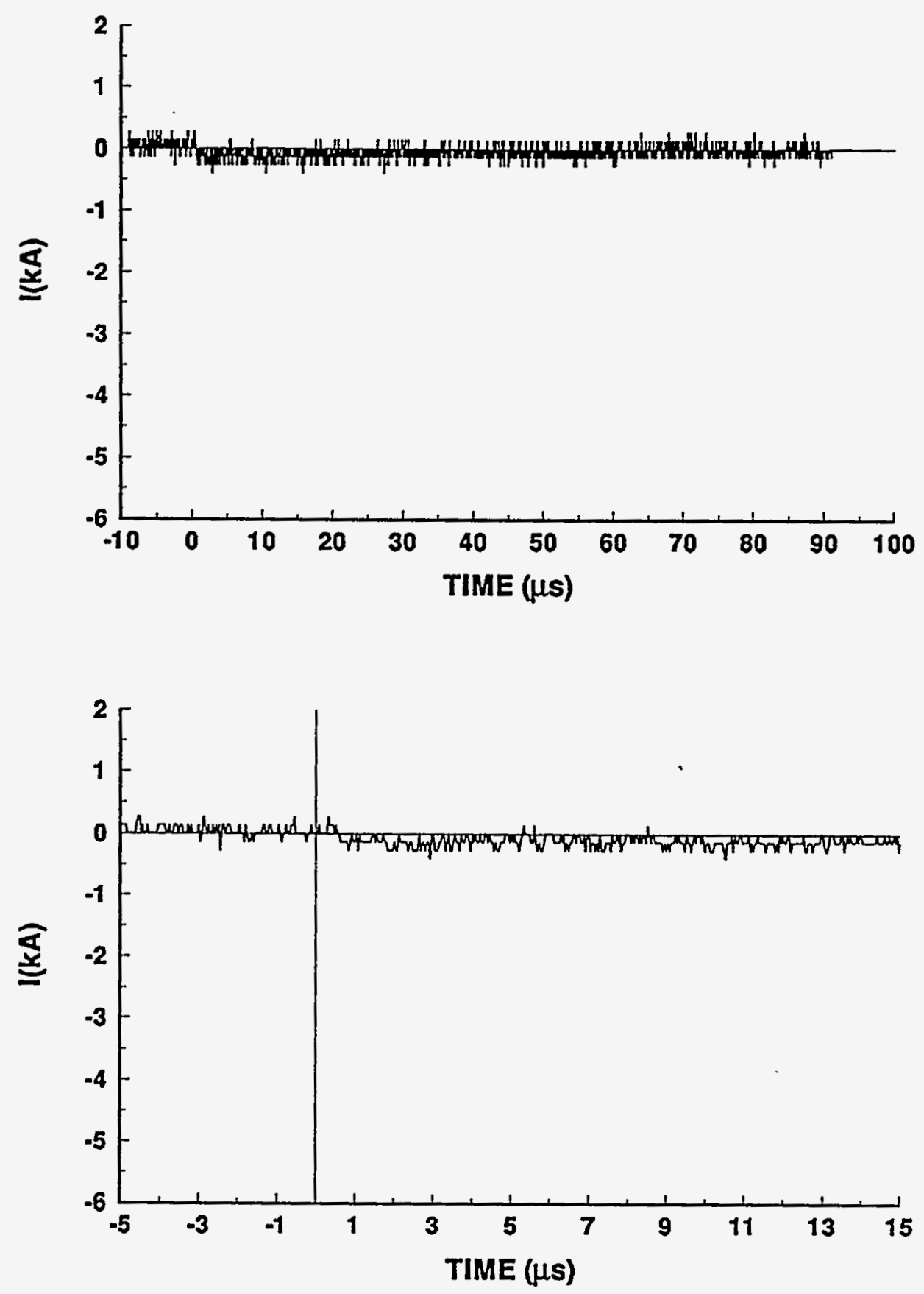


\section{4-22 STROKE 1 TEST POINT 6}
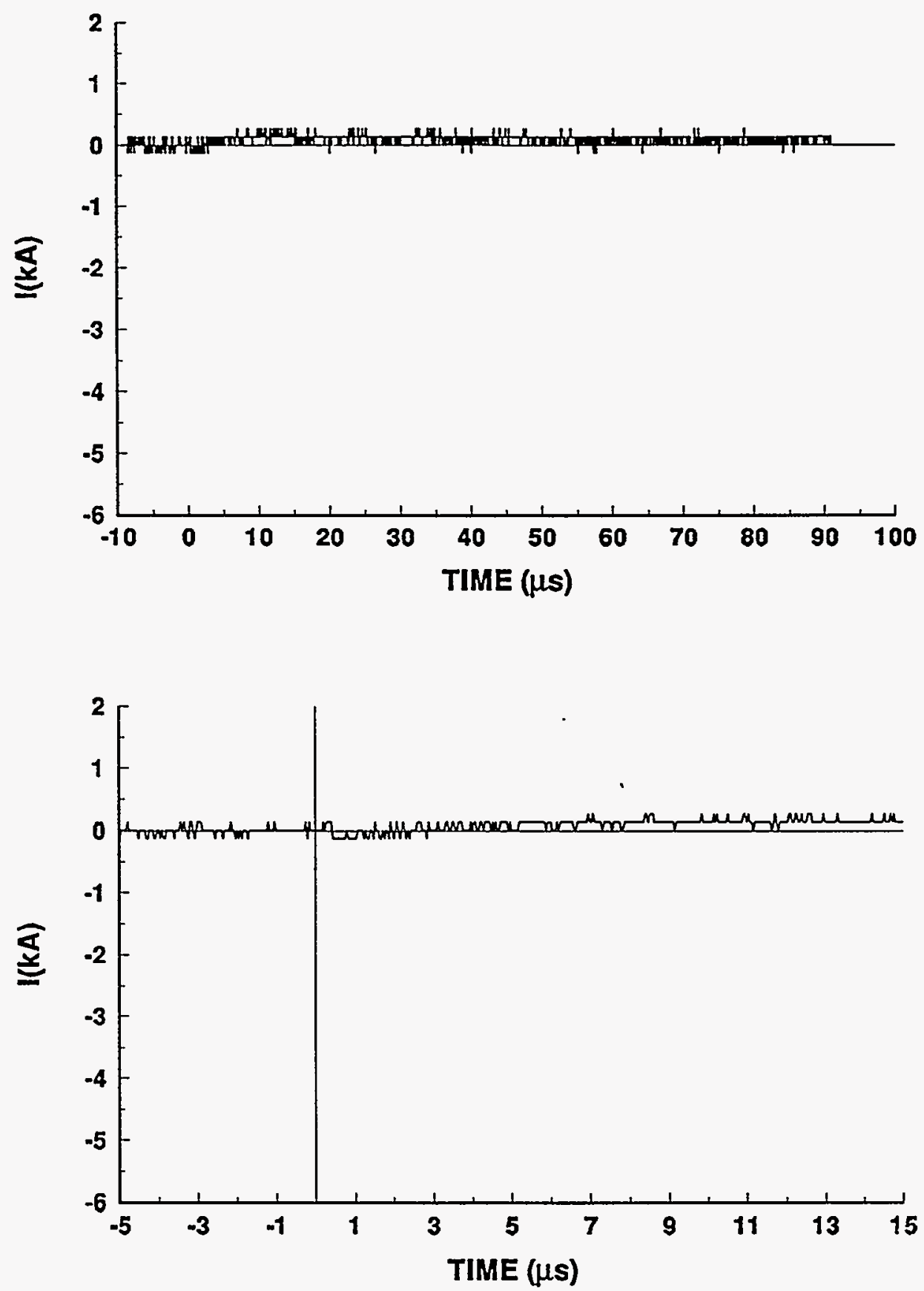


\section{4-22 STROKE 1 \\ TEST POINT 5'}

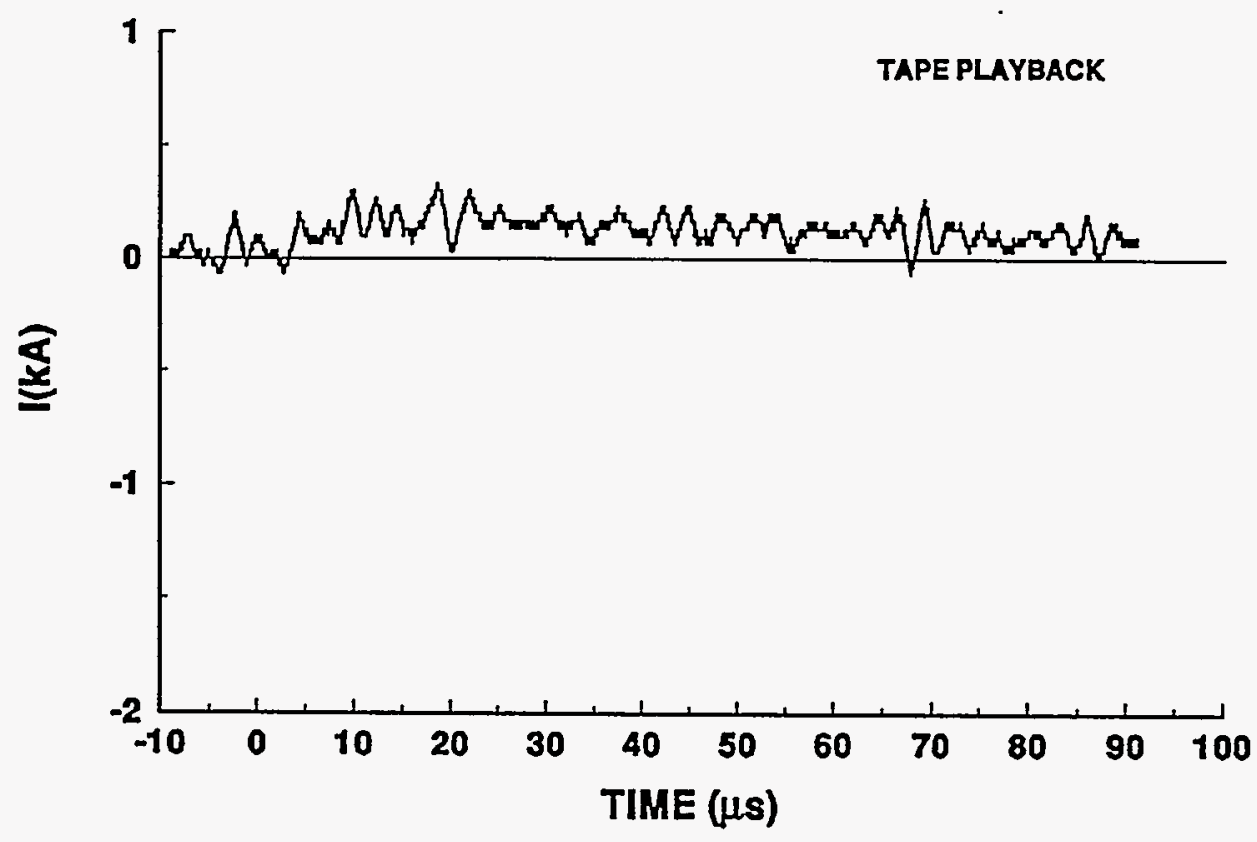

94-22 STROKE 1

TEST POINT 6'

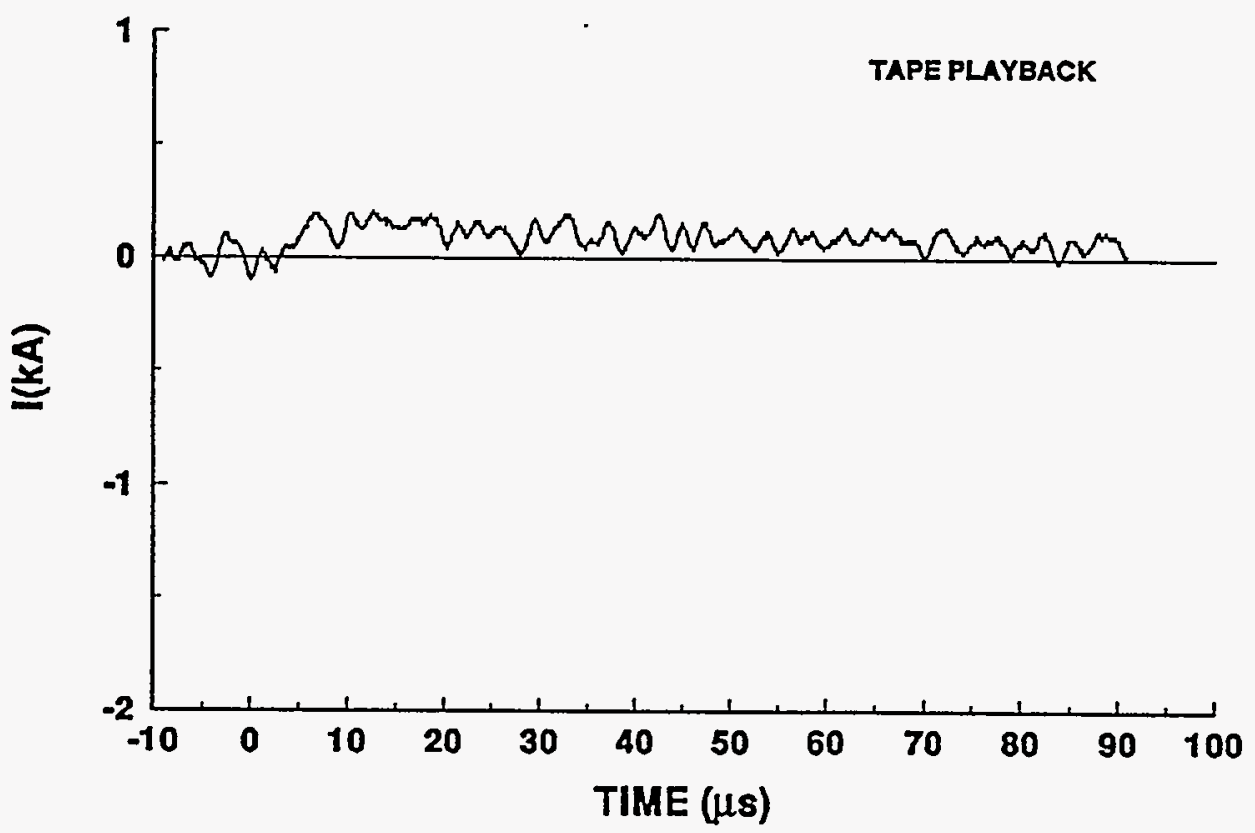




\section{4-22 STROKE 1}

TEST POINT 10

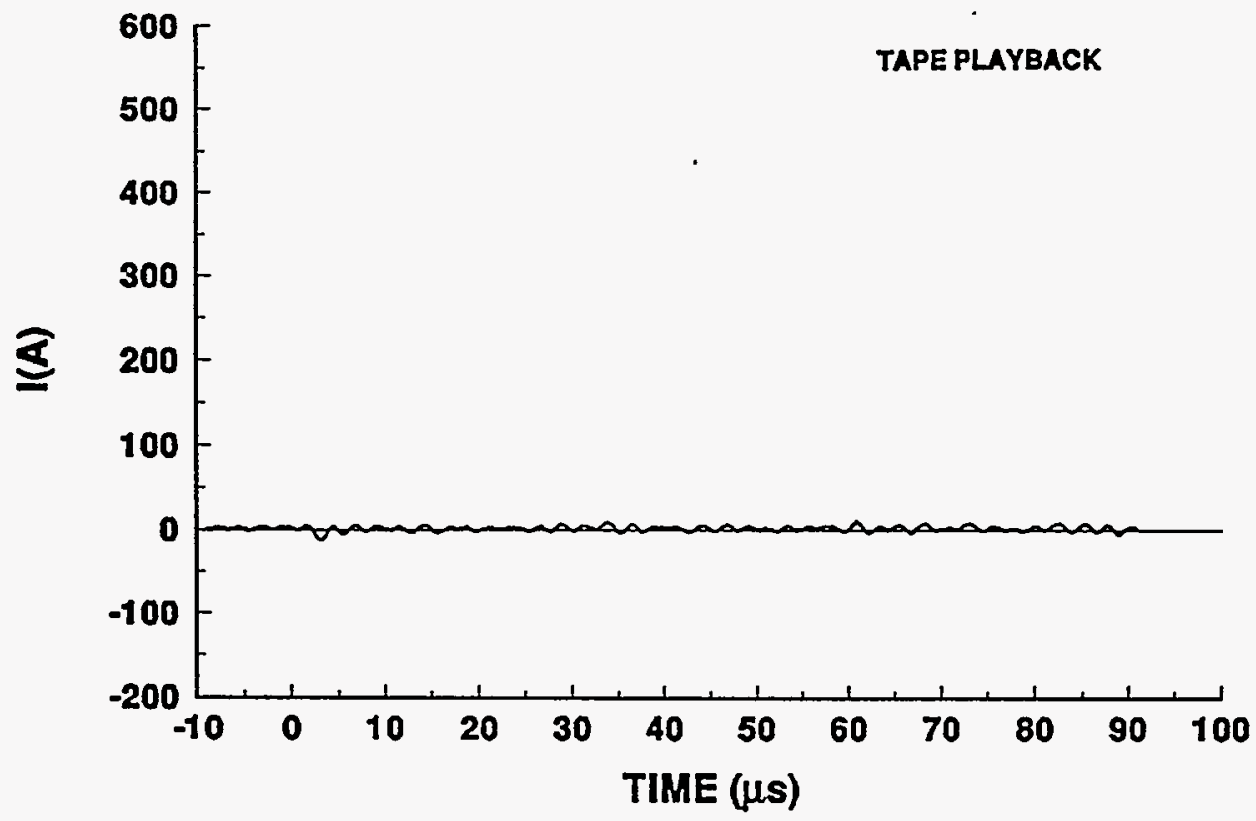

94-22 STROKE 1

TEST POINT 11

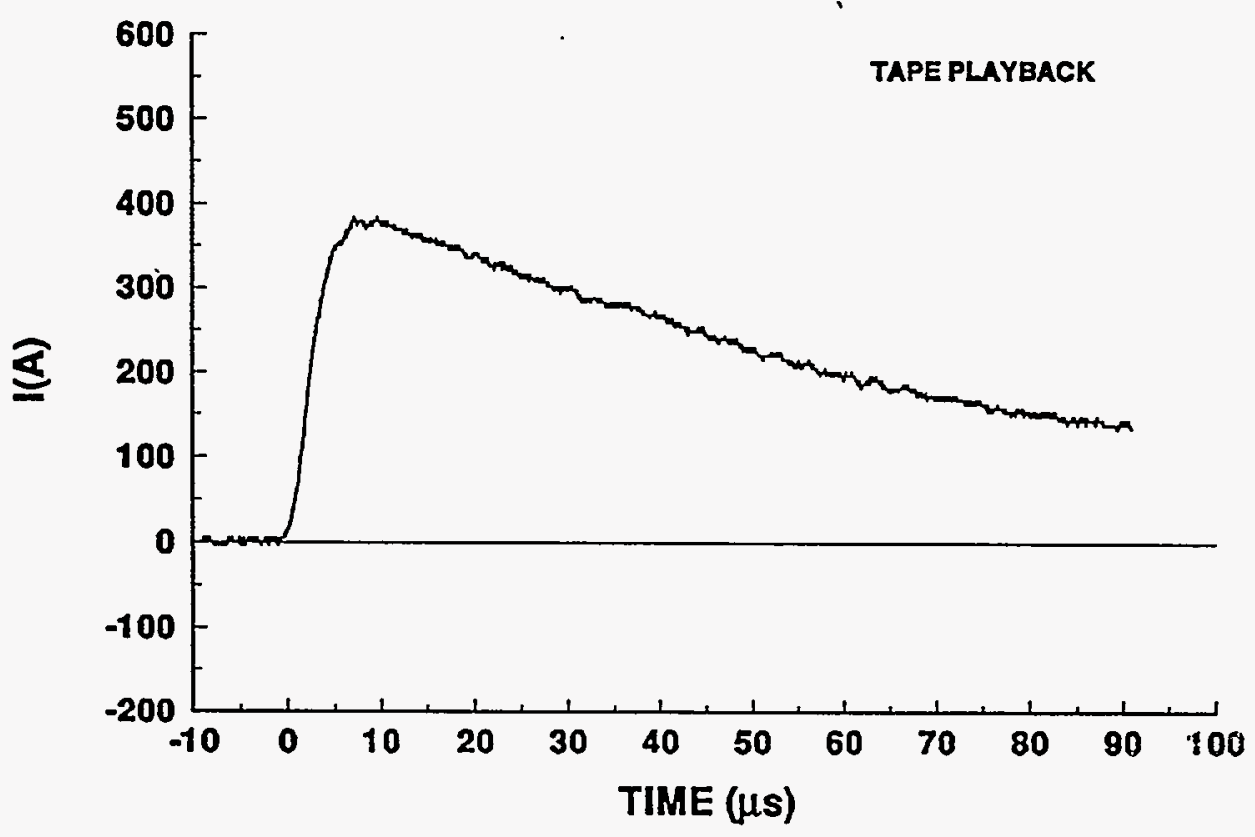




\section{4-22 STROKE 1}

\section{TEST POINT 12}

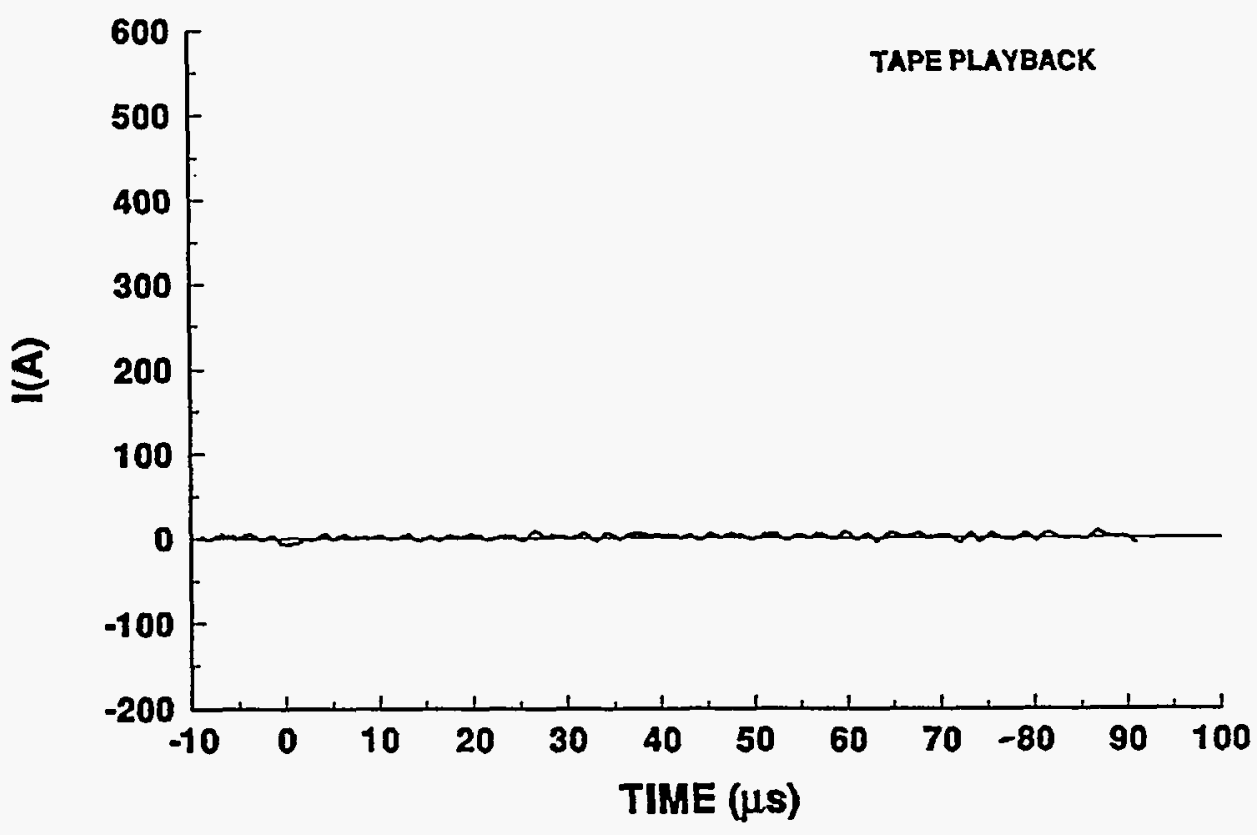

\section{4-22 STROKE 1}

TEST POINT 13

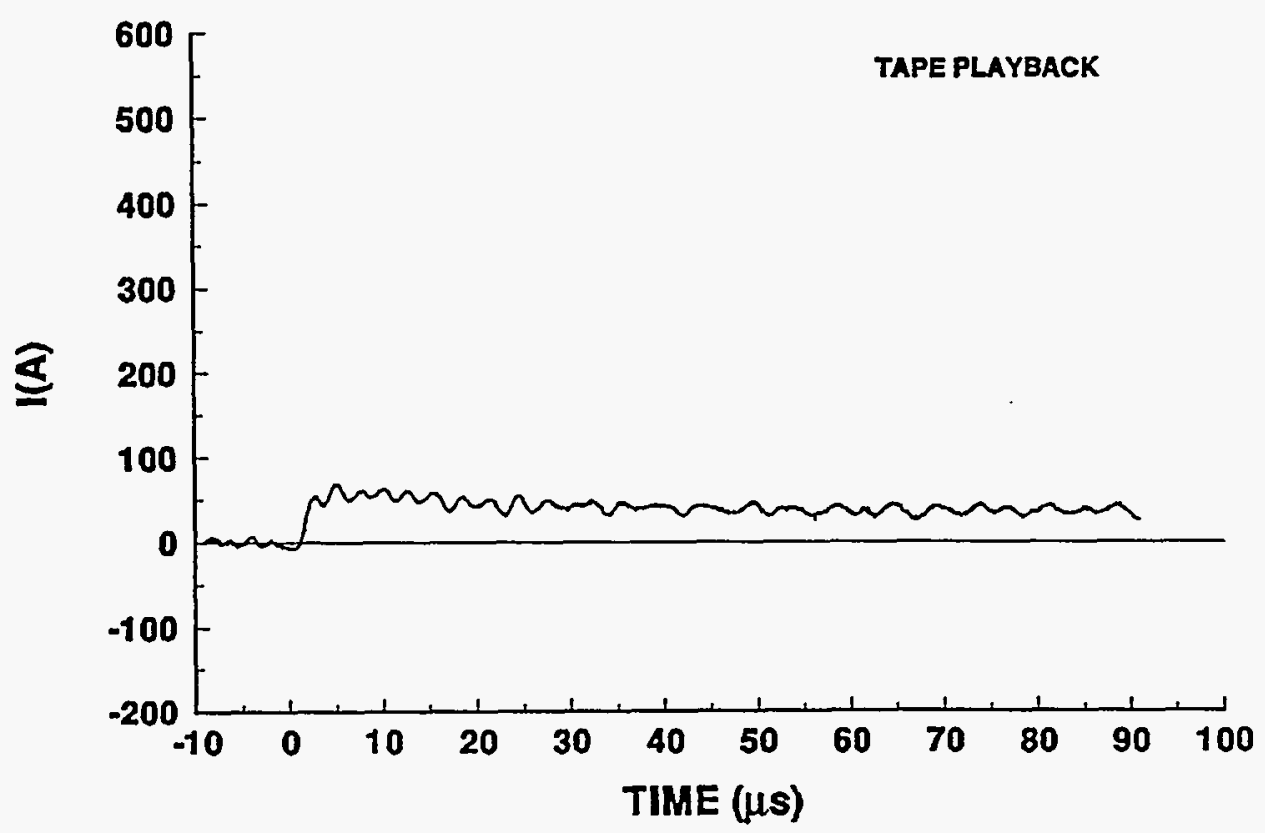




\section{4-22 STROKE 1}

TEST POINT 14
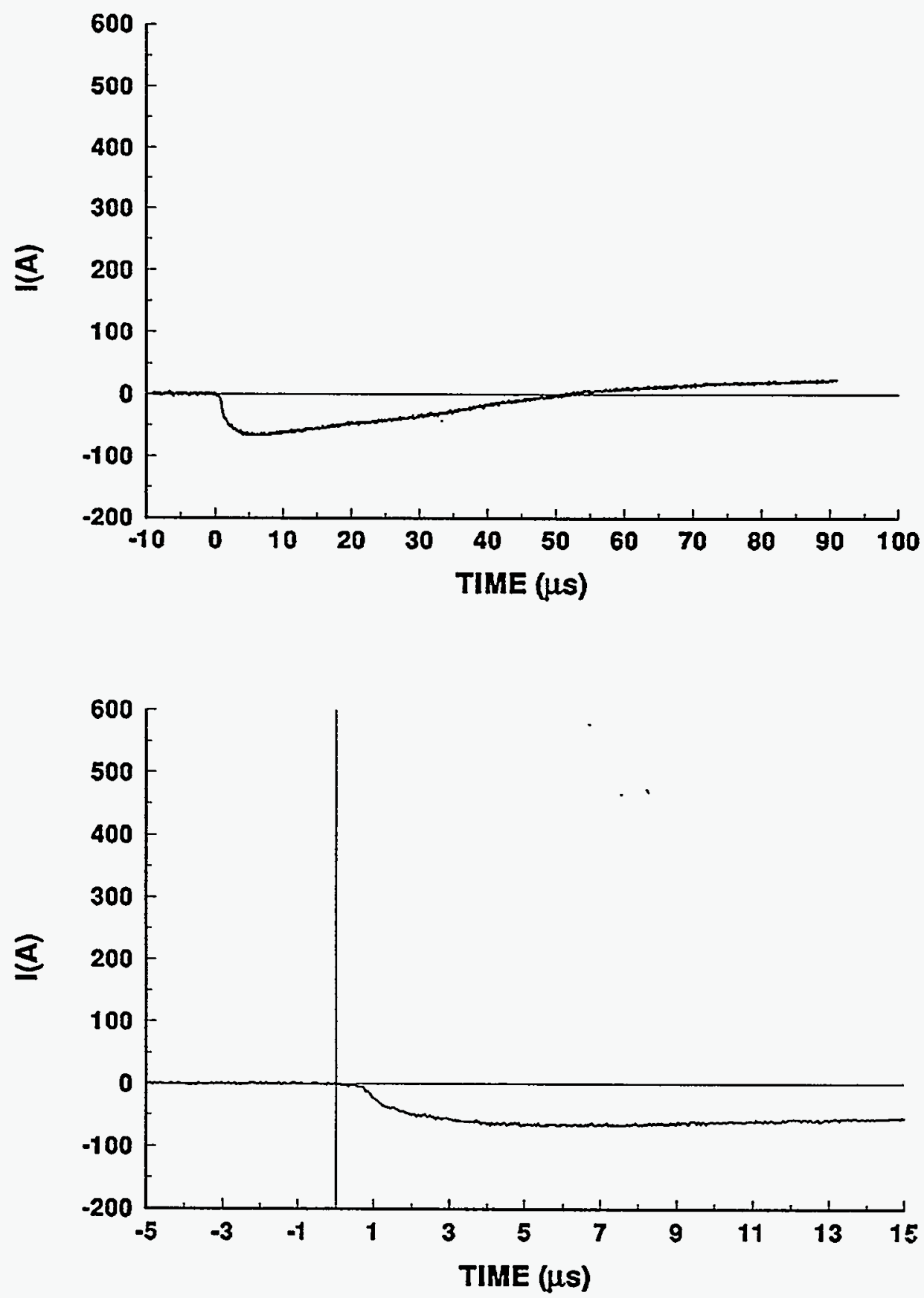


\section{4-22 STROKE 1}

TEST POINT 15
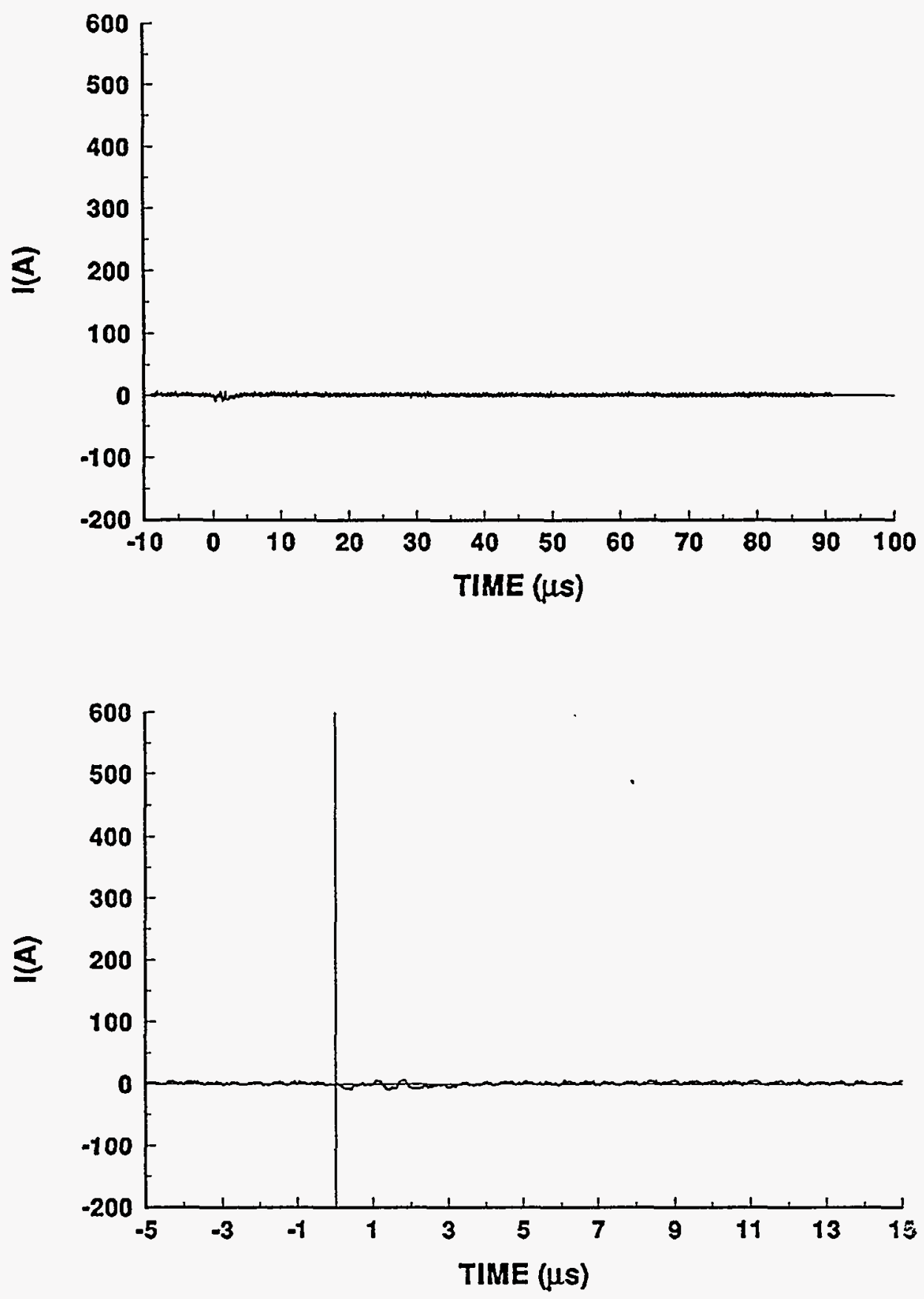


\section{4-22 STROKE 1}

TEST POINT 20

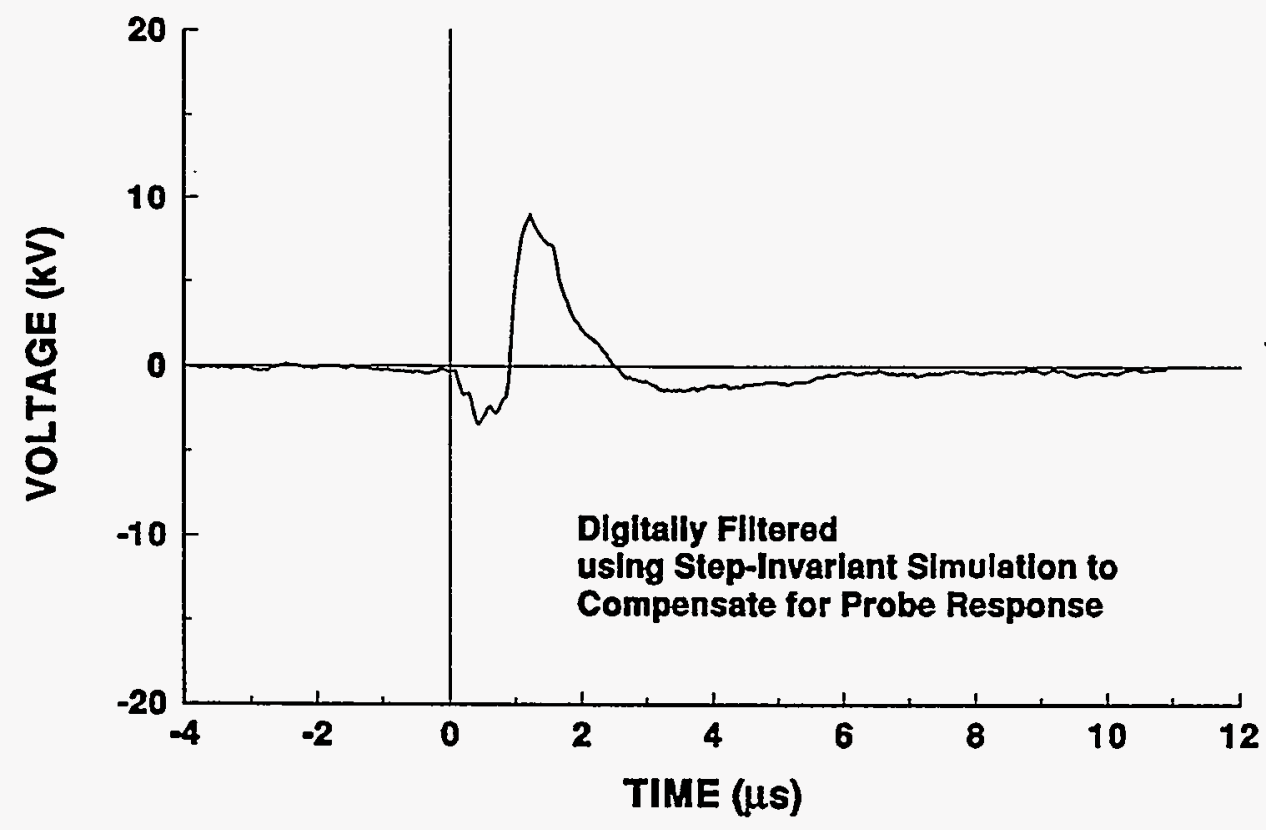

\section{4-22 STROKE.1}

TEST POINT 21

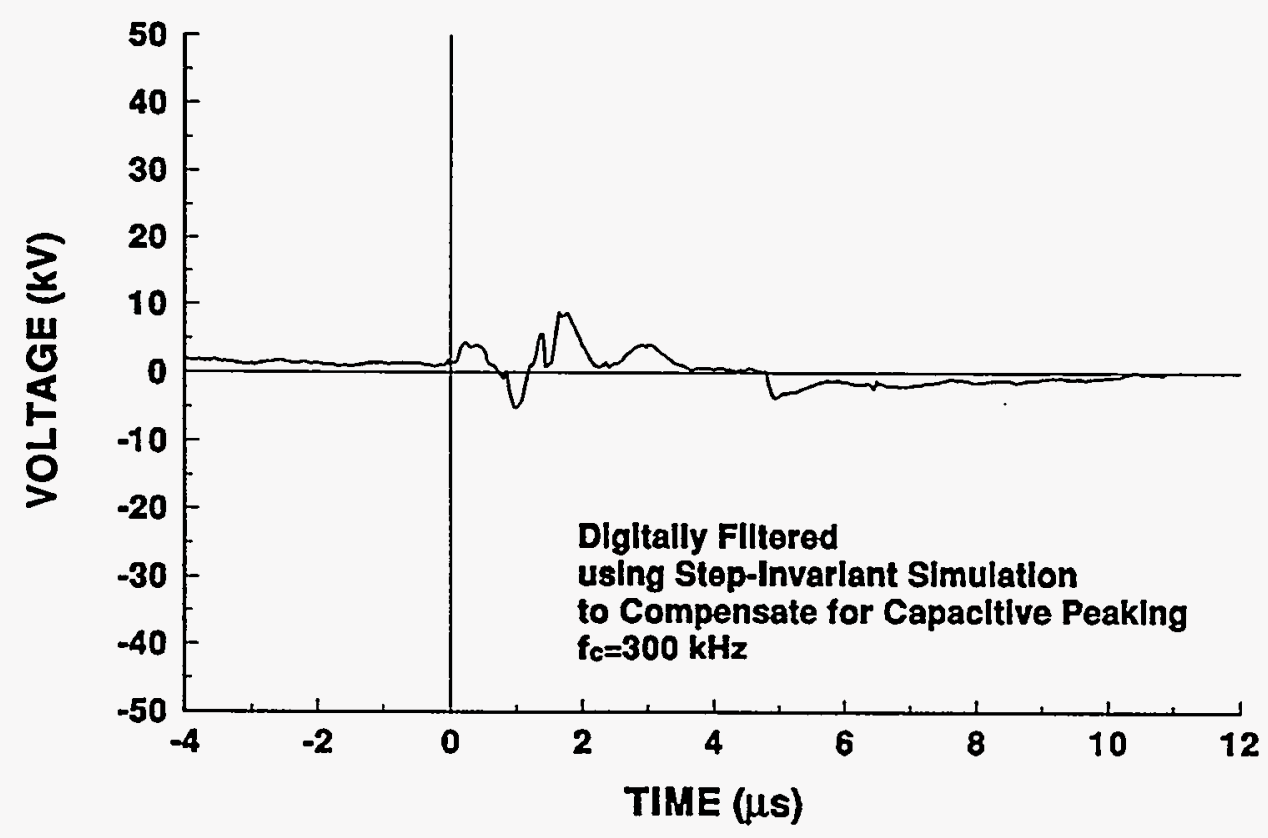




\section{4-22 STROKE 1}

TEST POINT 22

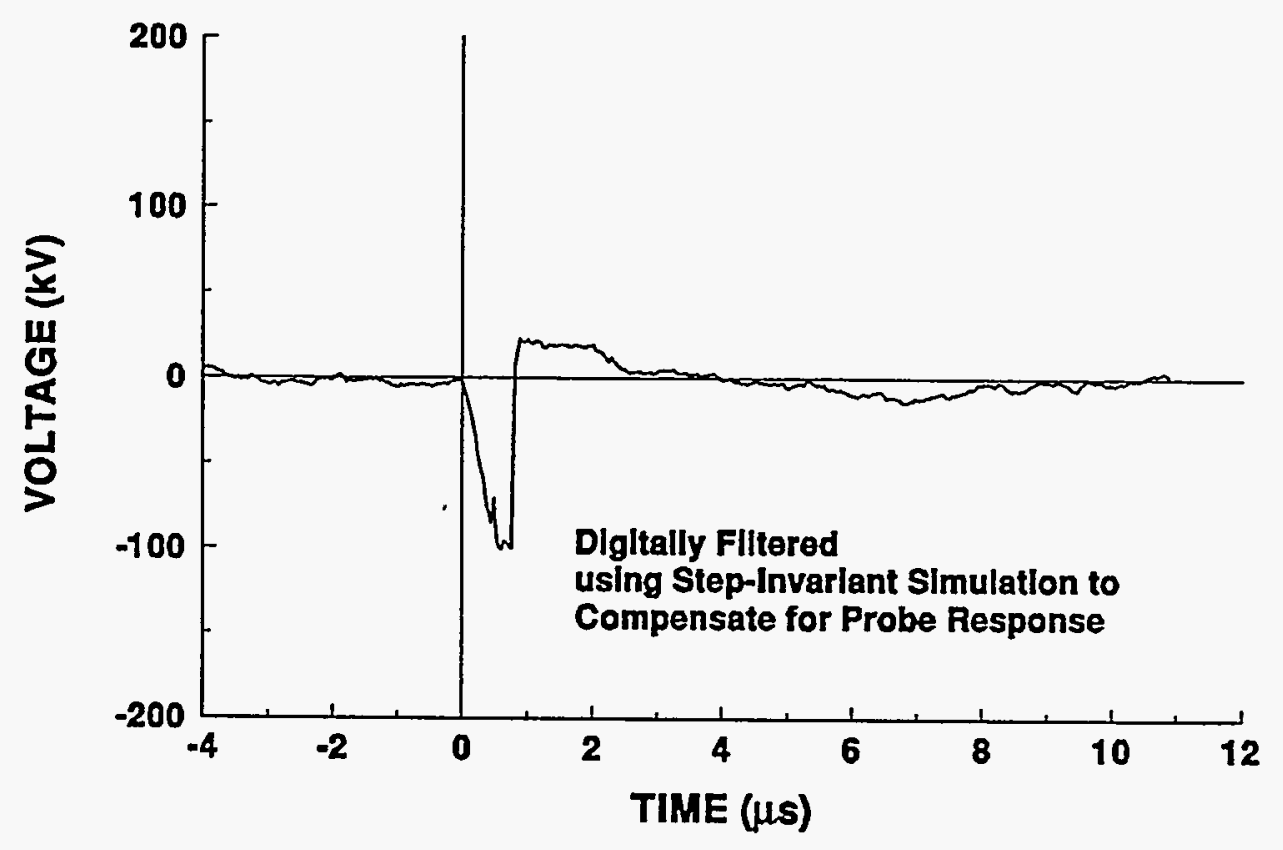




\section{4-22 STROKE 1 \\ TEST POINT 23}

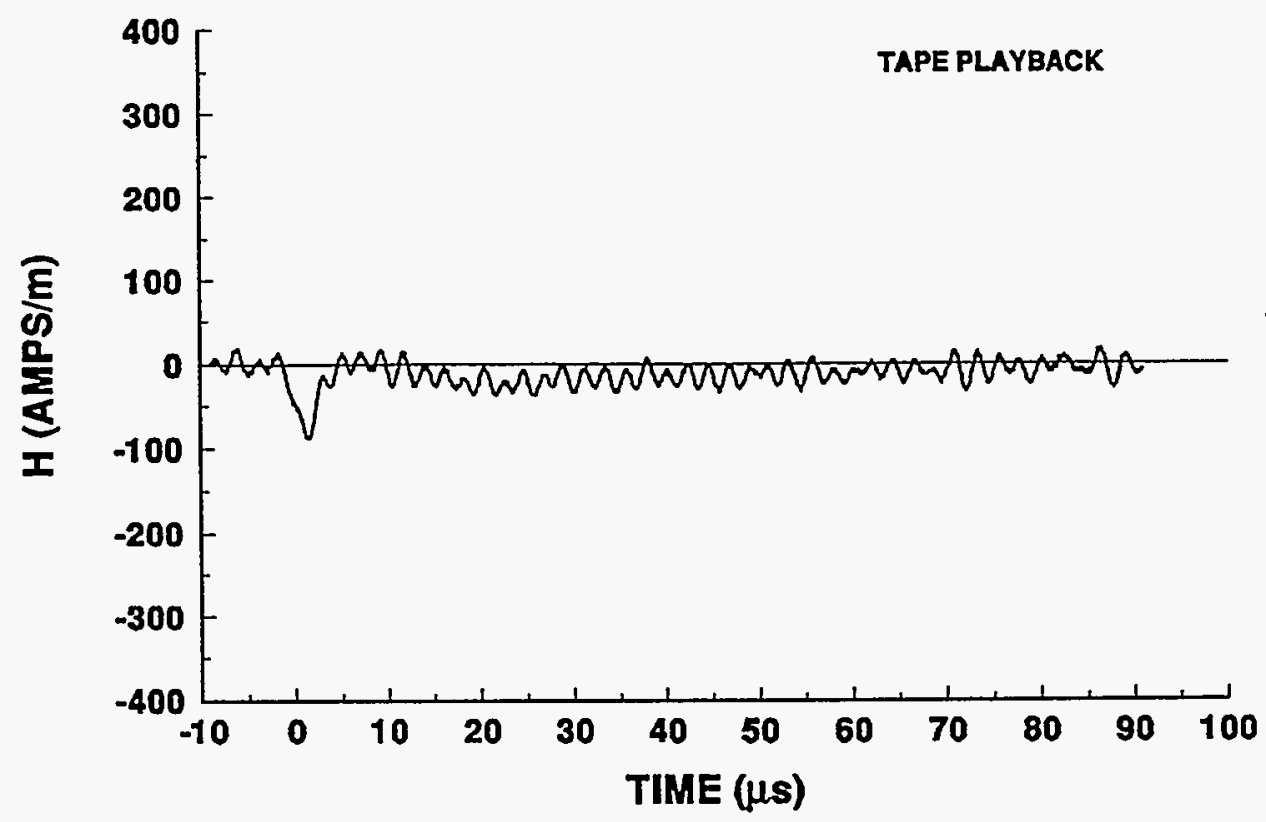

94-22 STROKE-1

TEST POINT 24

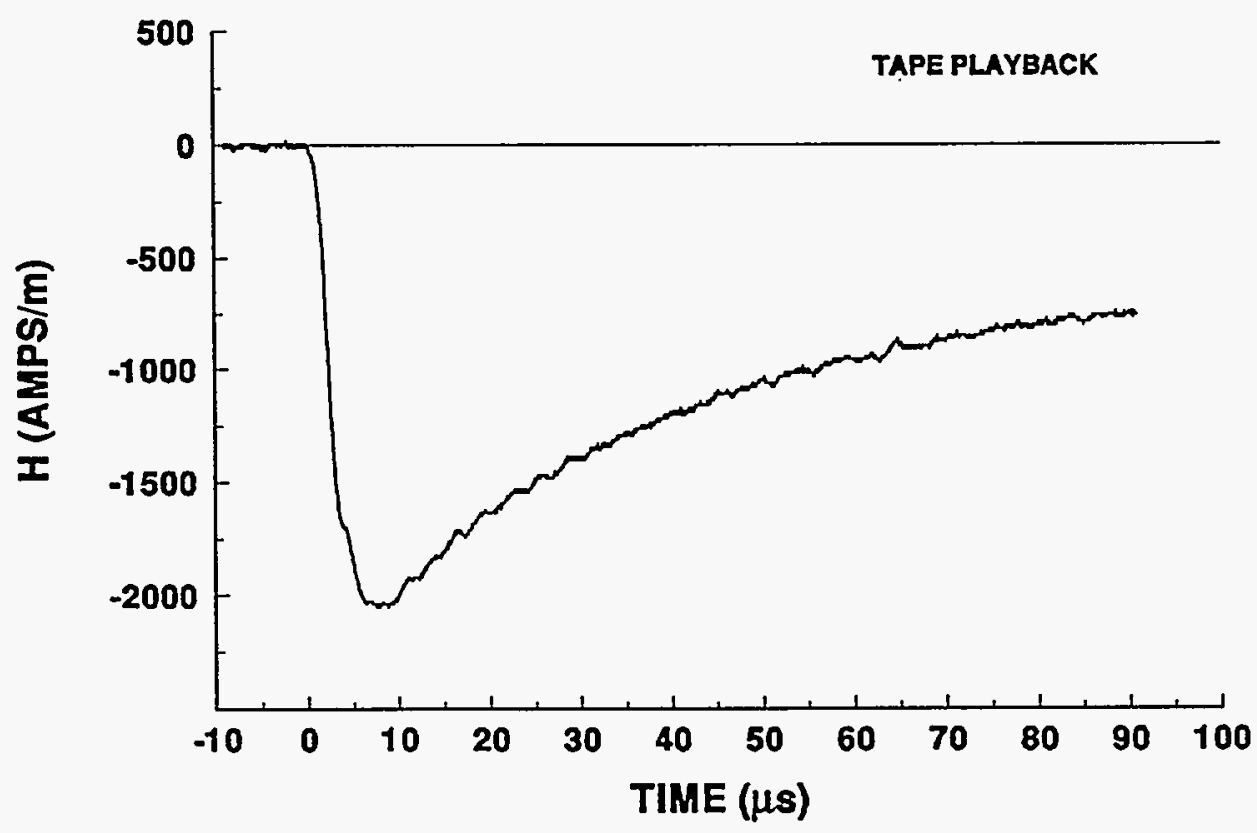




\section{4-22 STROKE 2 \\ INCIDENT CURRENT}
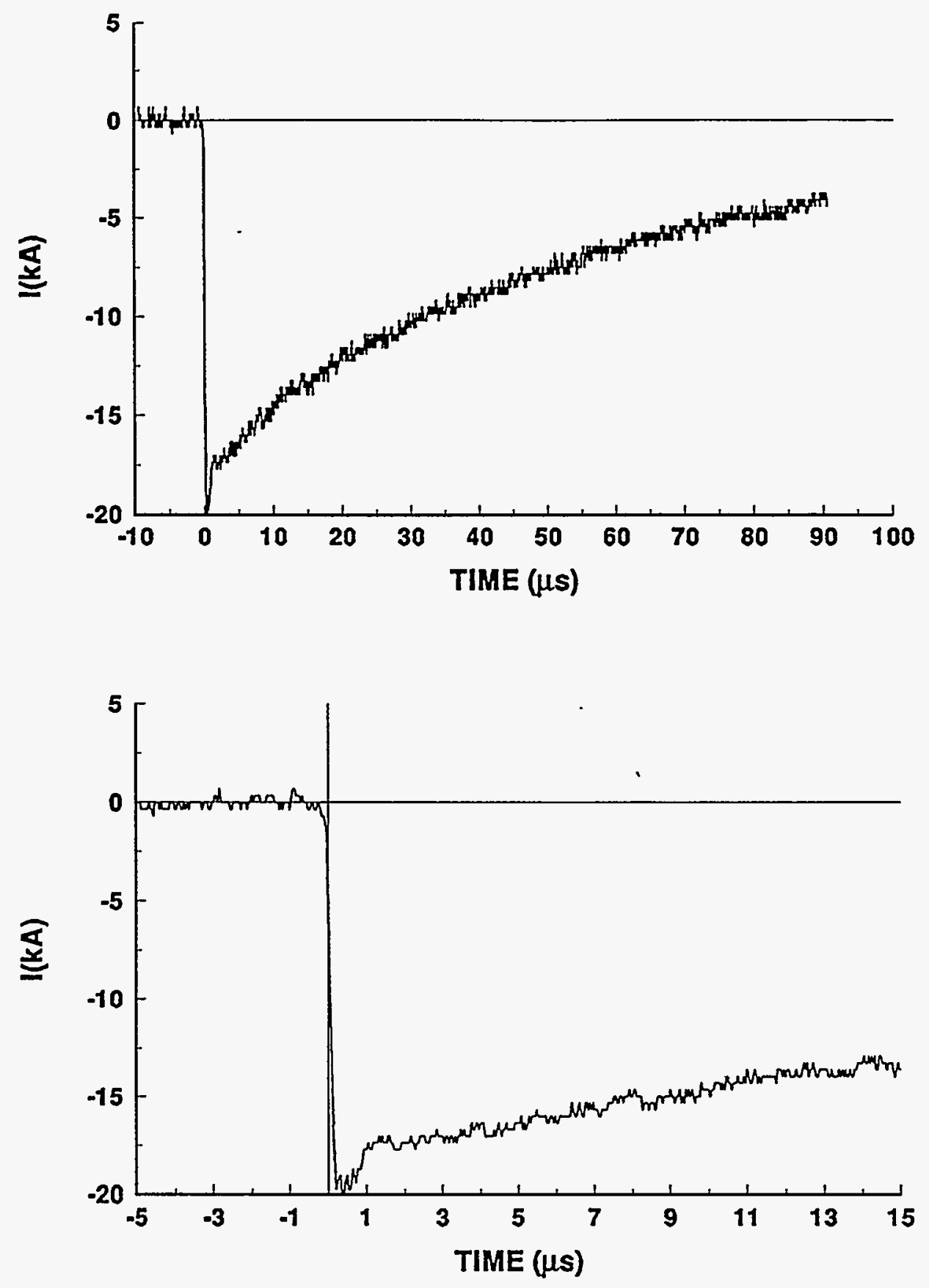
94-22 STROKE 2

TEST POINT 1
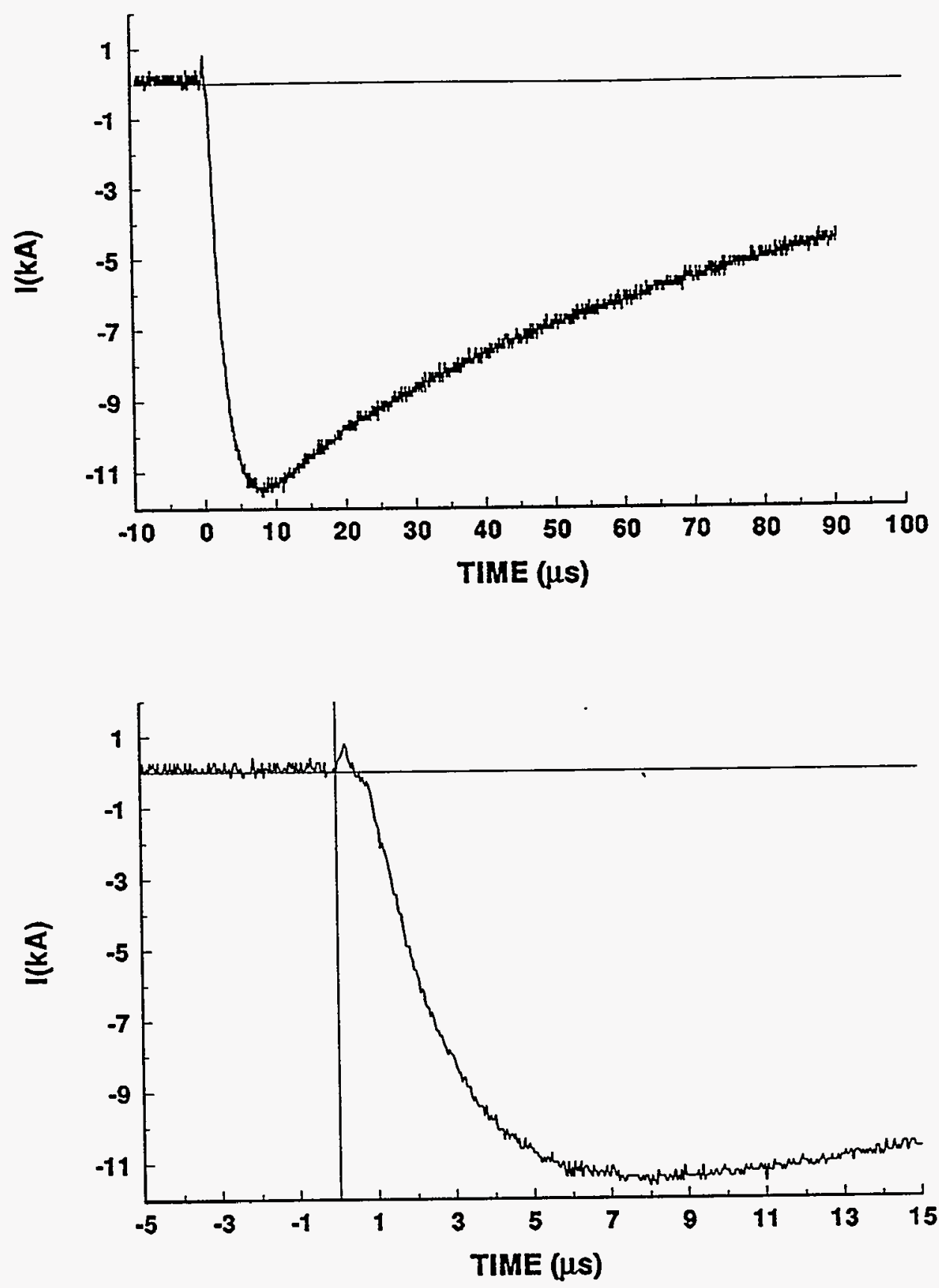


\section{4-22 STROKE 2}

\section{TEST POINT 2}
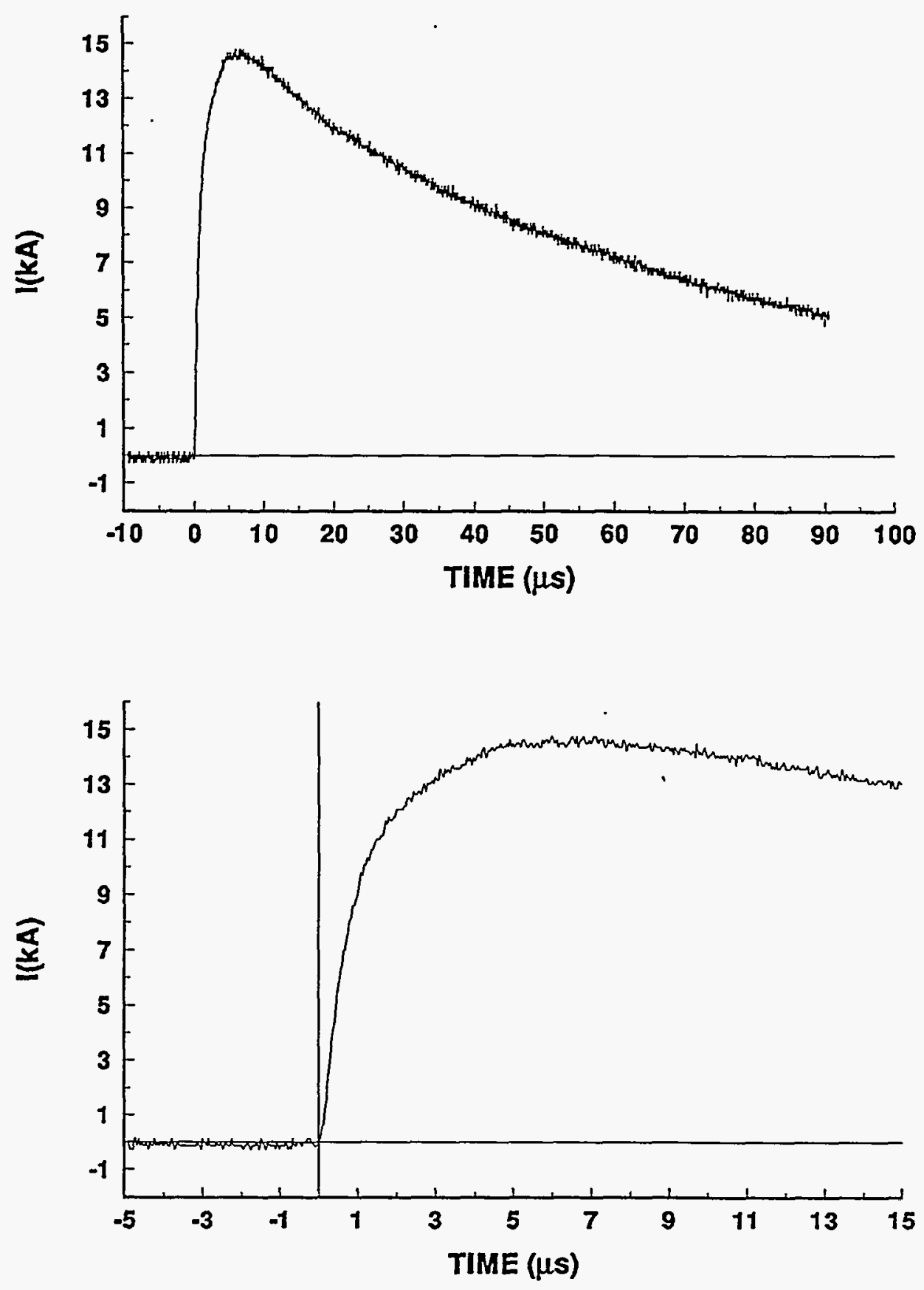


\section{4-22 STROKE 2 \\ TEST POINT 5}
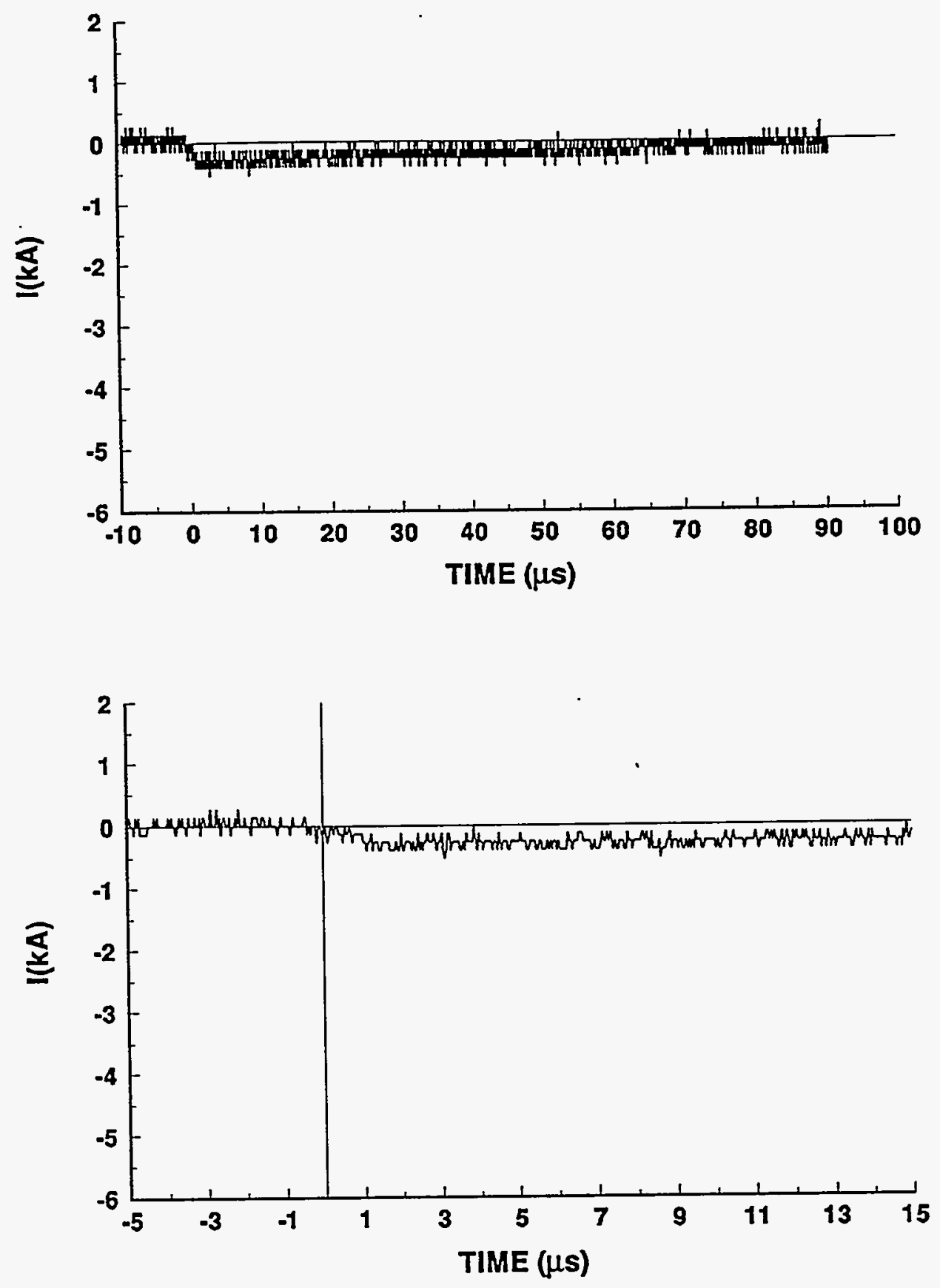


\section{4-22 STROKE 2}

\section{TEST POINT 6}
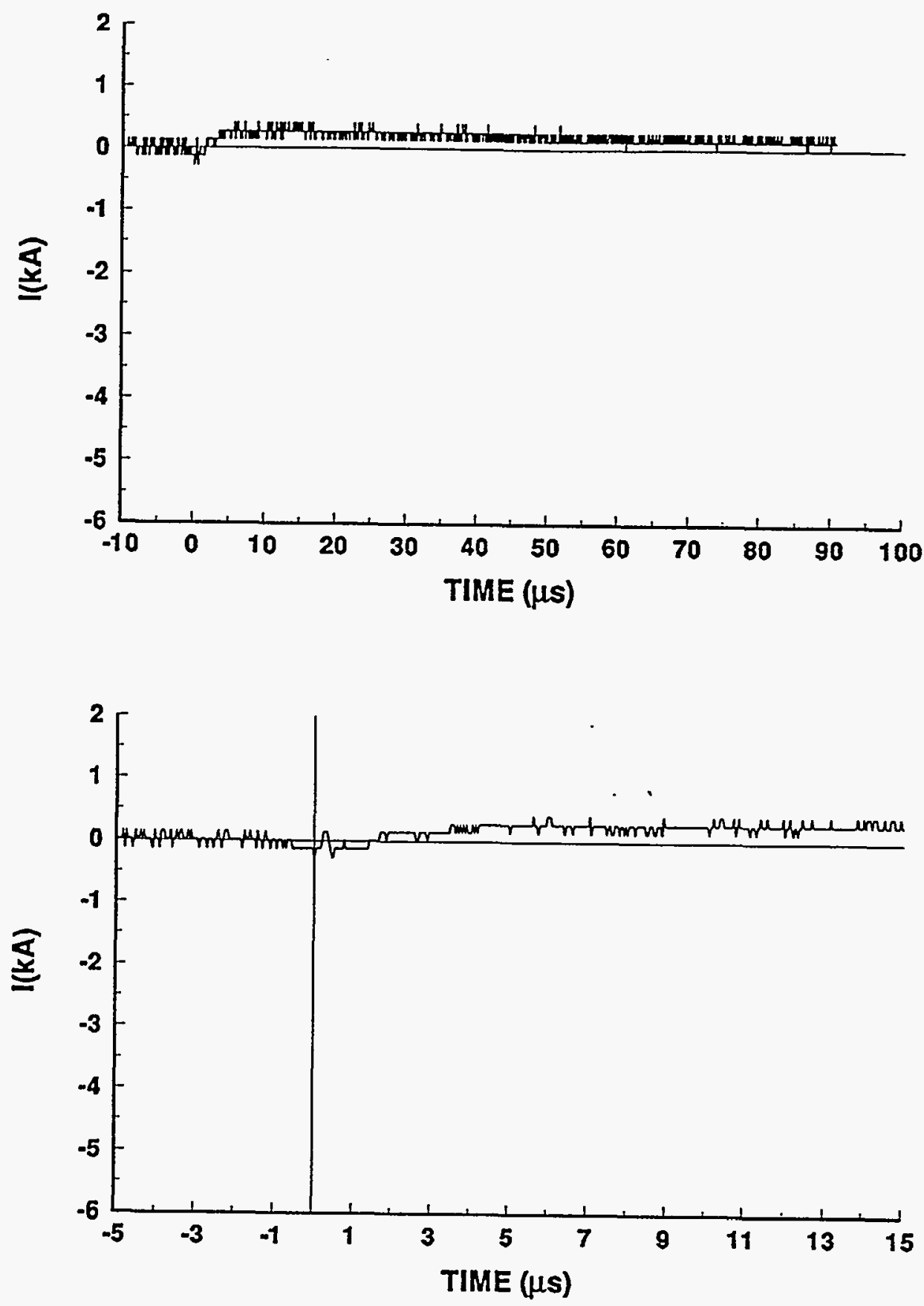
94-22 STROKE 2

TEST POINT 5'

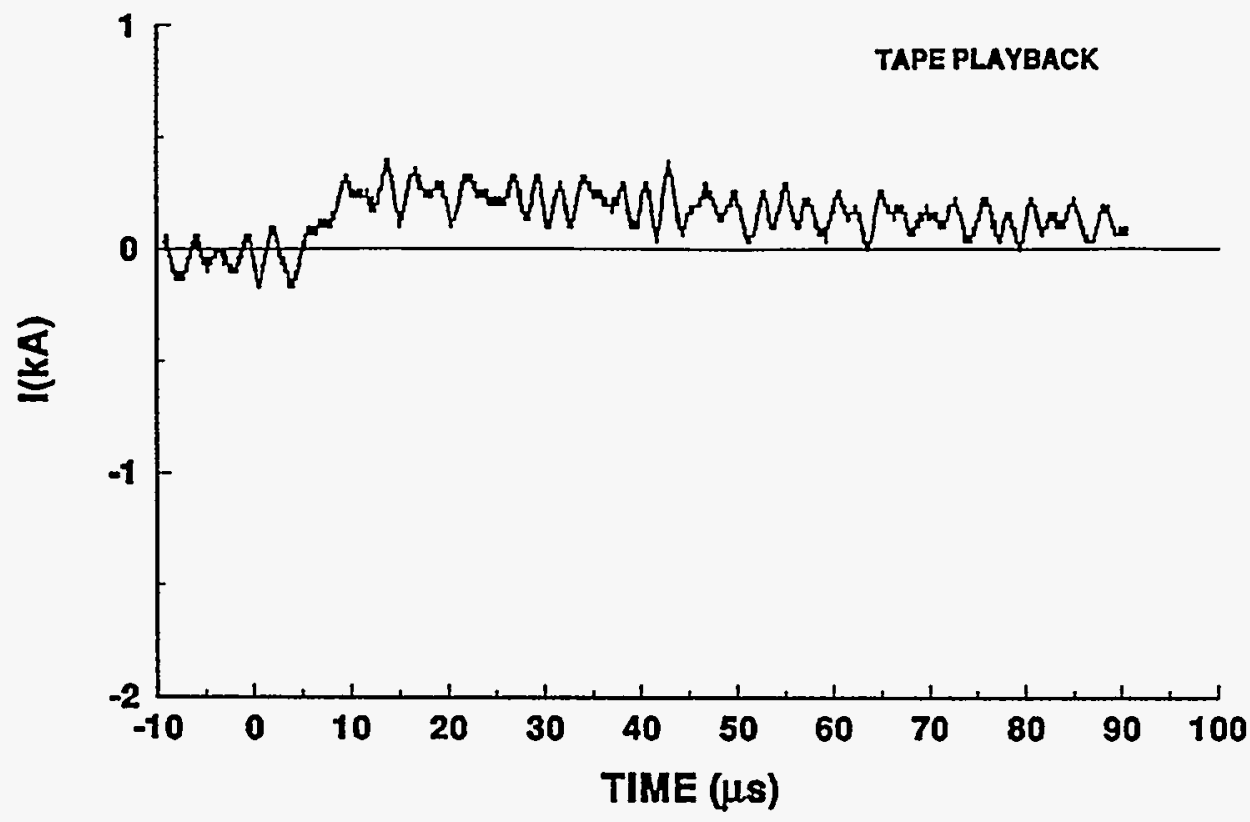

\section{4-22 STROKE 2}

TEST POINT 6'

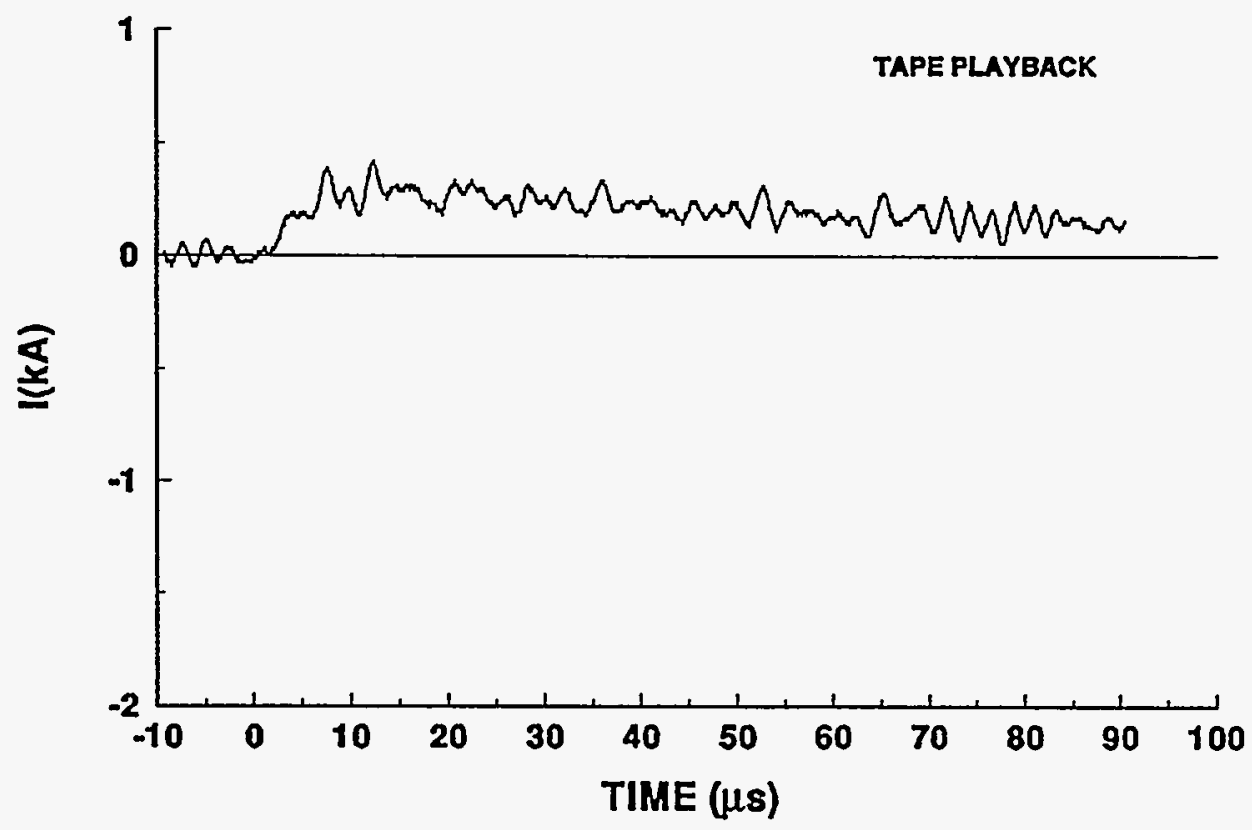




\section{4-22 STROKE 2}

TEST POINT 10

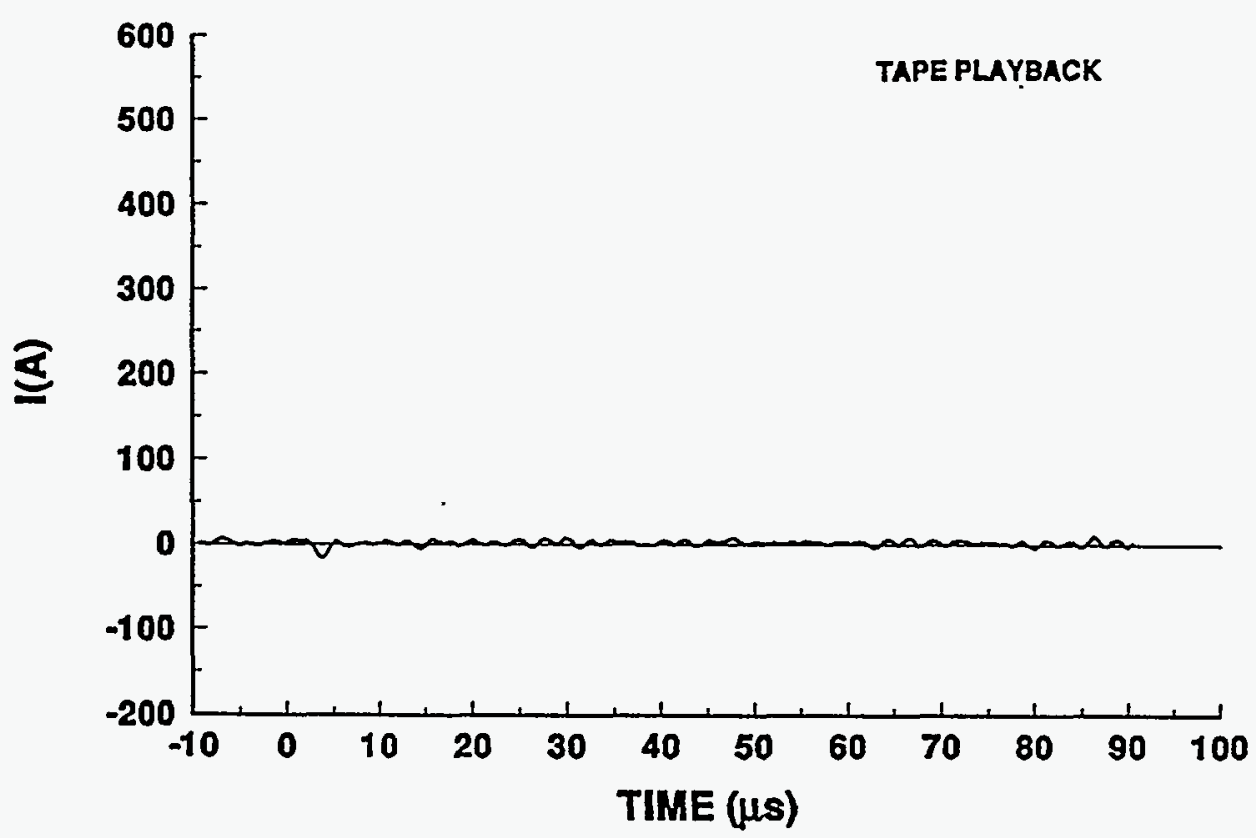

94-22 STROKE 2.

TEST POINT 11

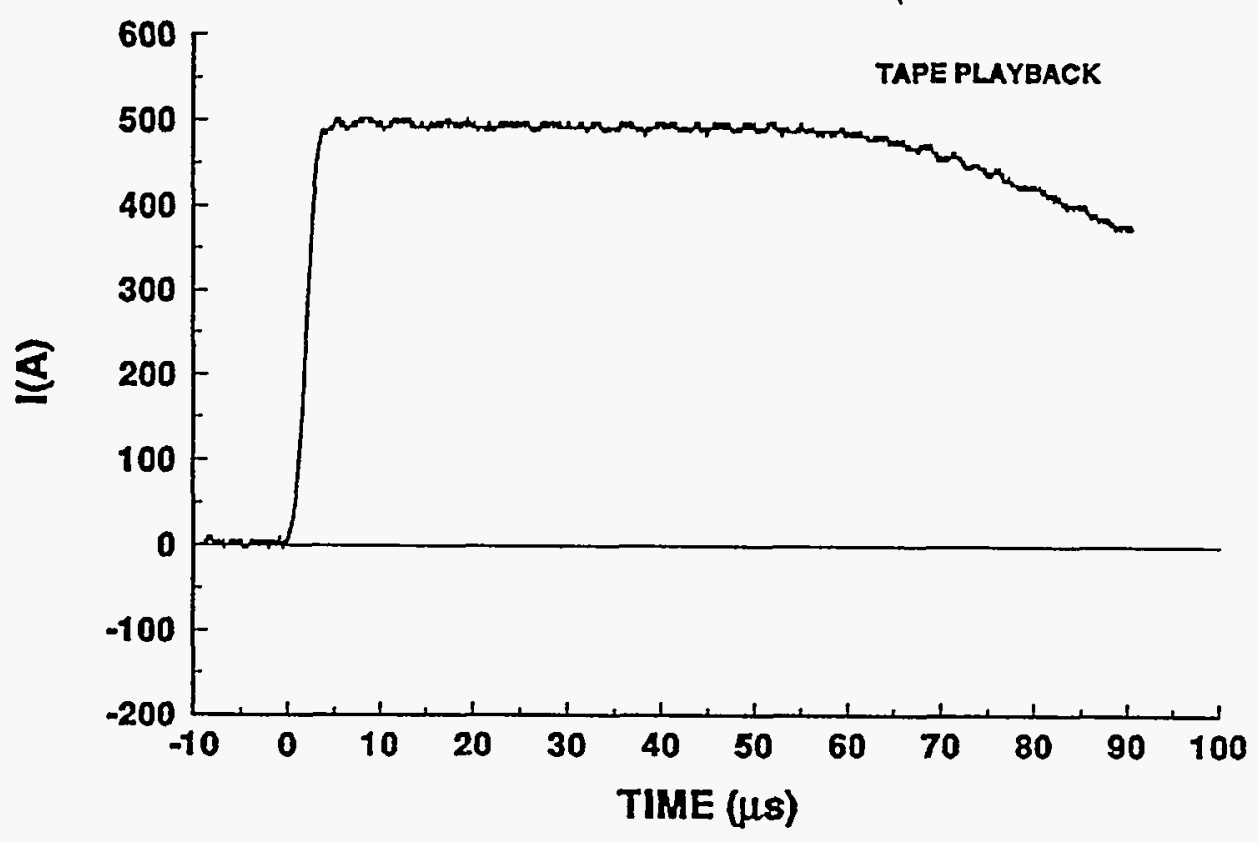




\section{4-22 STROKE 2}

\section{TEST POINT 12}

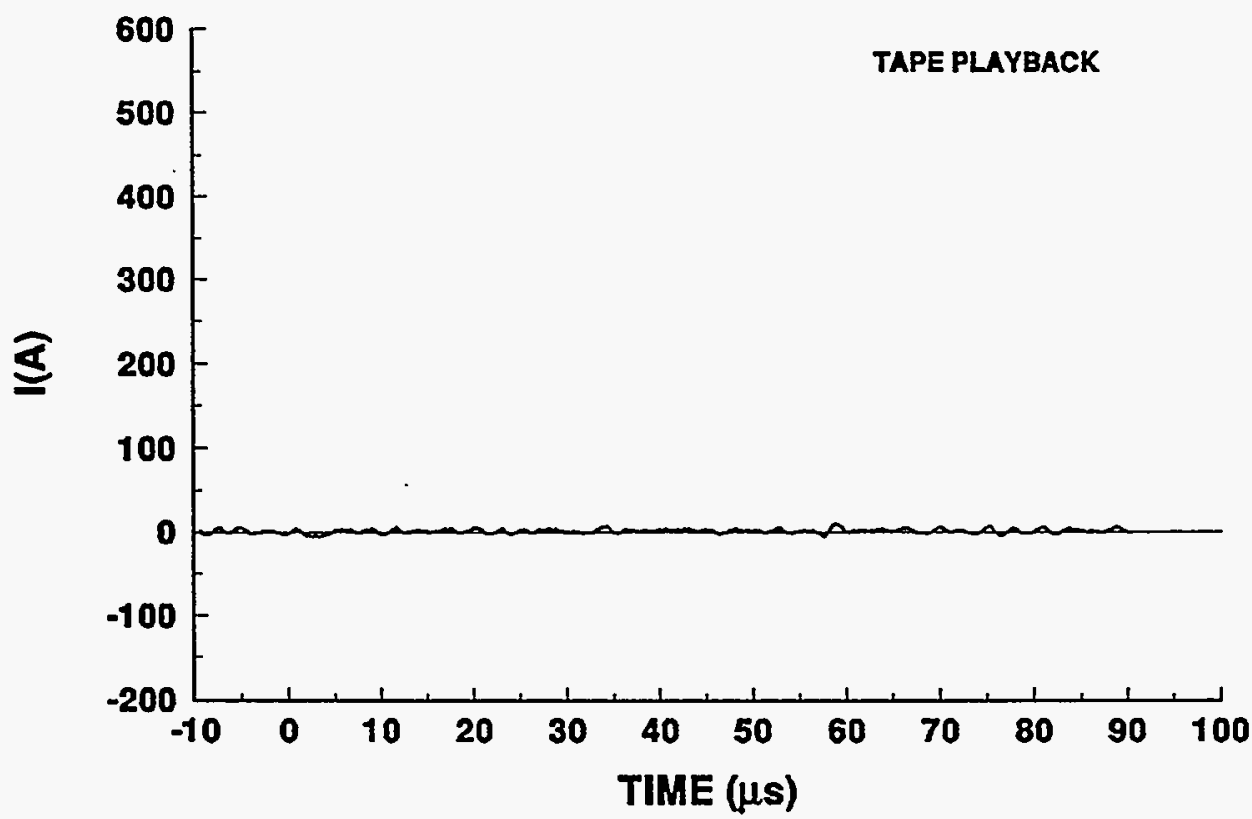

\section{4-22 STROKE. 2}

TEST POINT 13

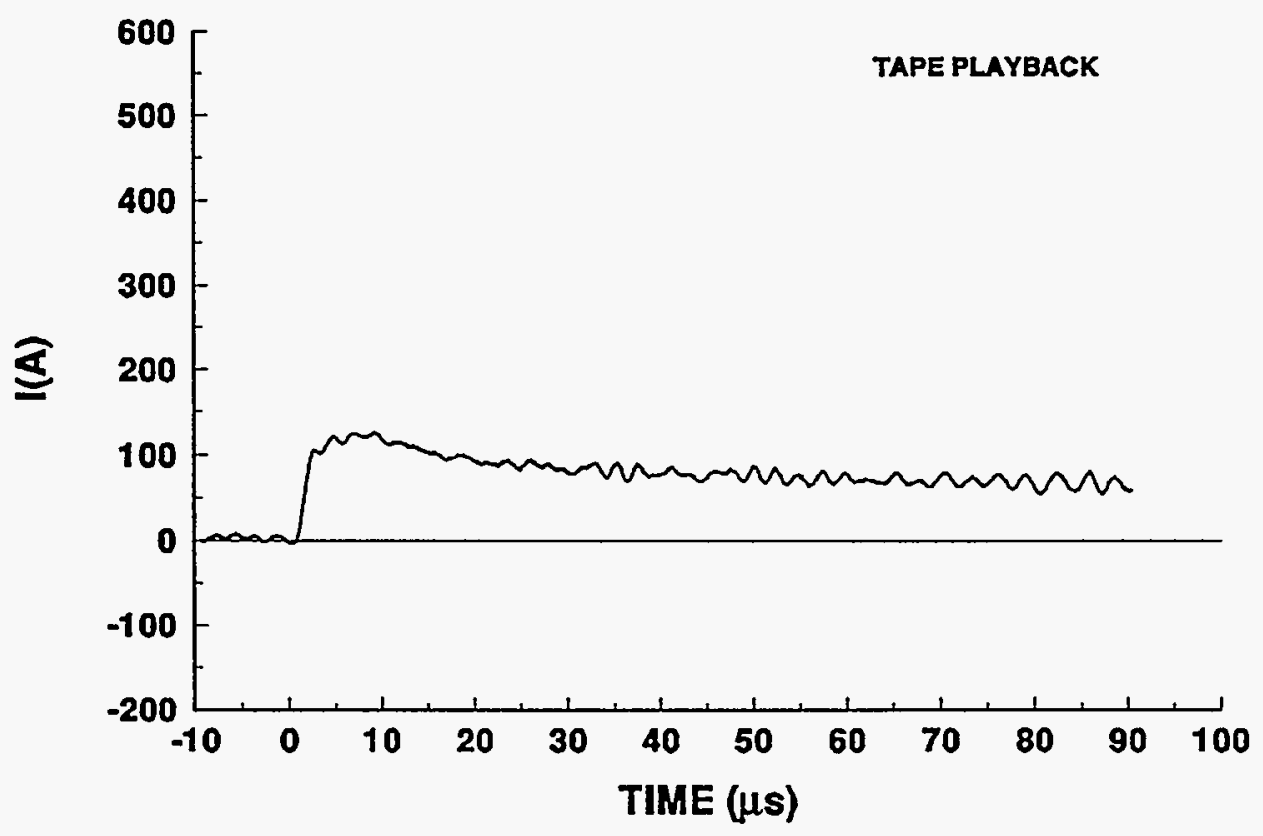




\section{4-22 STROKE 2}

TEST POINT 14
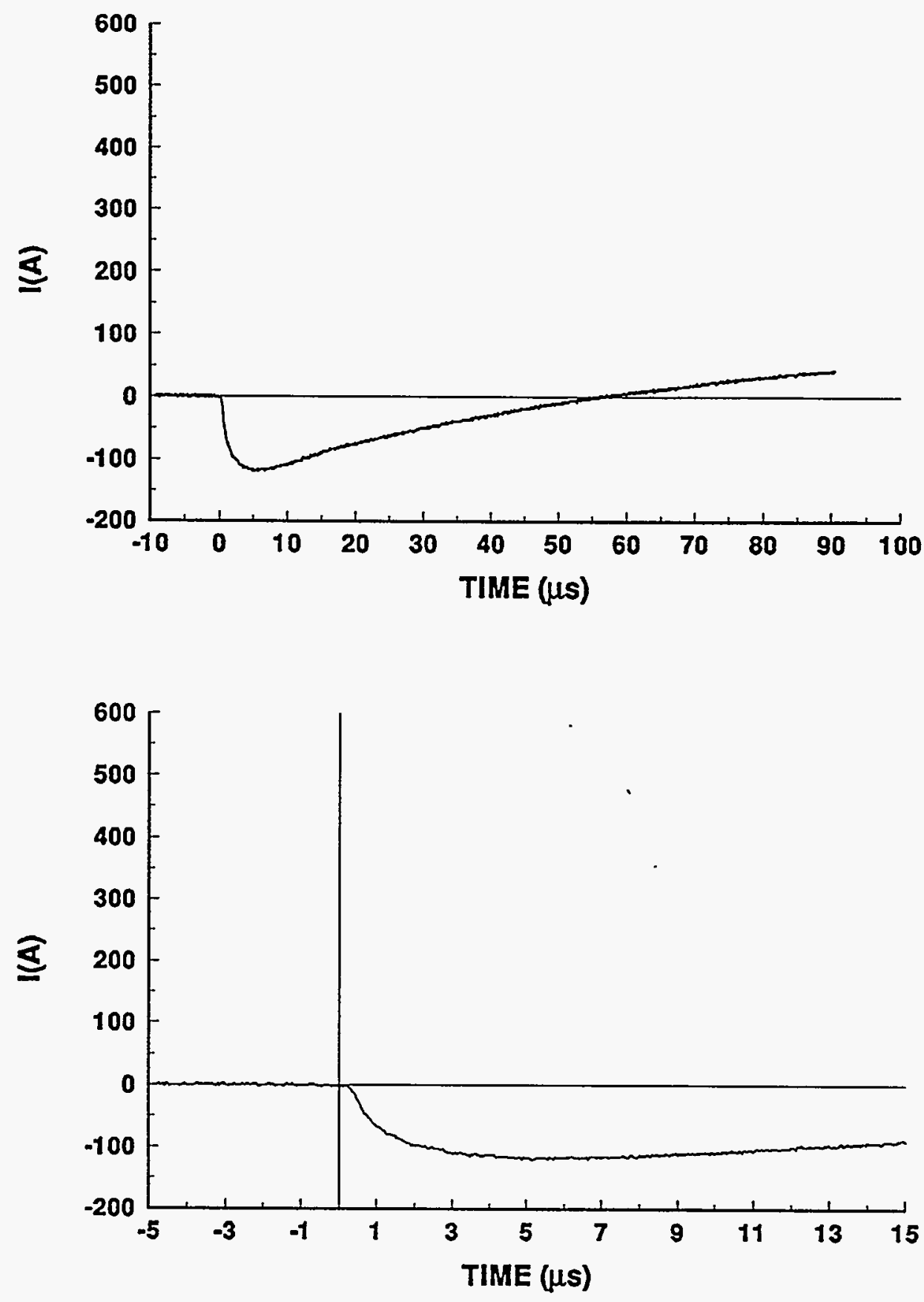


\section{4-22 STROKE 2}

TEST POINT 15
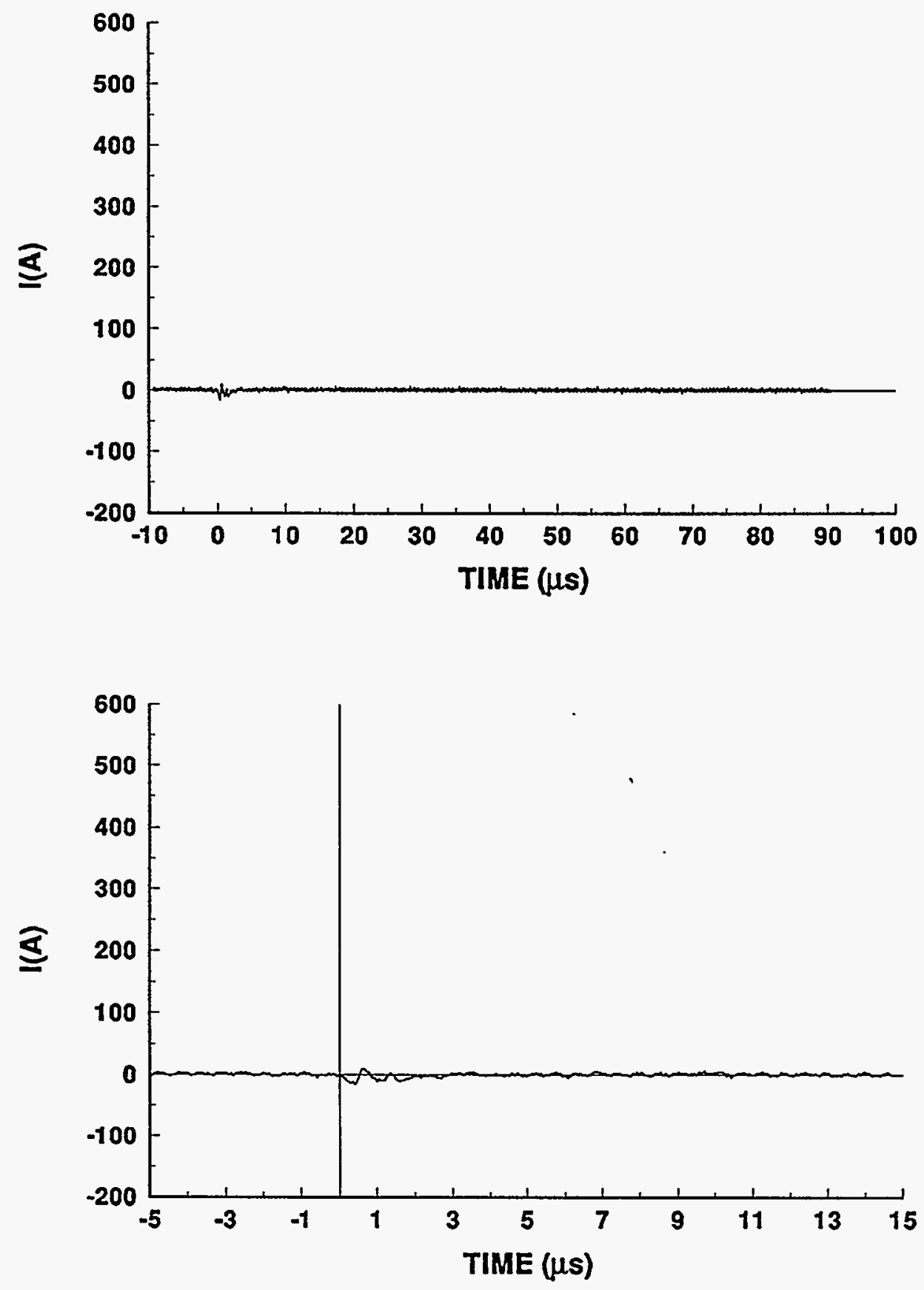


\section{4-22 STROKE 2}

TEST POINT 20

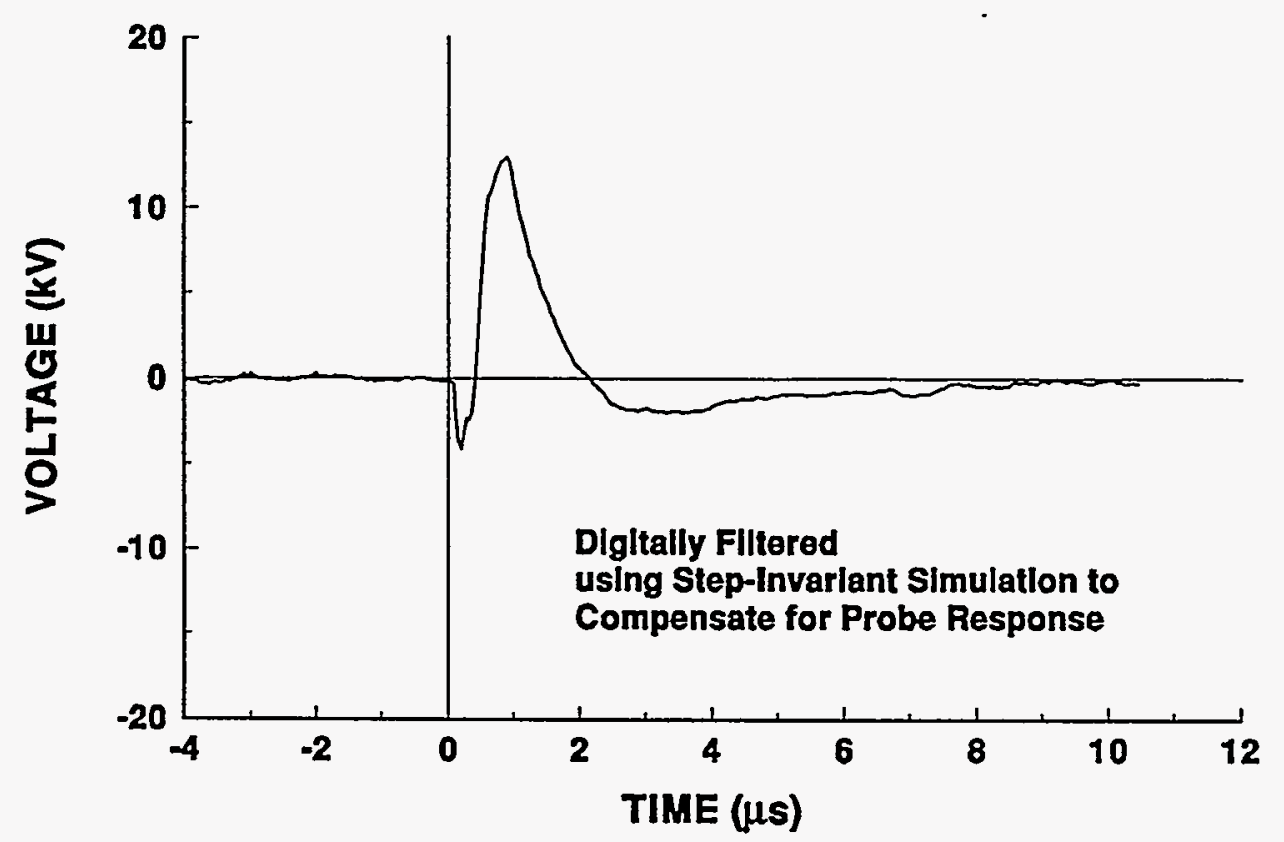

\section{4-22 STROKE 2}

TEST POINT 21

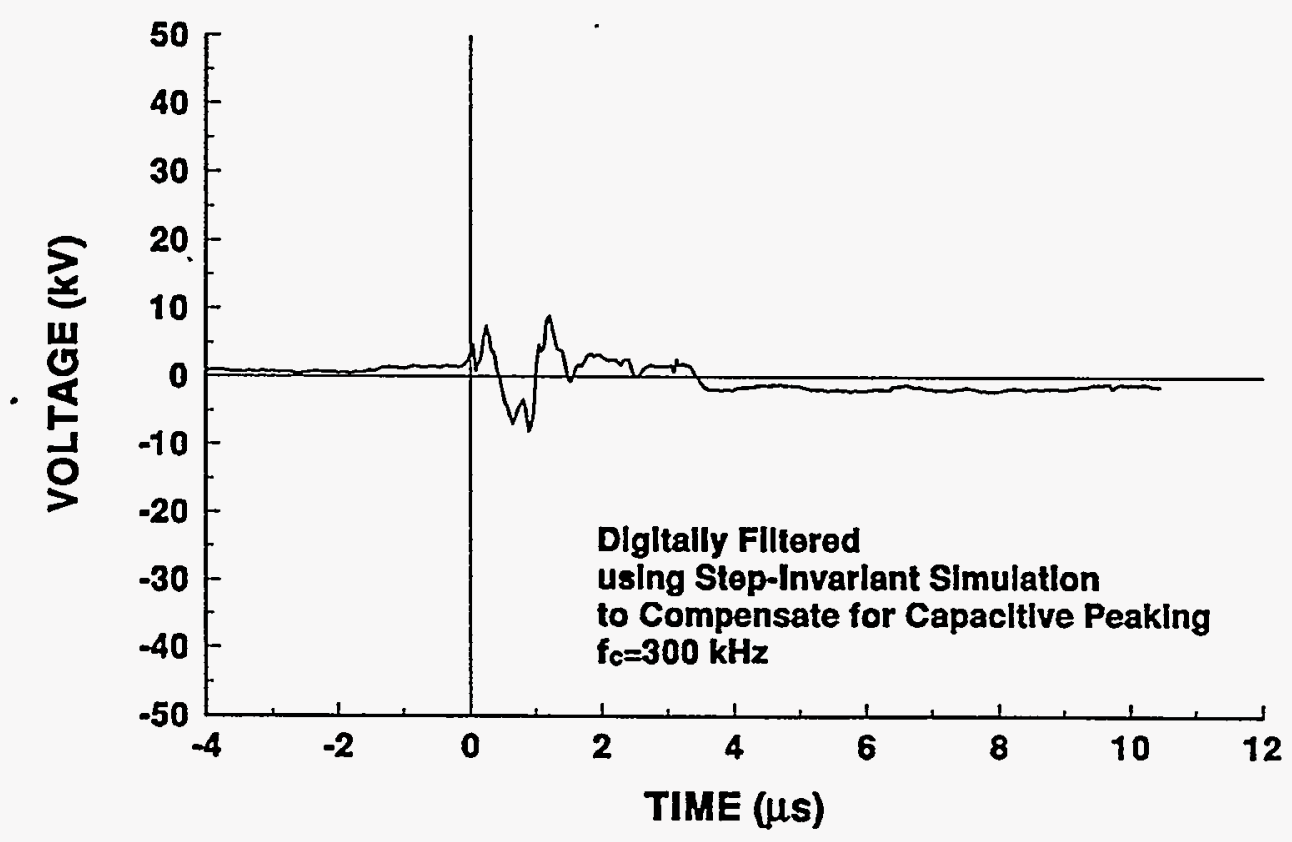




\section{4-22 STROKE 2}

\section{TEST POINT 22}

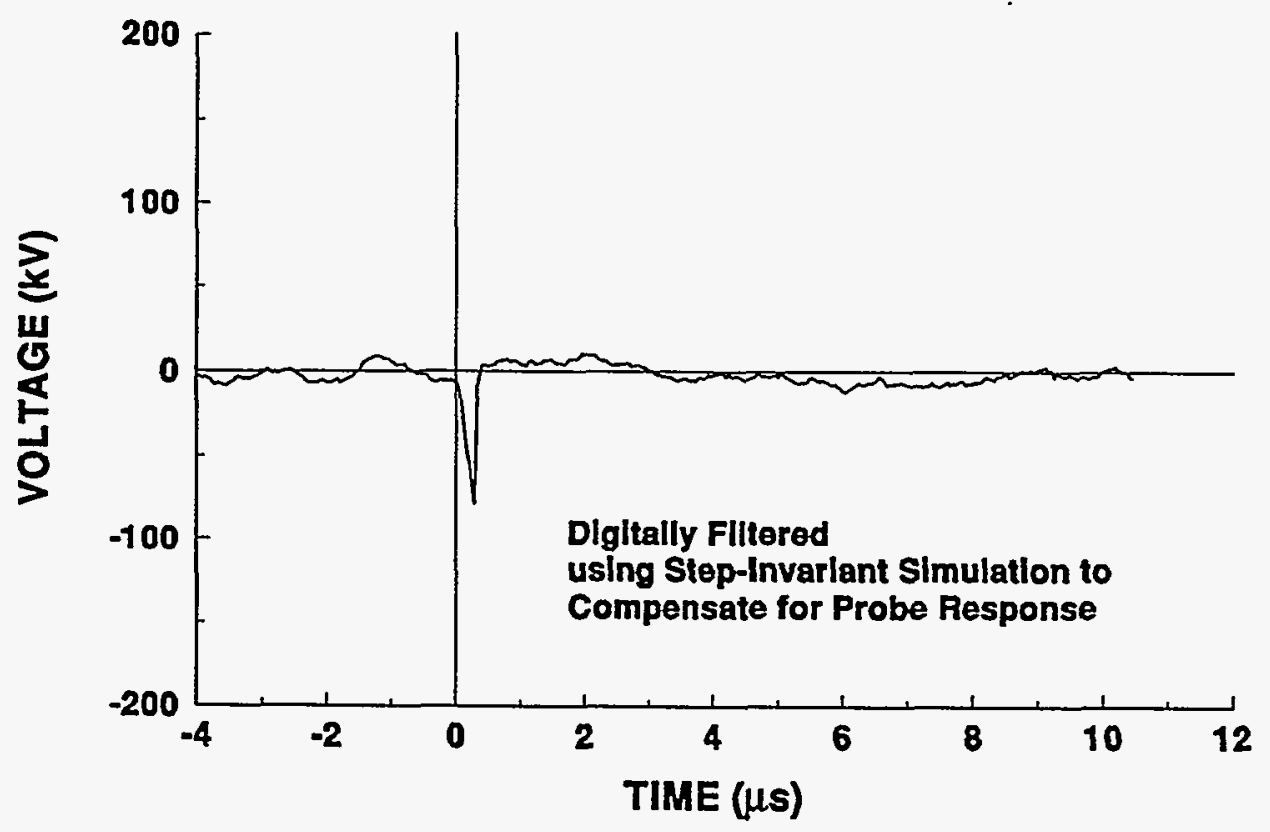




\section{4-22 STROKE 2}

TEST POINT 23

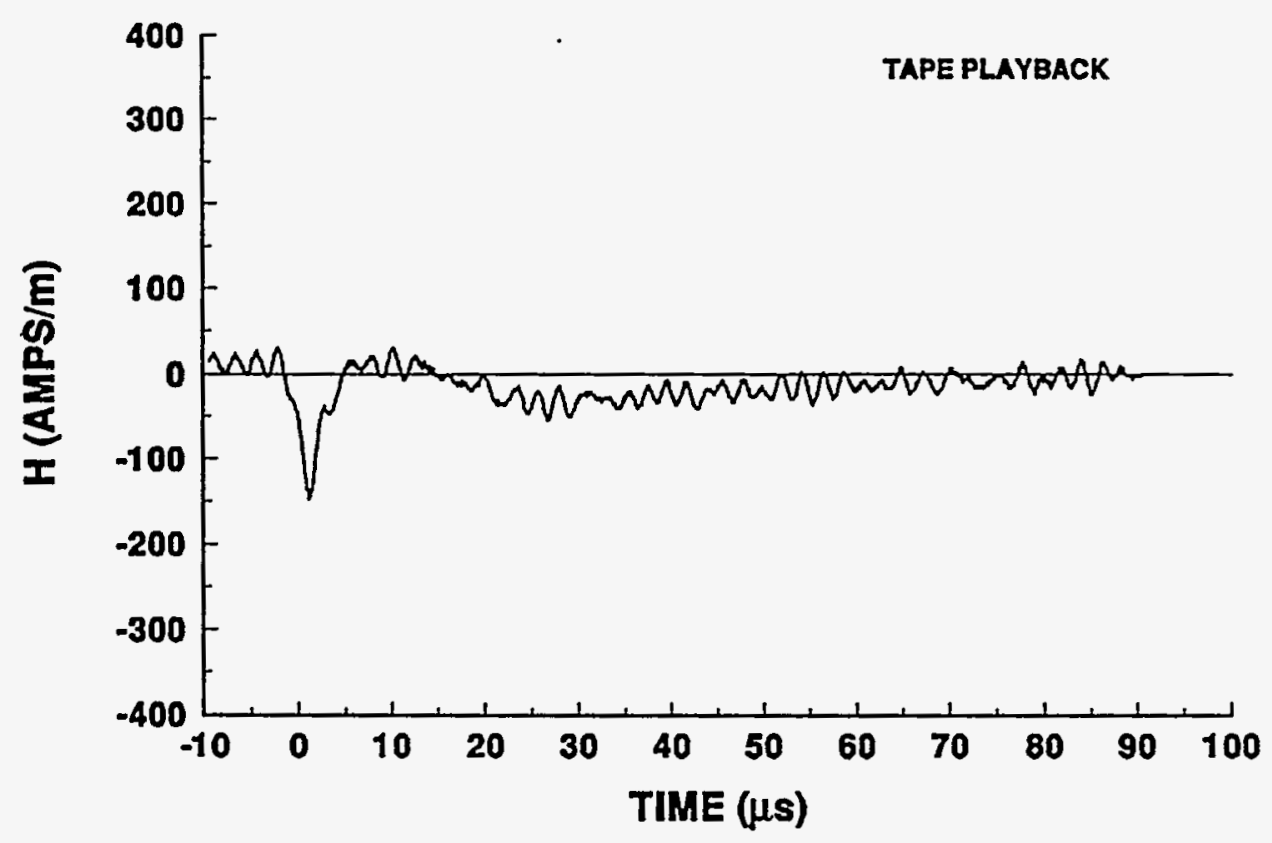

94-22 STROKE 2

TEST POINT 24

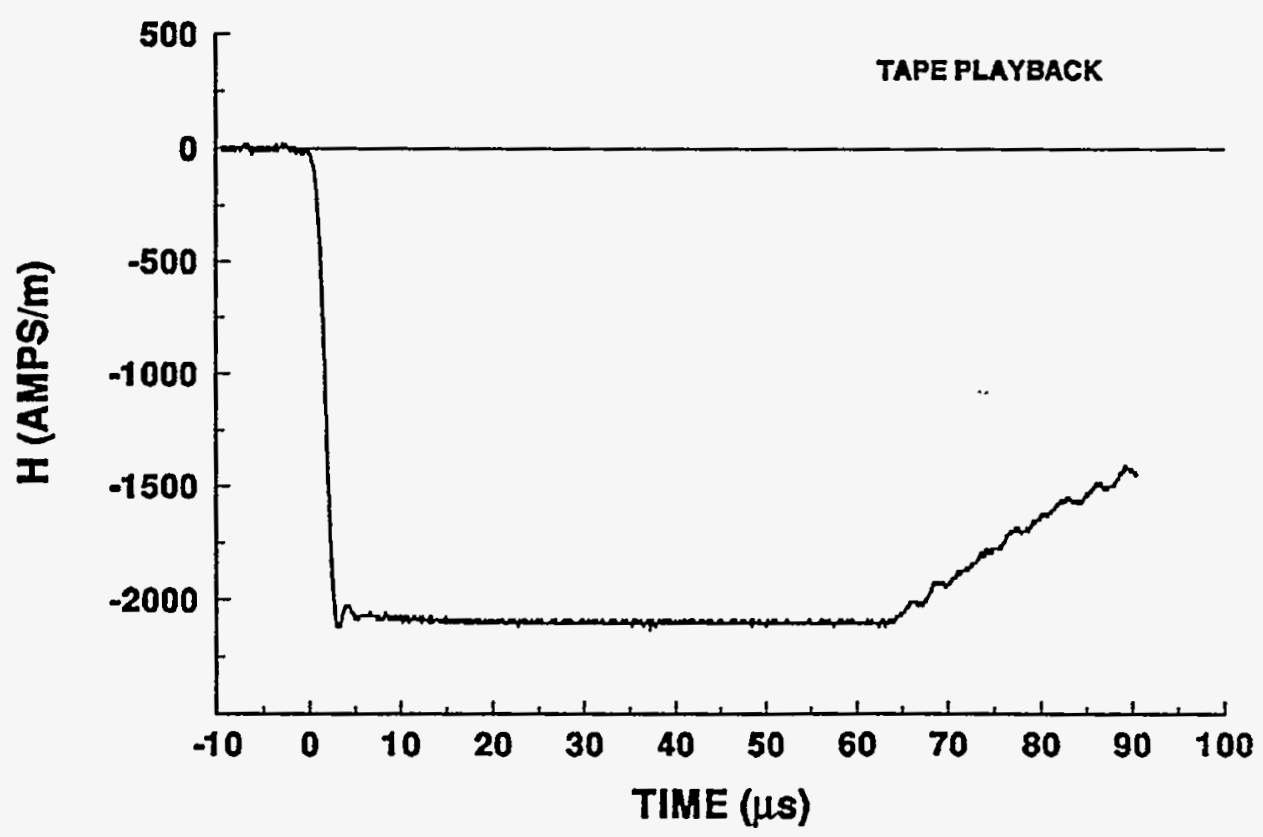




\section{4-22 STROKE 3}

TEST POINT 23

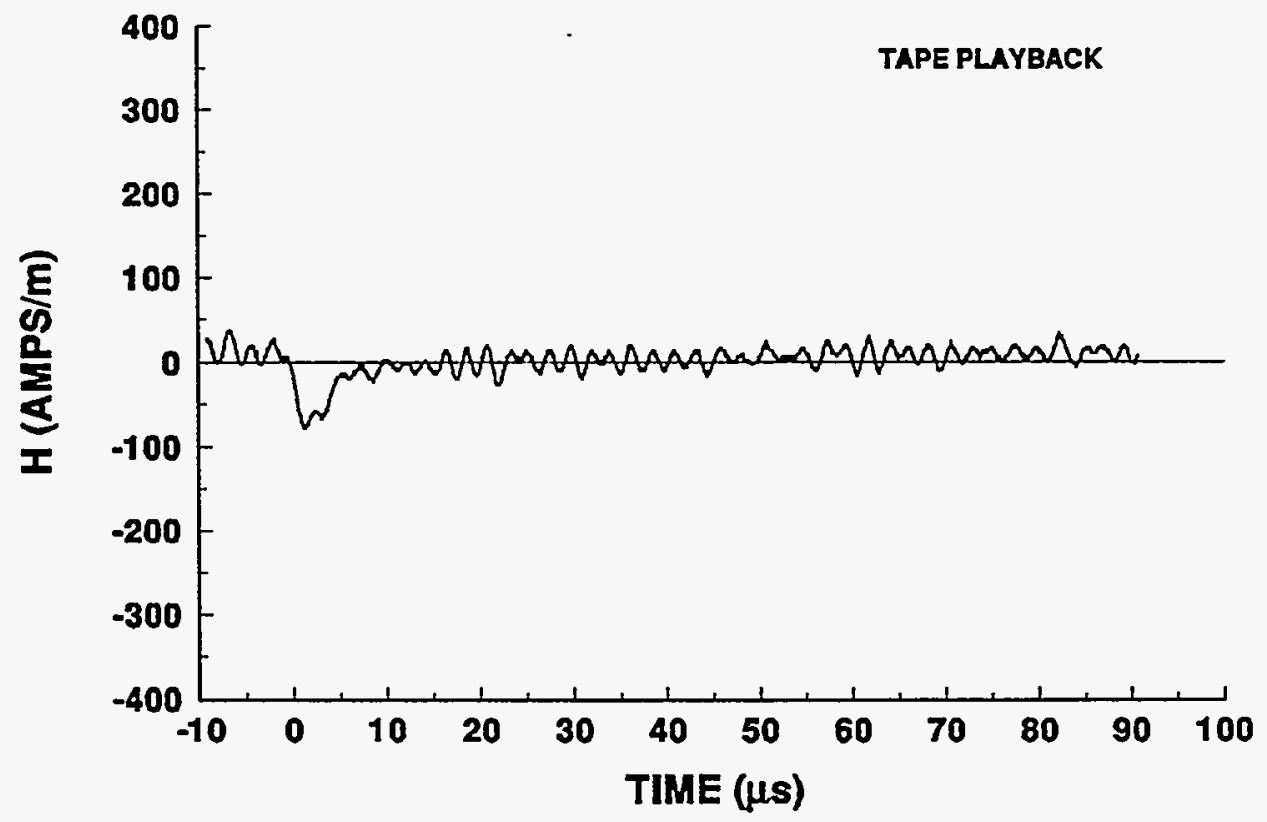

94-22 STROKE 3 TEST POINT 24

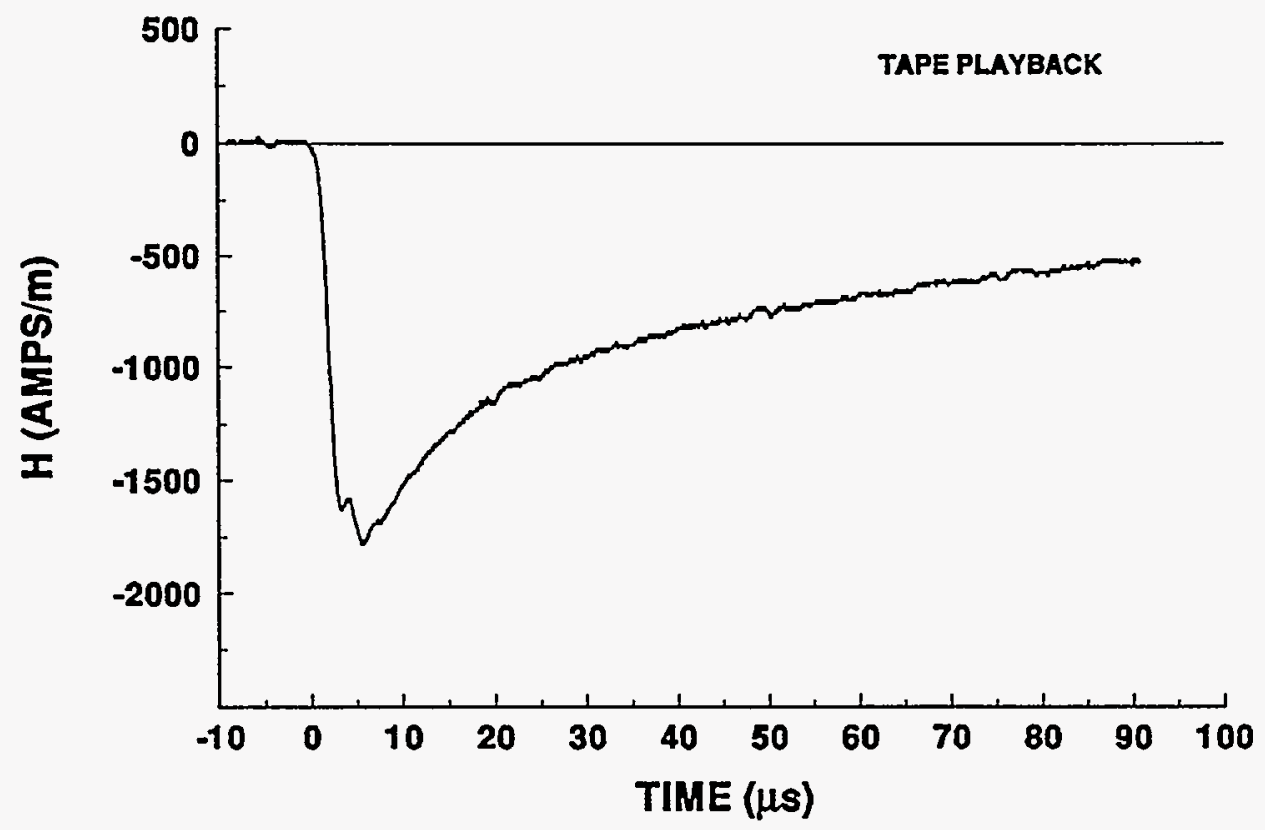




\section{4-24 STROKE 1 \\ INCIDENT CURRENT}
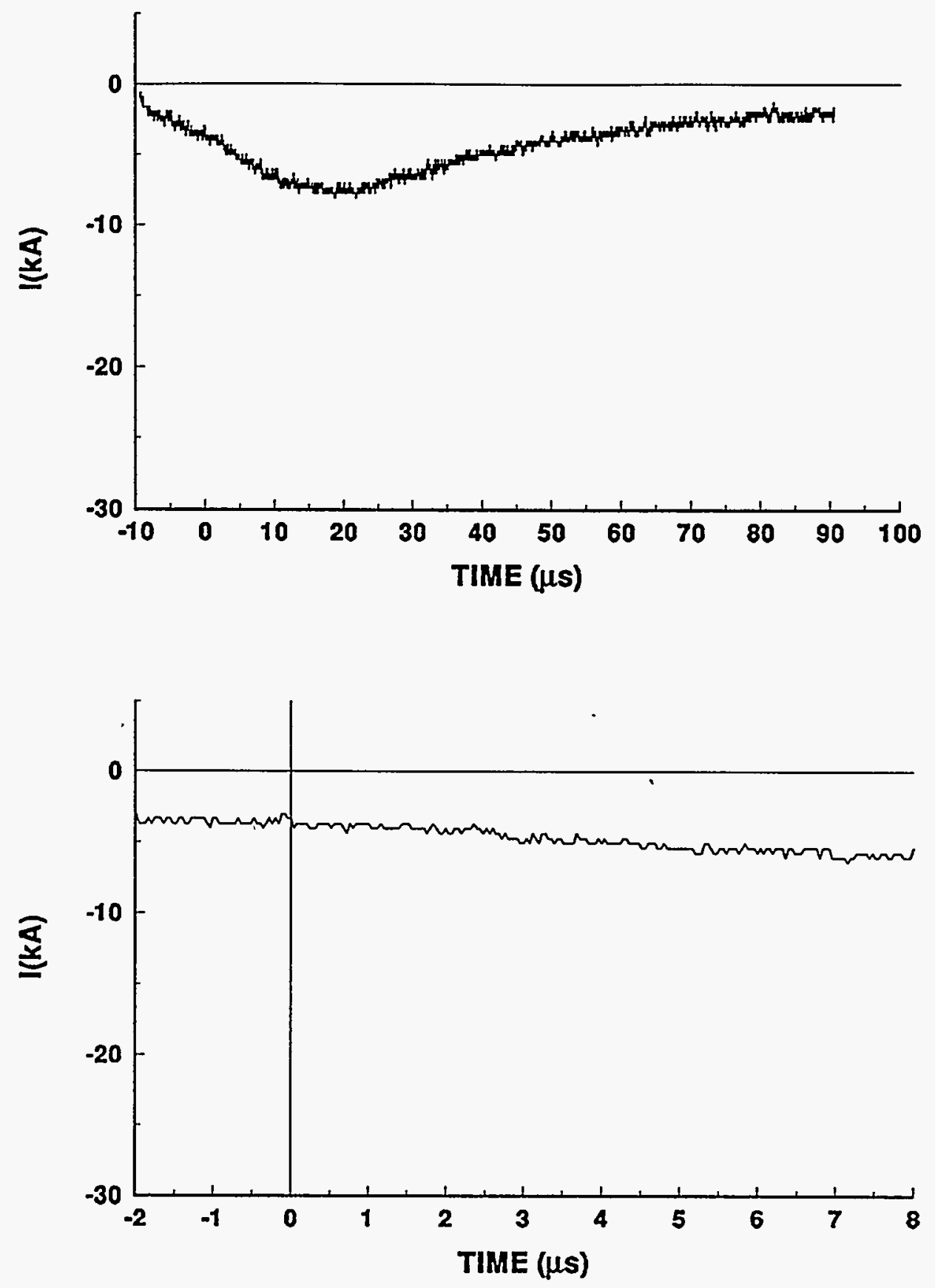


\section{4-24 STROKE 1}

TEST POINT 1
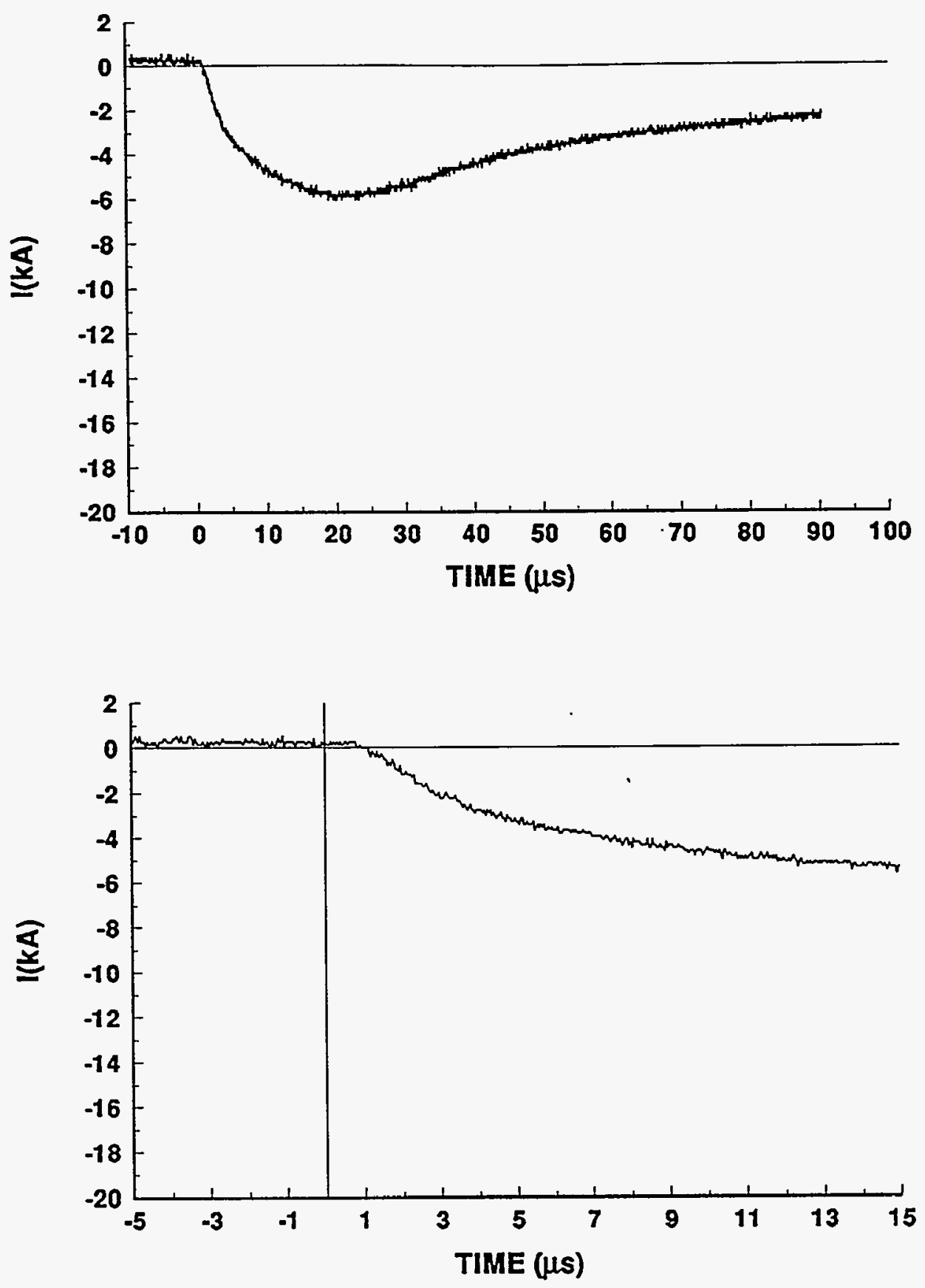


\section{4-22 STROKE 3 \\ INCIDENT CURRENT}
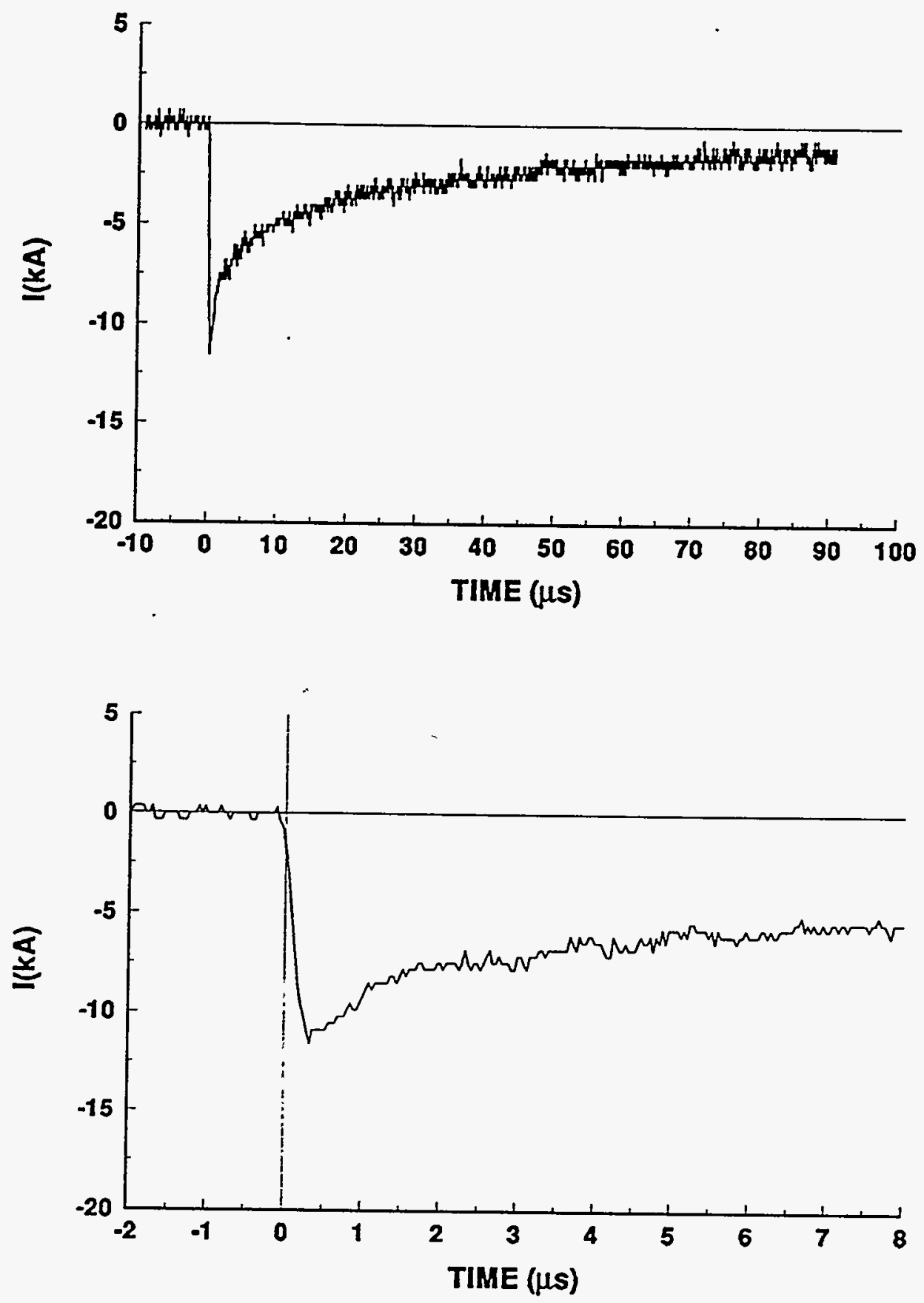


\section{4-22 STROKE 3}

TEST POINT 1
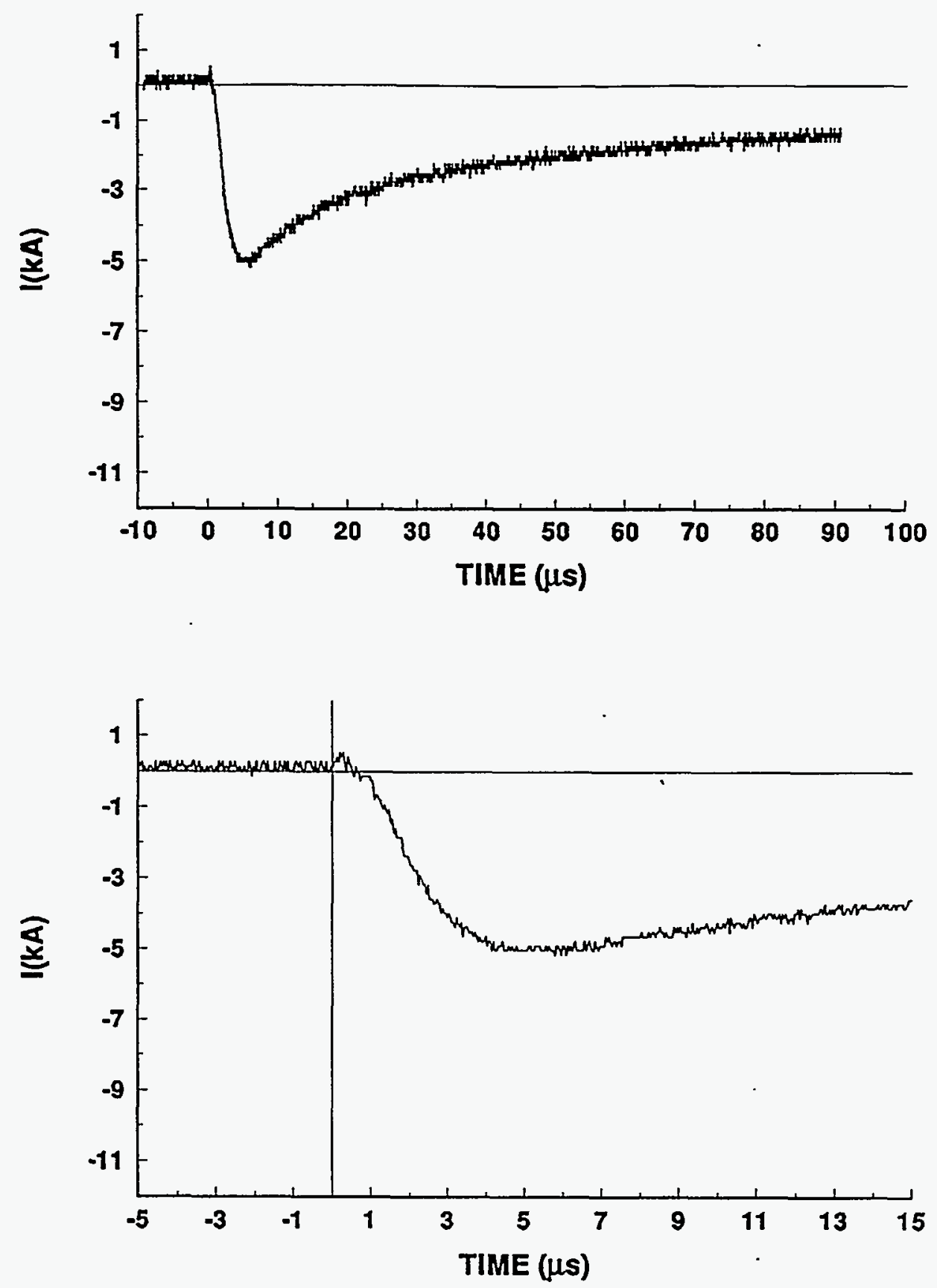


\section{4-22 STROKE 3}

\section{TEST POINT 2}
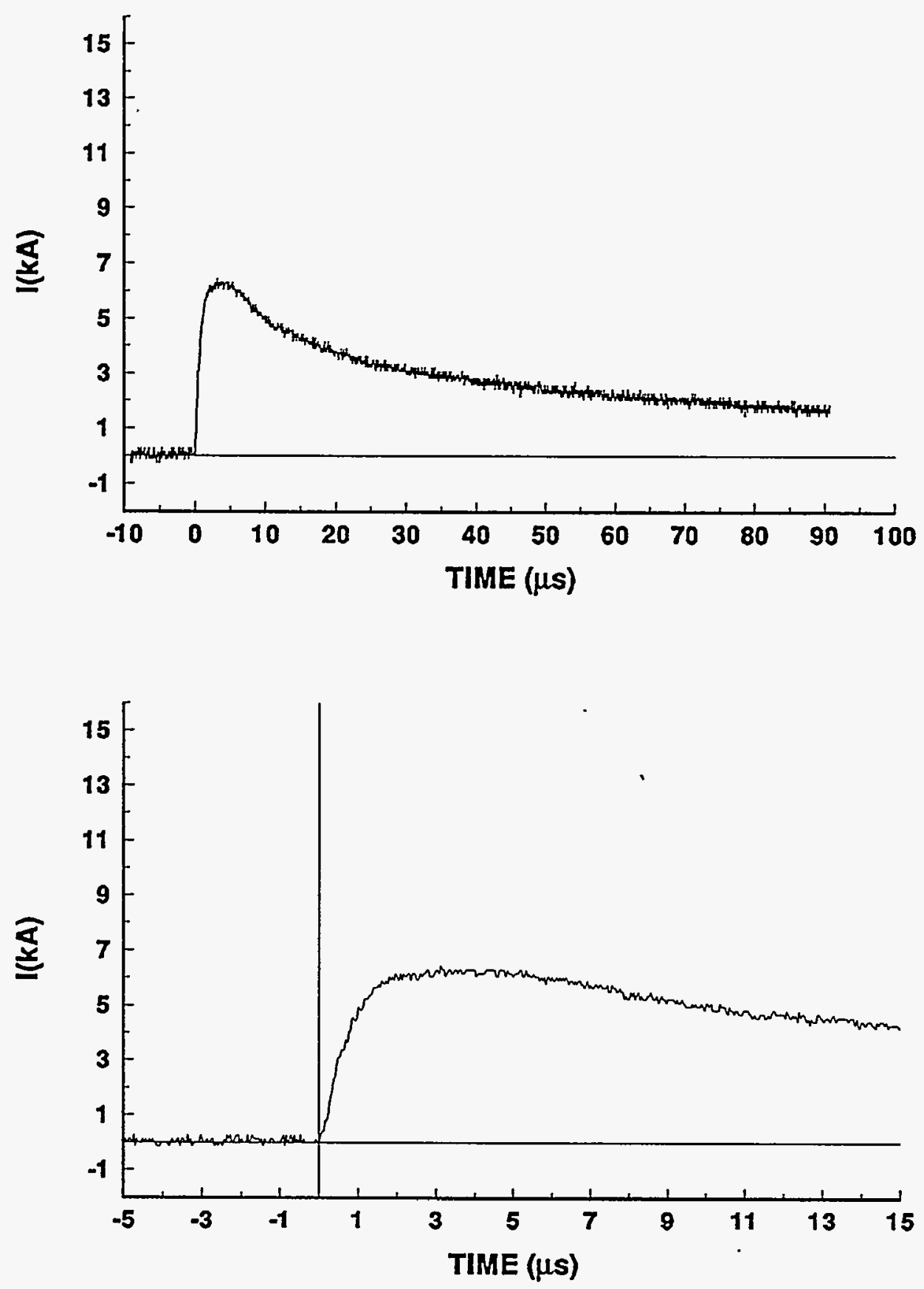


\section{4-22 STROKE 3}

TEST POINT 5
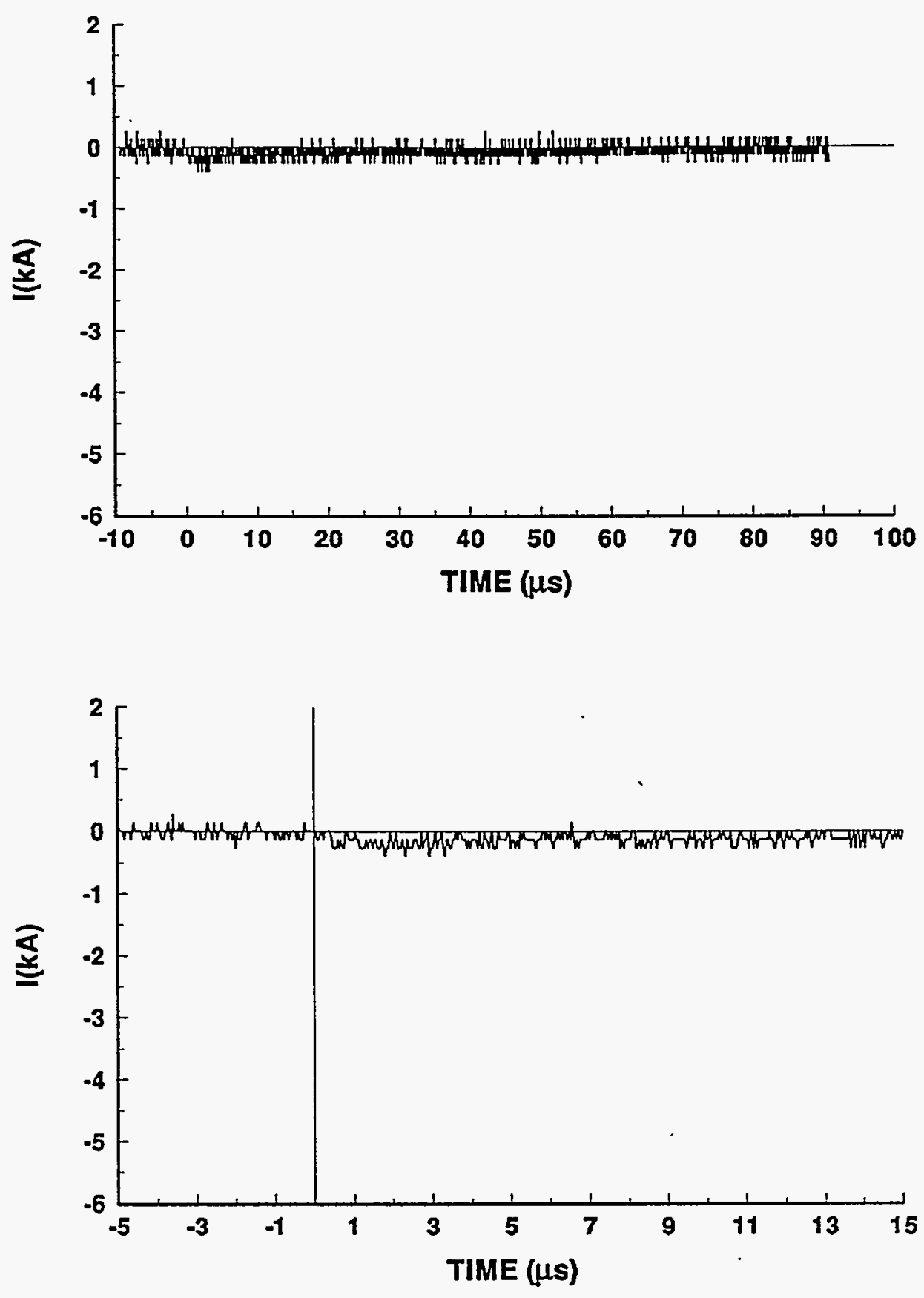


\section{4-22 STROKE 3}

TEST POINT 6
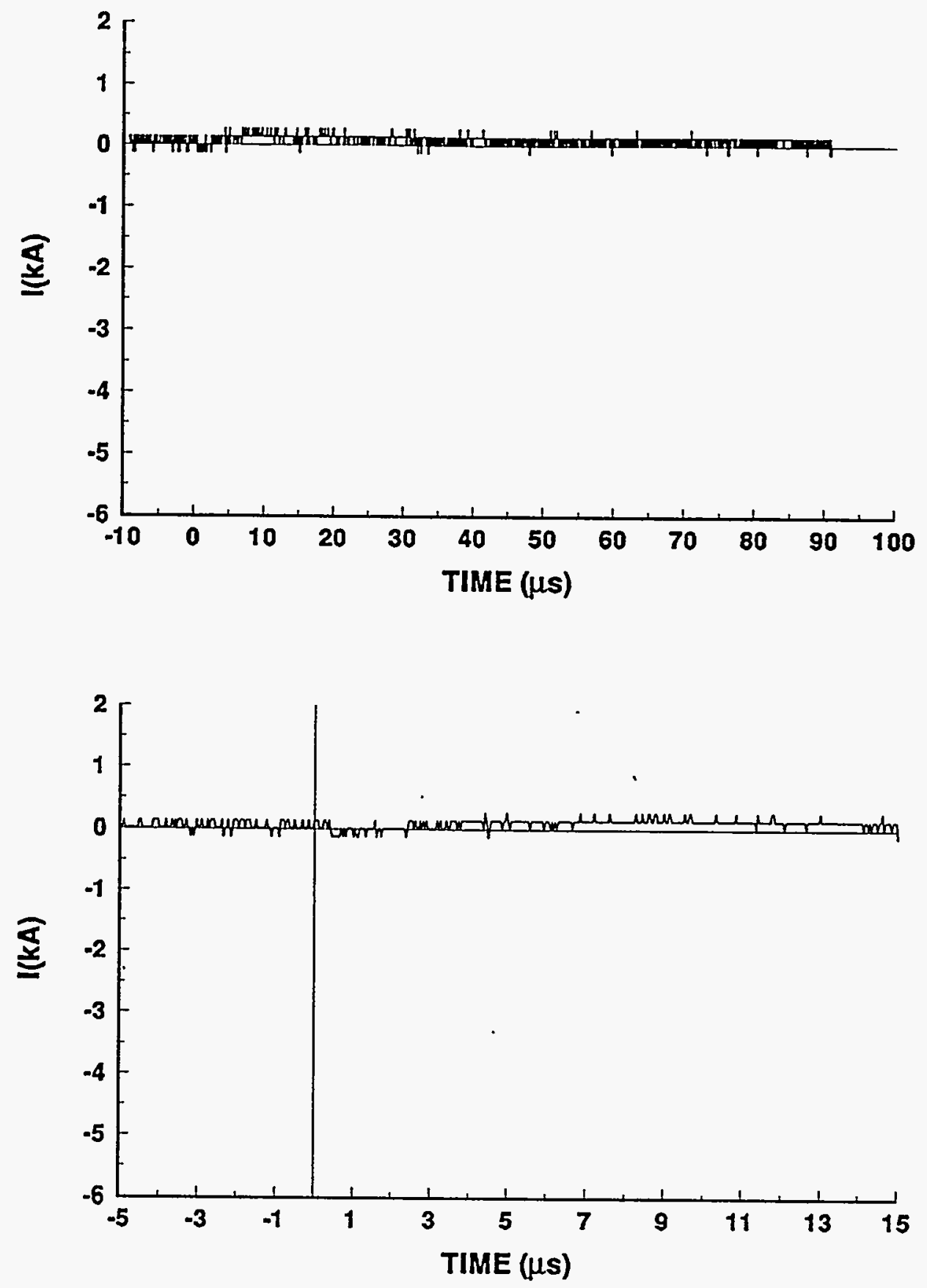


\section{4-22 STROKE 3}

\section{TEST POINT 5'}

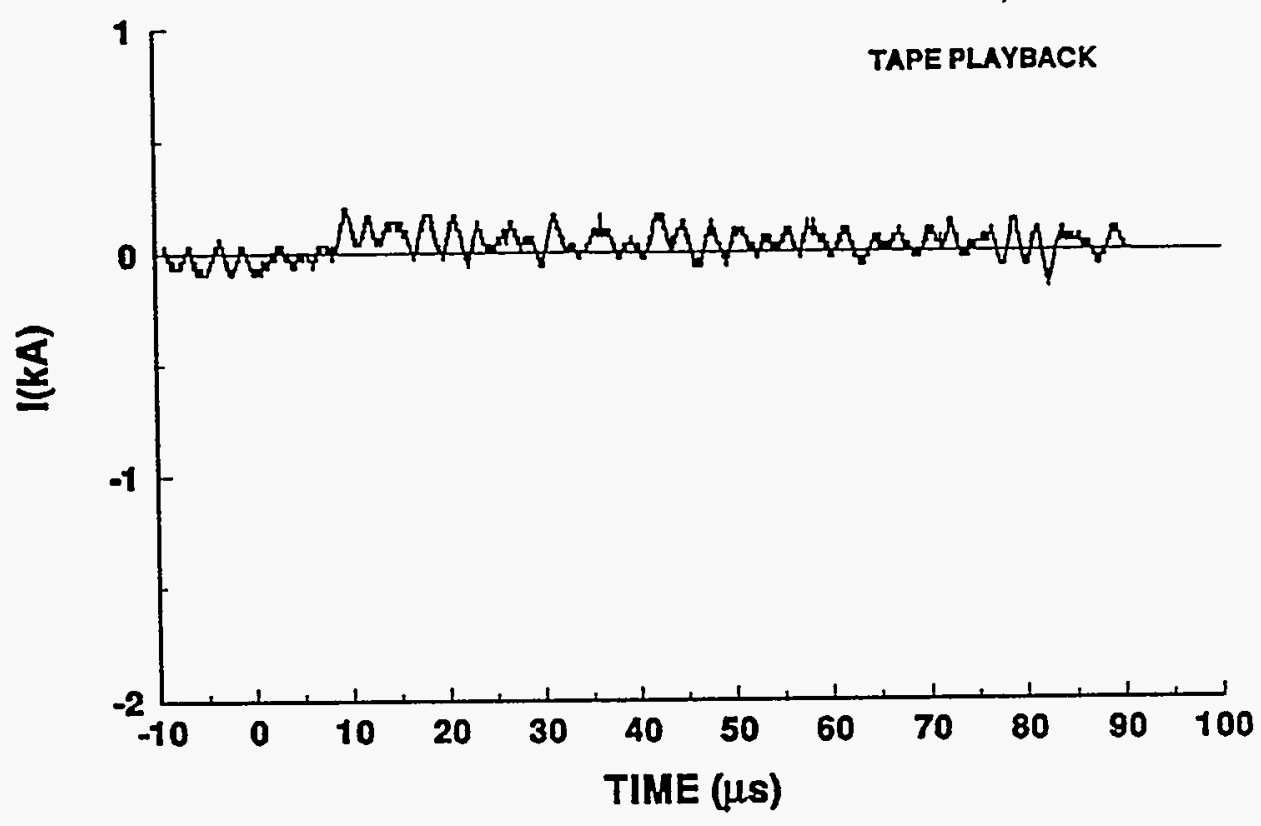

\section{4-22 STROKE 3}

TEST POINT 6'

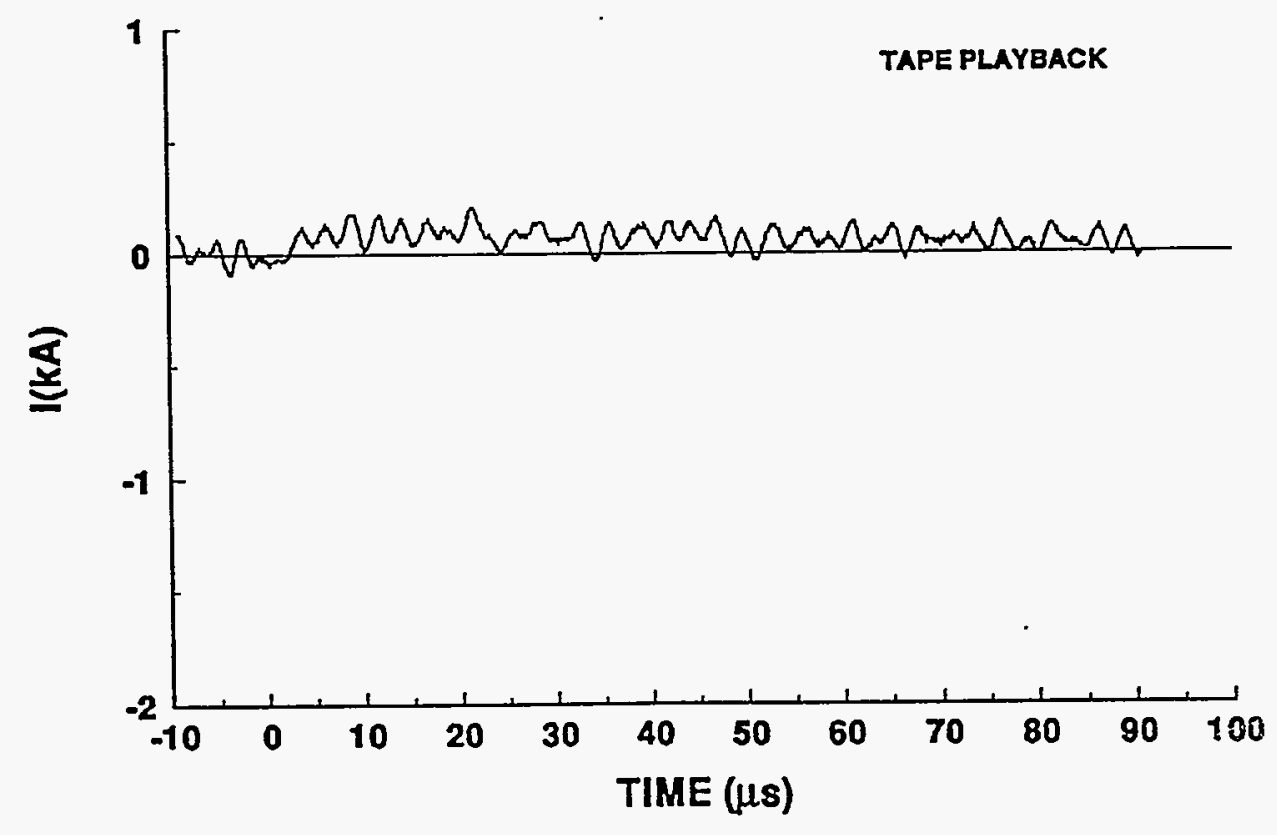




\section{4-22 STROKE 3}

TEST POINT 10

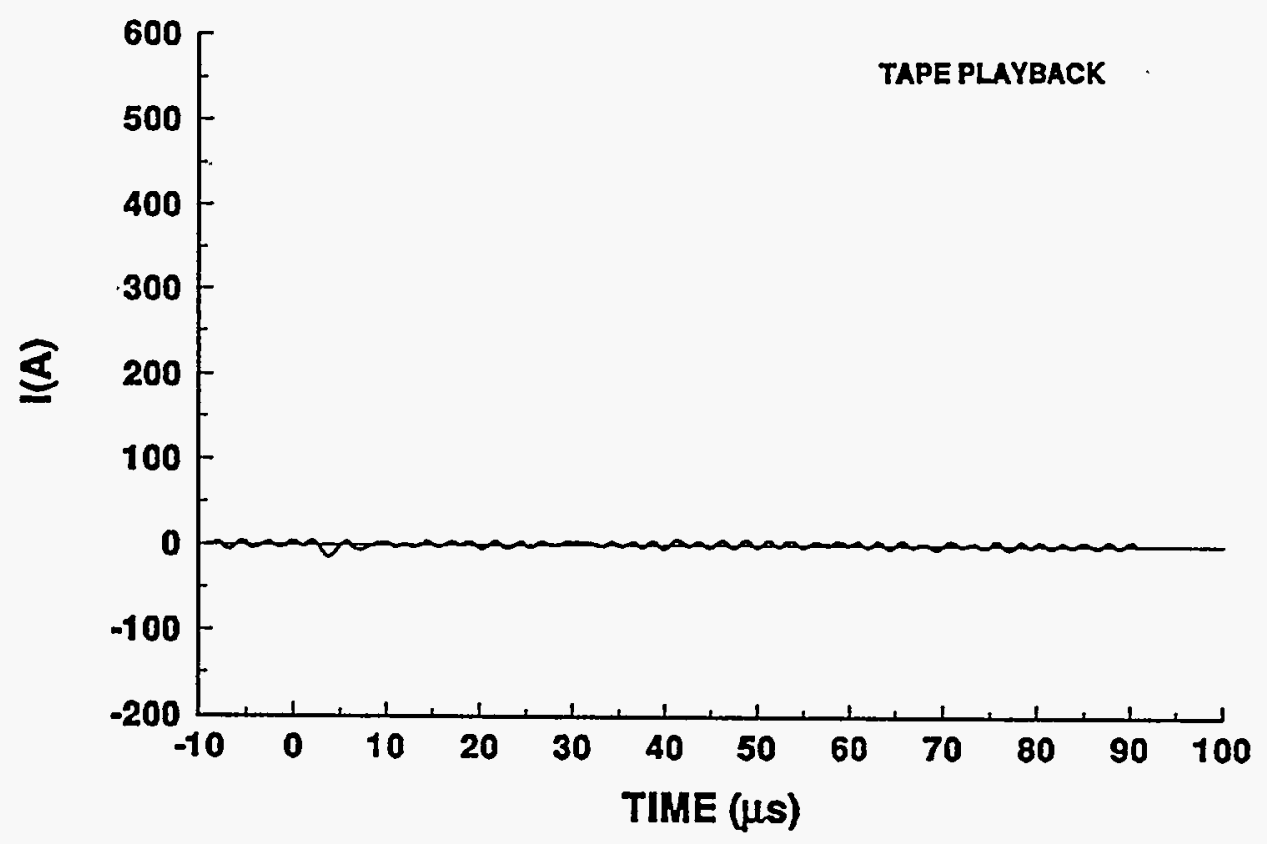

\section{4-22 STROKE 3}

TEST POINT 11

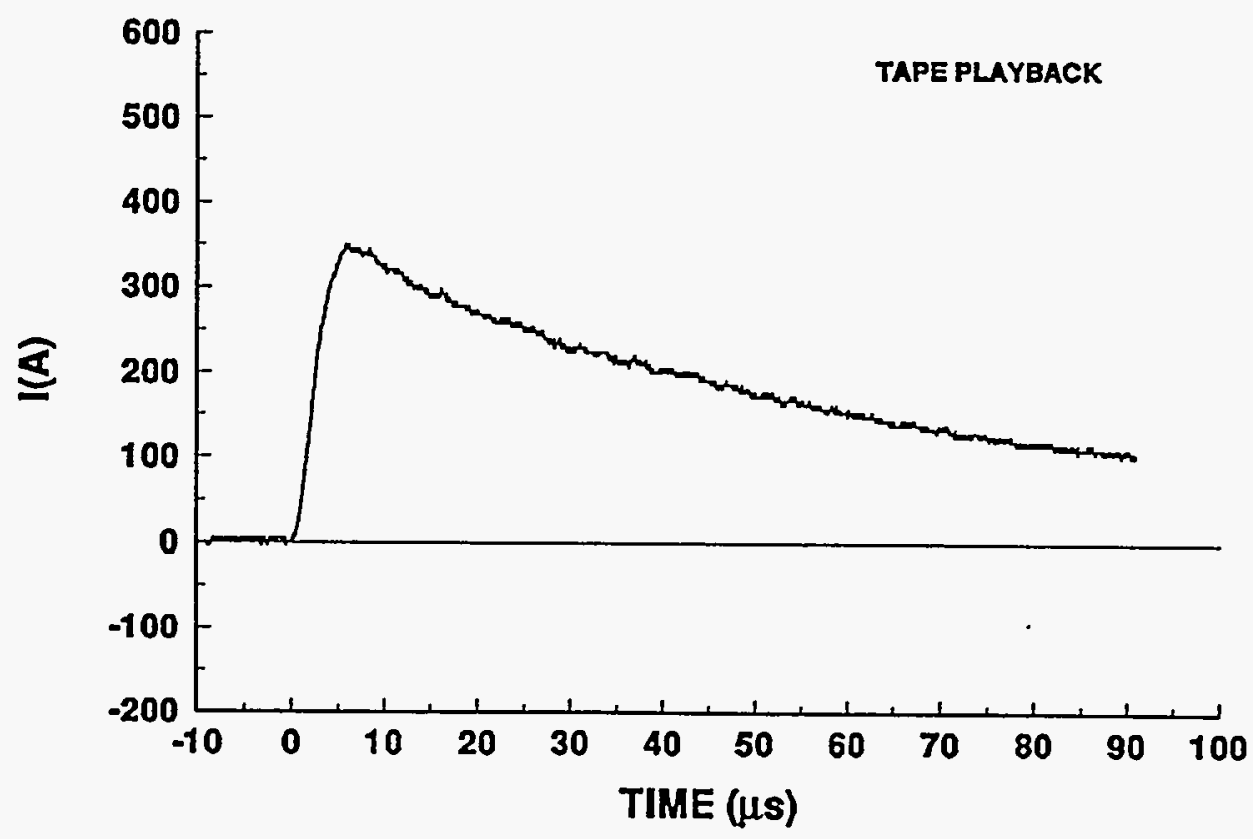


94-22 STROKE 3

TEST POINT 12

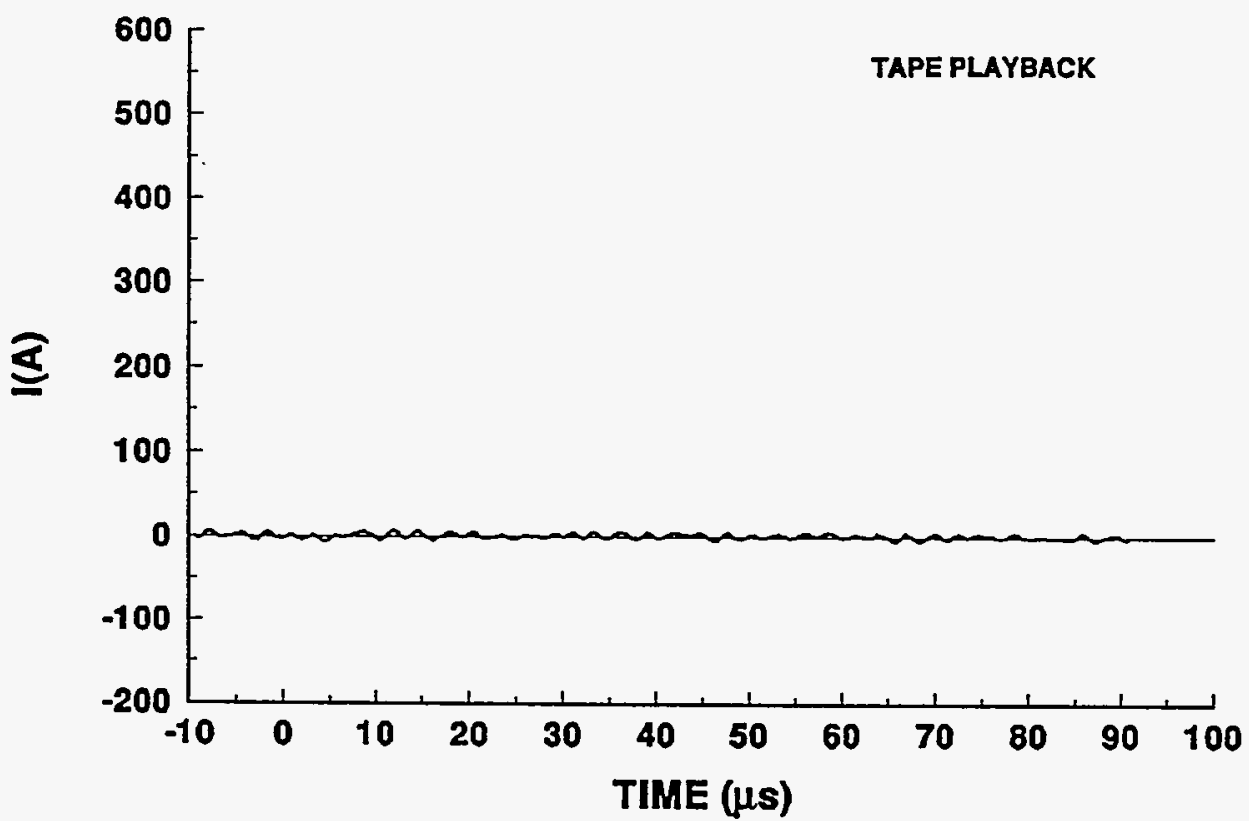

94-22 STROKE 3

TEST POINT 13

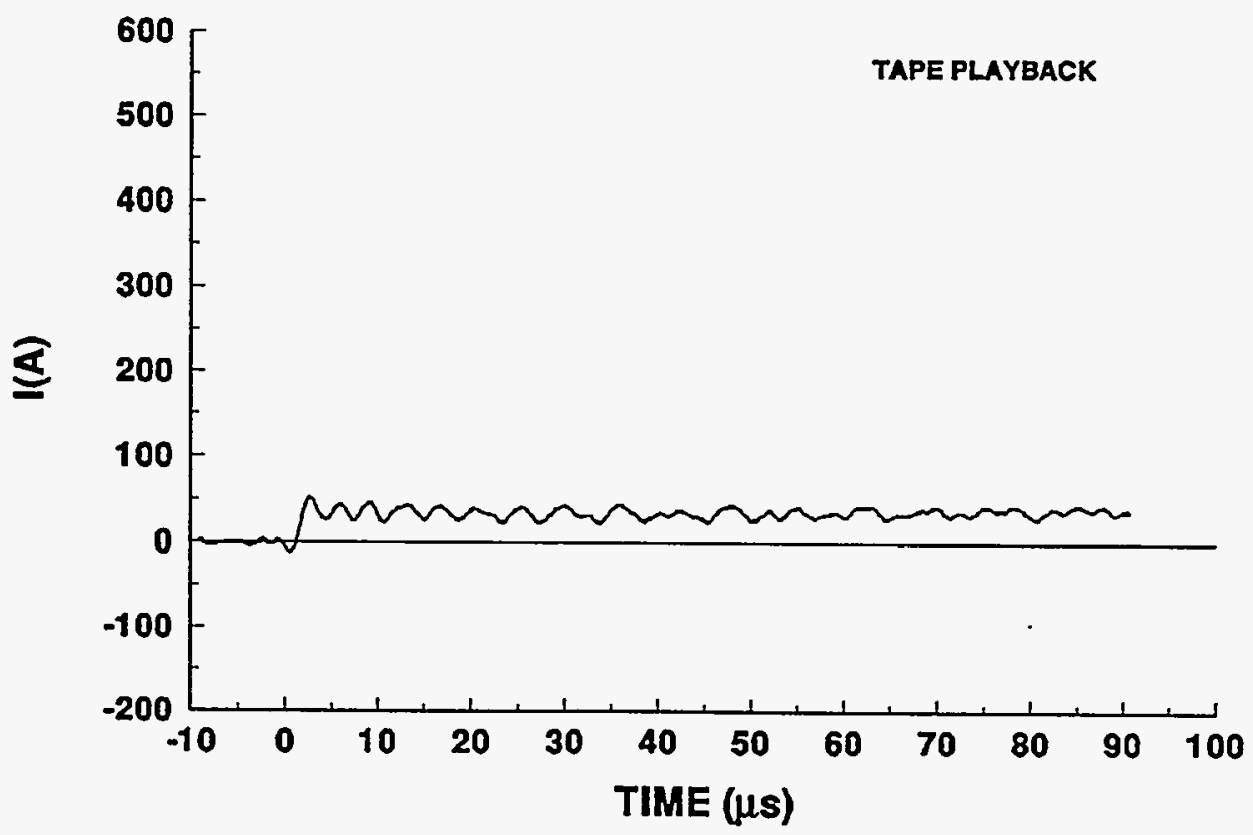




\section{4-22 STROKE 3}

\section{TEST POINT 14}
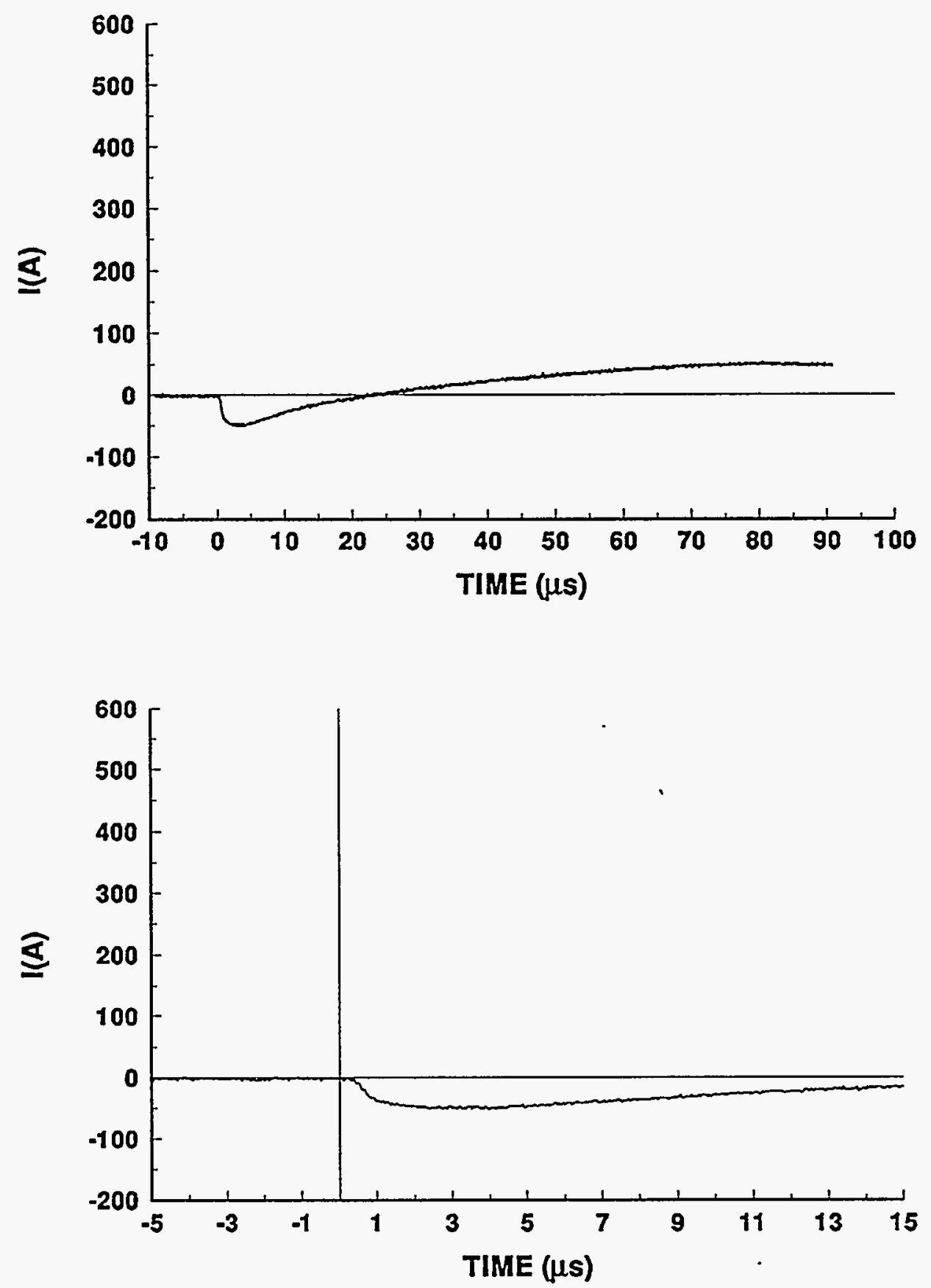


\section{4-22 STROKE 3}

TEST POINT 15
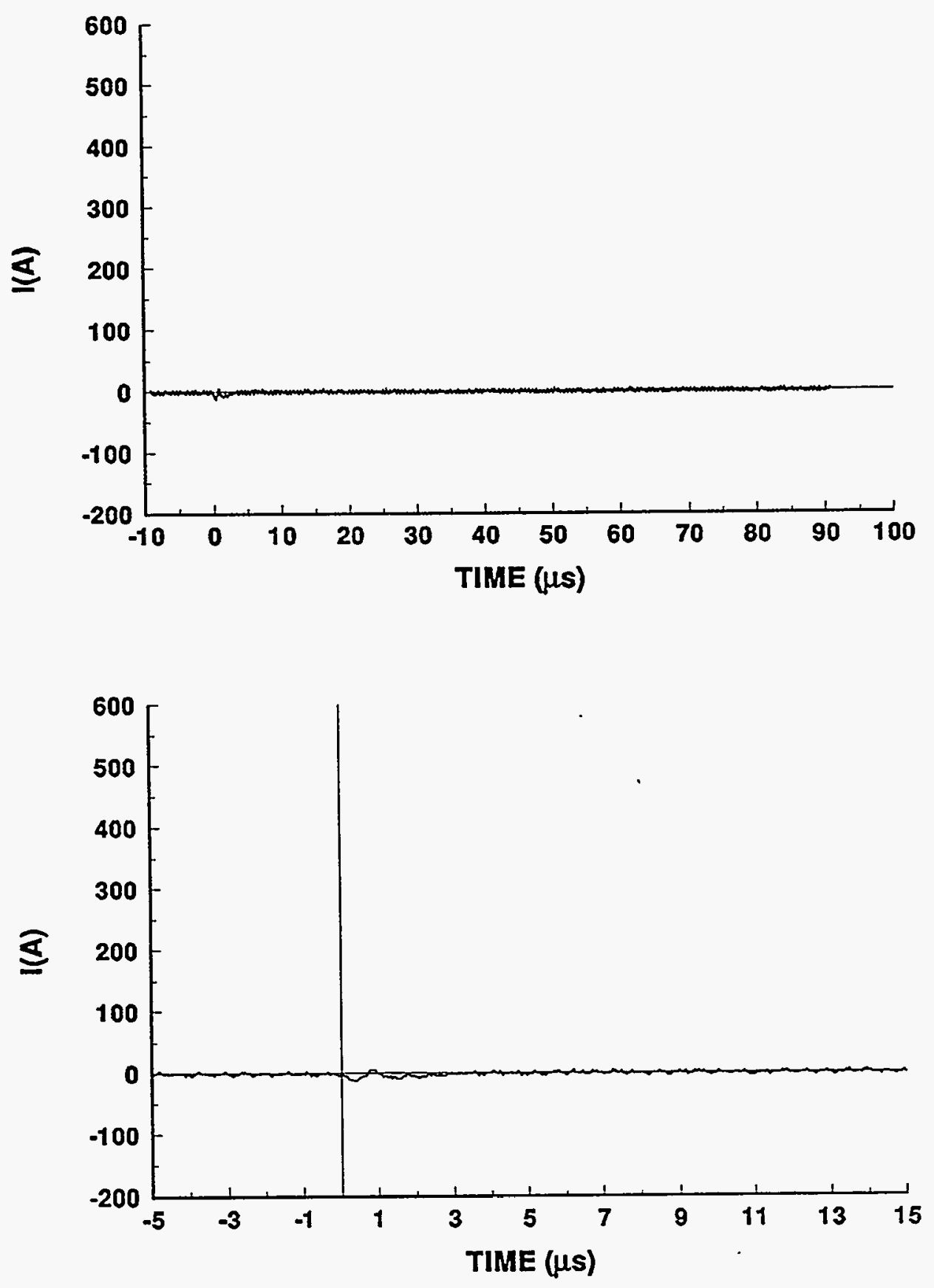


\section{4-22 STROKE 3}

TEST POINT 20

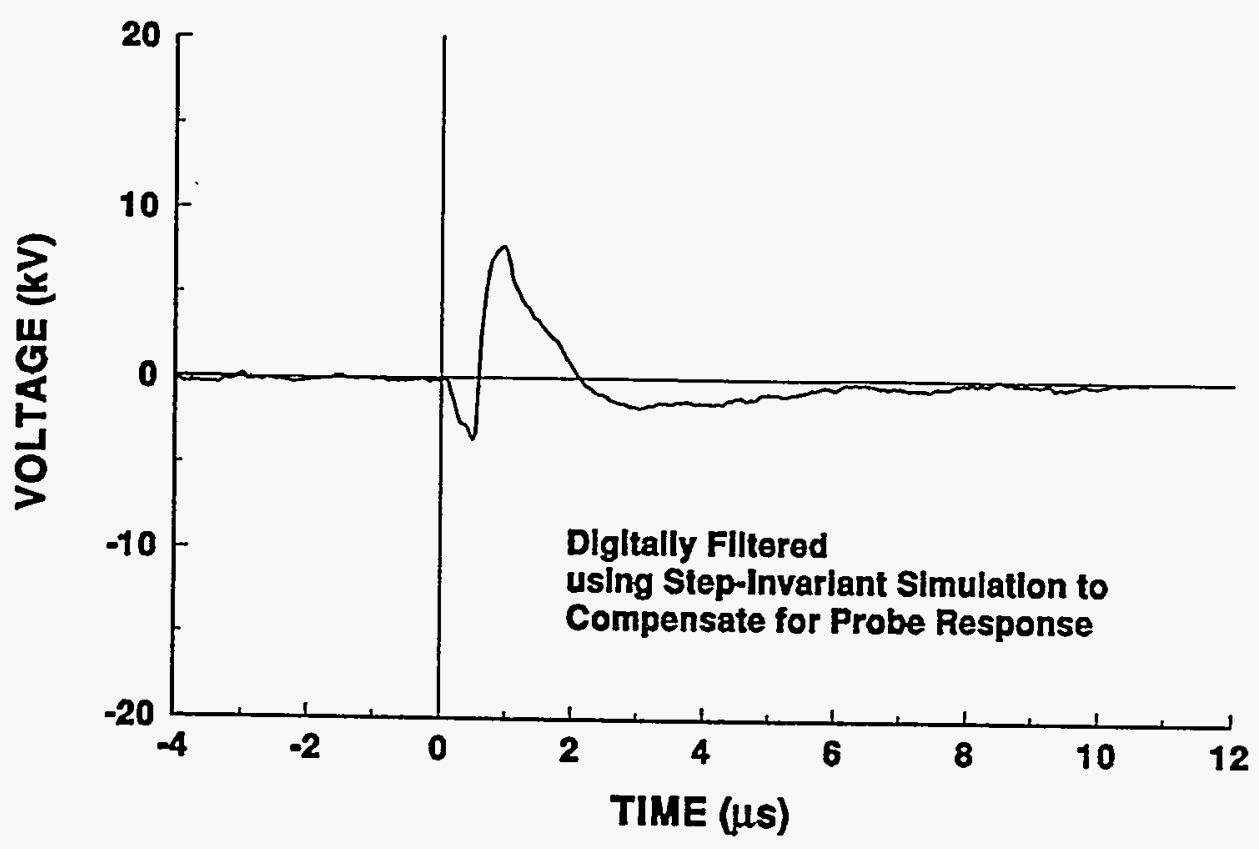

94-22 STROKE 3

TEST POINT 21

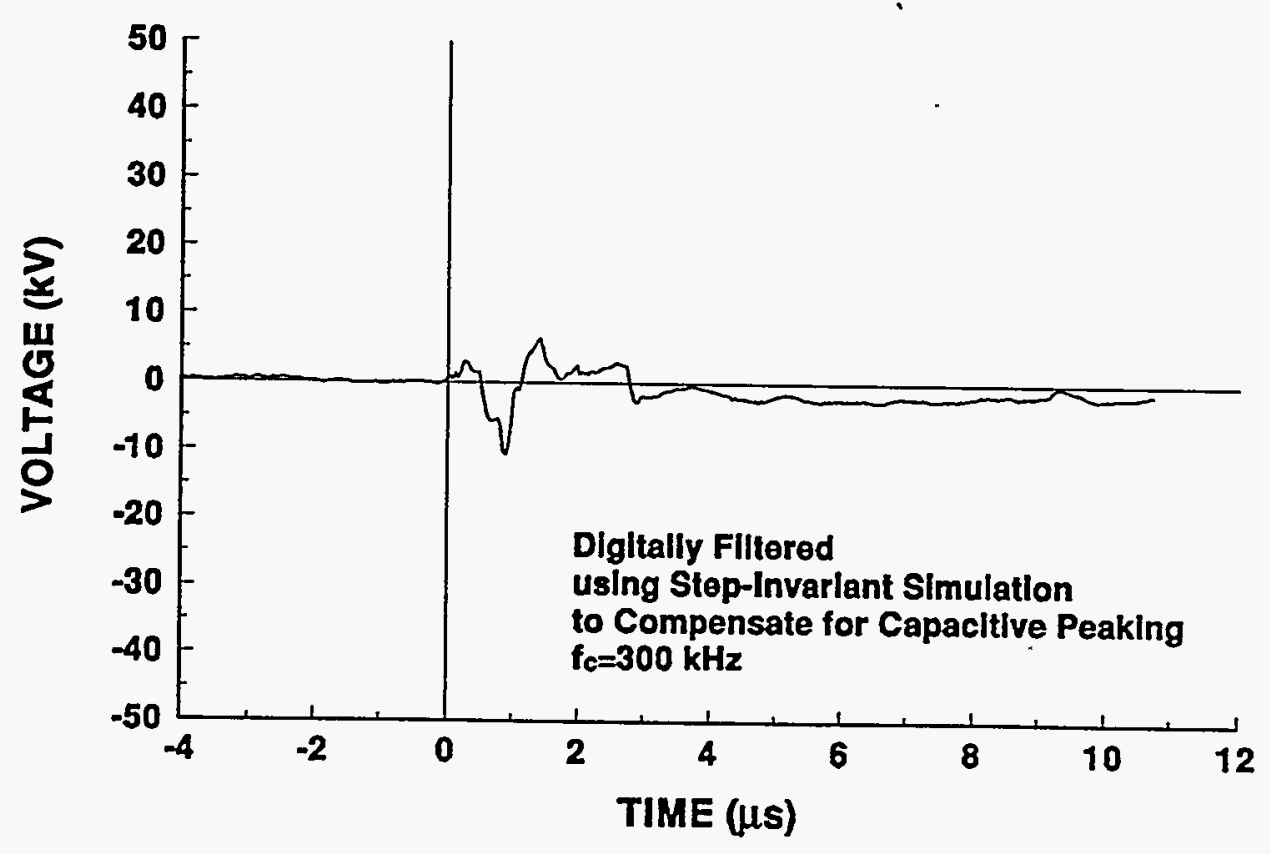




\section{4-22 STROKE 3}

TEST POINT 22

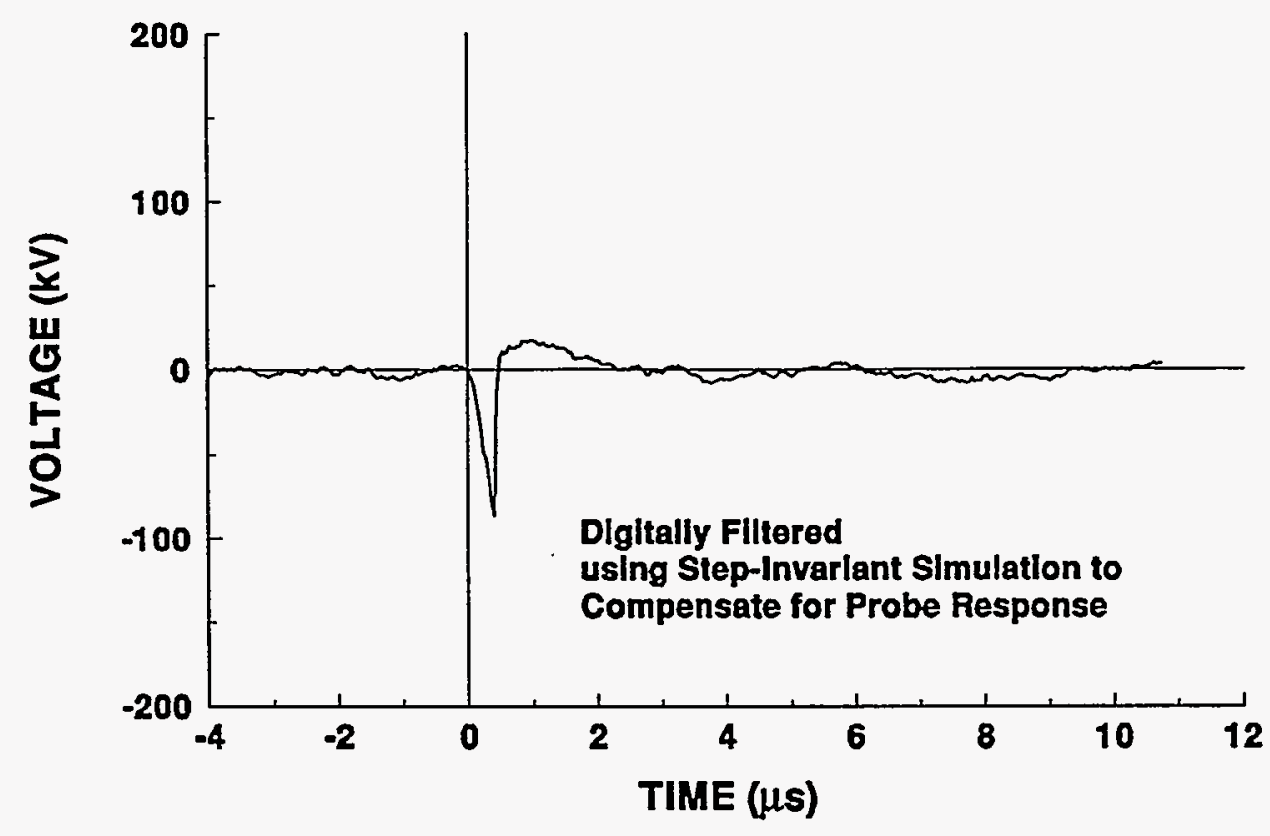




\section{4-24 STROKE 1}

TEST POINT 2
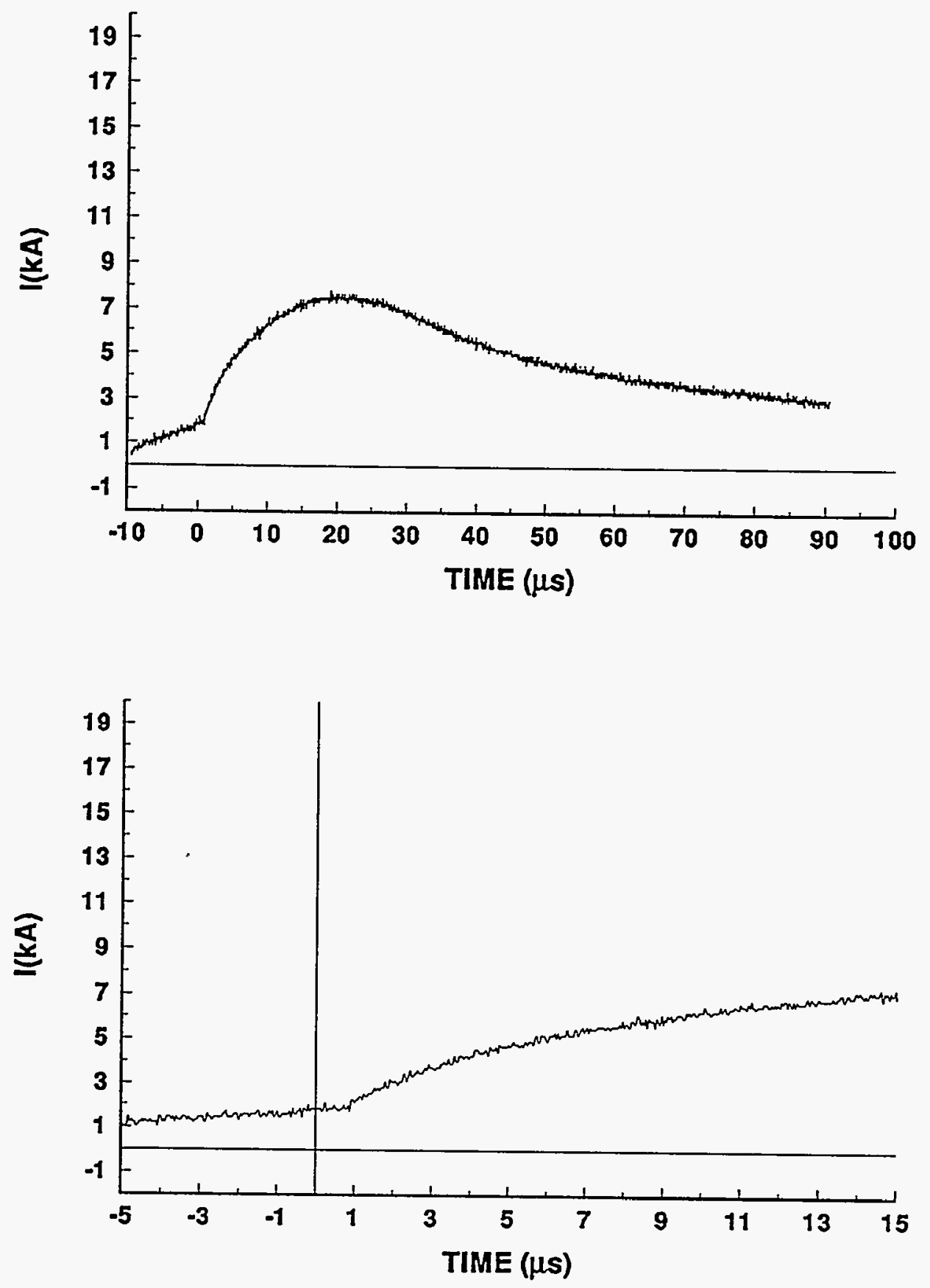


\section{4-24 STROKE 1}

\section{TEST POINT 5}
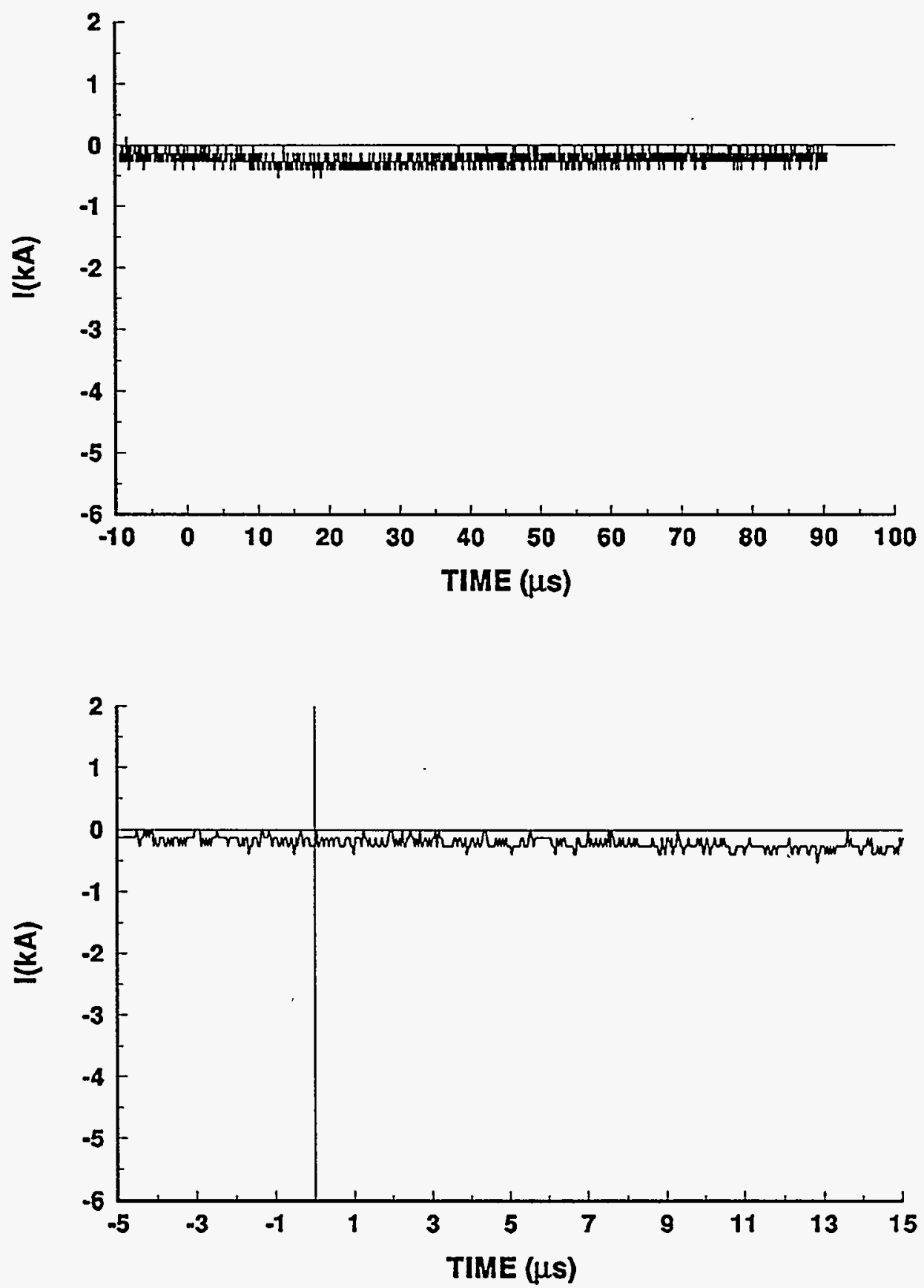


\section{4-24 STROKE 1}

TEST POINT 6
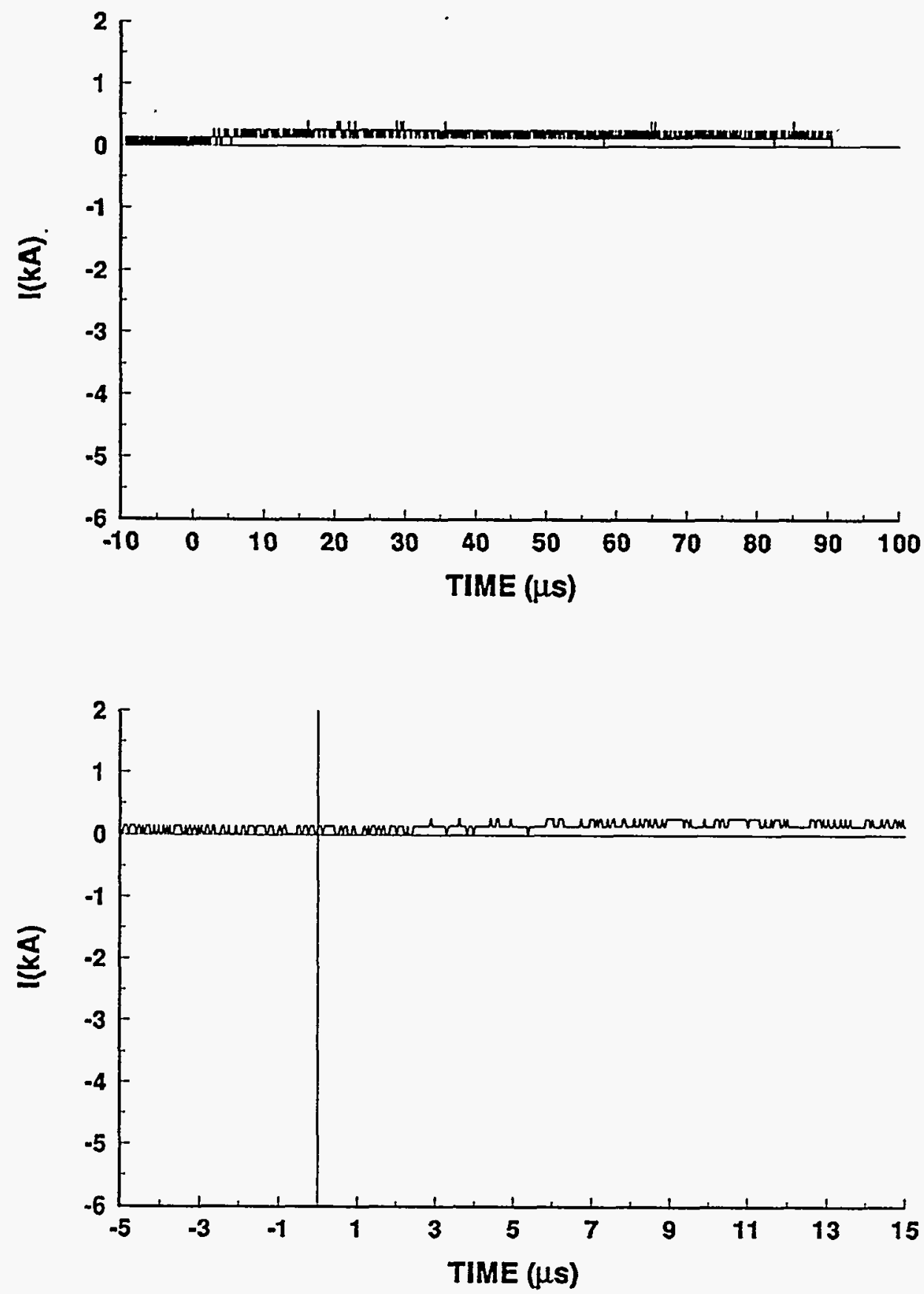
94-24 STROKE 1

TEST POINT 5'

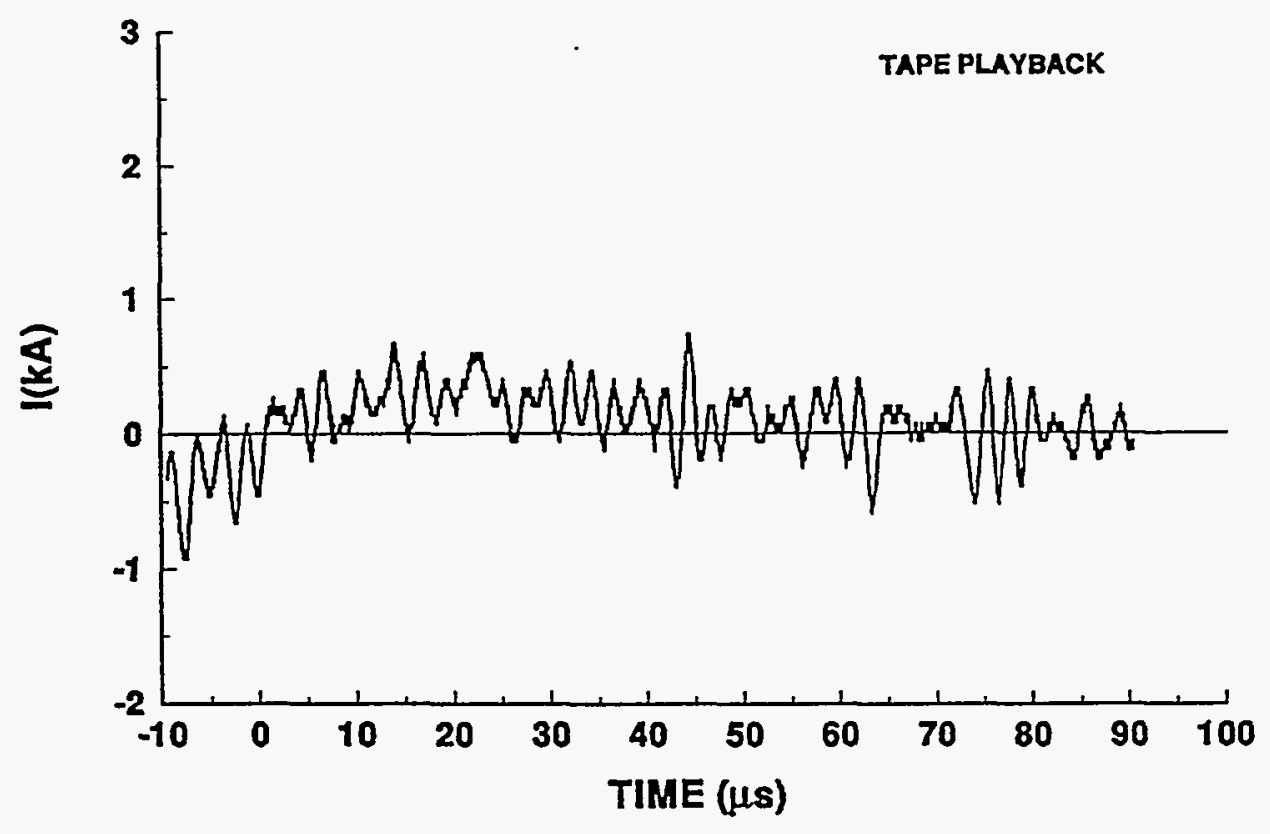

94-24 STROKE 1

TEST POINT 6'

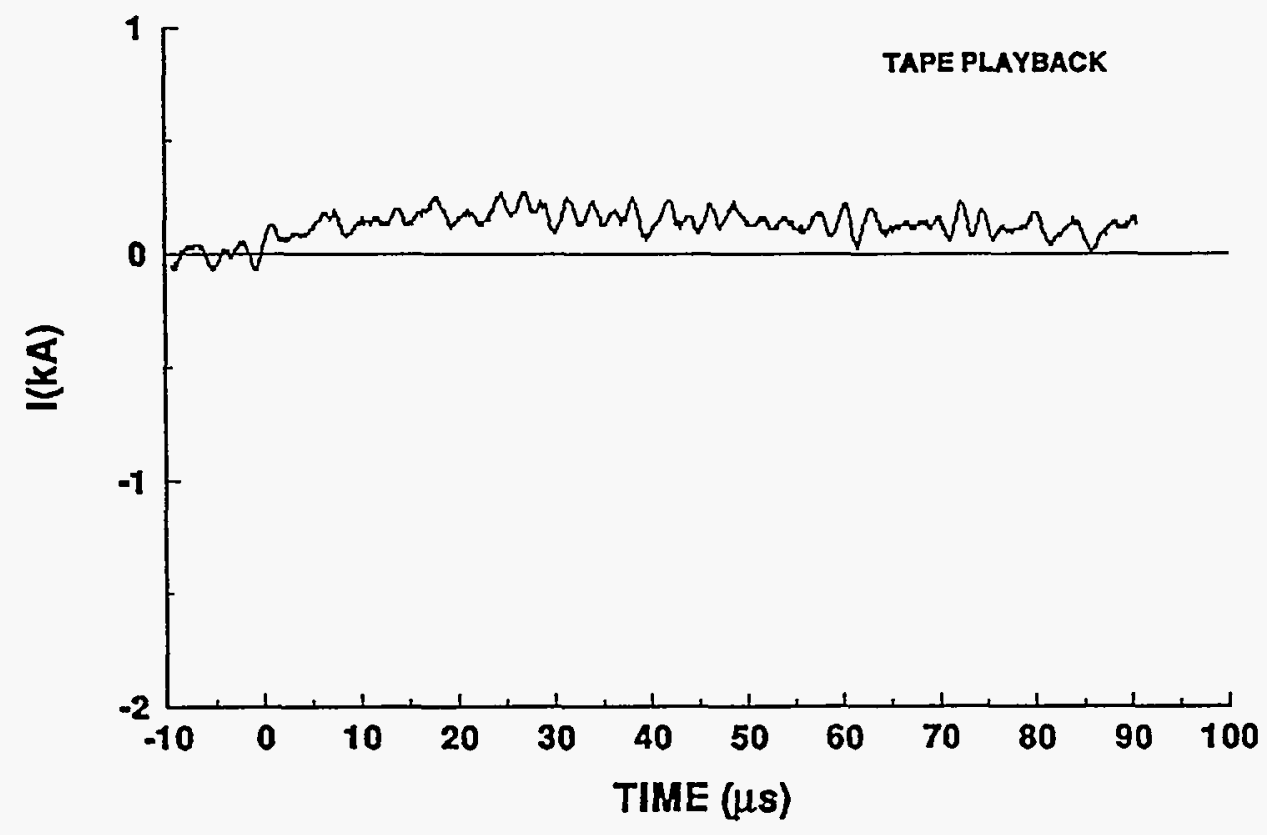


94-24 STROKE 1

TEST POINT 10

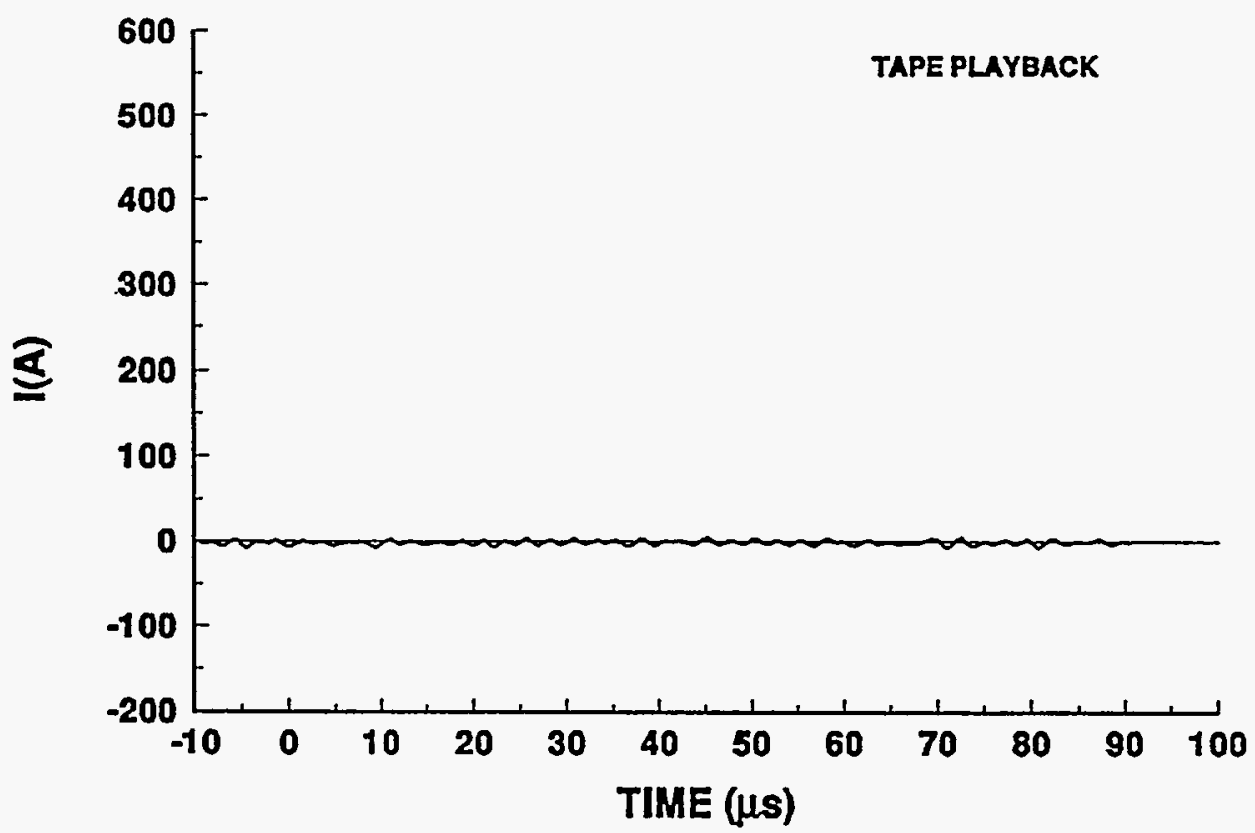

94-24 STROKE 1

TEST POINT 11

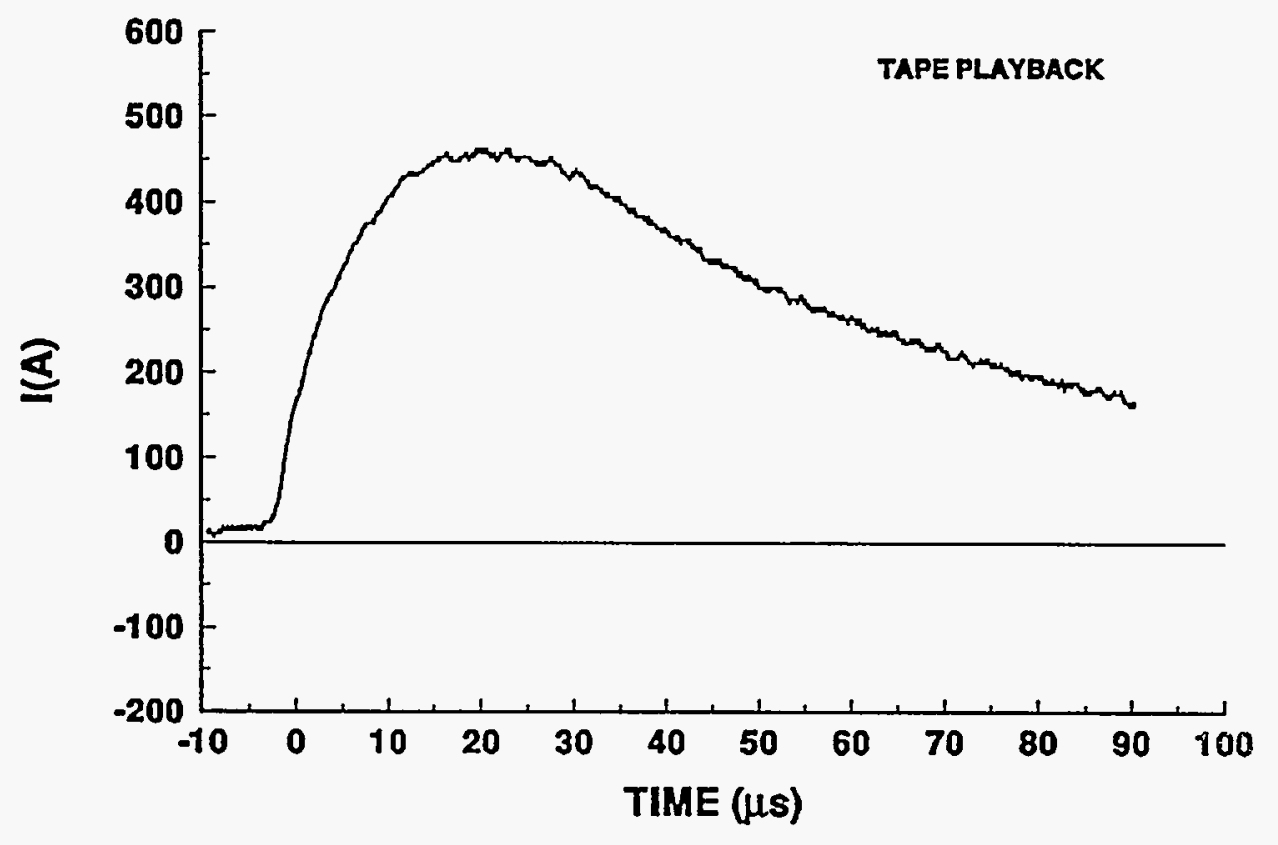


94-24 STROKE 1

TEST POINT 12

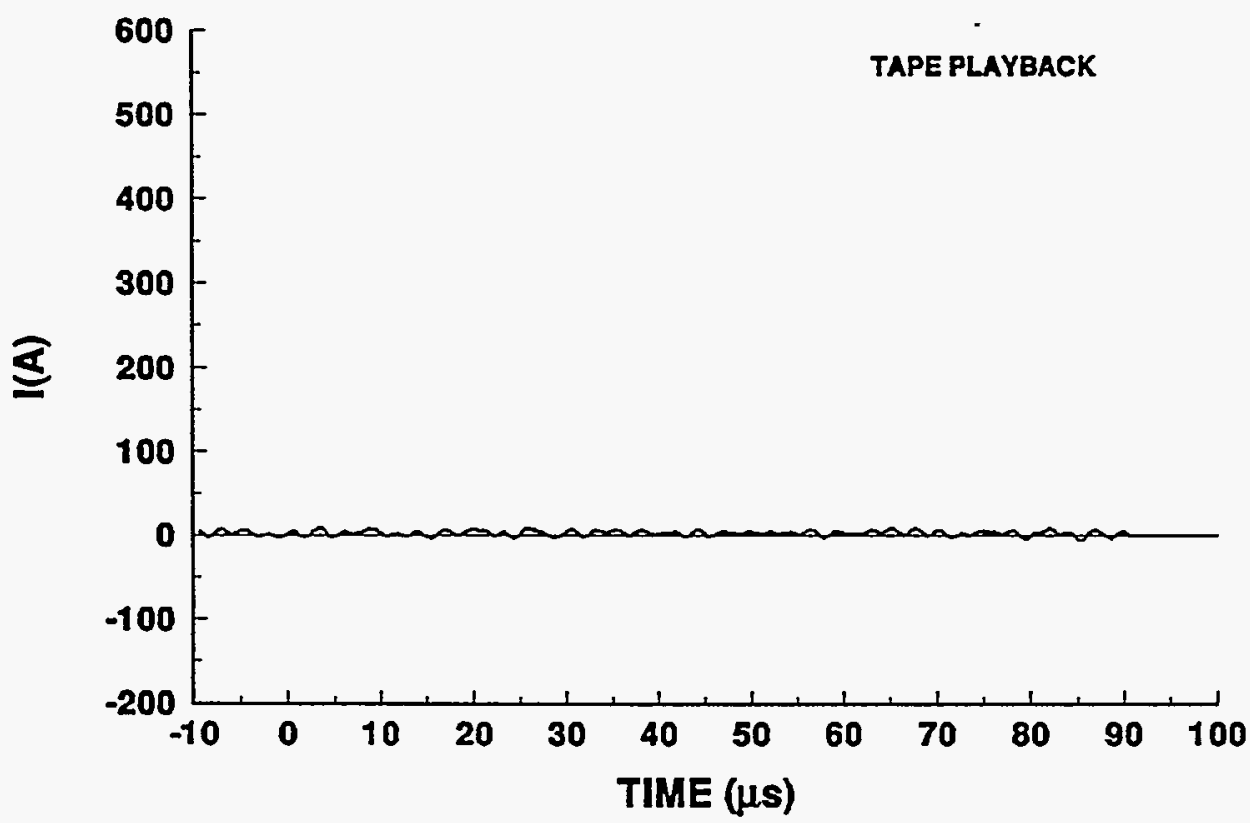

94-24 STROKE 1

TEST POINT 13

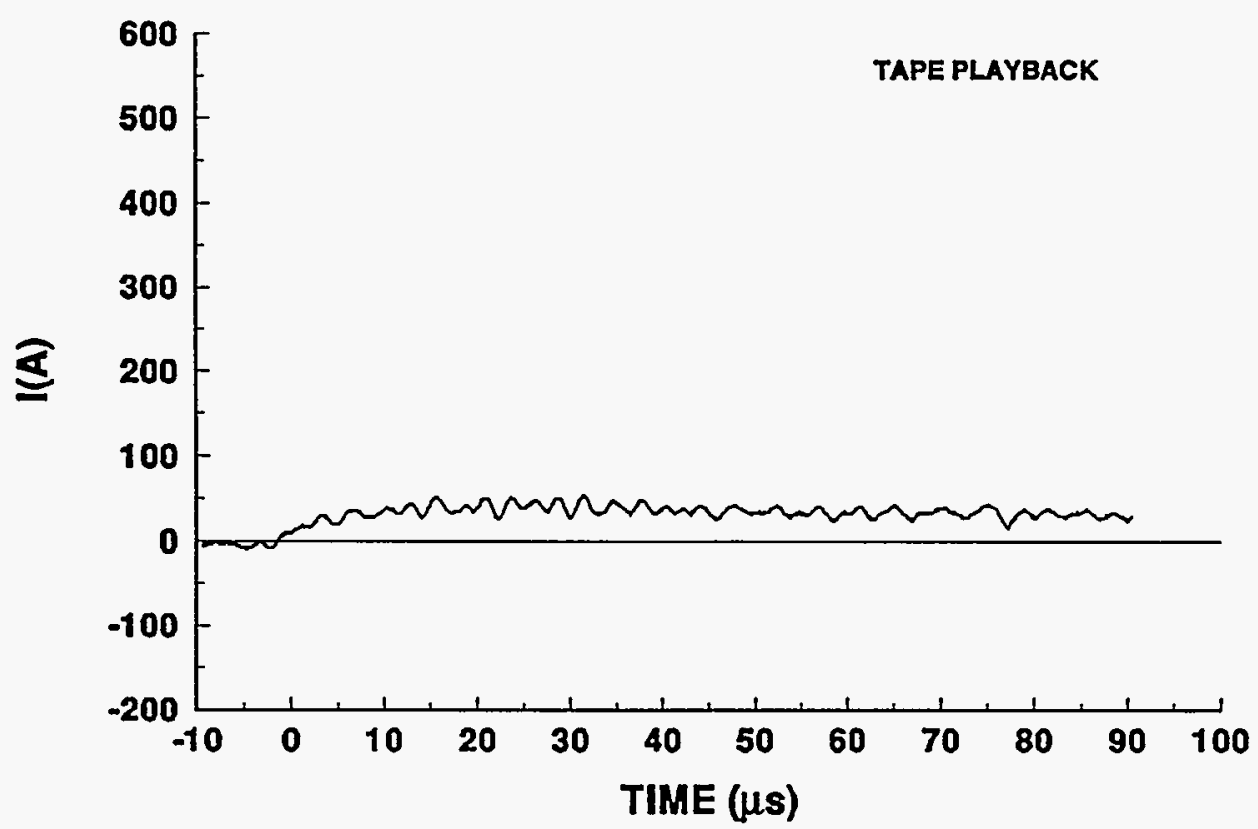




\section{4-24 STROKE 1}

TEST POINT 14
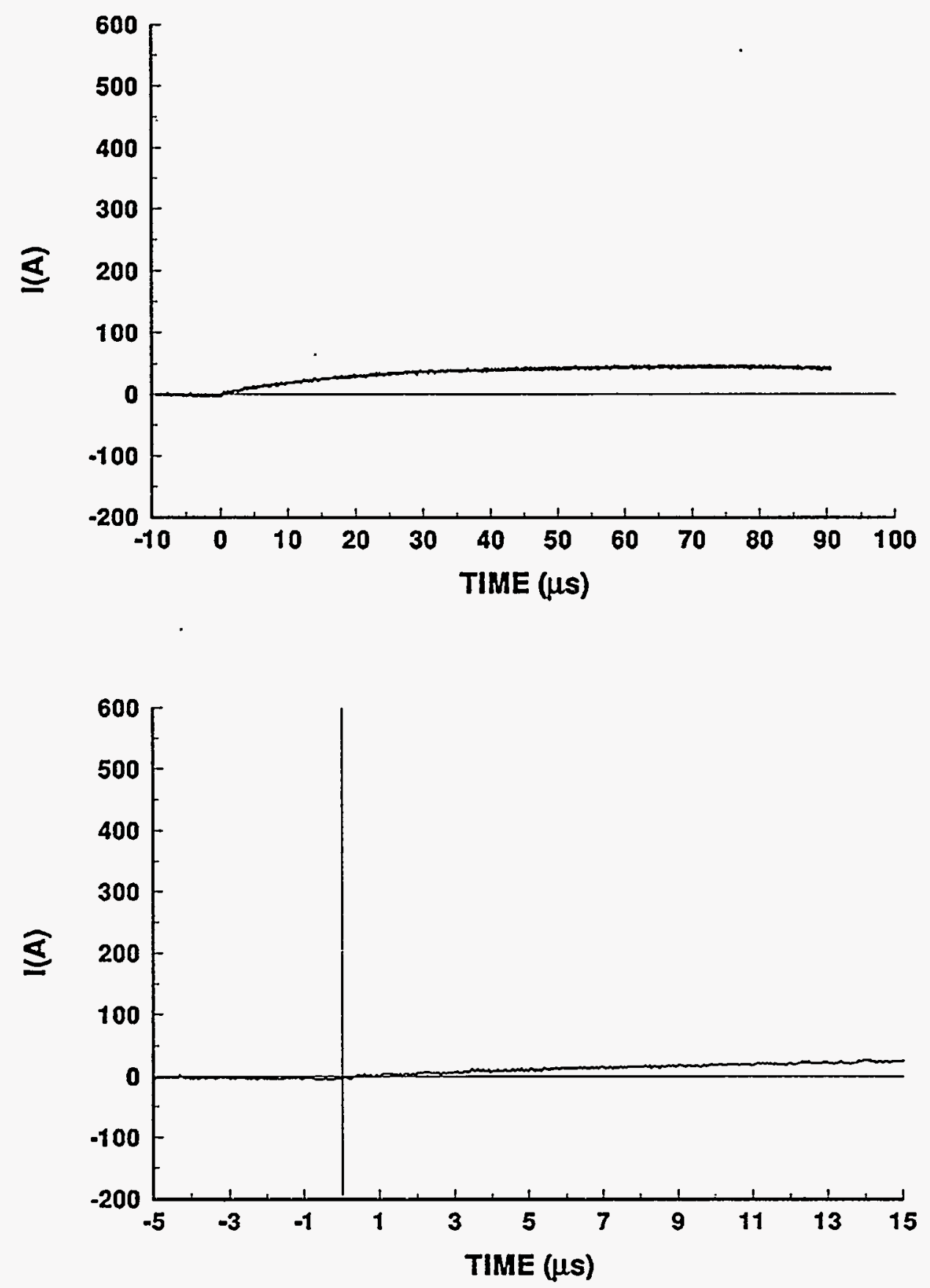
94-24 STROKE 1

TEST POINT 15
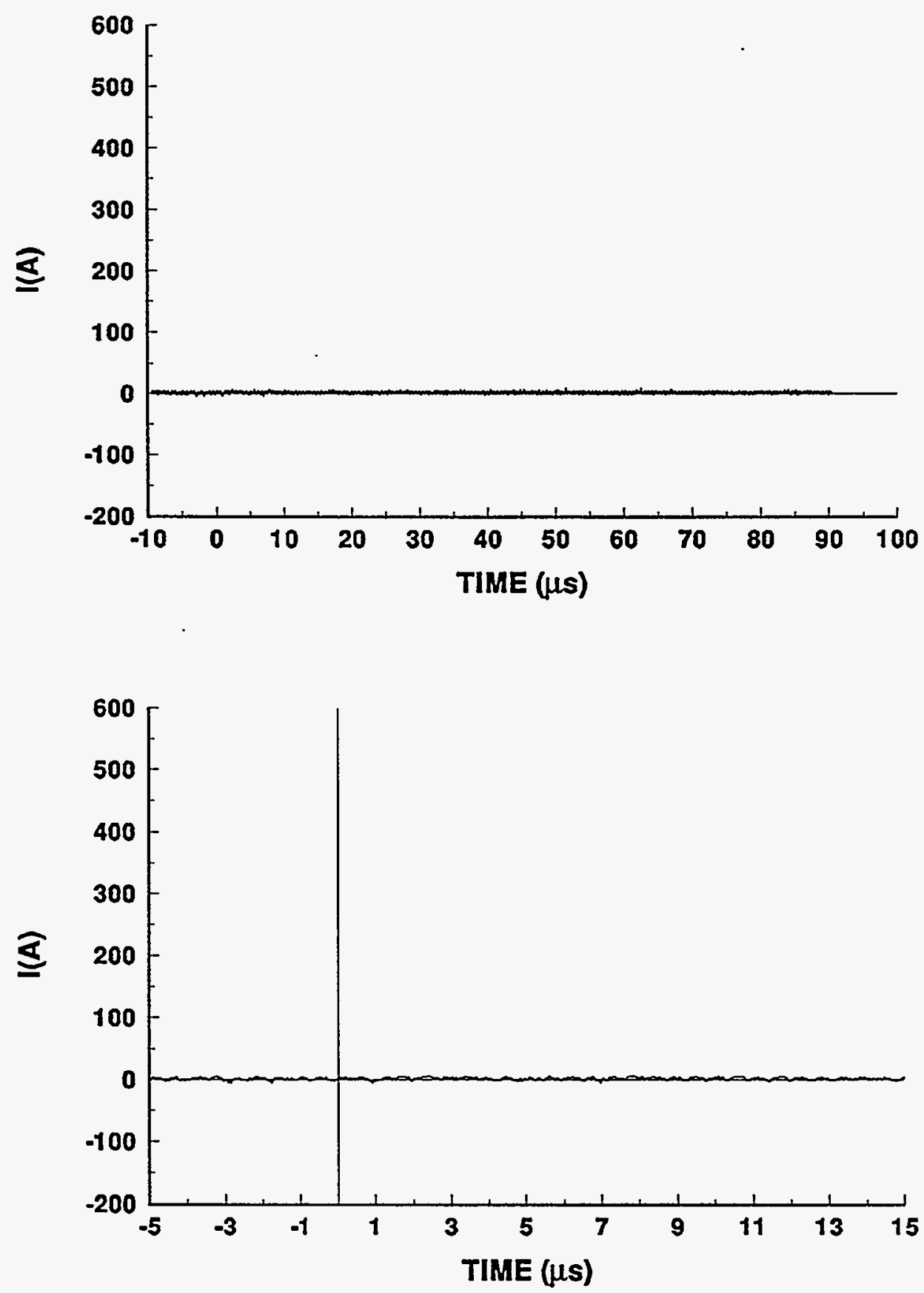


\section{4-24 STROKE 1}

TEST POINT 20

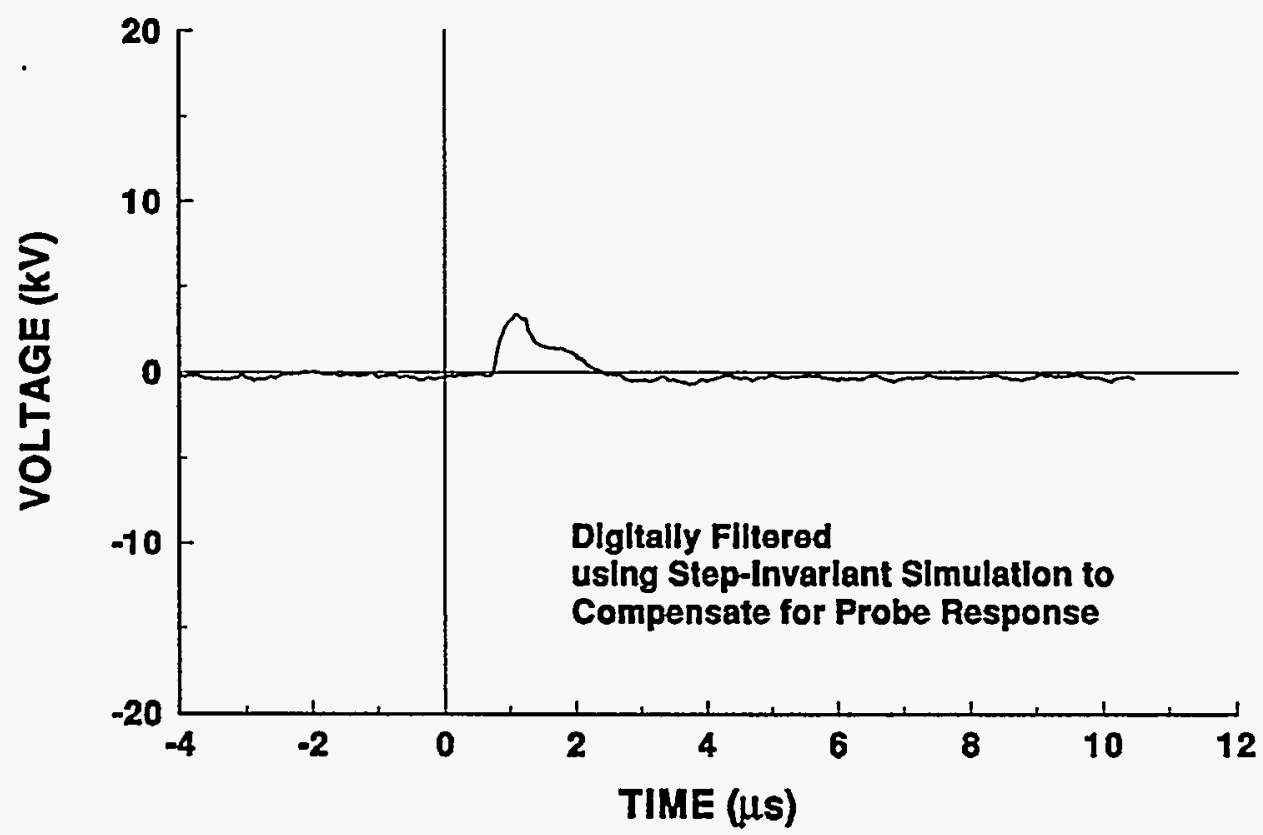

\section{4-24 STROKE 1} TEST POINT 21

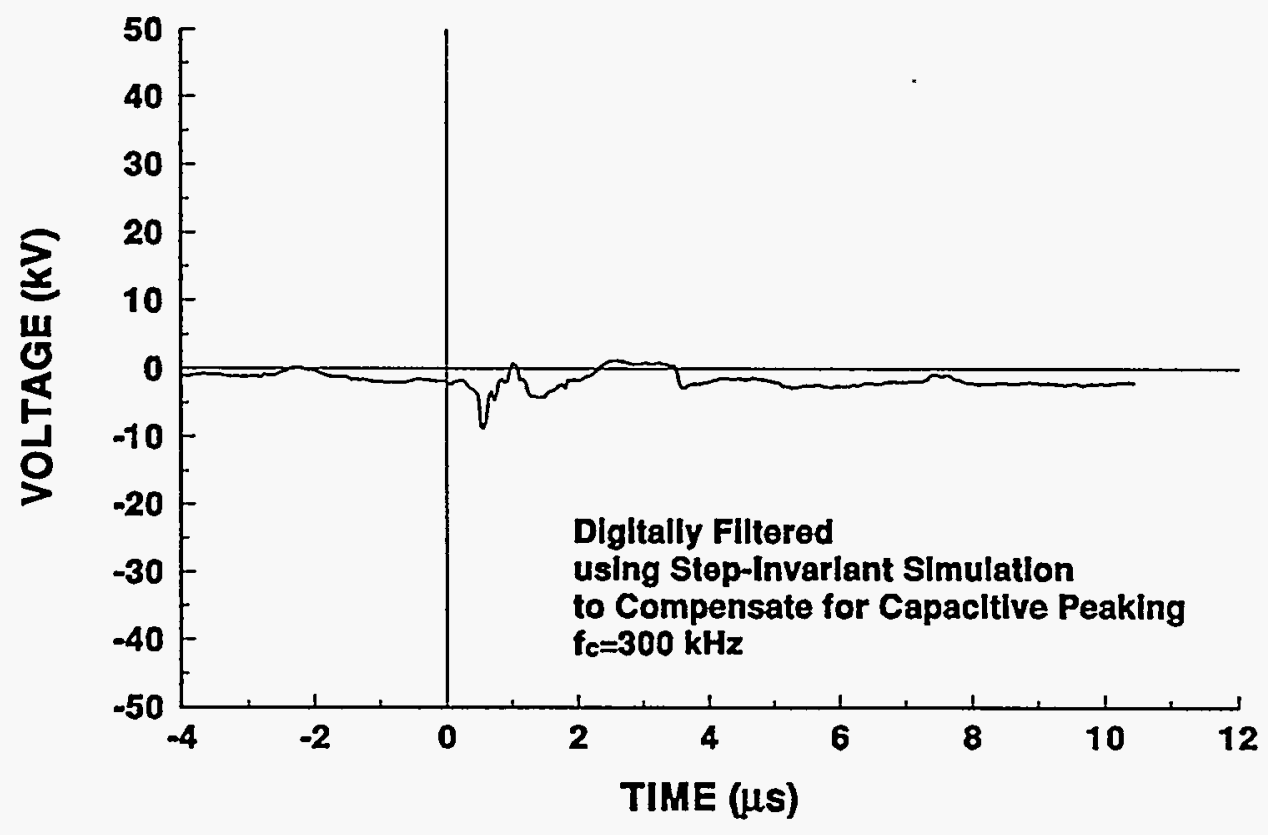




\section{4-24 STROKE 1}

TEST POINT 22

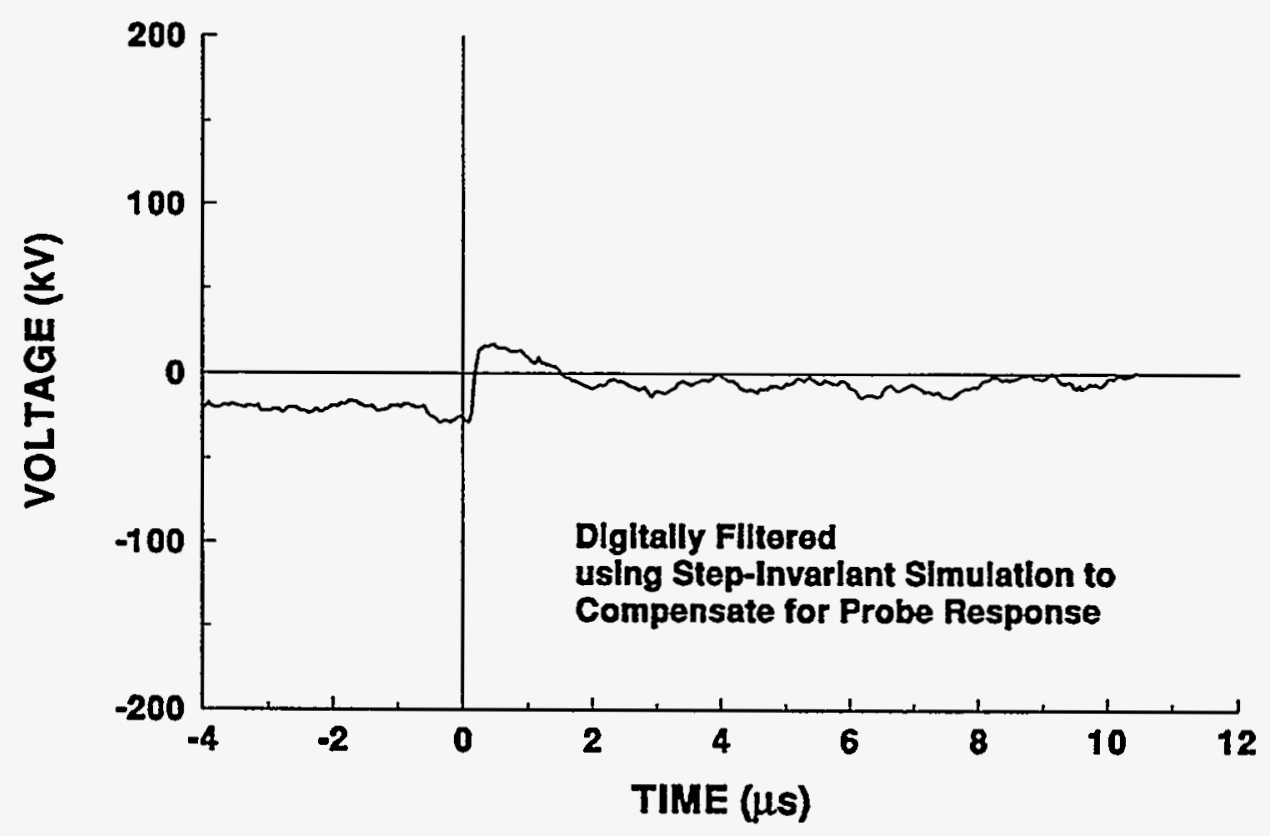




\section{4-24 STROKE 1}

\section{TEST POINT 23}

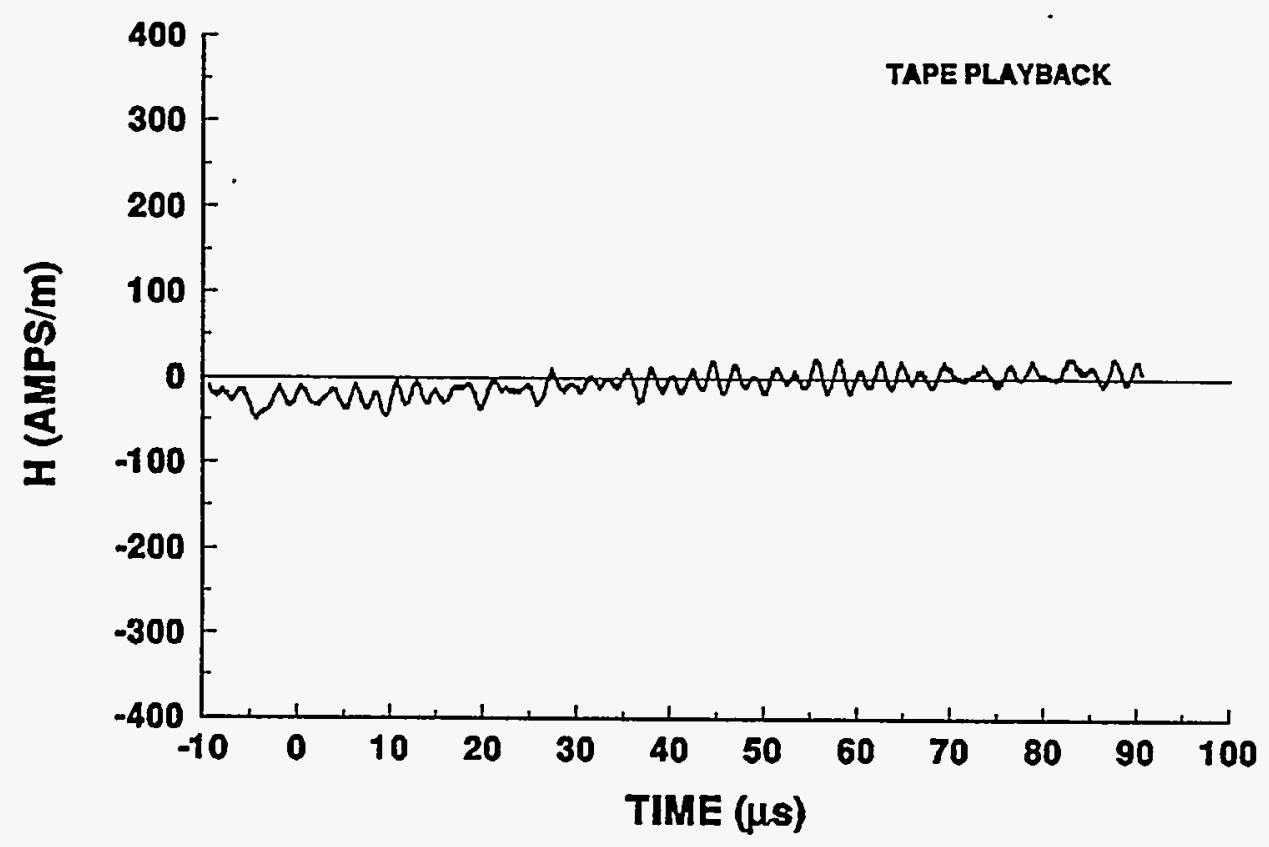

94-24 STROKE 1 TEST POINT 24

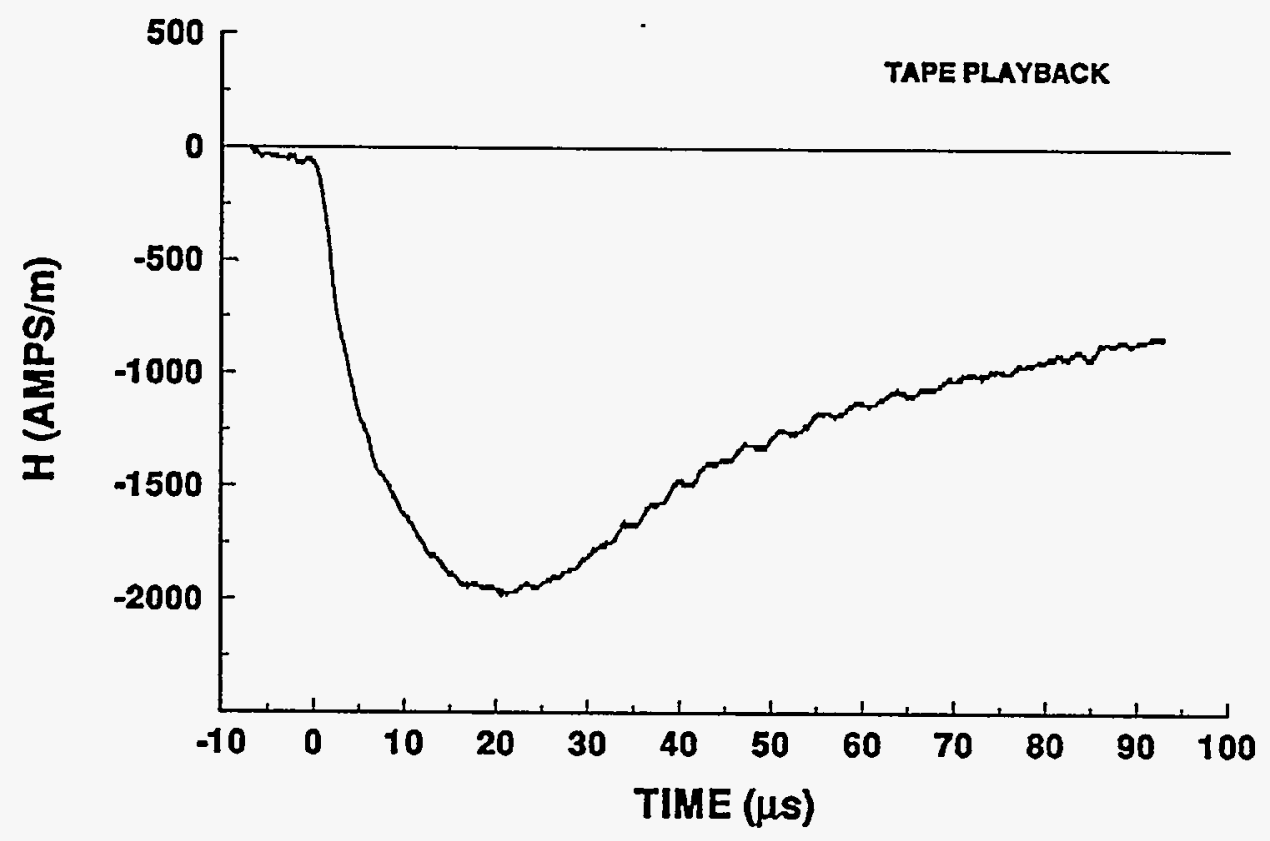




\section{4-24 STROKE 2 \\ INCIDENT CURRENT}
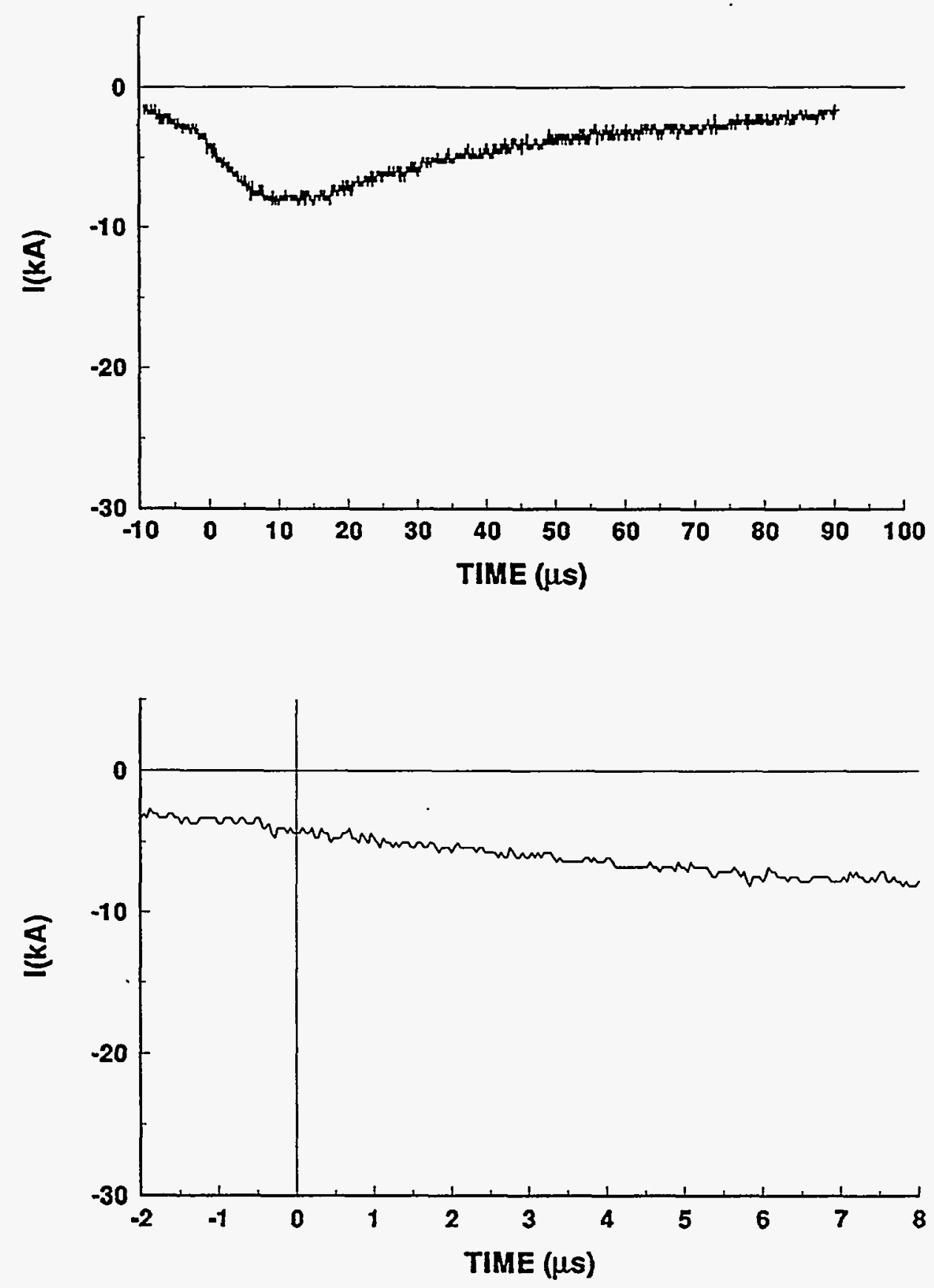


\section{4-24 STROKE 2}

\section{TEST POINT 1}
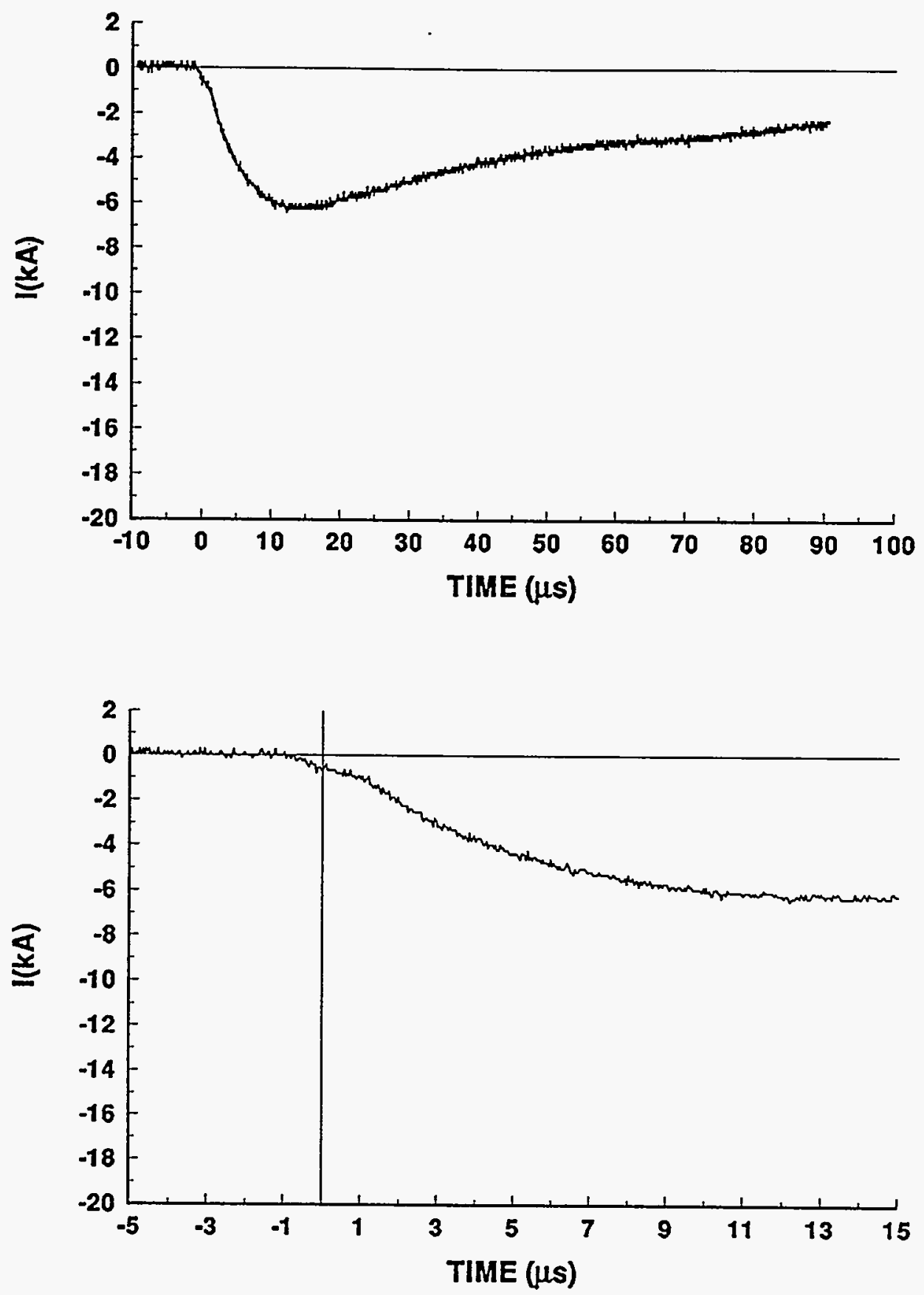


\section{4-24 STROKE 2}

TEST POINT 2
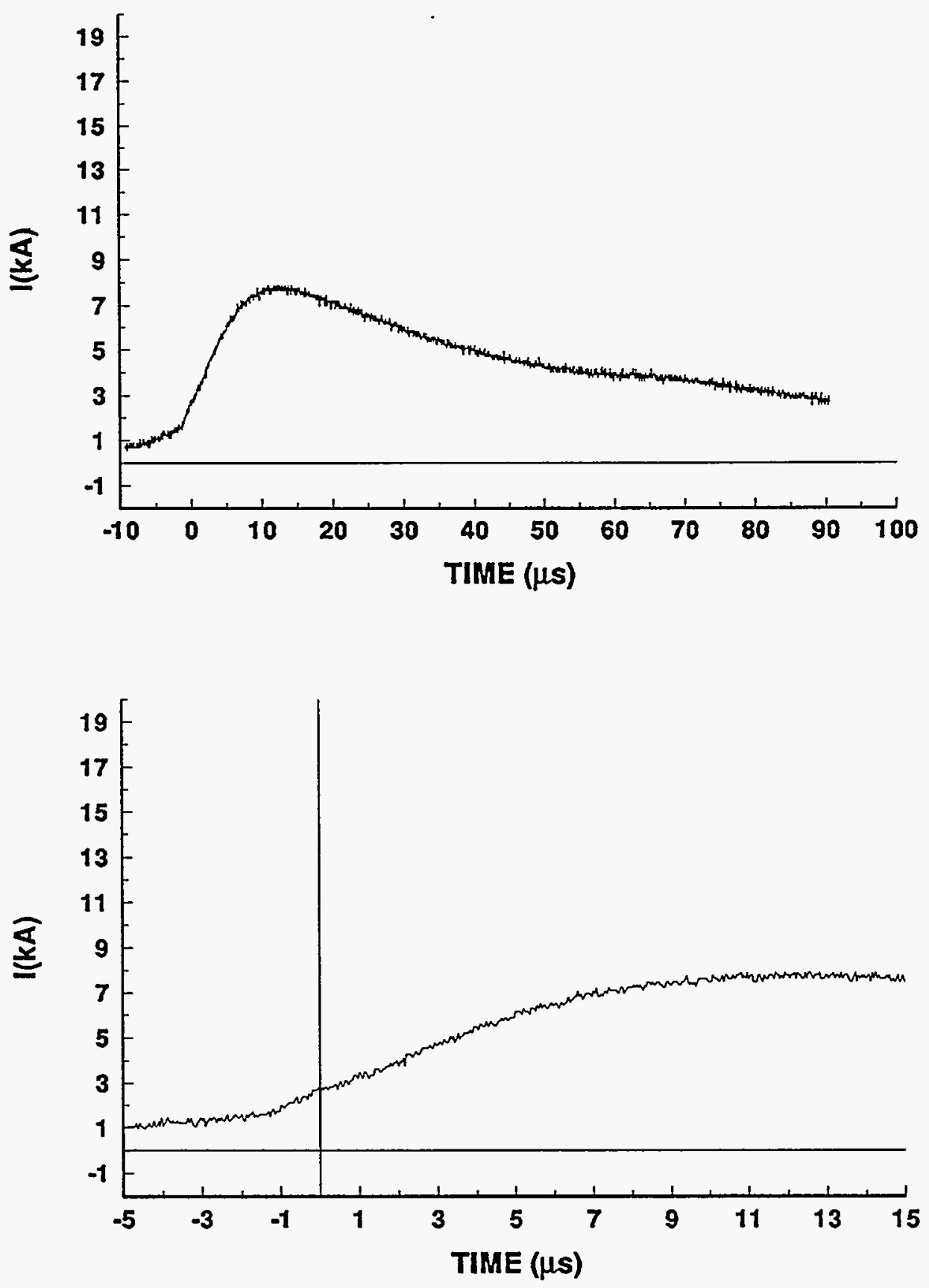


\section{4-24 STROKE 2}

TEST POINT 5
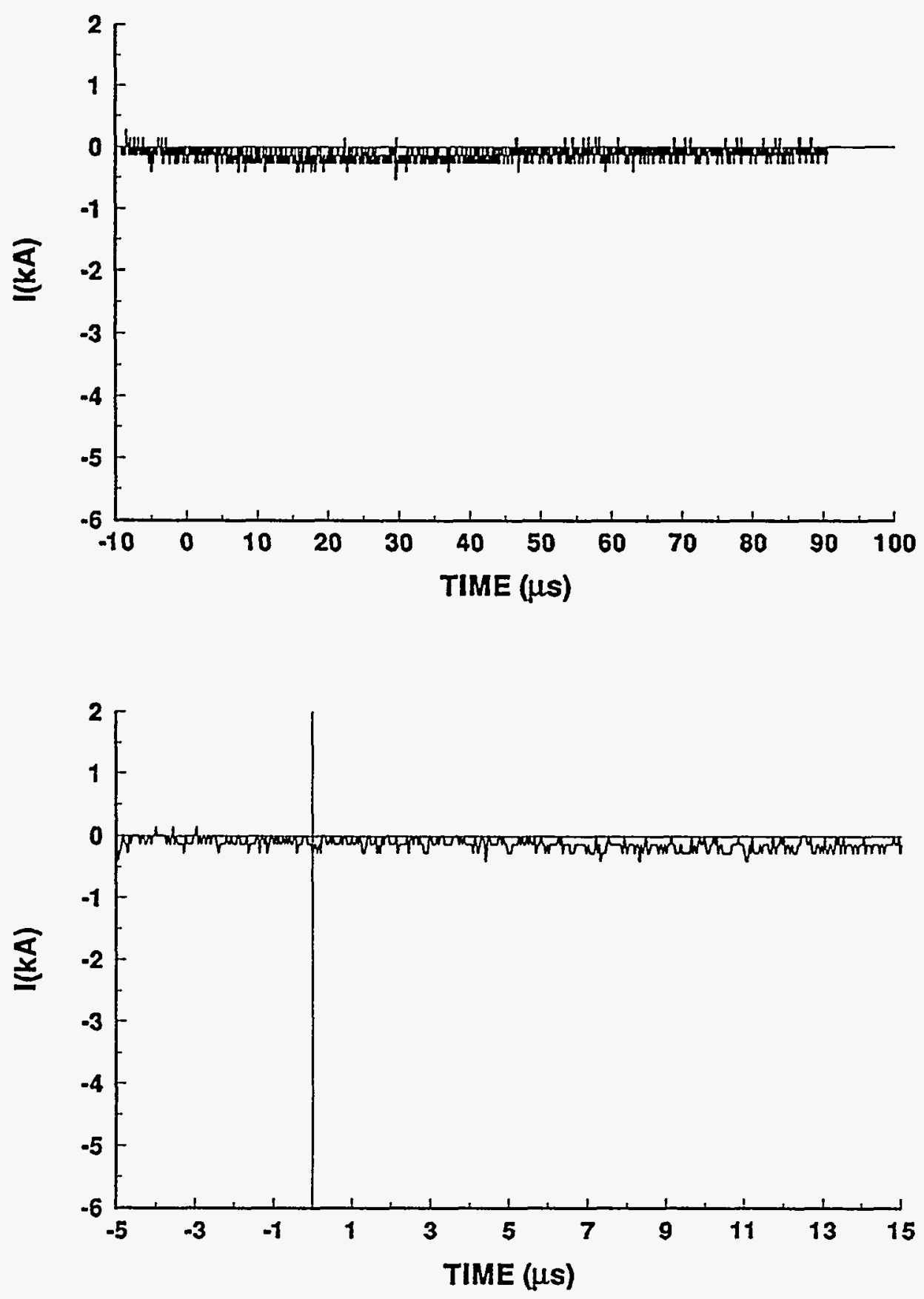


\section{4-24 STROKE 2}

TEST POINT 6
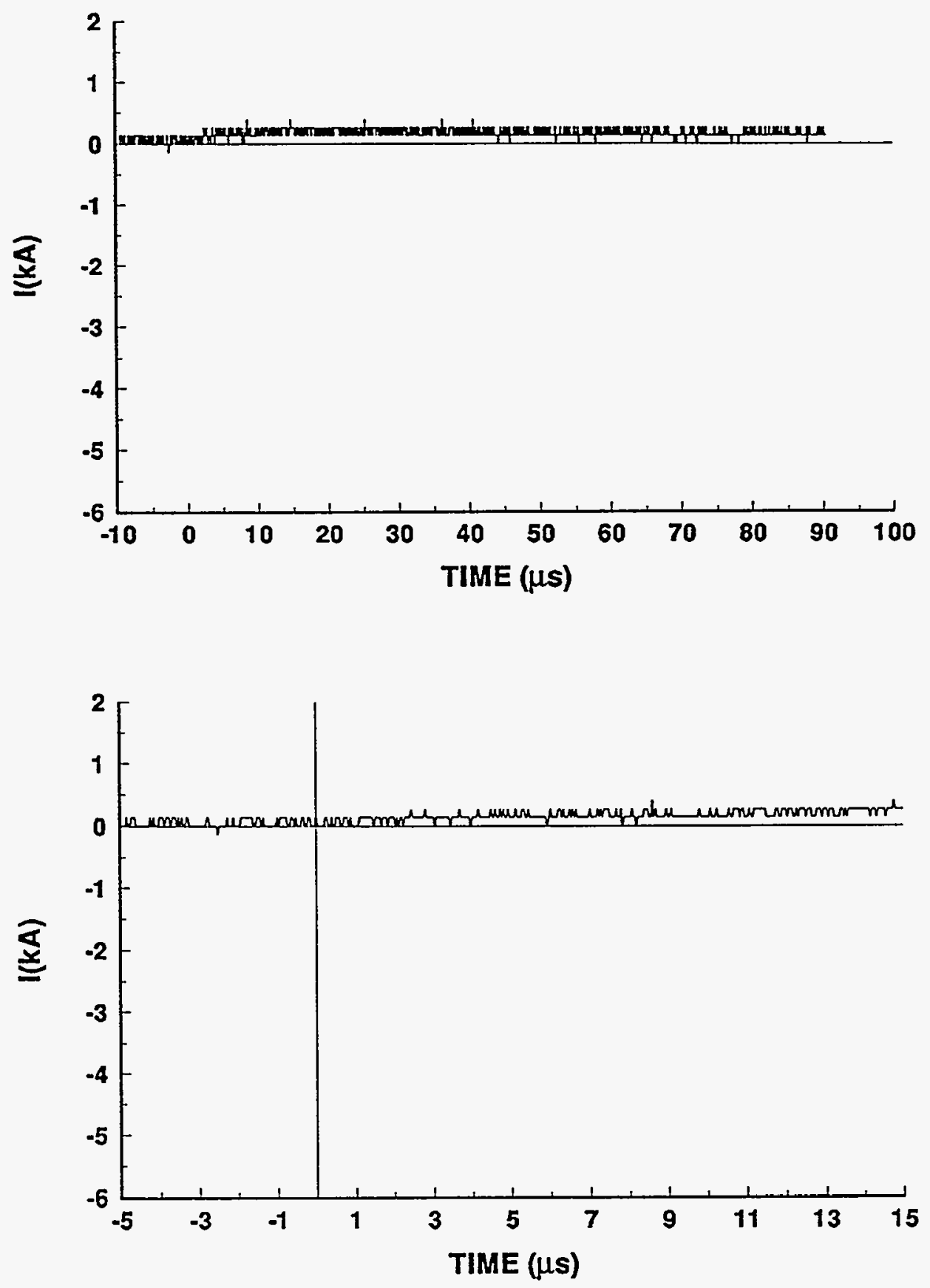


\section{4-24 STROKE 2}

TEST POINT 5'

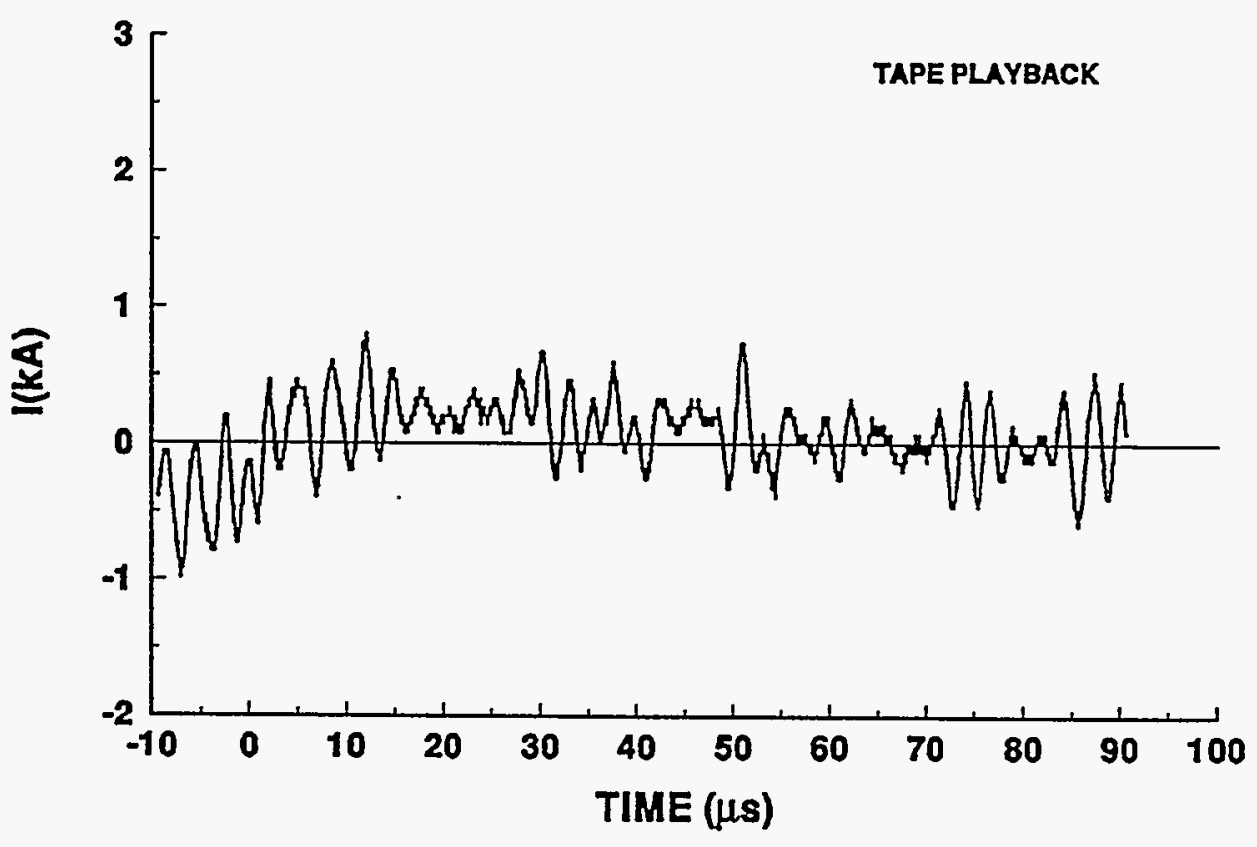

94-24 STROKE 2

TEST POINT 6'

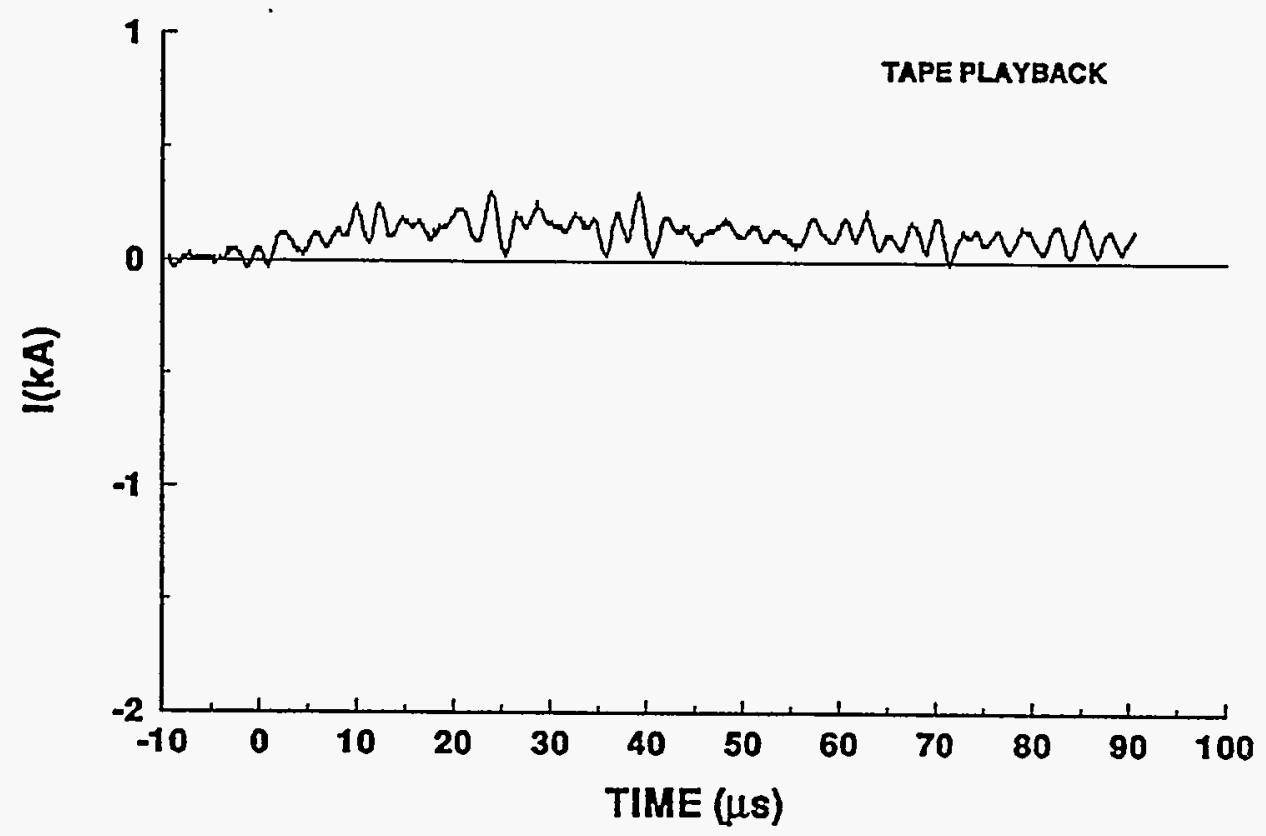


94-24 STROKE 2

TEST POINT 10

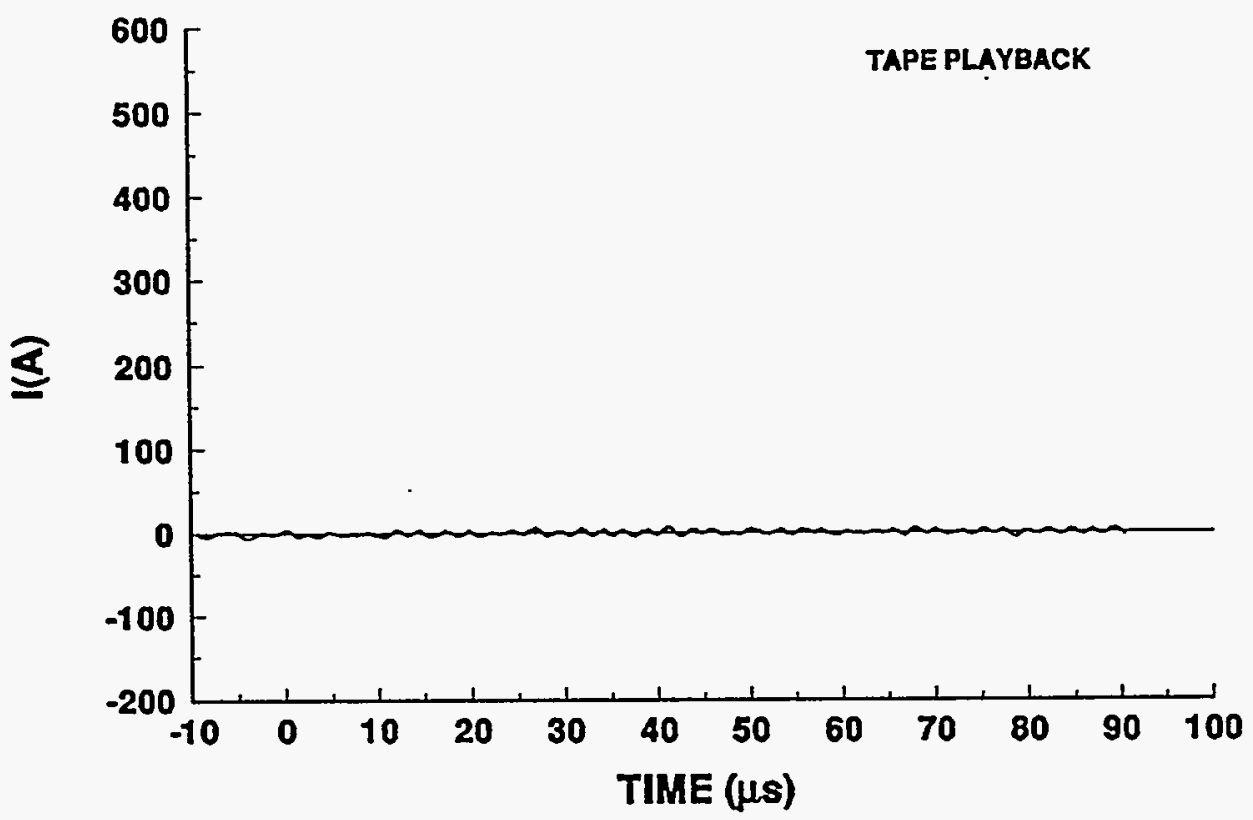

94-24 STROKE 2

TEST POINT 11

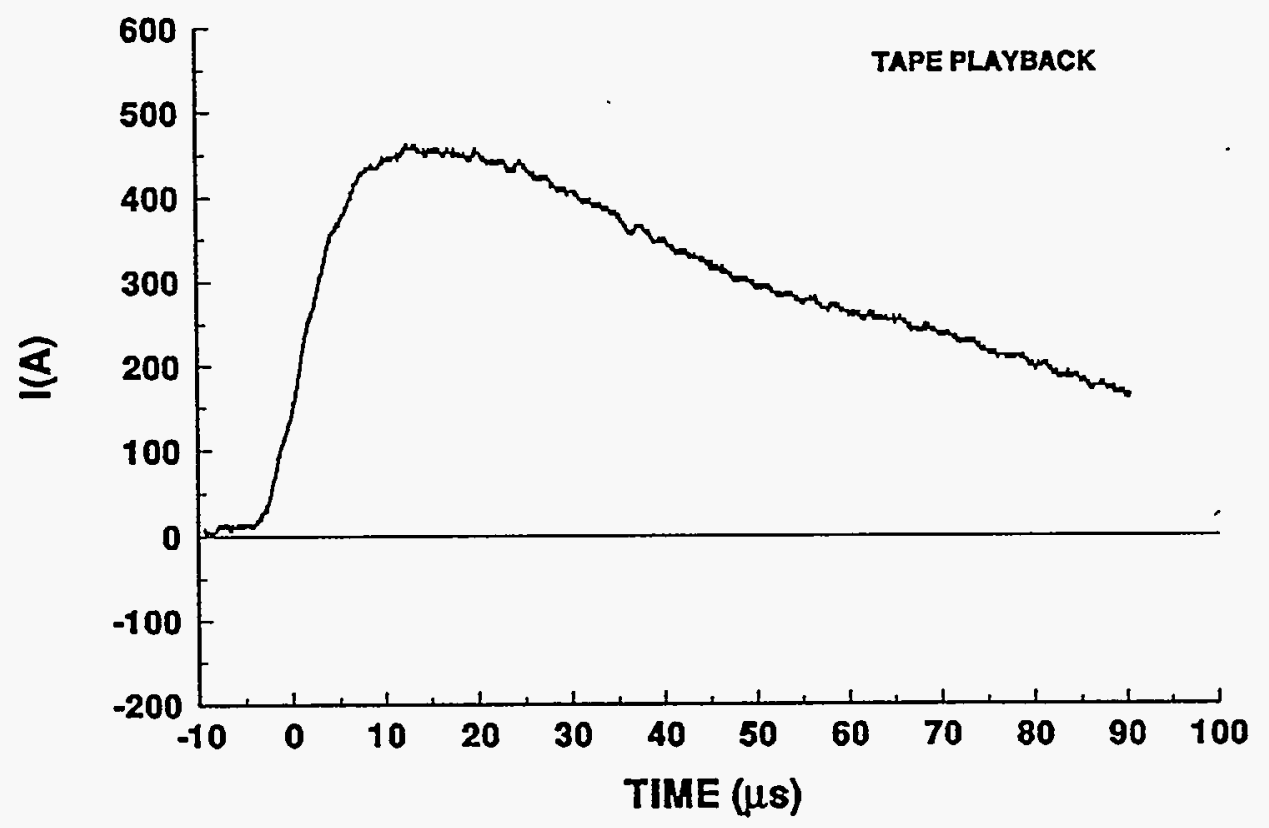




\section{4-24 STROKE 2}

\section{TEST POINT 12}

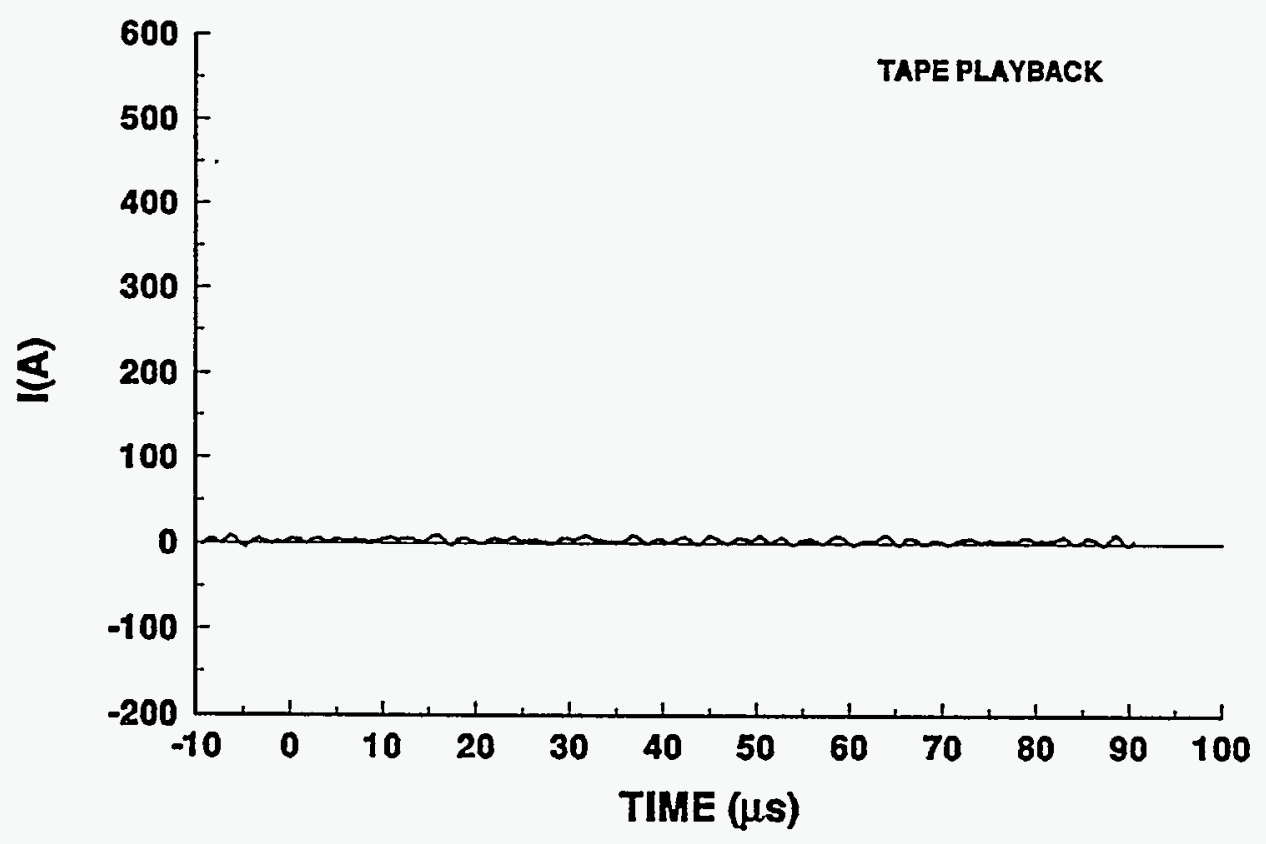

94-24 STROKE 2

TEST POINT 13

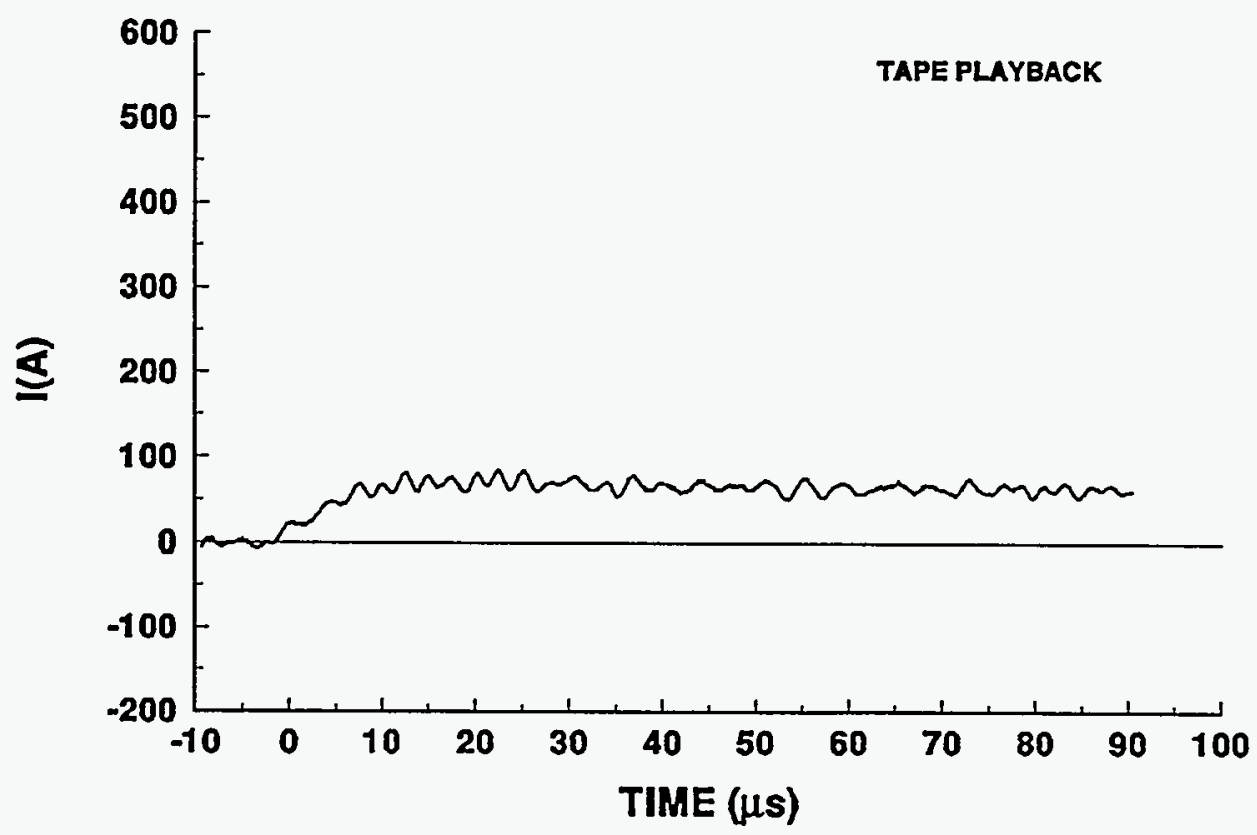




\section{4-24 STROKE 2}

TEST POINT 14
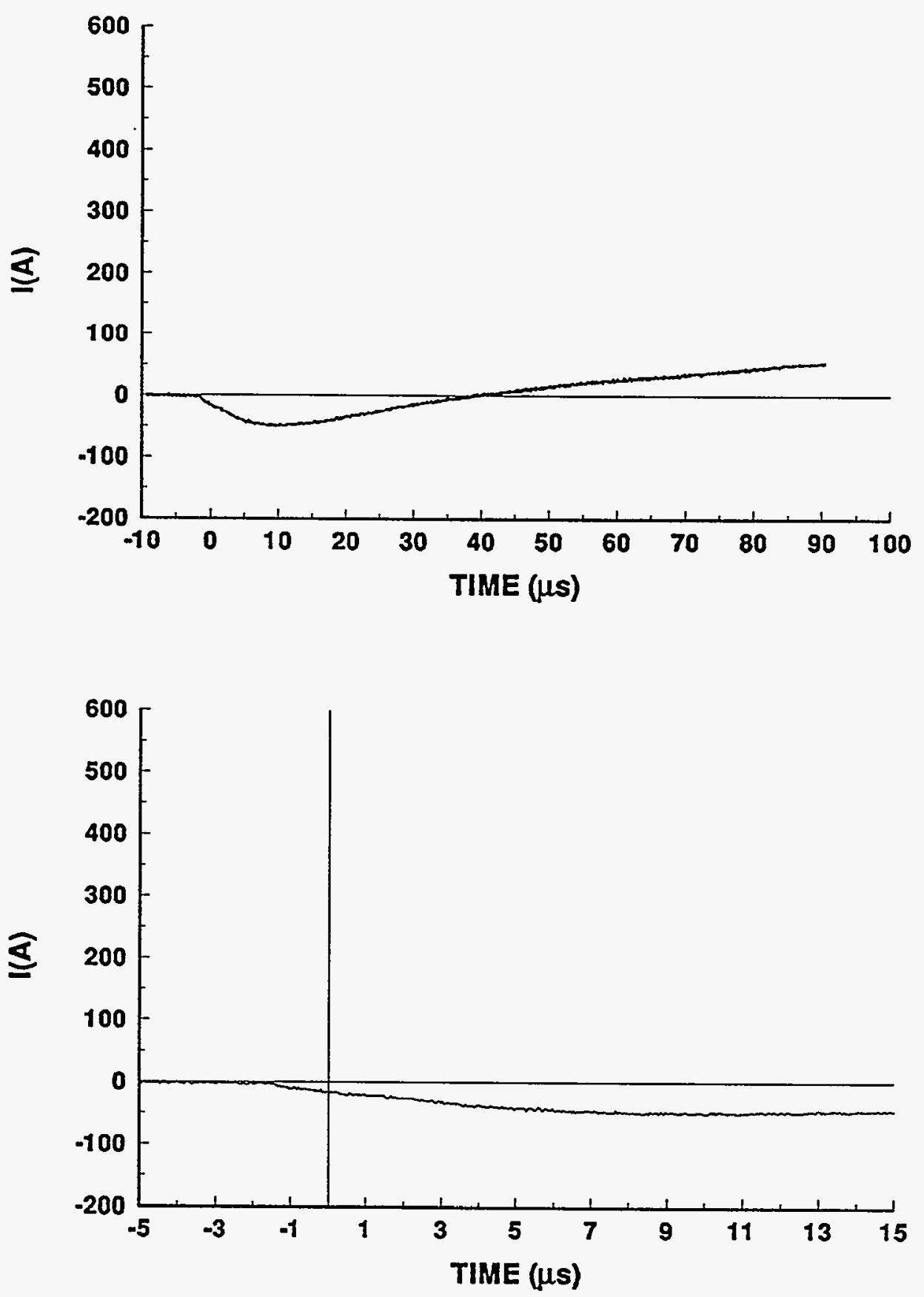


\section{4-24 STROKE 2}

TEST POINT 15
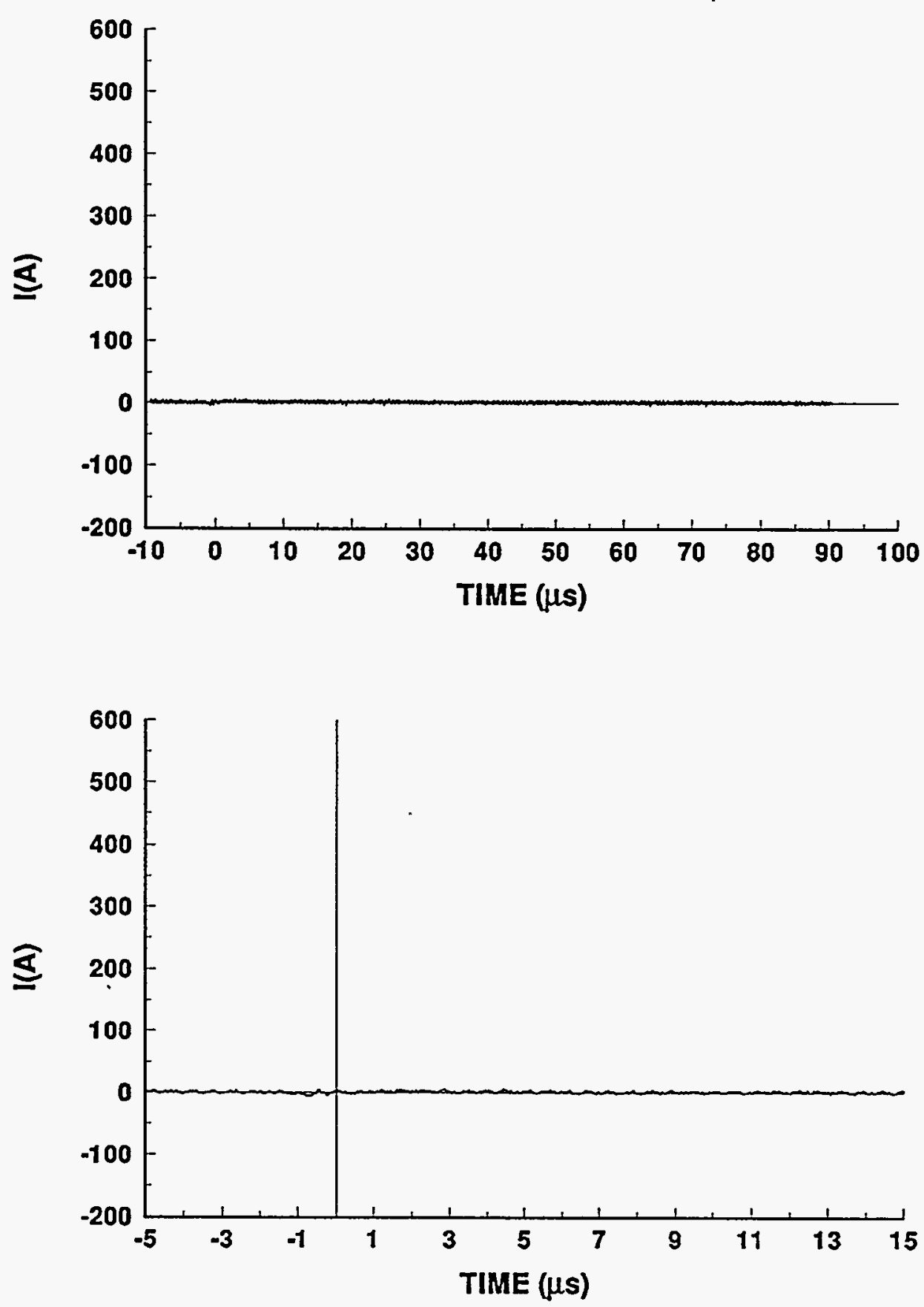


\section{4-24 STROKE 2}

TEST POINT 20

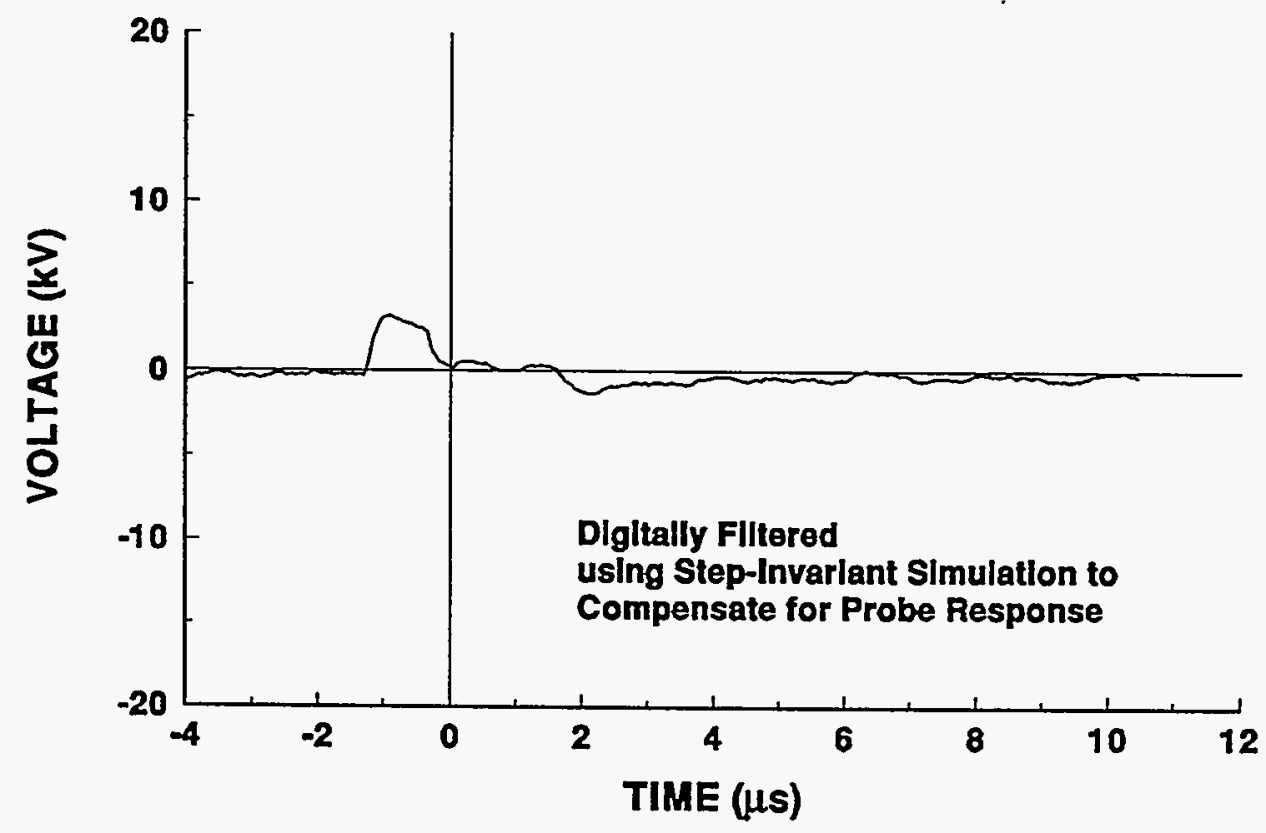

94-24 STROKE 2

TEST POINT 21

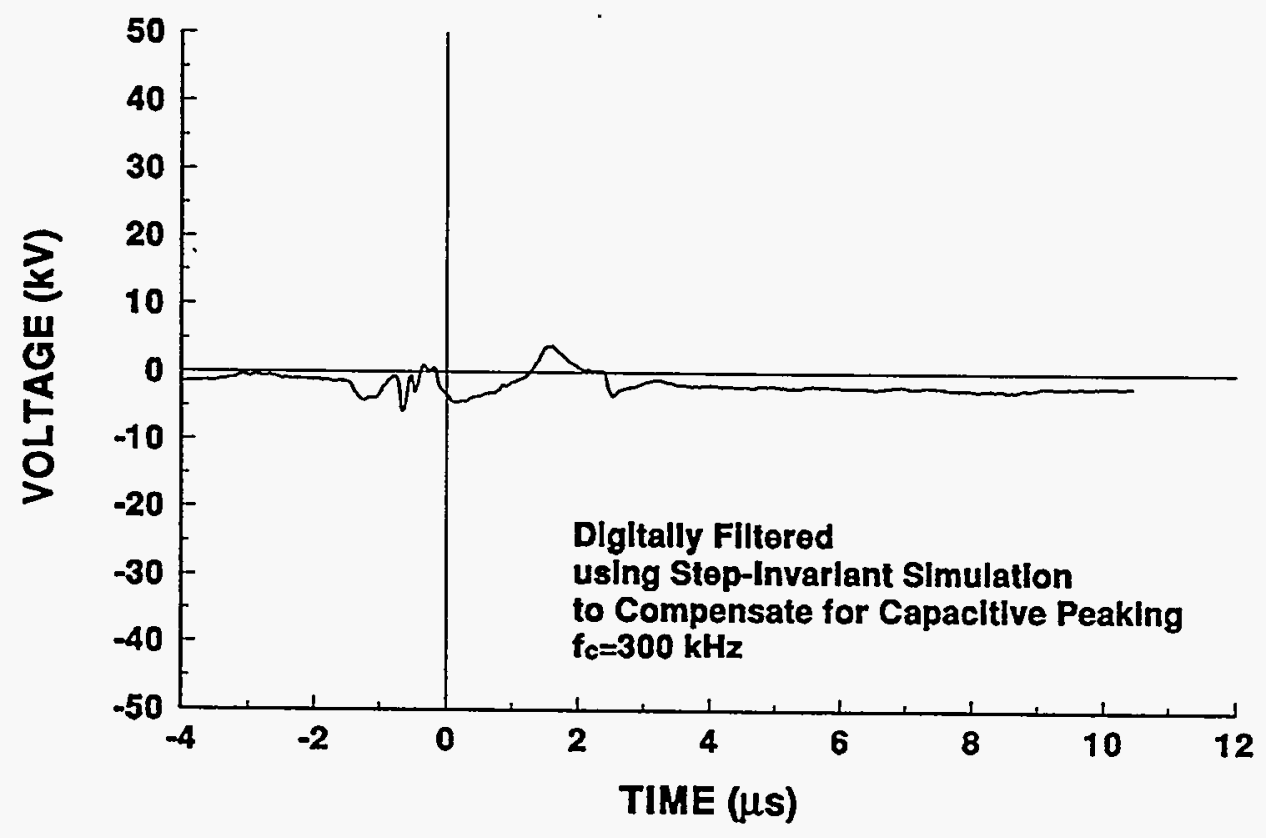




\section{4-24 STROKE 2}

\section{TEST POINT 22}

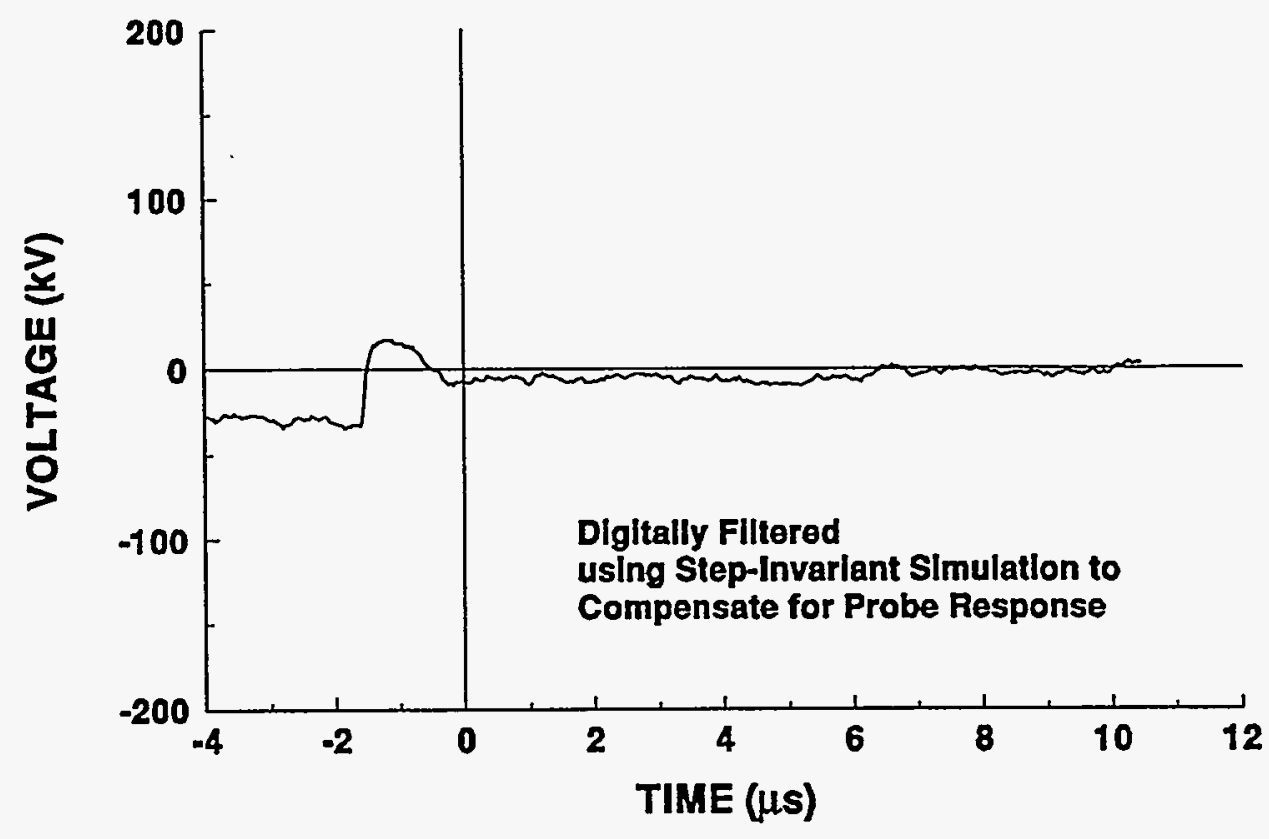




\section{4-24 STROKE 2}

\section{TEST POINT 23}

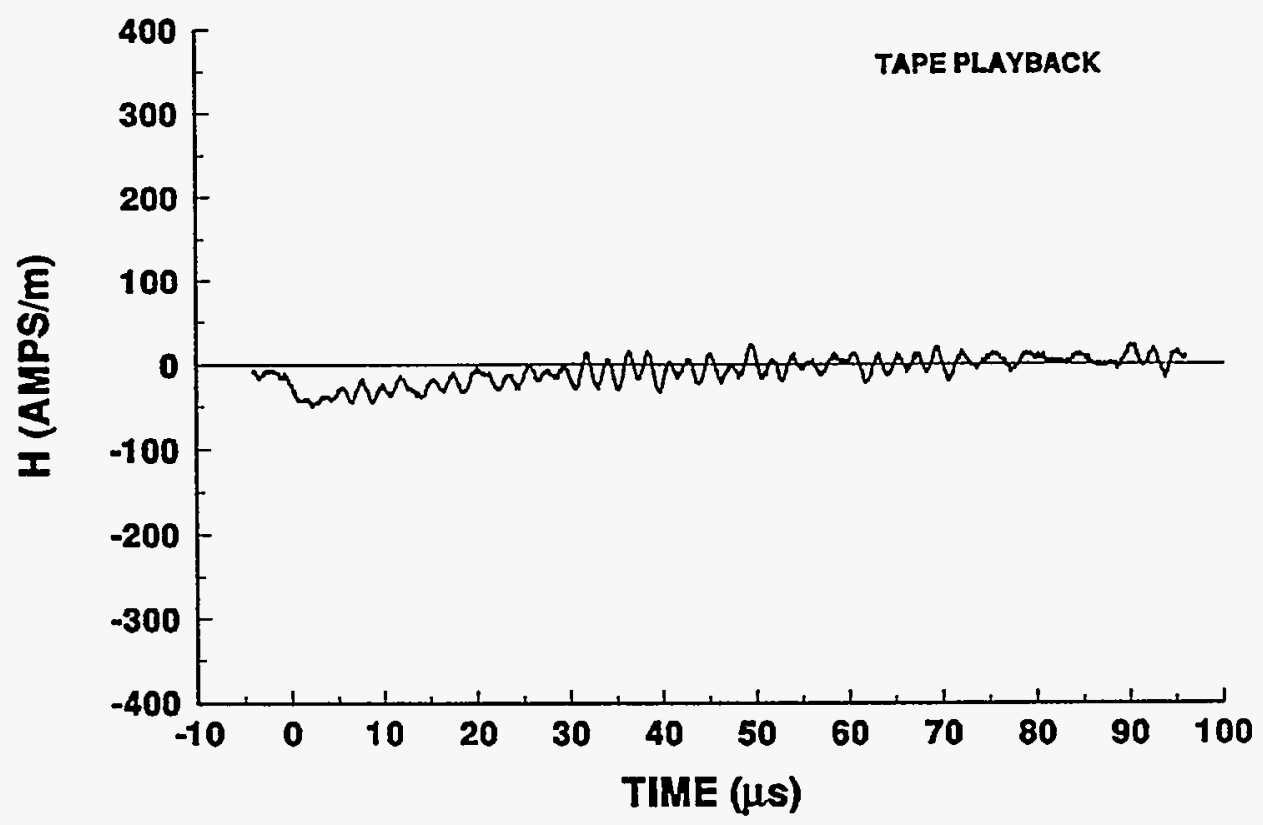

94-24 STROKE 2

TEST POINT 24

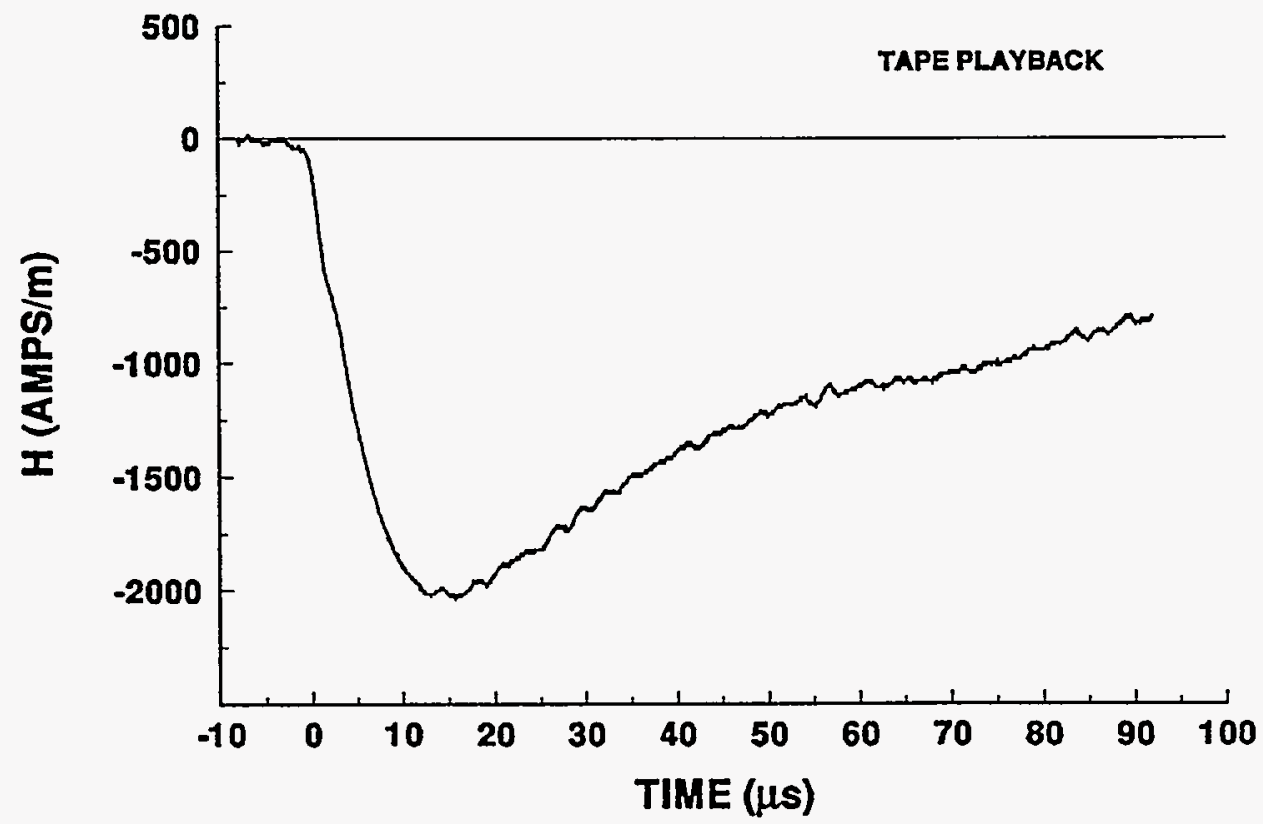




\section{4-24 STROKE 3 \\ INCIDENT CURRENT}
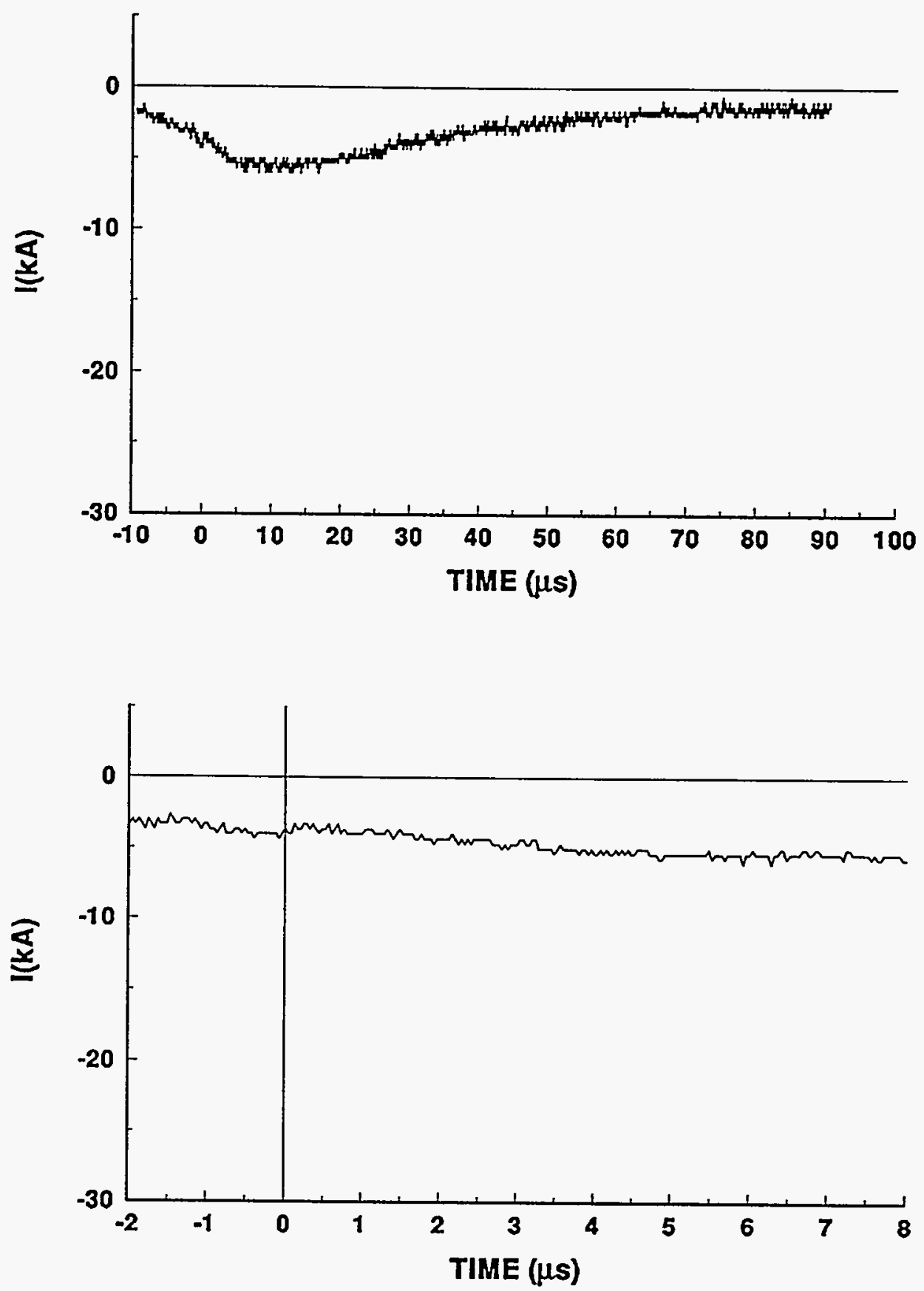


\section{4-24 STROKE 3 \\ TEST POINT 1}
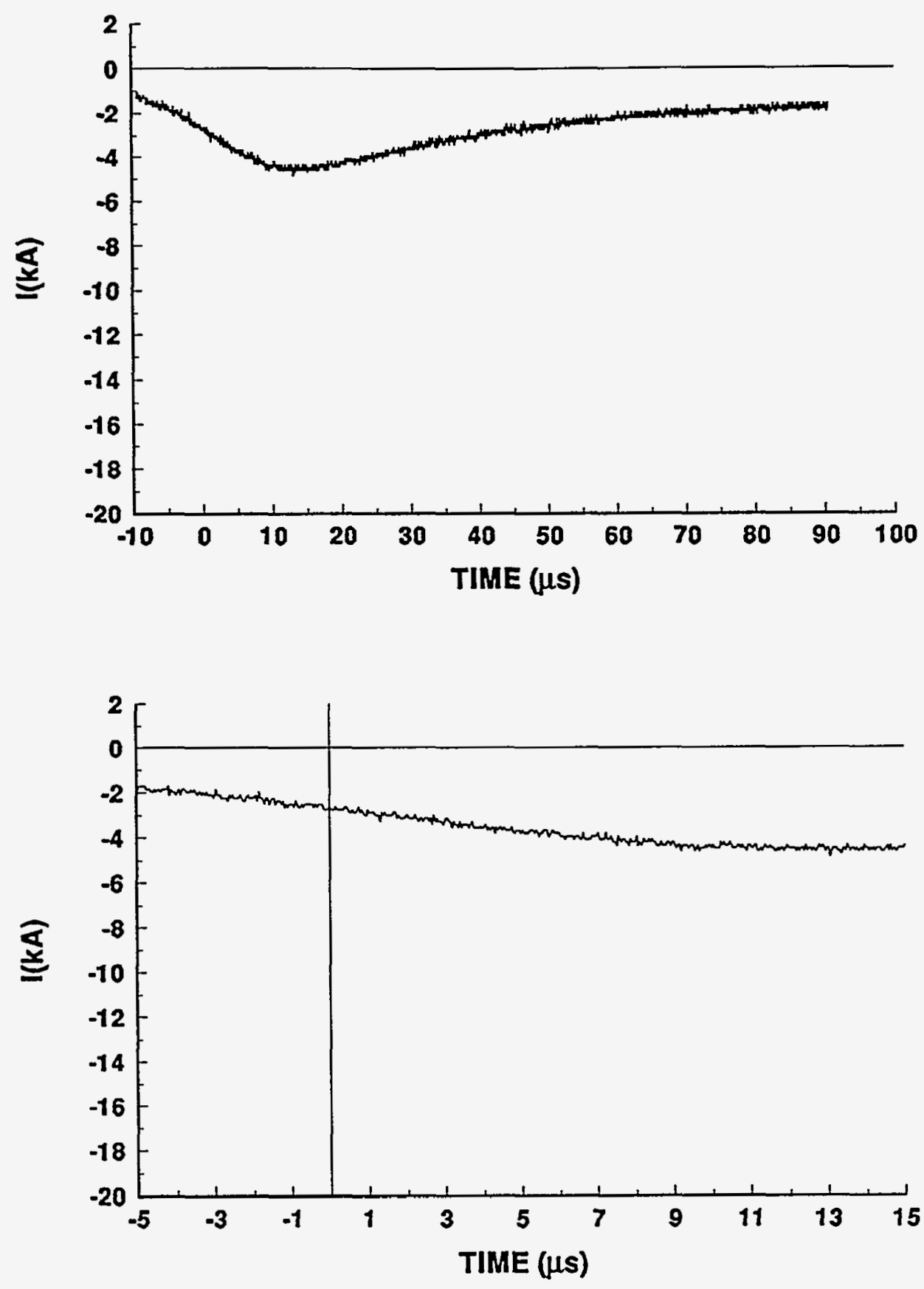


\section{4-24 STROKE 3}

TEST POINT 2
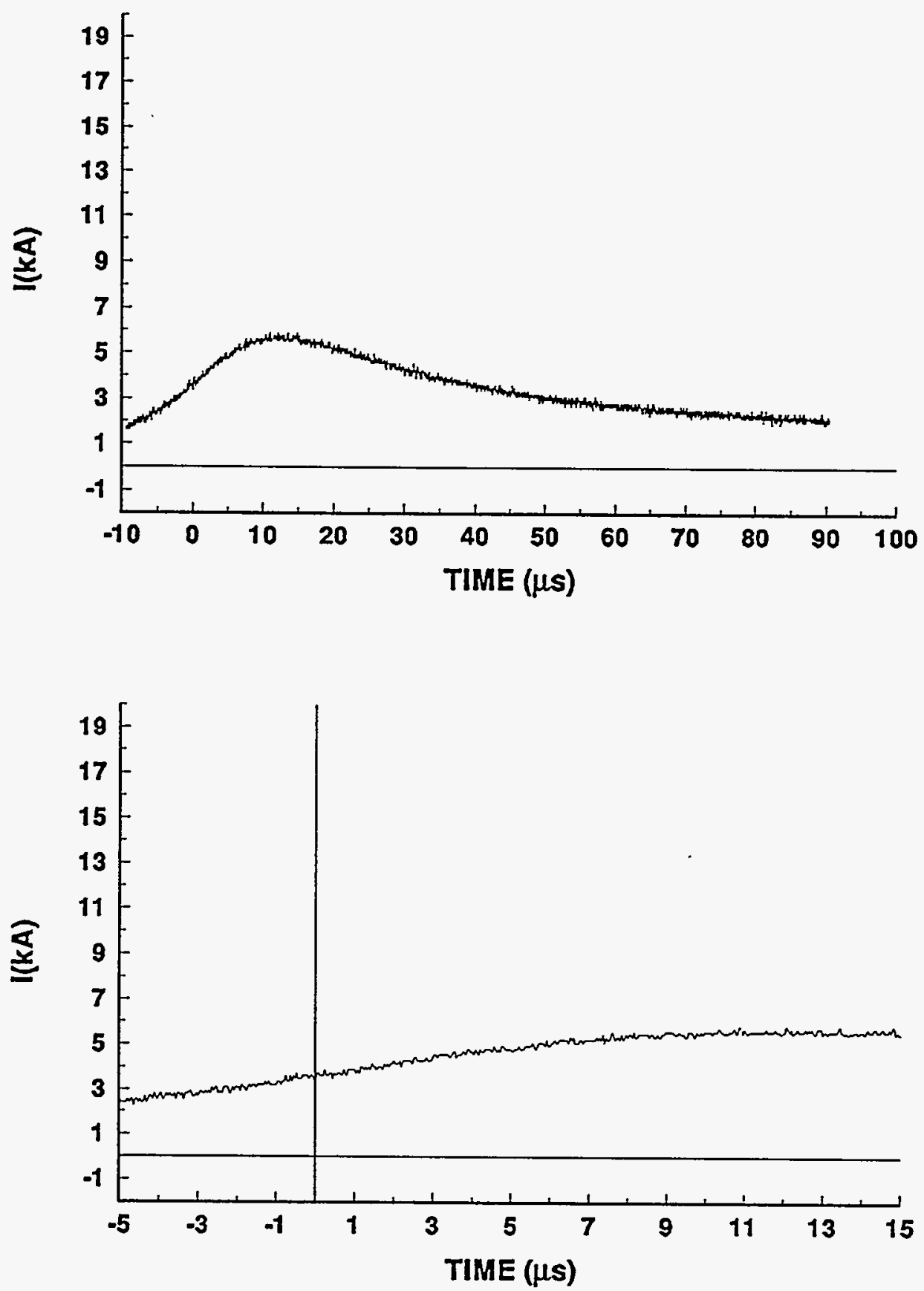
94-24 STROKE 3

TEST POINT 5
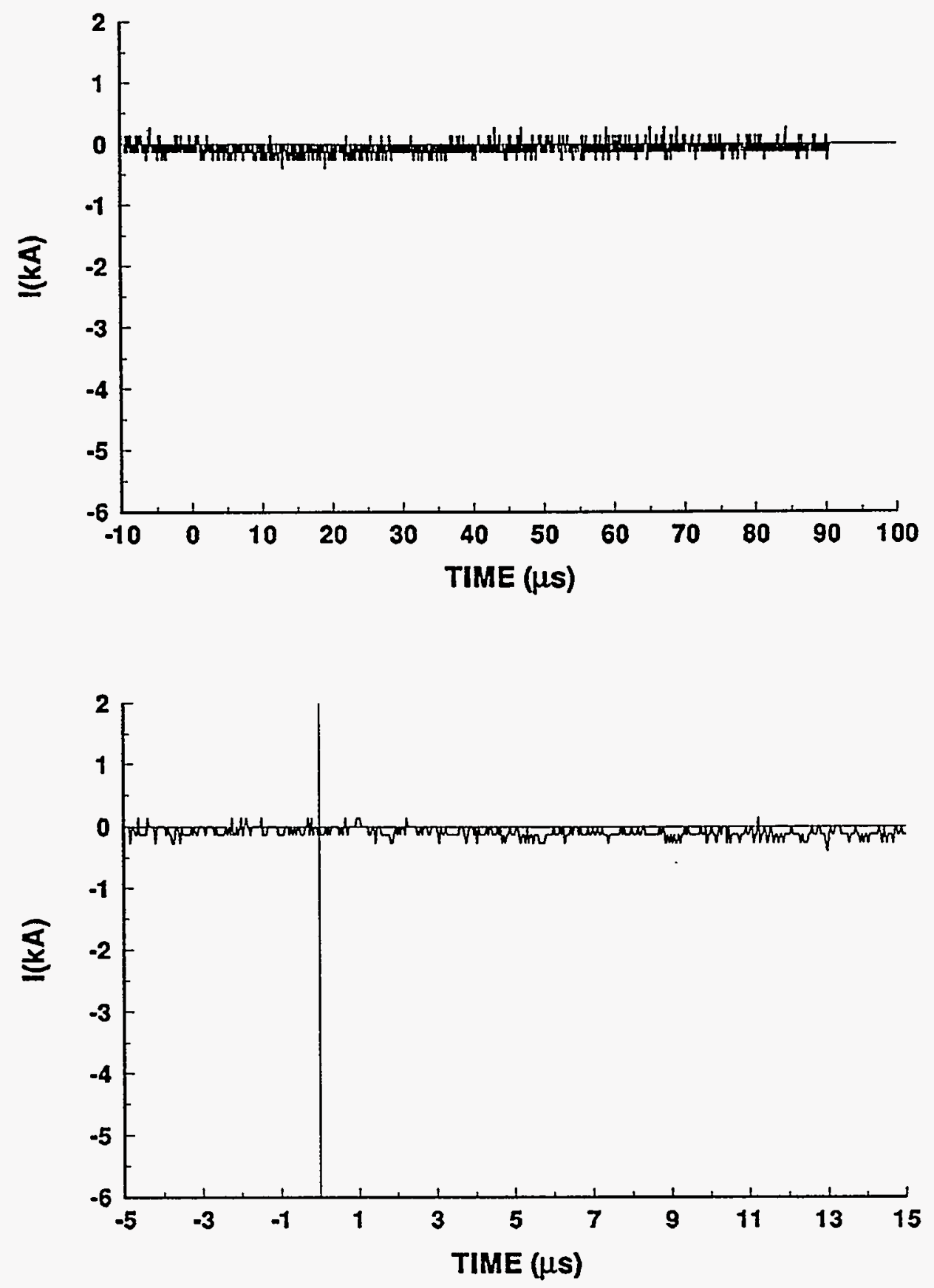


\section{4-24 STROKE 3}

TEST POINT 6
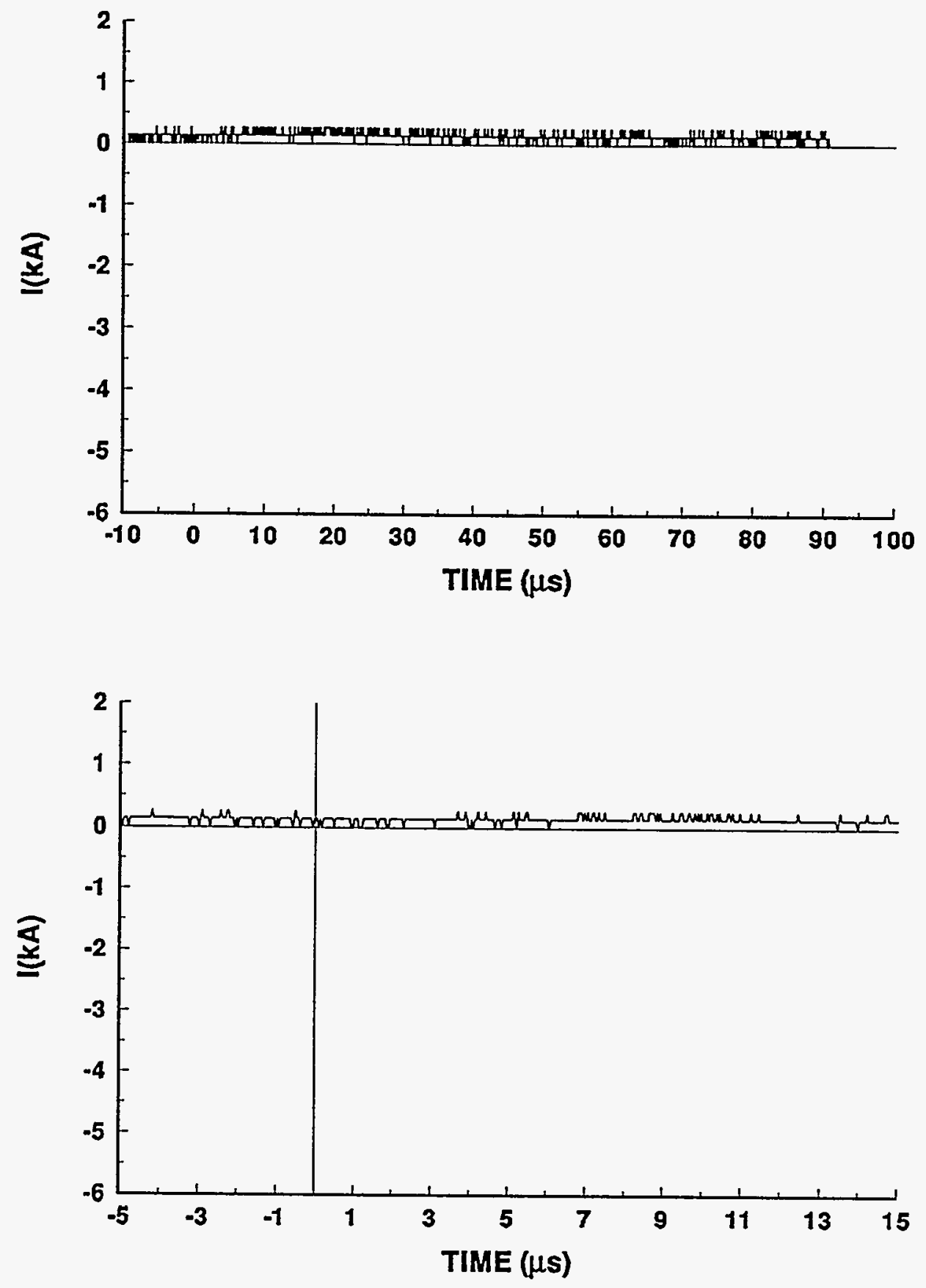


\section{4-24 STROKE 3}

TEST POINT 5'

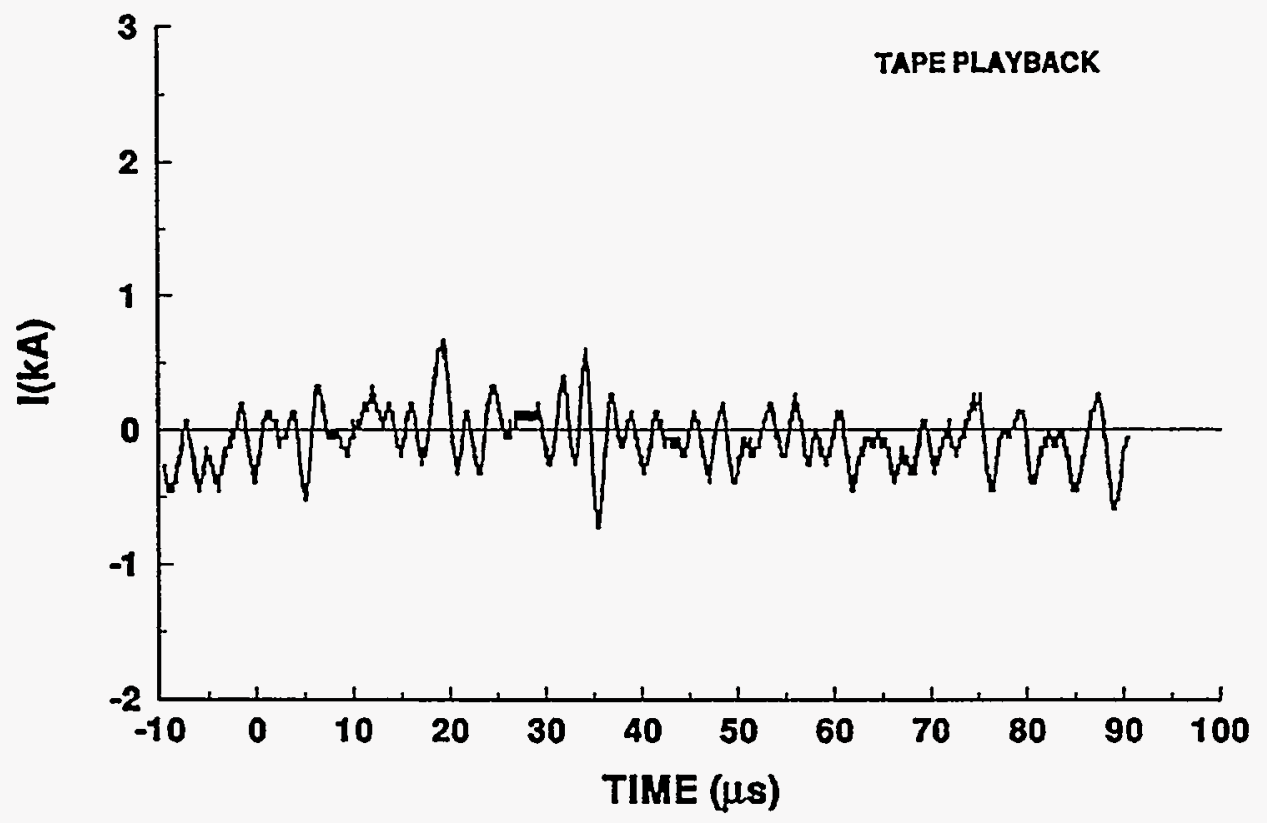

94-24 STROKE 3

TEST POINT 6'

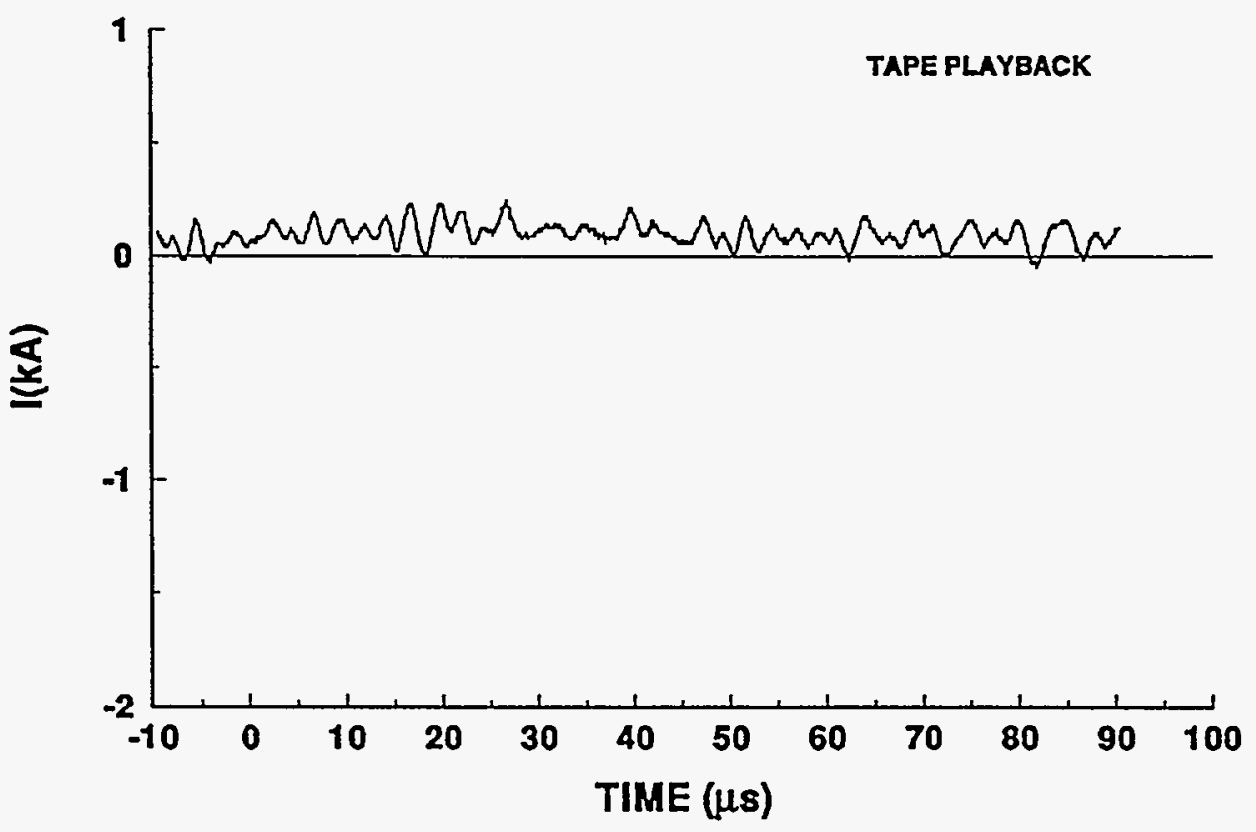




\section{4-24 STROKE 3}

\section{TEST POINT 10}

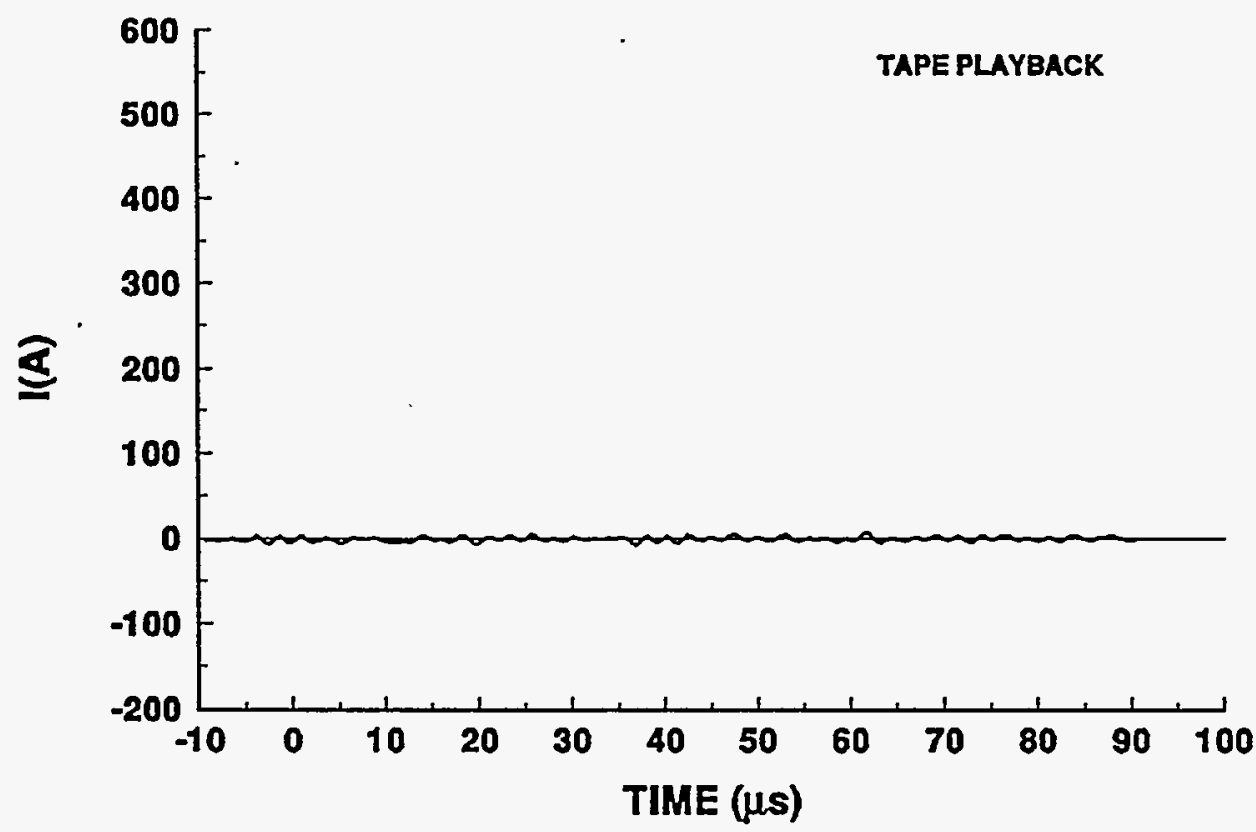

94-24 STROKE 3

TEST POINT 11

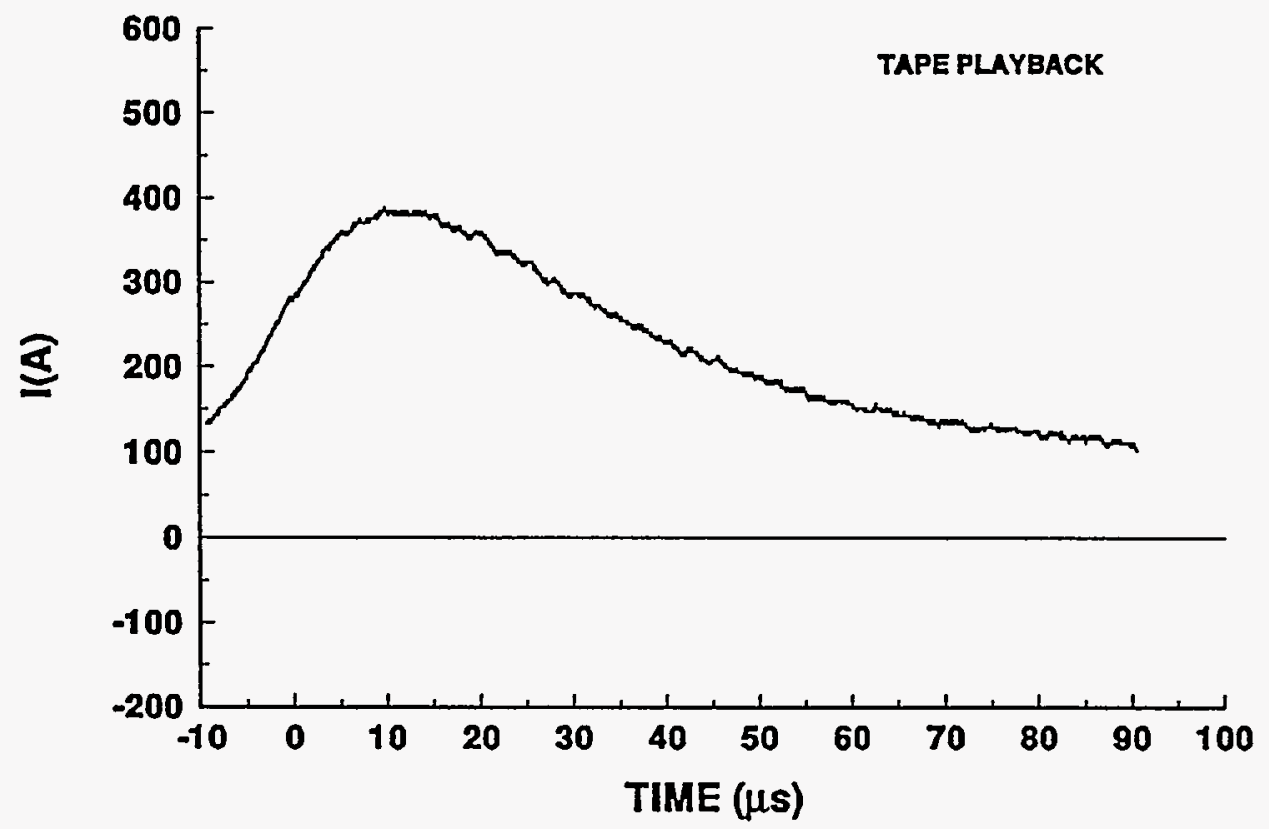




\section{4-24 STROKE 3}

TEST POINT 12

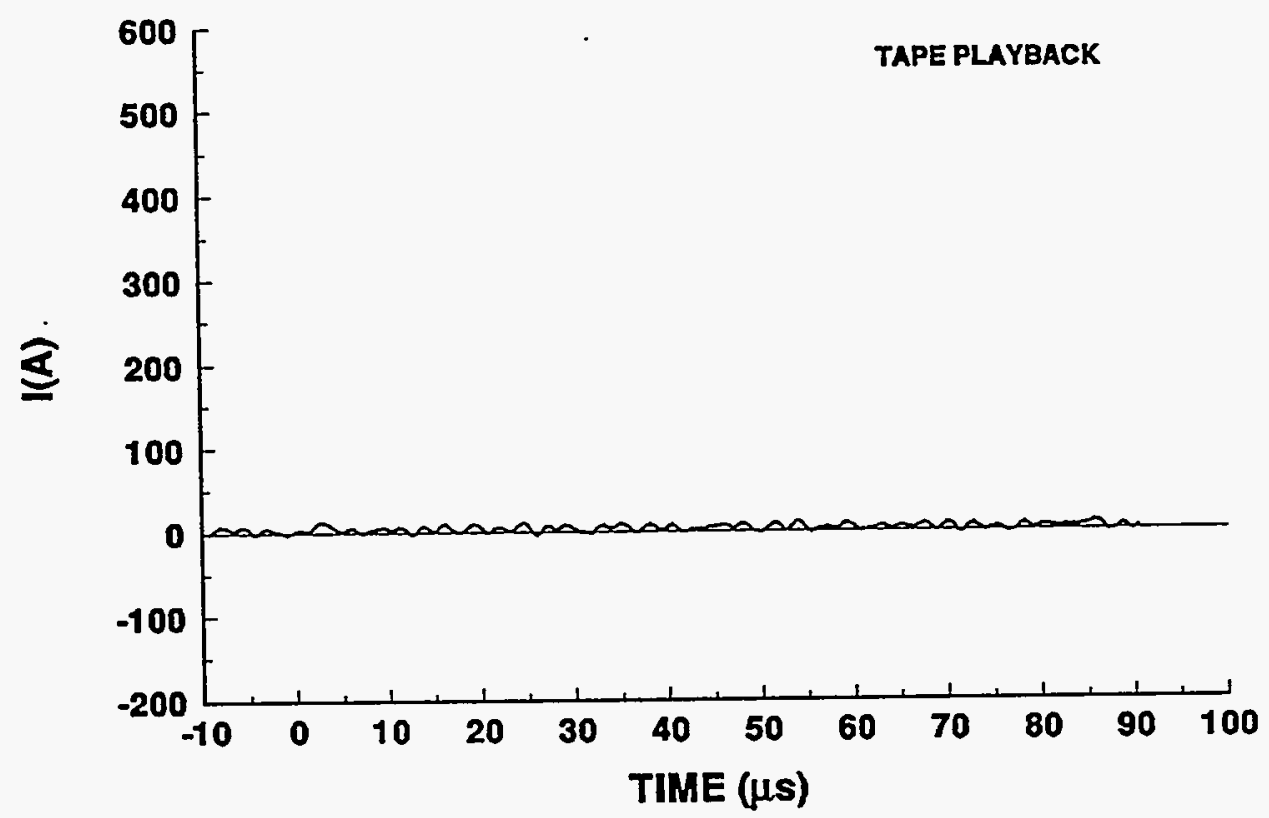

\section{4-24 STROKE 3}

TEST POINT 13

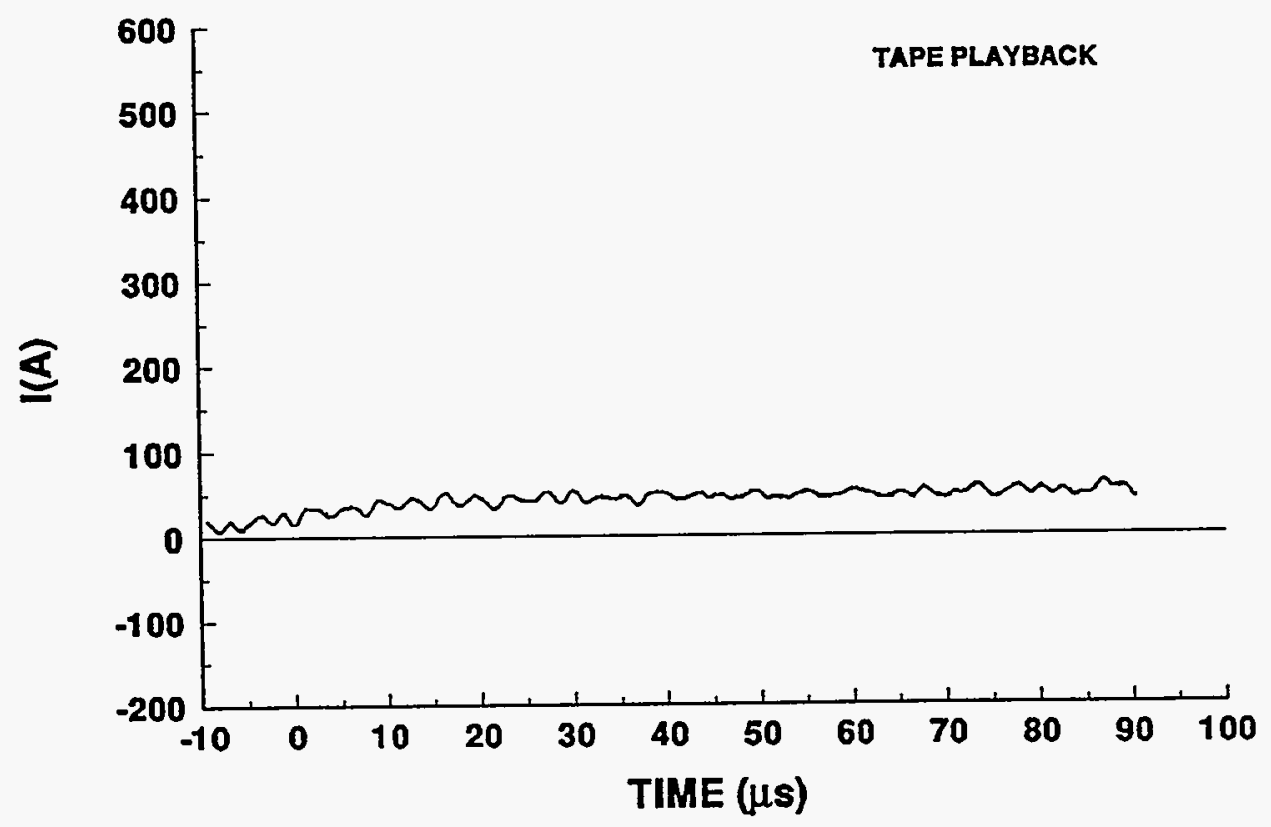




\section{4-24 STROKE 3}

\section{TEST POINT 14}
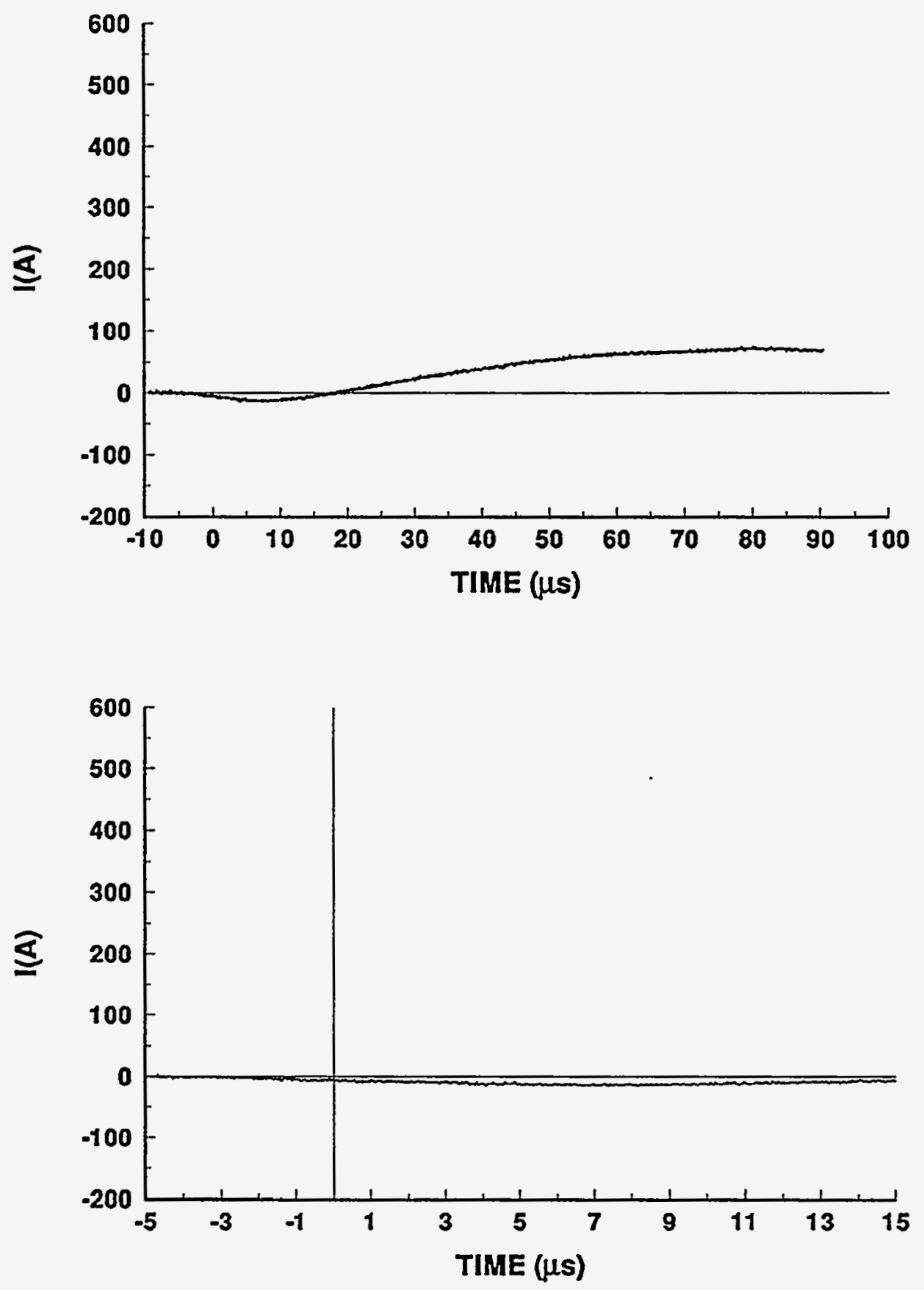


\section{4-24 STROKE 3}

TEST POINT 15
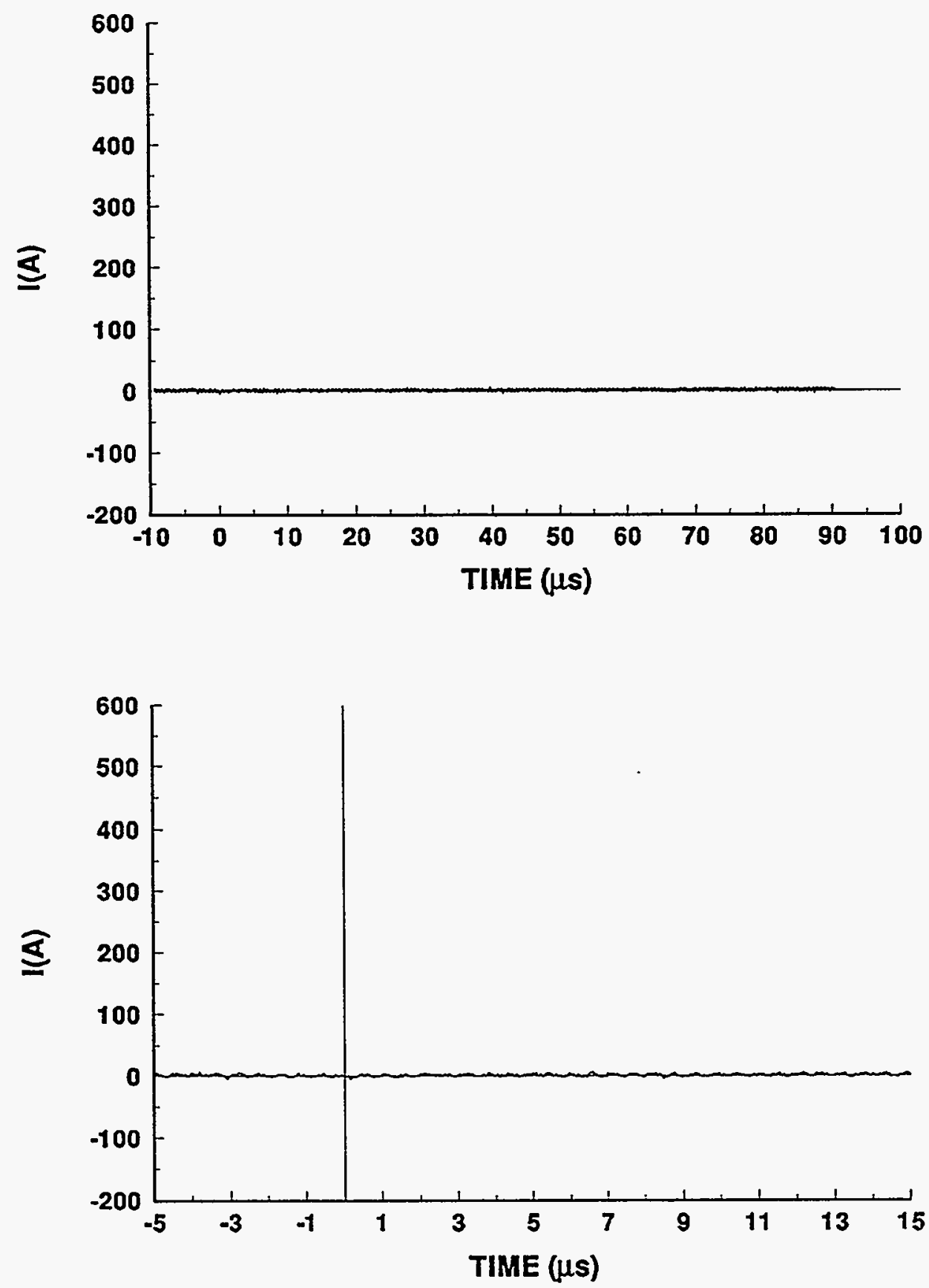


\section{4-24 STROKE 3}

\section{TEST POINT 20}

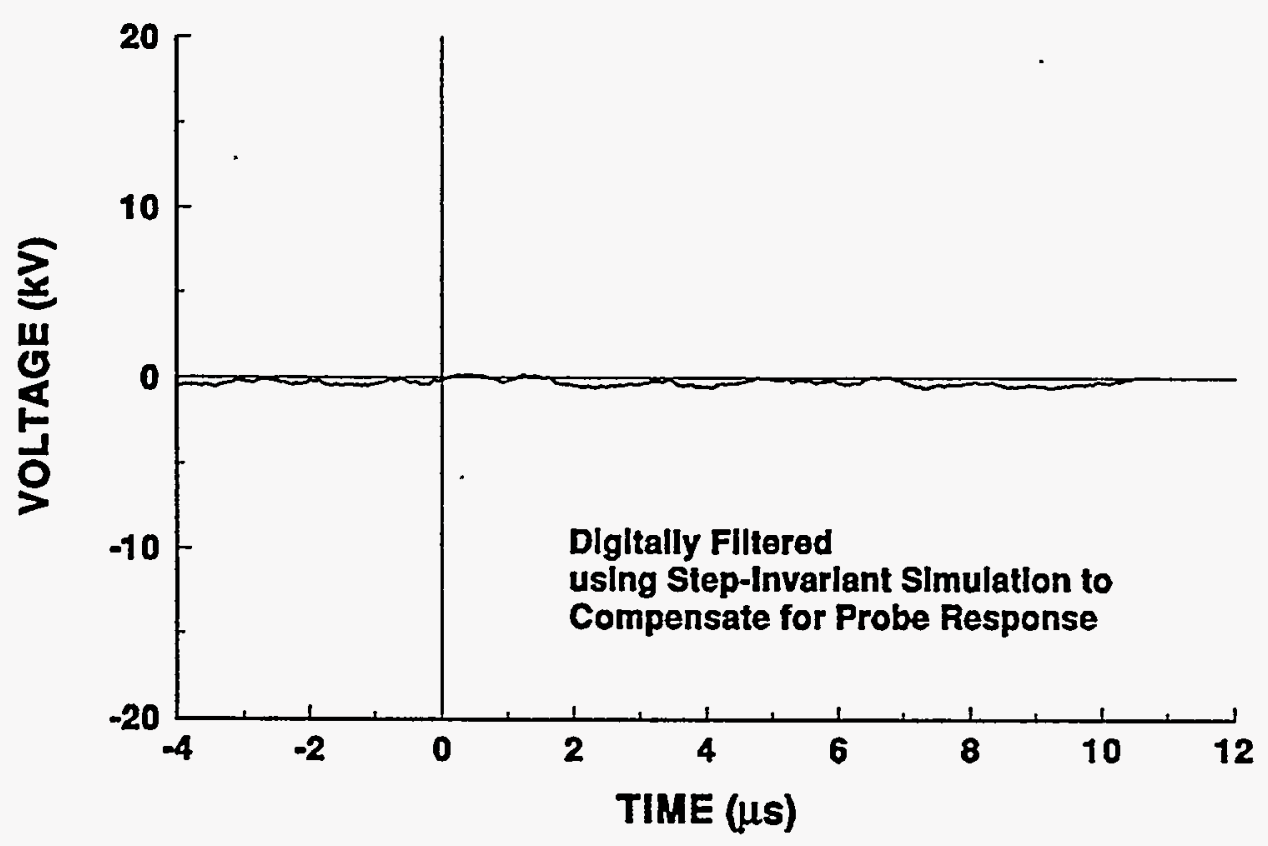

94-24 STROKE 3

TEST POINT 21

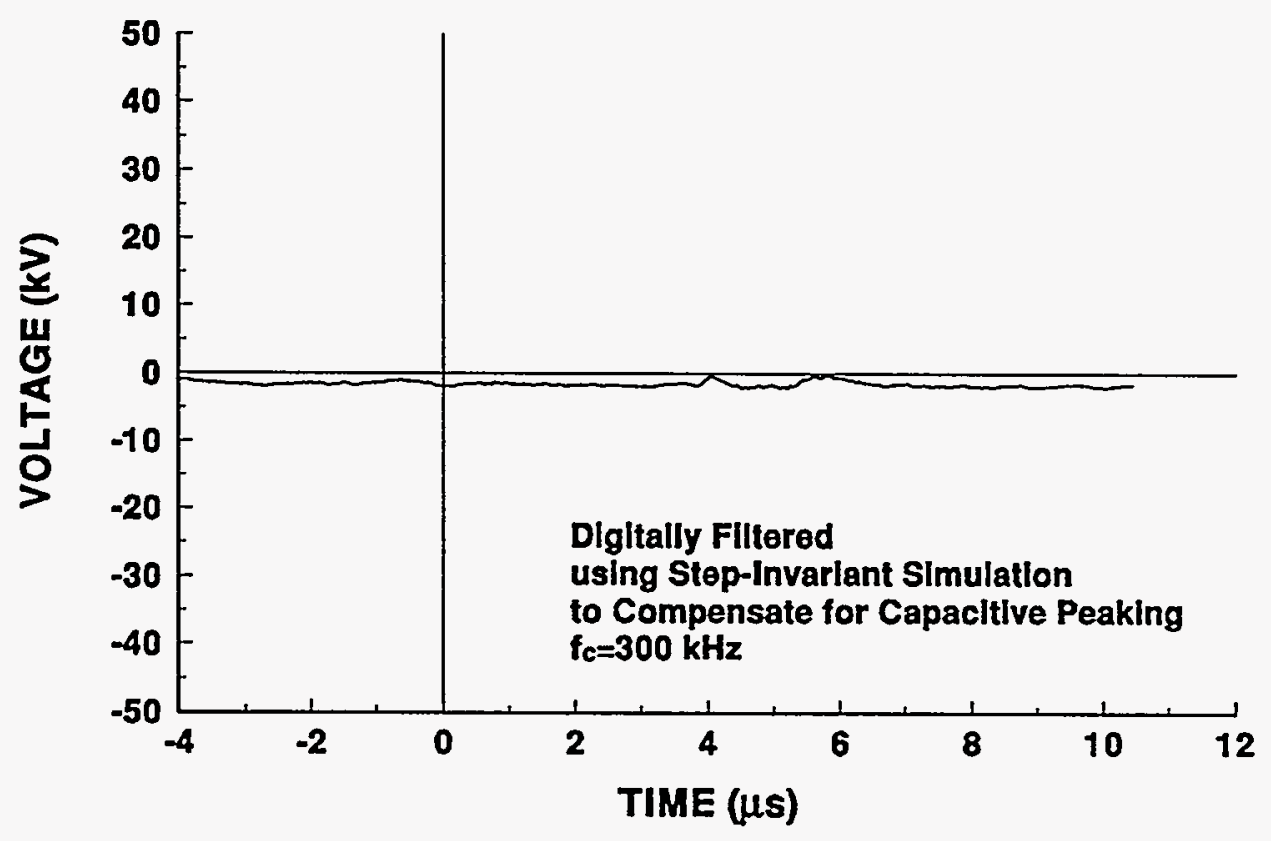




\section{4-24 STROKE 3}

TEST POINT 22

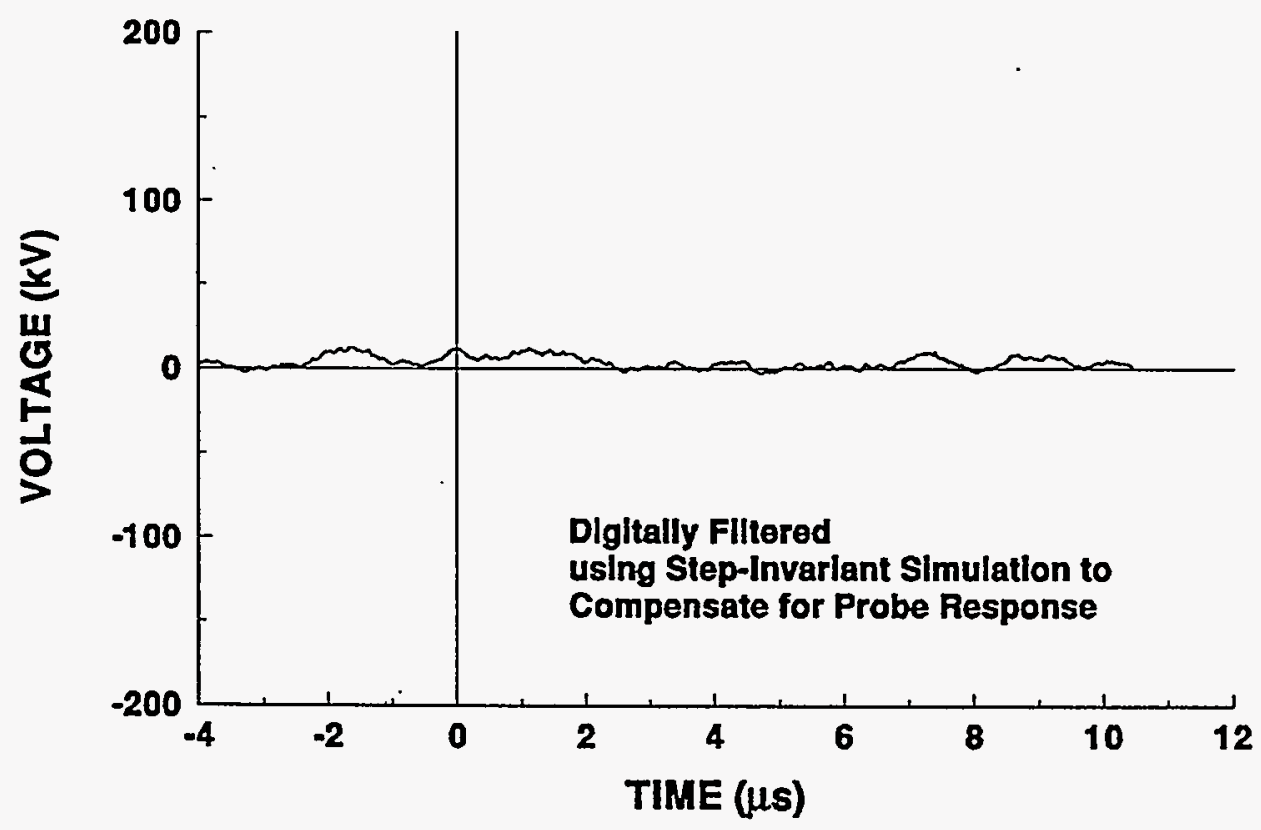




\section{4-24 STROKE 3}

\section{TEST POINT 23}

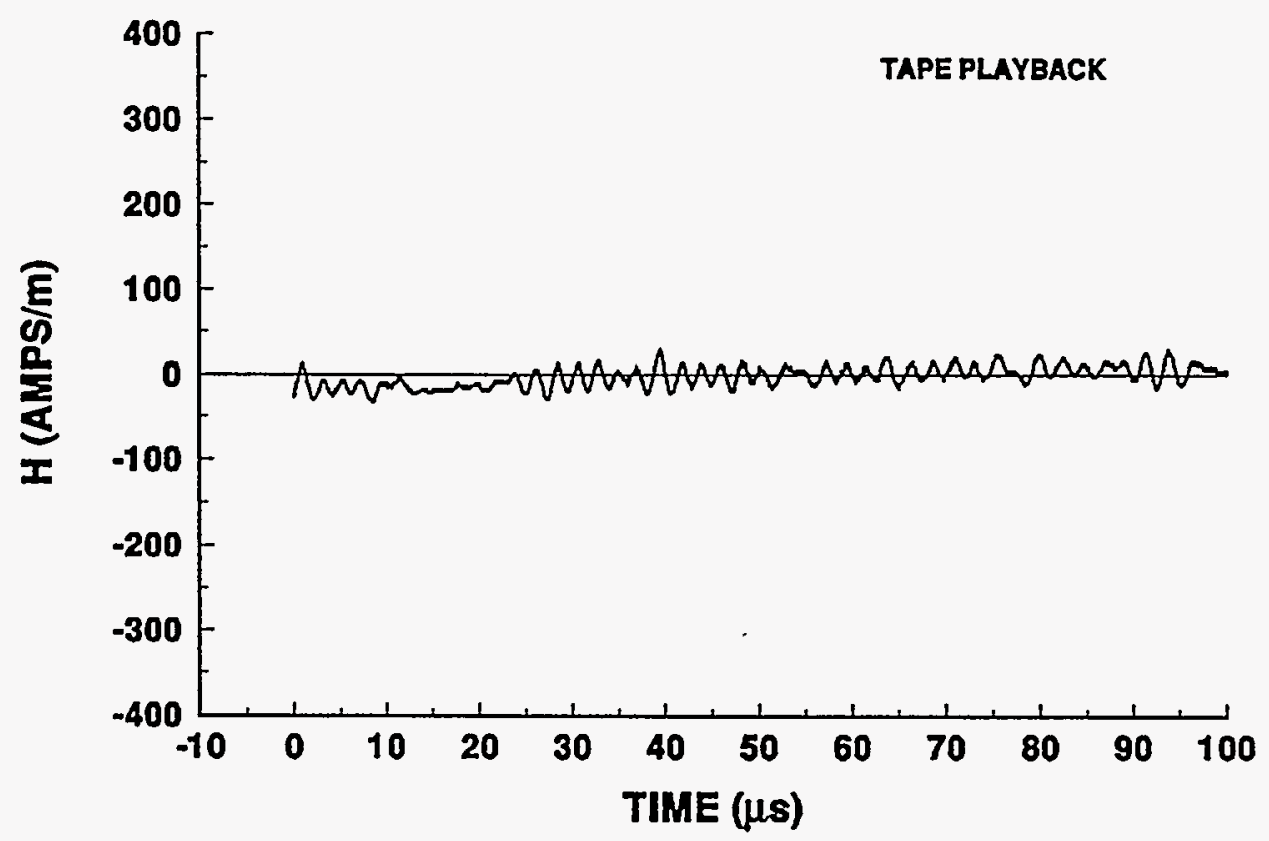

94-24 STROKE 3

TEST POINT 24

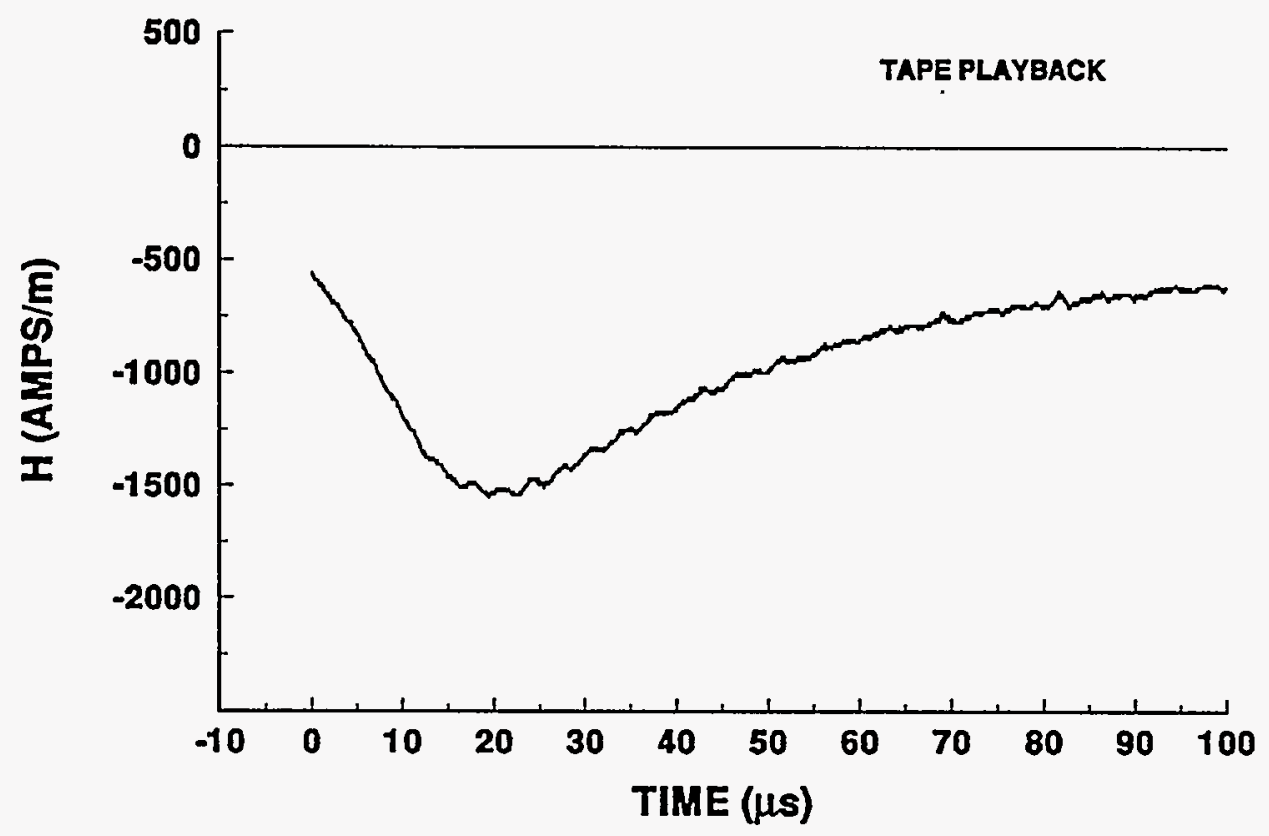




\section{4-24 STROKE 4 INCIDENT CURRENT}
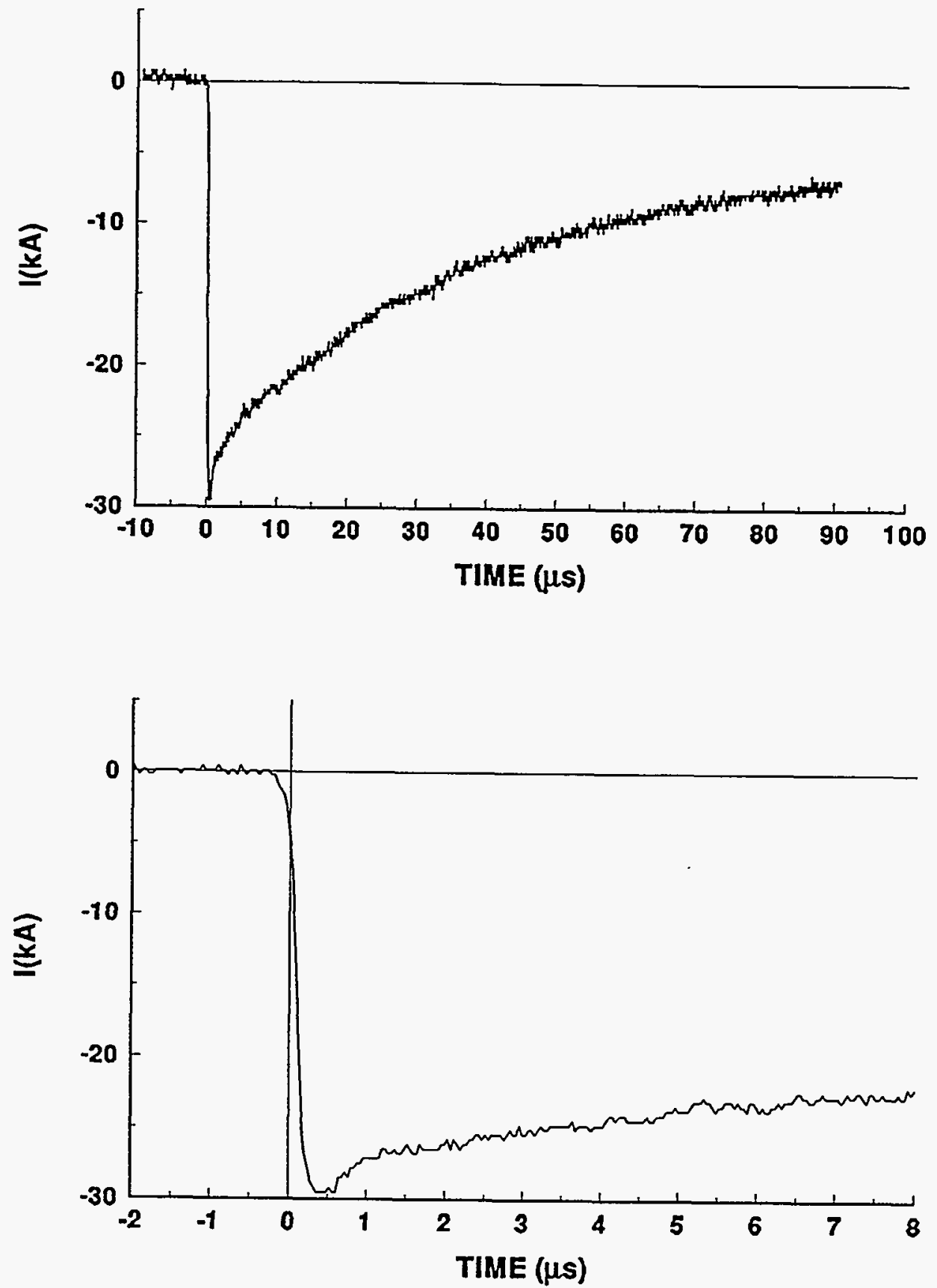
94-24 STROKE 4

TEST POINT 1
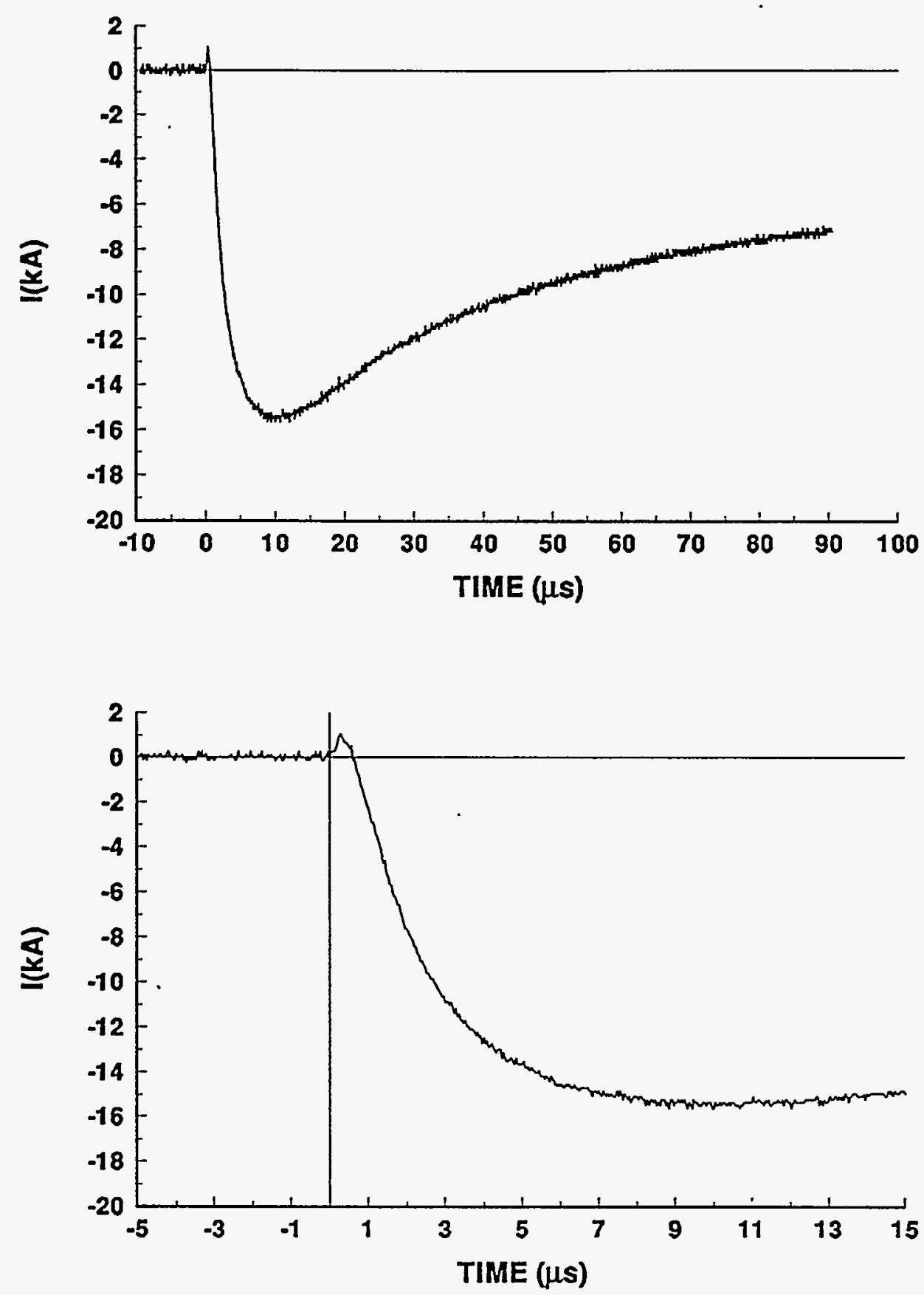
94-24 STROKE 4

TEST POINT 2
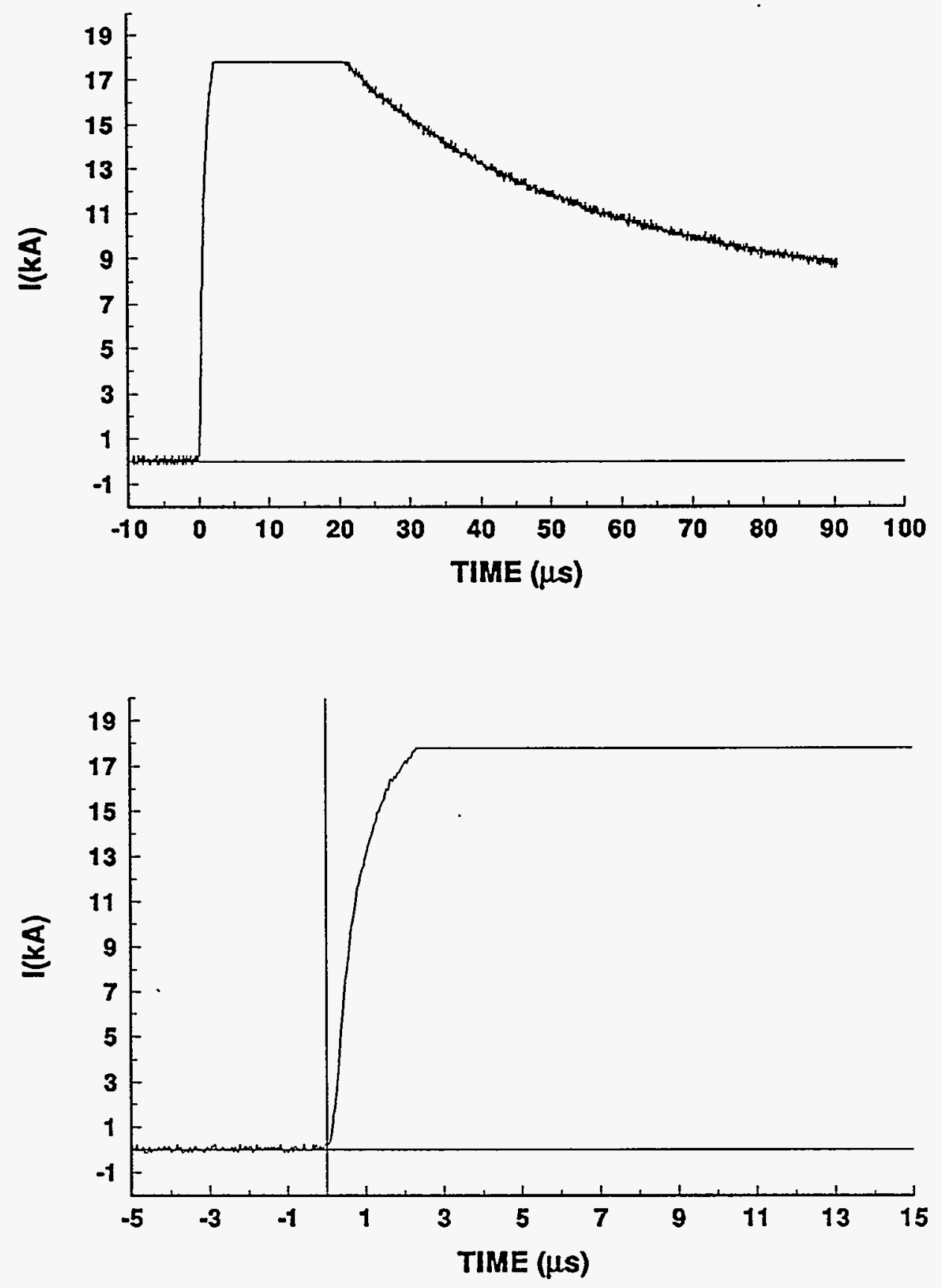


\section{4-24 STROKE 4 \\ TEST POINT 5}
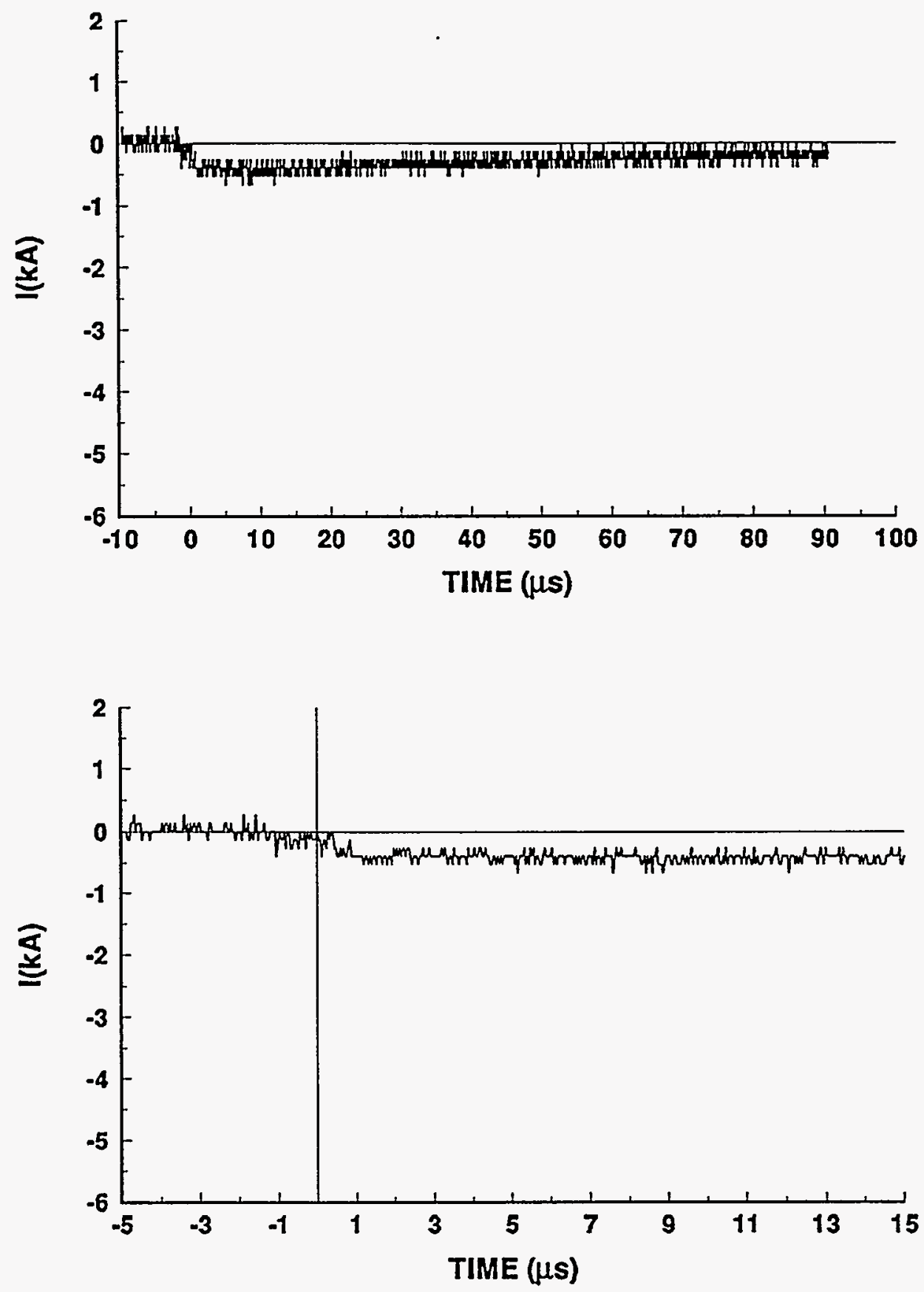


\section{4-24 STROKE 4}

TEST POINT 6
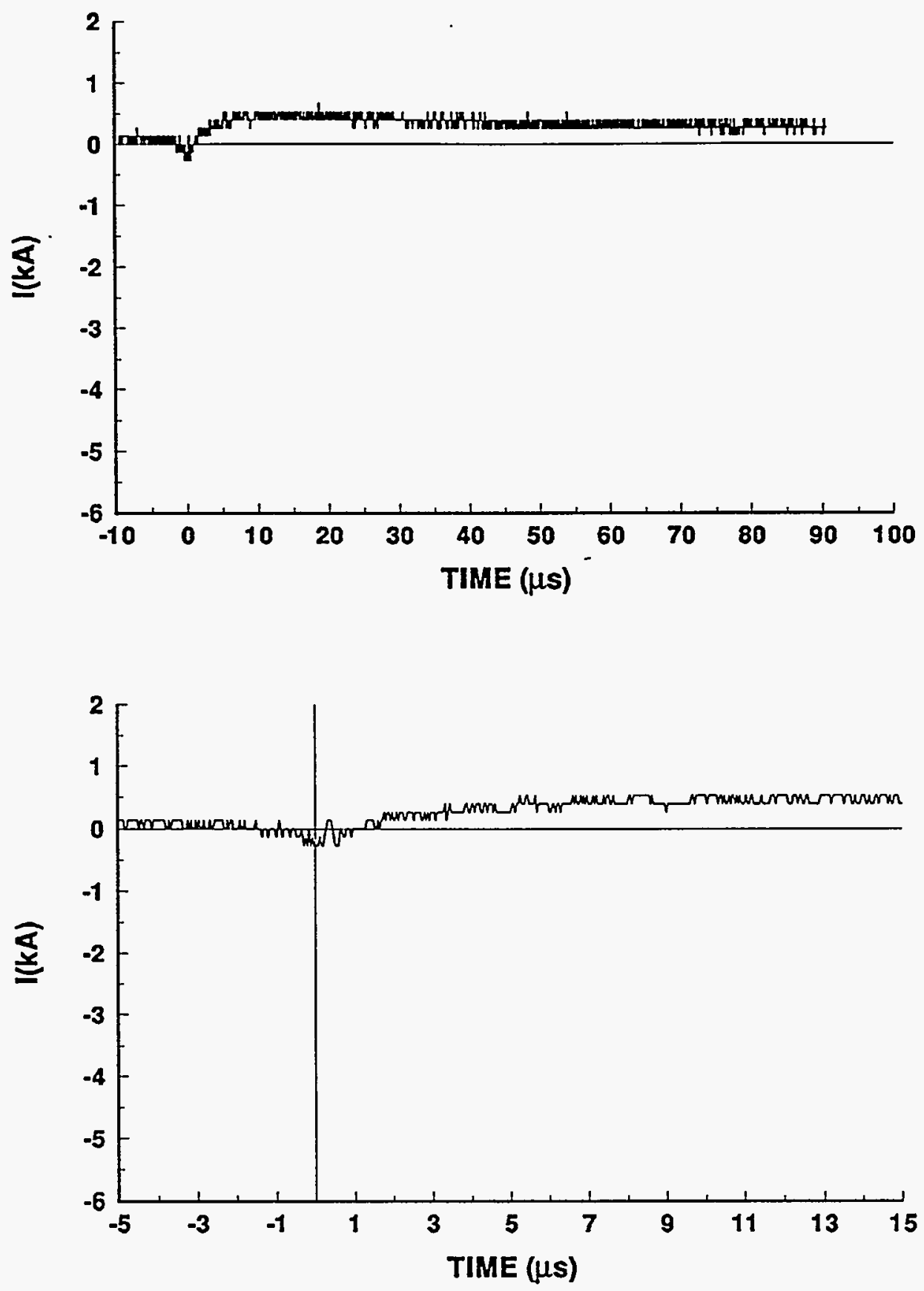


\section{4-24 STROKE 4}

TEST POINT 5'

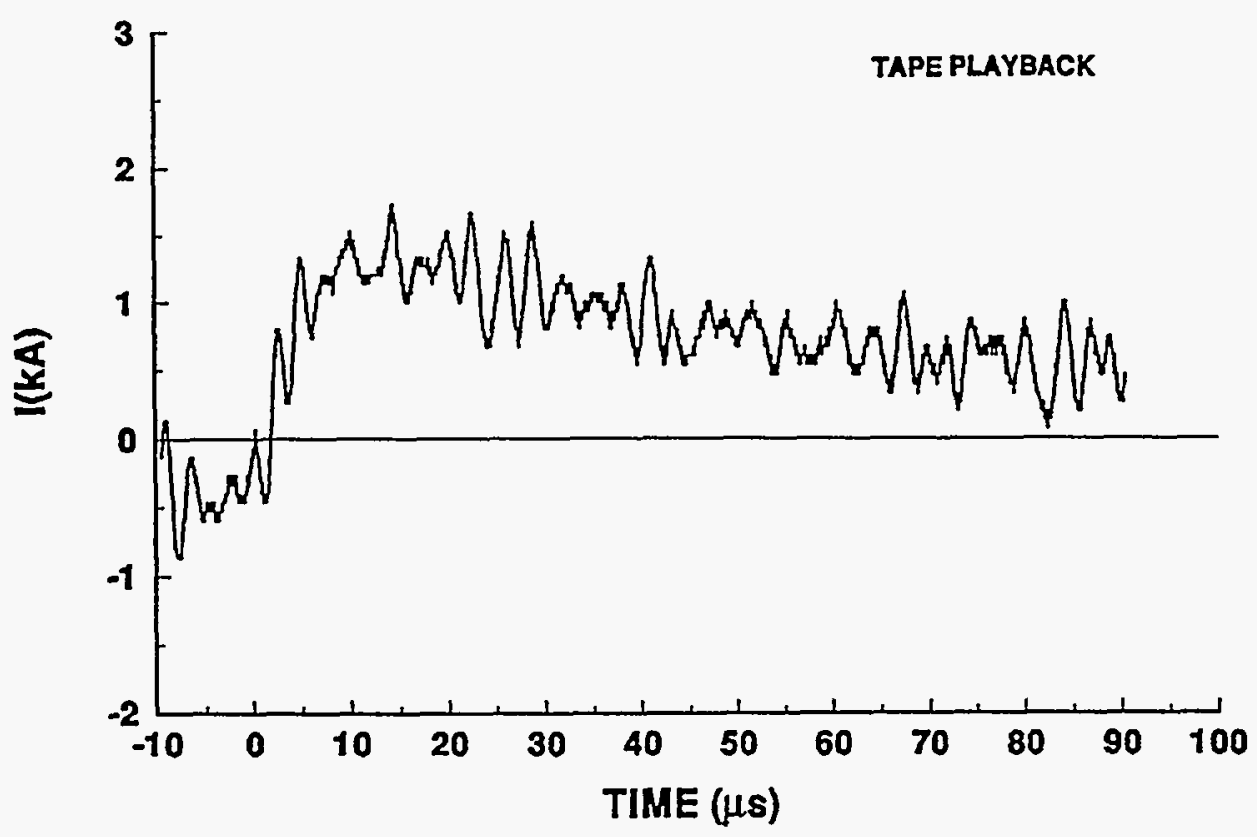

\section{4-24 STROKE 4}

TEST POINT 6"

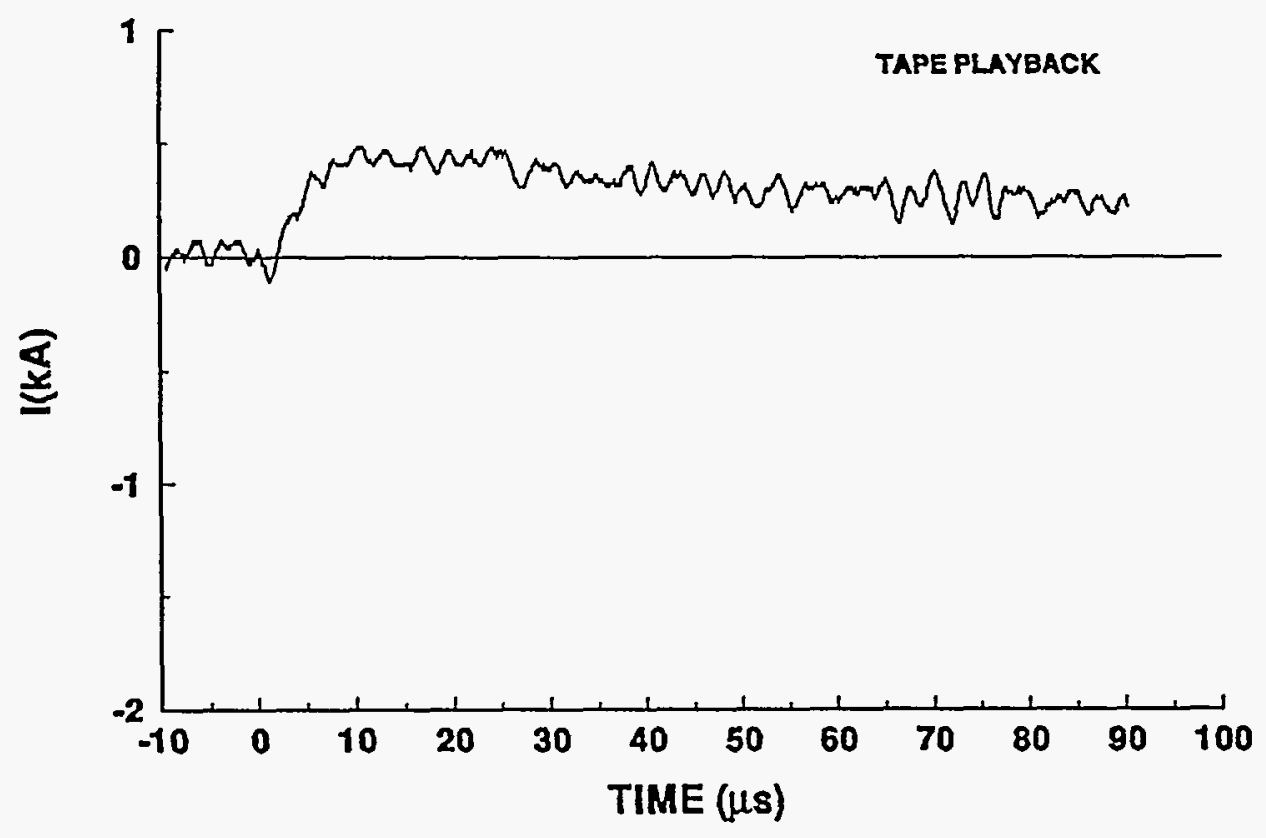


94-24 STROKE 4

TEST POINT 10

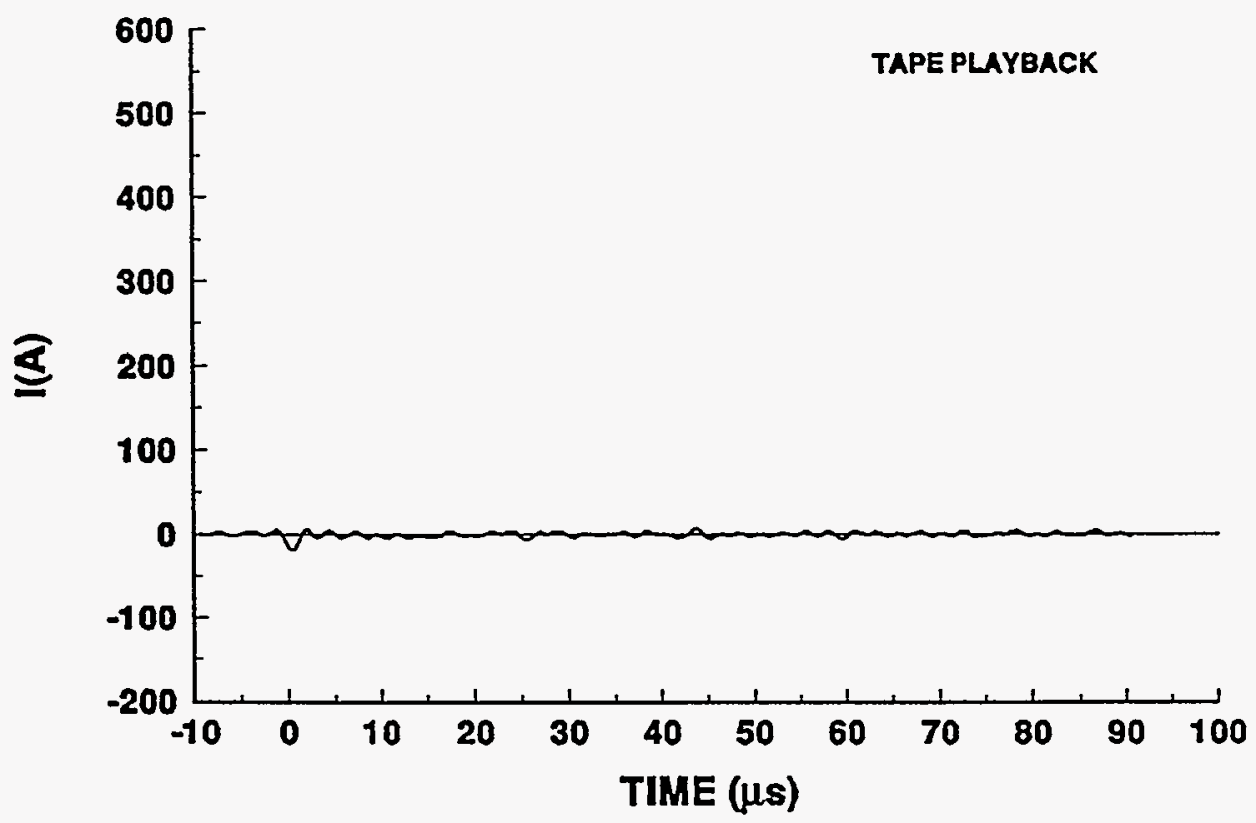

94-24 STROKE 4

TEST POINT 11

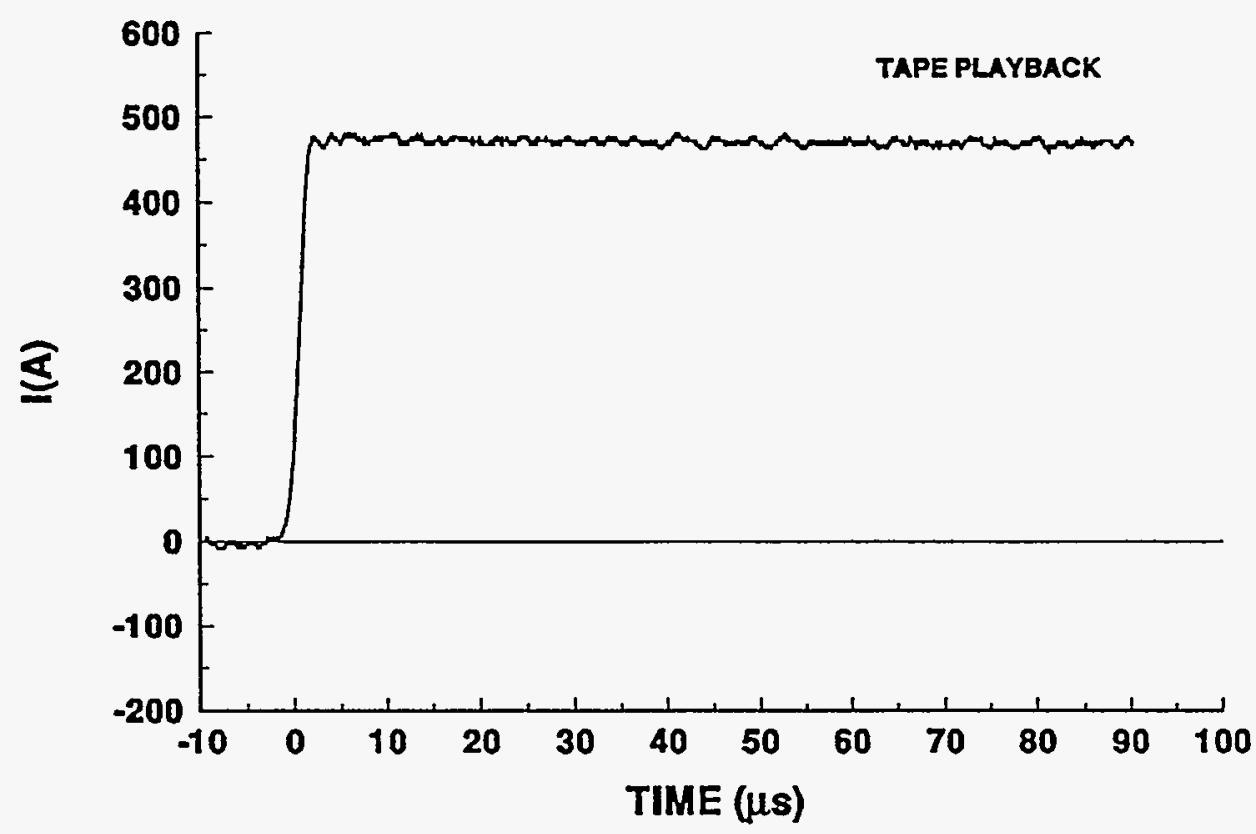




\section{4-24 STROKE 4}

\section{TEST POINT 12}

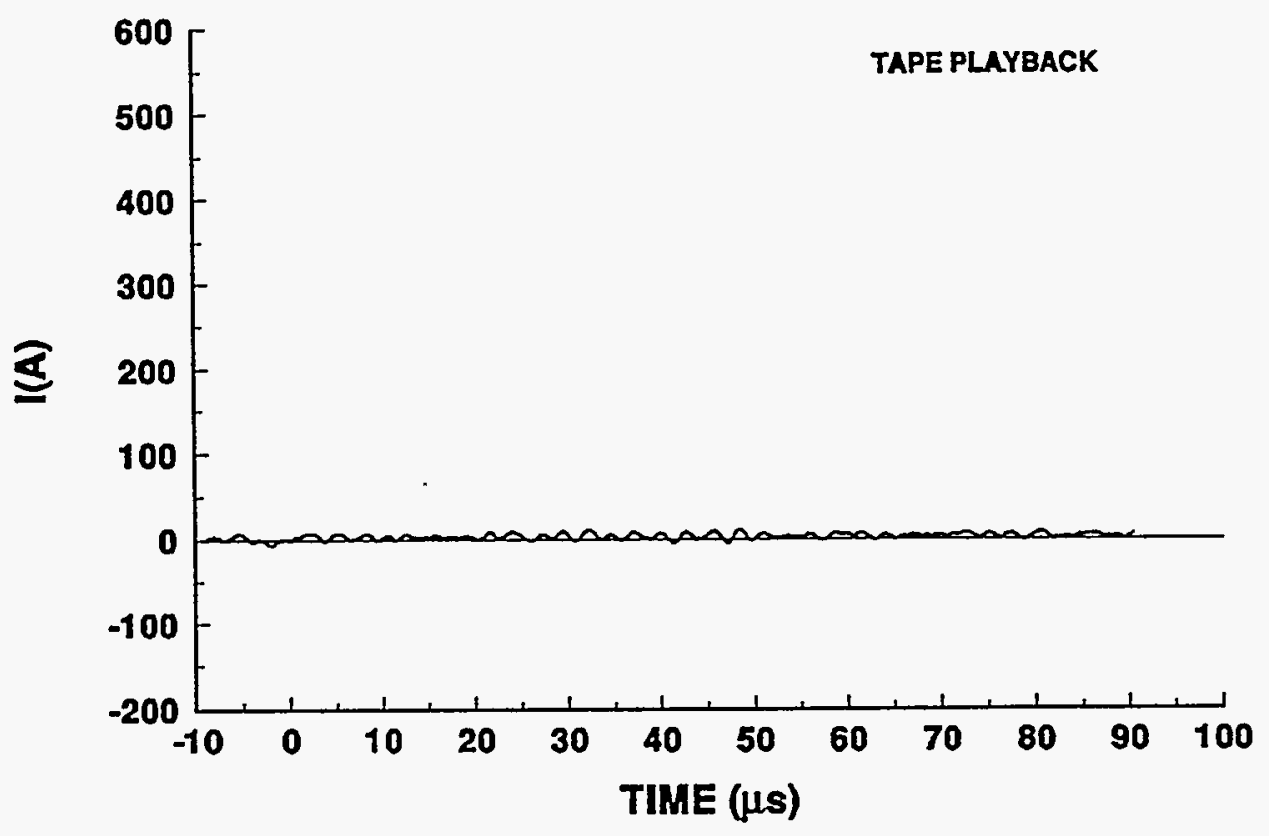

\section{4-24 STROKE 4}

\section{TEST POINT 13}

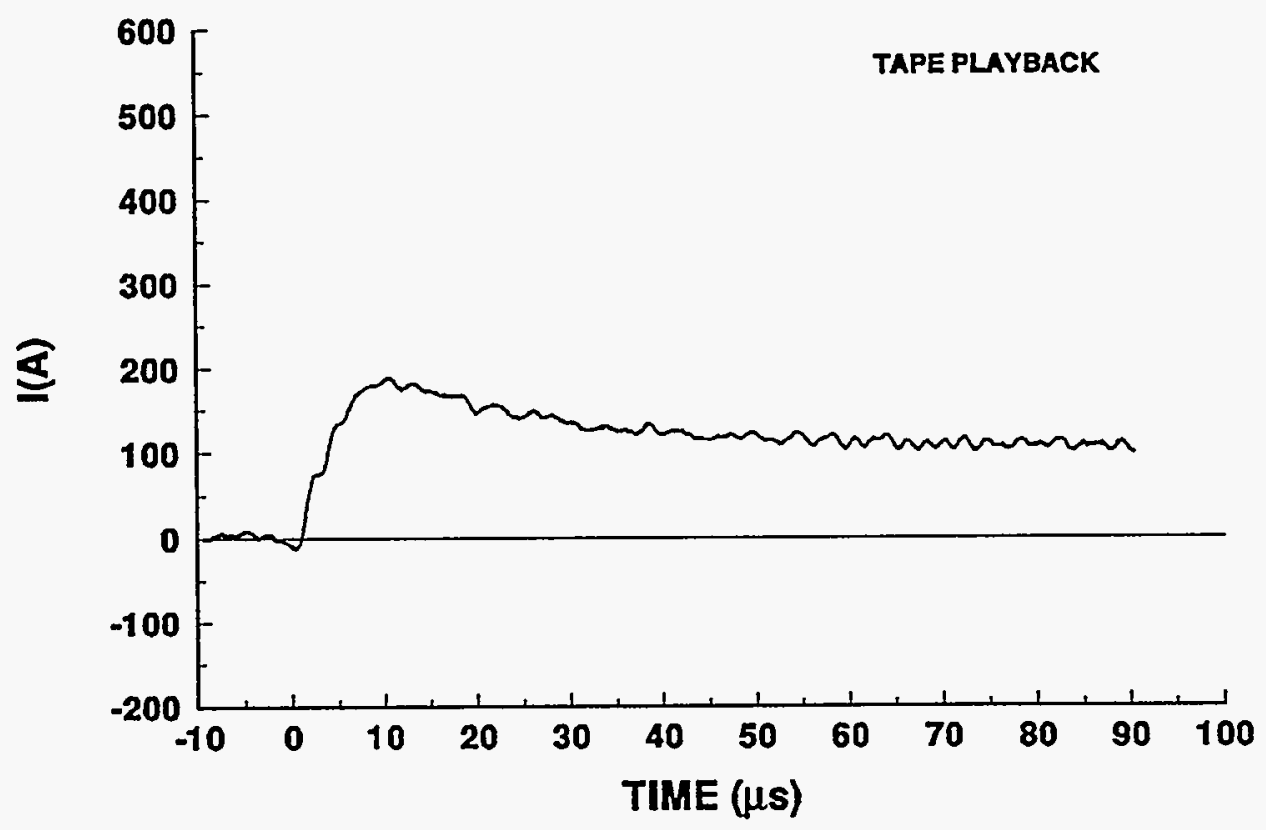




\section{4-24 STROKE 4}

TEST POINT 14
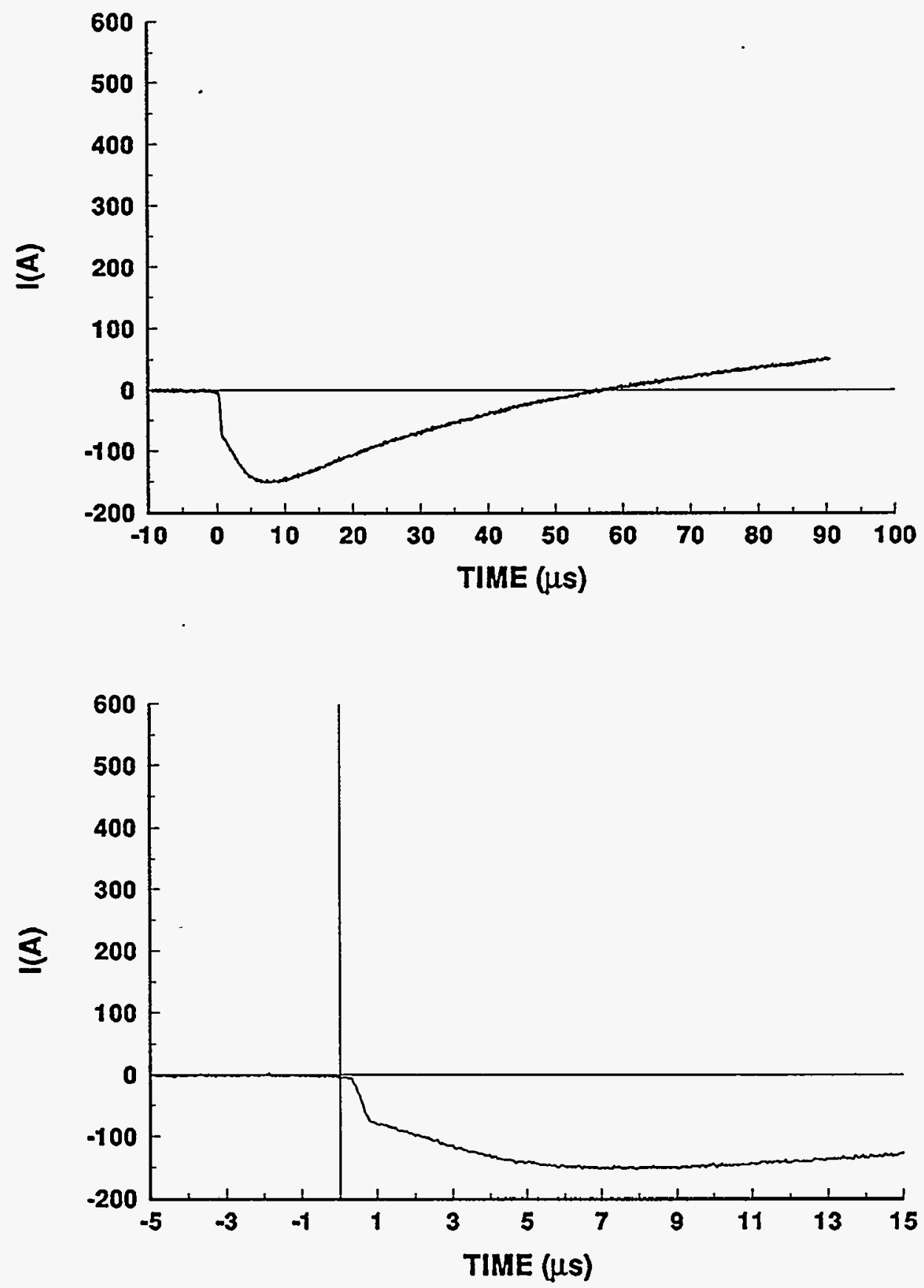


\section{4-24 STROKE 4}

TEST POINT 15
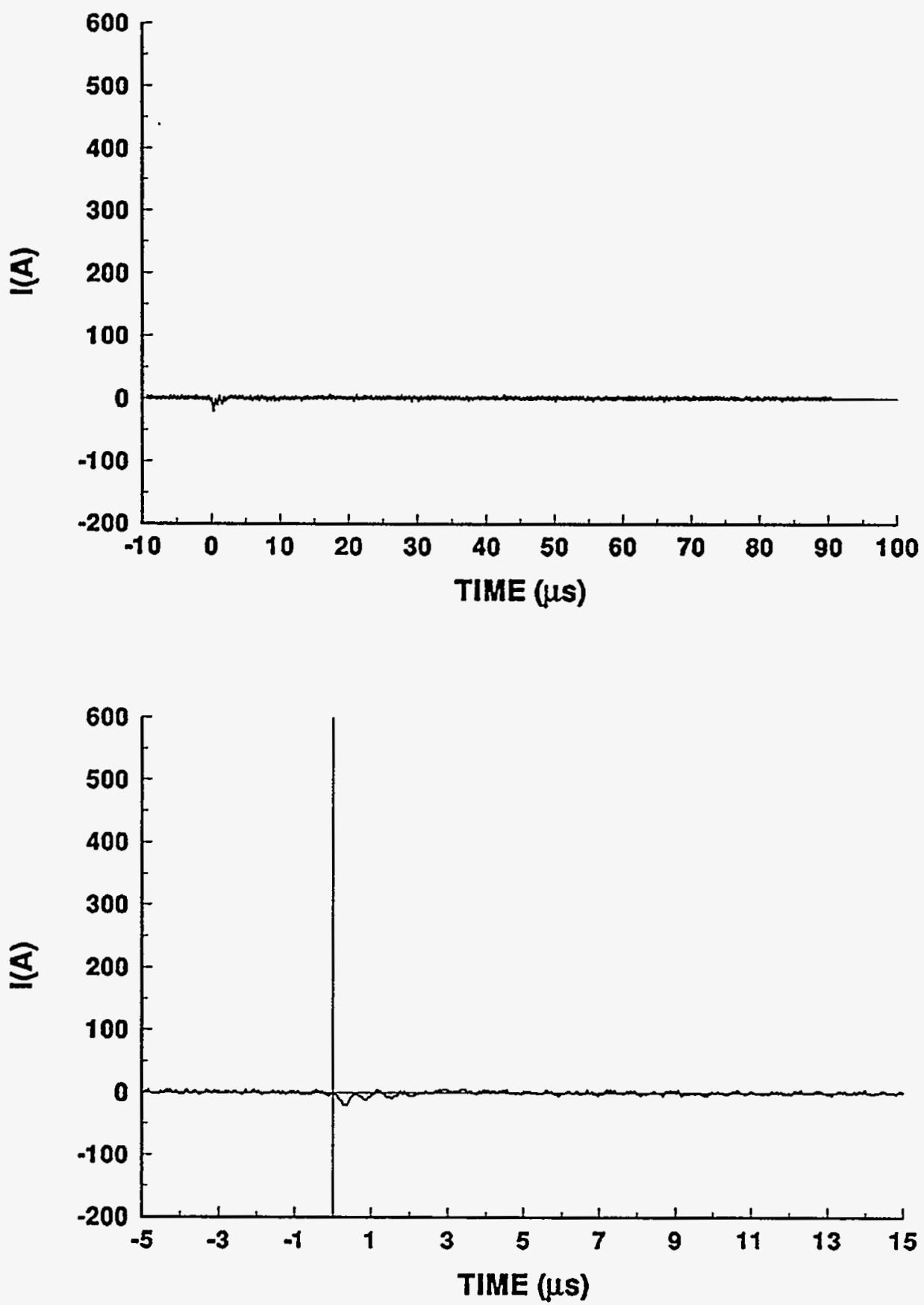


\section{4-24 STROKE 4}

TEST POINT 20

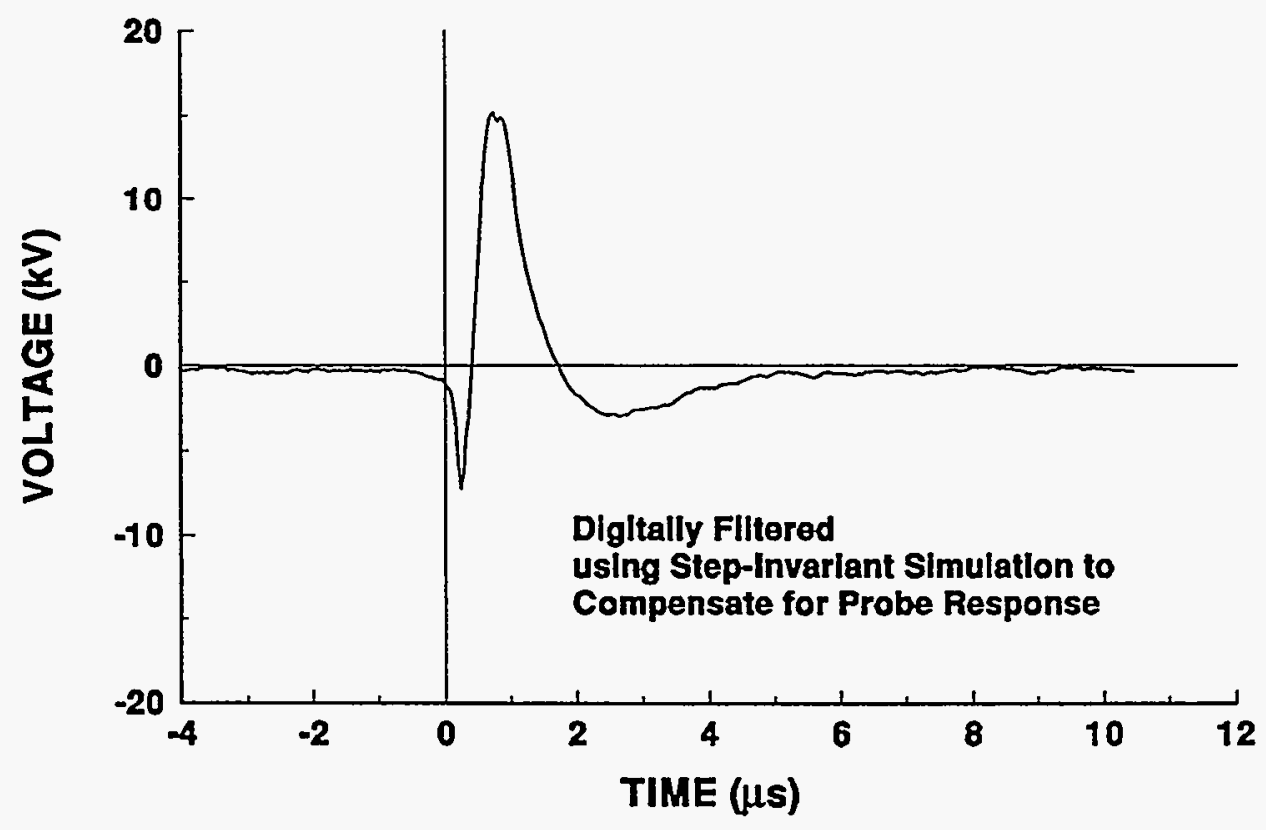

\section{4-24 STROKE 4} TEST POINT 21

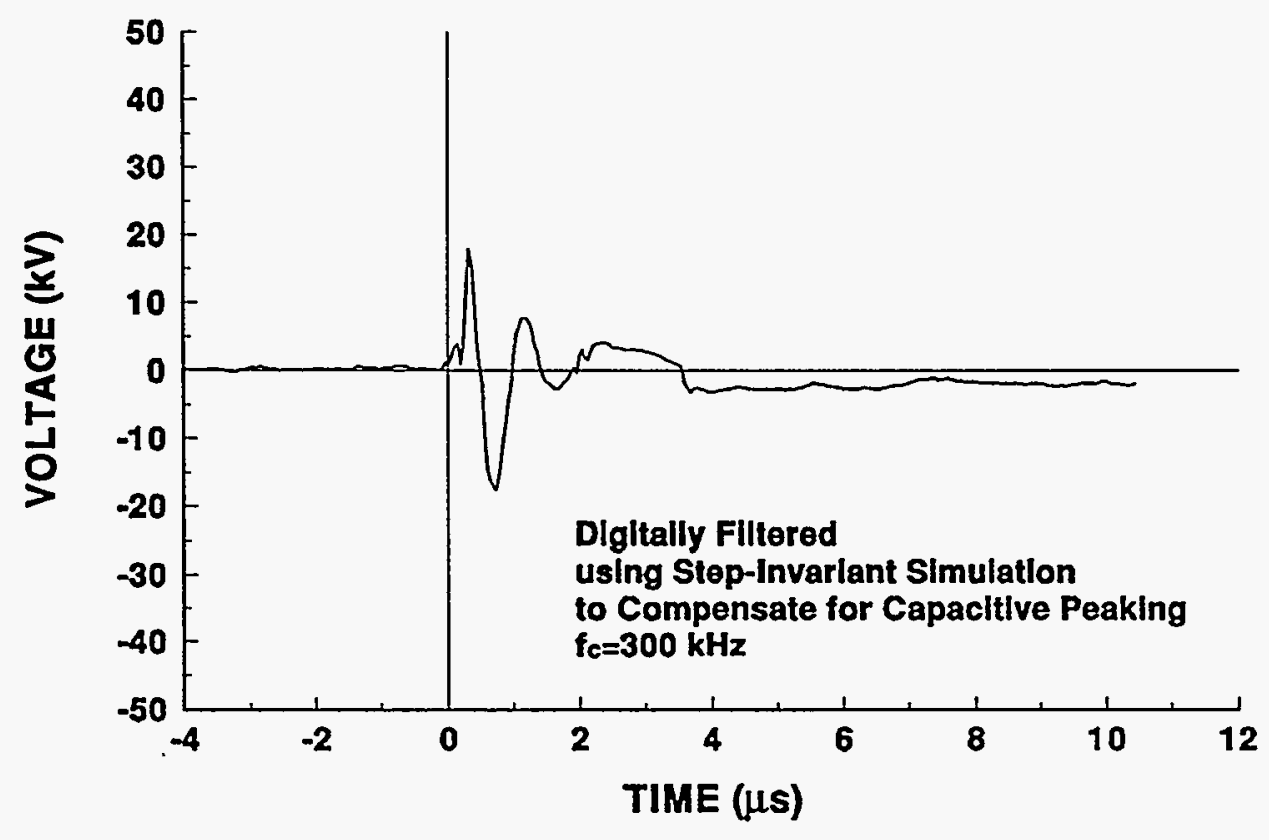




\section{4-24 STROKE 4}

TEST POINT 22

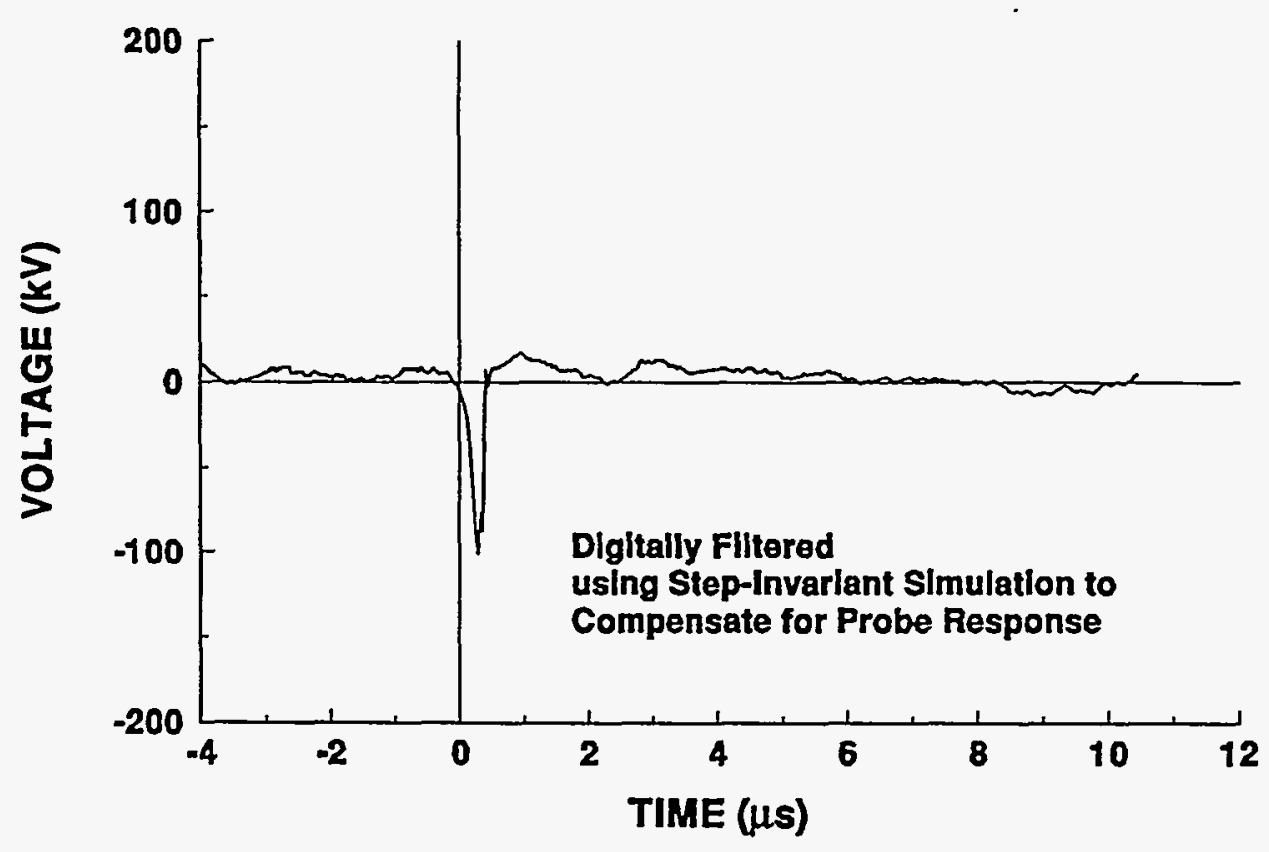


94-24 STROKE 4

TEST POINT 23

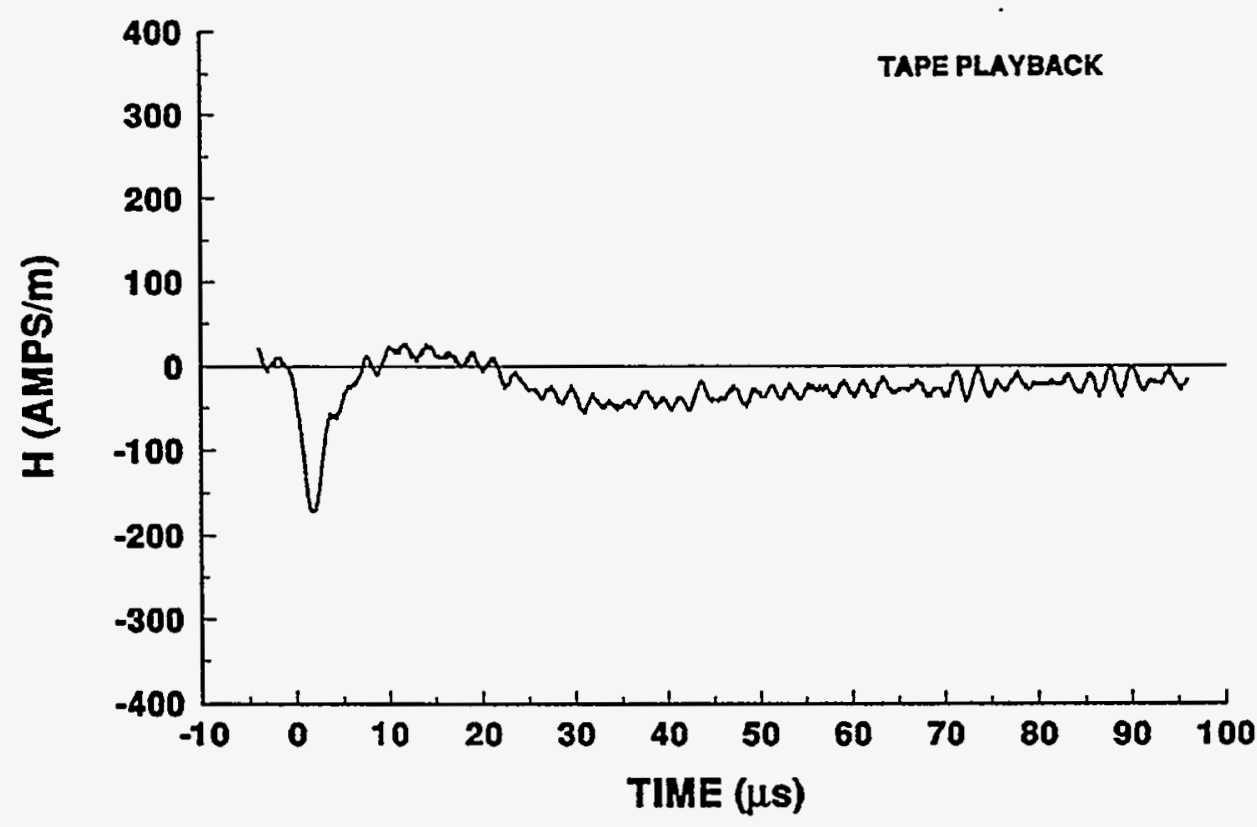

94-24 STROKE 4

TEST POINT 24

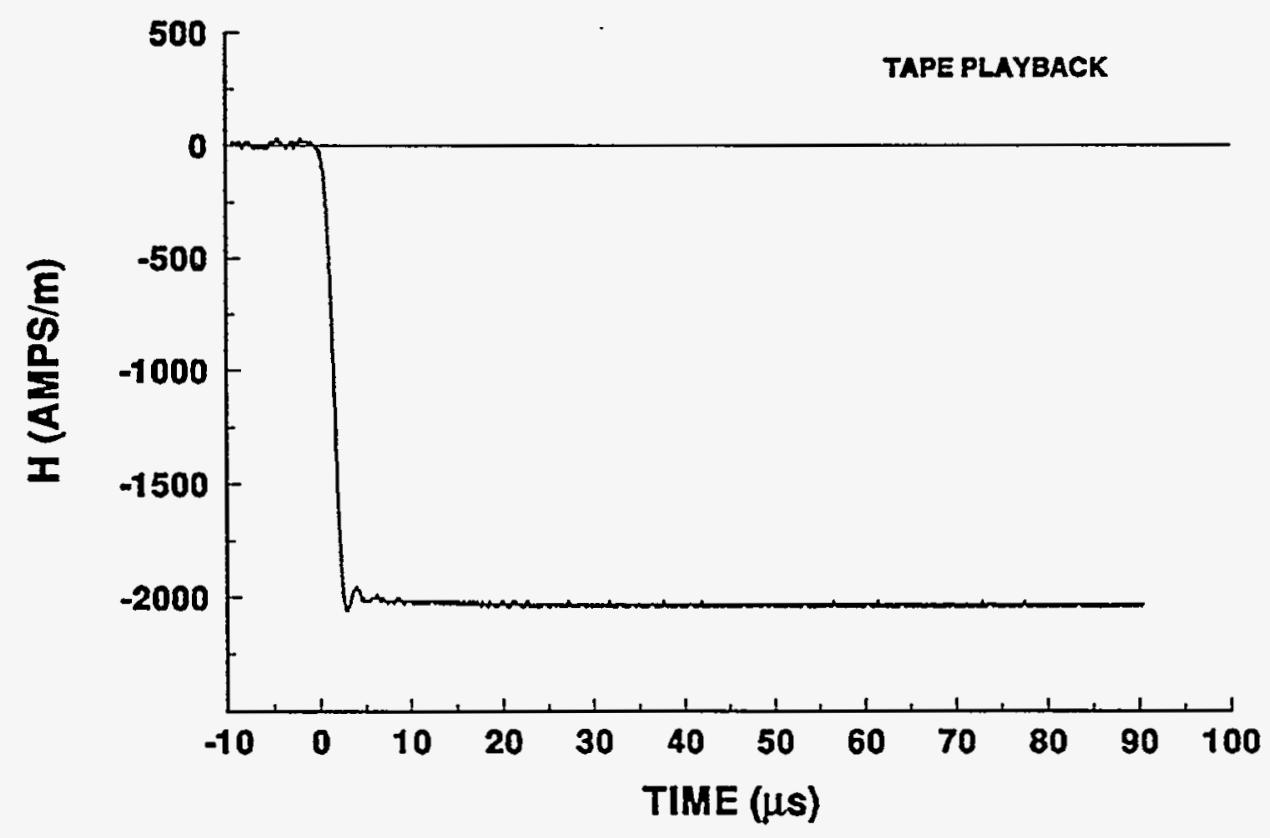




\section{4-24 STROKE 6}

INCIDENT CURRENT
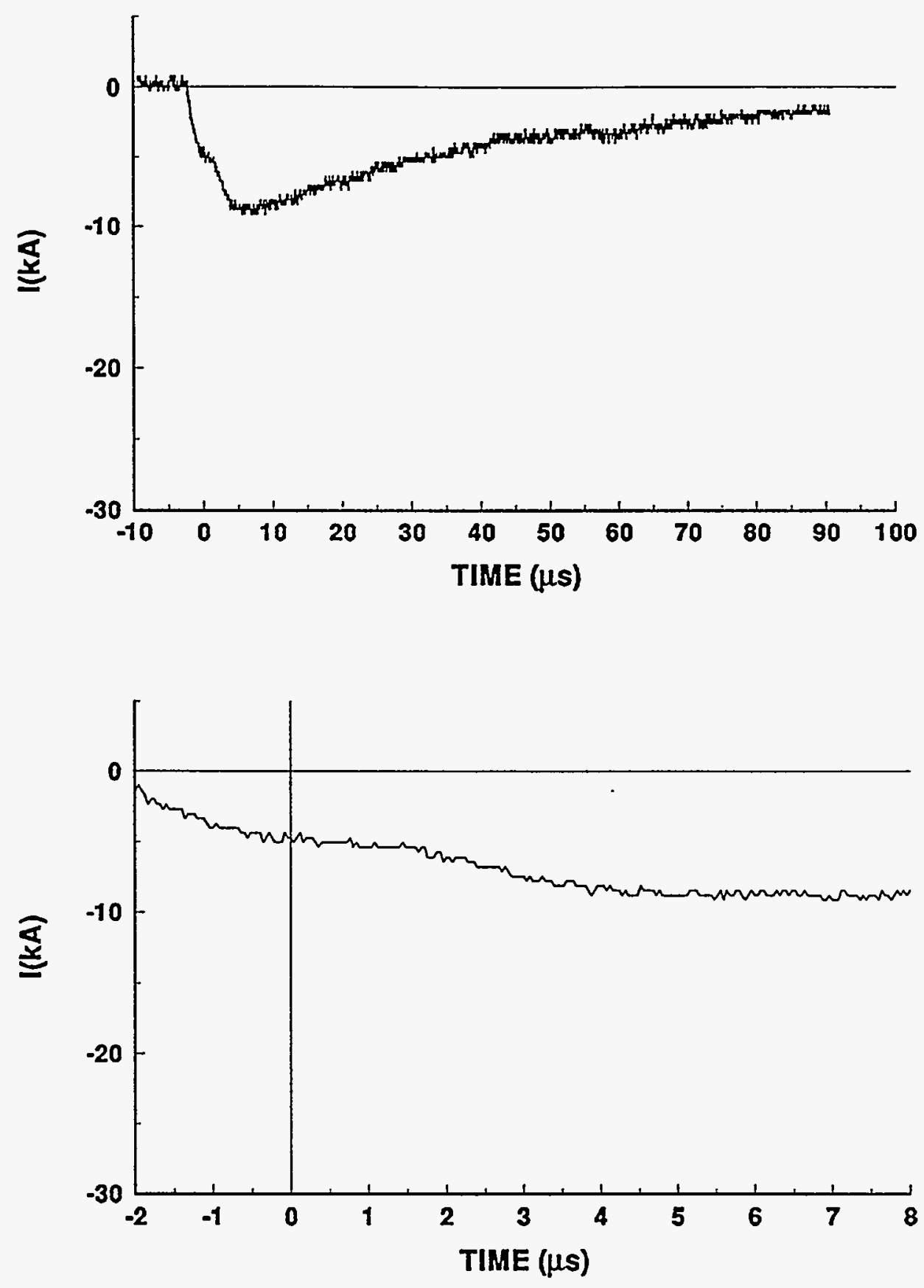


\section{4-24 STROKE 6}

TEST POINT 1
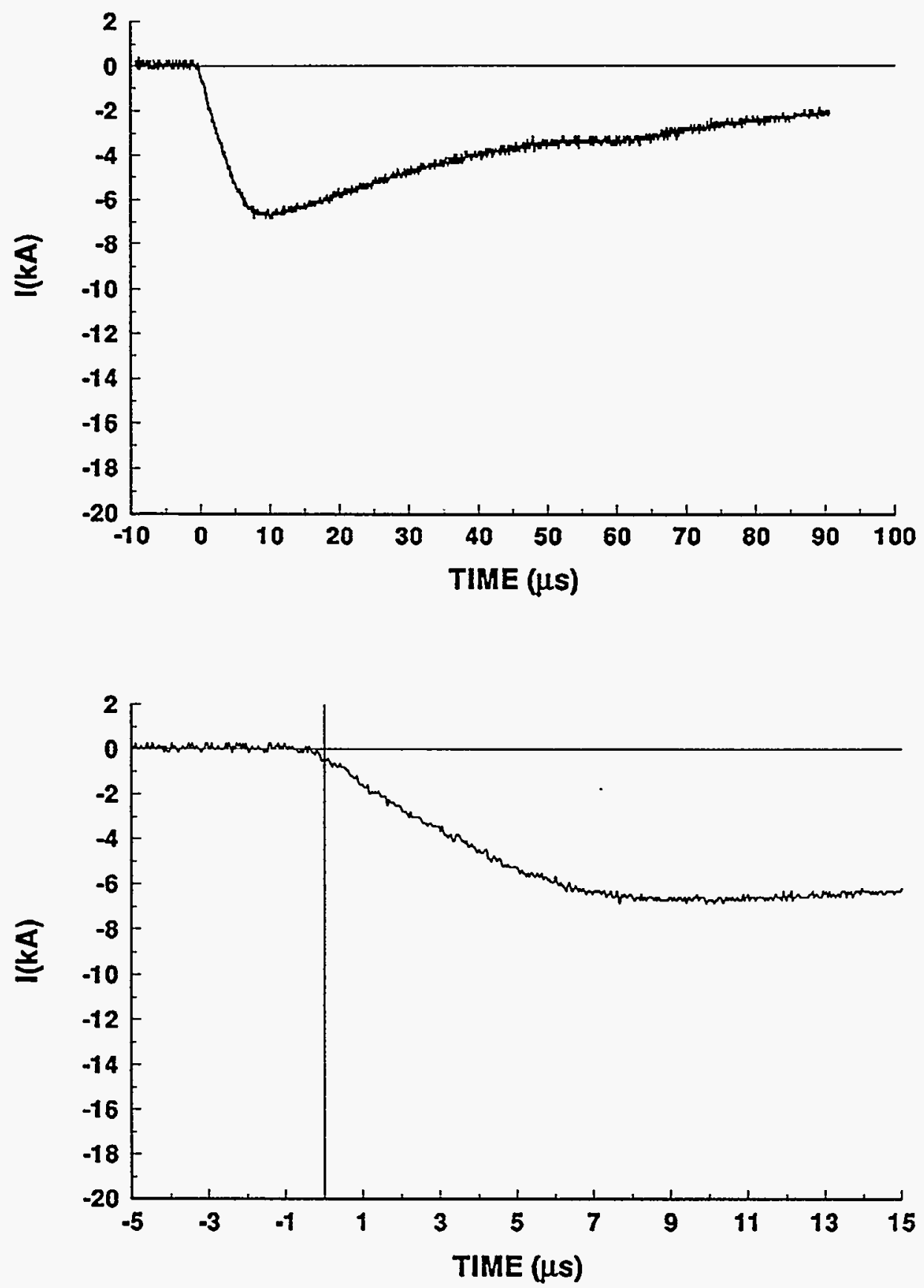
94-24 STROKE 6

TEST POINT 2
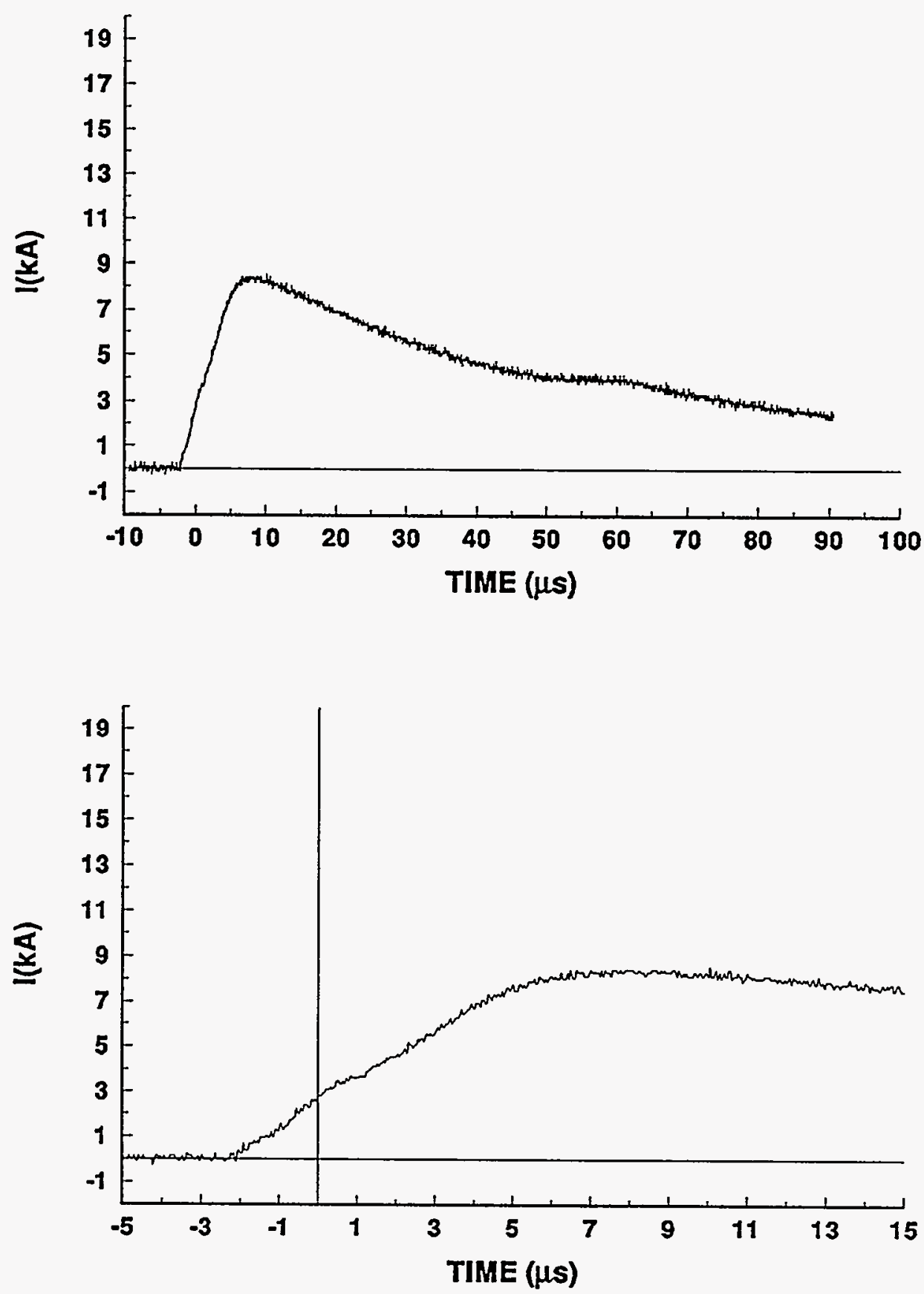


\section{4-24 STROKE 6 \\ TEST POINT 5}
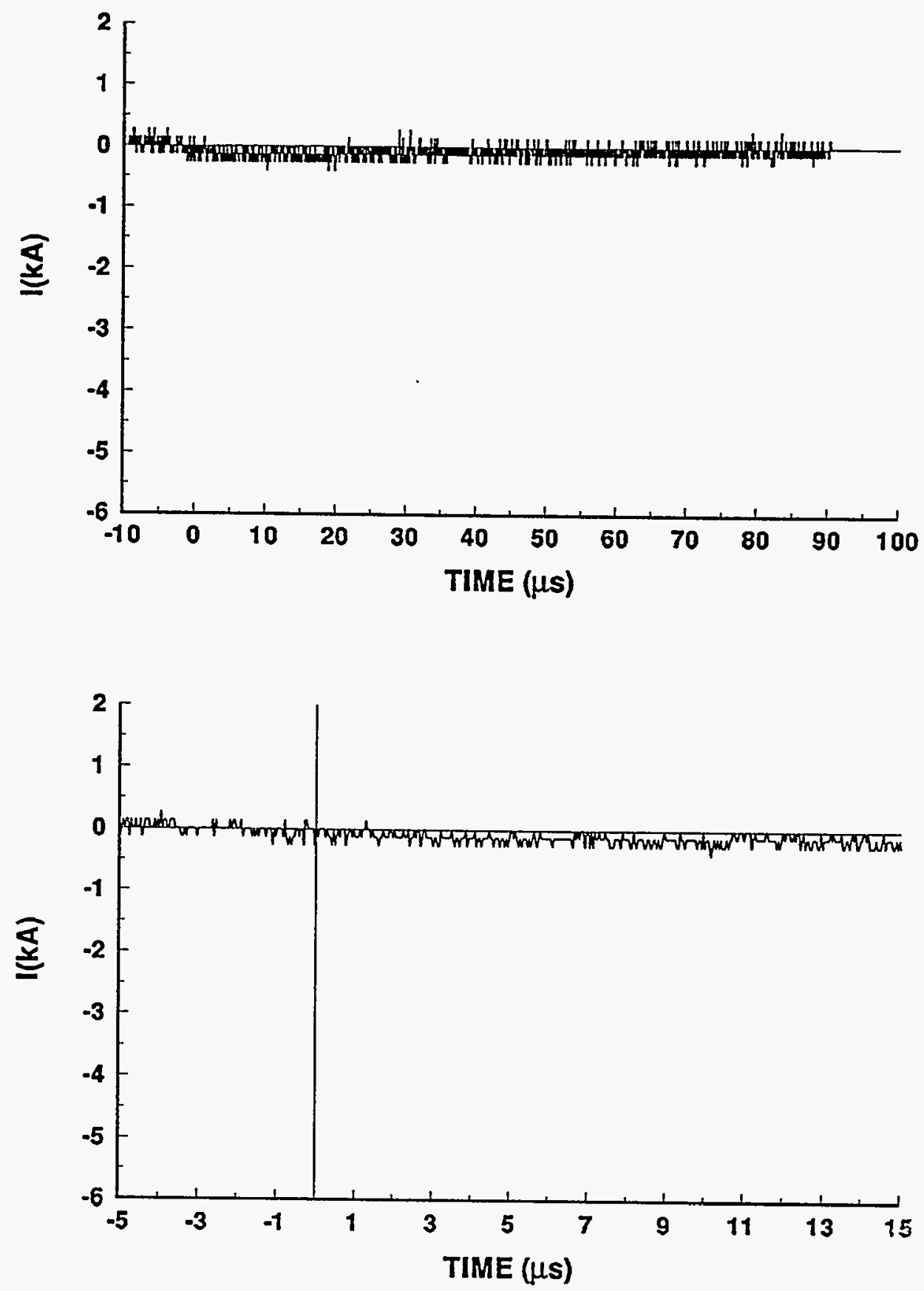


\section{4-24 STROKE 6}

TEST POINT 6
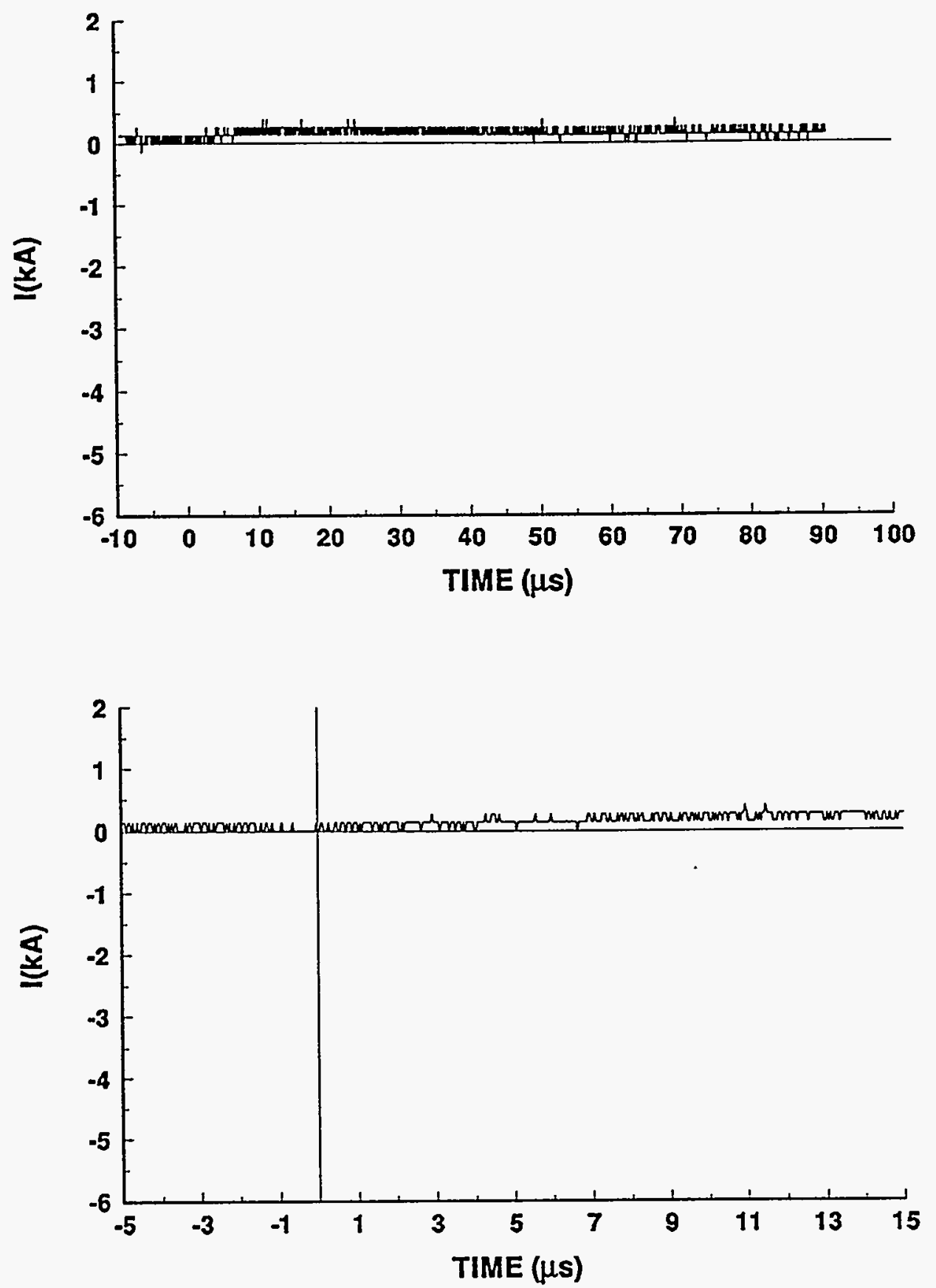


\section{4-24 STROKE 6 \\ TEST POINT 5'}

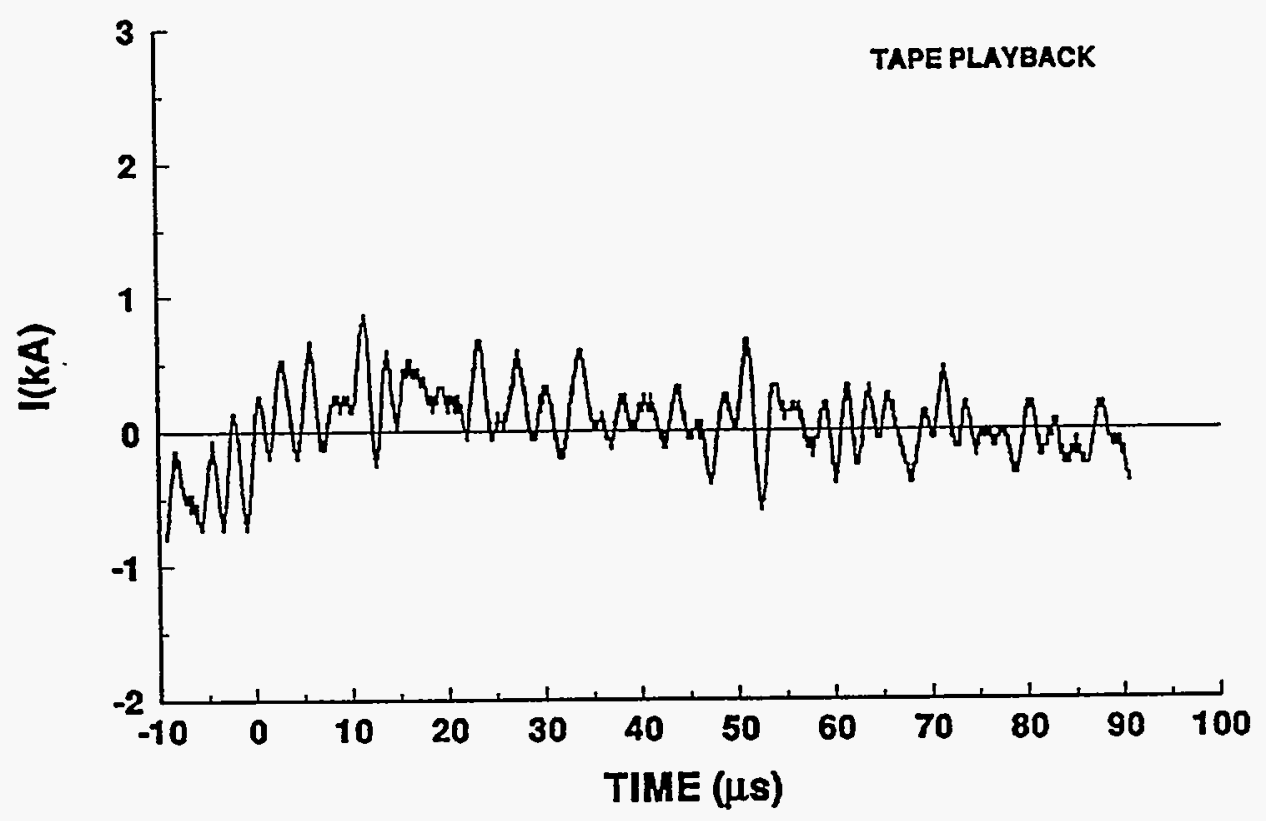

\section{4-24 STROKE 6}

TEST POINT 6'

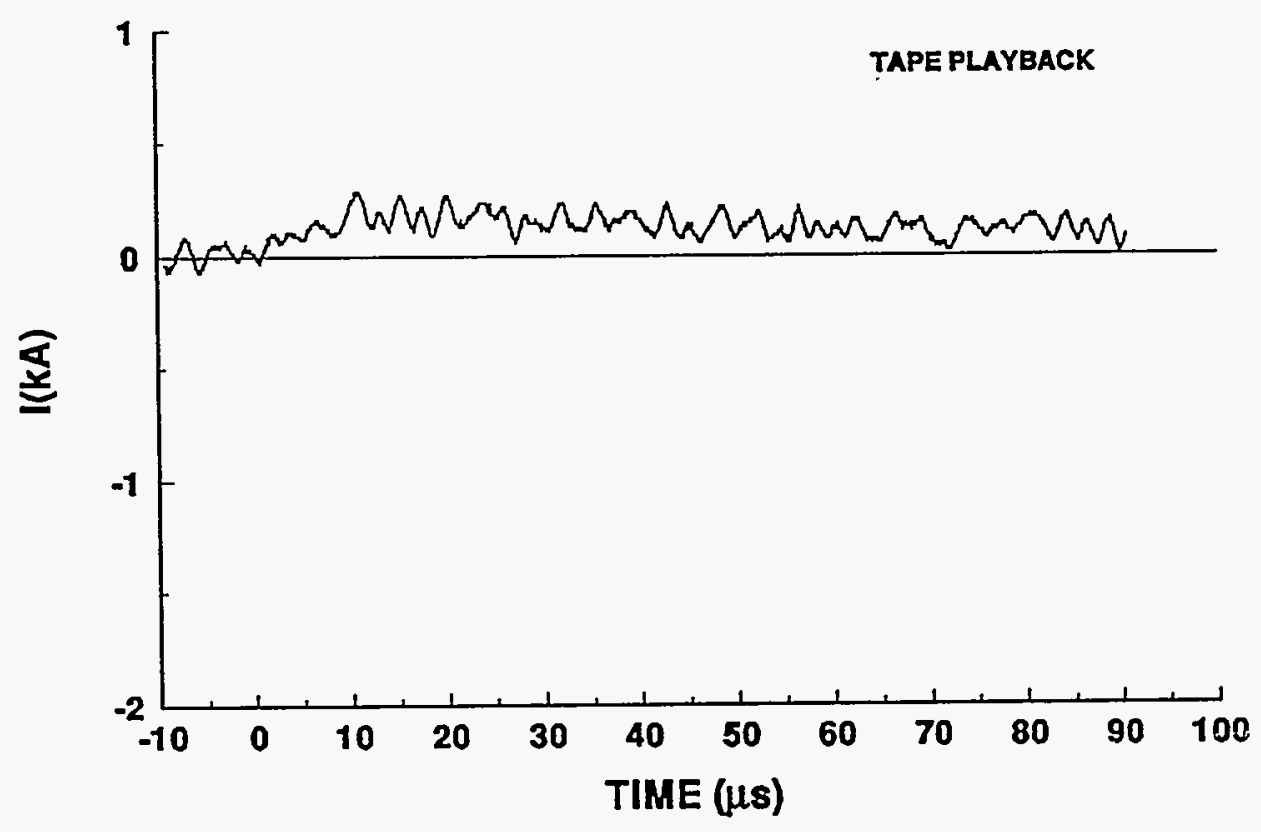


94-24 STROKE 6

TEST POINT 10

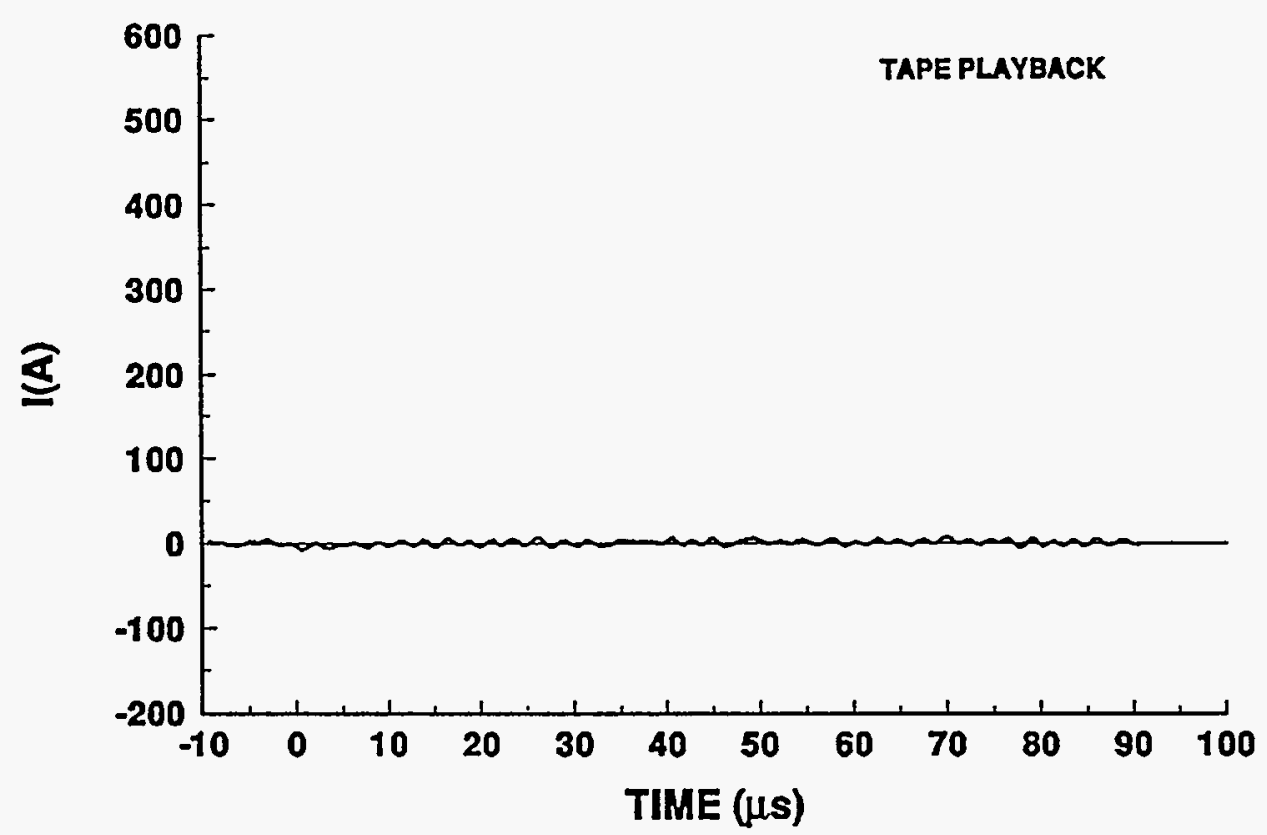

94-24 STROKE 6

TEST POINT 11

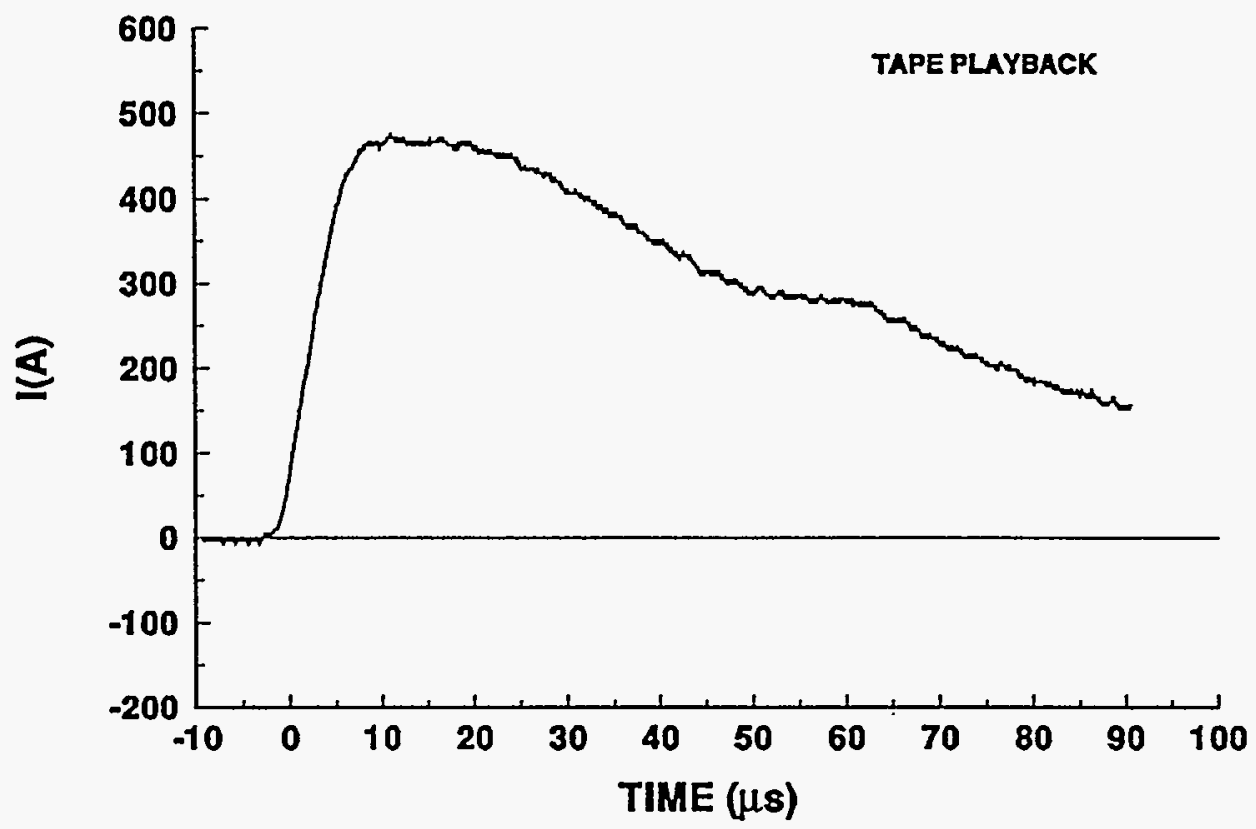


94-24 STROKE 6

TEST POINT 12

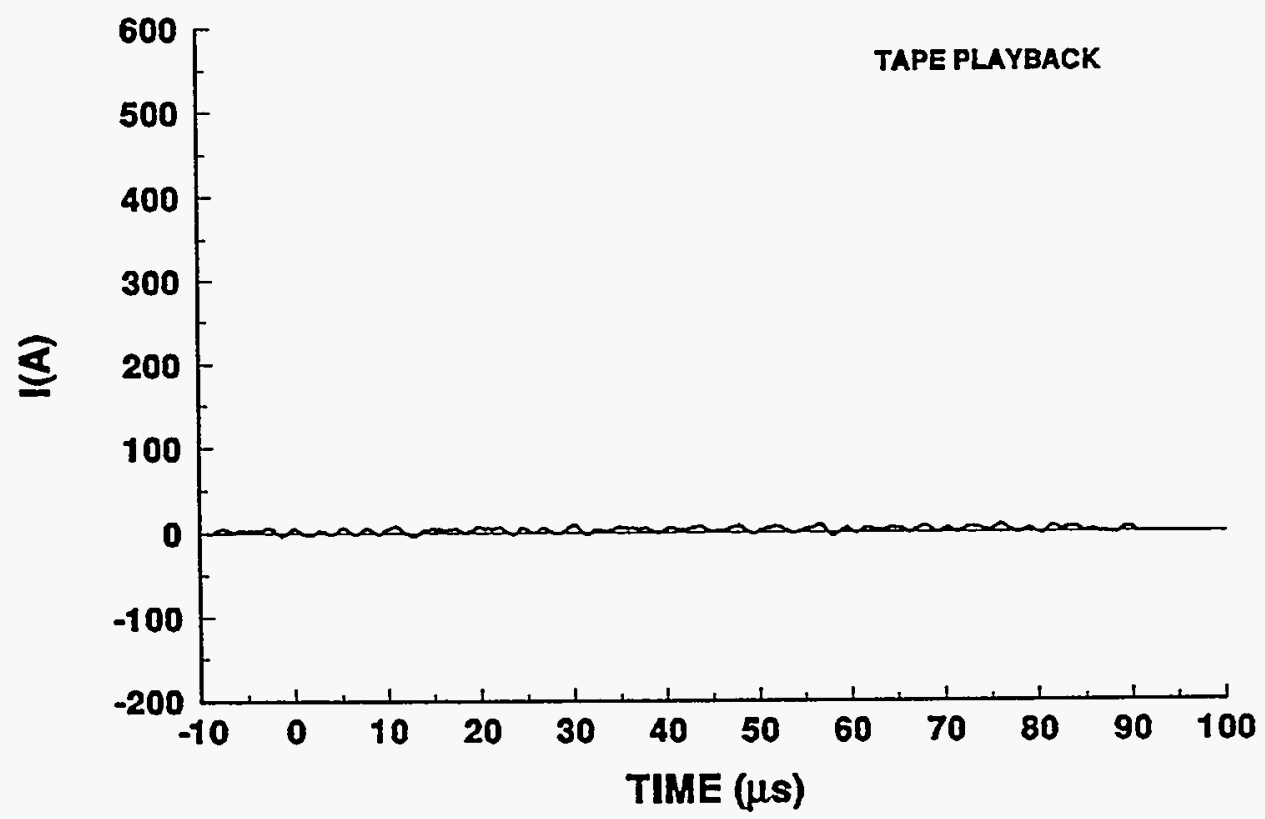

94-24 STROKE 6

TEST POINT 13

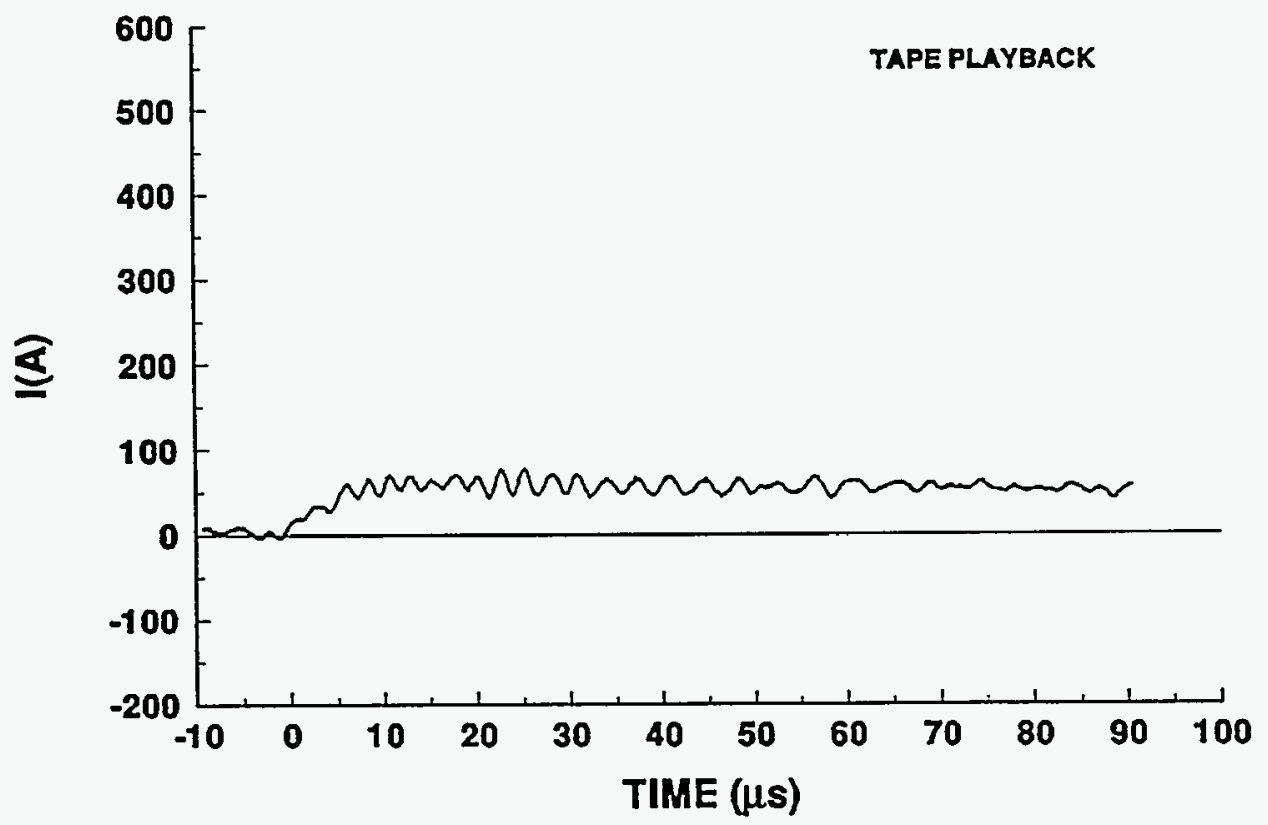




\section{4-24 STROKE 6}

TEST POINT 14
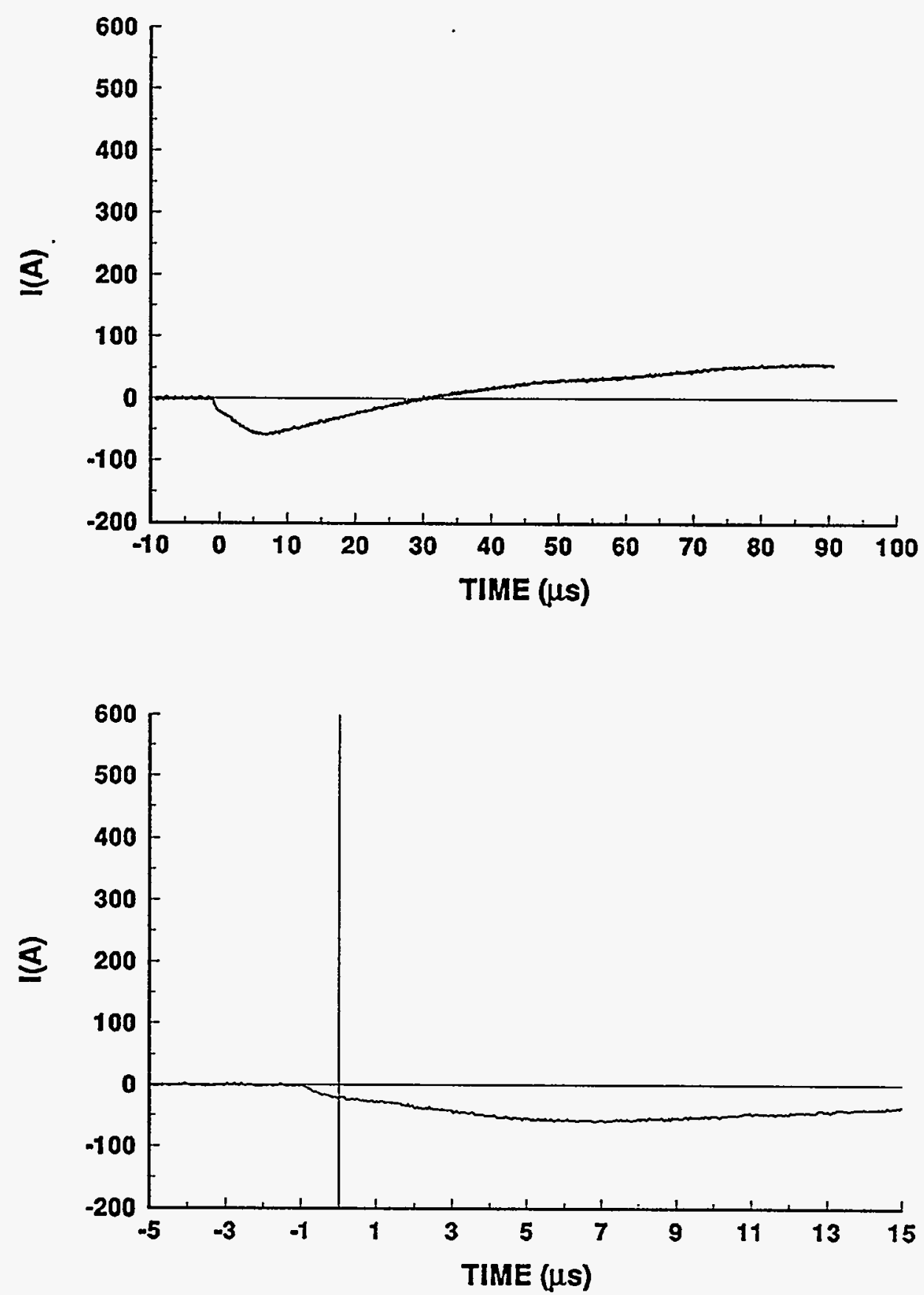


\section{4-24 STROKE 6}

TEST POINT 15
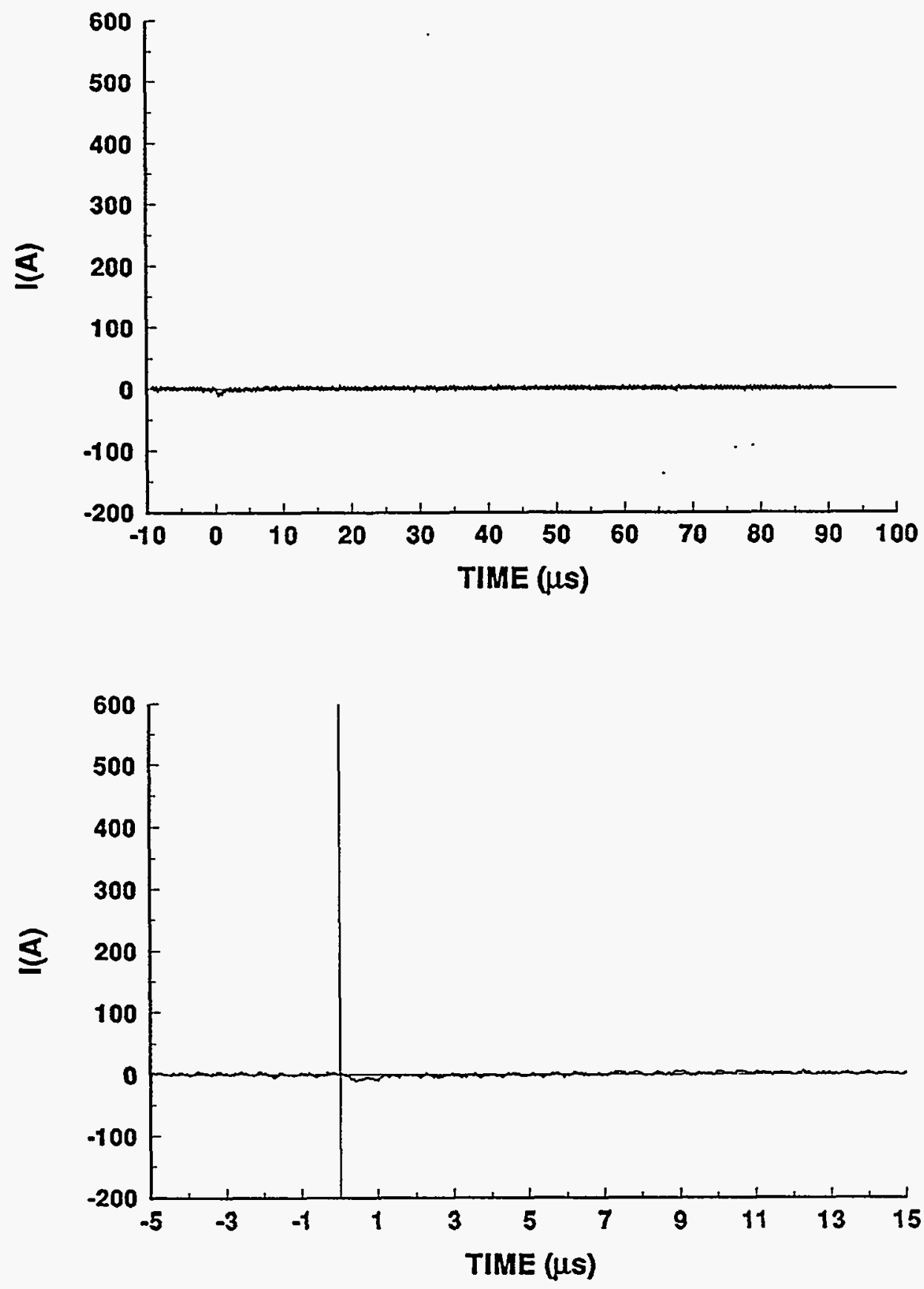


\section{4-24 STROKE 6}

TEST POINT 20

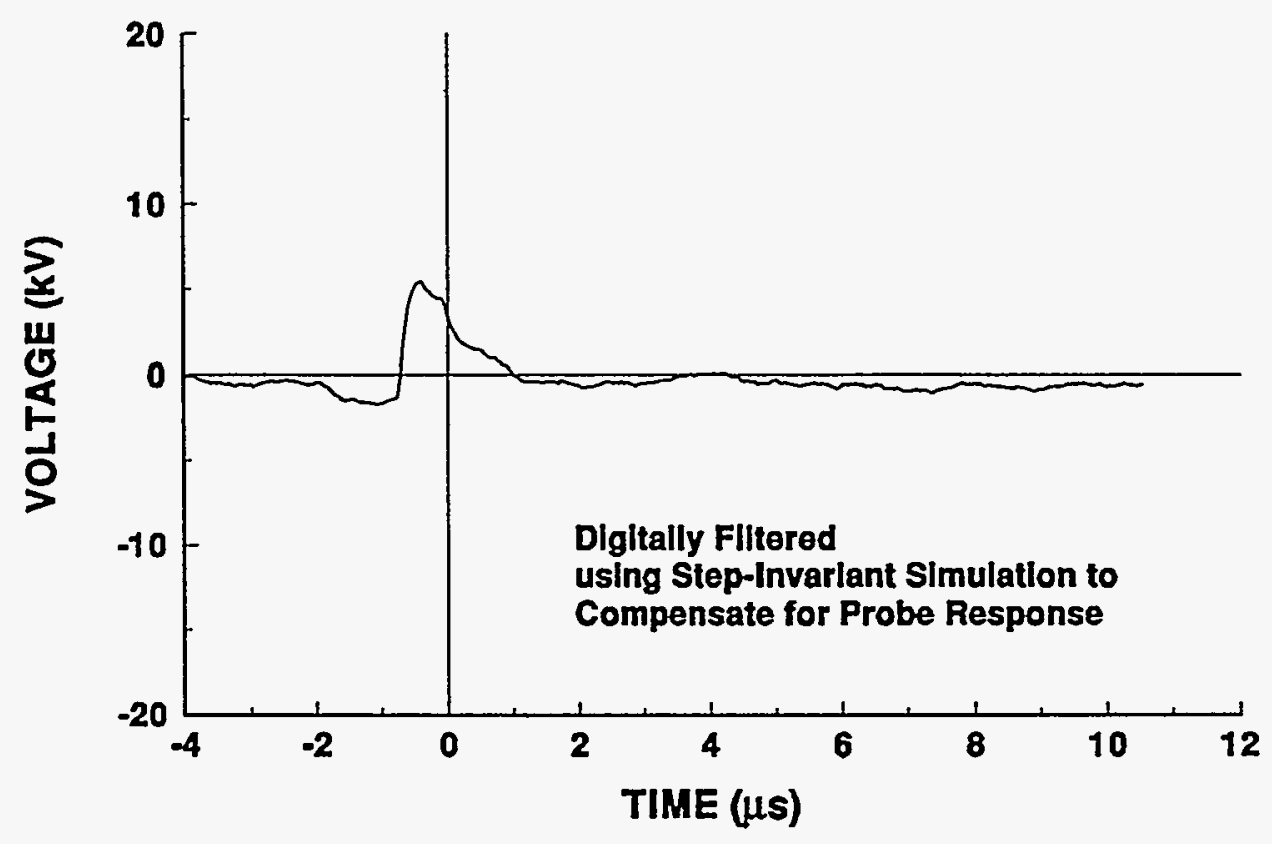

94-24 STROKE 6 TEST POINT 21

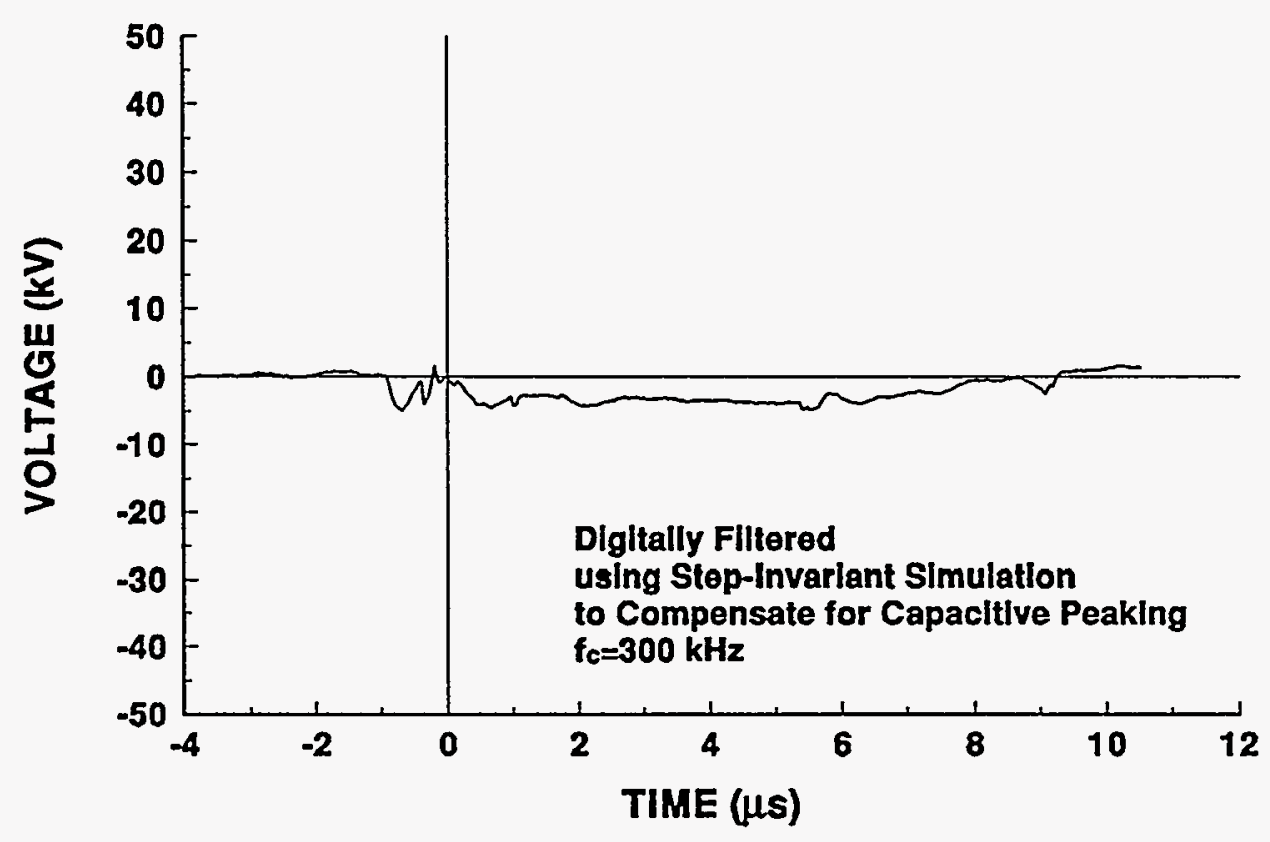




\section{4-24 STROKE 6}

TEST POINT 22

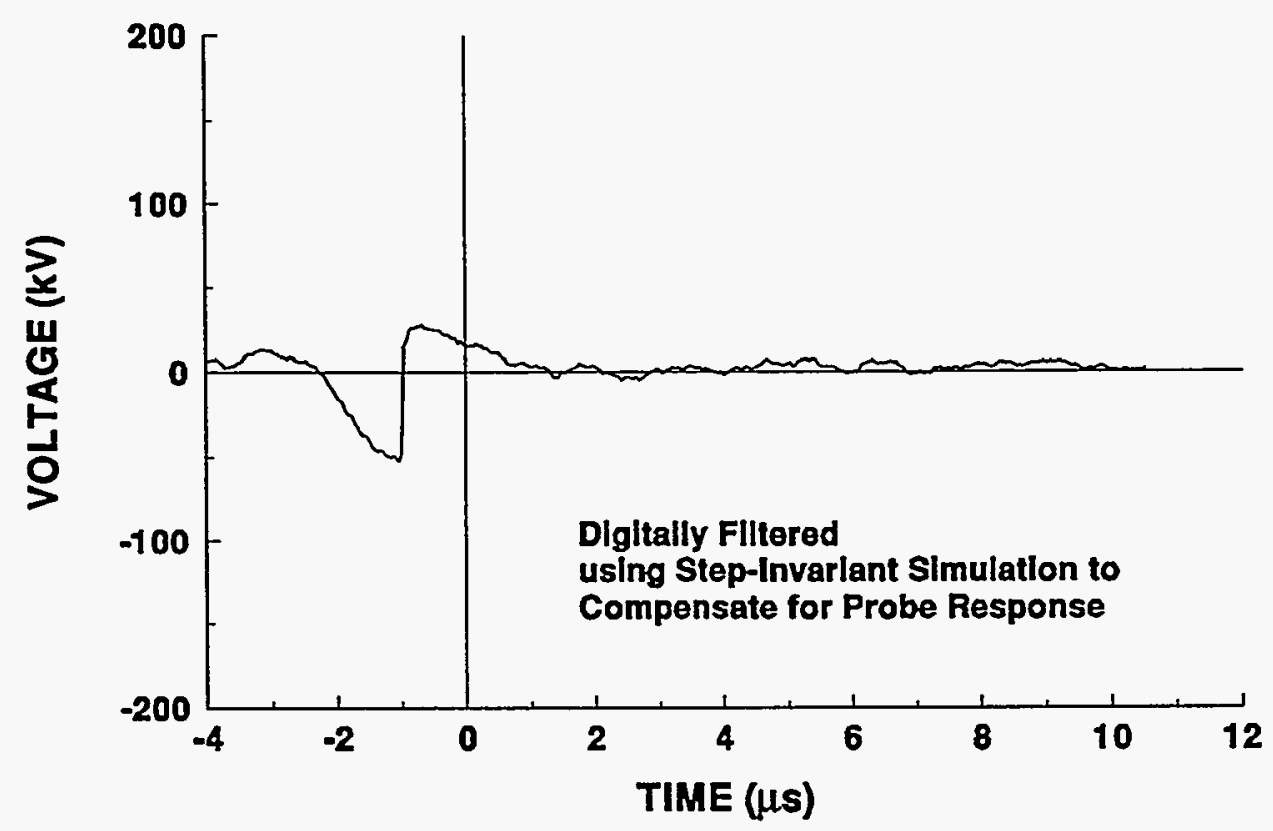




\section{4-24 STROKE 6}

\section{TEST POINT 23}

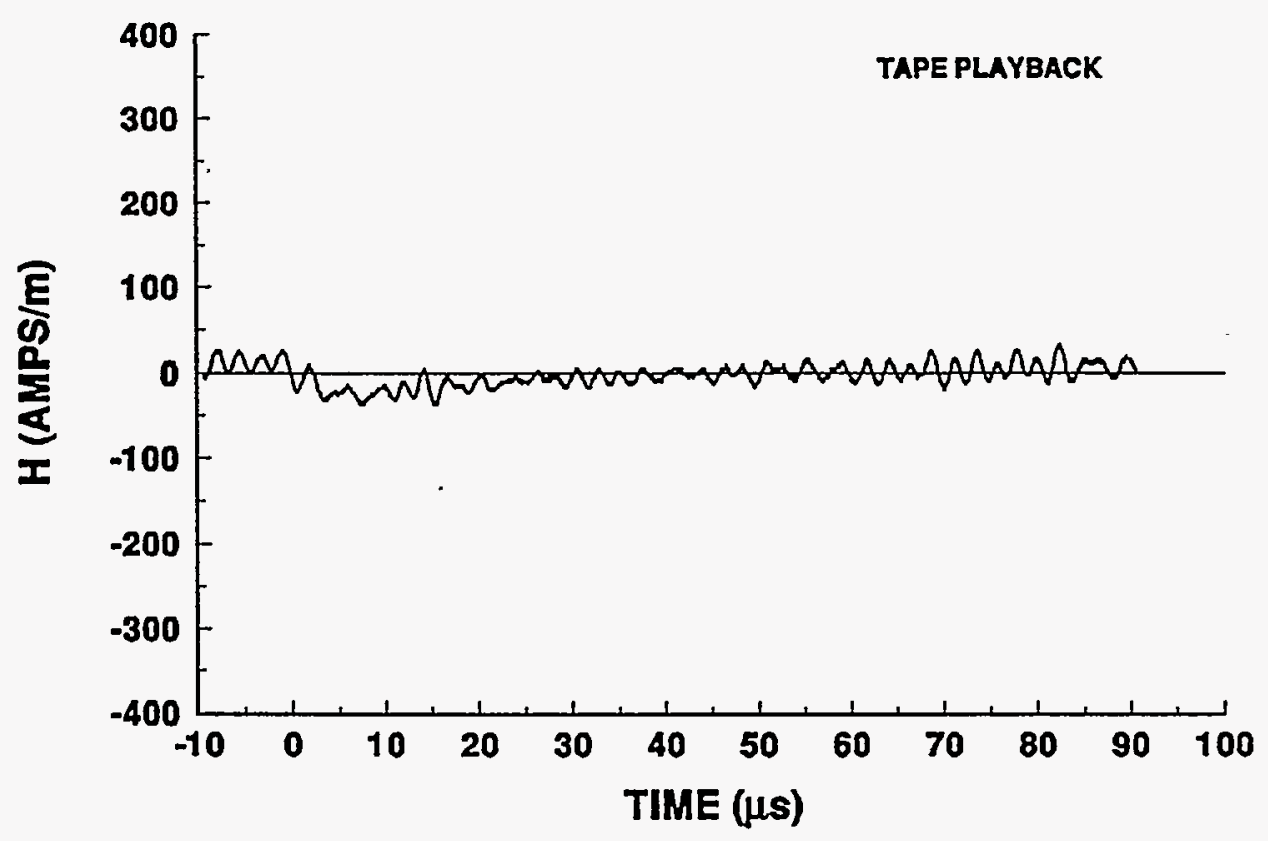

94-24 STROKE 6 TEST POINT 24

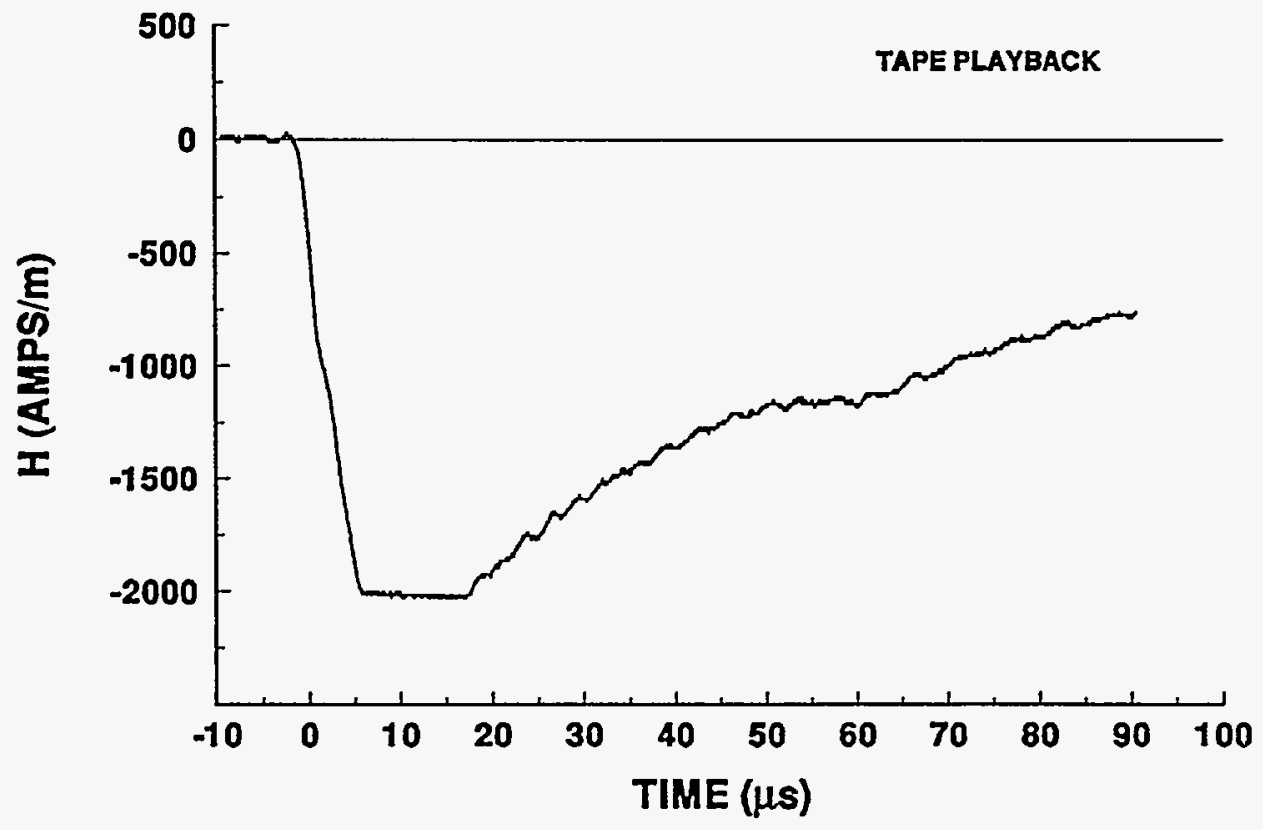




\section{4-24 STROKE 7 \\ INCIDENT CURRENT}
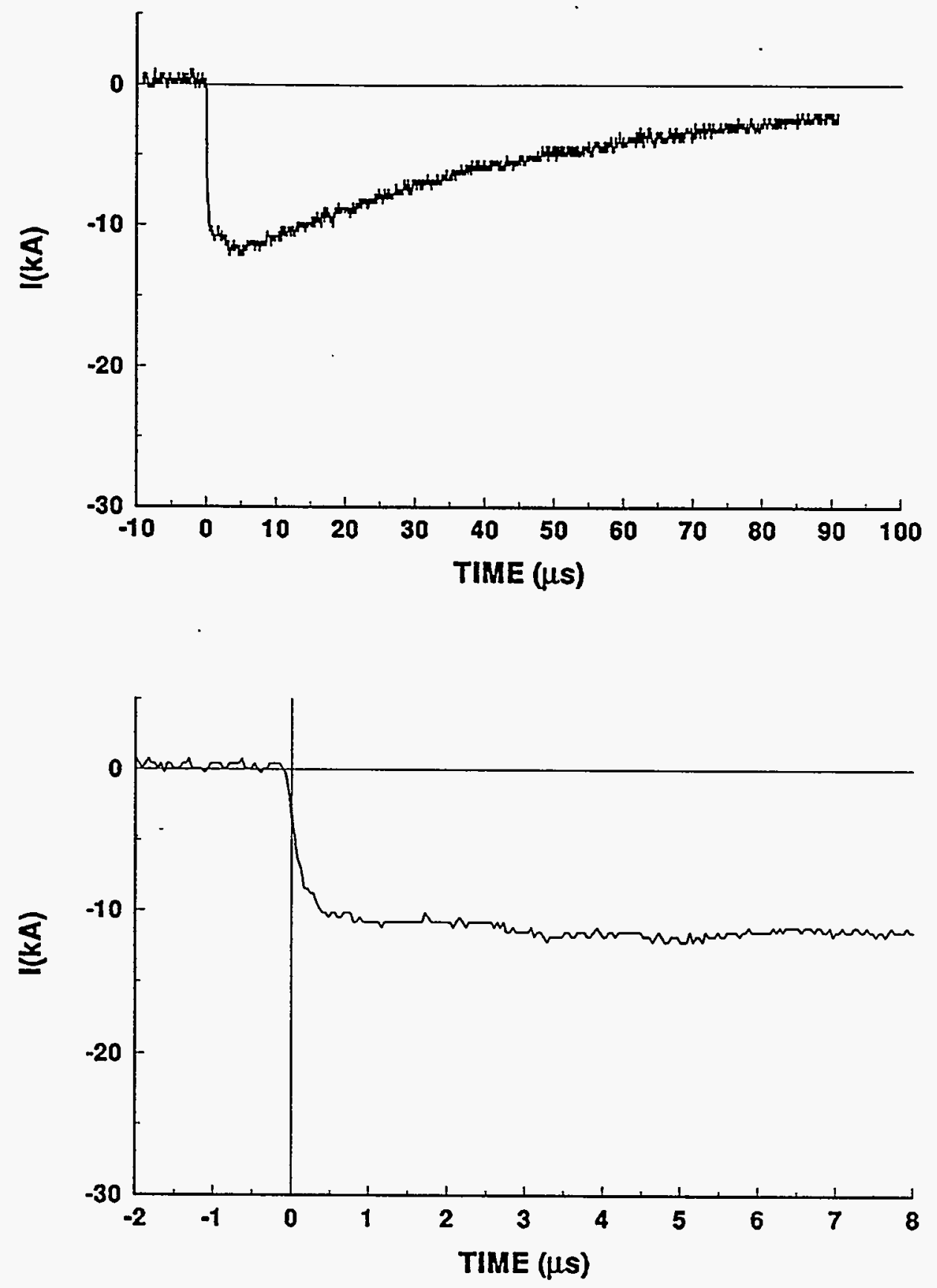


\section{4-24 STROKE 7}

\section{TEST POINT 1}
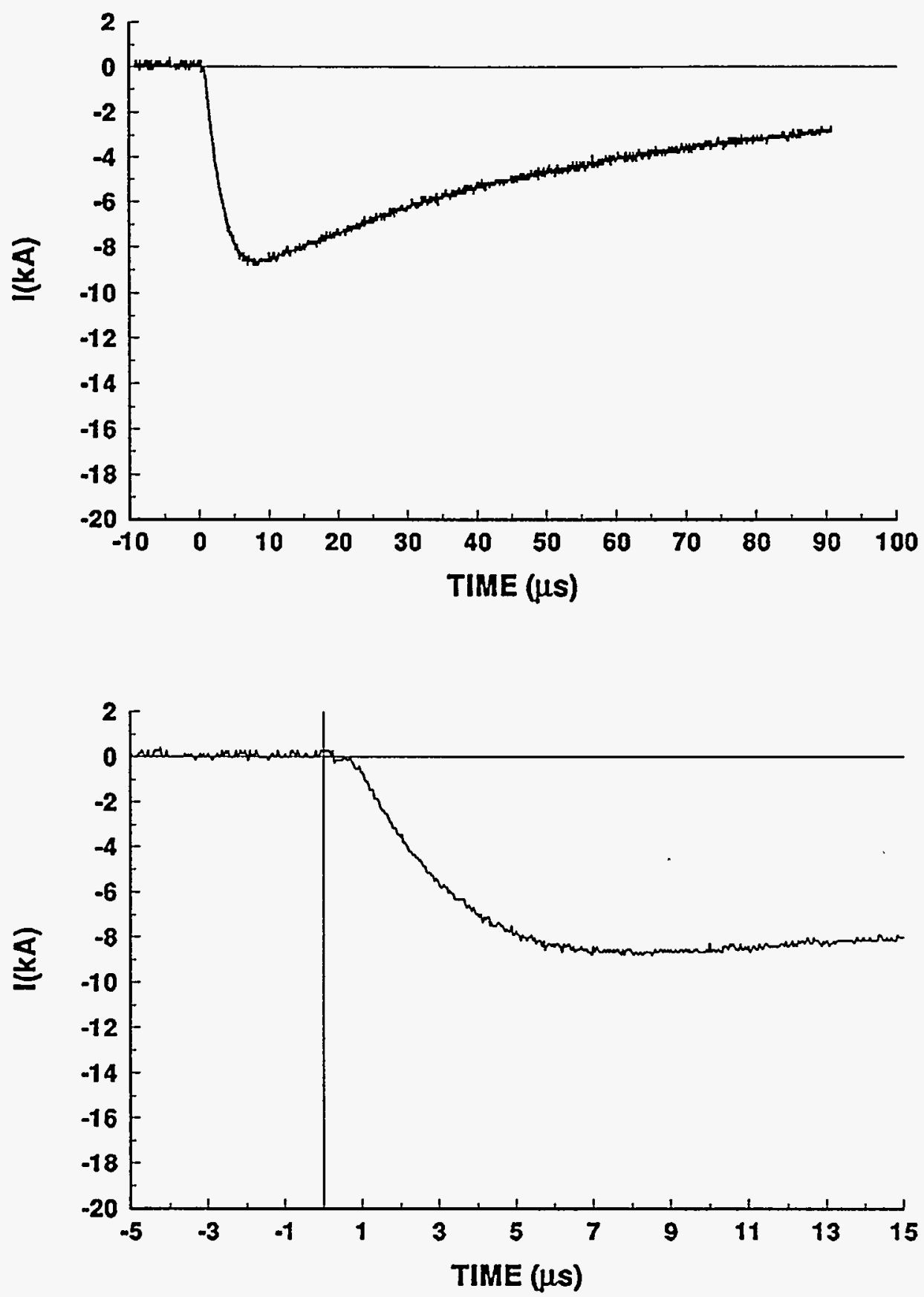


\section{4-24 STROKE 7 \\ TEST POINT 2}
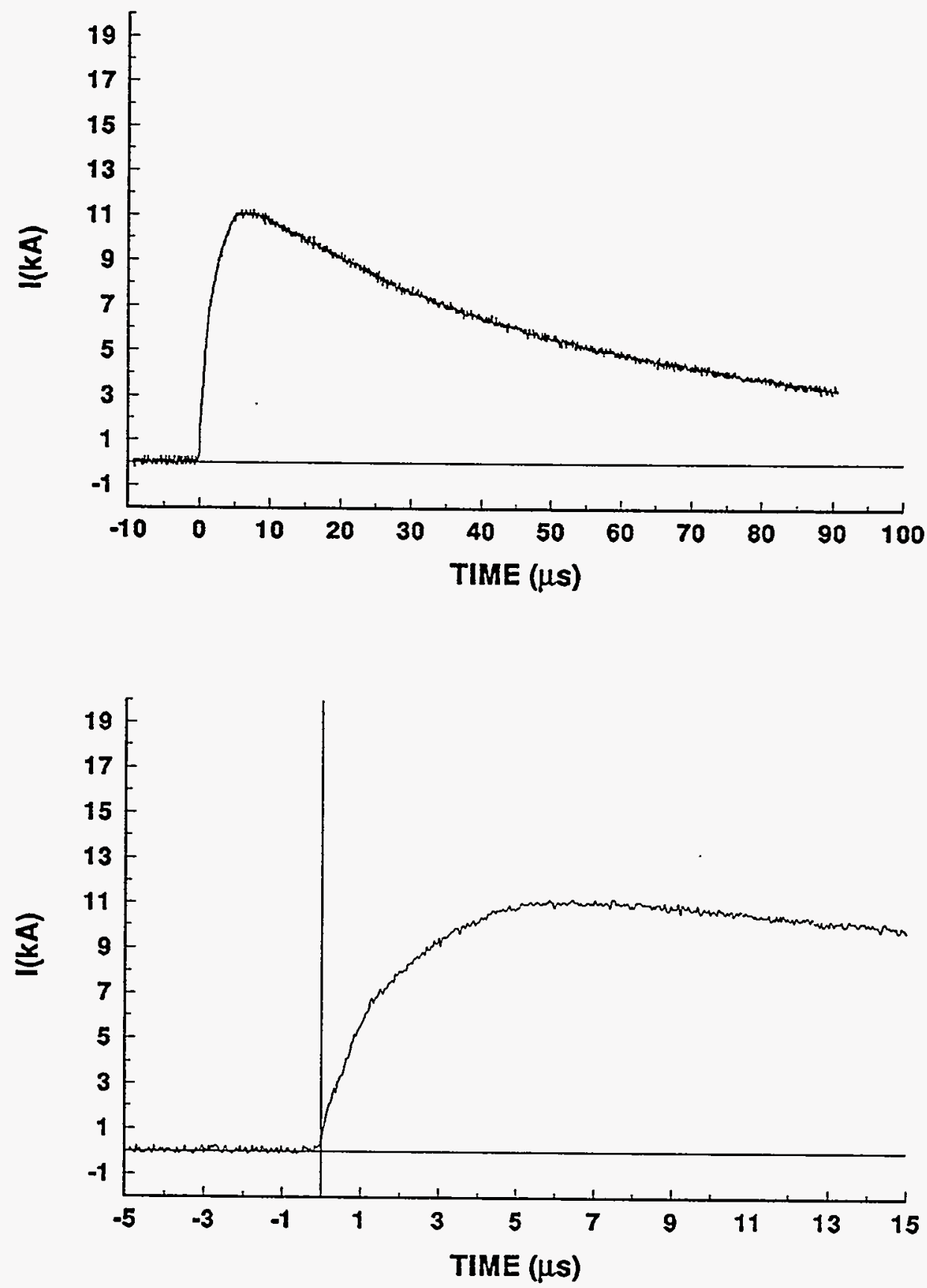


\section{4-24 STROKE 7}

TEST POINT 5
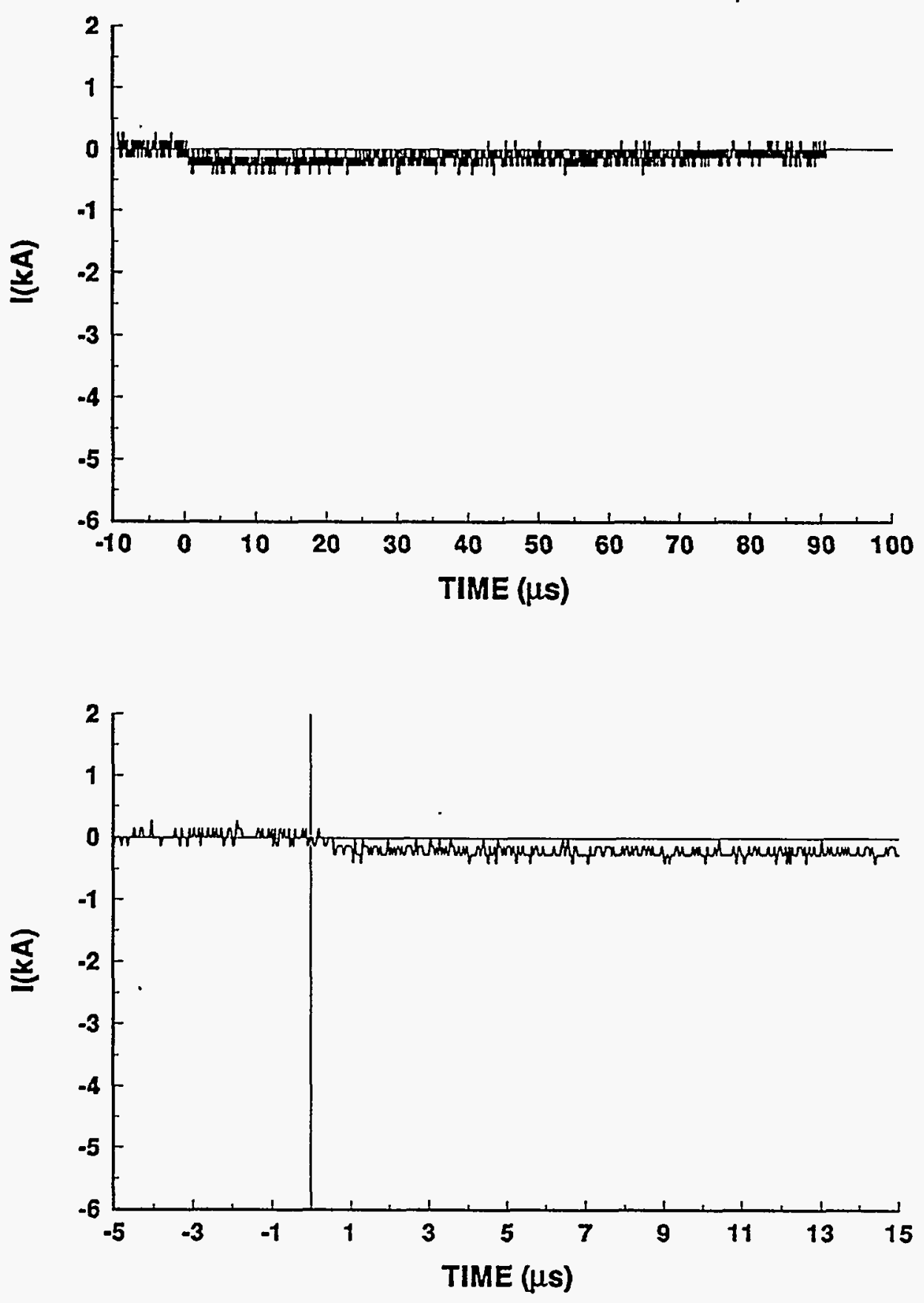


\section{4-24 STROKE 7 \\ TEST POINT 6}
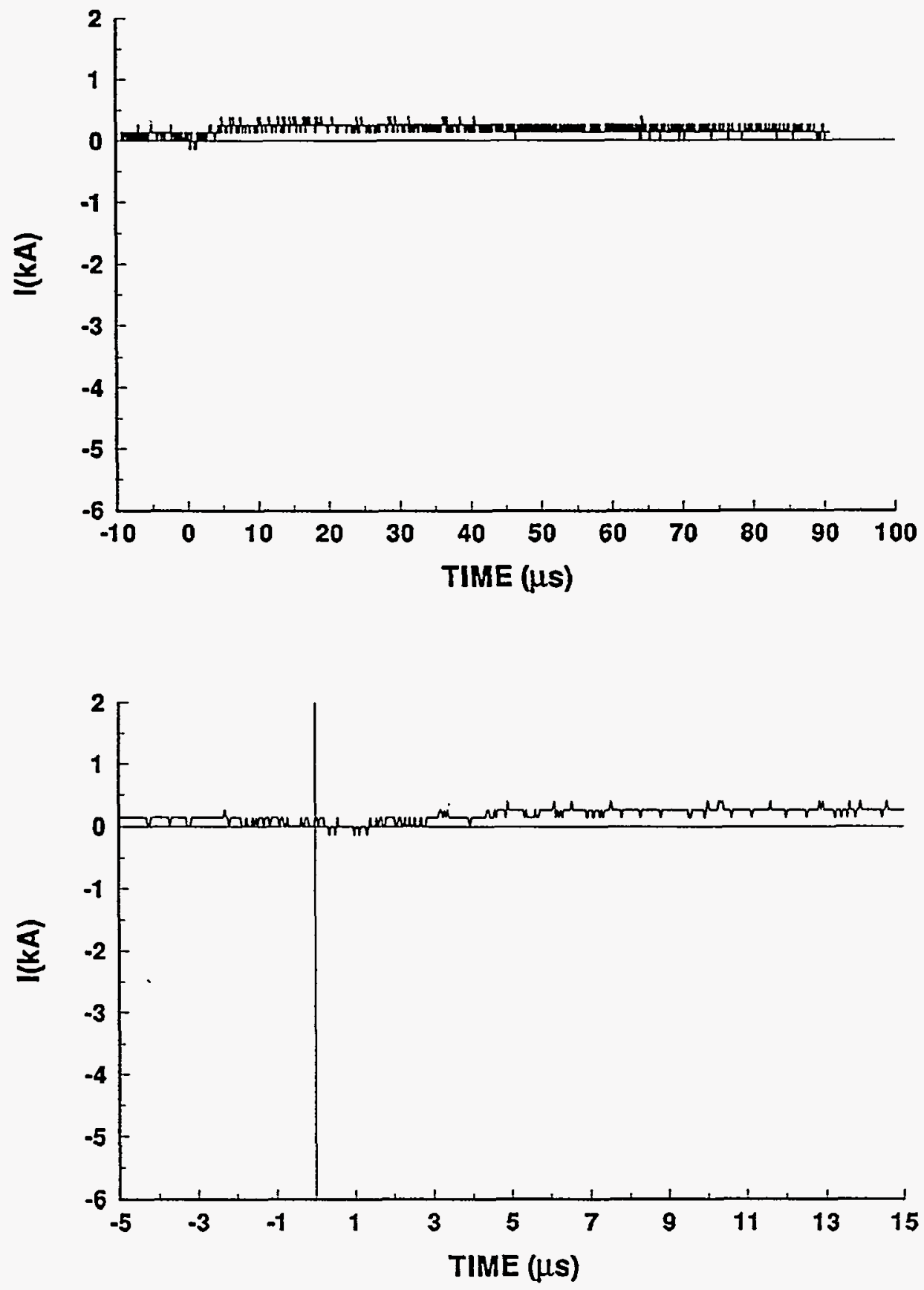


\section{4-24 STROKE 7}

TEST POINT 5'

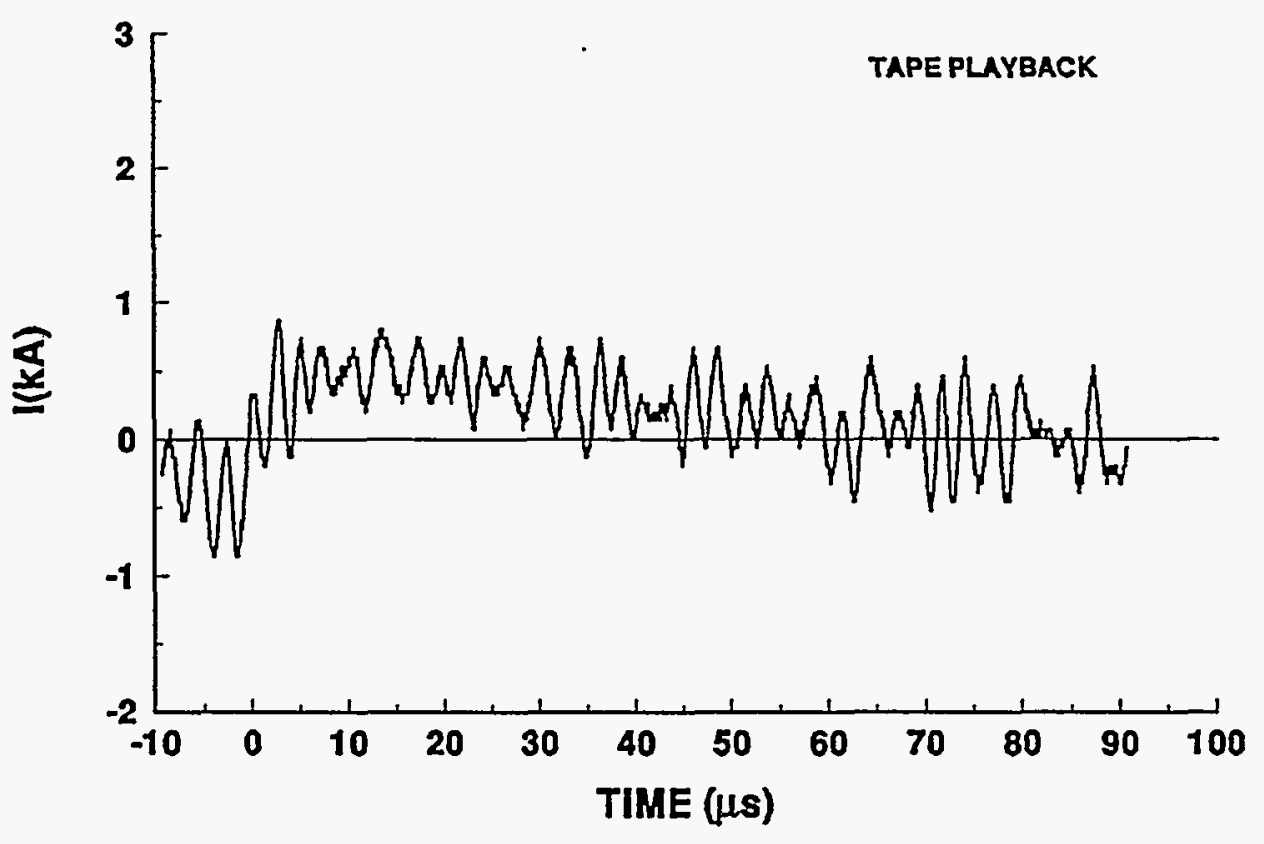

\section{4-24 STROKE 7}

\section{TEST POINT 6'}

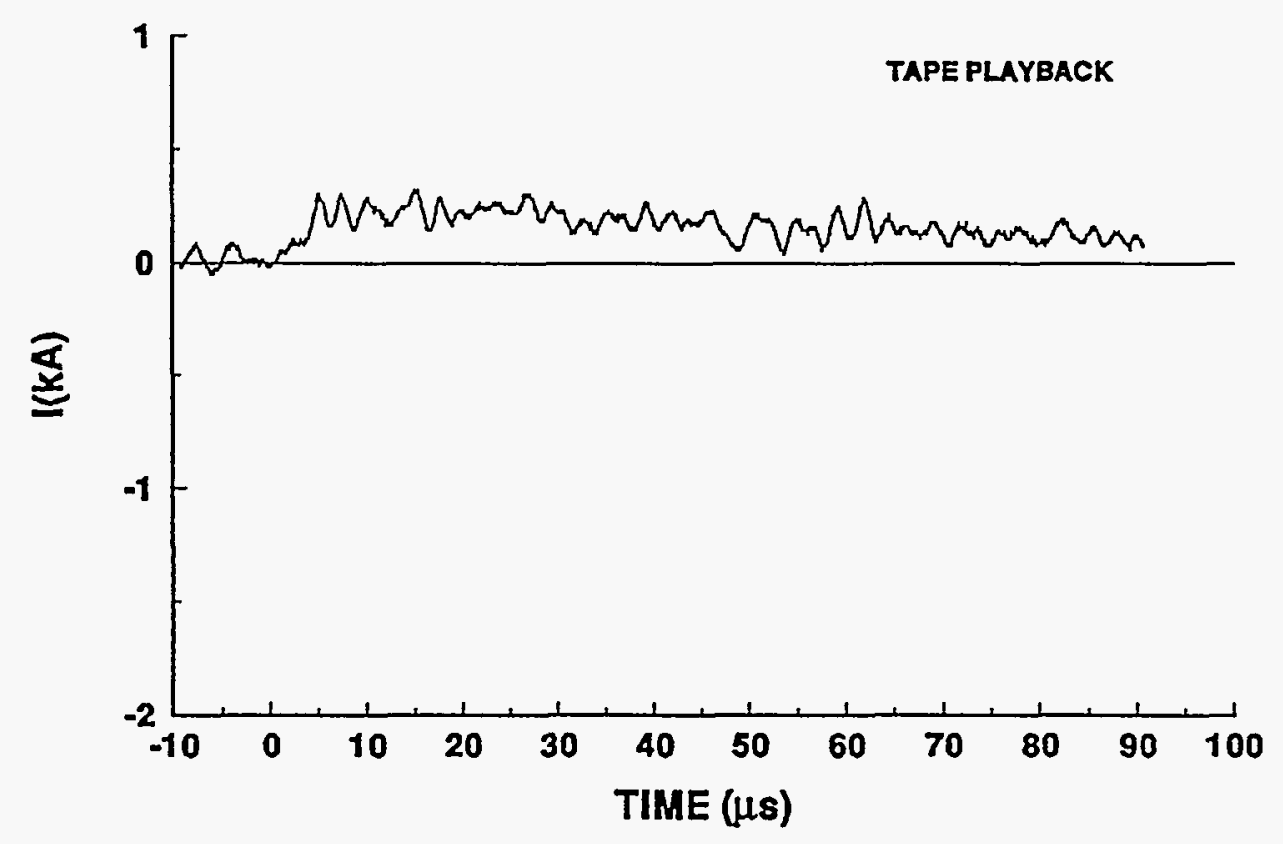


94-24 STROKE 7

TEST POINT 10

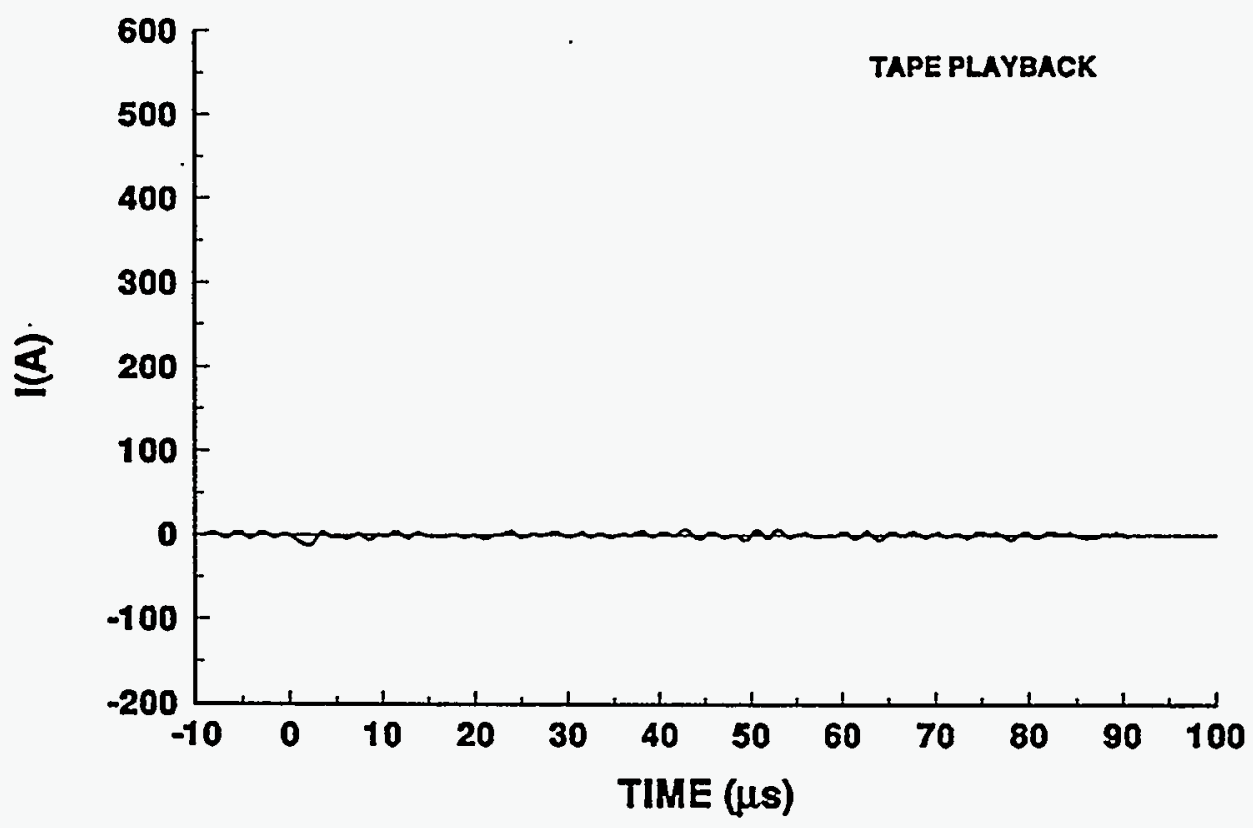

94-24 STROKE 7

TEST POINT 11

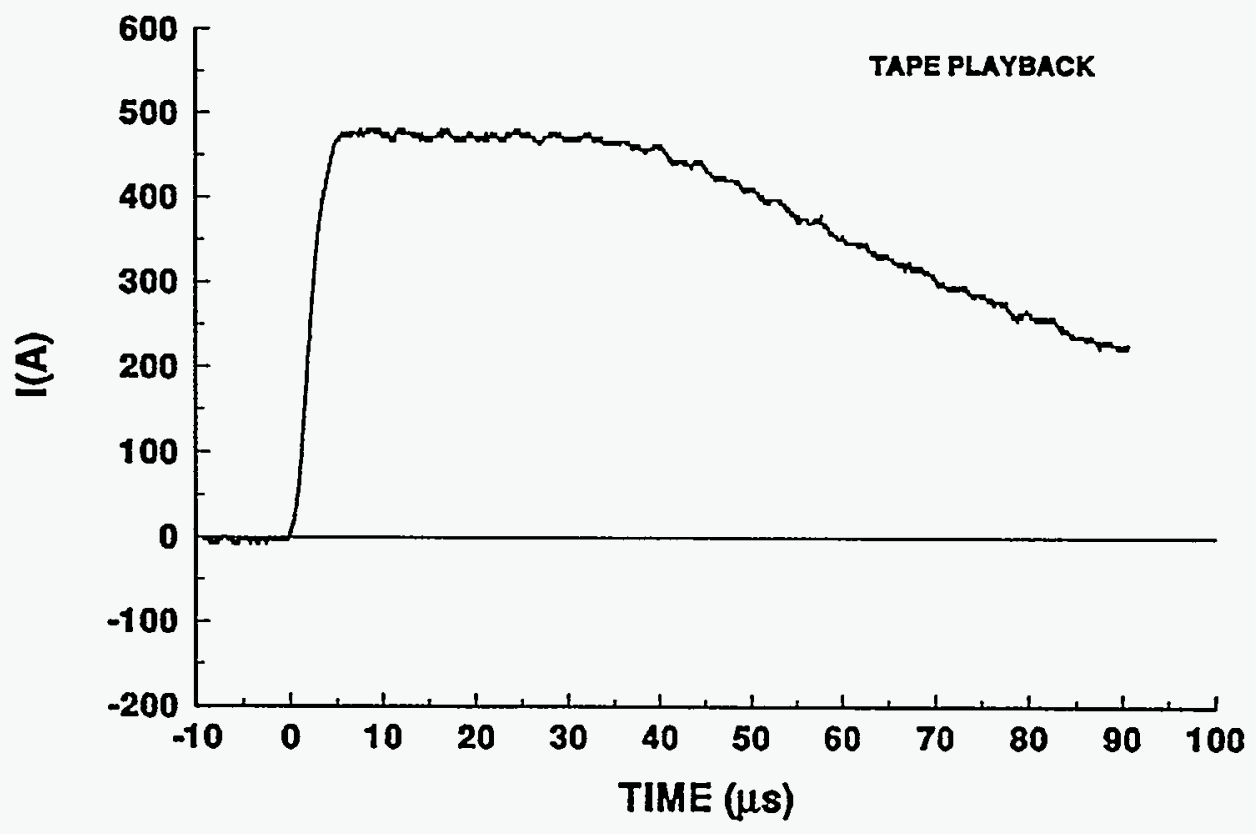




\section{4-24 STROKE 7}

TEST POINT 12

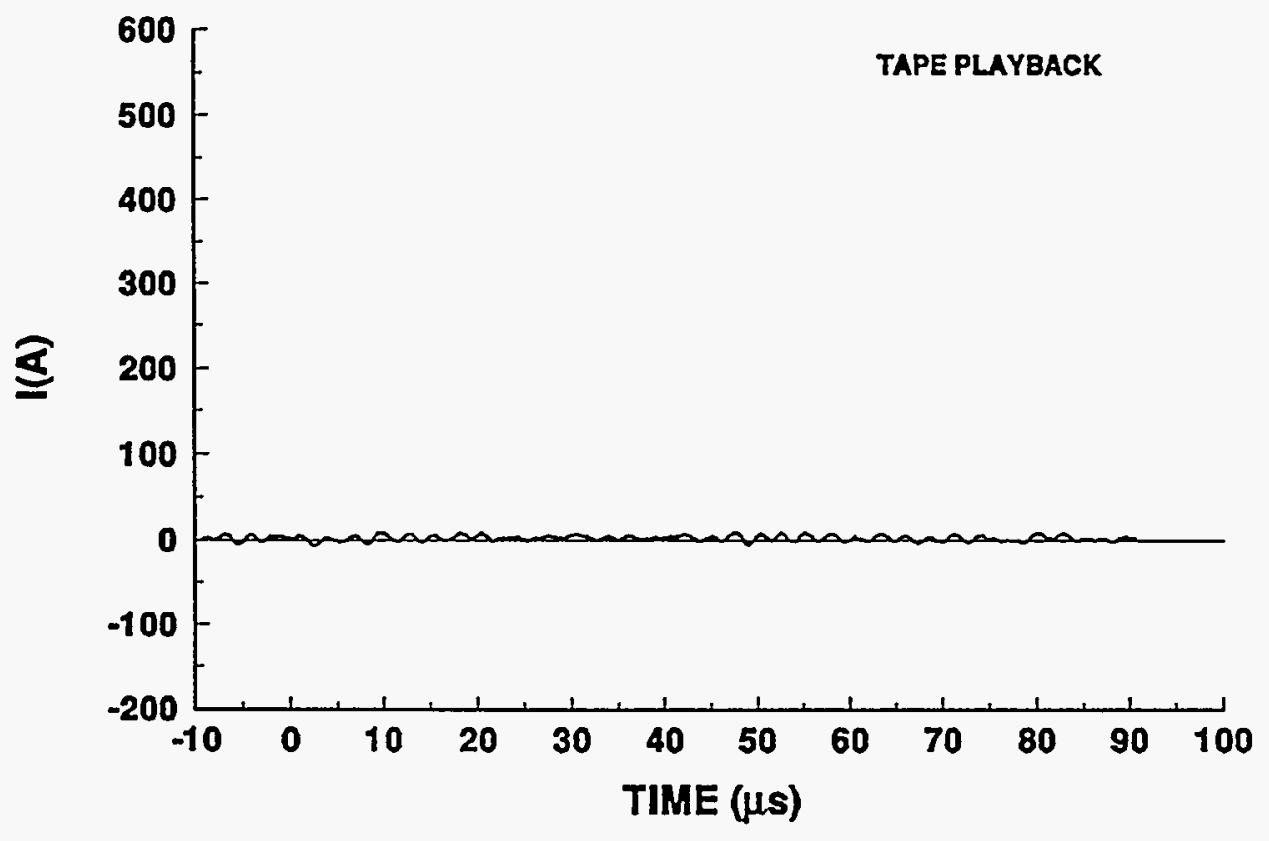

94-24 STROKE 7

TEST POINT 13

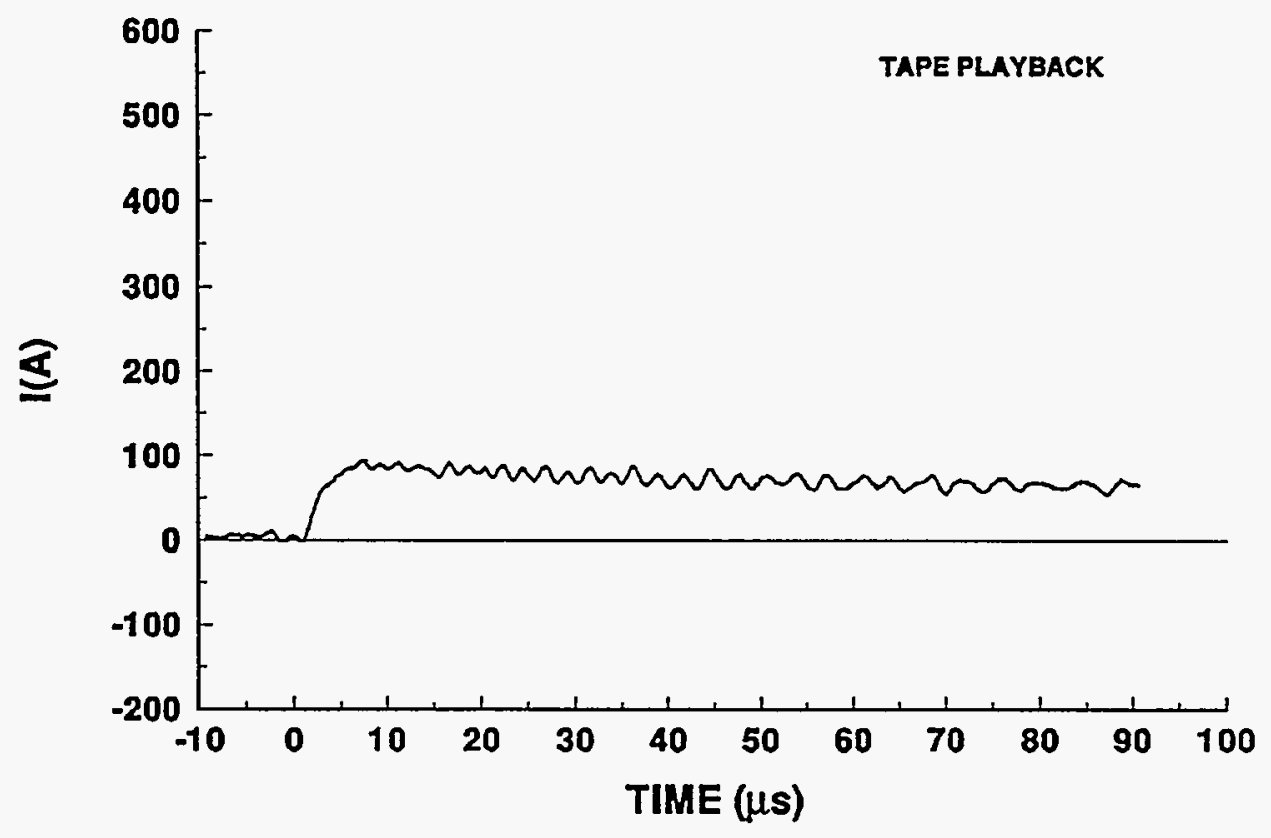


94-24 STROKE 7

TEST POINT 14
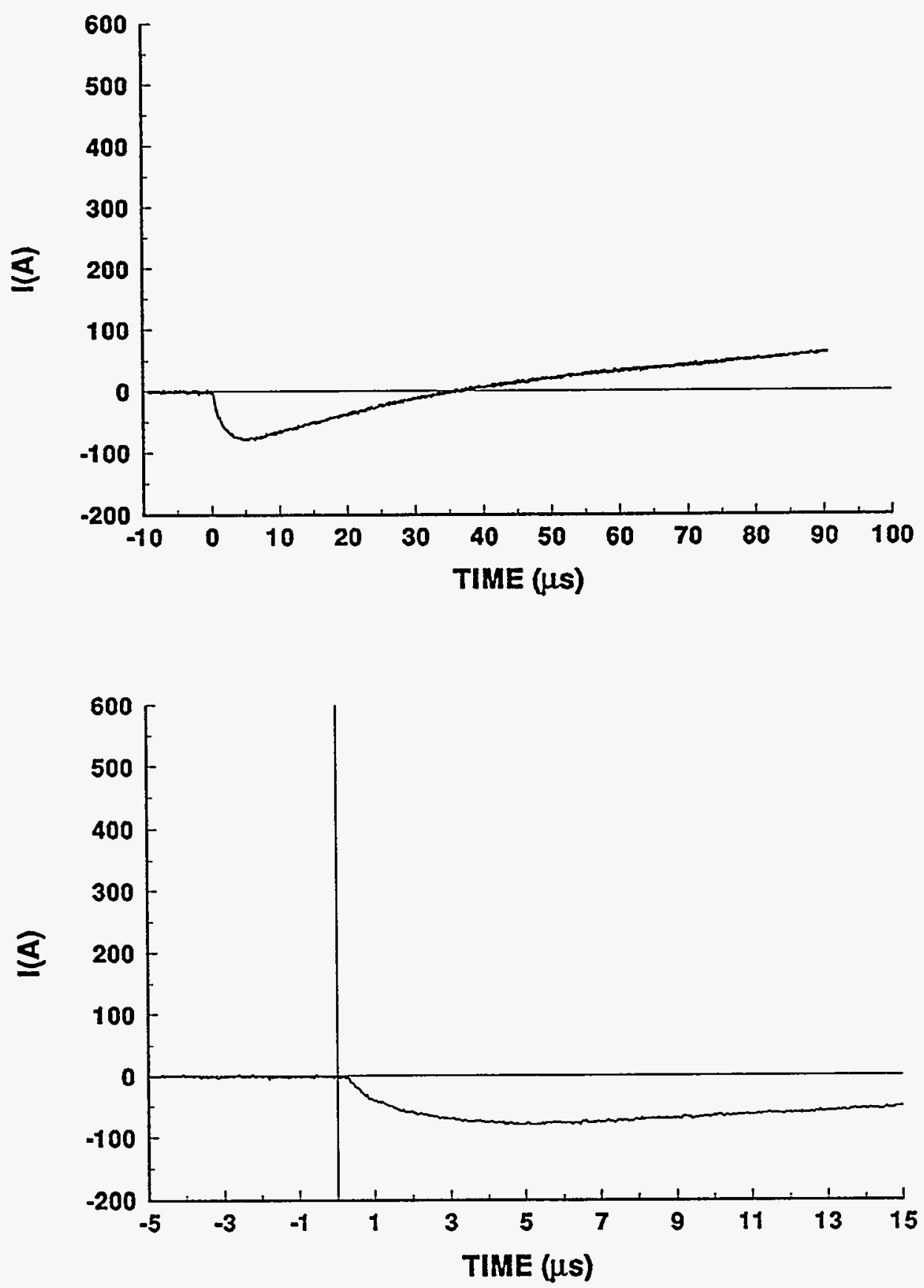


\section{4-24 STROKE 7}

TEST POINT 15
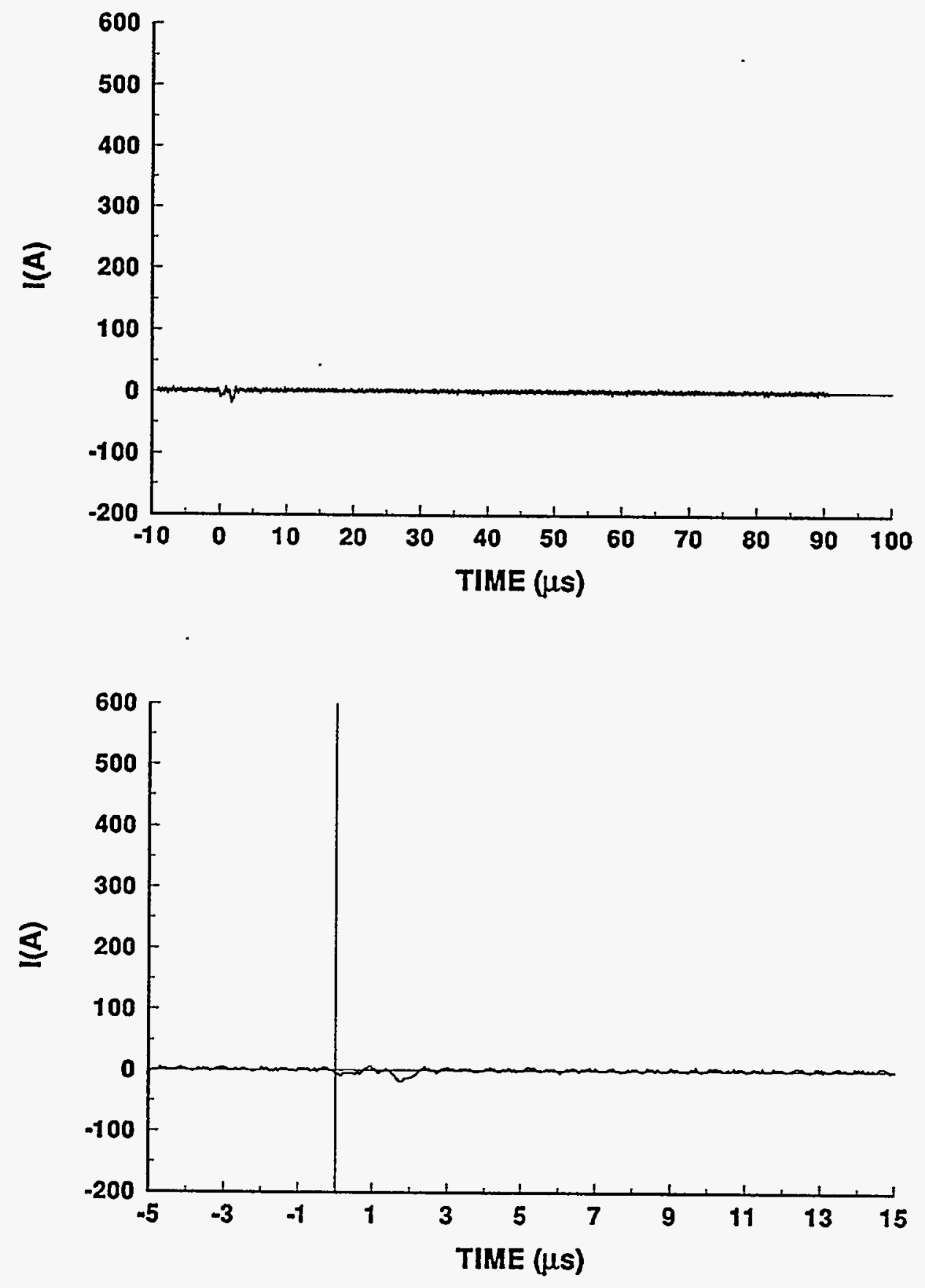


\section{4-24 STROKE 7}

TEST POINT 20

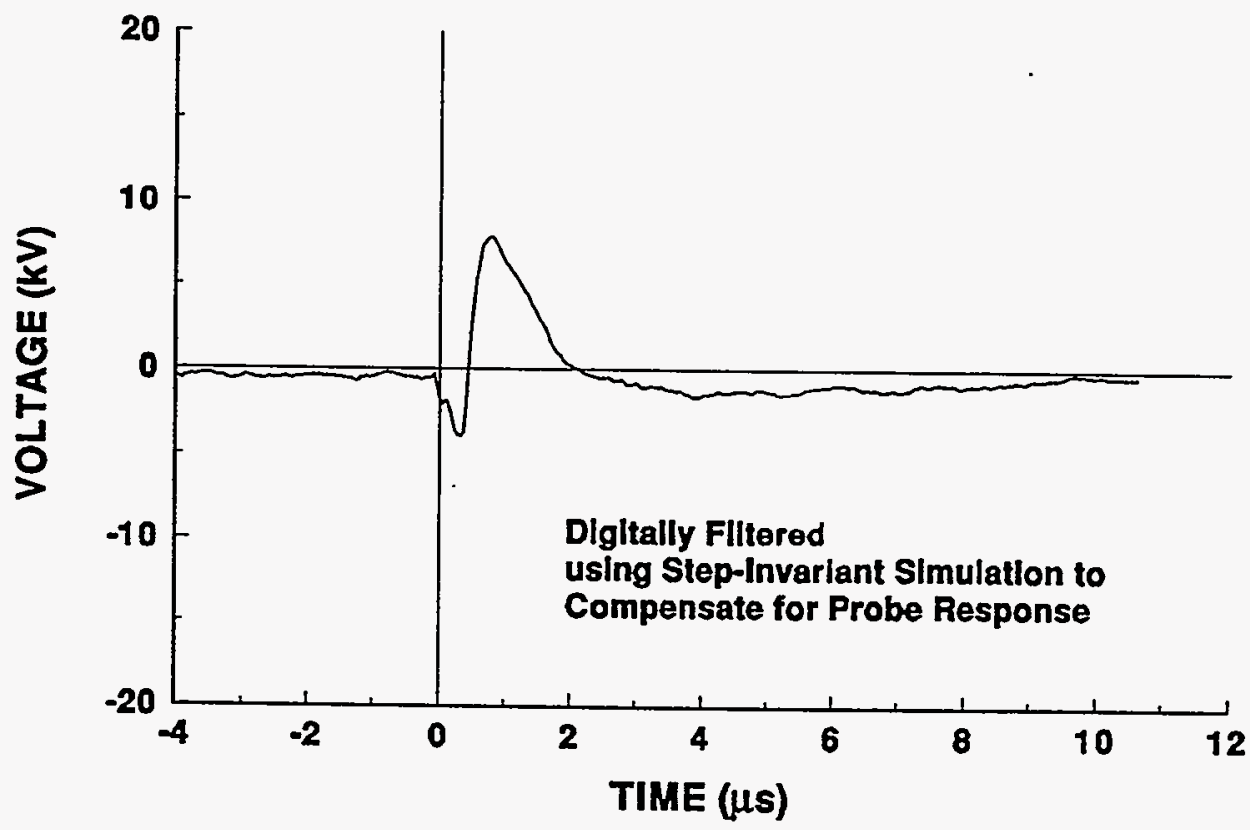

94-24 STROKE 7

TEST POINT 21

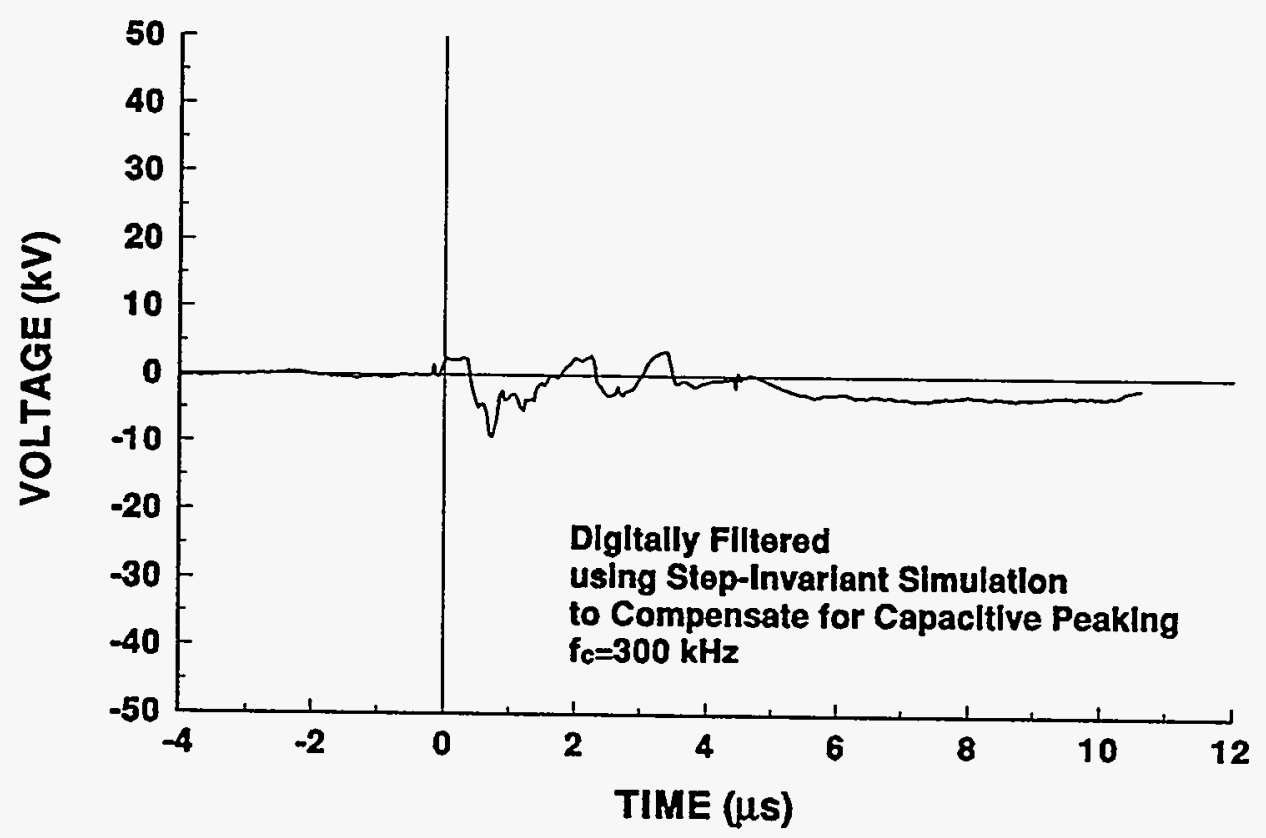




\section{4-24 STROKE 7}

TEST POINT 22

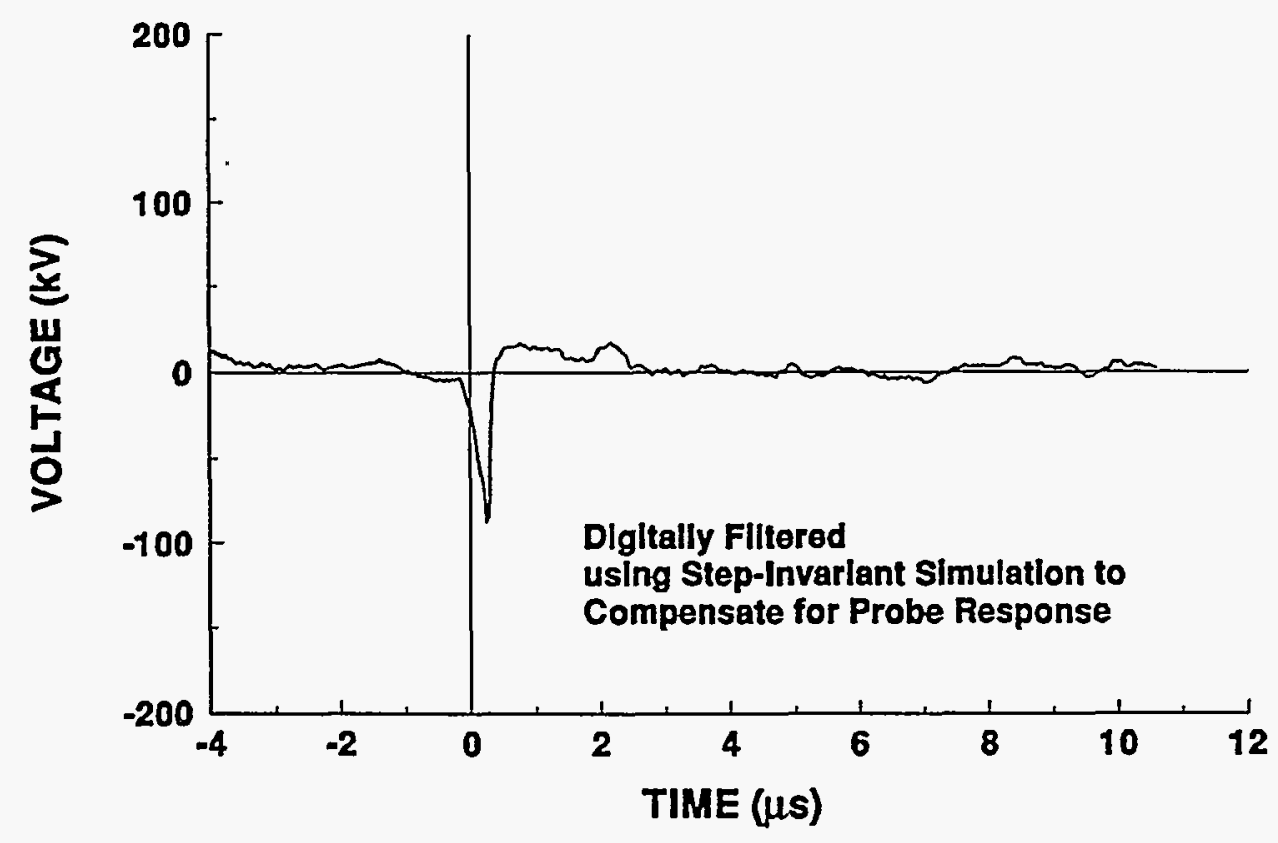


94-24 STROKE 7

TEST POINT 23

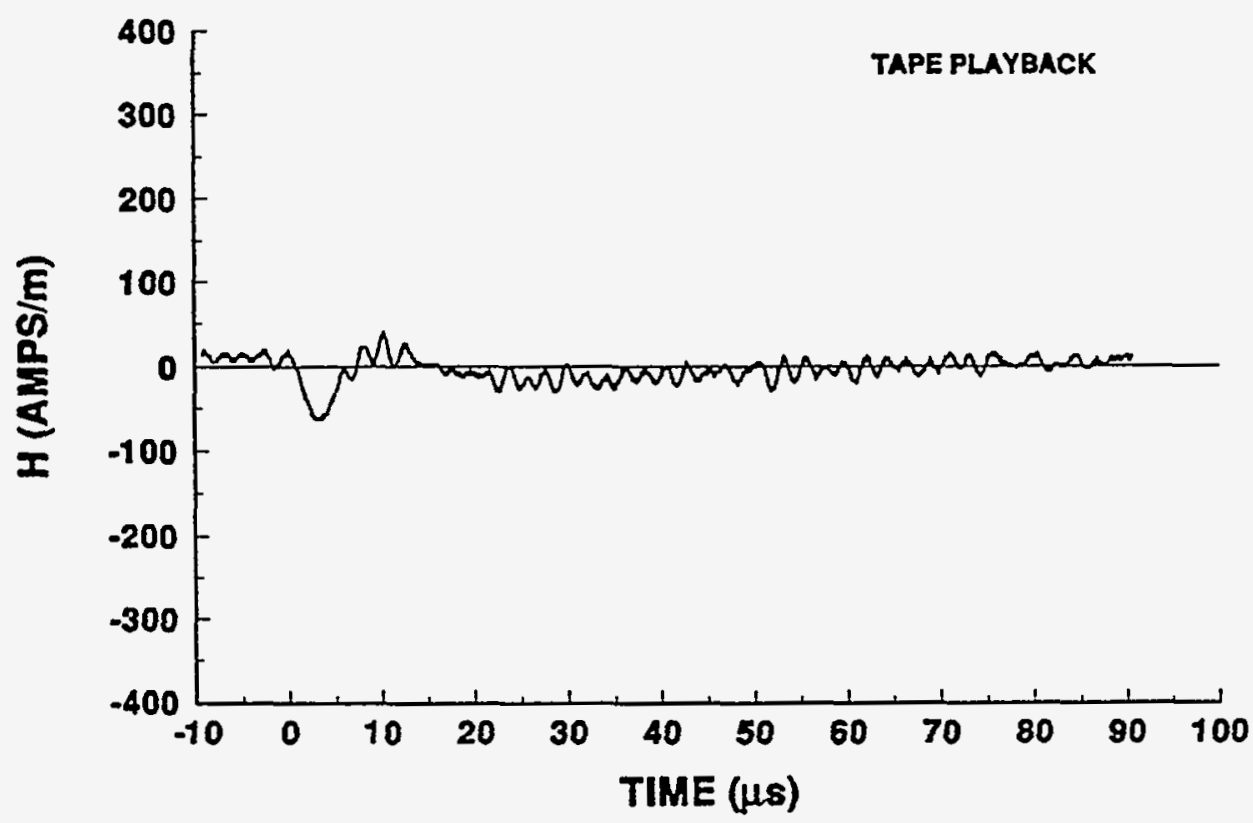

94-24 STROKE 7

TEST POINT 24

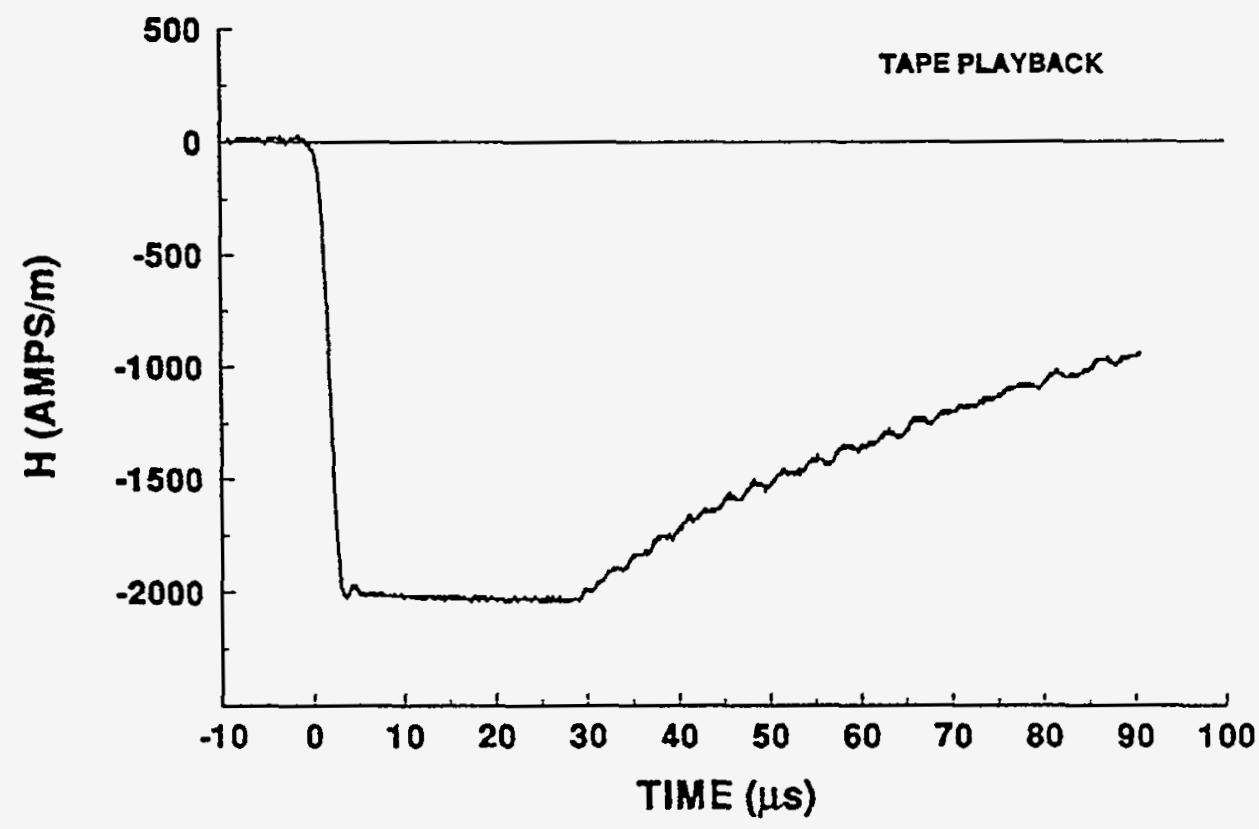




\section{4-24 STROKE 8 \\ INCIDENT CURRENT}
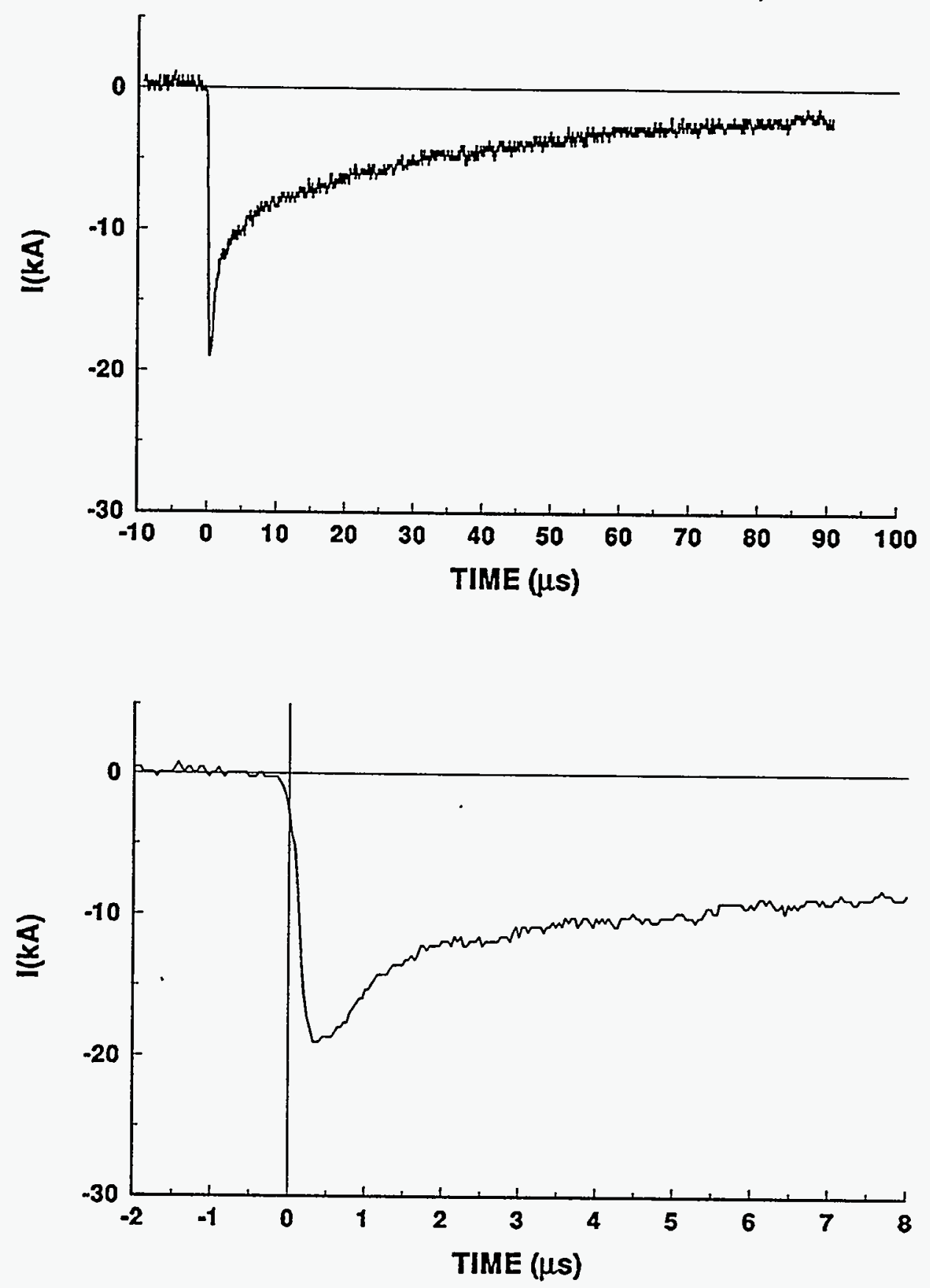


\section{4-24 STROKE 8 \\ TEST POINT 1}
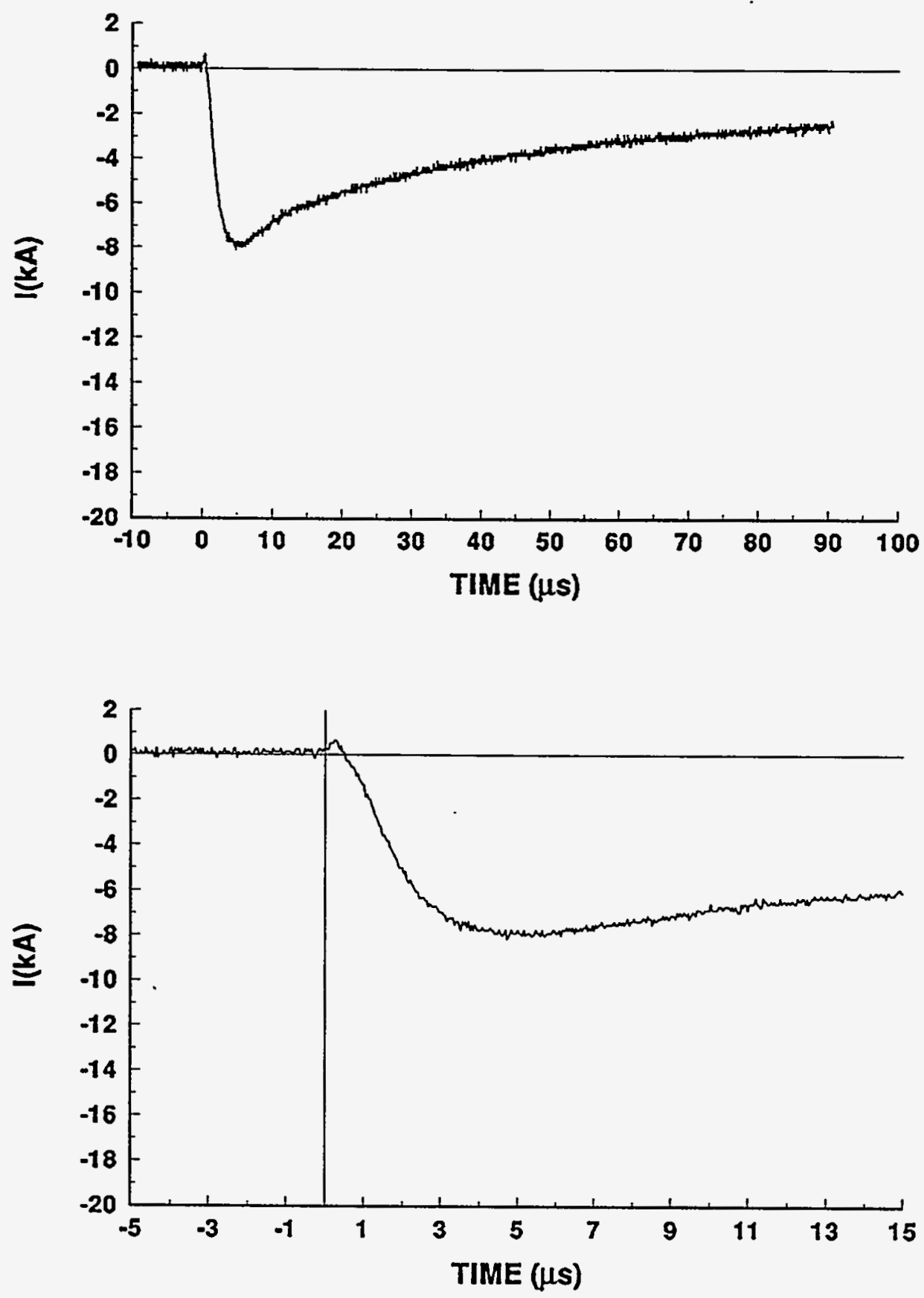


\section{4-24 STROKE 8 \\ TEST POINT 2}
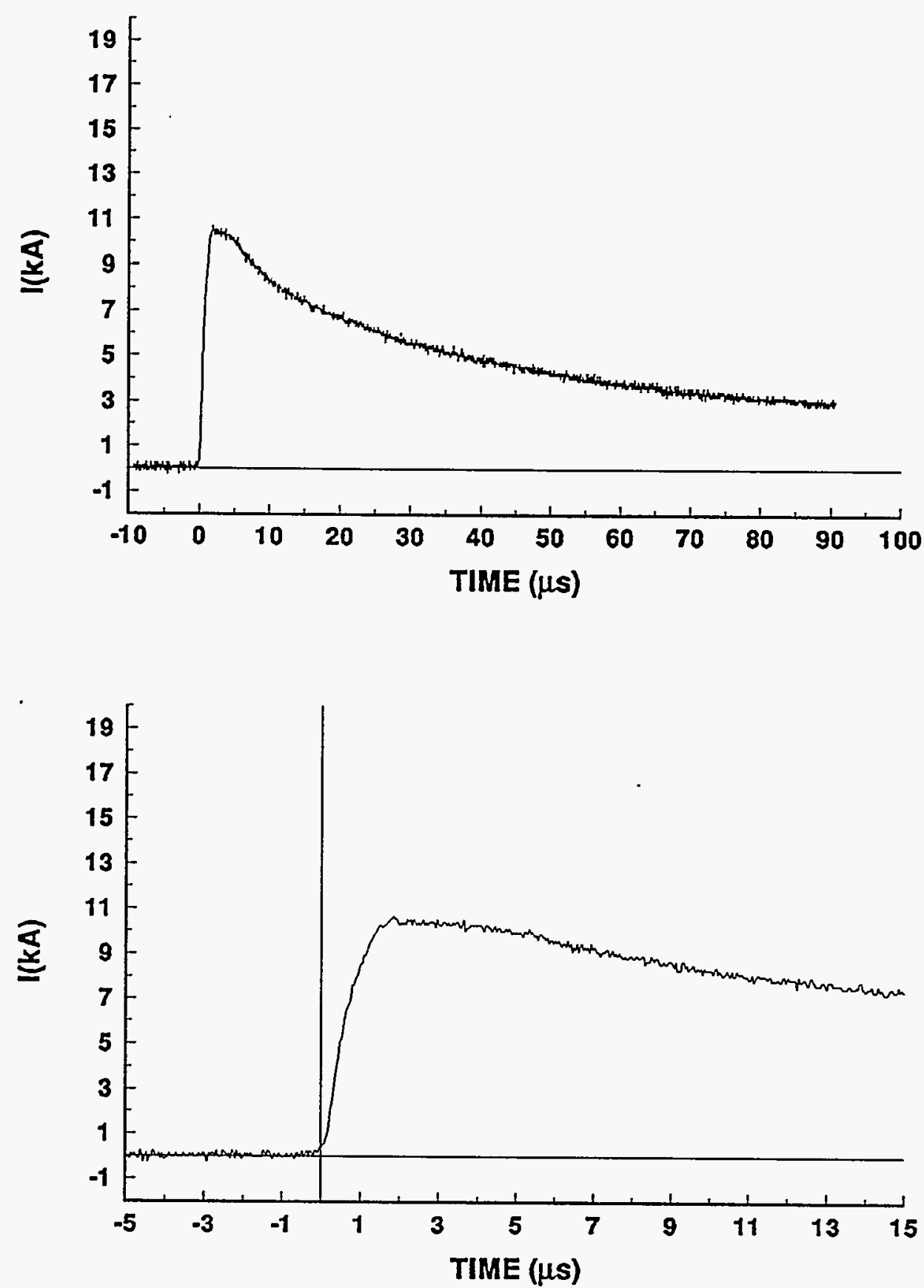


\section{4-24 STROKE 8}

TEST POINT 5
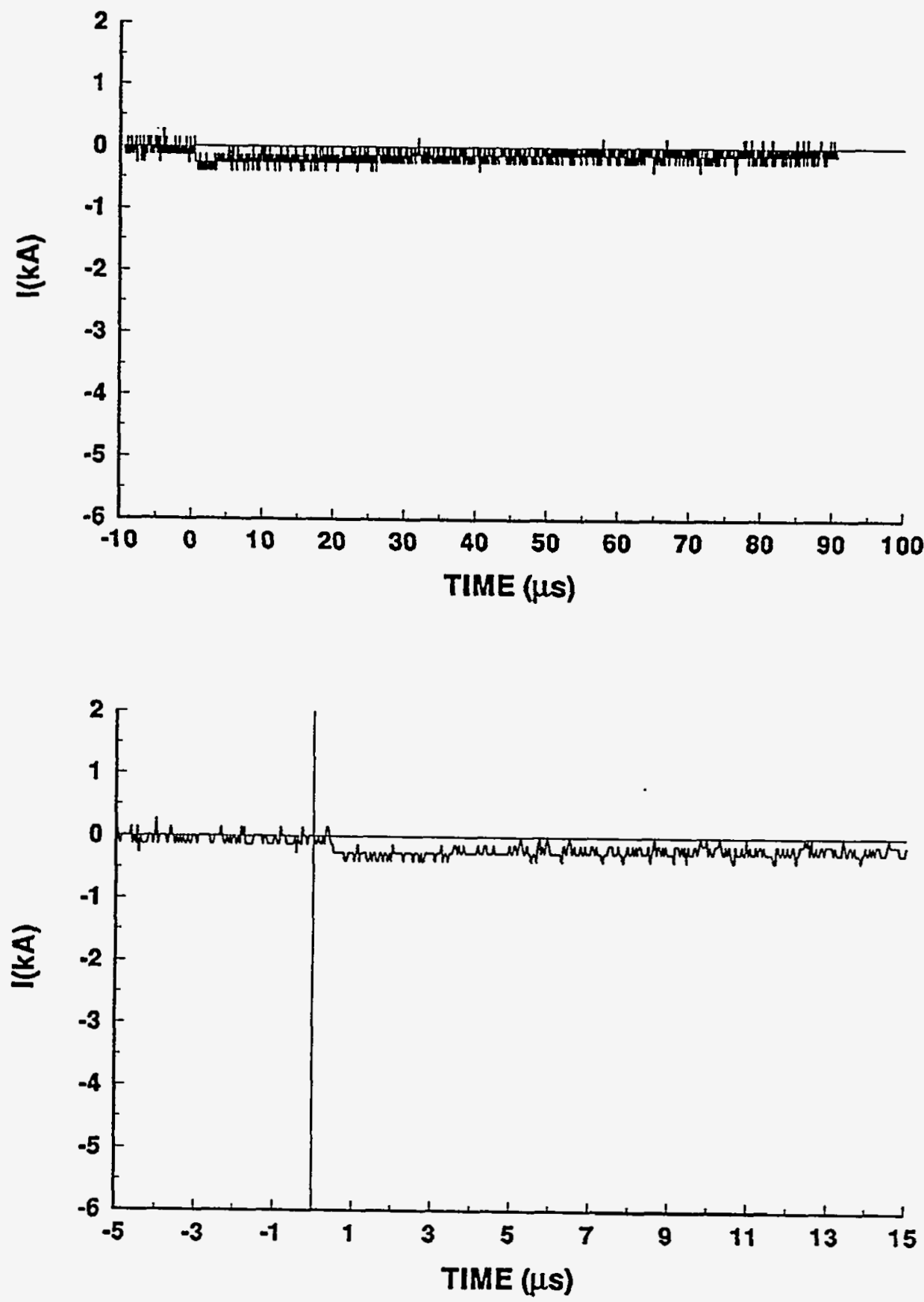
94-24 STROKE 8

TEST POINT 6
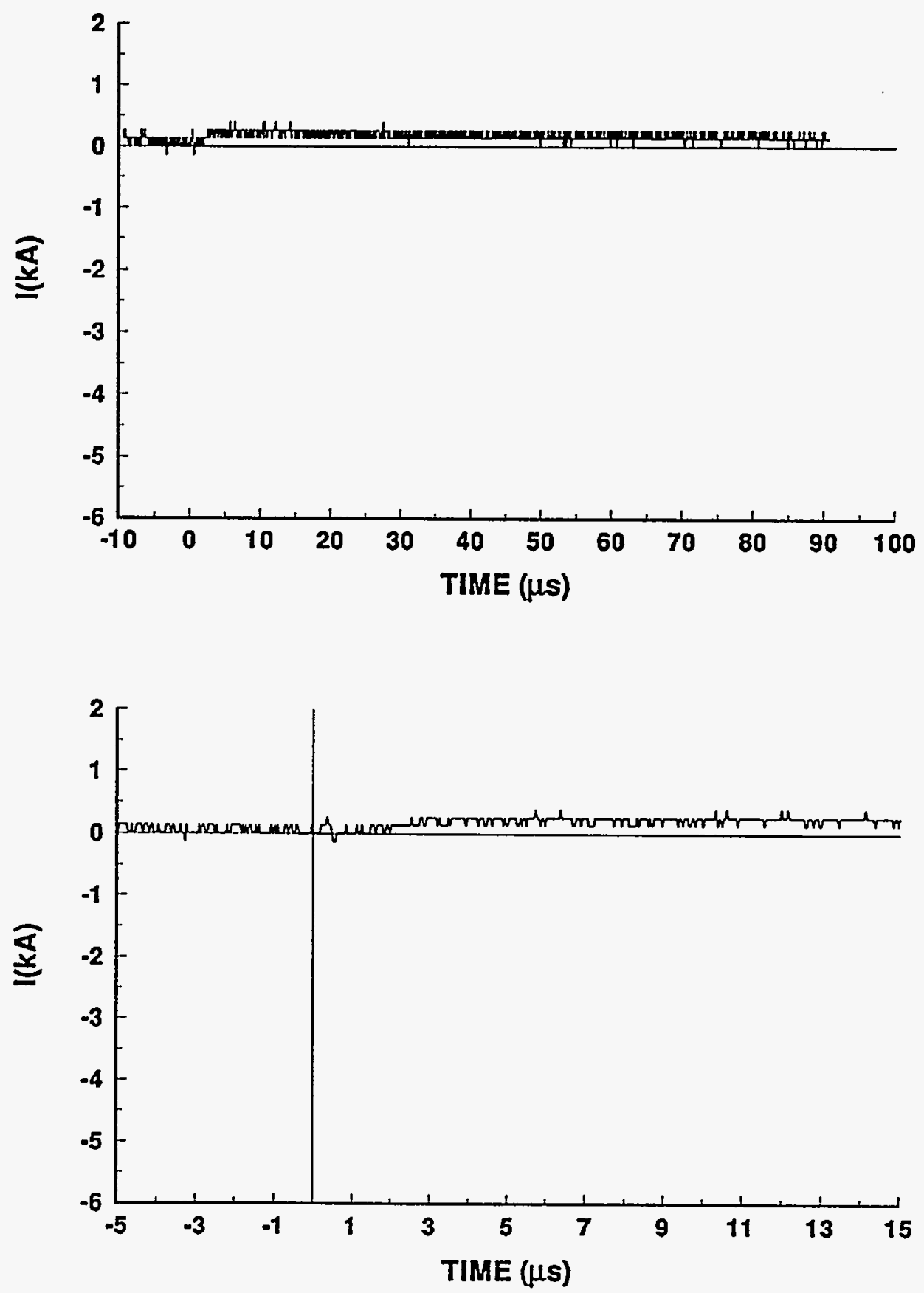
94-24 STROKE 8

TEST POINT 5'

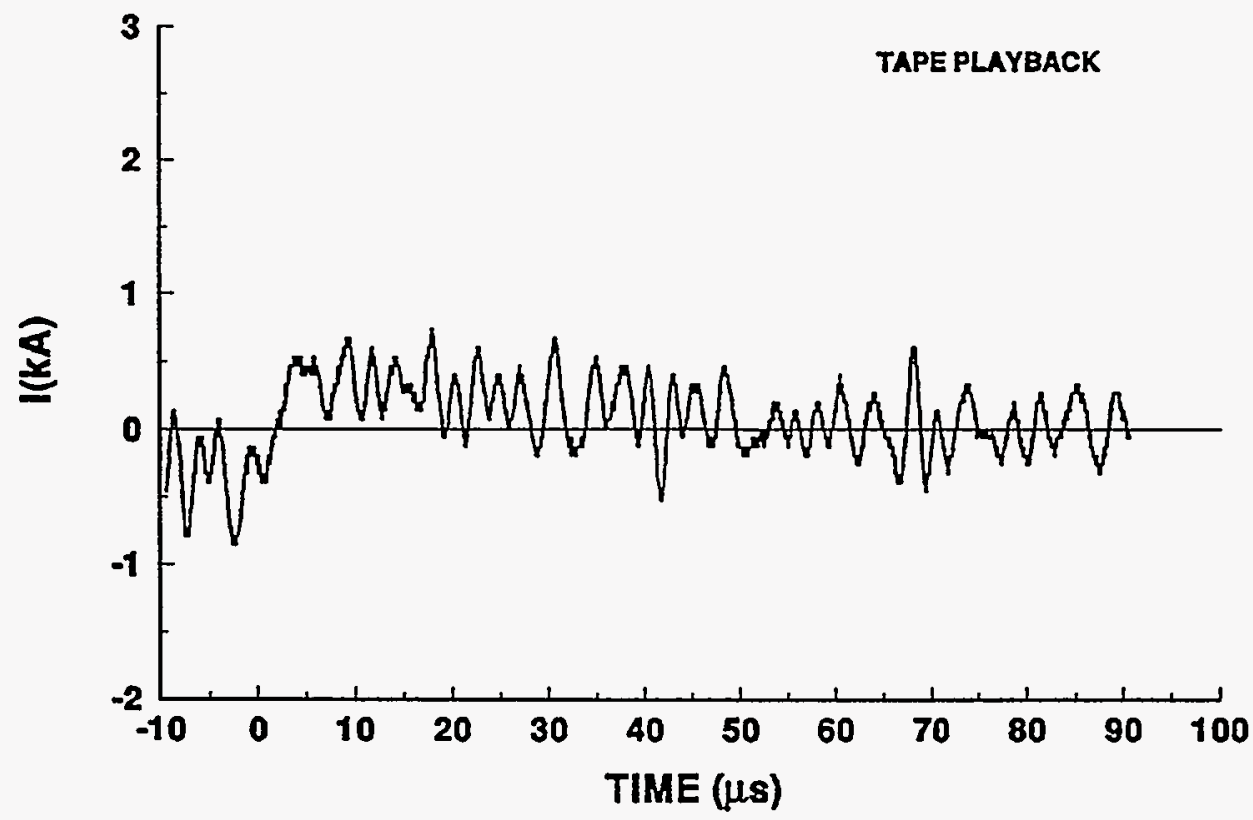

94-24 STROKE 8

TEST POINT 6'

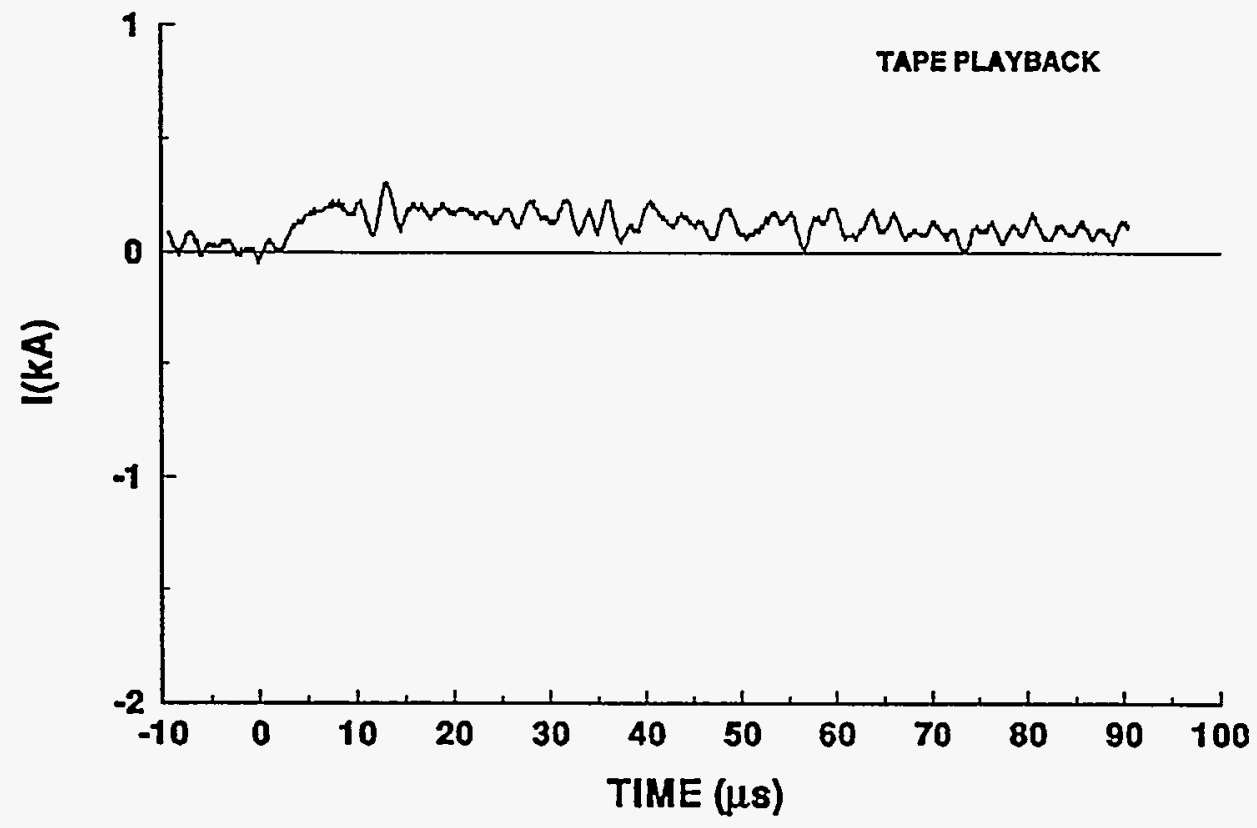




\section{4-24 STROKE 8}

TEST POINT 10

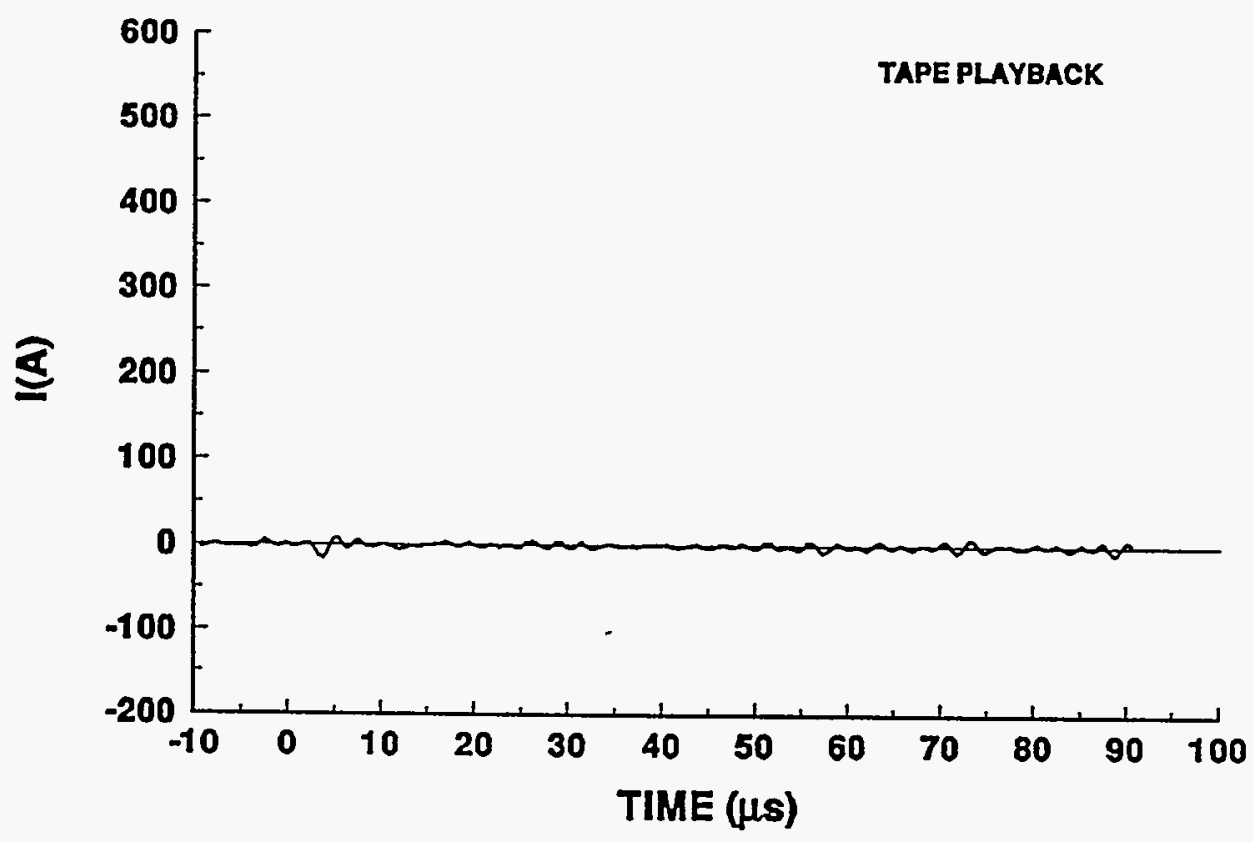

94-24 STROKE 8

TEST POINT 11

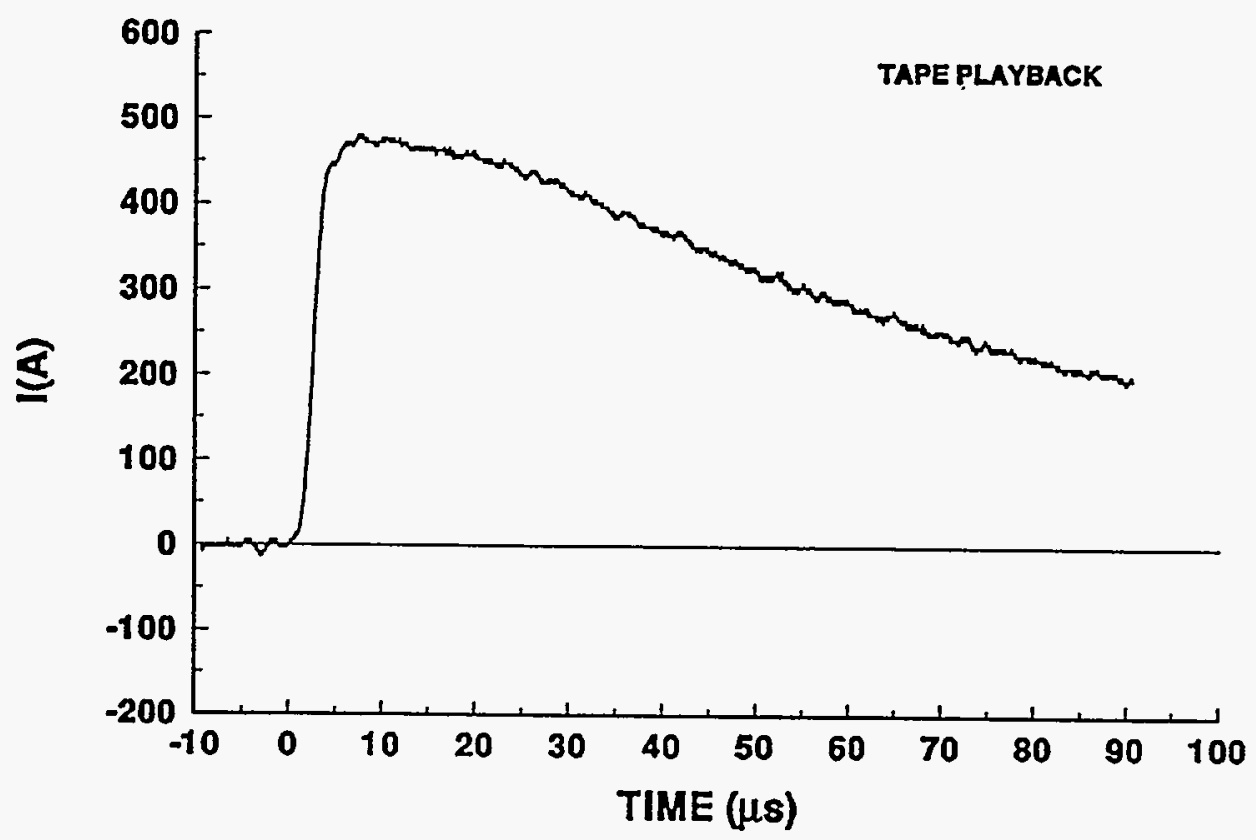


94-24 STROKE 8

TEST POINT 12

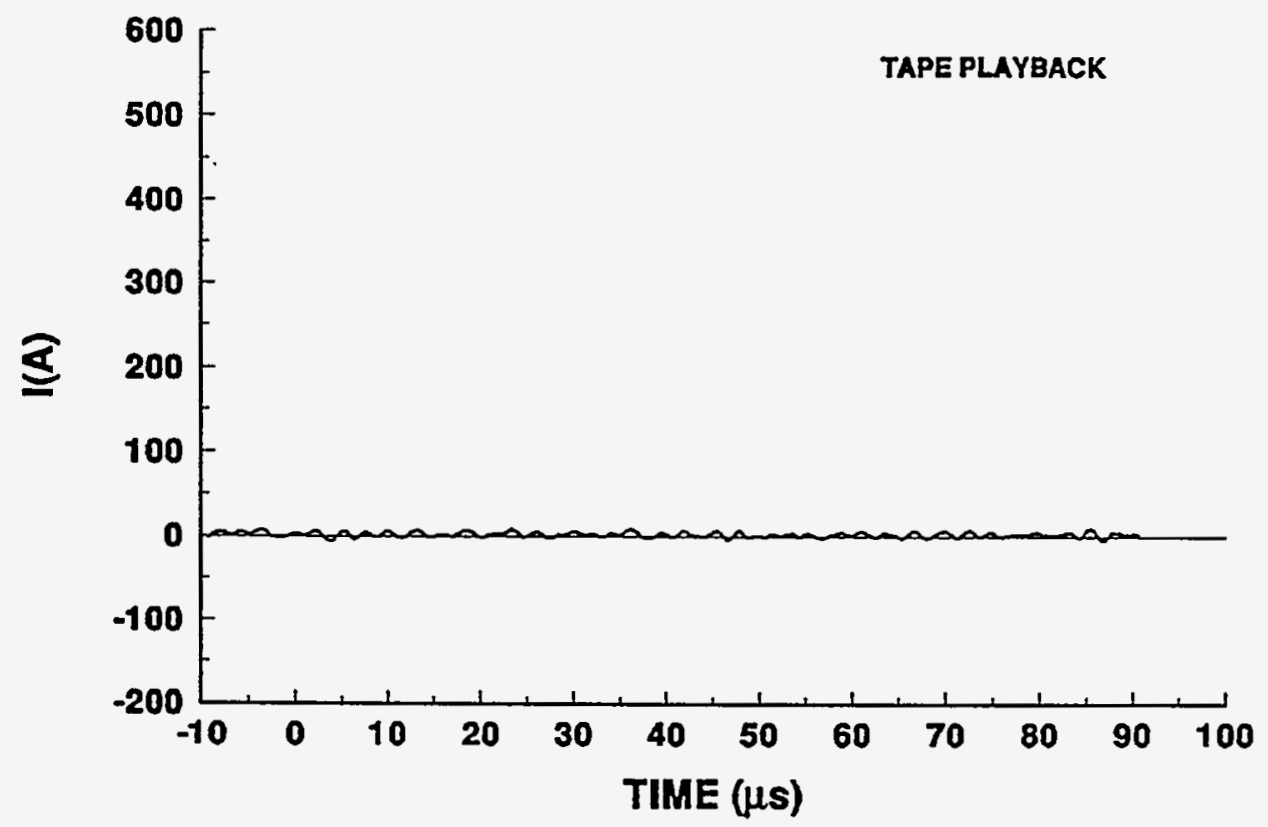

94-24 STROKE 8

TEST POINT 13

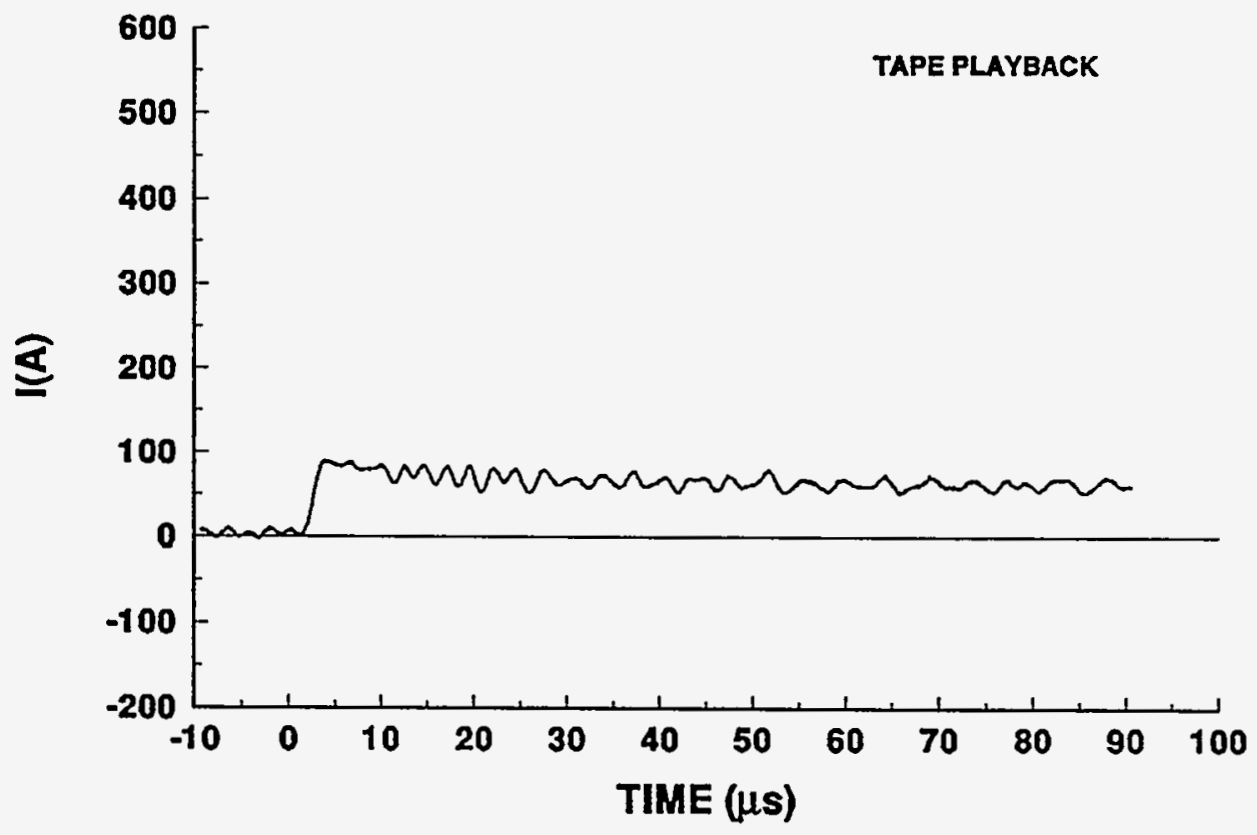




\section{4-24 STROKE 8}

TEST POINT 14
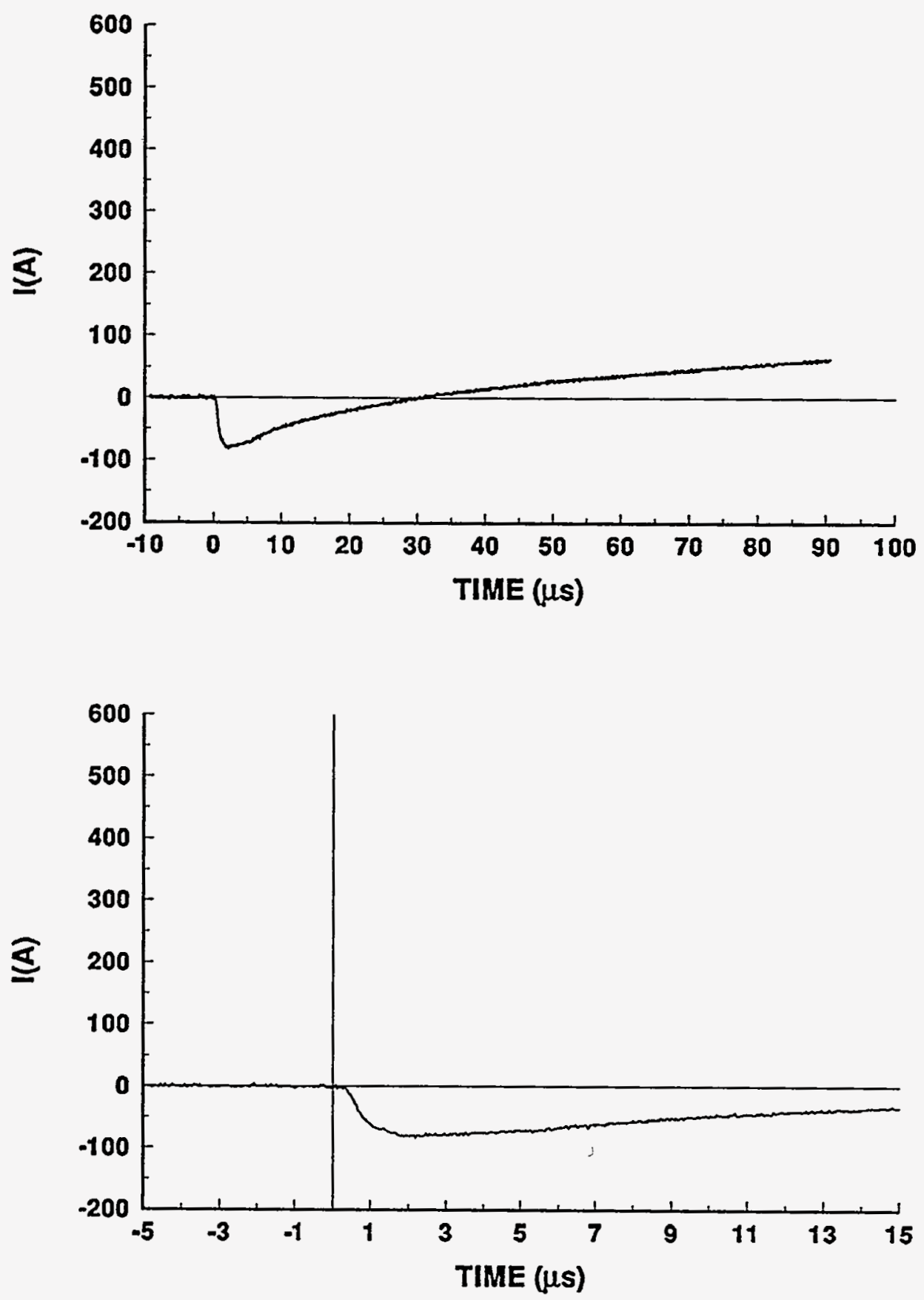


\section{4-24 STROKE 8}

TEST POINT 15
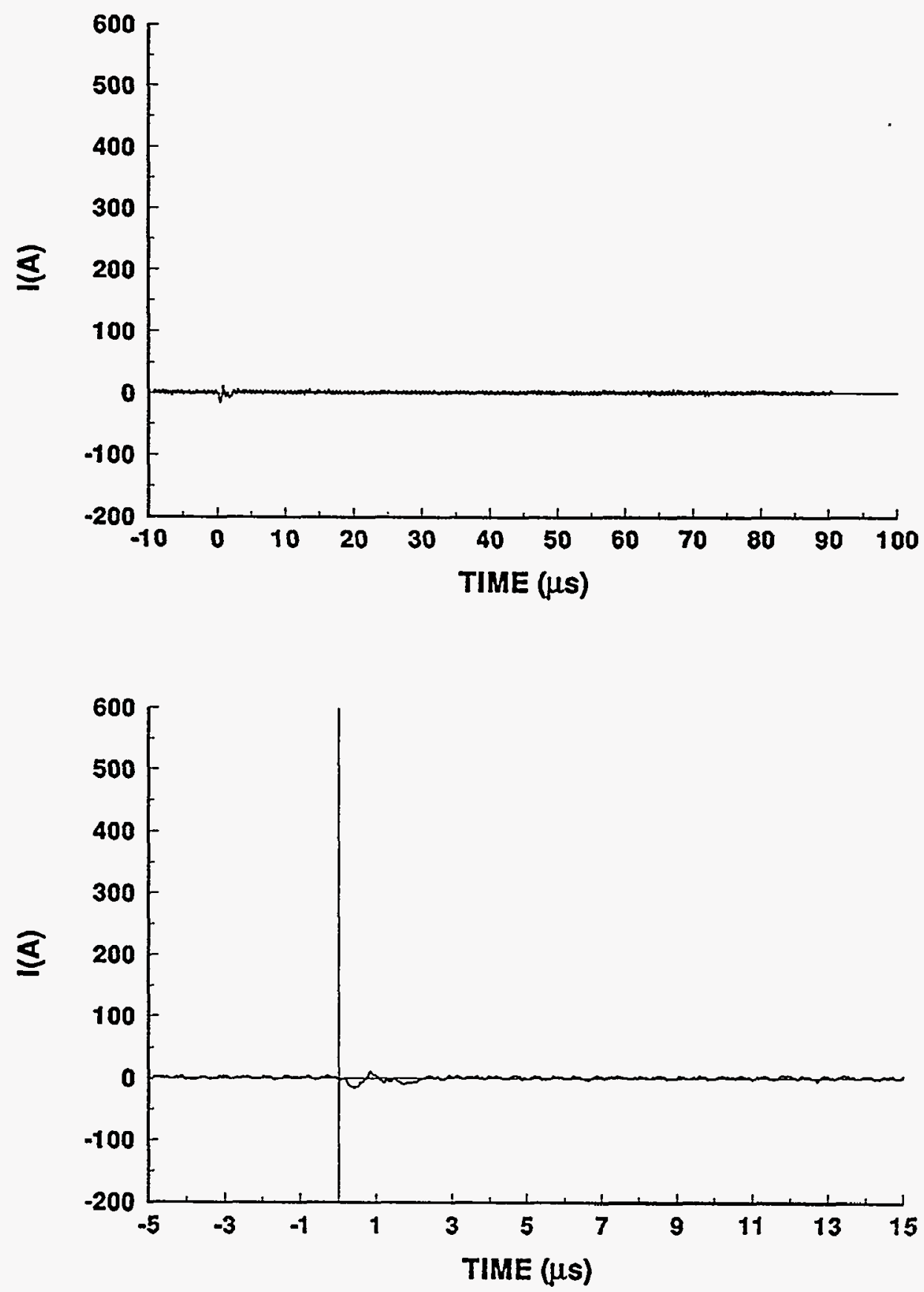


\section{4-24 STROKE 8}

\section{TEST POINT 20}

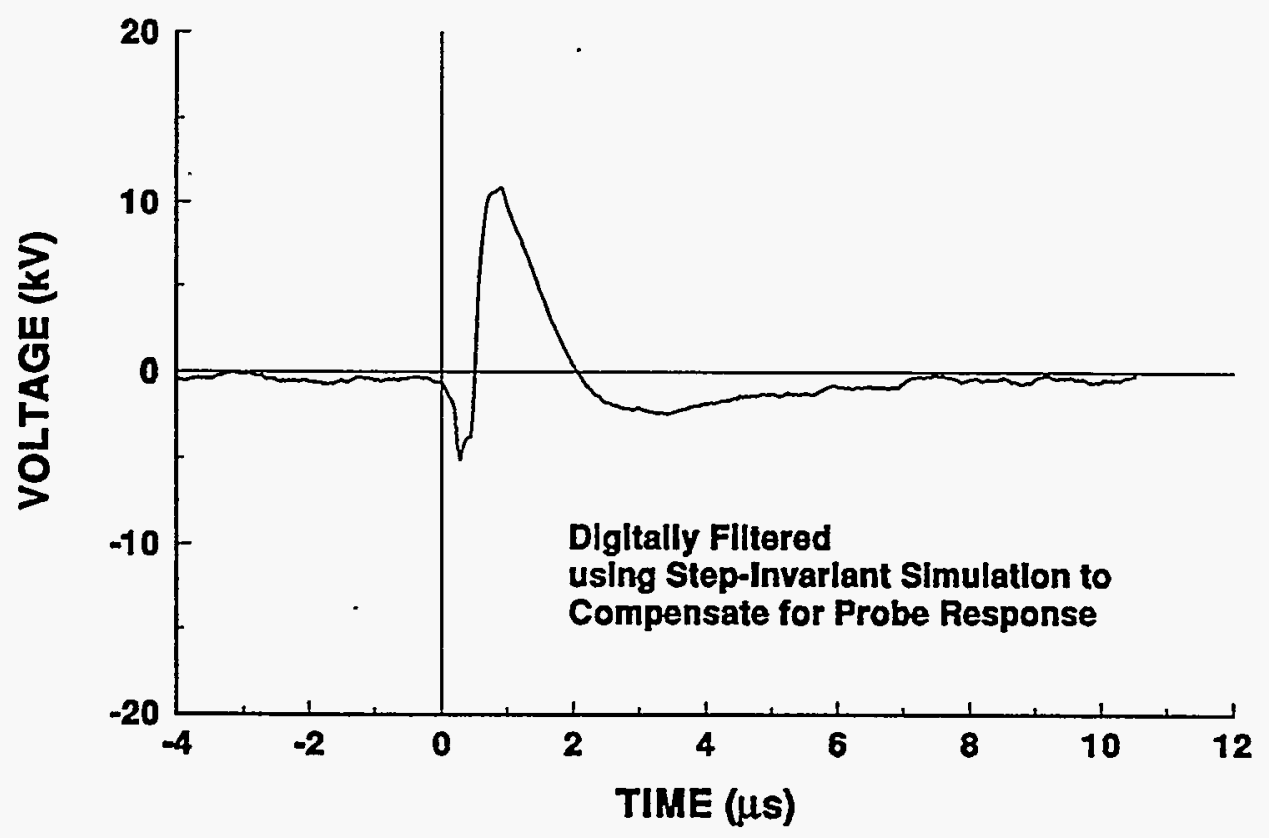

94-24 STROKE 8

TEST POINT 21

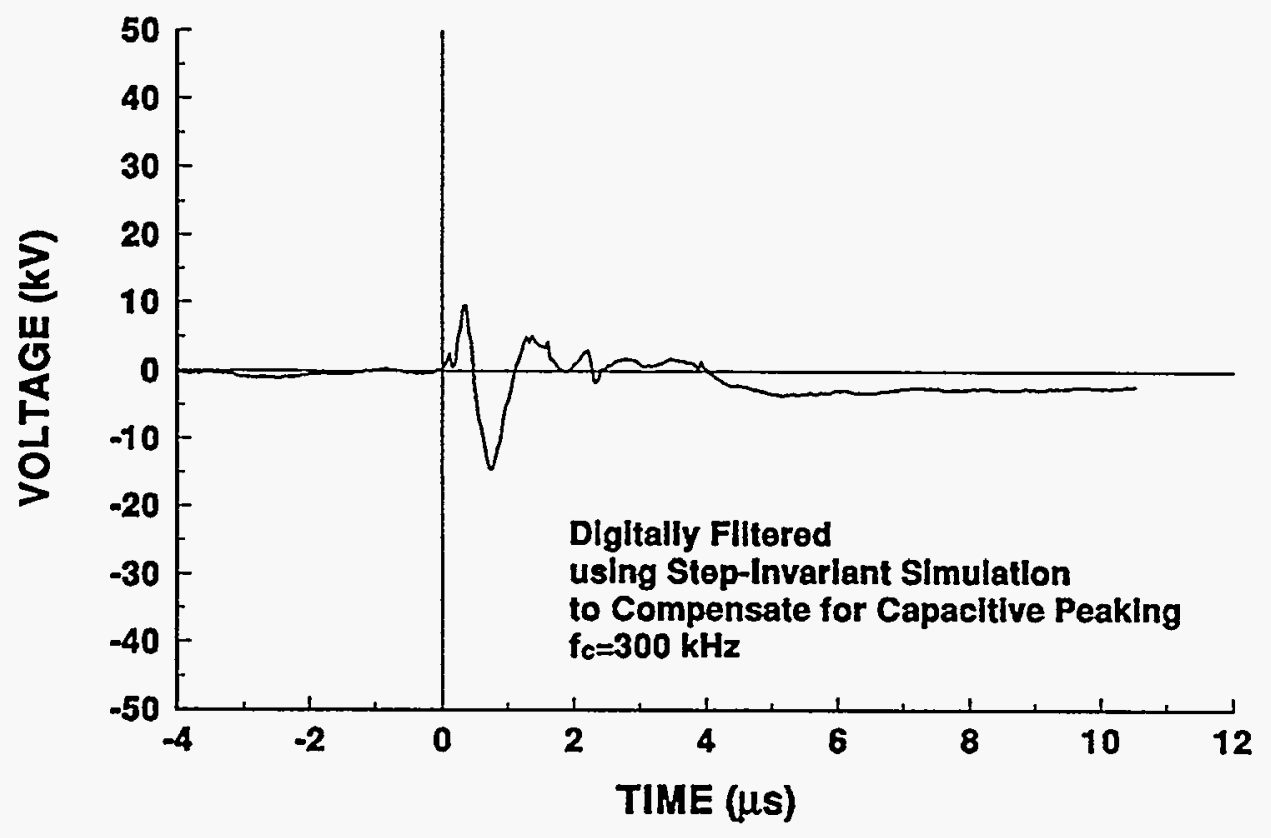




\section{4-24 STROKE 8}

TEST POINT 22

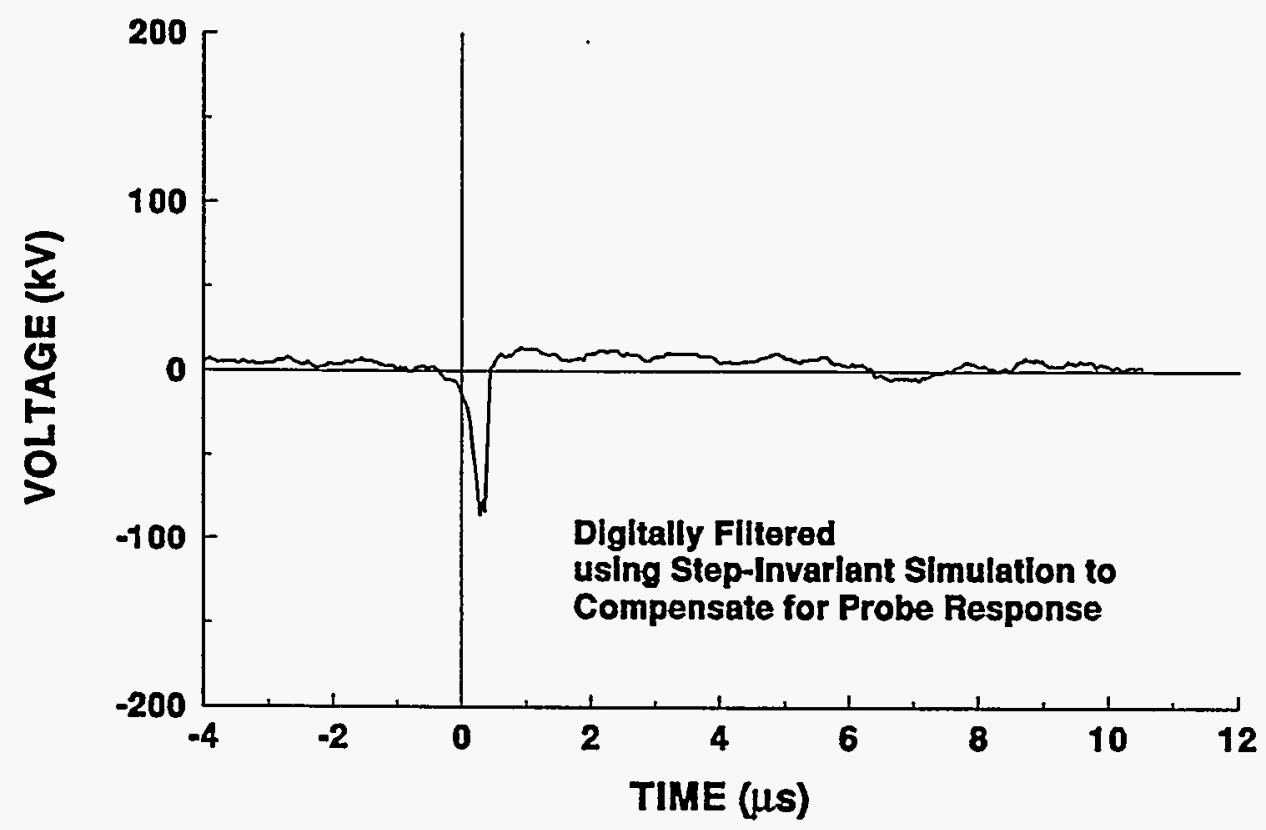




\section{4-24 STROKE 8}

\section{TEST POINT 23}

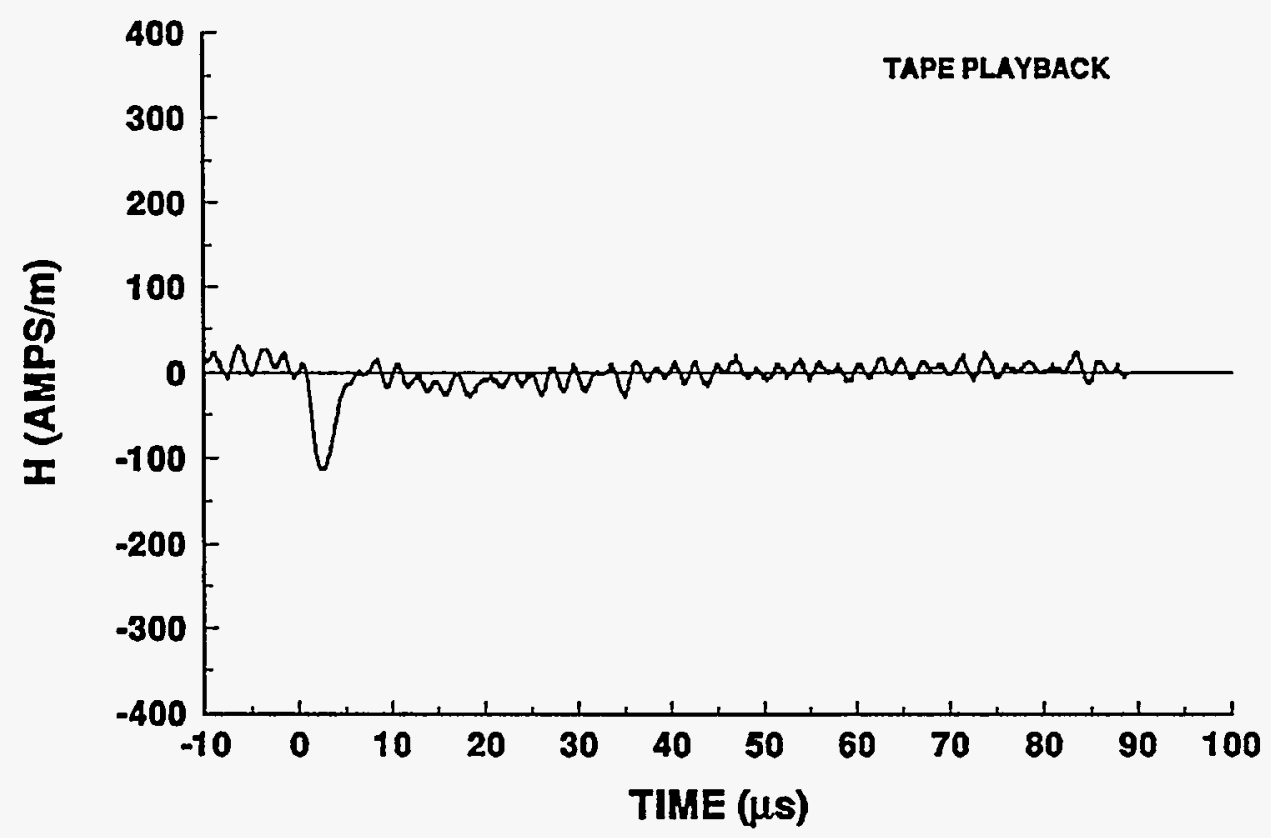

\section{4-24 STROKE 8}

TEST POINT 24

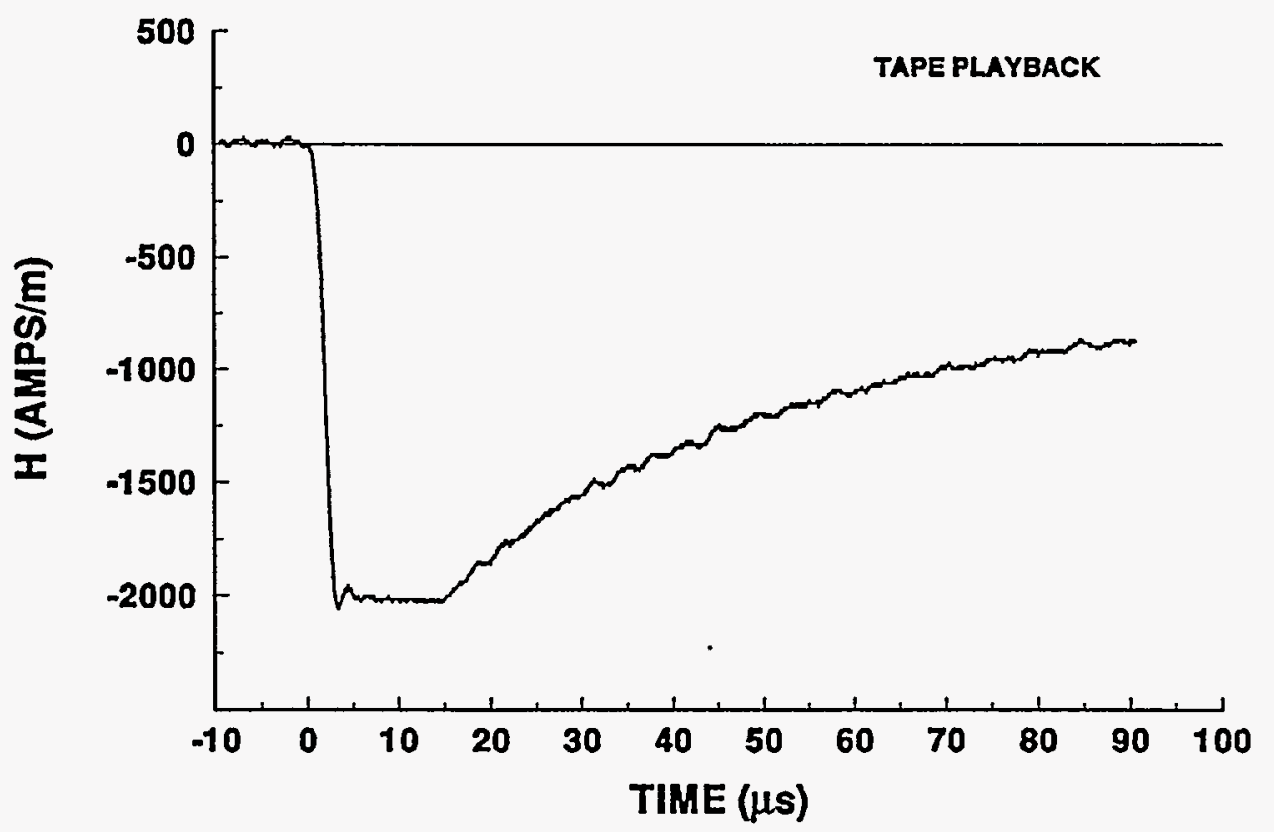




\section{Distribution}

1 Roger E. Baldwin

Building D3, Room 003

Culham Laboratory

Abingdon

Oxfordshire OX14 3DB

United Kingdom

1 Mr. Brian Burrows

5 Willow Lane

Milton

Abingdon

Oxfordshire OX14 4EG

United Kingdom

1 Dr. Vernon Cooray

Institute of High Voltage Research

Uppsala University

Husbyborg

S-755 92 Uppsala

Sweden

1 Dr. Rajeev Thottappillil

Institute of High Voltage

Uppsala University

Husbyborg

Uppsala S7528

Sweden

$1 \quad$ Dr.-Ing. Wolfgang Zischank

Universitat Der Bundeswehr Munchen

Institut ET/7

Werner-Heisenberg-Weg 39

D-8014 Neubiberg

Germany

1 Prof. Matt Darveniza

Department of Electrical Engineering

University of Queensland

Brisbane, Australia 4072

1 Andre Eybert-Berard

ST1/LASP

C.E.N.G. Avenue Des Martyrs

85X 38041 Grenoble Cedex

France 


\section{Distribution (Continued)}

5 Richard J. Fisher

1797 Pleasant Grove Road

Claysville, PA 15323

3 University of Florida

Attn: Martin A. Uman

Dept. of Electrical Engineering

University of Florida

216 Larsen Hall

Gainesville, FL 32611-6200

1 Prof. Vince Idone

State University of New York, Albany

1400 Washington Ave.

Albany, NY 12222

1 Professor E. P. Krider

Institute of Atmospheric Physics

University of Arizona

Tucson, AZ 85721

1 Mr. J. A. Plumer

Lightning Technologies, Inc.

10 Downing Parkway

Pittsfield, MA 01201

$1 \quad$ Mr. Jake Struck

45 Esplanong Rd.

Lake Hopatcong, NJ 07849

50 MS 0865 M. E. Morris (Org. 2753)

1 MS 0865 K. C. Chen (Org. 2753)

1 MS 0865 R. D. Jones (Org. 2753)

1 MS 0865 R. E. Jorgenson (Org. 2753)

1 MS 0865 K. O. Merewether (Org. 2753)

3 MS 0865 G. H. Schnetzer (Org. 2753)

$1 \quad$ MS 0865 L. K. Warne (Org. 2753)

1 MS 9018 Central Technical Files (Org. 8523-2)

$5 \quad$ MS 0899 Technical Library (Org. 13414)

$1 \quad$ MS 0619 Print Media (Org. 12615)

2 MS 0100 Document Processing (for DOE/OSTI) (Org. 7613-2) 